Balsa, Juan Javier

Consolidación y desvanecimiento del mundo chacarero. Transformaciones de la estructura agraria, las formas sociales de producción y los modos de vida en la agricultura bonaerense, 1937-1988

\section{Tesis presentada para la obtención del grado de Doctor en Historia \\ Director: Alfredo R. Pucciarelli \\ Codirectora: Noemí Girbal-Blacha}

Este documento está disponible para su consulta y descarga en Memoria Académica, el repositorio institucional de la Facultad de Humanidades y Ciencias de la Educación de la Universidad Nacional de La Plata, que procura la reunión, el registro, la difusión y la preservación de la producción científico-académica édita e inédita de los miembros de su comunidad académica. Para más información, visite el sitio

www.memoria.fahce.unlp.edu.ar

Esta iniciativa está a cargo de BIBHUMA, la Biblioteca de la Facultad, que lleva adelante las tareas de gestión y coordinación para la concreción de los objetivos planteados. Para más información, visite el sitio www.bibhuma.fahce.unlp.edu.ar

\section{Cita sugerida}

Balsa, J. J. (2004) Consolidación y desvanecimiento del mundo chacarero. Transformaciones de la estructura agraria, las formas sociales de producción y los modos de vida en la agricultura bonaerense, 1937-1988 [en línea]. Tesis doctoral. Universidad Nacional de La Plata. Facultad de Humanidades y Ciencias de la Educación. Disponible en:

http://www. fuentesmemoria.fahce.un/p.edu.ar/tesis/te.153/te.153.pdf

\section{Licenciamiento}

Esta obra está bajo una licencia Atribución-No comercial-Sin obras derivadas 2.5 Argentina de Creative Commons.

Para ver una copia breve de esta licencia, visite http://creativecommons.org/licenses/by-nc-nd/2.5/ar/.

Para ver la licencia completa en código legal, visite http://creativecommons.org/licenses/by-nc-nd/2.5/ar/legalcode. 
UNIVERSIDAD NACIONAL DE LA PLATA

FACULTAD DE HUMANIDADES Y CIENCIAS DE LA EDUCACIÓN DOCTORADO EN HISTORIA

\title{
CONSOLIDACIÓN Y DESVANECIMIENTO \\ DEL MUNDO CHACARERO
}

Transformaciones de la estructura agraria, las formas sociales de producción y los modos de vida en la agricultura bonaerense, 1937-1988

\author{
Tesista: Juan Javier Balsa
}

Director: Alfredo R. Pucciarelli Co-Directora: Noemí Girbal-Blacha 
“ 'En el largo plazo', se dice, 'estaremos todos muertos'. Pero no siempre. Para el largo plazo del pasado, nosotros somos el resultado. Estamos aquí, ahora. Nuestro presente es el producto de todas aquellas tendencias de largo y corto término hasta la actualidad." (Wimberley, "Trends and Dimensions in U.S. Agricultural Structure")

"Los entornos y las experiencias modernos atraviesan todas las fronteras de la geografía y la etnia, de la clase y la nacionalidad, de la religión y la ideología: se puede decir que en este sentido la modernidad une a toda la humanidad. Pero es una unidad paradójica, la unidad de la desunión: nos arroja a todos en una vorágine de perpetua desintegración y renovación, de lucha y contradicción, de ambigüedad y angustia. Ser modernos es formar parte de un universo en el que, como dijo Marx: 'todo lo sólido se desvanece en el aire'." (Marshall Berman, Todo lo sólido se desvanece en el aire). 


\section{INDICE}

$\begin{array}{ll}\text { Introducción } & 4\end{array}$

$\begin{array}{ll}\text { 1. Los conceptos ordenadores y los interrogantes teóricos } & 7\end{array}$

2. Los interrogantes historiográficos específicos $\quad 37$

3. El recorte temporo-espacial y el énfasis temático en la agricultura y en los productores $\quad 40$ medios

4. Presentación de las metodologías empleadas $\quad 50$

\section{Capítulo Primero $\quad 56$}

Las formas sociales de producción predominantes en la agricultura bonaerense al final de la primera expansión (1937) ¿Una vía "argentina" de desarrollo del capitalismo en la agricultura?

1. Presentación sintética de la historia previa de las tres zonas estudiadas 63

2. La estructura de la propiedad o el estigma del latifundio 72

3. La estructura productiva

4. La relación de la agricultura con la ganadería: chacras, estancias y explotaciones 93 "mixtas"

5. Las formas sociales de producción en la agricultura 103

6. Significación y características de las formas sociales de producción en la agricultura 123

$\begin{array}{ll}\text { 7. Las vías de desarrollo de la agricultura bonaerense } & 133\end{array}$

8. El modo de vida chacarero y la construcción de un mundo rural pampeano 143

\section{Capítulo Segundo 161}

¿"Farmerización" de los chacareros o reconstitución de las grandes estancias ganaderas en las décadas del cuarenta al sesenta?

1. Retracción agrícola y avance ganadero 163

2. Una drástica modificación en las formas de tenencia y sus interpretaciones $\quad 170$

3. Las transformaciones en la estructura de la propiedad entre 1939 y 1960/64 177

4. Políticas y modificaciones en la estructura agraria 183

5. Acceso a la propiedad y procesos de concentración 206

6. Las transformaciones en las formas sociales de producción de la agricultura 221

7. ¿La posibilidad de un desarrollo farmer a partir de los años setenta? 257

\section{Capítulo Tercero $\quad 262$}

Expansión agrícola y transformaciones sociales en el agro bonaerense en los años setenta y ochenta. ¿Cuál fue el sujeto que protagonizó el "boom" agrícola?

1. La "segunda revolución agrícola" 268

2. Las transformaciones en la estructura agraria 275

3. Modificaciones en la producción agrícola 300

4. Las formas sociales que protagonizaron la expansión agrícola 316 
Capítulo Cuarto

La transformación del modo de vida de los productores y el desvanecimiento del mundo rural chacarero durante la segunda mitad del siglo $\mathrm{XX}$

1. La urbanización de los productores agropecuarios 340

2. La educación de los hijos como factor de la urbanización 350

3. Socialización primaria, autoconsumo y consumismo 363

4. Asalarización, terciarización y rol gerencial 374

5. Confort, sociabilidad y negocios en la ciudad 392

6. Modo de vida, estructuras del sentir y aburguesamiento 405

7. Valoraciones del campo y la ciudad, y estrategias de diferenciación social 419

8. El campo despoblado y los pueblos que desaparecen 437

\section{Reflexiones Finales $\quad \mathbf{4 5 2}$}

Algunas hipótesis acerca de la relación entre los cambios en el modo de vida, las formas sociales de producción y las vías de desarrollo del capitalismo en el agro pampeano

1. Cambios estructurales, modo de vida, carácter social y formas de producción 453

2. La posibilidad de una vía farmer de desarrollo agrario en las pampas 472

3. ¿Una vía realmente capitalista de desarrollo agrario? 479

\section{Apéndices}

Apéndice 1. Metodología y datos complementarios del Capítulo Primero 492

Apéndice 2. Estadísticas y Análisis complementarios del Capítulo Segundo 499

Apéndice 3. Estadísticas y Análisis complementarios del Capítulo Tercero $\quad 540$

Apéndice 4. Evolución de la población de las localidades $\quad 557$

Apéndice 5. Estadísticas Agrícolas $\quad 569$

Apéndice 6. Características de los entrevistados $\quad 585$

$\begin{array}{lr}\text { Fuentes y Bibliografía } & 591\end{array}$ 
Introducción 
El tema de la presente tesis doctoral se fue prefigurando durante las entrevistas realizadas para la tesis de maestría, que estudiaba el impacto de la crisis del treinta en el agro pampeano (Balsa, 1994). Nos llamó la atención la distancia social existente entre aquellos chacareros de los años veinte, que surgían a través de los relatos (por lo general, efectuados por sus hijos), y las características que presentaban los propios entrevistados y sus descendientes, a comienzos de los noventa. Esta distancia no sólo se constituía en términos de dotación de recursos económicos (por cierto muy diferentes), sino también en sus formas de vida, sustancialmente modificadas. Cuando nos comentaban los detalles de su infancia en la chacra, parecía que estaban hablando de otro mundo, del que en el agro de los noventa ya no quedaban casi elementos objetivos y muy pocos rasgos subjetivos. De allí surgió nuestro interés por dar cuenta de los cambios en el agro pampeano entre los años treinta y el comienzo de los noventa, focalizándonos en las zonas de la provincia de Buenos Aires con mayor orientación hacia la agricultura.

Sin embargo, detrás de este origen y de esta formulación tan simple (que de hecho sirvió como enunciado de presentación para las entrevistas realizadas especialmente para esta tesis), se esconden motivaciones teóricas mucho más complejas. El estudio historiográfico de una realidad particular tiene la virtud de poner en entredicho las abstracciones que, por definición, contienen las teorías. La tensión que se presentó entre nuestras lecturas previas y la realidad agraria con que nos habíamos encontrado, funcionó como disparador de un doble proceso de indagación. Por un lado, nos llevó a profundizar la revisión bibliográfica sobre las elaboraciones conceptuales acerca de los desarrollos agrarios, especialmente en regiones del planeta con características agrícolas similares. Por otro lado, nos condujo a indagar con mayor detenimiento las especificidades de las formas sociales de producción en la región pampeana y su evolución a lo largo del siglo XX, no sólo en sus dimensiones estructurales sino también en los aspectos subjetivos de los productores rurales que podían estar incidiendo sobre el tipo de desarrollo agrario regional y que han sido muy poco estudiados hasta ahora. 
Por lo tanto, la presente tesis, si bien tiene como objetivo central el conocimiento de las transformaciones sociales en el agro pampeano entre los años treinta y comienzos de los noventa, presenta también una preocupación teórica.

En primer lugar, los conceptos teóricos, utilizados como "conceptos ordenadores"1, sirvieron de guía para abrir las dimensiones con las que intentamos dar cuenta del proceso histórico específico. Es decir, si bien el núcleo de la tesis presenta un tono relativamente descriptivo, no pretende dar cuenta de "la realidad tal cual es". Explícitamente, se ha partido de determinadas miradas teóricas, que sugirieron detenerse en el análisis de algunas dimensiones claves e indagar en sus relaciones. En este sentido, la teoría ha sido utilizada en su función heurística, a fin de disparar preguntas (y no buscando en ella las respuestas) ${ }^{2}$. Si bien compartimos esta actitud epistemológico-metodológica sobre el lugar de las teorías al comienzo de toda investigación historiográfica ${ }^{3}$, en el caso de los estudios agrarios esto es ineludible, ya que ni siquiera contamos con una teoría abarcativa suficientemente corroborada.

En segundo lugar, abordar el estudio de las características específicas de un fenómeno histórico teniendo en claro las formulaciones teóricas que subyacen detrás de los conceptos utilizados, permite regresar sobre las cuestiones teóricas una vez analizado el fenómeno concreto. En este sentido, esta tesis intentará brindar elementos, a partir del caso pampeano, para avanzar sobre los interrogantes teóricos que todavía se

1 Sobre los "conceptos ordenadores" como herramientas para abrir la percepción hacia determinados tipos de fenómenos, puede consultarse Saltalamacchia (1994 y 1997).

2 Las teorías tienen dos papeles diferentes en un proceso de investigación: una función explicativa, que presenta una imagen acabada del hecho, o una función heurística que permite abrir la percepción hacia ciertos campos de investigación. Un detalle de estas reflexiones se encuentran en Saltalamacchia (1994 y 1997) y en Zemelman (1992).

3 La idea de que en los estudios historiográficos, "la definitiva determinación conceptual no puede darse al principio, sino al término de la investigación", y que deber respetarse la "individualidad histórica", la encontramos en Weber (1905: 41). Una reformulación de esta propuesta epistemológica y metodológica la realiza Saltalamacchia (1994), quien afirma que, cuando abordamos el análisis de un fenómeno histórico concreto, "hacer el estudio de un determinado proceso no puede ser el equivalente de una 'homologación' entre teoría (conocimiento de lo general) y hecho, en la que el caso singular se considere simplemente un 'paso al acto' de una idea universal. Por el contrario, el objeto del conocimiento histórico social es siempre un caso específico, en el que sus imágenes teóricas tienen que ser cada vez producidas; tanto en lo que guardan de semejanza como en lo que son diferentes a los otros casos. En esa medida, en sentido estricto, no hay conceptos ni hay teoría desde los cuales pueda ser deducida una hipótesis que pretenda ser verificada en el caso singular..." (Saltalamacchia, 1994: 54). 
encuentran en debate en los estudios agrarios. Especialmente el último capítulo, de reflexiones finales, buscará articular los resultados de la investigación concreta con las distintas proposiciones teóricas que a continuación detallamos.

Es por ello que, antes de precisar los interrogantes historiográficos que guiaron nuestro trabajo, destinaremos el siguiente apartado (relativamente extenso, por cierto) a exponer algunas formulaciones teóricas sobre el desarrollo agrario que cumplen este doble papel en la tesis.

\section{Los conceptos ordenadores y los interrogantes teóricos}

A modo de presentación preliminar, podemos decir que esta tesis espera poder aportar elementos que, a partir del caso pampeano, ayuden a comprender por qué el capitalismo ha tenido tantas dificultades para transformar la agricultura en una producción basada en la mano de obra asalariada y organizada en grandes empresas. En relación con este objetivo, también analizaremos cuál es la vigencia del modelo de agro capitalista que formulara Marx en el tomo tercero de El Capital a partir del caso inglés.

\subsection{El enfoque de los modelos de desarrollo agrario en sociedades capitalistas}

Capitalismo y agricultura nunca han sido dos conceptos fáciles de conjugar en los estudios sociales. La simpleza del modelo de Marx de un agro típicamente capitalista $^{4}$ no parece haber adquirido relevancia histórica. Este modelo no sólo tenía este carácter ideal por ubicarse en el país/modelo de capitalismo desarrollado, sino porque cada sujeto social se identificaba con un recurso y un ingreso puros: el terrateniente recibía renta, el capitalista agrario, ganancia, y los asalariados rurales, un salario. No era sólo una cuestión didáctica la que lo llevó a escoger el caso inglés, sino

4 En la sección sexta del tomo tercero de El Capital Marx proponía partir "...de la hipótesis de que la agricultura, lo mismo que la industria manufacturera, se encuentra sometida al modo capitalista de producción, es decir, que la practican capitalistas que en primera instancia sólo se distinguen de los otros por el sector en que se encuentra invertido su capital..." (Marx, 1894: 613). Entonces, "aquí se reúnen y enfrentan las tres clases que constituyen los marcos de la sociedad moderna: el obrero asalariado, el capitalista industrial y el terrateniente" (Marx, 1894: 617). 
que, para Marx, éste era el ejemplo de un agro claramente capitalista, sin los resabios campesinos del caso francés que estudiara en otras obras (Marx, 1850 y 1852). Incluso también Weber le concedió al caso inglés este carácter de agro plenamente desarrollado (1922: 132). Siguiendo a Weber, ahora metodológicamente, hemos encontrado de utilidad, a lo largo de la tesis, tener al modelo tripartido de Marx como un tipo ideal, la forma pura de agro capitalista, donde cada agente tiene un recurso específico y, por ende, una lógica propia, y avanzar desde allí en la identificación de agentes "mixtos".

Para fines del siglo XIX resultaba evidente que el capitalismo aún no había transformado las formas de producción agrarias de modo que predominase el trabajo asalariado y las grandes unidades, como sí ya ocurría en vastas ramas de la producción secundaria. Dos seguidores de Marx se dedicaron a estudiar esta situación casi al mismo tiempo: Lenin y Kaustky. Lenin hizo explícita la diferenciación entre distintas vías para el desarrollo del capitalismo en el agro, distinguiéndolas del modelo inglés. Por un lado, conceptualizó el desarrollo prusiano como "vía junker", en la que los terratenientes de origen feudal asumían también el papel de capitalistas. En este sentido, el caso prusiano sería el de un "capitalismo desde arriba" (Lenin, 1899 y 1907). Como lo ha analizado en detalle Winson (1994), incluso luego de la emancipación formal del campesinado, los terratenientes establecieron nuevos tipos de obligaciones sobre la población rural, sujetándolos otra vez a la tierra, a través de formas atrasadas de tenencia (situación que sólo fue desapareciendo cuando llegaron grandes masas de trabajadores migrantes desde el Este). Por otra parte, el concepto de "vía prusiana" dio lugar a una interesante perspectiva para analizar la hacienda latinoamericana, aunque también se han señalado las diferencias con el caso original (Murmis, 1980). Según este autor, una de las utilidades de este modelo es que permite pensar en un terrateniente activo en el proceso de producción, reactualizando la cuestión de la relación entre renta del suelo y ganancia capitalista. En este sentido, surge la pregunta acerca de si la vía "junker" limita el desarrollo de las fuerzas productivas fuera y dentro del agro. Para Murmis no siempre es así, y esta cuestión merece estudios específicos para cada caso histórico. Dos trabajos de Murmis utilizan el concepto de "terratenientes-capitalistas" para analizar la dinámica del agro pampeano (1979 y 1988). 
Por otro lado, como situación opuesta, Lenin analizó el caso norteamericano, la "vía farmer", en la que la producción quedaba en manos de medianos productores propietarios que en principio se basaban en la mano de obra familiar (pero que, según Lenin, se diferenciarían rápidamente surgiendo una clase burguesa, y una mayoría proletarizada). En este sentido, es calificado por Lenin como "capitalismo desde abajo" (Lenin, 1899 y 1917). Lo cierto es que, si bien la forma "farmer" de organizar la producción en el campo, en base al trabajo familiar y a la propiedad del suelo, generó — tal como Lenin predecía - un influjo intenso para el desarrollo industrial nacional, no se produjo su rápida diferenciación y evolución hacia formas de producción capitalistas (Byres, 1996). La producción de tipo familiar se habría estabilizado, muchos habrían ido incrementando sus posibilidades de acumulación, capitalizándose especialmente en maquinaria, pero a pesar de ello, el trabajo asalariado siguió ocupando un lugar

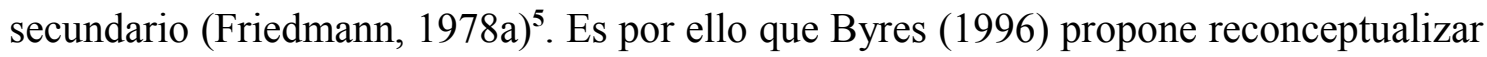
la vía norteamericana como una vía de desarrollo agrario "desde abajo", basada en la "pequeña producción mercantil avanzada"6.

Sobre el concepto de "vía de desarrollo del capitalismo en el agro" corresponde precisar que, dentro del mismo, usualmente se yuxtaponen tres cuestiones: (1) la relación entre el tipo de desarrollo económico del agro y el desarrollo industrial de una determinada formación económico-social; (2) el modo en que el espacio agrario se vincula más estrictamente con el mercado, a través de la transformación de los agentes centrados en la producción para el autoconsumo, en productores netos de mercancías, y (3) las formas en que se articulan trabajo, tierra y capital en la producción agropecuaria, considerando en particular, la pervivencia o la reaparición de formas de producción no enteramente capitalistas en el agro. Como veremos a continuación, esta última es la

5 En realidad se ha generado una extensa discusión sobre la caracterización del farmer norteamericano, que como toda forma intermedia y compleja (ya que combina trabajo familiar, propiedad de la tierra y significativas inversiones de capital) se torna muy difícil de conceptualizar.

6 La pequeña producción mercantil avanzada se diferencia, según Byres (1996: 389-390) de la producción capitalista en que no utiliza mano de obra asalariada, no necesita asegurarse una tasa de ganancia media $\mathrm{y}$, además, puede pasar de la producción para la acumulación (Dinero-Mercancía-Dinero) a la producción para la subsistencia (Mercancía-DineroMercancía) por períodos prolongados. 
pregunta central de Kautsky (1899), mientras que las dos primeras cuestiones (que tienen como base a esta tercera) preocuparon a Lenin en sus varios trabajos sobre el desarrollo del capitalismo en el agro. A lo largo de la presente tesis nuestra preocupación central tendrá que ver con la tercera, y más acotada, definición del problema de la "vía de desarrollo del capitalismo en el agro", que tal vez convenga redefinir como "vías de desarrollo agrario en sociedades capitalistas", para eludir el preconcepto de que las formas sociales de producción agrarias presentes en dichas sociedades sean necesariamente formas típicamente capitalistas.

Para el caso pampeano, el concepto de vías o modelos de desarrollo capitalista en el agro fue utilizado por Pucciarelli (1986) para su caracterización del período 1880-1930, y por Ansaldi (1998) al proponer la existencia de una "vía argentina", tal como veremos en el primer capítulo de esta tesis.

Sin embargo, tanto para el caso pampeano, como para los países desarrollados, no se ha continuado utilizando para el siglo $\mathrm{XX}$ este concepto de vías o modelos de desarrollo agrarios. Consideramos que esta perspectiva continúa teniendo vigencia ya que, incluso en economías de alto desarrollo capitalista, las formas de producción de la agricultura difieren claramente del modelo de agro capitalista propuesto por Marx, e incluso, como veremos, no existe un claro predominio de lo que serían empresas típicamente capitalistas. Justamente, nuestra propuesta es intentar conceptualizar el desarrollo agrario pampeano posterior a los años treinta en términos de estos modelos. En primer lugar caracterizaremos el modelo presente al final de la primera etapa expansiva (fines de los años treinta), y, al finalizar la tesis, una vez estudiada detenidamente la evolución, intentaremos conceptualizar el/los modelo/s presentes durante el resto del siglo XX. Analizaremos, entonces, dicho desarrollo teniendo en cuenta cómo se articularon las formas no típicamente capitalistas de producción, con la penetración del capital en el agro y las formas preexistentes de distribución de la propiedad. Para pensar estas cuestiones, retomaremos el modelo abstracto de agro capitalista formulado por Marx, a modo de tipo ideal, pero no para mantenerlo incuestionado, sino tal sólo como parámetro de comparación. Al mismo tiempo, la vía 
farmer, permanente referente para muchos argentinos, también será otro parámetro de comparación.

En este punto quisiéramos formular una aclaración. Toda caracterización de un proceso social impone cierto ejercicio de simplificación que resalte sus elementos centrales. En el caso del desarrollo agrario, esto es particularmente difícil por la elevada heterogeneidad de situaciones que habitualmente han surgido, y que en el caso del agro pampeano parecen ser incluso más destacadas que en otras regiones del planeta. En este sentido, en las últimas décadas, varios autores han hecho hincapié en la "heterogeneidad" social presente en el agro pampeano. Si bien el destacar los matices y las situaciones diversas ha sido una medida saludable frente a la abundancia de simplificaciones que terminaban imponiendo visiones estereotipadas, la idea de "heterogeneidad" no nos exime de buscar conceptualizaciones que sinteticen las características centrales del desarrollo agrario pampeano, sin que esto implique negar la diversidad. Este ha sido el espíritu que nos ha guiado a la hora de intentar caracterizar en términos de modelos agrarios a dicho desarrollo.

\subsection{Un enfoque analítico}

Además de trabajar en base a la idea de modelos de desarrollo agrario, hemos utilizado también un enfoque más analítico, basado en el estudio de cada una de las principales dimensiones utilizadas para caracterizar a las explotaciones agropecuarias. Este enfoque retoma algunos elementos desarrollados por Kautsky (1899). Su obra tiene un planteo menos evolucionista que el que se encuentra en Lenin, ya que se detiene a analizar las peculiaridades de la producción agraria que se combinan para frenar el desarrollo de las formas de producción claramente capitalistas en el agro. En este sentido, no sólo conceptualiza como "pre-capitalistas" a las formas distintas a la capitalista, sino también como "no capitalistas". En el Prólogo a La Cuestión Agraria señala que "incluso si la hubiese terminado [Marx, a la parte sobre la renta de la tierra en el tercer tomo de El Capital], no encontraríamos en ella las explicaciones que buscamos ahora, puesto que, consecuente con su proyecto de trabajo, allí sólo trata de la agricultura capitalista; y en cambio lo que más nos ocupa hoy en día es precisamente el papel, dentro de la sociedad capitalista, de las formas precapitalistas y no capitalistas de 
la agricultura" (Kautsky, 1899: cix). De este modo, abre la posibilidad de pensar que las peculiaridades del agro generarían formas "no capitalistas" distintas de las formas preexistentes, en un programa de trabajo que consideramos mantiene plena vigencia un siglo más tarde, a pesar que difícilmente Kautsky hubiera previsto esta perdurabilidad. Es por ello que su obra aporta importantes elementos para analizar las transformaciones sociales en el agro de las sociedades capitalistas contemporáneas. Justamente, el "descubrimiento" de Kautsky por la sociología rural de habla inglesa (su obra fue traducida, y de forma parcial, a este idioma recién en los años setenta), junto con la lectura de Chayanov (1924) y una menos explícita pero evidente presencia de las mencionadas obras de Lenin, dieron pie (en los años setenta y ochenta) a interesantes elaboraciones acerca del desarrollo agrario en los países centrales durante el siglo XX. Sin embargo, tal vez como reacción frente a cierta idealización previa de la "family farm" por parte de la sociología rural norteamericana, estos textos se preocupan más por encontrar indicios de que el capitalismo avanzaba en la agricultura que por analizar sus peculiaridades $^{7}, \mathrm{y}$, cuando reconocen los límites que el capital encuentra en el agro tienden a pensarlos como limitaciones de tipo natural (Mann y Dickinson, 1978). En este sentido, ha sido la obra de un brasileño quien, tomando distancia de la perspectiva leninista, caracteriza al desarrollo agrario de los países centrales destacando la supervivencia de las unidades familiares (Abramovay, 1998). Por cierto, la propia sociología y antropología de América del Norte habían generado una serie de trabajos que analizaban las peculiaridades de las unidades familiares y el porqué continuaban predominando en la agricultura cerealera que comentaremos más adelante (como los trabajos de Reinhardt y Barlett, 1989; Salamon, 1992, y Mooney, 1988, entre otros). En esta línea, una obra de gran impacto ha sido la de Harried Friedmann, quien, a partir de un estudio histórico de la agricultura de las praderas en la primer etapa expansiva (Friedmann, 1978a), elaboró una serie de conceptualizaciones teóricas muy fructíferas para pensar la relación entre la producción mercantil simple y el capitalismo en la agricultura (1978b y 1980). De estos trabajos retomaremos, entre otras cosas, su propuesta de hablar de "formas sociales de producción" para caracterizar a las unidades productivas en la agricultura, en vez de usar el concepto de "modos de producción" que

7 Un ejemplo de esta línea de reflexión son los trabajos compilados por Buttel y Newby (1980). 
tantos problemas ha generado en esta aplicación en particular ${ }^{8}$. Según Friedmann, este concepto tiene una doble especificación ya que incluye las características de la unidad de producción pero también a los rasgos de la formación social en la que se inserta. Este contexto, en combinación con la estructura interna de la unidad, determina las condiciones de reproducción, descomposición o transformación de la forma social de producción (Friedmann, 1980: 160). Entonces, cada forma está caracterizada por relaciones sociales específicas y un rango de tecnología particular; además, sostiene relaciones especiales con las unidades mayores de la organización social: con la formación social dentro de la que se inserta, y con los mercados (nacionales o internacionales) a los que venden sus productos (Friedmann, 1978b: 553). En este sentido, el concepto se diferencia tanto del de "modo de producción" (porque se aplica explícitamente a las unidades individuales y no a una generalidad) y del de "relaciones sociales de producción" (en tanto las formas sociales de producción están caracterizadas por un rango de tecnologías productivas, además de por unas relaciones sociales específicas).

Como las peculiaridades del agro han hecho que su desarrollo económico dentro de las sociedades capitalistas presentara una elevada complejidad y heterogeneidad social, las simplificaciones conceptuales que asumen rápidas asociaciones entre algunas características, no logran dar cuenta de la realidad. Es por ello que debemos ser consecuentemente analíticos al estudiar a los sujetos sociales agrarios y evitar los preconceptos que asocian niveles y comenten este tipo de falacias. El problema es que tampoco podemos trabajar sin teorías y conceptos ${ }^{9}$. Tal vez una perspectiva que permita

8 Si bien Friedmann utiliza el término "form of production" nosotros lo tradujimos como "forma social de producción", a fin de evitar equívocos ya que en algunas ocasiones sin el término "social", la expresión "forma de producción" ha sido empleada en Argentina para describir las características técnico-productivas de las distintas explotaciones.

9 Sabemos que, incluso para comprender el caso individual, debemos utilizar conceptos que nos permitan tomar conciencia de sus peculiaridades y, en este sentido, las tipologías sociales son especialmente útiles. El problema es que toda tipología es una conceptualización, y conceptualizar es generalizar hasta un cierto grado (McKinney, 1968). Entonces, lo que hacemos es reducir el número de objetos/personas, concibiendo a algunos de ellos como idénticos, tanto sincrónica como diacrónicamente. Este es un ejercicio que genera especial tensión en los historiadores, siempre interesados en lo específico y en no descuidar la 
conjugar mejor conceptos (por definición generalizadores) y la captación de las particularidades de un determinado proceso histórico, se logre a través de desagregar las dimensiones fundidas en las tipologías.

Especialmente en las tipologías, los conceptos (tanto los de matriz más vinculada con el sentido común como aquellos de origen o reformulación científica) contienen la combinación de determinados valores de distintas dimensiones. Las teorías, en su función explicativa, proponen la existencia de vínculos sistemáticos entre determinados valores de distintas dimensiones (por ejemplo, entre un determinado tamaño y un tipo de organización social del trabajo; de modo que, a la idea de "explotación capitalista" se agrega, subrepticiamente, la característica de que es una unidad de gran extensión, e incluso la inversa, de que toda unidad de gran extensión es capitalista). Pero la aceptación a priori de estas vinculaciones obtura la posibilidad de descubrir otras relaciones, de situaciones "atípicas". Esta limitación adquiere particular gravedad en el caso de los estudios agrarios, ya que en ellos resulta muy habitual que surja una elevada heterogeneidad de posiciones sociales.

Entonces, la recomendación de no cosificar las tipologías, teniendo siempre presente su carácter de tipos construidos (McKinney, 1968), resulta insuficiente para no cometer este tipo de falacias. Nuestra propuesta es utilizar los conceptos en su función heurística (Saltalamacchia, 1994). Para ello, debemos realizar un ejercicio de "substrucción" (Barton, 1973: 213 y ss.), desmadejando las tipologías que habitualmente enredan varias dimensiones en un mismo concepto. A través de un examen detenido, se revela que muchos "tipos" constituyen "haces de atributos

dimensión temporal. Así, por ejemplo, aunque encontremos útil para analizar el agro pampeano el concepto de "explotación familiar", muy probablemente las características que le adjudicaremos a una unidad familiar a comienzos del siglo XX serán muy distintas de las que encontraremos en una explotación familiar al final de ese siglo. De modo que se pone en duda la ventaja de utilizar este tipo de conceptos.

Ahora bien, sin conceptos se hace imposible, ya no sólo interpretar, sino describir la realidad. $\mathrm{Si}$, a veces, los historiadores nos olvidamos de este papel ineludible de la conceptualización, es porque las propias fuentes disponibles (o las habitualmente utilizadas) para una determinada cuestión, han ya preseleccionado un número reducido de dimensiones simplificándonos la percepción de la realidad (por ejemplo, confundiendo realidad con la información que pasa a través de los tamices de preguntas, respuestas y ediciones que significa la práctica social de un censo). De modo que nos olvidamos que toda fuente constituye una cierta configuración práctica instituida socialmente, tal como lo señala Samaja (1994: 257). 
distintos". De este modo se toma conciencia de las dimensiones, muchas veces implícitas detrás de las tipologías habituales ${ }^{\mathbf{1 0}}$.

La invocación a distintas dimensiones cuando nos referimos a un tipo, no siempre es conciente; muchas veces se agrega con el "halo semántico" que traen las palabras (Bourdieu y otros, 1975:39). Por ejemplo, la palabra "terrateniente" -que en principio sólo hace referencia a alguien que es dueño de una extensión de tierra ( $\sin$ importar su tamaño)- trae consigo la idea de dueños de grandes extensiones, en general con una productividad no muy elevada, e investidos de un poder que no sólo es económico. Pero estos vínculos entre determinadas características de la tenencia del suelo, el tamaño, la productividad y el poder extraeconómico deben ser relaciones a investigar en los casos históricos correspondientes, y no presupuestos a priori ${ }^{\mathbf{1 1}}$.

A fin de avanzar en el abordaje analítico de cada una de las dimensiones que utilizaremos a lo largo de la presente tesis, en las siguientes páginas revisaremos algunas elaboraciones teóricas acerca de la penetración del capitalismo en el agro y una serie de cuestiones, tanto estructurales como subjetivas: la tenencia del suelo, la concentración de la producción, el nivel de capitalización y la organización social del trabajo, pero también la racionalidad económica de los productores y su modo de vida ${ }^{12}$.

10 En este sentido, volviendo al ejemplo del concepto de "explotación familiar", podemos ver que muchas veces remite, en general de un modo no sistemático, a características de la composición de la mano de obra, de la racionalidad económica, del tamaño e incluso de la tenencia del suelo.

11 Cabe aclarar que no nos proponemos hacer aquí una "nosografía" de los términos empleados (Bourdieu y otros, 1975:39). Tan sólo queremos ser concientes de esta cuestión, controlándola hasta donde podamos. En este sentido, a veces utilizaremos los mismos términos, aunque otras veces hemos sido más cuidadosos en evitar algunos términos muy cargados de significaciones.

12 No haremos hincapié en la diferenciación entre productores que producen para el mercado o para la subsistencia, ya que en el caso del agro pampeano del período estudiado es claro que todos los productores tienen la venta como destino central de sus productos. En este sentido, les caben las consideraciones de Lenin: "En el régimen capitalista el pequeño agricultor se transforma -quiéralo o no, tenga o no conciencia de ello- en productor de mercancías. Y es en este cambio donde reside toda la esencia de la cuestión. Ese cambio, inclusive cuando todavía el pequeño agricultor no explota a obreros asalariados, es suficiente para convertirlo en antagonista del proletariado, para convertirlo en pequeño burgués. El vende su producto, el proletario vende su fuerza de trabajo" (Lenin, 1917: 101). 


\subsubsection{La tenencia del suelo}

En principio, no parece haber una relación directa entre el desarrollo del capitalismo en el agro y alguna forma en particular de tenencia del suelo. En la literatura especializada ha existido cierta idealización de la tendencia que unió propiedad con producción, que ha llevado en algunos trabajos a confundir estas dos estructuras $^{13}$. Incluso se ha pensado que las formas capitalistas típicas son aquellas en las que el productor rural es el propietario del suelo. Pero este "olvido" también se vincula con una visión neoclásica, que equipara a la tierra con los bienes de capital, sin tener en cuenta que no es un producto del trabajo humano, sino la apropiación de una porción de la naturaleza por sólo algunos seres humanos, convirtiéndola en propiedad privada capitalista.

Aunque en muchas circunstancias históricas ambos recursos (tierra y capital) se hayan presentado en un mismo sujeto, este hecho no anula las determinaciones materiales diferenciadas que inciden sobre la conducta. Para Weber (1906 y 1922) el ideal de empresa capitalista tiene algún grado de desvinculación con los problemas que conlleva la propiedad, y afirma que la separación entre capital y propiedad de la tierra es la fórmula más acorde con el capitalismo. Al enumerar los supuestos que permiten alcanzar "el grado máximo de racionalidad formal del cálculo de capital en las empresas de producción", incluye la separación entre explotación y propiedad ${ }^{14}$, tal como ha ocurrido en Inglaterra ${ }^{15}$. Esta situación no es un resabio precapitalista, sino que es el propio resultado del desarrollo capitalista ${ }^{16}$.

En este sentido, Weber realiza una distinción entre terrateniente y empresario similar a la que había propuesto Marx. Como ya dijimos, este autor elaboró un modelo

13 De este modo, no son pocos los trabajos de historiadores que a partir de los datos censales, hablan de una concentración de la propiedad, cuando uno de los defectos de los censos agropecuarios argentinos es no relevar la estructura de la propiedad.

14 Para Weber "el grado máximo de racionalidad formal del cálculo de capital en las empresas de producción", incluye la "separación lo más completa posible entre la explotación y su destino, por una parte, y la hacienda y el destino del patrimonio, por otra; y particularmente entre el capital de la empresa y su conservación y el patrimonio del propietario y sus peripecias a través de la herencia. Este sería, en general, el caso formalmente óptimo para las grandes empresas: 1) reelaboradoras de materias primas, de transporte y de minería, en la forma de sociedades por acciones libremente enajenables y garantía de capital sin responsabilidad personal, 2) en la agricultura, en la forma del arriendo a largo plazo (relativamente)" (Weber, 1922: 131). 
de capitalismo agrario en el que el terrateniente se distingue del capitalista agrario, quien le arrienda sus campos y los pone en producción con personal asalariado (Marx, 1894: 613-617). Tal como analiza Neocosmos (1986), el lugar del terrateniente dentro del agro capitalista tampoco es planteado por Marx como un resabio feudal o como el producto de la específica historia inglesa (de la que abstrajo el esquema anterior), sino como un elemento propio del mismo. Es el capitalismo el que transforma las viejas formas de propiedad de la tierra, en la forma capitalista, separada del trabajo y del capital.

Unos años más tarde, Kautsky apuntaba que "la escisión del agricultor propietario en dos personas, el terrateniente y el empresario, es una consecuencia necesaria de la propiedad privada de la tierra en el modo de producción capitalista" (Kautsky, 1899: 102). Por otra parte, agregaba que también era posible que el terrateniente sea capitalista, pero sostenía que esta figura mixta había sido una excepción y continuaría siéndolo ${ }^{17}$.

Casi un siglo más tarde, al evaluar las opiniones de los "clásicos", Newby sostuvo que "las predicciones sobre la aparición de un sistema universal terratenientearrendatario como característico de la agricultura capitalista han demostrado ser muy

15 “...la separación en Inglaterra de las explotaciones de arriendo con cálculo de capital de la propiedad territorial vinculada fideicomisariamente no es algo casual, sino expresión del desarrollo que venía allí produciéndose desde hace siglos (por ausencia de protección al campesino, consecuencia de la situación insular). Toda unión de la propiedad del suelo con su cultivo transforma al suelo en un bien de capital, aumenta por eso la necesidad y el riesgo de capital, impide la separación entre hacienda y explotación (las indemnizaciones hereditarias gravan a la explotación en forma de deudas), impide la libertad de movimiento del capital de los cultivadores, y grava por último el cálculo de capital con partidas irracionales. Formalmente corresponde, pues, la separación de la propiedad y el cultivo a la racionalidad de las explotaciones con cálculo de capital (la valoración material del fenómeno es cosa aparte y puede ser muy diferente según los puntos de vista que se adopten)" (Weber, 1922: 132).

16 Weber sostenía que el propio desarrollo capitalista incrementaba la importancia de los terratenientes improductivos: "El fuerte impulso de la competencia capitalista moderna se enfrenta en la agricultura con una corriente conservadora opuesta y, en los viejos países civilizados, esta contracorriente se ve aumentada precisamente por el capitalismo naciente. El uso de la tierra como inversión de capital, y la tasa de interés decreciente en relación con la tradicional valoración social de las propiedades rurales, hacen subir el precio de la tierra de modo tal que éste siempre se paga en part au fonds perdu, es decir, como entrée, como derecho de entrada en ese estrato social. Así, al aumentar el capital necesario para las operaciones agrícolas, el capitalismo causa un aumento en el número de arrendadores de tierras ociosos" (Weber, 1906: 138). 
limitadas en su alcance" (Newby, 1983: 64). Por el contrario, agregamos nosotros, existió una tendencia a identificar la propiedad como la forma de tenencia más apropiada a la expansión agrícola ${ }^{18}$ y a calificar al arrendamiento como un anacronismo disfuncional dentro del desarrollo capitalista ${ }^{19}$. Esta idea de que el arriendo no es funcional con el capitalismo se vincula con dos líneas de reflexión. Por un lado, existió toda una tradición de crítica a la inseguridad generada por el arriendo y la aparcería que impedía la realización de inversiones productivas. Por otro lado, desde el análisis marxista, se enfatizó en la traba que significaba para el desarrollo capitalista la apropiación de una ganancia extraordinaria (la renta del suelo) por parte de la clase terrateniente. En esta línea, Neocosmos (1986) sostuvo que la solución de este obstáculo podía provenir tanto de un proceso de nacionalización de la tierra, como de la conjunción entre propiedad y producción ${ }^{20}$. Esto último podría ocurrir por la transformación del terrateniente en un capitalista agrario, o por la compra de la tierra por los capitalistas. Sin embargo, lo que no visualiza Neocosmos es el carácter dual que presentan estos sujetos, en tanto perceptores de renta y de ganancia. Ellos tan sólo podrían llegar a dejar de percibir la renta absoluta porque, en tanto productores, nunca analizarían la posibilidad de dejarlas inactivas ${ }^{21}$; de todos modos, la renta absoluta

17 Kautsky afirmó que "...además del sistema de arriendo y del sistema hipotecario, una tercera combinación es posible. El propietario terrateniente puede ser al mismo tiempo un capitalista, vale decir, puede poseer, además de su propiedad, dinero suficiente para organizar con sus propios medios una explotación moderna y para obtener además de la ganancia del empresario, la renta del suelo íntegra. Sin embargo, esta fusión de propietario terrateniente y capitalista en una sola persona ha sido hasta ahora una excepción en la historia, y será una excepción en el desarrollo futuro de la producción capitalista. La razón de esto debe ser buscada, por una parte, en la superioridad de la gran hacienda respecto de la pequeña, y por la otra, en la propiedad privada de la tierra" (Kautsky, 1899: 106).

18 Incluso, como lo señaló Capstick, a menudo se afirmaba que "el propietario cultivador es el mejor agricultor porque acepta una perspectiva a largo plazo y conserva su tierra y su equipo en mejores condiciones que el arrendatario, especialmente cuando este último no tiene seguridad en la tenencia de la tierra", aunque según este autor no existía fundamento para sostener una asociación entre la forma de tenencia y el nivel de la agricultura (Capstick, 1970: 29).

19 Frente a lo cual Llovet destaca el ejemplo norteamericano, donde el arriendo en combinación con la propiedad presenta las unidades de mayor tamaño, para mostrar que es compatible con sistemas de alta productividad (Llovet, 1988: 250-251)

20 Cada una de estas transformaciones, da lugar a distintas vías de desarrollo capitalista, no sólo en el campo, sino a nivel nacional.

21 Esto igualmente es relativo, y habría que corroborarlo empíricamente en relación con las tierras más pobres que aportan al mercado mundial, que son las que en teoría fijan la renta 
normalmente tiende a ser de muy baja magnitud ${ }^{22}$. Pero, indudablemente, los terratenientes-capitalistas (o capitalistas-terratenientes) continúan apropiándose de la renta diferencial. Como lo plantea Flichman, "aunque coincida la figura del capitalista con la del terrateniente, todo lo dicho acerca de la renta continúa teniendo validez [...] el terrateniente-capitalista debe imputar intereses al capital-dinero que invirtió en la tierra para efectuar su cálculo económico. Y estos intereses no son otra cosa que una forma trasfigurada de la renta agraria" (Flichman, 1977: 57).

Entonces, si acordamos con Flichman, existen dos tipos de factores (tierra y capital), dos tipos de retribuciones (renta y ganancia), que pueden, o no, sintetizarse en un mismo sujeto; pero que indudablemente marcarán conductas económicas muy diferenciadas. Un sujeto que sólo es propietario y da en arriendo su campo no necesita reinvertir los ingresos que recibe (la renta del suelo) para mantener su posición social. El ciclo productivo funciona en base a las inversiones y desembolsos del arrendatario, independientemente del terrateniente. Además, éste ha percibido, en varios períodos, otro ingreso (no realizado) por la valorización de sus campos, ya que, en general, todo aumento de la productividad de la tierra que se generaliza, termina siendo captado por los dueños de la misma (sólo al principio es renta diferencial II, percibida, en ese caso, por el arrendatario). En cambio, todo empresario rural (arrendatario capitalista) que no reinvierte en modernizarse, en el largo plazo es desplazado por la competencia.

En los diversos desarrollos agrarios se han presentado toda una serie de combinanciones entre las tres figuras típicas del agro capitalista de Marx. Como lo plantea Murmis (en un trabajo destinado a analizar a los terratenientes-capitalistas pampeanos en la coyuntura de los años setenta), esta situación hace necesaria la realización de investigaciones específicas para caracterizar a los distintos sujetos que surgen de dichas combinaciones (Murmis, 1979: 16-17) ${ }^{23}$.

absoluta.

${ }^{22}$ Al respecto ver el análisis elaborado por Flichman (1977: 36).

23 En otra obra, Murmis (1988: 330) proponía la hipótesis que ligaba la expansión del arriendo con los períodos de crecimiento de la agricultura en la región pampeana. 
La presente tesis intentará avanzar en el estudio de estas relaciones entre desarrollo del capitalismo y formas de tenencia del suelo a partir del caso pampeano durante el período posterior a los años treinta, buscando identificar tendencias y factores que inciden sobre las mismas. En esta tarea se tendrá en cuenta que las formas de nopropiedad de la tierra presentan importantes diferencias internas ${ }^{24}$ y que no deben pensarse las formas de tenencia solamente como formas puras, sino que hay que considerar también las formas mixtas.

\subsubsection{La concentración de la producción}

A diferencia de las formas de tenencia del suelo, en el caso de la evolución en el tamaño de las explotaciones agropecuarias existe cierto consenso en relacionar el desarrollo del capitalismo con la concentración de la producción. Sin embargo, también existirían factores que retrasarían este proceso de concentración.

Las ventajas de la gran explotación sobre la pequeña ya fueron señalados por Marx. Al comentar las causas de la declinación de las pequeñas explotaciones, incluía "la competencia de la gran explotación capitalista o de las plantaciones. Es preciso agregar, además, los perfeccionamientos de la agricultura, que por un lado provocan el descenso de los precios de los productos agrícolas y exigen, por el otro, inversiones más elevadas y medios materiales de producción más costosos..." (Marx, 1894: 788).

24 En la "Génesis de la renta capitalista del suelo" (Marx, 1894: 768-793) las diferencias entre las distintas formas de no-propiedad son vinculadas con la evolución de los tipos de tenencia previos a un agro plenamente capitalista, es decir donde sólo existe el arriendo capitalista. Sin embargo, el propio desarrollo del capitalismo ha recreado formas de tenencia no plenamente capitalistas (sobre esta cuestión resulta muy interesante el estudio de Wells, 1987).

Las denominaciones que históricamente se han utilizado para caracterizar estas distintas formas adolecen de los problemas vinculados a los orígenes y resignificaciones que les han ido dando los propios actores, la terminología legal y los diversos criterios de clasificación utilizados en los censos. Para clarificar esta cuestión, proponemos partir de tres subdimensiones: (1) qué parte de las inversiones realiza el terrateniente; (2) qué riesgos comparte con el productor, en el sentido de cómo se distribuyen los beneficios y las pérdidas económicas del resultado de una campaña (considerando los avatares que inciden en el volumen producido y aquellos que afectan el precio de venta del producto), y (3) cómo se distribuye el producto. Entonces, consideramos que es útil diferenciar las formas de tenencia en no-propiedad, y no calificarlas simplemente como "arrendamiento". Sin embargo, como el término "no propiedad" no nos convenció, en los casos en que, más adelante, simplifiquemos la tipología aunando las distintas formas de "no propiedad", hemos seguido utilizando, a veces, el término "arrendamiento" en su sentido amplio. 
Pero quien desde el materialismo histórico analizó con mayor detalle los procesos de concentración fue Kautsky. Además de la posibilidad de aplicar plenamente los avances tecnológicos, la ventaja más importante que obtiene la gran empresa es la capacidad de utilizar la división del trabajo entre manual e intelectual, habilitando una "dirección científica" de la explotación. Sin embargo, el propio Kautsky también analizó los obstáculos que existen para la expansión de las grandes unidades agrícolas. Entre ellos destacaba que, a diferencia del sector industrial (donde la acumulación ampliada habitualmente precede la concentración: las empresas que se expanden, desarrollan ventajas económicas que les permiten adueñarse de porciones crecientes del mercado) en el agro, debido a su base territorial, la acumulación ampliada necesita de un proceso previo de concentración, de apropiación de varias unidades productivas (Kautsky, 1899: 169). Para poder constituir grandes explotaciones, es necesario que desaparezca, previamente, un elevado número de pequeñas unidades. Mientras el pequeño productor pueda resistir, se constituye en un obstáculo a la concentración capitalista, especialmente si posee la propiedad de su predio ${ }^{25}$. En este sentido, la capacidad de los productores familiares de sustraerse a una dinámica completamente capitalista -tal como lo planteó Kautsky $(1899)^{26}$ y más recientemente Friedmann

25 Mann y Dickinson (1978), en cambio, sostienen que no encuentran la razón de la continuidad de la pequeña producción mercantil dentro del capitalismo desarrollado ni en las características subjetivas de la fuerza de trabajo familiar, ni en la adopción de nuevas tecnologías, sino en que (en aquellos productos agrícolas donde existe un exceso de tiempo de producción en relación con el tiempo de trabajo efectivamente empleado) surgen problemas graves para el capital. Entre ellos se destacan la subutilización del capital constante, las dificultades para la contratación de mano de obra calificada, las bajas tasas de ganancia, y los obstáculos para la realización. En Perelman (1979) y en Singer, Green y Gilles (1984) puede seguirse el debate que generó este enfoque.

${ }^{26}$ En una posición extrema, "si la explotación agrícola del pequeño campesino se sustrae a la esfera de la producción de mercancías y si constituye simplemente una parte de la administración doméstica, queda todavía fuera del radio de acción de las tendencias centralizadoras del modo de producción capitalista. Por irracional y dispendiosa que pueda ser su economía parcelaria, el campesino le es fiel como su mujer es fiel a esa administración doméstica miserable, que aun empleando el máximo gasto de fuerza de trabajo rinde resultados infinitamente mezquinos" (Kautsky, 1899: 198). Además, sostiene que la pequeña explotación puede oponer a las ventajas de la grande, "la mayor laboriosidad y los cuidados más asiduos del trabajador que trabaja para sí mismo, en contraste con el trabajador asalariado, y la sobriedad del pequeño campesino, que supera aun la del obrero agrícola [...] Pero el campesino no sólo se condena él mismo al trabajo, sino también condena a su familia." (Kautsky, 1899: 124). Y más adelante agrega que el "pequeño campesino, para conservar su independencia, es capaz de soportar una masa increíble de privaciones" (Kautsky, 1899: 129). 
$(1978 b)^{27}$ - puede permitirles resistir, especialmente si el tamaño de su predio no eleva sustancialmente sus costos de producción en relación con las grandes unidades. Al respecto, Madden (1967) ha considerado que las explotaciones con un tamaño menor al óptimo no están necesariamente forzadas a salir de la producción ${ }^{28}$. Además, el incremento de tamaño de las explotaciones agropecuarias es frecuentemente limitado por la incertidumbre y las dificultades de coordinación que aumentan en las explotaciones mayores. En consonancia con estas afirmaciones, Reinhardt y Barlett (1989) sostienen que la competitividad de las explotaciones familiares deriva de la interacción de una serie de factores: existencia de deseconomías de escala, límites a la especialización de las tareas, diferente cálculo de los costes y efectos benéficos del ciclo familiar.

Como vemos, una serie de cuestiones se atraviesan al proceso de concentración en el agro, que no depende entonces simplemente de cuestiones relativas a la innovación tecnológica ni a los movimientos de precios relativos. Una estructura de tenencia con predominio de la propiedad, en principio, dificulta el proceso de concentración (excepto las crisis de las unidades hipotecadas, que lo facilitaría). En cambio, el arriendo pareciera ser una forma de tenencia más flexible y su uso permitiría una adaptación más rápida a los requerimientos de las economías de tamaño. Por otra parte, las formas de producción basadas en el trabajo familiar y con una racionalidad más sustantiva en torno a la preservación de la explotación, podrían ser las bases de un desarrollo rural menos favorable a la concentración en unas pocas unidades. Al

27 Las categorías de costos de la producción familiar son, en general, diferentes de los de la producción capitalista. No hay requerimientos estructurales de ganancias, absolutas o relativas. El consumo personal es flexible, dentro de los marcos de la formación social. Estas son ventajas competitivas sobre la producción capitalista, pero requieren de una condición muy estricta: que los requerimientos técnicos permitan la combinación de los medios de producción con la cantidad de trabajo promedio disponible dentro de las explotaciones familiares (Friedmann, 1978b: 563).

28 Estas unidades pueden continuar mientras que su beneficio potencial sea suficiente para cubrir los costos de oportunidad y el precio de reserva del pequeño productor. Los costos de oportunidad generalmente se mantienen bajos para muchos productores que no tienen las habilidades, la educación y la movilidad para ser atraídos en empleos fuera de la explotación. Los productores probablemente continúen asignando un bajo precio de reserva a su capacidad organizativa de unos pocos trabajadores, y otorgando altos precios de reserva para grandes y complejas actividades. Más aún, es posible que los productores también continúen asignando un relativamente bajo precio de reserva a su función empresarial en pequeñas explotaciones (Madden, 1967: 18). 
contrario, formas basadas en el trabajo asalariado y en el cálculo racional de todos los costos de oportunidad de los factores, impulsarían la concentración. Una cuestión importante para permitir la concentración es la existencia, en un momento histórico determinado, de un elevado número de individuos preparados para hacerse cargo de las tareas de gerenciamiento y organización de las tareas agropecuarias de grandes unidades, y que estén dispuestos a trabajar como asalariados y no prefieran tentar suerte como productores independientes -si es que pueden acceder a los requerimientos mínimos de capital ${ }^{29}$. Por último, las políticas agrarias han tenido gran influencia en acelerar o retardar los procesos de concentración.

En la presente tesis estudiaremos la evolución en las distintas etapas de la significación de los diferentes estratos de extensión de las explotaciones agropecuarias considerando tanto su número, como la superficie total y el área agrícola que ocupaban. En esta línea, analizaremos los estímulos y las limitaciones que el proceso de concentración encontró en el agro pampeano entre los años treinta y noventa, prestando atención, entre otros factores, a las formas de tenencia del suelo, al desarrollo tecnológico y a las políticas agrarias.

\subsubsection{El nivel de capitalización}

Una de las dimensiones características de un desarrollo capitalista es justamente el incremento en la importancia del capital en el conjunto de los recursos productivos. Aquí corresponde diferenciar dos procesos. Por un lado, puede tener lugar un aumento en la relación entre capital y unidad de superficie, que produce un aumento de la productividad por unidad de extensión ${ }^{30}$; fenómeno sobre el que ya había llamado la atención Lenin en sus estudios sobre el agro norteamericano ${ }^{31}$. Por otro lado, puede

29 La mayoría de las reflexiones teóricas han dejado de lado esta importante cuestión de la oferta de mano de obra calificada para las tareas gerenciales en el agro.

30 En este sentido, el arrendatario capitalista se quedaría con la renta diferencial de tipo II, al menos hasta que no se generalice la innovación tecnológica en una determinada región y, entonces, los terratenientes puedan quedarse con esa ganancia extraordinaria, o se extienda en el conjunto de la producción, desciendan los precios y, por lo tanto, dicha renta diferencial se evapore. Sobre estas cuestiones puede consultarse Marx (1894: capítulos XL a XLIII) o Abramovay (1998: capítulo 8).

31 Lenin (1917: 59) señala que "el capitalismo se desarrolla bajo una doble forma: aumentando las dimensiones de las explotaciones que se sustentan sobre una base técnica antigua, y 
ocurrir un incremento en la relación capital/trabajo, sin que la proporción entre ambos recursos y la tierra se modifique sustancialmente. En este último caso, con la misma productividad por hectárea se reduciría la cantidad de mano de obra necesaria, o, lo que es lo mismo, se expandiría la capacidad de trabajo manteniendo constante el número de brazos. La generalización de este último proceso manteniendo el perfil familiar de la mayor parte de la mano de obra, llevó a conceptualizar a estas unidades productivas como "familiares capitalizadas"32. De este modo se las diferenciaba de las explotaciones familiares más tradicionales, caracterizadas por su bajo nivel de mecanización e importante peso de la mano de obra en el conjunto de recursos disponibles ${ }^{33}$. En este sentido, los productores familiares capitalizados son un claro producto del desarrollo capitalista, pues sólo con la expansión de la producción fabril de maquinaria agrícola y, sobre todo en las últimas décadas, de insumos químicos y genéticos, ha sido posible que unidades basadas en la mano de obra familiar lograran trabajar extensiones tan importantes y generar niveles de producción que, en el pasado, requerían del aporte de un elevado número de trabajadores ${ }^{34}$.

Por último, queremos aclarar que para nosotros es más útil pensar esta dimensión en forma gradual. De este modo, más que catalogar a los productores en "capitalizados" o "no capitalizados", permite diferenciar las distintas capacidades para tomar parte en una tendencia generalizada hacia crecientes niveles de capitalización. En

creando nuevas, en particular las pequeñas y muy pequeñas por su superficie de tierra, dedicadas a cultivos comerciales especializados que se caracteriza por desarrollar sobre una superficie insignificante un volumen extraordinariamente grande de producción y el empleo en gran escala del trabajo asalariado".

32 Una detallada propuesta para diferenciar a las unidades familiares puede encontrase en Basco (1981).

33 Archetti y Stölen (1975) prefieren conceptualizarlos como "farmers", pero consideramos preferible reservar este término para un tipo de productores familiares capitalizados, aquéllos que poseen la propiedad de sus campos (de hecho los colonos estudiados por estos autores tienen sus campos en propiedad).

34 Para algunos autores, esta incorporación de capital convierte en capitalistas a las unidades productivas. Así por ejemplo, parece sostenerse en Lenin (1917: 107) cuando afirma que "El trabajo manual predomina sobre la máquina incalculablemente más en la agricultura que en la industria. Pero la máquina avanza sin cesar, elevando la técnica de la explotación, tornándola cada vez más importante, más capitalista". Sin embargo, nosotros hemos preferido el término "capitalizada", reservando el concepto de "capitalista" para una organización social del trabajo basada en la mano de obra asalariada, algo que por cierto, también sostenía Lenin en el mismo texto: "El signo principal y el índice del capitalismo en la agricultura es el trabajo asalariado" (1917: 107). 
este sentido, al menos en el agro pampeano, es difícil encontrar productores completamente descapitalizados (como veremos, nuestra agricultura "nació", a fines del siglo XIX, mecanizada), al tiempo que tampoco todos están siempre haciendo uso de los últimos adelantos tecnológicos.

\subsubsection{La organización social del trabajo}

Tal vez una de las especificidades más notorias del sector agropecuario es que las inversiones de capital no parecen generar necesariamente la organización de la producción en base a mano de obra asalariada. La mecanización y el uso de agroquímicos han reducido notoriamente los requerimientos de fuerza de trabajo para las labores rurales, por lo cual superficies cada vez más extensas pueden ser trabajadas con un par de hombres. De este modo se abre la posibilidad de que incluso unidades bastante extensas se organicen en base a mano de obra familiar.

Si bien el enfoque neoclásico -y de algún modo la propuesta de Errington y Gasson (1994)- no presta mayor atención a si la fuerza de trabajo es familiar o asalariada, tanto desde el enfoque chayanoviano como desde el marxista se afirma que la diferencia en la composición de la mano de obra tiene importantes consecuencias sobre la unidad productiva. Esencialmente, tal como veremos en el apartado sobre la racionalidad, en la medida en que la fuerza de trabajo no es asalariada, no resulta necesario remunerarla a su costo de mercado. Por otra parte, en la medida en que la fuerza de trabajo forma parte de su familia, el productor no puede disponer de ella como si fuera un recurso variable (Madden, 1967). Entonces, la composición de la fuerza de trabajo, si bien es una característica estructural, incide sobre la conducta del productor.

Más allá de reconocer su importancia, resta todavía establecer una forma de identificar a las unidades, ya como familiares, ya como capitalistas. Sobre esta cuestión intentaremos avanzar a lo largo de nuestra investigación.

El tema de la identificación de las explotaciones familiares ha sido una cuestión de tradicionales controversias dentro de la sociología rural y se ha reactualizado a través del interesante debate entre especialistas europeos (Errington y Gasson, 1994; Djurfeldt, 
1996, y Errington, 1996) ${ }^{35}$. En cambio, existen muy pocos trabajos que se detengan en la caracterización de las unidades capitalistas, evitando las rápidas simplificaciones de que todo lo que no es familiar, es capitalista. Ghorayshi (1986) rescata el requisito que establece Marx para que una explotación sea considerada una unidad capitalista: "que cada capital individual emplee simultáneamente a un número comparativamente grande de trabajadores". Y esto se vincula con la posibilidad de que entre en juego la ley del valor, en la medida en que las diferencias individuales de cada trabajador se compensan y el trabajo se vuelve abstracto. Marx parece aceptar que cinco trabajadores sería el mínimo requerido para que un empleador funcione adecuadamente como un capitalista (Ghorayshi, 1986: 149). Además, esta cantidad permitiría al productor liberarse del trabajo manual, pasar de ser un pequeño maestro a ser un capitalista, y restringir su actividad a los roles de control y supervisión. Por lo tanto, para Ghorayshi, sólo cuando nos encontramos con explotaciones que emplean al menos cinco asalariados estaríamos en presencia de unidades capitalistas, "típicamente capitalista" agregaríamos nosotros. Este criterio, que nos parece acertado, resulta mucho más exigente que los usualmente empleados para categorizar a una explotación como capitalista ${ }^{36}$.

Lo que resulta más interesante para nuestro tema de tesis, es que entre las unidades estrictamente familiares, que no contratan asalariados, y las unidades típicamente capitalistas con al menos cinco empleados, se abre un espacio intermedio,

35 Sintéticamente, Errington y Gasson opinan que existen otras dimensiones que permiten caracterizar a las unidades familiares de mejor modo que la composición de la fuerza de trabajo, y de esta manera podrían obviarse los obstáculos que tiene la operacionalización de esta variable. Además de este problema, argumentan que, cuando los inputs de la producción agrícola fueron la tierra y el trabajo, la escala y la naturaleza de las actividades de las explotaciones familiares estaban fuertemente determinadas por la cantidad de trabajo que la familia podía aportar (pesaban el número y género de los hijos, la etapa del ciclo familiar, la edad y salud del productor y su esposa). Pero con el paso del tiempo, el capital (especialmente en forma de maquinaria) ha ayudado a superar las limitaciones que la dependencia del trabajo familiar imponían a las explotaciones familiares, y de allí que ya no sea una dimensión imprescindible para identificar a las unidades familiares (Errington y Gasson, 1994: 295).

En cambio, Djurfeldt (1996) afirma que el dejar de lado el trabajo acerca a estos autores a la visión neoclásica. Su propuesta es la de combinar el criterio de la composición del trabajo (con todos sus problemas) con el criterio de la reproducción (una unidad familiar sería aquella donde el ingreso sea suficiente para cubrir las necesidades de consumo del hogar y el costo de reproducción de la explotación misma).

36 El propio Ghorayshi (1886) describe los criterios utilizados habitualmente: que contrate, aunque sea temporariamente un asalariado; que emplee al menos un asalariado-año, o que el trabajo asalariado sea más importante que el familiar 
de difícil conceptualización y que requiere de un estudio detenido en cada caso histórico particular $^{37}$.

Por último, la conceptualización de la organización social de la producción se complejiza aún más con la expansión de la contratación de servicios de terceros, más estudiada para el caso pampeano, pero que en la agricultura europea también ha cobrado importancia. Se ha denominando "telephone agriculture" a la modalidad en la cual los productores que se limitan a contratar a terceros para que realicen las labores. En estos casos se ha considerado que el productor actúa meramente como propietario de la tierra, pero con un carácter activo, en tanto busca el mejor modo de incrementar su renta del suelo (Blanc, 1994: 285). Desde nuestra perspectiva lo consideraremos un cuasirentista, pues invierte capital variable en el proceso productivo, además del recurso tierra.

A lo largo de la presente tesis analizaremos cómo fue la evolución de la organización social del trabajo agrícola en la región pampeana desde los años treinta. Esperamos que este estudio permita brindar elementos que relacionen estos cambios con el proceso de mecanización, con los cambios en el tamaño y en las formas de tenencia del suelo, pero también con otras dimensiones como la racionalidad y los modos de vida (que presentaremos en los siguientes apartados).

37 Por otra parte, existe otra cuestión en relación con la organización social del trabajo, destacada por Errinton y Gasson (1994) y Errington (1996). En lo que estos autores denominan "farm family business", la propiedad de la empresa está en combinación con el control gerencial en manos del productor. Esta sería para ellos una situación muy particular, ya que una de las transformaciones socio-económicas más profundas que ocurrieron en los últimos 150 años en los países desarrollados ha sido justamente el auge de formas económicas en las que la propiedad del capital se ha ido separando del control gerencial. Creemos que, dejando de lado el término "familiar", que reservamos para la composición de la mano de obra, esta observación de Errington y Gasson resulta muy interesante. En este sentido, habría que discriminar entre explotaciones administradas por su dueño (el productor) y aquellas que delegan la administración en otra persona o en un equipo empresarial (empresa de administración). El problema de esta subdimensión es que, como se trata de una característica propia de las explotaciones rurales (tal como señalan los propios Errington y Gasson), pareciera presentar un muy pequeño poder de discriminación al interior del sector agrario, y más específicamente en la actividad agrícola (en la ganadería resulta más habitual el tener encargados de los campos). 


\subsubsection{La racionalidad}

Avanzando ahora sobre aspectos más subjetivos, podemos decir que los estudios agrarios tampoco han establecido una clara asociación entre el incremento en las inversiones de capital y la expansión de una racionalidad formal o típicamente capitalista.

En la tradición neoclásica todo productor tiene como único objetivo la maximización de los beneficios y, para ello calcula todos los costos de oportunidad de los factores a su disposición y escoge los usos que maximicen la utilidad del conjunto. En este enfoque, el productor actúa racionalmente (realizando un cuidadoso cálculo del mejor empleo de todos sus factores) con una finalidad formalmente establecida: la maximización de los beneficios que le pueden aportar la conjunción de todos los factores a su disposición. En cambio, la mayoría de los estudios agrarios han enfatizado la existencia de diferencias cualitativas en la racionalidad de los productores, tanto en los objetivos que persiguen, como en las formas en que realizan los cálculos de producción.

La base principal de una racionalidad diferente se encontraría en la simbiosis entre unidad de producción y unidad familiar, tan característica del sector agrícola. Ya Kautsky planteaba que "una de las diferencias más notables entre la industria y la agricultura es que en la agricultura la conducción de la empresa y la economía doméstica constituyen todavía una unidad inseparable, mientras en la industria - excepción hecha de algunos sectores muy rudimentarios- ambas cosas son absolutamente independientes" (Kautsky, 1899: 108).

Tal vez quien con más énfasis ha señalado la existencia de otra racionalidad económica en los campesinos ha sido Chayanov. Para este autor, "el estimulo básico de la familia trabajadora para la actividad económica es la necesidad de satisfacer las demandas de sus consumidores" (Chayanov, 1924: 56). "Tomamos la motivación de la actividad económica del campesino no como la de un empresario que como resultado de la inversión de su capital recibe la diferencia entre el ingreso bruto y los gastos generales de producción, sino más bien como la motivación del obrero por un peculiar sistema de salario a destajo que le permite determinar por sí mismo el tiempo y la 
intensidad de su trabajo" (Chayanov, 1924: 33). Cabe aclarar que, según este autor, las reglas de la organización de la unidad económica campesina no son producto de una determinada psicología campesina (aunque, a nuestro entender, esto resulta contradictorio con varias afirmaciones presentes en esta misma obra), sino de las determinaciones económicas (Chayanov, 1924: 40). A partir de esta lógica es que explica la variabilidad del nivel de autoexplotación del campesino, según su capacidad para satisfacer las necesidades de consumo de su familia ${ }^{38}$.

La idea de la dualidad de las formas de producción agraria es retomada por Galeski cuando plantea como característica básica de la explotación campesina (entendida como ya mercantilizada ${ }^{39}$ ) "la fusión o (más exactamente) la identificación de la empresa (es decir, el establecimiento de producción de mercancías ${ }^{40}$ ) con la economía doméstica del hogar familiar" (Galeski, 1977: 47). "Ni las consideraciones comerciales (como creen ciertos economistas) ni consideraciones de consumo solas, como creía Chayanov, explican plenamente su funcionamiento" (Galeski, 1977: 232). "Los principios del funcionamiento de la empresa son diferentes de los de la economía doméstica. La empresa produce valores de cambio, que necesariamente implican la evaluación de todas las operaciones desde el punto de vista de la relación entre el output con el imput, así como de la rentabilidad, mientras que la economía doméstica se refiere principalmente al uso de valores que se miden de acuerdo con las necesidades que satisfacen y la medida en que lo hacen" (Galeski, 1977: 48).

Consideramos que para el caso de formaciones sociales donde los elementos comunitarios (que a nuestro entender son inherentes a las unidades campesinas) no tienen casi significación ${ }^{41}$, resulta más apropiada, para analizar el problema de la fusión entre unidad doméstica y empresa, la diferenciación weberiana entre tipos de

38 Sobre la lógica campesina, y algunos aspectos aplicables al caso norteamericano, ver Shejtman (1980).

39 Galeski tiene como punto de referencia al campesinado europeo y, más precisamente, al polaco de los años sesenta.

40 En Galeski no se asocia el término "empresa" necesariamente con "empresa capitalista".

${ }^{41}$ De todos modos, indudablemente muchos inmigrantes trajeron todo un bagaje campesino europeo que no ha sido casi reconocido en los estudios sobre el agro pampeano, a diferencia de varios análisis del Corn Belt que han partido de analizar hasta qué punto estas conductas han pervivido entre sus agricultores. 
racionalidad. Esta es una línea de análisis propuesta por Mooney (1988), quien la utilizó para caracterizar al farmer norteamericano.

Para Weber el capitalismo genera una particular racionalidad económica, en la cual "la ganancia no es un medio para la satisfacción de necesidades vitales materiales del hombre, sino que más bien éste debe adquirir, porque tal es el fin de su vida". Por eso afirma que "para el común sentir de las gentes, esto constituye una 'inversión' antinatural de la relación entre el hombre y el dinero; para el capitalismo, empero, ella es algo tan evidente y natural, como extraña para el hombre no rozado por su hálito" (Weber, 1905: 48). Queda así abierta la posibilidad de distinto tipo de racionalidades, que Weber especificará en Economía y sociedad. En la terminología weberiana, la racionalidad formal (la típica de las empresas capitalistas) es la que sólo se guía por el cálculo y cuyo único objetivo es la maximización de la ganancia. En cambio, la racionalidad material, aunque también recurre al cálculo racional, está orientada por distintos tipos de postulados de valor (según consideraciones éticas, políticas, utilitarias, hedonistas, estamentales, o igualitarias, entre otras). En este caso, la racionalidad de la conducta económica se mide según la relación entre los resultados de la gestión y el postulado de valor que la guía ${ }^{42}$.

42 Weber distingue estas dos racionalidad del siguiente modo: "Llamamos racionalidad formal de una gestión económica al grado de cálculo que le es técnicamente posible y que aplica realmente. Al contrario, llamamos racionalmente material al grado en que el abastecimiento de bienes dentro de un grupo de hombres (cualesquiera que sean sus límites) tenga lugar por medio de una acción social de carácter económico orientada por determinados postulados de valor (cualquiera que sea su clase), de suerte que aquella acción fue contemplada, lo será o puede serlo, desde la perspectiva de tales postulados de valor. Estos son en extremo diversos." (Weber, 1922: 64). Y afirma un poco más adelante, "debe llamarse 'racional en su forma' a una gestión económica en la medida en que la 'procuración', esencial en toda economía racional, pueda expresarse y se exprese en reflexiones sujetas a número y cálculo [...] Por el contrario, el concepto de racionalidad material es completamente equívoco. Significa sólo este conjunto de cosas: que la consideración no se satisface con el hecho inequívoco (relativamente) y puramente formal de que se proceda y calcule de modo 'racional' con arreglo a fines con los medios factibles técnicamente más adecuados, sino que se plantean exigencias éticas, políticas, utilitarias, hedonistas, estamentales, igualitarias o de cualquiera otra clase y que de esa suerte se miden las consecuencias de la gestión económica -aunque sea plenamente racional desde el punto de vista formal, es decir, calculable- con arreglo a valores o fines materiales. Los puntos de vista valorativos, en este sentido racionales, son en principio ilimitados [...] la función 'puramente formal' del cálculo en dinero puede aparecer como subalterna o incluso como enemiga de sus postulados" (Weber, 1922: 64-65). 
Cuando ocurre la fusión entre unidad familiar y empresa resulta más probable que nos encontremos con una racionalidad material que con una racionalidad formal ${ }^{43}$. En general el productor familiar apunta a obtener determinados objetivos concretos (tales como ser propietario, mantener la explotación como un bien familiar transgeneracional, continuar con un modo de vida rural) y no es guiado por una racionalidad formal, que define su objetivo sin valores, sino tan sólo por el cálculo formal que apunta a la maximización de la ganancia.

Mooney (1988) retomó la diferenciación weberiana entre tipos de racionalidad y la combinó con el concepto de artesano de Wright Mills. Según este autor, el artesano es libre de controlar su trabajo, y no existe un corte entre trabajo y juego, entre trabajo y cultura. "La forma de subsistencia del artesano determina e inunda todo su modo de vida" (Mills, 1951:220). El concepto de artesano unifica varias de las orientaciones según valores, proveyendo una racionalidad diferenciada de la racionalidad formal capitalista (Mooney, 1988: 67). Para el "family farmer" exitoso (en tanto dispone de recursos suficientes, no como el que califica de "marginal") "farming" es un modo de vida, y no una forma de hacer dinero. Para este tipo de sujetos, la independencia es un valor esencial. Además, no desea abandonar la vida rural (es más, el ritmo de la vida urbana los pone nerviosos, según Mooney) ${ }^{44}$. Esta propuesta de Mooney se entronca perfectamente con una tradición de estudios antropológicos sobre el agro norteamericano, que ya habían detectado patrones de conducta diferentes de los atribuidos a los empresarios capitalistas ${ }^{45}$.

La cuestión de la racionalidad ha sido planteada dentro de la tradición marxista a partir de la distinción de las diferentes formas de calcular los costos de producción incluso dentro de una economía capitalista, según estemos en presencia de "productores mercantiles simples"46 o de empresarios típicamente capitalistas. Al respecto, Kautsky sostenía que "en la producción simple de mercancías querer determinar los precios de las mercancías producidas en base a los costos de producción no tendría sentido"

43 Siempre debemos recordar que estamos en el plano de los tipos ideales weberianos y que nunca una acción es completamente racional, ya que siempre existen elementos tradicionales o habituales. Por ejemplo, muchos de los productores agrícolas pampeanos continuaban realizando prácticas tradicionales del campesinado europeo, que se fueron desdibujando con el correr del siglo.

44 La propuesta teórica de Mooney concitó las críticas de Mann y Dickinson (1987a), la réplica de Mooney (1987), con la consiguiente contra-réplica de Mann y Dickinson (1987b). 
(Kautsky, 1899: 72). "El campesino que vende sus productos, que no ocupa o que ocupa solamente un escasísimo número de asalariados, que no es propiamente capitalista, sino simple productor de mercancías, calcula de otro modo" (Kautsky, 1899: 200).

Este concepto de "producción mercantil simple" ha sido de gran utilidad para pensar a los productores del Corn Belt norteamericano, para autores como Byres (1996) y Friedmann (1978a), entre otros. Esta última investigadora define a la producción mercantil simple como una forma de producción que identifica a una clase de trabajadores y, a la vez, propietarios insertos en una economía capitalista (Friedmann, 1980). Se caracterizan por tener diferentes categorías de costos que los empresarios capitalistas y, por lo tanto, distintas bases para analizar la viabilidad económica de sus explotaciones, sin estar directamente determinados por la tasa de ganancia, ya que para estas explotaciones no existen requerimientos estructurales de ganancia, absoluta o relativa. Como el consumo personal es flexible, dentro de los estándares existentes en la formación social (Friedmann, 1978b: 563), las decisiones sobre consumo o inversión son subjetivas, y no se discriminan los ingresos por sus orígenes. Por otra parte, Friedmann (1980) señala que las diferencias con las formas campesinas se deben,

45 Tal vez la autora más importante en esta tradición sea Salamon, quien ha vinculado la pervivencia de determinadas tradiciones étnicas, con diferentes estilos de hacer agricultura. En sus trabajo (Salamon, 1989 y 1992) distingue entre estilos "yeoman" y "entrepreneurial". El primero, vinculado con una tradición germana, tiene como objetivo la reproducción de la explotación y su transmisión intergeneracional. Para alcanzar este objetivo, el productor prefiere tener la propiedad de la tierra, y expandir su escala sólo lo necesario para que sus hijos puedan trabajar hasta tanto se realiza el traspaso. Toda expansión es hecha de un modo muy conservador, evitando riesgos financieros elevados que puedan poner en peligro la continuidad. En cambio, un "entrepreneur" piensa la explotación como un negocio que optimiza los retornos financieros en el corto plazo. Las expansiones están determinadas por su habilidad y su disponibilidad de capital, y no por el contexto familiar. Está más dispuesto a asumir riesgos financieros. A diferencia de los "yeomen", tienden a tener explotaciones más grandes y más especializadas.

Debido a que la tierra en propiedad es considerada "sagrada", los "yeomen" son muy contrarios a venderla, especialmente si allí está su hogar familiar. Los "entrepreneurs", en cambio, tienen una conducta más desaprensiva y evalúan más fácilmente su posible venta. En el largo plazo, en las áreas estudiadas por Salamon (1989), la tierra fue quedando en manos de los productores "yeomen", mientras que los "entrepreneurs" fueron golpeados muy duramente por las crisis. Esta capacidad para sobrepasar la crisis (de los ochenta) por parte de los productores más cautos, más contrarios al endeudamiento, que no utilizaban mano de obra asalariada, que mantenían una ética del trabajo y un modelo de consumo frugal, ha sido señalada por otra antropóloga (Barlett, 1993).

46 La producción mercantil simple implica un productor que produce, con su propio trabajo (y el de su familia) y con sus propios medios de producción, bienes que esencialmente realiza en forma de mercancías. 
esencialmente, a la distinta relación con la economía nacional, penetrados como están los productores simples por las relaciones mercantiles. Friedmann (1980) opina que mientras que la transformación de una economia campesina en una capitalista implica la descomposición de complejas instituciones, el tránsito desde la producción mercantil simple sólo requiere la intensificación de la mercantilización.

Esta diferencia en la forma de calcular los costos de producción también la encontraron Archetti y Stölen en su estudio de los colonos del norte de Santa Fe en los años setenta. El colono "no contabiliza como gasto su trabajo y el trabajo de los miembros del grupo doméstico [...] La tierra para el colono no es 'capital' sino un medio y un objeto de producción, el colono no piensa que debe retribuir a la tierra como se retribuye al Banco o a la cooperativa por el crédito otorgado" (Archetti y Stölen, 1975: $147-148$ y 151$)^{47}$.

A lo largo de la presente tesis analizaremos algunos aspectos de la racionalidad económica de los productores (aunque no hemos investigado de un modo sistemático esta cuestión ${ }^{48}$ ), y su articulación con los modos de vida, dimensión ésta que sí hemos podido estudiar con mayor detalle.

\subsubsection{El modo de vida}

El modo de vida de los productores rurales y su transformación dentro de las sociedades capitalistas desarrolladas aún no han sido explorados en profundidad,

47 Por otra parte, afirman que "el desarrollo de una suerte de capitalismo agrario, predominio de las relaciones de producción basadas en el trabajo asalariado, se enfrenta con la ‘conciencia del productor' como uno de los obstáculos principales. El colono busca nueva tierra, pretende expandir su propia frontera interna, pero allí donde va reproduce el sistema de relaciones sociales que encontramos en la colonia: el trabajo propio es un componente sustancial del proceso productivo" (Archetti y Stölen, 1975: 48-49). "Este tipo de organización del trabajo desde nuestra perspectiva teórica no permite dos operaciones importantes para el pasaje al capitalismo: plena utilización de los recursos productivos disponibles sin limitaciones extraeconómicas (las únicas limitaciones provienen de la rentabilidad por hectárea) y posibilidad de calcular objetivamente la relación entre gastos y los ingresos (Archetti y Stölen, 1975: 147-148).

48 El análisis específico de la racionalidad económica hubiera requerido de un trabajo muy extenso y detenido, pero, además, hubiera sido muy difícil realizar retrospectivamente. 
aunque la cuestión ha estado presente de un modo implícito en algunos estudios ${ }^{49}$. En nuestro caso, como decíamos al comienzo de esta Introducción, la notoria diferencia que observamos entre el modo de vida de los productores de los años treinta y el de los años noventa, fue uno de los disparadores de la investigación.

El concepto de "modo de vida", como lo usamos en esta tesis, pretende abarcar las características particulares de un amplio conjunto de actividades propias de la vida cotidiana. Pero, además de los patrones de conductas observables y rutinarias, también queremos incluir los valores y actitudes que se imbrican en estas actividades, tal como propone Stebbins (1997: 349). Incluso, queremos integrar dentro del concepto de "modo de vida" no sólo a las dimensiones de la vida social vinculadas con el empleo del tiempo libre, el ocio y los patrones de consumo (tal como habitualmente lo han hecho los estudios sobre los "estilos de vida"50), sino también a las actitudes y valores relacionados con el trabajo y la profesión. Como Veal (1993), creemos que hay que considerar el amplio rango de las actividades diarias sin privilegiar unas sobre otras (patrones de consumo, actividades ociosas, prácticas domésticas y trabajo remunerado). Por ello dejamos de lado la expresión "estilos de vida" o "lifestyle" (aunque muchos autores la utilizan en un sentido amplio y similar al que nosotros le damos, por ejemplo el propio Veal y también Stebbins), y empleamos "modo de vida", retomando la terminología weberiana.

Para Weber, los modos de vida constituyen una de las bases de los distintos "estamentos", teniendo un lugar central la "profesión" (Weber, 1922: 246). "El honor correspondiente al estamento encuentra normalmente su expresión ante todo en la exigencia de un modo de vida determinado a todo el que quiera pertenecer a su círculo [y ejemplifica luego:] "... se ha desarrollado así la formación de 'estamentos' a base de modos de vida convencionales en Norteamérica" (Weber, 1922: 688). Esta es una

49 En varios trabajos se ha asociado "modo de vida rural" con "forma de producción campesina". Para una reseña de estos desarrollos teóricos puede consultarse Domínguez Martín (1993: 100-103). Sin embargo, a pesar de que esta línea de reflexión vincula justamente modos de vida con formas de producción, podría promover la esencialización de la relación entre "rural" y "campesino", cuando prescisamente nuestro interés se centra en los modos de vida rurales de productores claramente no campesinos.

so En Veal (1993) puede consultarse una sistematización de los distintos enfoques existentes sobre el concepto de estilo de vida. Una presentación más breve se encuentra en Rocchi (2002). 
conceptualización que recuperó Bourdieu (1979), aunque él emplea el término "estilo de vida" ["style de vie"], tal vez porque particularmente retoma la idea weberiana de que se produce una "estilización de la vida"51 (Bourdieu, 1979: 59), en tanto se orienta a analizar la diferenciación en los consumos, especialmente estéticos.

En relación con la inclusión no sólo de conductas observables, sino también de actitudes y valores, retomamos a Schütz (1974: 43) cuando afirma que cada endogrupo posee un modo de vida que considera natural, bueno y correcto, en tanto sus miembros comparten un sistema de significaciones. Por lo tanto, como dirían Berger y Luckmann (1968), compartir un modo de vida implica participar de un mismo mundo intersubjetivo del sentido común; tener en común una forma de ver el mundo, de nombrarlo, de valorarlo, que normalmente se internaliza durante el proceso de socialización primaria. En este sentido, la continuidad de un modo de vida también implica la re-producción de un mundo social diferenciado, en tanto los sujetos y las instituciones reproducen y legitiman determinadas formas de actuar, y de percibir y comprender el orden social.

Para finalizar necesitamos formular algunas aclaraciones. En primer lugar, compartimos el criterio de Veal (1993) de que no deber prejuzgarse la existencia de coherencia entre las diversas prácticas que conforman un modo de vida, sino más bien analizar la existencia o ausencia de coherencia. Del mismo modo, se deben estudiar las determinaciones materiales y no materiales de los modos de vida. En relación a esta última cuestión, las situaciones de menor pobreza abrirían posibilidades de mayor capacidad de "elección" sobre el estilo de vida (Veal, 1993: 245-247), lo cual consideramos resulta muy pertinente para reflexionar sobre los productores rurales medios.

En segundo lugar, frente a cierta asociación fuerte que aparece en Weber entre "estamento" y "modo de vida", quisiéramos evitar partir de una concepción de "modo de vida" necesariamente estructurado en torno a un "estamento" o grupo social. Si bien, el modo de vida es a menudo un fenómeno grupal, tiene un cariz individual. Al respecto,

51 Weber plantea que "toda 'estilización' de la vida, cualesquiera que sean sus manifestaciones, tiene su origen en la existencia de un estamento o es conservada por él" (Weber, 1922: 691). 
Stebbins señala que un "estilo de vida" sólo requiere compartir una serie de características de la vida individual (como los patrones de consumo, de apariencia, o las actividades de esparcimiento): aquéllos que tienen un estilo de vida en común, no son necesariamente interdependientes, ni actúan de conjunto, ni comparten una historia, a diferencia de una "comunidad" (Stebbins, 1997: 349).

El uso del término "comunidad" nos impulsa a formular una última aclaración. Consideramos que no corresponde esencializar el concepto de "modo de vida", sino que sus características deben ser determinadas a partir de un trabajo historiográfico específico. En este sentido, no debe entenderse que, cuando hablamos de la presencia de un determinado "modo de vida rural", estemos sugiriendo la existencia de algo similar a una "comunidad" (por oposición a "sociedad"), según la dicotomía formulada por Tönnies y Weber, entre otros.

Lo que analizaremos en la presente tesis es hasta qué punto se construyó un modo de vida rural por parte de los agricultores pampeanos durante la primer gran expansión, cuáles fueron sus particularidades y cómo se transformó luego. El interrogante teórico apunta a investigar la relación entre el desarrollo del capitalismo y la construcción, reformulación y/o desaparición de modos de vida específicos del campo y, por lo tanto, diferenciados de los modos de vida urbanos (por lo que no trabajaremos con una imagen ideal de "modo de vida rural" de tipo atemporal).

En fin, esperamos que, además de mejorar la comprensión de la historia agraria pampeana del siglo $\mathrm{XX}$, la presente tesis genere elementos para, desde el caso pampeano (un agro que, más allá de insertarse en una economía capitalista dependiente, ha presentado rasgos de modernización importantes), repensar la relación entre desarrollo agrícola y capitalismo en términos de modelos y de cada una de las dimensiones anteriormente comentadas. 


\section{Los interrogantes historiográficos específicos}

Más allá del sustrato teórico que, como vimos, poseen las cuestiones estudiadas, la presente tesis tiene como objetivo central la resolución de una serie de interrogantes específicos acerca de las características del desarrollo agrario pampeano desde fines de los años treinta hasta fines de los noventa, que a continuación enumeramos.

En el primer capítulo intentaremos conceptualizar el desarrollo agrario pampeano de fines del siglo XIX y primeras décadas del siglo XX, focalizándonos en la situación existente para el final de este período y poniendo especial atención en la caracterización de la producción agrícola (pues presenta mayores problemas de información y conceptualización que la producción ganadera). En este capítulo, partiremos de la reflexión teórica sobre las vías de desarrollo, para realizar luego un detenido examen de la información disponible del Censo Nacional Agropecuario de 1937 y, a partir de algunos supuestos, se estimará la importancia dentro de la agricultura bonaerense de las distintas formas sociales de producción. Además, para lograr una mejor caracterización de dichas formas, trabajamos con entrevistas orales y con una detenida lectura de los informes técnicos y obras de los especialistas agrarios de los años veinte hasta comienzos de los cuarenta. Asimismo, hemos analizado la estructura de la propiedad de la tierra existente en 1939 y su evolución previa, a fin de conocer la significación real del latifundio y su articulación con la estructura productiva. Por otra parte, se analizaron específicamente, entre otras cuestiones, el impacto de la mecanización sobre las formas productivas, la importancia de la subordinación de la agricultura hacia la ganadería, y el surgimiento de un modo de vida chacarero y la constitución del mundo rural pampeano. A fin de situar históricamente al lector, el capítulo comienza con una breve descripción de la evolución previa de cada una de las zonas estudiadas.

El segundo capítulo presenta como interrogante central en qué medida la intervención estatal (especialmente en el mercado de tierra), durante los años cuarenta a sesenta, transformó el modelo agrario anterior y en qué sentido lo hizo. Esta temática había suscitado importantes polémicas durante el propio período, no sólo debido a la preocupación que la cuestión social agraria todavía tenía en la Argentina, sino porque se 
asociaban los problemas de la tenencia del suelo con el estancamiento agrícola que, a su vez, no generaba las exportaciones necesarias para mantener el desarrollo industrial por sustitución de importaciones. Dos líneas centrales de trabajo nos permitieron avanzar sobre nuestra pregunta básica: un análisis de la evolución de 280 propiedades entre 1939 y mediados de los años sesenta, y el reprocesamiento de los datos originales del Censo Nacional Agropecuario de 1969 a fin de posibilitar una más exacta comparación intercensal con los Censos de 1937 y 1947, estudiando los cambios en la tenencia, el tamaño y la composición de la mano de obra, medidos en el número de explotaciones, en la superficie de las mismas y en el área agrícola. El trabajo con informes técnicos, tesis y publicaciones de la época, junto con los testimonios orales recogidos nos permitieron completar el estudio de estas tendencias desde otras perspectivas y, además, avanzar sobre otros interrogantes secundarios. Entre ellos, podemos destacar la medición de los efectos directos de las políticas de colonización, de los fraccionamientos "voluntarios" de los grandes latifundios, la importancia de la expulsión o el abandono de los campos por parte de los arrendatarios y aparceros, los procesos de concentración y su relación con la creciente mecanización agrícola. El capítulo concluye con una caracterización del modelo de desarrollo agrario presente para finales de los años sesenta.

En el tercer capítulo investigamos la relación entre la expansión agrícola de los años setenta y ochenta y la estructura social agraria, intentando dilucidar quién fue el sujeto que protagonizó dicho "boom". Para ello fue especialmente valiosa la posibilidad de reprocesar la información original de los Censos Nacionales Agropecuarios de 1969 y 1988. También continuamos el seguimiento de la evolución de las propiedades muestradas, y trabajamos con numerosos informes técnicos, tesis, publicaciones especializadas y las mencionadas entrevistas de historia oral. De este modo, también se indagó, entre otras cuestiones, acerca de cuán importante fue la concentración de la producción, si tuvo lugar una expansión de las unidades basadas en el trabajo asalariado, y cuál fue la real importancia del contratismo tantero y de la terciarización de labores en esta expansión agrícola. 
En el cuarto capítulo, abrimos una perspectiva, a nuestro entender novedosa, que pone énfasis en estudiar las modificaciones en los modos de vida de los productores rurales ocurridos durante el siglo XX y su impacto en la configuración del mundo rural pampeano. Trabajando esencialmente a partir de las historias de vida recogidas (aunque también agregando algunos datos de los censos agropecuarios), analizamos el proceso de urbanización, el creciente interés por la educación, las modificaciones en la socialización primaria, las transformaciones en la relación entre familia y unidad productiva y su impacto en la organización social del trabajo, los cambios en el rol del productor, las modificaciones en los espacios de sociabilidad y en los patrones de consumo, entre otras cuestiones. Además, hemos indagado acerca de la radicación urbana de los productores a través del reprocesamiento del Censo de 1988, y hemos reconstruido la evolución de la población que residía en el campo y en cada una de las localidades de las zonas estudiadas utilizando los Censos Nacionales de Población de 1947, 1960, 1970, 1980 у 1991.

En el último capítulo, a modo de reflexiones finales, formulamos algunas hipótesis acerca de la relación entre los cambios en el modo de vida, las formas sociales de producción y las vías de desarrollo del capitalismo en el agro pampeano. Las mismas intentan poner en relación las transformaciones analizadas en los capítulos anteriores, pero también regresan a los interrogantes teóricos que formulamos en esta introducción.

\section{El recorte temporo-espacial y el énfasis temático en la agricultura y en los productores medios}

Consideramos que buena parte de las discrepancias existentes en la bibliografía especializada a la hora de caracterizar socialmente al agro pampeano tienen su origen en la consideración de referentes empíricos diferentes (además, por supuesto, de la incidencia de las distintas perspectivas teóricas puestas en juego). Distintas etapas y subregiones fueron caracterizadas por el predominio de formas de producción agrícolas específicas, y con particulares articulaciones con la actividad ganadera. Sin embargo, especialmente durante el período 1880-1930, en un contexto territorialmente expansivo, 
las nuevas formas no siempre desplazaban a las anteriores, sino que muchas veces se yuxtaponían en un mosaico que tampoco presentaba una total homogeneidad subregional.

Por lo tanto, creemos que es necesario no sólo conceptualizar, sino también medir la significación productiva de las distintas formas sociales de producción prestando especial atención a las diferencias subregionales.

La selección de las subregiones la hemos efectuado en base a nuestro interés especial en dar cuenta de las transformaciones sociales que tuvieron lugar en la producción agrícola durante el siglo XX. Este interés no se basó en cierta predominancia de la agricultura sobre la ganadería dentro del valor global de la producción agropecuaria ${ }^{52}$, sino en que consideramos que las formas sociales de la producción ganadera se encontraban mejor caracterizadas en los estudios preexistentes ${ }^{53}$. Posiblemente una relativa menor complejidad social y/o un mejor ajuste con un modelo teórico previo (sintetizado en la figura del terrateniente-capitalista), combinados con un nivel de transformaciones tecnológicas y sociales a lo largo del siglo de una intensidad mucho menor que en el caso de la agricultura, hayan colaborado en permitir la emergencia de ajustadas caracterizaciones sobre las formas sociales de producción ganadera. En cambio, en el caso de la agricultura, creemos que las conceptualizaciones insuficientes, los debates abiertos y la persistencia de imágenes desfasadas en el tiempo necesitaban de estudio específico que ayudara a develar las transformaciones sociales en la producción agrícola.

Quisiéramos aclarar que este especial interés en estudiar las formas sociales de la agricultura pampeana no significa que desconozcamos la importante imbricación

52 De hecho, para el quinquenio 1935-39 el valor de la producción agrícola en la región pampeana, representaba el $58 \%$ del total de la producción agropecuaria, frente al $42 \%$ de la producción ganadera (Giberti, 1964: 70). Si bien durante las décadas siguientes la ganadería superó a la agricultura, para 1964 la relación volvió a ser nuevamente favorable a la agricultura $(54 \%$ a $46 \%)$, y a partir de entonces, se consolidaría la mayor importancia económica de esta actividad: en 1974 la agricultura tenía el 56\% y en 1995 alcanzó al 64\%, frente al 36\% de la ganadería (Milesi, 1975: 426; Giberti, 1988: 107 y Fiorentino, 1998: 130).

53 Ver, entre otros, los trabajos de Giberti (1981), Murmis (1979), Peretti y Gómez (1991), Pucciarelli (1986, especialmente el capítulo IV, y 1997b), Reguera (2000), J. Sábato (1979), Sesto (2002) e H. Sábato (1989), en este último caso para la segunda mitad del siglo XIX, pero con importantes consecuencias posteriores. 
existente entre esta producción y la actividad ganadera. De hecho, hemos analizado con cierto detalle cómo era esta relación y de qué manera se transformó durante el período estudiado, más allá de los estereotipos preexistentes en la literatura especializada.

En fin, debido a este énfasis en el estudio de la agricultura, hemos escogido para nuestro estudio a las tres subregiones de la provincia de Buenos Aires con distintas formas de desarrollo agrícola: zonas norte, oeste y sur (ver Mapa 1). Seleccionamos a esta provincia por ser la que presenta una mayor variedad de perfiles productivos y, dentro de ella, escogimos a estas tres zonas ya que consideramos que cada una de ellas representa los tres tipos de agricultura principales de la región pampeana y su distinta vinculación con la actividad ganadera. La zona norte se ha caracterizado históricamente por el cultivo del maíz, y en las últimas décadas asistimos a la expansión de la soja (combinándose su cultivo con el del trigo). La zona oeste constituye el núcleo del área de invernada, donde se engordan los vacunos alcanzándose las carnes de mejor calidad y tradicionalmente destinadas a la exportación, por ello dedica una porción considerable de su superficie a las forrajeras (entre la que se destacó la alfalfa), mientras que los cultivos principales han sido el trigo y el maíz, muchas veces utilizado como forrajera. Por último, la zona sur es un espacio donde siempre se combinaron la agricultura (trigo y avena) y la ganadería (vacunos y lanares, concentrando en el siglo XX el grueso de los rodeos de ovinos de la región pampeana). Al comienzo del primer capítulo se ofrece una historia de la evolución productiva de estas zonas hasta 1937, y luego en cada capítulo se analizan los cambios subsiguientes.

La subregionalización utilizada ha sido una combinación de la propuesta realizada por Slutzky (1968) -retomada luego por Barsky y Pucciarelli (1991)- con la zonificación elaborada por Gómez y otros $(1991)^{54}$.

La zona norte corresponde a los partidos bonaerenses de la "zona predominantemente agrícola" de la clasificación de Gomez y otros (1991), que

54 La interesante y precisa propuesta de zonificación elaborada por Andrés Barsky (1997) no ha sido utilizada, no sólo porque se basaba sólo en los datos de 1988, sino, esencialmente porque su publicación fue posterior al procesamiento de la mayor parte de los datos utilizados en la presente tesis, que incluyó el procesamiento especial del censo de 1988 en base a las tres zonas escogidas, y que hubiera obligado a volver a solicitar este arduo trabajo a la Dirección Provincial de Estadística. 
prácticamente coincide con la "zona agrícola del Norte" de Slutzky ${ }^{55}$. De este modo, la zona norte quedó conformada por los partidos de Baradero, Bartolomé Mitre, Carmen de Areco, Capitán Sarmiento, Colón, Chacabuco, General Arenales, Junín, Pergamino, Ramallo, Rojas, Salto, San Antonio de Areco, San Nicolás y San Pedro (ver el detalle de los partidos en el Mapa 2)

La zona oeste corresponde a los partidos bonaerenses de la subzona 5 de la "zona predominantemente mixta" (con un uso agrícola y ganadero) de la clasificación de Gomez y otros (1991), y coincide con los partidos ubicados más al Oeste dentro de la "zona de invernada" de Slutzky. Quedan entonces, los partidos de Carlos Tejedor, Florentino Ameghino, General Pinto, General Villegas, Leandro N. Alem, Lincoln, Pellegrini, Rivadavia, Salliqueló, Tres Lomas y Trenque Lauquen.

Por último, la zona sur integra las dos zonas del sur (ambas "mixtas") de la provincia de Buenos Aires de la zonificación realizada por Gomez y otros (1991) y su intersección con la "zona agrícola del Sur" de Slutzky $(1968)^{56}$. Los partidos que, entonces, constituyen nuestra zona sur son los de Adolfo González Chaves, Bahía Blanca, Coronel de Marina Rosales, Coronel Dorrego, Coronel Pringles, Coronel Suárez, General Alvarado, Lobería, Monte Hermoso, Necochea, Puán, Saavedra, San Cayetano, Tornquist y Tres Arroyos.

55 Solo deja fuera a los partidos de 25 de Mayo, Bragado, Alberti, Chivilcoy, Campana y Zárate (e incluye a Carmen de Areco, que Slutzky coloca en la zona tambera).

56 De este modo quedan fuera Guaminí y Adolfo Alsina (que están en la zona "Sur Oeste" de Gómez, pero no en la zona de Slutzky) y los dos partidos patagónicos: Villarino y Patagones (incluídos en Slutzky, pero no en Gómez). Además hemos dejado fuera de esta zona tres partidos que estaban en ambas clasificaciones: Tandil, Balcarce y General Pueyrredón, ya que la importancia de la producción hortícola y papera podrían haber incluido un factor de confusión en el análisis de los datos (especialmente el tamaño de las explotaciones). 
Mapa 1. Las tres zonas bonaerenses seleccionadas

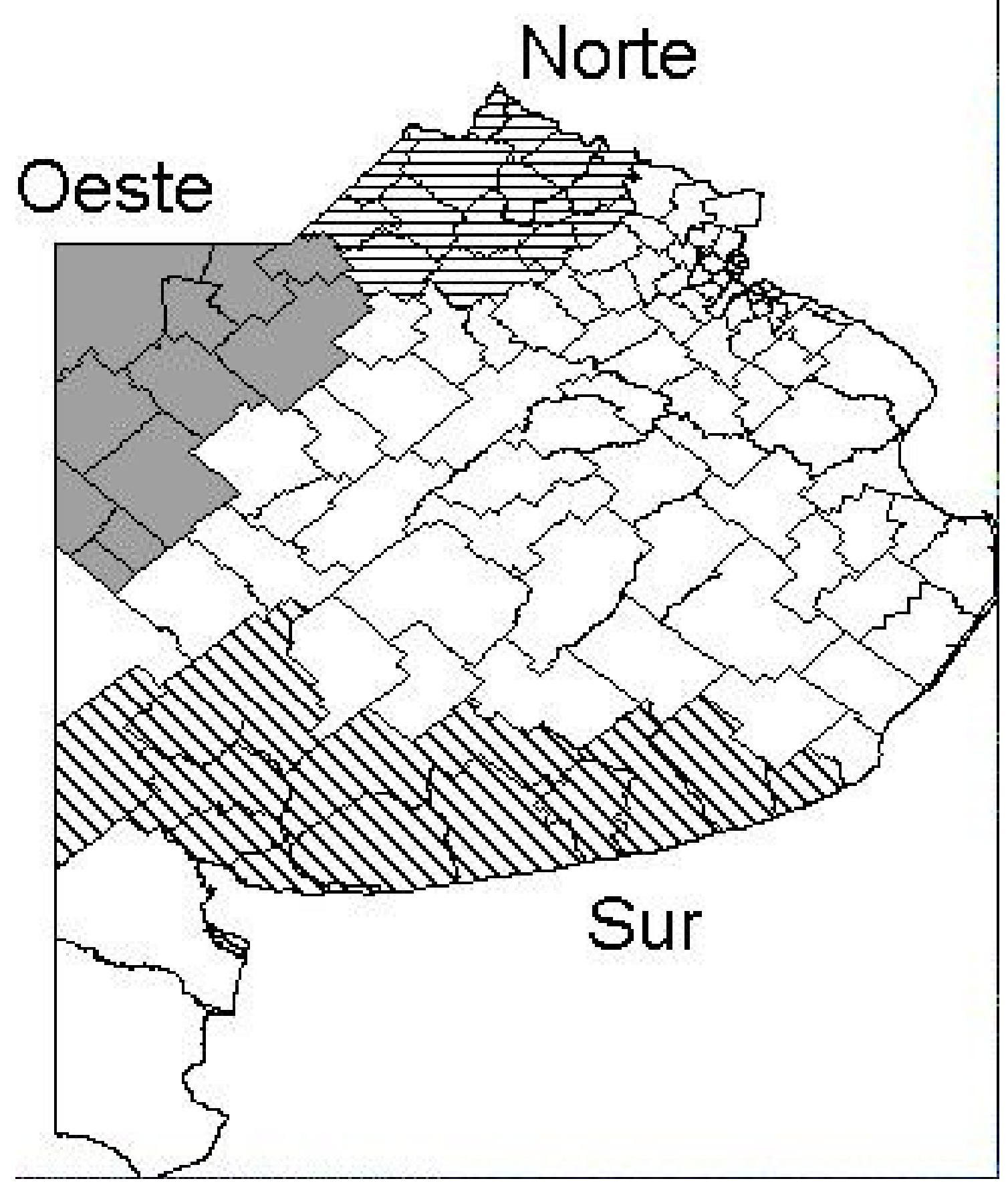


Mapa 2. Partidos que conforman cada una de las zonas

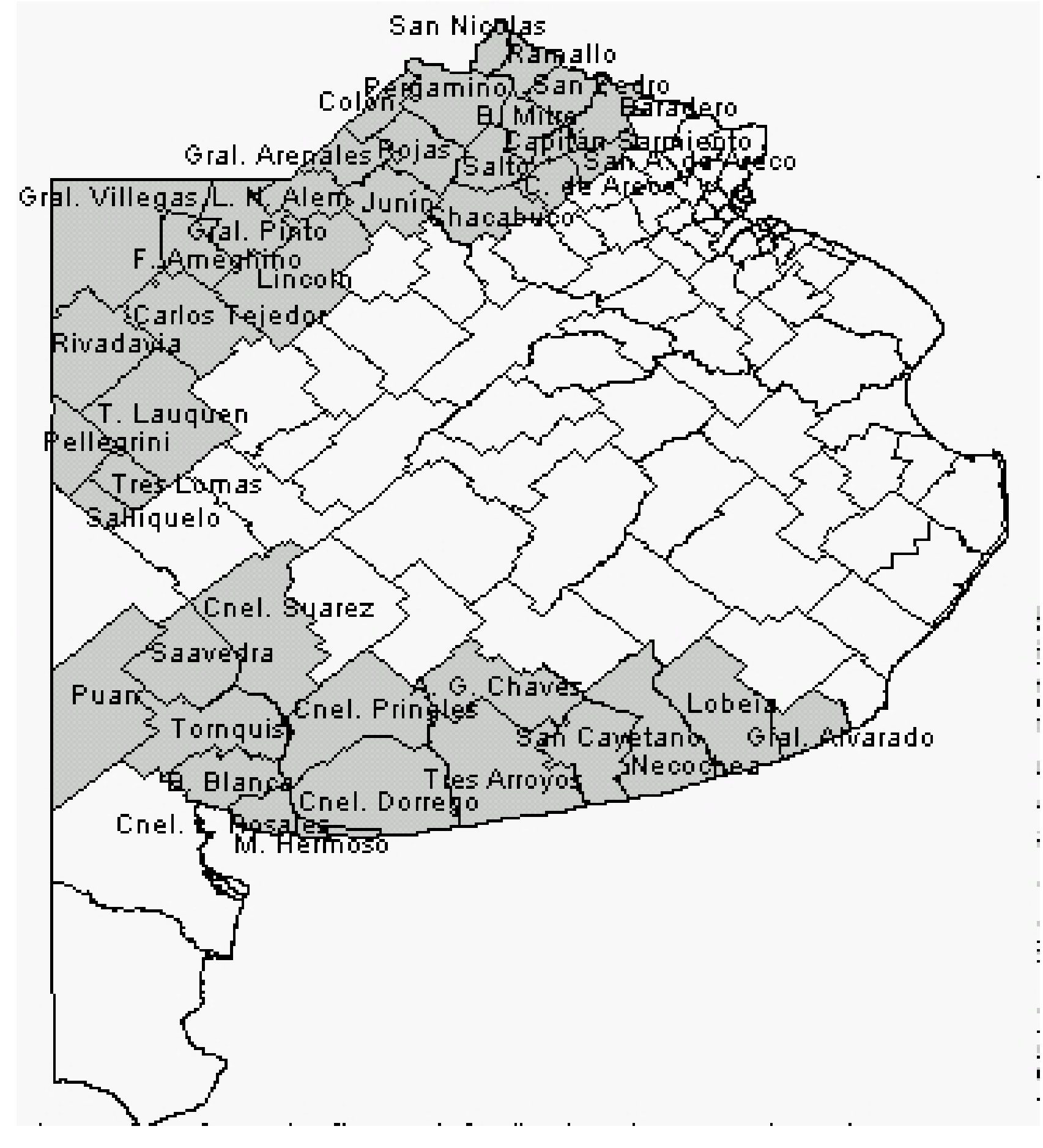


Además, en cada zona, hemos escogido un partido arquetípico en el que los rasgos zonales estuvieran más claramente destacados. Tanto los análisis de las transformaciones en la estructura de la propiedad, como las entrevistas de historia oral a productores rurales fueron efectuados en estos partidos. Para la zona norte,

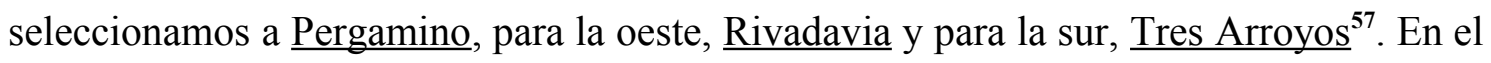
Mapa 3 podemos observar su ubicación geográfica.

Mapa 3. Partidos escogidos en cada una de las tres zonas

\section{Pergamino}

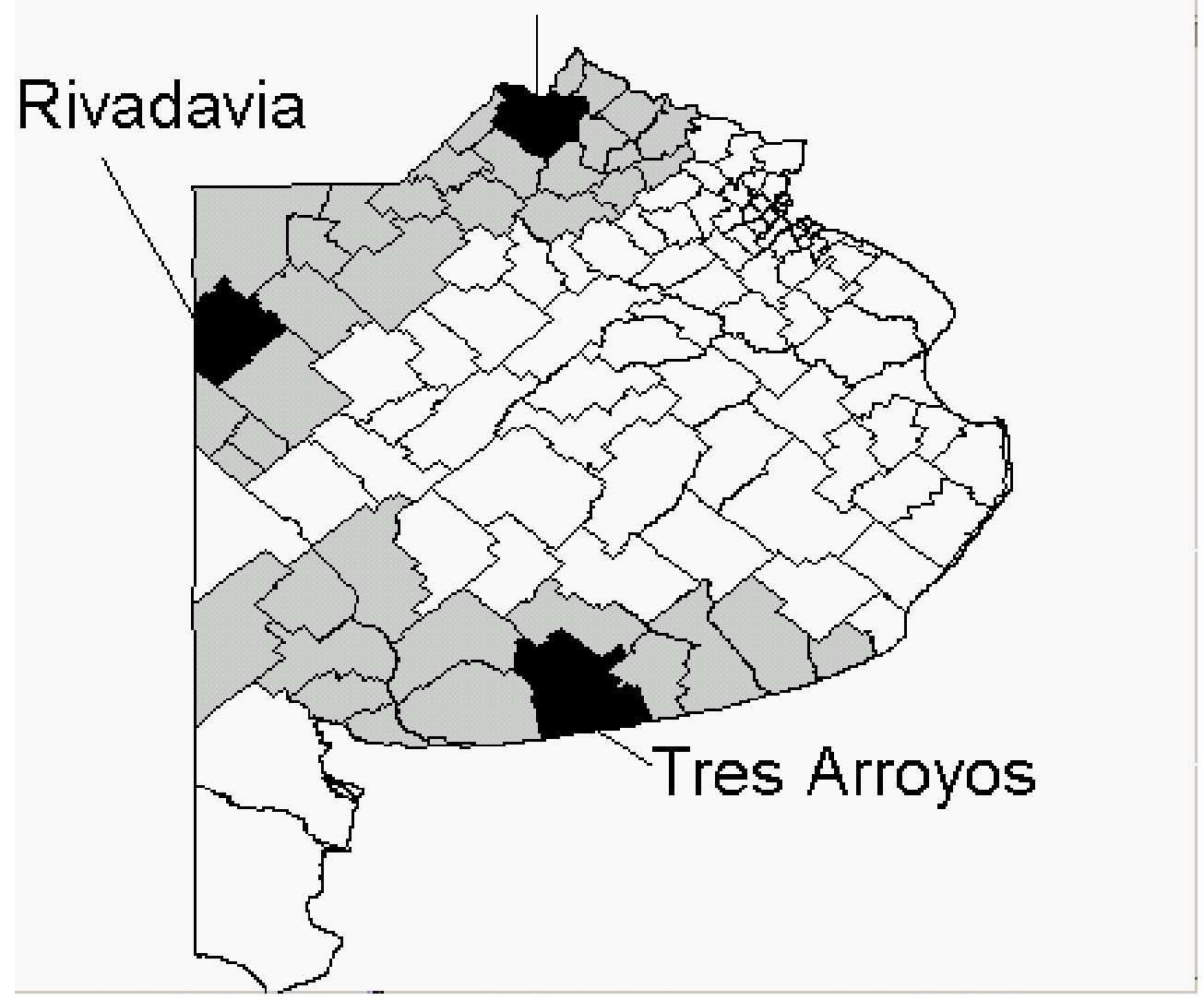

57 Escogimos a estos partidos por la combinación de dos motivos. Por un lado, cada uno de ellos son los partidos que usualmente se han utilizado para representar a estas zonas y para los cuáles, entonces, se cuenta con mayor cantidad de trabajos previos. Esto es especialmente claro en el caso de Pergamino, donde la presencia de la Estación Experimental ha generado un enorme número de estudios sobre dicho partido. Por otro lado, el análisis de la información estadística nos confirmó que estos tres partidos presentaban de un modo más destacado las características distintivas de cada una de las zonas, tanto en su perfil productivo como en la estructura agraria. En este sentido, no constituyen partidos con las características promedio de las zonas, sino partidos arquetípicos. 
En cuanto al recorte temporal, quisimos estudiar procesos en un lapso relativamente prolongado, cercano a lo que podría ser el "largo plazo" para nuestra corta historia regional (aunque en términos internacionales sería claramente un mediano plazo). Por ello, hemos abordado los dos períodos subsiguientes a la gran expansión agrícola pampeana de fines del siglo XIX y comienzos del XX. El primero, que como veremos estuvo caracterizado por la intervención estatal y el "estancamiento" agrícola, abarca desde fines de los años treinta (cuando la primera expansión agrícola alcanzó su climax) hasta los años sesenta. La década del sesenta constituyó un momento de clivaje ya que entonces comenzó una recuperación de la agricultura y concluyó la fuerte intervención estatal en la regulación del mercado de tierras. Entre fines de los sesenta y mediados de los ochenta tuvo lugar una extraordinaria expansión agrícola en la región, tanto en superficie como en volúmenes cosechados. Una nueva retracción en esta actividad durante la segunda mitad de los ochenta, nos permite diferenciar este período de lo que aconteció en los noventa (nueva expansión productiva en un contexto de sustancial retracción de la intervención estatal). La existencia de dos censos agropecuarios cuando finalizaron ambas etapas expansivas (1937 y 1988) ${ }^{58}$ propiciaron establecer como límites temporales de esta investigación el período 1937-1988, independientemente de que varias cuestiones serán estudiadas para los años anteriores y posteriores a dichas fechas.

Por último, si bien casi todas las cuestiones presentadas se estudiarán en el conjunto de los productores rurales, la presente tesis tiene, en ciertos apartados, un enfoque centrado en los productores medios, entendidos en un sentido amplio del término.

Es muy difícil definir claramente qué es un productor mediano, a pesar de que es un concepto ampliamente utilizado en la historia y la sociología rural ${ }^{59}$. El problema de

58 Estos censos, a diferencia de otros censos agropecuarios, nos brindan una gran cantidad de información detallada. En el caso del de 1937 por los numerosos cuadros publicados, y en el de 1988 gracias a poder acceder a los datos originales archivados en forma magnética.

59 Una interesante y sistemática propuesta para operacionalizar el concepto de "mid-size farms", fue realizada por Gladwin (1989). Para esta antropóloga, las explotaciones medianas eran aquellas que podían sobrevivir, considerando que esto ocurriría en caso de que las unidades proveyeran un nivel de vida equivalente al de un hogar promedio nacional. Es decir, el tamaño daría cuenta del nivel de vida al que permitía acceder la explotación. La mejor 
fondo es que "tamaño" es una dimensión que habitualmente posee una escasa base teórica de respaldo ${ }^{60}$. A pesar de nuestro interés por la teoría, ésta será una cuestión que no abordaremos en esta tesis ya que nuestro interés por el tamaño es simplemente el de encontrar una categoría lo suficientemente abarcativa como para incluir a todos los sujetos cuya conducta económica no estuviera fuertemente determinada por su dotación de recursos. En este sentido no nos interesaba estudiar tan en detalle a los pequeños productores minifundistas o cercanos a la situación de simple subsistencia, y tampoco a los grandes productores capitalistas que utilizan una considerable cantidad de asalariados. Un concepto amplio de "productores medianos" nos permite no poner énfasis en estos dos tipos extremos, y, en cambio, prestar especial atención al heterogéneo conjunto de productores que queda entre medio de estas situaciones polares

forma de operacionalizar esto era, por un lado, según el nivel de ingresos netos que brinda cada explotación, y por el otro con la mediana del ingreso de los hogares de todo el país. Como así sólo se obtenía un valor puntual, se optó por utilizar un rango que fuera desde un valor equivalente a la mitad de la mediana hasta 1,5 veces este valor. Por debajo de la primer cifra, nos encontraríamos con explotaciones pequeñas, y por encima de la segunda, con grandes unidades. Esta metodología, presenta la ventaja de poder analizar la evolución de la importancia de las "mid-size farms" a lo largo del tiempo, calculando siempre cuáles son los valores comparables con la mediana nacional del ingreso de todos los hogares.

Sin embargo, en muchas ocasiones históricas este método presenta el problema de agrupar prácticamente todas las unidades dentro de las categorías de medianas o grandes, y dejar prácticamente vacía la de pequeñas. Esto nos ha ocurrido a nosotros cuando intentamos aplicarla al agro pampeano de los años noventa. De todos modos esta propuesta no deja de resultar útil para situar a los productores dentro del conjunto de la sociedad nacional y puede ser un tema de interesante debate teórico-metodológico

60 A la mayoría de los autores le resulta evidente la diferencia entre una explotación grande y una pequeña; sin embargo muy pocos han analizado qué significa "grande" o "pequeña". Tres problemas se superponen en esta cuestión: de qué cualidad da cuenta el tamaño (¿qué se mide?), qué variable lo operacionaliza mejor (¿cómo se mide?) y cuántas categorías de tamaño sería útil distinguir (¿cómo se clasifica?), habida cuenta de que, en general, se utilizan variables continuas y que, por lo tanto, existe un número infinito de valores posibles. Increíblemente, la mayoría de nosotros avanzó sobre la tercer cuestión, sin haber dado mayores precisiones sobre la primera, y empleando las variables que los datos censales nos brindaban en la respuesta a la segunda pregunta. En general, se ha optado por una categorización tricotómica, ya que casi todos los trabajos dividen en explotaciones pequeñas, medianas y grandes. En todo caso, luego subdividen a las medianas (en medianas-chicas y medianas-grandes), o distinguen a las explotaciones "muy grandes" de las sólo "grandes".

Ahora bien, ¿de qué da cuenta el tamaño?, ¿del poder económico del productor frente a los otros productores, frente al resto de la sociedad? ¿Del control del área agropecuaria que posee? ¿Del nivel de ingresos que genera? ¿Del estándar de vida que permite? Tan sólo después de responder esta pregunta tiene sentido buscar una variable que operacionalice la dimensión tamaño, y establecer categorías que diferencien a las explotaciones. 
y que, por otra parte, han tenido a su cargo la mayor parte de la producción agrícola regional, tal como veremos a lo largo de la tesis ${ }^{61}$.

\section{Presentación de las metodologías empleadas}

La diversidad de cuestiones teóricas e interrogantes historiográficos que intentamos resolver nos impuso el diseño de una estrategia metodológica que combina enfoques cuantitativos y cualitativos. Así, en algunos casos, procuramos medir con la mayor precisión posible algunos fenómenos, como por ejemplo la importancia de las distintas formas sociales de producción, utilizando los datos censales; pero, en otros casos, buscamos captar cambios en la subjetividad de los productores rurales, a través, fundamentalmente de sus testimonios orales. Por lo tanto, se diseñaron instrumentos metodológicos específicos para abordar cada una de las distintas dimensiones que incluye el complejo objeto de estudio construido.

${ }^{61}$ Jorge Sábato, sin brindar mayores precisiones, utiliza también un concepto amplio de "sector medio" (aunque no tan dilatado como el nuestro) definido por las explotaciones de 100 a 1.000 hectáreas, y aclara que "la amplitud de los límites adoptados puede hacer pensar que ese 'sector medio' es demasiado heterogéneo como para constituir una categoría de análisis". Pero luego afirma que "este sector a pesar de su diversidad es bastante homogéneo en la organización productiva de las explotaciones y respecto del tipo de tecnología que puede usar" (Sábato, 1980: 35-36). Sin embargo, no pretendemos nosotros en este punto de la tesis formular ninguna hipótesis sobre posibles homogeneidades dentro del concepto de "productores medianos", sino delimitar un espacio social a analizar en profundidad.

Por otra parte, uno de los pocos intentos en Argentina de definir el tamaño en base a una medida económica, ha sido desarrollado por Pucciarelli (1997). Si bien, este autor hubiera querido utilizar el volumen y el valor total de la producción (datos ausente en la información censal), han sido reemplazados por el valor de la tierra, partiendo de una serie de seis presupuestos (que como tales están abiertos a crítica). Esto le permite equiparar dos explotaciones con extensiones territoriales y estrategias productivas muy diferentes, pero que pueden ser consideradas del mismo "tamaño", por sus beneficios, su valor de producción y la magnitud del volumen de inversión en tierras y en capital" (Pucciarelli, 1997: 231-232). De todos modos, no nos resuelve el problema de las categorías, ya que el criterio de corte entre las mismas se establecen arbitrariamente a partir de determinadas cantidades de cabezas de animales de las explotaciones ganaderas y su equiparación para las unidades agrícolas. 
Si bien las metodologías empleadas serán explicitadas a lo largo de la tesis y en los apéndices correspondientes, quisiéramos presentar aquí sintéticamente cómo hemos trabajado la información censal, catastral y las historias de vida recogidas.

En cuanto a la información censal, para la presente tesis hemos trabajado detenidamente con los Censos Nacionales Agropecuarios de 1937, 1947, 1960, 1969 y 198862. En los tres primeros casos tuvimos que remitirnos exclusivamente a la información édita, ya que no pudimos encontrar los datos originales que, todo hace presumir, se han perdido definitivamente. Para el caso del Censo de 1960 hemos localizado algunos reprocesamientos de los tarjetas originales elaborados por el CONADE (1965). La limitación que implica tener que ceñirse a los datos publicados se ha visto compensada, en el caso del Censo de 1937, porque su edición presenta numerosos cuadros detallados por partido o departamento.

Entonces, para los censos de 1937, 1947 y 1960 hemos cargado y procesado toda la información censal disponible relevante para nuestra investigación, de cada uno de los partidos de las tres zonas que seleccionamos para esta tesis. Un trabajo tedioso que no es visible en el texto, donde sólo se consignaron las sumatorias del total zonal, pero que permite lograr una importante representatividad en las afirmaciones realizadas ya que los datos cubren las más importantes áreas agrícolas de la provincia de Buenos Aires.

Para el caso del Censo Agropecuario de 1969, la cantidad de información publicada era sumamente escasa (un sólo tomo con apenas seis cuadros con datos por partido). A fin de recuperar más información y poder efectuar el cruce de las dimensiones analizadas trabajamos con los datos originales de las cintas de computación. Luego de algunos avatares y un trabajo detallado que efectuamos sobre los archivos ${ }^{63}$, logramos construir un único archivo que unifica la información contenida

62 Para reconstruir la evolución demográfica y productiva de las tres zonas estudiadas, que consignamos al comienzo del primer capítulo, hemos utilizado los Censos Nacionales de 1869, 1895, 1908 y 1914, y los Censos Provinciales de 1881 y 1938 (ver referencias completas de los mismos en Fuentes y Bibliografía / Censos y Estadísticas Oficiales).

63 En primer lugar surgieron problemas técnicos en el manejo de los datos cargados en las viejas cintas informáticas del INDEC. Luego de su recuperación, volvió a surgir un comentado obstáculo para su procesamiento: una gran cantidad de explotaciones duplicadas. Personalmente, dilucidé de qué modo correspondía procesar la información contenida en estos registros en apariencia duplicados, pero que en realidad contenían datos que no habían 
en las fichas sobre mano de obra, tenencia del suelo y uso de la tierra ${ }^{64}$ de cada una de las explotaciones de la provincia de Buenos Aires, procesando luego con el SPSS los datos para las tres zonas escogidas ${ }^{65}$.

En relación con el Censo Agropecuario de 1988, se diseño un procesamiento especial de sus datos originales, que fue realizado por el personal de la Dirección Provincial de Estadística y Planificación General de la Provincia de Buenos Aires. Ya que no se pudimos acceder a los datos originales (debido al secreto estadístico), se solicitó una matriz de datos que discriminara a las unidades productivas según la zona en que se ubicaban, su tamaño, la tenencia del suelo, la orientación productiva, el tipo de mano de obra, la forma de organización de las labores agrícolas, y la residencia del productor en la explotación o $\mathrm{no}^{66}$. A partir de este procesamiento (que a su vez consignaba para cada tipo, sus características en otras 28 variables) hemos analizado esta matriz según el análisis de tablas multivariadas, ponderando los tipos de productores según la cantidad de casos que presentaban.

Gracias a estos reprocesamientos de los datos originales de 1969 y 1988 no sólo hemos podido identificar con una precisión hasta ahora no utilizada las distintas formas sociales de producción (al poder cruzar las distintas dimensiones), sino que también pudimos establecer comparaciones intercensales mucho más ajustadas (entre 1937 o 1947 y 1969 , y entre 1969 y 1988).

podido ser cargados en el primer registro de cada explotación.

${ }^{64}$ Estas son las únicas variables que pudieron ser leídas, ya que el resto de los datos cargados se encuentra encriptado.

65 Las sumatorias de todas las variables resultaron altamente congruentes con los totales provinciales publicados, excepto la superficie sembrada con forrajeras anuales, pero que no ha sido incluida en los análisis contenidos en el presente trabajo. Asimismo, hemos dejado de lado un ínfimo porcentaje de las explotaciones para las cuales existía una elevada discrepancia entre la superficie relevada según forma de tenencia y según uso del suelo -en la mayoría de los casos, parecieran ser problemas de carga-.

${ }_{66}$ La combinatoria de todas estas posibilidades nos arrojó una matriz con 8.064 tipos de explotaciones, y para 2.968 encontramos al menos un caso. A fin de resguardar el secreto estadístico, en la matriz de datos los tipos con uno o dos casos fueron unificados. Para solucionar este problema, en el análisis subsiguiente hemos estimado la cantidad de casos para estos tipos en base a la diferencia entre la cantidad de explotaciones registradas por el Censo para cada una de las zonas, y la sumatoria de los tipos con más de tres casos. 
En cuanto a la información sobre la propiedad de la tierra trabajamos con el Mapa Catastral de la Provincia de Buenos Aires, ordenado en 1937 y confeccionado alrededor de 1939, y con los Mapas Rurales de los años sesenta y ochenta, además de los Mapas Catastrales de los años veinte. Cabe aclarar que los Mapas Rurales, a pesar de ser una publicación privada, son elaborados a partir de la información catastral oficial e, incluso, como tienen una amplia difusión en los partidos, son sometidos a la crítica constante en el ámbito local (en la oficina de La Plata, se recogen los comentarios críticos que les envían sus representantes).

Para trabajar con los mapas, en primer lugar, seleccionamos por muestreo aleatorio simple, sin repetición, a través de un sistema de coordenadas, cien propiedades en los partidos de Pergamino, otras cien de Tres Arroyos y cincuenta propiedades en Rivadavia. En segundo lugar, se agregaron al estudio todas aquellas propiedades con más de 1.500 hectáreas en el caso de Pergamino, y con más de 2.500 en los otros dos partidos, para evitar todo tipo de error muestral que afectara a las grandes propiedades (especialmente sensibles por su escaso número). Luego se procedió a analizar la evolución de las propiedades escogidas tanto durante el período 1939-1960/64, como entre 1960/64-1988/89.

Buena parte de la tesis se basa en el uso de la historia oral, en los tres partidos seleccionados (Pergamino, Rivadavia y Tres Arroyos), se realizaron 43 entrevistas orales en profundidad a productores rurales y otras cinco a ingenieros agrónomos y veterinarios radicados en dichos partidos $^{67}$ (independientemente de las entrevistas

67 Como la presente tesis fue comenzada durante nuestra Beca de Perfeccionamiento del CONICET, centrada en el estudio de la zona sur de la provincia de Buenos Aires, primero se realizó el trabajo de campo en el partido de Tres Arroyos. Es por ello que contamos con un mayor número de testimonios recogidos en este partido (34 entrevistas). Luego, al ampliarse la investigación a las zonas norte y oeste, se realizaron dos viajes a Pergamino (efectuándose ocho entrevistas) y uno a Rivadavia (seis testimonios) a fin de complementar los análisis ya realizados a las entrevistas de productores de Tres Arroyos. Si bien se encontraron algunas peculiaridades en estos partidos que diferencian a sus productores de los de la zona sur (tal como se verá a lo largo de la presente tesis), no se percibió la necesidad de realizar un mayor número de entrevistas en ellos. Seguramente un incremento en el número de testimonios en estos dos partidos permitirían profundizar en el conocimiento de algunas cuestiones, pero consideramos que se alcanzaron niveles de saturación muy consistentes con los fenómenos detectados en Tres Arroyos y no se percibió la necesidad de generar más testimonios para sostener las afirmaciones que se desarrollan a lo largo de la presente tesis. 
realizadas para la tesis de maestría sobre el impacto de la crisis del treinta). En las entrevistas se utilizó la técnica de la historia de $v i^{6}{ }^{68}$. La mayoría de las entrevistas tuvieron una duración de una hora y media a dos horas, y no se utilizó cuestionario, sino que se buscó que los productores relataran su vida con énfasis en las cuestiones vinculadas a la actividad agropecuaria y a los cambios en sus modos de vida. Se hizo hincapié en que nos interesaba su historia personal, más que sus apreciaciones de tipo general sobre qué había acontecido al conjunto de los productores rurales. En cambio, sí se solicitaron algunos datos sobre las trayectorias de sus vecinos linderos. En general, las entrevistas fluyeron de un modo muy natural y espontáneo. Al ir finalizando las mismas, se controlaba que todas las cuestiones previstas en la guía de pautas hubieran sido abordadas, y recién entonces se formulaban algunas preguntas más específicas que no hubieran sido tratadas de forma "espontánea"69.

El muestreo empleado ha sido un muestreo teórico ${ }^{70}$, que para empezar tuvo en cuenta formas de tenencia del suelo y tamaño de las unidades que poseían los productores o sus padres al comienzo del período, y que luego fue agregando otras dimensiones como sexo, edad, origen étnico y residencia en el campo o la ciudad, buscando que la muestra no estuviera sesgada en algunos valores de estas dimensiones (de todos modos, existió una clara predominancia de hombres y de elevada edad). La técnica empleada para conseguir entrevistados fue la "bola de nieve", a cada

68 Si bien la historia de vida puede constituir un objetivo en sí mismo de la historia oral, aquí fue utilizada como técnica, en tanto que el permitirle al entrevistado que vaya recorriendo su propia vida tiene una serie de ventajas. Por un lado, le permite un desenvolvimiento más seguro, pues no está tan pendiente de las preguntas del entrevistador, pero además ayuda a que se ubique temporalmente en cada momento de su pasado (reduciendo las imprecisiones temporales propias de las respuestas puntuales), estimula sus recuerdos y permite que su propio relato contextualice algunos comentarios que de otro modo podrían ser autocensurados, por ser social o políticamente incorrectos en el presente.

69 No presuponemos que la entrevista en profundidad, por menos estructurada que sea, constituya una forma "natural" de conversación. Vale recordar, frente a cierto discurso etnográfico que tiende a naturalizarlo, lo artificial que es ponerse a contar detalles de su vida, e incluso construir una narración en torno a ella, frente a un completo extraño.

70 El muestreo teórico, a diferencia de los muestreos probabilísticos, va reconfigurando la muestra a medida que avanza el proceso de análisis de las entrevistas. Se parte de algunas dimensiones que se presumen claves para diferenciar a las unidades de análisis (en este caso los productores rurales), y luego se incluyen nuevas dimensiones que se encuentran relevantes para profundizar la indagación, tratando, entonces, que la muestra garantice variabilidad en estas dimensiones. Sobre el muestreo teórico puede consultarse Glaser y Strauss (1967: capítulo III) o Saltalamacchia (1992: capítulo 4). 
entrevistado se le solicitaban los nombres de otros productores rurales a quienes poder entrevistar.

Las entrevistas fueron desgrabadas en su totalidad y luego codificadas, empleándose, para esta tarea y para la posterior recuperación de los fragmentos, el programa informático especializado para análisis de material cualitativo Nud-ist $4.0^{71}$.

Tal como se les aseguró a los entrevistados, hemos utilizado el criterio etnográfico de mantener el anonimato de los mismos, a pesar de que la tradición historiográfica es más afín a dar cuenta de sus nombres y apellidos. Nuestra propia experiencia como entrevistadores y como entrevistados nos hizo preferir garantizarles a nuestros entrevistados que ninguno de sus comentarios podría llegar a ser identificado con su persona, especialmente considerando que en la mayoría de los casos nuestra carta de presentación era tan sólo algún otro productor amigo o conocido a quien habíamos entrevistado previamente. En el Apéndice I hemos consignado algunos datos básicos de cada entrevistado de modo de poder referir a ellos los testimonios transcriptos en el texto de la tesis. Para ello, al final de cada fragmento se consignan dos letras de identificación (que, cabe aclarar, no son las iniciales del entrevistado).

Por último, aunque no resulta necesario brindar aquí mayores explicaciones sobre su tratamiento metodológico, quisiéramos agregar que hicimos un amplio uso de fuentes escritas éditas e inéditas para abordar la mayoría de las cuestiones de la presente tesis. Entre estas fuentes se incluyen informes técnicos, tesis de grado y posgrado, artículos de revistas agropecuarias, y obras de especialistas contemporáneos a los fenómenos. En el apartado Fuentes y Bibliografía / Material primario editado (al final de la tesis) se ha consignado el listado completo de este tipo de fuentes, además de las referencias correspondientes que se encuentran en el cuerpo de la tesis a medida que fueron utilizadas.

71 Unas pocas entrevistas, realizadas al comienzo de la investigación, no fueron grabadas sino recogidas en forma "taquigráfica", ya que preferimos no presentarnos a los primeros contactos con un grabador. Para diferenciar los fragmentos aquí reproducidos, hemos consignado un asterisco $(*)$ al lado de las letras de identificación. 
Una última aclaración: a fin de no interrumpir excesivamente nuestra línea de argumentación, especialmente en los capítulos segundo y tercero, hemos transferido a dos apéndices algunos de los cuadros y de los análisis más detallados del material estadístico, dejando en el cuerpo del texto las conclusiones de dicho trabajo. En todos los casos se incluyó en el cuerpo del texto la correspondiente referencia a los apartados específicos de los apéndices donde se detallan estos datos. 


\section{Capítulo Primero}

Las formas sociales de producción en la agricultura bonaerense al final de la primera expansión (1937)

¿Una vía "argentina" de desarrollo del capitalismo en la agricultura? 
La caracterización del desarrollo agrario pampeano durante la primera expansión agrícola se dificulta no sólo porque existe un elevado nivel de heterogeneidad social, sino porque los "caminos" o "vías" hasta ahora utilizados para conceptualizar los desarrollos del capitalismo en el agro no parecen dar cuenta del caso pampeano.

Por un lado, contamos con la "vía clásica" o inglesa, que describió Marx (1894). Como ya vimos, en este modelo -la forma más abstracta de agro capitalista- cada sujeto encarna un factor de producción. Las relaciones sociales básicas son las que entablan terratenientes completamente rentísticos, capitalistas que les arriendan sus campos, y asalariados rurales que los trabajan. Por lo tanto, cada sujeto tiene una lógica económica diferenciada. El modelo quedó un tanto olvidado, porque fuera del ejemplo inglés ${ }^{1}$ no se encontraron muchos casos en que se desarrollara. Pero, más allá del debate sobre la importancia analítica o histórica de este modelo, el mismo no parece resultar apropiado para caracterizar a la agricultura pampeana de la primer expansión, donde las formas familiares habrían tenido tanta significación. Sin embargo, tanto algunos autores de época, como historiadores actuales han llamado la atención sobre el peso que tenía el trabajo asalariado en la producción agrícola del período.

El mismo Marx describió otra forma de desarrollo agrario, que mantenía una base productiva campesina en creciente subordinación al capital financiero: el modelo francés (Marx, 1850: 147-151 y 1852: 133-139; ver una síntesis en Pucciarelli, 1986: 21-25). Desde una perspectiva teórica diferente, en la obra de Chayanov (1924) encontramos también una teorización sobre la explotación de los campesinos por el capital financiero y comercial. Más allá del origen campesino de buena parte de los agricultores pampeanos y del hecho de que perduraran algunas de sus costumbres y valores, las condiciones de producción distaron enormemente de este modelo. Sin embargo, para muchos autores existió una fuerte subordinación de los agricultores pampeanos hacia el capital comercial, que también financiaba el proceso productivo, de modo que no desatenderemos completamente esta conceptualización.

Como ya hemos comentado, Lenin (1899 y 1907) conceptualizó el desarrollo prusiano como "vía junker", en la que los terratenientes de origen feudal asumían

1 Incluso en el caso de Inglaterra, durante la segunda mitad del siglo XIX y el siglo XX tuvo lugar una expansión de las explotaciones familiares, en detrimento de los arrendatarios capitalistas (Abramovay, 1998: capítulo VI). 
también el papel de capitalistas, pero estableciendo nuevos tipos de obligaciones sobre la población rural, sujetándolos nuevamente a la tierra, a través de formas atrasadas de tenencia, como lo describe en detalle Winson (1994). En todo caso, una primera aproximación nos marca que la mayor parte de la agricultura en la región pampeana no estuvo a cargo directo de los grandes terratenientes $y$, entonces, el modelo prusiano no resultaría heurísticamente útil. Sin embargo, las relaciones "poco capitalistas" entre terratenientes y medieros o arrendatarios en especie pueden evocar ciertos elementos característicos de la vía prusiana. Retomaremos más adelante estas cuestiones.

Por último, como situación opuesta, Lenin (1899 y 1917) analizó el caso norteamericano, la "vía farmer", en la que la producción queda en manos de medianos productores propietarios que en principio se basaban en la mano de obra familiar. El pronóstico de Lenin de una rápida diferenciación y evolución hacia formas de producción capitalistas no tuvo lugar, estabilizándose la producción de tipo familiar (Friedmann, 1978a y Byres, 1996). En la Argentina la vía (norte)americana pareció ser la línea de evolución inicial de la agricultura pampeana durante el período expansivo que comenzara a mediados del siglo XIX en torno a las colonias del Litoral. Luego de superar una serie de avatares (Gaignard, 1989; Bonaudo y Sonzogni, 1998), los inmigrantes que lograron permanecer se consolidaron como un sector de pequeños propietarios (Gallo, 1983), posible de identificar con el farmer norteamericano. Incluso existió cierto predominio discursivo en favor de copiar el desarrollo agrario norteamericano en nuestras pampas ${ }^{2}$.

Sin embargo, no fue el modelo (norte)americano el que finalmente prevaleció. Cuando, a fines del siglo XIX, la expansión agrícola comenzó a desarrollarse en otras zonas de la región pampeana (especialmente en la provincia de Buenos Aires), los

2 Un análisis del "vasto consenso que propone la colonización agrícola de la campaña como solución no sólo para el atraso de ésta sino para los problemas socio-políticos de la entera nación", y de cómo "este consenso no va a ser nunca recusado" pero los dirigentes van a ir aceptando el nuevo orden rural que se fue gestando a partir de mediados del siglo XIX y que no se acercaba al modelo propuesto, puede verse en Halperín Dongui (1982: 120-138). Por otra parte, Adelman (1989: 109-110) afirma que los dirigentes políticos intentaron con firmeza emular a los Estados Unidos en sus políticas de colonización, aunque fracasaron por el contexto de circunstancias políticas, económicas y sociales. 
inmigrantes se encontraron con una distribución previa de la tierra concentrada en un pequeño grupo de familias terratenientes (Gaignard, 1989) ${ }^{3}$.

Estos propietarios tuvieron poco interés en favorecer la vía de desarrollo (norte)americana que incluía la venta de la tierra a los productores agrícolas familiares. Habían encontrado una mejor forma de expansión de la agricultura, que les permitía captar de un modo permanente la renta del suelo, y valorizar sus campos al mismo tiempo: la aparcería y el arrendamiento. Asimismo, este esquema posibilitaba -a través de contratos especiales- el alfalfado de los campos (luego de cosecharse lino y trigo), necesario para el engorde refinado de las haciendas destinadas a la exportación enfriada. En este contexto, fracasaron los centros agrícolas de colonización privada (Girbal, 1980). Vendida ya casi toda la tierra pública de la provincia, la ley provincial de 1887 intentó fomentar con crédito público la constitución de colonias agrícolas en las que la tierra terminara en manos de los agricultores. A pesar de haberse afectado más de un millón y medio de hectáreas (en su mayor parte de propiedad privada) y otorgado créditos hipotecarios por las tierras de los "centros agrícolas", el número de colonospropietarios terminó siendo ínfimo. En realidad, las colonias resultaron un verdadero negocio para los empresarios-terratenientes, salvo honrosas excepciones, incluso en los casos en que se afectó tierra pública (Girbal, 1980). La diferencia con el Corn Belt norteamericano resulta notable: en esa región gran parte de las tierras fueron entregadas directamente a los colonos y, más allá de la especulación inicial, antes de fin de siglo las compañías ferroviarias y los capitalistas especuladores habían vendido sus campos en forma fraccionada a favor de los agricultores ${ }^{4}$.

Ansaldi (1998:10) sostiene que tuvo lugar, entonces, una "vía argentina" de desarrollo del capitalismo en el agro. Habiéndose cerrado la línea posible de desarrollo

3 En el siguiente apartado describiremos la concentración de la propiedad en cada una de las tres zonas que hemos estudiado de la provincia de Buenos Aires.

4 Si a mediados del siglo XIX había en Iowa una decena de grandes terratenientes (con propiedades de más de 30.000 hectáreas), durante el resto del siglo las fueron vendiendo en forma fraccionada. En 1880 había 428 explotaciones con más de mil acres (405 hectáreas), pero para 1940 sólo quedaban 201, y de ellas sólo dos tenían más de 2.000 hectáreas (Murray, 1946). De este modo, el tamaño medio de las explotaciones de Iowa en 1860 era de 164,6 acres y para 1900 (cuando se alcanza la máxima ocupación agropecuaria de la superficie del estado) se redujo a 151,2 acres (Heady, 1947). 
farmer, se habría abierto otra "basada en el trípode alambrado de campos-mestizaje de vacunos-alfalfado de lotes arrendados a agricultores inmigrantes (chacareros)". Este sería el "camino argentino", en el cuál los agentes "mutágenos" habrían sido los terratenientes ganaderos (Ansaldi, 1998: 12).

Esta caracterización se encuentra en sintonía con la visión más tradicional, que destaca la relación dual agricultura-ganadería, encarnada en el chacarero arrendatario y el terrateniente ganadero, y que se estructura en torno a la relación chacra-estancia ${ }^{5}$. Sin embargo, varios trabajos han impugnado la validez de la base empírica de esta visión tradicional. No sólo sostienen que buena parte de la actividad agrícola era relativamente independiente de la ganadería (Pucciarelli, 1986), sino que también destacan la importancia de la agricultura realizada en explotaciones de escala considerable y con mano de obra asalariada ${ }^{6}$. Por otra parte, algunos llaman la atención sobre el acceso a la

5 En este sentido el trabajo de Ansaldi comparte algunos postulados con la visión tradicional, aunque el objetivo central de su exposición (que retomaremos en el siguiente capítulo) destaca cómo se modificó el perfil de los chacareros, al acceder a la propiedad a mediados del siglo XX.

6 Según Pucciarelli (1986: 103) en 1908 sólo un 21\% de las hectáreas cultivadas con cereales y oleaginosas correspondían a las explotaciones familiares propiamente dichas (menores a 100 hectáreas), un $25 \%$ a unidades indefinidas (100 a 200 hectáreas), pero el $54 \%$ restante estaba en manos de empresas capitalistas (mayores a 200 hectáreas).

Por su parte, Sartelli, a partir de una serie de cálculos sobre las horas de trabajo necesarias para cada tarea del cultivo de trigo y de maíz hacia principios de siglo, ha estimado que los peones estacionales asalariados serían responsables del 53\% del trabajo agrícola en el caso del trigo ( $24 \%$ el productor familiar y $23 \%$ el peón de siembra) y del $64 \%$ en el caso del maíz (26\% el chacarero y $9 \%$ el peón de siembra. Por lo tanto, concluye que la producción cerealera argentina estaba dominada por la producción asalariada y era minoritaria (aunque no despreciable) la de la mano de obra familiar (Sartelli, 1994). Sus cálculos, aunque interesantes y teóricamente correctos (en su hincapié en considerar la cantidad de trabajo incorporado y no el tiempo de crecimiento de las plantas), tienden a subvalorar el trabajo no estacional y las labores auxiliares y a estacionalizar en demasía las labores de cosecha (cuando los productores familiares tendían a prolongar los períodos a fin de realizar la mayor cantidad de tareas posibles sin utilizar asalariados); por lo tanto, queda subestimado el aporte de la fuerza de trabajo familiar. Por otra parte, no tiene en cuenta que los asalariados transitorios que forman parte de los equipos de trilla, no son ni contratados ni, por ende, explotados por los chacareros, sino por los dueños de las trilladoras. Por último, sobre todo durante la década del veinte asistimos a una muy importante incorporación de maquinaria agrícola que multiplicó la capacidad de trabajo de la mano de obra familiar (especialmente en la cosecha fina, tal como analizaremos más adelante) reduciendo notoriamente la importancia del trabajo asalariado transitorio, cuestión que el propio Sartelli también ha estudiado en otros trabajos (Sartelli, 1997). 
propiedad de la tierra por parte de un número importante de chacareros relativamente exitosos, especialmente durante la década del veinte ${ }^{7}$.

En síntesis, nos encontraríamos con una situación compleja en la que diferentes características estarían dando lugar a la presencia de elementos de cada uno de los distintos modelos de desarrollo agrario capitalistas, pero sin que ninguno de ellos predomine de un modo claro como para dar cuenta del conjunto. En el caso del desarrollo de la agricultura en la pampa argentina, a las dificultades para conceptualizar las formas complejas que históricamente han predominado en la agricultura (incluso de las sociedades capitalistas más avanzadas), se agregaría una elevada heterogeneidad social en la estructura productiva que caracterizó el desarrollo agrícola desde mediados del siglo XIX hasta la década de 1930. Esta heterogeneidad se complejiza aún más por sus diversas articulaciones con las también diferentes formas de producción ganaderas.

El objetivo central de este capítulo será, justamente, analizar detenidamente la evidencia empírica existente, a fin de lograr una caracterización lo más precisa posible de las formas sociales de producción presentes en la agricultura bonaerense del final de la etapa expansiva, de modo de poder sopesar la significación de los elementos de cada uno de los modelos de desarrollo agrario antes expuestos.

En esta línea de trabajo, tal como comentáramos en la introducción, prestaremos especial atención a las diferencias zonales. A fin de evitar rápidas generalizaciones, realizadas muchas veces desde referentes empíricos diferentes, nos ceñiremos a las tres zonas escogidas de la provincia de Buenos Aires. Como veremos en el siguiente apartado, las distintas subregiones fueron caracterizadas por el predominio de formas de producción agrícolas específicas, y con particulares articulaciones con la actividad ganadera.

Entonces, para ubicar al lector, el capítulo comenzará con una presentación de cada una de las tres zonas, con énfasis en su historia productiva entre 1880 y 1937.

7 El número de propietarios en la región pampeana se elevó de 21.337 en 1909/10 a 47.833 en 1925/26, aunque la crisis de 1929-1934 habría implicado un retroceso de esta tendencia (Barsky, 1988: 95-96). 
Continuará con un análisis de la estructura de la propiedad y del perfil de sus explotaciones agropecuarias, cruzando después ambas cuestiones; deteniéndonos, finalmente, en la cuestión de las formas de producción de la agricultura, de modo de poder resolver el interrogante sobre la especificidad de la vía de desarrollo de la agricultura en esta región. El núcleo de este análisis se basa en el trabajo sobre la amplia información editada del Censo Agropecuario Nacional de $1937^{8}$, a la que agregamos una serie de supuestos necesarios para poder estimar las distribuciones condicionales (cruces de variables) que nunca fueron publicadas. Así, utilizando la metodología explicitada en el Apéndice 1 (Apartado 1) hemos estimado, por ejemplo, cómo se distribuía la superficie según la tenencia del suelo cruzada por el tamaño de las unidades, o por el tipo de mano de obra utilizada.

En el último apartado de este capítulo, nos abocamos a la reconstrucción del modo de vida de los chacareros y a la caracterización del mundo rural en las tres zonas estudiadas, para lo cual, además de las fuentes escritas, nos hemos basado en los testimonios orales que recogimos personalmente.

8 Esta fecha puede considerarse como el momento final de la primer expansión. Aunque muchos autores lo ubican en torno a 1914 y otros en 1930, durante los años veinte la superficie agrícola continuó expandiéndose (en la provincia de Buenos Aires se duplicó). La crisis de los años treinta, si bien afectó más duramente a la agricultura que a la ganadería, tuvo como primera respuesta una intensificación de la actividad agrícola (el área sembrada continuó creciendo). A pesar que los precios relativos aconsejaban una reorientación hacia la ganadería, la mayoría de los chacareros pampeanos no se encontraban en su mejor momento para invertir en la compra de ganado. Palacio (1992a) sostiene que sí tuvo lugar este reemplazo de agricultura por ganadería durante la crisis. Para una crítica de su análisis, ver Balsa (1994b). 


\section{Presentación sintética de la historia previa de las tres zonas estudiadas}

Cada una de las tres zonas estudiadas se articuló de un modo diferente dentro de la gran expansión agrícola y ganadera desarrollada durante la segunda mitad del siglo XIX y las tres primeras décadas del siglo XX. Estas diferencias no sólo se debieron a los factores naturales, sino también a los distintos procesos de ocupación del territorio. A continuación, presentamos una breve síntesis de la ocupación, y la evolución productiva y demográfica de estas tres zonas.

En la zona norte, la franja cercana al río Paraná fue ocupada tempranamente por los españoles. En la primera parte del siglo XVIII, se fundaron varios pueblos, tanto en el litoral como en el interior, especialmente en el camino hacia Córdoba, que pasaba por Pergamino. Durante el virreinato, la frontera se ubicó más hacia el sur, estableciéndose una línea de fortines que cruzaba por Carmen de Areco y Rojas. Entonces, para fines del siglo XVIII, la mayor parte de nuestra zona norte se encontraba dentro de la frontera (ver Mapa 4). En 1826 se avanzó algo más, construyéndose el fortín Federación (hoy Junín). De esta forma tan sólo el actual partido de General Arenales quedaba fuera de la frontera (ver Cortés Conde, 1979: 53), incorporándose recién en la década de 1860. De todos modos, los indígenas incursionaron sobre buena parte de la zona hasta mediados del siglo XIX: así, por ejemplo, el último gran malón en la zona de Pergamino tuvo lugar en 1857. 
Mapa 4. Evolución histórica de la frontera

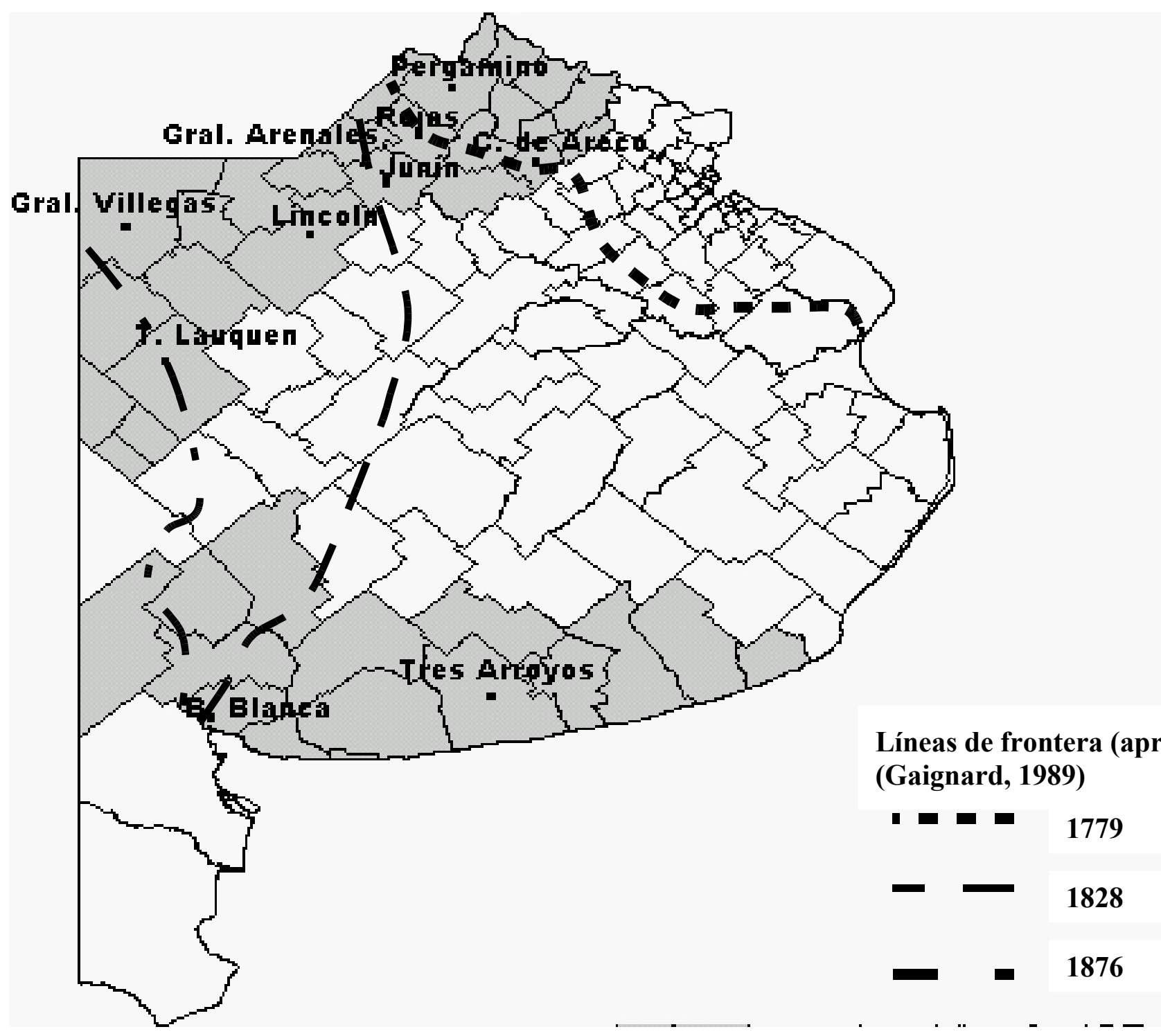


Hasta los años ochenta, en que se construyeron las primeras líneas férreas (el ferrocarril llegó a Pergamino en 1882 y a Junín en 1885), la zona norte se había dedicado predominantemente al vacuno y, desde mediados del siglo, al lanar. Recién con el arribo del ferrocarril comenzó la expansión de la agricultura en esta zona. De modo que, en 1881, sólo el $2 \%$ de la superficie de la zona estaba dedicada a la agricultura, mientras que había cinco lanares ${ }^{9}$ y 0,4 vacunos por cada hectárea (ver Cuadro 1.1). Sin embargo, para 1895, la agricultura ya ocupaba el 16\% de la zona, habiendo retrocedido notoriamente el ovino. Para 1914, la mitad del área era dedicada a los cultivos, el lanar había prácticamente desaparecido, y el vacuno mantenía su lugar (ver Cuadro 1.1). Al final de la etapa expansiva (1937) la superficie agrícola casi llegaba al $60 \%$ y había 0,36 vacunos por hectárea. En la zona norte predominaban los cultivos para cosecha (en primer lugar el maíz ${ }^{10}$, y luego otros cultivos como trigo, lino y girasol) y, en un segundo plano, se encontraba la ganadería vacuna.

$9 \quad$ En el cuadro 1.1 hemos consignado la cantidad de cabezas de lanar por hectárea dividas por cinco, a fin de hacerlas relativamente equiparables con la carga de un vacuno o un equino. De hecho el tema de los equivalente de cargas ganaderas y su evolución histórica constituye todo un problema metodológico que ha abordado Giberti (2001). Sin embargo, en la presente tesis, no nos detendremos en esta cuestión, ya que nuestro principal interés está puesto en la producción agrícola.

10 Hemos consignado al maíz como un cultivo para cosecha ya que en 1937 se cosechó el $76 \%$ de la superficie implantada con este cereal en la provincia de Buenos Aires. 
Cuadro 1.1.

Evolución productiva entre 1881 y 1937. Proporción de hectáreas sembradas sobre la superficie total y cantidad de cabezas por hectárea.

\begin{tabular}{|c|c|c|c|c|c|c|}
\hline \multirow{2}{*}{\begin{tabular}{c|} 
\\
Zona
\end{tabular}} & \multicolumn{3}{|c|}{$\begin{array}{c}\text { Porcentaje de la superficie total } \\
\text { sembrada con }\end{array}$} & \multicolumn{3}{|c|}{ Cabezas de ganado por hectárea } \\
\hline & $\begin{array}{r}\text { cultivos } \\
\text { para } \\
\text { cosecha }\end{array}$ & $\begin{array}{r}\text { doble } \\
\text { propósito }\end{array}$ & $\begin{array}{r}\text { forrajeras } \\
\text { permanentes }\end{array}$ & vacunos & $\begin{array}{c}\operatorname{ovinos} / 5 \\
(*)\end{array}$ & equinos \\
\hline \multicolumn{7}{|l|}{ Norte } \\
\hline 1881 & $1.7 \%$ & $0.1 \%$ & $0.4 \%$ & 0.391 & 1.097 & 0.194 \\
\hline 1895 & $16.3 \%$ & $0.4 \%$ & $1.3 \%$ & 0.310 & 0.548 & 0.073 \\
\hline 1908 & $29.4 \%$ & $1.4 \%$ & $5.1 \%$ & 0.461 & 0.304 & 0.125 \\
\hline 1914 & $50.1 \%$ & $2.2 \%$ & $\mathrm{~s} / \mathrm{d}$ & 0.338 & 0.103 & 0.168 \\
\hline 1937 & $58.4 \%$ & $1.6 \%$ & $7.0 \%$ & 0.365 & 0.036 & 0.159 \\
\hline \multicolumn{7}{|l|}{ Oeste } \\
\hline 1881 & $0.1 \%$ & $0.0 \%$ & $0.0 \%$ & 0.037 & 0.010 & 0.015 \\
\hline 1895 & $1.6 \%$ & $0.0 \%$ & $0.8 \%$ & 0.154 & 0.158 & 0.036 \\
\hline 1908 & $15.9 \%$ & $1.9 \%$ & $17.5 \%$ & 0.284 & 0.085 & 0.073 \\
\hline 1914 & $15.2 \%$ & $4.7 \%$ & $\mathrm{~s} / \mathrm{d}$ & 0.379 & 0.055 & 0.084 \\
\hline 1937 & $17.4 \%$ & $10.1 \%$ & $25.9 \%$ & 0.547 & 0.045 & 0.070 \\
\hline \multicolumn{7}{|l|}{ Sur } \\
\hline 1881 & $0.0 \%$ & $0.0 \%$ & $0.0 \%$ & 0.160 & 0.144 & 0.045 \\
\hline 1895 & $1.1 \%$ & $0.1 \%$ & $0.1 \%$ & 0.194 & 0.404 & 0.054 \\
\hline 1908 & $14.1 \%$ & $2.0 \%$ & $1.3 \%$ & 0.241 & 0.272 & 0.099 \\
\hline 1914 & $18.6 \%$ & $8.3 \%$ & $\mathrm{~s} / \mathrm{d}$ & 0.151 & 0.157 & 0.097 \\
\hline 1937 & $32.6 \%$ & $15.6 \%$ & $1.0 \%$ & 0.253 & 0.161 & 0.098 \\
\hline
\end{tabular}

Fuentes: Censo General de la provincia de Buenos Aires, 1881; Censos Nacionales de 1895 y 1914; Censo Nacional Agropecuario, 1908 y 1937.

(*) Hemos dividido a los ovinos por cinco a fin de hacer relativamente equiparable su carga ganadera con la de un vacuno o un equino. 
Este desarrollo agrícola se centró en las llamadas "colonias agrícolas", en realidad campos que no habían sido colonizados -en el sentido de ser entregados en propiedad a los agricultores ${ }^{11}$. En cambio, habían sido subdivididos en lotes y cedidos en aparcería a un conjunto de pequeños productores. Gallo (1984: 72) las denominó como "colonias particulares"12 y fueron detalladamente descriptas por Blanco (2001: 196-233) sobre todo para el partido de Pergamino a comienzos de los años cuarenta.

En esta zona, para 1937 el tipo de explotación que predominaba eran las "chacras" (unidades dedicadas a la agricultura, sin considerar su tamaño, según la clasificación empleada en el Censo Nacional Agropecuario ${ }^{13}$ ). Como se observa en el cuadro 1.2, estas unidades ocupaban alrededor del 58\% de la superficie censada de la zona norte. En cambio, los distintos tipos de unidades ganaderas controlaban el $29 \%$ y las explotaciones "mixtas" el 13\%.

11 Este desinterés de los terratenientes por vender en forma fraccionada sus latifundios explica que, a pesar de ser la zona con mejor aptitud agrícola y mejor conectada con los puertos y la ciudad de Buenos Aires, sólo se habían solicitado y concedido la instalación de 21 "centros agrícolas" (destacándose Junín, con diez centros) de los 191 autorizados para 1890 en toda la provincia (Girbal, 1980: 108-109).

12 Gori (1987: 114) afirma que, de este modo, se desvirtúa la palabra "colonización".

13 La publicación del Censo agrupó las explotaciones en distintos tipos. Si bien no se explicitan los criterios empleados para dicha clasificación (que de hecho no estaba presente en el cuestionario censal, sino que debió haber sido hecha durante el proceso de carga y análisis de los datos), resulta claro que se habrían basado en la orientación productiva de las unidades. Por lo tanto, las denominaciones empleadas no deben ser leídas incluyendo ninguna dimensión de tamaño o de forma de tenencia del suelo, problema habitual ya que, por ejemplo, el término "chacra" puede evocar la idea de una explotación pequeña. Los tipos empleados han sido los siguientes: chacra, mixta (sobre el que luego nos detendremos), huerta, quinta, monte frutal, cría de ganado, invernada, tambo, con ganadería (esta últimas cuatro categorías, las hemos unificado para algunas descripciones como explotaciones "ganaderas), además de viñedos, unidades dedicadas a la caña de azúcar y "no determinadas". 


\section{Cuadro 1.2.}

Superficie censal por tipo de explotaciones.

\begin{tabular}{|l|c|c|c|}
\hline & chacras & mixtas & ganaderas \\
\hline zona norte & $58 \%$ & $13 \%$ & $29 \%$ \\
zona oeste & $13 \%$ & $21 \%$ & $66 \%$ \\
zona sur & $18 \%$ & $52 \%$ & $30 \%$ \\
\hline
\end{tabular}

Fuente: Elaboración propia en base al Censo Nacional Agropecuario de 1937.

En el aspecto demográfico, la zona norte presentó un importante crecimiento poblacional hasta 1938, aunque cabe señalar que para finales de la década de 1860 se encontraba mucho más poblada que las zonas oeste y sur (ver Cuadros $1.3 \mathrm{y} 1.4, \mathrm{y}$ Gráfico 1.1). De unos 60.000 habitantes que tenía en ese primer momento, para fines de la década de 1930 había alcanzado los 400.000 .

\section{Gráfico 1.1}

\section{Evolución de la población}

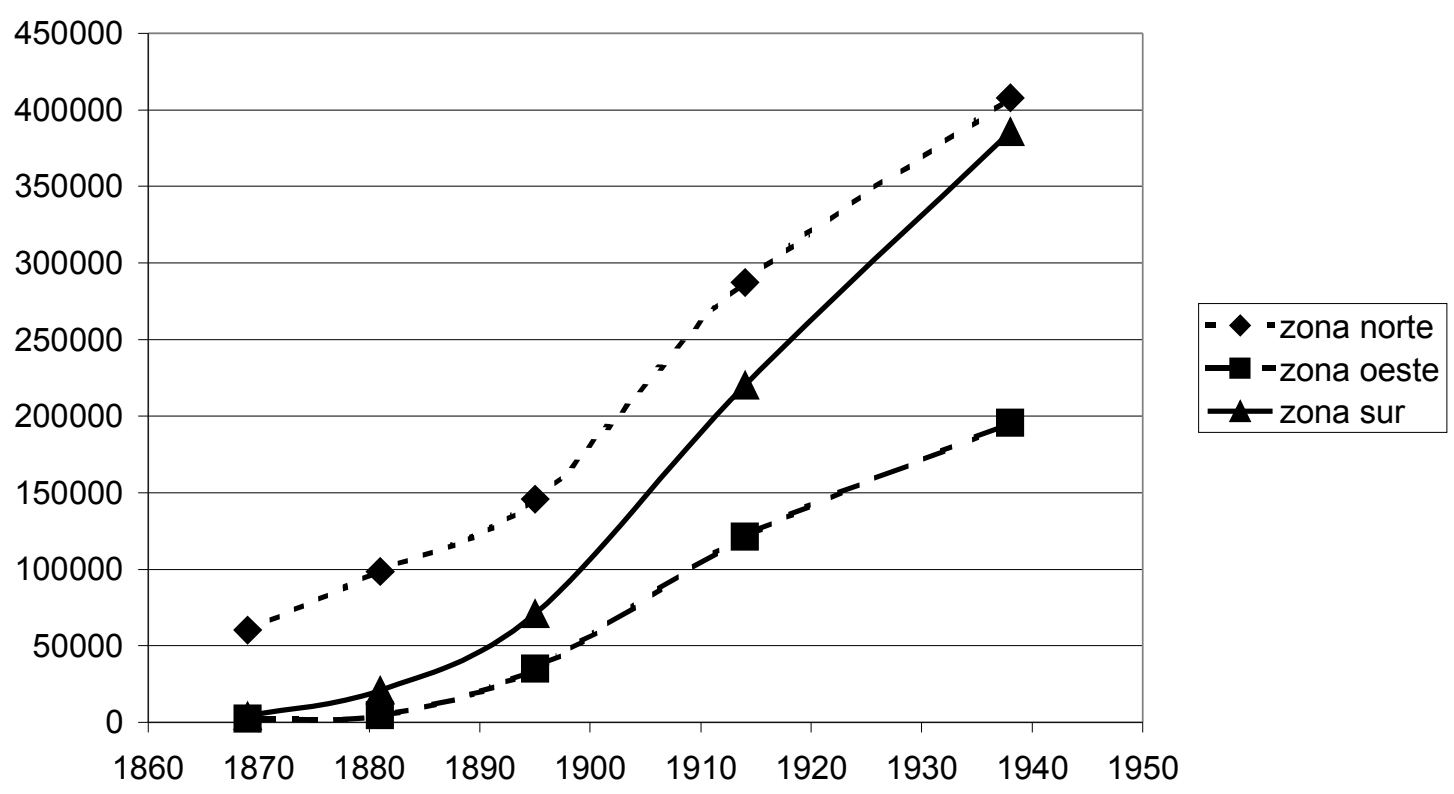

Fuentes: Censos 1869, 1881, 1895, 1914 y 1938 


\section{Cuadro 1.3}

Evolución de la población entre 1869 y 1938

\begin{tabular}{|l|r|r|r|r|r|}
\hline & $\mathbf{1 8 6 9}$ & $\mathbf{1 8 8 1}$ & $\mathbf{1 8 9 5}$ & $\mathbf{1 9 1 4}$ & $\mathbf{1 9 3 8}$ \\
\hline zona norte & 60235 & 98548 & 145686 & 287287 & 407706 \\
\hline zona oeste & 2250 & 4476 & 35147 & 121193 & 195564 \\
\hline zona sur & 4356 & 20848 & 70915 & 220278 & 385852 \\
\hline
\end{tabular}

Fuentes: Censos Nacionales de 1869, 1895 y 1914, y Censo de Población de la provincia de Buenos Aires, 1881 y 1938.

\section{Cuadro 1.4}

Tasas de crecimiento anual de la población entre 1869 y 1938

\begin{tabular}{|l|r|r|r|r|}
\hline & $\mathbf{1 8 6 9 - 1 8 8 1}$ & $\mathbf{1 8 8 1 - 1 8 9 5}$ & $\mathbf{1 8 9 5}-\mathbf{1 9 1 4}$ & $\mathbf{1 9 1 4 - 1 9 3 8}$ \\
\hline zona norte & $4.2 \%$ & $2.6 \%$ & $3.6 \%$ & $1.5 \%$ \\
\hline zona oeste & $5.9 \%$ & $14.7 \%$ & $6.7 \%$ & $2.1 \%$ \\
\hline zona sur & $13.9 \%$ & $8.5 \%$ & $6.1 \%$ & $2.5 \%$ \\
\hline
\end{tabular}

Fuente: Cálculos propios a partir de los datos del cuadro anterior.

La zona oeste estuvo bajo el dominio indígena prácticamente hasta fines de la década de 1860. En los años setenta se avanzó con la fundación de fortines y la construcción de la "zanja de Alsina", que pasaba por Trenque Lauquen, englobando entonces a la mayor parte de esta zona dentro de la frontera (ver Mapa 4). Lo cierto es que recién a partir de 1879 esta área quedó completamente bajo el dominio blanco. Si bien algunos caseríos se establecieron en esos años (Lincoln en 1876), la mayoría de los pueblos (hoy cabeceras de los partidos de la zona) se fundaron entre 1888 y 1905. El censo de 1881 tan sólo registró unos 4.500 habitantes en esta zona, pero ya en 1895 residían 35.000 personas: un crecimiento del orden del 15\% anual entre estas dos fechas (ver Cuadros 1.3 y 1.4, y Gráfico 1.1). En los años noventa se tendieron las primeras líneas férreas: el ferrocarril llegó a Trenque Lauquen en 1890 y, otra línea, arribó en 1896 a General Villegas.

Debido a esta incorporación tardía, se observa que al momento de realizarse el censo de 1881 esta zona casi no había entrado en producción. Para 1895 nos 
encontramos con un incipiente desarrollo de la ganadería lanar y vacuna, pero la agricultura no alcanzaba a representar el $2 \%$ de la superficie de la zona oeste. Pero, a partir de esos años, en esta zona se desarrolló la invernada de vacunos, para producir carne de exportación, en campos alfalfados luego de su preparación con el previo cultivo de trigo y lino en los dos años anteriores. Para lo cual se desarrollo un sistema de mediería trianual, ya muy comentado en la bibliografía especializada (ver, por ejemplo Giberti, 1981: 181-186 o Adelman, 1989: 113-118). La expansión de este sistema, desalentó la colonización, porque los terratenientes estaban interesados en mantener sus estancias para la ganadería refinada ${ }^{14}$. Como se observa en el Cuadro 1.1, para 1908, los campos alfalfados representaban el 18\% de la superficie de la zona, y según los datos de 1914, los cereales y el lino ocupaban el 16\% del área, y otro 5\% estaba cultivado con plantas forrajeras anuales, que también eran en muchos casos cosechadas luego del pastoreo invernal (avena, cebada y centeno). Para 1937, la superficie agrícola había aumentado levemente, mientras que las forrajeras anuales ahora detentaban el 10\% del área total y la alfalfa un 26\%. En esta zona predominaban las explotaciones ganaderas (controlaban el 66\% de la superficie censada en 1937), mientras que las unidades "mixtas" detentaban el 21\% y las "chacras" sólo el 13\% del área.

El crecimiento poblacional siguió siendo acelerado y para 1914 residían más de 120.000 personas en los partidos de esta zona. En el año 1938, había casi 200.000 habitantes (ver Cuadros 1.3 y 1.4, y Gráfico 1.1).

La zona sur fue una espacio en permanente disputa entre los indios y los criollos durante casi todo el siglo XIX, aunque ya en 1828 se había fundado el fuerte Protectora Argentina (hoy Bahía Blanca). Así, por ejemplo, el último malón indígena importante en la zona de Tres Arroyos tuvo lugar en marzo de 1876 (Eiras y Pérez Vassolo, 1981). En la porción occidental de esta zona, el avance de los ganaderos criollos fue más temprano, repartiéndose las tierras desde la década de 1820, primero, en enfiteusis y,

14 En estos partidos se concentraron 44 de los "centros agrícolas" aprobados hasta 1890 , destacándose el partido de Trenque Lauquen con 18 centros, donde todos resultaron "un verdadero fracaso" (Girbal, 1980: 153). 
luego vendiéndose (a partir de los años cincuenta). En cambio, en la porción oriental el dominio indígena perduró hasta la década de 1870, cuando se estableció una línea de fortificaciones y luego se los derrotó y exterminó en 1879.

$\mathrm{Si}$ bien algunos caseríos se habían ido desarrollando en torno a las fortificaciones, la mayoría de los pueblos de la zona sur (hoy cabeceras de los partidos) fueron fundados en la década de 1880. La escasa población presente en 1869 había crecido a una tasa anual del 14\% y para 1881 superaba los 20.000 habitantes. El crecimiento seguiría a tasas muy altas hasta 1914, cuando la población de la zona alcanzó los 220.000 habitantes (ver Cuadros 1.3 y 1.4, y Gráfico 1.1).

Durante las últimas décadas del siglo XIX, la zona asistió a un constante crecimiento productivo, basado en el lanar y el vacuno criados en pasturas naturales. Este desarrollo se vio facilitado por la instalación de ferrocarriles y puertos: la línea Buenos Aires-Bahía Blanca se inauguró en 1884 (en 1886 llegó a Tres Arroyos); una serie de puertos se desarrollaron desde 1885 en la zona de Bahía Blanca, y en 1926 se terminó otro importante puerto en Quequén.

El desarrollo de la agricultura se dio en esta área de modo más tardío que en el norte bonaerense o en la provincia de Santa $\mathrm{Fe}^{15}$. Como se observa en el Cuadro 1.1, en 1895 sólo estaba sembrado el 1\% de la superficie total de la zona sur. En cambio, en 1908 se destinaba a la agricultura el 14\% y en 1914 el 19\%. Pero sobre todo durante los años veinte la agricultura se constituyó en la principal actividad de la zona, destacándose el trigo, pero también la avena (una planta de doble propósito, ya que se la pastoreaba en invierno y cosechaba en verano). Seguían en importancia el lino, la cebada y el centeno, mientras que ni el maíz ni la alfalfa tuvieron relevancia en la zona. Para 1937, un tercio de la superficie de la zona se dedicaba al trigo y un 16\% a las plantas de doble propósito (avena, cebada y centeno). Dentro de la ganadería, los vacunos habían desplazado a un segundo lugar a los ovinos, aunque éstos seguían siendo importantes (a diferencia de las otras dos zonas estudiadas, donde se habían reducido a un lugar muy marginal para 1937). Para entonces el tipo de explotación predominante en esta zona eran las unidades "mixtas", que controlaban el 52\% de la

15 También en esta zona proliferaron las solicitudes y las concesiones de "centros agrícolas" (44 para 1890), aunque en su enorme mayoría no se constituyeron como tales (Girbal, 1980). 
superficie, mientras que los establecimientos ganaderos detentaban el 30\% y las "chacras", el 18\% (ver Cuadro 1.2).

\section{La estructura de la propiedad o el estigma del latifundio}

\subsection{La concentración originaria}

Como decíamos en la introducción a este capítulo, un rasgo básico del desarrollo agrario pampeano fue el reparto altamente concentrado de la tierra. Sin entrar en la polémica sobre la distribución de la tierra durante el período colonial, e incluso aceptando que en las zonas de vieja colonización habría habido una progresiva reducción del tamaño medio de las explotaciones durante el siglo XVIII (Barsky y Gelman, 2001: 123), para fines del siglo XIX la concentración de la propiedad era indudablemente muy elevada ${ }^{16}$. Así, incluso en una zona de antiguo poblamiento como el partido de Baradero (en el norte bonaerense) hacia 1890 el 74\% de la superficie estaba en propiedades de más de 1.000 hectáreas, y un $24 \%$ en latifundios de más de 5.000 hectáreas (Cortés Conde, 1979: 114).

Casi toda la zona oeste fue vendida entre 1881 y 1884 , en lotes de 40.000 hectáreas en la mayoría de los casos (Gaignard, 1989: 258-259). Pero incluso, con anterioridad, en 1879 en el partido de Lincoln fueron vendidas 119.900 hectáreas, a un promedio de 7.053 hectáreas cada propietario. La concentración continuó siendo increíblemente alta luego del reparto inicial: en 1890 el 96\% del partido de General Villegas estaba en propiedades de más de 5.000 hectáreas, e incluso un 34\% en latifundios de más de 20.000 hectáreas cada uno (Cortés Conde, 1979: 114).

En cuanto a la zona sur, su parte occidental se había cedido en enfiteusis en enormes lotes; por ejemplo, en el caso de la mayor parte de Tres Arroyos, los lotes eran de 30.000 hectáreas cada uno (Eiras y Pérez Vassolo, 1981), y luego se realizaron arriendos y ventas en escalas tan sólo algo menores. En el trabajo de Barba (1976) se

16 Probablemente, no sólo por las políticas de tierras desarrolladas antes de mediados del siglo XIX, sino también por las distribuciones posteriores. Así, por ejemplo, las cesiones en arriendo por la ley de 1857 fueron en Junín, Chacabuco, Rojas y Pergamino de unas 8.560 hectáreas de promedio (Gaignard, 1989: 115). 
confirma el patrón altamente concentrado de la distribución de la propiedad en el sur bonanerense tanto en los años sesenta, como con las posteriores ventas realizadas a través de la ley de tierras de $1878^{17}$. Según nuestros cálculos realizados en base al Registro Gráfico de 1890, el $82 \%$ del partido de Tres Arroyos se concentraba en propiedades de más de 5.000 hectáreas (las mayores de 20.000 detentaban un $21 \%$ del total).

La parte occidental de la zona sur, fue vendida entre 1881 y 1884 , en lotes incluso mayores a lo observado en la parte oriental. Entre los compradores se destaca Eduardo Casey y Cía. con 275.000 hectáreas en la zona de Sierra de la Ventana, pero también otros seis propietarios con campos entre 30.000 y 85.000 hectáreas cada uno. De la observación del mapa elaborado por Gaignard (1989: 256-257) queda claro que casi la totalidad de esta parte oriental de la zona sur estaba, para 1890, repartida en propiedades de más de 15.000 hectáreas.

Si éste había sido el patrón para 1890, la duda que queda es hasta qué punto se mantuvo cuando tuvo lugar el intenso desarrollo de la agricultura. En el siguiente apartado intentaremos resolver este interrogante.

\subsection{La situación a mediados de los años veinte y su evolución hasta fines de la década del treinta}

Hemos analizado en los tres partidos seleccionados el peso de todas las grandes propiedades para mediados de los años veinte, a partir de los mapas catastrales elaborados por la Dirección de Geodesia, Catastro y Mapas (Ministerio de Obras y

17 Barba (1976: 37) ha encontrado que para 1864, en los actuales partidos de Necochea, Benito Juárez, San Cayetano, Tres Arroyos, Gonzáles Chaves, Coronel Rosales y Coronel Dorrego, estaban ocupadas 1.108,3 leguas repartidas entre 134 propietarios, siendo el promedio por propietario de 8,02 leguas (20.050 hectáreas). Algunos terratenientes llegaron a acumular extensiones aún mayores, con 30.000 y hasta 100.000 hectáreas. Unos años más tarde, luego de la derogación de la ley de tierras de 1876 (que buscaba fomentar la pequeña y mediana propiedad), y sancionada la de 1878 , se vendieron 836.107 hectáreas de los partidos de Tres Arroyos (que incluía también los actuales partidos de Coronel Suárez, Coronel Pringles y Coronel Dorrego) y de Bahía Blanca (que abarcaba a los actuales Coronel Rosales y Tornquist), al tiempo que estaban en liquidación otras 89.050 y en tramitación 171.625, haciendo un total de 1.096782 hectáreas en manos de tan sólo 152 compradores, es decir con un tamaño medio de 7.216 hectáreas cada uno (Barba, 1976: 51). 
Servicios Públicos de la provincia). Para Pergamino registramos todas las propiedades de más de 1.500 hectáreas y para Rivadavia y Tres Arroyos, todas las mayores a 2.500 hectáreas. Luego, estudiamos las transformaciones que sufrieron esas propiedades durante la segunda mitad de la década del veinte y los años treinta, cotejando con el Plano Catastral de 1939. Por último, a partir de una muestra de las propiedades de menor tamaño (ya comentada en la Introducción), hemos estimado el peso de los distintos estratos de propiedades para esta última fecha.

Encontramos que para 1924, en Pergamino (el partido escogido para representar a la zona norte) las grandes propiedades ya no tenían un peso tan determinante. Las propiedades de más de 2.500 hectáreas constituían el 30\% del partido, y las de $1.500 \mathrm{a}$ 2.500 hectáreas sumaban un 7\% más. Alrededor del $62 \%$ de Pergamino estaba distribuida en propiedades de menos de 1.500 hectáreas ${ }^{18}$.

Durante el resto de la década del veinte y la siguiente, estas grandes propiedades no sufrieron subdivisiones importantes, en el sentido de que pudieran inferirse procesos de venta a los pequeños medieros o arrendatarios. En general, las subdivisiones parecen deberse a la transmisión hereditaria, según surge del mero análisis de los apellidos consignados en el Mapa Catastral de 1939 y del tamaño de los nuevos predios. Cotejando ambas fuentes, observamos que de las cinco propiedades que en 1924 tenían más de 5.000 hectáreas, dos se mantuvieron inalteradas durante estos 15 años, y las tres restantes se subdividieron en grandes $\operatorname{parcelas}^{19}$.

18 De todos modos, la tierra estaba más concentrada que lo que encontró Cortés Conde en Baradero (otro partido de la zona norte). Según sus análisis, para 1920 sólo el 16\% de la superficie de Baradero se concentraba en propiedades de más de 1.000 hectáreas (Cortés Conde, 1979: 114). En cambio, Barsky y Pucciarelli (1991: Cuadro 18) hallaron que en Ramallo (partido por ellos escogido para representar a la zona norte bonaerense) las propiedades de más de 500 hectáreas (es decir, unidades que podrían ser grandes explotaciones agrícolas) concentraban el $74 \%$ de la superficie del partido, incluso las mayores de 1.000 hectáreas detentaban el 61\% del área (estudio realizado en base a la Guía Edelberg de 1923). Se destacaba el intervalo de 2.500 a 5.000 hectáreas, porque estos latifundios tenían el 34\% del partido de Ramallo.

19 Una en cuatro propiedades (con un tamaño medio de 3.420 hectáreas cada una), otra en seis (de un promedio de 864 hectáreas) y la tercera en 17 unidades, de las cuales alrededor de una decena mantienen el mismo apellido del titular en 1924. 
En el caso de las nueve propiedades que en 1924 tenían entre 2500 y 5.000 hectáreas, sólo dos permanecieron inalteradas, mientras que del resto, sólo una se había fraccionado en pequeños lotes ${ }^{20}$. Por su parte, de las diez propiedades que en 1924 tenían entre 1500 y 2.500 hectáreas, nueve permanecieron iguales y sólo una se había subdividido entre cinco herederos y ocho muy pequeños lotes.

En síntesis, como podemos ver el Cuadro 1.5, entre 1923 y 1939 tan sólo tuvo lugar un pequeño proceso de subdivisión de las unidades mayores a 2.500 hectáreas (que perdieron unas 30.800 hectáreas), pero dirigido fundamentalmente hacia las de 1.500 a 2.500 hectáreas (que incorporaron unas 23.200 hectáreas).

\section{Cuadro 1.5.}

Pergamino. Distribución de la propiedad de la tierra, 1923 y 1939

\begin{tabular}{|l|r|r|r|r|}
\hline & \multicolumn{2}{|c|}{1923} & \multicolumn{2}{|c|}{1939} \\
\hline Tamaño (ha.) & Hectáreas & & Hectáreas & \\
\hline menos 1500 & 168766 & $62.4 \%$ & 176381 & $65.3 \%$ \\
\hline $\mathbf{1 5 0 0 - 2 5 0 0}$ & 20034 & $7.4 \%$ & 43246 & $16.0 \%$ \\
\hline $\mathbf{2 5 0 0 - 5 0 0 0}$ & 30847 & $11.4 \%$ & 18480 & $6.8 \%$ \\
\hline $\mathbf{5 0 0 0 - 1 0 0 0 0}$ & 18672 & $6.9 \%$ & 13933 & $5.2 \%$ \\
\hline $\mathbf{1 0 0 0 0}$ y & 31969 & $11.8 \%$ & 18247 & $6.8 \%$ \\
\hline & 270300 & $100 \%$ & 270300 & $100 \%$ \\
\hline
\end{tabular}

Fuente: Cálculos propios a partir del Mapa Catastral de Pergamino (1923) y el Plano Catastral (1939), elaborados por la Dirección de Geodesia, Catastro y Mapas de la provincia de Buenos Aires.

Esta relativa descentralización (y la propia situación de 1923) no debe interpretarse como el predominio de las pequeñas propiedades. Podría resumirse la distribución diciendo que tanto las propiedades menores a 200 hectáreas, como las de 200 a 1.000 y las de 1.000 a 2.500 , controlaban un $27 \%$ cada una, mientras que las superiores a esta última escala poseían el 19\% restante (ver Cuadro 1.6). Es, pues, una

20 Una había pasado a estar en propiedad del Banco Hipotecario Franco Argentino), tres se habían fraccionado por herencia en tres, cuatro y seis lotes (de un tamaño medio de 1.181, 750 y 442 hectáreas, respectivamente), otras tres se habían fraccionado en una combinación de propiedades medianas o grandes (en general manteniendo el apellido original) y de pequeñas, y una última propiedad había sido fraccionada por el Banco Hipotecario Nacional en 130 lotes de 55 hectáreas cada uno, algunos de los cuales ya tenían propietario en 1939 (que poseían uno, dos y, en algunos casos, tres o cuatro de estos lotes). 
concentración mucho más intensa que la dispersión existente en las unidades de producción $^{21}$.

\section{Cuadro 1.6.}

Propiedades, porcentaje de la superficie total ocupado según estratos de tamaño, 1939.

\begin{tabular}{|l|c|c|c|}
\hline Tamaño (ha.) & Pergamino & Rivadavia & Tres Arroyos \\
\hline menor a 100 & $16 \%$ & $2 \%$ & $2 \%$ \\
\hline $100-200$ & $11 \%$ & $9 \%$ & $4 \%$ \\
\hline $200-500$ & $16 \%$ & $3 \%$ & $19 \%$ \\
\hline $500-1000$ & $11 \%$ & $11 \%$ & $14 \%$ \\
\hline $1000-2500$ & $27 \%$ & $27 \%$ & $32 \%$ \\
\hline $2500-5000$ & $7 \%$ & $12 \%$ & $12 \%$ \\
\hline mayor a 5000 & $12 \%$ & $36 \%$ & $17 \%$ \\
\hline
\end{tabular}

Fuente: estimaciones propias elaboradas en base a los Planos Catastrales de 1939.

21 Como veremos en el siguiente apartado, más del 90\% de las explotaciones de Pergamino tenían, en 1937, menos de 200 hectáreas de extensión. Incluso, considerando, no el número, sino la superficie que ocupaban, estas unidades daban cuenta del 67\% de la extensión total del partido. En cambio, según nuestro análisis basado en el Mapa Catastral de 1937/39 (Cuadro 1.6), las propiedades menores a 200 hectáreas sólo detentaban el 27\% del partido de Pergamino, mientras que las mayores a 500 hectáreas concentraban el $57 \%$ de la superficie del partido. Incluso, si nos limitamos a las propiedades de más de 1.000 hectáreas, éstas detentaban el 46\% del área total. 
La zona oeste, representada por el partido de Rivadavia, continuó con una estructura de propiedad de altísima concentración ${ }^{22}$. Para el año 1923, según nuestro análisis en base al mapa catastral de la Dirección de Geodesia de la provincia, las unidades de más de 5.000 hectáreas concentraban el 45\% de la superficie del partido de Rivadavia, y otro $10 \%$ estaba en manos de propiedades de 2.500 a 5.000 hectáreas (ver Cuadro 1.7$)^{23}$.

Entre 1923 y 1939, casi no existieron procesos de fraccionamiento de las grandes propiedades en Rivadavia, detectándose sólo algunas divisiones hereditarias ${ }^{24}$. Sólo tuvo lugar el fraccionamiento de unidades muy grandes (mayores a 10.000 hectáreas), que perdieron unas 35.000 hectáreas (el $35 \%$ de la superficie que controlaban), en favor del estrato de propiedades menores a las 2.500 hectáreas, y en menor medida de las de 2.500 a 5.000 hectáreas. Pero estas modificaciones sólo afectaron al 9\% de la superficie total del partido de Rivadavia.

${ }^{22}$ Incluso Cortés Conde reconoce esta situación en la zona oeste, al comentar que en 1920 un 53\% del partido de General Villegas se encontraba en latifundios de más de 5.000 hectáreas; y destacamos nosotros que, según sus datos, el $84 \%$ de la superficie estaba en propiedades de más de 1.000 hectáreas (Cortés Conde, 1979: 114).

23 Las cifras coinciden parcialmente con el estudio que también para Rivadavia realizaron Barsky y Pucciarelli en base a la Guía Edelberg del mismo año 1923. Ellos encontraron que el $54 \%$ del área estaba ocupada por propiedades de más de 5.000 hectáreas. Además, calcularon que las propiedades de más de 1.000 hectáreas tenían el 84\% del partido (Barsky y Pucciarelli, 1991: Cuadro 16).

${ }^{24}$ Así, de las siete propiedades de más de 10.000, tres se mantuvieron inalteradas, dos tan sólo fraccionaron una parte muy pequeña de su superficie total (en dos y ocho lotes de $500 \mathrm{y}$ de 100 a 300 hectáreas, respectivamente), y los dos restantes se dividieron por herencia en dos y cuatro grandes propiedades. En el caso de las diez unidades de 5.000 a 10.000 hectáreas presentes en 1923, cinco se mantuvieron sin cambios, cuatro se dividieron en grandes lotes por herencia (en dos, tres, cuatro y ocho propiedades) y solo la restante aparece en 1939 a nombre del Banco de la Nación Argentina, dividido en lotes de 50 a 100 hectáreas cada uno, pero todavía sin haber sido transferidos. Por último, ocho de las diez propiedades que en 1923 tenían entre 2.500 y 5.000 hectáreas no sufrieron cambios durante estos años, mientras que las dos restantes se fraccionaron por herencia en tres lotes cada una. 


\section{Cuadro 1.7}

Rivadavia. Distribución de la propiedad de la tierra, 1923 y 1939

\begin{tabular}{|l|r|r|r|r|}
\hline & \multicolumn{2}{|c|}{1923} & \multicolumn{2}{|c|}{1939} \\
\hline Tamaño (ha.) & Hectáreas & & Hectáreas & \\
\hline menos 2500 & 179438 & $45.4 \%$ & 206345 & $52.2 \%$ \\
\hline $\mathbf{2 5 0 0 - 5 0 0 0}$ & 37407 & $9.5 \%$ & 48928 & $12.4 \%$ \\
\hline $\mathbf{5 0 0 0 - 1 0 0 0 0}$ & 76847 & $19.4 \%$ & 73505 & $18.6 \%$ \\
\hline $\mathbf{1 0 0 0 0}$ y + & 101808 & $25.7 \%$ & 66722 & $16.9 \%$ \\
\hline & 395500 & $100 \%$ & 395500 & $100 \%$ \\
\hline
\end{tabular}

Fuente: Cálculos propios a partir del Mapa Catastral de Rivadavia (1923) y el Plano Catastral (1939), elaborados por la Dirección de Geodesia, Catastro y Mapas de la provincia de Buenos Aires.

Por lo tanto, para 1939, Rivadavia se caracterizaba por continuar con el patrón altamente concentrado de la propiedad. Las propiedades de más de 2.000 hectáreas (que indudablemente serían grandes explotaciones ganaderas) concentraban el $72 \%$ de la superficie del partido ${ }^{25}$. Si incluimos a las propiedades menores (lo que hicimos a través de la muestra seleccionada) se observa que las propiedades con menos de 500 hectáreas sólo tenían el 14\% del partido, y las de 500 a 1.000, el 11\%. El grueso de la superficie ocupada por propiedades de menos de 2.500 hectáreas, estaba en lotes de 1.000 a 2.500 hectáreas (ver Cuadro 1.6).

En la zona sur la concentración continuaba siendo muy elevada en los años veinte. Según nuestras estimaciones, realizadas en base al mapa catastral de $1926^{26}$, las propiedades de más de 5.000 hectáreas poseían el 61\% de la superficie de $\underline{\text { Tres }}$ $\underline{\text { Arroyos }}^{27}$ (ver Cuadro 1.8).

Pero aquí, a diferencia de Rivadavia, sí tuvo lugar un importante proceso de fraccionamiento de estos grandes latifundios entre 1926 y 1939. Se dividieron las 13

25 Tres intervalos se destacaban: de 2.000 a 3.000 hectáreas (26\% del área), de 8.000 a 11.000 hectáreas $(17 \%)$ y de 13.000 a 16.000 hectáreas (14\%).

26 También contamos con un plano de propiedades de 1919: José Montano (agrimensor), "Plano del partido de Tres Arroyos".

27 Esta cifra es incluso más elevada que la que encontraron Barsky y Pucciarelli al analizar la Guía Edelberg de 1923 para Tres Arroyos. Para ellos, las propiedades con más de 5.000 hectáreas detentaban el $45 \%$ de la superficie del partido. Si agregamos a las mayores de 1.000 hectáreas, controlaban el 78\% (Barsky y Pucciarelli, 1991: Cuadro 17). 
propiedades que en 1926 tenían más de 10.000 hectáreas $^{28}$. En el caso de las 22 propiedades de 5.000 a 10.000 hectáreas, sólo dos permanecieron iguales, en tres casos hubo fraccionamiento hereditario en dos o cinco grandes lotes, pero en los 17 casos restantes tuvo lugar un intenso fraccionamiento ${ }^{29}$. Por último, entre las 25 propiedades que tenían entre 2.500 y 5.000 hectáreas en 1926, la mayoría sufrió un proceso de subdivisión ${ }^{30}$.

En síntesis, de las 59 propiedades de más de 2.500 hectáreas que había en 1926 en Tres Arroyos, surgieron 96 pequeños lotes (menores a 100 hectáreas), 445 propiedades de 100 a 500 hectáreas, 106 propiedades de 500 a 1.000, y 57 propiedades de 1.000 a 2.500 hectáreas. En términos de la distribución de la superficie, esto significó que de las 460.000 hectáreas que las propiedades mayores a 2.500 hectáreas tenían en 1926, unas 257.000 (el 56\%) pasaron a formar parte de los estratos de propiedades menores a las 2.500 hectáreas (ver Cuadro 1.8$)^{31}$.

\section{Cuadro 1.8}

Tres Arroyos. Distribución de la propiedad de la tierra, 1923 y 1939

\begin{tabular}{|l|l|l|}
\hline & 1926 & 1939 \\
\hline
\end{tabular}

28 Una quedó en manos de dos bancos; siete se fraccionaron, manteniendo, por un lado, una o, a veces, dos grandes propiedades (mayores a las 5.000 hectáreas) y, por otro lado, generando un conjunto de tres a nueve propiedades de un tamaño en torno a las 600 hectáreas (en un caso dio lugar a 28 propiedades); en las cinco grandes propiedades restantes, el fraccionamiento fue muy intenso, surgiendo entre 17 y 51 propiedades, con tamaños medios de 355 a 871 hectáreas.

En Alvarez y Zeberio (1991: 81) se describe la liquidación de dos grandes latifundios, el de María Bellocq de 21.390 hectáreas y el de Alfredo Wolfradt de más de 20.000, y la constitución de empresas locales de venta de tierras en Tres Arroyos y Necochea.

29 En dos de estos casos, perduró una propiedad de más de 1.500 hectáreas, pero en el resto el fraccionamiento fue total, con propiedades de un tamaño de entre 300 y 600 hectáreas de promedio.

30 Seis se mantuvieron inalteradas, tres se fraccionaron en tres o cuatro lotes, seis en seis a nueve lotes cada una, y diez se dividieron generando de diez a 18 lotes cada una. En general estos lotes surgidos del fraccionamiento tenían un tamaño de 250 a 380 hectáreas.

31 Una desconcentración similar ocurrió en estas décadas en el partido de Saavedra, según el estudio de Bardomás (1994: 62-82). A partir del análisis de la Guía Edelberg, esta autora encuentra que en 1921 el 57\% de la superficie del partido estaba en manos de propiedades de más de 2.500 hectáreas, y que para 1939 (según el mapa catastral) este porcentaje se había reducido al 31\% (cifra, esta última, muy similar a la proporción que esta escala de propiedades tenía entonces en Tres Arroyos, según nuestro cálculos). 


\begin{tabular}{|l|r|r|r|r|}
\hline Tamaño & Hectáreas & & Hectáreas & \\
\hline menos 2500 & 159060 & $25.9 \%$ & 436770 & $71.1 \%$ \\
\hline $\mathbf{2 5 0 0 - 5 0 0 0}$ & 80862 & $13.2 \%$ & 70440 & $11.5 \%$ \\
\hline $\mathbf{5 0 0 0 - 1 0 0 0 0}$ & 154247 & $25.1 \%$ & 85447 & $13.9 \%$ \\
\hline $\mathbf{1 0 0 0 0}$ y + & 219831 & $35.8 \%$ & 21343 & $3.5 \%$ \\
\hline & 614000 & $100 \%$ & 614000 & $100 \%$ \\
\hline
\end{tabular}

Fuente: Cálculos propios a partir del Mapa Catastral de Rivadavia (1923) y el Plano Catastral (1939), elaborados por la Dirección de Geodesia, Catastro y Mapas de la provincia de Buenos Aires.

Como resultado de este importante fraccionamiento, la distribución de la propiedad se modificó sustancialmente en Tres Arroyos: para 1939 las mayores de 5.000 hectáreas sólo detentaban el 17\% del partido, aunque las mayores a 1.000 tenían el $61 \%$. Sin embargo, esto no significa que predominaran las pequeñas propiedades, sino las grandes; pero no las muy grandes, como ocurría hasta comienzos de los años veinte. En todo caso, si consideramos que por encima de las 1.000 hectáreas nos encontrábamos con grandes explotaciones (ya que en este partido predominaban las unidades "mixtas") podemos afirmar que las grandes propiedades continuaban detentando la mayor parte de la superficie de Tres Arroyos (Cuadro 1.6). Más específicamente, se destaca la concentración entre las 1.700 y las 2.600 hectáreas (44\% del área).

Del examen de la distribución de la propiedad hacia 1939 podemos concluir que el grado de concentración era muy superior en la zona oeste. Sin embargo, este fenómeno, no debe oscurecer la percepción de que los niveles de concentración eran también muy elevados en las otras dos zonas. Para tener un parámetro de comparación internacional, podemos considerar la situación en el Midwest norteamericano, otra región agrícola que había entrado en producción especialmente en la segunda mitad del siglo XIX (es decir, sin una tradición campesina previa, como el caso europeo, donde las dimensiones eran mucho menores ${ }^{32}$ ). Lo que observamos en el Midwest es que era

32 Según los datos consignados en Kautsky (1899), el tamaño medio de las todas las fincas agropecuarias en Francia en 1892 era de 9 hectáreas, y en 1895 el promedio en Alemania era de 7 hectáreas, y en Gran Bretaña de 25 hectáreas. 
muy reducido el peso de las grandes propiedades. Por ejemplo, en 1946, en la región denominada "North Central"33 (una amplia región que incluye las zonas especializadas en el cultivo del maíz y del trigo, y actividades ganaderas diversas) las propiedades con más de 1.012 hectáreas (2.500 acres) detentaban sólo el 11\% de la superficie (Inman y Fippen, 1949: 20). En cambio, en Pergamino las propiedades de más de 1.000 hectáreas controlaban el 46\% del partido, en Tres Arroyos, el 61\% y en Rivadavia, el 75\%. Si incluimos a las propiedades de más de 405 hectáreas (1.000 acres) las diferencias son aun mayores: mientras que en la North Central Region esta escala de propiedades ocupaba el 20\% el área, tenían el 59\% de Pergamino, el 78\% de Tres Arroyos y el 88\% de Rivadavia.

Por último, quisiéramos agregar que en las tres zonas bonaerenses estudiadas, si bien las propiedades de 1.000 a 2.500 hectáreas podrían no ser consideradas como latifundios, alrededor de la mitad de estos predios estarían en manos de grupos familiares que concentraban enormes extensiones cada uno (más de 10.000 hectáreas), o de entidades financieras. Para llegar a esta estimación hemos trabajado con los listados de familias terratenientes elaborados por Harispuru (1986) en base a la Guía Edelberg y otras fuentes. A fin de no extender más el texto con estas cuestiones, hemos consignado en el Apéndice 1 (Apartado 2), el análisis detallado de la pertenencia a estas familias o a entidades de las propiedades de más de 1.000 hectáreas en Tres Arroyos y Rivadavia, y de más de 500 hectáreas en el caso de Pergamino.

Hasta aquí abordamos la estructura de la propiedad, en el siguiente apartado analizaremos el tamaño de las unidades de producción y sus formas de tenencia del suelo, y de qué modo se articulaban con esta concentrada distribución de la propiedad de la tierra.

33 La North Central Region incluye los estados de Illinois, Indiana, Iowa, Kansas, Michigan, Minnesota, Missouri, Nebraska, North Dakota, Ohio, South Dakota y Wisconsin (Inman y Fippin, 1949) 


\section{La estructura productiva}

\section{1. El tamaño de las unidades de producción}

Tal vez por el contraste con la fuerte presencia de propiedades de inmensas dimensiones, en la literatura especializada existió cierta tendencia a sostener que la mayoría de las explotaciones pampeanas eran de extensión pequeña, y que se yuxtaponían con algunas grandes estancias. Sin embargo, realizando una comparación con regiones de similar producción en el mundo, se observa que los establecimientos pampeanos presentaban tamaños muy considerables.

En realidad, parte de la controversia surge de observar dos indicadores diferentes para medir la importancia de las explotaciones de diversos tamaños: el peso numérico y la significación territorial de cada escala de tamaño. En este sentido, cada variable da cuenta de cuestiones distintas. Si la cantidad de explotaciones puede permitir inferencias sobre la importancia social de los distintos tipos de productores, la superficie que ocupaban nos brinda información sobre la significación productiva de cada tipo de unidades productivas (de un modo por cierto indirecto, pero único, a falta de otra medición publicada).

Por otro lado, un análisis que discrimine subregiones permite descubrir que, parte de las opiniones encontradas, surge de considerar espacios geográficos distintos, pues, como veremos, el tamaño de las explotaciones típicas (especialmente según su significación territorial) era muy diferente según las zonas analizadas.

En primer lugar, observamos que en la zona norte, el predominio numérico de las explotaciones de menos de 100 hectáreas, era abrumador (76\% de las unidades), pero también eran importantes en la zona oeste (52\%). En cambio, en la zona sur sólo algo más de un cuarto de las explotaciones tenían menos de 100 hectáreas. En esta zona se destacaban las unidades de 200 a 1.250 hectáreas que constituían la mitad de las unidades productivas. En las tres zonas las explotaciones de más de 1.250 hectáreas eran numéricamente escasas, tal como podemos ver en el Cuadro 1.9.

Cuadro 1.9. Distribución porcentual de las explotaciones según tamaño, 1937. 


\begin{tabular}{|l|c|c|c|c|c|c|c|}
\hline & $\begin{array}{c}\text { menos 25 } \\
\text { ha. }\end{array}$ & $\mathbf{2 5 / 1 0 0}$ & $\mathbf{1 0 0 / 2 0 0}$ & $\mathbf{2 0 0 / 3 0 0}$ & $\mathbf{3 0 0 / 6 2 5}$ & $\mathbf{6 2 5 / 1 2 5 0}$ & $\begin{array}{c}\text { más de } \\
\mathbf{1 2 5 0} \text { ha. }\end{array}$ \\
\hline zona norte & $26 \%$ & $50 \%$ & $17 \%$ & $3 \%$ & $2 \%$ & $1 \%$ & $0,5 \%$ \\
zona oeste & $20 \%$ & $32 \%$ & $20 \%$ & $10 \%$ & $9 \%$ & $5 \%$ & $3 \%$ \\
zona sur & $12 \%$ & $17 \%$ & $20 \%$ & $15 \%$ & $23 \%$ & $11 \%$ & $2 \%$ \\
\hline
\end{tabular}

Fuente: Estimaciones propias en base a los datos por partido del Censo Agropecuario de 1937.

Sin embargo, si dejamos de lado la cantidad de explotaciones y consideramos la superficie que ocupaban los diferentes estratos, resulta claro que cada zona se caracterizaba por la preeminencia de un tamaño de explotación. Tal como podemos observar en el Cuadro 1.10., las explotaciones de 25 a 200 hectáreas predominaban claramente en la zona norte ( $54 \%$ de la superficie censada), las unidades de 300 a 1.250 hectáreas caracterizaban a la zona sur (52\% de la superficie) y los establecimientos de más de 2.500 hectáreas se destacaban en la zona oeste $(41 \% \text { de la superficie })^{34}$. Pero, además, debemos señalar el hecho de que las explotaciones de 300 a 1.250 hectáreas también ocupaban un lugar destacado en las zonas Norte y Oeste.

De todos modos no debemos considerar que las unidades de la zona norte eran tan pequeñas, ya que el tamaño medio de las explotaciones de esta zona casi duplicaba al de las unidades del Corn Belt norteamericano ${ }^{35}$. Ya Taylor (1948: 6-7 y 226-227) destacaba que las explotaciones de la pampa maicera, en arriendo de 150 a 300 acres

34 El tamaño promedio de las explotaciones nos brinda una primera visión de similitudes y diferencias entre las tres zonas: en la zona norte era de 99 hectáreas, en la zona oeste de 333 hectáreas y en la zona sur de 365 hectáreas. Si excluimos a las unidades de menos de 25 hectáreas, para reducir la incidencia de las explotaciones más pequeñas (cuya orientación productiva muchas veces era la producción hortícola para el mercado local y que, además, pareciera que los censos las registraron con distinta exhaustividad) la explotación promedio de la zona norte era para entonces de 130 hectáreas, mientras que las de las zonas Oeste y Sur coincidían en 414 hectáreas.

35 Así, por ejemplo, en 1940 el tamaño medio de las explotaciones de la zona norte bonaerense era de 99 hectáreas, mientras que en Illinois (en el núcleo de la zona maicera norteamericana) era de 59 hectáreas (según los datos censales norteamericanos). 
(61 a 122 hectáreas) y con un tamaño medio de 260 acres, eran de "gran escala en comparación con las del Corn Belt norteamericano". También señalaba la diferencia con Iowa en la presencia de grandes estancias ganaderas -resabios de un período puramente ganadero- entre medio de los campos agrícolas (Taylor, 1948:6).

Cuadro 1.10. Distribución porcentual de la superficie censal según el tamaño de las explotaciones, 1937

\begin{tabular}{|l|c|c|c|c|c|c|c|c|c|}
\hline & $\begin{array}{c}\text { menos } \\
\mathbf{2 5} \text { ha. }\end{array}$ & $\mathbf{2 5 / 1 0 0}$ & $\begin{array}{c}\mathbf{1 0 0 / 2 0} \\
\mathbf{0}\end{array}$ & $\begin{array}{c}\mathbf{2 0 0 / 3 0} \\
\mathbf{0}\end{array}$ & $\begin{array}{c}\mathbf{3 0 0 / 6 2} \\
\mathbf{5}\end{array}$ & $\begin{array}{c}\mathbf{6 2 5} / \\
\mathbf{1 2 5 0}\end{array}$ & $\begin{array}{c}\mathbf{1 2 5 0} / \\
\mathbf{2 5 0 0}\end{array}$ & $\begin{array}{c}\mathbf{2 5 0 0 /} \\
\mathbf{5 0 0 0}\end{array}$ & $\begin{array}{c}\text { más de } \\
\mathbf{5 0 0 0} \\
\text { ha. }\end{array}$ \\
\hline zona norte & $3 \%$ & $30 \%$ & $24 \%$ & $7 \%$ & $9 \%$ & $8 \%$ & $5 \%$ & $6 \%$ & $9 \%$ \\
zona oeste & $1 \%$ & $6 \%$ & $9 \%$ & $7 \%$ & $13 \%$ & $14 \%$ & $8 \%$ & $12 \%$ & $29 \%$ \\
zona sur & $0,3 \%$ & $3 \%$ & $8 \%$ & $9 \%$ & $27 \%$ & $25 \%$ & $7 \%$ & $9 \%$ & $12 \%$ \\
\hline
\end{tabular}

Fuente: Estimaciones propias en base a los datos por partido del Censo Agropecuario de 1937.

\subsection{Formas de tenencia del suelo}

No existen controversias sobre la forma de tenencia del suelo que predominó en la etapa de la expansión agrícola: todos los autores destacan la importancia del arriendo y de la aparcería. Este fenómeno mantuvo su importancia hasta el momento del Censo de 1937, ya que la crisis de los años treinta significó un duro golpe a los intentos de acceder a la propiedad que habían intentado muchos arrendatarios a través del crédito hipotecario (Boglich, 1937; Barsky, 1988 y Balsa, 1994a). Ya en esos años, Cánepa (1940) afirmó que entre 1914 y 1937 no había tenido lugar una disminución del peso del arrendamiento en la región pampeana.

En nuestro análisis de las tres zonas seleccionadas hemos confirmado este predominio de las formas en no propiedad. A pesar de las notorias diferencias en el tamaño y en el uso del suelo que presentaban las tres zonas entre sí, la forma de 
tenencia de la tierra eran muy similar: los arrendatarios y aparceros constituían más de dos tercios de los productores (tal como podemos observar en el Cuadro 1.11). Sin embargo, cabe consignar que el porcentaje de unidades productivas a cargo de los dueños de la tierra no puede ser soslayado.

\section{Cuadro 1.11. Distribución porcentual de las explotaciones según formas de tenencia de la tierra, 1937}

\begin{tabular}{|l|c|c|c|}
\hline & Propietarios & $\begin{array}{c}\text { Arrendatarios y } \\
\text { aparceros }\end{array}$ & Otras formas \\
\hline zona norte & $28 \%$ & $68 \%$ & $3 \%$ \\
zona oeste & $32 \%$ & $65 \%$ & $3 \%$ \\
zona sur & $25 \%$ & $72 \%$ & $3 \%$ \\
\hline
\end{tabular}

Fuente: Estimaciones propias en base a los datos por partido del Censo Agropecuario de 1937.

Entonces, la situación de 1937 pareciera acercarse a la división -en teoría típica del desarrollo capitalista- entre propiedad de la tierra y producción. La mayor parte de las explotaciones se constituían sobre campos de propietarios total o predominantemente rentísticos.

\subsection{Estructura de producción y estructura de propiedad}

¿A quiénes arrendaban el campo los arrendatarios y aparceros? ¿hasta qué punto los terratenientes eran meros rentistas u organizaban la producción en forma directa? los interrogantes de mayor profundidad surgen en torno a la relación entre la estructura de la propiedad y la de las unidades de producción. Lamentablemente, ni los datos censales, ni los registros catastrales vinculan ambos tipos de unidades: los primeros sólo tratan de "explotaciones" (editadas de forma agregada y anónima) y los segundos de “parcelas" o "propiedades" (en este caso, consignándose el nombre de su dueño). 
Nos hemos propuesto, a partir de algunos supuestos, cruzar nuestro análisis de la estructura de la propiedad en tres partidos seleccionados (Pergamino de la zona norte, Rivadavia de la zona oeste y Tres Arroyos de la zona sur), con los datos censales sobre las unidades productivas presentes en los mismos. De este modo surgen "desfasajes" entre ambas estructuras, que establecen un piso (mínimo) de situaciones rentísticas ${ }^{36}$.

Encontramos que en los tres partidos estudiados, la propiedad de la tierra se encontraba más concentrada que la estructura productiva. Era en Pergamino donde la diferencia entre el tamaño de las propiedades y el de las explotaciones resultaba más profunda. Allí, las unidades productivas de más de 625 hectáreas ocupaban el 21\% de la superficie del partido, mientras que las propiedades de ese tamaño daban cuenta del $52 \%$ del área (ver Cuadro 1.12 y Gráfico 1.2). Entonces, podemos estimar que los grandes propietarios estarían cediendo dos tercios de la superficie que controlaban en Pergamino, manteniendo para en producción directa sólo el tercio restante ${ }^{37}$. Al mismo

36 Así, por ejemplo, si las propiedades de más de 5.000 hectáreas ocupaban, por poner un ejemplo, el 20\% de la superficie de un partido, y las unidades productivas de este tamaño sólo daban cuenta del $10 \%$, es posible estimar que la mitad de las grandes propiedades (o al menos de su área) estaban entregadas en arriendo a explotaciones de menor tamaño. En el otro extremo, si las propiedades de menos de 200 hectáreas poseían un 5\% del área y las explotaciones de este tamaño ocupaban un $15 \%$ de la misma, inferimos que al menos dos tercios de éstas últimas se realizaban bajo arriendo. Cabe aclarar que estos "desfasajes" esconden situaciones más complejas, por ejemplo, podían entregarse en arriendo campos enteros, y por lo tanto en un mismo estrato, sin que se lo pueda visualizar de este modo; o un gran campo podía entregarse parcialmente en arriendo, pero continuar una parte en producción en propiedad, consignándose en un estrato de explotaciones inferior. Es por ello que sólo se estima, de este modo, un mínimo de situaciones rentísticas. Las cesiones en arriendo de campos enteros no son determinadas con esta metodología porque no generan "desfasajes". Para subsanar esta falencia, hemos, por otra parte, estimado cuánto de la superficie en arriendo o aparcería era tomada de propiedades del mismo estrato que las explotaciones, y cuánto de propiedades de mayor tamaño. Para ello, hemos partido de la superficie que estimamos estaba en arriendo o aparcería y la confrontamos con el área "desfasada" entre los distintos estratos de propiedad y explotaciones. Como el Censo de 1937 no sólo no publicó el cruce entre tamaño y tenencia del suelo, sino que tampoco brindó cifras de la superficie ocupadas por las distintas formas de tenencia (tan sólo tenemos la cantidad de unidades por forma de tenencia, discriminadas por tipo de explotación), hemos tenido que estimar la superficie. Para ello, consideramos la relación cantidad y superficie por forma de tenencia que brindó el Censo de 1947. Más allá de las transformaciones que tuvieron lugar durante los diez años que separan ambos censos, podemos a través de la proyección de la relación cantidad/superficie, estimar la superficie ocupada por cada forma de tenencia en 1937. Para el caso de Tres Arroyos, podemos controlar esta relación con los datos de 1928, y pudimos observar que la estimación en base a los datos de 1947 no discrepa demasiado con los datos de 1928.

37 En realidad, podría también ocurrir que mantuvieran en propiedad fracciones de escalas menores, y en este caso el porcentaje en producción directa sería mayor. Sin embargo, 
tiempo, el desfasaje inverso, que aparece en los tamaños más pequeños, nos indica que los grandes propietarios entregaban en arriendo o aparcería sus campos a pequeños y medianos agricultores (de 25 a 200 hectáreas).

El análisis de los desfasajes nos permite realizar otra estimación sobre la relación entre arrendatarios y arrendadores. Como los desfasajes suman el $42 \%$ de la superficie del partido, mientras que la estimación de la superficie en arriendo o aparcería totalizaba el 56\%, podemos concluir que el 75\% de la superficie en arriendo o aparcería se ubicaba en campos fragmentados de grandes propietarios e incluso mediano-grandes (de más de 625 ha). El cuarto restante de la superficie en arriendo podría deberse a arriendos en dimensiones similares a las propiedades (ya sea pequeñas o medianas, eran pocas las grandes explotaciones en este partido).

también ocurría que cedían en arriendo campos completos, fenómeno que no podemos detectar con esta metodología de identificar "desfasajes". Suponiendo que ambos fenómenos se equiparasen en su importancia, las cifras anteriores serían buenos indicadores del peso de las conductas rentísticas de los propietarios de este partido. 


\section{Gráfico 1.2}

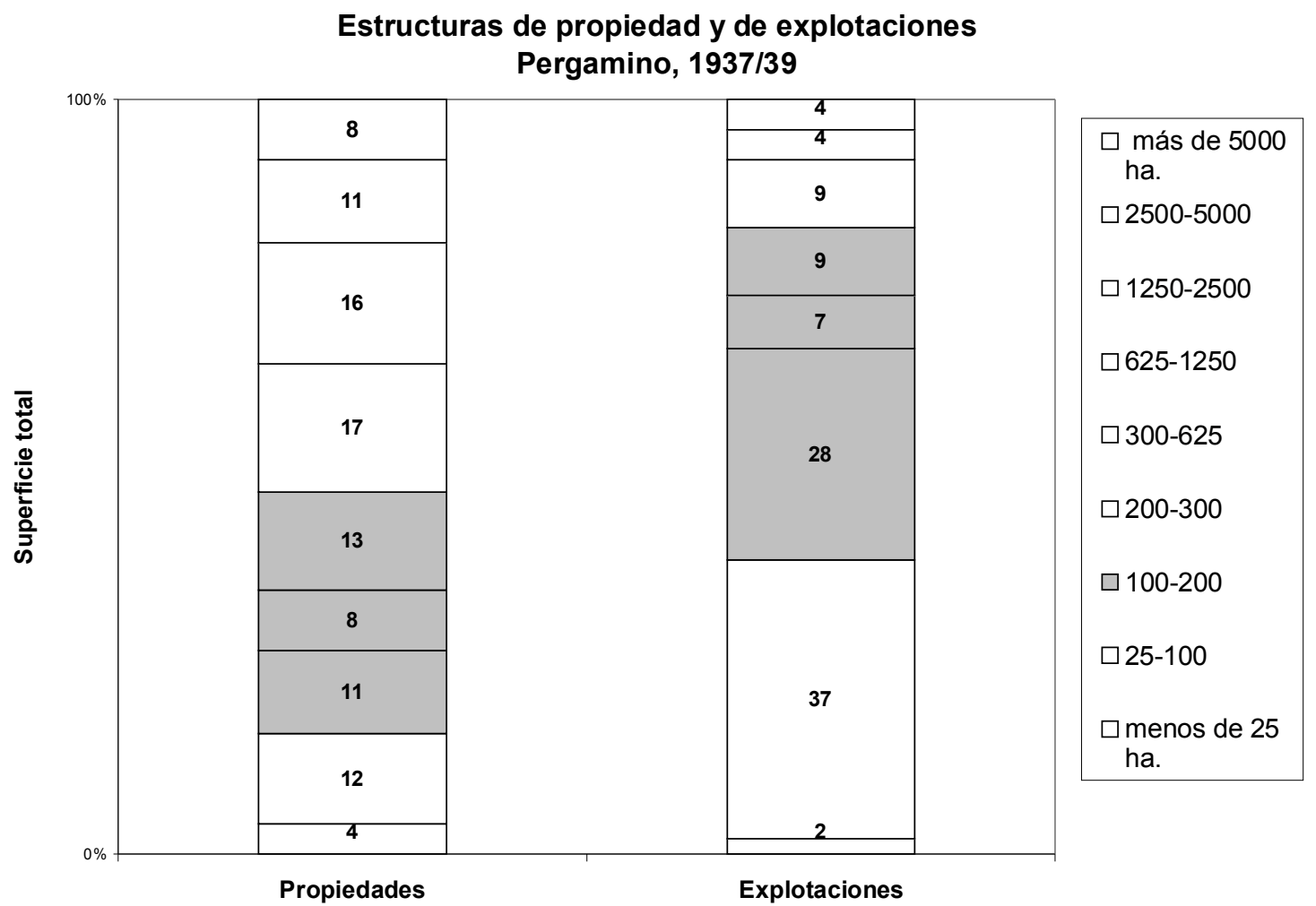

Fuentes: Para las unidades de producción, estimaciones propias en base a los datos por partido del Censo Agropecuario de 1937, y para las unidades de propiedad, estimaciones propias elaboradas según metodología explicitada en la Introducción .

\section{Cuadro 1.12. Estructura de propiedad y estructura productiva, Pergamino, 1937.}

Porcentajes del área total

\begin{tabular}{|l|l|l|l|l|l|}
\hline Extensión & $\begin{array}{l}\text { Unidades } \\
\text { de } \\
\text { propiedad }\end{array}$ & $\begin{array}{l}\text { Unidades } \\
\text { de } \\
\text { producción }\end{array}$ & $\begin{array}{l}\text { Tenencia } \\
\text { en } \\
\text { propiedad } \\
\text { (estimac.) }\end{array}$ & $\begin{array}{l}\text { "sobrante" } \\
\text { (estimac.) }\end{array}$ & $\begin{array}{l}\text { "faltante" } \\
\text { (estimac.) }\end{array}$ \\
\hline+5.000 ha & $8 \%$ & - & - & $8 \%$ & - \\
\hline 2.500 a 4.999 ha & $11 \%$ & $4 \%$ & $4 \%$ & $7 \%$ & - \\
\hline 1.250 a 2499 ha & $16 \%$ & $4 \%$ & $4 \%$ & $12 \%$ & - \\
\hline 625 a 1.250 ha & $17 \%$ & $9 \%$ & $9 \%$ & $8 \%$ & - \\
\hline 300 a 625 ha. & $13 \%$ & $9 \%$ & $9 \%$ & $4 \%$ & - \\
\hline 200 a 300 ha. & $8 \%$ & $7 \%$ & $7 \%$ & $1 \%$ & - \\
\hline 100 a 200 ha. & $11 \%$ & $28 \%$ & $11 \%$ & - & $17 \%$ \\
\hline 25 a 100 ha. & $12 \%$ & $37 \%$ & $12 \%$ & - & $25 \%$ \\
\hline-25 ha. & $4 \%$ & $2 \%$ & $2 \%$ & $2 \%$ & - \\
\hline
\end{tabular}

Fuentes: Idem Gráfico 1.2. 
En el caso del partido de $\underline{\text { Rivadavia, }}$, encontramos una muy fuerte concentración de la propiedad: el 40\% de la superficie del partido estaba en propiedades de más de 5.000 hectáreas. Sin embargo, también las explotaciones eran de gran tamaño, aunque algo menor. Así, las explotaciones de más de 1.250 hectáreas ocupaban el 54\% de la superficie, mientras que las propiedades, el 76\%. Este "desfasaje" se reubicaba en las unidades productivas de 25 a 625 hectáreas (ver Cuadro 1.13 y Gráfico 1.3).

Entonces, en Rivadavia los grandes propietarios no cedían tanta superficie en arriendo a las pequeñas unidades. Sin embargo, esto no se debe al predominio de conductas no rentísticas, sino que ocurre otro interesante fenómeno. Encontramos que los desfasajes totalizan sólo el $22 \%$ de la superficie del partido, mientras que hemos estimado la superficie arrendada en 59\%. Por lo tanto, tan sólo el 37\% de la superficie arrendada se explicaría por la entrega en arriendo de parcelas fraccionadas por parte de grandes propietarios. El 63\% restante serían campos que se entregarían en parcelas similares al tamaño total de las propiedades (predominando los de más de 1.250 hectáreas). Tanto Taylor (1948) como Barsky (1997) han llamado la atención sobre el fenómeno de los arriendos realizados para ganadería ${ }^{38}$. Por otro lado, en Egusquiza (1988) encontramos una interesante historia de vida de un gran arrendatario ganadero.

De modo que un $28 \%$ de la superficie del partido formaría parte de explotaciones en arriendo de más de 1.250 hectáreas. De ser esto así, los grandes propietarios estarían cediendo un $37 \%$ de sus campos a grandes arrendatarios, un $22 \%$ a pequeños y medianos arrendatarios (tal vez para regenerar los campos), y tan sólo mantendrían en su producción directa el $41 \%$ de sus tierras.

38 Taylor (1948) destaca que no todos los productores ganaderos vivían en mansiones, sino que algunos eran arrendatarios que sólo tenían unos pocos centenares de cabezas vacunas y vivían en casas humildes (aunque muchos de sus entrevistados negaban la existencia de estos arrendatarios ganaderos). También señala la existencia de pequeñas estancias, en propiedad o también en arriendo. 
Gráfico 1.3.

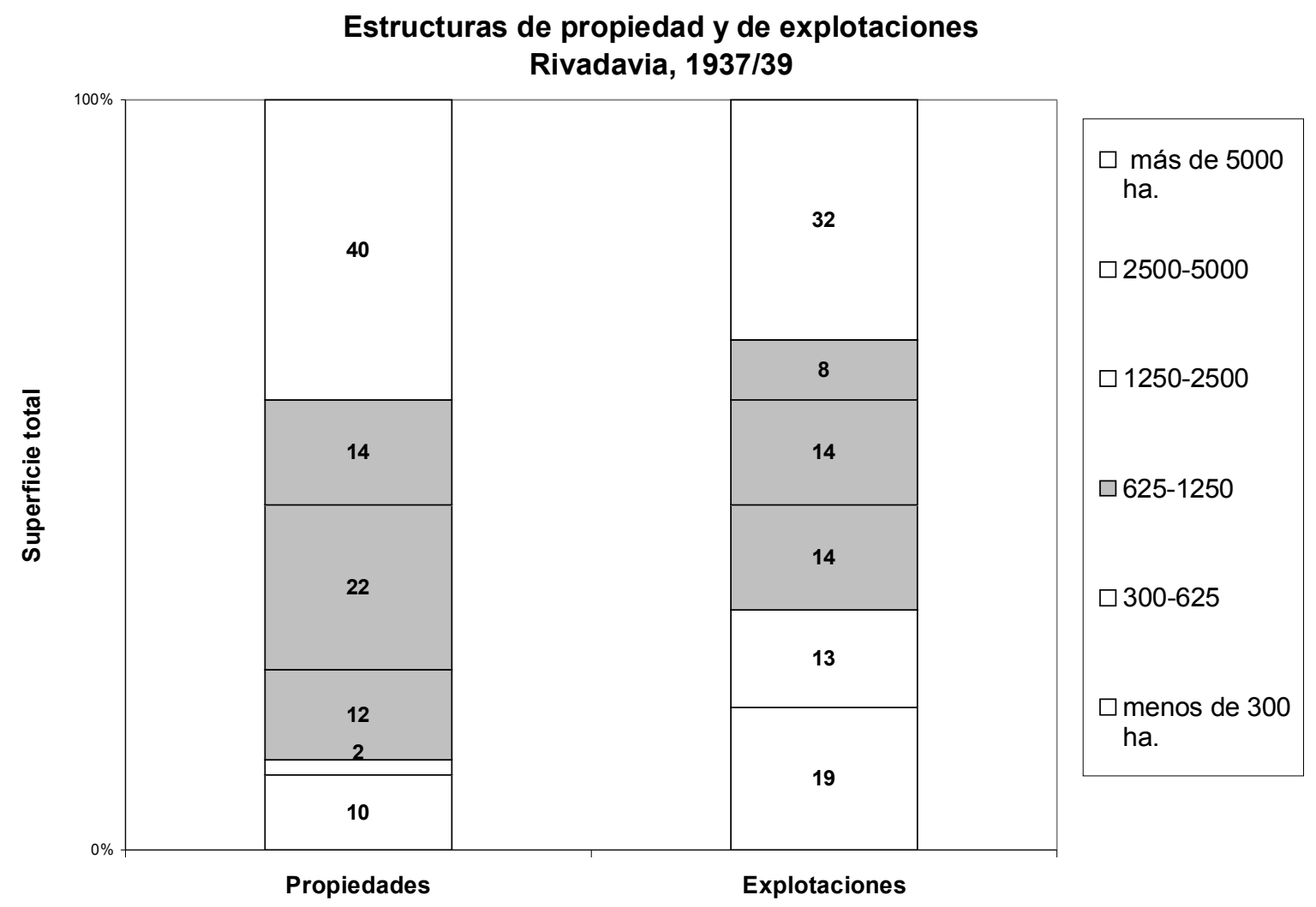

Fuentes: Idem Gráfico 1.2.

Cuadro 1.13. Estructura de propiedad y estructura productiva, Rivadavia, 1937.

Porcentajes del área total

\begin{tabular}{|l|l|l|l|l|l|}
\hline Extensión & $\begin{array}{l}\text { Unidades } \\
\text { de } \\
\text { propiedad }\end{array}$ & $\begin{array}{l}\text { Unidades } \\
\text { de } \\
\text { producción }\end{array}$ & $\begin{array}{l}\text { Tenencia } \\
\text { en } \\
\text { propiedad } \\
\text { (estimac.) }\end{array}$ & $\begin{array}{l}\text { "sobrante" } \\
\text { (estimac.) }\end{array}$ & $\begin{array}{l}\text { "faltante" } \\
\text { (estimac.) }\end{array}$ \\
\hline+5.000 ha & $40 \%$ & $32 \%$ & $32 \%$ & $8 \%$ & - \\
\hline 2.500 a 4.999 ha & $14 \%$ & $8 \%$ & $8 \%$ & $6 \%$ & - \\
\hline 1.250 a 2499 ha & $22 \%$ & $14 \%$ & $14 \%$ & $8 \%$ & - \\
\hline 625 a 1.250 ha & $12 \%$ & $14 \%$ & $12 \%$ & - & $2 \%$ \\
\hline 300 a 625 ha. & $2 \%$ & $13 \%$ & $2 \%$ & - & $11 \%$ \\
\hline-300 ha. & $10 \%$ & $19 \%$ & $10 \%$ & - & $9 \%$ \\
\hline
\end{tabular}

Nota: Por cuestiones del muestreo (eran pocos casos) se tuvo que agrupar a los estratos de menos de 300 hectáreas y analizarlos de conjunto.

Fuentes: Idem Gráfico 1.2. 
En Tres Arroyos, la situación se parecía más a la de Pergamino, las explotaciones de más de 1.250 hectáreas poseían el $9 \%$ del partido, mientras que las propiedades de igual tamaño el 54\% (ver Cuadro 1.14 y Gráfico1.4). Resulta claro el predominio de una conducta rentística por parte de los terratenientes con campos en este partido. Estarían cediendo alrededor del $83 \%$ de la superficie que poseían en Tres Arroyos (el porcentaje más elevado de los tres partidos ${ }^{39}$ ). Pero a diferencia de la zona norte, aquí la superficie que las propiedades no trabajaban directamente, era cedida a unidades medianas y medianas-grandes, de 300 a 1.250 hectáreas, y no tanto a explotaciones más pequeñas.

$\mathrm{Si}$, entonces, alrededor del $64 \%$ de la superficie del partido estaba en manos de arrendatarios y aparceros, y los "desfasajes" entre propiedad y explotaciones según intervalos sumaban 44\%: el 68\% de la superficie arrendada podría explicarse por la cesión de parcelas por parte de los grandes propietarios (de más de 1.250 hectáreas) a los medianos productores. El 32\% restante del arriendo podría deberse a propiedades que se arrendaban sin mayores fraccionamientos. Muy probablemente, este fenómeno ocurriera en los estratos de 200 a 1.250 hectáreas, donde se concentraba el mayor número de unidades productivas.

39 Pareciera que la distancia hubiera incidido para que los grandes terratenientes residentes generalmente en la ciudad de Buenos Aires, arrendaran muchas veces sus campos enteros a chacareros. En nuestro análisis previo (Balsa, 1994a) encontramos que muchas de las grandes propiedades del partido de Tres Arroyos estaban entregadas por completo en arriendo, a fines de los años veinte. 


\section{Gráfico 1.4}

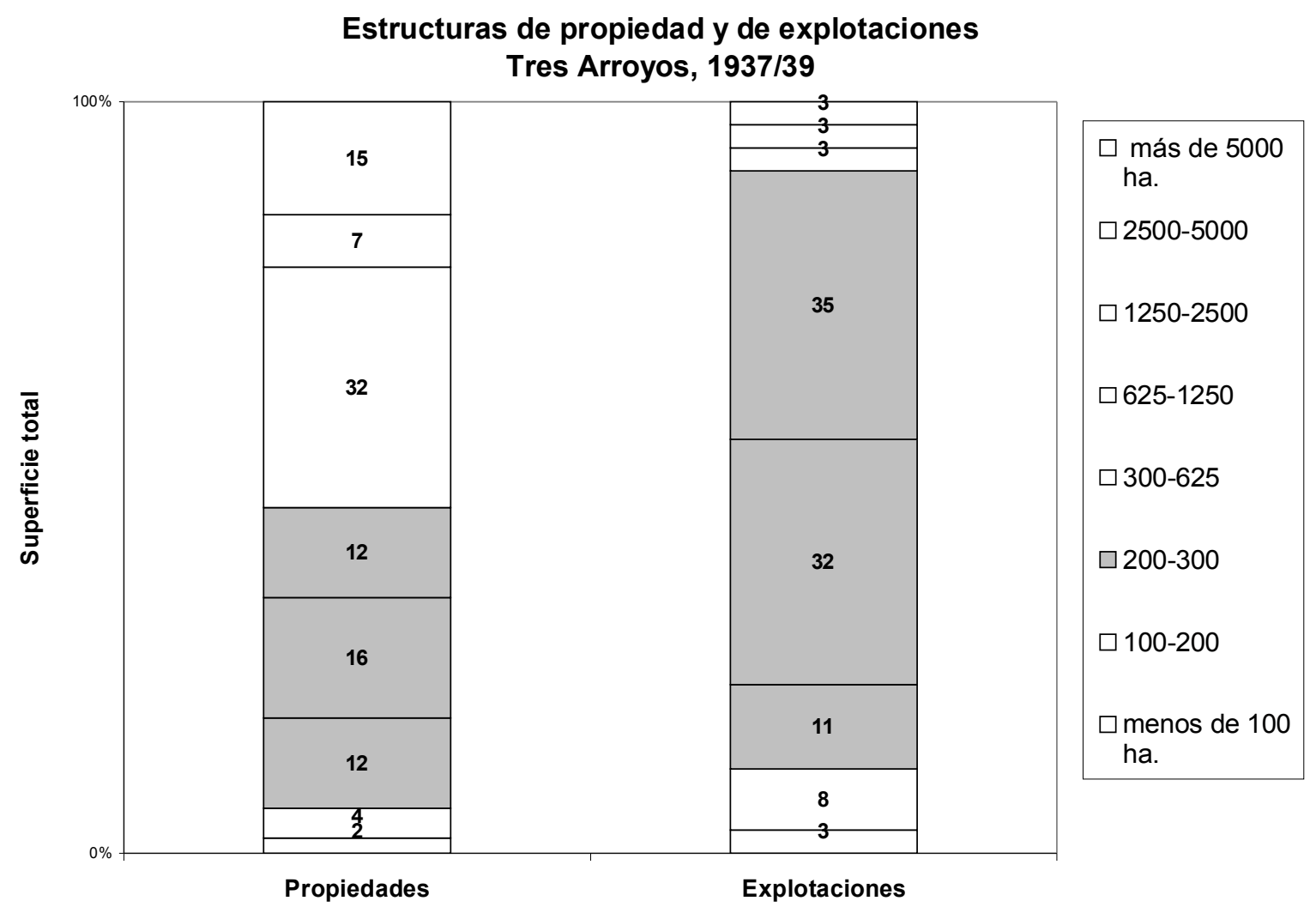

Fuentes: Idem Gráfico 1.2.

\section{Cuadro 1.14. Estructura de propiedad y estructura productiva, Tres Arroyos,} 1937.

Porcentajes del área total.

\begin{tabular}{|l|l|l|l|l|l|}
\hline Extensión & $\begin{array}{l}\text { Unidades } \\
\text { de } \\
\text { propiedad }\end{array}$ & $\begin{array}{l}\text { Unidades } \\
\text { de } \\
\text { producción }\end{array}$ & $\begin{array}{l}\text { Tenencia } \\
\text { en } \\
\text { propiedad } \\
\text { (estimac.) }\end{array}$ & $\begin{array}{l}\text { "sobrante" } \\
\text { (estimac.) }\end{array}$ & $\begin{array}{l}\text { "faltante" } \\
\text { (estimac.) }\end{array}$ \\
\hline+5.000 ha & $15 \%$ & $3 \%$ & $3 \%$ & $12 \%$ & - \\
\hline 2.500 a 4.999 ha & $7 \%$ & $3 \%$ & $3 \%$ & $4 \%$ & - \\
\hline 1.250 a 2499 ha & $32 \%$ & $3 \%$ & $3 \%$ & $29 \%$ & - \\
\hline 625 a 1.250 ha & $12 \%$ & $35 \%$ & $12 \%$ & - & $23 \%$ \\
\hline 300 a 625 ha. & $16 \%$ & $32 \%$ & $16 \%$ & - & $16 \%$ \\
\hline 200 a 300 ha. & $12 \%$ & $11 \%$ & $10 \%$ & $1 \%$ & - \\
\hline 100 a 200 ha. & $4 \%$ & $8 \%$ & $4 \%$ & - & $4 \%$ \\
\hline-100 ha. & $2 \%$ & $3 \%$ & $2 \%$ & - & $1 \%$ \\
\hline
\end{tabular}

Fuentes: Idem Gráfico 1.2. 
Se podría llegar a interpretar que los resultados del análisis hasta aquí expuesto (la presencia de grandes estancias ganaderas y de más extensos latifundios, junto con una gran cantidad de pequeñas explotaciones, predominantemente agrícolas) estarían abonando la tesis de la subordinación de las chacras hacia las estancias, correlato de una agricultura dependiente de la actividad ganadera (visión tradicional del agro pampeano, sintetizada críticamente en Barsky y Pucciarelli, 1991). Hasta qué punto puede mantenerse esta imagen será la cuestión que abordaremos en a continuación.

\section{La relación de la agricultura con la ganadería: chacras, estancias y explotaciones "mixtas"}

\subsection{La agricultura, ¿subordinada a la actividad ganadera?}

Según la tesis precisada por Tenembaum (1946) en la región pampeana existía una fuerte subordinación de la agricultura hacia la actividad ganadera. A partir de fines del siglo pasado, la agricultura habría tenido como su función primordial el preparar los suelos para las pasturas permanentes (alfalfa), y luego, ante la crisis de los alfalfares (a partir de los años veinte), la de producir cereales que sirvieran como pasturas para el refinamiento del ganado (de allí la expansión del maíz). Sin embargo, varios trabajos han planteado que esta relación debe situarse histórica y geográficamente (especialmente, Barsky y Pucciarelli, 1991). En este sentido, se ha señalado que no se presentaba esta relación en los años treinta ni en el partido de Pergamino (Giberti, 1998), ni en el de Tres Arroyos (Balsa, 1993).

Los datos de 1937 permiten confirmar que en las zonas norte y sur, la alfalfa presentaba una significación ciertamente marginal (7\% y $1 \%$ de la superficie total de cada zona, respectivamente). En cuanto a los cereales, en la zona norte el maíz era en su inmensa mayoría cosechado y no utilizado como forrajera, mientras que la avena, la cebada y el centeno tan sólo ocupaban el 2\% del área censada. En la zona sur, si bien el maíz era prácticamente inexistente, tenían importancia estos últimos cultivos (16\% de la superficie total). Como su articulación con la producción agrícola presenta algunas 
peculiaridades será analizada en el apartado que hemos dedicado a las explotaciones "mixtas".

En la zona oeste resulta posible que existiera esta subordinación de la agricultura hacia la ganadería tanto a través de su papel como preparadora de campos alfalfados, como con la utilización de los cereales para el pastoreo. En esta zona, tradicionalmente catalogada como "de invernada", a fines del siglo XIX y comienzos del XX se había establecido un sistema trianual (lino, trigo $\mathrm{y}$, luego, alfalfa) que brindaba a los terratenientes ganaderos las pasturas necesarias para la terminación de los animales con carne de primera calidad para la exportación enfriada.

Sin embargo, el lino había perdido este papel (en la zona oeste tan sólo se sembraron 10.100 hectáreas con lino en la campaña 1936/37). En cambio, el trigo continuaba con una presencia muy importante en la zona: 351.000 hectáreas sembradas. Aunque estimamos que, como máximo, alrededor de un $60 \%$ de esta superficie triguera podría estar directamente vinculada con la preparación de alfalfares ${ }^{40}$.

Por otra parte, ante la deficiencia en la producción de alfalfa (por "cansancio" de los suelos), muchos estancieros se habrían orientado hacia los cereales como forrajeras: avena, cebada, centeno e, incluso, maíz. De allí la diferencia entre superficie sembrada y superficie cosechada (Tenembaum, 1946). Para 1937 en la zona oeste se cosechaba el $38 \%$ de las llamadas "plantas de doble propósito" (avena, cebada y centeno), mientras que se cosechaba el $44 \%$ de la superficie sembrada con maíz.

Entonces, del total de la superficie sembrada con todo tipo de cereales y lino en la zona oeste (1.077.000 de hectáreas), podemos considerar que un 38\% estaba directamente relacionado con la actividad ganadera por su utilización exclusiva como forrajeras anuales. Incluso, buena parte de la superficie cosechada, era utilizada con

40 En un principio, los alfalfares tenían una vida de diez años. Incluso cuando su vida se haya acortado a cinco años para la década de 1930, por cada hectárea alfalfada era necesario tan sólo unas 0,2 hectáreas con trigo para ir preparando los suelos para nuevos alfalfares. Los ejemplos transcriptos en el libro de Taylor (1948), también plantean que un agricultor iba rotando durante cinco años sembrando trigo y luego alfalfa, hasta regresar al primer lote. Si en la zona oeste en 1937 había aproximadamente 1.015.000 hectáreas con alfalfa, tan sólo requerían que estuviesen sembrados anualmente unas 200.000 hectáreas con trigo. Concluimos que el 57\% del trigo podría llegar a haber estado vinculado directamente con la preparación de campos para la alfalfa. Sin embargo, pudiera ser que, ante la crisis de los alfalfares, se haya optado por una rotación más extensa con trigo para recuperar los campos. 
"doble propósito", es decir, era pastoreada durante el invierno ${ }^{41}$. Por otra parte, además de la superficie de trigo destinada a preparar directamente los campos para su alfalfado, otra parte del trigo cumplía el papel de interesar a los aparceros para que sembrasen luego forrajeras anuales.

Podemos concluir, entonces, que en el caso de la zona oeste la mayor parte de la superficie sembrada con cereales y lino presentaba algún grado de subordinación con la dinámica ganadera, pero no en las zonas norte ni sur.

\subsection{Las chacras, ¿apéndices de las estancias ganaderas?}

La subordinación técnica de la agricultura a la ganadería tenía, en la visión tradicional, su correlato en la explotación económica de la pequeña chacra por la gran estancia ganadera y en la dominación social del terrateniente criollo sobre el pequeño productor familiar extranjero (como lo analizan Barsky y Pucciarelli, 1991: 313). Esta subordinación -analizada conceptualmente en Sábato (1979) y con un claro ejemplo empírico en Palacio(1992b)- según Barsky y Pucciarelli (1991: 334) "se apoya en un supuesto fundamental, aunque no explicitado: la existencia de una cierta forma de contigüidad territorial entre las grandes praderas ganaderas y las pequeñas explotaciones agrícolas". Luego de analizar la información de cinco partidos de la provincia, representativos de sus distintas zonas agropecuarias, concluyen que "en las subregiones donde predomina el gran latifundio ganadero hay muy poca presencia de pequeñas unidades agrícolas y, a la inversa, en las subregiones agrícolas o ganaderotamberas combinadas con la agricultura, la enorme proliferación de pequeñas unidades va acompañada con la inexistencia virtual o la leve presencia de grandes latifundios". En el presente apartado intentaremos profundizar esta línea de análisis para el conjunto de los 34 partidos de las tres zonas que estamos investigando.

Encontramos que en los distritos donde predominaban las grandes explotaciones ganaderas (de más de 5000 hectáreas), las pequeñas chacras (de hasta 100 hectáreas) casi no tenían ninguna significación territorial. Y a la inversa, en aquellos partidos

${ }_{41}$ Según, la reconstrucción de una estancia realizada por Palacio (1992b), en algunos casos este pastoreo sería realizado por animales del estanciero en campos con avena sembrada por chacareros, que luego la cosechaban (ellos habían sembrado el año anterior trigo, y permitían "gratis" este pastoreo en sus cultivos, pues así lo establecían los contratos). 
donde las chacras ocupaban la mayor parte de la superficie, las grandes estancias resultaban completamente marginales. En el Gráfico 1.5 podemos observar cómo se distribuyen los partidos según la importancia territorial, medida en la proporción que ocupaban de la superficie total del partido, de las pequeñas chacras (eje de las ordenadas) y de las grandes explotaciones ganaderas (eje de las abscisas). Entonces, la relación no sólo no es positiva, como lo sostenía implícitamente la visión tradicional, sino negativa (en los partidos donde las grandes estancias ganaderas eran importantes, las pequeñas chacras carecían de importancia, y viceversa).

\section{Gráfico 1.5}

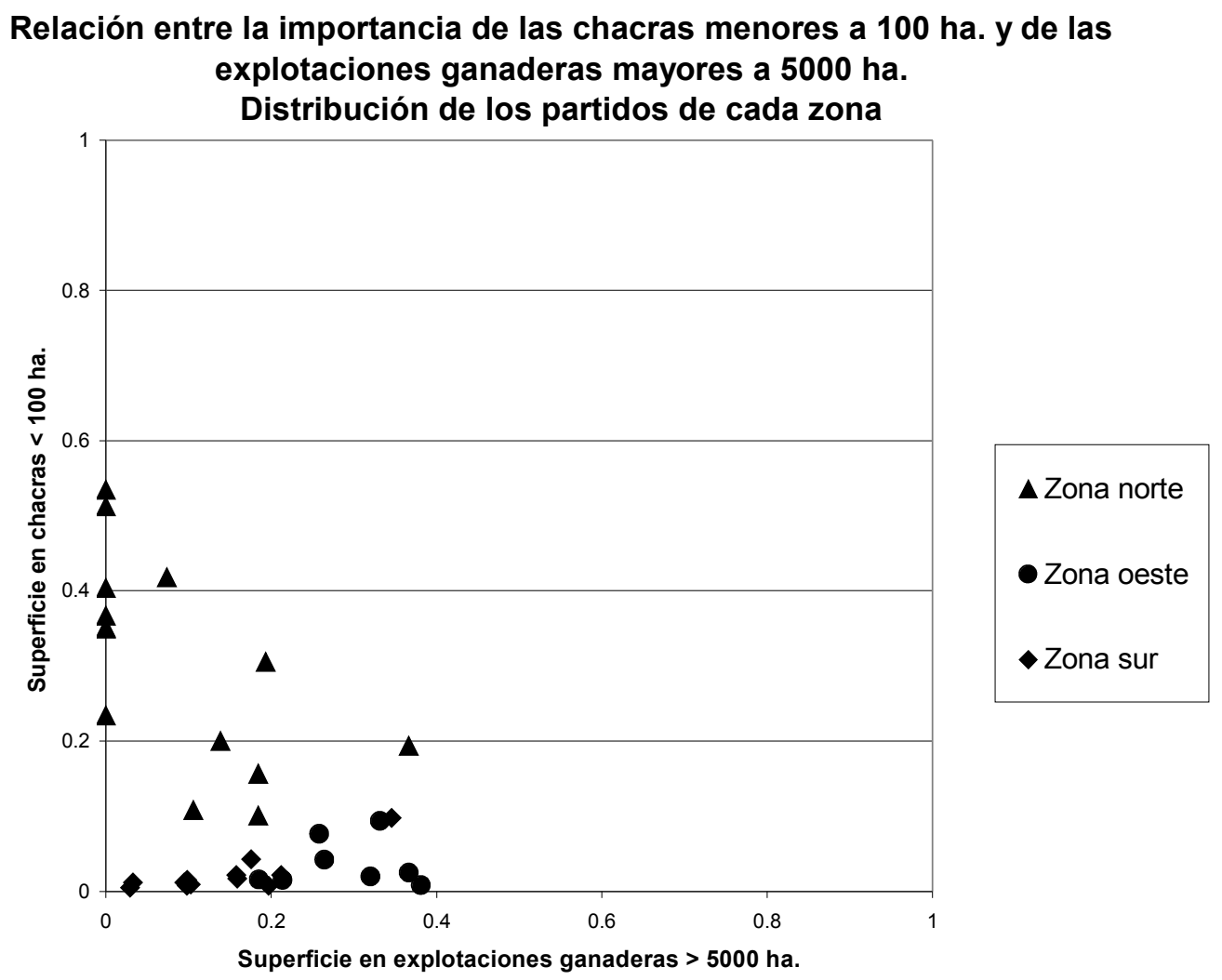

Fuente: elaboración propia en base a los datos del Censo Agropecuario de 1937.

Incluso si ampliamos los criterios y analizamos la relación entre la presencia de chacras de hasta 200 hectáreas y la de estancias ganaderas de más de 2500 hectáreas, la relación continúa siendo negativa (ver Gráfico 1.6). Tan sólo en seis distritos de la zona 
norte ambos tipos de explotaciones tenían cierta importancia simultáneamente (más del $20 \%$ de la superficie censada).

\section{Gráfico 1.6}

Relación entre la importancia de las chacras menores a 200 ha. y de las explotaciones ganaderas mayores a 2500 ha.

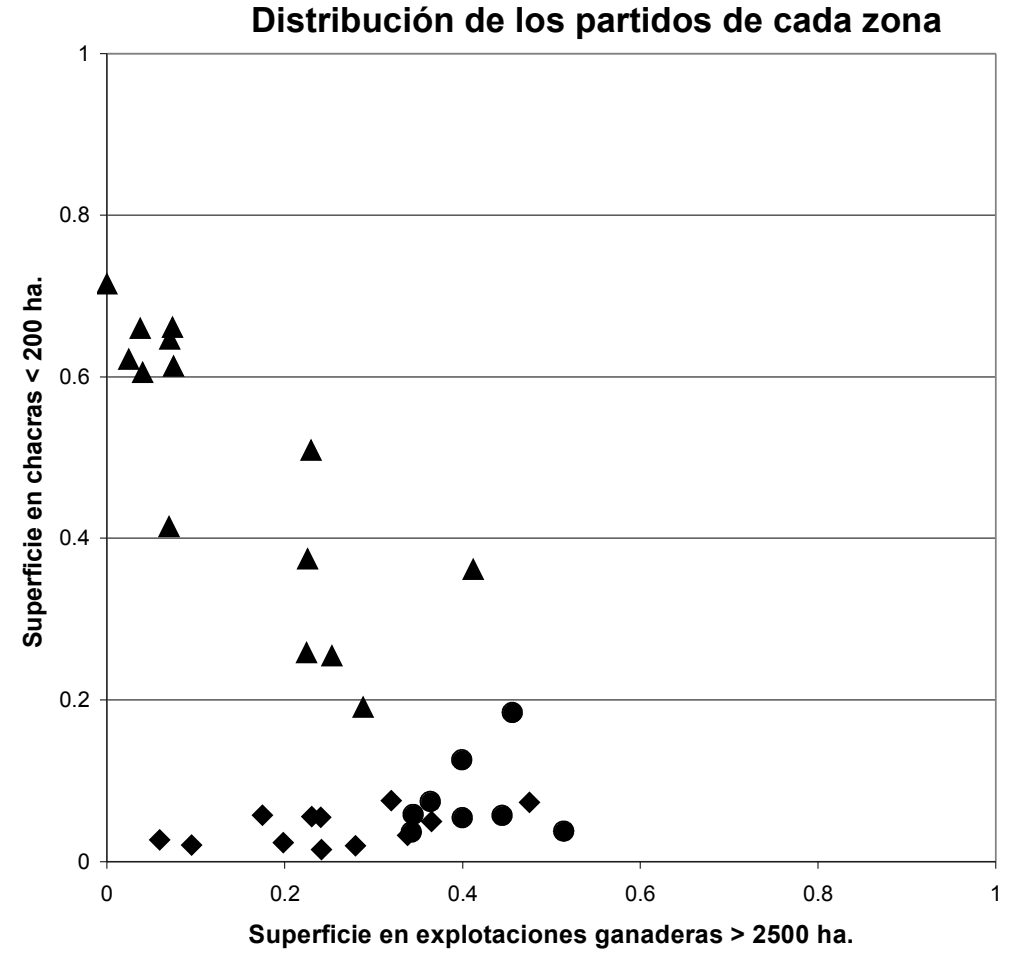

$\Delta$ Zona norte

- Zona oeste

- Zona sur

Fuente: elaboración propia en base a los datos del Censo Agropecuario de 1937.

Podría contraargumentarse que las pequeñas chacras (potencialmente subordinadas a las grandes estancias ganaderas) si bien no ocupaban un área significativa dentro de varios distritos, sí dieran cuenta de la mayor parte de la superficie agrícola de los mismos. Para chequear esa posibilidad, hemos calculado el porcentaje de la superficie agrícola de la que daban cuenta las chacras de hasta 200 hectáreas, y analizado su relación con la importancia territorial de los establecimientos ganaderos de más de 2.500 hectárea. Tal como podemos observar en el Gráfico 1.7, 
tampoco existe una relación positiva entre ambas variables. En los partidos donde las chacras menores a 200 hectáreas controlaban más del 80\% de la agricultura, las grandes explotaciones ganaderas no tenían significación. En cambio, donde las estancias ganaderas de más de 2.500 hectáreas controlaban más del 30\% de la superficie total del partido, menos de la mitad de la agricultura se encontraba en explotaciones con más de 200 hectáreas de extensión. Incluso en la zona oeste, donde las grandes estancias ganaderas tenían mayor importancia, la mayor parte de la agricultura no se realizaba en las pequeñas chacras. La única excepción, un partido con importante desarrollo agrícola, en el que esta producción está en manos de unidades menores a las 200 hectáreas $(71 \%$ de la superficie agrícola), y al mismo tiempo las explotaciones ganaderas mayores de 2.500 hectáreas tienen fuerte presencia (41\% del área total), es el norteño partido de Colón. Pues, el otro partido con altos valores en ambas variables es General Alvarado, dónde la agricultura no ocupaba un lugar muy destacado. 


\section{Gráfico 1.7}

Relación entre grandes explotaciones ganaderas (mayores a 2.500 ha.) y la importancia agrícola de chacras mayores de 200 ha.

Distribución de cada partido.

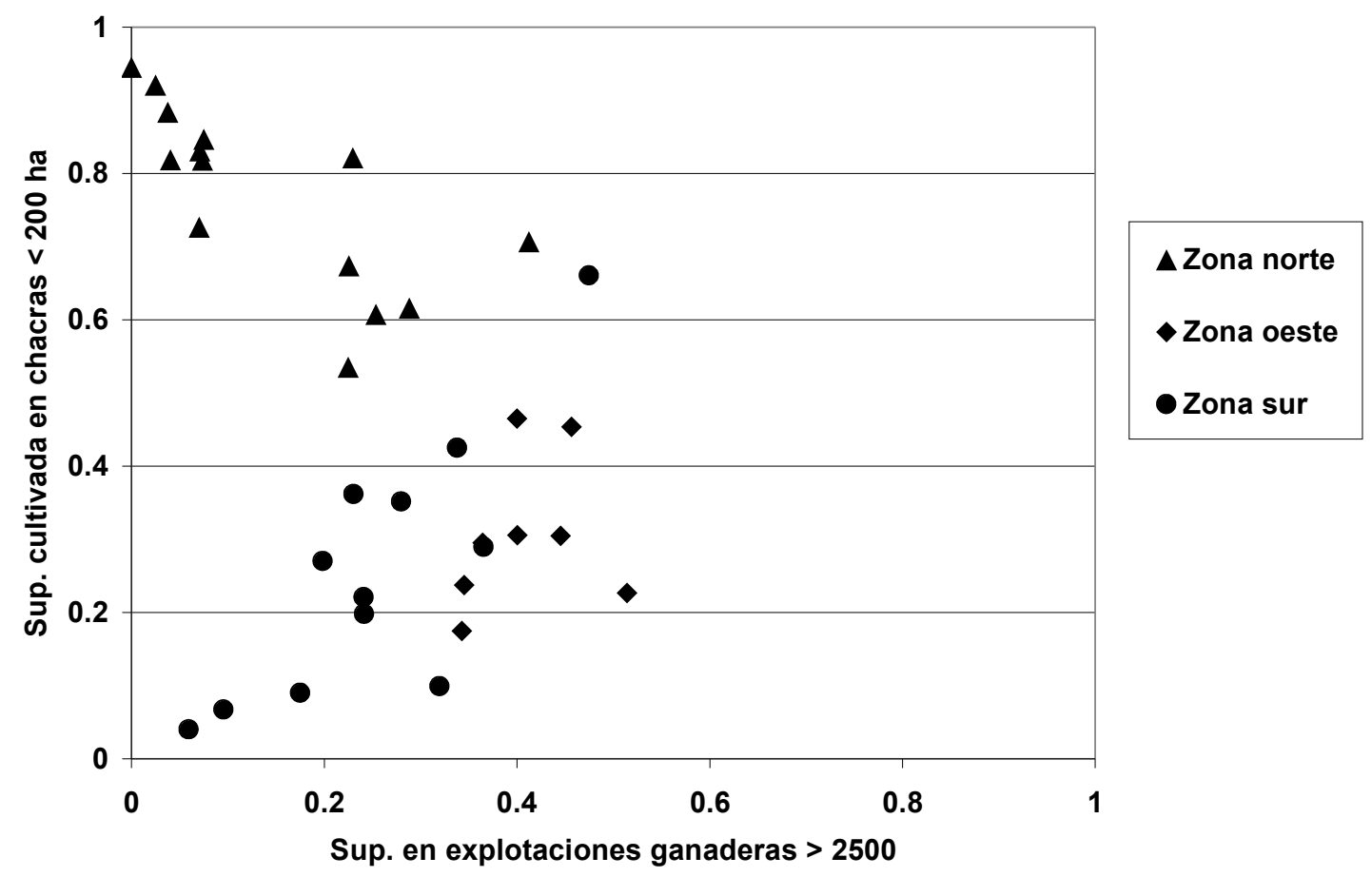

Fuente: elaboración propia en base a los datos del Censo Agropecuario de 1937.

Con estos argumentos no queremos negar la existencia de una relación de subordinación entre muchos pequeños agricultores no propietarios y las grandes estancias dedicadas a la invernada. Pero sí quisiéramos relativizar su importancia en el total de la superficie cultivada. En este sentido, corresponde considerar la significación de la agricultura que se realizaba fuera de las explotaciones categorizadas como "chacras". 


\subsection{La agricultura en explotaciones "mixtas"}

Resulta interesante destacar otro tipo de relación entre la agricultura y la ganadería: la que se daba al interior de las unidades denominadas "mixtas" por el Censo. Si bien no existe ninguna explicitación del criterio para catalogar a un establecimiento dentro de esta categoría ${ }^{42}$, resulta claro que eran unidades que combinaban la agricultura y la ganadería, ambas como actividades importantes para la explotación. Es por ello que, la importancia de estas "explotaciones mixtas" (donde ambas actividades estaban en manos de un mismo productor), nos lleva a relativizar la significación de las "estancias mixtas" (en las que la agricultura era desarrollada por arrendatarios y/o medieros, como actividad subordinada a la dinámica ganadera que estaba a cargo del terrateniente) $)^{43}$.

Generalmente se ha pensado la agricultura como una actividad realizada centralmente en las chacras. Incluso Frigerio (1953), en su detallado estudio realizado a partir del Censo de 1937, realiza sus estimaciones de la diferenciación social presente en la actividad agrícola considerando sólo a las chacras. Sin embargo, esta imagen debe ser revisada. Si bien las chacras podrían dar cuenta de casi toda la superficie agrícola de la zona norte (suponiendo que cada chacra sembraba el $90 \%$ de su extensión, dejando el resto para la cría de los equinos necesarios para las labores agrícolas, y para la huerta y la cría de cerdos), no ocurre lo mismo en las zonas oeste y sur. En ellas las chacras, como máximo, realizarían el $58 \%$ y el $30 \%$ de la agricultura, respectivamente (ver Gráfico 1.8$)^{44}$. El resto de la superficie cultivada se ubicaba en explotaciones "mixtas"

42 La categorización de las unidades fue realizada por los técnicos que procesaron la información contenida en los cuestionarios, con criterios que no han sido explicitados. En los cuestionarios no estaba previsto que se consignase el tipo de explotación.

43 No debe confundirse la "explotación mixta" (categoría censal), en la cual el mismo productor tiene a su cargo las actividades agrícolas y las ganaderas, con la "estancia mixta" (concepto historiográfico) en la que el terrateniente se dedica a la ganadería y realiza contratos de arriendo o aparcería con agricultores (a los que el censo cataloga como productores independientes), que finalizan con la implantación de pasturas para los ganados del dueño del campo (desarrollado teóricamente por Sábato, 1979). Errores de este tipo aparecen en las reflexiones de Palacio (2002: 13-14) y confunden su línea argumental, llevandolo a afirmar que durante el período de entreguerras habría habido una expansión de las "estancias mixtas" a partir de la significación de las "explotaciones mixtas" en el Censo de 1937.

44 Por lo motivos expuestos en el anterior apartado, hemos considerado como superficie estrictamente agrícola en la zona oeste a las hectáreas sembradas con trigo o lino (independientemente de su relación con la preparación de suelos para su alfalfado), y a la 
$y$, en alguna proporción, en establecimientos que el censo catalogó como ganaderos ("cría", "invernada", "tambo" o "con ganadería"). Ya que no es posible establecer esta última proporción, hemos trabajado en base al supuesto de que toda la agricultura no realizada en las chacras era efectuada en las "mixtas"45.

\section{Gráfico 1.8}

Superficie agrícola según tipo de explotación

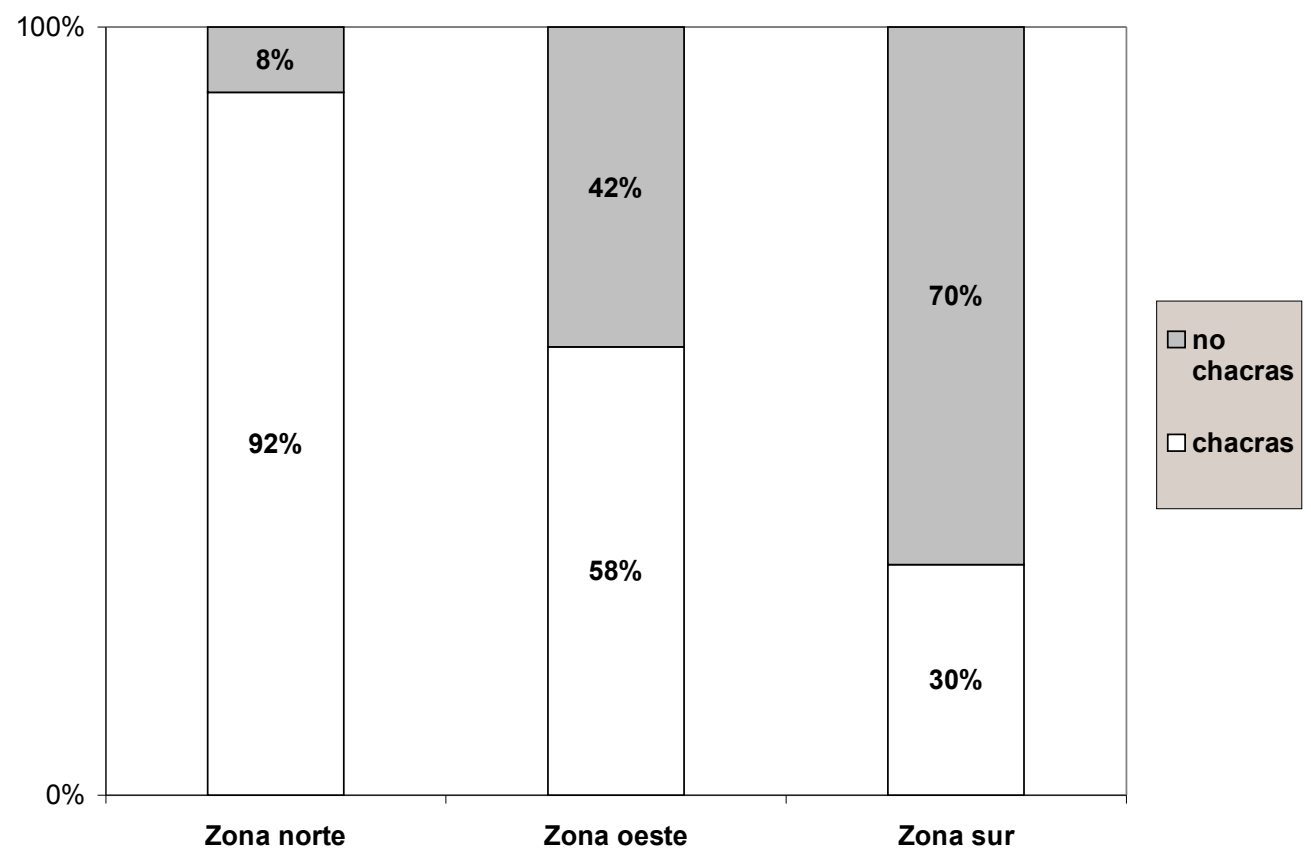

Fuente: elaboración propia en base a los datos del Censo Agropecuario de 1937.

Podemos concluir, entonces, que existían marcadas diferencias zonales en la relación entre agricultura y ganadería. En la zona norte, casi la totalidad de la agricultura se realizaba en explotaciones exclusivamente agrícolas y con poca relación

superficie cosechada con maíz, avena, cebada y centeno. Arrojando una sumatoria total de 665.000 hectáreas.

45 Esta es una simplificación, pues indudablemente también se haría alguna agricultura en las explotaciones consignadas como ganaderas. Sin embargo, consideramos que esta simplificación no tendrá importantes consecuencias en las posteriores estimaciones sobre el tamaño de las unidades que realizaban agricultura, pues la superficie agrícola ubicada en este tipo de explotaciones no habría sido muy elevada y, en todo caso, se ubicaría en unidades de escalas similares a las mixtas (quedaría como error insalvable estimar la superficie agrícola ubicada en unidades ganaderas de más de 1.250 hectáreas -que suponemos relativamente pequeña-, pues las mixtas no se diferencian por encima de las 625 hectáreas). 
con la actividad ganadera. La ganadería de esta zona se desarrollaba fundamentalmente en base a praderas naturales, complementada con algunas pasturas perennes, que representaban el 7\% del total de la superficie de la zona. Es muy probable, tal como lo afirma Giberti (1998) para Pergamino, que las unidades ganaderas se ubicaran en las tierras sin aptitud agrícola, pues el área total de estas explotaciones coincidía con el de las tierras de aptitud ganadera.

En la zona oeste, un máximo del 58\% de la agricultura se realizaba en chacras. El restante $42 \%$ se localizaba en explotaciones "mixtas" o ganaderas. En realidad, sería aun menor la superficie agrícola en chacras, ya que parte de esta estimación se basa en considerar que este tipo de unidades se dedicaban exclusivamente a cultivos para cosecha. Sin embargo, una porción de la superficie sembrada en las chacras era para pastoreo, por lo cual su peso en la actividad agrícola debía ser incluso menor, y por lo tanto, las unidades mixtas habrían tenido incluso un mayor peso en la agricultura, superando seguramente a las chacras.

En la zona sur, donde el cultivo de alfalfa era casi inexistente, resulta claro que la imbricación entre agricultura y ganadería no tenía lugar en las "estancias mixtas". En esta zona, las "explotaciones mixtas" concentraban alrededor del 70\% de la superficie agrícola. Por lo tanto, aquí había una fuerte asociación entre agricultura y ganadería, pero que se daba al interior de las unidades productivas, y no a partir de la subordinación de la chacra a la estancia ganadera. Como hemos visto, aquí no eran importantes las forrajeras perennes, pero sí lo eran las anuales. La avena, las cebadas y el centeno eran usados con un doble propósito, pastoreándolas durante el invierno (evitando hacerlo en exceso) y cosechándolas al finalizar el año. Incluso los campos sembrados con trigo eran, a veces, pastoreados ${ }^{46}$.

46 Sobre el efecto del pastoreo sobre avena, cebada y centeno e incluso sobre trigo y lino, la Chacra Experimental de "La Previsión" ubicada en Barrow (Tres Arroyos), realizó una serie de experimentos entre 1930 y 1938 midiendo los resultados de la posterior cosecha que se detallan en su Boletín (tomos I y II). En general, encontraron que si las condiciones eran buenas, el pastoreo durante el invierno mermaba muy poco el rendimiento de la cosecha. 
Luego de haber logrado un panorama global de la estructura agraria de las tres zonas escogidas y de haber analizado las diferencias zonales de la relación entre ganadería y agricultura, vamos a regresar a nuestra pregunta inicial acerca de la importancia de las distintas formas sociales de producción en esta última actividad.

\section{Las formas sociales de producción en la agricultura}

\subsection{El tamaño de las explotaciones agrícolas}

En general, se asoció a la agricultura con las pequeñas unidades de producción, especialmente en contraste con las extensas explotaciones ganaderas. Sin embargo, Boglich (1937) sostenía que la mayor parte de la superficie agrícola estaba en manos de explotaciones medianas (de 100 a 200 hectáreas) y grandes (mayores a 200 hectáreas).

También, desde otra perspectiva ideológica, Campolieti (1929), a partir de sus estudios técnicos, señalaba que las unidades agrícolas tenían un tamaño excesivo que las obligaba a contratar asalariados, y propuso un modelo de explotación más pequeña, intensiva, basada exclusivamente en el aprovechamiento integral (a lo largo del año) de la mano de obra familiar a través de la combinación de agricultura y ganadería.

A comienzos de los años cincuenta, Frigerio diferenciaba, en base al Censo de 1937, entre el peso social y la importancia productiva de los distintos tamaños de las "chacras"47. Vamos a reproducir este tipo de análisis, pero considerando también la agricultura realizada en las unidades "mixtas".

47 Destacaba que había una "gran importancia numérica de las pequeñas y medianas explotaciones de chacras de 10 a 200 hectáreas" (Frigerio, 1953: 88), constituyendo "una numerosa población chacarera". Sin embargo, había un "predominio económico de la mediana y grande explotación en la producción agrícola de la zona cerealera", midiéndolo en la superficie que ocupaban las chacras de 50 a 200 y de más de 200 hectáreas sobre el total de superficie ocupada por las chacras. 
La agricultura de las tres zonas se diferencia por el tamaño de las unidades productivas que la efectuaban (ver Cuadro 1.15). La zona norte se destaca por la primacía, no sólo numérica, sino también en términos de superficie agrícola, de las unidades de menor extensión. Hemos estimado que más del $80 \%$ de la superficie cultivada se encontraba en explotaciones de hasta 200 hectáreas, y prácticamente la mitad en unidades de hasta 100 hectáreas.

En la zona sur, en cambio, las explotaciones menores a 200 hectáreas apenas alcanzaban a dar cuenta del $15 \%$ del área cultivada. Por el contrario, se destacaban las explotaciones de 300 a 625 hectáreas que cultivaban el 38\% del área agrícola, y las unidades de más de 625 hectáreas que trabajaban un tercio de la superficie agrícola.

La zona oeste presentaba un perfil intermedio entre las otras dos zonas. Su estructura productiva era, entonces, más heterogénea: las unidades de todas las escalas tenían su significación en la producción agrícola.

Cuadro 1.15. Distribución de la superficie agrícola según tamaño de la explotación

\begin{tabular}{|l|c|c|c|}
\hline Tamaño & zona norte & zona oeste & zona sur \\
\hline hasta 100 ha & $48 \%$ & $17 \%$ & $4 \%$ \\
\hline $\mathbf{1 0 0}-\mathbf{2 0 0}$ ha & $33 \%$ & $23 \%$ & $11 \%$ \\
\hline $\mathbf{2 0 0}-\mathbf{3 0 0}$ ha & $7 \%$ & $16 \%$ & $14 \%$ \\
\hline $\mathbf{3 0 0}-\mathbf{6 2 5}$ ha & $7 \%$ & $24 \%$ & $38 \%$ \\
\hline 625 ha y más & $4 \%$ & $19 \%$ & $33 \%$ \\
\hline
\end{tabular}

Fuente: Estimaciones propias en base a los datos por partido del Censo Agropecuario de 1937.

\subsection{La tenencia del suelo y la producción agrícola}

La información censal no resulta explícita en la superficie agrícola de la que daban cuenta las distintas formas de tenencia del suelo. La bibliografía especializada ha asociado fuertemente agricultura con tenencia en arriendo o en aparcería (Campolieti, 1929; Nemirosvky, 1933; Tenembaum, 1946; Flichman, 1977). Algunos autores destacan que también hubo una expansión de las formas de tenencia en propiedad dentro de los agricultores durante los años veinte, aunque la crisis subsiguiente llevó a la pérdida de sus campos a muchos agricultores que no pudieron hacer frente a las 
hipotecas con que habían intentado pasar a ser propietarios (Boglich, 1937; Barsky, 1988).

En el censo se consigna sólo la cantidad de explotaciones que se encontraban en arriendo en dinero o en especies, por tipo de explotación. En base a las proporciones en arriendo de chacras y mixtas, hemos estimado la superficie agrícola según el tipo de tenencia del suelo (ver Apéndice 1, Apartado 1 donde se explicita la metodología). Más allá de la diferente importancia de la organización del trabajo y de los distintos intervalos de tamaño en las tres zonas, la significación de la producción en propiedad era similar: alrededor de un tercio de la superficie agrícola. En relación con las formas en no propiedad, se diferencia la zona norte por presentar un predominio de la aparcería ${ }^{48}$. En cambio, en las dos zonas restantes ocupaba una posición marginal (ver Cuadro 1.16).

\section{Cuadro 1.16. Distribución de la superficie agrícola según la tenencia del suelo,} 1937

\begin{tabular}{|l|c|c|c|}
\hline & zona norte & zona oeste & zona sur \\
\hline Propiedad & $33 \%$ & $30 \%$ & $34 \%$ \\
\hline Arriendo & $25 \%$ & $55 \%$ & $55 \%$ \\
\hline Aparcería & $42 \%$ & $15 \%$ & $11 \%$ \\
\hline
\end{tabular}

48 En el censo fueron registradas como explotaciones en "arriendo en especie". Sin embargo, las disposiciones legales las encuadrarían dentro de la "aparcería". Este término, siempre ha resultado polémico para su conceptualización. Originariamente se lo utilizó para describir contratos en los que el propietario, además de su tierra, ponía parte de la inversión necesaria para la producción, y en este sentido arriesgaba, junto con el productor. Sin embargo, en la agricultura esta práctica fue siendo dejada de lado (lo mismo había ocurrido con la aparcería durante la expansión del lanar, Korol y Sábato, 1981, quienes distinguen entre esos dos tipos de aparcería). Ahora bien, en la medida en que el propietario al aportar su campo está cediendo el costo de oportunidad de arrendarlo en dinero, y corre el riesgo de obtener una renta menor si la cosecha no es buena, consideramos que sigue siendo una situación que podemos conceptualizar como "aparcería".

Según nuestros criterios, con los "arrendatarios en especie" del censo de 1937, estaríamos en presencia de un tercer tipo de aparcería. Pues, en ella, la inversión productiva es realizada por entero por el productor (en los casos en que el terrateniente efectúa parte de las inversiones, sería una aparcería de tipo II), pero los riesgos de producción y de realización son compartidos entre el terrateniente y el productor (pues el canon dependería del volumen de la cosecha y del precio de mercado, amen de las maniobras que en la venta podía realizar el terrateniente o su intermediario).

Reservamos el término "arriendo en especie" para los casos en que se fija un monto de cereal determinado (o su equivalente monetario) como canon de arriendo. En este caso, el terrateniente no comparte los riesgos de producción, pero sí los de realización. 
Fuente: Estimaciones propias en base a los datos por partido del Censo Agropecuario de 1937.

\subsection{La organización social del trabajo en la agricultura}

Este ha sido quizás el punto más problemático en los análisis de la estructura productiva del agro pampeano. Como los censos no discriminan a las explotaciones según su organización social del trabajo, y tampoco los informes técnicos avanzan más allá de consignar -a veces- la cantidad de brazos necesarios para la explotación "tipo" de la zona que consideran, la mayor parte de los trabajos formulan impresiones generales o se ven impelidos a sustentarse en supuestos muy generales para precisar sus apreciaciones. Entre estos trabajos podemos diferenciar a los que destacan el carácter familiar de la mayor parte de la producción agrícola, aunque reconociendo que buena parte de las explotaciones hacían uso de asalariados para los momentos de mayor actividad (Campolieti, 1929; Flichman, 1977; Forni y Tort, 1992; Ansaldi, 1998), y los que enfatizan el papel de la mano de obra asalariada (Boglich, 1937; Frigerio, 1953; Pucciarelli, 1986; Sartelli, 1997).

Es en el texto de Taylor donde encontramos algunas descripciones precisas de la mano de obra presente en distintos tipos de explotaciones. En la zona maicera comenta de una estancia de 18.000 hectáreas, que trabajaba en forma directa 6.000 hectáreas, empleaba un encargado, su asistente y 28 asalariados (la mayor parte de la misma era dedicada a pasturas y producción ganadera, aunque también se sembraba algo de maíz). La superficie restante era trabajada por 105 arrendatarios; éstos, con explotaciones de 60 a 120 hectáreas, hacían un intenso uso de la mano de obra familiar, pero por su extensión también requerían de asalariados. Taylor también describe una estancia en la zona de invernada de 4.050 hectáreas (1.600 vacunos y 3.500 ovinos) que empleaba un mayordomo y 18 hombres, aunque en los últimos años, había reducido la dotación a once asalariados. Por otra parte, una explotación de 365 hectáreas en una colonia oficial en Artalejos, dedicada al ovino, era trabajada por el productor, su hijo adolescente y un asalariado, que lo empleaba hasta que su hijo pudiera reemplazarlo (Taylor, 1948: 361). 
Para poder avanzar en la medición de la importancia dentro de la producción agrícola, de las distintas unidades discriminadas por la composición de su mano de obra, hemos trabajado en base a los datos del Censo de 1937 utilizando algunos supuestos.

Aclaramos de entrada que en el censo no se discrimina a las unidades por su organización social del trabajo. Entonces, la hemos estimado a partir del número total de explotaciones que contrataban asalariados fijos y la cantidad de estos trabajadores por partido, que es la única información que se editó sobre la mano de obra (en el Apéndice 1, Apartado 1, explicitamos los supuestos y el modo de estimación ${ }^{49}$ ).

Según nuestras estimaciones, la mayor parte de la agricultura de las tres zonas estaba organizada en base al trabajo familiar, en todo caso con el auxilio de uno o dos trabajadores asalariados permanentes. Entre el 67\% y el $89 \%$ de la superficie agrícola de las tres zonas estaría a cargo de estas unidades basadas en la mano de obra familiar, en forma exclusiva o con el apoyo de un asalariado (o, a veces, dos). Sin duda, también tenían la colaboración de asalariados transitorios especialmente durante el mes de cosecha. Como veremos en el siguiente apartado, éstos eran particularmente importantes en las unidades medianas de la zona norte, donde la cosecha del maíz se realizaba por entero de forma manual. Sin embargo, la cosecha del resto de los cereales y del lino se había mecanizado gracias a la expansión del uso de cosechadoras de arrastre durante los años veinte. De este modo, el peso del trabajo asalariado transitorio se había reducido de un modo notable en la zona sur -y en menor medida en el oeste- ya que las innovaciones tecnológicas había permitido a la mano de obra familiar abarcar crecientes superficies agrícolas.

Si analizamos las estimaciones con mayor detalle (Cuadro 1.17), se observa que, como común denominador, en las tres zonas las explotaciones familiares con el auxilio de uno o dos asalariados se hacían cargo de alrededor de un $40 \%$ de la superficie cultivada. Era en la organización del trabajo del área restante donde existían diferencias.

49 La base de la estimación se estructuró a partir de asociar el tamaño de las explotaciones con la contratación de asalariados en forma permanente. Si bien esto contradice el postulado explicitado en la Introducción, de no asociar directamente dimensiones de distinto orden, creemos que, como explicamos en el Apéndice 1 (Apartado 1), alterar levemente este supuesto no altera sustancialmente las estimaciones realizadas. 
En la zona norte predominaba la agricultura realizada en explotaciones basadas exclusivamente en la mano de obra familiar: las unidades sin asalariados permanentes tenían el $52 \%$ de la superficie agrícola de esta zona ${ }^{50}$.

\section{Cuadro 1.17.}

Distribución de la superficie agrícola según la organización social del trabajo, 1937

\begin{tabular}{|l|c|c|c|}
\hline & zona norte & zona oeste & zona sur \\
\hline Familiar & $43 \%$ & $38 \%$ & $28 \%$ \\
\hline Familiar con asalariados transitorios ** & $9 \%$ & $3 \%$ & - \\
\hline Familiar con asalariados (1 o 2 asal. permanentes) & $36 \%$ & $39 \%$ & $39 \%$ \\
\hline Empresarial pequeño (3 a 5 asal. permanentes) & $7 \%$ & $19 \%$ & $33 \%$ \\
\hline $\begin{array}{l}\text { Empresarial mediano o grandes (más de 5 } \\
\text { asalariados permanentes) }\end{array}$ & $4 \%$ & $*$ & $*$ \\
\hline
\end{tabular}

* no ha sido posible distinguir a las unidades con tres o más asalariados en las zonas oeste y sur.

** Unidades con asalariados transitorios al momento de realizarse el Censo (30 de junio)

Fuente: Estimaciones propias en base a los datos por partido del Censo Agropecuario de 1937.

En la zona sur (más allá del peso de los que contrataban uno o dos asalariados) se destacaba la agricultura realizada en unidades con tres a cinco asalariados permanentes: concentraba el 33\% de la superficie agrícola de la zona. En este tipo de explotaciones, además del trabajo asalariado, en muchos casos, se agregaban uno o dos trabajadores familiares, por lo que las podríamos caracterizar como unidades empresariales pequeñas. Sin embargo, en la superficie estimada se encuentran también sumadas las unidades que contrataban un mayor número de asalariados, pero que no las hemos podido diferenciar ${ }^{51}$. En el otro extremo, las explotaciones estrictamente familiares estarían dando cuenta del $28 \%$ de la superficie sembrada en la zona sur.

50 Aquí sumamos el $43 \%$ que ocupaban las unidades sin ningún tipo de asalariados, y el 9\% que tenían las explotaciones que tenían al menos un asalariado transitorio al momento de efectuarse el censo.

${ }^{51}$ No ha sido posible distinguir a las unidades de más de 625 hectáreas, por lo tanto tampoco se pudo diferenciar internamente a las explotaciones con más de tres asalariados. Sin embargo, por toda la información recogida a través de los testimonios orales y fuentes escritas, suponemos que la mayoría de la agricultura era realizada en unidades con tres a cinco asalariados permanentes, y no en explotaciones con seis o más asalariados permanentes. 
Por último en la zona oeste, las unidades familiares que no contrataban asalariados en forma permanente tenían un $41 \%$ de la superficie sembrada en esta zona $^{52}$. En cambio, las explotaciones empresariales sólo concentraban el 19\% de dicha área.

En síntesis, en las tres zonas la mayor parte de la agricultura se encontraba en manos de distintos tipos de unidades familiares capitalizadas. Por un lado, explotaciones con un elevado nivel de mecanización que se basaban casi exclusivamente en el trabajo familiar (al que incorporaban un par de asalariados temporarios al momento de la cosecha), pero que, como veremos en el siguiente apartado, gracias a las maquinarias podían trabajar importantes extensiones. Por otro lado, unidades también basadas en el trabajo familiar pero con un nivel de mecanización más básico y que debían recurrir a contratistas para la cosecha y/o la trilla. Por último, en los dos extremos de las unidades familiares encontramos pequeñas unidades que trataban de realizar la mayor parte de las labores sin contratar nunca asalariados, y explotaciones basadas en la mano de obra familiar pero a la que agregaban un par de peones permanentes, y a veces algunos temporarios, y que con niveles de mecanización muy significativos, desarrollaban la agricultura en grandes extensiones.

Para poder comprender la simultaneidad del predominio de las unidades familiares en un contexto de explotaciones con importantes extensiones ${ }^{53}$, es que debemos analizar con detalle el proceso de mecanización que se había desarrollado en la agricultura pampeana desde fines del siglo XIX, prestando especial atención a su incidencia en la organización social del trabajo. Si bien el siguiente apartado puede resultar un tanto detallista en la descripción de las maquinarias, consideramos que resulta imprescindible para, por un lado, desterrar ciertas imagenes de un agro escasamente mecanizado y con productores cuasi-campesinos, y por el otro, para resaltar el impacto, sobre las formas sociales de producción, de la difusión de la

\footnotetext{
${ }^{52}$ Sumando el $38 \%$ sin asalariados y el 3\% con asalariados temporarios.

53 Especialmente en la zona sur, pero también en el oeste (donde el $60 \%$ de la superficie agrícola estaba en unidades de más de 200 hectáreas). Incluso el 52\% de la superficie agrícola de la zona norte se encontraba en explotaciones de más de 100 hectáreas.
} 
cosechadora de arrastre en los años veinte y treinta, cuestión un tanto descuidada en la literatura especializada.

\section{4. La mecanización de la agricultura pampeana}

En líneas generales puede afirmarse que la agricultura pampeana se desarrolló desde finales del siglo XIX con un muy alto nivel de mecanización. Aunque se mantuvo la tracción animal, todas las labores fueron rápidamente mecanizadas, con la excepción de la cosecha del maíz. Las enormes extensiones cultivadas (las unidades eran mucho más grandes que las de la mayoría de las otras regiones agrícolas del planeta) y la escasez de brazos determinaron que fuera no sólo costoso sino materialmente imposible realizar las labores de modo manual, tal como lo analizara Sartelli (1997).

A continuación describimos la mecanización en cada una de las diferentes labores. 


\section{Roturación y siembra}

En cuanto a las labores de roturación, en la región pampeana, desde fines del siglo XIX asistimos a un reemplazo del arado de mancera tirado por bueyes, por el arado de asiento con dos rejas impulsado por caballos ${ }^{54}$. Esta transformación en la técnica de roturación redujo el requerimiento de trabajo de 4,9 días/hombre por hectárea en 1872, a sólo 0,6 días/hombre en 1904 (según estimaciones realizadas por Frank, 1970). Además, en la década del veinte encontramos una incipiente incorporación de tractores (la arada con tractores y cuatro rejas reducía el tiempo de arada de una hectárea a 1,5 horas, según Coscia y Cacciamani, 1978: 9). Algunos de estos tractores, que tenían ruedas de metal, eran adquiridos solos y otros venían con las trilladoras nuevas (a kerosene) que unos pocos productores compraron en los años veinte. Según los testimonios que hemos recogido, los tractores resultaron poco eficaces ya que se rompían muy frecuentemente y por lo tanto su difusión fue escasa hasta la década del cuarenta. Sin embargo, tampoco debe inferirse que los tractores eran tan extraños en el agro pampeano, especialmente en algunas zonas. Por ejemplo, en 1928, en Tres Arroyos había un tractor cada cinco explotaciones según nuestros cálculos basados en el registro de la editorial Kraft (1929) ${ }^{55}$. Pero en el conjunto de la provincia de Buenos Aires sólo había en 19378.481 tractores ubicados en 7.698 explotaciones. Frente a un total de 108.649 explotaciones en la provincia, tenemos que sólo el 7\% de los establecimientos estaban tractorizados, con un promedio de 1,1 tractores en cada uno de ellos.

En cuanto a la siembra, en un primer momento se sembraba "a maleta" (con una bolsa desde arriba del caballo), pero rápidamente se introdujo el uso de las sembradoras tiradas por caballos.

\section{La cosecha fina}

54 Entre nuestros entrevistados, muchos recordaban que sus padres o abuelos comentaban que a fines del siglo pasado y principios de éste se araba con arados de mancera, o al menos esta era la herramienta con que comenzaban las labores los que recién se insertaban en la producción agrícola de la zona. El uso de los arados de dos rejas con asientos aparece en nuestros relatos hacia la década del diez y algo más tarde el empleo de los de tres rejas.

55 Hemos acotado el análisis cuantitativo de la información consignada en esta fuente a los productores con explotaciones mayores de 50 hectáreas y menores de 3.000 , debido a que sólo en esta escala parece poseer representatividad del conjunto de los productores del Partido. Por razones de espacio no podemos explicitar aquí nuestro análisis de la representatividad del relevamiento efectuado por la editorial Kraft. El mismo se encuentra en Balsa (1994a). 
En el caso de la cosecha de los cereales finos, las actividades de segado y de trilla evidenciaron importantes progresos en las primeras décadas del siglo XX. Cabe aclarar que prácticamente desde el comienzo de la expansión agrícola estas actividades se realizaron de forma mecánica ${ }^{56}$. Según las estimaciones de Frank (1970: 4) se requerían ocho días de trabajo con hoz o cuatro con guadaña para segar una hectárea de trigo. En cambio, una segadora cortaba cuatro hectáreas en un sólo día. Por lo tanto, desde fines del siglo XIX se segaba estos cereales con una segadora ${ }^{57}$. En torno al cambio de siglo, se las reemplazó por las espigadoras ${ }^{58}$ que poseían un elevador que depositaba el cereal en una chata que la seguía al costado (Frank, 1970: 7) ${ }^{59}$. Tanto en las entrevistas como en Miatello (1904) se describe la presencia de siete trabajadores en torno a la espigadora ${ }^{60}$. Otra modificación de las actividades de segado ocurrió con la introducción de las atadoras, que incorporaban un sistema automático de atado en gavillas del cereal ${ }^{61}$.

56 Incluso Adelman (quien evalúa la mecanización agrícola existente hasta 1914 como atrasada en relación con Canadá) opina que en las máquinas para cosechar el trigo no existía este atraso (Adelman, 1989: 440-447).

57 Estas máquinas cortaban al cereal y lo iban tirando al costado, excepto que se les adosase una plataforma donde varios peones fueran cosiendo gavillas. Luego se lo recogía y llevaba con rastras hasta donde estaba, o iba a estar, la trilladora.

58 Las espigadoras también eran denominadas cortadoras Tanto los productores entrevistados, como Estancias y chacras (Kraft, 1929) utilizan esta denominación para las máquinas de segado que no ataban al cereal ni lo trillaban. El término resulta ajeno a la bibliografía de la época. Podemos suponer que se debería referir a las espigadoras, ya que su difusión, según los relatos, fue posterior a la primera década de nuestro siglo.

59 Las espigadoras tenían una cuchilla más ancha que las segadoras y que, además, recogía sólo las espigas de trigo.

${ }^{60}$ Estas máquinas requerían de un sólo hombre que las condujese y de seis a diez caballos que la propulsasen según el tamaño de su plataforma de corte. Pero además se necesitaban unos tres chateros y un pistín para transportar el cereal, además de un emparvador y un ayudante, ya que, por lo general, en espera de la llegada de la trilladora se emparvaba el cereal para evitar los efectos de las inclemencias climáticas. Seguramente, en explotaciones de dimensiones reducidas, algunas de estas labores podían escalonarse en el tiempo, reduciendo la cantidad de hombre necesarios.

${ }^{61}$ En general iban dos hombres en esta máquina: un conductor adelante y uno atrás para que atara manualmente por si fallaba el sistema de atado (el "pajarito"). Se necesitaban, además, dos peones para llevar las gavillas con rastras, dos amontonadores, un horquillero y un emparvador. 
Por su parte, si bien en un comienzo se utilizó la trilla "a pata de yegua" (Frank, 1970), hacia fines de siglo las trilladoras a vapor se impusieron definitivamente. En un principio eran trasladadas con bueyes pero ya en este siglo eran autopropulsadas por su motor. Se instalaban en un lugar del campo y trillaban todo el cereal que, por lo tanto, había que llevarlo hasta allí ${ }^{62}$. Estas enormes máquinas requerían del trabajo duro y constante de alrededor de 20 a 25 hombres. Se necesitaban varios carros para transportar el cereal hasta la trilladora, es así que se veía avanzar por los campos pequeñas formaciones que, como trenes, eran impulsadas por el motor a vapor y avanzaban a paso de hombre.

Durante la década del veinte aparecieron trilladoras más chicas y a kerosene. Estas requerían de siete a once personas y su tractor era utilizable en la tracción de herramientas agrícolas (arados, atadoras, etc.). Era móvil, así que no se emparvaba sino que se trasladaba la trilladora hasta donde estaba el cereal en pequeños montículos. Sin embargo, este modelo de trilladora tuvo escasa difusión, ya que, como veremos, en esa misma década se extendió el uso de la cosechadora.

Luego de la trilla, de la que salía el cereal embolsado, el último paso era, o bien apilar el cereal en los galpones, o transportarlo hasta la estación ${ }^{63}$. Según la importancia económica de los agricultores era el tamaño de sus galpones. Para los trabajos de acomodar las bolsas dentro de ellos se contaba con la mano de obra asalariada contratada para la cosecha. Aquellos medianos chacareros que poseían galpones trataban de realizar esta labor con sus hijos y ahorrarse el gasto de los salarios, sobre todo si la cosecha no había sido buena.

62 La trilladora constaba de un motor a vapor, con una caldera calentada a paja, y de la trilladora propiamente dicha, a la que el motor transmitía su fuerza a través de una cinta. Dos elementos la perfeccionaron: un tubo de salida que directamente formaba las eras con la paja (antes había que hacerlas manualmente) y un embocador que ahorraba mano de obra (inventado, según los entrevistados, en Tres Arroyos).

${ }_{63}$ El transporte hasta la estación se hacía en carros o, excepcionalmente y hacia finales de la década del veinte, en camiones. Si la distancia a la estación era pequeña, muchos agricultores realizaban el traslado personalmente. Si en cambio estaba más distante o carecía de carros, lo hacía un carrero. Los carros eran grandes, transportaban 120 a 180 bolsas. Algunos grandes productores habían adquirido camiones para realizar esta tarea. 
Este desarrollo tecnológico se correspondió con modificaciones en la organización social del trabajo. En un primer momento, la agricultura se desenvolvió en base a medieros (o "medianeros") y encargados asalariados alentados o contratados por mayordomos, administradores, terratenientes ganaderos, almaceneros o agricultores connacionales. El que así comenzaba utilizaba herramientas de escasísimo costo (muchas de ellas facilitadas por el que otorgaba el campo): se roturaba con arado de mancera o de una reja, se sembraba a maleta y se segaba con una segadora. Había muy pocas trilladoras en cada partido y había que esperarlas, por lo tanto se emparvaba inevitablemente. Las extensiones cultivadas eran pequeñas, de 50 o 100 hectáreas en la zona sur e incluso menores en el norte y el oeste, y se realizaban las labores con la mano de obra familiar, con excepción del trillado que lo realizaba un contratista con asalariados al que se le pagaba por bolsa y en dinero.

A medida que la agricultura se extendió y los medieros se convirtieron en arrendatarios y se capitalizaron, el proceso de mecanización se incrementó. Los agricultores poseían ahora arados de una o dos rejas, sembradoras y atadoras. Extendieron progresivamente la superficie cultivada hasta las 200-400 hectáreas (especialmente, en la zona sur) e incorporaron algún asalariado para la arada (sobre todo si sus hijos eran todavía pequeños ${ }^{64}$ ) y otros más para la cosecha. La actividad de trillado continuaban realizándola equipos de contratistas externos, con excepción de las chacras o estancias que poseían sus propias trilladoras.

Pero la transformación social más significativa en relación con la cosecha se dio al incorporarse las cosechadoras: una misma máquina segaba y trillaba el cereal en una sola operación.

64 En la zona sur, al menos, muchos de los inmigrantes llegaron con una edad de 15 a 25 años entre 1905 a 1920. Por lo tanto sus hijos tuvieron 15 años recién durante la década del veinte o del treinta. 


\section{La incorporación de las cosechadoras de arrastre}

En las décadas del diez y comienzos del veinte, algunos pocos agricultores habían adquirido cosechadoras australianas, también denominadas "golondrinas", pero estas máquinas presentaron una serie de inconvenientes técnicos y tuvieron poca aceptación ${ }^{65}$.

Fue en la década del veinte cuando se expandió el uso de las cosechadoras o máquinas de corta-trilla, en las que el trillado lo hacía un cilindro impulsado por un motor a nafta o kerosene ${ }^{66}$. Estas máquinas requerían de tres a cuatro personas. Además, se necesitaban dos carreros y, por lo general, también trabajaban dos hombres más para acarrear las bolsas hasta el galpón, pero esta labor la podían realizar después los mismos que manejaban la cosechadora (dependía de la calidad de la cosecha y la extensión cosechada).

Una cosechadora mediana cosechaba unas quince a veinte hectáreas por día (según el tamaño de la cuchilla), y llegaban a cosechar unas 200 a 300 hectáreas por cosecha, ya que los diferentes cereales y el lino tenían fechas de maduración distintas y los productores diversificaban sus cultivos ${ }^{67}$. También era común que se combinase el uso de cortadoras o atadoras (con el sistema de atado desactivado) para segar el cereal sino se hacía a tiempo con la cosechadora. Luego se trillaba con la cosechadora fija, si

${ }_{65}$ Impulsadas por caballos, tenían una gran rueda con un engranaje que trasmitía de este modo la fuerza de avance de la cosechadora a dos planchas que iban trillando el cereal. El grano era enviado a un pequeño cajón, de la capacidad de unas tres bolsas, que periódicamente se debía descargar a una chata. Su sistema de corte era similar a las actuales cuchillas para maíz, y presentaba el problema de que arrancaba las plantas si la tierra estaba húmeda. Además, tenían reiteradas fallas en el mecanismo de trillado.

66 La propulsión de la máquina seguía siendo a caballos, (de diez a catorce según el tamaño de la cuchilla), excepto unos pocos productores que poseían tractor. El cereal era transportado por unas lonas desde la cuchilla (que era similar a la de las cortadoras o atadoras) hasta el sistema de trillado.

67 Según nuestros cálculos basados en los datos relevados por la editorial Kraft (1929), la explotación promedio de Tres Arroyos en 1928 tenía el 77\% de la superficie cultivada, restando un $23 \%$ para ganadería, sin obviar que parte de los cultivos deberían ser usados como forrajes. De la superficie total del establecimiento promedio, un $40 \%$ era sembrado con trigo, un $19 \%$ con avena, un $7 \%$ con cebadas, un $4 \%$ con lino y el resto con otros cultivos. El porcentaje de la superficie total sembrada con trigo era bastante estable entre los distintos tamaños de explotaciones y formas de tenencia del suelo (oscilando entre el $47 \%$ y el $26 \%$ ). De este modo si una cosechadora de tamaño mediano cosechaba unas 135 hectáreas de trigo, la diversificación de los cultivos aumentaba su superficie de trabajo hasta unas 245 hectáreas cultivadas. 
se había agrupado el cereal, o con un dispositivo recolector, si se lo había dejado en hileras en el campo. Esta combinación con la cortadora era necesaria ya que la cosechadora requería que el cereal estuviera maduro y seco, dos cualidades que no siempre se encontraban unidas. Además, al estar maduro, el grano corría el riesgo de caerse. Por estos motivos surgieron voces críticas a la expansión de las cosechadoras ${ }^{68}$.

Sin embargo, a pesar de cierta resistencia de algunos productores adeptos de la trilladora, las cosechadoras tuvieron una rápida difusión durante la década del veinte. La incorporación de la cosechadora transformó sustancialmente la organización social del trabajo agrícola en la zona, con claros beneficios para el agricultor. Por un lado, este cambio significó lograr un total control del proceso productivo (ya que no debía recurrir más al contratista de trillado). Al mismo tiempo, permitió una sustancial reducción de los requerimientos de fuerza de trabajo asalariada, la mano de obra familiar con alguna ayuda asalariada en el momento de la cosecha (dos a cuatro peones) podía realizar todas las labores, al menos en explotaciones de hasta 300 hectáreas (con algo más de 200 hectáreas cultivadas); y hasta las 600 hectáreas, la importancia de la fuerza de trabajo doméstica no era nada despreciable. Y, en tercer término, todo esto significaba importantes ahorros para el chacarero.

En cuanto a la primera cuestión, podemos recordar la subordinación en que, según varios autores, se hallaba el agricultor frente al contratista de trillado, muchas veces asociado al dueño del campo. En segundo lugar, la capacidad de realizar la cosecha con la mano de obra familiar lo liberaba al productor de los inconvenientes que podían surgir respecto de la contratación de asalariados. Bórea, de la Dirección de Economía Rural y Estadística, opinaba que "...Si la familia del agricultor es numerosa, [con una cosechadora] el jefe y dos o más hijos ejecutan ellos mismos casi todos los trabajos referentes a la cosecha, reduciendo pues, al mínimo el número de asalariados. Si las pretensiones de los jornaleros aumentaran excesivamente sería ésta la causa principal de la difusión de las cosechadoras, pues el agricultor que, en general, es jefe

${ }_{68}$ Muchos productores preferían continuar con el sistema de segado con cortadoras o atadoras y luego trillar con trilladoras cuando el cereal estuviera seco y maduro. En la encuesta que elaboró en 1925 la oficina de Ingeniería Rural del Ministerio de Agricultura de la Nación se encuentran variados testimonios de ingenieros agrónomos, molineros y cerealistas en contra de la difusión de la cosechadora, y todos ellos giran en torno a la menor calidad del trigo por ella cosechado (M.A.N., 1925). 
de una familia numerosa, haría todo lo posible para cosechar con la espigadoratrilladora con el intento de eliminar los asalariados, y al fin ser completamente libres para el corte y la trilla de las semillas finas" (M.A.N., 1925). Una de las causas que pudo haber acelerado su expansión, fueron los graves problemas que las huelgas de los asalariados rurales plantearon a la seguridad de las cosechas para finales de la década del diez. La huelga de Diciembre de 1919, dirigida por la anarquista Unión de Trabajadores Agrícolas (de tendencia pro-bolchevique, dentro de la FORA V Congreso), fue de particular importancia en la zona sur ${ }^{69}$.

En tercer lugar, el ahorro concreto que lograba un productor con una cosechadora era muy importante. Según nuestras estimaciones realizadas a partir de los datos elaborados por la oficina de Ingeniería Rural del Ministerio de Agricultura de la Nación, las erogaciones efectuadas por el productor se reducían a un menos de un tercio de las que realizaban con la combinación espigadora-trilladora o atadora-trilladora ${ }^{70}$.

Al mismo tiempo, si bien era una maquinaria costosa, según los testimonios recogidos en Tres Arroyos, la compra la realizaban con el saldo de una buena cosecha o a cuenta de la próxima. Del análisis de los ingresos de los productores agrícolas ${ }^{71}$ podemos observar que la erogación de la compra de una cosechadora era menor que los ingresos netos anuales de una explotación de 500 hectáreas. Muchas veces, el ahorro

69 Para mayores referencias ver Ascolani y Sartelli (1990)

70 Los cálculos del M.A.N. estimaban que en las cosechas 1923/24 y 1924/25 en la zona Sur de Buenos Aires los costos de producción de un quintal de trigo eran de $\$ 3,70$ si se hacía con espigadora propia y trillaba un contratista, $\$ 4$ si se usaba una espigadora-atadora y trillaba un contratista, y $\$ 2,68$ si se usaba una cosechadora propia (M.A.N., 1925). Pero estos cálculos incluyen tanto los gastos de amortización del capital invertido como sus intereses, y también computan los salarios del total de los trabajadores (incluyendo los que normalmente eran el productor y miembros de su familia), sus gastos de alimentación y los gastos de alimentación de los caballos. Si excluimos estos gastos y dejamos tan sólo las erogaciones que efectivamente el productor debía abonar (repuestos, reparaciones, lubricantes, combustible, hilo, salarios y gastos de trilla) podemos observar una diferencia aun mayor entre la realización de la cosecha con espigadora o atadora y trilladora o con cosechadora: $\$ 1,91, \$$ 2,20 y $\$ 0,62$ el quintal respectivamente.

71 Hemos estimado los ingresos netos en efectivo (ingresos brutos menos gastos en efectivamente pagados) anuales medios durante la década del veinte de un agricultor que sembrase 450 hectáreas de trigo en Tres Arroyos en unos $\$ 10.500$. Aun descontando unos $\$ 2.000$ de gastos de mantenimiento de la familia, le restarían $\$ 8.500$. Para mayores detalles ver Balsa (1994a: 49-58). 
que en una sola cosecha obtenía por el cambio de sistema era equivalente al valor de la cosechadora $^{72}$.

Además, la cosechadora les permitía obtener importantes ingresos extra, ya que era común que salieran con ella a realizar trabajos extraprediales. Algunos chacareros luego de cosechar su campo salían con su cosechadora a trabajar parcelas de vecinos.

Por lo tanto, a medida que sus hijos iban entrando en edad de trabajar (alrededor de los 14 años) la mayoría de los productores intentaba adquirir una cosechadora.

Otra consecuencia de la difusión de las cosechadoras que señala un ingeniero agrónomo de La Pampa fue la generalización de los arriendos en dinero, ya que la percepción del porcentaje por parte del terrateniente no podía ser controlada tan fácilmente como cuando mediaba un contratista de trillado impuesto por este último (M.A.N., 1925: 19).

Solberg (1987) había señalado la sorprendentemente rápida adopción de la cosechadora que tuvo lugar en la década del veinte. Explica este fenómeno por el interés que los chacareros pampeanos poseían en incorporar tecnología ahorradora de mano de obra para disminuir el alto costo de la cosecha y las huelgas que a veces las interrumpían. Según consigna Solberg, hacia 1930 existían 28.656 cosechadoras en la Argentina (todas ellas de origen importado) y para 1939 había 42.729. Para este autor, lo singular de este proceso fue que los productores que las adquirieron eran en su gran mayoría arrendatarios.

Los años veinte, especialmente a partir de 1923 fue el momento de mayor adquisición de estas maquinarias, interrumpiéndose el proceso con la crisis de comienzos de los treinta, para volver a incrementarse al ir mejorando la situación a partir de mediados de esta década. Este fenómeno lo hemos podido observar analizando las cifras de importación de cosechadoras ${ }^{73}$, pero también a través de las entrevistas

72 Según nuestras estimaciones, un productor que tuviera 450 hectáreas sembradas (vamos a suponer, para simplificar el cálculo, que fuera todo trigo), ahorraba por el cambio de un sistema al otro entre $\$ 3.600$ y $\$ 4.700$ por cosecha, por pasar de la espigadora o la atadora respectivamente (si utilizamos los costos tal como los estima el M.A.N.) y $\$ 4.600$ o $\$ 5.700$ (si tomamos las erogaciones en dinero).

\section{Importación de cosechadoras en Argentina.}

AñosNúmero de cosechadoras importadasAñosNúmero de cosechadoras importadas19193711931s/d192079719321761921151219337192269319344971923275219351500 
realizadas a los productores de Tres Arroyos ${ }^{74}$. Estas series, por otra parte, nos permiten verificar, tal como lo señala la bibliografía (CEPAL, 1959; Giberti, 1964 y Tort, 1980), que con la crisis se detuvo abruptamente la intensa adquisición de maquinaria agrícola que había tenido lugar en los últimos años de la década del veinte. Pero este corte no afectó demasiado a la producción agrícola, ya que los productores contaban con un abundante y casi nuevo parque de maquinaria. La no reposición de la maquinaria agrícola sería una de las estrategias que habría permitido a muchos productores continuar con las labores, como sostiene Villarruel (1988), sin tener en cuenta los gastos de amortización, o el ahorro necesario para adquirir una nueva máquina.

En cuanto a su distribución geográfica, la difusión de la cosechadora pareciera concentrarse en la zona Sur de la provincia de Buenos Aires. La encuesta elaborada por la oficina de Ingeniería Rural destaca a esta zona como el área en la que predominan ya para mediados de la década del veinte la cosecha con cosechadoras ( $70 \%$ de la actividad se realizaría con estas máquinas), y los comentarios en esta publicación consignan que por varios motivos (los salario más elevados, el clima más seco, sin rocíos que impidan trabajar por la mañana) era la zona óptima para su empleo (M.A.N., 1925). Síntoma de lo rápido de la difusión de la cosechadora en la zona sur, es que de los 589 productores de Tres Arroyos de los que tenemos información completa para 1928, 302 tenían una o más cosechadoras. El promedio era de 0,66 cosechadoras por productor. Si agregamos los productores que poseían su propia trilladora (125), observamos que el $67 \%$ de los productores contaban con algún sistema de trillado propio (cosechadora o trilladora o ambas). Además, si reducimos el análisis a los productores con explotaciones mayores a las 150 hectáreas este último porcentaje se eleva al $75 \%$.

$1924771219365801925135219371443192645651938321219275033193923421928 \mathrm{~s} / \mathrm{d} 1940109819$ 29s/d19416019302011Fuente: Boletín del Comercio Exterior Argentino. Dirección Nacional de Estadísticas y Censos.

\section{${ }^{74}$ Cosechadoras compradas por productores medios de Tres Arroyos.}

$\mathrm{n}^{\circ}$ de cosechadoras compradasn ${ }^{\circ}$ de productores que adoptaron la cosechadoraantes $1924 \quad 321924$ $\begin{array}{llllllllll}111925 & 521926 & 321926 & 111928 & 531929 & 3-1930 & --1931 & 111932 & 1-1933 & 1-1934\end{array}$ 1-1935 211936-37 64Fuente: entrevistas realizadas a viejos productores de Tres Arroyos. 
Socialmente, hemos podido observar que fueron los productores medios quiénes más rápido la adoptaron, tal vez porque los grandes ya contaban con máquinas trilladoras propias. En el partido de Tres Arroyos, en el año 1928, más de la mitad de las cosechadoras estaban en manos de arrendatarios de 150 a 600 hectáreas de extensión. A través de esta misma fuente podemos analizar la mecanización de los distintos tipos de productores $^{75}$.

\section{La cosecha del maíz}

Para finalizar con esta descripción del desarrollo tecnológico, debemos hacer una referencia a la actividad que menos transformaciones presentó durante este período: la cosecha del maíz. Las características de esta labor permanecieron inalteradas hasta mediados del siglo XX por una combinación, no del todo analizada ${ }^{76}$, de dificultades técnicas, disposición de relativamente abundante mano de obra familiar en explotaciones de dimensiones más reducidas que las de la zona triguera, y productores con menor solvencia económica para encarar la mecanización. Sin embargo, las dificultades técnicas no deben haber sido menores ${ }^{77}$.

75 En el siguiente cuadro puede observarse la cantidad de máquinas promedio para cada tipo de productores. Un análisis detallado de las características de los distintos tipos de productores, se encuentra en Balsa (1994a).

\section{Número de máquinas por productor}

\section{Arrendatarios}

ProductoresTrilladorasCosechadorasCortadorasAtadoras50-149 ha. $51.02 .29 .61 .10150-299$ ha. 134.06.66.75.18300-599 ha. 169.21.711.36.17600-999 ha. 53.51.871.98.261000-2999 ha.

\section{Propietarios*} 25.681.402.16.30

ProductoresTrilladorasCosechadorasCortadorasAtadoras50-149 ha. $\quad 35.03 .22 .53 .09150-299$ ha. 38.14.45.90.17300-599 ha. 35.19.631.48.15600-999 ha. 29.47.81.86.711000-2999 ha. 20.75.802.65.55* (incluye propietarios que además toman tierras en arriendo)

Fuente: elaboración propia en base a Kraft (1929).

76 Tal vez el intento más sistemático de abordar esta cuestión es el artículo de Sartelli (1993) dedicado, justamente, a la cosecha maicera.

77 Cabe consignar que en los Estados Unidos la mecanización de la cosecha del maíz recién ocurrió, en gran escala, a partir de 1945. 
La recolección del maíz se realizaba a mano con una aguja "chalera" y la espiga (ya deschalada) se arrojaba en una bolsa ubicada entre las piernas, denominada "maleta". Se requería el trabajo de un hombre durante 45 horas para cosechar una hectárea de maíz. Luego se recogían las bolsas, se entrojaba el maíz a la espera de la llegada de la desgranadora (una trilladora reformada para desgranar el maíz).

No hemos podido obtener información precisa sobre la organización social de la cosecha del maíz en las explotaciones de la zona norte. Por un lado, Boglich (1937) sostiene que sólo las unidades con menos de 10 hectáreas no hacían uso de mano de obra asalariada para la recolección, bastándose con la fuerza de trabajo familiar y la ayuda mutua entre vecinos (no queda claro si se refiere a la recolección, o también a las tareas de desgrane, que podían hacerse de modo manual; varios de los testimonios por nosotros recogidos relatan la realización familiar de estas tareas durante el invierno en las explotaciones más pequeñas). Por otro lado, algunos datos nos permiten estimar que un hombre podía cosechar unas 14 hectáreas de maíz en cada cosecha, con un rinde normal o elevado (datos compilados en Billard y otros, 1952). Por lo tanto, las unidades más pequeñas (de alrededor de 50 hectáreas, con unas 40 hectáreas de maíz, por ejemplo) podrían haber realizado la cosecha en base al trabajo del productor y los miembros de su familia ${ }^{78}$.

En Campolieti (1929) hemos encontrado que, al describir una chacra de 85 hectáreas ubicada en Salto, de las cuáles 50 estaban sembradas con maíz, contabiliza un gasto de \$ 2.700 para la cosecha de este cereal. Más adelante, plantea que "hay que restar el costo del trabajo que presta el colono con su familia durante la cosecha. No hay posibilidad de sacar ningún término medio, por cuanto responde a la actividad de cada persona de la familia, que es variable en extremo. Pondremos $\$ 1.000$, lo que ya es mucho". En este caso, podría inferirse que una familia podría cosechar unas 19 hectáreas.

78 Sartelli (1993: 96) arriba a conclusiones relativamente similares cuando afirma que la "la durabilidad del maíz [dentro de la chala] explica la posibilidad del chacarero de realizar con su familia todas las tareas desde la siembra hasta el transporte a la estación ferroviaria. En efecto, había tiempo suficiente para recoger el grano y desgranarlo si el tamaño de la chacra era menor (menos de 50 has.)." 
Entonces, con la excepción de la cosecha del maíz, la intensa mecanización del agro pampeano, a pesar de su incipiente tractorización, había permitido que la fuerza de trabajo familiar estuviera en condiciones de trabajar, sola o con el apoyo de un asalariado permanente y/o algún asalariado transitorio (tal vez un par, si no había hijos jóvenes en la explotación), extensiones realmente importantes si las consideramos en términos de una comparación internacional.

\section{Significación y características de las formas sociales de producción en la agricultura}

Para finalizar esta descripción estructural de la situación existente en 1937, hemos estimado la significación productiva de las diferentes combinaciones entre tenencia y organización social del trabajo, a las que agregamos luego una caracterización de estas formas sociales de producción. Para ello utilizaremos los testimonios orales, información editada, pero también hemos estimado cuáles serían las características (tipo de explotación y tamaño detallado en el censo de $1937^{79}$ ) con real significación en términos productivos de cada una de las tres zonas, dejando de lado las combinaciones de tipo y tamaño de escasa importancia en cada forma productiva ${ }^{80}$.

Al estimar la distribución de la superficie agrícola, observamos que en las tres zonas predominaban los arrendatarios familiares sin asalariados o con uno o dos peones

79 Hemos tenido que trabajar con el supuesto de independencia entre las variables que el Censo no cruzó: tenencia y mano de obra, tenencia y tamaño, y tipo de explotación y mano de obra. En el caso de tamaño y mano de obra, hemos supuesto que las más grandes eran las que contrataban asalariados en forma permanente. Contamos, en cambio, con los cruces entre tenencia y tipo de explotación, y entre tipo y tamaño. Para más detalles, ver el Apéndice 1 (Apartado 1).

80 Así por ejemplo, en la zona norte existían arrendatarios familiares en unidades mixtas de más de 100 hectáreas, pero ocupaban tan sólo el $0.3 \%$ de la superficie agrícola trabajada por arrendatarios o aparceros familiares. Por lo tanto, los hemos ignorado a la hora de describir a los arrendatarios o aparceros familiares de la zona norte. Entonces, en este caso, nos concentramos en las chacras de hasta 100 hectáreas, que en esta zona, ocupaban el $89 \%$ de la superficie agrícola en manos de arrendatarios o aparceros familiares. 
permanentes. Estas formas sociales de producción daban cuenta del $61 \%$ de la agricultura de la zona norte, del $57 \%$ en la zona oeste y del $45 \%$ en la zona sur.

En primer lugar, como se observa en el Gráfico 1.9, los arrendatarios familiares

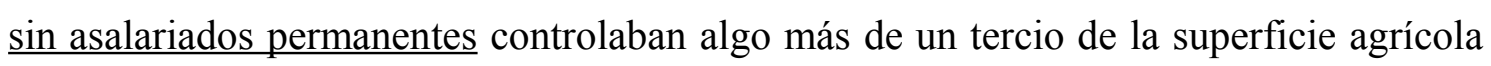
de la zona norte, un poco menos en la zona oeste y un 19\% en la zona sur.

\section{Gráfico 1.9}

Formas sociales de producción Distribución de la superficie agrícola

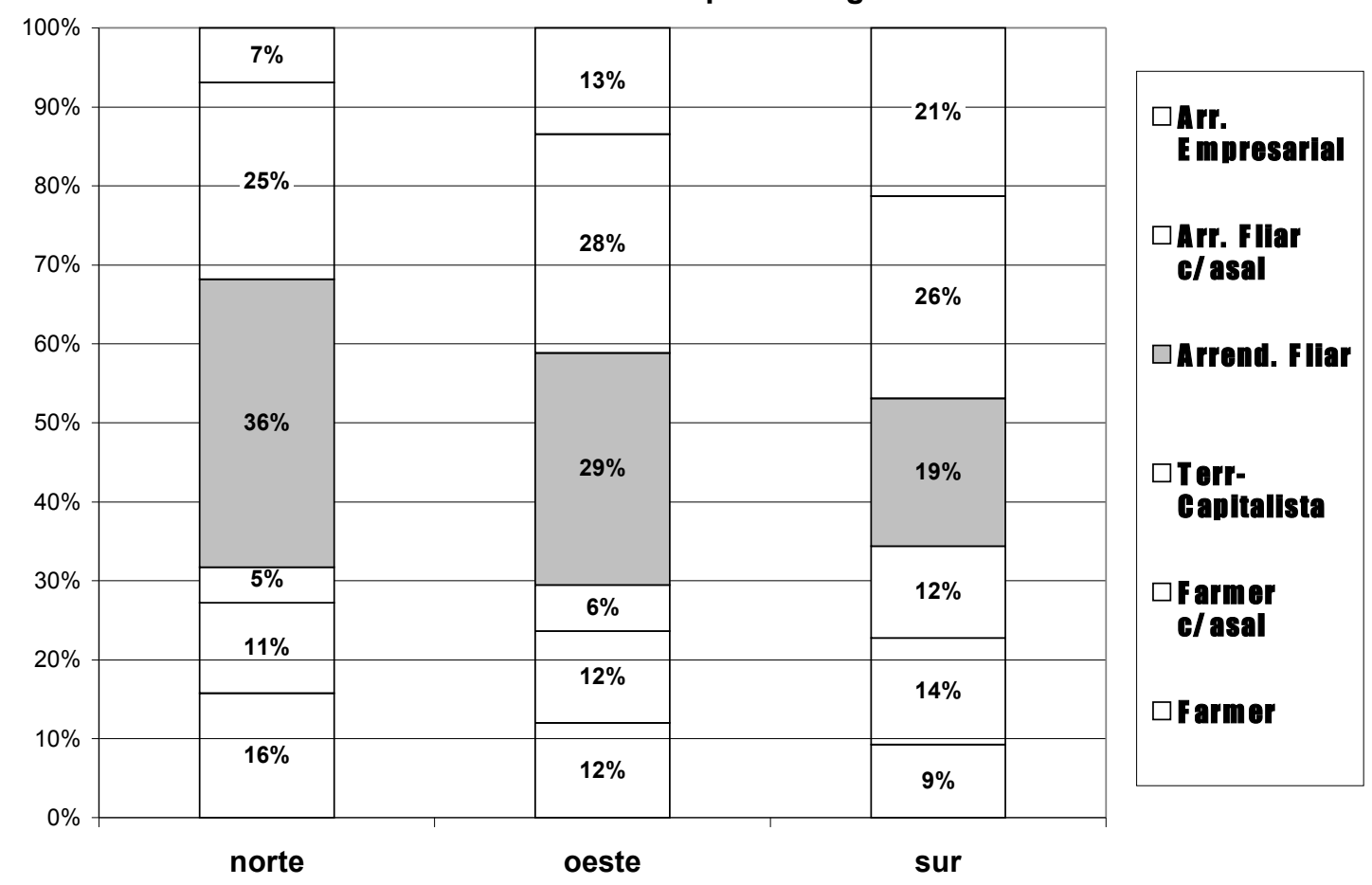

Fuente: estimaciones propias a partir de los datos del Censo Agropecuario de 1937.

Dentro de los arrendatarios sin asalariados encontramos dos sujetos sociales con envergaduras económicas muy diferentes. Por un lado, estaban aquellos a cargo de chacras pequeñas en las zonas norte y oeste (de hasta 100 hectáreas). Contaban con un pequeño capital (unos $\$ 6.000$ estimados como los necesarios para montar una pequeña chacra, Frigerio, 1953: 76), y utilizaban otro tanto -o algo más- para realizar cada cosecha (generalmente a cuenta de la producción final, financiados por el almacén de 
ramos generales). En caso de ser aparceros, no necesitaban ni adelantar parte del alquiler, ni asumían el riesgo de su pago, ya que abonaban con un porcentaje de la cosecha. Como contracara de esta ventaja, el porcentaje que entregaban al propietario solía ser muy elevado. Para las chacras de la zona norte el canon medio pagado para la cosecha 1936/37 había sido del 34,3\%, equivalente al pago de un arriendo de \$ 55 por hectárea, mientras que los arrendatarios pagaban un canon medio de $\$ 33,6$ en el conjunto de la zona norte ${ }^{81}$, según los propios datos censales ${ }^{82}$. Además, según la bibliografía de la época, la relación que se establecía con el terrateniente en los casos de aparcería, habitualmente incluía exacciones de otros tipos. Al respecto, pueden consultarse las descripciones efectuadas por Tenembaum (1946) y las transcripciones de contratos realizadas por Blanco (2001). En este último trabajo se detallan las cláusulas de arriendo de las "colonias agrícolas" de Pergamino, en la primera parte de la década del cuarenta: los cánones son muy altos (del 40\% al 45\% de la cosecha) y se intentaba garantizar que se dispusiera de la mejor parte, para lo cual se reservaba la administración tener prioridad para disponer de la misma y que el arrendatario "no venderá cereales sin autorización escrita de la administración de la colonia". A fin de garantizar esto se estipulaba el control de la trilla por parte de un empleado de la administración. Por otra parte, existían una serie de cláusulas que buscaban garantizar que no se redujera la superficie cosechada ni el rendimiento, pastoreándose con animales: se estipulaba un mínimo de superficie con maíz (75\%), el cultivo más productivo en dicha zona, un máximo de superficie (5\%) para el emplazamiento de la casa-habitación, huerta y pastoreo de animales de trabajo. Es más, si deseaba hacer ganadería (para lo cual estaba legalmente habilitado), debía hacerlo a costa de esta superficie (en evidente violación de lo especificado por la legislación), o se establecía un canon en dinero por el pago del uso ganadero excesivamente elevado; un máximo de

81 En este sentido, no se confirma la opinión de Flichman de que la mayor parte del canon de arriendo tenía como base material la renta diferencial y no las exacciones al factor trabajo o capital, pues el canon pagado por los aparceros casi duplicaba al de los arrendatarios, quienes estarían pagando una renta capitalista.

82 La diferencia era mucho más amplia si el precio del cultivo se elevaba extraordinariamente, como en 1937/38 que llegó a los \$10, representando el canon de aparcería \$ 82 por hectárea. En cambio, en los años de la crisis, con precios del maíz en torno a los $\$ 4$, el maíz entregado por el aparcero valía unos $\$ 32,9$, cercanos al precio del arriendo. Unicamente, si la cosecha, además, le resultaba mala (por factores climáticos o la aparición de plagas), terminaba entregando una cantidad de maíz de un valor muy inferior al costo del arriendo en dinero. 
vacas lecheras (3) cerdos (6) y aves de corral (las necesarias a juicio del administrador). Estas medidas tenían, al mismo tiempo, la finalidad de asegurar que la mano de obra se dedicase exclusivamente al cultivo de la cosecha que sería repartida al final del año. En este sentido se establecían plazos para cada siembra, la obligatoriedad del cuidado contra las malezas. Además, en algunos casos, se establecía la prohibición de trabajar, por sí o con sus máquinas fuera del lote arrendado (contrato firmado en 1944 en Pergamino, citado en Blanco, 2001: 194). También se exigía la contratación de seguros obligatorios contra granizo (con pago por el arrendatario, pero cobro compartido).

Queda el interrogante de la causa de la existencia de estas cláusulas tan severas, que establecían una relación de subordinación al punto de coartar las libertades propias de un productor "capitalista". Tal vez éste podría ser uno de los objetivos latentes, mantener un lazo de subordinación que lo acercasen en tanto mediero, al lugar del trabajador a destajo, que pusieran en acto la relación de poder del terrateniente. Sin embargo, también resulta probable que buena parte de estas medidas tuvieran el objetivo de asegurar que la superficie y el trabajo familiar se dedicaran casi exclusivamente a la producción a compartir, ya que los cánones de arriendo eran en porcentaje de las cosechas. El terrateniente necesitaba que se maximizace la cosecha a repartir, por sobre cualquier otro objetivo, y luego necesitaba medir exactamente el volumen cosechado (amen de que el terrateniente también tratase de captar todo posible ingreso que la situación de inferioridad económica del aparcero le permitía extraerle). Resulta sintomático que en el caso de los contratos en dinero, este tipo de cláusulas fueran mucho más laxas.

Más allá de esta cuestión irresuelta sobre las causas de este tipo de cláusulas en los contratos y del nivel de explotación, resulta claro que la situación económica de estos aparceros, especialmente en el caso de los que tenían unidades de dimensiones muy reducidas, no se diferenciaría sustancialmente de la de los asalariados rurales ${ }^{83}$.

83 La elevada variabilidad de precios y costos hace muy difícil evaluar la real situación económica de los pequeños aparceros y arrendatarios, pero si su capital era de unos $\$ 10.000$, a una tasa de ganancia media en torno al $5 \%$, sus ingresos teóricos serían de $\$ 500$ al año (sin contabilizar los ingresos de su trabajo y el de su familia), mientras que un peón obtenía $\$ 600$ (a $\$ 50$ de ingresos mensuales). 
Por otro lado, estaban los arrendatarios familiares que poseían chacras y unidades mixtas de tamaño medio (100 a 625 hectáreas), más importantes en la zona sur. Según algunas contabilidades privadas que hemos recogido, para encarar una chacra de, por ejemplo, 500 hectáreas, a finales de los años treinta, eran necesarios unos $\$ 25.000$ de inversiones fijas ${ }^{84}$. Además, los contratos de pago en dinero (aunque el canon era más bajo que el equivalente monetario del pago en un porcentaje del producto) establecían el pago a semestre adelantado del arriendo (fecha $1^{\circ}$ de julio) y no tenían la mayoría de las cláusulas que regulaban el tipo de producción que presentaban los contratos a porcentaje de los aparceros de la zona norte ${ }^{85}$. En muchos casos permanecían en un mismo lote por varios contratos (Alvarez y Zeberio, 1991: 78; y Balsa, 1994a: 90-100). Al menos en la zona sur, los arrendatarios no se diferenciaban de los propietarios de similar tamaño ni en sus estrategias productivas ni en sus niveles de mecanización (Zeberio, 1993, y Balsa, 1994a). Pues, como ya hemos comentado en el anterior apartado, estos arrendatarios medianos estaban muy bien mecanizados, contando la mayoría de ellos con cosechadoras de arrastre que les permitían cosechar importantes extensiones con unos pocos trabajadores familiares.

Más allá de estas diferencias económicas, ambos tipos de arrendatarios familiares (pequeños y medianos) articulaban su producción en torno al trabajo físico de los miembros de la familia y compartían una serie de valores y pautas culturales que caracterizaron la vida rural de la expansión agrícola pampeana, y que describiremos en el último apartado del presente capítulo.

Los arrendatarios familiares que contrataban uno o dos asalariados en forma permanente tenían una importancia similar en las tres zonas, concentrando alrededor de un cuarto de la superficie agrícola. En cada zona estaban a cargo de explotaciones de tipo y tamaño diferentes: especialmente de chacras de 100 a 200 hectáreas en la zona norte, de chacras y explotaciones mixtas de 200 a 625 hectáreas en la zona oeste, y

84 En Balsa (1994a) pueden consultarse estimaciones de las posibilidades de reproducción ampliada de los medianos productores de la zona sur de la provincia.

85 Ver por ejemplo, los contratos que analiza Reguera (1993) para Necochea y los de las "colonias agrícolas" de Bolívar y Benito Juárez transcriptos por Blanco (2001: 226-233). 
sobre todo de unidades mixtas de 300 a 625 hectáreas en la zona sur. La organización social del trabajo continuaba siendo centralmente familiar, pero se sumaba la colaboración de uno o dos asalariados permanentes. En casi todos los relatos queda claro que su función era la de auxiliar del productor ${ }^{86}$. En general, en las escalas más pequeñas o mediano-pequeñas, su presencia obedecía más a una carencia de brazos familiares, en general porque los hijos aún eran demasiado jóvenes para realizar las tareas más duras. En muchos testimonios, se ha descripto que una vez que el entrevistado y/o su/s hermano/s fueron mayores, su padre dejó de contratar asalariados en forma permanente.

Estos productores eran, en su mayoría, los hijos de los inmigrantes que, en algunos casos, habían podido salir de la posición de pequeños y pobres agricultores arrendatarios gracias a un "golpe de suerte": una serie de buenas cosechas que les permitían captar una porción de renta diferencial no prevista $\mathrm{y}$, por lo tanto, no computada en el canon de arriendo. Por otra parte, como veremos en el último apartado de este capítulo, los modos de vida de estos arrendatarios no diferían de los que tenían los productores familiares puros.

Por último, dentro de los no propietarios, encontramos a los arrendatarios empresariales, quienes sólo tenían verdadera significación productiva en la zona sur, donde habrían dado cuenta del $21 \%$ de su superficie agrícola (en la zona norte presentaban una importancia marginal, mientras que en el oeste realizaban el 13\% del área cultivada). Estaban constituidos esencialmente por productores a cargo de unidades mixtas de más de 625 hectáreas. Si bien en las entrevistas hemos encontrado casos de muy grandes productores arrendatarios ${ }^{87}$ (con 6.000 hectáreas, por ejemplo), en general cuando alcanzaban cierta escala se inclinaban por la adquisición de, al menos, uno de los campos que trabajaban ${ }^{88}$. En la escala más baja de estos productores (en torno a las 600 hectáreas), la producción se organizaba en torno a cuatro a cinco asalariados

86 En general, se les asignaban las tareas más pesadas, liberando entonces de ellas al productor y/o a sus hijos.

87 Existen muy pocos testimonios sobre las características de estas grandes unidades agrícolas en arriendo. Para el arriendo ganadero en gran escala, ver la biografía de Juan Alberto Harriet (Egusquiza, 1988). 
dirigidos por el productor y sus hijos. Estos, en general, comenzaban de jóvenes trabajando a la par de los peones, pero luego iban asumiendo responsabilidades de control y dirección. Las explotaciones de mayor tamaño utilizaban un número mucho mayor de asalariados y se aproximarían a la forma clásica de capitalista, tanto porque no percibían renta, como porque el trabajo familiar no tendría casi significación en el volumen total de la fuerza de trabajo y poseían personal jerarquizado (Ghorayshi,1986).

Las formas de vida de estos arrendatarios empresariales eran un tanto diferentes de la de los arrendatarios familiares. El vínculo con el pueblo era más estrecho, y en muchos casos, cuando los hijos podían hacerse cargo de la dirección de la explotación, el padre adquiría o alquilaba una casa en la ciudad dónde se retiraba.

Dentro de las formas en propiedad, que como ya dijimos tenían mucho menos importancia en la agricultura que las formas en arriendo, se destacaban los farmers (propietarios sin asalariados permanentes o con uno o dos peones). Ellos daban cuenta de un cuarto de la agricultura de cada una de las zonas (en el Gráfico 1.9 se pueden observar los porcentuales discriminados entre farmers que contrataban asalariados en forma permanente y aquellos que no lo hacían). También estos productores presentaban características diferenciales según las zonas: principalmente estaban a cargo de chacras de hasta 200 hectáreas en la zona norte, de mixtas de 200 a 625 hectáreas en la zona sur, y de un conjunto mucho más heterogéneo de unidades en la zona oeste (chacras de menos de 625 hectáreas y mixtas de 100 a 625 hectáreas). El acceso a la propiedad podía obedecer a distintos procesos. Algunos habían logrado cancelar una adquisición hipotecaria durante los años veinte, antes de que llegara la crisis del treinta. Pero en muchos casos fue posible por radicarse tempranamente en zonas de reciente ocupación, con escasez de agricultores y predominio de ganadería de baja calidad, que mantenía bajos los arriendos, aún cuando la productividad agrícola fuera excelente (proceso que

88 Usualmente, los grandes arrendatarios tomaban un conjunto de parcelas, ya sea porque eran los campos que podían conseguir, ya porque de este modo podrían diversificar riesgos al desarrollar distintos tipos de producciones según la aptitud de los suelos y del clima. 
hemos analizado más en detalle en Balsa, 1993, y también lo han hecho Alvarez y Zeberio, 1991).

Las unidades de las que recogimos información a través de las entrevistas, combinaban el empleo de la fuerza de trabajo del productor y de un familiar, con el auxilio de uno o, eventualmente, dos asalariados. La familia funcionaba como un equipo de producción sin presentar diferencias con las características de los productores no propietarios. Quizás el único punto distinguible era una menor exigencia hacia los hijos. El trabajo infantil aparece en los relatos más como un juego que como una necesidad (como surge en los testimonios de los que eran hijos de aparceros o arrendatarios). Asimismo, varios intentaron enviar a sus hijos a la escuela secundaria, o escuelas de contabilidad, aunque muchos de ellos no se adaptaron a la vida urbana y desearon regresar pronto al campo. Sin embargo, algunos incluso fueron a la Universidad. De modo similar que los grandes arrendatarios, algunos padres cuando se retiraban dejando el campo a sus hijos, se instalaban en una casa en la ciudad.

Si bien la percepción de una renta por la propiedad del campo aún no había cambiado drásticamente la forma de vida de la mayoría de estos productores, ni su organización social del trabajo, lentamente estaba comenzando a modificarlas. El retiro a una vivienda urbana creemos que es el principal indicador de este cambio. Para tener un indicador de cómo podía estar incidiendo la propiedad sobre sus conductas, podemos considerar el peso de la tierra en el conjunto de los bienes de un farmer. Así, por ejemplo, en la zona sur, un farmer con 500 hectáreas tenía un capital en inversiones fijas de unos \$25.000, mientras que sus campos valían unos \$ 92.500 (según el valor promedio de la tierra con aptitud agrícola en los partidos de la zona sur en 1937). En el caso de un propietario de 100 hectáreas de la zona norte, su capital fijo ascendía a unos $\$ 6.000$, mientras que su campo valía unos \$ 41.900 .

Por último, como podemos observar en el Gráfico 1.9, las formas empresariales combinadas con la propiedad de los campos tenían escasa significación en la agricultura. Solo un 5\% de la superficie agrícola de la zona norte y un $6 \%$ de la zona 
oeste estaba a cargo de los que podemos denominar terratenientes-capitalistas. En la zona sur presentaban una importancia mayor, con el 12\% del área agrícola. Somos concientes que incluimos bajo esta conceptualización a productores cuyos campos no siempre era muy extensos, y que la mayoría ocupaban entre tres y cinco asalariados. Por lo cual el término "terrateniente" puede llevar a equívocos. Aquí tan sólo significa dueño de tierra, de una extensión al menos suficiente como para requerir el trabajo de tres o más asalariados, pero esto no lo convertía necesariamente en un gran propietario, podía ser un terrateniente-capitalista pequeño ${ }^{89}$. Eran fundamentalmente productores propietarios de unidades mixtas de más de 625 hectáreas. Nuevamente, surge el problema del límite superior abierto que dejó la edición del censo. Quedan, entonces, dentro de esta categoría dos tipos de productores sustancialmente diferentes (por establecer algún corte arbitrario, ya que lo que encontramos es una gran continuidad ${ }^{90}$ ).

Por un lado, encontramos propietarios de un campo de hasta 1.000 hectáreas que organizaban su explotación en base a un grupo de tres a cinco asalariados permanentes bajo la dirección de su persona o la de sus hijos, quienes muchas veces también asumían la realización de trabajo físico. Presentaban una mayor mercantilización de sus consumos que los farmers, aunque seguían realizando alguna producción para el autoconsumo tanto a cargo de familiares como de asalariados (algún peón viejo, por ejemplo, se encargaba de la quinta). En general, continuaban viviendo en el campo, aunque usualmente alquilaban o compraban una casa en la ciudad para que los hijos pudiera seguir la escuela secundaria, y para retirarse a vivir una vez llegada la vejez.

Por otro lado, existían propietarios de mayores extensiones que tenían al menos un encargado o capataz para organizar las distintas tareas que se realizaban en sus establecimientos, en general hacían agricultura combinada con ganadería en diferentes proporciones $^{91}$.

89 Sobre la conceptualización de este sujeto social agrario, ver Murmis (1979).

90 Así, por ejemplo, los análisis de las unidades de Tres Arroyos descriptas en Kraft (1929), no presentan ningún corte, sino una continuidad en el tamaño de las explotaciones por encima de las 625 hectáreas.

91 En la zona sur, hemos detectado dos grupos al interior de este estrato. Unos eran propietarios de mayor antigüedad en la zona, que luego de iniciarse como ganaderos había ido incluyendo, en las primeras dos décadas del siglo XX, actividades agrícolas en su explotación. Otros, llegado a comienzos del siglo, habían realizado la escalera mediero-arrendatario-propietario 
Excepto, entonces, el caso de los arrendatarios empresariales y los terratenientes-capitalistas (que sumados serían responsables de sólo el 12\% de la superficie agrícola de la zona norte, del 19\% en la oeste y del 33\% en la sur), el trabajo familiar ocupaba un lugar significativo en el conjunto de la mano de obra utilizada en la producción agrícola hacia 1937. Incluso en las explotaciones medianas su importancia resultaba innegable. Este fenómeno se relaciona estrechamente con que la mayoría de los agricultores compartía un modo de vida rural. Sobre todo en los estratos más altos de estos productores medios, resulta obvio que muchas de estas características se mantenían más por tradición cultural que por necesidad económica -aunque frente a la reciente crisis de los años treinta, se habían extremado las estrategias de austeridad y esfuerzo familiar (Balsa, 1994a). En el último apartado abordaremos la cuestión del modo de vida, pero antes intentaremos caracterizar el tipo de desarrollo que habría tomado la agricultura en la provincia de Buenos Aires.

de un modo muy exitoso, y se habían expandido adquiriendo varios campos, poniendo a hijos o yernos a cargo de los mismos. Estos presentaban un perfil mucho más agrícola, aunque también incluían la cría de vacunos y ovinos. Estos terratenientes-capitalistas de mayor tamaño podían vivir en el campo o en la ciudad. En general, los de origen más temprano y orientación principalmente ganadera residían en la ciudad, mientras que los de que presentaban una orientación más agrícola, continuaban viviendo en sus explotaciones (más detalles en Balsa, 1993). 


\section{Las vías de desarrollo de la agricultura bonaerense}

A lo largo del presente capítulo hemos corroborado que, más allá de las especificidades zonales, la mayor parte de la producción agrícola bonaerense estaba en manos de productores no propietarios -arrendatarios o aparceros-. Asimismo, entre ellos predominaban los que organizaban la producción en base a la mano de obra familiar, con o sin el auxilio de uno o dos asalariados permanentes. Esta caracterización podría dar la impresión que ha sido correcta la "imagen tradicional" de un agro pampeano en el cual la agricultura estaba en manos de pequeños y pobres agricultores dominados por grandes terratenientes que los utilizaban para obtener pasturas para sus campos. Sin embargo, consideramos necesario formular una serie de aclaraciones, acerca de qué significaba este predominio de las formas familiares en arriendo. Aclaraciones que delinean una caracterización de la agricultura de la región con notorias diferencias frente a esta "imagen tradicional", pero que no implican adherir a la postura opuesta que negó el peso del latifundio y las limitaciones que implicó en las posibilidades de acumulación y de desarrollo social de los agricultores pampeanos.

En primer lugar, no siempre la agricultura se presentaba subordinada a la dinámica ganadera, ni todas las chacras eran dependientes de las estancias. Como hemos visto, de las tres zonas estudiadas, tan sólo en el Oeste resulta clara la dependencia entre actividades, pero incluso allí alrededor de la mitad de la agricultura no se realizaba en chacras sino en unidades mixtas. En estas explotaciones, la relación agricultura/ganadería era internalizada por un mismo productor. Este tipo de explotaciones predominaba claramente en la agricultura de la zona sur. Y, si en la zona norte, esta actividad estaba localizada en las chacras, aquí la ganadería se restringía a los campos sin aptitud agrícola, por lo cual tampoco era importante la rotación sistemática de los agricultores para preparar los campos a la ganadería. Esto no significa que los agricultores no estuvieran subordinados a los terratenientes, pero lo estaban sobre todo por su carácter de dueños de la tierra, más que por el perfil ganadero que tenían algunos de ellos. Resulta claro que era mucho más importante la conducta rentística de los grandes terratenientes que su interés por vincular a los agricultores a las actividades 
ganaderas que ellos podían realizar Esto ocurría tanto en las áreas dónde era notoria la aptitud agrícola de los suelos (zona norte), como en áreas mixtas (zona sur).

En segundo lugar, corresponde aclarar que el carácter familiar tampoco debe interpretarse como sinónimo de pequeña explotación escasamente capitalizada. Esta podía ser la característica de la mayoría de las unidades de la zona norte ${ }^{92}$, y de una porción de las de la zona oeste, pero claramente no era la realidad de la zona sur. Aquí la mecanización había expandido notoriamente las capacidades de trabajo de la mano de obra familiar. Entonces, casi la totalidad de la superficie agrícola de las unidades familiares de la zona sur (aproximadamente, el 84\%) estaba en manos de productores a cargo de campos de 100 a 625 hectáreas (la mayoría de los cuales contaba con capacidad de cosecha propia). Además, en la zona oeste la mayoría (58\%) de la superficie a cargo de explotaciones familiares, se ubicaba en unidades de más de 100 hectáreas. Sí debe asociarse el predominio de las formas familiares con la consolidación de un modo de vida rural (cuestión que analizaremos en el siguiente apartado) y con una mentalidad de los productores que buscaba el esfuerzo de todo el grupo familiar en pos del ascenso social, ya sea a través de la expansión en superficie y en maquinarias, ya sea con el acceso -por cierto más difícil- a la propiedad de la tierra.

En relación con la última cuestión mencionada, corresponde realizar una tercera aclaración. El hecho de que predominaran las formas de tenencia en arriendo o en aparcería, no significaba que no se realizara agricultura en campos en propiedad. Según nuestras estimaciones, si bien era pequeña la superficie agrícola desarrollada por los terratenientes-capitalistas ${ }^{93}$, no era tan marginal el lugar jugado por los farmers (alrededor de un cuarto del área agrícola de cada una de las zonas). De todos modos,

92 Aquí el $90 \%$ de la superficie agrícola trabajada por productores que no contrataban asalariados permanentes estaba ubicada en unidades de menos de 100 hectáreas.

93 Salvo excepciones, los terratenientes no encaraban en forma directa la producción agrícola en grandes extensiones, ya que esto hubiera requerido una compleja organización del trabajo y grandes inversiones de capitales, sin claras economías de escala (es más, posiblemente había deseconomías de escala), cuando una conducta meramente rentística aseguraba ingresos por demás elevados. Así, por ejemplo, 20.000 hectáreas en Tres Arroyos, con los precios del arriendo de fines de los años veinte (\$20 la hectárea), le retribuían a un terrateniente (que podemos considerar mediano, en relación con los grandes grupos que concentraban más de 100.000 hectáreas cada uno) un ingreso de $\$ 400.000$ al año. Una cifra que permitía acceder a todo tipo de lujos y que, por su carácter de renta del suelo, podía ser gastada por entero, ya que no se requería ningún tipo de inversiones para asegurar la continuidad del ciclo productivo, pues todos los gastos estaban a cargo de los arrendatarios. 
resulta claro que la mayoría de la tierra continuaba en manos de los terratenientes y no había sido adquirida por los agricultores, como, por ejemplo, había ocurrido en las praderas norteamericanas. Las causas de la ausencia de ventas fraccionadas es un tema que no ha sido estudiado en profundidad. Por un lado, es claro que para los terratenientes resultaba ventajoso esperar captar toda la valorización de sus campos. Esto es, mientras lo mantenían arrendado, recibían anualmente la renta del suelo, pero también su valorización ${ }^{94}$. Pero esto no significó que no existiera un mercado de tierras importante, en el que entre 1914 y 1929 se vendieron 48 millones de hectáreas en las provincias pampeanas, equivalentes al $80 \%$ de la superficie agropecuaria de la región (Barsky y Pucciarelli, 1991: 380). Tal vez, las dificultades para acceder al crédito hipotecario por parte de pequeños arrendatarios sea el elemento clave de la explicación, tal como lo sostiene Adelman (1989: 140 y 333-355). Pero la situación se agravó por la existencia de un círculo vicioso que hizo que el propio desarrollo agrícola encarnado por estos inmigrantes empujase constantemente el precio de la tierra por encima de sus posibilidades de acumulación ${ }^{95}$. Si algo se había avanzado en el fraccionamiento apoyado en el crédito hipotecario durante los años veinte, la crisis del treinta frenó y deshizo buena parte de este proceso, tal como hemos analizado anteriormente (Balsa, 1994a).

Como respuesta a la pregunta inicial de este capítulo, en torno a la caracterización de la agricultura pampeana, podemos decir que el predominio del arriendo no permite asimilar el caso pampeano al "camino inglés", ya que nuestros

94 El incremento del precio de la tierra parecía ilimitado hasta la crisis del treinta. Según los cálculos de Cortés Conde (1979: 159-176), el valor promedio de ventas de tierras realizadas por la casa Bullrich, pasó de \$13 en 1883 a \$69 en 1903 (deflacionados por los proecios de exportación), a pesar de dejar fuera del análisis a las zonas que al comienzo del período eran consideradas de frontera. Y luego, utilizando los precios registrados por la Dirección General de Ecnomía Rural, estima que en el conjunto de la provincia, subieron de \$44 en 1903 a \$ 128 en 1912. Por su parte, Barsky y Pucciarelli (1991: Cuadro 32) registran un incremento del valor promedio por hectárea en la región pampeana de $\$ 436$ en 1914 a $\$ 772$ en 1929 . Por nuestra parte, en base a la información registrada en Kraft (1929), observamos que en Tres Arroyos el precio de la hectárea subió de unos \$34 en 1895-99, a \$123 para 1905-09, y \$400 en 1925-28.

95 Por ejemplo, en Tres Arroyos, en los últimos años del siglo XIX el valor bruto de la producción de una hectárea de trigo casi duplicaba el precio de compra de esa extensión. En cambio, en 1910-14, esa producción sólo alcanzaba al 40\% del precio de la tierra (Balsa, 1993: 115-117). 
arrendatarios no pueden conceptualizarse como plenamente capitalistas, en tanto que la mayoría aportaba la fuerza de trabajo propia y de los miembros de su familia. Tan sólo un $7 \%$ y un $13 \%$ de la superficie agrícola de las zonas norte y oeste, respectivamente, estaban en manos de explotaciones en arriendo con al menos tres asalariados permanentes. Pero, en la zona sur, donde un $21 \%$ de la agricultura estaba a cargo de arrendatarios capitalistas, el "modelo inglés" habría tenido cierta vigencia.

Por otra parte, el perfil familiar que presentaba la mayoría de los agricultores, no los acercaba a la situación del campesinado parcelario europeo, tanto porque no tenían la propiedad, como porque las extensiones que trabajaban eran muy superiores y su orientación al mercado era total. Tal vez, los medieros más pequeños de las zonas norte y oeste (con lotes de 20 a 50 hectáreas) se asemejasen a estos tipos campesinos por las graves limitaciones en su capacidad de acumulación y su total dependencia del capital comercial. Estos mismos sujetos también permiten evocar la imagen de una vía "junker", en tanto era habitual que estuviesen relegados a los intereses ganaderos de un terrateniente-capitalista que les imponía una serie de limitantes a sus "libertades capitalistas" en los contratos. Pero, en primer lugar, estas cláusulas eran bastante menos rígidas que la fijación a la tierra practicada en Prusia; en segundo lugar, en las zonas agrícolas la mayoría de los terratenientes no tenían un perfil productivo-capitalista orientado hacia la ganadería, sino que cedían sus campos por entero en arriendo; y, por último, era muy reducida la importancia de estos aparceros muy pequeños dentro de la superficie agrícola (excepto, tal vez, en parte de la zona oeste). En cambio, el concepto de una vía "junker", en un sentido amplio, resulta más fructífero para describir la producción ganadera. Es claro que esta rama estuvo hegemonizada por la figura del terrateniente que a la vez se hacía cargo de la producción invirtiendo capital y contratando trabajo asalariado. El trabajo de Pucciarelli (1986: capítulo IV) contiene una muy detallada descripción de los distintos tipos de terratenientes-capitalistas y su significación en el desarrollo ganadero entre fines del siglo XIX y comienzos del $\mathrm{XX}^{96}$.

En el caso de la agricultura es la "vía (norte) americana" la que presenta mayores puntos de contacto con el desarrollo pampeano. En ambas regiones, la producción

96 Para el período anterior, en el que todavía tenían alguna significación los ganaderos de tipo familiar, ver Sábato (1989). 
agrícola estaba en manos de productores medianos (en el caso pampeano, de mayor extensión que los de las praderas estadounidenses). Además, orientaban su producción centralmente hacia el mercado, y no hacia la autosubsistencia como los productores campesinos. También eran productores principalmente familiares, aunque en la región pampeana combinando la fuerza de trabajo familiar con asalariados. Asimismo, en ambos casos, estaban muy mecanizados.

La diferencia principal, era la tenencia del suelo. Si bien el arriendo había ido incrementando su importancia en el Corn Belt norteamericano ${ }^{97}$, esta expansión fue producto de las formas de traspaso intergeneracional de las explotaciones (Friedberger, 1988: 48) y no la consecuencia del surgimiento de una clase de grandes terratenientes. La mayor parte de la tierra arrendada era propiedad de personas que vivían en esos campos $^{98}$ o muy cerca de ellos ${ }^{99}$. Los arrendatarios a menudo eran parientes de los arrendadores o, como mínimo, eran sus vecinos (Friedberger, 49). Desde fines del siglo XIX, en el Corn Belt la aparcería y el arrendamiento se habían convertido en parte del ciclo vital, en tanto era el punto de comienzo para un joven productor que la arrendaba a sus familiares o a sus vecinos hasta que podía comprar su propia tierra, en la denominada "escalera agrícola"100. En el caso de la región pampeana, la escalera se

97 En Iowa, por ejemplo, pasaron de ser un 23,8\% de los productores en 1880 a un $49,6 \%$ en 1935 (Murray, 1946: 12 y Yoder, 1997: 463)

98 En un estudio realizado en los trece estados de la North Central Region en 1946, se encontró que el $44 \%$ de los propietarios que cedían toda su tierra en arriendo ("Non-operating landlords") residían en la explotación (Timmons y Barlowe, 1949: 869).

99 Así, por ejemplo, en el centro-este de Illinois a fines de los cincuenta, el $85 \%$ de los "landlords" (arrendadores) vivían a 50 millas de su propiedad arrendada, y tres de cada cuatro eran productores rurales, productores retirados, viudas de productores o habían realizado labores rurales (Reiss, 1961: 55). Así también, el Oeste de Illinois en los años sesenta, el 90\% de los "landlords" vivían dentro de un radio de una hora de manejo de su propiedad (Reiss, 1968: 44).

100 Como lo reseña Wells (1987: 224) esta interpretación a dado lugar a opiniones controvertidas. El arrendamiento fue conceptualizado como un "peldaño" de una "escalera agrícola", que comenzaba con el trabajo en la explotación de los padres durante la adolescencia, continuaba con el trabajo asalariado en otras unidades, y seguía con el arriendo, para terminar con la compra de una parcela en la madurez. Este esquema fue propuesto por primera vez por R.T. Ely en 1917 y tiñó, tal vez de un modo excesivo, la visión del arrendamiento durante buena parte del siglo XX. (Friedberger, 1988: 47-49). Cabe destacar que, según los datos censales de 1920, el 42\% de los productores propietarios habían salteado dos "peldaños", pasando directamente, de trabajar en la explotación familiar, a ser sus dueños (Friedberger, 1988: 49). Además, la crisis del treinta significó un duro golpe para las posibilidades de subir la "escalera". Sin embargo, uno de los estudios realizado en los años 
había cortado, y los aparceros y arrendatarios no parecían presentar, al menos en la mayoría de los casos, vínculos familiares con los propietarios de los campos que tomaban. Aunque siempre existieron pequeños propietarios que, sin hijos a quienes dejar la explotación, arrendaban sus campos al retirarse, y también era común el arriendo realizado de hermanas a hermanos ${ }^{101}$, en general, en las tres zonas estudiadas hemos observado que eran grandes propiedades las que cedían en arriendo pequeños o medianos lotes a muchos productores.

Podemos concluir que el predominio de las formas familiares en arriendo, con las precisiones que hemos enumerado, constituiría una vía particular de desarrollo agrícola, y en tal sentido, podríamos denominarla "vía argentina", o mejor, "vía pampeana" -para no generalizar al resto del país una situación regional-, en tanto se diferencia de las otras vías ya conceptualizadas, aunque combina algunos elementos de cada una de ellas.

Este "camino pampeano" de desarrollo agrícola en un contexto económico capitalista, estaría caracterizado por el predominio de las explotaciones familiares, pero abiertas a la contratación de mano de obra asalariada, ya sea en forma transitoria para los momentos de mayor demanda de trabajo, o de modo permanente (uno o, en todo caso dos peones) tanto porque los hijos del productor eran todavía muy pequeños, o porque había logrado expandirse territorialmente. Pues otra característica de este modelo, es que las unidades tenían extensiones considerables, en comparación con la agricultura cerealera de otros países, y que estos tamaños se fueron incrementando a lo largo de este período, gracias a la mayor disponibilidad de capitales por parte de los arrendatarios más exitosos, y a las posibilidades que la mecanización brindaba para

cuarenta, demostró la vitalidad de la "escalera agrícola", aunque con la presencia de empleos urbanos en sus "peldaños" intermedios. Así, esta investigación encontró que la mitad de los propietarios de Iowa habían realizado la "escalera agrícola" (un $27 \%$ siguiendo todos sus "peldaños", y un 23\% incorporando, además, trabajo no agrícola en el medio de la "escalera"); un 30\% de los propietarios no habría sido ni asalariado agrícola ni arrendatario (había trabajado en la explotación familiar, y eventualmente también en empleos no agrícolas antes de convertirse en propietario) y sólo un $16 \%$ de los propietarios no trabajaron al comienzo en la explotación de sus padres (Strohbehn y Timmons, 1960: 20).

${ }^{101}$ Sobre las estrategias de transmisión y preservación del patrimonio resulta clave el trabajo de Zeberio (1995). 
cultivar superficies cada vez mayores con la misma (o incluso menor) dotación de fuerza de trabajo.

El arriendo en dinero, la forma de tenencia del suelo típica de la agricultura de las zonas oeste y sur de la provincia de Buenos Aires, resultaba particularmente flexible para poder concretar estas expansiones territoriales, aunque la aparcería, característica de la zona norte, tampoco era en sí un obstáculo (a pesar de que las posibilidades de acumulación de los pequeños aparceros estaba seriamente limitada por los excesivos cánones que cobraban los terratenientes y las imposiciones que establecían).

La otra característica del modelo pampeano era que estos arriendos y aparcerías se realizaban sobre campos de grandes propietarios, meramente rentísticos en las zonas norte y sur, y de orientación ganadera en la zona oeste. Especialmente en la zona norte, pero también en el oeste, se generaba una relación de asimetría extremadamente desigual entre terratenientes muy importantes, y arrendatarios y aparceros de escasa capacidad económica.

Esta relación asimétrica, pero sobre todo la ecuación entre oferta y demanda de tierras en cada una de las zonas y en los distintos momentos, determinaron las posibilidades de acumulación de los arrendatarios y aparceros, que fueron muy importantes en la zona sur, donde al comienzo de la expansión agrícola había mucha oferta de tierra para cultivar y poca demanda por parte de agricultores. También esto parece haber ocurrido en la zona oeste hacia 1900, según la descripción de Adelman (1989: 115 y 226). Por lo tanto, no podría establecerse una relación directa entre no propiedad e imposibilidades de acumulación por el peso que la apropiación de la renta imponía a la reinversión del capital. De hecho, la principal inversión necesaria para la expansión productiva agrícola era la mecanización, y, tal como hemos visto, los medianos arrendatarios de la zona sur, pero no sólo ellos, habían desarrollado un intenso proceso de mecanización en los años veinte ${ }^{102}$. En perspectiva, observamos que esta

102 Entonces, si bien el acceso a la propiedad era un objetivo que claramente casi todos los chacareros perseguían, otras posibilidades de acumulación no eran menospreciadas. Convertirse en un gran arrendatario, era una opción interesante. De hecho, según Lahitte (1912: 35) la esperanza de aumentar su capital por medio de la agricultura extensiva, convertía al chacarero en un arrendatario de 200 hectáreas antes que en dueño una propiedad de 20 hectáreas. 
inversión resultó mucho más ventajosa que los intentos de adquirir un campo en la década del veinte, a través del crédito hipotecario, pues en general éstos terminaron con la pérdida de la propiedad durante la crisis del treinta. No por ello, desconocemos las inseguridades que el arriendo generaba y el bloqueo que producía para realizar mejoras en el campo y en las condiciones edilicias.

Justamente, los procesos de acumulación de los medianos productores alcanzaban para que se mecanizasen, pero no para que se convirtieran en propietarios de los predios que alquilaban (tal como lo hemos estudiado en Balsa, 1993 y 1994a). Entonces, en cuanto a la tenencia del suelo, el "camino pampeano" se había cristalizado, a través de un proceso circular en el que el propio esfuerzo de los arrendatarios los iba alejando progresivamente del acceso a la propiedad, al menos como experiencia colectiva. Pues, la propia valorización de los campos que, como hemos visto, generó la expansión agrícola realizada por los arrendatarios, los hacía cada vez menos accesibles. Como lo describió Taylor (1948), la escalera agrícola se había cerrado. Si bien, un importante número de inmigrantes habían recorrido la escalera que pasaba por el trabajo asalariado, la mediería y el arrendamiento, hasta alcanzar la propiedad de la tierra, la mayoría de los que habían alcanzado este último peldaño lo había logrado antes de la segunda década del siglo XX.

Durante todo el período expansivo, al menos hasta fines de los años veinte, el sueño de acceder a una relativamente extensa propiedad en la región pampeana (que aunque fuese en muchos casos pequeña, era mucho mayor a las parcelas europeas) había funcionado como un aliciente que permitió a los agricultores aceptar una gran cantidad de privaciones (que comentaremos en el siguiente apartado) y arbitrariedades impuestas por los terratenientes, y, entonces, constituyó un elemento clave del funcionamiento del modelo agroexportador pampeano. Como lo analiza Pucciarelli (1986: 132-133), incluso para algunos arrendatarios pobres tenía que existir un acotado proceso de acumulación que posibilitara el ingreso de una minoría en los canales de movilidad social ascendente, de modo de generar en la mayoría expectativas de rápido enriquecimiento $^{103}$. Acumulación que podía ser en maquinarias, en el arriendo de

${ }^{103}$ Sin embargo, incluso en los años veinte, como los arrendatarios y aparceros más pequeños no tenían reales posibilidades de ascenso, surgieron voces de alarma que afirmaban que los hijos de los agricultores no continuaban con la profesión de sus padres y que se marchaba "a la disolución de nuestra familia rural" (Campolieti, 1929). 
superficies cada vez mayores, pero también a través de la compra de tierra (al menos como meta). En este sentido, consideramos que el objetivo final de la mayoría de los chacareros, al menos hacia los años veinte, era convertirse en propietarios. No compartimos, en este sentido, la apreciación que se difundido en los últimos años de que el arrendamiento era una opción escogida por los inmigrantes (por ejemplo, en Adelman, 1989). Si bien, esta reflexión resultó pertinente para criticar la visión preexistente que enfatizaba la imposibilidad de acumulación por parte de los agricultores (ejemplificada a través de su no acceso a la propiedad), no deben olvidarse las limitaciones materiales que existieron para la compra. El argumento de que comprar no era una buena táctica para sujetos que todavía estaban pensando en regresar a sus países de origen, no contempla la realidad de que el mercado de tierra estaba bien activo, y que por lo tanto, comprar no implicaba la incompatibilidad de realizar esta inversión en un futuro (y seguramente a mucho mejor precio). En todo caso, como lo plantea Ansaldi (1998: 15) conviene no sobredimensionar la persistencia de la condición de inmigrantes de los chacareros, pues a pesar de ser un dato importante, cede frente al de las condiciones estructurales.

De acuerdo con nuestra apreciación, el objetivo de comprar un lote de tierra apareció como la respuesta principal de los chacareros en una pequeña encuesta realizada por Coni (1920). Del mismo modo, para comienzos de los cuarenta, Taylor encontró que, preguntados en qué gastarían una hipotética duplicación de sus ingresos durante unos años, todos respondieron "comprarían una explotación", si eran arrendatarios, o si eran propietarios: "construiríamos una casa mejor" o "compraríamos más tierra" (Taylor, 1948: 292) ${ }^{104}$.

Por eso, en la medida en que las posibilidades de acceso a la tierra se fueron cerrando, se generó una tensión social que terminó poniendo en cuestión la estructura social agraria. Entonces, este "camino pampeano", si bien en términos económicos parece evidenciar una fuerte consistencia, no la tuvo en términos socio-políticos. El esquema de agricultores alquilando campos de terratenientes permitió una muy rápida expansión de la agricultura, no sólo en el período inicial (ver reflexiones de Adelman, 1989: 159), sino también durante los años veinte, sin la necesidad de que los

104 En ningún caso, mencionaron la educación de sus hijos, la compra de mejor ropa, de un automóvil o la adquisición de bienes culturales o servicios (Taylor, 1948: 292). 
productores inmovilizaran grandes sumas de capital en la compra de las parcelas. E incluso, el sistema de arriendos y aparcerías resultó más flexible para hacer frente a la crisis de los años treinta que la compra por hipotecas (como analizamos en Balsa, 1994a). Sin embargo, los arrendatarios y los aparceros siempre mantuvieron una gran vulnerabilidad frente a las decisiones arbitrarias de los terratenientes, y esto nunca dejó de ser una característica indeseada desde el lado de los agricultores. Como veremos, esta situación alcanzó una mayor relevancia en la coyuntura de fines de los años treinta. Muchos arrendatarios y aparceros vieron peligrar su lugar en la sociedad rural a partir de 1938, cuando la relación de precios se volcó claramente en favor de la actividad ganadera. En el siguiente capítulo analizaremos hasta qué punto las políticas que se implementaron para frenar este tipo de medidas transformaron la estructura agraria bonaerense. Pero antes quisiéramos brindar una caracterización del modo de vida y del mundo rural de los chacareros a fines de los años treinta. 


\section{El modo de vida chacarero y la construcción de un mundo rural pampeano}

Los inmigrantes no sólo generaron una extraordinaria puesta en producción de la pampa argentina, sino que construyeron un mundo rural particular, muy diferente, especialmente en las áreas con desarrollo agrícola, del que existía previamente a su llegada (más allá de que perduraran una serie de elementos "gauchescos") ${ }^{105}$. Un primer indicador de este cambio, es el drástico aumento de la densidad poblacional ${ }^{106}$. Pero este no fue sólo un cambio en términos de crecimiento demográfico, sino que, además, los agricultores se transformaron en los principales habitantes del campo, al menos en las áreas agrícolas. Los grandes terratenientes (ya sea que se dedicaran a la ganadería o arrendasen su campo totalmente) casi invariablemente residían en la Capital Federal. Los rentistas de tamaños menores, en general, vivían en las ciudades cabeceras de los partidos, pero casi nunca en el campo que arrendaban, y lo mismo sucedía con los estancieros medianos, aunque entre ellos era un poco más habitual vivir en su establecimiento, al menos parte de la semana.

En cambio, casi todos los pequeños y medianos productores agrícolas vivían en su explotación ${ }^{107}$. Este patrón de residencia, similar al caso de las praderas norteamericanas, se diferenció claramente del asentamiento en aldeas, propio del campesinado europeo (Rösener, 1995). Como lo señala Vapñarsky (1995:241), “en la Argentina es casi desconocida la aglomeración del tipo 'aldea agrícola', residencia de campesinos que trabajan en campo abierto cercano. La pauta típica de asentamiento se caracterizó por la residencia de la población dedicada al agro en el predio mismo donde trabaja".

${ }^{105}$ No estamos en condiciones, ni es éste el lugar para realizar un balance de los cambios y continuidades entre el mundo rural "ganadero" de las últimas décadas del siglo XIX, y el mundo "chacarero" de las primeras del siglo XX.

${ }^{106}$ En 1895 había un total de siete habitantes por $\mathrm{km}^{2}$ en la zona norte (contabilizando áreas urbanas y rurales), y sólo un habitante en las zonas oeste y sur; para 1938 había 19 habitantes por $\mathrm{km}^{2}$ en la zona norte, cinco en la zona oeste y siete en la sur, según nuestro cálculos a partir del Censo Provincial de Población de dicho año.

107 Las entrevistas realizadas confirman la residencia rural de los productores pequeños y medianos: tan sólo uno de los productores entrevistados no residía en el campo para fines de los años treinta. 
Este era un campo lleno de productores agrícolas, pero también de pequeños ganaderos que residían en sus establecimientos. A ellos se agregaban peones asalariados fijos, pero que no llegaban a alterar el predominio demográfico de los productores agrícolas y sus familiares. Dos indicadores nos revelan esta importancia de los productores en relación con los asalariados permanentes en este mundo rural bonaerense de fines de los años treinta. Por un lado, los productores, esposas y otros familiares mayores (excluyendo a los niños) constituían el 83\% de la población que trabajaban en forma permanente en la explotación en la zona norte, mientras que los asalariados sólo eran el $17 \%$ restante $^{108}$. En la zona oeste, los productores y familiares eran el $68 \%$, y en la zona sur, el 63\%. Por otro lado, también según el censo de 1937, el 79\% de las unidades de la zona norte no tenían asalariados en forma permanente. Este porcentaje se reducía al $73 \%$ en la zona oeste y al $59 \%$ en la zona sur. Pero, incluso en muchas de las unidades donde se contrataba asalariados fijos, éstos eran sólo uno o dos, manteniéndose el predominio demográfico de los trabajadores familiares: el promedio de asalariados fijos en las explotaciones que los contrataban era de 2,3 en la zona norte y 2,6 en la zona sur; en cambio, en la zona oeste este valor medio alcanzaba los 3,9 asalariados fijos por establecimiento ${ }^{109}$.

Es que, como hemos visto en los apartados anteriores, incluso en las explotaciones medianas el trabajo familiar ocupaba un lugar significativo en el conjunto de la mano de obra utilizada. Si bien, algunos de los inmigrantes al alcanzar una edad avanzada había ido abandonando la actividad física, en estos casos sus hijos realizaban labores manuales. Según el conjunto de nuestras entrevistas, en algunas explotaciones medianas se combinaba la mano de obra familiar con un peón; en otras había un número de asalariados permanentes que duplicaba a los familiares. Sin embargo, también

${ }^{108}$ Sobre esta cuestión, ha causado alguna confusión el cuadro del censo en que se detalla las personas que trabajan en la explotación. Como bien sostiene Giberti (1964: 50) no queda claro si "hombres de la familia del productor" incluye a los productores. En este trabajo él presenta los cálculos con ambas posibilidades. Sin embargo, algunos investigadores han interpretado que los productores están sumados en la columna de "hombres de la familia del productor". Si bien la publicación censal no resulta explícita al respecto, si consideramos que los hijos varones mayores de 15 años residentes en las explotaciones (consignados en otro cuadro del mismo censo) representaban una cifra cercana a la de "hombres de la familia del productor", y tenemos en cuenta que agregando los "otros familiares" que vivían en la explotación se supera la cantidad de "hombres" que trabajaban, resulta claro que los productores no han sido sumados en la columna de "hombres de la familia".

109 Todos cálculos propios en base al Censo de 1937. 
existían establecimientos medios trabajados exclusivamente por el productor y sus familiares, gracias al alto nivel de mecanización que, como vimos, caracterizaba a las explotaciones de la zona sur. En tiempos de cosecha el escenario cambiaba drásticamente con el arribo de multitud de trabajadores temporarios que acompañaban el recorrido de las trilladoras ${ }^{110}$. Aunque ya en los años veinte, la rápida adopción de las cosechadoras de arrastre fue provocando una sustancial reducción de esta mano de obra transitoria, sobre todo en la zona sur.

Por lo tanto, el mundo rural que se construyó durante la expansión agrícola fue un mundo eminentemente chacarero. Pues, como veremos, la profesión de agricultor estaba asociada con un modo de vida chacarero ${ }^{111}$. Aunque diferenciados en la dotación de recursos, la mayoría de los productores pequeños y medianos no se distinguían demasiado en sus modos de vida. Se constituyó, de esta forma, un modo de vida rural asociado fuertemente con la profesión de agricultor, e incluso con el concepto más vasto de productor agropecuario, si dejamos fuera de esta categoría a los terratenientes, tanto locales como nacionales ${ }^{112}$.

110 Sartelli habla de la existencia de "infantería ligera del capital" que se trasladaba estacionalmente al campo para realizar las labores de cosecha y cuyo trabajo en torno a la trilladora se asemejaba "a la de la racionalización taylo-fordista de la gran industria, porque en última instancia el conjunto motor-trilladora constituye una fábrica móvil de producir grano seco en bolsas" (Sartelli, 1997: 96). Una descripción detallada de las actividades en torno a la trilladora se encuentra en Sartelli (2000: 135-138). También en Adelman (1989: 154 y ss.) se describe la migración estacional de trabajadores desde las ciudades para la cosecha.

111 Como ya hemos comentado en la Introducción, de los distintos enfoques existentes sobre el concepto de modo de vida (ver su sistematización en Veal, 1993), nos hemos apoyado más en la tradición weberiana. Además, hemos recogido algunas de las propuestas de Veal para analizar el estilo de vida: considerar el amplio rango de actividades diarias sin privilegiar unas sobre otras (patrones de consumo, actividades ociosas, prácticas domésticas y trabajo remunerado); tener presente que es a menudo un fenómeno grupal, pero que tiene un cariz individual; analizar la coherencia -o su falta- entre las diversas prácticas, y estudiar la determinación material -o no- de los modos de vida. En relación a esta última cuestión, las situaciones de menor pobreza abrirían posibilidades de mayor capacidad de elección sobre el estilo de vida (Veal, 1993: 245-247), lo cual consideramos resulta muy pertinente para reflexionar sobre los productores rurales medios.

112 Sobre la burguesía terrateniente local radicada en las ciudades pampeanas puede consultarse Balsa (1993). 
En el chacarero se combinaban los elementos campesinos (que traían los inmigrantes europeos devenidos en productores rurales pampeanos) con sus expectativas de ascenso social, junto con las limitaciones, pero también las posibilidades estructurales y coyunturales que abría la pampa argentina (no hay que menospreciar el efecto que podía tener la combinación de una serie de buenas cosechas $\mathrm{y}$ de precios elevados de los cereales ${ }^{113}$. La austeridad, el ahorro y la reinversión en maquinarias o tierras (en arriendo, o eventualmente en propiedad) guiaban la economía familiar en la búsqueda de un lugar en la sociedad pampeana. Coscia (1983: 10) señala que "la familia agrícola se caracterizó hasta mediados de este siglo por conservar muchos de los rasgos y modalidades de sus países de origen. Sus costumbres eran austeras, hasta simples, y con una marcada propensión al trabajo y al ahorro. En muchos productores, especialmente en los que decidían radicarse definitivamente en el país, la meta ambicionada era llegar a constituirse en propietarios de la tierra que trabajaban". Al respecto nos parece adecuada la caracterización que propone Mascali del arrendatario pampeano: "El intento de una reproducción ampliada de la unidad puso de relieve la funcionalidad de la dimensión ideológica sobre la toma de decisiones. En efecto, el agricultor arrendatario pampeano no consideraba en sus proyectos la reproducción de la unidad como tal a la manera del campesino. Precisamente si tuvo éxito el estímulo de los propietarios para que les arrendaran más tierra, fue porque estaban creadas las condiciones en el plano ideológico de los arrendatarios para que así ocurriera. Es así que categorías tales como el ahorro, austeridad y trabajo, virtudes tan características de nuestros chacareros fueron realmente operativas en la toma de decisiones de los mismos. El objetivo era acumular para obtener la propiedad, y el medio fue la vida austera, el ahorro y el trabajo" (Mascali, 1986: 15-16).

El sueño de acceder a una propiedad relativamente extensa, les permitió soportar las duras condiciones de vida que sufrieron la mayoría de los chacareros. En Scobie (1968, especialmente capítulo IV) encontramos una detallada descripción de las características de la vida chacarera de fines del siglo XIX y comienzos del XX. Allí se

113 Debió ser muy importante el impacto que para un campesino europeo, acostumbrado a trabajar unas pocas hectáreas, significó pasar a cultivar 50,100,200 o más hectáreas. Algunos entrevistados que habían trabajado en Europa, hicieron hincapié en la sensación de libertad que les produjo este cambio en la escala. 
comenta que la vivienda más común era el rancho de barro y paja, con muy pocos muebles en su interior (unas pocas sillas o banco, una mesa, a veces, una cama para el chacarero y su esposa, sino sólo montículos de cueros de oveja y ponchos, sin calefacción). También señala Scobie que la vestimenta se limitaba a los artículos esenciales, y que las instalaciones sanitarias eran desconocidas.

Para fines de los años treinta, más allá de los efectos de la crisis recién pasada, la vida de los chacareros no era tan dura como la que aparece en la obra de Scobie, pero en el caso de los pequeños aparceros tampoco se diferenciaba notoriamente. En los testimonios recogidos se la recuerda insistentemente como una vida "dura", cubriéndose sólo las necesidades más básicas ${ }^{114}$, y sin otras alternativas.

Escogimos el siguiente testimonio, del hijo de un tambero del partido de Rivadavia (que para mediados de los años cuarenta logró comprar su campo), porque no sólo da cuenta de las condiciones de vida limitadas, sino también de la sensación de que esa era la única forma de vida posible:

"Era duro pero no había muchas más alternativas en ese momento. La casa era de material, con piso de tierra. Nada de agua caliente, ni baño privado como hay ahora. La única luz eléctrica que teníamos era de un molinillo para el viento y con una batería común. Eso nos daba luz para la casa, controlándola mucho porque era una batería pequeña, y si no había viento, no había luz. Con eso alimentábamos la radio, también. Mi padre compró la radio en el año '41. Hasta entonces no había radio para escuchar la novela, los programas de la noche. Esa era un poco la vida del campo" (GA).

Desde el presente, nuestros entrevistados describen a su niñez y adolescencia como llenas de privaciones. Sin embargo, esa no sería la imagen que tenían en esos años, al menos no sus padres. La mayoría de los cien productores de todo el país con quienes dialogó Taylor ${ }^{115}$ le manifestaron que estaban, entonces (1942), viviendo en

\footnotetext{
114 Así lo rememoró un productor de Tres Arroyos: "Era una chacra corriente, nunca nos faltó nada de lo elementalísimo. De lo demás, nos faltó todo. Era una vida monótona, una vida de trabajo, dura..." (ET).

115 El libro de Taylor (1948), un tanto olvidado por la historiografía rural argentina, ha sido particularmente valioso para la elaboración de este apartado, ya que dedica varios capítulos a describir la vida rural en las pampas a comienzos de los años cuarenta.
} 
circunstancias mucho más favorables que en el pasado y que sus hijos tenían oportunidades que ellos no habían disfrutado cuando habían sido jóvenes (Taylor, 1948: 292). Las excepciones surgían entre aquellos inmigrantes que habían llegado a la Argentina con la esperanza de convertirse en propietarios, pero habían sido condenados a permanecer como arrendatarios por 20 o 25 años. Sin embargo, pocos de ellos consideraban que les hubiera ido mejor si se hubiesen quedado en sus tierras natales (Taylor, 1948: 294). Pero para Taylor, también revelaron, inadvertidamente, insatisfacción y aspiraciones: "la vida es suficientemente amarga, como para tomar mate amargo", según le dijo una entrevistada.

En el extremo opuesto, los que habían conseguido comprar un lote y, en particular, los colonos de las colonias oficiales de la provincia de Buenos Aires, le testimoniaron a Taylor, entusiasta y unánimemente, su satisfacción por sus nuevas condiciones de vida, en contraste con su situación como arrendatarios y aparceros (destacaban, por ejemplo, la existencia de baños, luz eléctrica y electrodomésticos).

En las unidades chacareras, la familia constituía un equipo de producción en el que la mujer y los niños se encargaban, por lo general, de los bienes para el autoconsumo. Como lo señaló una de nuestras entrevistadas: "todo el mundo trabajaba, todo se hacía en la casa" (MD). En la propia chacra se realizaba la cría de cerdos y su posterior procesamiento (elaborando facturas que duraban todo el año, de invierno a invierno, conservadas en grasa ${ }^{116}$ ), el ordeñe de algunas vacas lecheras y la preparación de crema, manteca y quesos, la cría de pavos y pollos (con recolección de una gran cantidad de huevos), el cultivo de hortalizas y, eventualmente, árboles frutales. Además, las mujeres confeccionaban la mayor parte de la ropa. Indefectiblemente todos nuestros entrevistados recordaron que la mayoría de las actividades recién enumeradas, se realizaban en su chacra. Muchas veces, algunos parientes ancianos se encargaban de la quinta u otras actividades secundarias. De hecho, la mayoría de nuestros entrevistados manifestaron que no compraban casi ningún tipo de alimentos, pues todo lo producían en la chacra. Se adquiría únicamente el pan (o la galleta), la yerba, el azúcar, la sal y el

\footnotetext{
${ }^{116}$ Incluso uno de los entrevistados recordó que de chico, en su chacra se hacía charqui.
} 
vino, y eventualmente, la carne (cuando las familias que no tenían ovejas para el consumo).

En muchos casos las generaciones se superponían en una misma explotación. Taylor encontró varios casos de "familias extendidas" entre los españoles e italianos, y sostiene que no era infrecuente hallar hijos adultos y sus esposas e hijos viviendo y trabajando con sus padres y abuelos, especialmente si los padres eran propietarios, pero incluso también cuando eran arrendatarios. Taylor entrevistó padres que decían "yo los mantuve cuando fueron jóvenes, ahora ellos deben mantenerme cuando me estoy volviendo viejo"117. En el mismo sentido Bagú (1949: 57) afirma que "muchos padres confían en sus hijos para poder ganar en la vejez el descanso que merece su esfuerzo de toda la vida". En este sentido, "al matrimonio de la clase media rural -menos culto [que el urbano], por lo común, y enfrentado a una realidad económica distinta- no le alcanzan los mismos razonamientos [sobre la limitación de la cantidad de hijos]. Cada hijo es un productor en potencia y su manutención es relativamente barata" (Bagú, 1949: 57) ${ }^{118}$. Por su parte las madres entrevistadas por Taylor sostenían que "la familia debe mantenerse unida, no me gustaría que mis hijos se fueran de casa". Muchos padres afirmaban que "mis hijos son libres de irse si quieren, pero estoy contento de que se queden". Si bien el número de hijos por matrimonio no era muy grande, los grupos familiares tenían a menudo más miembros, en un tipo de vecindario de parentesco. Sin embargo, no debe exagerarse esta imagen de familias extensas. El propio Taylor afirma que muchas familias arrendatarias y la mayoría de las propietarias seguían el esquema de una generación por explotación (Taylor, 1948: 328).

117 Podemos, interpretar que existía cierta lógica de reciprocidad intrafamiliar en un ciclo de adelantos y restituciones características de las unidades domésticas (Meillassoux, 1987).

118 Para Bagú (1949: 56-57) "el hijo es, para el matrimonio de la clase media urbana, un acontecimiento excepcional, para el cual es menester encontrarse material y espiritualmente preparado. Muchas veces, está precedido de varios años de cálculos de recursos y de consultas. Cuando llega, los padres tratan de darle un máximo de comodidades y piensan en su educación. Sin duda, cuando el hijo es tan costoso, no es posible afrontar el riesgo de su multiplicación indefinida. Además, el matrimonio de clase media urbana nunca se resuelve del todo a sacrificar sus propias apetencias mundanas y culturales por la presencia de la prole $\mathrm{y}$, para satisfacerlas, es menester ante todo que la prole no sea numerosa". 
Según Taylor los comportamientos de la familia seguían a los de los países de origen. Los padres eran la cabeza indiscutida, y eran sucedidos por el hijo varón mayor. La madre, sin embargo, era muy respetada por los hijos, quienes eran fácil y estrictamente disciplinados por ambos padres. En las entrevistas nunca la esposa se sentó, aun cuando participara en la conversación con Taylor (especialmente, si era española). Las mujeres realizaban muchas tareas pero raramente en el campo. En este mismo sentido, algunas mujeres que nosotros hemos entrevistado manifestaron que "se quedaron con las ganas" de realizar labores rurales, pero que ni siquiera se les dio la oportunidad de hacerlo cuando éstas se mecanizaron por completo (por ejemplo, de manejar el tractor $)^{119}$. Otras, en cambio, sí realizaban tareas en el campo ${ }^{120}$. Taylor enumera que las mujeres cocinaban, lavaban y planchaban, cuidaban la huerta y el corral; al tiempo que, prácticamente, carecían de artefactos domésticos que aliviasen su labor (Taylor, 1948: 331). A partir de esta división sexual del trabajo, las hijas del productor tenían considerable tiempo libre y a menudo empleaban muchas horas escuchando la radio o visitando a sus vecinos.

En cambio, Taylor destaca que los hijos varones colaboraban en las labores desde muy jóvenes y cuando tenían 13 o 14 estaban realizando trabajos de hombre con ganado o en la agricultura. Los padres españoles, pero también los italianos, trataban de pasar el trabajo pesado de la explotación a sus hijos tan rápido como era posible, y asumían un rol de control.

Según nuestras entrevistas, los niños, a medida que crecían, iban asumiendo tareas de mayor envergadura y responsabilidad ${ }^{121}$. De los testimonios surge claramente que la socialización primaria incluía el trabajo físico como un elemento clave de la

119 En este mismo sentido, una encuesta rural realizada a comienzos de los años setenta encontró que en dos colonias entrerrianas de origen alemán, sólo siete de las cuarenta esposas de productores entrevistadas realizaban labores en el campo, a pesar de que 26 de ellas residían en la explotación y no en el pueblo (Elena, 1973).

${ }^{120}$ Como nos relató la esposa de un productor de Pergamino: "en época de cosecha hacía de boyerito. Me encantaba andar a caballo, así que todo el trabajo de boyero lo hacía yo. Cuidar los animales, si había que correr los cerdos, también. Esas cosas me gustaban." (mujer de FL).

${ }^{121}$ En el siguiente testimonio de un productor de Tres Arroyos observamos el comienzo de este ascenso: "En el verano hacíamos de todo. De chiquito, juntar gavillas, las que se perdían, avena guacha. Y después, al otro año, ya me daban de aguatero, a los trece, catorce años. A los quince, ya era cosedor arriba de la máquina" (KA). Unos años más tarde ya quedó a cargo de uno de los campos de su padre. 
formación de un futuro chacarero. Todos los entrevistados habían realizado, en mayor o menor medida, tareas auxiliares durante su infancia. El juego se mezclaba con el trabajo, como nos dijo un productor de Pergamino: "Cuidaba los chanchos y todas esas cosas, jugar poco"; a lo que su esposa acotó: "los juegos eran mientras se hacían las tareas" (FL y mujer). En el mismo sentido, otro entrevistado afirmó: "Eramos chicos, la vida nuestra era ayudar a los mayores, cuidábamos los caballos, los chanchos, juntábamos maíz a mano, cortábamos yuyos en el campo" (ML) ${ }^{122}$. Incluso aquellos que habían logrado un importante nivel de acumulación (comprando, por ejemplo, 500 hectáreas o más) continuaban induciendo a sus hijos al trabajo físico en su adolescencia, aunque luego fueran destinándolos a tareas de dirección y supervisión ${ }^{123}$.

Entonces, los niños maduraban en un contexto de duro trabajo agropecuario que se internalizaba como el estilo de vida. De este modo, la dedicación exclusiva a las labores agropecuarias era el resultado "natural" de este proceso, luego de finalizada la educación formal. Como nos respondió un entrevistado de Tres Arroyos a nuestra pregunta de si le costó empezar a trabajar cuando dejó la escuela: "Uno no pensaba tanto en eso, porque era natural, era el proceso común y corriente. Terminaba la escuela y empezabas a trabajar" (RY).

Unos pocos grados de escuela (en general los hijos de los chacareros pequeños no finalizaban la enseñanza primaria) no modificaban esta situación ${ }^{124}$. Ni siquiera lo hacía, en la mayoría de los casos, el completar la primaria, e incluso tampoco el recibir

Pero incluso de pequeños ya desempeñaban algunas tareas que ningún chico de ciudad asumía. Como relató un productor de Tres Arroyos: "Yo en la cosecha manejaba. Me daban que llevara la mercadería a la trilladora en un Ford T que había, que para mí era una gloria. Tenía siete años, creo, u ocho. Era un chico..." (ME).

${ }^{122}$ Como diversión seguían trabajando a la noche: "como nosotros éramos tantos, te sentaban en un cajón, en lugar de mirar televisión como hoy, y con una varilla de hierro, como se usaba para los alambrados, ahí se desgranaba el maíz con facilidad" (MD).

${ }^{123}$ En el caso de los hijos de productores medianos-grandes, comenzaban realizando todo tipo de labores, pero al alcanzar los 15 años, o algo más adelante, iban adquiriendo tareas con algún mando sobre asalariados, de un modo paulatino.

Como lo relató un productor de Tres Arroyos, para entonces hijo de uno de los hermanos que, en sociedad, controlaban unas 6.000 hectáreas (la mayoría en propiedad): "Nosotros nos encargábamos de la tarea administrativa y de apoyo. Tal vez por eso mismo nuestros padres nos reservaban para esas tareas de apoyo. Ahí, sin haberlo pensado antes, se me está ocurriendo ahora, que debió haber sido el sentido de no ponernos en las tareas más pesadas, sino reservarnos para la tarea que podía importar más, que era la tarea de apoyo a la realización de los trabajos, que era el mantenimiento de la maquinaria, el abastecimiento del personal" (VS). 
algún tipo de aprendizaje posterior, como era el caso de los hijos de los productores medios. Casi todos los entrevistados destacan que, cuando eran jóvenes, se encontraban "mucho más a gusto en el campo que en el pueblo". Los que pudieron asistir a la escuela primaria o secundaria de la ciudad, se encontraban ansiosos por regresar a la explotación de sus padres ${ }^{125}$.

Entonces, los hijos de los chacareros iban internalizando su rol laboral (internalización propia del proceso de socialización secundaria ${ }^{126}$ ) a lo largo de un continuum que no presentaba rupturas con su socialización primaria. De este modo se naturalizaba la "opción" se seguir como chacarero, a pesar de no haber una tradición familiar de más de una o dos generaciones.

Así se conformó una identidad chacarera, que no giraba tanto en torno a una conciencia de clase, sino a un modo de vida y que, incluso, englobaba posiciones de clase diferentes. Es más, la idea de "modo de vida" tampoco implica la existencia de una comunidad, ya que sólo requiere compartir una serie de características de la vida

124 Por otra parte, existían formas educativas adaptadas a los requerimientos de la actividad agrícola: maestros de campo (educadores que se trasladaban por las chacras impartiendo conocimientos directamente aplicables a la economía de las explotaciones) y escuelas privadas de contabilidad en los pueblos (a las que concurrían, luego de la educación primaria, los hijos de chacareros con alguna mayor capacidad económica).

${ }^{125}$ A continuación, reproducimos los testimonios más elocuentes sobre esta inadecuación entre su socialización primaria y la vida urbana:

"Nosotros estábamos acostumbrados acá, al campo, a mí se me hacía cuesta arriba, en esa época la maestra sabía explicar, agarraba el libro y claro... yo me acuerdo que la maestra decía: 'Néstor, estás pensando en las vacas, el caballo' (a mí me gustaba mucho andar a caballo), y era cierto." (VD).

"Estaba obligado por el colegio [a estar en la ciudad de Tres Arroyos], si estaba deseando volver para el campo. El pueblo no lo quería nunca [...] El que más, el que menos, en ese entonces la juventud no queríamos el pueblo, era distinto." (DS).

"Secundaria vine, en el 36, 35. Hice primero nacional y abandoné porque no me gustaba, y me obligó mi padre a hacer taquigrafía y contabilidad, y me recibí. Pero no me gustaba, a mí me gustaba vivir en el campo". (ER).

"A los nueve vine al pueblo. Pero estaba el paisano medio acostumbrado al campo y en el pueblo no andaba, estaba triste, entonces volví a la escuela en el campo. Pero acá no fui más que seis u ocho meses". (MÑ).

${ }^{126}$ Al respecto, ver Berger y Luckman (1986). 
individual, como los patrones de consumo, de apariencia, o las actividades de esparcimiento (ver Stebbins, 1997: 349).

Nos parece muy sugerente el análisis de Ansaldi (1993) cuando plantea que los chacareros "son y se hacen", en tanto "chacarero" define, para él, una clase social específica del capitalismo agrario argentino, y, además, el sujeto se constituía, a través de su propio accionar, en una clase (aunque con una identidad de clase incompleta, ocluida por su propia "conciencia de la movilidad social"). Sin embargo, consideramos que como definición de clase-en-sí el concepto de chacarero engloba posiciones sociales diferenciadas $^{127}$, y hasta su principal denominador común -el carácter de no propietarios- desaparecerá a en las siguientes décadas. Por otro lado, en tanto clasepara-sí, el proceso de accionar político-social siempre dejó un gran número de productores que no se asumieron en tanto clase, que no se sumaron al movimiento colectivo (más allá de la renuncia que detalla Ansaldi para el pasaje del momento económico-corporativo al más estrictamente político). Entonces, sin negar la posible utilidad del concepto "chacarero" para dar cuenta de la identidad de clase de los agricultores pampeanos, creemos que resulta con seguridad útil para dar cuenta de un modo de vida. Más allá de si los chacareros "eran" o si "se hacían", con seguridad "vivían" el mundo como chacareros.

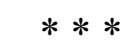

Decimos que vivían el mundo como chacareros porque además su mundo era eminentemente chacarero, en un doble sentido.

Por un lado, en términos demográficos, la familia chacarera dominaba el campo de las zonas agrícolas (tal como ya lo hemos descripto) y, al mismo tiempo, este campo tenía un peso propio dentro de la población de los partidos: concentraba alrededor de la mitad de la población de las zonas norte, oeste y sur. Más precisamente, en $1947^{128}$

127 Unos eran pequeños burgueses, otros burgueses pequeños y otros "farmers", en tanto propietarios y perceptores de renta del suelo.

${ }^{128}$ Lamentablemente, no hay datos sobre la población de las pequeñas localidades para el Censo de 1914 (sólo se detallan las mayores a 2.000 habitantes) y resultan inhallables estos datos para el Censo Provincial de 1938 (anulado por la Intervención Federal). Sobre este último censo, a pesar de nuestras búsquedas en direcciones provinciales y nacionales, sólo pudimos encontrar los datos de la población total por partido, gracias a que un decreto del Poder 
residía "en el campo" el 46\%, el 51\% y el 38\% de cada zona, respectivamente. En términos absolutos, en 1947 vivían en el campo 186.504 personas en la zona norte, 171.799 en el oeste y 255.911 en el sur. En el Cuadro 1.18 se detalla la distribución de la población de cada zona.

Ejecutivo provincial aprobara en 1942 los datos de población a nivel partidos y conjunto de la Provincia.

En cambio sí contamos con información muy detallada para 1947, que nos permite diferenciar la población que habitaba en el campo, de aquella que lo hacía en estas pequeñas localidades. Hemos podido calcular, entonces, un indicador más preciso que la "población rural" (que incluye las personas que habitan en localidades de menos de 2.000 habitantes): la población "en el campo". 
Cuadro 1.18. Distribución de la población en 1947

\begin{tabular}{|l|c|c|c|}
\hline Categoría & zona norte & zona oeste & zona sur \\
\hline Ciudades medianas & $32 \%$ & $14 \%$ & $28 \%$ \\
Cuidades pequeñas & $12 \%$ & $18 \%$ & $16 \%$ \\
Pueblos grandes & $5 \%$ & $5 \%$ & $12 \%$ \\
Pueblos chicos & $5 \%$ & $12 \%$ & $6 \%$ \\
"En el campo" & $46 \%$ & $51 \%$ & $38 \%$ \\
& $100 \%$ & $100 \%$ & $100 \%$ \\
\hline
\end{tabular}

Hemos distinguido las localidades en "ciudades" -poblaciones cabeceras de partidos que, además, todas ellas contaban con más de 3.000 habitantes en 1947- (diferenciadas en medianas y pequeñas según un corte en 10.000 habitantes) y "pueblos" ("pequeños" o "grandes", con otro corte en 1.000 habitantes).

Fuente: cálculos propios efectuados en base a la información del Censo Nacional de Población de 1947.

Por otro lado, la familia chacarera constituía un mundo claramente rural, en tanto separado del mundo urbano. En varios aspectos era un espacio diferenciado de la vida de las ciudades, incluso de las localidades cabeceras de los partidos, muchas de las cuáles tenían menos de una decena de miles de habitantes.

La sociabilidad chacarera, que aunque reducida no era inexistente, se centraba alrededor de sus vecinos y el pequeño pueblo cercano a su explotación. Un primer espacio de sociabilidad de los chacareros se constituyó en torno a las visitas dominicales a vecinos o familiares ${ }^{130}$. Taylor (1948: 280) señala, en el mismo sentido, que las

129 Para el análisis poblacional hemos excluido a los partidos de Bahía Blanca, Coronel de Marina Rosales y General Alvarado, por presentar núcleos urbanos con dinámicas muy diferenciadas del devenir rural.

${ }^{130}$ Los testimonios han sido muy coincidentes en este aspecto. A continuación reproducimos tres, a modo de ejemplo:

"Los domingos nada más, porque los días de semana a trabajar. Los domingos sí nos íbamos una vez a una chacra y nos juntábamos ahí, nos poníamos a jugar a la pelota, y otro domingo le tocaba a otro..." (FL).

"Mí señora era de la zona, éramos vecinos. Nos conocíamos entre vecinos, se hacían bailes en las chacras, todo eso desapareció completamente. Cuando llovía jugábamos a las cartas y tomábamos mate con buñuelos." (GR).

"Teníamos una costumbre muy linda, todas las familias de colonos eran muy unidas, entonces cada domingo nos reuníamos a jugar en una casa distinta, tomábamos el té y todo en la casa donde íbamos". Tan frecuentes eran las visitas que "todas las noches, sábado y domingo, 
familias visitaban a sus vecinos y, a veces, viajaban a visitar a familiares residentes en otras localidades no muy lejanas. Otras instancias de sociabilidad habituales, que surgieron en las entrevistas que realizamos, eran las reuniones en el almacén de ramos generales $^{131}$, las fiestas de las colectividades correspondientes ${ }^{132}$, los bailes de los clubes, los festejos organizados en las fechas $\operatorname{patrias}^{133}$ y -particularmente importantes- los campeonatos de fútbol entre las distintas colonias o localidades ${ }^{134}$. En general, la mayor parte de estas actividades se realizaban en torno a los pueblos más cercanos a cada establecimiento. Sin embargo, no debemos magnificar la frecuencia de estas reuniones, que se reducían a algunas fechas a lo largo del año.

El agricultor viajaba al pueblo con relativa poca asiduidad. Los testimonios orales que hemos recogido comentan que sólo iban a la localidad más cercana una vez al mes, como mucho. Por su parte, Taylor encontró que muchos disfrutaban cierto grado de soledad. Como un "próspero y progresista" productor argentino le dijo: "La ciudad es un buen lugar a donde ir por un rato, pero yo soy un hombre de la tierra y pertenezco al

había que salir temprano porque sino no podíamos salir [pues] siempre venía gente" (MU).

${ }^{131}$ Para algunos, también la salida a misa significaba una ocasión de encuentro social, tal como lo describe este entrevistado de origen danés: "Nosotros siempre íbamos a la misa, no tanto por la misa sino porque nos juntábamos con otra gente, y después, a la tarde, había café con masas. Después, a la noche, los mayores iban a jugar a las cartas, entonces nosotros hacíamos baile. Esa era la fiesta." (PL).

${ }^{132}$ Así, por ejemplo, un productor de Tres Arroyos de la colectividad danesa recordó todo el calendario de sus fiestas: "Nosotros íbamos mucho a las fiestas, fiestas dinamarquesas, había pocas pero... Había una en el Colegio, esa era, para juntar becas para los alumnos que no podían pagar. Y después el primero de mayo, había en Aparicio, Club Danés de Aparicio. El 25 de mayo, en el Colegio Danés. Esa ya era fiesta de la Sociedad Protestante. Después el 9 de julio, otra vez Aparicio. Después venía la fiesta grande de la Sociedad de Socorros Mutuos Dinamarquesa. Hacía una fiesta muy grande acá, en Tres Arroyos, que era la única vez, prácticamente, en el año que veníamos al pueblo. Y entonces, ahí tardaba tres días, traían películas de Dinamarca, bailes, ahí se gastaba mucha plata. Y después, en el mes de septiembre empezaban los torneos atléticos [en el Colegio Danés]" (PS).

${ }^{133}$ En la zona oeste, también eran habituales las fiestas que se organizaban en torno a la yerra "...ahí sí venían todos los vecinos. Era un día de fiesta, era un domingo. Entonces era el clásico asado, la empanada... Eso lo hacían los chacareros, y [...] papá como sabía castrar [...], castraba a todos animales de los vecinos" (MD).

134 Así, por ejemplo, lo recordó un productor de Tres Arroyos: "Se jugaba al fútbol, todo el mundo jugaba al fútbol, allí mismo, en Hueso Clavado, había un equipo, en los parajes de campo, como todo el mundo jugaba, de manera que se hacía el campeonato con Orense, con San Francisco, con el Carretero, con algún equipo de Tres Arroyos" (ET).

O como relató un productor de Pergamino: "Hace muchos años cada colonia tenía su equipo de futbol. Era una vida más linda, había mucha más gente en el campo" (GR). 
campo". Los productores trabajaban muchas horas en soledad sin sentir angustia por ello, aunque disfrutaban las visitas de sus vecinos. De hecho, la mayoría de ellos preferían las relaciones con vecinos, a las asociaciones más impersonales de grupos más grandes y formales (Taylor, 1948).

El factor que hacía posible este relativo aislamiento de los productores en sus chacras, era la producción secundaria orientada esencialmente para el autoconsumo y eventualmente el trueque a vendedores ambulantes, ya que reducía notoriamente la necesidad de concurrir periódicamente al poblado para comprar alimentos.

En cuanto a los pueblos, debemos decir que, aunque el patrón de poblamiento no se basó en aldeas campesinas, una consecuencia de este desarrollo agrícola fue el surgimiento de pequeñas localidades a lo largo de las vías férreas, donde se localizaban los servicios. Las estaciones de ferrocarril, espaciadas cada diez o quince kilómetros, oficiaban de nexo entre el campo y el puerto. En las zonas de densa población agrícola, la estación alcanzaba jerarquía de pueblo, donde el almacén de ramos generales, la escuela, el destacamento policial y la estafeta de correos integraban el cuadro de los servicios ofrecidos a una población de limitadas exigencias (Cammarata y otros, 1975: 151-152). Los testimonios por nosotros recogidos dan cuenta de una intensa actividad pueblerina: bares atiborrados, almacenes de ramos generales ampliamente surtidos (vendiendo desde comestibles hasta grandes cosechadoras de arrastre), escuelas llenas de alumnos que habitaban las chacras y tambos de los campos cercanos y no tan cercanos, la cooperativa local en plena expansión a partir de los años treinta, y la estación ferroviaria con sus inmensos galpones ${ }^{135}$.

Contamos con información muy detallada sobre estas pequeñas localidades para 1947. En cada una de las tres zonas hallamos más de medio centenar de pueblos (de 100 a 3.000 habitantes), donde se encontraba entre un $10 \%$ y un $18 \%$ de la población zonal (en el Cuadro 1.18, diferenciamos la población que se encontraba en las localidades con menos de 1.000 habitantes, de aquella situada en pueblos con 1.000 a 3.000 habitantes).

135 Para Tenembaum (1946), en cambio, estos pequeños poblados no eran suficientes, y los agricultores vivían en un aislamiento impresionante, a largas distancias unos de otros y sin un pequeño núcleo de población. Destaca la existencia de numerosas estaciones sin población, pues "el propietario no quiere formar pueblo". 
En promedio, cada partido contaba con cuatro a seis de estas pequeñas localidades (que tenían una media de 669 habitantes), donde acudían periódicamente los agricultores (en el Apéndice 4 se puede consultar la población de cada una de estas localidades en 1947, como así también su posterior evolución hasta 1991, que será analizada en el capítulo cuarto).

Por último, en cada partido existía una localidad de más de 3.000 habitantes, casi siempre la cabecera del partido, a la cuál el chacarero viajaba de un modo excepcional, una o dos veces en el año, especialmente si su establecimiento no se encontraba cerca de la misma. En el caso de los niños, obtuvimos testimonios que relatan haber conocido la ciudad recién a los diez años.... Sin embargo, en el caso de los productores medianos, equipados la mayoría de ellos con automóviles ${ }^{136}$, los viajes a la ciudad resultaban más frecuentes.

En estas ciudades se localizaba entre un $32 \%$ y un $44 \%$ de la población de cada zona (ver Cuadro 1.18). Estas ciudades tenían un tamaño promedio de 12.116 habitantes en la zona norte, 5.541 en la zona oeste y 9.454 en la zona sur (excluyendo Bahía Blanca). Tan sólo seis localidades de la zona norte, dos de la oeste y cuatro de la sur, tenían más de 10.000 habitantes. Taylor (1948: 272) comentaba que, en contraste con los Estados Unidos, en vez de existir numerosas pequeñas localidades de 1.000 a 5.000 habitantes, el patrón de ciudad rural argentina tendía hacia un número más reducido de pequeñas ciudades de 10.000 a 40.000 habitantes y a pequeños pueblos con muy poco desarrollo económico y prácticamente sin función social.

En las cabeceras de los partidos (especialmente las de mayor tamaño), se desarrollaba una vida urbana mucho más sofisticada. Hourcade ha analizado para el sur santafecino la manera en que proliferaron "en las nuevas localidades, entre principios de siglo y los años veinte, periódicos, revistas de distinto tipo, grupos artísticos inclinados a la ópera o al teatro, grupos de iniciación a la literatura o de estudiosos de diversos temas que se reunían para formar bibliotecas. [...] Tales realizaciones parecen posibles

136 En 1928, en Tres Arroyos, casi todos los productores con más de 300 hectáreas tenían automóvil; más detalles en Balsa (1993: 130). 
por una representación de lo que debía ser una vida urbana 'elevada', o simplemente 'civilizada', y de las exigencias que ello imponía sobre lo cotidiano" (Hourcade, 1999: 167-168). Si bien para Hourcade existía un nivel de integración social fuerte en estas sociedades de las localidades pampeanas, personalmente considero que quedaban fuera la mayoría de los chacareros, residentes en el campo y con visitas muy esporádicas a estas poblaciones. La única excepción podrían ser aquellos productores que, viviendo cerca de la ciudad, la utilizaban como su centro de aprovisionamiento. Al respecto, Taylor describe que los productores raramente asistían a reuniones informales como ocurría en las localidades de Estados Unidos. Los habitantes de las ciudades rurales y los chacareros no eran parte de la misma comunidad en un sentido social. Así, por ejemplo, todos los comercios estaban cerrados en la tarde del domingo, el único día en que los productores habitualmente iban a las ciudades. Existía muy poco tráfico cultural entre los habitantes de las pequeñas ciudades y la gente del campo (Taylor, 1948: 272-273).

Por otra parte, era casi completa la ausencia de contactos sociales verticales. Pocos hijos de productores se convertían en profesionales y había una gran distancia cultural entre los tipos de conocimiento e ideas que prevalecían en los diferentes niveles de vida. Existían claras barreras ante la ausencia de expectativas de ascenso social (de peón a arrendatario y de éstos a propietarios), a pesar de la existencia de constantes contactos (Taylor, 1948: 273). Sin embargo, en otro apartado, Taylor destaca que entre los prósperos productores de las colonias santafesinas se comentaba que demasiados hijos de estos colonos habían dejado la explotación para dedicarse a los negocios o para convertirse en abogados o médicos (Taylor, 1948: 13). Este fenómeno, todavía seguramente acotado, de una integración pero por la vía de la urbanización, estaba preanunciando que la disociación entre vida urbana y vida rural no se mantendría a lo largo de todo el siglo XX y que se resolvería a través de la desruralización del productor. Pues, como veremos en el capítulo cuarto, el modo de vida de los productores rurales se modificará notoriamente. Pero antes de analizar este proceso, dedicaremos dos capítulos a estudiar las profundas transformaciones estructurales que tuvieron lugar entre 1937 y 1988. 
Capítulo Segundo

¿"Farmerización" de los chacareros o reconstitución de las grandes estancias ganaderas en las décadas del cuarenta al sesenta? 
Desde fines de los años treinta, luego de varias décadas de expansión casi ininterrumpida, la agricultura pampeana entró en una etapa de retracción (el llamado "estancamiento") de la que recién saldría tímidamente durante los años sesenta. Aunque la retracción agrícola fue acompañada de un incremento de la actividad ganadera, en conjunto asistimos a una disminución del producto bruto agropecuario (especialmente grave en la coyuntura de comienzos de los años cincuenta).

Además, este período estuvo signado por una fuerte intervención estatal en el agro y por una sustancial transformación en la forma de tenencia del suelo: del predominio de las unidades productivas en arriendo o en aparcería se pasó al de las explotaciones en propiedad. Detrás de esta simbiosis entre propiedad y producción que muestran los datos censales, la literatura especializada ha interpretado la existencia de dos fenómenos socialmente contrapuestos. La discusión central gira en torno al sujeto que protagonizó el incremento de la tenencia en propiedad: si hubo un proceso de "farmerización" donde los chacareros arrendatarios se convirtieron en propietarios, o si, expulsados éstos, fueron los terratenientes (en buena parte, rentistas al comienzo del período) quienes se hicieron cargo de las explotaciones, recomponiendo las viejas estancias o constituyendo nuevas, en consonancia con el viraje hacia la ganadería ocurrido en esos años.

En el presente capítulo intentaremos dilucidar esta cuestión. Comenzaremos con una sucinta descripción de las modificaciones que tuvieron lugar en la orientación productiva de las tres zonas estudiadas. En segundo lugar, presentaremos los cambios en la tenencia del suelo observables a partir de la información censal y comentaremos las interpretaciones contrapuestas que se elaboraron en base a estos datos. En la tercera parte, analizaremos los procesos de subdivisión de la propiedad de la tierra, mientras que en el siguiente apartado reseñaremos las políticas agrarias y las acciones de colonización realizadas en este período. Llegados a este punto, sopesaremos las evidencias en favor de la hipótesis de la "farmerización" o de la reconstitución de las estancias ganaderas, considerando también el proceso de concentración de las unidades productivas que ocurrió a lo largo de estas décadas. Para finalizar, analizaremos las transformaciones en las formas sociales de producción de la agricultura, cotejando las 
situaciones de 1937 y 1969 en términos de la distribución de la superficie agrícola, y estudiando el impacto del proceso de mecanización de la agricultura pampeana.

\section{Retracción agrícola y avance ganadero}

Desde mediados del siglo pasado hasta fines de la década de 1930, el agro pampeano se había caracterizado por un constante crecimiento productivo. Durante esos años, las recurrentes crisis -que por cierto tuvieron lugar- fueron rápidamente superadas: al poco tiempo los niveles productivos estaban por encima de los previos al momento crítico.

En cambio, a partir de 1937, el sector pierde este dinamismo, y la mayoría de los autores hablan de un "estancamiento" del agro pampeano. Aunque algunos analistas destacan que, en forma paralela al estancamiento agrícola, tuvo lugar un importante avance de la ganadería ${ }^{1}$, esta reorientación en el uso del suelo de la agricultura hacia la ganadería (que se mantuvo hasta muy entrada la década de 1960) no compensó el retroceso agrícola. El valor total de la producción agropecuaria pampeana se retrajo y luego sólo mostró un lento crecimiento. Si analizamos el valor indexado de la producción de la región pampeana calculado por Reca (1967), observamos que recién a mediados de los años sesenta comienza cierto despegue productivo y se logra distanciar significativamente de los niveles de finales de los años veinte (ver Cuadro 2.1) ${ }^{2}$. Por lo tanto, podemos confirmar que, durante las décadas de 1940 a 1960, el agro pampeano se habría, al menos, estancado (ya que en términos relativos a la población total del país, resulta indudable su retroceso). ${ }^{3}$

1 Es más, para Osvaldo Barsky (1988), habría que hablar de caída y recuperación agrícola, con lo cual el dinamismo típico de la anterior etapa no se habría quebrado de un modo tan claro.

2 Ya a mediados de los años setenta Piñeiro (1975) no sólo llamaba la atención sobre el crecimiento relativo de la agricultura pampeana entre 1960 y 1973 (tratando de revisar la "verdad incontrovertible, la creencia que la producción agregada del sector agropecuario [...] ha estado estancada en las últimas décadas"), sino que también intentaba interpretar las causas de esta recuperación. Para Piñeiro (1975: 12) el factor explicativo fue la adopción masiva y generalizada de la semilla híbrida en el cultivo del maíz y el sorgo, y del paquete tecnológico que, generalmente, acompañó la adopción de ésta.

3 Por otra parte, la recuperación agrícola durante los años sesenta, fue un fenómeno más ligado a un incremento en los rendimientos que a un cambio en el uso del suelo (comparar ambas 
Cuadro 2.1.

Producto Bruto Agropecuario de la Región Pampeana

(índice 100=1935-39).

\begin{tabular}{|l|l|l|l|}
\hline & Cereales & Ganadería & Total \\
\hline $1923-27$ & 82.5 & 86.6 & 85.6 \\
\hline $1928-32$ & 98.2 & 89.5 & 95.7 \\
\hline $1933-37$ & 101.2 & 95.5 & 98.8 \\
\hline $1938-42$ & 102.5 & 111.1 & 105.8 \\
\hline $1943-47$ & 87.4 & 133.6 & 102.8 \\
\hline $1948-52$ & 77.6 & 120.2 & 94.7 \\
\hline $1953-57$ & 95.2 & 133.7 & 110.6 \\
\hline $1958-62$ & 103.2 & 132.0 & 114.5 \\
\hline $1963-65$ & 115.6 & 130.5 & 121.6 \\
\hline
\end{tabular}

Fuente: Reca (1967: 9).

\subsection{Evolución del área sembrada y el volumen cosechado en la región pampeana}

Considerando la superficie sembrada con cultivos para cosecha, observamos en el Gráfico 2.1 que en el conjunto de la región pampeana tuvo lugar una considerable reducción de esta área durante la década del cuarenta (con una extensión mínima en 1951). Luego, durante los años cincuenta, la superficie se mantuvo estable en niveles claramente inferiores a los del 1938, y recién en la década del sesenta se observa una muy tibia recuperación en el área sembrada, pero que ni siquiera alcanzó al 80\% de la superficie dedicada a la agricultura en 1938. En el mismo gráfico se puede ver que la evolución del volumen cosechado no fue muy diferente: una tendencia claramente descendente en la década del cuarenta (con fuerte oscilaciones), una cierta estabilización en los cincuenta (con cosechas que significaban un 70\% del volumen recogido en 1938) y una leve recuperación en los años sesenta. Entre la evolución de los diferentes cultivos, se destacan el maíz y el lino por sus tendencias fuertemente descendentes en los años cuarenta, de la que sólo el maíz se recuperará parcialmente en los sesenta. En el Apéndice 2 (Apartado1.1) hemos analizado más detalladamente la evolución de la

líneas en el Gráfico 2.1). 
superficie sembrada y el volumen cosechado discriminando cada uno de los cultivos, y agregando la información para la provincia de Buenos Aires, en particular.

\section{Gráfico 2.1.}

\section{Región Pampeana. Evolución de la Superficie Sembrada y el Volumen Cosechado \\ (trigo, maíz, lino, girasol y cebada cervecera) $100=1938$}

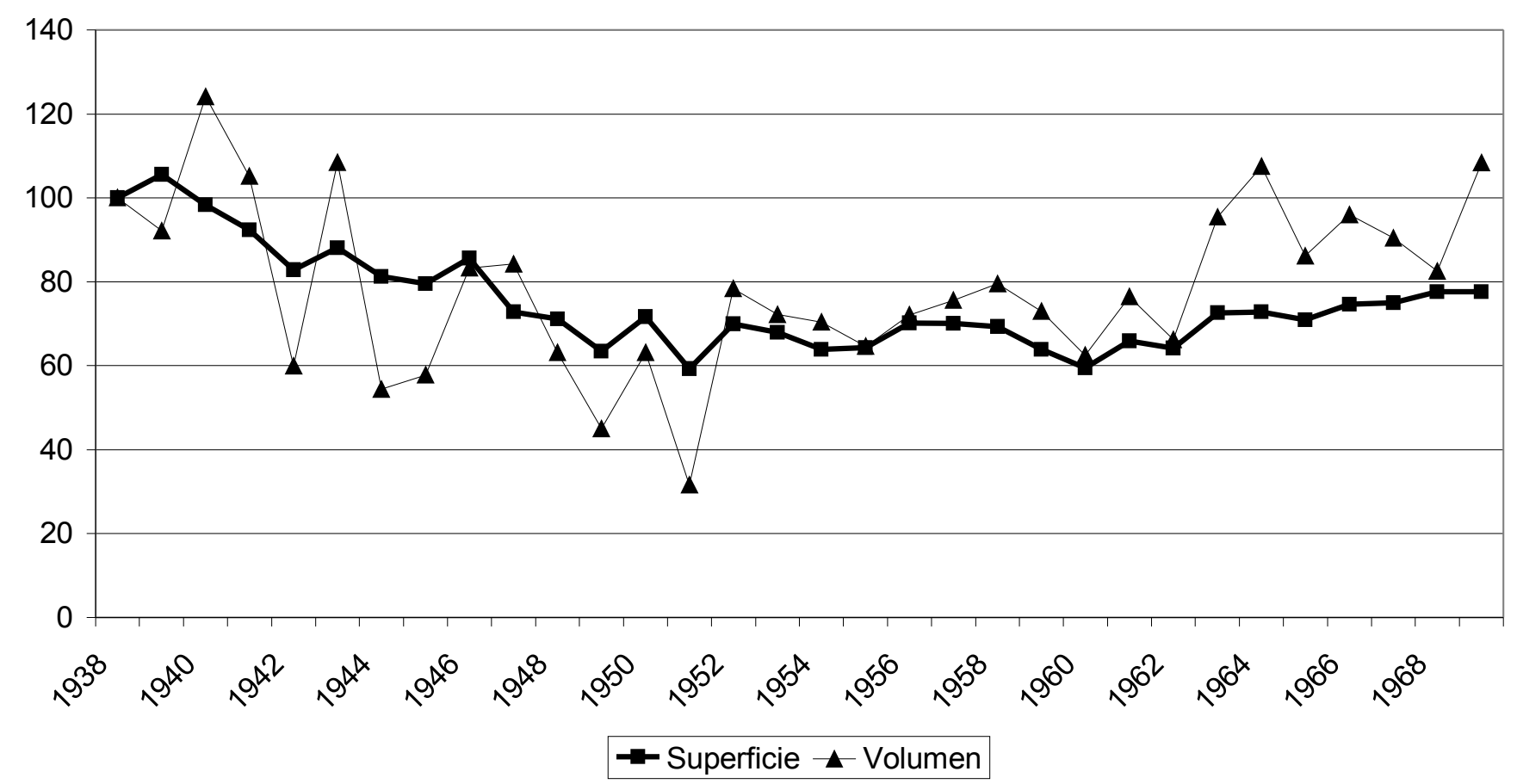

Fuente: Cálculos propios en base a las Estimaciones Agrícolas de la Secretaría de Agricultura y Ganadería.

Nota: La base 100 de la campaña 1938/39 corresponde a una superficie sembrada de 16.833 .490 hectáreas y a un volumen cosechado de 14.204.759 toneladas. 


\subsection{Los cambios productivos en las tres zonas analizadas}

A partir de las Estimaciones Agrícolas elaboradas por la Secretaría de Agricultura y Ganadería de la Nación, hemos calculado la superficie sembrada, el volumen cosechado y los rendimientos de las tres zonas en estudio para cada uno de los años analizados, a partir de los datos de los ocho principales cultivos de cada uno de los cuarenta partidos (para ejemplificar el modo en que hemos trabajado, en el Apéndice 5 reprodujimos uno de estos cuadros). A fin de sintetizar la presentación, aquí sólo reproducimos las sumatorias del total de cultivos para cada zona ${ }^{4}$.

Como podemos ver en Gráfico 2.2., durante la década del cuarenta, observamos una clara disminución del área sembrada en las tres zonas, pero mucho más marcada en la zona oeste (reduciéndose a la mitad del área inicial). En estos años en la zona norte tuvo lugar una relativa expansión del trigo, que ocupó el lugar que antes tenía el maíz.

Durante los años cincuenta la superficie sembrada se mantuvo en niveles muy bajos; sólo tuvo lugar cierta recuperación en la zona sur, pero sin alcanzar el área sembrada en 1938. En estos años se destacó el girasol que se convirtió en el tercer cultivo en importancia en las zonas norte y oeste.

Por último, durante la década del sesenta se incrementó la superficie sembrada en las zonas sur (donde llegó a superar el nivel de 1938) y oeste (donde tan sólo alcanzó a un $70 \%$ de dicho nivel, destacándose el aumento de la superficie con trigo). En cambio, en la zona norte, el área sembrada se mantuvo relativamente estable, en torno al 80\% de la superficie sembrada en 1938 (en estos años el maíz volvió a recuperar su lugar y se retrajo la superficie triguera en la zona norte).

4 En el mismo Apéndice 5 hemos transcripto los cuadros con la información agregada por zonas sobre las tres variables procesadas y analizadas. Asimismo, en el Apéndice 2 (Apartado 1.2) se pueden consultar los gráficos y los comentarios sobre cada uno de los distintos tipos de cultivos en las tres zonas estudiadas. 


\section{Gráfico 2.2.}

\section{Evolución de la Superficie Sembrada \\ (trigo, maíz, lino, girasol y cebada cervecera) \\ $100=1938$}

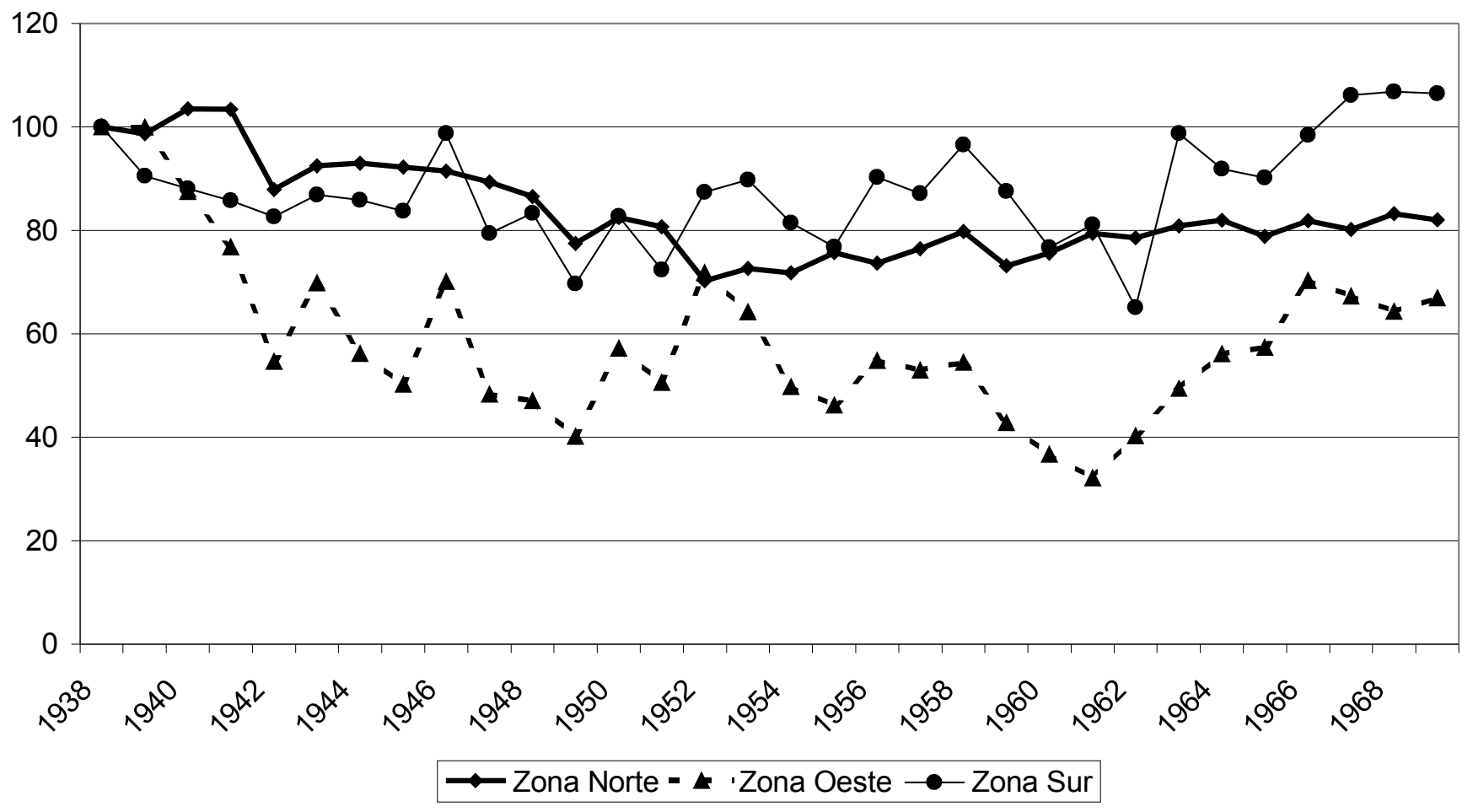

Fuente: Cálculos propios en base a las Estimaciones Agrícolas de la Secretaría de Agricultura y Ganadería.

Nota: La base 100 de la campaña 1938/39 corresponde a una superficie sembrada de 1.212.087 hectáreas en la zona norte, de 782.586 hectáreas en la zona oeste y de 1.964.200 hectáreas en la zona sur.

Este retroceso agrícola, fue acompañado por una expansión de la ganadería vacuna (especialmente intensa en la zona norte) y, en el caso de la zona sur también del ovino, como puede observarse en el Cuadro 2.2. Esta expansión de la ganadería fue acompañada por un incremento en las superficie dedicadas a forrajeras. En las zonas norte y sur, las forrajeras anuales tuvieron una importante expansión. En cambio, en la zona oeste, donde estas plantas ya eran importantes, sobresale el aumento de la superficie destinada al centeno. Por otro lado, los caballos perdieron significación en las tres zonas, en parte por la retracción agrícola, pero sobre todo por la tractorización que se desarrolló a lo largo de los años cincuenta y sesenta. 
Cuadro 2.2. Proporción de superficie implantada, sobre el total censado y cabezas de ganado por hectárea

\begin{tabular}{|c|c|c|c|c|c|c|c|c|}
\hline & & \multirow{2}{*}{$\begin{array}{c}\text { forrajeras } \\
\text { perma- } \\
\text { nentes } \\
\text { (ha.) }\end{array}$} & \multicolumn{3}{|c|}{ Cabezas de ganado } & \multicolumn{3}{|c|}{$\begin{array}{c}\text { Cabezas de ganado por } \\
\text { hectárea }\end{array}$} \\
\hline & & & vacunos & ovinos & equinos & vacunos & $\begin{array}{c}\text { ovinos } / 5 \\
(*)\end{array}$ & equinos \\
\hline \multirow{4}{*}{ zona norte } & 1937 & 139 & 721 & 356 & 315 & 0,36 & 0,04 & 0,16 \\
\hline & 1947 & $\mathrm{~s} / \mathrm{d}$ & 1192 & 291 & 279 & 0,62 & 0,03 & 0,15 \\
\hline & 1960 & 356 & 1550 & 260 & 151 & 0,78 & 0,03 & 0,08 \\
\hline & 1969 & 481 & 1574 & 161 & $\mathrm{~s} / \mathrm{d}$ & 0,82 & 0,02 & $\mathrm{~s} / \mathrm{d}$ \\
\hline \multirow{4}{*}{ zona oeste } & 1937 & 1015 & 2146 & 889 & 274 & 0,63 & 0,05 & 0,08 \\
\hline & 1947 & $\mathrm{~s} / \mathrm{d}$ & 2707 & 1400 & 227 & 0,79 & 0,08 & 0,07 \\
\hline & 1960 & 1147 & 2808 & 1622 & 127 & 0,82 & 0,10 & 0,04 \\
\hline & 1969 & 1114 & 3061 & 974 & $\mathrm{~s} / \mathrm{d}$ & 0,84 & 0,05 & $\mathrm{~s} / \mathrm{d}$ \\
\hline \multirow{4}{*}{ zona sur } & 1937 & 54 & 1347 & 4288 & 524 & 0,25 & 0,16 & 0,10 \\
\hline & 1947 & $\mathrm{~s} / \mathrm{d}$ & 2046 & 4095 & 392 & 0,38 & 0,15 & 0,07 \\
\hline & 1960 & 194 & 2324 & 7068 & 150 & 0,44 & 0,27 & 0,03 \\
\hline & 1969 & 382 & 2247 & 5735 & $\mathrm{~s} / \mathrm{d}$ & 0,42 & 0,21 & $\mathrm{~s} / \mathrm{d}$ \\
\hline
\end{tabular}

(*) Hemos dividido a los ovinos por cinco a fin de hacer relativamente equiparable su carga ganadera con la de un vacuno o un equino.

Fuente: cálculos propios efectuados en base a la información desagregada por partidos de los Censos Agropecuarios Nacionales de 1937, 1947, 1960 y 1969. 
En cuanto al volumen de la producción agrícola, en el Gráfico 2.3., observamos que en los años cuarenta tuvieron lugar fuertes oscilaciones en las tres zonas estudiadas (muy marcadas en la zona norte, por las intensas variaciones en la cosecha del maíz), pero siempre con una tendencia descendente que alcanzó sus niveles más bajos a comienzos de los años cincuenta. A lo largo de esta última década tuvo lugar cierta recuperación productiva, que sólo en la zona sur logró superar los niveles de 1938. En los años sesenta los volumenes fueron creciendo en las tres zonas, destacándose la zona sur (con un importante aumento de la cosecha de trigo). Nuevamente, recordamos que en el Apéndice 2 (Apartado 1.2) se encuentran más detalles sobre la evolución de cada uno de los cultivos.

\section{Gráfico 2.3.}

\section{Evolución del Volumen Cosechado}

(trigo, maíz, lino, girasol, avena, centeno y cebada cervecera)

$100=1938$

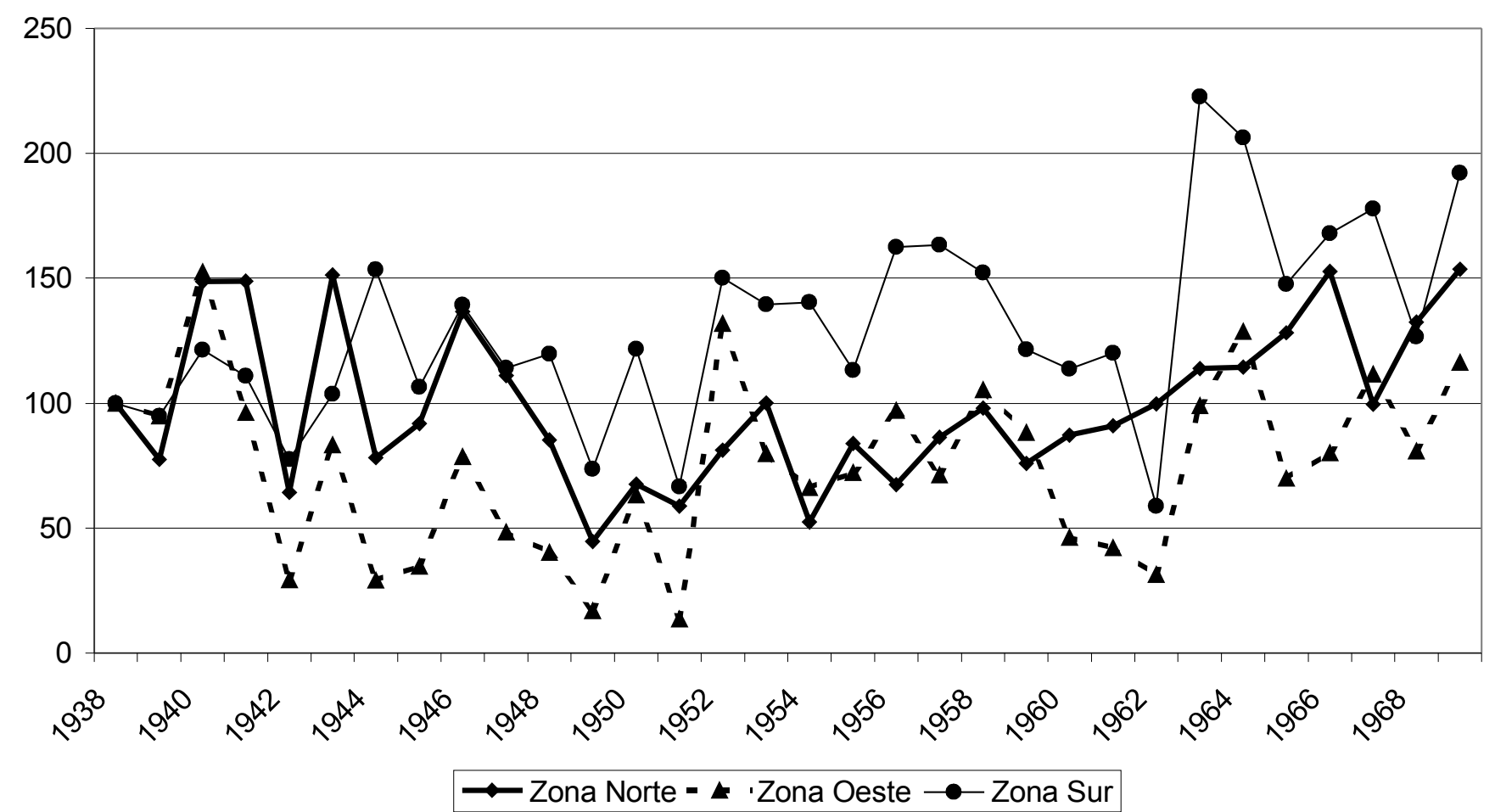

Fuente: Cálculos propios en base a las Estimaciones Agrícolas de la Secretaría de Agricultura y Ganadería.

Nota: La base 100 de la campaña 1938/39 corresponde a un volumen cosechado de 1.176.619 toneladas en la zona norte, de 521.696 toneladas en la zona oeste y de 1.751 .100 toneladas en la zona sur. 


\section{Una drástica modificación en las formas de tenencia y sus interpretaciones}

\subsection{Cambios en la tenencia del suelo}

A partir de la información censal se observa claramente el fin del sistema de arrendamiento característico del período de expansión agrícola. Datos globales de la provincia de Buenos Aires y de la región pampeana muestran un claro proceso de incremento del peso relativo del número de propietarios y de la superficie en propiedad entre 1937 y 1969.

Evolución del porcentaje de propietarios sobre el total de productores, 1937-1960

\begin{tabular}{|l|c|c|c|}
\hline & 1937 & $1947 *$ & 1960 \\
\hline Buenos Aires & $30,9 \%$ & $38,5 \%$ & $59,1 \%$ \\
\hline Total región pampeana & $35,5 \%$ & $43,2 \%$ & $62,7 \%$ \\
\hline
\end{tabular}

* En 1947 incorpora a formas mixtas que incluyen propiedad.

Fuente: Barsky (1997: 123 y 128).

Evolución del porcentaje de superficie en propiedad sobre el área total censada, 1947-1969

\begin{tabular}{|l|c|c|c|}
\hline & 1947 & 1960 & 1969 \\
\hline Buenos Aires & $49,8 \%$ & $61,6 \%$ & $71,8 \%$ \\
\hline Total región pampeana & $52,1 \%$ & $64 \%$ & $73,1 \%$ \\
\hline
\end{tabular}

Fuente: Barsky (1997: 129). 
En las tres zonas bonaerenses estudiadas el proceso ha sido similar al ocurrido en el conjunto de la región: si en 1937 predominaban los arrendatarios y aparceros, en 1969 los propietarios superaban ampliamente en número a los no propietarios ${ }^{5}$. En el Cuadro 2.3 puede observarse que, en esta última fecha, el predominio de los propietarios era asombrosamente semejante en las tres zonas, constituyendo casi el ochenta por ciento de los productores.

Cuadro 2.3. Cantidad de productores según formas de tenencia

\begin{tabular}{|c|c|c|c|}
\hline & & 1937 & 1969 \\
\hline \multirow{3}{*}{ Zona norte } & Propietarios & $32 \%$ & $79 \%$ \\
\hline & No propietarios & $68 \%$ & $21 \%$ \\
\hline & & $100 \%$ & $100 \%$ \\
\hline \multirow[t]{3}{*}{ Zona oeste } & Propietarios & $29 \%$ & $78 \%$ \\
\hline & No propietarios & $71 \%$ & $22 \%$ \\
\hline & & $100 \%$ & $100 \%$ \\
\hline \multirow[t]{3}{*}{ Zona sur } & Propietarios & $34 \%$ & $77 \%$ \\
\hline & No propietarios & $66 \%$ & $23 \%$ \\
\hline & & $100 \%$ & $100 \%$ \\
\hline
\end{tabular}

Fuente: cálculos propios en base a la publicación del Censo de 1937, y al reprocesamiento de los datos originales del Censo de 1969

Un fenómeno semejante se observa en relación con la superficie que ocupaban las distintas formas de tenencia, aunque para esta comparación sólo podemos partir de los datos de 1947, debido a que en el censo de 1937 no se registró la superficie que ocupaba cada forma de tenencia. Como se observa en el cuadro 2.4, en la zona norte fueron las unidades en propiedad pura las que captaron la mayor parte $(+20 \%$ de la superficie total) de la drástica reducción de la superficie ocupada por arrendatarios

5 En el censo de 1937 no se aclaró de qué manera se codificaron las explotaciones que presentaban formas mixtas de tenencia del suelo, ya que sólo se distinguió a los arrendatarios en dinero o en especies. De todos modos, en 1947 las formas mixtas que combinaban propiedad con otro tipo de tenencia sólo representaban el 5,7\% de los productores de la zona norte, y el 8,4\% en las otras dos zonas (cálculos propios en base al Censo Agropecuario de 1947). Entonces, para poder realizar la comparación, hemos catalogado las unidades de 1969 como en propiedad en los casos en que al menos el $10 \%$ de la superficie total estuviera bajo esta forma de tenencia. Esto ha sido posible porque hemos reprocesado los datos originales del censo de 1969. 
( $-26 \%$ de la superficie total) y por aparceros $(-6 \%)$. Sin embargo, en términos relativos, la expansión fue mayor en el caso de las explotaciones que combinaban propiedad con arriendo, y propiedad con aparcería (que pasaron del 9\% al $17 \%$ y del 1\% al 5\% de la superficie total, respectivamente).

En la zona oeste, la fuerte disminución del área ocupada por los arrendatarios ( $-28 \%$ de la superficie total) pasó casi exclusivamente a los propietarios puros $(+26 \%)$. Por último, en la zona sur, donde la disminución del área ocupada por los arrendatarios fue muy intensa $(-36 \%)$, también fue captada por las unidades en propiedad pura $(+26 \%)$, pero algo también por las que combinaban propiedad y arriendo.

El arriendo (como forma de tenencia pura) y también la aparcería -para el caso de la zona norte donde había tenido cierta importancia en el pasado- quedaron reducidos a un lugar marginal en la estructura productiva del agro bonaerense, al tiempo que se incrementaba su importancia en forma combinada con la propiedad.

Cuadro 2.4. Superficie según formas de tenencia

\begin{tabular}{|l|c|c|c|c|c|c|c|c|}
\hline & & $\begin{array}{c}\text { Propiedad } \\
\text { pura }\end{array}$ & $\begin{array}{c}\text { Prop. y } \\
\text { arriendo }\end{array}$ & $\begin{array}{c}\text { Prop. y } \\
\text { aparcería }\end{array}$ & $\begin{array}{c}\text { Arrenda- } \\
\text { miento }\end{array}$ & Aparcería & $\begin{array}{c}\text { Otras } \\
\text { formas }\end{array}$ & \\
\hline $\begin{array}{l}\text { zona } \\
\text { norte }\end{array}$ & 1947 & $41 \%$ & $9 \%$ & $1 \%$ & $37 \%$ & $9 \%$ & $3 \%$ & $100 \%$ \\
\cline { 2 - 9 } & 1969 & $61 \%$ & $17 \%$ & $5 \%$ & $11 \%$ & $3 \%$ & $5 \%$ & $100 \%$ \\
\hline $\begin{array}{l}\text { zona } \\
\text { oeste }\end{array}$ & 1947 & $40 \%$ & $15 \%$ & $1 \%$ & $40 \%$ & $1 \%$ & $3 \%$ & $100 \%$ \\
\cline { 2 - 10 } & 1969 & $66 \%$ & $17 \%$ & $1 \%$ & $12 \%$ & $1 \%$ & $4 \%$ & $100 \%$ \\
\hline $\begin{array}{l}\text { zona } \\
\text { sur }\end{array}$ & 1947 & $30 \%$ & $15 \%$ & - & $50 \%$ & $1 \%$ & $4 \%$ & $100 \%$ \\
\cline { 2 - 10 } & 1969 & $56 \%$ & $21 \%$ & $3 \%$ & $14 \%$ & $2 \%$ & $4 \%$ & $100 \%$ \\
\hline
\end{tabular}

Fuente: Datos por partido del Censo Agropecuario de 1947 y reprocesamiento de los datos originales del Censo de 1969.

Detrás de esta simbiosis entre propiedad y producción que muestran los datos censales, la literatura especializada ha interpretado la existencia de dos fenómenos opuestos. Tal como adelantáramos al comienzo del presente capítulo, la discusión central gira en torno al sujeto que protagonizó la expansión de la tenencia en propiedad: si hubo un proceso de "farmerización" (acceso a la propiedad) de los chacareros arrendatarios, o si los terratenientes recompusieron las viejas estancias o constituyeron nuevas, luego de echar a los no propietarios. Por lo tanto, no existe acuerdo sobre los 
impactos en la estructura agraria que tuvieron, entre otros factores, la coyuntura crítica para la agricultura, las variadas medidas políticas implementadas, el accionar de los terratenientes y las estrategias que los agricultores desarrollaron durante estas décadas. En el siguiente apartado reseñaremos estas posiciones contrapuestas.

\subsection{Interpretaciones de la significación social del cambio en la forma de tenencia}

No existe un claro consenso acerca de las transformaciones en la estructura social agraria durante las décadas del cuarenta al sesenta. Nadie discute el dato censal del avance de la propiedad como forma de tenencia de las explotaciones, la discusión central se ubica entonces, en el sujeto que protagonizó la expansión de esta forma de tenencia.

Flichman (1978) enfatiza el proceso por el cual una gran parte de los arrendatarios logró acceder a la propiedad de la tierra. En el mismo sentido, Lattuada, si bien destaca la presencia de los dos fenómenos (adquisición y concentración), sostiene que el primero “... permitió el surgimiento y consolidación de un estrato de nuevos pequeños y medianos propietarios rurales de unidades de producción de tipo familiar, principales actores del cambio tecnológico en el sector, y quienes a través del aprovechamiento de una política crediticia y de desgravaciones impositivas posibilitaron un progresivo reemplazo de la energía biológica (animales-hombres) por la energía mecánica en el proceso productivo.” (Lattuada, 1986: 199).

Para Forni y Tort, "un balance sobre la proporción de arrendatarios que pasaron a convertirse en propietarios de explotaciones viables señalaría que alcanzaron esas situaciones varias decenas de millares en estas áreas cerealeras. Estas explotaciones varían en tamaño y están muchas veces inmersas en sistemas de incorporación o, a la inversa, de ubicación de excedentes de mano de obra y maquinarias. Otra buena cantidad no se arriesgó o no pudo adquirir una explotación; parte de ellos, capitalizados con maquinarias, pasaron a integrar la actividad de contratistas en tanto otros debieron abandonar el sector. Como resumen, podemos decir que a finales de los años 60, a través de la consolidación de la propiedad y la mecanización sustitutiva de mano de obra, están dadas finalmente las condiciones para la desaparición de los chacareros y la 
consolidación de la ‘farmerización"” Forni y Tort (1992: 152-153)6. También Ansaldi (1998) destaca la conversión de los chacareros en farmers (en tanto categoría analítica, aunque se mantenga la denominación histórica de "chacareros").

En la posición opuesta a estos autores, Slutzky (1968) sostiene que el desarrollo capitalista produjo un proceso de concentración que significó una disminución de la clase media rural, un aumento de la participación de los asalariados en la fuerza de trabajo y una mayor mecanización. Sin negar la existencia de un proceso de adquisición de la tierra por los antiguos arrendatarios, Slutzky destaca el proceso inverso de su abandono o desalojo de la explotación para dar lugar a la reconstitución de unidades de mayor dimensión en manos de los propietarios originales. Este autor plantea que “...ante esta situación [de baja rentabilidad de las explotaciones agrícolas], muchos chacareros arrendatarios de la zona cerealera remataron sus enseres de trabajo y se refugiaron en las ciudades, puesto que la prórroga de los arrendamientos y la congelación del precio de los mismos no era incentivo suficiente como para permanecer en el campo, o también porque no tenían lo suficiente como para permanecer en el campo, o también porque no tenían la suficiente capacidad financiera para adquirirlo. Por otra parte, los propietarios trataron por todos los medios -maniobras jurídicas o indemnizaciones- de recuperar sus campos para dedicarlos íntegramente a la cría de ganado -cuyo precio era altamente retributivo en relación al de los granos- o para realizar un tipo de agricultura mecanizada, por su propia cuenta o mediante contratos por una cosecha." (Slutsky, 1968: 111). Por otra parte, plantea que “... la creciente tecnificación y utilización de mano de obra asalariada en las explotaciones de las provincias de Buenos Aires y Santa Fe es un proceso paralelo a la eliminación de la pequeña producción de las explotaciones subfamiliares y es, además, la causa de la disminución de la clase media rural que hemos comprobado. Quiere decir que en la zona de más desarrollo agrícola se produce un proceso de concentración capitalista que debe ser medido, no tanto por el aumento de la extensión de las explotaciones como por la creciente densidad de

6 Por su parte, Barsky (1992: 24) señala la existencia de elementos de continuidad, al destacar que los chacareros que consiguieron la propiedad después de 1940 “... ampliaron al sector de explotaciones familiares propietarias preexistentes, cuya existencia estaba velada por el peso social de los arrendatarios, dado que su crítica situación centraba la atención de gobiernos y fuerzas políticas en diversos períodos.” 
máquinas y de personal asalariado y por el volumen de la producción. En síntesis, el impacto capitalista produce en la zona de mayor desarrollo (pampeana) el aniquilamiento de la pequeña producción y la emigración del productor, el reemplazo de agricultura por ganadería extensiva y la sustitución del antiguo arrendatario agricultor por una agricultura mecanizada realizada por medio de administradores o 'contratistas'." (Slutsky, 1968: 116-117).

Compartiendo en parte esta perspectiva, Llovet señala que desde la Segunda Guerra Mundial hasta finales de los años cincuenta “... el panorama que se va configurando es uno que implica el deterioro de las condiciones económicas de las explotaciones con poca dotación de tierra y asentadas en fuerza de trabajo familiar. Desde la perspectiva individual de estas explotaciones, las desventajosas condiciones internacionales pueden ser enfrentadas mediante incrementos en el producto obtenido por unidad de superficie o mediante la ampliación de la escala de operaciones, a través de la incorporación de nuevas tierras. Las políticas tecnológica y de tenencia no favorecen la realización de dichas alternativas. Su resultado es la declinación de este segmento de las explotaciones y la degradación de su carácter familiar..." (Llovet, 1988: 258).

Por otra parte, para este autor, durante la década del sesenta se manifiesta un cambio en la significación del arriendo: en 1969 “... existía una asociación positiva entre el tamaño de las empresas y la importancia que las tierras cedidas tenían en su conformación en tanto unidades económicas. Aunque no es posible sustentarlo cuantitativamente, esta asociación entre tenencia y tamaño es opuesta a la que existió, o se supone que existió, hasta la década del treinta en la provincia [de Buenos Aires], cuando las unidades productivas asentadas, total o parcialmente, sobre tierras cedidas, ocupaban fundamentalmente los niveles inferiores de la escala de tamaño." (Llovet, 1988: 274).

Por último, Barsky y Pucciarelli (1991) han detectado la presencia de dos tendencias contrapuestas. Señalan que “... si el proceso de desconcentración del período de moderado crecimiento (1914/39) afectó al latifundio y gran latifundio ganadero, en favor de un fuerte crecimiento del peso cuantitativo de las explotaciones familiares 
capitalizadas y las pequeñas y medianas empresas no familiares ni latifundistas, el mismo proceso -operado durante el período del estancamiento (1939/60)- tiene un significado y un efecto completamente diferente.

Castiga, en primer lugar, a las pequeñas unidades agrícolas familiares, sobre las cuales incide, simultáneamente, la reasignación de tierras a la ganadería y el amplio movimiento de recuperación de parcelas arrendadas, por parte de los grandes propietarios. La liquidación virtual de las formas de arriendo tradicional, que caracteriza este período, provoca un fuerte movimiento de éxodo hacia la ciudad, concomitante al proceso de industrialización pero acompañada, sin embargo, de una tendencia contrastante de signo opuesto: el acceso a la propiedad de la tierra por parte de exarrendatarios favorecidos tanto por la legislación agraria como por la política crediticia implantada en la década del cuarenta. En la intersección de ambos procesos se halla el punto de partida de la explicación de la nueva posición y la nueva forma de desempeño del chacarero pampeano, un fenómeno insuficientemente estudiado.

Agudiza, en segundo lugar, el movimiento de subdivisión que viene afectando a las grandes unidades de producción de más de 5.000 has., un grupo que pierde el $30 \%$ de la dotación de tierras controlada a fines de la década del treinta, durante el transcurso del nuevo proceso de ganaderización. El retorno a las estrategias económicas tradicionales no implica, en esta ocasión, la rehabilitación de las grandes estancias, superiores a las 5.000 has., sino lo contrario: la acentuación de un proceso de subdivisión de la cúspide, que coloca como protagonista principal al grupo de unidades de 1.000 a 5.000 has., y entre las cuales predominaron seguramente las estancias latifundistas de 2.500 a 5.000 has.” (Barsky y Puccieralli, 1991: 342-343).

En la siguiente sección intentaremos sopesar la importancia de estos fenómenos, analizando, en primer lugar, las transformaciones en la estructura de la propiedad.

\section{Las transformaciones en la estructura de la propiedad entre 1939 y 1960/64}

Analizando qué ocurrió entre 1939 y los años sesenta con las propiedades que habíamos descripto para 1939 en el capítulo primero, encontramos un intenso proceso 
de subdivisión de las grandes propiedades en los tres partidos seleccionados de la provincia de Buenos Aires?

En Pergamino, todas las grandes propiedades sufrieron un proceso de subdivisión muy intenso (ver Cuadro 2.5). Las ocho propiedades de más de 2500 hectáreas se fraccionaron dando lugar a 152 propiedades: seis de las ocho originaron más de once propiedades cada una, y sólo una se fraccionó en grandes parcelas ${ }^{8}$. El tamaño medio de las parcelas que surgieron de la división de las seis grandes propiedades que se fraccionaron intensamente era de 169 hectáreas.

Además, muchas propiedades de 500 a 2500 hectáreas también se subdividieron, aunque la mitad permaneció con similares dimensiones a las de 1939. En total, los 105 campos presentes en este estrato al comienzo del período habían dado lugar a 401 propiedades hacia 1960. Por último, cabe consignar que, a medida que descendemos en el tamaño, aumentaron los procesos de fusión?.

7 Debe recordarse que hemos trabajado con una muestra de propiedades para cada partido, por lo cual las cifras consignadas son sólo estimaciones.

8 En este análisis hemos unificado todas las parcelas a nombre de un mismo propietario que fueran linderas o que estuvieran próximas (por ejemplo, producto de la compra de lotes de una misma subdivisión de una propiedad mayor).

9 Al respecto, se destacan las propiedades que tenían menos de 100 hectáreas en 1937, pues 677 de ellas se habrían fusionado, 609 habrían permanecido iguales y sólo 113 se habrían subdividido. 
Cuadro 2.5. Transformaciones en la propiedad de la tierra, Pergamino, 1939 a 1960.

Cantidad de propiedades.

\begin{tabular}{|l|r|r|r|r|r|r|r|}
\hline & \multicolumn{1}{|c|}{ Transformación } & \multicolumn{5}{|c|}{ Evolución de las propiedades de 1939 } \\
\hline Tamaño & 1939 & $\begin{array}{c}\text { para } \\
1960 \\
\text { dieron } \\
\text { lugar a: }\end{array}$ & fusión & igual & $\begin{array}{c}\text { subdivi- } \\
\text { sión en } \\
2,3 \text { ó 4 } \\
\text { prop. }\end{array}$ & $\begin{array}{c}\text { subdivi- } \\
\text { sión en } \\
5 \text { a 10 } \\
\text { prop. }\end{array}$ & $\begin{array}{c}\text { subdivi- } \\
\text { sión en } \\
\text { más de } \\
11 \text { prop. }\end{array}$ \\
\hline+5000 & 3 & 50 & - & - & 1 & - & 2 \\
\hline $2501-5000$ & 5 & 102 & - & - & - & 1 & 4 \\
\hline $1001-2500$ & 55 & 313 & 5 & 22 & 10 & 9 & 9 \\
\hline $501-1000$ & 50 & 88 & - & 29 & 21 & & \\
\hline $201-500$ & 161 & 195 & 34 & 93 & 34 & & \\
\hline $101-200$ & 229 & 169 & 157 & 60 & 12 & & \\
\hline-100 & 1399 & 1196 & 677 & 609 & 113 & & \\
\hline Total & 1902 & 2113 & 873 & 813 & 191 & & 10 \\
\hline
\end{tabular}

Fuente: estimaciones propias elaboradas en base al Plano catastral de 1939 y al Mapa rural de 1960. 
En Rivadavia, las subdivisiones no fueron tan intensas como en Pergamino, pero afectaron sobre todo a las grandes propiedades (ver Cuadro 2.6). De 14 campos con más de 5000 hectáreas en 1939, tan sólo tres permanecieron iguales, cinco se dividieron en dos a diez propiedades cada uno y seis sufrieron un fraccionamiento intenso. La subdivisión de estos seis grandes campos generó 185 nuevas propiedades, con un tamaño medio hacia 1964 de 367 hectáreas. En conjunto, los 14 campos de más de 5.000 hectáreas en 1939 dieron lugar a 217 propiedades en 1964.

Alrededor de dos tercios de las propiedades de 1000 a 5000 hectáreas permanecieron iguales y el resto tuvo subdivisiones más propias del fraccionamiento hereditario que de la venta a pequeños chacareros (ya que observamos grandes parcelas en 1964). Por su parte, en las propiedades de menos de 500 hectáreas predominaron los procesos de fusión.

\section{Cuadro 2.6. Transformaciones en la propiedad de la tierra, Rivadavia, 1939 a} 1964.

Cantidad de propiedades.

\begin{tabular}{|l|r|r|r|r|r|r|r|}
\hline & \multicolumn{1}{|c|}{ Transformación } & \multicolumn{5}{|c|}{ Evolución de las propiedades de 1939 } \\
\hline Tamaño & 1939 & $\begin{array}{c}\text { para } \\
\text { dieron }\end{array}$ & fusión & igual & $\begin{array}{c}\text { subdivi- } \\
\text { sión en } \\
\text { lugar a: }\end{array}$ & $\begin{array}{c}\text { subdivi- } \\
\text { sión en } \\
\text { prop. }\end{array}$ & $\begin{array}{c}\text { subdivi- } \\
\text { sión en } \\
\text { prop. } \\
\text { más de } \\
11 \text { prop. }\end{array}$ \\
\hline+5000 & 14 & 217 & - & 3 & 3 & 2 & 6 \\
\hline $2501-5000$ & 19 & 31 & - & 15 & 2 & 2 & \\
\hline $1001-2500$ & 51 & 76 & - & 31 & 20 & & \\
\hline $501-1000$ & 49 & 59 & - & 39 & 10 & & \\
\hline-500 & 333 & 222 & 222 & 111 & & & \\
\hline & 466 & 605 & 222 & 199 & 35 & & \\
Total & & & & & & & \\
\hline
\end{tabular}

Fuente: estimaciones propias elaboradas en base al Plano catastral de 1939 y al Mapa rural de 1964. 
En Tres Arroyos, todas las propiedades de más de 2500 hectáreas se fraccionaron intensamente: las 36 propiedades presentes en 1939 dieron lugar a 378 (ver Cuadro 2.7). Especialmente las mayores de 5000 hectáreas se caracterizaron por dividirse en más de diez parcelas cada una (10 de las 15 tuvieron esta evolución) dando lugar a propiedades de 409 hectáreas de tamaño medio. Los fraccionamientos intensos de los campos de 2500 a 5000 hectáreas generaron propiedades de 456 hectáreas promedio. Por lo general, los campos de 500 a 2500 se mantuvieron en el mismo tamaño de 1939, aunque un número importante se fraccionó en dos a cuatro campos cada uno. Las propiedades de menos de 500 hectáreas experimentaron cierto proceso de fusión (770 campos se convirtieron en 615), al parecer como resultado de procesos de reunificación de los patrimonios familiares ${ }^{10}$.

Cuadro 2.7. Transformaciones en la propiedad de la tierra, Tres Arroyos, 1939 a 1964.

Cantidad de propiedades.

\begin{tabular}{|l|r|r|r|r|r|r|r|}
\hline & \multicolumn{1}{|c|}{ Transformación } & \multicolumn{5}{|c|}{ Evolución de las propiedades de 1939 } \\
\hline Tamaño & 1939 & $\begin{array}{c}\text { para } \\
1964 \\
\text { dieron } \\
\text { lugar a: }\end{array}$ & fusión & igual & $\begin{array}{c}\text { subdivi- } \\
\text { sión en } \\
2,3 \text { ó 4 } \\
\text { prop. }\end{array}$ & $\begin{array}{c}\text { subdivi- } \\
\text { sión en } \\
5 \text { a 10 } \\
\text { prop. }\end{array}$ & $\begin{array}{c}\text { subdivi- } \\
\text { sión en } \\
\text { más de } \\
11 \text { prop. }\end{array}$ \\
\hline+5000 & 15 & 228 & - & - & 3 & 2 & 10 \\
\hline $2501-5000$ & 21 & 150 & - & - & 9 & 7 & 5 \\
\hline $1001-2500$ & 122 & 179 & - & 92 & 28 & 2 & \\
\hline $501-1000$ & 145 & 179 & 7 & 119 & 11 & 7 & \\
\hline $201-500$ & 481 & 392 & 242 & 207 & 32 & & \\
\hline $101-200$ & 148 & 115 & 66 & 82 & & & \\
\hline-100 & 141 & 108 & 67 & 74 & & & \\
\hline & 1073 & 1351 & 382 & 574 & 83 & 18 & 15 \\
\hline Total & & & & & & & \\
\hline
\end{tabular}

Aclaración: la gran mayoría de las fusiones fueron la reconstitución de campos divididos por cuestiones hereditarias. Las mismas representaron la totalidad de las fusiones en los intervalos "menos de 100 ha" y "501 a 1000 ha" y el 60\% en el intervalo "201 a 500 ha".

Fuente: estimaciones propias elaboradas en base al Plano catastral de 1939 y el Mapa rural de 1964.

10 Sobre estas estrategias en los años previos a 1930, consultar Zeberio (1995). 
En síntesis, casi todas las grandes propiedades (de más de 2500 hectáreas) de Pergamino y Tres Arroyos, se habrían dividido intensamente en parcelas de dimensiones mucho más reducidas, pero no pequeñas (de alrededor de 170 hectáreas en Pergamino, y de 410 en Tres Arroyos). Si, tal como estimáramos, hacia 1939, en estos dos partidos, las grandes propiedades eran abrumadoramente rentísticas, habría sido gracias a este fraccionamiento que se disolvió el sistema de arrendamientos tradicional (que ligaba los grandes latifundios con los pequeños chacareros arrendatarios). Por su parte, en Rivadavia el proceso de subdivisión intenso sólo afectó a la mitad de las propiedades de más de 5000 hectáreas. Resulta probable que las grandes estancias ganaderas continuaran indivisas (al respecto, recordemos que, en 1939, las conductas rentísticas no eran preponderantes en este estrato) ${ }^{11}$.

A la vez, en el otro extremo de las propiedades presentes en 1939, los procesos de fusión de parcelas (de menos de 200 hectáreas en Pergamino, y de menos de 500 hectáreas en Tres Arroyos y Rivadavia), indican que algunas unidades de propiedad tendieron a evitar procesos de subdivisión excesiva y a adecuarse a los nuevos requerimientos de escala de la agricultura mecanizada y la ganadería.

Cotejados los análisis de los planos catastrales con los de las entrevistas realizadas por nosotros a los productores agropecuarios de estos tres partidos, hemos encontrado una clara congruencia. De los 36 productores entrevistados que eran arrendatarios a comienzos de la década del veinte (ellos mismos o, en general, sus

11 Los análisis realizados a partir del mismo plano catastral de 1939 y los mapas rurales de 1958 para los partidos de Benito Juárez y de González Chaves por Blanco (2001: 251) muestran similares procesos de fragmentación de la propiedad de la tierra, aunque de menor intensidad que en Pergamino y en Tres Arroyos.

En Benito Juárez había 13 propiedades de más de 5.000 hectáreas en 1939 que concentraban el 25\% del partido, mientras que en 1958 quedaban 9 con el 12\%. En González Chaves estas propiedades se redujeron de 16 a 9 , y de detentar el $32 \%$ al $20 \%$ de la superficie del partido. En ambos partidos sólo hubo pequeñas reducciones del número y la superficie en propiedades de 2.000 a 5.000 hectáreas. En el caso de Juárez de las 65 propiedades mayores a 2.000 hectáreas en 1939, para 1958 se habían fragmentado 38, dando lugar a 205 propiedades, debido, en proporciones bastante similares, a tres causas: herencia, venta o venta y herencia (Blanco, 2001: 253). 
padres), sólo cuatro alcanzaron la propiedad en esa década (y no la perdieron luego, durante la Crisis); cinco la obtuvieron entre 1936 y 1942, y seis, después de 1955. En cambio, 21 arrendatarios pudieron comprar su lote entre 1943 y 1955. Más allá de no trabajar con una muestra probabilística, resulta claro que, entre 1943 y 1955, se triplicó la cantidad de adquisiciones por año en relación con los períodos anteriores y posteriores.

Ahora bien, cuáles fueron las causas de estos sustanciales cambios en la estructura de la propiedad, ¿fueron producto de una política de colonización estatal, o fueron el resultado de otro tipo de procesos? Para comprender mejor lo acontecido, en el siguiente apartado analizaremos los cambios ocurridos durante estas décadas en las políticas agrarias, con especial énfasis en la cuestión de la tenencia del suelo. 


\section{Políticas y modificaciones en la estructura agraria}

\subsection{El Estado interviene}

\subsubsection{La crisis agrícola y la "cuestión agraria" hasta 1943}

Ya en la etapa expansiva, e incluso antes, muchos políticos e intelectuales argentinos tomaron conciencia del impacto que esta estructura de la propiedad iba a tener sobre el modelo de sociedad que se estaba forjando (ver los análisis presentes en Barsky y otros, 1992; Girbal, 1990; Halperín Donghi, 1984). Al llegar al gobierno la Unión Cívica Radical, y sobre todo ante la tensión social de fines de la década del diez y principios de la siguiente, surgieron proyectos colonizadores que, sin embargo, no llegaron a ser debatidos en la Legislatura (Solberg, 1987; Girbal, 1989). Tan sólo obtuvo sanción (Ley 10.676 de 1919) el proyecto de ampliación y reforma de la ley orgánica del Banco Hipotecario Nacional, en favor de las pequeñas y medianas propiedades (Girbal, 1988: 21) ${ }^{12}$.

Las únicas políticas sobre tierras fueron las de regulación (tardía) de los contratos de arrendamiento, sancionadas luego de intensa presión por parte de los chacareros organizados en la Federación Agraria Argentina (Bonaudo y Godoy, 1985). En septiembre de 1921, la Ley 11.170 estableció los contratos de arrendamiento (no mayores a 300 hectáreas) por cuatro años, indemnizaciones por las mejoras realizadas, y la libertad de comerciar, asegurar y cosechar el cereal ${ }^{13}$. En octubre de 1932, la Ley 11.627 amplió el plazo mínimo a cinco años, suprimió el límite máximo de 300 hectáreas para los beneficios de esta legislación, y otorgó el derecho de compensar pérdidas de cosechas, derivándose el pago del arriendo al año siguiente, y declarando inembargable un mínimo de bienes del arrendatario ${ }^{14}$. En cambio, no prosperó el proyecto de ley para reajustar el precio de los arrendamientos, presentado en 1933 por el

12 En el ámbito de la provincia de Buenos Aires también se intentó implementar un "programa agrario", tendiente a alentar la formación de una clase media rural propietaria, que fue bloqueado por las propias diferencias internas del radicalismo (Ruffini, 1993).

13 "Ley 11.170", reproducida en Barry (1968: 327-330).

14 "Ley 11.627", reproducida en Barry (1968: 330-336). 
Ministro de Agricultura Antonio De Tomaso ${ }^{15}$. Este proyecto, elaborado en base a las sugerencias de la Comisión Especial ${ }^{16}$, proponía la creación, para tal efecto, de una Junta Central de Ajuste y Juntas locales.

Por otra parte, estas medidas (que tan sólo ponían un coto a las capacidades arbitrarias de los terratenientes) tenían un cumplimiento efectivo muy escaso: pese a la obligatoriedad de tener contrato escrito, sobre 200.300 arrendatarios, aparceros o medieros en todo el país, según el Censo Agropecuario de 1937, 111.100 carecían de tal instrumento (Giberti, 1964:56). En la región pampeana, el 50,3\% de los arrendatarios carecían de contrato formal (Barsky, 1997: 115) ${ }^{17}$.

En este contexto legal (luego de unos pocos años de relativo alivio para los agricultores $^{18}$ ), a partir de 1938 comenzó una crisis agrícola de larga duración. Los precios ganaderos no sufrieron esta retracción, generándose un vuelco hacia esta actividad que habría provocado, en algunas áreas, una generalización de los desalojos de los agricultores no propietarios. A los terratenientes que querían expandir o, en todo caso, (re)comenzar la actividad ganadera, les resultaba muy fácil recuperar sus campos expulsando a los agricultores que carecían de contrato escrito. Si bien existen múltiples testimonios de este fenómeno ${ }^{19}$ (incluso en las fundamentaciones de leyes y decretos), resulta muy difícil de confirmar estadísticamente ${ }^{20}$ y es probable que no hubiera llegado

15 Cámara de Diputados de la Nación (1943: 39).

16 La Comisión había propuesto, además, la prórroga de los contratos existentes por el lapso de tres años (Urien, 1933).

17 En la zona maicera el $44 \%$ de los arrendatarios y aparceros de Pergamino carecían de contrato (Giberti, 1998: 9).

18 Entre 1936-37 los costos de producción continuaban bajos y habían subido los precios de los cereales (Balsa, 1994a).

19 Ver, por ejemplo, las denuncias formuladas por el diario Crítica en otoño de 1940, denunciando las expulsiones y criticando las actitudes de los terratenientes "acostumbrados a vivir en el medio del lujo y del derroche" (citado en Hora, 2002: 327-328).

20 El censo siguiente al de 1937, es de 1947, cuando hacía varios años que se habían suspendido los desalojos. A pesar de estas limitaciones, hemos estudiado ambos datos censales y encontramos que el fenómeno de la recomposición de estancias a través de la expulsión de arrendatarios y medieros no parece haber alcanzado grandes propociones en la zona norte de la provincia de Buenos Aires, donde el incremento en el número de propietarios (+2292) resultó mucho mayor al de la disminución de los no propietarios (-404). En la zona oeste, las variaciones de ambos tipos de productores resultaron similares, aunque inversas (+600 y -770 , respectivamente), y en la zona sur habrían predominado los desalojos, ya que la disminución en el número de no propietarios (-1719) duplicó el incremento en la cantidad 
a afectar a la mayoría de los arrendatarios y medieros ${ }^{21}$. Pero, lo que es seguro es que la amenaza de su generalización debió ser efectivamente grave, ante el contexto tan desfavorable para la agricultura y con un marco legal tan endeble. En este mismo sentido, es probable que unos pocos casos (en relación con el conjunto de la región) resultaran de una visibilidad social imposible de soslayar: imaginemos el impacto que, en un partido cualquiera de la provincia de Buenos Aires, habrá tenido que un terrateniente dejase en la calle a una veintena de pequeños aparceros, para reemplazarlos por un millar de vacunos ${ }^{22}$.

Es por ello que ya durante los gobiernos conservadores comenzaron a esbozarse políticas más activas para garantizar la situación coyuntural de los agricultores no propietarios. En los fundamentos de estas políticas sobre la cuestión agraria se retomaron planteos colonizadores que se habían esbozado durante el período expansivo. La creación de dos instituciones estatales para la colonización y la inédita intervención del Estado prorrogando los contratos de arrendamiento vigentes, evidencian el "clima intelectual" que promovía el abordaje de la cuestión agraria (Taylor, 1948; Tecuanhey, $1988)^{23}$.

En julio de 1936, el gobernador de la provincia de Buenos Aires, Manuel Fresco, envió un proyecto de creación del Instituto de Colonización provincial, como ente autárquico; aprobado pocos meses más tarde por la Legislatura (Ley 4.418). Más allá de

de propietarios $(+850)$.

21 Puede que la mayor importancia de las conductas puramente rentísticas (que detectamos en los partidos estudiados) expliquen este resultado: si el terrateniente no tenía siquiera una mínima dedicación a la ganadería, carecía de la infraestructura, la organización, y, a veces, los conocimientos para encarar fácilmente esta actividad aunque pudiera expulsar a los arrendatarios.

22 Para transmitir esta noción, reproducimos el relato de Goñi (1987: 117) respecto de algunas expulsiones ocurridas a fines de los treinta: "... en el partido de Rojas, catorce familias de agricultores fueron expulsadas del campo, y sus útiles de labranza y muebles fueron arrojados a la calle. En la zona de Veinticinco de Mayo, cuarenta familias fueron desalojadas del campo "La Criolla", después de terminada la cosecha fina. En Miramar, partido de General Alvarado, quince familias lanzadas, que aún tenían sus campos sembrados, se dirigieron infructuosamente al Ministerio en demanda de justicia".

23 Como sostiene Hora (2002: 273-274): "el gran tema que recorre la literatura de análisis de los problemas agrarios y de denuncia de los terratenientes en la entreguerra, de la que las intervenciones [...] forman parte, no era el fracaso de la agricultura granífera de exportación sino, más bien, la crisis del agricultor independiente, y la frustración del sueño de ver nacer una sociedad de agricultores propietarios". 
las críticas que concitó el articulado del proyecto $^{24}$, el Instituto comenzó su actividad en 1937 adquiriendo tres campos que totalizaron 39.232 hectáreas (en los partidos de Carlos Casares y Tres Arroyos), e incorporando, al año siguiente, otros dos campos que sumaban 23.830 hectáreas (en Laprida y General Alvear). En las cinco colonias resultantes se generaron 239 lotes (con una superficie promedio de 242 hectáreas cada uno). Al mismo tiempo, se abrió un registro de propietarios interesados en vender sus campos al Instituto (para fines de 1938, éstos eran 77, y totalizaban 537.816 hectáreas) ${ }^{25}$. Pero este destacado comienzo pronto se detuvo: durante 1939 no hubo nuevas adquisiciones, en 1940 sólo se incorporaron dos campos fiscales, que sumaban 3.792 hectáreas (en General Pinto y Rauch), y al año siguiente se compraron dos propiedades que totalizaban 3.638 hectáreas (en Chacabuco, primer campo adquirido en la zona maicera $)^{26}$. Las dilaciones por parte del Poder Ejecutivo provincial en otorgar nuevos fondos al Instituto parecen haber sido el factor determinante de este estancamiento $^{27}$.

Peor comienzo tuvo la segunda institución, el Consejo Agrario Nacional. El 2 de septiembre de 1940 se sancionó la Ley 12.636 de colonización nacional, por la cual se asignaron las tierras fiscales a este Consejo, a la vez que le permitían la compra de tierras por licitación pública o por expropiación de los inmuebles necesarios (en caso de no poder adquirir tierra suficiente por compra), con la previa aprobación del Poder Ejecutivo (y sin el requisito de una ley de expropiación para cada caso) ${ }^{28}$. Sin embargo, el Consejo recién conmenzó su labor en 1943, cuando el Poder Ejecutivo puso a su

24 Resulta interesante el temor que surge sobre el probable incremento en el valor de la tierra que podría producirse por las adquisiciones realizadas por el Instituto, que redundarían en precios demasiado elevados para los futuros colonos (Legislatura de la Provincia de Buenos Aires, 1936: 72). Cabe destacar, por otra parte, que en el directorio del Instituto tenía reservado un lugar un representante de la Sociedad Rural Argentina.

25 Instituto de Colonización (1937 y 1940).

26 Instituto de Colonización (1942).

27 Ya que en las adquisiciones de 1937 y 1938 se gastaron casi 15 millones de pesos, de un total de 20 millones dispuestos inicialmente por la Ley 4.418. Al respecto, desde el Instituto Agrario Argentino, se propuso en 1947 reactivar la actividad del Instituto de Colonización a través de la asignación de 100 millones de pesos anuales (Liceaga, 1947).

28 Con la condición de que no fueran objeto de una explotación agraria racional, o constituyeran extensiones de tierra que excediesen las dos mil hectáreas de superficie ("Ley $\mathrm{n}$ ○12.636, Colonización Nacional”, reproducida en Barry, 1968: 172-196). 
disposición los fondos establecidos por ley $^{29}$. Si en el año de su creación contó con 13.858 hectáreas transferidas por el gobierno, en los dos años siguientes no incorporó nuevas tierras, y en 1943 tan sólo adquirió 24.339 hectáreas $^{30}$.

Otra prueba más de la creciente preocupación en torno a la cuestión agraria fue la sanción del impuesto al latifundio (Ley 4.834 de la provincia de Buenos Aires) promovida en 1942 por el gobernador Rodolfo Moreno (también conservador). El mensaje que acompañó el proyecto, destacaba que casi un sexto de la superficie total de la provincia estaba en manos de 272 personas. Al mismo tiempo, señalaba con preocupación "los desalojos de colonos, la eliminación de la agricultura y la dedicación de los campos a la ganadería con prescindencia del poblador al cual se elimina"31. El proyecto apuntaba a estimular el fraccionamiento de la tierra $\mathrm{y}$, de este modo, aliviar la situación de los arrendatarios y medieros. Para ello, proponía un gravamen adicional al impuesto inmobiliario vigente sobre las propiedades de más de 10.000 hectáreas, con una tasa progresiva que comenzaba con el 6 por mil, incrementándose un 2 por mil cada 5.000 hectáreas, llegando al 14 por mil para las propiedades de más de 30.000 hectáreas ${ }^{32}$. Si bien en las fundamentaciones tanto el Ministro de Hacienda, como varios legisladores oficialistas e incluso el propio Gobernador sostuvieron que los fondos que se fueran a producir por dicho gravamen se destinarían al fomento de la colonización

29 Consejo Agrario Nacional (1977).

30 En relación a la actividad colonizadora, en esos mismos años Taylor destacaba la distancia existente entre la amplia difusión de las ideas reformistas y el escaso desarrollo de la puesta en práctica de las mismas (Taylor, 1948).

31 Legislatura de la Provincia de Buenos Aires (1942: tomo I, 27).

32 El senador radical Giordano Echegoyen argumentaba el escaso peso de un impuesto del 6 por mil, ejemplificando en un propietario de 10.000 hectáreas, quien, dueño de dos millones de pesos de tierra (a \$ 200 la hectárea), sólo debería pagar un adicional de \$ 12.000 al año (citado en Lázzaro, 1991: 60-61).

Sin embargo, si estimamos que el arriendo de dicho campo brindaba unos $\$ 20$ por hectárea y el valor medio de la tierra en la provincia era de \$324 (según cifras del Censo de 1937), el impuesto del 6 por mil era de casi $\$ 2$, lo que representaba alrededor del $10 \%$ de la renta percibida por el terrateniente. En los casos de propiedades de más de 30.000 hectáreas, cuando el impuesto llegaba al 14 por mil, el gravamen habría representado algo más del $20 \%$ de la renta. Por lo tanto, según nuestros cálculos, la incidencia de este impuesto adicional pudo ser importante, si no fuera que, como veremos en la siguiente nota, la inflación fue licuando rápidamente la incidencia de este gravamen, al tiempo que los terratenientes implementaron estrategias de subidivisión ficticia para eludirlo (sobre este último fenómeno, para un período reciente, puede consultarse Martínez de Ibarreta y Pucciarelli, 1992). 
(más concretamente, al Instituto de Colonización), finalmente se imputaron a Rentas Generales (Lázzaro, 1991) ${ }^{33}$.

Por último, en septiembre de 1942 se aprobó la Ley 12.771 de Reajuste de arrendamientos rurales, por la cual se habilitaba el reajuste de precio si una de las partes lo pedía y, en caso de no llegarse a un acuerdo, el monto debía ser fijado por la Cámara Arbitral de Arrendamientos, según índices elaborados por el Poder Ejecutivo. Además, esta ley establecía que los contratos que vencieran durante la situación de emergencia (definida por las dificultades existentes en la comercialización exterior de cereales y oleaginosos) y hasta un año agrícola después, se considerasen prorrogados, a opción del locatario mientras durase esta coyuntura especial (no pudiéndose exceder dicha prórroga a más de tres años), al tiempo que se suspendían los juicios de desalojo. Finalmente, se declaraba nula toda cláusula que limitara la explotación ganadera hasta un $40 \%$ de la superficie (Cámara de Diputados, 1943).

Como lo ha rescatado Palacio (2002: 25), la Sociedad Rural Argentina advirtió con notable clarividencia los peligros que este tipo de legislación encerraba para los terratenientes pampeanos:

"La intervención del Estado para alterar las convenciones que libremente celebran las partes, es siempre de un efecto desmoralizador, porque habitúa a los contratantes a no tener por firmes las obligaciones contraídas y crea un ambiente de inseguridad en los negocios. En los arrendamientos agrícolas, como en todas las demás actividades, el libre juego de la oferta y la demanda obtiene de por sí los reajustes necesarios, ya que el valor de los productos de un campo influye normalmente en el precio que se paga pro su explotación [...]

Cree la Sociedad Rural Argentina que es inconveniente establecer, en momentos de emergencia, leyes de esta naturaleza, porque la experiencia demuestra que luego se las erige en conquista definitiva de los favorecidos, quedando así en forma permanente, en contra, sin duda, del espíritu que animó a los iniciadores de ese remedio, que debió ser transitorio". (Anales, 75:5, 1941: 365-67).

33 En 1947, se sancionó la Ley 5.127 que bajó el piso para la aplicación del impuesto inmobiliario adicional a las 5.000 hectáreas, elevándose en dos puntos por mil el impuesto para los siguientes intervalos de tamaño. Sin embargo, a pesar de haberse realizado una revaluación inmobiliaria durante 1948-1953, el proceso inflacionario redujo rápidamente la significación de dicho impuesto: medido en porcentaje del PBI Agropecuario provincial, cayó del 0,58\% en 1948 al 0,23 en 1951 y al 0,09 en 1956 (Junta de Planificación Económica, 1958: 148-149). 
Sin embargo, los grandes propietarios y la Sociedad Rural no salieron a confrontar abiertamente contra estas medidas a través de las cuáles los propios gobiernos conservadores tomaban distancia de la elite terrateniente, sino que prefirieron las vías de presión más discretas (Hora, 2002: 322), que en el caso de las políticas de colonización habían dado, como hemos visto, sus resultados.

\subsection{2. "La tierra para el que la trabaja": la cuestión social y las necesidades de la} Economía a partir de 1943

El Gral. Diego I. Mason, como Ministro de Agricultura del gobierno militar surgido del golpe del 4 de junio de 1943, impulsó una amplia política de colonización. En ese mismo año se adquirieron 24.399 hectáreas (16.035 hectáreas en el partido de Balcarce, haciendo uso de las facultades de expropiación directa del Consejo) y, en el año siguiente, 123.424 hectáreas $^{34}$. Asimismo, desarrolló una clara política de apoyo a los agricultores, con créditos de fomento granjero y brindando una mayor protección a los arrendatarios (Tecuanhey, 1988).

Las intromisiones del coronel Perón en las cuestiones de política agraria (especialmente, reglamentando las bolsas de trabajo temporario y elaborando el Estatuto del Peón) fueron cada vez más intensas y desembocaron en la renuncia del Ministro en octubre de 1944 (Tecuanhuey, 1988). A partir de entonces, Perón progresivamente fue tomando el control: los Decretos Ley 9.958 y 10.195 de mayo de 1945 dispusieron la intervención del Consejo Agrario Nacional (designando a Antonio Molinari como Presidente) y su dependencia de la Secretaría de Trabajo y Previsión. Desde allí, se desplegó una intensa propaganda en función de la campaña electoral de Perón, anunciándose que "la reforma agraria estaba en marcha" (Lattuada, 1986: 56-57). Durante 1945 el Consejo expropió 55.388 hectáreas, situadas en Buenos Aires y Corrientes (Consejo Agrario Nacional, 1977).

Frente a estas medidas, la Sociedad Rural Argentina encabezaba una férrea defensa del derecho de propiedad. Desde las páginas de los Anales, pero también en la prensa nacional (ver por ejemplo, La Prensa, 12 de Julio de 1943) intentaba equiparar la

34 Consejo Agrario Nacional (1977: 23). 
propiedad de la tierra con la de una fábrica y hasta con la de una manta o del salario ${ }^{35}$, aunque en su argumentación tenía que reconocer que la tierra no la había creado el dueño, lo que muestra indirectamente la fuerza con que contaba la propuesta reformista ${ }^{36}$. Incluso se veía en la necesidad de rebatir el razonamiento de que "los campos no deben ser de sus dueños sino de los que los toman en arrendamiento, porque los primeros no trabajan en ellos", contraargumentando que "con ese modo de plantear los asuntos, ¿quién se impondrá privaciones para ahorrar y comprar tierras, si es más conveniente llegar a ser propietario de ellas mediante un contrato de locación...?". Por último reconoce que, en ese caso, "la respuesta está lista: que sea del Estado, para que la entregue en arrendamiento al que la trabaje", pero aclara luego que esta propuesta fracasó en todo el mundo, y aquí con la enfiteusis rivadaviana (Anales, 1945: T. II., 519-521).

Sin embargo, la euforia reformista fue desinflada, en parte, desde el propio gobierno. Terminada la etapa de la campaña electoral, Farrell decretó que el Consejo Agrario se convirtiese en una simple dependencia del Banco de la Nación Argentina (Decreto Ley 14.959 del 24 de mayo de 1946), produciéndose la renuncia de Molinari, al tiempo que se conocía el nombre del futuro Ministro de Agricultura, Juan Carlos Picazo Elordy, miembro de la Sociedad Rural Argentina (Lattuada, 1986: 61-62). A pesar de este viraje político, el Banco de la Nación Argentina continuó la política colonizadora, adquiriendo tierras por compra o por expropiación (sobre todo en 1948, ante la escasez de tierras ofrecidas al Banco). Las adquisiciones fueron creciendo desde 57.084 hectáreas en 1946, a 78.961 en 1947 y a 274.659 hectáreas en 1948 (115.193 de las cuales eran producto de expropiaciones). La gran mayoría de estas futuras colonias se ubicaban en la región pampeana ${ }^{37}$.

35 "No ha sido incorporado a las legislaciones para comodidad y seguridad de los ricos, sino de todos. Es idéntico el interés social en asegurar la propiedad de la fábrica y del salario del obrero..." (Anales, 1945: T. II., 519-521).

36 "Todos los bienes del mundo que están en el comercio son igualmente respetables, porque todos han sido adquiridos con frutos del trabajo y del ahorro, sin excluir la propiedad de la tierra, porque si el dueño no la creó, creó los recursos pecuniarios con que compró su finca" ( Anales, 1945: T. II., 519-521).

37 Consejo Agrario Nacional (1977). 
Esta tendencia creciente iba a interrumpirse rápidamente: el 27 de octubre de 1948 se sancionó el Decreto 33.425 en el que se establecieron las primeras medidas tendientes a combatir la inflación. En el mismo se determinaba que las reparticiones descentralizadas no iniciarían nuevos juicios de expropiaciones de campos, tierras y/o inmuebles (Lattuada, 1986: 136). El Plan Económico de 1952 profundizó estas disposiciones. Como resultado de estas medidas, las adquisiciones (por compra o expropiación) decayeron a 102.100 hectáreas en 1949, 38.676 en 1950, y prácticamente fueron nulas en los últimos cinco años del gobierno peronista (en total, se incorporaron sólo 1.913 hectáreas) $)^{38}$.

Este retraimiento en la actividad colonizadora fue acompañado por un cambio en el discurso del presidente Perón. Si, en la campaña electoral, la prédica había sido claramente reformista ("la tierra debe ser del que la trabaja, y no del que vive consumiendo sin producir a expensas del que la labora" ${ }^{39}, 4$ de diciembre de $1944^{40}$ ), ante la caída en la producción buscó transmitir tranquilidad a los propietarios ("Si se hacen producir a veinte o cincuenta mil hectáreas y se le saca a la tierra una gran riqueza ¿cómo la vamos a dividir?” [...] "Si hay algún sector de la actividad nacional que necesita de seguridad y tranquilidad para producir, es precisamente el campo", 11 de junio de $1953^{41}$ ). La Sociedad Rural Argentina saludó estos cambios en el discurso y en la práctica ${ }^{42}$.

38 En esos años, desde los intelectuales de izquierda cercanos al peronismo se señalaba que "los informes oficiales indican la falta de un plan orgánico de expropiación del suelo, consecuencia lógica de la inexistencia de un plan orgánico de reforma agraria integral", y la consecuente "supervivencia del latifundio en la zona cereal" (Frigerio, 1953: 82-85).

39 Retomando las banderas que levantara en la década del diez la Federación Agraria Argentina.

40 Citado en Lattuada (1986: 55).

41 Citado en Lattuada (1986: 146-154)

42 “ [sobre la colonización]... varios de estos principios han sido comentados y ampliados por el Primer Magistrado en su disertación del 11 de junio a los agricultores, quien destacó el modo totalmente pacífico en que se opera la reforma agraria en nuestro país, así como el espíritu de justicia que regirá cualquier expropiación que haya que llevar a cabo. Señaló, por otra parte, el error de apreciación en que se incurre cuando se aconseja dividir explotaciones extensas por el mero hecho de que pertenezcan a un solo propietario, división que por tratarse de predios productivos se traduciría en perjuicios económicos.

Mucho nos complace poder manifestar que los lineamientos de la política oficial en esta materia coinciden totalmente con los principios fundamentales a que venimos ajustando nuestra labor en los últimos años, y que hemos creído conveniente declarar públicamente a fines de mayo último" (Sociedad Rural Argentina, 1953: 26-27). 
Lattuada analiza que cuanto mayores fueron las necesidades de un aumento de la producción agropecuaria para sostener el sistema, mayores fueron los esfuerzos del gobierno por eliminar medidas conflictivas para alguno de los sectores sociales rurales en particular, o para resolver los problemas existentes entre éstos, dentro de la estructura de relaciones sociales existentes (Lattuada, 1986: 98).

En síntesis, entre 1946 y 1955, el Banco de la Nación Argentina colonizó 767.190 hectáreas ( $\sin$ contabilizar las tierras de la Puna), a las que deben agregarse 13.730 hectáreas colonizadas por el Banco Hipotecario Nacional (Lattuada, 1986).

Pero, ¿cuán importante fue esa labor colonizadora en relación con el peso que los arrendatarios y aparceros tenían a comienzos del período? Según nuestros cálculos, en 1955, la gran mayoría de las colonias se ubicaba en la región pampeana, ocupando 558.575 hectáreas (el $72 \%$ de la superficie colonizada del país ${ }^{43}$. Esta área afectada resultó muy pequeña, representando tan sólo el $1.9 \%$ de la superficie ocupada por no propietarios en la región (en 1947 los arrendatarios tenían 26.884.000 hectáreas y los medieros y aparceros 1.682 .000 en las provincias pampeanas ${ }^{44}$ ).

Luego del derrocamiento del peronismo, el gobierno militar recreó el Consejo Agrario Nacional (Decreto Ley 2.964 de marzo de 1958), pero el mismo no incorporó nuevas tierras para colonización hasta fines de la década del sesenta. Entre otros motivos, porque Arturo Frondizi, una vez en el gobierno, abandonó rápidamente su discurso pre-electoral y el Programa de Avellaneda (que proponía una reforma agraria "inmediata y profunda"), para concentrarse en el problema del incremento de la productividad (Lázzaro, 1997).

En la provincia de Buenos Aires, durante el período peronista, el Instituto de Colonización ${ }^{45}$ y luego la Dirección de Colonización del Ministerio de Asuntos

43 Datos desagregados por colonias (Consejo Agrario Nacional, 1977, Cuadro n ${ }^{\circ} 3$ ).

44 Censo Agropecuario Nacional de 1947.

45 Cuyas atribuciones habían sido ampliadas con la Ley 5.286 (Ley Orgánica de Colonización de la Provincia de Buenos Aires, sancionada el 15 de julio de 1948), que además cambiaba la composición de su Directorio, dejando fuera la Sociedad Rural Argentina, e incluyendo a un representante de las sociedades rurales de fomento, otro de las cooperativas agrarias y un representante de los consejos de colonos. 
Agrarios (que absorbió al Instituto en 1949) retomaron la labor colonizadora. El gobernador Mercante se preocupó por impulsar esta tarea, incluso cuando a nivel nacional se había detenido. Así, observamos que en 1949 firma una serie de decretos expropiatorios de grandes propiedades ${ }^{46}$ para destinarlas a la colonización ${ }^{47}$. Muchos de estos campos se colonizarán durante la gestión del gobernador Aloé ${ }^{48}$, de modo que se destacan, por la cantidad de hectáreas colonizadas, los años 1946 (con 37.373 hectáreas adjudicadas), 1952 (49.302 hectáreas) y 1953 (49.279 hectáreas) ${ }^{49}$. En total, entre 1945 y 1955 se colonizaron 314.484 hectáreas en la zona pampeana de la provincia $^{50}$. Nuevamente, confrontada esta política con la magnitud de los problemas de tenencia, se observa su escasa incidencia. Las tierras colonizadas representaban el 2,4\% de las 13.062.000 de hectáreas ocupadas en la provincia de Buenos Aires por arrendatarios y aparceros en 1947.

Luego de un período de parálisis, se retomó el proceso de colonización durante la gobernación de Oscar Alende (radicalismo intransigente, pero diferenciado del gobierno nacional) con un nuevo marco legal: la Ley de Reforma Agraria (Ley 6.264) y su organismo de aplicación, el Instituto Agrario de la provincia de Buenos Aires (que recibía el $15 \%$ de lo recaudado en base al impuesto inmobiliario básico y adicional). Más allá del pretencioso título, durante su corta vigencia (1962-66) tan sólo se

46 Aunque no siempre formaban parte de los grandes latifundios de la oligarquía argentina, sino muchas veces eran propiedades grandes, pero no inmensas (ver varios ejemplos en este sentido en Blanco, 2001).

47 En cambio, tal como analiza Blanco (2001) la mayoría de los proyectos de leyes expropiatorias terminaron caducando, a pesar de contar con la sanción de una de las Cámaras. Corresponde destacar que los proyectos presentados y con media sanción, no eran sólo del peronismo, sino también de la bancada radical. Según su análisis, los grandes terratenientes habrían tenido cierto éxito en frenar los procesos expropiatorios en su contra (Blanco, 2001: 132-161).

48 Son adjudicaciones de tierras apropiadas con antelación, ya que durante la gobernación de Aloé, iniciada en 1952, no se adquirieron nuevas tierras para colonizar (Blanco, 2001: 101).

49 Cálculos propios en base a información inédita de la Dirección de Colonización del Ministerio de Asuntos Agrarios.

50 Además, en el partido de Patagones se colonizaron 292.583 hectáreas. 


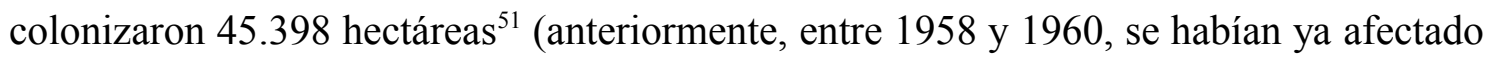
con este propósito 32.044$)^{52}$.

Focalizando el análisis en las tres zonas de la provincia de Buenos Aires que hemos estudiado, se puede observar que entre 1945 y 1950 el gobierno nacional adquirió 26 campos, constituyendo 19 colonias en un total de 174.206 hectáreas (no hubo nuevas adquisiciones a partir de 1951). En la zona norte se colonizaron once campos (64.679 hectáreas, que representaban el 3,4\% de la superficie de la zona); en la zona oeste, nueve campos (51.134 hectáreas, 1,4\% del total), y en la zona sur, seis campos (58.393 hectáreas, $1,1 \%$ del total). También en estas tres zonas, como en el conjunto del país, 1948 resultó el año donde este proceso adquisitivo cobró mayor intensidad (Cuadro 2.8).

51 Exceptuándose los campos situados en el partido de Patagones (fuera de la región pampeana).

52 Cálculos propios en base a información inédita de la Dirección de Colonización del Ministerio de Asuntos Agrarios. 


\section{Cuadro 2.8. Colonización nacional y provincial.}

Consejo Agrario Nacional y Banco de la Nación Argentina, e Instituto de Colonización y Ministerio de Asuntos Agrarios de la Provincia de Buenos Aires, 1945-1955

Adquisiciones de campos para colonizar (por las entidades nacionales) y adjudicaciones de campos (por las entidades provinciales) en las zonas norte, oeste y sur de la provincia de Buenos Aires

\begin{tabular}{|c|c|c|}
\hline Año & $\begin{array}{c}\text { Consejo Agrario Nacional y } \\
\text { B.N.A }\end{array}$ & $\begin{array}{c}\text { Instituto de Colonización y } \\
\text { M.A.A. }\end{array}$ \\
\hline 1945 & 20.840 & \\
\hline 1946 & 10.780 & 30.662 \\
\hline 1947 & 36.476 & 1470 \\
\hline 1948 & 64.936 & 5.086 \\
\hline 1949 & 12.596 & 2.822 \\
\hline 1950 & 28.578 & - \\
\hline 1951 & - & 25.100 \\
\hline 1952 & - & 23.674 \\
\hline 1953 & - & \\
\hline
\end{tabular}

Fuentes: Elaboración propia en base a los datos desagregados por colonias (Consejo Agrario Nacional, 1977) e información inédita de la Dirección de Colonización del Ministerio de Asuntos Agrarios de la Pcia. de Buenos Aires.

En cuanto a la labor de las instituciones provinciales, entre 1945 y 1955, en estas tres zonas se colonizaron 16 campos, por un total de 88.814 hectáreas. En la zona norte, se constituyeron tres colonias (15.019 hectáreas, el $0,8 \%$ de la superficie total); en la zona oeste, siete colonias (27.695 hectáreas, el 0,8\% del total), y en la zona sur, seis colonias (46.100 hectáreas, el $0,9 \%$ del total $)^{53}$.

Podemos concluir afirmando que la sumatoria de las políticas de colonización nacionales y provinciales sólo afectaron una pequeña proporción del área que estaba ocupada por arrendatarios y aparceros al comienzo del período en las tres zonas estudiadas. Más exactamente representó el 8,6\% de la superficie de la zona norte en manos de arrendatarios, aparceros y otras formas de tenencia en 1947, 5\% en el caso de la zona oeste y $3,6 \%$ en la zona sur.

53 Cálculos propios en base a información inédita de la Dirección de Colonización del Ministerio de Asuntos Agrarios. 


\section{2. "Campo tomado": prórrogas, expropiaciones y temores}

La importante transformación en la tenencia del suelo, que analizaremos en el siguiente apartado, no se debió tanto a las políticas directas dirigidas a permitir el acceso a la propiedad de la tierra por parte de los productores arrendatarios o medieros, sino a los efectos indirectos de las políticas de intervención estatal en el mercado de tierras, la sensación de inseguridad generada por las expropiaciones ${ }^{54}$ y la amplia política crediticia destinada a promover el acceso a la propiedad por parte de los arrendatarios y aparceros.

\subsubsection{Prórrogas y congelamientos}

La ya mencionada prórroga de los contratos de arrendamiento establecida por la Ley 12.771 de septiembre de 1942, fue derogada en noviembre de 1943 por el gobierno militar, y reemplazada por el Decreto 14.001. El mismo dispuso la rebaja obligatoria en un $20 \%$ en el precio de los arriendos vigentes en julio de 1940, suspendió los juicios de desalojo, prorrogó los contratos que vencieran en 1944/45, otorgó libertad para cambiar la forma de pago de dinero en especie, y estableció multas a los propietarios que no registraran los contratos de arrendamiento. A pesar de las disposiciones legales anteriores sobre la obligatoriedad del contrato escrito, recién con esta última medida comenzaron a registrarse masivamente los contratos en los Juzgados de Paz (Blanco, 1994).

Entre 1945 y 1948, se sucedieron una serie de leyes y decretos que continuaron prorrogando los contratos de arrendamiento ${ }^{55}$. En septiembre de 1948, se sancionó una ley de arrendamientos y aparcería que intentaba regular estas formas de tenencia de modo menos coyuntural. En la misma, se garantizaba la estabilidad de los locatarios por ocho años (contratos de cinco años, con una opción a tres años más). Todos los contratos vencidos o a vencer quedaban prorrogados hasta mayo de 1953, a la vez que se autorizaba un aumento del 20\% (volviéndose, en realidad, a los cánones previos a 1943). Se establecía también que, a partir de 1950, regiría el precio de arrendamiento o porcentaje de distribución que las partes acordasen, facultándose al Poder Ejecutivo

54 Más allá de que, según los casos analizados por Blanco, el precio pagado por la expropiación no habría estado demasiado alejado de los precios del mercado ni de lo solicitado por el propietario (Blanco, 2001: 104-105).

55 Decreto $18.290 / 46$ y Leyes $12.842 / 46,12.995 / 47$ y $13.198 / 48$. 
para fijarlo con medidas de carácter general en caso de desacuerdo ${ }^{56}$. La previsible consecuencia fue que, en 1950, las Cámaras Paritarias de Conciliación y Arbitraje Obligatorio (creadas ad-hoc por la ley) se llenaron de pleitos entre propietarios y arrendatarios, sin que pudiera funcionar el convenio entre las partes. Nuevamente, en 1952 (cuando vencía el plazo establecido de cinco años), el gobierno concedió una nueva prórroga para que pudieran hacer uso generalizado de la opción de tres años, y autorizó un aumento del 15\% en los cánones, a todas luces insignificante en relación con el aumento del índice de precios (Lattuada, 1986: 117-119).

Derrocado Perón, a pesar de las expectativas de los terratenientes, el gobierno militar volvió a prorrogar los contratos por el plazo de un año, al tiempo que conformó una Comisión para el estudio del régimen legal vigente en materia de arrendamientos y aparcerías rurales ${ }^{57}$. En base al informe de dicha Comisión ${ }^{58}$, en febrero de 1957 se estableció el (primer) Plan de Transformación Agraria, a través del cual se buscaba acabar con "la prolongación indefinida de un régimen de emergencia" arrendatarios o aparceros debían realizar una oferta de compra, en un plazo de 180 días; en caso de no hacerlo, deberían restituir los predios dentro de los seis meses subsiguientes, a menos que conviniesen nuevos contratos con los propietarios (si el propietario no aceptaba la oferta de compra, el locatario podía permanecer hasta mayo de 1960$)^{60}$.

Restituida la legalidad constitucional, el Congreso Nacional, a través de las Leyes 14.434 y 14.451 prorrogó los contratos hasta mayo de 1962, y abrió otra vez un sistema de opción de compra similar al anterior (Segundo Plan de Transformación Agraria). Por medio de éste, si el propietario no aceptaba la oferta del arrendatario, los

56 Ley 13.246, reproducida en Barry (1968: 336-357).

57 Decreto-ley 7095, en Barry (1968: 396-397).

58 Diego J. Ibarbía propuso "un plan que contempla la solución buscada sin precipitaciones ni violencias", pues "no es posible pasar de un régimen de congelación a un régimen de libertad en forma repentina. Se creará un clima de grave inestabilidad social, ya que afectaría un número superior a 240.000 arrendatarios" (Ibarbía, 1956: 1-2).

59 Decreto-ley 2.187, en Barry (1968: 397-405).

60 El decreto establecía también las formas de pago posibles. En caso de divergencia sobre el precio, la institución de crédito -luego cambiada por la Cámara Regional Paritaria correspondiente, según el Decreto-ley 9.991, en Barry (1968: 405-412)- fijaría el mismo de acuerdo a la productividad estimada del predio (en caso de no aceptarlo, las partes se atenían a la prórroga ya comentada). 
contratos se consideraban prorrogados hasta mayo de $1965^{61}$. En 1963, se otorgó una nueva opción de compra sin limitación de plazo; el arrendatario obtenía, si el propietario no aceptaba su oferta, una nueva prórroga por el plazo de tres años ${ }^{62}$. En 1964 volvieron a prorrogarse todos los contratos que vencían a fin de año, por un año más ${ }^{63}$ y, al cumplirse ese plazo, se extendieron primero hasta mayo de 1966, y luego hasta mayo de $1969^{64}$. Pero, en abril de 1967, la dictadura de Onganía dió un corte final a estas prórrogas sucesivas: se derogó la legislación vigente y se estableció que todos los contratos en dinero vencerían indefectiblemente en mayo de 1968, y los establecidos en porcentaje, en diciembre de 1968. El decreto correspondiente incluía la opción de compra, pero el rechazo de la oferta por parte del propietario no generaba ningún derecho para el arrendatario. Por último, el Consejo Agrario Nacional (reactivado a partir de entonces) debería darle prioridad en los planes de colonización a los productores desalojados ${ }^{65}$.

Toda esta legislación "de emergencia" hizo que los terratenientes perdieran, durante 26 años, el dominio de la tierra que tenían arrendada con anterioridad a septiembre de 1942 (excepto si conseguían presionar al arrendatario, o convenir su retiro $\left.^{66}\right)$.

Hemos reproducido adrede toda esta sucesión de leyes y decretos de prórrogas (de lectura, sin duda, farragosa), a fin de trasmitir al lector la sensación de pérdida de control que sintieron los rentistas sobre sus propiedades, sobre todo en la medida en que, incluso las disposiciones legales que buscaban devolverles el dominio de sus campos al cabo de una nueva prórroga, resultaban "burladas" por una disposición siguiente que posibilitaba la continuidad de los arrendatarios por un nuevo lapso.

${ }^{61}$ Leyes 14.434 y 14.451, en Barry (1968: 428-440).

62 Decreto-ley 4.403, en Barry (1968: 457-460).

63 Ley 16.655, en Barry (1968: 463).

${ }^{64}$ Leyes 16.676, 16.683 y 16.883, en Barry (1968: 463-483).

65 Ley 17.253, en Barry (1968: 486-504).

66 Frigerio (1953:75) destacó que la Ley 13.246 no había impedido que los terrateninetes obtuviesen a través de maniobras jurídicas o "indemnizaciones", desalojos de muchos de los mejores campos. 
Al mismo tiempo, la regulación estatal de los cánones de arriendo significó una rápida licuación de la parte de la renta del suelo percibida por los arrendadores ${ }^{67}$. Según los cálculos del CIDA (1965), las utilidades que representaban los cánones de arriendo en dinero se redujeron en 1943-47 al 39\% de lo percibido en 1935-39, y para 1956-58 tan sólo eran un $6,8 \%$ de dicho valor inicial. Según una encuesta realizada en Pergamino en 1961, el cánon de arriendo pagado al terrateniente representaba alrededor del 1\% y 1,5\% del valor de la tierra (Gilles, 1965: 32). En el conjunto de la región pampeana, los valores percibidos por las aparcerías (no afectados por la inflación) se mantuvieron en torno al 60\%-80\% de los montos de 1935-39 (CIDA, 1965). En el estudio sobre Pergamino en 1961 se encontró que los aparceros abonaban un promedio del 20\% del maíz cosechado, y el 24\% en el caso del trigo y el girasol (Gilles, 1965: 32). Estos porcentajes eran claramente inferiores a los censados en 1937 (34,3\%) para el conjunto de la zona norte, o los hallados por Blanco (2001) entre el $40 \%$ y el 50\% para comienzos de los años cuarenta en Pergamino, que comentamos más detenidamente en el capítulo anterior. Por otra parte, estimaciones propias en base a los datos recabados por la Cámara Central de Arrendamientos y Aparcerías Rurales, muestran que en 1948/49 el monto del arriendo en dinero correspondía a sólo un 30,3\% del que se hubiera obtenido en base a una distribución proporcional de la producción del campo (arriendo a porcentaje sin intervención estatal), mientras que, para 1955/56, se había reducido a tan sólo el 9,8\% de esta estimación testigo ${ }^{68}$.

Tan intensa fue la licuación del canon de arriendo que, en 1958, el Decreto-Ley 14.890 estipuló que cuando los inmuebles estuvieran arrendados en dinero, y mientras durara la vigencia de las leyes de emergencia sobre congelamiento de alquileres y desalojos, los impuestos inmobiliarios básico y adicional no podrían exceder el $33 \%$ de los alquileres o arrendamientos ${ }^{69}$.

67 Tanto habían caído los montos pagados por los arrendatarios que algunos de los entrevistados manifestaron que muchos de sus vecinos prefirieron continuar arrendado que aceptar las ofertas de venta de los propietarios, y que luego fueron expulsados con la legislación dictada por Onganía.

68 Cálculos propios efectuados en base a los datos consignados en Ibarbía (1956: Cuadro 2).

69 Junta de Planificación Económica (1958: 147). 
La combinación de la pérdida de control sobre la tierra arrendada, con la licuación de la renta percibida impulsó a muchos terratenientes a vender sus campos a los chacareros.

\subsubsection{Clima desfavorable a los latifundios}

También indujeron la venta fraccionada, los discursos y el clima de amenaza que se ciñó sobre la gran propiedad durante estas décadas. En particular, el discurso preelectoral de Perón y el propio accionar del Consejo Agrario Nacional contribuyeron a esa sensación de peligro para los terratenientes (Lattuada, 1986: 54-62). Aunque, como hemos comentado, ya al asumir emitió señales de moderación, y su discurso crítico hacia el latifundio fue languideciendo hasta resultar coincidente con el de la Sociedad Rural Argentina, el clima favorable a las transformaciones radicales continuó durante varios años. Los arrendatarios y los asalariados rurales presionaban por transformaciones profundas; a la vez que la Federación Argentina de Trabajadores Rurales y Estibadores fijaba en sus estatutos (1947) que propendería a la concreción de una amplia reforma agraria que permitiese transformar a los obreros rurales y estibadores en dueños de la tierra que trabajaban, fomentando la creación de colonias agrícolas y explotación de latifundios en forma colectiva por sus afiliados (Luparia, 1973: 198) ${ }^{70}$. Asimismo, cuando el Banco de la Nación Argentina detuvo su accionar colonizador al comenzar la década del cincuenta, no faltaron los sectores que reclamaron la expropiación pagada con títulos públicos (Frigerio, 1953: 85).

Derrocado Perón, la "reforma agraria" no dejó de estar presente en las propuestas políticas mayoritarias, tal es así que, en el contexto del (primer) Plan de Transformación Agraria, la Sociedad Rural Argentina llamaba a los propietarios a arribar a soluciones razonables con los arrendatarios (que ofrecían comprar los campos) a fin de no dar motivo a que las fuerzas de izquierda aprovechasen la situación para solicitar medidas que hicieran peligrar en forma absoluta el derecho de propiedad (Lázzaro, 1996: 14)

$70 \mathrm{Al}$ respecto, algunos de los chacareros entrevistados comentaron que varios peones esperaban poder convertirse en pequeños propietarios gracias a la política colonizadora del primer peronismo.

71 Un intento de refutar el clima favorable a la realización de una reforma agraria, lo encontramos en el artículo de Garbarini Islas, "No hay razón para una reforma agraria", 
En este contexto, muchos terratenientes sintieron el peligro de perder sus campos. Aunque las expropiaciones fueron territorialmente poco significativas (tal como ya analizamos), no fueron pocas y resultaban "palpables" por su cercanía para cada terrateniente en particular. En las tres zonas analizadas de la provincia de Buenos Aires hemos contabilizado la adquisición de 42 campos, por un total de 263.020 hectáreas (buena parte se hizo a través de expropiación). Es decir, que en la mayoría de los partidos analizados se colonizó, al menos, una gran propiedad. Al mismo tiempo, en cada latifundio cedido en arriendo, había decenas de familias chacareras que anhelaban convertirse en propietarios y que ahora tenían concretas posibilidades de ejercer una presión política sobre legisladores y funcionarios de los gobiernos provincial y nacional $l^{72}$. De modo que sus pedidos de compra a los terratenientes tenían una fuerza que nunca antes habían tenido ${ }^{73}$. Incluso, cuando los propietarios realizaban maniobras para recuperar sus campos (consiguiendo colocar cláusulas de improrrogablidad o intentando desalojar a los arrendatarios y aparceros) podían generar un efecto inverso, propiciando la expropiación ${ }^{74}$.

Boletín del Museo Social Argentino, Entrega 307, Julio-Diciembre de 1958; p.p. 5-7. En este texto, el entonces presidente del Museo (que por cierto había abandonado por completo la línea reformista previa a la intervención de esta institución por parte del peronismo), no sólo señala los perjuicios que generaría al país, "por la falta de confianza que engendraría en los inversores", sino que afirma que "se ha producido ya en nuestro país una verdadera reforma agraria ya que son muchos los propietarios que han recuperado para trabajarlas sus tierras arrendadas, aún pagando primas a los arrendatarios, o han vendido a éstos total o parcialmente sus tierras arrendadas, aumentando así en una u otra forma considerable el número de propiedades explotadas directamente por propietarios".

72 Entre 1946 y 1951 se presentaron aproximadamente sesenta proyectos de expropiaciones en la legislatura de la provincia de Buenos Aires, afectando a la mayor parte de los partidos de la misma, aunque finalmente en su mayoría terminaron archivados (Blanco, 2001: 133).

73 En los testimonios surge claramente que los arrendatarios percibían que los terratenientes temían la expropiación y que, en varios casos, los colonos se organizaron y fueron a presionar a los dueños para que vendiesen.

74 Ejemplos en este sentido, encontramos en el trabajo de Blanco: cuando José Zabalza había logrado que prosperara el juicio de desalojo de los arrendatarios de su campo de 3.409 hectáreas en Juárez (haciéndoles firmar un escrito donde aparecían como intrusos, luego de doce o catorce años de arrendar su campo), éstos obtuvieron la expropiación por decreto, solicitándolo al gobernador Mercante. (Blanco, 2001: 118-121). En otro caso, Eduardo Otto Bemberg había logrado que sus arrendatarios de la Colonia "El Socorro" (en Pergamino) firmaran contratos con cláusulas de inafectabilidad ante posibles prórrogas legales. Pero justamente en 1948 la propiedad resultó expropiada por el Banco de la Nación, siendo entregada en 25 lotes a sus ex-arrendatarios (Blanco, 2001: 222-224). 
En síntesis, en un contexto de arriendos prorrogados "in eterno", con precios reales en franca caída, y con la permanente amenaza de la expropiación, la venta parecía una estrategia adecuada para los grandes terratenientes ausentistas ${ }^{75}$.

\subsubsection{Apoyo crediticio a las ventas fraccionadas}

Al mismo tiempo, la opción de venta era fomentada por el Estado a través de una amplia política crediticia oficial. Gracias a ella, los terratenientes obtenían entre el $60 \%$ y el $100 \%$ del valor de tasación de los campos, mientras que los chacareros recibían una financiación a largo plazo y a tasas de interés muy convenientes ${ }^{76}$. Desde el Banco de la Nación Argentina se otorgaron, entre 1946 y 1955, 14.488 préstamos para la adquisición de inmuebles rurales o la introducción de mejoras (especialmente dirigidos a arrendatarios o pequeños y medianos propietarios), aunque no resulta posible discriminar ambos objetivos. Asimismo, otorgó 3.778 préstamos a los arrendatarios para la adquisición de sus predios (Lattuada, 1986: 166-177). Durante esos años, el Banco Hipotecario Nacional dio, al menos, 2.402 préstamos para la adquisición de inmuebles rurales con hipoteca (Lattuada, 1986: 180-183). Por su parte, el Banco de la Provincia de Buenos Aires amplió el crédito hipotecario hasta el 100\% del precio de compra. En muchos casos, los propios terratenientes gestionaban ante la banca el otorgamiento de créditos hipotecarios subdivididos en un número determinado de cuentas, facilitando la adquisición en lotes a los futuros compradores (Girbal, 1993: 88-89). Si observamos la serie anual de la superficie de los inmuebles con créditos hipotecarios de dicho banco que fueron fraccionados, puede comprobarse la clara intensificación de esta operatoria durante los primeros años del gobierno peronista (Cuadro 2.9) ${ }^{77}$.

75 Incluso a precios de venta mucho menores que los que tenían los campos desocupados. Los testimonios de varios entrevistados son coincidentes en señalar que los campos se vendían a la mitad de su valor. En algunos caso se triangulaba la venta hacia algún chacarero más solvente.

${ }^{76}$ Las tasas eran de alrededor del 6\% anual, claramente negativas en términos reales, ya que los incrementos anuales de los precios mayoristas agropecuarios rondaron entre el $14 \%$ y el $45 \%$, entre 1949 y 1953 (Díaz Alejandro, 1983: 446). Por ejemplo, el trigo aumentó en un 23,6\% anual promedio entre 1945 y 1953, y la carne lo hizo en un 21,1\% anual promedio (según los datos de Vitelli, 1986).

Al respecto, uno de los productores entrevistados señaló que ahora le da vergüenza haber pagado tan poco por los créditos. 
Cuadro 2.9. Banco de la Provincia de Buenos Aires. Sección Crédito Hipotecario. Divisiones de Préstamos

\begin{tabular}{|l|r|r|r|}
\hline Año & Prestamos originales & Préstamos divididos en & $\begin{array}{c}\text { Superficie de los inmuebles } \\
\text { fraccionados }\end{array}$ \\
\hline 1942 & 53 & 184 & 62.462 \\
\hline 1943 & 52 & 229 & 75.383 \\
\hline 1944 & 73 & 258 & 90.402 \\
\hline 1945 & 86 & 384 & 205.032 \\
\hline 1946 & 57 & 189 & 112.763 \\
\hline 1947 & 61 & 405 & 385.165 \\
\hline 1948 & 86 & 552 & 198.373 \\
\hline 1949 & 66 & 395 & 114.352 \\
\hline 1950 & 67 & 473 & 19.453 \\
\hline Total & & & 1.125 .540 \\
$1944-50$ & 496 & 2.656 & \\
\hline
\end{tabular}

Fuente: Banco de la Provincia de Buenos Aires, Memoria, año 1950, p. 77 (elaborado por Girbal, 1993: $89)$.

En el mismo sentido, varios de los casos analizados por Blanco muestran que los terratenientes, luego de lograr que no se concreten pedidos legislativos de expropiación, intentaron la venta, de al menos parte de la propiedad, para recuperar el resto, o en otros casos vendieron a los arrendatarios ante la mera presentación del proyecto (Blanco, 2001: 263 y 272$)^{78}$.

77 Por su parte, Blanco encontró, en un grupo de 62 transacciones de compra-venta obtenida de la consulta de Actas Notariales de 1937 a 1955 en el partido de Bolivar (sin ser una muestra probabilística), que el $63 \%$ de estas operaciones fueron realizadas a partir de créditos hipotecarios, en su mayoría del Banco de la Nación. De los compradores, 26 eran exarrendatarios de los campos que adquirieron. Los plazos eran de 10 o 15 años a un interés del 4\% anual (Blanco, 2001: 336-337). Como ya vimos, esas tasas eran claramente negativas en términos reales.

78 Incluso algunos terratenientes vendieron en forma fraccionada propiedades que estaban libres de arrendatarios (Blanco, 2001: 299). Entonces, podría inferirse que los precios de venta, en general con créditos oficiales de por medio, no serían singularmente bajos. 


\subsubsection{Estrategias de recuperación de los campos}

Como vimos, una estrategia muy difundida para recuperar parte de los campos era gestionar créditos para sus arrendatarios, venderles una porción de la propiedad y, de este modo, liberar el resto.

Pero no todos los terratenientes vendieron total o parcialmente sus campos. Muchos soportaron las licuaciones de los cánones y el clima político que amenazaba la continuidad de su propiedad, y finalmente recuperaron sus campos, a partir de 1955 y especialmente cuando las prórrogas concluyeron en 1968. En la tesis de Blanco (2001) se reseñan muchos casos de terratenientes que lograron que fracasaran los proyectos de expropiación de sus campos (en general apellidos tradicionales de la oligarquía argentina) y otros que ni siquiera tuvieron esa amenaza concreta a pesar de ser dueños de enormes propiedades cedidas en su mayor parte en arriendo o aparcería ${ }^{79}$.

En algunos casos los terratenientes otorgaron importantes indemnizaciones con tal de recuperar los lotes (ver el ejemplo descripto en Blanco, 2001: 343). Estas prácticas se incrementaron a partir de 1958, con los planes de transformación agraria. Aunque también combinaban estas medidas con presiones para recuperar los campos, especialmente después de 1955, cuando el "peligro peronista" había pasado ${ }^{80}$.

En otros casos, los terratenientes recuperaban la parcela porque el arrendatario había envejecido y no tenía hijos ni otros descendientes hasta en segundo grado que lo pudieran reemplazar. Otros terratenientes habían arrendado sus campos a productores que quedaron fuera de la legislación que prorrogaba los arriendo. La Ley 13.246/48 establecía en su artículo 52 que los organismos correspondientes podrían acordar excepciones a la prórroga legal prevista en el artículo 50 (que prorrogaba los contratos hasta diciembre de 1952) entre otros casos "cuando el arrendatario o aparcero sea a su vez propietario, arrendatario o aparcero de una fracción de campo que constituya una

79 Por otra parte, Blanco (2001: 278) ha encontrado "cierta relación entre la preservación de las propiedades y la mayor presencia de sus titulares en el quehacer de las comunidades en que tienen sus predios rurales".

80 En un comienzo, en los años cuarenta, cuando se oficializan los contratos, algunos se preocupan por dejar constancia de que se están estableciendo "nuevas relaciones contractuales" con el artificio de cambiarlos de lotes ("se hace constar que el sr. es el primer año que trabaja la fracción de campo arrendada, habiendo entrado al mismo el $1^{\circ}$ de mayo del corriente año [1946]" rezaba uno de los contratos analizados por Blanco (2001: 181). 
unidad económica de acuerdo con las condiciones de la región donde esté ubicada"; "cuando el arrendatario sea una sociedad anónima". Asimismo el artículo 53 preveía la excepción de la prórroga "cuando el arrendatario o aparcero o sus ascendientes, descendientes o cónyuge no hayan residido en el predio arrendado, o en sus proximidades, ni realizado en este último caso los trabajos personalmente o bajo su directa vigilancia"; "cuando el arrendatario o aparcero desarrolle actividades comerciales, industriales, profesionales o cuente con capitales, de suerte que la explotación agraria constituya una fuente de recursos complementaria de su economía familiar" 81 . De modo que fueron recuperando sus campos a medida que se vencían los plazos de estos contratos.

Estos productores que eran expulsados, justamente por estar en mejor situación económica, sentían que se estaba cometiendo una injusticia, ya que por lo común eran excelentes cumplidores de los contratos, y en muchos casos el terrateniente les pedía disculpas, según hemos recogido en los testimonios de arrendatarios y arrendadores. Pero, al mismo tiempo, a estos productores cada vez les fue más fácil conseguir nuevas tierras en alquiler, ya que otros terratenientes que recuperaban sus campos, los escogían para dárselos en arriendo, sabedores de que quedaban fuera de la posibilidad del sistema de prórrogas.

Por último, algunos de los pequeños y medianos propietarios que habían cedido sus campos en arriendo, lograron recuperarlos en base a reclamarlos para su puesta en producción en forma directa, ya que la legislación lo permitía, aunque era muy rigurosa en sus cláusulas ${ }^{82}$.

81 Ley 13.246/48, transcripta en Barry (1968: 352-354).

82 El ya mencionado artículo 52 contemplaba como excepciones a las prórrogas "cuando el que formule el pedido sea persona física.. se comprometa a explotar directamente el campo o por intermedio de su cónyuge, ascendientes o descendientes en primer grado, por el plazo mínimo de cinco años y no explote otro inmueble rural de su propiedad constitutivo de una unidad económica, a menos que necesitara más tierra para racionalizar esta explotación" [previéndose sanciones si no lo cumpliera]; "cuando el propietario en las condiciones del inciso anterior, que no explote más de una unidad económica, desee independizar económicamente a uno de sus hijos, iniciándolo en la explotación agraria, siempre que éste se comprometa a explotar directa y personalmente el predio por un plazo mínimo de cinco años" (Barry, 1968: 352-353). 


\section{Acceso a la propiedad y procesos de concentración}

\section{1. ¿"Farmerización" o expulsión de los arrendatarios y aparceros?}

El notorio fraccionamiento de los latifundios de Pergamino y Tres Arroyos, y de la mitad de los ubicados en Rivadavia, podrían dar a entender que primó un proceso de "farmerización" de todos los arrendatarios y aparceros presentes al comienzo de este período, y que las expulsiones no tuvieron relevancia. Sin embargo, el fraccionamiento tiene que ser estudiado más detenidamente y puesto en relación con otras fuentes para poder estimar lo realmente acontecido. En esta dirección, hemos trabajado con dos enfoques.

En primer lugar, pusimos en relación la cantidad de explotaciones censadas en 1937 con las propias estimaciones sobre lo ocurrido con las propiedades presentes en la misma época. Esta comparación brinda pistas para relativizar los efectos "democratizadores" del fraccionamiento de los grandes latifundios. Las subdivisiones detectadas no pueden haber resuelto la situación de todos los arrendatarios y aparceros, sino tan sólo abierto el acceso a la propiedad a alrededor de un cuarto de ellos (más específicamente entre un quinto y un tercio, según los partidos estudiados).

En el caso de Tres Arroyos, en 1937, había 1254 arrendatarios y el fraccionamiento de las propiedades de más de 1000 hectáreas dio lugar -según nuestras estimaciones- a tan sólo 399 nuevas propiedades, aunque haya afectado una superficie considerable. En Pergamino, en 1937, había 2152 no propietarios, y las subdivisiones de los campos de más de 1000 hectáreas dieron lugar a sólo 402 nuevas propiedades. Por su parte, en Rivadavia el proceso de subdivisión intenso sólo afectó a la mitad de las propiedades de más de 5000 hectáreas. Es probable que las grandes estancias ganaderas 
continuaran indivisas ${ }^{83}$. Los fraccionamientos que se realizaron dieron lugar a 240 nuevas propiedades, cuando en 1937 había habido 640 arrendatarios en Rivadavia.

Corresponde aclarar que estas diferencias, entre nuevas parcelas producto del fraccionamiento y cantidad de no propietarios, tampoco deben interpretarse necesariamente como indicadoras de un proceso de expulsión de los arrendatarios, ya que sólo contabilizamos las subdivisiones de las grandes propiedades. No hemos podido registrar los procesos de venta de pequeñas o medianas propiedades (donde no hubo subdivisión o esta no fue importante), porque nos hemos basado en la comparación de mapas catastrales.

En segundo lugar, abordamos esta cuestión a partir de la cantidad de explotaciones discriminadas según los tipos de tenencia registrados en los censos. En el Cuadro 2.10, observamos que en las tres zonas el aumento en el número de propietarios fue inferior a la reducción en la cantidad de no-propietarios. Entonces, si bien la mayoría (entre un 55\% y un $60 \%$ ) de los arrendatarios y aparceros podrían haber accedido a la propiedad de los predios que trabajaban, una gran cantidad de los mismos no pudieron hacerlo. Además, para 1969, restaba una cantidad de no-propietarios, mucho menor a la de 1937 , pero bastante significativa ${ }^{84}$.

83 Como analizamos en el Capítulo Primero, en 1937 las conductas rentísticas no eran preponderantes en este estrato. A diferencia de Pergamino y Tres Arroyos, en Rivadavia las grandes explotaciones podían dar cuenta del $80 \%$ de la superficie que tenían las grandes propiedades.

84 En la zona norte, en 1969 existían 2882 explotaciones menos que en 1937. Por lo tanto, aunque todo nuevo propietario hubiera sido un ex-arrendatario o ex-aparcero, un $21 \%$ de los arrendatarios y aparceros presentes en 1937 habrían abandonado sus predios (entre ambos censos mediaron más de treinta años, por lo cual nos estamos refiriendo a categorías censales y no a sujetos concretos). Un $22 \%$ continuaría sin haber accedido a la propiedad, y sólo un $57 \%$ lo habría conseguido.

En la zona oeste, como se observa en el Cuadro 2.10, desaparecieron 1225 unidades, lo cual representa el $18 \%$ de las explotaciones en arriendo o aparcería en 1937. Un $22 \%$ permanecería en arriendo, mientras que el $60 \%$ habría accedido a la propiedad (como máximo), nuevamente con las mismas salvedades que para la zona norte. Del mismo modo, en la zona sur, al desaparecer 1878 explotaciones, las unidades en arriendo o aparcería existentes en 1937 habrían abandonado la actividad rural en un 17\%, permanecido como tales en un $28 \%$, y accedido a la propiedad en un 55\% (como máximo). 


\section{Cuadro 2.10. Cantidad de unidades según formas de tenencia}

\begin{tabular}{|l|r|r|r|}
\hline & \multicolumn{1}{|c|}{1937} & \multicolumn{1}{c|}{$\mathbf{1 9 6 9}$} & \multicolumn{1}{c|}{ evolución } \\
\hline Zona norte & & & 8234 \\
\hline Propietario* & 5706 & 13940 & -11117 \\
\hline No propietario & 14338 & 3221 & -2882 \\
\hline Total & 20044 & 17162 & \\
\hline & & & 4176 \\
\hline Zona oeste & & & -5401 \\
\hline Propietario* & 3308 & 7484 & -1225 \\
\hline No propietario & 6923 & 1522 & \\
\hline Total & 10231 & 9006 & 5973 \\
\hline & & & -7852 \\
\hline Zona sur & & & -1878 \\
\hline Propietario* & 3694 & 9667 & \\
\hline No propietario & 10949 & 3097 & \\
\hline Total & 14643 & 12765 & \\
\hline
\end{tabular}

$\left(^{*}\right)$ En 1969 , con al menos un $10 \%$ de la superficie de la explotación en propiedad

Fuente: Datos por partido del Censo Agropecuario de 1937 y reprocesamiento de los datos originales del de 1969

Ahora bien, este porcentaje, cercano a un $60 \%$ de no-propietarios que pudieron haberse convertido en propietarios, marca un máximo posible de acceso a la propiedad, ya que un fenómeno que seguramente tuvo lugar ha sido el fraccionamiento de las grandes estancias por herencia, o incluso de campos antes arrendados, cuyos propietarios (o sus herederos) comenzaron a administrarlos de forma directa. Entonces, una parte del incremento de explotaciones en propiedad tendría como origen la expansión de este segmento de medianas-grandes y grandes explotaciones, que reemplazaban tanto a muy grandes estancias como a latifundios antes entregados por completo -o casi- en arriendo.

Como pudimos ver, es muy difícil responder claramente a la pregunta que abre este apartado, ya que a partir de las dos perspectivas de análisis empleadas surgen estimaciones de distinto tipo y de diferentes magnitudes. Con certeza, solamente 
podemos decir que, como mínimo, un cuarto de los arrendatarios y aparceros presentes en 1937 habrían accedido a la propiedad de la tierra gracias al fraccionamiento de los grandes latifundios; y, como máximo, un $60 \%$ de ellos podrían haberse convertido en propietarios, según la cantidad de explotaciones registradas en ambos censos.

Sin embargo, podemos reducir un poco el rango de variabilidad de estas estimaciones. Tal como comentáramos, la primera de estas cifras deja de lado todas las ventas de propiedades a arrendatarios que ocurrieron dentro de un mismo intervalo de tamaño, como así también a las que surgieron a partir de propiedades de menos de 1.000 hectáreas. Por lo tanto, la consideramos una estimación demasiado conservadora. En cambio, los procesos de división y puesta en producción por parte de terratenientes antes ausentistas, no habrían constituido un número importante de nuevos productores ${ }^{85}$. Entonces, la segunda estimación sólo habría sobrestimado levemente el porcentaje de ex-arrendatarios y ex-aparceros que accedieron a la propiedad. En términos aproximados, podemos concluir que, en las tres zonas estudiadas, alrededor de la mitad de los arrendatarios y aparceros presentes en 1937 (o sus descendientes) se habrían convertido en propietarios, mientras que la otra mitad habría abandonado sus predios, algunos atraídos por las oportunidades laborales de la industrialización urbana y otros expulsados, legal o ilegalmente, por los terratenientes.

Entonces, si bien fue muy elevado el porcentaje de latifundios antes cedidos en arriendo que fueron fraccionados $\mathrm{y}$ vendidos a medianos productores, no podemos olvidarnos de la otra cara de la historia, los miles de pequeños arrendatarios y aparceros que fueron expulsados o que, debido a sus miserables condiciones económicas y sociales, prefirieron migrar hacia las grandes ciudades. En este sentido, consideramos que resulta equivocada la conceptualización del proceso ocurrido en estas décadas como una "reforma agraria", tal como lo afirma Hora (2002). Una reforma agraria implica una política deliberada de garantizar el acceso a la propiedad a los productores no propietarios $\mathrm{y}$, en muchos casos, también de los trabajadores rurales (amen de otras

85 Por ejemplo, frente a 8.234 nuevos propietarios que vimos había en la zona norte entre 1937 y 1969, la cantidad de explotaciones de más de 625 hectáreas sólo se incrementó en 251 unidades. En la zona oeste, habían aparecido 4.176 nuevos propietarios, y sólo pasó a haber 311 explotaciones más mayores de 625 hectáreas entre 1937 y 1969. Por último, en la zona sur, surgieron 5.973 propietarios, y sólo se registraron 115 explotaciones más en el intervalo de más de 625 hectáreas. 
medidas tendientes a favorecer su desarrollo económico). Aquí solamente asistimos al acceso a la propiedad de una fracción de los productores arrendatarios (muchas veces, de aquéllos en mejor situación), como resultado indirecto de las políticas oficiales.

El abandono/expulsión de arrendatarios y aparceros se relaciona con otro fenómeno que puede ser visualizado a partir de los datos censales: la concentración de la estructura productiva.

\subsection{Concentración de la estructura productiva}

Paralelamente a la división de las grandes propiedades en las décadas aquí estudiadas, habría tenido lugar un proceso inverso en la estructura productiva. Se trata de un fenómeno relativamente extraño al agro pampeano. Durante las primeras décadas del siglo XX tuvo lugar una desconcentración de la estructura productiva pampeana, con la expansión de la agricultura (Barsky y Pucciarelli, 1991), seguramente por el alto grado de concentración del patrón inicial de producción ganadera de la segunda mitad del siglo XIX. Sin embargo, a partir de fines de los años treinta comienza un claro proceso de concentración. No sólo el giro hacia la ganadería y la expansión de establecimientos "mixtos" habrían impulsado este proceso. La propia actividad agrícola comenzó a sentir claras economías de escala en torno a la incorporación de innovaciones tecnológicas como la cosechadora automotriz, la cosecha a granel y la tractorización ${ }^{86}$. Además, la propia intervención estatal tuvo una consecuencia indeseada. Cuando los terratenientes lograban recuperar sus campos, en la mayoría de los casos no volvían a arrendarlos, y si querían continuar con la producción agrícola, lo hacían con contratistas de labores, o con contratos a plazos no mayores a un año (exceptuados de las prórrogas legalmente establecidas ${ }^{87}$ ). Incluso aquéllos que

86 Si bien no existen estudios que incorporen todas las dimensiones que son necesarias para analizar correctamente las economías de escala, o mejor dicho de tamaño (sobre esta distinción conceptual puede consultarse Madden, 1967), hemos encontrado algunos trabajos específicos y consideraciones incluidas en publicaciones más generales que nos permiten tener una aproximación general al problema. En el apartado sexto del presente capítulo se analiza el impacto de la mecanización sobre la organización social del trabajo y el tamaño de las explotaciones.

87 En la Ley 13.246 (1948) se establecía: "Quedan excluidos de las prescripciones de esta ley los contratos en virtud de los cuales se conceda el uso y goce de un predio con destino exclusivo para pastoreo, celebrado por un plazo no mayor de un año $\left(\operatorname{art.~} 3^{\circ}\right)$, y "Quedan 
entregaban nuevamente sus propiedades en arriendo preferían, claramente, a productores más grandes, y sobre todo a aquellos que ya tenían algún campo en propiedad (exceptuados de la solicitud de prórroga según la propia legislación ${ }^{88}$ ).

Analizando los datos censales observamos que en las tres zonas perdieron peso numérico y territorial las unidades pequeñas y mediano-pequeñas (especialmente las de 25 a 200 hectáreas en la zona norte, las de 25 a 300 en la zona oeste, y las de 25 a 625 en la zona sur). En cambio, se incrementó la importancia de las explotaciones de 1.250 a 2.500 hectáreas, el sector de los terratenientes-capitalistas medianos, quienes lograron expulsar a los arrendatarios a quienes alquilaban sus campos, tal como lo analizan Slutzky (1968) y Murmis (1979), entre otros. Cabe destacar que la crisis de las pequeñas explotaciones no significó la reconstitución de las muy grandes estancias ganaderas $^{89}$. (Para mayores detalles, consultar el Apéndice 2, apartado 2, donde se consignan los cuadros y un análisis más detallado del proceso de concentración).

Combinando el análisis de los cambios en la estructura de la propiedad con el de los datos censales, podemos concluir dos cuestiones. En primer lugar, si es posible hablar de una "farmerización" de los chacareros pampeanos durante las décadas del cuarenta y cincuenta, debemos tener en claro que significó la consolidación del estrato de 200 a 1.000 hectáreas, y no el de las unidades de 25 a 200 hectáreas, aunque éstas tampoco desaparecieron por completo. En segundo lugar, esta transformación fue

excluidos de la prescripciones de esta ley los contratos en que se convenga, por su carácter accidental, el cultivo de un predio por una sola cosecha (Art. 39).

De hecho, estas excepciones no estaban presentes en la legislación anterior sobre arriendos (leyes 11.170 de 1921 y 11.627 de 1932, en esta última sólo se exceptuaba a los contratos con fines exclusivos de pastoreo a breve término, en su artículo $1^{\circ}$ ).

Un posible antecedente a la inclusión de esta excepción en la legislación de 1948 serían las consideraciones vertidas en el artículo "A propósito de arrendamientos agrarios" donde el Museo Social Argentino (1933) sienta su posición institucional frente a las propuestas para mejorar la situación de los arrendatarios durante la crisis. Allí sugiere flexibilizar la ley 11.627 durante la emergencia para contratos de breve duración (dando ejemplos a un año) para que las partes puedan llegar a arreglos transitorios que alivien las tensiones.

${ }^{88}$ Ver inciso (d) del artículo 52 de la mencionada ley, ya transcripto en el apartado anterior.

89 El número de explotaciones mayores de 5.000 hectáreas se redujo en la zona norte (de 18 a 10 unidades) y en la zona oeste (de 99 a 84), mientras que en la zona sur se mantuvo en las 71 explotaciones de este tamaño. 
posible fundamentalmente gracias a la subdivisión de los grandes latifundios (unidades de propiedad) que se mantenían total o parcialmente rentísticos, y no al fraccionamiento de las grandes estancias ganaderas (unidades de producción).

\subsection{Equiparación de las estructuras de propiedad y producción}

La existencia de un proceso de concentración de la producción en unidades de mayor tamaño, al tiempo que ocurría un proceso de desconcentración de la estructura de propiedad, condujo a cierta equiparación entre propiedad y producción.

En cuanto a la estructura de la propiedad, podemos observar en los Gráficos 2.4 a 2.6 que el grado de concentración de la propiedad de la tierra en manos de grandes parcelas se había reducido considerablemente: las propiedades de más de 5.000 hectáreas daban cuenta de sólo el $2 \%$ de la superficie de Pergamino y el $4 \%$ de la de Tres Arroyos ${ }^{90}$. Unicamente en Rivadavia este intervalo continuaba teniendo un lugar significativo, pero mucho menor que el de 27 años atrás: en 1964 tenía el 14 \% del área, frente al 36\% en 1939. Sin embargo, esta reducción en la significación territorial de los latifundios, no determinó un predominio espacial de las pequeñas propiedades (excepto, quizás en Pergamino, donde los campos de menos de 200 hectáreas daban cuenta del $38 \%$ del área $\left.{ }^{91}\right)$. La mayor parte de la superficie se concentró en los estratos intermedios, entre las 200 y las 2500 hectáreas: con una importancia mayor en los niveles más elevados en el caso de Rivadavia y de Tres Arroyos (el estrato de 500 a

90 Recordemos que para las propiedades de más de 1.000 hectáreas en Pergamino, y las de más de 2.500 en Tres Arroyos y Rivadavia hemos computado todas las propiedades existentes. Por debajo de estas cifras trabajamos con un muestreo probabilístico de 250 propiedades. Como explicamos en la Introducción, para 1939 trabajamos en base al Mapa Catastral, pero para los años sesenta nos basamos en los Mapas Rurales.

91 Cabe señalar que el estudio realizado por la Junta de Planificación Económica de la Provincia de Buenos Aires (1958), trabajo efecuado por Alfredo Eric Calcagno, la distribución de la propiedad en la "zona norte" (que comprendía los partidos de San Nicolás, Ramallo, San Pedro, Pergamino, Colón, Rojas, General Arenales, Salto y Bartolomé Mitre) era bastante similar a la que encontramos en Pergamino en 1960. El 58\% de la superficie estaba en manos de propiedades de menos de 300 hectáreas, sólo un $2 \%$ en latifundios de más de 5.000 hectáreas, mientras que las propiedades de 300 a 500 hectáreas tenían el $8 \%$, las de 500 a 1.000 el $10 \%$ y las de 1.000 a 5.000 el $22 \%$ restante. 
2500 hectáreas daba cuenta del 58\% y del 60\% de cada partido respectivamente) $)^{92}$ y con una distribución más repartida entre todos los estratos en Pergamino.

92 También se observa cierta adecuación entre nuestras estimaciones, para mediados de los años sesenta, y las de la Junta de Planificación Económica (1958). En la "zona oeste" de este estudio (General Villegas, General Pinto, Lincoln, Carlos Tejedor, Rivadavia, Pehuajó, Trenque Lauquen, Carlos Casares, Pellegrini y Adolfo Alsina) las propiedades de más de 5.000 hectáreas tenían el $8 \%$ de la superficie, y las de 1.000 a 5.000 poseían el 36\%, destacándose el peso de las parcelas de 50 a 300 hectáreas con el 28\% de la zona. En la "zona sudeste" (Tandil, Balcarce, General Alvarado, Lobería, Necochea, Juárez, González Chaves, Tres Arroyos y Coronel Dorrego) las propiedades de más de 5.000 hectáreas sólo tenían el $4 \%$ de superficie, las de 1.000 a 5.000 el $34 \%$ y las de 500 a 1.000 el $20 \%$. 


\section{Gráfico 2.4.}

Pergamino, supeficie en propiedades

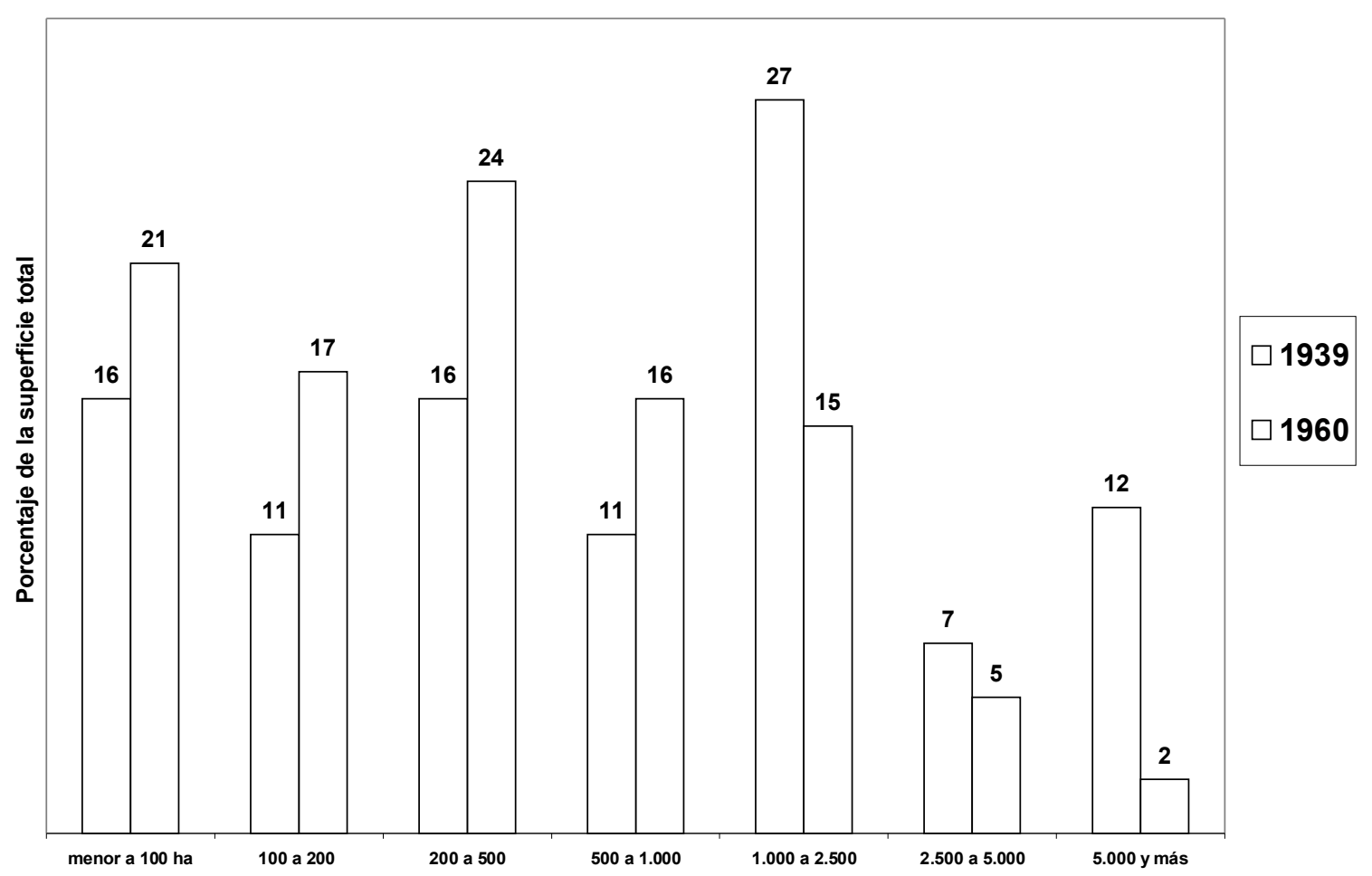

Fuente: Estimaciones propias en base al Mapa Catastral de 1939 y el Mapa rural de 1960. 
Gráfico 2.5.

Rivadavia, supeficie en propiedades

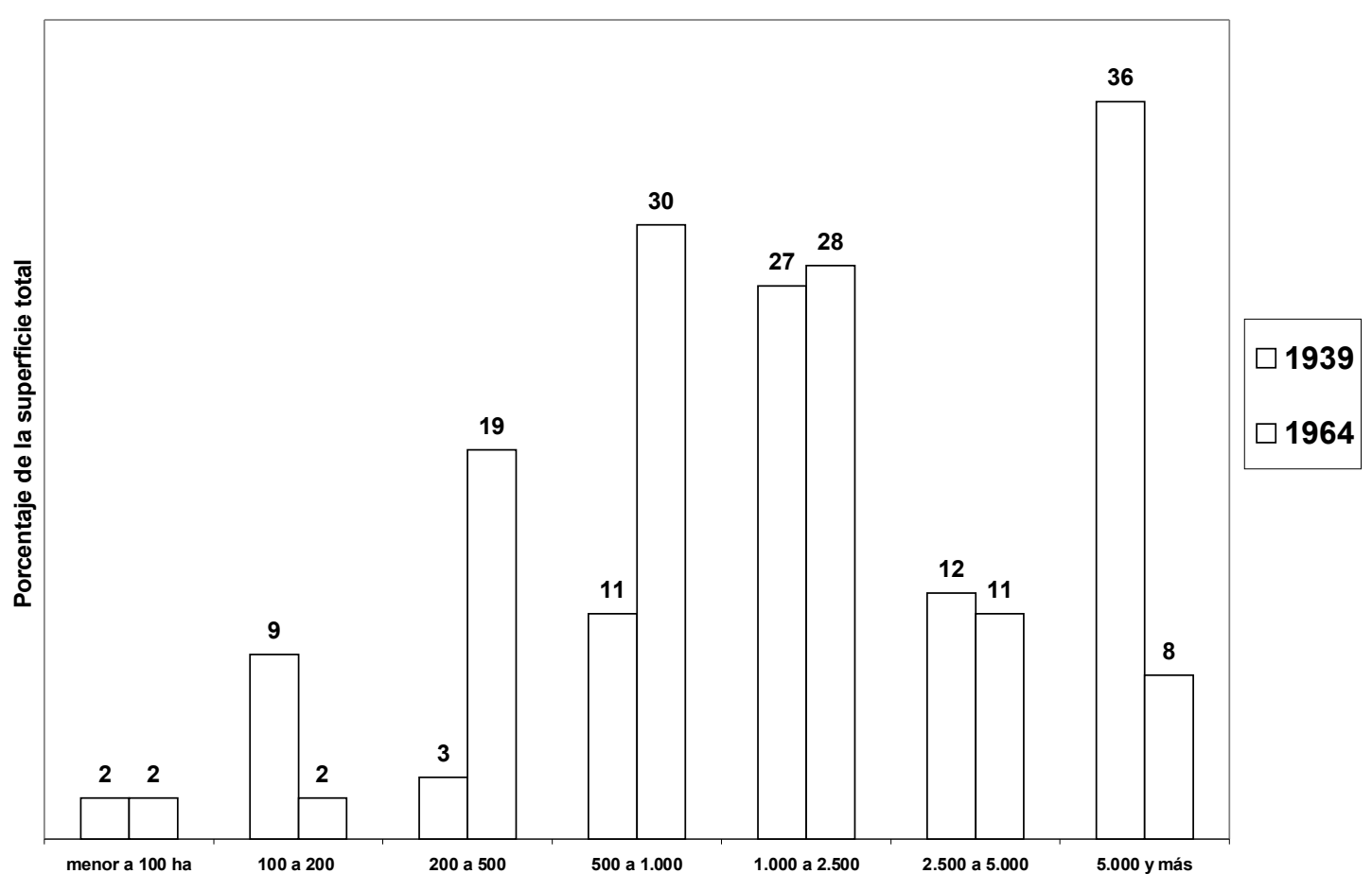

Fuente: Estimaciones propias en base al Mapa Catastral de 1939 y el Mapa rural de 1964. 


\section{Gráfico 2.6.}

Tres Arroyos, supeficie en propiedades

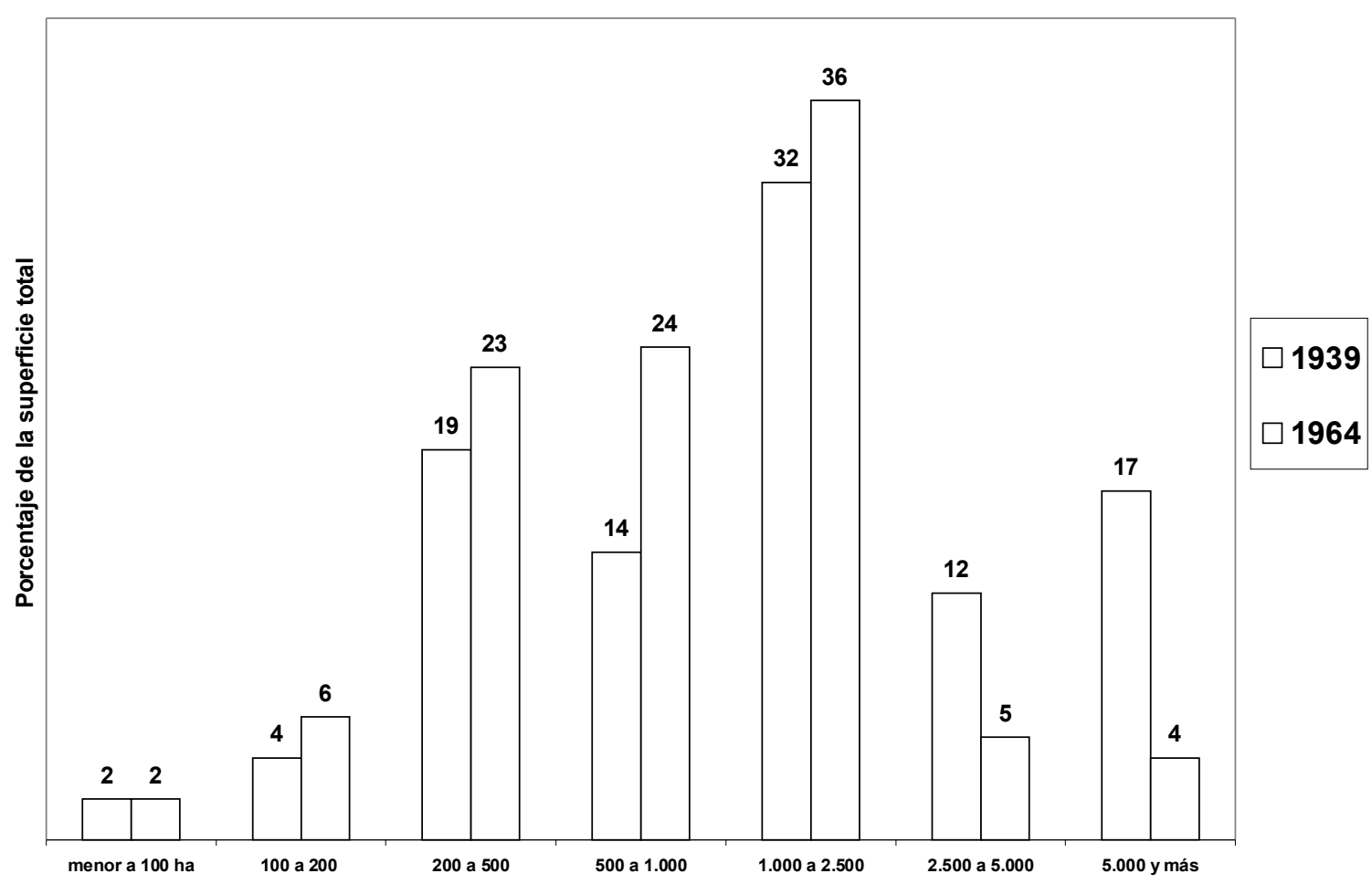

Fuente: Estimaciones propias en base al Mapa Catastral de 1939 y el Mapa rural de 1964.

Además, hemos repetido para principios de la década del sesenta, el análisis que cruza la estructura de la propiedad y la distribución de las explotaciones según su tamaño, tal como lo hiciéramos para $1937 / 39^{93}$. Se debe recordar que solo podemos detectar los "desfasajes" entre ambas distribuciones, y que los interpretamos como cesiones en arriendo entre los distintos estratos de tamaño.

Tal como podemos observar en los Cuadros 2.11 a 2.13 y los Gráficos 2.7 a 2.9, en los tres partidos encontramos una armonización entre ambas estructuras. Ya no está

93 Para una explicación detallada de la metodología de comparación entre ambas estructuras, ver el apartado 3.3 del capítulo primero. 
presente ese desfasaje sustancial entre propiedad y unidades productivas en los tamaños más elevados (característico de 1937/39), fundamentalmente porque han casi desaparecido las muy grandes propiedades. Es más, en los años sesenta en Tres Arroyos y en Rivadavia las explotaciones de más de 2500 hectáreas ocupaban una superficie mayor que la que poseían las propiedades de este tamaño ${ }^{94}$. Seguramente esta situación esconde procesos de centralización de la producción, manteniéndose algunas de las grandes estancias productivas, a pesar de las divisiones hereditarias de la propiedad. En Pergamino ya no cedían en arriendo las propiedades de más de 1000 hectáreas, sino las de 200 a 1000 (un $13 \%$ de la superficie del partido), fundamentalmente hacia las explotaciones de menos de 100 hectáreas ${ }^{95}$.

94 En Tres Arroyos son las propiedades de 1000 a 2500 hectáreas las que estarían cediendo campos (18\% del área en total) para las unidades mayores (3\%), así como para las de $200 \mathrm{a}$ 1000 hectáreas (12\%). En Rivadavia, aparecen captando superficie las grandes explotaciones, proveniente de propiedades medianas, aunque también estaría tomando las menores a 200 hectáreas.

95 Gaignard y colaboradores (1967), reproducido por Devoto (1987) comparan las estructuras de propiedad (en base a la Guía de Contribuyentes de la provincia de Buenos Aires de 1963, con los datos sobre explotaciones del Censo Nacional Agropecuario de 1960 para el partido de Colón (vecino del de Pergamino). Los resultados son sintetizados en el siguiente cuadro, en el que se puede observar que las explotaciones de 26 a 400 hectáreas superan a las propiedades de este mismo tamaño, en $19 \%$ de la superficie total. Por el contrario, en el estrato de más de 400 hectáreas, las propiedades presentaban un $18 \%$ más de superficie total que las explotaciones.

Distribución de la superficie del partido de Colón. Propiedades (1963) y explotaciones (1960)

\section{Estratos}

(ha)PropiedadesExplotaciones0-253,5\%2,7\%26-10016,1\%30,3\%101-40014,6\%19,4\%401$100010,5 \% 5,8 \%+$ de $100055,1 \% 41,7 \% 100 \% 100 \%$ Fuente: Gaignard y otros (1967), citado por Devoto (1987: 6). 


\section{Gráfico 2.7.}

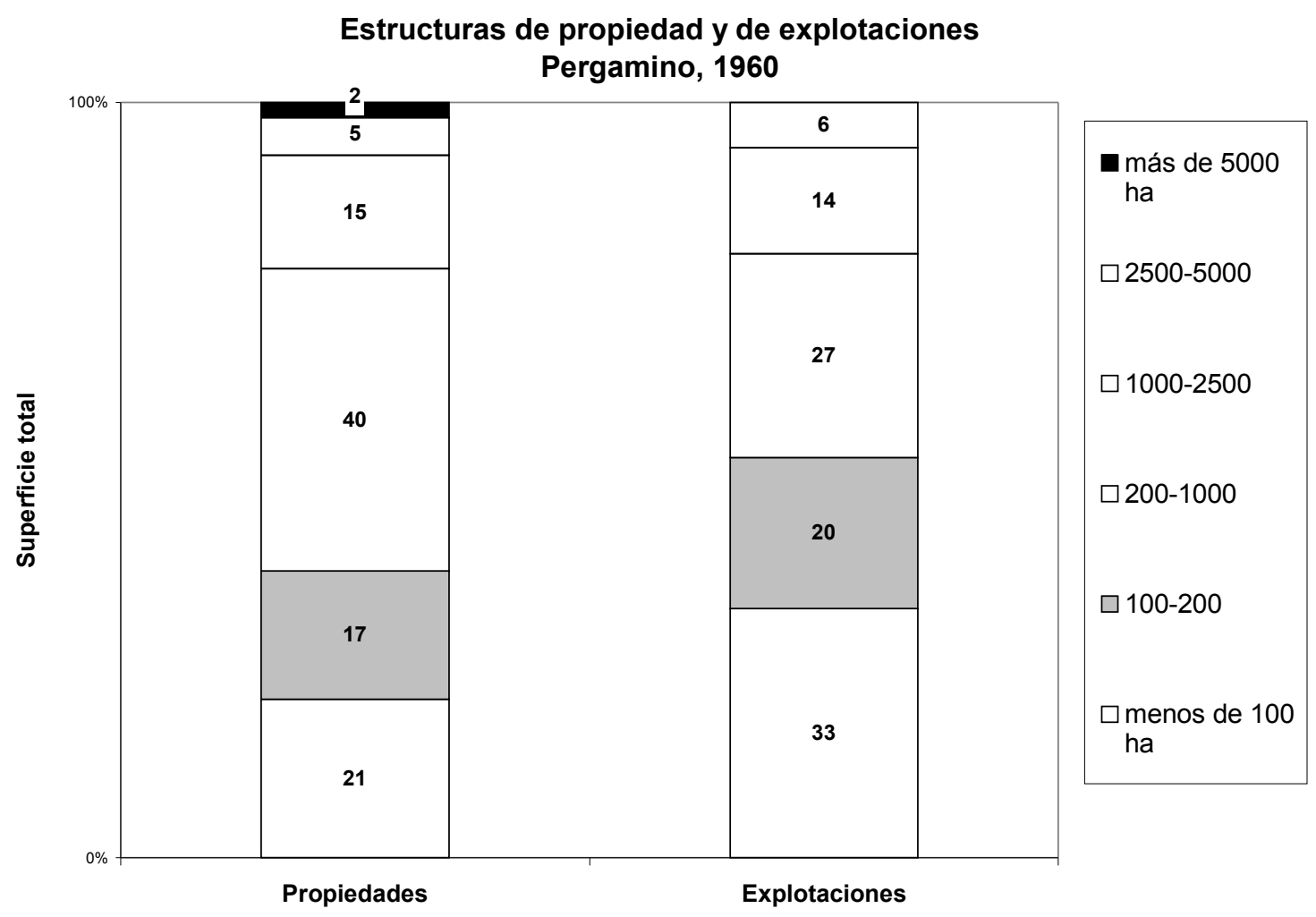

Cuadro 2.11. Estructura de propiedad y estructura productiva. Pergamino, 1960. Porcentajes del área total

\begin{tabular}{|c|c|c|c|c|c|}
\hline Extensión & $\begin{array}{c}\text { Unidades } \\
\text { de } \\
\text { propiedad }\end{array}$ & $\begin{array}{c}\text { Unidades } \\
\text { de } \\
\text { producción }\end{array}$ & $\begin{array}{c}\text { Tenencia } \\
\text { en } \\
\text { propiedad } \\
\text { (estimac.) }\end{array}$ & $\begin{array}{c}\text { "sobrante" } \\
\text { (estimac.) }\end{array}$ & $\begin{array}{c}\text { "faltante" } \\
\text { (estimac.) }\end{array}$ \\
\hline + 5.000 ha & $2 \%$ & - & - & $2 \%$ & - \\
\hline 2.500 a 4.999 ha & $5 \%$ & $6 \%$ & $5 \%$ & - & $1 \%$ \\
\hline 1.000 a 2499 ha & $15 \%$ & $14 \%$ & $14 \%$ & $1 \%$ & - \\
\hline 200 a 1.000 ha & $40 \%$ & $27 \%$ & $27 \%$ & $13 \%$ & - \\
\hline 100 a 200 ha. & $17 \%$ & $20 \%$ & $17 \%$ & - & $3 \%$ \\
\hline - 100 ha. & $21 \%$ & $33 \%$ & $21 \%$ & - & $12 \%$ \\
\hline
\end{tabular}

Fuentes: Propiedad según análisis de mapa catastral de 1960, y Unidades productivas según Censo Agropecuario de 1960. 
Gráfico 2.8.

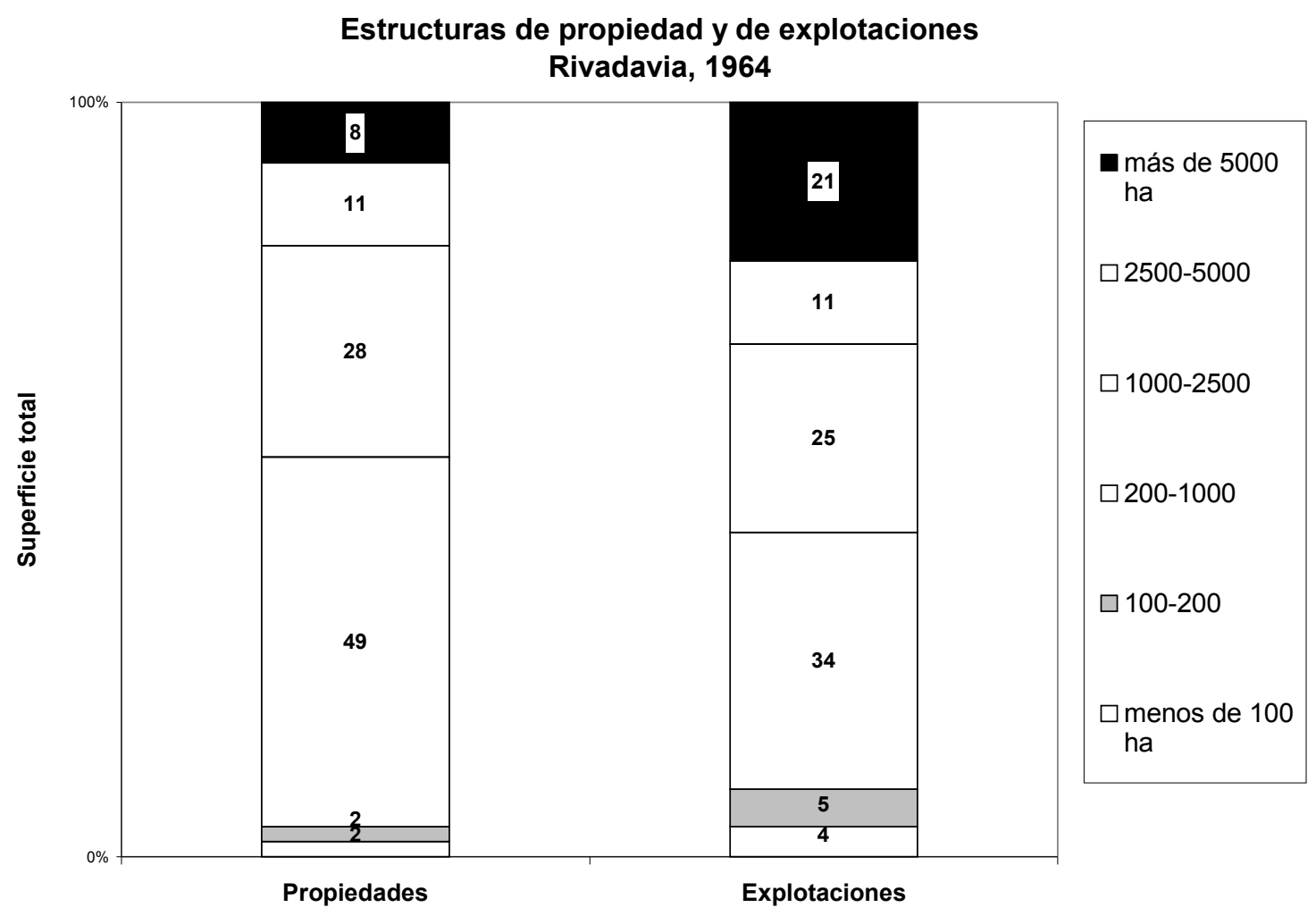

Cuadro 2.12. Estructura de propiedad y estructura productiva. Rivadavia, 1960 y 1964. Porcentajes del área total

\begin{tabular}{|c|c|c|c|c|c|}
\hline Extensión & $\begin{array}{c}\text { Unidades } \\
\text { de } \\
\text { propiedad }\end{array}$ & $\begin{array}{c}\text { Unidades } \\
\text { de } \\
\text { producción }\end{array}$ & $\begin{array}{c}\text { Tenencia } \\
\text { en } \\
\text { propiedad } \\
\text { (estimac.) }\end{array}$ & $\begin{array}{c}\text { "sobrante" } \\
\text { (estimac.) }\end{array}$ & $\begin{array}{c}\text { "faltante" } \\
\text { (estimac.) }\end{array}$ \\
\hline+5.000 ha & $8 \%$ & $21 \%$ & $8 \%$ & - & $13 \%$ \\
\hline 2.500 a 4.999 ha & $11 \%$ & $11 \%$ & $11 \%$ & - & - \\
\hline 1.000 a 2499 ha & $28 \%$ & $25 \%$ & $25 \%$ & $3 \%$ & - \\
\hline 200 a 1.000 ha & $49 \%$ & $34 \%$ & $34 \%$ & $15 \%$ & - \\
\hline 100 a 200 ha. & $2 \%$ & $5 \%$ & $2 \%$ & - & $3 \%$ \\
\hline - 100 ha. & $2 \%$ & $4 \%$ & $2 \%$ & - & $2 \%$ \\
\hline
\end{tabular}

Fuentes: Propiedad según análisis de mapa catastral de 1964, y Unidades productivas según Censo Agropecuario de 1960. 
Gráfico 2.9.

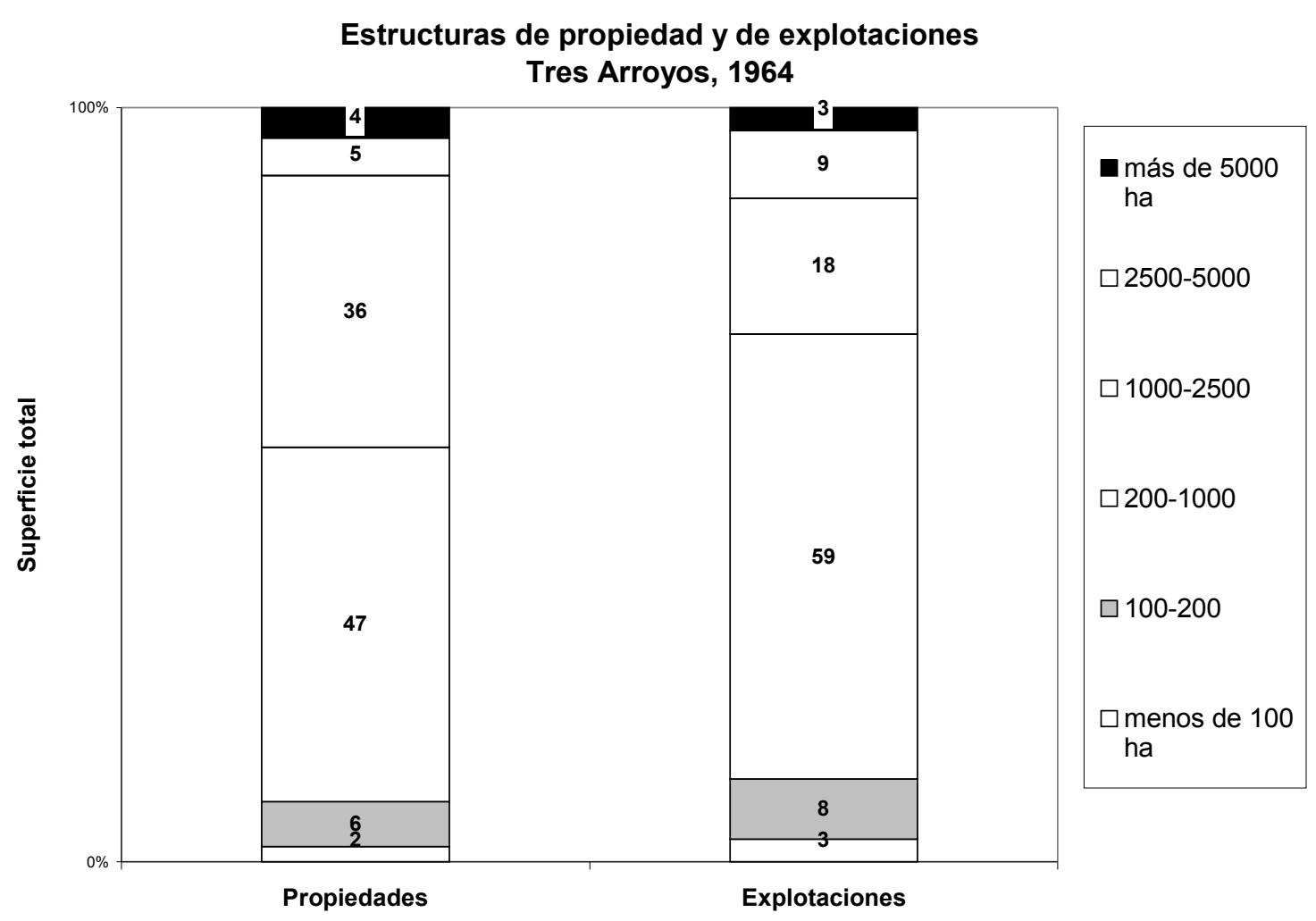

Cuadro 2.13. Estructura de propiedad y estructura productiva. Tres Arroyos, 1960 y 1964. Porcentajes del área total

\begin{tabular}{|c|c|c|c|c|c|}
\hline Extensión & $\begin{array}{c}\text { Unidades } \\
\text { de } \\
\text { propiedad }\end{array}$ & $\begin{array}{c}\text { Unidades } \\
\text { de } \\
\text { producción }\end{array}$ & $\begin{array}{c}\text { Tenencia } \\
\text { en } \\
\text { propiedad } \\
\text { (estimac.) }\end{array}$ & $\begin{array}{c}\text { "sobrante" } \\
\text { (estimac.) }\end{array}$ & $\begin{array}{c}\text { "faltante" } \\
\text { (estimac.) }\end{array}$ \\
\hline+5.000 ha & $4 \%$ & $3 \%$ & - & $1 \%$ & - \\
\hline 2.500 a 4.999 ha & $5 \%$ & $9 \%$ & $5 \%$ & - & $4 \%$ \\
\hline 1.000 a 2499 ha & $36 \%$ & $18 \%$ & $18 \%$ & $18 \%$ & - \\
\hline 200 a 1.000 ha & $47 \%$ & $59 \%$ & $47 \%$ & - & $12 \%$ \\
\hline 100 a 200 ha. & $6 \%$ & $8 \%$ & $6 \%$ & - & $2 \%$ \\
\hline - 100 ha. & $2 \%$ & $3 \%$ & $2 \%$ & - & $1 \%$ \\
\hline
\end{tabular}

Fuentes: Propiedad según análisis de mapa catastral de 1964, y Unidades productivas según Censo Agropecuario de 1960.

Hasta aquí hemos considerado las transformaciones en el número de explotaciones y en la superficie total agropecuaria. Resta analizar específicamente qué ocurrió con la actividad agrícola. 


\section{Las transformaciones en las formas sociales de producción de la agricultura}

Este apartado está dedicado, centralmente, al análisis de los cambios, entre 1937 y 1969, en las características de las unidades que desarrollaban la agricultura. Consideraremos el tamaño de las explotaciones, la composición de la mano de obra en cada unidad y su forma de tenencia del suelo, midiendo la importancia de los distintos tipos de establecimientos según la proporción de la superficie agrícola que tenían a su cargo. Además, para comprender mejor las transformaciones en la organización social del trabajo, analizaremos el proceso de mecanización durante estas décadas y su impacto en dicha organización.

\subsection{Tamaño de las unidades productivas, agricultura y productividad por hectárea}

En líneas generales, entre 1937 y 1969 la concentración de la superficie agrícola fue más intensa que la que ocurrió en el área total agropecuaria, analizada en el apartado anterior. Por un lado, la mecanización elevó el tamaño óptimo económico (en cuanto a costos unitarios de producción) y, sobre todo, incrementó los requerimientos de extensión mínimos para el pleno uso de la maquinaria, como así también de la mano de obra (tal como veremos en el siguiente apartado). Por otro lado, como efecto de este mismo proceso, los ingresos por hectárea tendieron a disminuir y cada vez fue necesaria más superficie para poder sostener en nivel de vida de una familia rural, con estándares de consumo paulatinamente mayores. En tercer lugar, muchos estancieros comenzaron a realizar la agricultura de forma directa con asalariados o con contratistas de servicios, sin ceder los campos a agricultores arrendatarios o medieros.

Como podemos ver en el gráfico 2.10 , en la zona norte tuvo lugar una fuerte concentración de la agricultura en las explotaciones de más de 625 hectáreas ${ }^{96}$ (que pasaron de controlar el 4\% del área agrícola en 1937, a tener el 29\% en 1969). En cambio, las unidades de menos de 200 hectáreas redujeron su peso en la agricultura (del

96 Debimos mantener este poco común corte en las 625 hectáreas para poder comparar los datos de 1969 con los de 1937, que dejó como último intervalo abierto el de "625 hectáreas y más" para las chacras y las explotaciones "mixtas". 
$81 \%$ al $48 \%)^{97}$. Esta concentración más intensa que la ocurrida con la superficie total, está dando cuenta de la reducción de la dedicación de la agricultura en las pequeñas unidades (que se hicieron más mixtas), y del incremento de la actividad agrícola en las grandes. Como resultado de estas transformaciones, la agricultura de la zona norte quedó repartida entre unidades pequeñas, medianas y grandes, tal como puede observarse en el mencionado gráfico.

\section{Gráfico 2.10.}

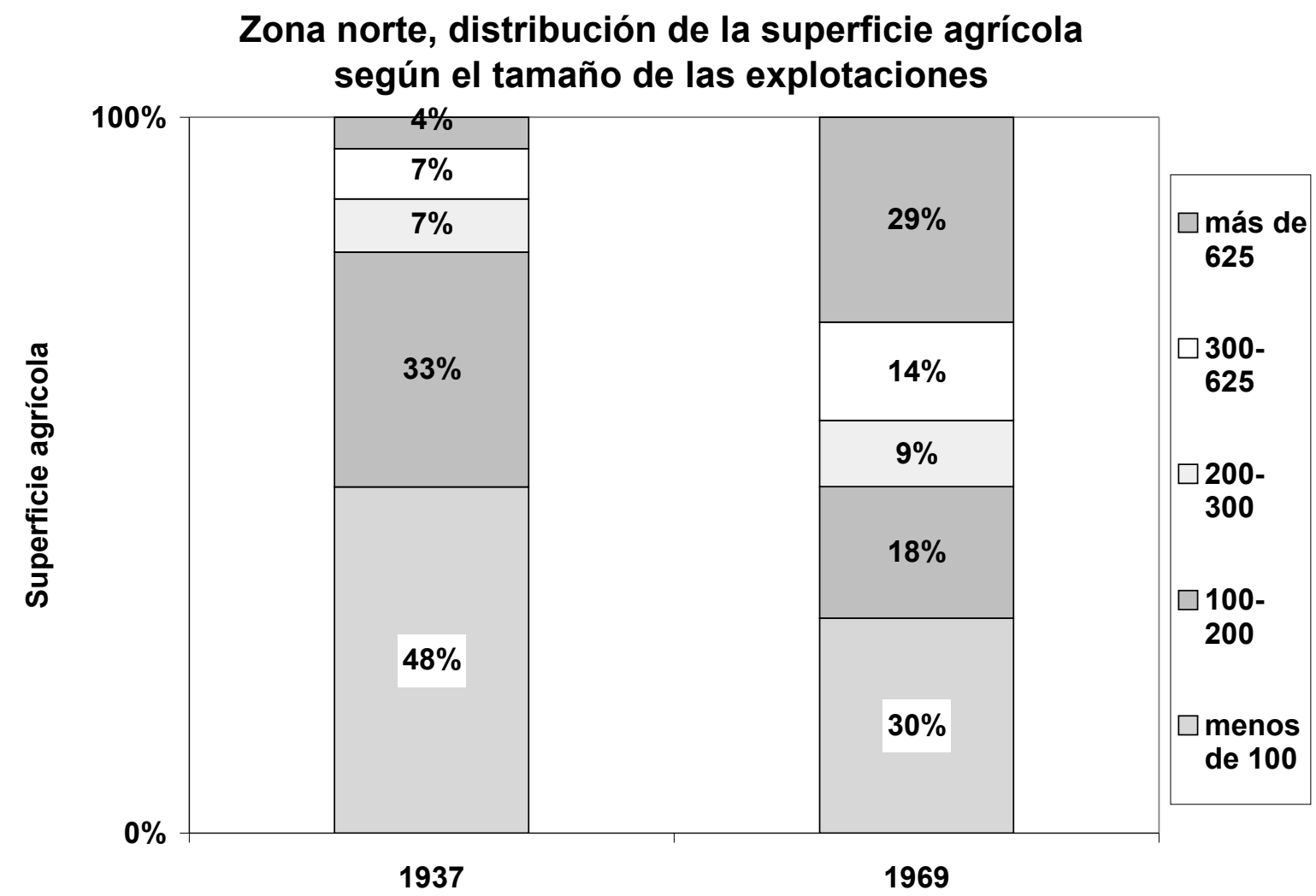

Fuentes: Estimaciones propias basadas en los datos por partido del Censo de 1937 y cálculos a partir de los datos originales del Censo de 1969.

En la zona oeste, la agricultura dejó de ser una actividad ubicada en las explotaciones pequeñas y medianas, para localizarse en las unidades mediano-grandes y

97 Recordar que las cifras para 1937 son una estimación de la distribución de la superficie agrícola a partir de una serie de supuestos, explicitados en el Apéndice 1. En cambio, la distribución de la superficie agrícola en 1969 está realizada en base al reprocesamiento de los datos originales del censo de 1969. 
grandes (ver gráfico 2.11). Las unidades de más de 625 hectáreas pasaron a captar dos tercios de esta actividad. Todas las explotaciones menores a este tamaño, redujeron su participación relativa hasta quedar representando un papel marginal en la agricultura de esta zona. Así, las explotaciones de menos de 300 hectáreas, que en 1937 controlaban el $57 \%$ de la superficie agrícola de la zona oeste, en 1969 sólo daban cuenta del 19\% de esta área $^{98}$. Vemos aquí el efecto combinado de la crisis de las pequeñas unidades y la expulsión de alrededor de la mitad de los arrendatarios y aparceros presentes en 1937, junto con la expansión del sector de productores mediano-grandes que ahora se han volcado también a la agricultura (veremos más adelante, en este apartado que, de todos modos, tenían un perfil más ganadero, aunque, por su importancia territorial, la mayor parte de la superficie agrícola quedó en sus manos).

98 De todos modos, recordar que las estimaciones realizadas para 1937 (debido a los supuestos empleados) podrían estar subvalorando la importancia de la agricultura realizada en las explotaciones de mayor tamaño. 


\section{Gráfico 2.11.}

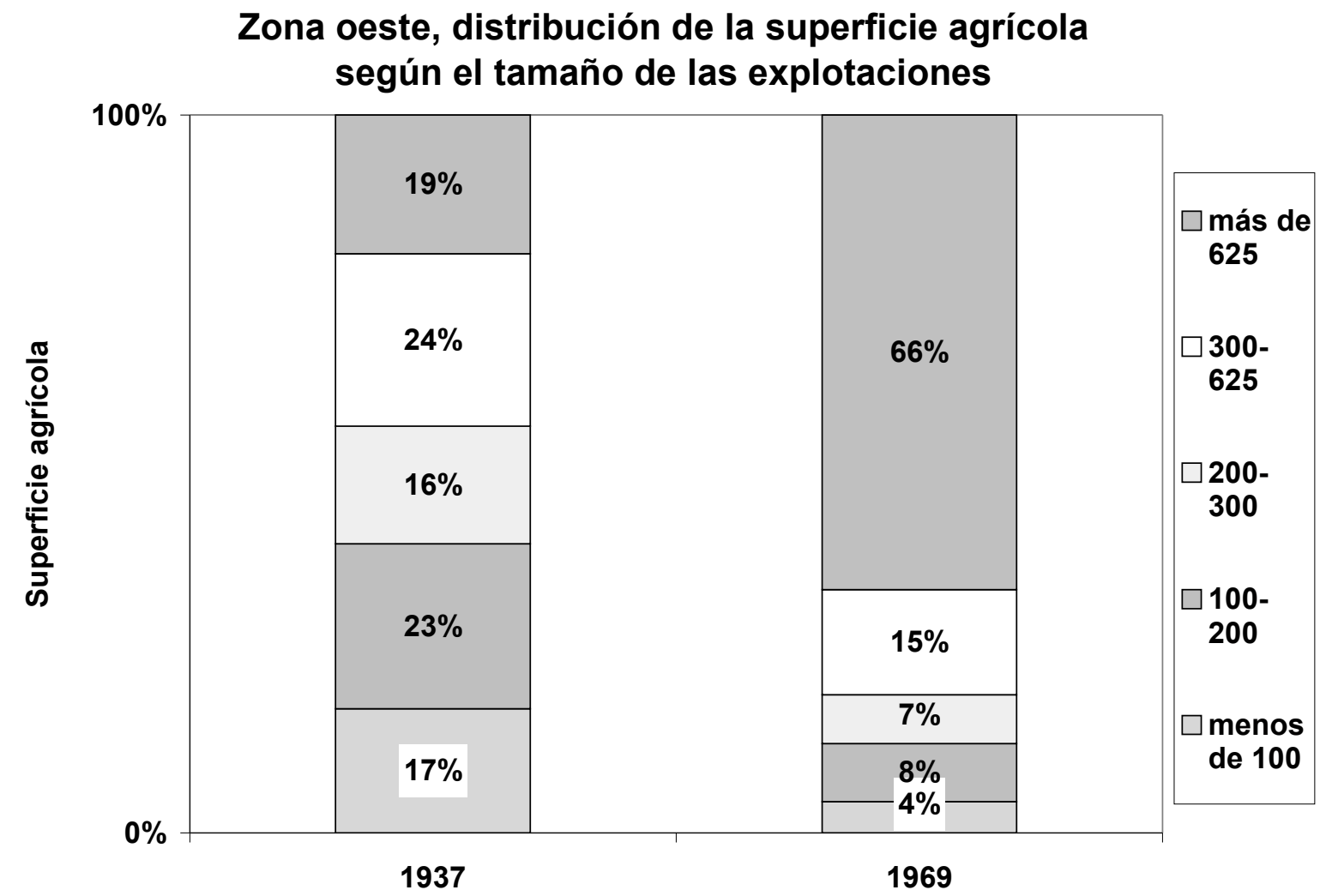

Fuentes: Estimaciones propias basadas en los datos por partido del Censo de 1937 y cálculos a partir de los datos originales del Censo de 1969. 
En la zona sur, no tuvieron lugar cambios tan drásticos en los tamaños de las unidades que hacían la agricultura, tal vez porque ya estaba bastante concentrada en 1937. Igualmente las explotaciones de menos de 625 hectáreas perdieron un $17 \%$ de su participación relativa, en favor de las mayores a dicha extensión (ver gráfico 2.12).

\section{Gráfico 2.12.}

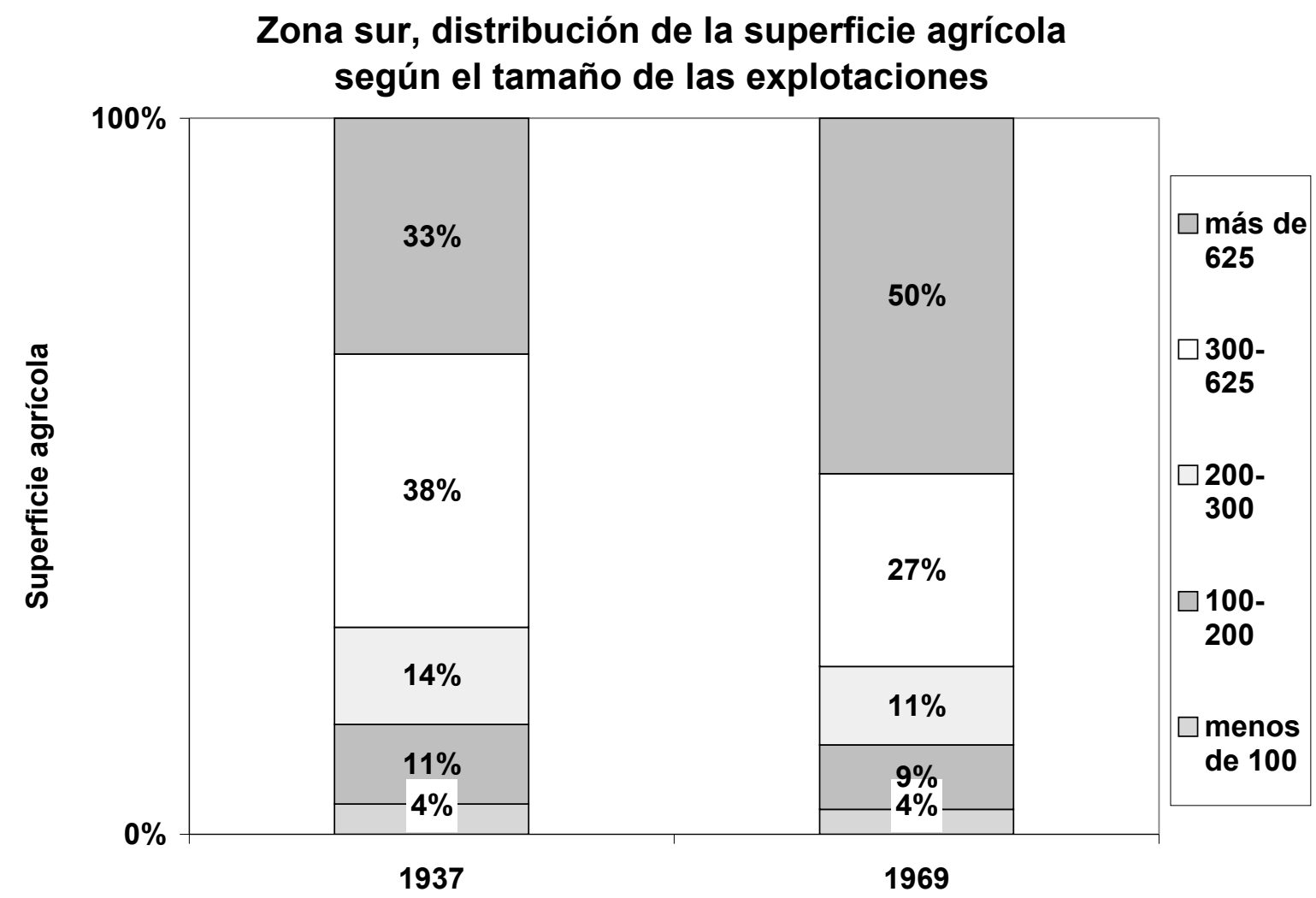

Fuentes: Estimaciones propias basadas en los datos por partido del Censo de 1937 y cálculos a partir de los datos originales del Censo de 1969. 
Gracias al reprocesamiento de los datos originales del Censo Nacional Agropecuario de 1960 realizado por el CONADE (1965), pudimos estimar la evolución de este proceso de concentración de la producción agrícola. El análisis detallado de los datos de 1960 y su puesta en relación con los de 1937 y 1969 se encuentra en el Apéndice 2, Apartado 3.1. De dicho análisis concluimos que en la zona norte, el proceso de concentración de la producción agrícola no había avanzado tanto entre 1937 y 1960, como lo haría a lo largo de la década del sesenta; en cambio, en la zona oeste, la mayor parte de la concentración ya había tenido lugar antes de 1960, mientras que en el caso de la zona sur no hubo un proceso de concentración importante, pues ya en 1937 la agricultura estaba situada en unidades de gran extensión.

Por otra parte, el análisis de los datos elaborados por el CONADE confirma que el valor de la producción agrícola (en pesos) no presenta mayores diferencias en su distribución por estratos con la distribución que tenía la superficie agrícola (excepto en algunos estratos, que se detallan en el Apéndice 2, Apartado 3.2 $)^{99}$.

El interrogante que ahora nos queda planteado es ¿cuál habrá sido la incidencia de este proceso de concentración, sobre la forma en que socialmente se organizaban las labores agrícolas?

\subsection{La mecanización y la organización social del trabajo agrícola}

\subsubsection{La distribución de la agricultura según el tipo de mano de obra}

El estudio de la organización social del trabajo rural ha sido siempre un tema muy difícil de abordar debido a las falencias en los cuestionarios censales sobre las dimensiones laborales, que se ahondan aun más porque esta cuestión ha sido siempre relegada a la hora de la publicación de los resultados. Nosotros hemos estimado, por un

99 En este mismo apartado del Apéndice 2 se observa que la zona norte se destacaba por su altísima productividad por hectárea, duplicando a la de la zona sur y (casi) a la de la zona oeste. Además, en líneas generales, en las tres zonas la productividad por hectárea disminuía notoriamente al aumentar el tamaño de las explotaciones. 
lado, la cantidad de asalariados permanentes por explotación para 1937 según una serie de supuestos explicitados en el Apéndice 1, y, por otro, hemos caracterizado a las unidades de 1969 según esta misma variable, gracias al reprocesamiento de los datos originales. Sin embargo, no hemos podido avanzar por sobre las limitaciones de los cuestionarios y de la información disponible, de modo que no podemos comparar la importancia ni de los asalariados transitorios ${ }^{100} \mathrm{ni}$ de los aportes laborales de productores y familiares ${ }^{101}$. Por lo tanto, discriminaremos las explotaciones según la cantidad de asalariados permanentes que poseían: ninguno (unidades que consideraremos como "familiares"), uno o dos (en estos casos la mano de obra familiar podía superar a los asalariados o equipararse a ella, por lo cual la denominamos "familiares con asalariados"), tres o cuatro ( organizasen las tareas, "empresarial pequeña"), y con cinco o más asalariados permanentes ("empresarial grande"). De todos modos, como para 1937 no ha resultado muy confiable este último corte, hemos agrupado en una sola categoría a todas las "unidades empresariales", incluyendo a toda explotación con tres o más asalariados permanentes.

El principal hallazgo de nuestro análisis es que, a pesar de los intensos cambios en la tenencia y el tamaño de las explotaciones que acontecieron en estas décadas, no tuvieron lugar grandes variaciones en la importancia que, en la agricultura, presentaban las distintas formas de organización social del trabajo. Tal como puede verse en el Gráfico 2.13, en la zona norte prácticamente no se registran grandes modificaciones en la distribución del área agrícola. Las unidades que no contrataban asalariados en forma permanente continuaron controlando algo más de la mitad de la superficie dedicada a la agricultura (en el Apéndice 2, Apartado 4, se transcriben algunos estudios de la época sobre este tema). Tan sólo existió un incremento en el área a cargo de explotaciones con

100 Lamentablemente la información censal sólo ha registrado la cantidad de asalariados transitorios que se encontraban en las explotaciones el día en que se realizaron los censos: el 30 de junio de 1937 y el 30 de septiembre de 1969.

${ }^{101}$ Los censos no dicen nada respecto del aporte de trabajo físico por parte del productor y sus familiares: sólo consignan el número de familiares "que trabajan", y descuentan que el productor lo hace, ya que no diferencian las tareas físicas de las de dirección. En general queda a cargo del productor considerar si sus hijos "trabajan" o no, por lo que las diferencias censales podrían deberse, en parte, a distintas percepciones. 
tres o más asalariados permanentes, en detrimento de aquéllas que tenían uno o dos; probablemente debido a la dedicación a la agricultura en forma directa de los grandes propietarios que habían recuperado sus campos. La mecanización, que describiremos en el siguiente apartado, hizo posible que aunque la producción se concentrara en unidades de mayor tamaño, esto no significara una asalarización del trabajo. En el mismo sentido, en la zona sur incluso creció la importancia dentro de la superficie agrícola de las unidades que no contrataban asalariados en forma permanente. En la zona oeste, en cambio, tuvo lugar una retracción en el área controlada por unidades basadas en el trabajo familiar, incluso de aquellas con uno o dos asalariados permanentes, expandiéndose la agricultura ubicada en unidades con trabajo asalariado (ver Gráfico 2.13). Lo cual puede explicarse por el desarrollo de agricultura -en general contratando el servicio de arada y/o cosecha de terceros- en las estancias antes dedicadas a la ganadería (al menos en el área que en los años treinta tenían bajo su producción: la superficie que en 1937 las grandes propiedades daban en arriendo para la agricultura constituía otras unidades censales). 
Gráfico 2.13.

\section{Distribución de la superficie agrícola según la cantidad de asalariados permanentes, 1937-1969}

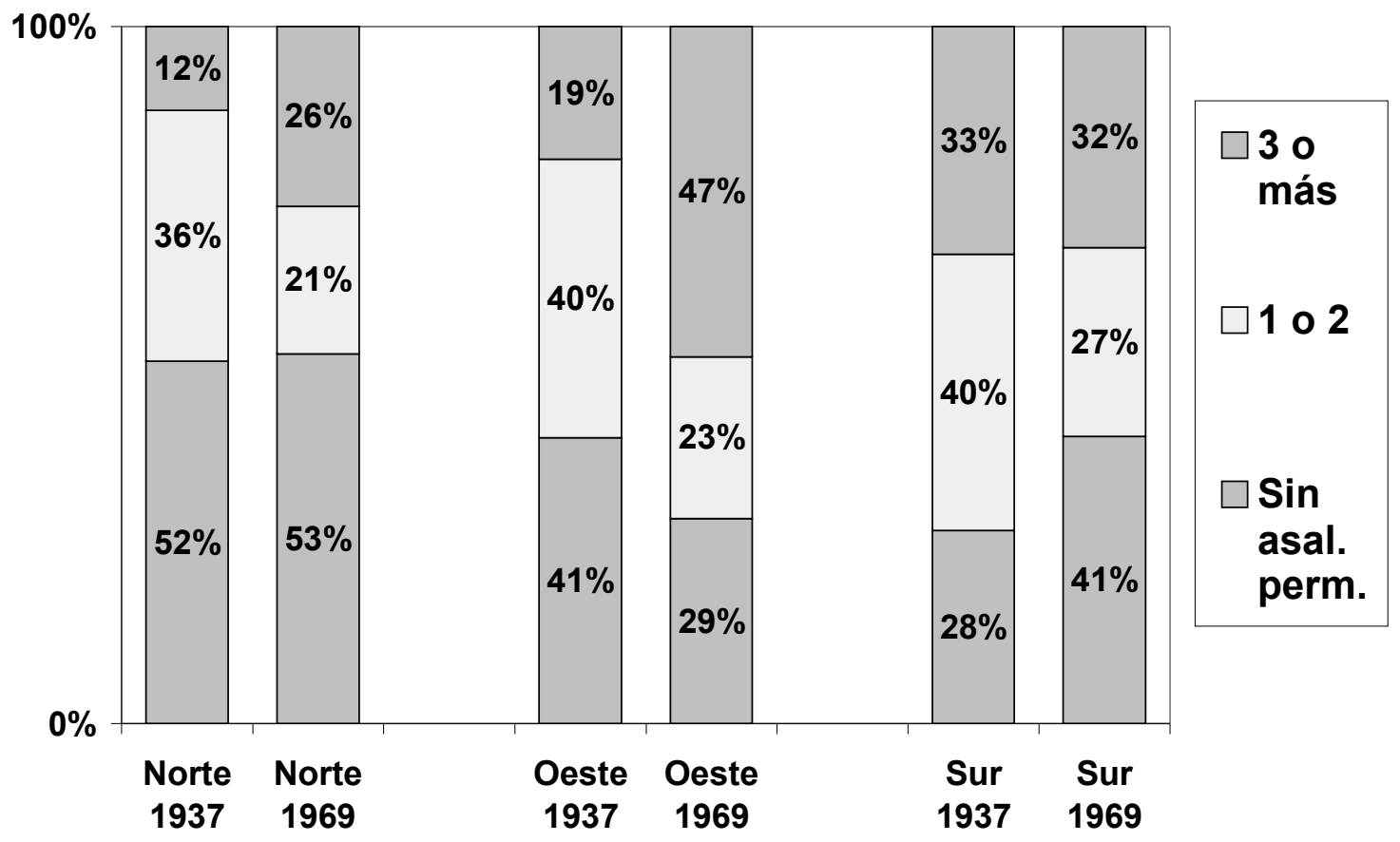

Fuentes: Estimaciones propias basadas en los datos por partido del Censo de 1937 y cálculos a partir de los datos originales del Censo de 1969.

Para poder comprender mejor las causas de la continuidad de las formas familiares de producción, a pesar del intenso proceso de concentración que había tenido lugar ${ }^{102}$, es necesario estudiar el proceso de mecanización y su impacto en la organización social del trabajo.

${ }^{102}$ Corresponde aclarar que si bien existe una asociación entre la extensión de las explotaciones y la composición de su mano de obra, esta última no está totalmente determinada por aquella. Existe un amplio rango de variación al interior de cada intervalo de tamaño, que nos muestra un nivel de indeterminación no siempre reconocido por la literatura especializada. Al respecto, en el Apartado 5 del Apéndice 2, hemos analizado la distribución de las explotaciones según su extensión y la cantidad de asalariados permanentes que presentaban en 1969. 


\subsubsection{La mecanización agrícola}

Especialmente en las décadas del cincuenta y sesenta tuvo lugar una notable mecanización agrícola con importantes consecuencias sobre las formas productivas predominantes. En primer lugar, redujo sustancialmente los requerimientos de mano de obra para las tareas agrícolas, lo cual habría abierto la posibilidad para la explotación con mano de obra familiar de extensiones cada vez mayores. Pero, al mismo tiempo, promovió el proceso de concentración tanto porque la utilización óptima de las nuevas maquinarias elevó el tamaño mínimo necesario para la maximización del recurso maquinaria, como porque se incrementaron los requerimientos de capital necesarios para incorporar la nueva tecnología. Por último, la adopción de estas maquinarias habría traído significativos beneficios económicos para aquellos que pudieron adquirirlas, pero sólo mientras su uso no se generalizó.

\section{Ahorro de mano de obra y organización del trabajo}

Sabemos que durante estas décadas la oferta de tecnología agropecuaria incorporó una serie de maquinarias que permitieron reducir los requerimientos de mano de obra. Sin embargo, las estimaciones más precisas realizadas en esos años se restringieron a evaluar la reducción, que cada innovación produjo, en la cantidad de horas-hombre por hectárea trabajada. Ahora bien, estas estimaciones de los requerimientos de mano de obra según el avance tecnológico (que reproduciremos a continuación) no nos indican directamente su incidencia sobre la organización social del trabajo. No sólo porque no analizan los factores subjetivos presentes en la decisión de realizar una tarea con mano de obra familiar o con asalariados, sino porque no sabemos cómo evolucionó la cantidad de hombres mínimamente necesarios para realizar cada tarea. La estacionalidad de las labores agrícolas hace muy importante esta cuestión: no siempre es posible prolongar temporalmente determinada tarea para poder realizarla con pocos hombres y por lo tanto resultan imprescindibles más hombres trabajando un número menor de días. A través de las entrevistas hemos podido recoger alguna información, pero esencialmente éste constituye un tema que requeriría profundizar su estudio para poder realizar estimaciones ajustadas al respecto. Pese a estas limitaciones, 
podemos plantear una clara tendencia a un menor requerimiento de hombres para cada tarea y por lo tanto, para un rango creciente de estratos de tamaño, se abriría la posibilidad de realizar las labores agrícolas con un número de hombres acorde a la dotación de fuerza de trabajo familiar. En los siguientes apartados analizaremos estas cuestiones para cada tipo de labores.

La innovación que sin duda generó el mayor impacto fue la cosechadora de maíz. Recordemos que hasta comienzos de los años cuarenta la juntada de este cereal se realizaba por entero en forma manual. A fines de los cuarenta comenzó a fabricarse en Pergamino una juntadora o espigadora, que tan sólo recogía y deschalaba las espigas, y que tuvo buena aceptación por los productores, alcanzando una cierta difusión (Coscia, 1983: 66). Pero el cambio realmente trascendental fue la adaptación de la cosechadora de granos finos al maíz, que lograron realizar varias empresas nacionales a principios de la década del cincuenta (siendo, luego, adoptada en los Estados Unidos ${ }^{103}$ ). Se incluyó una plataforma especial para el maíz y se introdujeron algunos ajustes en el funcionamiento del cilindro y en la limpieza para poder realizar el desgrane en la misma operación de segado. Como destaca Coscia (1983) entre otras ventajas permitía utilizar la misma cosechadora para ambas cosechas, mientras que la juntadora se empleaba sólo en el maíz. Según el trabajo de Coscia y Torchelli (1968), recién en la primera parte de los años sesenta desapareció la cosecha manual. Al parecer la juntadora no había alcanzado mucha difusión, ya que no es considerada como característica de ninguno de los diez niveles de tecnificación por los que habría pasado el cultivo del maíz para estos autores (Coscia y Torchelli, 1968). Sin embargo, tampoco debe soslayarse su importancia, ya que estas máquinas podrián haber llegado a juntar alrededor del $20 \%$ del maíz en la provincia de Buenos Aires hacia $1960^{104}$. Lo cierto es que en unos pocos

${ }^{103}$ Coscia (1983: 67)

${ }^{104}$ En el censo nacional agropecuario de 1960 (tal vez, el momento de mayor expansión de las juntadoras), se registraron en el conjunto de la provincia de Buenos Aires 1.135 juntadoras de maíz (con tracción mecánica, no se especificaron con tracción animal). De ellas, 323 eran de un surco, 468 de dos surcos y 344 de tres surcos (Censo Nacional Agropecuario, 1960, Buenos Aires: 179, Cuadro 27). Podemos estimar, a partir de la capacidad de recolección diaria de las juntadoras que establece Billard (1957: 88), que el conjunto de juntadoras presentes en la provincia podían cosechar, utilizadas al máximo de sus posibilidades (algo por demás improbable), 273.660 hectáreas de las 717.300 hectáreas cosechadas con maíz en Buenos Aires en ese mismo año. Suponiendo que cada juntadora haya, en promedio, 
años más, la juntadora fue completamente desplazada por la cosechadora automotríz con plataforma maicera ${ }^{105}$. Un trabajo de Coscia (1965: 9) sostenía que si bien la aparición de la cosechadora de maíz había tenido lugar a principios de la década del cincuenta, su generalización se ubicaba entre 1960 y 1965, y que para la fecha del informe todavía no había concluido, ya que un cierto porcentaje de productores seguían realizando la recolección manual del maíz.

Para tener una noción del ahorro de trabajo que significó la cosechadora adaptada para este grano debemos recordar que la cosecha manual insumía 45 horashombre por hectárea y unas 5 horas más para levantar las bolsas, entrojar las espigas y desgranarlas. En cambio, con la cosechadora se alcanzaba el mismo resultado con tan sólo 7 horas-hombre -5 de cosecha y 2 dedicadas a levantar las bolsas y estibarlas(Coscia y Torchelli, 1968). Pero no fue sólo un cambio cuantitativo, ahora ya no era necesaria la contratación de un gran número de asalariados para realizar la juntada del maíz o para operar la desgranadora, pues dos o tres hombres sobre la cosechadora eran suficientes y luego podían trabajar en el juntado y la estiba de las bolsas, si la explotación era pequeña, o contratar un par de hombres que lo hicieran, si la explotación era de mayor extensión. La fuerza de trabajo familiar habría, entonces, expandido notoriamente su capacidad de trabajo. Al respecto, si tomamos algunos de los parámetros explicitados por Billard (1957), estimamos que en 60 días efectivos de cosecha del maíz (o 90 teóricos), las juntadoras (a cuatro hectáreas por día las de dos surcos y cinco hectáreas las de tres surcos) recolectaban el cereal de 240 hectáreas o 300 hectáreas como máximo. En el caso de las cosechadoras (con plataformas de cuatro surcos), en el mismo lapso, cosechaban 300 hectáreas.

La otra innovación más destacada durante estas décadas fue la difusión del tractor. Asistimos a un proceso de completa mecanización de las labores de preparación

recolectado el maíz de la mitad de su máxima utilización, estas máquinas podrían haber estado juntando alrededor del 20\% del maíz bonaerense. Al mismo tiempo, el censo de 1960 registró 706 plataformas para cosechar maíz, 473 de cuatro surcos y 233 de cinco surcos, que tan sólo podrían haber cosechado (utilizadas al máximo) 225.780 hectáreas de maíz..

105 En el Corn Belt norteamericano las juntadoras había alcanzado una gran difusión y su reemplazo por las cosechadoras se demoró. En Illinois en 1956 el $96 \%$ era cosechado por juntadoras mecánicas, e incluso en 1960 ese porcentaje era del 80\%. Recién en 1966 era el 43\%, superada por la cosechadora. (Scott y Cagley, 1968: 3). 
y siembra, que hasta fines de los años treinta se basaban, casi por completo, en la tracción animal. La tractorización había sido incipiente durante las tres primeras décadas del siglo XX, y luego la crisis de los treinta y la segunda guerra mundial dificultaron el incremento de las importaciones de tractores. Pero desde mediados de los cincuenta comenzó un creciente proceso de adquisición de tractores de producción nacional. De este modo, si bien entre 1937 y 1952 el número de tractores en uso en Argentina se mantuvo en torno a las 20.000 unidades, para 1956 alcanzaban las 60.000, para 1961, las 120.000, y para 1966 había 145.000 tractores en uso (Tort, 1980).

En el caso de la provincia de Buenos Aires en 1937 había 8.481 tractores (tal como comentáramos en el capítulo anterior), es decir un tractor cada 12,8 explotaciones. En cambio, en 1960 había 34.462 tractores en la provincia, lo que correspondía a un promedio de un tractor cada 2,9 explotaciones. El hecho de que no todas las explotaciones tuvieran su tractor, no significaba que las labores se realizaran en todos los casos con tracción animal, ya que se habían difundido los servicios contratados de roturación y siembra.

De todos modos en las zonas donde predominaban los productores medianos los niveles de tractorización eran mucho más elevados. Así, en la zona de Necochea y Tres Arroyos, según la encuesta que el INTA realizara en la zona en 1958, el 77\% de los establecimientos contaban con al menos un tractor (Halliburton, 1963).

La adopción del tractor y, luego, el incremento de la potencia de los mismos redujo considerablemente los tiempos de trabajo necesarios para las tareas de arada, el otro momento clave (junto con la cosecha) demandante de trabajo en la agricultura. Según las estimaciones de Coscia y Torchelli (1968: 6-9), la cantidad de horas-hombre por hectárea para arar se redujo de seis horas (cuando se hacía con seis caballos y una o dos rejas), a sólo una hora y media, al realizarse con un tractor de 45 a 55 HP y un arado de 4 rejas. Luego, con un tractor de 110 a 133 HP y un arado de 10 rejas se araba una hectárea en sólo 25 minutos.

Por otra parte, si bien la ventaja más importante de la incorporación del tractor se ubica en las tareas de roturación, también redujo los tiempos de trabajo en todas las otras labores. Si sumamos todas las principales actividades en las que el tractor suplantó 
a la tracción animal (arar, disquear, rastrear, sembrar y transportar las bolsas), la aparición de esta maquinaria (aun en el primer momento, con motores de baja potencia) significó una reducción de las horas-hombre por hectárea de 17 hs 10 ' a 5 hs 50'.

Sin embargo, para las unidades pequeñas o medianas-pequeñas, donde sólo se trabajaba con un arado, una rastra o un carro, la incorporación del tractor no redujo la cantidad de hombres que realizaban estas tareas. Lo más importante es que permitió aumentar notoriamente la superficie susceptible de ser trabajada por el mismo número de trabajadores. Así, por ejemplo, si en 15 días, con jornadas de 12 horas un arador podría arar 30 hectáreas (a seis horas-hombre por hectárea). El mismo trabajador podía arar 120 hectáreas (a una hora y media por hectárea), y el equipo mínimo podía, rotando turnos, arar el doble de esta superficie (como pudimos registrar en varias entrevistas, muchos productores aprovechaban que el tractor podía arar incluso de noche, y armaban turnos durante las 24 horas).

Si bien la tractorización y la mecanización de la cosecha de maíz fueron las innovaciones mecánicas de mayor impacto en estas décadas, también tuvieron lugar otras incorporaciones de gran importancia. Ya hemos analizado el impacto de la adopción de la cosechadora de arrastre en los años veinte y treinta que permitió reemplazar, en la cosecha fina, el sistema de trillado con trilladora a vapor. A partir de los años cincuenta tuvo lugar un importante reemplazo de las cosechadoras de arrastre por las cosechadoras automotrices, aunque muchos productores continuaron utilizando las máquinas de arrastre, ahora impulsadas con los tractores, y no con los caballos. En 1960 se censaron 8.816 cosechadoras de arrastre y 5.555 automotrices en la provincia de Buenos Aires. Con la incorporación de la cosechadora automotriz no tuvo lugar una reducción notoria en los requerimientos mínimos de hombres necesarios para la cosecha, pero al incrementarse la velocidad de la máquina y el tiempo de trabajo, fue posible cosechar más hectáreas en el mismo tiempo, con una cantidad similar de hombres. Según Coscia y Cacciamani (1978: 7-8) el tiempo requerido para la cosecha de una hectárea de trigo se redujo de 6 horas-hombre con la cosechadora de arrastre a 3 horas-hombre con una automotríz (cosechando en bolsa en ambos casos). 
Otra innovación importante, tanto para la cosecha gruesa como para la fina, fue la incorporación de silos y chimangos en los años cincuenta y sesenta que permitieron reemplazar la bolsa y todas las tareas de su acarreo (antes, la incorporación a partir de los años cuarenta de la cinta transportadora había aliviado las tareas de la estiba). Si con la cosecha en bolsa del trigo se insumían 7 1/2 horas-hombre por hectárea para realizar todas las labores de la cosecha hasta el centro de acopio, con la cosecha a granel pasaron a demandar 3 horas-hombre (Coscia y Cacciamani, 1978). En el caso del maíz se ha estimado que estas labores insumían unas 8 hs 40' hombre por hectárea cuando se cosechaba en bolsa, y 5 horas-hombre con la cosecha a granel. Para las explotaciones medianas donde estas labores eran realizadas por hombres distintos a los que cosechaban el cereal (según los testimonios orales recogidos, en las unidades más pequeñas la recolección y manejo de las bolsas eran efectuadas por los mismos trabajadores que cosechaban), el número de trabajadores mínimos para la cosecha se redujo sustancialmente: de unos seis trabajadores a tres o cuatro.

Una última innovación ahorradora de mano de obra, aunque en este caso no siempre a cargo del productor sino de terceros, fue la difusión del camión, que reemplazó a los carros tirados a caballo. Según Coscia y Cacciamani (1978: 7), la producción de una hectárea de trigo que antes necesitaba de 7 h. 40' hombre para ser cargada y transportada, con el camión requería sólo 5 hs. 10' (tiempo que también contabiliza las labores de acarreo de las bolsas).

Pero no sólo las innovaciones mecánicas ahorraron gran cantidad de mano de obra, durante estas décadas se difundió el uso de herbicidas que implicaron una reducción de 30 horas-hombre por hectárea de maíz cuando se combatían las malezas con azada, a 25 minutos por hectárea para pulverizar y controlar malezas con herbicidas (según datos de Coscia y Torchelli, 1968: 7). En el caso de una hectárea de trigo, sólo contamos con la estimación de unas 4 horas-hombre por hectárea para la limpieza de malezas para fines del siglo XIX (realizada por Latzina, citado en Frank, 1970: 7), frente a las 24 minutos-hombre necesarios para pulverizar con herbicida una hectárea con la utilización de un tractor a comienzos de los años sesenta (Nocetti, 1963b). 
En síntesis, la mecanización permitió realizar las tareas agrícolas con un número cada vez menor de trabajadores y en superficies mayores, y por lo tanto sin la necesidad de contratar asalariados temporarios. Aclaramos que estamos analizando sólo la factibilidad de esta cuestión, ya que existen una serie de elementos subjetivos que también inciden sobre la determinación de la organización social del trabajo, que recién abordaremos en el capítulo cuarto.

Como podemos observar, a través de estas innovaciones se abría la posibilidad de realizar todas las tareas de la cosecha con un número de operarios similar a la mano de obra familiar, cuestión que resultaba imposible de efectuar, en explotaciones de tamaño comercial cuando el sistema de cosecha que requería la utilización de trilladoras o la cosecha manual del maíz. Así, en los años sesenta, tanto para la arada, como para la cosecha del maíz (los dos momentos de máximo requerimiento de mano de obra) un equipo consistente en un tractor de $50 \mathrm{HP}$ y una cosechadora con plataforma de cuatro surcos, podrían estar trabajando unas 240 hectáreas, sin requerir más que un par de hombres.

\section{Requerimientos de capital}

Sin embargo, no todos los productores habrían estado en condiciones de incorporar las innovaciones, ya que muchas veces éstas significaban fuertes inversiones de capital. Pero, para los productores medianos los costos de las nuevas tecnologías no debieron ser tan difíciles de afrontar ${ }^{106}$.

${ }^{106}$ Más allá de la precisión o no de las cifras, uno de los entrevistados nos señaló esta situación favorable y la facilidad para mecanizarse, comentada también por la mayoría de los entrevistados:

"En esos años valía bien el trigo y la inflación ayudó mucho. La hacienda valía bien. Se podía comprar un tractor con 50.000 kilos y hoy se necesitan 400.000 kilos. Con una cosecha se compraba un tractor u otra máquina. Con 10.000 kilos se compraba una camioneta, hoy con 150.000 kilos y además había buenas facilidades de pago" (DP*)

Por otra parte, en el anterior capítulo, hemos comentado la facilidad con que los productores medianos pudieron adquirir las cosechadoras de arrastre hacia finales de los años veinte y el elevado porcentaje de productores que contaban con al menos una de estas máquinas para 1928. 
Para tener una noción acerca de la significación económica de las inversiones requeridas, hemos estimado el ingreso bruto (sin descontar ningún tipo de gastos) de la producción de trigo (medido en hectáreas) necesario para la adquisición de algunas de las nuevas maquinarias. A finales de la década de 1920, se podía comprar una cosechadora de arrastre por el equivalente al ingreso bruto producido por unas 50 hectáreas de trigo ${ }^{107}$. En 1947 para comprar un tractor de $36 \mathrm{HP}$ era necesario el producto bruto de 73 hectáreas de trigo ${ }^{108}$. Los cálculos del CONADE arrojaron resultados similares para 1947: entre 70 y 75 hectáreas sembradas con trigo en la zona de Pergamino producían lo suficiente como para adquirir un tractor de $36 \mathrm{HP}$ (CONADE, 1968: 21 y 31) $)^{109}$.

Según nuestras estimaciones, hacia 1960 la relación se mantenía en niveles similares. Era necesario el producto de 82 hectáreas para adquirir un tractor de similares características y 127 hectáreas para uno de $50 \mathrm{HP}^{110}$. Para ese año, el CONADE estimaba que se necesitaban entre 74 y 80 hectáreas de trigo para un tractor de $36 \mathrm{HP}$ y entre 115 y 118 para uno de 50 HP (en el caso del maíz, eran suficientes 90 hectáreas para adquirir uno de $50 \mathrm{HP}$ ). Sin embargo, para mediados de la década del sesenta el valor de un tractor se equiparaba a unas 40 hectáreas, en el caso de uno de $36 \mathrm{HP}$, y 60 hectáreas, uno de $50 \mathrm{HP}$; con 50 hectáreas de maíz alcanzaba para este último tractor (CONADE, 1968: 21, 31 y 36). En síntesis, en el primer lustro de la década del sesenta, el precio del tractor en relación con los ingresos brutos por hectárea cultivada, se había reducido a alrededor de la mitad.

Una cosechadora automotriz en 1963 costaba, según nuestros cálculos, el equivalente al valor bruto de la producción de 108 a 140 hectáreas de trigo, según los

107 Cálculos realizados con el costo de la cosechadora en $\$ 6.000$, y el precio del trigo en $\$ 12$ el quintal, y con un rinde de 10 quintales por hectárea.

${ }^{108}$ El tractor valía unos $\$ 16.100$, el quintal de trigo \$ 17 y el rinde se había incrementado a 13 quintales por hectárea.

${ }^{109}$ Las estimaciones de Giberti (1965) mostraban que entre 1935/39 y 1965 el precio del tractor deflacionado con distintos precios osciló con un punto mínimo en 1946, ascendió hasta 1955, para decaer luego hasta 1964, cuando se ubicó en valores similares al momento inicial, o levemente superiores. Sin embargo, Giberti aclara que "si se consideran algunas de las principales mejoras técnicas introducidas [durante estas décadas], el precio deflacionado del tractor en los últimos años es sustancialmente inferior al de antaño" (Giberti, 1965: 32).

110 Ahora valía $\$ 420.000$ el tractor de $36 \mathrm{HP}$ y $\$ 652.800$ el de $50 \mathrm{HP}$, el quintal de trigo \$ 343 y el rinde era de 15 quintales por hectárea. 
diferentes modelos ${ }^{111}$. Por último, instalar un sistema a granel ${ }^{112}$, en el año 1962, era igual al producto bruto de 78 hectáreas de trigo.

Como pudimos observar, estas inversiones, sin ser pequeñas, no representaban montos inalcanzables para los productores medianos, especialmente en años de buenos precios y cosechas abundantes, que es cuando los productores adquirían la maquinaria. En los testimonios, la incorporación de nuevas maquinarias es recordada por todos los entrevistados como algo relativamente fácil de realizar, ya sea por el crédito oficial, como por la inflación, como así también, por los ahorros que significaba su utilización para los costos de la explotación. En este sentido, se ha estimado que entre 1956 y 1969 los subsidios implícitos en los créditos otorgados por el Banco de la Nación para la compra de tractores oscilaron entre el 19\% y el 56\% del precio nominal del tractor (Sábato, 1980: 91), con un nivel promedio de 33,8\%. Por otra parte, analizando los datos reproducidos en Fiorentino (1984) observamos que entre 1950 y 1969 las tasas de interés de los créditos al sector agropecuario fueron negativas en términos reales (deflacionadas en relación con los precios de cereales y oleaginosas ${ }^{113}$ ) en 17 de estos 20 años. Tasas negativas que llegaron en dos años a ser del - 35\% y el - 57\%, debido a la alta inflación; pero que en otros siete años se ubicaron entre el - $14 \%$ y el - $20 \%{ }^{114}$. Por su parte, en los únicos tres años con tasas positivas, éstas fueron relativamente moderadas $(14 \%, 2 \%$ y 14\%). Aunque es cierto que estas tasas tan subsidiadas no estaban aseguradas "a priori" ya que dependían de la "erraticidad" de la tasa inflacionaria (Fiorentino, 1984: 49).

Estas tasas negativas con que se financió la compra de maquinaria agrícola nos permiten comprender porqué muchos productores se sobremecanizaron, en el sentido en que adquirieron maquinaria para predios cuyo tamaño no permitía utilizar estos implementos de un modo pleno. Si revisamos los cálculos presentes en todos los

${ }^{111}$ Una máquina de 12 pies de cuchilla y naftera costaba $\$ 1.155 .000$ y una automotriz de 15 pies y diesel valía $\$ 1.495 .000$.

112 Equipo consistía en dos silos, dos acoplados, un elevador y un motor, como para un campo de unas 210 hectáreas, y el valor total ascendía a \$668.000.

${ }^{113}$ La proporción de años con tasas negativas es similar si utilizamos para la deflacción a los precios mayoristas agropecuario o los del ganado.

${ }^{114}$ En los ocho años restantes las tasas reales oscilaron entre el - 0,5\% y el - 7,8\%. 
trabajos ya citados y también en algunos otros ${ }^{115}$, todos presuponen un costo de oportunidad de la inversión o "interés del capital" que implica tasas de interés positivas (por ejemplo del $10 \%$ en términos nominales ${ }^{116}$, es decir sin contabilizar la inflación), y no negativas como en realidad muchos productores pagaron.

De hecho, según el informe CIDA (1965:48-49), en la región pampeana las unidades familiares tenían inversiones por hectárea mucho más importantes que las multifamiliares (en 1960 las inversiones en capital, excluyendo la tierra, eran para el caso de las unidades familiares de $\$ 4.000$ por hectárea, frente a $\$ 2.300$ de las multifamiliares medianas y $\$ 2.900$ de las multifamiliares grandes), e incluso entre 1960 y 1963 las explotaciones familiares invirtieron mucho más que las multifamiliares medianas ( $\$ 650$ por hectárea, frente a \$290; mientras que las multifamiliares grandes invirtieron \$560).

\section{Beneficios}

Las posibilidades económicas de incorporar nueva tecnología por parte de las pequeñas y medianas explotaciones deben analizarse conjuntamente con los beneficios económicos que estas innovaciones trajeron a los productores. Las innovaciones tecnológicas redujeron costos por hectárea (o, menos frecuentemente, redujeron los costos por unidad de producto aumentando la producción). Pero además, debemos analizar estas ventajas teniendo en cuenta las economías de tamaño, es decir, si eran viables de ser aplicadas por las pequeñas o medianas explotaciones agropecuarias.

La primera de las innovaciones mencionadas, la cosechadora de arrastre, redujo sustancialmente los costos unitarios de la cosecha del trigo. Según nuestras estimaciones, en los años veinte, el valor presente de la inversión ${ }^{117}$ en una cosechadora (con un costo de $\$ 6.000$, de una vida útil de unos ocho años, a una tasa de interés de

115 Ver "Mediante la mecanización se tiende a disminuir los costos de producción", $\underline{\text { Mundo }}$ Rural, $n^{\circ}$ 146, Junio de 1962; p. 50; "Mecanización Agrícola", La Chacra, ${ }^{\circ}$ 326, Enero de 1958; p. 72, por J.R. Portalis.

116 Esta es una tasa utilizada en muchos trabajos, como por ejemplo en Nocetti (1963a). Por su parte, Ramperti y Amigo (1963) utilizan una tasa de interés sobre los silos del 9\%.

${ }^{117}$ El valor presente es el cambio en la riqueza del tomador de decisiones que resulta de realizar un determinado proyecto. Ver Mansfield (1987: cap. 17: "Las elecciones intertemporales y el cambio tecnológico"). 
6\% anual) habría sido de \$13.622 para una explotación que cosechara unas 245 hectáreas. ${ }^{118}$ En cambio, una explotación que sólo cosechase la mitad de esta superficie habría ahorrado al cabo de los ocho años, sólo $\$ 3.811$ con esta compra.

Resulta evidente que los productores que no realizaban agricultura en importantes extensiones, o que no salían a cosechar campos ajenos no obtenían grandes ventajas económicas con la adquisición de la cosechadora.

Hemos realizado una estimación similar, del beneficio presente, para la adquisición del sistema a granel. En 1962/63, para una explotación de 260 hectáreas, el costo era de $\$ 668.000$ y los ahorros por año eran de unos $\$ 206.482 .{ }^{119}$ Suponiendo una tasa de interés del 9\% anual (que utiliza para sus cálculos la fuente), al cabo de 16 años (vida útil ponderada de los diferentes implementos del sistema a granel), los beneficios actualizados totalizaban alrededor de un millón de pesos. Estos beneficios serían mayores aun, ya que estas inversiones eran comúnmente financiadas a tasas de interés por debajo del incremento de los precios agropecuarios.

Por otra parte, la mecanización redujo los requerimientos de mano de obra, en un momento histórico en que la relación con los asalariados se había tornado particularmente conflictiva. Varios de los entrevistados que en esos años estaban a cargo de explotaciones grandes, establecieron en sus testimonios una relación directa entre los conflictos (reales o potenciales) con el personal e incrementos salariales, por

118 Los gastos de segado y trillado con espigadora propia y trilla a cargo de un contratista ascendían hacia 1925 en la zona sur de Buenos Aires a unos \$3,70 el quintal de trigo y a $\$ 4$ con espigadora-atadora. En cambio, con una cosechadora de arrastre se reducían a sólo $\$ 2,68$ el quintal (un $28 \%$ menos que con espigadora).

Pero estos cálculos de costos (realizados por el Ministerio de Agricultura de la Nación) incluyen tanto los gastos de amortización del capital invertido como sus intereses, y también computan los salarios del total de los trabajadores (incluyendo los que normalmente eran el productor y miembros de su familia), sus gastos de alimentación y los gastos de alimentación de los caballos. Para nuestro cálculo excluimos estos gastos y dejamos tan sólo las erogaciones que efectivamente el productor debía abonar (repuestos, reparaciones, lubricantes, combustible, hilo, salarios y gastos de trilla), con lo cual podemos observar una diferencia aun mayor entre la realización de la cosecha con espigadora o atadora y trilladora o con cosechadora: $\$ 1,91, \$ 2,20$ y $\$ 0,62$ el quintal respectivamente.

119 Todos los datos sobre la cosecha a granel fueron tomados de Ramperti y Amigo (1963). 
un lado, y la incorporación de maquinaria ahorradora de mano de obra, por el otro. Debemos destacar que, en algunos casos, habían continuado hasta mediados de la década del cuarenta realizando la trilla con trilladoras, lo cual implicaba, durante la cosecha, una importante concentración de asalariados temporarios (más de cuarenta) ${ }^{120}$. En esta misma línea, las imposiciones oficiales durante el peronismo en el sentido de obligar a los chacareros a hacer uso de mano de obra asalariada para las cosechas, especialmente intensas en el área maicera, también podrían haber estimulado la mecanización (Mascali, 1986).

Pero además de estos beneficios monetarios que se obtenían en cada labor, existía otro beneficio (mucho más difícil de cuantificar) debido a la reducción del tiempo requerido para las tareas. Esta disminución resultaba clave para las explotaciones mixtas en las cuales los cultivos y los ganados competían y se complementaban (por ejemplo, una parcela podía ser pastoreada durante más tiempo, gracias a que el tractor permitía ararla con mayor velocidad y seguridad que con tracción animal). ${ }^{121}$

${ }^{120}$ El siguiente es el testimonio más claro de esta situación que hemos recogido:

"[dejó la trilladora, tenía 85 personas en la cosecha], cuando vino todo el lío de la CGT, que los peones decían 'ahora se le va a terminar la historia a A., porque lo vamos a liquidar' y qué se yo... si, a mí me citaron acá en Tres Arroyos, tenía que pagar tanto. Cuando me dijeron cuanto tenía que pagar, dije 'no yo eso no lo pago', se me escapó, 'no eso no lo pago', '¿y cuanto quiere pagar?' Ah!, así que aquí que hay arreglo, pensé. Digo 'bueno, yo sé perfectamente bien que tengo que pagar más, plena conciencia de que voy a pagar más, no tengo ningún inconveniente, pero no lo que ustedes piden, vamos a repartir la diferencia' [...] 'Bueno, perfecto', dicen. Se hicieron todos los papeles y yo les pagué a todos los tipos. Y a todos los peones que no me demandaron, les digo 'ustedes me dan la dirección, yo ahora les doy lo que les corresponde del sistema viejo, yo se que tengo que doblarlo, después les mando la plata cuando sé cuánto tengo que darles. Porque lo que van a recibir los otros lo van a recibir ustedes también'. [...] Se terminó el asunto ahí, entonces se empezó a trabajar con tractores y con cosechadoras y la trilladora se archivó, porque no se podía con el personal." (AM)

${ }^{121}$ Así lo manifestaron varios entrevistados, como el siguiente testimonio de un productor de Tres Arroyos:

"Luego comenzó a subir el valor de la hacienda vacuna y convino poner tractores para liberar los campos con yeguarizos. [...] Si bien es difícil medir cuántas hectáreas ocupaban, pues variaba con los años, la cuenta es sencilla: donde había 150 yeguarizos podía haber 150 vacunos. Además, con el caballo el tiempo se va: si hay que herrar se pierde un día. Hacía muy pocas hectáreas por día. En cambio con el tractor es más rápido, se podían hacer turnos, con luz, no se cansa como los caballos, no hay límite. Esto permitía decidir dejar 15 días más las vacas en un cuadro y arar más tarde." (AA*) 
Además la tractorización permitió liberar campos necesarios hasta entonces para alimentar a los equinos. El número de ganado equino en la región pampeana descendió de 8,1 millones en 1930 y 7 millones en 1937, a 5,1 millones en 1947, 2,9 millones en 1960 y 1,3 millones en 1974 (Tort y Mendizábal, 1980: 56). Si en 1930 se ha estimado que los equinos ocupaban 7 millones de hectáreas en la región pampeana, podemos tener una noción de la cantidad de tierras que se liberaron para su uso directamente productivo gracias a la tractorización. En una explotación de hasta 60 hectáreas, se necesitaban 12 caballos (pues, para la arada se requerían seis animales, que debían cambiarse al promediar la jornada). Estos caballos necesitaban alrededor de 12 hectáreas para su alimentación, superficie en la cuál podían ser criados unos 18 vacunos en pastoreo (Nocetti, 1963a: 10). 
Aumento del tamaño necesario para dar pleno uso al equipamiento mínimo actualizado

Por una serie de cuestiones los productores estaban interesados en realizar todas las labores con equipamiento propio y no contratar servicios de maquinaria ${ }^{122}$. Pero, para darle plena utilidad a la maquinaria (o al menos un uso que justificase su adquisición) era necesario contar con una superficie mínima ${ }^{123}$.

Varios especialistas estudiaron estas cuestiones en los años cincuenta y sesenta, según consta en numerosos informes técnicos. Así Nocetti (1963a) estimó que para menos de 50 hectáreas cultivadas era mejor la contratación del tractor; entre 60 y 125 hectáreas aconsejaba utilizar caballos, y sólo por encima de las 125 hectáreas de maíz o girasol y de las 165 de trigo, lino o sorgo granífero, sugería el tractor e implementos $\operatorname{propios}^{124}$.

En cuanto al tamaño requerido para que fuera rentable abandonar el sistema a bolsa, Ramperti y Amigo (1963) estimaron que recién para explotaciones mayores de 83 hectáreas la cosecha a granel resultaba más económica que la realizada embolsando, y sólo por encima de las 200 hectáreas se maximizaba la utilización de esta inversión.

Billard (1957) estimó que sólo con más de 90 hectáreas era preferible la cosecha mecánica del maíz, en relación con la recolección manual, con un óptimo (costos mínimos por unidad de producto) en el uso máximo de la cosechadora automotriz (con plataforma de cuatro surcos) ubicado en las 300 hectáreas. Sin embargo, ya por encima de las 200 hectáreas, a medida que continuaba aumentando la extensión, las reducciones en los costos iban siendo cada vez menos importantes, tal como puede observarse en el Gráfico 2.14 .

${ }^{122}$ Cuestiones que iban desde intentar retener la ganancia del contratista de servicios, hasta el prestigio y sensación de seguridad de tener máquinas propias, pasando por la seguridad real que significaba contar con los equipos para hacer las labores en el momento más apropiado desde el punto de vista agronómico.

${ }^{123}$ Un problema adicional que estudió en su momento Giberti, era el excesivo peso de los costos fijos si la cosecha era de muy bajos rendimientos. Estimó que sólo si los rindes eran elevados se justificaba el incremento de los costos fijos que significa una mayor mecanización agrícola (Giberti, 1969).

${ }^{124}$ El tamaño óptimo para la plena utilización del tractor eran 185 hectáreas de maíz o 267 de trigo (Nocetti, 1963a). 


\section{Gráfico 2.14 .}

Costos de cosecha de maíz (1957)

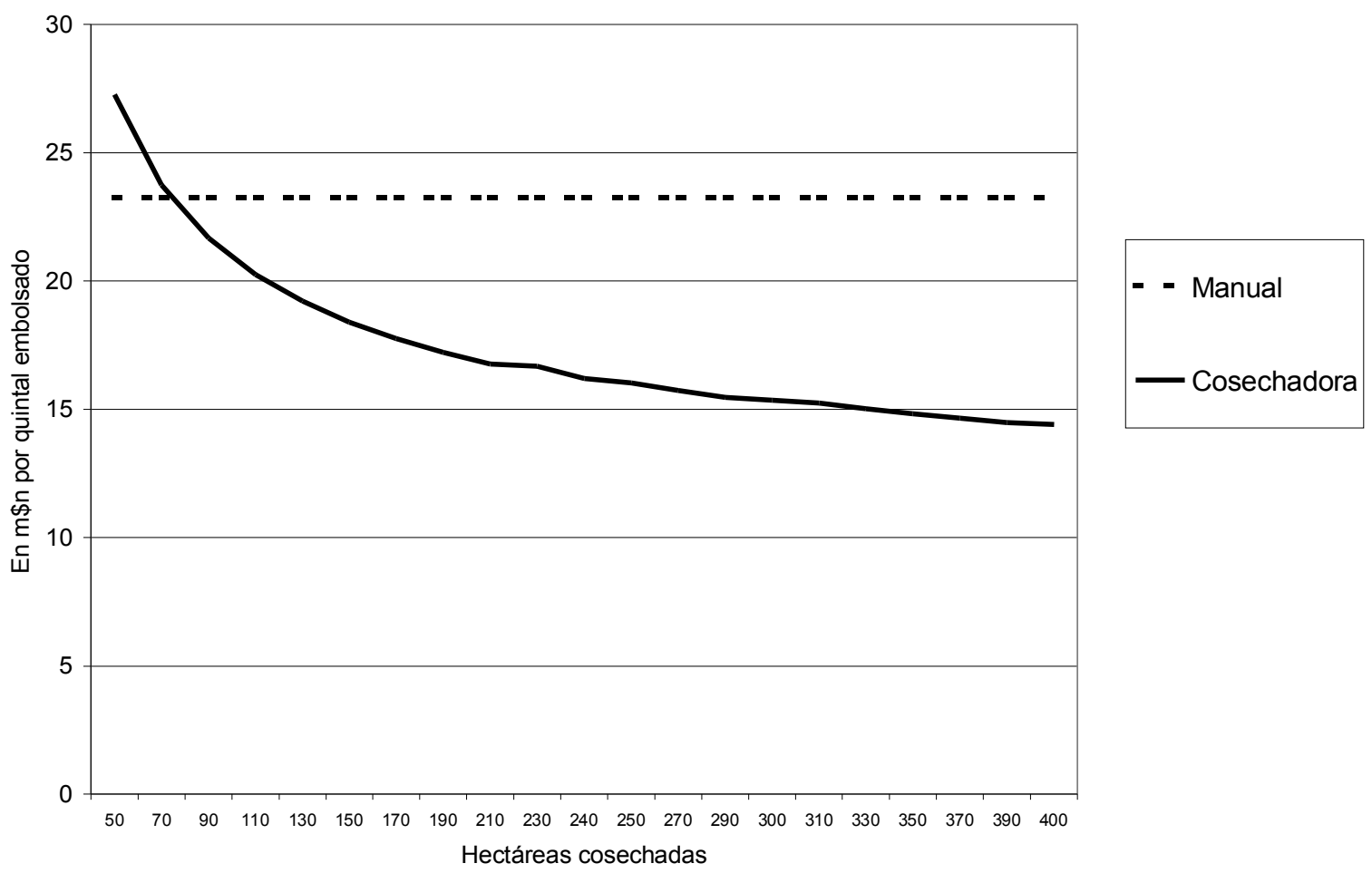

Fuente: elaboración propia en base a datos consignados por Billard (1957: 87).

Por su parte, Frank (1968) estableció que entre 253 y 326 hectáreas resultaba indiferente la utilización de maquinaria propia o contratada; por debajo de las 253 hectáreas era aconsejable contratar equipos externos, y por encima de las 326, no hacerlo $^{125}$.

${ }^{125}$ Sin embargo, dos estudios basados en grandes unidades ubicadas en la zona oeste de Buenos Aires elevan sustancialmente la estimación del tamaño aconsejado para la utilización de equipos propios. Ostrowski (1970) estima que para un uso eficiente del tractor y los implementos de labranza, se deberían cumplir 15 a 20 hectáreas sembradas por cada HP, de otro modo sería aconsejable contratar equipos externos. De este modo, para un tractor de $40 \mathrm{HP}$ se necesitarían 600 hectáreas, y para uno de $100 \mathrm{HP}$, unas 1.500 como mínimo. Santamarina (1971) plantea que los establecimientos con superficies menores a 1.500 hectáreas no presentan casos donde la utilización de los equipos propios resulte económica. 
Podemos concluir este apartado señalando que la oferta tecnológica posibilitó a las medianas explotaciones una reducción de costos y de requerimientos de mano de obra, fenómeno este último que permitió la viabilidad técnica de la explotación predominantemente familiar para tamaños de explotaciones cada vez mayores. Por otra parte, ni los costos de la mecanización, ni las escalas que las nuevas maquinarias requerían constituyeron problemas graves para los productores medianos, aunque sí para los más pequeños ${ }^{126}$.

Tal vez el mayor problema no fue tanto la inversión requerida para adquirir las nuevas maquinarias, sino la imposibilidad de darle pleno uso, tanto a su inversión como a su mano de obra familiar. En este sentido, por un lado, muchas unidades estaban sobremecanizadas. Por ejemplo, en la zona de invernada un estudio realizado por Nocetti (1970: 62) encontró que muchas empresas utilizaban el tractor por debajo de su capacidad de trabajo (menos de 700 horas anuales). Por otro lado, en la medida que los productores se mecanizaban, sino lograban salir a trabajar otros campos vecinos, buena parte de la mano de obra familiar quedaba subocupada. Por ejemplo, una familia chacarera que antes realizaba la arada y la siembra con su propia mano de obra araba con caballos unas 60 hectáreas para un determinado cultivo, para los años sesenta, con un tractor, había cuadruplicado su capacidad de arada, llegando a las 240 hectáreas por cultivo. Sin embargo, muy difícilmente tuviera el capital para dar semejante "salto" en su escala de producción, aunque tuviera el dinero necesario para adquirir el tractor. Mayor aún era el "salto" que habilitaba la cosechadora automotriz para maíz, que permitía cosechar nueve veces más superficie con la misma mano de obra que antes hacía la cosecha manual. Por lo tanto, la mecanización generó un importante excedente de mano de obra familiar en las pequeñas explotaciones ${ }^{127}$.

${ }^{126}$ Por ello, la mayoría de los productores más pequeños no tenían tractor incluso a comienzos de los años setenta. En el partido de Pergamino, según una encuesta realizada en 1972, sólo el $25 \%$ de los productores con menos de 20 hectáreas tenían tractor. En cambio, en los estratos inmediatos superiores, el porcentaje de productores que poseían tractor se elevaba rápidamente: con 20 a 30 hectáreas, $58 \%$, y con 30 a 40 hectáreas, $64 \%$ tenían tractor (Torchelli, 1972: 21).

127 En el Apendice 2 hemos transcripto la afirmación de Schaefer (1960: 101-102) en este sentido. Además, luego otros autores encontraron evidencias en la misma dirección, como por ejemplo Coscia (1965: 8) y Nocetti (1970: 63 y 115). 
Los que sí pudieron aprovechar claramente los beneficios de la mecanización fueron los productores medianos, que antes contrataban asalariados para la arada $\mathrm{y}$, especialmente, la cosecha del maíz, y ahora podrían realizar todas estas labores con mano de obra familiar, reduciendo notoriamente los costos.

\subsection{Formas de tenencia del suelo, agricultura y valor de la producción}

En relación con las formas de tenencia del suelo, en las tres zonas se observa el mismo proceso: la agricultura pasó de ser una actividad que estaba en manos de los arrendatarios ( $\mathrm{y}$ en la zona norte, también de los aparceros) a ser realizada por propietarios. La magnitud de la transformación y la similitud en las superficies agrícolas realizadas por las distintas formas de tenencia en las tres zonas (que puede observarse en el Cuadro 2.14), nos eximen de comentarios más sutiles. Esta modificación se produjo por acceso a la propiedad de los ex-arrendatarios y ex-aparceros tradicionalmente dedicados a la agricultura, pero también por un giro hacia esa actividad durante los sesenta por parte de los grandes propietarios.

Cuadro 2.14. Superficie agrícola según tenencia, 1937 y 1969

\begin{tabular}{|l|l|c|c|}
\hline & & $\mathbf{1 9 3 7}$ & $\mathbf{1 9 6 9}$ \\
\hline \multirow{4}{*}{ Zona norte } & Propietarios & $32 \%$ & $79 \%$ \\
\cline { 2 - 4 } & No propietarios & $68 \%$ & $21 \%$ \\
\cline { 2 - 4 } & & $100 \%$ & $100 \%$ \\
\hline \multirow{3}{*}{ Zona oeste } & Propietarios & $29 \%$ & $78 \%$ \\
\cline { 2 - 4 } & No propietarios & $71 \%$ & $22 \%$ \\
\cline { 2 - 4 } & & $100 \%$ & $100 \%$ \\
\hline & Propietarios & $34 \%$ & $77 \%$ \\
\cline { 2 - 4 } & No propietarios & $66 \%$ & $23 \%$ \\
\cline { 2 - 4 } & & $100 \%$ & $100 \%$ \\
\hline
\end{tabular}

Nota: la superficie de 1937 ha sido estimada según la metodología detallada en el Apéndice 1.

Fuentes: Censo Agropecuario de 1937 y reprocesamiento de los datos originales del de 1969.

Hemos realizado un análisis más detallado de la relación entre tenencia del suelo y agricultura en base a los reprocesamientos de los datos del censo de 1960 (efectuados por el CONADE) y del de 1969 (realizados personalmente), junto con la información contenida en varios informes técnicos de la época. Dicho análisis lo hemos transcripto 
en el Apéndice 2 (Apartado 6). Aquí podemos sintetizar que, en primer lugar, en las zonas norte y sur para 1960 el proceso de transformación en la distribución de la agricultura hacia la tenencia en propiedad se encontraría a mitad de camino, mientras que en la zona oeste ya estaba entonces muy avanzado. En segundo lugar, los arrendatarios y aparceros presentaban una mayor orientación hacia la agricultura que los propietarios de similar escala (excepto en la zona oeste, donde la diferencia era poco significativa). En tercer lugar, en parte debido a su inclinación hacia la agricultura, los arrendatarios presentaban una productividad por hectárea mayor que la de los propietarios o las formas mixtas de tenencia.

\subsection{Las formas sociales de producción en la agricultura}

Para finalizar, intentaremos articular las tres dimensiones hasta ahora analizadas (tenencia, tamaño y mano de obra), a fin de analizar las transformaciones en las formas sociales de producción de la agricultura bonaerense. Primero brindaremos una descripción general, para dar luego un análisis en detalle de cada forma de producción. Tal como nos permite recordar la barra de la izquierda de los gráficos 2.15 a 2.17 en las tres zonas predominaban en 1937 los arrendatarios familiares, incluyendo entre ellos a los que tenían uno o dos asalariados permanentes (como analizamos en detalle en el Capítulo Primero). Esta forma productiva concentraba en 1937 el 61\% de la superficie agrícola de la zona norte, el $57 \%$ de la zona oeste y el $44 \%$ de la zona sur. Tres décadas más tarde, en 1969, la mayoría de la superficie agrícola estaba en manos de productores familiares propietarios, quienes controlaban el 58\%, el 40\% y el 50\% respectivamente. Estos farmers poseían unidades mucho más extensas que los farmers o los arrendatarios familiares de $1937^{128}$.

${ }^{128}$ Si comparamos el tamaño medio de los farmers sin asalariados -siempre con más de 25 hectáreas- encontramos que entre 1937 y 1969 se había incrementado en un 55\% en la zona norte (de 58 a 89 hectáreas), un $74 \%$ en el oeste (de 109 a 190) y un $51 \%$ en el sur (de 174 a 263). En cambio, los farmers con uno o dos asalariados tenían explotaciones solo un $20 \%$ más grandes en 1969 que en 1937 tanto en la zona oeste (de 383 a 461 hectáreas) como en la zona sur (de 417 a 501). En la zona norte, por el contrario, su tamaño medio se incrementó en un $66 \%$ (de 131 a 218$)$. 
Otro sector que había visto crecer su importancia dentro de la producción agrícola fueron los terratenientes-capitalistas, especialmente en la zona oeste (donde llegaron a controlar el 39\% del área agrícola), pero también en la zona norte (con el $21 \%)$ y en la zona sur (26\%). Una interesante caracterización de estos sujetos la encontramos en Murmis (1979).

En cambio, los capitalistas arrendatarios no se expandieron como forma productiva, e incluso, en la zona sur perdieron el lugar relativamente destacado que poseían en 1937 (muy probablemente muchos de ellos accedieron a la propiedad). 


\section{Gráfico 2.15.}

\section{Zona norte, distribución de la superficie agrícola}

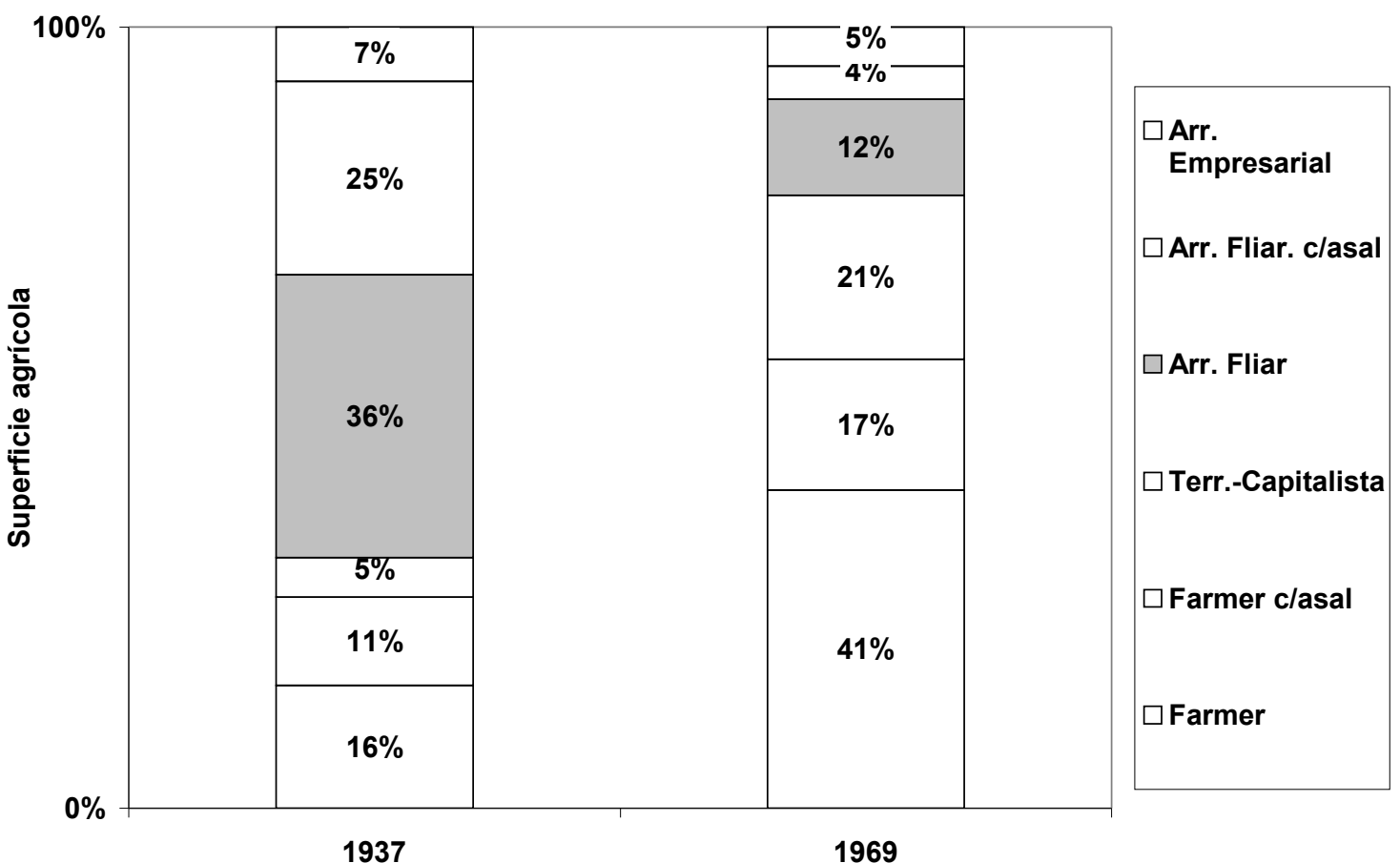

Fuentes: Estimaciones propias basadas en los datos por partido del Censo de 1937 y cálculos a partir de los datos originales del Censo de 1969. 


\section{Gráfico 2.16}

Zona oeste, distribución de la superficie agrícola

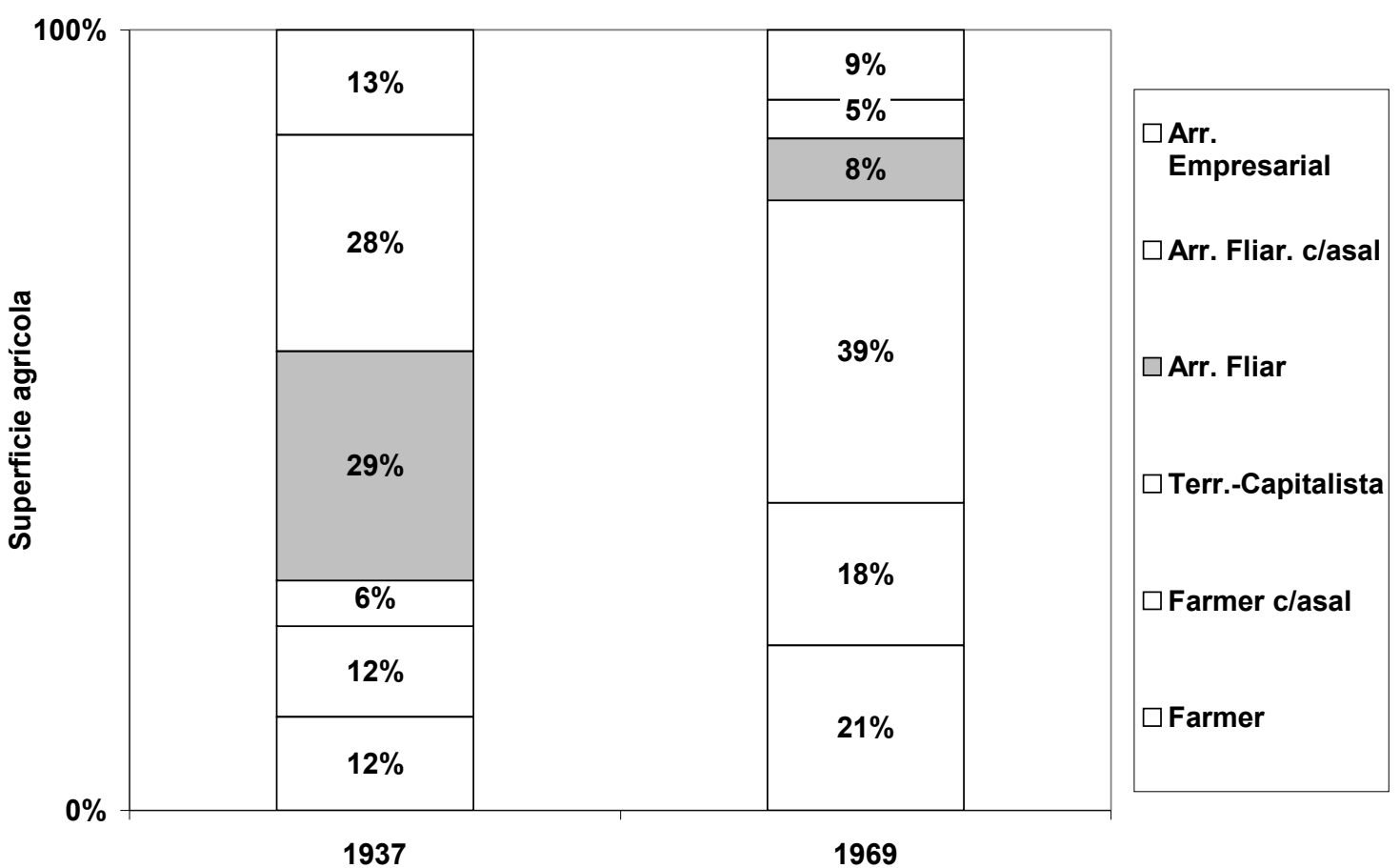

Fuentes: Estimaciones propias basadas en los datos por partido del Censo de 1937 y cálculos a partir de los datos originales del Censo de 1969. 


\section{Gráfico 2.17.}

Zona sur, distribución de la superficie agrícola

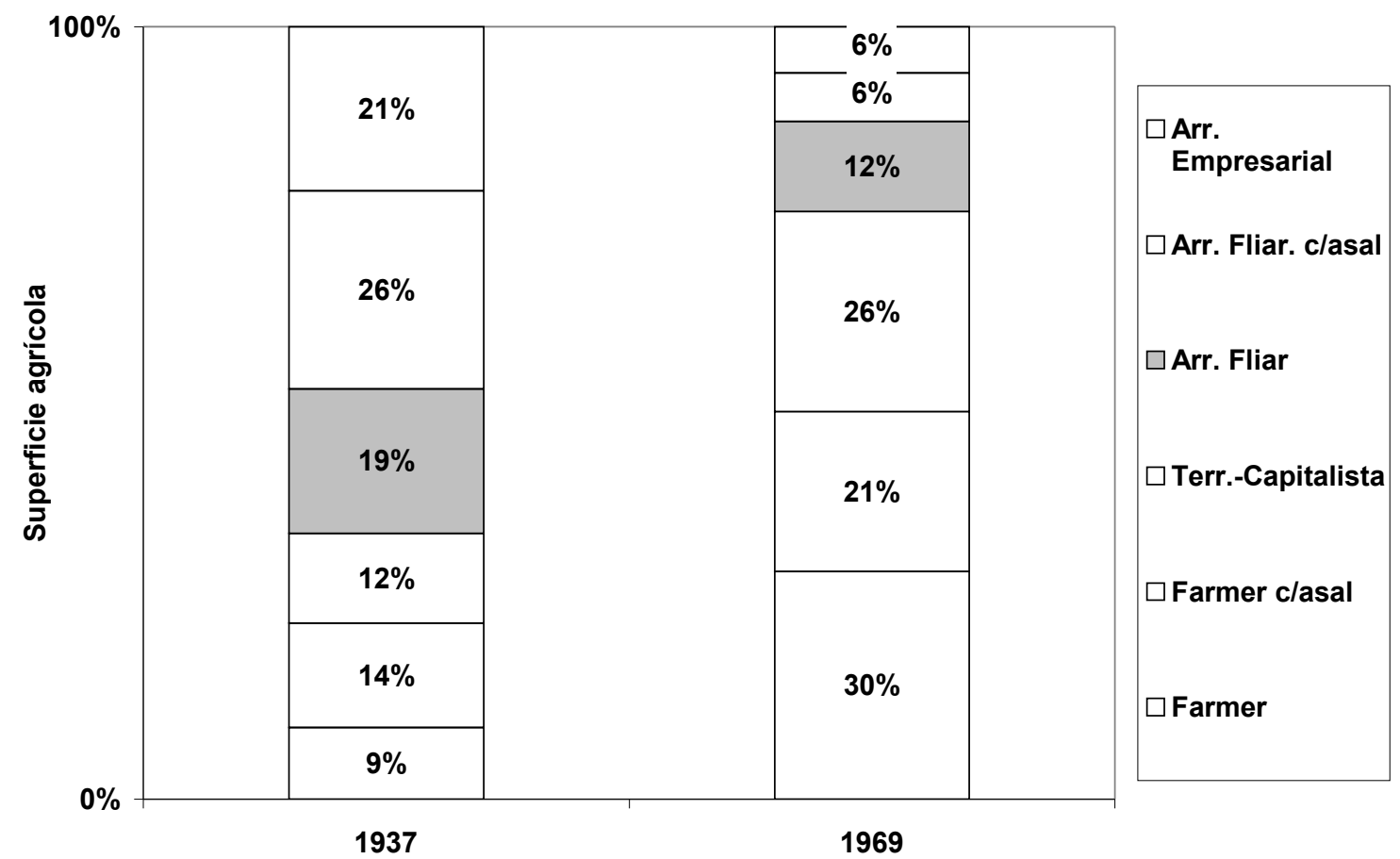

Fuentes: Estimaciones propias basadas en los datos por partido del Censo de 1937 y cálculos a partir de los datos originales del Censo de 1969.

Antes de avanzar con la caracterización más detallada de las distintas formas sociales de producción, necesitamos formular una aclaración. La creciente importancia de los servicios de maquinaria (que lamentablemente no es posible analizar a partir de la información hoy procesable del censo de 1969) y el registro muy parcial del trabajo asalariado transitorio generan una agregación de productores bastante diferentes dentro de las mismas categorías analíticas. Así, por ejemplo, entre los farmers quedan incluidos tanto un productor que trabajaba su predio sólo él y su familia, como también otro que lo hacía contratando varios asalariados transitorios para las labores más importantes (arada y cosecha), aportando él y su familia sólo las tareas de control y apoyo logístico, y alguna que otra labor menor que se realizaba a lo largo del año. Del mismo modo, 
también entraría dentro de esta categoría de farmer, un productor que solamente realizaba estas labores menores, y que contrataba servicios de maquinaria tanto para la arada y siembra, como para la cosecha. Lamentablemente no es posible estimar la significación de estas distintas variedades y todas ellas han quedado dentro de la categoría de farmer. Problemas similares aparecen en el resto de las categorías.

Los arrendatarios familiares (que no tenían asalariados permanentes) en 1969 tenían un peso mucho menor en el conjunto de la actividad agrícola que en 1937. Así, por ejemplo, en la zona norte, donde habían concentrado el 36\% de la superficie cultivada en 1937 (incluyendo a los aparceros), para 1969 sólo detentaban el 12\% de la misma. En la zona oeste, este porcentaje había pasado del $29 \%$ al $8 \%$, y en el sur, del $19 \%$ al $12 \%$.

Ahora bien, de igual forma que en 1937, detrás de esta categoría se encontraban sujetos bastante diferentes según las zonas. En la zona norte, el arrendatario (o aparcero) familiar tenía, en promedio, unas 65 hectáreas, mientras que en la zona sur alcanzaba las 204 (en el oeste presentaba una situación intermedia, con 122 hectáreas de tamaño medio). Pero tampoco en cada zona existía una homogeneidad en torno a estos valores promedio $^{129}$.

También diferían en su orientación productiva (medida por la proporción de la superficie de la explotación que dedicaban a los cultivos anuales para cosecha). Los arrendatarios familiares de la zona norte, como también los de la zona sur, tenían en promedio el $54 \%$ de sus predios dedicados a la agricultura, pero en el oeste sólo el $16 \%$ estaba afectado a cultivos anuales para cosecha. Cabe señalar que no existía homogeneidad en las orientaciones productivas al interior de las zonas. Así, por

${ }^{129}$ En el Apartado 7 del Apéndice 2 se transcriben los percentiles que muestran la distribución de las explotaciones según las formas sociales de producción según el tamaño, y también se grafica esta distribución con "gráficos de caja".

En este caso, en la zona norte, la mitad central de los arrendatarios familiares (es decir, los ubicados entre el primer y el tercer cuartil, y representados por la "caja" de los gráficos del apéndice) se encontraban entre las 13 y las 70 hectáreas; en el oeste, entre las 20 y las 152 hectáreas, y en el sur, entre las 40 y las 250 hectáreas. 
ejemplo, más de un cuarto de los arrendatarios familiares de la zona norte no habían sembrado este tipo de cultivos.

Estos arrendatarios familiares eran aquéllos que no habían podido comprar los campos que alquilaban, pero que habían logrado permanecer en sus predios, por diversas circunstancias, a pesar de las expulsiones. En algunos casos, según los testimonios por nosotros recogidos, habían establecido cierto vínculo personal con el terrateniente que, a cambio de algún arreglo de actualización del canon, les había prometido no desalojarlos, o venderles el campo más adelante.

Si los arrendatarios familiares habían reducido notoriamente su importancia dentro de la agricultura, la disminución más drástica la sufrió la categoría de los arrendatarios que contrataban uno o dos asalariados permanentes. De controlar en 1937 alrededor de un cuarto del área agrícola en las tres zonas, pasaron a detentar en 1969 sólo un $5 \%$ de la misma, aproximadamente ${ }^{130}$. Esto no significa que la mayoría de ellos hubieran sido expulsados o dejado la actividad. Por el contrario, muy probablemente, la mayoría de estos productores habían logrado acceder a la propiedad en la coyuntura ya analizada.

Para fines de los años sesenta, estos arrendatarios familiares con asalariados alquilaban extensiones que en promedio triplicaban a la de los arrendatarios que no contrataban mano de obra. Así, en la zona norte el tamaño medio era de 235 hectáreas, en el oeste, $440 \mathrm{y}$ en el sur, $472^{131}$.

Presentaban, en 1969, una orientación marcadamente agrícola en la zona sur (53\% del predio dedicado a cultivos anuales para cosecha) y también en el norte (48\%), mientras que en el oeste sólo dedicaban a la agricultura el 15\% de la superficie. En esta dimensión, prácticamente no presentaban diferencias con los arrendatarios familiares sin asalariados.

${ }^{130}$ Mientras que en 1937 controlaban el 25\% del área agrícola de la zona norte, para 1969 sólo ocupaban un $4 \%$ de la misma; en el oeste pasaron del $28 \%$ al $5 \%$, y en el sur, del $26 \%$ al $6 \%$.

131 También en esta forma existía una amplia dispersión de casos en torno a estos valores medios. El 50\% central se ubicaba entre las 60 y las 262 hectáreas en la zona norte, entre las 120 y las 622 en el oeste, y entre las 226 y las 600 hectáreas en el sur. 
Los arrendatarios empresariales (aquellos que contrataban tres o más asalariados permanentes) redujeron notoriamente la importancia que tenían en la zona sur en 1937: de controlar el $21 \%$ del área agrícola, pasaron a sólo el $6 \%$, aunque seguramente la enorme mayoría se habrían transformado en terratenientes-capitalistas. En la zona oeste, redujeron su significación a la mitad (del 14\% al $8 \%$ de la superficie agrícola), y en el norte se mantuvieron en un lugar marginal (pasando del 7\% al 5\%). Para 1969, a estos arrendatarios capitalistas podemos discriminarlos, gracias a disponer de los datos originales, entre aquellos que contrataban de tres a cinco asalariados permanentes (capitalistas pequeños) y los que tomaban seis o más (capitalistas medianos y grandes). En la zona sur, la importancia en la superficie agrícola era similar entre estas dos categorías (2,8\% cada una); en cambio, en las otras dos zonas era mayor el peso de los capitalistas medianos y grandes (en la zona norte, éstos tenían el 3,1\% de la superficie agrícola, y los pequeños el 1,6\%; y en la zona oeste, la distribución era 5,5\% y 2,9\%, respectivamente).

Un arrendatario capitalista pequeño en la zona norte presentaba un tamaño medio de 821 hectáreas, en la zona oeste de 1.276 y en el sur, de 1121. En cambio, un arrendatario capitalista mediano o grande, tenía una extensión promedio de 1.522 hectáreas en el norte, 4.335 en el oeste y 3.170 en el sur.

Tanto en las zonas norte como sur, los arrendatarios capitalistas pequeños presentaban una importante orientación hacia la agricultura, con un promedio de superficie dedicada a esta actividad sólo levemente inferior a los arrendatarios familiares ( $47 \%$ en el norte y $49 \%$ en el sur). En cambio, los capitalistas medianos y grandes mostraban una menor inclinación por la agricultura, los cultivos para cosecha ocupaban el $36 \%$ de sus explotaciones en la zona norte, y el 35\% en el sur. En la zona oeste, ambos tipos de arrendatarios capitalistas tenían una baja orientación hacia la agricultura (con el 13\% del área afectada a estos cultivos).

Los farmers (productores propietarios que no contrataban asalariados permanentes) fueron la forma de producción que más incrementó su peso dentro del área agrícola. En la zona norte pasó de controlar el 16\% de la superficie cultivada en 1937, al 41\% en 1969. En el oeste, creció del 12\% al 21\%, y en el sur, del $9 \%$ al 30\%. 
En general, en 1969 presentaban un tamaño relativamente similar a los arrendatarios familiares de su zona. En el norte, tenían una extensión promedio levemente inferior a estos arrendatarios (59 hectáreas); en la zona oeste, tenían un tamaño dos veces mayor a los de la zona norte (135 hectáreas) y que era algo superior al que presentaban los arrendatarios familiares en esta zona, y en la zona sur, tenían 208 hectáreas $^{132}$.

En las zonas norte y sur, los farmers tenían una marcada orientación agrícola, aunque un poco menor a la de los arrendatarios familiares $(48 \%$ de la superficie dedicada a cultivos para cosecha en el norte, y $45 \%$ en el sur). En la zona oeste, le daban este uso a sólo el $11 \%$ del área.

Los farmers que contrataban uno o dos asalariados en forma permanente habían incrementado en un 50\% su importancia en la agricultura. En la zona norte pasaron de tener el $12 \%$ del área agrícola en 1937 , al $17 \%$ en 1969 . En el oeste, subieron del $12 \%$ al $18 \%$, y en el sur, del $14 \%$ al $21 \%$. Estos productores presentaban tamaños promedio similares a los arrendatarios familiares con asalariados, extensiones que, a su vez, triplicaban a las superficie que tenían los farmers sin asalariados permanentes, en su respectiva zona. Así en la zona norte, el tamaño medio era de 198 hectáreas, en el oeste, 411 , y en el sur, 505. Como en todos los casos, existía una fuerte dispersión ${ }^{133}$.

Si en la zona sur, el farmer con asalariados promedio tenía una importante inclinación hacia la agricultura (dedicaba a cultivos para cosecha el $44 \%$ de su predio), en la zona norte afectaba una superficie mucho menor que los farmers sin asalariados (38\%, frente a $48 \%$ ). En el oeste, como casi todos los productores, sólo daba este uso al $11 \%$ de la explotación.

Los terratenientes-capitalistas vieron crecer notoriamente su importancia dentro de la actividad agrícola en la zona oeste. Aquí, según nuestras estimaciones, ellos

${ }^{132} \mathrm{Su}$ dispersión era similar a la de los arrendatarios familiares. En la zona norte, el 50\% central oscilaba entre las 12 y las 75 hectáreas, en la zona oeste se ubicaba entre las 23 y las 160 hectáreas, y el sur, la mitad central se encontraba entre las 31 y las 280 hectáreas.

${ }^{133}$ La mitad central de casos se ubicaba entre las 60 y las 243 hectáreas en la zona norte, entre las 120 y las 553 hectáreas en el oeste, y entre las 248 y las 632 hectáreas en el sur. 
detentaban el 17\% del área agrícola en 1937, y para 1969 tenían el 39\%. El crecimiento también habría sido notorio en el norte, donde pasaron del 5\% al 21\%; mientras que en el sur se mantuvo su peso en torno al 25\% de la superficie agrícola. Para 1969 podemos discriminar entre terratenientes-capitalistas pequeños (con tres a cinco asalariados permanentes) y medianos o grandes (con más de cinco asalariados). Tanto en las zonas norte como sur, ambos tipos tenían una importancia similar. En cambio, en la zona oeste, los medianos y grandes controlaban casi tres veces más superficie agrícola que los terratenientes-capitalistas pequeños.

El tamaño medio de los terratenientes-capitalistas pequeños iba de 588 hectáreas en la zona norte (donde eran bastante más chicos que los arrendatarios capitalistas pequeños), hasta 1.040 y 1.189 hectáreas en las zonas oeste y sur, respectivamente (en estas zonas se asemejaban a estos arrendatarios). Como en los demás tipos, también en este caso existían productores con escalas muy diversas ${ }^{134}$. En la zona sur presentaba una fuerte orientación hacia la agricultura, pues se sembraba con cultivos anuales para cosecha, el $42 \%$ de la superficie de los predios. En cambio, en el norte sólo daban a ese destino el 34\% (en el oeste, el 12\%).

Por último, los terratenientes-capitalistas medianos y grandes tenían un tamaño medio de 1.563 hectáreas en la zona norte, 3.163 en el oeste, y 2.960 en el sur. Tampoco en esta categoría había homogeneidad en las escalas ${ }^{135}$. En las tres zonas eran el tipo de productor que menos proporción de sus campos dedicaba a la agricultura: el 34\% en el sur, el $28 \%$ en el norte, y el $10 \%$ en el oeste.

${ }^{134}$ Incluso considerando sólo al 50\% central, la dispersión iba de 196 a 801 hectáreas en la zona norte, de 381 a 1.507 hectáreas en la zona oeste, y de 593 a 1.500 hectáreas en la zona sur.

${ }^{135}$ La mitad central de los casos se dispersaba entre las 545 y las 2.023 hectáreas en la zona norte; entre las 1.365 y las 4.160 hectáreas en la zona oeste, y entre las 1.335 y las 3.809 hectáreas en el sur. 


\section{7. ¿La posibilidad de un desarrollo farmer a partir de los años setenta?}

Sintetizando los análisis hasta aquí realizados, en las tres décadas que duró el período analizado en este capítulo, hemos observado un proceso de concentración que redujo entre un 12 y un $14 \%$ el número de explotaciones, afectando particularmente a las unidades de extensiones más reducidas (así, por ejemplo, desaparecieron un tercio de las explotaciones de 25 a 200 hectáreas en la zona norte). Más intensa fue incluso la concentración de la producción agrícola, perdiendo las unidades de menor extensión el lugar preponderante que tenían en las zonas norte y oeste al comienzo del período, y produciéndose una expansión de la agricultura desarrollada en unidades de más de 625 hectáreas.

Pero, como hemos visto, la transformación más importante que tuvo lugar durante estos años ocurrió en las formas de tenencia del suelo, produciéndose un drástico giro hacia la posesión en propiedad. En relación con las reflexiones que comentáramos en nuestra Introducción, esta modificación no fue producto de un proceso estrictamente económico, sino que estuvo claramente determinado por la intervención estatal sobre el mercado de tierras ${ }^{136}$. Al respecto, resulta interesante señalar cómo una medida de emergencia (la prórroga de los arriendos) implementada para hacer frente a una situación coyuntural (determinada por la segunda guerra mundial) terminó generando un cambio estructural de magnitud. La conjugación de un clima de ideas favorable a ciertas reformas en el sistema agrario, con la conformación de una alianza populista que buscó ganar el apoyo de los chacareros y de posteriores gobiernos que no quisieron agravar la situación social, fue haciendo que dicha prorroga se continuase durante 26 años e, indirectamente, promovió la liquidación de los grandes latifundios de tipo absolutamente rentístico.

Por otro lado, el incremento de la superficie en propiedad, también fue el resultado de las estrategias de muchos terratenientes y sus herederos que pugnaron por recuperar el control de sus campos (expulsando arrendatarios y aparceros) y que luego

${ }^{136} \mathrm{Si}$ puede identificarse una tendencia relativamente autónoma de dicha intervención estatal, ésta ha sido la expansión de las formas mixtas de tenencia que combinaban propiedad con arriendo o, en menor medida, aparcería. 
llevaron adelante la puesta en producción de los mismos de forma directa, aunque en muchos casos con el auxilio de contratistas de labores. Esta conducta también fue determinada indirectamente por las medidas gubernamentales, ya que la mayoría de los propietarios no querían volver a correr riesgos entregando sus campos en arriendo.

Por último, llama la atención el hecho de que, a pesar de esta drástica transformación en las formas de tenencia y el importante proceso de concentración, no se hayan registrado cambios notorios en la organización social del trabajo, que continuó basándose, centralmente, en la fuerza de trabajo familiar. Como hemos visto, la clave para entender este fenómeno fue el impacto de la mecanización sobre los requerimientos de mano de obra.

Entonces, cuando comenzó la recuperación agrícola de los años sesenta y terminó todo el proceso de intensa intervención estatal en el mercado de tierras, nos encontramos que se había consolidado el lugar de los productores familiares de mayor tamaño, ahora propietarios de sus campos o, al menos, de buena parte de ellos, y que habían logrado capitalizarse en maquinaria. Los que habían perdido claramente su lugar fueron los arrendatarios y aparceros familiares más pequeños, con dificultades para capitalizarse y para acceder a la propiedad; muchos habían sido expulsados o abandonaron el campo atraídos por las mejores oportunidades existentes en las ciudades. Por otra parte, la mecanización no sólo habría favorecido a los familiares capitalizados, permitiéndoles trabajar extensiones cada vez más amplias, sino que también había posibilitado el surgimiento de un nuevo sector: los contratistas de servicios, quienes se encargaron de las labores de roturación, siembra y cosecha de los productores más pequeños, como también de una importante proporción de los más grandes.

Si bien muchos chacareros, especialmente los más pequeños, se habían ido del campo (voluntariamente o expulsados), aquellos que lograron permanecer habían afianzado su posición. Para fines de los años sesenta, la gran mayoría eran propietarios y de importantes extensiones. De algún modo, las transformaciones habían contribuido a consolidar las bases materiales del mundo chacarero descripto en el primer capítulo. 
Aunque, como lo plantea Ansaldi (1998), a pesar de que seguían autodenominándose "chacareros", se habían convertido en farmers (cuestión que, como veremos en el Capítulo Cuarto, no dejará de tener profundas consecuencias en la redefinición del mundo rural bonaerense).

En todo caso, resulta claro que la "vía pampeana" de desarrollo agrario no se había estabilizado en el largo plazo. Las formas de producción de la agricultura cambiaron sustancialmente durante el "estancamiento", y no corresponde continuar utilizando los parámetros del período anterior para pensar el agro regional ${ }^{137}$. Si bien, como en el pasado, la mayor parte de la producción agrícola continuaba realizándose en unidades de tipo familiar (sobre todo en las zonas norte y sur, y algo menos en la zona oeste), la agricultura ya no se basaba más en el arriendo o la aparcería, sino en la propiedad de la tierra.

El predominio dentro de la agricultura de fines de los años sesenta de las unidades en propiedad que no tenían asalariados permanentes o sólo contrataban uno o dos, nos lleva a afirmar que estructuralmente el agro pampeano se había acercado al "modelo (norte)americano".

En ambas regiones nos encontramos con unidades a cargo de la fuerza de trabajo familiar. Así, por ejemplo, en 1969, en Iowa, sólo el 7\% de las explotaciones contrataban asalariados en forma permanente ${ }^{138}$. Incluso, considerando únicamente a las unidades de más de 105 hectáreas, observamos que sólo el 14\% tenían asalariados permanentes (estos establecimientos presentaban un promedio de apenas 1,4 asalariados por explotación) ${ }^{139}$. En la agricultura bonaerense, existía un perfil más abierto a la contratación de asalariados. Incluso en la zona norte, el 17\% del total de explotaciones

${ }^{137}$ Este ha sido el error mayor de la visión tradicional, señalado certeramente por Viñas (1973). Aunque consideramos que este autor extrema su posición al sólo destacar las formas de producción capitalistas en el agro pampeano.

${ }^{138}$ Hemos computado tan sólo a las mayores de 50 acres (20 hectáreas) y con ventas por encima de los 2.500 dólares anuales (datos en U.S. Department of Commerce, 1969 Census of Agriculture).

${ }^{139}$ Cálculos propios en base al Census of Agriculture, 1969, Iowa: Tabla 26. 
contrataban asalariados en forma permanente (el $30 \%$ en las otras dos zonas estudiadas) y, de las unidades con más de 100 hectáreas el 48\% tenían asalariados todo el año en la zona norte (y porcentajes similares en las otras dos zonas). Pero, como ya hemos analizado, entre los establecimientos con asalariados, la enorme mayoría solo empleaban uno o dos hombres de forma permanente. También hemos visto que, entonces, la mayor parte de la superficie agrícola de las zonas estudiadas se realizaba en explotaciones familiares puras o con el auxilio de uno o dos asalariados.

Pero si esta relativa similitud entre ambas regiones cerealeras en la organización social del trabajo ya existía a fines de los años treinta, ahora también coincidían en que la mayor parte de las unidades estaban bajo la forma de tenencia en propiedad. Así, para 1969, el 46\% de los productores de Iowa eran propietarios puros, un $28 \%$ eran propietarios que además arrendaban otros lotes, y un $26 \%$ eran arrendatarios. Si consideramos sólo a las unidades de más de 105 hectáreas, también predominaban los propietarios, pero en formas de tenencia mixtas $(47 \%$, frente al $25 \%$ de los propietarios puros), mientras que el peso numérico de los arrendatarios se mantenía en valores similares al conjunto $(28 \%)^{140}$. En las zonas estudiadas de la provincia de Buenos Aires, como ya hemos visto, también predominaban claramente los propietarios en 1969. Más específicamente, vemos que era más fuerte la presencia de los propietarios puros. Así, por ejemplo en la zona norte el $67 \%$ de los productores eran propietarios, el 14\% combinaban la propiedad con parcelas en arriendo y el 19\% eran arrendatarios ${ }^{141}$. En el caso de los productores con unidades de más de 100 hectáreas, se incrementaba el peso de la tenencia "mixta" (27\%), pero seguían predominando los propietarios puros (57\%), mientras que el $16 \%$ eran arrendatarios.

Por último, al menos en la zona norte (que es la que presenta mayores similitudes productivas con el Corn Belt) los tamaños de las explotaciones eran relativamente similares a las unidades de esta región. El tamaño medio de las unidades de Iowa en 1969 era de 97 hectáreas, frente a 117 que tenían en la zona norte

\footnotetext{
${ }^{140}$ Cálculos propios en base al Census of Agriculture, 1969, Iowa: Tabla 24.

${ }^{141}$ En las otras dos zonas, la distribución era muy similar. En la zona oeste, el 69\% eran propietarios, el $14 \%$, propietarios y arrendatarios, y el 17\%, arrendatarios. En la zona sur, los porcentajes eran $60 \%, 16 \%$ y $24 \%$, respectivamente.
} 
bonaerense. Las extensiones medias de las zonas oeste y sur eran 387 y 412 hectáreas, respectivamente.

Podemos, entonces, concluir que el proceso de concentración y "farmerización" habría generado, en la región pampeana, una estructura relativamente similar a la del Corn Belt norteamericano, si se quiere con menores problemas de escala. Estos farmers podrían haber constituido una interesante base social para la expansión agrícola que comenzó en los años sesenta y se desarrolló más intensamente durante las dos décadas siguientes. La propiedad de las unidades, el mayor tamaño que presentaban ahora las explotaciones familiares y su capitalización en maquinarias podrían haber resultado un punto de partida relativamente sólido para encarar la "agriculturización" basada en una "vía farmer".

Hasta qué punto se consolidó este modelo en la nueva etapa, y los farmers fueron el sujeto que protagonizó la siguiente expansión agrícola, será el principal interrogante que intentaremos resolver en el siguiente capítulo. 


\section{Capítulo Tercero}

Expansión agrícola y transformaciones sociales en el agro bonaerense en los años setenta y ochenta.

¿Cuál fue el sujeto que protagonizó el "boom" agrícola? 
Durante la década de 1960 la producción agrícola pampeana se incrementó en un tercio, recuperando -luego de casi dos décadas de "estancamiento"- el nivel alcanzado en los años veinte y treinta: en torno a las 16 millones de toneladas. Sin embargo, fue en los convulsionados años setenta cuando se produjo un vertiginoso incremento de la producción agrícola regional, con un aumento del 60\%. Este ritmo de crecimiento fue mayor aún durante los primeros cinco años de la década del ochenta, hasta alcanzar la cosecha récord de 1984/85: 36 millones de toneladas de cereales y oleaginosas en la región pampeana y 44 millones de toneladas en el conjunto del país (Cirio, 1984; Obschatko, 1988; Pizarro y Cascardo, 1991). A partir de esa campaña, la producción declinó considerablemente ${ }^{1}$. Debido a este "nuevo estancamiento" agrícola y al cambio de contexto de política económica de los años noventa, sin lugar a duda podemos recortar, como una etapa claramente expansiva, al período comprendido entre finales de los años sesenta y mediados de los ochenta. Por su dinámica de moderado crecimiento, la década del sesenta podría haberse incorporado a esta etapa, pero, como ya vimos, durante sus primeros ocho años continuó existiendo una fuerte intervención estatal en el mercado de tierras con medidas de protección hacia los arrendatarios y aparceros. Por lo tanto, preferimos incluir estos años en la etapa anterior. Un segundo motivo nos impulsó a centrarnos en el período escogido: hemos podido trabajar sobre la base de datos original de una serie de importantes variables del Censo Nacional Agropecuario de 1969. De este modo ha sido posible cruzar a nivel de explotación agropecuaria las variables de mano de obra, tamaño, tenencia del suelo y uso de la tierra, que casi nunca habían sido trabajadas de este modo ${ }^{2}$. Por otra parte, hemos extendido el análisis hasta 1988, por el mismo motivo. En dicho año se realizó el siguiente relevamiento censal agropecuario, y hemos efectuado otro procesamiento especial a partir de los datos por

1 Esta retracción agrícola, ha sido explicada por la caída de precios internacionales (Cirio, 1988), agravada por un incremento en las retenciones a las exportaciones durante el primer momento del Plan Austral (Reca y Katz, 1991).

2 La publicación oficial de este censo ha sido la más restringida de todas las publicaciones sobre censos agropecuarios de nuestro país. Una serie de problemas de tipo organizativo e informático dificultaron el acceso a esta base por parte de los investigadores interesados. Una excepción ha sido un interesante trabajo que consideró la relación entre las variables tamaño y tenencia del suelo, posible gracias a un procesamiento especial de los datos del censo de 1969 realizado en la década del ochenta (Llovet, 1988). 
establecimiento $^{3}$, que nos permite comparar la evolución de las diferentes formas de producción durante estas dos décadas en base a las mencionadas variables.

Para aclarar nuestro punto de partida, vamos a comenzar con un breve recorrido por las bibliografía especializada considerando los problemas que se encuentran irresueltos y sobre los que es factible avanzar a partir de la gran cantidad de información contenida en estas fuentes censales ${ }^{4}$.

El problema del "estancamiento" del agro pampeano durante las décadas de 1940 y 1950 había estimulado un intenso debate en torno a sus causas, muy marcado por implicancias políticas. En cambio, el despegue agrícola de las décadas posteriores no suscitó este tipo de controversias, quizás porque el agro, a raíz justamente de su situación expansiva, dejó de estar en el centro de los problemas nacionales. La mayoría de los análisis destacan el desarrollo tecnológico como el elemento decisivo del despegue (Cirio, 1984; Obschatko, 1988; Pizarro y Cascardo, 1991). El énfasis se puso en los procesos de mecanización, la utilización de semillas nuevas, la adopción de agroquímicos y las mejoras en el manejo agronómico. En cambio, según una visión muy aceptada, ni los precios de los productos, ni las políticas públicas (por cierto, muy disímiles durante estas décadas), ni tampoco cambios en la estructura social agraria podrían explicar la expansión agrícola (Obschatko, 1988). Sobre este último punto, son pocos los trabajos que llaman la atención acerca del olvido del "factor social" en la explicación del despegue (Barsky, 1988; CEPA, 1990). Como señala este último trabajo, "la disponibilidad de técnicas es una condición necesaria para la ocurrencia de los cambios productivos, pero no suficiente [...] presentándose las oportunidades de mercado [en torno a algunos granos], la forma específica de su aprovechamiento

3 Agradezco a de la Dirección Provincial de Estadística y Planificación General de la Provincia de Buenos Aires y especialmente la labor realizada por Lucrecia Fernández para poder procesar los datos originales.

4 De todos modos, no contábamos con todas las dimensiones que hubiéramos deseado. Son conocidas las limitaciones que presentan los censos agropecuarios argentinos, y las mismas se ven agravadas, en el caso del censo de 1969, porque muchas de las variables relevadas o bien no fueron procesadas o, si lo fueron, no pueden leerse en las citas informáticas donde hoy se encuentran almacenadas. 
depende de la estructura social vigente" (CEPA, 1990: 216-217). En este mismo sentido, existe una pregunta que consideramos clave para comprender socialmente la "agriculturización" y que no ha sido directamente abordada por la bibliografía especializada: ¿este desarrollo fue posible por las transformaciones sociales ocurridas durante el "estancamiento" o fueron los nuevos sujetos sociales, que se expandieron durante los años setenta y ochenta, los que posibilitaron el despegue? Hemos formulado el interrogante de un modo dicotómico, pero sin duda la respuesta deberá ser dada en términos porcentuales.

Como sintetizábamos al final del capítulo anterior, en 1969 existía un claro predominio de los productores propietarios basados en la mano de obra familiar, pero con un tamaño mucho mayor que el que en promedio presentaban los productores familiares de $1937^{5}$. Cabe la posibilidad que estos "farmers" puedan haber constituido la base social del despegue agrícola de las décadas siguientes, haciendo -de un modo bastante indirecto- realidad la tesis tradicional de la necesidad del acceso a la tierra por parte de los productores directos como base para un desarrollo agrícola regional. Sin embargo, más allá de alguna frase al respecto $^{6}$, la mayoría de los autores no han abordado esta cuestión. En general, han dejado de lado el estudio de las posibles continuidades con las transformaciones sociales previas, y se han detenido en el análisis de las rupturas que en términos sociales se produjeron en el agro regional durante la expansión. Al respecto, han destacado dos fenómenos.

Por un lado, los trabajos que analizan los cambios sociales durante el crecimiento agrícola señalan la expansión de una novedosa forma de producción: el contratismo tantero. Este modo peculiar de arrendamiento a corto plazo, mezclado con características de mediería, para algunos autores constituiría la forma de tenencia típica

5 El tamaño medio de los arrendatarios y aparceros que no contrataban asalariados en forma permanente en 1937 lo hemos estimado en 58 hectáreas para la zona norte, 107 en la zona oeste y 169 en la zona sur (el tamaño medio de los propietarios familiares era muy similar). En cambio, para 1969 los productores propietarios que no contrataban asalariados permanentes tenían un tamaño medio de 89 hectáreas en la zona norte, 190 en la zona oeste y 263 en la zona sur.

6 Véase Flichman (1978: 15) y CEPA (1990: 217). Una interesante información que nos invita a avanzar en este sentido la encontramos en Pucciarelli (1997: 245) cuando estima que el $43 \%$ de la superficie agropecuaria de la provincia de Buenos Aires se hallaba en 1988 en manos de explotaciones "medianas-chicas", conceptualizadas según el valor de estimado de su producción. 
del proceso de "agriculturización" de las últimas décadas (Flichman, 1978; Baumeister, 1980; Solá, 1985; Llovet, 1988 y 1991; Devoto, 1988; Devoto et al., 1990; Pizarro y Cascardo, 1991; Posadas, 1995) ${ }^{7}$.

Por otro lado, la mayoría de los especialistas -incluso también aquellos que sostienen que tuvo lugar una previa "farmerización" de los chacareros- han coincidido en afirmar que la expansión habría conllevado la crisis de las pequeñas explotaciones, e incluso de muchas de las medianas (Obschatko, 1986; Giberti, 1988; Barsky y Pucciarelli, 1991; Pizarro y Cascardo, 1991; Forni y Tort; 1992).

Una variante entre los que destacan los procesos de concentración remarca el lugar que habría tenido la cúpula terrateniente en la expansión agrícola, articulando la producción con la especulación financiera. De este modo, habrían consolidado (e incluso incrementado) el espacio que ocupaban en el agro regional, aumentando la concentración de la propiedad de la tierra (Basualdo y Khavise, 1993; Basualdo, 1995).

Estas líneas interpretativas resultan de indudable interés para explicar los cambios sociales asociados a la agriculturización. Sin embargo, no llegan a dar cuenta del conjunto del proceso. En la medida en que no tienen en cuenta las continuidades, pueden llegar a brindar una imagen distorcionada de la estructura social de la producción agrícola pampeana, en la cual podría parecer que predominaban los grandes productores capitalistas y los contratistas tanteros.

En este sentido nos parece muy productiva la idea de Murmis (1988) de analizar la heterogeneidad social del agro pampeano y prestar atención a la compleja combinación de diferentes tipos de organización social del trabajo y distintas formas de tenencia del suelo que se entrelazaban en la producción agropecuaria pampeana. La asalarización, pero también la terciarización de labores agrícolas, junto con las nuevas

7 Murmis (1988: 330) plantea que "sin duda el arrendamiento capitalista es forma esperada en la teoría clásica del desarrollo del capitalismo, pero siempre atendiendo a su doble faz de facilitadora de la movilidad de factores y a la vez de limitante en el proceso de acumulación agrario. El caso argentino muestra ambos aspectos en el momento de las primeras grandes expansiones productivas. También se puede ver cómo la posterior caída y lenta recuperación de la producción se asocian con mayor asunción de la organización de la producción por los propietarios y la nueva expansión aparece ligada al renacimiento de formas de arrendamiento encarnadas en la figura del contratista". 
formas de arriendo, merecen ser medidas e interpretadas con detenimiento. Estos serán entonces los objetivos del presente capítulo.

En primer lugar, reseñaremos la evolución productiva que tuvo lugar durante las décadas del setenta y el ochenta en la región pampeana, en general, y en las tres zonas escogidas, en particular.

En segundo lugar, analizaremos las transformaciones ocurridas en la estructura agraria en estos años en términos de tamaño de las unidades, formas de tenencia del suelo y composición de la fuerza de trabajo, como así también en la estructura de la propiedad de la tierra.

En tercer, y último, lugar, intentaremos abordar una serie de interrogantes más específicamente centrados en la producción agrícola: ¿hasta qué punto la agricultura quedó en manos de las grandes unidades de producción?; ¿hasta dónde el aumento de la producción agrícola estuvo vinculado con el desarrollo del contratismo accidental?; ¿cuál fue el papel jugado por los productores farmerizados en las décadas previas? y ¿hasta dónde la expansión puede haberse debido a la orientación hacia la agricultura de los terratenientes capitalistas?; ligada a esta cuestión, ¿el desarrollo tuvo como correlato una expansión de las relaciones capitalistas de producción?, y, por último, ¿hasta qué punto la terciarización de buena parte de las labores agrícolas transformó las características de lo que tradicionalmente se consideraba un productor familiar y, del mismo modo, un productor capitalista? 


\section{La "segunda revolución agrícola"}

\subsection{Evolución del área sembrada y el volumen cosechado en la región pampeana}

Durante los años setenta asistimos a una expansión de la superficie sembrada en la región pampeana, especialmente a partir de la cosecha 1974/75, que se hizo más intensa en los primeros años de la década del ochenta ${ }^{8}$ (ver Gráfico 3.1). La superfície máxima se alcanzó entre 1982/83 y 1985/86, para decaer luego. El área sembrada con cultivos para cosecha se incrementó en un 25\% entre 1969 y 1985 . Descomponiendo esta información por cultivos, observamos que fue extraordinaria la expansión de la soja. También se incrementó el área sembrada con trigo (cuyo cultivo se efectuaba muchas veces combinado con el de la soja en un mismo año) y con girasol, mientras que el maíz presentó una tendencia decreciente a lo largo de todo el período, lo mismo que el centeno y la cebada cervecera. (En el Apéndice 3, Apartado 1, hemos analizado mucho más detenidamente este proceso, brindando también los datos para la provincia de Buenos Aires, en particular).

8 Una expansión que se correspondía con las estimaciones más elevadas de las proyecciones realizadas a comienzos de esta década (Cirio, 1984). 


\section{Gráfico 3.1.}

\section{Región Pampeana. Evolución de la Superficie Sembrada y el Volumen Cosechado \\ (trigo, maíz, lino, girasol y cebada cervecera) $100=1969$}

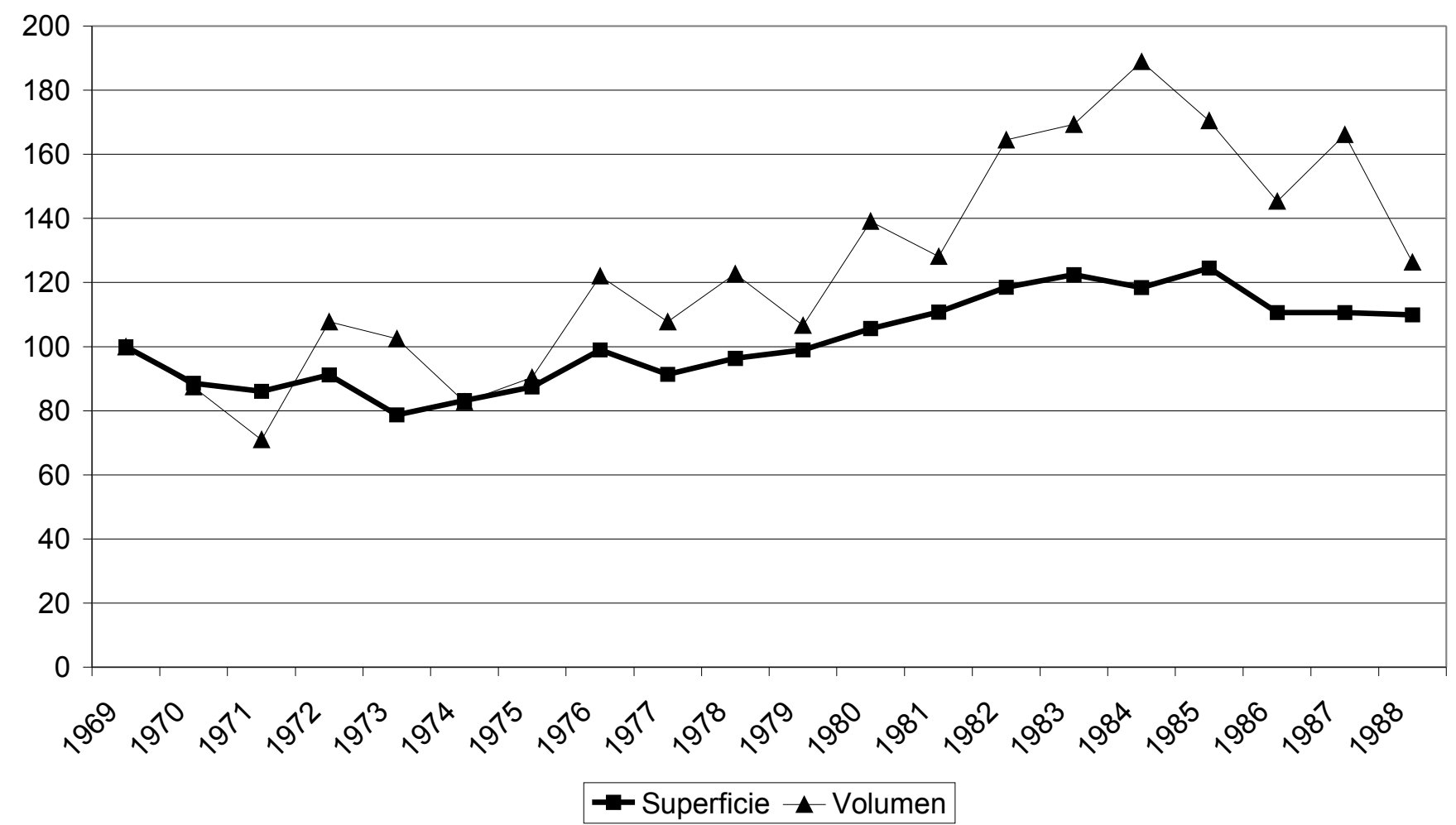

Fuente: Cálculos propios en base a las Estimaciones Agrícolas de la Secretaría de Agricultura y Ganadería.

Nota: La base 100 de la campaña 1969/70 corresponde a una superficie sembrada de 13.066 .520 hectáreas y a un volumen cosechado de 18.021.704 toneladas.

Si la expansión del área sembrada fue importante, el aumento en el volumen de producción resultó mucho más significativo: en 1984/5 se cosechó un $89 \%$ más que en 1969/70, tal como puede observarse en el Gráfico 3.1. Esta diferencia se debe a un notorio aumento en los rendimientos de los cultivos. Para observar este fenómeno puede consultarse los datos anuales transcriptos en el Apéndice 5. Un análisis de este incremento en la productividad por unidad de superficie puede encontrarse en Pizarro y 
Cascardo (1991: 152-180). Además del explosivo incremento de la producción de soja ${ }^{9}$, también el trigo y el girasol presentaron una tendencia creciente hasta mediados de los ochenta. En cambio, el maíz se mantuvo estancado en sus niveles productivos, más allá de fuertes oscilaciones anuales, pues el incremento en los rindes se compensó con la reducción en el área sembrada ${ }^{10}$. (Nuevamente, remitimos al Apéndice 3 , Apartado 1, para mayores detalles).

En la bibliografía se ha distinguido una primer etapa hasta 1977 en la que agricultura y ganadería se expandieron relativamente juntas y una segunda, llamada de “agriculturización", ya que a partir de esa fecha se contrapuso la evolución de ambas actividades (ver Cuadro 3.1). Campos que durante las tres o cuatro décadas anteriores se habían destinado a la ganadería, ahora se dedicaban a la agricultura.

Cuadro 3.1. Existencias bovinas en la región pampeana

\begin{tabular}{|l|l|}
\hline & Existencias bovinas (cabezas) \\
\hline 1960 & 39.920 .000 \\
\hline 1974 & 38.597 .000 \\
\hline 1977 & 41.363 .000 \\
\hline 1982 & 34.758 .000 \\
\hline 1986 & 34.489 .000 \\
\hline
\end{tabular}

Fuente: Peretti y Gómez (1991:272).

$9 \quad$ A pesar de que los márgenes brutos de la soja se fueron reduciendo a lo largo de estos años (Actis y Justo, 1989), aunque menos que lo que disminuyeron los del maíz (Actis, 1989).

10 El fenómeno fue en realidad más complejo, ya que el maíz fue desplazado (por la combinación trigo-soja) de la zona predominantemente agrícola (donde se encuentra nuestra zona norte) hacia las áreas mixtas (agrícolo-ganaderas) donde sus rindes son comparativamente menores. Para más detalles puede consultarse Pizarro y Cascardo (1991: 166-170). 


\subsection{Cambios productivos en las tres zonas estudiadas}

Si 1969/70 había sido una campaña en la que la superficie sembrada había sido una de las más altas de la década del sesenta y la producción había alcanzado un pico en relación con los años anteriores en las tres zonas, este nivel se mantendría durante los setenta y sería paulatinamente superado, especialmente a comienzos de los ochenta.

En la zona norte tuvo lugar un extraordinario aumento de la superficie sembrada, del orden del 44\% entre 1969/70 y 1985/86 (ver Gráfico 3.2). Este incremento se explica no sólo por la reducción del área con pasturas naturales y por la disminución de la cantidad de hectáreas con forrajeras permanentes (ver Cuadro 3.2), sino por la realización de dos siembras durante el mismo año agrícola gracias a la combinación de trigo y soja, que reemplazaron al maíz como principal cultivo de esta zona. En términos de volúmen cosechado (Gráfico 3.3), en esta zona la expansión tuvo una magnitud similar a la expansión del área sembrada (47\%, entre 1969/70 y 1985/86). En el Apéndice 3 (apartado 1) se analiza detenidamente este proceso, con los datos para cada uno de los cultivos.

Durante estos años la ganadería vacuna redujo su importancia en la zona norte, tal como podemos ver en el Cuadro 3.2. 


\section{Gráfico 3.2.}

\section{Evolución de la Superficie Sembrada \\ (trigo, maíz, lino, girasol y cebada cervecera) $100=1969$}

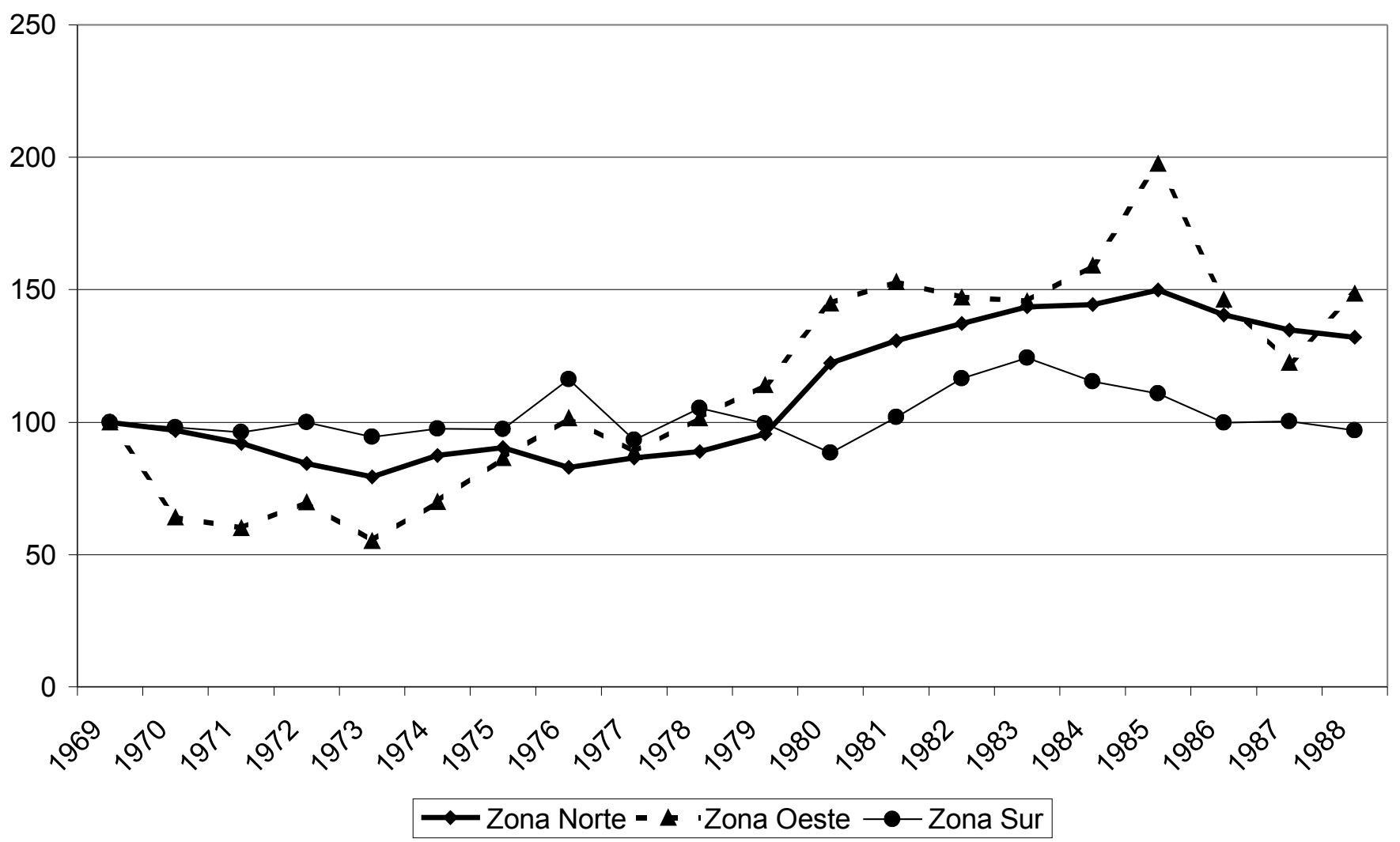

Fuente: Cálculos propios en base a las Estimaciones Agrícolas de la Secretaría de Agricultura y Ganadería.

Nota: La base 100 de la campaña 1969/70 corresponde a una superficie sembrada de 994.320 hectáreas en la zona norte, de 523.700 hectáreas en la zona oeste, y 2.098.000 hectáreas en la zona sur. 
Cuadro 3.2. Forrajeras anuales, existencias ganaderas y cabezas de ganado por hectárea, 1969 y 1988.

\begin{tabular}{|c|c|c|c|c|c|c|c|c|}
\hline & \multirow{2}{*}{$\begin{array}{c}\text { forrajeras } \\
\text { perma- } \\
\text { nentes } \\
\text { (ha.) }\end{array}$} & \multicolumn{3}{|c|}{ Cabezas de ganado } & \multicolumn{3}{|c|}{$\begin{array}{c}\text { Cabezas de ganado por } \\
\text { hectárea }\end{array}$} \\
\hline & & & vacunos & ovinos & equinos & vacunos & $\begin{array}{c}\text { ovinos } / 5 \\
(*)\end{array}$ & equinos \\
\hline \multirow{2}{*}{ zona norte } & 1969 & 481 & 1574 & 161 & $\mathrm{~s} / \mathrm{d}$ & 0,82 & 0,02 & $\mathrm{~s} / \mathrm{d}$ \\
\hline & 1988 & 305 & 997 & 34 & 27 & 0,50 & 0,00 & 0,01 \\
\hline \multirow[t]{2}{*}{ zona oeste } & 1969 & 1114 & 3061 & 974 & $\mathrm{~s} / \mathrm{d}$ & 0,90 & 0,05 & $\mathrm{~s} / \mathrm{d}$ \\
\hline & 1988 & 902 & 2972 & 182 & 59 & 0,87 & 0,01 & 0,02 \\
\hline \multirow[t]{2}{*}{ zona sur } & 1969 & 382 & 2247 & 5735 & $\mathrm{~s} / \mathrm{d}$ & 0,42 & 0,21 & $\mathrm{~s} / \mathrm{d}$ \\
\hline & 1988 & 695 & 2661 & 1556 & 52 & 0,50 & 0,06 & 0,01 \\
\hline
\end{tabular}

Fuente: Cálculos propios en base a los datos de los respectivos Censos Nacionales Agropecuarios.

\section{Gráfico 3.3.}

\section{Evolución del Volumen Cosechado}

(trigo, maíz, lino, girasol, avena, centeno y cebada cervecera) $100=1938$

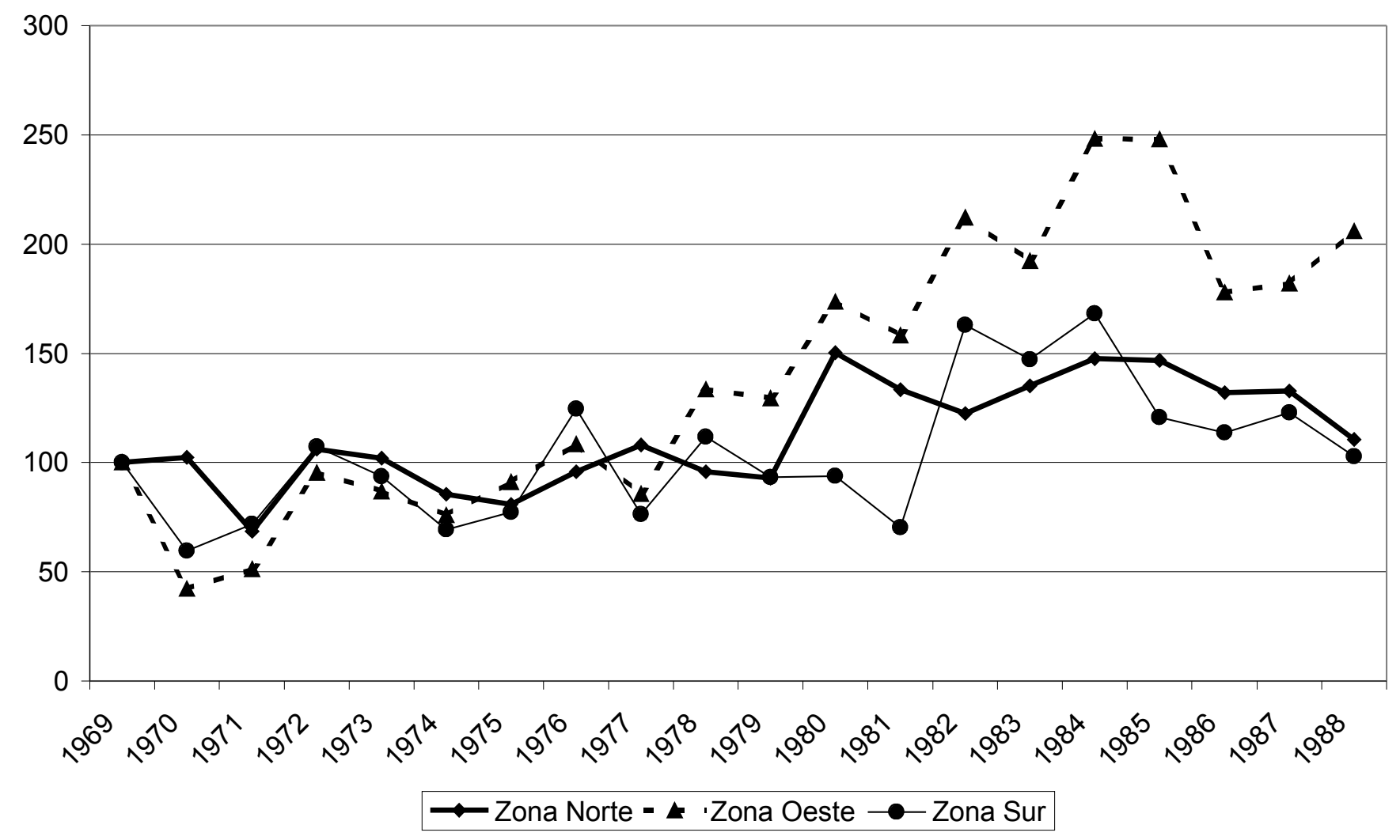

Fuente: Cálculos propios en base a las Estimaciones Agrícolas de la Secr. de Agricultura y Ganadería.

Nota: La base 100 de la campaña 1969/70 corresponde a un volumen cosechado de 2.703 .212 toneladas en la zona norte, de 596.032 toneladas en la zona oeste, y 3.051.466 toneladas en la zona sur. 
En la zona oeste tuvo lugar un extraordinario y sostenido aumento del área sembrada con cultivos para cosecha a partir de 1973/74 y hasta 1985/86. Entre estas dos fechas esta superficie se triplicó, destacándose el comportamiento del trigo y el girasol. Merece señalarse que redujeron su importancia tanto el centeno (una forrajera anual) como las forrajeras permanentes (aunque en este caso sólo levemente), al tiempo que en estas décadas la cantidad de vacunos en la zona oeste se mantuvo relativamente estable (en cambio, los ovinos prácticamente desaparecieron de la escena productiva).

En términos productivos la expansión fue incluso más notable que la del área sembrada: la cosecha 1985/86 fue cuatro veces mayor que la de 1971/72, tal como puede verse en el Gráfico 3.2.

Así como en el período anterior la zona sur se había destacado porque la reducción en el área sembrada había sido muy leve, en esta etapa la expansión no alcanzó la magnitud que tuvo en las otras dos zonas estudiadas. Como se observa en el Gráfico 3.2, sólo las campañas entre 1982/83 y 1985/86 presentaron una superficie sembrada claramente superior a la del promedio del período (destacándose el girasol).

En cuanto a la actividad ganadera observamos en el Cuadro 3.2 una fuerte reducción de la cantidad de ovinos (en 1988 quedaban menos de un ovino de cada tres que había en 1969), que no fue compensada por el leve aumento del número de vacunos (18\%). Sin embargo, el área sembrada con forrajeras permanentes casi se duplicó en este lapso.

En el nivel productivo, se destacan las excepcionales cosechas de las campañas 1982/83 a 1984/85, cuando el volumen cosechado casi duplicó al promedio del período 1969/70-1981/82. 


\section{Las transformaciones en la estructura agraria}

En este apartado intentamos resolver una serie de interrogantes sobre la importancia de los procesos de concentración, los cambios en las formas de tenencia del suelo y las modificaciones en la organización social del trabajo que ocurrieron durante los años setenta y ochenta.

\subsection{Los cambios en las condiciones de producción}

Las condiciones de producción se modificaron notoriamente a partir de los años setenta, afectando a la estructura social agraria. En primer término, los requerimientos de capital y extensión de las explotaciones para un completo aprovechamiento de las innovaciones tecnológicas, habrían hecho muy difícil la situación a los pequeños productores agropecuarios (Pizarro y Cascardo, 1991; Forni y Tort, 1992; Peretti, 1994). En segundo término, el contexto económico de alta inflación, caída de los precios ganaderos y altas tasas de interés, también habría jugado en contra de la estabilidad de estos productores (Fiorentino, 1984; Solá, 1985). Finalmente, este cuadro económico se vio agravado por el retroceso del Estado en su papel de promotor de inversiones y apoyo a los pequeños productores, y por las políticas cambiarias e impositivas, que comentaremos en el siguiente apartado.

Los estudios técnicos que hemos analizado marcan que, en líneas generales, entre las 100 y las 200 hectáreas se encontraron importantes reducciones en los costos de producción, evidenciándose un incremento en la escala óptima a lo largo del período. Con respecto a las economías de tamaño, Schaefer (1960) encontró una rentabilidad 2,6 veces mayor en las unidades mayores de su muestra (de 102 a 136 hectáreas) de Pergamino que en las más pequeñas (de 37 a 48 hectáreas). Además, en las pequeñas no se podía utilizar todo el trabajo familiar disponible. Lo mismo concluyeron Gilles y Nocetti (1962) para las unidades de Pergamino con menos de 100 hectáreas. Peyrou (1971), estudiando los partidos de Pergamino, Salto, Rojas y Bartolomé Mitre, encontró costos totales por hectárea decrecientes al aumentar el tamaño de los predios. En el caso de la producción agrícola se reducían hasta un 57\% respecto de los valores del estrato "chico" (50 a 120 hectáreas), y del 86\% en la producción ganadera. Más que un decrecimiento progresivo, halló un salto que se producía en torno a las 200 hectáreas 
(Peyrou, 1971: 27-28). Sin embargo, descubrió que, como los ingresos por hectárea eran decrecientes por tamaño, el resultado final era una escasa variación de los ingresos netos por hectárea en relación con el tamaño de las explotaciones analizadas (Peyrou, 1971: 32). Finalmente, las diferencias de rentabilidad tampoco eran muy importantes entre los distintos estratos. En cambio, a comienzos de los ochenta, a partir de los datos de Pizarro y Cacciamani (1981), podemos ver que los costos de cosecha de trigo se incrementaban en un 51\% al pasar de 100 a 200 hectáreas; los del maíz un 49\% al pasar de 140 a 280 hectáreas; y los de la soja un $48 \%$ de 140 a 280 hectáreas. Pero no todos los estudios concuerdan en la importancia de las economías de tamaño: un estudio específico sobre productores de los partidos de Lobería, Necochea, Tres Arroyos, San Cayetano y González Chaves a cargo de explotaciones mixtas y predominantemente agrícolas de 161 a 500 hectáreas, con datos de los años 1979 y 1982, no encontró economías o deseconomías de escala en la producción agrícola, al menos dentro de este intervalo (Manchado, 1988).

Seguramente, mucho más importantes para favorecer el proceso de concentración que las diferencias en las economías de tamaño (que refieren al óptimo económico), fue la tendencia decreciente en los ingresos netos por hectárea trabajada (cabe la posibilidad de que se produzca con costos por unidad de producto no muy lejanos a los óptimos, pero recibir un monto total de ingresos netos insuficientes, si se trabaja una extensión reducida). En este sentido, cada vez eran necesarias más hectáreas para obtener los ingresos imprescindibles para sostener al productor y a su familia. Así, por ejemplo, a comienzos de los años setenta, en la zona de Pergamino, aunque la mayoría de las explotaciones con menos de 46 hectáreas presentaban una productividad de la tierra similar a las de mayor tamaño, sus ingresos eran menores o iguales al salario de un oficial tractorista, por lo cual fueron catalogadas como "minifundios" (Torchelli, 1972: 19-21).

Las economías de tamaño (asociadas al desarrollo tecnológico) y los bajos ingresos que percibían los pequeños productores (al potenciarse la escasa superficie con la indiferenciación productiva y las economías de tamaño) habrían afectado gravemente a las explotaciones más pequeñas, por debajo de las 200 hectáreas en la zona norte, e incluso a unidades medianas en las otras dos zonas. En los trabajos de Pizarro y Cacciamani (1993a y 1993b) puede observarse claramente la situación diferencial que 
presentaban los pequeños y mediano-pequeños productores de la zona norte, frente a los que tenían un mayor tamaño ${ }^{11}$.

Al mismo tiempo, como veremos en el siguiente apartado, las políticas agrarias habían dejado desprotegidos a los pequeños productores. En qué medida, estos condicionantes técnico-económicos produjeron realmente un proceso de concentración de la producción, será el interrogante que abordaremos luego de reseñar el cambio en el contexto político.

\subsection{El proceso social regresivo en el sector agrario}

Si el período anterior había finalizado con la expulsión de arrendatarios y aparceros ordenada por Onganía, esta etapa comenzó con un intento de transformar económica y socialmente el agro pampeano en un sentido progresista a través de un instrumento tributario (el impuesto a la renta normal potencial de la tierra). Sin embargo, luego del fracaso de esta breve experiencia, todo el resto del período estuvo signado por el retroceso de la intervención estatal, dejando a los pequeños productores

11 A comienzos de los noventa, lo que Pizarro y Cacciamani (1993a) denominan "productor tradicional capitalizado" (propietario de 96 hectáreas, con mano de obra familiar, maquinaria propia, excepto para la cosecha, que realiza con contratistas) obtenía, según sus estimaciones, un ingreso efectivo de $\$ 1.157$ al mes, y un ingreso neto (descontando las amortizaciones) de $\$ 589$, que "no alcanza para retribuir totalmente la mano de obra del productor y su familia. Como resultado de ello tanto la retribución al capital utilizado como el Beneficio del Capital son negativos". Asimismo, un "productor propietario contratista" (propietario de 96 hectáreas pero que arrienda a terceros 184 hectáreas a un año, pagando un porcentaje sobre la producción lograda, que cuenta con maquinaria para todas las labores, y que también se basa sólo en la mano de obra familiar) obtiene ingresos mensuales en efectivo de $\$ 2.451$, e ingresos netos de $\$ 813$, que tampoco cubría el aporte de trabajo familiar. En ambos casos, "lo que en realidad sucede es que el productor se apropia para su supervivencia de los que corresponde en carácter de reposición del capital (amortizaciones) con lo que se agudiza el proceso de descapitalización de la empresa" (Pizarro y Cacciamani, 1993a: 4).

En cambio, un propietario-contratista que en la misma zona norte trabajara 638 hectáreas (129 en propiedad y 510 arrendadas a terceros), también se basara en la mano de obra familiar y sólo recurriera a asalariados en forma transitoria (gasto anual en mano de obra asalariada igual a $\$ 1.890$ ) tendría un ingreso efectivo de $\$ 5.130$ por mes, y un ingreso neto de $\$ 2.992$ que alcanzarían para cubrir el valor del trabajo del productor (valuado en $\$ 585$ por mes, y de sus familiares, estimado en $\$ 1.024$ ), dejando un ingreso del capital de $\$ 16.599$ al año, lo que significaba un beneficio del capital del 2,78\% anual (Pizarro y Cacciamani, 1993b). 
indefensos frente a la dinámica del mercado y de las tendencias hacia la concentración que, como vimos, generaban las economías de tamaño y la caída de los ingresos netos por hectárea.

Desde mediados de la década del setenta y, especialmente, durante la última dictadura militar, la sociedad argentina asistió no sólo a una represión de niveles hasta entonces inimaginados que buscó, con éxito, revertir el estado de movilización y radicalización que se había gestado desde fines de los años sesenta, sino también a la instrumentación de una serie de medidas tendientes a transformar las bases sociales de esta capacidad de cuestionamiento a los sectores del poder. Corresponde, entonces, entender el conjunto de acciones como un proceso social regresivo que excedió a los militares y a los tecnócratas neoliberales que ocuparon el Estado, y que, por el contrario, tuvo múltiples agentes a lo largo de casi todas las instituciones sociales, accionando para disciplinar y producir un nuevo orden ${ }^{12}$. Luego, el primer gobierno democrático no pudo, o no quiso, alterar la situación estructural heredada, mientras que la siguiente gestión profundizó las políticas neoliberales desmantelando a los restos del Estado de Bienestar y reconfigurando la sociedad argentina en torno a la construcción de la hegemonía del gran capital nacional e internacional ${ }^{13}$.

El sector agrario no fue ajeno a este proceso, e incluso varios de sus actores tuvieron un lugar prominente en el mismo. Así, los sectores más tradicionales, conformados por terratenientes-capitalistas, encabezaron las acciones tendientes a frenar los intentos reformistas, $\mathrm{y}$, luego, apoyaron y/o formaron parte de los gobiernos que promovieron los proceso de concentración de la producción y la desregulación estatal, como reseñamos brevemente a continuación.

Con la llegada del peronismo al gobierno, en 1973, y con Horacio Giberti a cargo de la Secretaría de Agricultura y Ganadería, se intentó plasmar una política reformista para el agro. En principio, se apelaba a un instrumento tributario que esperaba promover el incremento de la producción, al tiempo que estimular la fragmentación de los latifundios improductivos: el impuesto a la renta normal potencial

\footnotetext{
12 Para un análisis detallado de este proceso social regresivo, ver Villarreal (1985).

13 Sobre estas cuestiones, puede consultarse Balsa (2001).
} 
de la tierra (de antecedentes previos en los gobiernos de Illia y del propio Onganía) ${ }^{14}$. En el contexto de fuerte movilización popular y radicalización que caracterizaron a dicho año, este impuesto fue aprobado por ambas Cámaras. Analizando los discursos de los legisladores, podemos ver con qué facilidad la retórica reformista para el agro -que estuvo presente desde los años treinta o cuarenta en las plataformas partidarias de los partidos mayoritarios- se entroncó con el clima "revolucionario" del año $1973^{15}$. En un comienzo, únicamente la CRA, y particularmente la CARBAP, se opusieron frontalmente, en un tono abiertamente maccartista ${ }^{16}$, a las políticas impulsadas por Giberti (incluso la SRA había firmado el Acta de Compromiso que incluía entre otras cláusulas el mencionado impuesto ${ }^{17}$ ). Murmis (1979) ha analizado cómo fueron los terratenientes-capitalistas medianos, con menor capital que los representados por la Sociedad Rural Argentina, y por ende más dependientes de la renta del suelo, quienes fueron la punta de lanza contra el proyecto reformista, que finalmente naufragó ${ }^{18}$. Para

14 Además habían elaborado un anteproyecto de "Ley Agraria" que preveía medidas más drásticas contra los latifundios improductivos y que pese a una primera aprobación en la Comisión de Política Concertada, luego fue repudiada por casi todos los sectores (incluso la CGE), excepto la FAA (ver Villar Araujo, 1974: 20).

15 Cámara de Diputados de la Nación, Diario de Sesiones, 1973, Tomo III, pp. 1612-1638

16 La CARBAP se retiró de la Comisión Nacional de Política Concertada con el Agro y el Sector Forestal, en septiembre de 1973 (ver "Fundó CARBAP su oposición al acuerdo", La Nación, 7/9/73, p. 6), y en junio de 1974 el Consejo Directivo de CARBAP denunció ante el Presidente Perón "la infiltración ultraizquierdista existente a nivel de la Secretaría de Agricultura y Ganadería, por sabotear sistemáticamente la producción" y por "el proyecto de ley agraria que deliberadamente lesiona los legítimos intereses de todo productor agropecuario abriendo ancho cause a la arbitrariedad y a la fractura del ordenamiento jurídico vigente, promoviendo con irresponsabilidad la desunión y quizá la violencia en la comunidad nacional" (CARBAP, Memoria y Balance, $41^{\circ}$ Ejercicio. $1^{\circ}$ de Abril de 1973 al 31 de Marzo de 1974. Buenos Aires, 1974: 25-27, y Memoria y Balance, $42^{\circ}$ y $43^{\circ}$ Ejercicios. $1^{\circ}$ de Abril de 1974 al 31 de Marzo de 1976. Buenos Aires, 1976: 42-43). En esta última publicación, se reseñan, además, las declaraciones y denuncias contra la "Ley Agraria".

${ }^{17}$ Ver "El acta con las pautas políticas para el agro", La Nación, 7/9/73, p.6.

18 Los títulos de los editoriales de los Anales de la SRA son un rápido indicio de cómo esta entidad fue girando hacia posiciones de mayor confrontación con la política impulsada por Giberti a medida que el clima político nacional también iba cambiando: "La contribución del agro en la hora actual" (mayo de 1973), "La prudencia" (junio-julio de 1973), "La incognita de una opción" (agosto de 1973), "Palermo y las temperaturas" (septiembre-octubre de 1973), "1974: Hacia la Argentina potencia?" (noviembre-diciembre de 1973), "Amor no correspondido" (enero-febrero de 1974), "Emergencias sumergidas" (marzo-abril de 1974), "El abogado ausente" [porque Giberti no actuaba como defensor del sector] (mayo-julio de 1974), "La 'Ley agraria' y la inseguridad jurídica" (agosto de 1974), y "Un deseable reencuentro" (septiembre-octubre de 1974), cuando Giberti se había alejado de la Secretaría. 
entender, en parte, la derrota de este proyecto, además de considerar el giro que tomó la política nacional con la presidencia de Perón, primero, y la de Isabel, luego, tenemos que tener en cuenta que la estructura agraria de comienzos de los setenta, ya no era la de los años cuarenta, con un numeroso sector de arrendatarios y aparceros dispuestos a movilizarse contra los terratenientes ausentistas, al tiempo que el peso de éstos se había reducido notoriamente y se había incrementado el de los terratenientes-capitalistas medianos. Con Isabel Perón en la presidencia, cayó la gestión de Gelbard (Ministro de Economía) y Giberti, y se desmantelaron los equipos encargado de la instrumentación técnica del impuesto. Por último, en septiembre de 1976 los militares derogaron dicha ley.

Tanto la SRA como la CRA aportaron miembros a los gabinetes de la dictadura y apoyaron los objetivos de este gobierno cuya política agraria se basó en los principios liberal-conservadores de estas dos corporaciones (Lattuada, 2002) ${ }^{19}$. Más allá de las políticas coyunturales ${ }^{20}$ (cuyo análisis hemos dejado de lado en la presente tesis), la dictadura instrumentó dos tipos de medidas que repercutieron en la estructura agraria. Por un lado, decretó una reforma financiera que significó el fin de los crédito subsidiados para el agro (Fiorentino, 1984). Como resultado de esta desregulación, el porcentaje de carteras de productores agropecuarios con problemas financieros creció de sólo el 1\% en 1975, a alrededor del 18\% para 1982 (Giberti, 1994: 80).

Por otro lado, se comenzó a desarmar la estructura estatal de regulación de la producción y de colonización. En este sentido, en 1980 se disolvió el Consejo Agrario Nacional, entidad encargada de la colonización oficial (Pagliettini y otros, 2002: 32). En otros casos, sin llegar a su desmantelamiento, se afectó seriamente la capacidad de gestión de otros organismos. Por ejemplo, en la Junta Nacional de Granos se

19 En cambio la FAA fue afectada por las normas restrictivas denominadas "pausa gremial". De esta situación la entidad se enorgullecía, en tanto interpretaba que era la única entidad que en ser indirectamente reconocida como gremial agropecuaria. Por su parte, CONINAGRO recibió esperanzada el golpe militar y luego, aunque señaló discrepancias con la instrumentación de la política económica de la dictadura, mantuvo durante un largo período una clara adhesión a las ideas básicas del "Proceso" y su política represiva (Giberti, 2002: 129-130).

20 En un comienzo, la eliminación de las retenciones a las exportaciones y un dólar alto, mejoraron notoriamente los precios recibidos por los productores. Sin embargo, la fijación relativa del tipo de cambio, terminó en un dólar bajo, que redujo notoriamente dichos precios, en un contexto de caída de los precios internacionales (Pagliettini y otros, 2002: 20). 
privatizaron estructuras, se expulsó al personal más capacitado y se decretó una normativa legal que la enajenó de sus funciones principales de control e intervención (Lattuada, 2002). Asimismo, se decretó una nueva ley de contratos de arrendamientos y aparcerías (Ley 22.298, de octubre de 1980), que redujo el plazo mínimo de contrato a sólo tres años (recordar que hasta entonces era de cinco años con opción a tres más), suprimió la prohibición absoluta de subarrendar, y excluyó de las disposiciones de esta ley a los contratos accidentales de hasta dos cosechas como máximo, cuando se realicen en distinta superficie, al igual que los contratos para pastoreo por un plazo inferior a un año (Pagliettini y otros, 2002: 32).

La llegada de la democracia no revirtió completamente las políticas de la dictadura, tal vez por el predominio de un sesgo "productivista" en las esferas oficiales que regían la política económica y sectorial (León, 1991). Esto ya podía preverse si se analizaban las plataformas políticas de los principales partidos en la campaña electoral de 1983 (Lattuada, 2002: 9). Al comienzo del gobierno de Alfonsín se diseñó el PRONAGRO (Programa Nacional Agropecuario). El mismo tenía un perfil orientado al aumento de la producción exportable, mientras que las cuestiones estructurales ocupaban un lugar claramente secundario. Incluso estos temas (nueva legislación sobre arriendos accidentales, o planes de colonización para zonas extrapampeanas) nunca superaron la etapa de consultas previas y borradores de anteproyectos debido a la resistencia que generaba en los grandes propietarios (Lattuada, 2002: 9). Incluso la propuesta de crear un mecanismo estabilizador de los precios, frente a la alta vulnerabilidad a las fluctuaciones del mercado internacional (como existe en todos los países que son grandes productores y exportadores de granos) tuvo la férrea oposición de SRA y CRA. El gobierno logró el respaldo inicial de FAA y CONINAGRO para algunos proyectos; sin embargo, en la medida en que la situación del sector se vio afectada negativamente por decisiones tomadas en otros ámbitos del gobierno (el Ministerio de Economía o, incluso, la Secretaría de Comercio), la construcción de consensos para llevar adelante las propuestas fue cada vez más difícil ${ }^{21}$. El

${ }^{21}$ A partir de la campaña 1985/86 tuvo lugar una abrupta caída de la producción agrícola pampeana, que sería la respuesta de los productores frente a la reducción de los precios, debida a una disminución de los precios internacionales no compensada por una reducción de los derechos de exportación, combinada con expectativas negativas para el corto plazo y un mayor costo de oportunidad del capital. Las posteriores reducciones de estos derechos, no lograron reconstruir la confianza necesaria para mantener la dinámica expansiva de las 
PRONAGRO sería abandonado definitivamente en 1987, al asumir la SEAyG un hombre de confianza de los intereses tradicionales del agro. Del mismo modo, también naufragó el proyecto de un Impuesto a la Tierra Libre de Mejoras (Lattuada, 2002).

En síntesis, durante el gobierno de Alfonsín fracasaron los tibios intentos de regulación estatal en el sector agrario, como en el resto de la economía (incluso en los casos en los que se buscaron consensos con los grandes grupos económicos o las entidades representativas de los sectores más concentrados) y se desembocó en la coyuntura hiperinflacionaria de 1989. La salida menemista de esta situación, significó la profundización de las políticas neoliberales comenzadas por la dictadura. En el sector agrario impulsaron explícitamente la concentración de la producción y la desregulación completa del sector (así, por ejemplo, disolvieron la Junta Nacional de Granos y la Junta Nacional de Carnes; el INTA logró sobrevivir, pero con recursos muy disminuidos), pero estas cuestiones quedan ya fuera del período analizado ${ }^{22}$.

Sin lugar a dudas, durante la mayor parte de las décadas del setenta y ochenta, el Estado redujo su nivel de intervención en el sector y dejó a las pequeñas explotaciones a merced de la incidencia de las economías de tamaño y de otras adversidades económicas que las afectaron especialmente. El interrogante que queda planteado es hasta qué punto las pequeñas explotaciones pudieron sobrevivir en este contexto adverso y cuál fue la importancia del proceso de concentración de la producción.

décadas previas (Reca y Katz, 1991: 18-21).

22 Para mayores detalles ver Azcuy Ameghino (2000), y Barsky y Gelman (2002: 374-387). 


\section{3. ¿Cuán importante fue la concentración de la producción?}

Existen diferentes maneras de considerar el grado de concentración. A partir de los datos disponibles, podemos analizar la evolución del número total de unidades productivas, de la cantidad de unidades por intervalos de tamaño, y de los porcentajes de la superficie total agropecuaria por intervalo de tamaño (dejamos para el tercer apartado del presente capítulo el estudio de la concentración según la distribución de la superficie dedicada a la agricultura). A continuación presentamos las conclusiones de estos análisis, ya que los cuadros y el análisis más detallado los hemos transcripto en el Apartado 2 del Apéndice 3.

Si medimos la concentración a través de la evolución de la cantidad de explotaciones, nos encontramos con una importante reducción del número de unidades productivas. Incluso si dejamos de lado las unidades menores a 25 hectáreas (la drástica reducción en su número podría deberse en parte a distintos criterios censales de registro), en la zona norte en 1988 había un 22\% menos de explotaciones que en 1969, un $9 \%$ en la zona oeste, y en $16 \%$ en la zona sur.

Las explotaciones de 25 a 100 hectáreas fueron fuertemente afectadas por el proceso de concentración (según las zonas, entre un cuarto y dos quintos de las unidades de este intervalo desaparecieron durante las dos décadas analizadas, siendo la zona norte donde la reducción fue más intensa) En la zona sur, incluso las unidades medianas sufrieron un importante reducción en su número. En el extremo superior de la escala también observamos una reducción en la cantidad de explotaciones ${ }^{23}$. En cambio, los tipos de unidades que vieron incrementar significativamente su número fueron las explotaciones de 200 a 1.000 hectáreas en la zona norte, y las de 400 a 2.500 en el oeste y en el sur, especialmente las de 1.000 a 2.500 hectáreas.

Como las que desaparecieron fueron las unidades más pequeñas, la concentración no afectó a una porción tan importante de la superficie de cada área. El hecho de que la concentración de la superficie tuviera mayor importancia en la zona norte, caracterizada en 1969 por la importancia de las unidades pequeñas, condujo a

23 Las unidades de más de 2.500 hectáreas redujeron su número entre un $21 \%$ y un $37 \%$ según las zonas, aunque es probable que aquí los cambios del registro censal hayan llevado a agrupar unidades. Más detalles en el Apéndice 3 (Apartado 2). 
cierta reducción de las diferencias zonales. Sin embargo, debido a que no afectaron un porcentaje importante del área total, las disparidades no desaparecieron, y la estructura agraria resultante continuaba mostrando situaciones diferenciales entre las zonas. En la zona norte, casi todos los estratos de tamaño presentaban en 1988 un peso territorial importante. En las zonas oeste y sur, continuaron predominando las unidades de más de 400 hectáreas, un poco más grandes en la primera de las zonas ${ }^{24}$.

Resulta difícil sintetizar una única respuesta al interrogante que encabeza este apartado. Es indudable que las unidades pequeñas (especialmente hasta las 100 hectáreas) sufrieron una fuerte crisis durante estas dos décadas. Sin embargo, debido justamente al reducido tamaño de las explotaciones que desaparecieron, la concentración de la superficie agropecuaria no tuvo gran envergadura, aunque cabe acotar que en la zona norte afectó al 12\% de la superficie total, y que en las zonas oeste y sur ya en 1969 las grandes unidades controlaban buena parte del área.

Una breve comparación con la zona maicera norteamericana, nos permite tomar conciencia del grado de concentración que existía en la región pampeana. En el estado de Illinois, las unidades con más de 405 hectáreas, en 1987, ocupaban sólo el 26\% de la superficie del estado, y en el caso de Iowa, el 16\% (a pesar del fuerte proceso de concentración que había tenido lugar en el Corn Belt durante las décadas anteriores ${ }^{25}$ ). En cambio, en la zona norte bonaerense, las explotaciones con más de 400 hectáreas detentaban el 54\% del área, en 1988; y en las zonas oeste y sur, estos porcentajes se elevaban al $80 \%$ y el $81 \%$, respectivamente.

Un elemento que no debemos soslayar a la hora de considerar el proceso de concentración de la producción es el contratismo, que abordaremos con más detalle en el subsiguiente apartado. El contratismo habría tenido un papel dual. Por un lado, el

\footnotetext{
${ }^{24}$ Nuevamente, más detalles se encuentran en el Apéndice 3 (Apartado 2).

25 En 1940 las unidades de más de 405 hectáreas sólo habían tenido el 1\% de la superficie de Illinois y otro tanto en Iowa, según nuestros cálculos en base a los Census of Agriculture.
} 
contratismo de maquinaria ${ }^{26}$ puede haber favorecido la continuidad de explotaciones pequeñas (aunque esto no parece haber impedido la crisis de una gran proporción de estas unidades). Pero, por el otro lado, el contratismo tantero se constituyó en una forma que brindó la posibilidad de mantener la propiedad, aunque disociada de la producción. Cuando los requerimientos de capital y tierras se elevaron, y, al mismo tiempo, se desvanecían la mayoría de las medidas de protección y apoyo hacia los pequeños productores pampeanos, surgió la opción para los pequeños propietarios de ceder sus campos a contratistas tanteros ${ }^{27}$. Entonces la expansión de esta figura facilitó un fenómeno novedoso, al menos en el agro pampeano, la concentración de las unidades productivas pero con dispersión de la propiedad. De algún modo, y sin revertir por completo el proceso de simbiosis entre propiedad y producción, el desarrollo agrícola habría estimulado un proceso de constitución de sectores meramente rentísticos, pero muy diferentes por cierto de los grandes latifundistas que predominaban hacia 1937.

Pero antes de adentrarnos en el análisis de la tenencia del suelo y la estructura de la propiedad, estudiaremos el impacto de la concentración productiva en la organización social del trabajo.

\section{4. ¿Tuvo lugar una expansión de las relaciones de producción capitalistas?}

La desaparición de una gran cantidad de pequeñas explotaciones y la concentración de la superficie agropecuaria, podrían llevar a pensar que tuvo lugar una concentración de la producción en las unidades de tipo capitalista. Para poder avanzar en la medición de este fenómeno, deberíamos delimitar qué es una unidad claramente capitalista.

26 La contratación de servicios de maquinaria que se encargan, por lo general, de todas las actividades de la roturación y siembra o de la cosecha. Este fenómeno no es completamente nuevo en la región pampeana: recordemos la enorme importancia que tuvieron los contratistas de trilladoras, pero en estos casos, los productores realizaban todo el resto de las tareas de cosecha: sesgado, emparvado, acarreo de las bolsas, etc.

27 Campos que eran muy reducidos para una explotación económica capitalista, y, por entonces, muchos pequeños propietarios habían perdido sus características de productores familiares, desde donde hubieran podido resistir. 
Una primera aproximación, podría llevar a considerar como capitalistas a toda unidad que contrate mano de obra asalariada en forma permanente (de hecho resulta imposible comparar el peso de los asalariados temporarios entre ambos censos ${ }^{28}$ ). Entre 1969 y 1988, hubo una expansión de la importancia de este tipo de unidades. En la zona norte, las unidades que contrataban al menos un asalariado permanente pasaron de ser el 24\% del total de unidades en 1969 a representar el 44\% en 1988. En la zona oeste, crecieron del $34 \%$ al $50 \%$ de las explotaciones, y en el sur, del $38 \%$ al $58 \%$.

En términos de superficie censal, las explotaciones con al menos un asalariado permanente ocupaban el 58\% de la zona norte en 1969 y llegaron a dar cuenta del 76\% en 1988 (tal como puede observarse en el Cuadro 3.3). En la zona oeste este aumento fue del $76 \%$ al $86 \%$, y en la zona sur, del $65 \%$ al $84 \%$ del área. Sin embargo, resulta poco sostenible el criterio de caracterizar como capitalista a toda unidad que contrate asalariados, ya que obviamente, estaríamos catalogando como tales a muchas explotaciones en las que la mano de obra familiar realizaría un aporte muy superior al de un único asalariado permanente.

Como comentábamos en la Introducción, una posición diametralmente opuesta es la sostenida por Ghorayshi (1986), para quien las explotaciones agrarias capitalistas son aquellas en las que se emplea al menos a cinco asalariados. Si el límite inferior lo ubicamos en los cinco asalariados, es claro que no sólo presentaban una significación casi nula en términos de cantidad de unidades en ambos censos, sino que tampoco poseían una gran importancia territorial, excepto en la zona oeste, pero incluso allí la extensión que ocupaban se redujo entre 1969 y 1988, en vez de aumentar.

28 En 1969 se registraron los que trabajaban en el día del censo (el día 30 de septiembre). En 1988 se preguntó por la cantidad de jornales contratados a lo largo del año. 


\begin{tabular}{|c|c|c|c|c|c|c|c|c|c|}
\hline & \multicolumn{3}{|c|}{ Norte } & \multicolumn{3}{|c|}{ Oeste } & \multicolumn{3}{|c|}{ Sur } \\
\hline & 1969 & 1988 & & 1969 & 1988 & & 1969 & 1988 & \\
\hline $\begin{array}{l}\text { Sin asal } \\
\text { perm }\end{array}$ & $42.10 \%$ & $23.60 \%$ & $-18.50 \%$ & $23.80 \%$ & $13.60 \%$ & $-10.20 \%$ & $34.80 \%$ & $16.40 \%$ & $-18.40 \%$ \\
\hline $\begin{array}{l}1-2 \text { asal } \\
\text { perm }\end{array}$ & $23.10 \%$ & $44.20 \%$ & $21.10 \%$ & $22.30 \%$ & $36.50 \%$ & $14.20 \%$ & $25.60 \%$ & $47.90 \%$ & $22.30 \%$ \\
\hline $\begin{array}{l}\text { 3-4 asal } \\
\text { perm }\end{array}$ & $10.30 \%$ & $14.60 \%$ & $4.30 \%$ & $11.20 \%$ & $14.90 \%$ & $3.70 \%$ & $12.50 \%$ & $11.20 \%$ & $-1.30 \%$ \\
\hline $\begin{array}{l}5 \text { y más } \\
\text { asal perm }\end{array}$ & $24.40 \%$ & $17.60 \%$ & $\begin{array}{l}-6.80 \% \\
\end{array}$ & $42.80 \%$ & $35.00 \%$ & $-7.80 \%$ & $27.10 \%$ & $24.50 \%$ & $-2.60 \%$ \\
\hline & $100.00 \%$ & $100.00 \%$ & & $100.00 \%$ & $100.00 \%$ & & $100.00 \%$ & $100.00 \%$ & \\
\hline
\end{tabular}

Fuente: Reprocesamiento de los datos originales de los Censos Agropecuarios de 1969 y 1988.

Frente a estas posiciones extremas, hemos tomado un criterio intermedio incluyendo como claramente capitalistas a todas las unidades con tres o más asalariados permanentes. En estos casos, incluso contabilizando al productor y a un familiar ${ }^{29}$, el trabajo asalariado sería la mayoría de las veces superior a la mano de obra familiar. Con este criterio, en la zona oeste la mitad de la superficie agropecuaria estaría a cargo de este tipo de productores. Sin embargo, en la zona norte tan sólo un 32\% del área podría considerarse en manos de empresas capitalistas, y en la zona sur un $36 \%$. Incluso, en las tres zonas, el área ocupada por este tipo de unidades capitalistas sería levemente inferior a la que tenían en $1969^{30}$.

El fenómeno que resulta más notorio en relación con las transformaciones en la composición de la fuerza de trabajo rural es el incremento de la superficie agropecuaria a cargo de unidades que contrataban uno o dos asalariados permanentes ${ }^{31}$. Estas

29 Lamentablemente la información censal nada nos dice respecto del aporte de trabajo físico por parte del productor y sus familiares, tan sólo consignan en número de familiares "que trabajan", y descuentan que el productor lo hace, ya que no diferencian las tareas físicas, de las de dirección, por ejemplo.

30 En cantidad de explotaciones la proporción de establecimientos capitalista presentes en 1988 sería muy poco significativa: $6 \%$ en la zona norte, $11 \%$ en el oeste y $9 \%$ en el sur (en 1969 , las cifras habría sido de $5 \%, 10 \%$ y $10 \%$ respectivamente).

31 Lo único que sabemos es que para 1969, en alrededor del $70 \%$ de las unidades que se ubicaban en esta categoría, la cantidad de familiares del productor (excluyendo a éste) que se consignaron como trabajando no alcanzaba al $20 \%$ de la sumatoria de familiares y asalariados permanentes. Sin embargo, en el $75 \%$ de estas explotaciones sin peso del trabajo de los familiares del productor, sólo se contrataba un asalariado permanente (en el resto se tomaban dos); por lo cual, si el productor realizaba tareas manuales, los aportes familiares y asalariados podrían ser equiparables. Las cifras para 1988 sólo se modifican levemente: el $83 \%$ de las unidades "familiares con asalariados" presentaban un aporte menor al $20 \%$ por 
unidades podrían caracterizarse como "familiares con asalariados". Suponemos que en algunos casos los asalariados prestarían un apoyo a la fuerza de trabajo familiar (ya que si tanto el productor como uno o dos hijos varones realizaban trabajo físico, su aporte habría superado a la fuerza de trabajo asalariada). Sin embargo, en otros casos serían unidades basadas en la fuerza de trabajo asalariada (el productor realizaría sólo tareas de dirección y apoyo logístico al trabajo asalariado).

Sobre la cuestión del aporte de trabajo físico por parte del productor contamos con los datos de la encuesta a productores rurales de Pergamino y Colón realizada por INTA/CEIL a mediados de los años ochenta ${ }^{32}$. En ella se encontró que un importante porcentaje de productores a cargo de unidades pequeñas o sus familiares no realizaban labores físicas. Así, en Pergamino incluso en el estrato de 20 a 70 hectáreas el 20,9\% de los propietarios o familiares que trabajaban sólo realizaban tareas administrativas (y no físicas), y en el estrato de 71 a 200 hectáreas este porcentaje era del 18,2\%

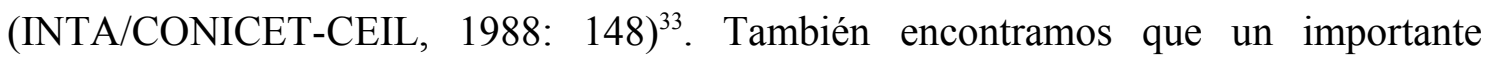
porcentaje de familiares del productor que declararon trabajar en la explotación sólo lo hacían menos de 100 días por año, incluso en las unidades de menor tamaño: en las de 20 a 70 hectáreas, el 32,5\%, y en las de 71 a 200, el 36,4\% (INTA/CONICET-CEIL, 1988: 142$)^{34}$.

Entonces, careciendo de información confiable sobre el verdadero aporte de trabajo físico del productor o los miembros de su familia es imposible estimar el peso de uno o dos asalariados permanentes sobre el total del trabajo realizado. Por estas consideraciones que nos limitaremos a denominar a las unidades con esta cantidad de asalariados como "explotaciones con uno o dos asalariados", aunque en los gráficos y

parte de los familiares, y en estas explotaciones un $70 \%$ contrataban un sólo asalariado permanente en las zonas norte y sur, y un $44 \%$ en el oeste.

32 Los detalles de esta importante investigación y el cuestionario aplicado se encuentran en INTA/CONICET-CEIL (1986).

33 El porcentaje de propietarios y familiares que sólo realizan tareas administrativas se elevaba notoriamente en los siguientes estratos de tamaño: $50 \%$ en el de 201 a 400 hectáreas, $44,4 \%$ en el de 401 a 800 , y $94,7 \%$ en el de más de 800 hectáreas. Para el caso de Colón los porcentajes presentan la misma tendencia (INTA/CONICET-CEIL, 1988: 148).

${ }_{34}$ De este modo, deben relativizarse ciertas conclusiones de este mismo trabajo cuanto llama la atención sobre la importancia que guardaba la organización laboral basada en fuerza de trabajo familiar aun en las unidades productivas de hasta 800 hectáreas en propiedad en Pergamino (INTA/CONICET-CEIL, 1988: 35). 
cuadros conservemos la denominación "familiar con asalariados" para permitir su comparación con la misma categoría utilizada para el análisis de los censos anteriores.

Lo cierto es que este tipo de unidades con uno o dos asalariados permanentes, en muchos casos "mixtas" en cuanto a la composición de su mano de obra, pasaron de tener el $23 \%$ de la superficie de la zona norte a controlar el $44 \%$. En la zona oeste pasaron del $22 \%$ al $37 \%$, y en la zona sur, del $26 \%$ al $48 \%$.

En síntesis, podemos decir que, en los años setenta y ochenta, tuvo lugar un desarrollo de la producción en base a formas que contrataban un pequeño número de asalariados (tal vez combinándolos con trabajo familiar), a costa de las unidades familiares $\sin$ asalariados permanentes, mientras que las unidades claramente capitalistas mantuvieron la significación territorial que tenían al comienzo del período.

\section{5. ¿Cuán importantes fueron los cambios en las formas de tenencia del suelo?}

Como reseñábamos al comienzo del capítulo, la mayoría de los autores han destacado al contratismo tantero como la forma de tenencia característica de estas décadas. La primer dificultad que encontramos para testear esta visión es que el contratismo no ha sido registrado del mismo modo en ambos censos. En el de 1969 se distinguieron los arriendos y las aparcerías con contrato menor de un año, de aquellos con contratos por uno año o más ${ }^{35}$. En cambio, el "contrato accidental" catalogado en 1988 hacía referencia a la adquisición del uso y goce de un predio por dos años o menos. A pesar de estas limitaciones para la comparación intercensal, daremos una mirada a los datos disponibles.

En el caso de 1969, los contratos por menos de un año ocupaban alrededor de un tres por ciento del total de las zonas (más específicamente, el 2,8\% de la zona norte, el 2,3\% de la zona oeste y el 3,1\% del sur). En cambio, para 1988 encontramos que los contratos accidentales tenían significación diferencial según las zonas, dando cuenta del

35 Es muy probable, tal como lo señala Llovet (1988: 279), que buena parte de los contratistas fueran también incluidos en otras formas residuales de tenencia. Al respecto, según nuestros cálculos en 1969 las unidades catalogadas como "ocupante en otras formas con permiso" y "ocupante de hecho" sumaban alrededor del $4 \%$ de la superficie total de cada zona. 
$17 \%$ de la zona norte, el 1\% de la zona oeste y el $8 \%$ de la zona sur. Es claro que, más allá de los criterios distintos de registro, el contratismo tantero se había expandido en la zona norte, algo en el sur, y no tenía casi relevancia en la zona oeste.

Pero, más allá del papel de contratismo, ¿qué aconteció con las otras formas de tenencia? Para responder este interrogante, hemos cotejado, la importancia de las formas de tenencia según el peso de la tenencia en propiedad: explotaciones totalmente en propiedad, aquéllas donde la propiedad se combinaba con parcelas en arriendo, aparcería, contratismo u otras formas de tenencia (ya sea en forma mayoritaria o minoritaria), y las unidades en las cuales toda la superficie estaba en formas no $\operatorname{propietarias}^{36}$.

En principio, no hemos detectado modificaciones en la tenencia del suelo de la envergadura de las acaecidas en el período anterior. Observamos que en la zona norte se expandió la superficie controlada por los que combinaban otras formas de tenencia con una parcela menor en propiedad (incrementaron su superficie en un 9\% del área total), mientras que perdía significación la propiedad pura (ver Cuadro 3.4). En cambio, en la zona oeste esta última forma incrementó su importancia $(6 \%)$, ante la reducción de la superficie controlada por los no propietarios. En el sur, también perdieron peso este último tipo de productores, pero se incrementó la importancia de las formas mixtas de tenencia (para mayores detalles, consultar el Cuadro 3.4).

36 Incluimos en el primer grupo a los productores que tenían al menos el $90 \%$ del tamaño total de su explotación bajo el régimen de propiedad; en el segundo grupo ubicamos a los que tenían en propiedad entre el $50 \%$ y el $90 \%$; en el tercero, a los que tenían entre el $10 \%$ y el $50 \%$, y en el último, a los que eran dueños de menos del $10 \%$ del tamaño total de su unidad productiva. 
Cuadro 3.4. Distribución de la superficie agropecuaria según la tenencia del suelo

\begin{tabular}{|l|r|r|r|r|r|r|r|r|r|}
\hline & \multicolumn{3}{|c|}{ Norte } & \multicolumn{3}{c|}{ Oeste } & \multicolumn{3}{c|}{ Sur } \\
\hline & $\mathbf{1 9 6 9}$ & $\mathbf{1 9 8 8}$ & difer. & $\mathbf{1 9 6 9}$ & $\mathbf{1 9 8 8}$ & difer. & $\mathbf{1 9 6 9}$ & $\mathbf{1 9 8 8}$ & difer. \\
\hline Propietarios & $60.30 \%$ & $51.90 \%$ & $-8.40 \%$ & $66.00 \%$ & $72.20 \%$ & $6.20 \%$ & $55.90 \%$ & $54.90 \%$ & $-1.00 \%$ \\
\hline $\begin{array}{l}\text { Propietario y } \\
\text { otras formas }\end{array}$ & $12.90 \%$ & $12.80 \%$ & $-0.10 \%$ & $10.40 \%$ & $12.40 \%$ & $2.00 \%$ & $13.60 \%$ & $20.10 \%$ & $6.50 \%$ \\
\hline $\begin{array}{l}\text { Otras formas y } \\
\text { propietario }\end{array}$ & $9.60 \%$ & $18.10 \%$ & $8.50 \%$ & $7.00 \%$ & $7.50 \%$ & $0.50 \%$ & $10.40 \%$ & $13.20 \%$ & $2.80 \%$ \\
\hline No propietario & $17.20 \%$ & $17.20 \%$ & $0.00 \%$ & $16.50 \%$ & $8.00 \%$ & $-8.50 \%$ & $20.20 \%$ & $11.80 \%$ & $-8.40 \%$ \\
\hline & $100 \%$ & $100 \%$ & & $100 \%$ & $100 \%$ & & $100 \%$ & $100 \%$ & \\
\hline
\end{tabular}

Nota: Propietario y otras formas, incluye a las explotaciones con más del 50\% de la superficie en propiedad, y el resto con otras formas de tenencia.

Otras formas y propietario, comprende a las unidades con más del 50\% de la superficie en no-

propiedad, y el resto en propiedad.

Fuente: Reprocesamiento de los datos originales de los Censos Agropecuarios de 1969 y 1988.

\section{6. ¿Se concentró la propiedad de la tierra o continuó el proceso de subdivisión del período anterior?}

En líneas generales podemos decir que continuó un proceso de fragmentación de la propiedad, aunque menos intenso que en las décadas anteriores.

Recordemos que hemos analizado la evolución de las propiedades de los tres partidos arquetípicos de cada zona (Pergamino, Rivadavia y Tres Arroyos), a partir del estudio de los mapas rurales de los años sesenta y finales de los ochenta (1960 y 1989 para Pergamino, 1964 y 1988 para Rivadavia, y 1964 y 1989 para Tres Arroyos). Hemos analizado una muestra de 100 propiedades en Pergamino y Tres Arroyos, y de 50 propiedades en Rivadavia, pero luego, para aumentar la precisión, hemos estudiado la totalidad de las propiedades de más de 1.000 hectáreas en Pergamino, y de más de 2.500 en Rivadavia y Tres Arroyos.

Antes de describir lo acontecido en cada partido, debemos aclarar una falencia de nuestra metodología, particularmente problemática para este segundo período: no da totalmente cuenta de la subdivisión ficticia de los campos, a los efectos de lograr una elusión impositiva (sobre la importancia de estas maniobras, ver Martínez de Ibarreta y 
Pucciarelli, 1992). Si bien hemos agregado todas las parcelas linderas a nombre de un mismo propietario, se nos escapan todas las divisiones realizadas entre los miembros de una misma familia y las parcelas no colindantes.

En el caso de Pergamino, tal como podemos observar en el Gráfico 3.4, tuvo lugar un aumento en la importancia de las propiedades de menos de 200 hectáreas (que absorbieron el 16\% del área total del partido), en detrimento de las mayores de 1.000 hectáreas (que perdieron el 11\%). Como resultado del largo proceso de desconcentración de la propiedad, este último estrato, que en 1939 detentaba el 46\% de la superficie del partido y en 1960 retenía el 22\%, en 1989, sólo tenía el 11\%.

\section{Gráfico 3.4.}

\section{Pergamino, supeficie en propiedades}

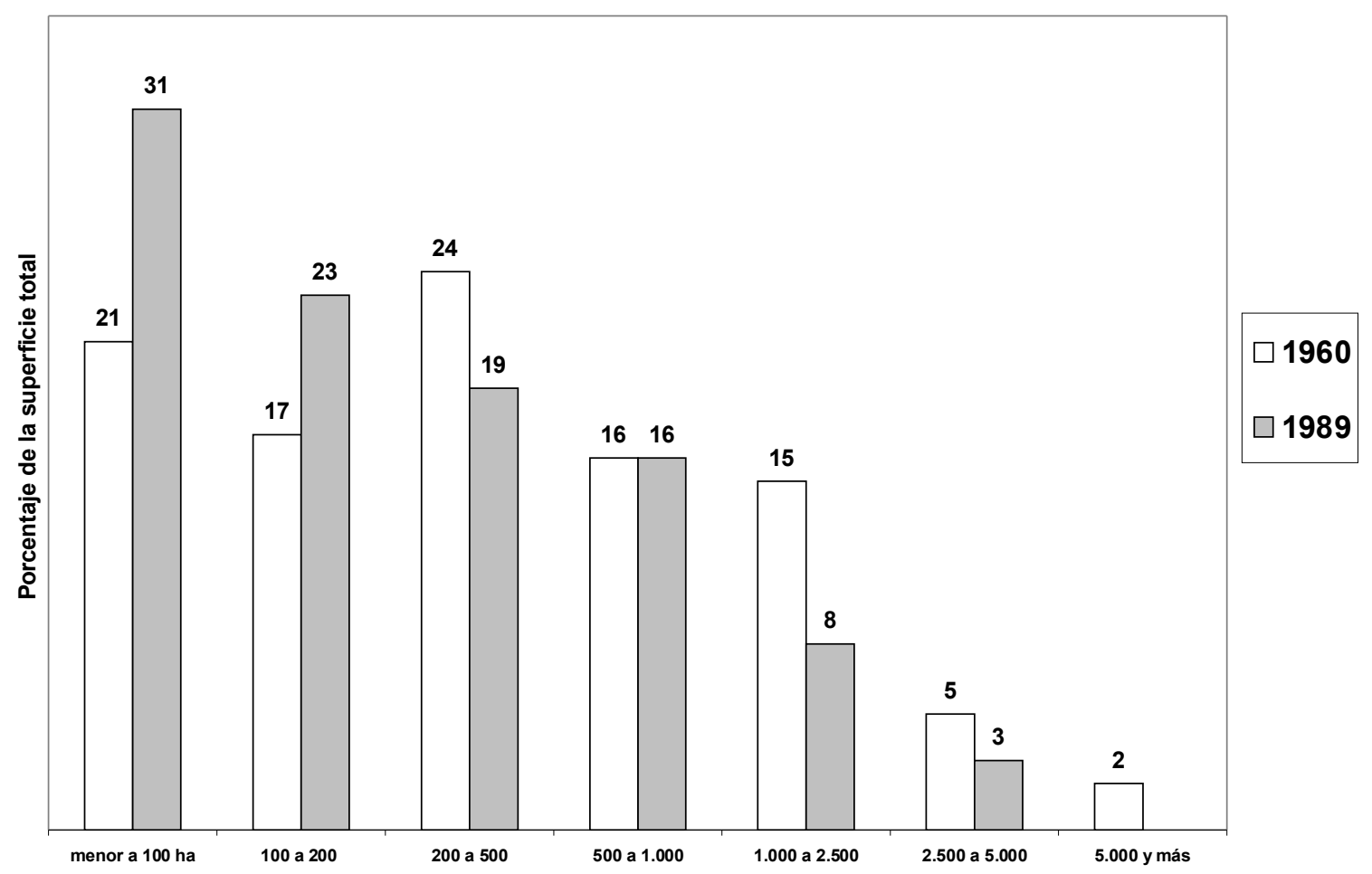

Fuente: Estimaciones propias a partir de los Mapas Rurales de 1960 y 1988. 
El fraccionamiento de las propiedades con más de 1.000 hectáreas, dio lugar a la aparición de 197 nuevas propiedades ${ }^{37}$. Es posible que alguna porción de estos fraccionamientos estén revelando un último proceso de subdivisión de las grandes propiedades en favor de los chacareros arrendatarios, todavía presentes en 1960. Por debajo de las 1000 hectáreas la mitad de los campos se mantuvieron con los tamaños de 1960, aumentando los procesos de fusión a medida que disminuye el tamaño. Sin embargo, predominó una tendencia desconcentradora de la propiedad que generó el comentado incremento en el peso territorial de las propiedades de menos de 200 hectáreas. Para más detalles de las transformaciones en las propiedades, ver el Cuadro 3.5 .

Cuadro 3.5. Transformaciones en la propiedad de la tierra, Pergamino, 1960 a 1988. Cantidad de propiedades.

\begin{tabular}{|l|l|c|l|l|l|l|l|}
\hline & \multicolumn{6}{|l|}{ Transformación } & \multicolumn{6}{l|}{ Evolución de las propiedades de 1960 } \\
\hline Tamaño & 1960 & $\begin{array}{c}\text { para } \\
1988 \\
\text { dieron } \\
\text { lugar a: }\end{array}$ & fusión & igual & $\begin{array}{l}\text { subdivi- } \\
\text { sión en } \\
2,3 \text { ó 4 }\end{array}$ & $\begin{array}{l}\text { subdivi- } \\
\text { sión en a 10 } \\
5 \text { and } \\
\text { prop. }\end{array}$ & $\begin{array}{l}\text { subdivi- } \\
\text { sión en } \\
\text { más de } \\
11 \text { prop. }\end{array}$ \\
\hline+5000 & 1 & 36 & - & - & - & - & 1 \\
\hline $2501-5000$ & 5 & 38 & - & 2 & 1 & - & 2 \\
\hline $1001-2500$ & 32 & 161 & - & 15 & 2 & 10 & 5 \\
\hline $501-1000$ & 70 & 132 & 4 & 40 & 22 & 4 & \\
\hline $201-500$ & 240 & 540 & 40 & 80 & 90 & 30 & \\
\hline $101-200$ & 353 & 662 & 42 & 187 & 83 & 41 & \\
\hline-100 & 1431 & 1576 & 338 & 750 & 340 & & \\
\hline Total & 2132 & 3145 & 424 & 1074 & 538 & 85 & 8 \\
\hline
\end{tabular}

Fuente: Estimaciones propias a partir de los Mapas Rurales de 1960 y 1988.

37 La única propiedad de más de 5.000 hectáreas presente en 1960, aparece dividida en 36 lotes para 1989. Del mismo modo, de las cinco propiedades de 2.500 a 5.000 hectáreas: dos se mantuvieron inalteradas, otra se partió en dos, una cuarta mantuvo un núcleo inalterado, pero fraccionó sus áreas linderas generando 23 pequeños lotes, y la restante se fraccionó en 11 propiedades 


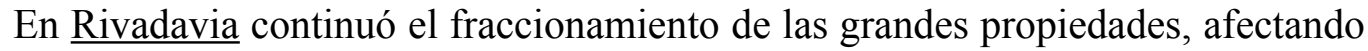
a dos tercios de los campos de más de 2500 hectáreas $^{38}$. Entre las propiedades menores a este tamaño, la mitad permanecieron iguales, pero una proporción importante se subdividió en dos a cuatro parcelas. Por debajo de las 500 hectáreas hubo importantes procesos de fusión (ver Cuadro 3.6).

Como resultados de estas trayectorias, las propiedades de más de 5.000 hectáreas perdieron significación en el conjunto de la superficie del partido (recordar que en 1939 detentaban el 36\% del área), pero no ocurrió lo mismo con las de 2.500 a 5.000 hectáreas. Y, a pesar de los procesos de fusión, en el Gráfico 3.5, observamos un aumento importante de la superficie que detentaban las propiedades de 100 a 200 hectáreas (y algo menos, de las de 200 a 500). Evidentemente, las subdivisiones ficticias o hereditarias habrían superado la incidencia de los procesos de fusión.

Cuadro 3.6. Transformaciones en la propiedad de la tierra, Rivadavia, 1964 a 1988. Cantidad de propiedades.

\begin{tabular}{|l|l|l|l|l|l|l|l|l|}
\hline & \multicolumn{6}{|l|}{ Transformación } & \multicolumn{6}{l|}{ Evolución de las propiedades de 1964 } \\
\hline Tamaño & 1964 & $\begin{array}{c}\text { para } \\
\text { dieron } \\
\text { lugar a: }\end{array}$ & fusión & igual & $\begin{array}{l}\text { subdivi- } \\
\text { sión en }\end{array}$ & $\begin{array}{l}\text { subdivi- } \\
\text { sión en ó }\end{array}$ & $\begin{array}{l}\text { subdivi- } \\
\text { prop. a }\end{array}$ & $\begin{array}{l}\text { sión en } \\
\text { más de } \\
\text { prop. } \\
11 \text { prop. }\end{array}$ \\
\hline+5000 & 4 & 28 & - & 1 & - & 2 & 1 \\
\hline $2501-5000$ & 13 & 48 & - & 5 & 5 & 3 & \\
\hline $1001-2500$ & 55 & 111 & 9 & 23 & 18 & 5 & \\
\hline $501-1000$ & 152 & 296 & 12 & 59 & 81 & & \\
\hline-500 & 363 & 388 & 119 & 162 & 82 & & \\
\hline Total & 587 & 871 & 140 & 250 & 186 & 10 & 1 \\
\hline
\end{tabular}

Fuente: Estimaciones propias a partir de los Mapas Rurales de 1964 y 1988.

38 Se fraccionaron tres de las cuatro propiedades que en 1964 tenían más de 5.000 hectáreas (generando cada una seis, siete y once propiedades de menor extensión). Entre las de $2.500 \mathrm{y}$ 5.000 hectáreas, la mayoría se mantuvo indivisa o se fraccionó en pocas propiedades, posiblemente por herencia. 


\section{Gráfico 3.5.}

Rivadavia, supeficie en propiedades

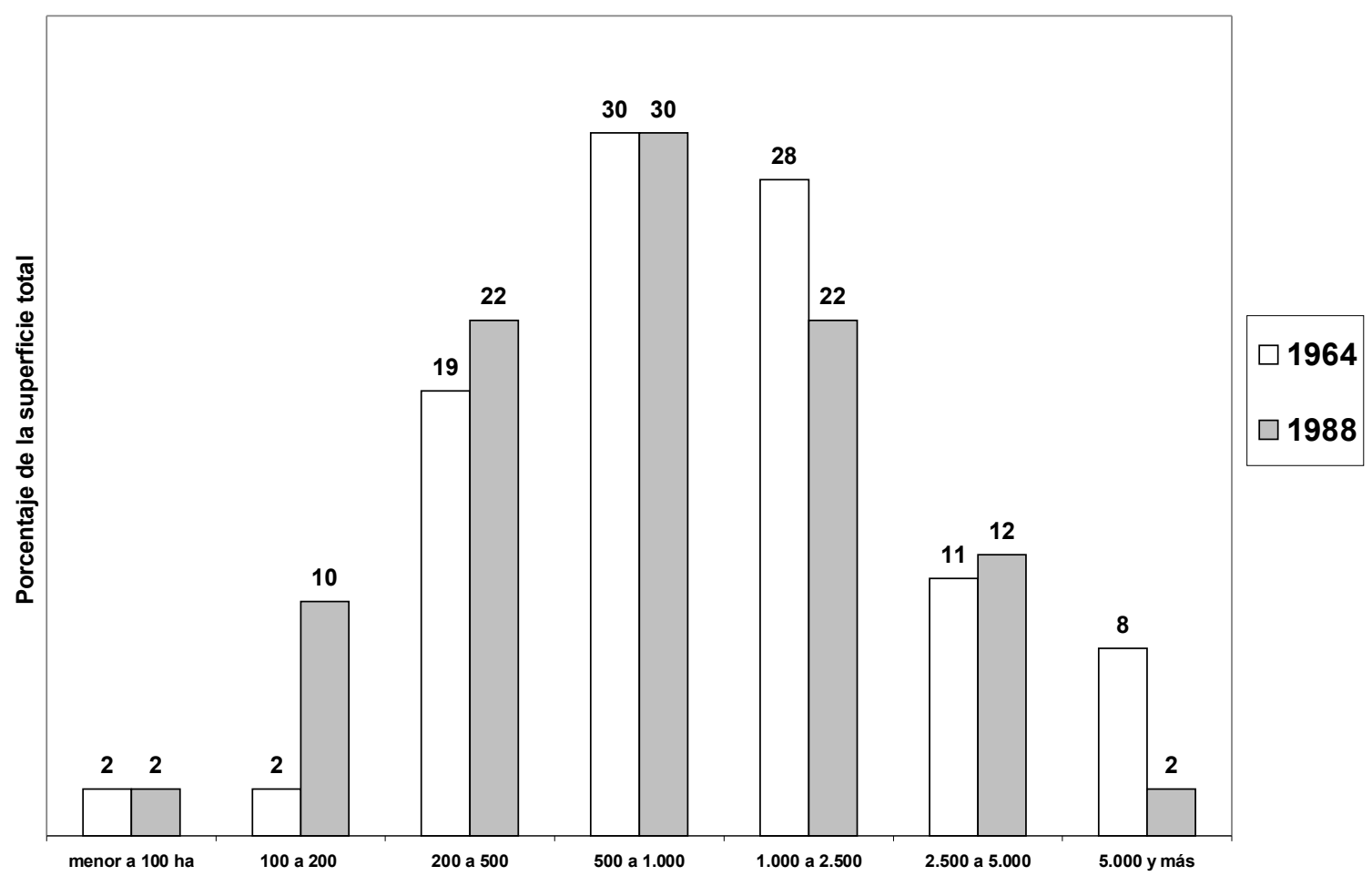

Fuente: Estimaciones propias a partir de los Mapas Rurales de 1964 y 1988.

En Tres Arroyos, el fraccionamiento afectó a buena parte de las propiedades mayores a 2.500 hectáreas, dando lugar a la aparición de 49 nuevas propiedades ${ }^{39}$ (ver Cuadro 3.7). En el estrato de 500 a 2500 hectáreas la mitad conservó su tamaño, mientras que la mayor parte del resto se dividió en dos a cuatro campos. Por debajo de las 500 hectáreas no hubo demasiadas transformaciones, la mayoría permaneció igual, pero los procesos de fusión se incrementaron en los niveles más bajos.

Analizando la distribución porcentual de la superficie total del partido (Gráfico 3.6.), observamos que las propiedades de más de 2.500 hectáreas casi no tenían

39 De las tres propiedades de más de 5.000 hectáreas presentes en 1964, una acrecentó levemente su superficie, otra se dividió en dos grandes porciones y la restante en once propiedades. En el caso de las doce propiedades de 2.500 a 5.000 hectáreas, tres se mantuvieron indivisas, cuatro se fraccionaron en dos a cuatro propiedades medianas, y las cinco restantes se dividieron en cinco a diez lotes cada una. 
significación en Tres Arroyos para 1989 (recordar que en 1937 todavía controlaban el $29 \%$ del partido, y en 1923, el 74\%). Incluso las propiedades de 1.000 a 2.500 hectáreas, que en el período 1939-1964 habían acrecentado levemente su importancia (del 32\% al 36\% de la superficie total), para 1989 habían reducido su extensión al 22\% del área del partido.

Cuadro 3.7. Transformaciones en la propiedad de la tierra, Tres Arroyos, 1964 a 1989. Cantidad de propiedades.

\begin{tabular}{|c|c|c|c|c|c|c|c|}
\hline & \multicolumn{2}{|c|}{ Transformación } & \multicolumn{5}{|c|}{ Evolución de las propiedades de 1964} \\
\hline Tamaño & 1964 & $\begin{array}{c}\text { para } \\
1989 \\
\text { dieron } \\
\text { lugar a: }\end{array}$ & fusión & igual & $\begin{array}{l}\text { subdivi- } \\
\text { sión en } \\
2,3 \text { ó } 4 \\
\text { prop. }\end{array}$ & $\begin{array}{l}\text { subdivi- } \\
\text { sión en } \\
5 \text { a } 10 \\
\text { prop. }\end{array}$ & $\begin{array}{l}\text { subdivi- } \\
\text { sión en } \\
\text { más de } \\
11 \text { prop. }\end{array}$ \\
\hline+5000 & 3 & 14 & 1 & - & 1 & - & 1 \\
\hline $2501-5000$ & 12 & 50 & - & 3 & 4 & 5 & - \\
\hline $1001-2500$ & 135 & 256 & 34 & 50 & 39 & 11 & 1 \\
\hline $501-1000$ & 224 & 379 & - & 118 & 105 & 1 & \\
\hline $201-500$ & 464 & 603 & 34 & 320 & 110 & & \\
\hline $101-200$ & 244 & 235 & 34 & 202 & 8 & & \\
\hline-100 & 135 & 118 & 34 & 101 & & & \\
\hline Total & 1217 & 1625 & 137 & 794 & 267 & 17 & 2 \\
\hline
\end{tabular}

Fuente: Estimaciones propias a partir de los Mapas Rurales de 1964 y 1989. 


\section{Gráfico 3.6.}

\section{Tres Arroyos, supeficie en propiedades}

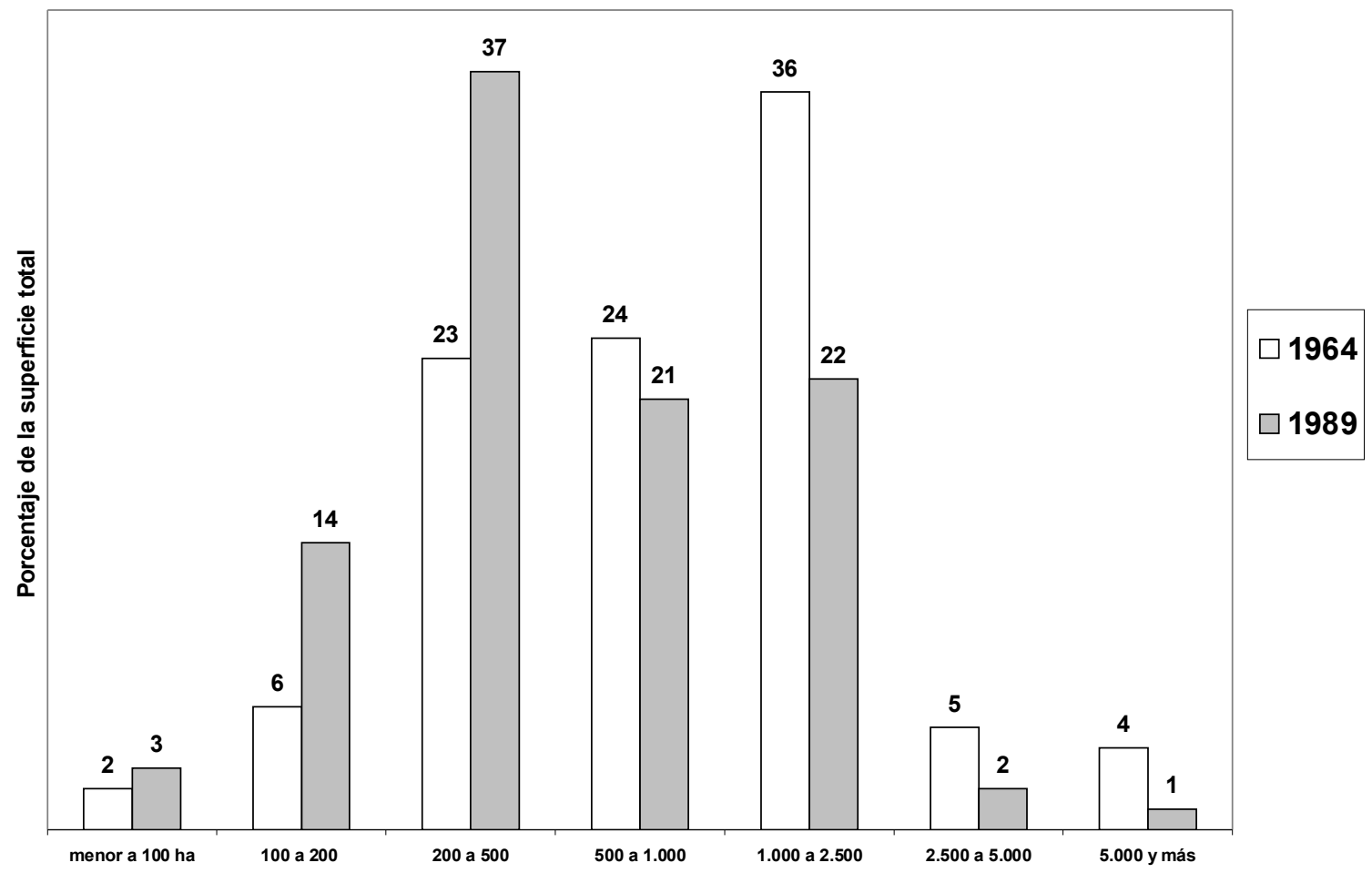

Fuente: Estimaciones propias a partir de los Mapas Rurales de 1964 y 1989.

\subsection{La propiedad de la tierra y las características de las unidades productivas} hacia 1988

Del mismo modo que para 1937 y para 1960, hemos calculado los "desfasajes" que surgían entre la estructura de la propiedad y la estructura productiva. Si en los años sesenta se había llegado a cierta armonización entre ambas, para finales de los ochenta el proceso de subdivisión de la propiedad a que hemos hecho referencia, combinado con el acrecentamiento del tamaño de las explotaciones, redundó en una concentración de la producción en unidades de mayor superficie que las propiedades. Sin embargo, debemos ser concientes que mientras que nuestro registro diferencia todas las 
propiedades a nombre del mismo propietario pero que no eran linderas en 1988 (como así también las puestas a nombres de familiares), el Censo Agropecuario Nacional de dicho año unificó en una misma explotación a todas las parcelas del mismo productor en toda la provincia.

A fines de los ochenta, en los tres partidos analizados las grandes y medianasgrandes explotaciones no tenían como contraparte grandes propiedades, y a la inversa, el área que ocupaban las pequeñas y medianas-pequeñas propiedades excedía a la que poseían estas unidades productivas (ver Cuadros 3.8 a a 3.10). Es decir, que había concentración de la producción sin concentración de la propiedad (aunque en parte este fenómeno puede estar ocultando las subdivisiones ficticias para evasión impositiva, a pesar de que en nuestro caso hemos agregado todas las parcelas linderas bajo el nombre de un mismo propietario).

En Rivadavia las unidades de más de 1000 hectáreas necesitaban, además de la superficie en propiedad de dicho estrato, una superficie equivalente al $27 \%$ del área del partido. En cambio, las propiedades de 100 a 1000 hectáreas excedían en dicho valor a la superficie ocupada por explotaciones de este tamaño.

En Pergamino los intervalos de unidades productivas más "deficitarios" eran el de 200 a 500 hectáreas y el de 1000 a 2500, mientras que las propiedades de menos de 200 hectáreas “cedían” un $25 \%$ del área del partido ${ }^{40}$.

En Tres Arroyos eran las unidades medianas-grandes las que reclamaban un plus del orden del $19 \%$ del partido, aportado por las propiedades de 100 a 500 hectáreas.

40 Según el estudio realizado por INTA/CONICET-CEIL (1988: 73) en Pergamino a mediados de los ochenta los propietarios de parcelas de 20 a 70 hectáreas cedían en arriendo el 32,3\% de su superficie (algunos arrendando parte y otros toda su pequeña propiedad), y en el caso de los propietarios de 71 a 200 hectáreas cedían el 45,7\% de su superficie. El estrato que menos cedía en arriendo era el de 401 a 800 hectáreas, que sólo entregaba el 7,9\%. Cabe aclarar que, al mismo tiempo, muchos pequeños propietarios (el $45 \%$ en el caso de los que tenían parcelas de 20 a 70 hectáreas) tomaban tierras en arriendo para obtener alguna escala (en este sentido pasaban a otro estrato, en términos de unidades productivas). Por otra parte, vemos que el $69 \%$ de la superficie que los pequeños propietarios cedían en arriendo era entregada a familiares de ellos, en procesos que intentaban mantener la explotación familiar original (INTA/CONICET-CEIL, 1988). 
Cuadro 3.8. Estructura de la propiedad y estructura de producción. Pergamino. Porcentajes del área total

\begin{tabular}{|c|c|c|c|c|c|}
\hline Extensión & $\begin{array}{c}\text { Unidades de } \\
\text { propiedad }\end{array}$ & $\begin{array}{c}\text { Unidades de } \\
\text { producción }\end{array}$ & $\begin{array}{c}\text { Tenencia en } \\
\text { propiedad } \\
\text { (estimac.) }\end{array}$ & $\begin{array}{c}\text { "sobrante" } \\
\text { (estimac.) }\end{array}$ & $\begin{array}{c}\text { "faltante" } \\
\text { (estimac.) }\end{array}$ \\
\hline$+5.000 \mathrm{ha}$ & - & $3 \%$ & - & - & $3 \%$ \\
\hline 2.500 a $4.999 \mathrm{ha}$ & $3 \%$ & $4 \%$ & $3 \%$ & - & $1 \%$ \\
\hline 1.000 a $2499 \mathrm{ha}$ & $8 \%$ & $15 \%$ & $8 \%$ & - & $7 \%$ \\
\hline 500 a $1.000 \mathrm{ha}$ & $16 \%$ & $16 \%$ & - & - & - \\
\hline 200 a 500 ha & $19 \%$ & $31 \%$ & $19 \%$ & - & $12 \%$ \\
\hline 100 a $200 \mathrm{ha}$ & $23 \%$ & $17 \%$ & $17 \%$ & $6 \%$ & - \\
\hline - 100 ha & $31 \%$ & $12 \%$ & $12 \%$ & $19 \%$ & - \\
\hline
\end{tabular}

Fuente: Estimaciones propias a partir de los Mapas Rurales de 1960 y 1988.

Cuadro 3.9. Estructura de la propiedad y estructura de producción. Rivadavia. Porcentajes del área total

\begin{tabular}{|c|c|c|c|c|c|}
\hline Extensión & $\begin{array}{c}\text { Unidades de } \\
\text { propiedad }\end{array}$ & $\begin{array}{c}\text { Unidades de } \\
\text { producción }\end{array}$ & $\begin{array}{c}\text { Tenencia en } \\
\text { propiedad } \\
\text { (estimac.) }\end{array}$ & $\begin{array}{c}\text { "sobrante" } \\
\text { (estimac.) }\end{array}$ & $\begin{array}{c}\text { "faltante" } \\
\text { (estimac.) }\end{array}$ \\
\hline$+5.000 \mathrm{ha}$ & $2 \%$ & $11 \%$ & $2 \%$ & - & $9 \%$ \\
\hline 2.500 a $4.999 \mathrm{ha}$ & $12 \%$ & $21 \%$ & $12 \%$ & - & $9 \%$ \\
\hline 1.000 a $2499 \mathrm{ha}$ & $22 \%$ & $31 \%$ & $22 \%$ & - & $9 \%$ \\
\hline 500 a $1.000 \mathrm{ha}$ & $30 \%$ & $15 \%$ & $15 \%$ & $15 \%$ & - \\
\hline 200 a $500 \mathrm{ha}$ & $22 \%$ & $14 \%$ & $14 \%$ & $8 \%$ & - \\
\hline $100 \mathrm{a} 200 \mathrm{ha}$ & $10 \%$ & $6 \%$ & $4 \%$ & $4 \%$ & - \\
\hline - 100 ha & $2 \%$ & $1 \%$ & $1 \%$ & $1 \%$ & - \\
\hline
\end{tabular}

Fuente: Estimaciones propias a partir de los Mapas Rurales de 1960 y 1988.

Cuadro 3.10. Estructura de la propiedad y estructura de producción. Tres Arroyos. Porcentajes del área total

\begin{tabular}{|c|c|c|c|c|c|}
\hline Extensión & $\begin{array}{c}\text { Unidades de } \\
\text { propiedad }\end{array}$ & $\begin{array}{c}\text { Unidades de } \\
\text { producción }\end{array}$ & $\begin{array}{c}\text { Tenencia en } \\
\text { propiedad } \\
\text { (estimac.) }\end{array}$ & $\begin{array}{c}\text { "sobrante" } \\
\text { (estimac.) }\end{array}$ & $\begin{array}{c}\text { "faltante" } \\
\text { (estimac.) }\end{array}$ \\
\hline$+5.000 \mathrm{ha}$ & $1 \%$ & $3 \%$ & $1 \%$ & - & $2 \%$ \\
\hline 2.500 a $4.999 \mathrm{ha}$ & $2 \%$ & $11 \%$ & $2 \%$ & - & $9 \%$ \\
\hline 1.000 a $2499 \mathrm{ha}$ & $22 \%$ & $30 \%$ & $22 \%$ & - & $8 \%$ \\
\hline 500 a $1.000 \mathrm{ha}$ & $21 \%$ & $28 \%$ & $21 \%$ & - & $7 \%$ \\
\hline 200 a $500 \mathrm{ha}$ & $37 \%$ & $21 \%$ & $21 \%$ & $16 \%$ & - \\
\hline 100 a $200 \mathrm{ha}$ & $14 \%$ & $4 \%$ & $4 \%$ & $10 \%$ & - \\
\hline - 100 ha & $3 \%$ & $2 \%$ & $2 \%$ & $1 \%$ & - \\
\hline
\end{tabular}

Fuente: Estimaciones propias a partir de los Mapas Rurales de 1960 y 1988. 


\section{Modificaciones en la producción agrícola}

\section{1. ¿Qué tamaño de explotaciones fue el responsable de la expansión agrícola?}

Como vimos en el primer apartado de este capítulo, en las zonas norte y oeste tuvo lugar una importante expansión de la superficie sembrada, aunque para la cosecha 1987/88 (relevada en el censo) se había operado una reducción en el área sembrada (más pronunciada en el caso de la zona oeste, afectada además por las inundaciones). En la zona sur, en cambio, a pesar del incremento en los volúmenes cosechados -gracias al aumento en los rendimientos de los cultivos- el área sembrada en 1987/88 era prácticamente igual a la de 1968/69 ${ }^{41}$. Pero, lo que aquí nos interesa es qué tamaño de explotaciones incrementaron la superficie que sembraban, y cuáles la disminuyeron.

En este sentido, en la zona norte la expansión agrícola fue principalmente obra de las unidades que podríamos denominar "medianas" (de 200 a 1.000 hectáreas) y no de las grandes unidades. Al mismo tiempo, las explotaciones pequeñas, de menos de 200 hectáreas, no pudieron aprovechar este proceso de agriculturización (especialmente las menores a 100 hectáreas). Un detalle de los datos por intervalo puede obtenerse en el Gráfico $3.7^{42}$.

${ }^{41}$ En las estimaciones agrícolas la superficie sembrada con trigo, maíz, lino, girasol, soja y cebada cervecera en ambas cosechas es la misma (2.103.200 hectáreas en 1968/69 y 2.103.150 en 1987/88; cabe consignar que en 1983/84 se habían sembrado 2.605 .770 hectáreas). En los datos de los relevamientos censales se presenta una leve reducción (7\%) del área sembrada con cultivos anuales, pero puede deberse al cómputo de algunos cultivos en 1969, que no fueron incluidos en 1988 dentro de esta categoría

42 En dicho gráfico se observa que las explotaciones de 200 a 1.000 hectáreas, que en 1969 sembraban para cosecha unas 272.000 hectáreas, para 1988 cultivaban 632.000. De modo que, la mayor parte de la expansión agrícola fue responsabilidad de las unidades de 200 a 1.000 hectáreas (concentraron el 69\% del incremento). Por su parte, las explotaciones con más de 1.000 hectáreas generaron una cuarta parte del crecimiento agrícola, mientras que las explotaciones de 100 a 200, un 13\%, y las de menos de 100 hectáreas redujeron la superficie que cultivaban. 


\section{Gráfico 3.7.}

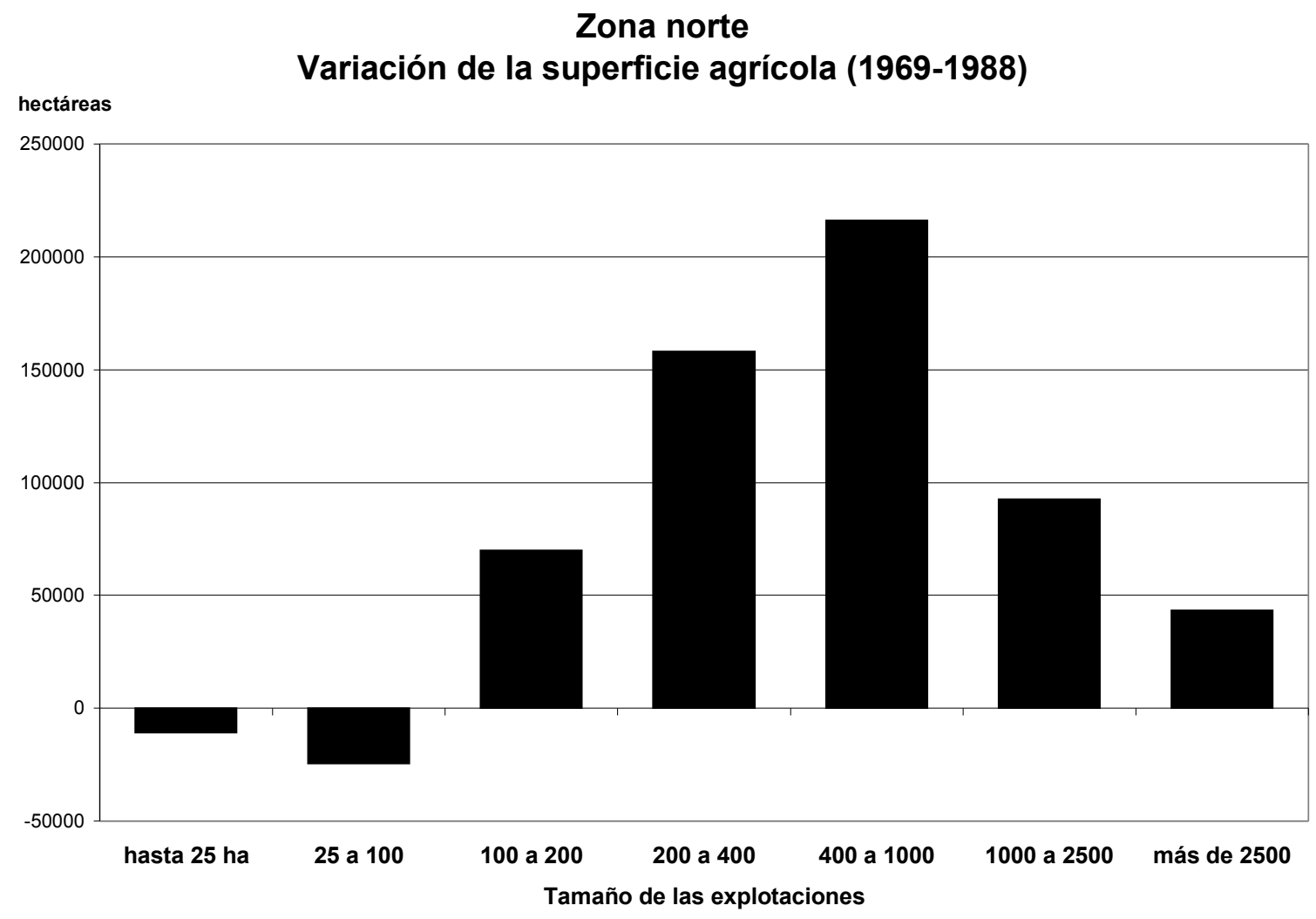

Fuente: Reprocesamiento de los datos originales de los Censos Agropecuarios de 1969 y 1988.

Como resultado de estos cambios tuvo lugar una concentración de la producción agrícola en la zona norte más intensa que la que sufrió el total de la superficie agropecuaria. Las unidades de más de 200 hectáreas incrementaron su peso en la producción agrícola, pasando de controlar el 51\% al 68\% de la misma. Por el contrario, las unidades por debajo de las 200 hectáreas redujeron su significación del 49\% al 32\% (tengamos presente que en 1937 habían controlado alrededor del 96\% de la agricultura de la zona norte $\left.{ }^{43}\right)$. Observando más detenidamente, podemos ver que las explotaciones que perdieron más protagonismo fueron las unidades de 25 a 100 hectáreas, y las que

43 Las metodología de estas estimaciones de la superficie agrícola según tipo de explotación para 1937 se encuentran en el Apéndice 1. 
más incrementaron su peso relativo en la superficie agrícola fueron las de 200 a 1.000 hectáreas (ver detalle en el Cuadro 3.11). Sin embargo, el resultado de este proceso de concentración, no implicó una homogenización de la agricultura de esta zona en torno a las grandes unidades. En la zona norte, alrededor de un tercio de la superficie agrícola seguía ubicándose en 1988 en las explotaciones de menos de 200 hectáreas. Las unidades medianas concentraban un $46 \%$, y las mayores a 1.000 , el $22 \%$ restante.

Cuadro 3.11. Distribución de la superficie agrícola según tamaño de las explotaciones

\begin{tabular}{|c|c|c|c|c|c|c|c|c|c|}
\hline & \multicolumn{3}{|c|}{ Norte } & \multicolumn{3}{|c|}{ Oeste } & \multicolumn{3}{|c|}{ Sur } \\
\hline & 1969 & 1988 & difer. & 1969 & 1988 & difer. & 1969 & 1988 & difer. \\
\hline hasta 25 ha & $3.50 \%$ & $1.30 \%$ & $-2.20 \%$ & $0.30 \%$ & $0.10 \%$ & $-0.20 \%$ & $0.40 \%$ & $0.10 \%$ & $-0.30 \%$ \\
\hline 25 a 100 & $26.60 \%$ & $14.20 \%$ & $-12.40 \%$ & $4.40 \%$ & $3.50 \%$ & $-0.90 \%$ & $3.20 \%$ & $1.90 \%$ & $-1.30 \%$ \\
\hline 100 a 200 & $18.50 \%$ & $16.30 \%$ & $-2.20 \%$ & $8.40 \%$ & $5.20 \%$ & $-3.20 \%$ & $9.10 \%$ & $5.90 \%$ & $-3.20 \%$ \\
\hline 200 a 400 & $15.00 \%$ & $20.40 \%$ & $5.40 \%$ & $11.80 \%$ & $8.20 \%$ & $-3.60 \%$ & $21.20 \%$ & $15.10 \%$ & $-6.10 \%$ \\
\hline 400 a 1000 & $18.00 \%$ & $25.80 \%$ & $7.80 \%$ & $24.30 \%$ & $17.90 \%$ & $-6.40 \%$ & $33.40 \%$ & $33.50 \%$ & $0.10 \%$ \\
\hline 1000 a 2500 & $12.30 \%$ & $14.80 \%$ & $2.50 \%$ & $22.90 \%$ & $23.70 \%$ & $0.80 \%$ & $19.90 \%$ & $26.30 \%$ & $6.40 \%$ \\
\hline más de 2500 & $6.00 \%$ & $7.20 \%$ & $1.20 \%$ & $27.80 \%$ & $41.30 \%$ & $13.50 \%$ & $12.90 \%$ & $17.20 \%$ & $4.30 \%$ \\
\hline & $100.00 \%$ & $100.00 \%$ & & $100.00 \%$ & $100.00 \%$ & & $100.00 \%$ & $100.00 \%$ & \\
\hline
\end{tabular}

Fuente: Reprocesamiento de los datos originales de los Censos Agropecuarios de 1969 y 1988. 
En la zona oeste, la expansión agrícola fue responsabilidad principalmente de las muy grandes unidades. Un detalle de estos cambios puede observarse en el Gráfico $3.8^{44}$.

\section{Gráfico 3.8.}

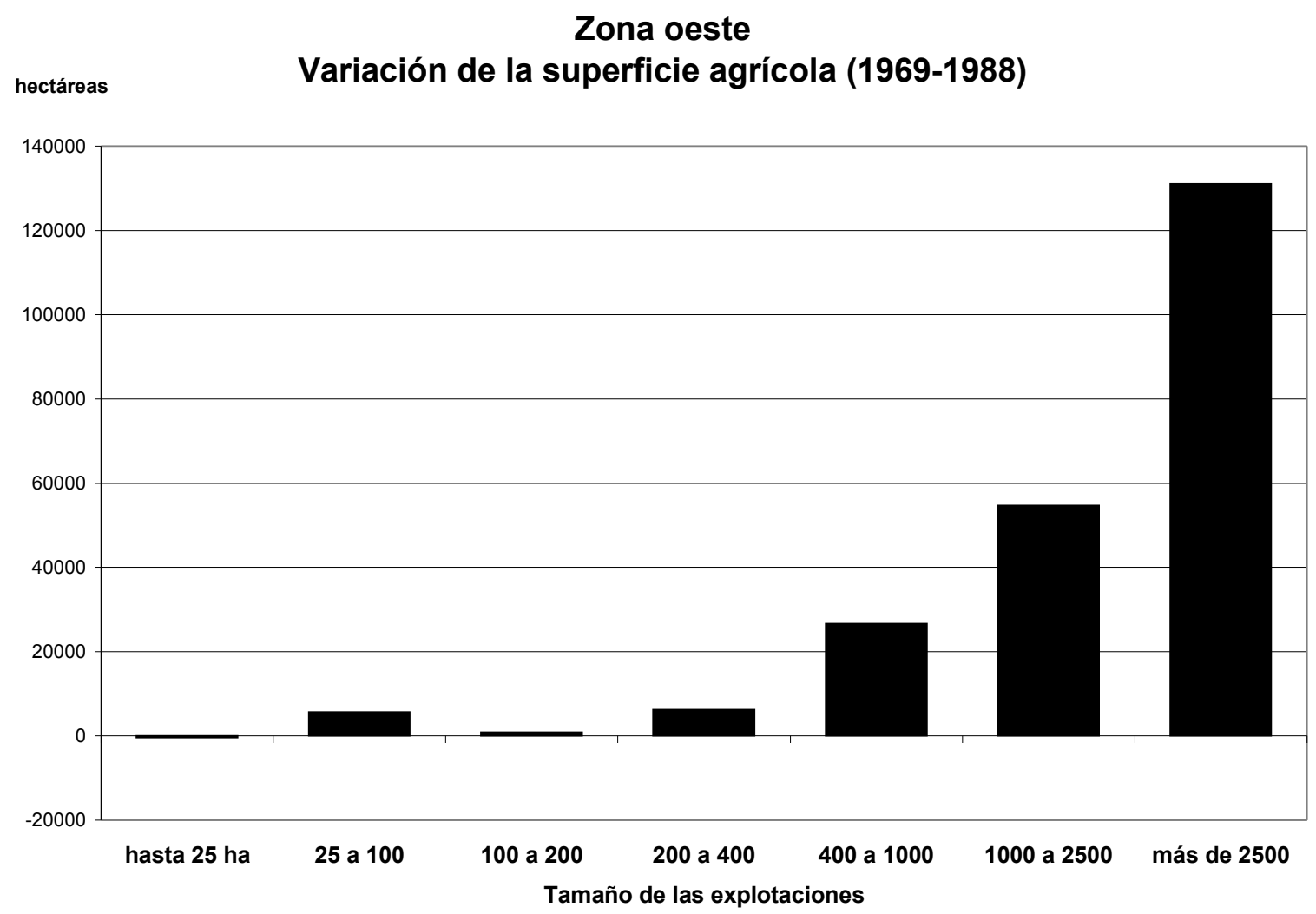

Fuente: Reprocesamiento de los datos originales de los Censos Agropecuarios de 1969 y 1988.

Por consiguiente, como puede observarse en el Cuadro 3.11, en la zona oeste la concentración de la agricultura incrementó el peso de las muy grandes unidades. Las explotaciones de más de 2.500 hectáreas pasaron a controlar el $41 \%$ de la agricultura de esta zona, cuando en 1969 tenían el 28\%. Se redujo la importancia de las unidades de

44 En dicho gráfico se observa que el $58 \%$ del incremento fue generado por las explotaciones de más de 2.500 hectáreas (las que pasaron de cultivar 99.000 hectáreas en 1969, a 240.000 en 1988), y un $24 \%$ por las de 1.000 a 2.500 (incrementaron esta superficie de 82.000 a 138.000 hectáreas). Al mismo tiempo, los establecimientos de 400 a 1.000 hectáreas contribuyeron con un $12 \%$ de la expansión, y las unidades con menos de esa escala apenas generaron un $6 \%$ de la misma. 
menos de 1.000 hectáreas, que de poseer el 49\% de la superficie agrícola, se quedaron con el 35\% (en 1937 las explotaciones de menos de 625 hectáreas ${ }^{45}$ habían controlado el $81 \%$ de la agricultura de la zona oeste). En esta zona, la agricultura en pequeñas unidades (que había tenido su importancia durante el primer período expansivo ${ }^{46}$ ) había prácticamente desaparecido: las explotaciones de menos de 200 hectáreas no alcanzaban el 9\% del área sembrada con cultivos agrícolas.

En la zona sur, la superficie agrícola total no se modificó; sin embargo, los productores de más de 1.000 hectáreas aumentaron en términos absolutos su superficie agrícola $^{47}$, mientras que perdían importancia los de 100 a 400 hectáreas (ver Gráfico 3.9).

Como resultado de estos cambios, tuvo lugar, también aquí, una concentración de la actividad agrícola, pero fue menos importante que en las otras dos zonas. Las unidades de 100 a 400 hectáreas redujeron su importancia del 30\% que controlaban en 1969, al 21\% en 1988. En cambio, las explotaciones de más de 1.000 pasaron de tener el 33\% del área agrícola a controlar el 44\%. Pero este menor proceso de concentración, tanto durante éste período como en la etapa anterior ${ }^{48}$, no debe llevar a pensar que aquí habían predominado las pequeñas unidades. Por el contrario, ésta ha sido una zona en la cual la agricultura fue desde el comienzo realizada en escalas muy importantes, por lo cual nunca las pequeñas unidades tuvieron un lugar destacado (como ya hemos visto en el primer capítulo). En cambio, tuvieron siempre importancia los establecimientos medianos, que durante la última etapa expansiva pasaron a compartir su lugar con las

45 Resulta imposible conocer el dato para el corte en 1.000 hectáreas, pues dicho censo utilizó intervalos de tamaño con cortes en 625 y 1.250 hectáreas.

46 Hemos estimado que para 1937 un $57 \%$ del área agrícola era controlado por las explotaciones de menos de 200 hectáreas.

47 En 1988, las unidades de 1.000 a 2.500 hectáreas dedicaban a la agricultura un área 19\% mayor que la que tenían en 1969 (pasaron de cultivar 418.000 hectáreas a 515.000 en 1988); mientras que las de más de 2.500, lo hicieron en un $16 \%$ (de 271.000 a 337.000 hectáreas). En cambio, las unidades de 25 a 400 hectáreas redujeron la superficie agrícola que tenían en 1969 en un 36\%. Entre estos productores, merece destacarse la reducción que en términos absolutos sufrieron los de 200 a 400 hectáreas, que pasaron de cultivar 446.000 hectáreas en 1969 a 296.000 en 1988.

48 En el período anterior (1937-1969), las explotaciones de 100 a 625 hectáreas habían pasado de controlar el $63 \%$ al $47 \%$ del total de la agricultura. 
grandes explotaciones: en 1988 las explotaciones de 200 a 1.000 hectáreas controlaban el 49\% del área agrícola, mientras que las mayores a esta última cifra, poseían el 44\%.

\section{Gráfico 3.9.}

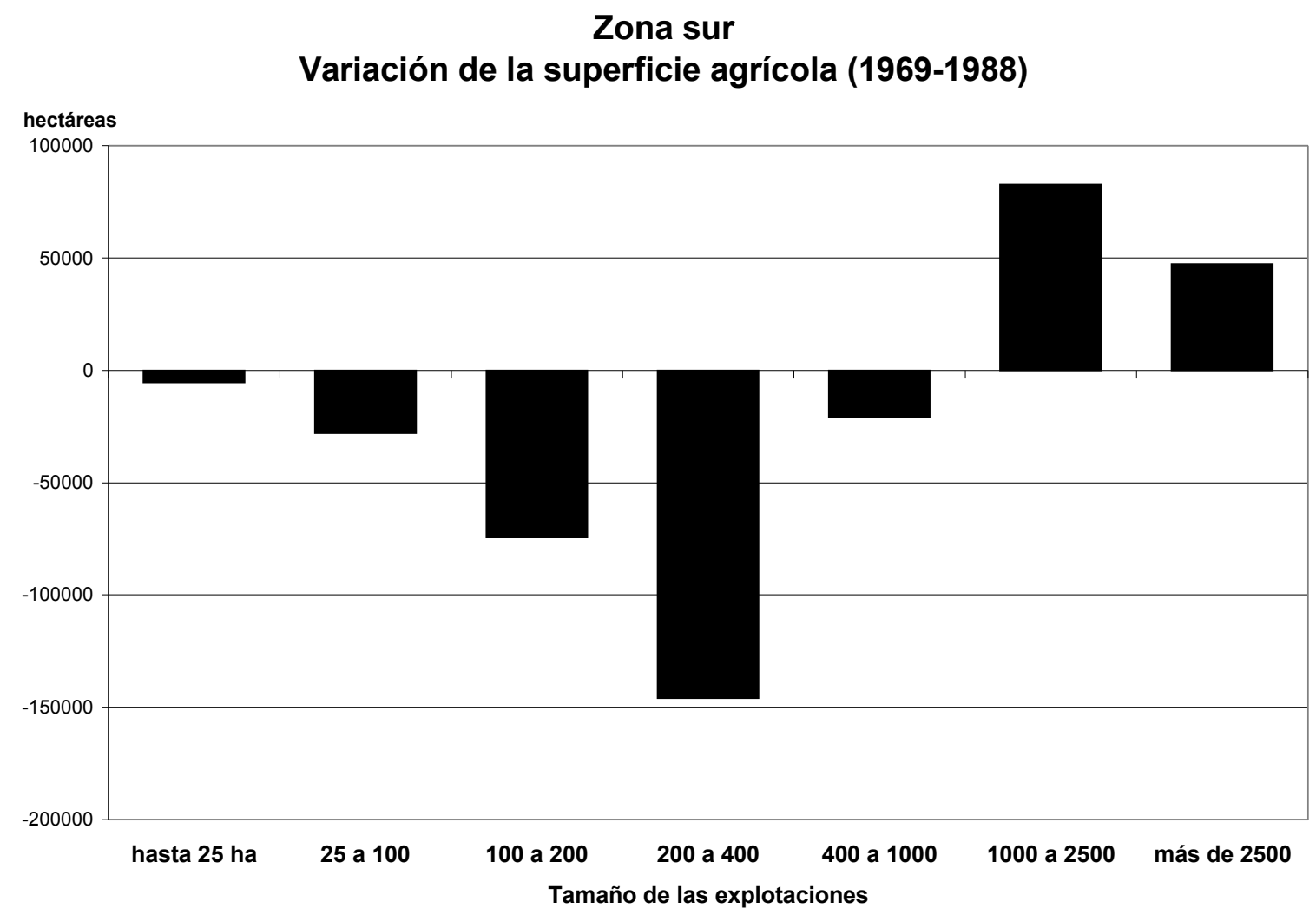

Fuente: Reprocesamiento de los datos originales de los Censos Agropecuarios de 1969 y 1988.

En síntesis, hemos podido identificar que el grueso de la expansión agrícola fue responsabilidad de unidades de 200 a 1.000 hectáreas en la zona norte, y de las de más de 1.000 en las zonas oeste y sur. Queda también claro que no pudieron aprovechar la expansión agrícola las explotaciones de menos de 200 hectáreas en la zona norte y de menos de 400 hectáreas en las otras dos zonas (particularmente en la zona sur, éstas sufrieron una fuerte retracción en la superficie agrícola en términos absolutos). 


\section{2. ¿Cuál fue la forma de tenencia del suelo que protagonizó el "boom" agrícola?}

$\mathrm{Si}$ analizamos la superficie agrícola que estaba en manos de los contratistas tanteros, encontramos que el fenómeno tuvo una importancia mayor al que encontramos en la distribución de la superficie agropecuaria total: el 26\% del área agrícola de la zona norte se encontraba en 1988 bajo esta forma de tenencia, el 13\% de los cultivos del sur, aunque tan sólo el 3\% en el oeste. En 1969, los porcentajes de la superficie agrícola bajo contratos de menos de un año habían sido de 4\%, 7\% y 4\% respectivamente ${ }^{49}$. Entonces, en relación con el crecimiento de la agricultura, podemos observar que los contratistas tanteros habrían sido responsables del 59\% de la expansión en la zona norte. Sin embargo, no debemos olvidar que los criterios de los registros censales subregistraron en 1969 el contratismo en relación con 1988. Por otra parte, no debe magnificarse su importancia, ya que sólo llegaba a dar cuenta de un cuarto de la superficie agrícola de la zona norte en 1988. En la zona oeste, en cambio, no jugaron ningún papel, ya que cultivaron menos extensión en 1988 que en 1969. En la zona sur resulta difícil expresar lo que aconteció, ya que el área agrícola total se retrajo levemente, mientras que el contratismo tantero habría incrementado su superficie agrícola (con las salvedades ya formuladas). Podemos decir que permitieron un incremento de dicha superficie en el orden del 9\% del total del área agrícola de 1969, que fue contrabalanceada por una retracción mayor de la superficie agrícola a cargo de otras formas de tenencia del suelo.

Resuelta la significación del contratismo tantero en la expansión agrícola, cabe considerar entonces, cuál ha sido el papel de las otras formas de tenencia del suelo dentro de este proceso.

En líneas generales, encontramos que los cambios han sido muy pequeños durante el período 1969-1988, en relación con las drásticas transformaciones ocurridas durante el período anterior. Como vimos en el capítulo anterior, en dicha etapa, la superficie agrícola en manos de propietarios había pasado, en números redondos, de un $30 \%$ a un $80 \%$ en las tres áreas estudiadas. En la etapa aquí analizada, no sólo los cambios fueron de menor importancia, sino que las modificaciones no tuvieron la

49 Llama la atención la retracción del contratismo en la zona oeste, incluso cuando el criterio de 1988 fue más inclusivo que el de 1969. Es probable que las inundaciones que asolaron esta zona a mediados de los ochenta llevaran a una retracción de los arriendo temporales. 
misma dirección en todas las áreas. Como podemos observar en el Gráfico 3.10, en la zona norte creció especialmente la importancia de la agricultura desarrollada por productores que combinaban algún campo en propiedad con otros campos de mayor tamaño en arriendo o contratos accidentales (este tipo de productores pasó de tener el $13 \%$ de la superficie agrícola total en 1969, a controlar el 26\% de la misma en 1988). En cambio, los propietarios puros quedaron con un 36\% del área agrícola (frente al 53\% que tenían en 1969). El resultado de esos cambios fue una estructura agrícola muy heterogénea en lo que respecta a la tenencia del suelo: tanto propietarios puros, como los que combinaban propiedad con arriendo o contratismo, pero también los no propietarios poseían un lugar destacado dentro de la agricultura de la zona norte.

También es posible analizar cuáles formas de tenencia tuvieron mayor significación en la expansión de la superficie agrícola. En este sentido, el 44\% del incremento se ubicó entre los productores que combinaban una mayor parte de su explotación en arriendo o contratismo y el resto en propiedad ${ }^{50}$. Un $29 \%$, fue responsabilidad de los arrendatarios o contratistas puros $^{51}$. Por lo tanto, los productores propietarios puros y aquellos que combinaban la propiedad con una superficie menor en arriendo no fueron los responsables de la agriculturización en la zona norte (sólo generaron un $10 \%$ y un $17 \%$ de la expansión, respectivamente).

${ }^{50}$ Estos productores pasaron de cultivar 109.000 hectáreas en 1969 , a 350.000 hectáreas en 1988.

51 Ellos pasaron de cultivar 175.000 a 334.000 hectáreas. 
Gráfico 3.10.

\section{Zona Norte}

Distribución de la superficie agrícola según tenencia del suelo

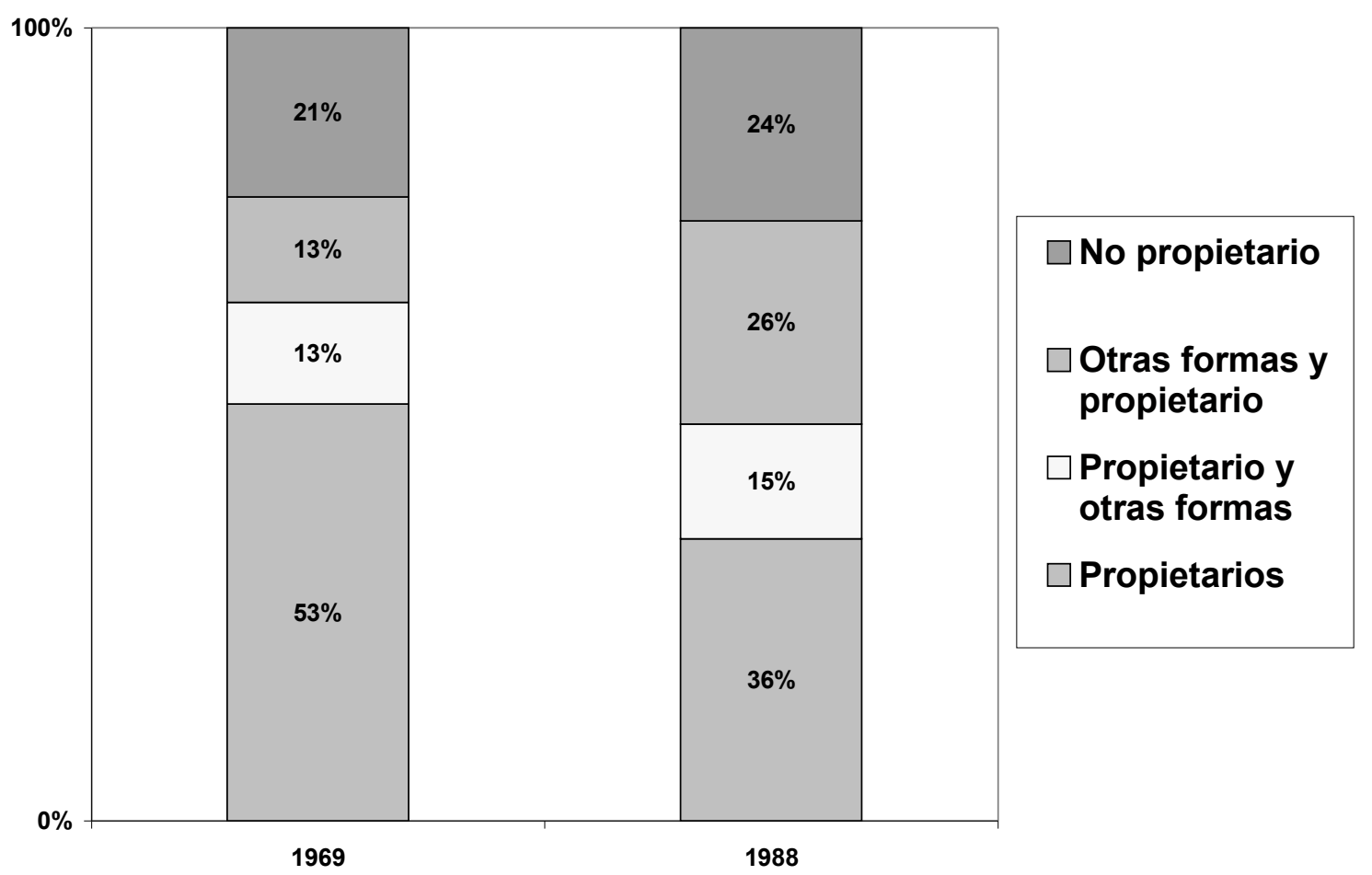

Fuente: Reprocesamiento de los datos originales de los Censos Agropecuarios de 1969 y 1988. 
En la zona oeste, como puede verse en el Gráfico 3.11, los propietarios consolidaron su lugar de preeminencia dentro de la agricultura, incrementando su control del área cultivada total de $58 \%$ en 1969 a $69 \%$ en 1988. Mientras tanto, los arrendatarios reducían su participación relativa del 22\% al 10\%. Entonces, en lo que respecta a la importancia de las distintas formas de tenencia del suelo en relación con la producción agrícola, la zona oeste -del mismo modo que en el tamaño de las unidadesera más homogénea en 1988 que en 1969. En términos absolutos, los propietarios puros generaron el $85 \%$ de la expansión agrícola en la zona oeste ${ }^{52}$.

\section{Gráfico 3.11.}

\section{Zona Oeste}

Distribución de la superficie agrícola según tenencia del suelo

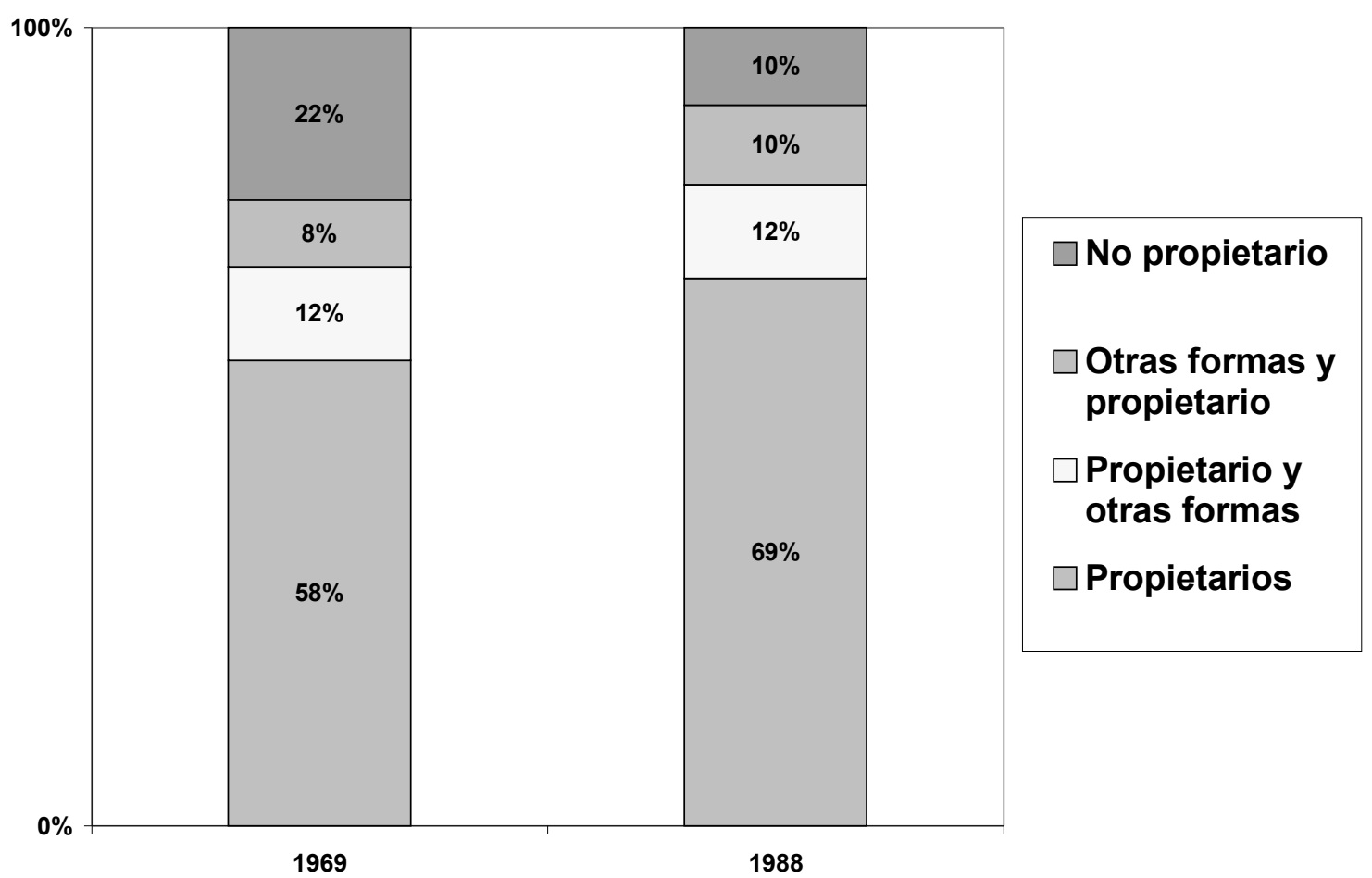

Fuente: Reprocesamiento de los datos originales de los Censos Agropecuarios de 1969 y 1988.

En la zona sur las formas puras perdieron importancia dentro de la agricultura en beneficio de las formas mixtas que pasaron de controlar el 27\% del área a tener el 39\%

\footnotetext{
${ }^{52}$ En términos absolutos, pasaron de cultivar 208.000 hectáreas en 1969, a 399.000 hectáreas en 1988
} 
para 1988 (ver Gráfico 3.12.). Estos cambio, sin embargo, no alteraron la primacía de la propiedad pura (que en 1988 tenía el 45\% del área total agrícola), repartiéndose en las otras tres formas de tenencia la superficie restante. Como aquí la superficie agrícola se mantuvo relativamente estable, no podemos describir las responsabilidades de las distintas formas en la agriculturización. Podemos señalar, sin embargo, que las formas mixtas de tenencia incrementaron la superficie agrícola a su cargo: en un 38\% aquéllas con predominio de la propiedad, y en un 33\% las que tenían más superficie en arriendo o contratismo ${ }^{53}$.

\section{Gráfico 3.12.}

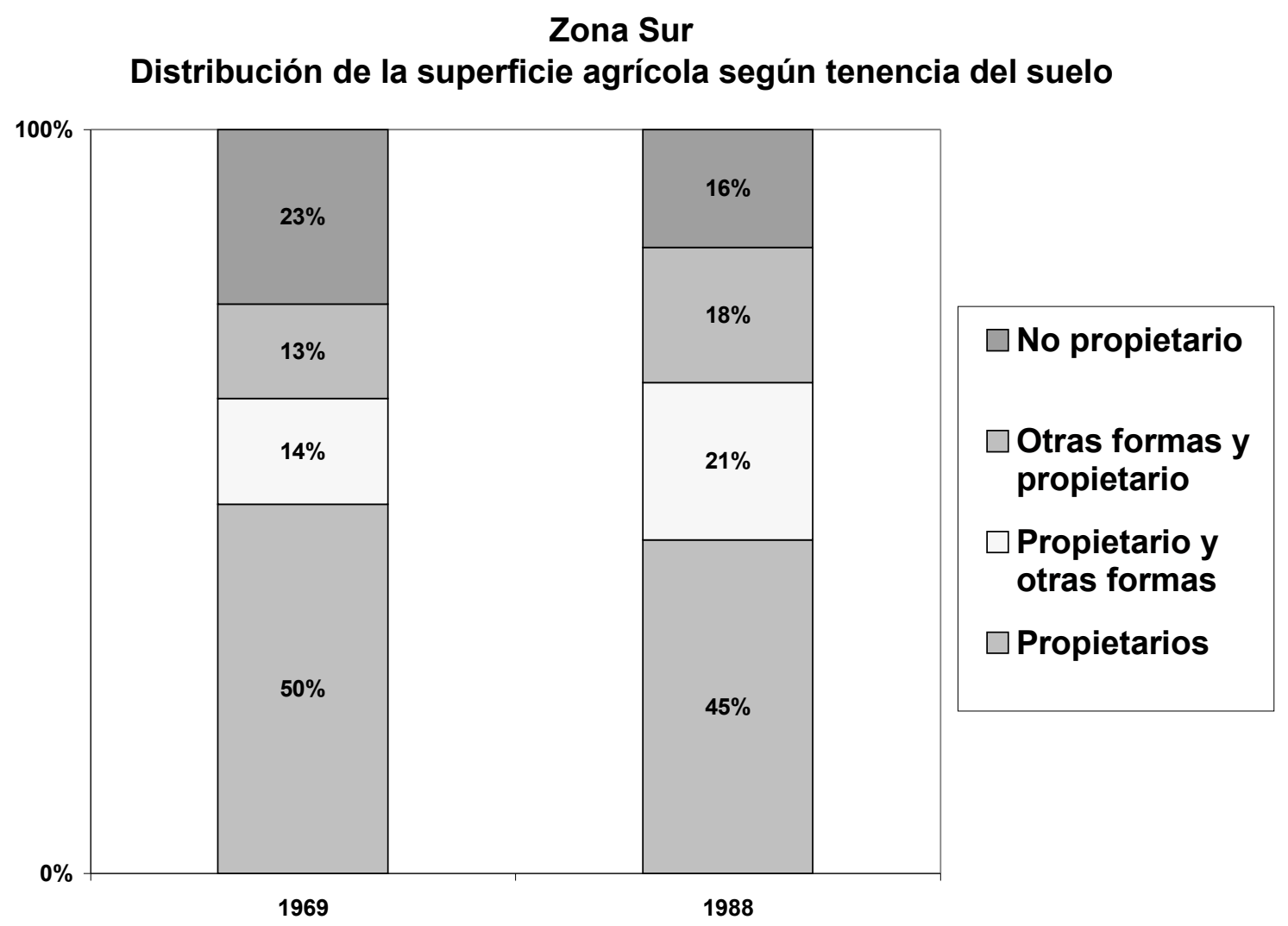

Fuente: Reprocesamiento de los datos originales de los Censos Agropecuarios de 1969 y 1988.

53 Las formas de tenencia mixta con predominio de la propiedad pasaron de cultivar 299.000 hectáreas en 1969 , a 413.000 en 1988 , mientras que aquéllas con predominio de la nopropiedad aumentaron de 267.000 a 356.000 hectáreas. 
En síntesis, la expansión agrícola de la zona norte estuvo fuertemente asociada a los contratistas tanteros, en forma pura, pero en mayor grado en combinación con parcelas en propiedad ${ }^{54}$. En cambio, en la expansión en la zona oeste el contratismo no jugó ningún papel, ya que estuvo a cargo de los propietarios puros. En la zona sur, sólo creció la superficie agrícola a cargo de las formas de tenencia mixtas, y dentro de ellas el contratismo tantero podría sido responsable de la mayor parte de esta expansión (aunque recordemos que sólo llegó a controlar el 13\% del área agrícola de 1988).

\section{3. ¿Expansión de las formas capitalistas?}

En estas décadas, cobraron notoria importancia dentro de la agricultura las explotaciones que contrataban uno o dos asalariados permanentes. En cambio, perdieron peso relativo dentro de la superficie agrícola las unidades sin asalariados permanentes (ver Cuadro 3.12), una tendencia similar a la que encontramos al analizar la distribución de la superficie total agropecuaria. En la zona norte, los productores sin asalariados permanentes pasaron de controlar el 53\% de la superficie agrícola en 1969, a detentar sólo el $29 \%$ en 1988. Mientras tanto, los productores que contrataban uno o dos asalariados aumentaban su importancia del 21\% al 47\% del área agrícola. En las otras dos zonas los cambios tuvieron la misma dirección y similar intensidad (ver Cuadro 3.12). En cambio, en ninguna de las tres zonas asistimos a la expansión de la importancia de la superficie en manos de unidades con más de tres asalariados permanentes $^{55}$.

54 Llovet (1988: 276) había destacado el importante papel que jugaban en la agricultura bonaerense las formas mixtas de tenencia ya en 1969.

55 Un elemento que tal vez explique este fenómeno sea la reducción en los requerimientos de mano de obra para realizar las labores agrícolas que continuó operándose en este período. Así, por ejemplo, en tan sólo una década, tuvo lugar una drástica reducción de la demanda de trabajo para cosechar el maíz. A fines de los sesenta, con una cosechadora de maíz se cosechaba una hectárea de este cereal en 7 horas-hombre -5 de cosecha y 2 dedicadas a levantar las bolsas y estibarlas-, recordar que antes demandaba 45 horas-hombre con la cosecha manual (Coscia y Torchelli, 1968). En cambio para 1979 una hectárea de maíz se cosechaba en 1 hora y 45 minutos-hombre (1 hora y 10 minutos para de cosecha, y 35 minutos de transporte interno y carga de silo), según las estimaciones de Pizarro y Cacciamani (1979). 
Esta uniformidad en los cambios no significa homogeneidad entre las distintas zonas en esta característica. En la zonas norte y sur, observamos un predominio en 1988 de las unidades con uno o dos asalariados (que controlaban el 47\% y el 52\% del área agrícola, respectivamente), mientras que en la zona oeste, junto con este tipo de unidades (que tenían el $42 \%$ de la agricultura), también controlan una porción sustancial del área agrícola las explotaciones con más de cinco asalariados (38\%).

Cuadro 3.12. Distribución de la superficie agrícola según los asalariados permanentes

\begin{tabular}{|l|r|r|r|r|r|r|r|r|r|}
\hline & \multicolumn{3}{|c|}{ zona norte } & \multicolumn{3}{|c|}{ zona oeste } & \multicolumn{3}{|c|}{ zona sur } \\
\hline & $\mathbf{1 9 6 9}$ & $\mathbf{1 9 8 8}$ & difer. & $\mathbf{1 9 6 9}$ & $\mathbf{1 9 8 8}$ & difer. & $\mathbf{1 9 6 9}$ & $\mathbf{1 9 8 8}$ & difer. \\
\hline Sin asal. perm. & $53 \%$ & $29 \%$ & $-25 \%$ & $30 \%$ & $12 \%$ & $-18 \%$ & $41 \%$ & $18 \%$ & $-23 \%$ \\
\hline 1-2 asal. perm. & $21 \%$ & $47 \%$ & $26 \%$ & $23 \%$ & $42 \%$ & $19 \%$ & $27 \%$ & $52 \%$ & $25 \%$ \\
\hline 3-4 asal. perm. & $8 \%$ & $11 \%$ & $3 \%$ & $10 \%$ & $8 \%$ & $-2 \%$ & $12 \%$ & $11 \%$ & $-1 \%$ \\
\hline 5 y más asal. & $18 \%$ & $14 \%$ & $-4 \%$ & $37 \%$ & $38 \%$ & $1 \%$ & $20 \%$ & $19 \%$ & $-1 \%$ \\
\hline & $100 \%$ & $100 \%$ & & $100 \%$ & $100 \%$ & & $100 \%$ & $100 \%$ & \\
\hline
\end{tabular}

Fuente: Reprocesamiento de los datos originales de los Censos Agropecuarios de 1969 y 1988.

Sin embargo, el examen de la cantidad de asalariados por explotación no completa el análisis de la organización social del trabajo al interior de las unidades productivas, ya que como veremos en el siguiente apartado, en 1988 había adquirido gran relevancia la contratación de terceros para realizar con su maquinaria buena parte de las labores agrícolas.

\section{4. ¿Hasta qué punto la terciarización de labores agrícolas modificó la} organización social del trabajo de unidades familiares y capitalistas?

En la agricultura pampeana históricamente ha tenido gran significación la contratación de servicios de maquinarias, es decir la terciarización de parte de las labores agrícolas. En la expansión de fines del siglo XIX y comienzos del XX, se destacó la presencia de contratistas de trillado quienes se trasladaban a lo largo de los campos trillando los cereales previamente recogidos por los productores o el personal 
por ellos contratado. A medida que se expandió el uso de las cosechadoras (de arrastre primero para la cosecha fina, y automotrices luego, ya entonces también para la cosecha gruesa) fue desapareciendo la importancia de este tipo de contratistas. Sin embargo, comenzó a difundirse la contratación de servicios de roturación y siembra y de cosecha, tanto a cargo de pequeños o medianos productores sobremecanizados en relación con el tamaño de sus propios cultivos, como de dueños de maquinarias que no tenían un predio de base propio, sino que se especializaban en brindar este tipo de $\operatorname{servicios}^{56}$. Lamentablemente, si bien la información sobre la cantidad de hectáreas para las cuáles se contrató distinto tipo de servicios fue registrada en el censo de 1969, e incluso cargada en las citas de computación correspondientes (tarjeta perforada número seis), actualmente no es posible descodificar esta información ${ }^{57}$. En cambio, sí contamos con los datos para 1988. A partir de ellos intentaremos evaluar hasta qué punto la terciarización modificaba la organización social del trabajo de los distintos tipos de productores.

En base a cálculos propios sobre los datos inéditos del Censo Agropecuario Nacional de 1988, hemos podido determinar que el 57\% de la superficie cultivada con cereales y oleaginosas era cosechado con contratistas de maquinaria en la zona Norte, el porcentaje era del 53\% en la zona Oeste y del 37\% en la zona Sur. Para las labores de roturación y siembra la significación era del 21\%, 42\% y 17\% respectivamente.

Para observar cómo inciden en la organización de las actividades agrícolas (incluyendo en este caso el sembrado de forrajeras anuales y perennes), hemos clasificado las explotaciones según la importancia que la terciarización tuvo sobre el total de actividades agrícolas realizadas: "producción directa" (que podía ser realizada con asalariados o con mano de obra familiar o ambas), cuando sólo terciarizaban menos

56 Ya en 1965 la existencia de este tipo de contratistas, denominados "changarines", es comentada por Valenti (1965: 98), quien comenta que estos propietarios de maquinaria recorrían toda la zona cerealista, desde el Chaco a Bahía Blanca y La Pampa, cosechando gran cantidad de hectáreas.

57 Algunas encuestas rurales brindan información sobre el uso de maquinaria propia o contratada para realizar la cosecha. Así por ejemplo, una encuesta realizada en el partido de Tornquist (ubicado en nuestra zona sur) en 1971, muestra que en el estrato de explotaciones de 151 a 350 hectáreas, el $64 \%$ de los productores realizó la cosecha con maquinaria propia; esta cifra se eleva al $80 \%$ en el estrato de 351 a 850 hectáreas, y vuelve a bajar al $64 \%$ en el de 851 a 3.150 hectáreas (Labarthe, 1973: 60). 
del 25\% de las labores de roturación-siembra y de cosecha ${ }^{58}$; "producción por contrato", cuando se terciarizaba más del $75 \%$ de las labores, y "producción directa y por contrato", en las situaciones intermedias.

Analizada de este modo, se puede observar (ver Gráfico 3.13.) que la terciarización no alteraba radicalmente la organización social del trabajo agrícola, al menos en las zonas norte y sur. En la zona norte, dos tercios de la superficie agrícola estaba directamente a cargo del productor (más allá de la composición de la fuerza de trabajo a su cargo), el resto lo realizaba parcial o totalmente en base a la contratación de servicios de terceros (tanto para las tareas de roturación y siembra, como para las de cosecha). En la zona sur, era incluso mayor la importancia de la producción directa, alcanzando las tres cuartas partes del área cultivada. En cambio, en la zona oeste menos de la mitad de la agricultura estaba a cargo directamente del productor. Alrededor de una cuarta parte era realizada de forma mixta (por productores que combinaban la producción directa con la contratación de servicios externos) y un $30 \%$ por productores que contrataban a terceros para que realizaran prácticamente la totalidad de las labores agrícolas.

58 En el censo de 1988 sólo se consignó la cantidad de hectáreas para las cuáles cada productor había contratado servicios de maquinaria, tanto para roturación y siembra, como para cosecha. Hemos estimado la superficie total cosechada como equivalente a la totalidad de hectáreas cultivadas con cereales y oleaginosas en cada unidad, y la superficie total roturada y sembrada como la anterior extensión más la superficie cultivada con forrajeras anuales y una séptima parte de la ocupada por forrajeras perennes. 


\section{Gráfico 3.13.}

Distribución de la superficie agrícola según

la organización de las actividades (1988)

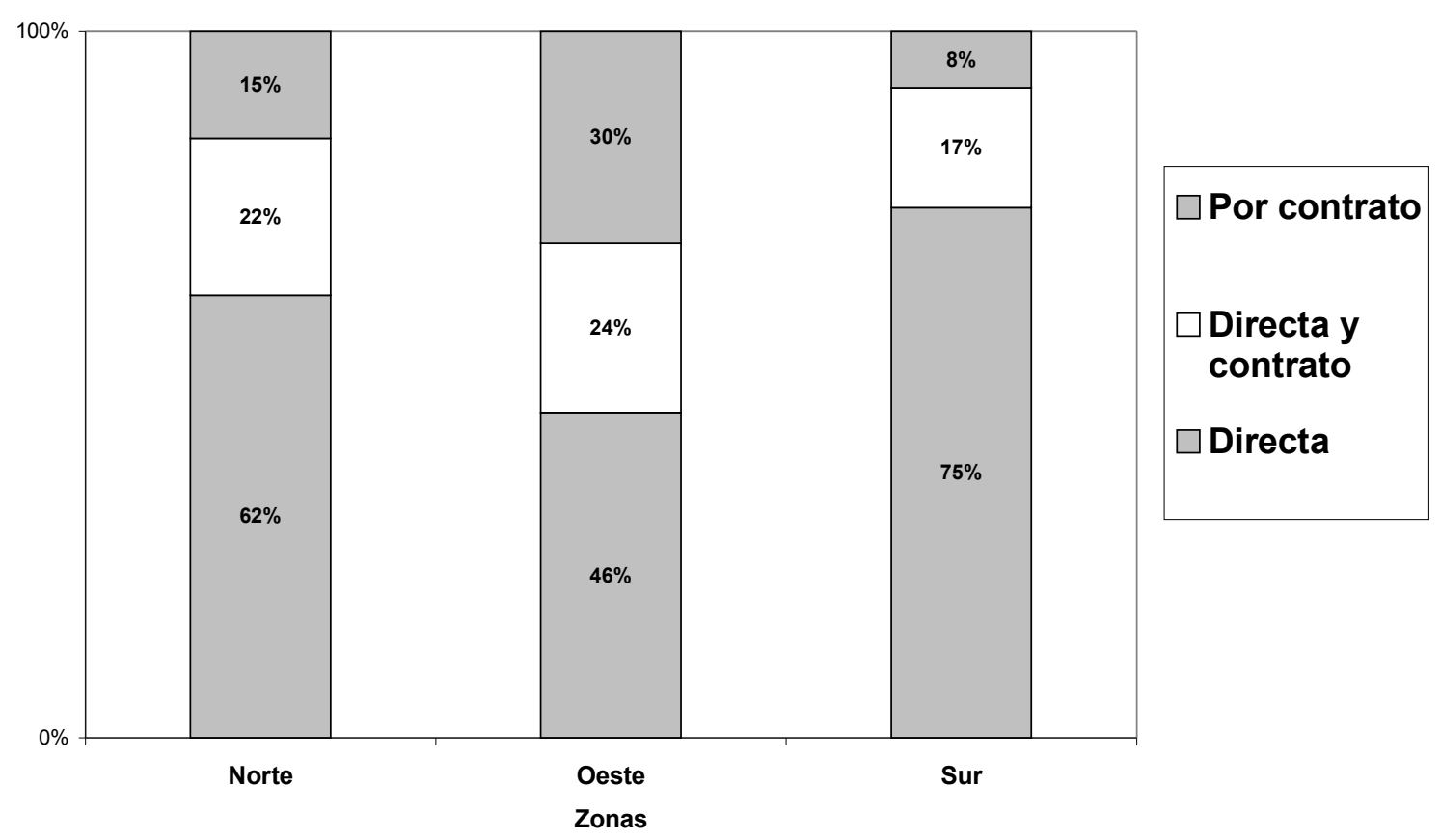

Fuente: Reprocesamiento de los datos originales de los Censos Agropecuarios de 1969 y 1988.

Sin embargo, nos queda la pregunta de hasta qué punto la expansión de la terciarización estaría modificando la correcta caracterización del productor, especialmente en el caso de los "familiares". Al respecto, nosotros hemos caracterizado como "familiar" a toda explotación que no contratara asalariados de forma permanente. Podría ocurrir que una gran proporción de estos "familiares" en realidad no realizaran las labores agrícolas en base a la mano de obra familiar, sino que estuviesen contratando servicios de maquinarias externos, lo cual merecería un trabajo mucho más detenido para poder avanzar en la comparación intercensal.

Para abordar esta cuestión hemos analizado las explotaciones según zona, tamaño, mano de obra y forma de organización de la actividad agrícola. Encontramos que la gran mayoría de las explotaciones sin asalariados se hacían cargo de la producción en forma directa, incluso cuando tenían extensiones importantes. Es más, la 
terciarización en el caso de unidades sin asalariados era más importante en los estratos menores. La gran capacidad de trabajo de los nuevos equipos de maquinarias incorporados por los productores medianos durante estos años, les habría permitido trabajar grandes extensiones sin contratar asalariados en forma permanente.

\section{Las formas sociales que protagonizaron la expansión agrícola}

El interrogante central de este capítulo es cuál ha sido la forma social de producción que llevó adelante la expansión agrícola. Para poder avanzar sobre esta pregunta, debemos formular antes dos aclaraciones metodológicas.

En primer lugar, necesitábamos una tipología de formas sociales de producción $\mathrm{y}$, para ello, resultaba imposible desplegar todas las combinaciones de los distintos valores de las dimensiones hasta ahora consideradas: el elevado número de tipos hubiera hecho imposible su exposición al lector. Toda tipología supone, entonces, una simplificación. En este caso, hemos escogido centrarnos en dos dimensiones, a nuestro entender claves para conceptualizar a los sujetos sociales agrarios: la organización social del trabajo y la tenencia del suelo (tal como hemos hecho en los capítulos previos). La primera de estas dimensiones la hemos operacionalizado en base a la única variable disponible para ambos censos: la cantidad de asalariados permanentes, con los cuatro valores ya utilizados en este trabajo. La tenencia del suelo la hemos dicotomizado (para reducir el número de tipos) en propietarios, si eran dueños al menos del 10\% de su explotación, y arrendatarios, en caso contrario ${ }^{59}$. Además, una tipología implica también etiquetar, con los problemas conceptuales que esto conlleva. En nuestro caso, hemos denominado "farmers" a los productores propietarios que no contrataban

59 Incluso en el caso de un productor que tuviese en propiedad el $15 \%$ de su explotación, la mayor parte de su capital sería fundiario (tierra más mejoras). En el ejemplo desarrollado por Pizarro y Cacciamani, un "productor-propietario-contratista" del área maicera tradicional que tenía 83 hectáreas en propiedad y 490 en arriendo, el 34,9\% de su capital era la tierra, el $11,6 \%$ las mejoras, el $34,2 \%$ la maquinaria y el 19,3\% el capital circulante (Pizarro y Cacciamani, 1993a: 9). 
asalariados de forma permanente, con el supuesto de que estos sujetos se asemejaban al típico productor familiar norteamericano, propietario de su parcela y con una fuerza de trabajo esencialmente basada en su propia labor y la de los miembros de su familia. Indudablemente, no todos los productores que no contrataban asalariados en forma permanente presentaban las características de las "family farms", pero suponemos que la gran mayoría tendría este perfil. En el extremo opuesto, denominamos "terratenientescapitalistas grandes", a los propietarios que contrataban cinco o más asalariados permanentes, cumpliendo así el criterio más estricto mencionado anteriomente (Ghorayshi, 1986), y destacando el carácter dual de estos sujetos (en tanto captaban renta y ganancia). Más difícil fue caracterizar a los productores que quedaron en medio de estos dos tipos extremos. Con tres o más asalariados permanentes, supusimos que la fuerza de trabajo asalariada superaba el aporte del productor y su familia, y lo denominamos "terrateniente-capitalista pequeño". Si tenía uno o dos asalariados, el aporte familiar podía ser igual o superior al de los asalariados, por lo cual lo caracterizamos como "farmer con asalariados". Sin embargo, también es posible que, en muchas de estas unidades, los asalariados permanentes hayan desarrollado la casi totalidad de las labores manuales, y sus dueños se acercasen más a un "terratenientecapitalista pequeño". Lamentablemente, no disponemos de información censal que nos permita avanzar en esta discriminación, más allá de la comentada en el apartado donde analizamos la mano de obra. Hemos utilizado los mismos criterios para distinguir a los arrendatarios (incluyendo a aparceros y contratistas): "arrendatarios familiares", "arrendatarios familiares con asalariados", "capitalistas pequeños" y "capitalistas grandes". Por último, quisiéramos exponer un problema vinculado con la historicidad. Todo uso comparativo en el tiempo de una tipología conduce a cierta cristalización de las caracterizaciones, ya que sólo se pueden analizar variaciones en identidades; pero en los fenómenos sociales no existen identidades inmutables. Este problema resulta especialmente significativo en el caso del "farmer con asalariados" (que justamente en este período cobra especial importancia en la estructura agraria), ya que nuestra información de fuentes cualitativas nos indica que los productores que encajaban en esta categoría en 1988, eran diferentes en muchas características a los que lo hacían en 
$1969^{60}$. Pero, nuevamente los datos censales sobre los cuales se basó el presente análisis no permiten formular diferencias y, concientes de estos límites, nos pareció útil avanzar con la comparación. En el final de este apartado volveremos sobre esta cuestión.

En segundo lugar, desarrollamos una metodología en base a la comparación de los datos de 1969 y 1988 en forma de una matriz con entradas y salidas, para estimar qué le ocurrió a los distintos productores presentes en 1969. Primero adjudicamos los cambios al interior de los estratos de tamaño, suponiendo transformaciones en la organización social del trabajo y/o de la tenencia del suelo (en este orden) ${ }^{61}$. Pero, si el estrato había incrementado su número (luego de estimar las transformaciones internas) se supuso que productores del estrato inmediato inferior del mismo tipo, habían logrado expandirse en superficie. Por el contrario, todas aquellas explotaciones presentes en estratos cuya cantidad se había reducido, y que no podían ser reubicadas en otros tipos ni otros estratos, se supuso que habían desaparecido y que su superficie había sido concentrada por unidades de mayor tamaño ${ }^{62}$.

A partir de este trabajo hemos estimado que en las tres zonas la forma de producción que lideró la expansión agrícola fue la de los farmers con uno o dos asalariados permanentes (incluyendo dentro de esta categoría a aquellos que tenían parte de sus explotaciones en propiedad y parte en arriendo o con contratos accidentales). En cambio, los farmers sin asalariados y los arrendatarios familiares perdieron importancia en términos numéricos y territoriales. En las zonas norte y sur los terratenientescapitalistas no ampliaron su participación en la producción agrícola, pero sí lo hicieron

60 En la tesis de Bardomás (1994) sobre Pigüé (partido de Saavedra) encontramos que, a comienzos de los noventa, casi todos los productores denominados por ella "familiares" (con unidades de entre 200 y 500 hectáreas) poseen al menos un asalariado permanente, al que suman el aporte de otro temporario en algunos momentos del año, y en cambio, resulta por lo general escaso el aporte de otros miembros de la familia que no fuesen el productor (incluso éste muchas veces aparece descripto como realizando fundamentalmente tareas de dirección, coordinación y apoyo).

${ }^{61}$ Por ejemplo, si en el estrato de 200 a 400 hectáreas aumentó la cantidad de farmers con asalariados, pero disminuyó el número de farmers sin asalariados, supusimos que algunos de estos últimos pasaron a contratar mano de obra.

62 Por los motivos explicitados en apartados anteriores, hemos analizado solamente a las explotaciones mayores de 25 hectáreas. 
en la zona oeste. En la zona norte también se destacó el papel jugado por los contratistas tanteros.

A continuación realizamos un análisis detallado de los cambios en la cantidad de explotaciones, en la superficie que ocupaban y en su participación en la expansión agrícola para cada una de las tres zonas estudiadas.

\subsection{Formas de producción y agricultura en la zona norte}

Alrededor de la mitad de los farmers sin asalariados de la zona norte habría continuado como tal entre 1969 y 1988 (en líneas generales con explotaciones de similar tamaño). En cambio, algo menos de un cuarto de los presentes en 1969 habrían incorporado uno o dos asalariados permanentes (ubicándose en la siguiente categoría), y el cuarto restante de los farmers habrían abandonado la producción (ver Gráfico $3.14^{63}$ ). En el otro extremo de los productores propietarios, los terratenientes-capitalistas redujeron levemente su número. Quienes sufrieron la mayor crisis fueron los arrendatarios familiares: su cantidad cayó en un 60\% (solo unos pocos de estos productores habrían pasado a contratar uno o dos asalariados permanentes). Por otra parte, la cantidad de arrendatarios capitalistas continuó siendo totalmente marginal en la zona norte.

El sector que realmente tuvo una expansión considerable fue el de los farmers con uno o dos asalariados: su cantidad casi se duplicó entre 1969 y 1988, como se observa en el Gráfico 3.14. Su importancia habría aumentado sobre todo por los farmers puros que incluyeron asalariados en su explotación ${ }^{64}$.

${ }^{63}$ En todos los siguientes gráficos, las flechas sólo indican las transformaciones estimadas que fueron más significativas, ya que los pequeños cambios, por un lado, podrían ser debidos a diferencias en los criterios de registro censal, y, por otro, su representación hubiera hecho perder claridad al gráfico.

64 De ellos 400 en un proceso de expansión territorial, y los otros 1.000 manteniéndose en escalas similares a las que tenían en 1969. 


\section{Gráfico 3.14.}

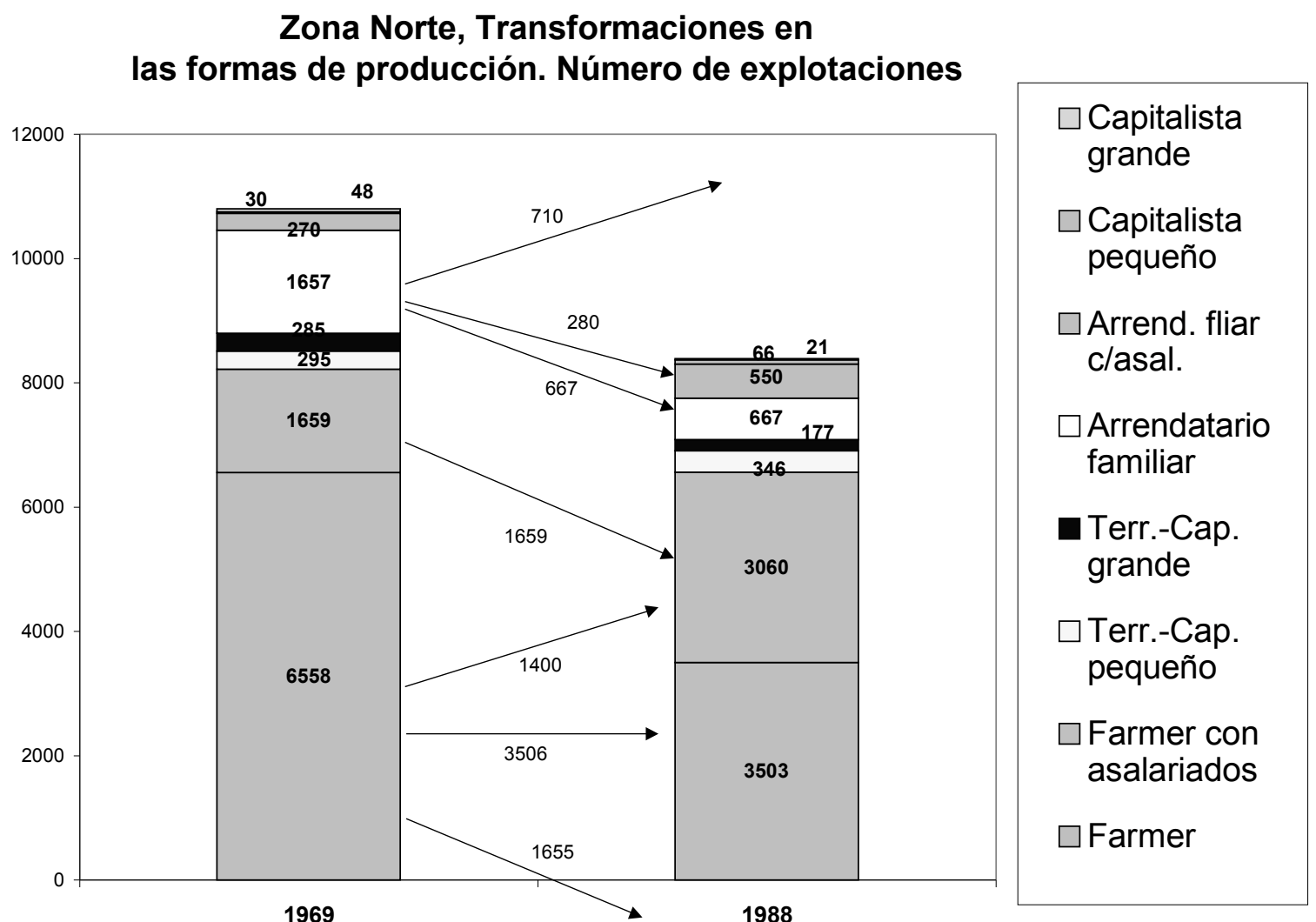

Fuente: Reprocesamiento de los datos originales de los Censos Agropecuarios de 1969 y 1988.

En términos de la superficie total censada encontramos que los farmers con uno o dos asalariados pasaron a ocupar el lugar preponderante (37\% en 1988) que antes tenían los farmers sin asalariados (34\% en 1969), como puede observarse en el Gráfico 3.15. El aumento se debió, por un lado, a que productores propietarios que ya tenían uno o dos asalariados en 1969 lograron expandirse durante estos años, sin cambiar sustancialmente la composición de su mano de obra (así se habría incrementado la superficie controlada por este tipo de productores en un $11 \%$ del área total) ${ }^{65}$; en general habría tomado tierras dejadas por propietarios $\mathrm{o}$ arrendatarios familiares que abandonaron la actividad. Por otro lado, la transformación de farmers que antes no

${ }_{65}$ Los estratos de los farmers con asalariados que más se expandieron en términos territoriales fueron los de 200 a 400 hectáreas (7\% del total), 100 a 200 (3\%) y 400 a 1.000 y más de 2500 (ambos, 2\%). 
contrataban personal habría incrementado la importancia territorial de los farmers con asalariados en alrededor de un 6\% del área total. En cambio, las formas empresariales (en propiedad o en arriendo) no sólo no incrementaron la superficie que controlaban sino que la redujeron levemente.

\section{Gráfico 3.15.}

Zona norte

Distribución de la superficie agropecuaria
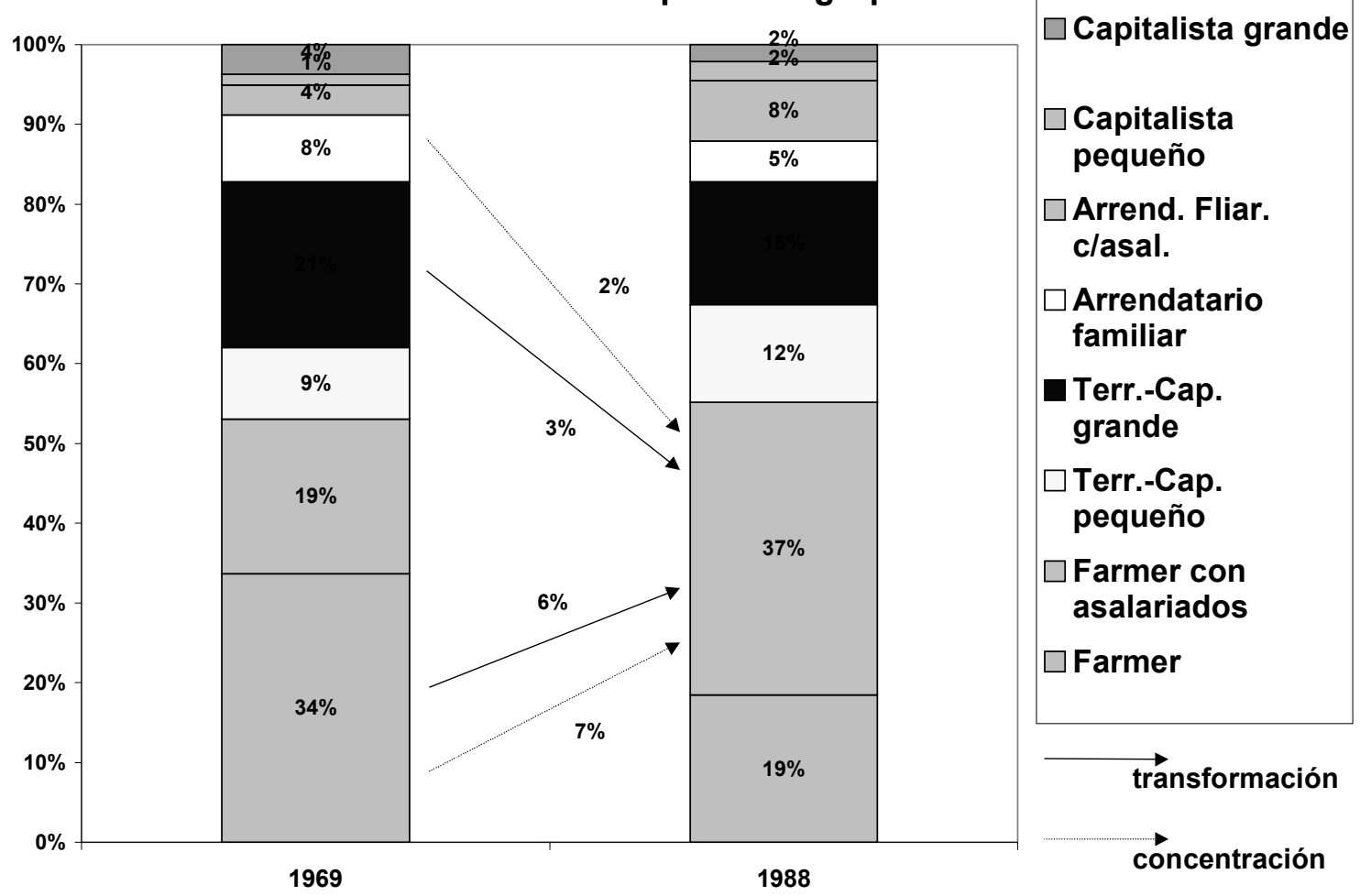

Fuente: Reprocesamiento de los datos originales de los Censos Agropecuarios de 1969 y 1988.

En relación con la expansión del área dedicada a la agricultura (del orden del $66 \%$ ), el $60 \%$ de este incremento habría sido realizado por farmers con uno o dos asalariados (ver Gráfico 3.16) ${ }^{66}$. Por su parte, los arrendatarios familiares con uno o dos

66 Dentro de ellos, la mayor parte de la agriculturización podría haberse realizado en tierras que estos productores ya tenían en 1969 (39\%), mientras que un 12\% podría haber tenido lugar en las tierras incorporadas a esta modalidad productiva. Por último, un $9 \%$ podemos adjudicarlo a farmers que habrían incorporado asalariados durante estas décadas. 
asalariados serían responsables de un crecimiento de la superficie agrícola del 18\%. Los terratenientes-capitalistas habrían generado un $12 \%$ de la expansión agrícola, y los arrendatarios-capitalistas, un $8 \%{ }^{67}$.

\section{Gráfico 3.16.}

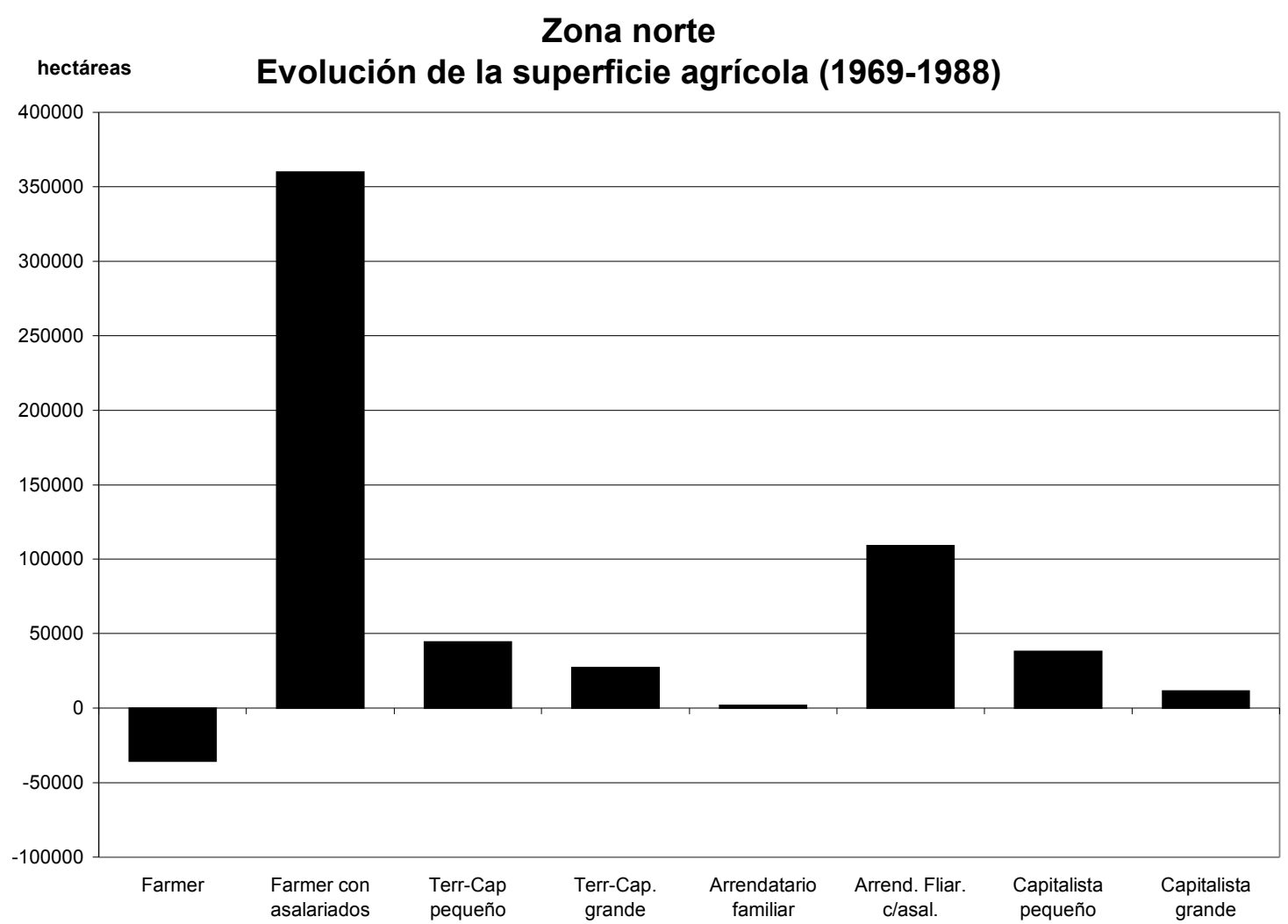

Fuente: Reprocesamiento de los datos originales de los Censos Agropecuarios de 1969 y 1988.

De este modo, la agricultura de la zona norte pasó a estar en manos de farmers con uno o dos asalariados permanentes ( $37 \%$ del área sembrada), y no predominaron ya los farmers, que en 1969 tenían el 41\%.

67 Incorporando al análisis el tamaño de las explotaciones, observamos que creció la importancia relativa de los farmers con uno o dos asalariados dentro de la superficie agrícola (con un tamaño de 200 a 2.500 hectáreas, especialmente en el intervalo de 400 a 1.000). Aumento de envergadura similar a la pérdida de significación de los farmers sin asalariados, entre los que se destaca la reducción especialmente entre los de 25 a 200 hectáreas. 
Si observamos en el Cuadro 3.13 cómo se modificaron los tamaños medios de las distintas formas sociales de producción entre 1969 y $1988^{68}$, encontramos que el tamaño medio de todas las unidades de la zona norte se incrementó en un 58\%, sin embargo algunas formas se mantuvieron con tamaños relativamente similares. Así por ejemplo, los farmers con uno o dos asalariados tuvieron incrementos de tamaño medio muy leves (lo mismo que los arrendatarios con ese mismo perfil de mano de obra): un farmer con asalariados en 1988 tenía en promedio una explotación de 207 hectáreas, cuando en 1969 había tenido198. Este escaso incremento estaría indicando que los aumentos en escala de algunos (presumiblemente de los que ya estaban en este estrato) se vieron contrarestados por la incorporación a esta forma productiva de farmers que antes no tomaban asalariados y que, seguramente, tenían menores tamaños.

Por otra parte, se destaca que los pocos arrendatarios familiares que perduraron en la zona, prácticamente duplicaron el tamaño que tenían en 1969 (pasaron de 60 a 112 hectáreas), seguramente buscando escala (proceso que los farmers puros apenas pudieron realizar, en 1988 tan sólo tenían 71 hectáreas de tamaño medio). Las formas con tres o más asalariados incrementaron su superficie media de un modo moderado (con excepción de los arrendatarios con tres o cuatro asalariados que vieron disminuir su escala).

68 Lamentablemente por el modo en que tuvimos que procesar la información original del Censo de 1988, no pudimos calcular la distribución en percentiles de los tamaños de cada forma, como sí pudimos hacerlo con los datos de 1969 y analizamos al final del capítulo segundo. 
Cuadro 3.13. Tamaño medio de las explotaciones según forma social de producción, 1969 y 1988. En hectáreas

\begin{tabular}{|c|c|c|c|}
\hline Zona & Forma & 1969 & 1988 \\
\hline \multirow[t]{9}{*}{ Norte } & Farmer & 59 & 71 \\
\hline & Farmer con asalariados & 198 & 207 \\
\hline & Terrateniente-capitalista pequeño & 555 & 676 \\
\hline & Terrateniente-capitalista grande & 1364 & 1640 \\
\hline & Arrendatario familiar & 60 & 112 \\
\hline & Arrendatario familiar con asalariados & 233 & 239 \\
\hline & Arrendatario empresarial pequeño & 799 & 707 \\
\hline & Arrendatario empresarial grande & 1415 & 1943 \\
\hline & Total & 116 & 183 \\
\hline \multirow[t]{9}{*}{ Oeste } & Farmer & 144 & 132 \\
\hline & Farmer con asalariados & 412 & 446 \\
\hline & Terrateniente-capitalista pequeño & 980 & 1372 \\
\hline & Terrateniente-capitalista grande & 2756 & 3136 \\
\hline & Arrendatario familiar & 122 & 121 \\
\hline & Arrendatario familiar con asalariados & 434 & 553 \\
\hline & Arrendatario empresarial pequeño & 1020 & 1494 \\
\hline & Arrendatario empresarial grande & 3822 & 2263 \\
\hline & Total & 391 & 484 \\
\hline \multirow[t]{9}{*}{ Sur } & Farmer & 208 & 225 \\
\hline & Farmer con asalariados & 507 & 547 \\
\hline & Terrateniente-capitalista pequeño & 1079 & 1391 \\
\hline & Terrateniente-capitalista grande & 2607 & 3151 \\
\hline & Arrendatario familiar & 193 & 218 \\
\hline & Arrendatario familiar con asalariados & 473 & 498 \\
\hline & Arrendatario empresarial pequeño & 1061 & 1433 \\
\hline & Arrendatario empresarial grande & 2665 & 4009 \\
\hline & Total & 410 & 563 \\
\hline
\end{tabular}

Fuente: procesamientos especiales de los datos originales de los Censos Nacionales Agropecuarios de 1969 y 1988.

Resumiendo todo este apartado, los terratenientes-capitalistas no incrementaron su importancia en la zona norte durante este período (a pesar de que cada uno de los que quedó aumentó su tamaño medio). Por su parte, los farmers parecen haber desarrollado 
un proceso de diferenciación social, y fueron los farmers con uno o dos asalariados los que se expandieron junto con la agriculturización, casi duplicando su número y el área que controlaban en $1969^{69}$. Dentro de ellos, la expansión agrícola se desarrolló con mayor importancia entre aquellos que combinaban la propiedad con una proporción mayor de parcelas con contratos accidentales (sin embargo, del total de la superficie en manos de farmers con asalariados sólo el 15\% era tomada con este tipo de contratos).

De este modo, los farmers con asalariados se convirtieron en la forma de producción predominante territorialmente en la zona norte, desplazando a los farmers sin asalariados. Este fenómeno tuvo lugar también en cuanto a la superficie agrícola. Un segundo lugar en la expansión, lo tuvieron los arrendatarios (incluyendo contratistas) con uno o dos asalariados.

\subsection{Formas de producción y agricultura en la zona oeste}

En la zona oeste, alrededor de tres cuartas partes de los farmers presentes en 1969 continuaban como tales hacia 1988 (ver Gráfico 3.17). Unos pocos habrían abandonado la producción, mientras que un quinto de los farmers habrían incorporado uno o dos asalariados permanentes, la mayoría de ellos sin incrementar el tamaño de sus campos. El aumento en el número de farmers con uno o dos asalariados fue del orden del $66 \%$. Su cantidad se vio incrementada, además de por la transformación de los farmers puros, por el acceso a la propiedad por parte de ex-arrendatarios, y porque algunos terratenientes-capitalistas habrían reducido su cantidad de asalariados, sumándose a esta forma productiva.

69 Recordemos que incluimos dentro de esta categoría a todo productor que al menos tuviera un $10 \%$ de sus campos en propiedad. 
Gráfico 3.17.

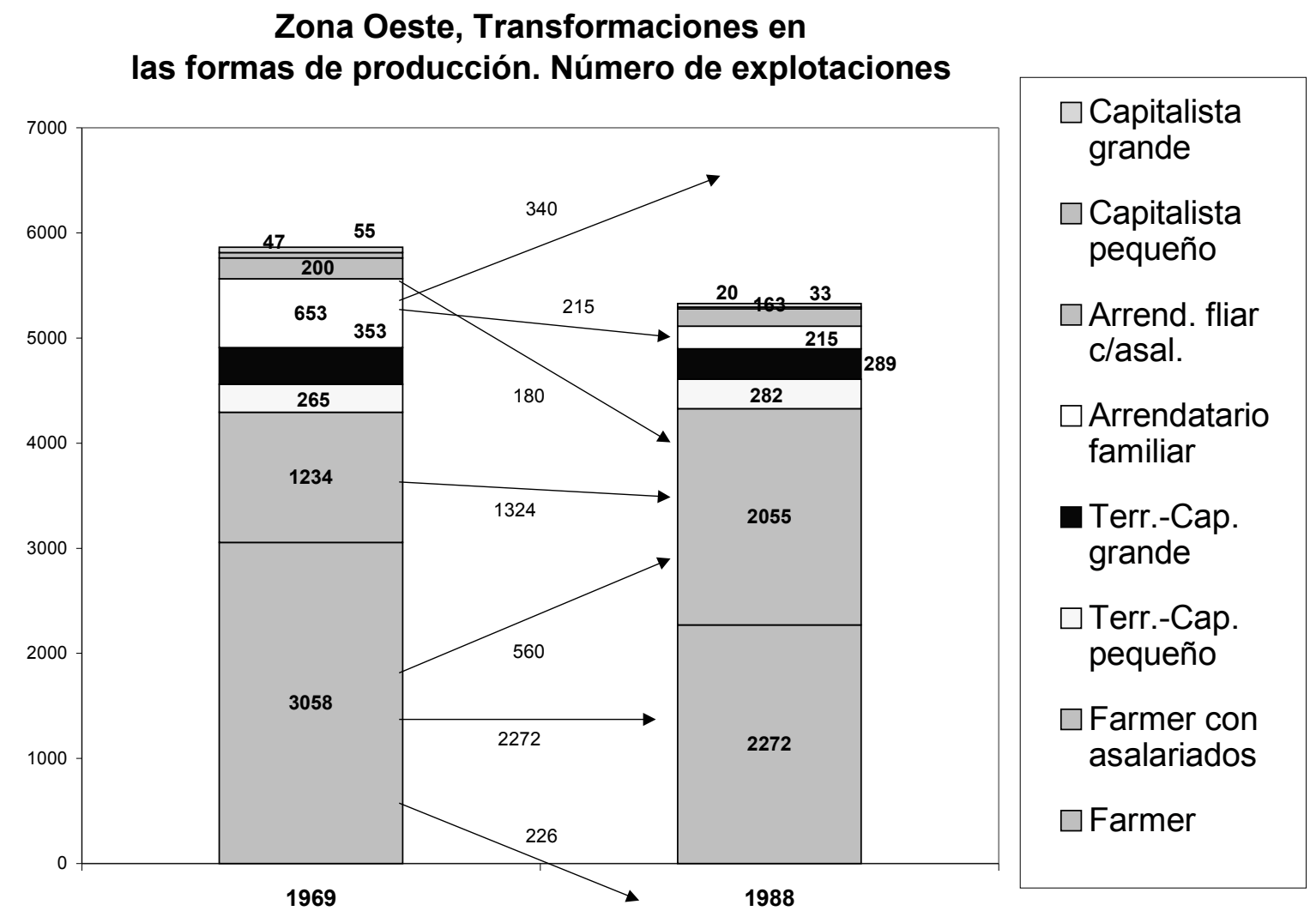

Fuente: Reprocesamiento de los datos originales de los Censos Agropecuarios de 1969 y 1988.\}

En cuanto a la distribución de la superficie censada, observamos en el Gráfico 3.18 que los farmers con asalariados aumentaron considerablemente el área que controlaban $^{70}$, mientras que los farmers y los arrendatarios familiares reducían su peso notoriamente. No hemos hallado casi modificaciones entre los terratenientescapitalistas, tan sólo un 3\% del área total habría pasado de los grandes a los pequeños terratenientes-capitalistas, creciendo la superficie en manos de terratenientes-capitalistas con 3 o 4 asalariados pero con campos de 1.000 a 2.500 hectáreas.

70 Observamos que el estrato que más ha crecido en superficie dentro de los farmers con asalariados ha sido el de 400 a 1.000 hectáreas, y luego el de más de 2.500 . 
Como resultado de estos cambios, también en esta zona los farmers con uno o dos asalariados se convirtieron en los productores con mayor importancia territorial (33\% del área), aunque los terratenientes-capitalistas grandes tenían una superficie similar (32\%).

\section{Gráfico 3.18.}

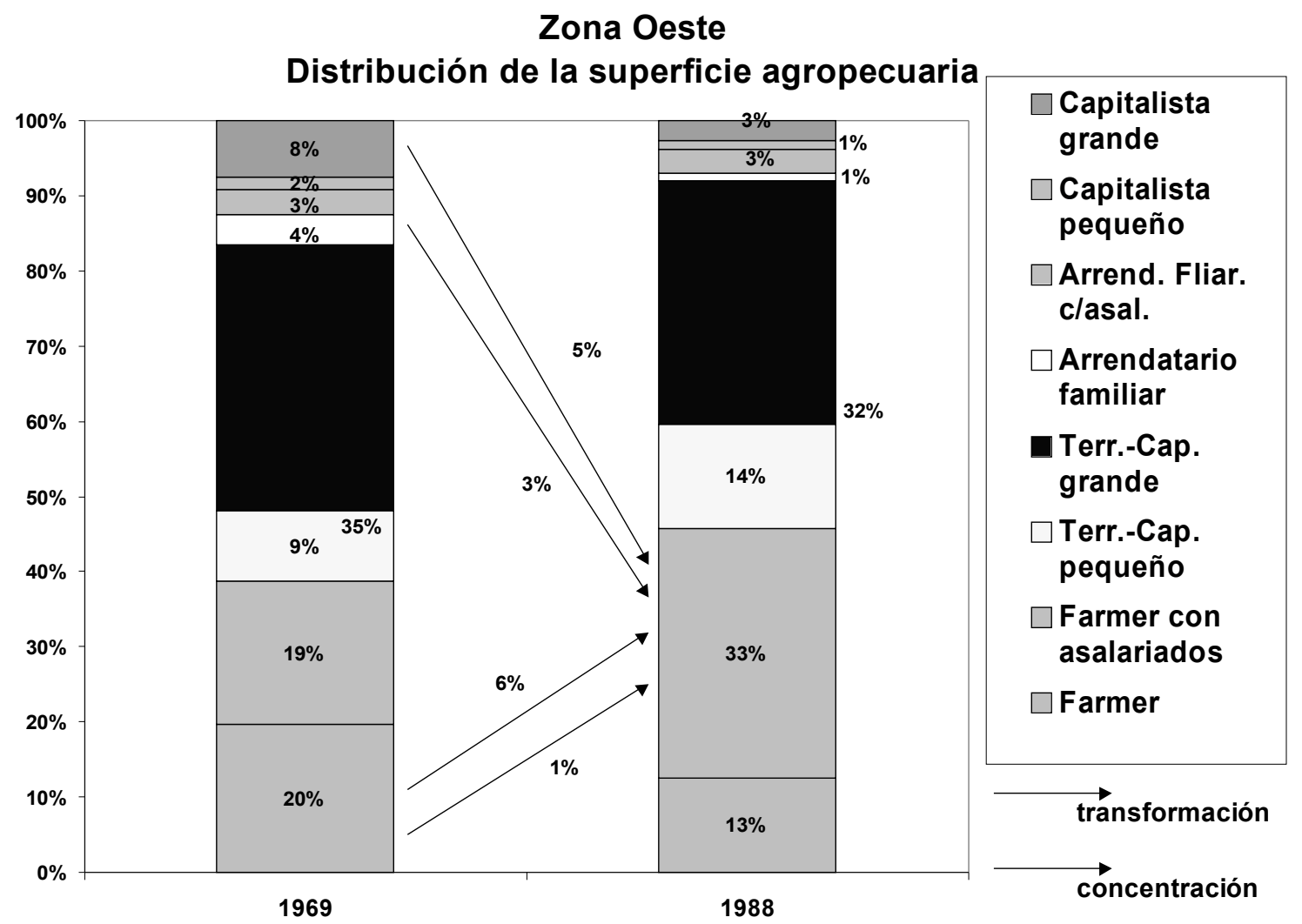

Fuente: Reprocesamiento de los datos originales de los Censos Agropecuarios de 1969 y 1988.

En cuanto al tamaño de cada una de estas formas productivas, en el Cuadro 3.13 podemos observar que si bien el promedio de todas las explotaciones de la zona oeste había aumentado en un 24\% entre 1969 y 1988, algunas formas presentaban cambios de magnitud mucho menor. Entre éstas se encontraban los farmers, que redujeron levemente su tamaño, siendo en 1988 de 132 hectáreas (cifra que, por cierto, casi duplica el tamaño medio de los farmers de la zona norte); los arrendatarios familiares 
(cuyas 121 hectáreas los equiparan a los de la zona norte); pero también los farmers con uno o dos asalariados, cuyo tamaño medio pasó de 412 a 446 hectáreas (más del doble de uno del norte). Por último, podemos destacar los importantes aumentos en el tamaño medio de los terratenientes-capitalistas pequeños y de los capitalistas pequeños.

Del aumento del $63 \%$ en la superficie agrícola que tuvo lugar durante estas dos décadas, la mayor parte (53\%) ha sido gracias a la expansión de la agricultura a cargo de los farmers con uno o dos asalariados (ver Gráfico 3.19) ${ }^{71}$. Pero también los terratenientes-capitalistas grandes fueron responsables de un $37 \%$ de la agriculturización, mientras que los pequeños terratenientes generaron un $6 \%$ del incremento del área agrícola.

71 Dentro de este tipo de productores, un $30 \%$ del aumento habría tenido lugar dentro de parcelas que estos productores ya controlaban en 1969, un 5\% por campos que los farmers con uno o dos asalariados de 1969 lograron sumar a sus lotes originales, un $10 \%$ por la incorporación, a esta forma, de farmers que no contrataban asalariados en 1969, y un $8 \%$ por el acceso a la propiedad de arrendatarios. 


\section{Gráfico 3.19.}

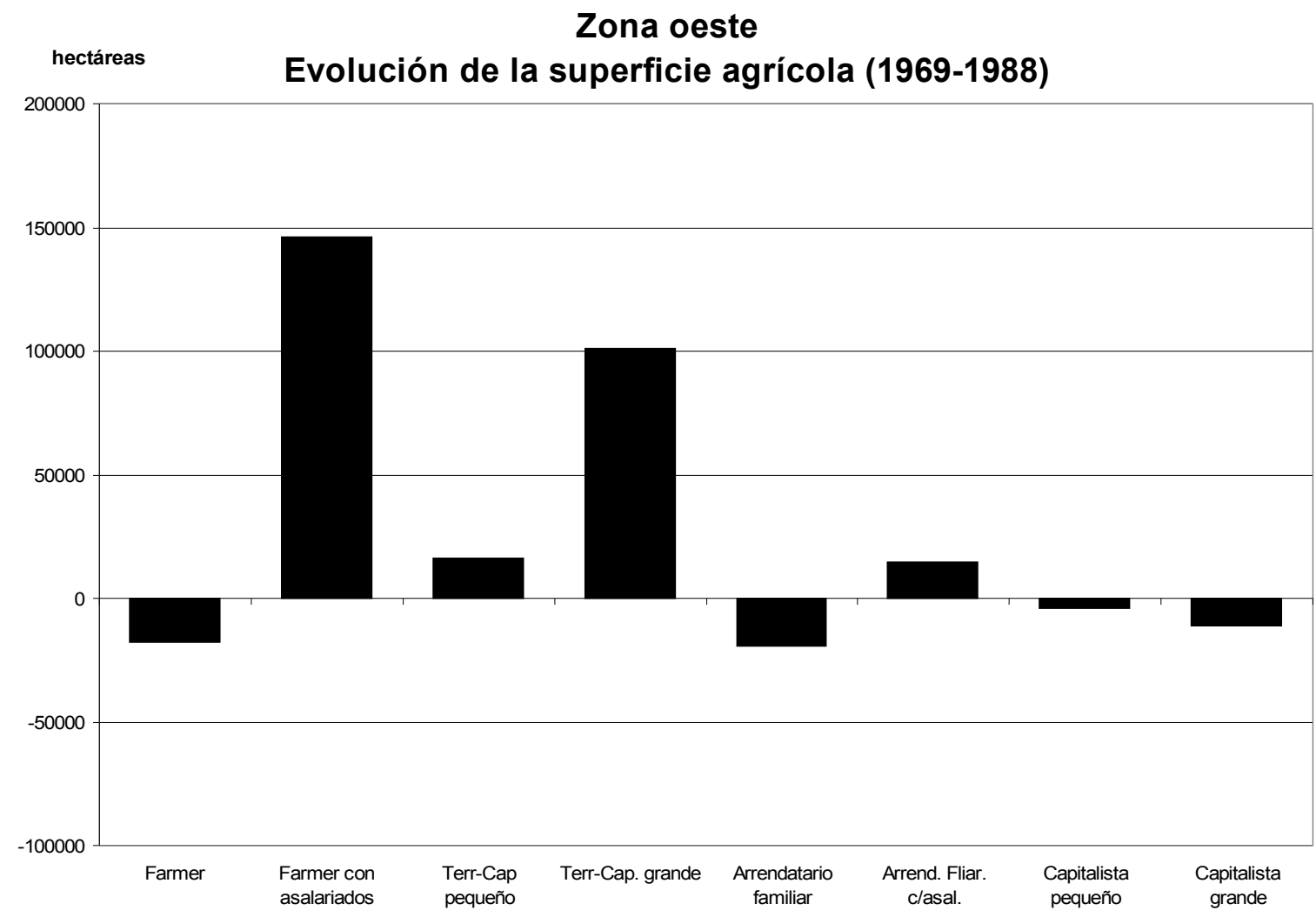

Fuente: Reprocesamiento de los datos originales de los Censos Agropecuarios de 1969 y 1988.

Todos estos cambios produjeron un crecimiento en la importancia de los farmers con uno o dos asalariados (aumentaron en un 9\% del total del área agrícola) y, en segundo plano, de los terratenientes-capitalistas con cinco y más asalariados permanentes $(6 \%)$, a costa de la importancia de los farmers, los arrendatarios familiares y los arrendatarios capitalistas. De este modo, los farmers con uno o dos asalariados lograron equiparar su importancia en la agricultura con los grandes terratenientescapitalistas (ambos, junto con los propietarios con tres o cuatro asalariados, poseían el $80 \%$ de la agricultura de la zona oeste). En cambio, los farmers puros perdieron la mitad de la superficie que controlaban en 1969 (de 21\% del total, pasaron al 10\%) y los arrendatarios familiares quedaron reducidos a una expresión totalmente marginal (del $8 \%$ al $2 \%$ de la superficie sembrada). 
En síntesis, en esta zona los farmers se mantuvieron, pero no lograron aprovechar el proceso de agriculturización. Quienes sí lo pudieron hacer fueron los farmers con asalariados. Además, a diferencia de la zona norte, aquí los terratenientescapitalistas generaron una gran parte de la expansión agrícola.

\subsection{Formas de producción y agricultura en la zona sur}

En la zona sur tuvo lugar una importante disminución en el número de farmers (del orden del 40\%), tal como puede observarse en el Gráfico 3.20. Algunos abandonaron la producción, mientras que un número mayor se habrían convertido en farmers con uno o dos asalariados permanentes (la gran mayoría de ellos se habría mantenido en campos de tamaños similares a los que tenían en 1969). Los arrendatarios familiares tuvieron una muy fuerte crisis: el 54\% de los presentes en 1969 habrían tenido que abandonar la producción ${ }^{72}$. Por su parte, la gran mayoría de los pocos arrendatarios capitalistas presentes en 1969, habrían accedido a la propiedad (al menos de una parte de sus campos), incorporándose probablemente a los farmers con asalariados.

También en la zona sur fueron los farmers con uno o dos asalariados la forma productiva que más creció en estas décadas: su número casi se duplicó ${ }^{73}$. En cambio la cantidad de terratenientes-capitalistas se redujo levemente.

72 De los restantes, un 34\% pudo haber permanecido como tal, y el $12 \%$ restante habría incorporado uno o dos asalariados.

73 Estimamos que del incremento en 1.846 unidades, el 79\% de ellas habría provenido de exfarmers sin asalariados, $12 \%$ de ex-arrendatarios, y $9 \%$ de ex-terratenientes-capitalistas. 
Gráfico 3.20.

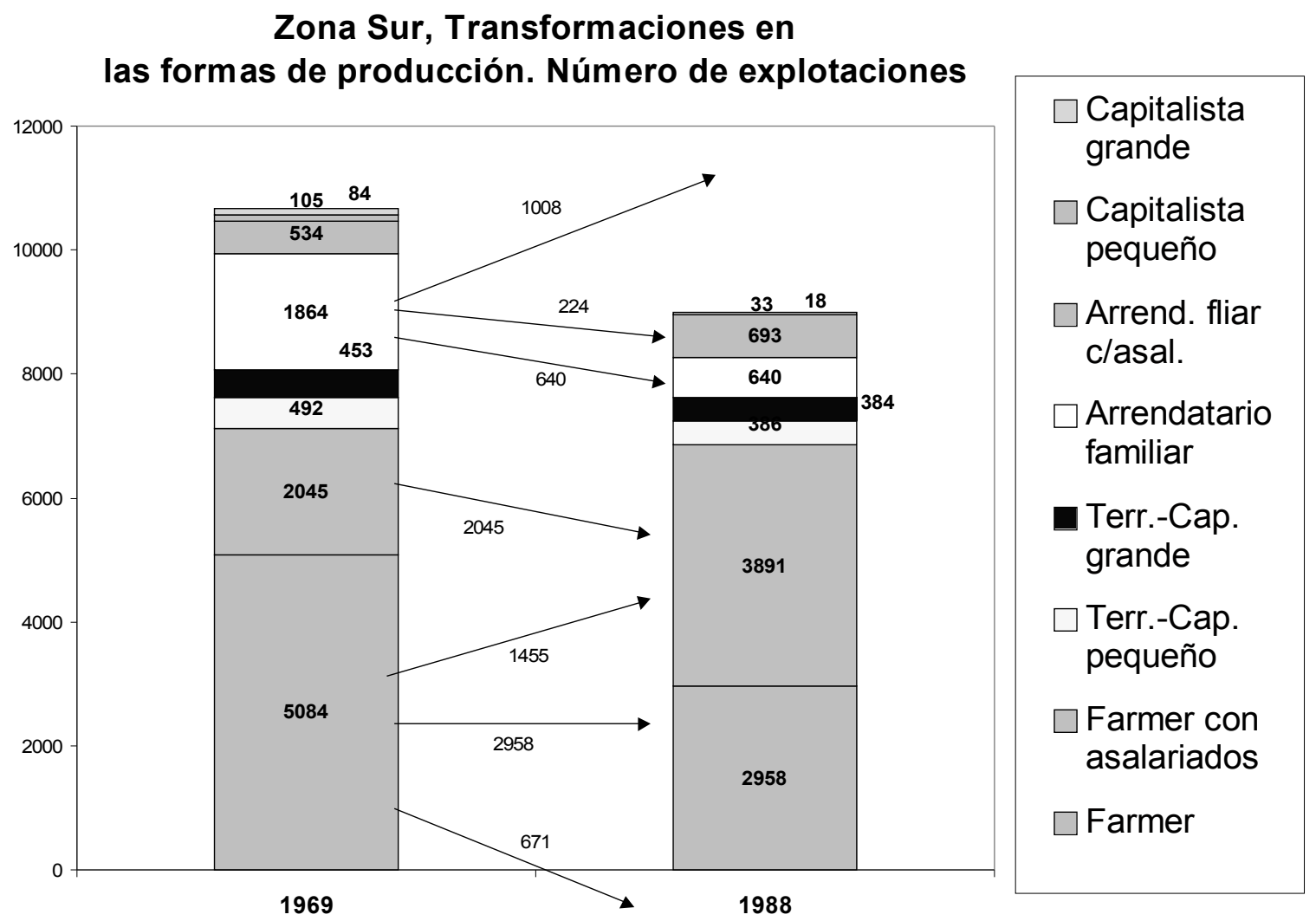

Fuente: Reprocesamiento de los datos originales de los Censos Agropecuarios de 1969 y 1988.

En términos del control de la superficie censada, los farmers con asalariados pasaron a ser la forma predominante (con el $41 \%$ del área $)^{74}$, tal como puede observarse en el Gráfico 3.21. Recordemos que, dentro de ellos, fueron los que combinaban propiedad y arriendo quienes más lo hicieron, aunque solo el $7 \%$ de su superficie era tomada en base a contratos accidentales.

${ }^{74}$ Calculamos que un $10 \%$ fue aportado por los ex-farmers, $3 \%$ por los ex-arrendatarios, y un $7 \%$ por la expansión de los propios farmers con asalariados presentes en 1969 (5\% habrían capturado del área controlada por arrendatarios en 1969, y 2\% por farmers que abandonaron la producción). 


\section{Gráfico 3.21.}

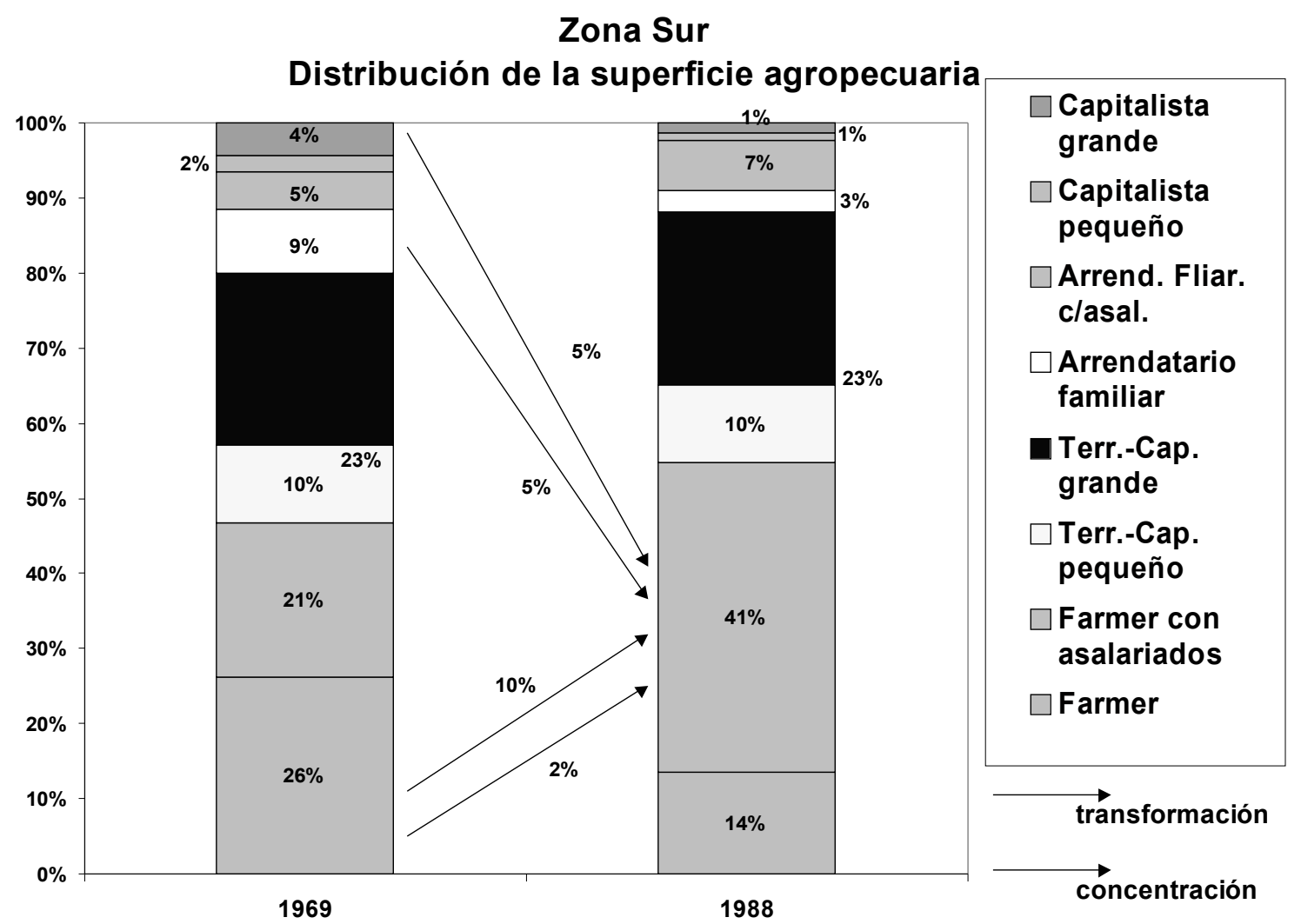

Fuente: Reprocesamiento de los datos originales de los Censos Agropecuarios de 1969 y 1988.

En cuanto al tamaño medio de cada una de estas formas (ver Cuadro 3.13), observamos que en su conjunto fue la zona donde más se incrementó (38\%) entre 1969 y 1988. Sin embargo, los aumentos importantes se circunscribieron a las formas capitalistas y terratenientes-capitalistas con aumentos del 21\% al 50\%. En cambio, las unidades de tipo familiar puro o con uno o dos asalariados presentaron sólo pequeños incrementos en sus tamaños medios. De todos modos estos productores tenían unidades de escalas importantes: los farmers con uno o dos asalariados alcanzaron las 547 hectáreas (más de dos veces y media mayores que los de la zona norte), o los farmers presentaban 225 hectáreas (más de tres veces la escala de los del norte, pero también casi el doble que los del oeste). 
En esta zona, tal como ya hemos comentado, la superficie agrícola se mantuvo relativamente estable entre 1969 y 1988. Sin embargo, tal como puede verse en el Gráfico 3.22, los farmers con uno o dos asalariados tuvieron un incremento de tal magnitud en la superficie agrícola que logra contrapesar el fuerte retroceso que tuvieron los farmers y los arrendatarios familiares. Alrededor de la mitad de este aumento en la superficie agrícola de los farmers con uno o dos asalariados habría tenido lugar al interior de campos controlados por este tipo de productores en 1969. Una sexta parte, se habría producido en campos incorporados por estos productores, y una cuarta parte, porque farmers puros habrían pasado a contratar asalariados.

\section{Gráfico 3.22.}

\section{Zona sur}

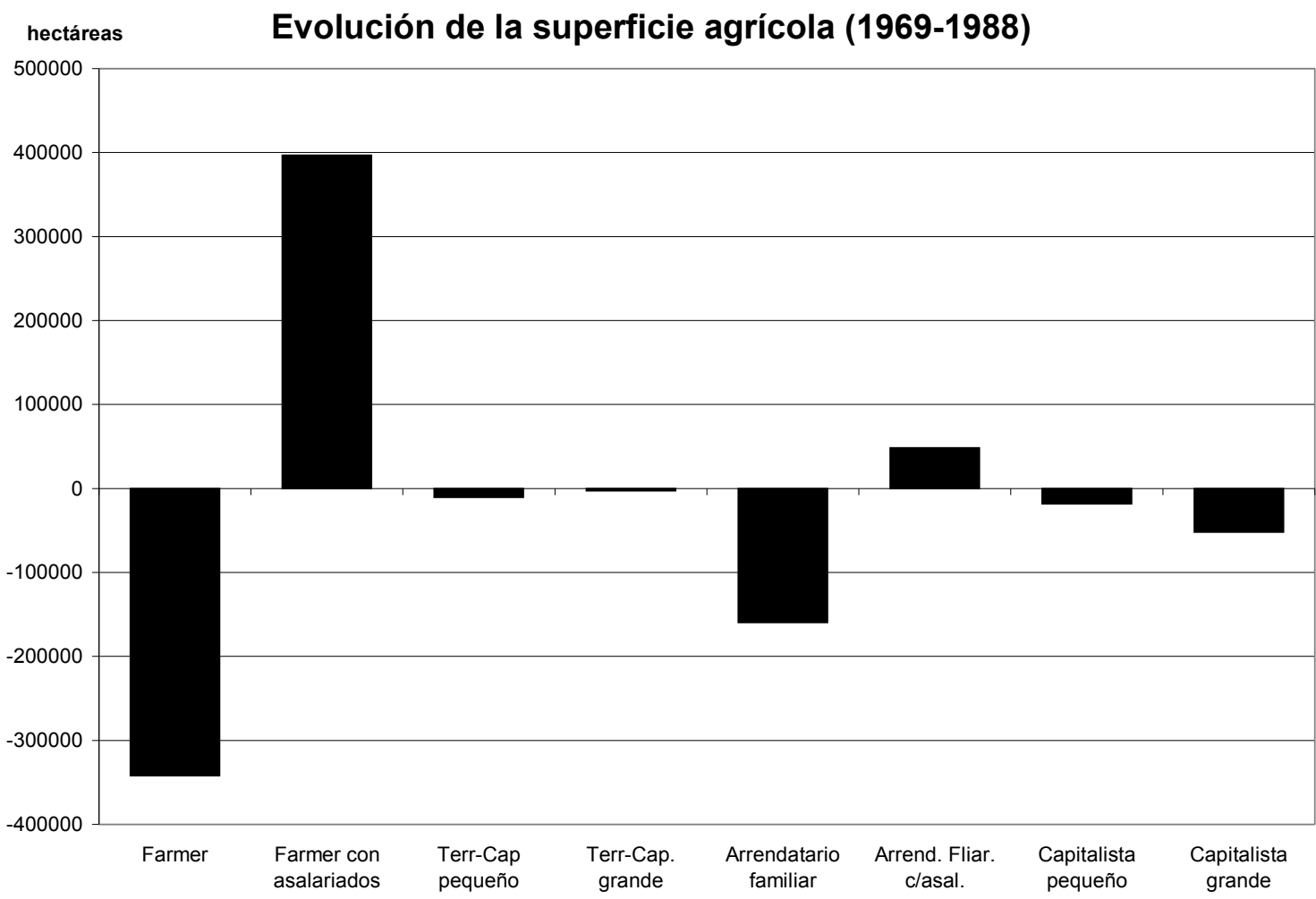

Fuente: Reprocesamiento de los datos originales de los Censos Agropecuarios de 1969 y 1988.

De este modo, también en esta zona los farmers sin asalariados perdieron protagonismo en la agricultura frente a los que contrataban uno o dos asalariados 
permanentes. Por su parte, los arrendatarios familiares sufrieron un drástica reducción en su significación. Los terratenientes-capitalistas prácticamente no modificaron su participación relativa. Así, los farmers con uno o dos asalariados se constituyeron en la forma productiva dominante en la agricultura (controlaban el $43 \%$ de la superficie implantada), desplazando a los farmers sin asalariados.

En síntesis, la mayoría de los farmers de la zona sur se mantuvieron como tales, reduciendo la superficie que dedicaban a la agricultura, pero casi un tercio incorporó asalariados en forma permanente. Fueron justamente los farmers con asalariados quienes expandieron notoriamente su superficie agrícola. Los terratenientes-capitalistas no se expandieron, y los arrendatarios familiares sufrieron una muy fuerte crisis.

\subsection{Balance de las transformaciones}

Tal como intuimos inicialmente, no es simple responder la pregunta sobre qué fenómenos posibilitaron la expansión agrícola en las dos décadas estudiadas (si la "farmerización" ocurrida durante el período anterior, o la aparición de nuevos sujetos sociales).

Las formas de producción relativamente novedosas, tanto el contratismo tantero como los grandes productores agrícolas capitalistas, no alcanzan a dar cuenta de la expansión agrícola. El contratismo tantero no tuvo ninguna relevancia en la zona oeste y mantuvo un papel secundario en la zona sur. Incluso en la zona norte sólo controlaba un cuarto de la superficie dedicada a la agricultura en 1988, aun incluyendo la parte correspondiente a las unidades que lo combinaban con la propiedad. Las unidades capitalistas -considerando todas las explotaciones con un mínimo de tres asalariados permanentes- no aumentaron en absoluto su peso ni en la actividad agrícola ni en el total de hectáreas censadas. 
Entonces, de una primera aproximación podría derivarse que los protagonistas de la expansión agrícola serían las unidades familiares en propiedad, de tamaño pequeño y mediano, justamente las que habían resultado del proceso de "farmerización" ocurrido entre los años cuarenta y sesenta. Sin embargo, otros indicios contradicen esta imagen. Por un lado, la mayor parte del incremento en la superficie agrícola de la zona norte debe adjudicarse a los contratistas tanteros -en primer lugar, en combinación con parcelas en propiedad, pero también en forma pura-, y dentro de la zona sur han sido estos productores los que más impulsaron la "agriculturización". Por otro lado, el crecimiento agrícola se desarrolló principalmente en las unidades de 200 a 1.000 hectáreas en la zona norte, y en las de más de 1.000 en las otras dos zonas. No pudieron aprovechar este proceso expansivo las explotaciones de menos de 200 hectáreas en la primera de las zonas, y las menores a 400 en las dos últimas.

Al integrar todas las dimensiones estudiadas, como acabamos de analizar en este apartado, encontramos que se desarrolló un proceso de diferenciación social de los farmers que no tenían asalariados en 1969. Algunos tuvieron que abandonar la producción, una mayoría se mantuvo sin poder sacar partido de la agriculturización, mientras que otros incorporaron uno o dos asalariados permanentes a su fuerza de trabajo. Dentro de estos últimos, unos pocos habrían logrado expandirse territorialmente.

En segundo lugar, quienes no pudieron sobrevivir fueron los arrendatarios familiares que todavía quedaban en 1969: su número se redujo intensamente en las tres zonas estudiadas. Podemos concluir que, aunque no aseguró las condiciones para su desarrollo, la propiedad posibilitó a los pequeños productores cierta capacidad de permanencia.

En tercer lugar, la expansión de los contratistas tanteros (sin parcelas en propiedad) en la zona norte sólo superó levemente la reducción del peso del arriendo y la aparcería; mientras que en la zona sur ni siquiera llegó a compensarla.

Por último, hemos determinado que la forma social de producción que más se expandió durante la "agriculturización" fue la de los productores propietarios de sus 
campos (en forma total o parcial) con uno o dos asalariados permanentes ${ }^{75}$. Este fenómeno no ha sido considerado por la bibliografía especializada. Gracias a la mayor capacidad de trabajo de las nuevas maquinarias (incorporadas a fines de los setenta y comienzos de los ochenta) estos sujetos lograron duplicar el tamaño de sus parcelas agrícolas (que, en general, tenían extensiones medianas al comienzo del período) sin aumentar la cantidad de brazos utilizados. Incluso, en 1988, en su mayoría contrataban un sólo asalariado permanente. Aunque los denominamos "farmers con asalariados", el aporte de los familiares del productor era ya pequeño en 1969, y resultaba menor para 1988. Mantenemos la denominación de "farmer" porque el aporte del productor podría resultar similar al del asalariado permanente. Sin embargo, como veremos en el capítulo cuarto, la familia ya no funcionaba como equipo de trabajo. Si para fines de los años sesenta varios de los que contrataban uno o dos asalariados todavía presentaban el perfil familiar de mediados de siglo, a fines de los ochenta muy pocos conservaban estas características.

Indudablemente la "farmerización" brindó la base material para que los productores propietarios con uno o dos asalariados lideraran la expansión agrícola, combinando la propiedad con otras formas de tenencia del suelo, y la producción directa con la contratación de servicios de maquinarias. Pero sólo algunos de los "farmers" (que no contrataban asalariados en 1969) pudieron tomar parte activa en esta expansión. En los años noventa tuvo lugar otro importante crecimiento de la producción agrícola, pero fue acompañado por un nuevo aumento del proceso de concentración, golpeando ahora no sólo a las explotaciones pequeñas y medianas-pequeñas, sino incluso a las unidades de 200 a 500 hectáreas de la zona norte (Azcuy Ameghino, 2000).

La "farmerización" no resultó suficiente para garantizar el crecimiento centrado en la explotación en propiedad basada en el trabajo familiar. Hacia fines de los sesenta, como culminación de más de cincuenta años de luchas políticas e ideológicas en torno a un modelo de desarrollo agrario, la estructura pampeana se había acercado como nunca al siempre mencionado ejemplo norteamericano. Sin embargo, una serie de factores se conjugaron para desbaratar la posibilidad de consolidar esta vía de desarrollo. El agro no fue ajeno al amplio proceso social regresivo que comenzó con la última dictadura

75 Más allá que en la zona oeste también los terratenientes-capitalistas lideraron el proceso de expansión agrícola. 
militar $^{76}$ y continuó luego, especialmente con el menemismo. En este sentido, no sólo fueron políticas puntuales, sino la imposición de toda una ideología indiferente a los efectos que tenía sobre la estructura agraria y la comunidad rural, la conjunción de un particular desarrollo tecnológico, la liberalización financiera y el desmantelamiento de la infraestructura estatal. De este modo, se dilapidó la segunda oportunidad de construir un desarrollo basado en las explotaciones familiares en propiedad, como ya se había hecho a fines del siglo XIX.

76 Tal vez, en el caso agrario su inicio puede fijarse en el año 1974 con el desplazamiento de Horacio Giberti de la Secretaría de Agricultura y Ganadería, y la no aplicación de la aprobada ley del impuesto a la renta normal potencial de la tierra. 


\section{Capítulo Cuarto}

La transformación del modo de vida de los productores y el desvanecimiento del mundo rural chacarero durante la segunda mitad del siglo $X X$ 
En unas pocas décadas, el modo de vida de los productores agropecuarios se modificó drásticamente y se desvaneció el mundo rural chacarero construido durante la primera etapa expansiva, que describiéramos al comienzo de esta tesis. Dos factores causaron esta transformación. Por un lado, la drástica reducción en la cantidad de pequeñas explotaciones agropecuarias que estudiamos en los anteriores capítulos. Por otro lado, la radicación urbana de la mayoría de los productores que lograron sobrevivir. Este cambio en el lugar de residencia tuvo claras implicancias en la relación entre la familia y la unidad productiva, y, a partir de ello, se generó un nuevo contexto de socialización para las sucesivas generaciones, desencadenándose otros efectos que serán analizados a lo largo del presente capítulo.

Este ha sido un proceso que, por sus múltiples aristas y las diferencias idiosincráticas, es difícil de fechar con precisión: algunos de sus elementos seguramente ya habían comenzado a desenvolverse en la primera mitad del siglo XX, pero la mayoría de ellos recién tomaron forma a partir de la década del sesenta. De hecho, para finales de los años ochenta algunos de estos procesos continuaban desarrollándose. Los ritmos de estos cambios fueron diversos, y pesaron fuertemente las características individuales de cada historia familiar; sin embargo, hemos detectado una tendencia clara a lo largo de todo el período a favor de la urbanización y de una notoria transformación en el modo de vida de los chacareros, con el consiguiente desvanecimiento del mundo rural que encarnaban. Recién durante los años noventa aparecieron elementos discordantes con esta tendencia semi-secular, al surgir algunos síntomas de retracción, cierta "vuelta al campo", a pesar de que otros aspectos continuaban desplegándose, quizás con intensidad creciente de la mano de la expansión de las políticas económicas y los valores neoliberales.

Debido a este carácter difuso en su temporalidad, no intentamos fechar expresamente cada uno de los cambios, y hemos optado por englobar el análisis de estas transformaciones en un único capítulo. La articulación de estos cambios con las modificaciones en las formas sociales de producción hasta aquí analizadas, se realizará en el último capítulo. 


\title{
1. La urbanización de los productores agropecuarios
}

\author{
"Hace años que en el campo no hay gente. \\ El campo es una tristeza."
}

Según los datos censales de 1988, un alto porcentaje de los productores rurales de las tres zonas estudiadas no residían en su explotación. Como se puede observar en el Cuadro 4.1, más de la mitad de los productores de la zona sur no vivían en sus establecimientos; en la zona norte esta cifra ascendía al 58\%, y en la oeste al $65 \%$. En el caso de los productores medianos estos porcentajes eran incluso más altos; así por ejemplo, el $71 \%$ de los productores de 400 a 1.000 hectáreas de la zona norte no residía en sus campos, y en la zona oeste, el 74\%. De los productores con extensiones mayores a las 1.000 hectáreas, alrededor del $80 \%$ no vivían en sus explotaciones. Por su parte, también entre los pequeños productores los niveles de no-residencia superaban en general el $50 \%{ }^{1}$.

1 Ya a comienzos de los años setenta, una encuesta a productores medios había detectado una tendencia "a migrar a los centros urbanos o pequeño-urbanos cercanos, sin abandonar la propiedad agraria ni su manejo inmediato; más aún, se sigue manteniendo la explotación como medio fundamental de vida. Se mantiene la residencia en el campo, pero se establece una nueva residencia en el pueblo, la cual pasa a ser la principal y permanente" (Brie y otros, 1977: 49). Sin embargo, los datos de la encuesta registran que de los productores medios sólo el 14,7\% vivía en el pueblo en el "Área Pergamino" (norte bonaerense y sur de Santa Fe, productores de más de 35 hectáreas), el 12,9\% en el "Área Balcarce" (sur y centro bonaerense, productores de más de 15 hectáreas), y el 7,4\% en el "Área Anguil" (oeste bonaerense y este de La Pampa, productores de más de 84 hectáreas). Sin embargo, estos porcentajes se elevaban en el caso de los propietarios. El trabajo ejemplifica esta situación con la zona de influencia de la Agencia INTA de Bordenave. Allí, de los 75 productores propietarios, 21 vivían en el pueblo y 54 en el campo. Y además encontraron que "hay una relación directamente proporcional entre la centralidad urbana y el mayor volumen de hectáreas en propiedad" (Brie y otros, 1977: 49). 
Cuadro 4.1. Explotaciones agropecuarias según residencia o no del productor, diferenciadas por escalas de tamaño y zona, 1988.

\begin{tabular}{|r|r|r|r|r|}
\hline & Tamaño & $\begin{array}{r}\text { Residencia del productor } \\
\text { en la explotación }\end{array}$ & Tota \\
\hline Zona & & Reside & No reside & \\
\hline Norte & hasta 25 ha & $54.5 \%$ & $45.5 \%$ & $100.0 \%$ \\
\hline & 25 a 100 & $44.5 \%$ & $55.5 \%$ & $100.0 \%$ \\
\hline & 100 a 200 & $40.8 \%$ & $59.2 \%$ & $100.0 \%$ \\
\hline & 200 a 400 & $36.8 \%$ & $63.2 \%$ & $100.0 \%$ \\
\hline & 400 a 1000 & $29.1 \%$ & $70.9 \%$ & $100.0 \%$ \\
\hline & 1000 a 2500 & $19.9 \%$ & $80.1 \%$ & $100.0 \%$ \\
\hline & más de 2500 & $8.3 \%$ & $91.7 \%$ & $100.0 \%$ \\
\hline & & $43.0 \%$ & $57.0 \%$ & $100.0 \%$ \\
\hline Oeste & Total & $48.1 \%$ & $51.9 \%$ & $100.0 \%$ \\
\hline & hasta 25 ha & $41.0 \%$ & $59.0 \%$ & $100.0 \%$ \\
\hline & 25 a 100 & $40.7 \%$ & $59.3 \%$ & $100.0 \%$ \\
\hline & 100 a 200 & $38.3 \%$ & $61.7 \%$ & $100.0 \%$ \\
\hline & 200 a 400 & $26.6 \%$ & $73.4 \%$ & $100.0 \%$ \\
\hline & 400 a 1000 & $19.9 \%$ & $80.1 \%$ & $100.0 \%$ \\
\hline & 1000 a 2500 & $12.3 \%$ & $87.7 \%$ & $100.0 \%$ \\
\hline & más de 2500 & $36.0 \%$ & $64.0 \%$ & $100.0 \%$ \\
\hline Sur & & & & \\
\hline & Total & $52.3 \%$ & $47.7 \%$ & $100.0 \%$ \\
\hline & hasta 25 ha & $42.5 \%$ & $57.5 \%$ & $100.0 \%$ \\
\hline & 25 a 100 & $50.6 \%$ & $49.4 \%$ & $100.0 \%$ \\
\hline & 100 a 200 & $53.7 \%$ & $46.3 \%$ & $100.0 \%$ \\
\hline & 200 a 400 & $49.5 \%$ & $50.5 \%$ & $100.0 \%$ \\
\hline & 400 a 1000 & $32.3 \%$ & $67.7 \%$ & $100.0 \%$ \\
\hline & 1000 a 2500 & $16.6 \%$ & $83.4 \%$ & $100.0 \%$ \\
\hline & más de 2500 & $47.0 \%$ & $53.0 \%$ & $100.0 \%$ \\
\hline
\end{tabular}

Fuente: cálculos propios en base a una matriz de datos elaborada conjuntamente con la Dirección Provincial de Estadística y Planificación General de la Provincia de Buenos Aires a partir de la información original del Censo Agropecuario Nacional de 1988.

Cuando realizamos las entrevistas a mediados de los años noventa, todos los productores fueron coincidentes en señalar que casi nadie vivía ya en el campo, que quedaban muy pocos productores residiendo en sus establecimientos ${ }^{2}$. El comentario de un productor de Tres Arroyos sintetiza las afirmaciones de todos los entrevistados: "No hay nadie viviendo en el campo; quedan, en algunos lugares, algunos puesteros. La

2 En su estudio centrado en el partido de Bolívar, Tort (1983) encontró que la mayor parte de los productores familiares y asalariados rurales viajaban diariamente a la explotación. 
mayoría de los campos se manejan a distancia" $(\mathrm{GN})^{3}$. Se llegó al punto en que vivir en el campo se había convertido en "una cosa rara"4. En las tres zonas estudiadas, en general, no quedaba viviendo en el campo casi ninguno de los vecinos linderos de los entrevistados; es más, en toda el área donde se encontraba la explotación de los entrevistados, sólo restaban uno, dos o tres productores. Si bien la metodología empleada no permite cuantificar el porcentaje de productores que residían en forma permanente en su explotación, éste pareciera ser muy pequeño. La gran cantidad de testimonios recogidos y su congruencia (incluso en los tres partidos analizados ${ }^{5}$ ) permiten suponer que el registro censal puede, incluso, haber sobrestimado la residencia ${ }^{6}$.

Según los testimonios de nuestros entrevistados, la mayoría de los productores que no residían en sus explotaciones, lo hacía en las ciudades cabeceras de sus partidos; una minoría lo hacía en las pequeñas localidades que quedaban aún más cerca de sus establecimientos, y otra minoría (en este caso, productores de gran tamaño) vivía en los grandes centros urbanos, especialmente en la ciudad de Buenos Aires.

Muchos testimonios denotan con crudeza este vaciamiento del campo: "No hay nadie, nos fuimos todos del campo", "los campos están vacíos"7. El contraste con el

3 Recordar que en Apéndice 6 se encuentra una breve descripción de cada uno de los entrevistados.

4 "En esa época todavía vivía bastante gente en el campo, cada vez menos, hasta hoy, que es una cosa rara" (OF).

5 Además, podemos agregar que de los 17 productores de Pigüé entrevistados a comienzos de los noventa por Bardomás (1994) sólo uno residía en su explotación, mientras que los restantes lo hacían en la localidad de Pigüé.

6 La pregunta del formulario censal era "Personas que residen en la explotación. Indique la cantidad de personas", sin especificar si era residencia permanente o temporaria, como sí se explicitaba en el rubro "Trabajo".

7 Los siguientes testimonios también ejemplifican la idea de vaciamiento del campo que trasmitieron todos los entrevistados:

"Ahora, en la actualidad, no hay nadie en el campo, no vive nadie en el campo. Toda esta zona de Pergamino no hay nadie. Usted va de día... Usted se encuentra... como nosotros que vamos todos los días allá a trabajar, pero a la noche nos venimos... y no hay nadie que viva en el campo" (FL).

"En el campo prácticamente no queda nadie, en las chacras ya no hay gente, muy poco. Ahí en la zona nuestra, nadie" (MD). 
pasado era evidente, tal como lo relató una entrevistada de Pergamino: "...cuando yo fui [a vivir al campo, a mediados de los sesenta] no había ninguna [chacra] vacía, ahora no hay ninguna ocupada" (DO). En la zona norte, la diferencia fue aun más notoria, pues a comienzos del período, los agrupamientos de chacareros en las estancias o ex-estancias conformaban "colonias"8, con toda una vida social comunitaria, y a mediados de los noventa estaban desiertas: de toda una "colonia" tan sólo un par de productores continuaba viviendo en sus explotaciones'. Incluso las colonias institucionalmente constituidas, en general durante el primer peronismo, se despoblaron en unas pocas décadas ${ }^{10}$.

A la imagen de las colonias despobladas se agrega la tristeza que transmiten las casas abandonadas, convertidas en "taperas" (como las describieron varios entrevistados). Esto sucede incluso en la zona de Tres Arroyos, donde muchos productores habían construido importantes viviendas durante el período anterior, y que hoy son "casas para los peludos"11. O como describió un productor de Pergaminio, "hace años que en el campo no hay gente. El campo es una tristeza. Todas taperas quedan, ya ni casas" (ML) ${ }^{\mathbf{1 2}}$.

8 Tanto en propiedad como en arriendo o aparcería.

9 "Hay poca gente joven que está trabajando, el resto se fueron todos, una colonia de 42-43 colonos que había en las Margaritas, que duermen [en el campo, hoy] son cinco" (GR).

"En la colonia están mis cuñados, y dos o tres vecinos nada más" (MU).

10 Forni y Tort (1991: 24-28) describen una colonia establecida en el partido de Colón a partir de una expropiación realizada en 1947 (250 explotaciones de alrededor de 50 hectáreas cada una) que en un comienzo estaba poblada por unos 2.000 habitantes y que para comienzos de los años ochenta sólo presentaba unos 50 agricultores y sus familias como residentes efectivos. Forni y Tort destacan que "la colonia, a pesar de su diseño original y de la distribución a escala familiar de la tierra, tiene ahora las mismas características de la zona agrícola donde está implantada".

11 Un productor de Tres Arroyos, que aún reside en su campo, nos relató el siguiente diálogo con un repartidor: "La vez pasada estábamos mirando con un hombre los campos, que no hay nadie, están taperas, se fueron. [...] Un muchacho que reparte el gas, que anda por los campos, y me decía, principalmente en la zona de Oriente, 'hay unas casas bárbaras y están nada más que los peludos', la gente vive en el pueblo. Esos bicharracos vienen y empiezan a hacer cuevas debajo de los pisos, rompen todo" (VD).

12 También en el libro de Coscia, de comienzos de los ochenta, hallamos referencias a esta situación: "Lo concreto es que las zonas agrícolas se encuentran actualmente en un avanzado proceso de despoblamiento. Las taperas o las pequeñas isletas de árboles dispersas en los campos agrícolas, resto de lo que fueron viviendas de productores hasta hace una década o poco más, constituyen hoy un elocuente testimonio de una agricultura que en pocos años ha sufrido cambios muy profundos en todos los órdenes." (Coscia, 1983: 79). 
Corresponde diferenciar, al menos, dos tipos de radicaciones urbanas. Por un lado, los casos en los que los productores o sus hijos abandonaban la actividad agropecuaria y fueron en busca de empleos urbanos. Este fenómeno se asoció históricamente con situaciones de crisis agrícolas y con expansiones industriales que demandaban mano de obra en las ciudades. La mayoría de los que se iban del campo eran los hijos de los pequeños productores, que no podían desplegar su capacidad de trabajo en unidades de dimensiones reducidas ${ }^{13}$, o los propios pequeños productores (en general medieros o arrendatarios), ya sea que fueran expulsados por los terratenientes o se hubieran desanimado con proseguir en condiciones muy adversas ${ }^{14}$. Los años treinta a cincuenta fueron los momentos de mayor éxodo rural.

Por otro lado, se encuentra el fenómeno que queremos describir en este capítulo, es decir, la radicación urbana sin abandonar la titularidad de la explotación

Por su parte, Ghersa, Martínez y León (1998: 61) describen los cambios en el paisaje de la "chacra" entre 1970 y 1990: "Se produce el abandono total de la casa rural por parte del chacarero que fija residencia en el pueblo o la ciudad. Como consecuencia se produce la aparición de la tapera en el lugar de la chacra. En muchos casos la casa sigue habitada pero es evidente la desorganización de todas las partes vitales características de la chacra, por ausencia de su propietario y su familia. Del jardín quedan sólo los canteros y las ornamentales perennes (rosales, camelias, lilas), ahora expuestos a los animales domésticos por desaparición del alambrado perimetral. También desaparecen la huerta y el monte frutal, que no se poda ni se repone. Desaparece el gallinero, sus corrales y las casillas para ponedoras. Los cercos de ligustro, faltos de poda durante las últimas décadas, forman umbrosos bosques que rodean el área de la chacra. Hay cítricos remanentes con mucha fruta desaprovechada al pie del árbol que sólo sirve de alimento para las gallinas."

13 Así, por ejemplo, en los años sesenta, un estudio del INTA realizado por Coscia (1965: 8) señalaba que en 1961 en Pergamino en las chacras de 20 a 50 hectáreas existían en promedio dos hombres aptos para trabajar y las tareas que se realizaban insumían el trabajo de sólo uno. Para las que tenían, entre 50 y 200 hectáreas la disponibilidad era de dos hombres y medio, y las tareas absorbían el trabajo de un hombre y medio. Por lo tanto, concluía que "la desocupación dentro de la familia o empresa agraria de la región cerealista puede estimarse entre 150 y 170 mil personas".

14 En este sentido, una muestra de la escasa capacidad de acceder a la tierra por parte de la juventud agraria y/o de su desinterés por hacerse cargo de unidades de dimensiones muy reducidas, es el promedio de edad de los pequeños productores de Pergamino a comienzos de los años setenta: sólo el $4 \%$ de los productores con hasta 40 hectáreas tenía menos de 30 años de edad, y un 13\% de 30 a 40 años. La edad promedio de los minifundistas era de 54 años (Torchelli, 1972: 32). 
agropecuaria, que habría comenzado a tomar envergadura desde fines de los cincuenta ${ }^{15}$. Según los entrevistados, esta radicación urbana de los productores (sin abandonar su rol) habría comenzado en los años sesenta o en los setenta (las opiniones se reparten en partes casi iguales sobre esta cuestión), prolongándose durante las décadas siguientes. La fecha promedio de radicación urbana de los productores que entrevistamos fue el año 1972 (sin que esta cifra pretenda ser representativa del conjunto, ya que no surge de un muestreo probabilístico) ${ }^{16}$.

En general, los entrevistados asociaron esta urbanización con coyunturas favorables para el agro (la otra urbanización, por el abandono de la actividad fue ubicada en los años cuarenta y cincuenta). En algunos casos se la situó en los "alegres sesenta"17 y otros durante el "boom" de la soja ${ }^{18}$, descripto por algunos como una época de "plata dulce". En este sentido, resulta interesante observar la generalizada percepción positiva de su propia situación que tenían los productores medios pampeanos a comienzos de los años setenta según se reveló en una encuesta: preguntado si "está

15 Una publicación geográfica de los años setenta diferenció dos etapas en el proceso de despoblamiento rural. La primera, durante las décadas del treinta y del cuarenta, habría estado signada por la crisis agrícola, la expansión ganadera y el éxodo de los agricultores hacia las pequeñas ciudades, "lugares de escala de una migración de más largo alcance que tuvo por destino final la urbe porteña. El censo de 1947 registró este fenómeno, acusando el desmedido crecimiento demográfico de la Capital Federal y las poblaciones suburbanas". En la segunda etapa, a partir de los años cincuenta, si bien "el éxodo rural persistió, en parte obedeció a causas diferentes, porque entraron en juego nuevos factores de localización" del productor rural que se radicó en las ciudades cercanas a sus explotaciones (Cammarata y otros, 1975: 151).

16 En una tesis de maestría realizada a comienzos de los setenta, se obtuvo la siguiente distribución de los productores del departamento de Gálvez (en el centro de Santa Fe) que ya estaban viviendo en la zona urbana: un $12 \%$ siempre había vivido en la ciudad, un $31 \%$ se había trasladado en la década del sesenta, un $24 \%$ en los años cincuenta, un $24 \%$ en la década del cuarenta y un 9\% en los años treinta (Felizia, 1970: 90).

Otra tesis, realizada en el mismo período pero en dos colonias entrerrianas de origen alemán (en el departamento de Diamante), encontró que el 65\% de los productores residían en el campo, y el 35\% en el pueblo (Cernuda, 1973).

17 Como contó un productor de Tres Arroyos: "En los años sesenta, cuando Frondizi, ahí... ¡Dios me libre!, si éramos los 'pachás' del mundo, no solamente acá, en Dinamarca pasó lo mismo... Cómo es que decían... 'los alegres sesenta'. Del sesenta al setenta fue una maravilla, había créditos de fomento... Era una joda, era una joda el país, para el agricultor-ganadero. En el '72, con 18 novillos gordos nosotros nos compramos un Falcon 0 kilómetro" (KA).

18 Sin embargo, otros testimonios señalan que en la zona de Pergamino, donde tenían su explotación, para fines de los sesenta ya quedaba poca gente viviendo en el campo: "nosotros fuimos los últimos en irnos, en el 69" (ML). 
mejor que antes", un 74\% respondió que sí, un 14\% que estaba igual, y sólo un 5\% que no, mientras que un 6\% no supo o no respondió (Brie y otros, 1977: 54).

Estos momentos de bonanza permitieron afrontar el incremento en los gastos que significó la radicación urbana ${ }^{19}$. Como comentó un productor y veterinario de Tres Arroyos, "la agricultura tuvo una muy buena época, una época de buenos ingresos, que permitía venirte a la ciudad. [...] En los buenos años, le alcanzaba para comprar una casa y comprar su auto para ir y venir, su camioneta, etcétera..." (VP). Por otra parte, un productor de Tres Arroyos de origen danés dejó traslucir (al utilizar el término "demasiado") que la radicación urbana fue producto de una prosperidad tal vez excesiva $\mathrm{y}$, en cierto sentido, perjudicial: "...la gente se vino a vivir al pueblo [por Tres Arroyos] ... será porque están demasiado bien, entonces compran o alquilan una casa en el pueblo y se vienen a vivir al pueblo..." (UN).

Entonces, la mayoría de los productores que pudieron aprovechar la expansión agrícola de mediados de los sesenta a mediados de los ochenta, utilizaron parte de sus ingresos para radicarse en la ciudad, con todas las inversiones y los incrementos de gastos que veremos que esto genera. Pero también se radicaron en las ciudades los arrendatarios expulsados que se convirtieron en contratistas, y los pequeños propietarios que tuvieron serios problemas de escala y que terciarizaban las labores o directamente cedían sus campos en arriendo. Los primeros, porque no tenían un campo propio y en la ciudad tenían ventajas operativas para organizar su actividad como contratistas de servicios o tanteros; los segundos, porque aquí podían buscar empleos urbanos para ellos o sus hijos e hijas, ya que la renta generada por los pequeños lotes no alcanzaba para mantener a toda la familia ${ }^{20}$, ni ofrecía una perspectiva para las nuevas

19 Un ingeniero agrónomo de la zona de Tres Arroyos lo analizó en estos términos: "hubo toda una etapa en que esa urbanización hizo que parte de la rentabilidad de la empresa... [se fuera al incremento de gastos generada por la urbanización], lo que pasa es que como la empresa era... la rentabilidad era muy favorable, [hizo que] se disimulara [este incremento en los gastos] (CJ).

20 Así lo describió la esposa de un productor de Pergamino: ".. los hijos se han ido, se han dedicado a otra cosa. No había rentabilidad para tanta gente, porque la subdivisión que hubo en la tierra... las parcelas eran chicas. Entonces se iban a trabajar afuera. [...] Sucedió que, como las parcelas eran chicas, no había futuro para los jóvenes. Un muchacho que quería formar su familia no podía vivir del campo, apenas vivían los padres" (DO) 
generaciones $^{21}$. En este sentido, un estudio del INTA realizado en 1969 sobre la ocupación y residencia de los jóvenes que habían sido miembros de los clubes juveniles 4-A (organizados por el Servicio de Extensión del INTA) entre 1955 y 1964 en la zona de Pergamino, encontró que la mayoría de ellos no seguían en la agricultura (se habían ido 335 de los 615 participantes), habiendo emigrado a las pequeñas ciudades y pueblos vecinos, más que a las grandes ciudades del país (Coscia, 1983: 105).

Si bien no contamos con datos censales previos a los de 1988, podemos afirmar que la residencia urbana de los productores no era totalmente novedosa. Sin embargo, en el pasado, para el caso de los chacareros, estaba fuertemente asociada con el retiro en la vejez ${ }^{22}$. Los padres de la mayoría de los entrevistados se habían ido a vivir a la ciudad (en algún caso al pueblo, en la zona norte) cuando a una edad en torno a los sesenta años se habían retirado, dejando la explotación a cargo de sus hijos en base a distintos

En el mismo sentido se pronunció un productor de Pergamino: "...Otra causa [de que se vaya la gente del campo] fue, en el '45, '48, '49, cuando los muchachos salieron de la colimba, fue el boom industrial toda la zona de Paraná, San Nicolás, Ramallo, Somisa, Acindar, y los muchachos tuvieron mucha posibilidad de trabajar. Muchos se fueron a Bs. As. En una chacra que había 8 chicos con 40 hectáreas, no hacían nada" (GR)

Un veterinario de Tres Arroyos analizó que "... ya paso más de una vez. No es más que una hipótesis, así, digamos, lanzada, por ejemplo, ¿qué tamaño tenía el promedio de las superficies entregadas o vendidas por el estado a los colonizadores, el Instituto de Colonización de la provincia de Buenos Aires?.... por ejemplo, una, dos, tres generaciones más tarde, ¿qué tamaño tenía eso?, ¿que relación tenía con la unidad mínima productiva? ¿y qué relación tenía con el hecho de que por ahí, muchos hermanos que vivían en el campo se encontraron con que ya no daba para las dos, tres o cuatro familias?. Y entonces algunos se trasladaron a la ciudad impulsados por el hecho de decir 'bueno, no da para todos, yo le vendo la parte a mi hermano, yo prefiero seguir mi camino por otro lado' y uno de los hermanos se quedaba con el campo y los otros tres se venían a vivir acá, ¿no sé si me explico?, como alternativa, digamos, para explicar el éxodo..." (VH).

21 El desarrollo industrial del cinturón del Paraná atrajo a buena parte de los ex-chacareros y a la mayoría de sus hijos, según lo recordó una de nuestras entrevistadas:

- "...en la época de Perón, cuando empezaron las fábricas en el conurbano, entonces de todas las provincias la gente se iba para Buenos Aires, porque en Buenos Aires... las fábricas.... Como medio Manuel Ocampo [partido de Pergamino] se fue a San Nicolás, claro con la siderúrgica...

P: -¿Pero quiénes se iban? ¿Los peones o los chacareros?

- Lo que pasa es que como eran arrendatarios, a lo mejor el porcentaje no les convenía y estaba esto... que decían que era una mina de oro... la gente se empezó a ir ..." (mujer de FL)

22 En el caso de los estancieros, productores propietarios de extensiones importantes, volcados a la ganadería y con más antigüedad en las zonas, era más habitual ya durante la primer mitad del siglo XX la radicación urbana y el manejo de los campos a través de encargados. 
arreglos (les otorgaban el manejo operativo, pero se reservaban las decisiones más importantes, o les arrendaban el campo, o se lo dejaban por completo, a través de la herencia en vida, a cambio de que se hicieran cargo de sus necesidades). Para este retiro urbano se habían comprado una casa en la ciudad, o algunos pocos la alquilaban.

El retiro en la ciudad, con sus comodidades y oportunidades de sociabilidad, parece haber sido una aspiración compartida por la mayoría de los productores, tal como se observa en los siguientes testimonios: "Siempre es una aspiración de todo hombre que está en el campo... cuando ha trabajado ya un tiempo... piensa en vivir en el pueblo porque tiene más confort...[explicando el retiro de su padre, dueño de un pequeño tambo, y su radicación en el pueblo de Tres Algarrobos, partido de Carlos Tejedor]" (GA); "Mi madre siempre decía [con deseo] 'una casita en el pueblo"' (MÑ); "Todos tendemos a venirnos al pueblo llegada a cierta edad, reunirnos con los amigos frecuentemente, tener un poco de vida social más intensa..." (OB). ${ }^{23}$

En todos los entrevistados, el retiro se asocia con la radicación urbana, y no aparece, en los testimonios recogidos, la idea de un retiro campestre. Probablemente esto se deba no sólo a la idea de mayor confort en la vida urbana, sino a que es necesario dejar el lugar (el campo y la casa rural) a las nuevas generaciones ${ }^{24}$.

Pero si durante la primera mitad del siglo el retiro urbano era un fenómeno bastante generalizado, a partir de los años sesenta la radicación en la ciudad no sólo

23 En el caso de un productor que recién se ha radicado en Tres Arroyos a los 68 años, señaló la existencia de problemas de adaptación, si este retiro urbano se realiza a una edad demasiado avanzada: "Ahora me acostumbré acá [Tres Arroyos], yo siempre tuve esa idea: que algún día iba a tener que venirse a la ciudad (llega una edad que uno necesita estar más cerca del médico), y no tenía que venir demasiado tarde, porque si es demasiado tarde uno no se acostumbra, uno tiene que adaptarse. Porque si yo vengo ya de viejo... no me iba a encontrar, eso me parecía a mí..." (PL).

24 "La gente tiene edad... y no hay lugar para todos en el campo, entonces se hacen la casa, o compran una casa en el pueblo..." (UN).

En algunos casos, no sólo es dejar un lugar a la generación siguiente, sino a su empuje, a sus posibilidades de innovar, al "modernismo": "El que quiere vivir del campo tiene que estar en el campo, hasta ahora hice ese reglamento. Ahora, si uno tiene muchos años, no puede trabajar, y no te podés oponer al modernismo que está hoy [por lo tanto, hay que dejar el lugar]" (DS). 
obedece a este motivo, pues se fueron a vivir a ella muchos productores que aún estaban en edad activa, un fenómeno por cierto novedoso.

Desde los años cincuenta se incrementó la frecuencia de los viajes a la ciudad. Recordemos que al comienzo del período estudiado, los chacareros se trasladaban a las ciudades muy esporádicamente, una o dos veces al mes. Luego este viaje se fue haciendo cada vez más frecuente al difundirse el uso del automóvil o las camionetas, al incrementarse la capacidad de los vehículos para transitar los caminos rurales, e incluso al mejorar la calidad de éstos y la extensión de las rutas asfaltadas ${ }^{25}$. Entonces muchos productores comenzaron a viajar dos o tres veces por semana hasta el pueblo o la ciudad. Finalmente, la mayoría terminó radicándose en las ciudades, y viajando diariamente a la explotación ${ }^{26}$, aunque en otros casos sólo iban día por medio, o un par de veces en la semana, si tenían algún personal asalariado residiendo en forma permanente en el campo $^{27}$. Dos entrevistados que se trasladaban todos los días a su campo, se compararon con un profesional que, viviendo en un barrio residencial del Gran Buenos Aires, viaja a su trabajo en el Centro. Las mejoras en el transporte automotor han sido consideradas como claves para explicar el proceso de urbanización de los productores pampeanos ${ }^{28}$.

25 Sin embargo, no podemos reducir la causal de este cambio en la frecuencia de los viajes a la disponibilidad de automóviles y la mejora vial, pues ya en los años veinte había una gran proporción de productores que poseían automóviles en Tres Arroyos, al menos, y los viajes no eran muy frecuentes. Como señaló una entrevistada de Rivadavía, en los años sesenta, "teníamos auto, pero uno no venía [a Rivadavia]... a lo mejor yo venía una vez al mes y te acostumbrás a esa vida..." (MD).

26 En este sentido, Coscia comenta que "... muchos productores optaron por radicarse en una localidad próxima pero sin abandonar su explotación; para ello, diariamente, por lo menos cuando lo requieren las tareas agrícolas, viaja al campo por la mañana para regresar luego al final del día." (Coscia, 1983: 78-79).

27 El desarrollo de radiofonía, y en los últimos años de telefonía celular, permiten al productor estar relativamente informado sobre los problemas de su explotación, sin tener que estar personalmente en el campo.

28 Cammarata y otros (1975: 151) señalaron que "a partir de los años cincuenta, [...] el éxodo rural [...] obedeció a causas diferentes [a las del período anterior], porque entraron en juego nuevos factores de localización [del productor rural]: motorización del productor, pavimentación de las rutas e industrialización [...] Ya no es necesaria la permanente presencia física del productor en el campo pues, cuando el trabajo lo requiere, la camioneta le asegura el rápido traslado desde la ciudad próxima, en la que goza de una vivienda confortable con todos los beneficios de la residencia urbana: servicios bancarios y comerciales, asesoramiento 
Sin embargo, el principal motivo que argumentaron todos los entrevistados, para dar cuenta de este cambio de lugar de residencia, fue el objetivo de garantizar una mejor educación para sus hijos. Consideraremos entonces con detalle la emergencia de esta motivación en las entrevistas.

\section{La educación de los hijos como factor de la urbanización}

"No pude estudiar ni tenía recursos. Entonces yo quería que los hijos míos estudien [...]; la madre le decía: 'yo quiero título'."

Si los hijos de los inmigrantes que llegaron a principios de siglo tuvieron una reducida escolarización (aunque, por cierto, casi siempre superior a la que habían tenido sus padres europeos), la generación siguiente alcanzó mayores niveles de escolarización. En general, los productores medianos (y, en algunos casos, pequeños) buscaron la mejor educación, según ellos, de las escuelas primarias de la ciudad y

técnico; para sus hijos, facilidad de acceso a la educación y en fin una sociabilidad que les estaría vedada de permanecer en la chacra o en la estancia".

En su estudio sobre el partido de Bolívar, Tort (1983) encontró que "la capacidad de acumulación [de los productores] se ha traducido en una generalizada disponibilidad de vehículos automotores, que junto a los mejores caminos, posibilitan esta fluida movilización [de la ciudad al campo]".

Vapñarsky afirma que hoy la actividad agropecuaria requiere más población en aglomeraciones que funcionan como centros de servicios que en el propio campo abierto. Al tiempo que, al haberse transferido "del tren al automotor la modalidad dominante en el transporte de personas, el cambio facilitó y generalizó el desplazamiento rápido de ida y vuelta sobre trayectos considerables. El propietario de un predio agropecuario, o el arrendatario y hasta el peón, se vieron inducidos así a cambiar su residencia desde el predio donde cada uno trabaja hasta alguna aglomeración cercana (no muy grande: alguna de la cohorte I [hasta 49.999 habitantes]). Al trastocarse así la pauta tradicional de residencia de quienes viven del agro tiene que haber disminuido la población que reside en campo abierto (la población dispersa) en mayor grado que la población que trabaja en campo abierto (la PEA agropecuaria)" (Vapñarsky, 1995: 243). 
también que sus hijos accedieran al nivel medio. En varios casos, estaban movidos por el ideal de que sus hijos lograran convertirse en profesionales universitarios.

Prácticamente la totalidad de los entrevistados -tanto aquellos que continuaron viviendo en el campo hasta una edad avanzada, como los que se fueron a la ciudadmanifestaron que los productores se trasladaron a la ciudad cuando los hijos tenían que asistir a la escuela, en algunos casos primaria, en otros secundaria. En este mismo sentido, una mejor educación para sus hijos fue el motivo central de la radicación urbana que mencionaron de forma espontánea casi todos los entrevistados que se habían trasladado ${ }^{29}$. Asimismo fue recordado, por quienes no se radicaron en la ciudad durante esas décadas, como la justificación que brindaba todo el que se iba a la ciudad, a una edad en la que aún podía trabajar en el campo. Incluso los entrevistados que permanecieron en sus explotaciones manifestaron que no vieron críticamente este proceso, de lo cual podemos inferir que existía una valorización compartida de la educación escolarizada como un objetivo importante $\mathrm{y}$, posiblemente, parte de un esperado ascenso social intergeneracional.

En la mayoría de los casos, al comienzo el padre o la madre llevaba a los niños a la ciudad diariamente, pero este esquema les resultó "enloquecedor"30. Los diferentes

29 En una tesis realizada a comienzos de los años setenta en el centro de Santa Fe (departamento de Gálvez), las razones "educativas" ("para que puedan estudiar nuestros hijos" o "porque nosotros estudiamos") fueron las razones por las cuales vivían en la ciudad que esgrimieron la mayor parte (36\%) de los productores que residían en el medio urbano. En segundo término dieron razones "económicas" ("por no tener casa en el campo", "convenía edificar en el pueblo que es donde la casa conserva más su valor", "para que los hijos puedan trabajar en otra actividad") y razones "de bienestar general" ("en el pueblo se está mucho mejor", "en el pueblo hay más comodidad", "vine a vivir al pueblo para descansar", "en el pueblo es mejor vida", "el pueblo lo atrae"), ambas con un 19\% de las respuestas. Con un $12 \%$ cada una, siguieron las razones "de salud" y las "razones basadas en que el campo no es la fuente de ingreso principal" (Felizia, 1970: 57 y 91).

30 Como relató un productor de Tres Arroyos, "1973, ese era el año que me estaba enloqueciendo. Porque tenía chicos en jardín de infantes, chicos en primario, chicos en secundario, y yo era concejal, tenía que venir también a la noche. Entonces, yo vivía en la ruta" (RY).

En igual sentido opinó un ingeniero agrónomo que trabajaba y vivía en Barrows, a unos diez kilómetros de la ciudad de Tres Arroyos: "... un día que llegamos a la conclusión de que era más práctico que nos viniéramos a vivir a Tres Arroyos, y que yo viajara al campo, porque si no, mi casa era un loquero. Porque mi mujer no sabía si estaba en Tres Arroyos, estaba en el campo, o arriba de un auto. Algunos de los chicos vivían arriba del auto, aunque prácticamente no tenían muchos compromisos, que el otro tenía clase de no sé qué, que inglés,.... entonces el chico andaba dando vueltas arriba del coche con la madre, porque si no, 
horarios escolares y las actividades complementarias de los niños generaban múltiples viajes, y los padres terminaron cansándose de tanto movimiento. Además, en el caso en que los llevara el hombre ${ }^{31}$, percibía que estaba desatendiendo la explotación ${ }^{32}$. Finalmente, optaron por radicar la familia en la ciudad. A veces, primero se establecían la mujer y los hijos, pero, al poco tiempo, indefectiblemente, el hombre también se iba a vivir con ellos. Los hijos asistían a la escuela y los colegios urbanos, y a una serie de actividades educativas extra-escolares, la mujer permanecía en la ciudad con ellos y el hombre viajaba en las mañanas a la explotación, y regresaba al anochecer.

Según el promedio de nuestros entrevistados, los productores se fueron a vivir a la ciudad a la edad de 40 años, al comenzar la escuela media el primero de sus hijos.

En todas las entrevistas este proceso de radicación urbana para que los hijos asistieran al colegio fue presentado como "inevitable" o "natural"33, tanto que muy pocos manifestaron haber dudado al momento de decidirse a ir a vivir a la ciudad ${ }^{34}$. Sin

estaba solo en la casa del campo." (CJ).

31 Cabe señalar que una encuesta realizada a 123 amas de casa del partido de Pergamino que residían en el campo, encontró que sólo 11 de ellas sabían manejar, a pesar de que el $63 \%$ de las familias contaban con auto o camioneta (Baca, 1966: 17).

32 "Era ridículo hacer todos los días un viaje a La Sortija, que era la localidad que estaba más cerca, son diez kilómetros, ir y venir dos veces durante el día, yo terminaba desatendiendo mis actividades." (GN).

33 El tono de la mayoría de los relatos sobre la urbanización se puede ejemplificar con el siguiente diálogo con un productor de Pergamino:

"P- ¿Pensaron mucho esto de venirse?

No, mucho no lo pensamos, porque había que venirse. Para llevar los chicos al colegio, sí o sí tenía que venir" (FL).

O con este otro diálogo con un productor de Tres Arroyos:

"P: - ¿A usted le gustaba vivir en el campo, o quería venirse a vivir a Tres Arroyos?

- No, nosotros no pudimos vivir en otra parte que no sea en el campo. Después se tuvo que venir al pueblo por el asunto del colegio..." (BM).

${ }^{34}$ Los siguientes dos diálogos testimonian las dudas que tuvieron algunos pocos productores a la hora de irse a vivir a las ciudades:

"- En el '84 cuando mi hija empezó el secundario; tenemos dos hijos que se llevan siete años, entonces el más chico iba a la primaria. Teníamos el problema de llevar al chiquito al pueblo y a la otra a Pergamino, porque en el pueblo sólo había primaria, entonces teníamos el dilema de no saber qué hacer.

P- ¿Dudaron de esa decisión?

- Sí, muchísimo yo no quería venir del campo, pero decidimos comprar esta casa, mi marido estaba en el campo y venía a la noche, pero yo [antes] estaba mucho con él y hasta el día de 
embargo, fue un fenómeno históricamente novedoso y generado por una combinación de factores que merecen analizarse, desnaturalizarse.

En primer lugar, existió un creciente deseo de que los hijos tuvieran un nivel educativo muy superior al del propio productor, que en muchos casos no había finalizado la escuela primaria ${ }^{35}$ y que había sufrido esta situación e incluso asoció el lugar de chacarero con cierto escaso desarrollo cultural ${ }^{36}$. De hecho, no sólo la mayoría de los chacareros de las primeras generaciones no habían podido finalizar la escuela primaria, sino que muchos tenían un escaso hábito de lectura (así, por ejemplo, en Pergamino incluso la mayoría de los asociados a las cooperativas no tenían libros en sus $\left.\operatorname{casas}^{37}\right)$.

hoy siento eso..." (DO).

"- Yo vine acá [Tres Arroyos] porque en un determinado momento analizamos la situación, hicimos un análisis muy largo, íbamos anotando los pro y los contra de seguir viviendo en el campo y seguir viviendo en la ciudad, íbamos anotando, anotando, anotando, y después de un tiempo medio largo, que ya no anotabamos más, hicimos el balance.

P: - ¿anotando cuestión por cuestión? ¿haciendo una listita?

- Sí, sí, sí. [...] Cuando hicimos el balance no nos quedaba absolutamente ninguna duda. Quedó la duda, la duda que quedó fue '¿qué hacemos, compramos una casa en la ciudad, o alquilamos una casa?', pero de quedarnos en el campo o venir a la ciudad, no nos quedó ninguna duda..." (RY).

35 En una encuesta focalizada en los miembros de las cooperativas del partido de Pergamino a comienzos de los años setenta encontró que entre los productores y familiares mayores de 60 años el $36 \%$ era analfabeto y un 51\% tenía la primaria incompleta (aunque el informe no aclara qué entiende por primaria incompleta, pareciera que fueran los siete años; cabe recordar que muchas escuelas rurales sólo tenían hasta cuarto grado); entre los de 40 y 60 años, el porcentaje de analfabetos caía al $11 \%$, pero los que tenían primaria incompleta llegaba al 69\%, recién entre aquéllos que tenían de 20 a 40 años, el analfabetismo había casi desaparecido (1\%), el 53\% tenía la primaria incompleta, y casi la mitad (46\%) había finalizado estos estudios (Arroyo, 1963: 57-59).

36 Un ingeniero agrónomo de Pergamino relató que "... notaba que siempre hay una preocupación. La mayoría de los productores siempre quisieron que sus hijos reciban una mejor educación que ellos quizás porque ellos eran muy limitados y sin un gran nivel de preparación. Entonces trataban de hacer el esfuerzo para que sus hijos se capacitaran. Eso también es porque sufrió en carne propia la diferenciación. Acá se solía decir 'chacarero, igual: bruto'. Entonces el tipo sintió eso y quiso revertir esa situación, 'a lo mejor el bruto soy yo, pero espero que mis hijos no'. La mayoría de la gente se preocupa por mejorar el nivel de educación de sus hijos" (ZR).

Todavía en los años noventa, algunos de nuestros entrevistados asoció "chacarero" con alguien que tiene dificultades para expresarse. Excusándose por su parquedad, dijo: "Lo que pasa es que yo soy chacarero, no tengo entrenamiento para explicar con palabras ese pensamiento ¿no es cierto? La gente que están entrenados, y ique!, le salen las cosas con una facilidad, y explican todo..." (RY). 
Que puedan estudiar, lo que yo no pude, pareciera haber sido el esquema de razonamiento de muchos chacareros ${ }^{38}$. Una encuesta realizada a comienzos de los setenta a productores medios pampeanos detectó este mecanismo compensador ${ }^{39}$. En general, entre nuestros entrevistados, el ideal que se buscaba era que los hijos alcanzaran una profesión universitaria. En los casos en que lo lograron, esto es motivo de constante orgullo: en nuestros encuentros destacaron los títulos alcanzados por sus hijos o hijas, con un tono especial, muy poco usado para referirse a los hijos que, sin terminar una carrera universitaria, los han reemplazado en la actividad agropecuaria.

En segundo lugar, no sólo buscaron que sus hijos avanzaran hacia niveles crecientes de escolarización, sino también que la educación fuera de la mejor calidad. Por lo tanto, trataron de evitar las escuelas rurales o la de las pequeñas localidades, donde según ellos el nivel era más bajo ${ }^{40}$. Lo extraño es que muchos de los productores entrevistados asistieron a esas escuelas rurales y no son críticos de la educación que recibieron. Aunque pocos lo manifestaron tan crudamente, pareciera que se fue generalizando una asociación entre "escuela rural" y "escuela para los hijos de los

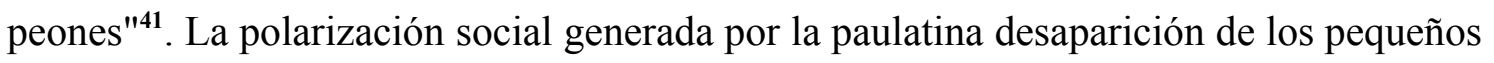

${ }^{37}$ Sólo el 44\% de los asociados poseían libros en sus casas, y de ellos la gran mayoría tenía sólo algunos libros instructivos. Cabe señalar que tampoco es que tuvieran el habito de pedir libros en préstamo (Arroyo, 1963: 51-52).

38 El contraste entre la imposibilidad de estudiar que muchos de nuestros entrevistados tuvieron en su infancia y su anhelo de que sus hijos tuvieran un título universitario, se observa claramente en este productor de Rivadavia: " [Yo hice] nada más que la primaria, pero ni la terminé, no fui hasta sexto. Porque estábamos muy lejos, en el campo, y después ya me dediqué al trabajo. De muy chico me hice cargo de la familia, muy joven, no pude estudiar ni tenía recursos. Entonces yo quería que los hijos míos estudien, después si no quieren... [que no ejerzan]. Bueno, me dice: 'yo voy a estudiar y te voy a traer el título', decía el hijo éste, pero 'ese [el título de contador] te lo voy a regalar a vos, mamá'...y se lo trajo así, arrolladito y dijo 'tomá mamá' y 'viejo...me voy al campo' y siempre él es el que compra los novillos, ahora los vende, cobra, paga. [...] La madre le decía.: 'yo quiero título' [...] y yo también [la hija, también contadora, sí ejerce la profesión en Santa Rosa, La Pampa]" (LM).

39 "Las expectativas educacionales de los padres respecto de sus hijos tienden a compensar las deficiencias del propio nivel educacional" (Brie y otros, 1977: 63-64). En dicha encuesta se estableció que en el $78 \%$ de los casos, los hijos presentaban un nivel educativo superior al de los padres, y que en el 22\% restante, un nivel similar, nunca inferior (Brie y otros, 1977: 35).

40 Como relató un productor de Rivadavia "... la gente tiene la necesidad de vivir en una casa en el pueblo para llevar a los chicos al colegio, porque de ninguna manera quieren recibir la educación para esos chicos en la escuela con cinco grados y catorce chicos por toda la educación, una maestra en una estación de ferrocarril perdida por ahí..." (OB).

${ }^{41}$ Un productor de Tres Arroyos fue explícito al respecto: "Había escuelas, pocas, y para los hijos de los peones [en Copetonas] y uno quiere un ambiente mejor para sus hijos. Por eso los 
chacareros debe haber incrementado esta asociación, pues cada vez fue habiendo menos hijos de chacareros en las escuelas rurales. En algunos casos, el primer hijo fue a estas escuelas, pero luego, cuando éste tuvo que ir al secundario, enviaron a todos a las escuelas de la ciudad. Además, en las ciudades los niños y los adolescentes podían acceder a otras actividades formativas y, como afirmó un productor de Tres Arroyos, "a otro tipo de cultura, no sólo la secundaria" (VS).

En tercer lugar, los padres no quisieron separarse de sus hijos; por ello, el modelo de colegios pupilos fue por lo general rechazado, a diferencia de lo que había ocurrido en la generación anterior. Los pocos entrevistados que habían asistido a colegios secundarios lo habían hecho en su mayoría como pupilos (en general, en La Plata), o residiendo con familiares en las ciudades de la zona ${ }^{42}$. Al parecer, los padres no querían que sus hijos sufrieran con la separación como ellos lo habían hecho. Como nos contó la esposa de un productor de Tres Arroyos:

"...estaba contenta porque estaba con mis chicos. Eso de tenerlos pupilos... Yo fui pupila cuando era chica, en Necochea. Entonces, sufría mucho siendo pupila, mis padres a veces no iban a verme porque lloraba tanto cuando se iban...Yo sufría de ver los chicos acá [al comienzo, estaban pupilos]. El varón, que estaba en el colegio del Padre, estaba contento, pero la nena, que estaba en el colegio de Hermanas, estaba desesperada. Aunque disimulaba, lloraba cuando nos habíamos ido. Como yo seguía teniendo chicos, cinco, entonces seguir así...'Yo quiero estar con los chicos'. [...] No podía estar sin mis chicos, entonces ahí nos vinimos, es terrible" (mujer de $\mathrm{BM})$.

Se estaba desarrollando otro tipo de relación con los hijos, de mayor cuidado y protección ${ }^{43}$. Esa transformación también se vincula a la reducción en la cantidad de hijos por familia. Si bien no contamos con datos censales al respecto, resulta evidente

querían llevar a las escuelas de la ciudad" (AA*).

42 Como parte de este proceso de rechazo a la opción del colegio pupilo, el Colegio Danés de Tres Arroyos, de educación primaria, que había congregado a la mayoría de los hijos de esta comunidad hasta mediados del siglo, también vio caer drásticamente su matrícula a partir de los años sesenta.

43 Elías ha destacado lo relativamente novedoso en Occidente de que los padres se interroguen sobre lo adecuado o no de su comportamiento hacia sus hijos, sobre sino les estarán causando algún daño, en vez de actuar de un modo más espontáneo, como lo hacían los padres grecoromanos o medievales (Elías, 1998: 418). 
que de las familias rurales con más de media docena de hijos que había en los años treinta, se pasó a familias con dos o tres hijos ${ }^{44}$.

El reconocimiento de la infancia como una etapa con requerimientos especiales ha sido un proceso generalizado en Occidente durante el siglo $\mathrm{XX}^{45}$. En el caso particular de los productores rurales pampeanos sobresale que esta transformación haya sido tan rápida y de profundo impacto sobre el modo de vida de los productores. Estos fueron reconociendo la infancia, e incluso la adolescencia, como una etapa autónoma del trabajo, como un período de juego, diversión y formación, separados de la economía de la unidad rural. Como veremos en el siguiente apartado, este cambio tuvo un particular efecto sobre la dinámica de las explotaciones agropecuarias.

En cuarto lugar, el objetivo de que los hijos accedieran a más altos niveles de educación y de mejor calidad, sin separarse de ellos, no implicó la exploración de la posibilidad de construir colectivamente alternativas que permitieran que los padres continuasen viviendo en los establecimientos agropecuarios. Dos entrevistados espontáneamente compararon lo acontecido en sus distritos, con la situación de los Estados Unidos ${ }^{46}$, Nueva Zelandia o Australia, e incluso con el partido de Juárez, cercano a Tres Arroyos, donde existen sistemas de transportes escolares que recorren los campos, gracias a las buenas cuadrículas de caminos rurales, y que permiten a las familias continuar viviendo en los campos, al tiempo que sus hijos pueden asistir a la

44 Coscia (1983: 107) señala que "De acuerdo al censo de 1937, la familia rural media de la región pampeana tenía entre cuatro y cinco hijos. Dado que en un censo entran todas las familias, incluso las de reciente constitución y aún con pocos hijos, corresponde suponer, por lógica, que la media de las que habían completado el ciclo procreativo era bastante más alta. En la actualidad, en cambio, las familias agrícolas asimilaron las características de la clase media urbana y en su gran mayoría tienen uno o dos o, a lo sumo, tres hijos."

45 Esto supone el reconocimiento de "la necesidad que tienen los niños de vivir su propia vida, una manera de vivir que en muchos sentidos es distinta del modo de vida de los adultos" (Elías, 1998: 410).

46 En 1997, vivían en su explotación el 85\% de los productores de 203 a 405 hectáreas en Iowa y el $82 \%$ en Illinois. Incluso el $79 \%$ de los productores con unidades mayores de 810 hectáreas de Iowa, y el 64\% de en Illinois residían en sus explotaciones (según nuestros cálculos en base al Census of Agriculture). Mientras que, como hemos visto, en 1988, en la zona norte tan sólo el $37 \%$ los productores de 200 a 400 hectáreas residía en su establecimiento, y lo hacía sólo el 18\% de los productores con más de 1.000 hectáreas. 
escuela $^{47}$. Sin menospreciar otros factores que alentaron la urbanización, y que analizaremos en los siguientes apartados, posiblemente la administración de la educación tan centralizada en Argentina, puede haber conspirado contra el surgimiento de movimientos colectivos entre los productores rurales para asegurar más y mejores escuelas rurales y sistemas de transporte que permitieran a los productores continuar viviendo en los campos. En sus análisis de comienzos de la década del cuarenta, Carl Taylor había destacado que un resultado inadvertido de que las escuelas fuesen nacionales o provinciales (como también la organización y el mantenimiento de las parroquias) era que no se había incentivado la participación frecuente o creativa en los asuntos públicos locales, como sí ocurría en los condados estadounidenses, donde continuaba el ideal y la pasión por controlar los asuntos del gobierno local iniciada por los colonos pioneros (Taylor, 1948: 269) ${ }^{48}$.

Por último, podemos decir que la envergadura de los cambios que generó el traslado a las ciudades para garantizarles una mejor educación a los hijos está mostrando que tuvo lugar una transformación profunda en el lugar que los hijos tenían para los padres y en la valoración de las opciones laborales que se abrían para ellos.

47 Estos dos testimonios marcan la conciencia de que es posible otro modelo de relación entre educación y lugar de residencia de la familia rural:

"Acá ha habido gente que ha ido a Estados Unidos, hay cuadrículas asfaltadas, acá en Juárez también, hay una serie de caminos entoscados, y hay unas combies que recolectan a los chicos y los llevan...No hay escuelas agrícolas, se llaman escuelas de concentración, las combies buscan los chicos en las tranqueras, o si no están tendrás que hacer 2, 3, 4 kilómetros y llevarlos, y te los trae a la vuelta. Eso ya sería otra cosa porque vos...el viaje para la educación de los chicos ya no lo tendría que hacer. Esa combie te los busca y te los lleva, y son caminos entoscados que aunque lluevan 200 milímetros, circulan, o sea que el chico sigue yendo al colegio [...] En Estados Unidos te los llevan a los chicos y a las 5 de la tarde te los dejan en la tranquera de tu casa. El tipo es el que anda arriba del tractor, la mujer es la que está en la casa..." (HU).

"... el problema ha sido la educación de los hijos..., no es como en Nueva Zelandia o Australia que pasa un ómnibus recorriendo a la mañana..., con asfalto...., nosotros no tenemos nada, aunque en Juárez, sí." (CG).

48 Una de las pocas iniciativas por parte de los productores de vincular educación con actividad productiva, ha sido la creación de una escuela agraria secundaria privada en Tres Arroyos, promovida por los miembros de los grupos CREA del partido. En 1996 esta escuela estaba intentando articularse con las escuelas rurales del distrito, justamente para mejorar la calidad de éstas y permitir que los productores puedan enviar a sus hijos a estos establecimientos sin sentir que sus hijos se perjudican. 
En el esquema tradicional-campesino, que mantuvieron en un comienzo muchos inmigrantes, los hijos eran los instrumentos que permitían la reproducción intergeneracional de la explotación, como mano de obra gratuita y como garantes del reemplazo en la dirección del establecimiento. Todavía a mediados de siglo, en las revistas agropecuarias se denunciaba que persistía la idea de que los hijos eran "peones sin sueldo" que debían trabajar sólo a cambio de una herencia futura, y que por ello no se los enviaban a la escuelas agropecuarias ${ }^{49}$. Pero ya entonces estaba cambiando el lugar de los hijos en la vida de los padres: cada vez más los hijos pasaban de ser un mero instrumento de la explotación, a convertirse en uno de los objetivo de la unidad productiva. Es decir, el sentido de la vida de los productores fue cambiando, de reproducir cierto esquema campesino europeo, a un nuevo sentido vital, en el que el centro parece ubicarse en que los hijos logren el mayor desarrollo personal posible. En última instancia, los hijos se transforman en depositarios de buena parte del sentido de la vida de los padres. En el marco de este objetivo, el que se conviertan en profesionales universitarios se va instalando como un norte compartido por muchos productores.

Consecuentemente, una porción importante de los ingresos generados por la explotación se destinan ahora a solventar la educación de los hijos, y especialmente a todos los gastos indirectos que se generan para garantizarla. Esto incluye la vivienda urbana, las mayores erogaciones de la sociabilidad en la ciudad, los gastos de la universidad con la necesaria radicación de los estudiantes en las grandes ciudades, e

49 "Lástima grande que por una economía mal entendida, los padres no se desprendan de sus hijos para mandarlos a una escuela. Al irse el hijo deben poner un peón en su lugar, y prefieren no realizar este gasto antes que hacer educar al jovencito, como si la única misión de padre fuera la de hacerlos trabajar en su provechos a cambios de comida, vestido y techo." En: "¿Sirven las escuelas rurales?", por Moisés Katzenelson, La Chacra, 315, febrero de 1957; p. 84-85.

"Existen aún padres que consideran a sus hijos como 'peones sin sueldo'. Los chacareros que desean evitar que sus muchachos los abandonen en la primera oportunidad deben hacerlos copartícipes de las ganancias. ¿Su chico de ocho años se encarga de engordar los cerdos o cuida de los pavos? Pues bien: entréguele un tanto por ciento de las ganancias para estimularlo y demostrarle que se aprecia el trabajo que realiza. Si tiene novia ayúdelo para que pueda independizarse, transfiriéndole algunos novillos, cediéndole una fracción de tierra o retribuyéndole en otra forma por el trabajo que efectúa para usted. No le diga: '¡Total, algún día tú heredarás la chacra!', pues semejantes perspectivas no reemplazan a las necesidades del momento. Satisfaciendo las justas, aunque frecuentemente inconfesadas, aspiraciones de los hijos -e hijas- éstos seguirán siendo los mejores amigos y colaboradores del chacarero." En: "Racionalización psicológica en las chacras", por Roberto Schopflocher, La Chacra, 334, septiembre de 1958; pp. 64-65. 
incluso el costo que significa utilizar mano de obra asalariada, pues los hijos retrasan notoriamente la edad en la que se suman plenamente a las labores, si es que no ocurre que nunca se vinculan de lleno a la actividad agropecuaria.

El deseo de que los hijos puedan ser profesionales independientes, o al menos que tengan oportunidades laborales más amplias gracias a una mayor educación, habría convertido la continuación de la tradición/explotación familiar en una opción vocacional más. Sintomático de este hecho es que casi nunca se orienta a los hijos hacia una educación universitaria agropecuaria ${ }^{\mathbf{5 0}}$, sino hacia las carreras "tradicionales": abogado, médico o contador.

Pareciera que el prestigio de ser productor agropecuario no era suficiente para los padres. Esto resulta un tanto extraño en el caso de los productores medianos, ya que contaban con capital e ingresos muy superiores a los que pueden obtenerse con una profesión independiente, al menos si no se es muy exitoso. Una encuesta realizada a comienzos de los setenta, entre productores medianos pampeanos, encontró que la respuesta más extendida sobre "las razones determinantes del prestigio social de un hombre", fue el "tener muchos estudios" (con un 38\% de las elecciones), triplicando la respuesta "ganar mucho dinero" (13\%), y dejando atrás a tener "una familia distinguida" (9\%), o "tener amigos influyentes" (7\%) (Brie y otros, 1977: 57-58) ${ }^{\mathbf{5 1}}$.

Resulta interesante destacar que en la colectividad danesa de Tres Arroyos en los años noventa existían muchos productores que continuaban viviendo en el campo, se

50 Una excepción es la ya comentada Escuela Agropecuaria de Tres Arroyos, organizada por los grupos CREA del partido, que brinda un secundario orientado a las actividades rurales.

51 En la misma encuesta se encontró que a la hora de responder "qué es más importante para salir adelante en la vida", un $49 \%$ optó por "habilidad y trabajo", un 17\%, por "honradez", y un $15 \%$, "estudio". Los autores analizaron que "en cuanto al ascenso social, expresado en términos de progreso, o de 'salir adelante', en el sector rural medio predominan indudablemente los valores tradicionales [...] Hay por consiguiente una clara contraposición con los valores de la sociedad urbano industrial donde predominan los valores económicos y los valores 'influencias'. Los valores tradicionales 'trabajo' y 'honradez', sin embargo, se ven complementados con un valor de modernidad: el 'estudio', como canal de movilidad" (Brie y otros, 1977: 57). 
preocupaban porque sus hijos los reemplazasen en la dirección de la explotación, y justamente eran aquellos que menos interés manifestaban en que asistieran a la universidad. Lo notorio es que, durante las primeras décadas del siglo XX, los inmigrantes daneses habían tenido un nivel de educación formal mucho más elevado que sus pares italianos o españoles. Esto pareciera confirmar el efecto compensador al que ya hemos hecho referencia.

Algunos de nuestros entrevistados manifestaron tener clara conciencia de la tensión que se generaba entre un nivel educativo elevado, por parte de los hijos, y la reproducción de las unidades agropecuarias. Así lo ejemplifica el siguiente testimonio de un productor de Tres Arroyos: "Hoy día es difícil que [los jóvenes] vuelvan al campo. Antes les gustaba, no querían ir a estudiar porque les gustaba estar en el campo. Hoy estudian y se van" (EG*). En la misma línea, otro productor de Tres Arroyos recordó el proverbio vasco que le trasmitió su padre: "Labriego, a la vez que agarra la pluma, no agarra más la azada" (AA*).

Esta desvinculación de la juventud con el campo generó alarma entre los "intelectuales" encargados de las revistas agropecuarias entre fines de los cincuenta y comienzos de los setenta (luego la preocupación fue desapareciendo de sus páginas, junto con una adecuación al cambio de rol laboral de los productores hacia papeles más gerenciales $)^{52}$. En estos años, en las revistas se recalca la necesidad de una educación que arraigue al hijo del productor en el campo, que lo prepare para aceptar las limitaciones de la vida rural, destacando sus virtudes. Pues, aquellos que "sienten el campo correr por sus venas, resisten esos embates con un estoicismo difícil de hallar en otros medios" si tienen una "preparación intelectual y espiritual para superar el ambiente, saber apreciar los halagos y recompensas de la vida campesina"53.

52 La llegada de las revistas agropecuarias entre los chacareros pampeanos no parece haber sido poca en estos años. Así por ejemplo, en 1960, entre los productores del partido de Pergamino asociados a cooperativas, el 16\% manifestó leer La Chacra, el 3,7\% $\underline{\text { Agro }}$ Nuestro y el 3,5\% Mundo Agrario (Arroyo, 1963). Seguramente en partidos como Tres Arroyos, donde los productores contaban con una mejor situación económica, el nivel de lectura de estas publicaciones debió haber sido más elevado.

53 El párrafo completo de donde se extrajo la cita es el siguiente: "Aparentemente existen dos causas que obligan a esas decisiones [la migración a las ciudades]. Una es económica, entendiendo por ello ciclos de malas cosechas, tenencia de la tierra o fenómenos como la erosión, que están fuera del alcance de una familia agrícola o un reducido número de ellas subsanar. Sin embargo, aquellas personas que sienten el campo correr por sus venas, resisten 
En cambio, la educación que recibían los hijos de los chacareros parecía contradecir el estilo de vida rural. En particular, la universidad aparece en estas revistas como una instancia que aleja aun más a los hijos, en particular de las explotaciones paternas y en general del campo (ya que muy pocos se inclinan por Ingeniería Agronómica o Medicina Veterinaria) ${ }^{54}$. Sin embargo, al mismo tiempo resultaba imprescindible una mayor educación para lograr que los productores adoptasen esquemas racionales de producción. En los artículos se critica la pervivencia de la organización de la producción de forma rutinaria, el aferrarse a "prácticas antieconómicas" (sin adoptar los estilos racionales de administración) y la “desconfianza por la teoría"55. La alternativa pregonada era que los productores enviasen sus hijos a las escuelas agropecuarias ${ }^{56}$. Sin embargo, estas escuelas deberían (pues no lo hacían) reforzar un vínculo sentimental con el campo: "...es fundamental vincular la enseñanza con el medio en que vive, de lo contrario con una enseñanza ajena y carente de vinculación, solamente formaremos un hombre indiferente al terruño que lo vio nacer. [...] El niño debe amar a la tierra..." ${ }^{57}$. La clave se encuentra en "despertar vocación por las actividades del campo"58, evitando generar aspiraciones en favor de una educación universitaria. Sus alumnos, entonces, "no tratarán de hacer valer sus

esos embates con un estoicismo difícil de hallar en otros medios. La otra causa es de carácter educativo, es decir, la preparación intelectual y espiritual para superar el ambiente, saber apreciar los halagos y recompensas de la vida campesina y plantar sus raíces constituyendo un sólido tronco rural de enormes beneficios para el progreso integral del país." En: "La educación de la familia rural", Mundo Agrario, 93, febrero de 1957; p. 4.

54 "Para un país como a Argentina, eminentemente agrícola, el número de escuelas es realmente pobre; sin embargo, sobran porque faltan alumnos. El año pasado los egresados de las escuelas llegaron a un promedio de catorce por unidad escolar, pues suman alrededor de 150 los que han terminado su preparación. ¿Cuántos jóvenes se han recibido de abogados, dentistas, médicos, etc., en este país agrícola?"... “En cambio [...] en las facultades de agronomía y veterinaria el escaso número de alumnos es un problema digno de ponderar. " En: "La educación de la familia rural", Mundo Agrario, 93, febrero de 1957; p. 4-5.

55 "El equilibrio perdido", por Manuel Luis Olivas, La Chacra, 340, marzo de 1959; p. 89; y "Cómo elegir una chacra", por Roberto Schopflocher, La Chacra, 345, agosto de 1959; p. 16-17.

56 Sobre la enseñanza agrícola en los años cuarenta y cincuenta puede consultarse Gutiérrez (1998).

57 En: "Los conocimientos deben empezar en la escuela", por Albino Alberto Aguilar, El campo en marcha, 63, diciembre de 1972; p. 5.

En este sentido, una ex-maestra rural del partido de Rivadavia (esposa de un productor agropecuario) sostuvo que en las últimas décadas, el maestro rural, ahora de origen urbano, "cumplía su función sí, pero no hizo amar la tierra" (MD). 
títulos entrando en competencia con egresados de escuelas superiores", sino que "apreciarán los halagos y las recompensas de la vida campesina", y se convencerán de que "eso es suficiente" 59. Hay que capacitar, pero también "orientar" y "disciplinar", pues por "falta de cultura agraria nuestra juventud se aleja rumbo a las grandes ciudades"60.

En síntesis, a los autores de los artículos les resultan evidentes tanto las limitaciones que el tradicionalismo impone al desarrollo, como los efectos negativos sobre los modos de vida rurales generados por la propia modernización/educación.

\section{Socialización primaria, autoconsumo y consumismo}

58 "La escuela debe preparar individuos no sólo humanísticamente sino despertar vocación por las actividades del campo y al mismo tiempo entregar los elementos indispensables para llevarla a la práctica." En: "Nuevas escuelas para nuestro campo", por Ernesto M. Lavorano, La Chacra, 337, diciembre de 1958; p. 78-79.

59 "... han habido bastantes polémicas sobre la cuestión del título y la habilitación para entrar en los cursos universitarios y obtener otro título. Lo fundamental es que los hijos de los chacareros adquieran conocimientos sobre técnicas modernas, y ser más versátiles en lo que respecta a los medios de vida en el campo, para ser, precisamente, mejores chacareros... y nada más. ¿No es, acaso, esto suficiente?.." "... si tranquilamente volvieran a sus chacras y progresaran ellos y la comunidad donde viven, porque servirían como vivos ejemplos de la conveniencia de aplicar buenas técnicas en la labor campesina, y no trataran de hacer valer sus títulos entrando en competencia con egresados de escuelas superiores." En: "La educación de la familia...", art. cit.

60 "Hay que evitar la despoblación de los campos, debemos orientar, capacitar y disciplinar esas fuerzas humanas tan bien representadas por la juventud que vive en nuestras chacras. [...]Ha llegado la hora de hacer algo por nuestros niños que viven en el medio rural, dotando a nuestras escuelas con un plan de enseñanza agrícola que esté de acuerdo a la naturaleza del niño y a las necesidades del medio ambiente. Por esa falta de cultura agraria nuestra juventud se aleja rumbo a las grandes ciudades, una escuela rural con programas prácticos y orientados a las necesidades del productor rural [sic]. El niño debe amar a la tierra, compenetrarse de sus inmensas posibilidades, dotándole de las facultades imprescindibles, para un trabajo que siempre no es fácil, pero que suele ser de una generosidad más amplia, que el de otros ambientes. Es que formar juventudes, es un hermoso ideario dentro de la civilización contemporánea, en que el egoísmo debe dejar paso a las inquietudes del espíritu, no habrá cambio en el mundo si no cambia el corazón del hombre." En: "Los conocimientos deben empezar en la escuela", por Albino Alberto Aguilar, El campo en marcha, 63, diciembre de $1972 ;$ p. 5. 
"Se ha perdido como costumbre, y es una forma de educación también, que el chico criado en el campo vea cómo se debe abastecer la familia, cómo se deben medir las necesidades, cómo se tienen que aprender a autoabastecerse. Yo creo que forma parte de una cultura agropecuaria que tiende a desaparecer..."

Desde mediados de siglo, la socialización de los hijos se fue tornando cada vez más atenta a su inserción en una sociedad más global, y no dirigida principalmente al reemplazo generacional en la dirección del establecimiento rural. Más allá de que para algunos productores ésta puede haber sido una decisión conciente, muy probablemente fue el resultado no conciente de la urbanización de la familia. La radicación urbana cambió drásticamente el contexto de socialización primaria. Los niños ya no crecían en el horizonte limitado de la dinámica de la explotación, sino en un mundo más vasto. La infancia, e incluso buena parte de la adolescencia, se desvinculó de los ritmos de la unidad productiva. Juego y educación se separaron, autonomizados del trabajo auxiliar hasta entonces desarrollado por los pequeños ${ }^{61}$. Por lo tanto, los niños ya no maduraban en el contexto del duro trabajo agropecuario que antes internalizaban como su forma de vida. El mundo rural ya no se "naturalizaba" como el único mundo posible para el hijo del chacarero ${ }^{62}$. Recién iban a la explotación a colaborar durante la cosecha de verano. Por lo tanto, lo percibía como una opción laboral más dentro de las múltiples (aunque no por ello ilimitadas) posibilidades que se le abrían. Se rompió la simbiosis que existía previamente entre socialización primaria y secundaria. Antes, al ser socializado en el

61 Elías analiza justamente la desvinculación entre juego y preparación para la profesión adulta en el Occidente actual a diferencia de las sociedades nómades o guerreras medievales, en las que se "presentaba una línea mucho más directa del juego infantil a las actividades de los adultos", donde "la estructura de las pulsiones y de los afectos requerida por la actividad de los adultos no está tan distante de la de los niños como en las sociedades industriales científicas", donde "se requiere un proceso de aprendizaje de muchos años" que provea "un horizonte de conocimiento muy amplio y de una capacidad muy diferenciada de autocontrol, de regulación afectiva, para poder sostenerse como adulto en sociedades de este tipo". (Elías, 1998: 434-436).

62 En el siguiente diálogo con un productor de Tres Arroyos se observa la "naturalización" del destino agropecuario en el pasado, y su "desnaturalización" en el presente:

"P: - y usted empezó a trabajar... dejó la escuela y empezó, ¿Cómo fue eso?, ¿Fue común... o le costó al principio?

- Era... yo diría que uno no pensaba tanto en eso, porque era natural, era el proceso común y corriente, terminaba la escuela y empezabas a trabajar. Muy pocos eran los que se dedicaban a otra cosa. La mayoría de los hijos de los productores se dedicaban al campo. Hoy cambian mucho más, ¿no es cierto?" (RY). 
mundo rural de la explotación, el niño iba internalizando su rol laboral en el marco de la socialización primaria, por lo cual este rol adquiría un carácter "natural". No había un momento de ruptura claro entre la niñez, la adolescencia y la vida adulta, al menos en el aspecto laboral. Tampoco había que tomar decisiones sobre diversas opciones laborales, sobre todo si en la explotación había lugar para todos los hijos. En cambio, a medida que transcurría el período estudiado, la socialización primaria dejó de contener elementos laborales. Ahora se producían claros cortes entre la niñez (totalmente desvinculada de la producción), la adolescencia (cuando el hijo habitualmente se sumaba en los momentos de la cosecha fina, que coincide con las vacaciones de verano) y la edad adulta (cuando debe decidir su orientación laboral y si ésta incluye una dedicación total, parcial o nula en relación con la explotación familiar).

Pero además de no trabajar en la producción secundaria de la explotación, los niños tampoco se sienten co-responsables de su devenir. Según varios testimonios, antes iban internalizando la importancia de su trabajo, pero también el impacto de los gastos familiares. En algunos caso, por ejemplo, iban ahorrando el producto de parte de su labores, y de allí tenían para sus gastos ${ }^{63}$. A veces, esta conducta era compartida con sus madres, quienes destinaban el dinero de la venta de la producción secundaria a distintos gastos de los hijos (vestimenta, educación, artículos para el hogar ${ }^{64}$ ). En cambio, con la

${ }^{63}$ Como relató un productor de Tres Arroyos, el trabajo infantil se vinculaba con cierta actitud económica y afán de superación:

"Y de chiquito, cuando tenía 7 siete años, siempre me gustó agarrar algún peso. En aquel entonces el cuerito de cordero valía, entonces yo cuereaba los corderos que mi padre no quería cuerear porque no valía nada, yo lo hacía y me armaba de algún peso; o igual cazaba una comadreja o un zorrino lo cuereaba y lo vendía, mi padre salía a cazar y me daba las liebres a mí. Con mi hermana mayor teníamos una cajita donde guardábamos los billetes, ¡los planchábamos!, y de vez en cuando los mirábamos. Aprendimos a hacer cosas lindas en el campo. Mi madre aprendió a hacer quesos y hacíamos quesos. Mi padre tenía quinta, y mi hermana y yo teníamos una quintita aparte, y nos esmerábamos a ver quien tenía mejor quintita. Siempre teníamos espíritu de superación" (MÑ).

64 "Yo criaba gallinas, vendía los huevos, con eso compraba las cosas para la casa, podía comprar la heladera, el lavarropas, todo con las gallinas [...] con eso hice estudiar a mi hija" (DO).

"Mi mamá, con lo que sacaba de los huevos y los pollos (venían tres gallineros por semana) nos vestía a nosotros. El gallinero llevaba de todo en el carro, zapatillas, telas, puntillas, jabón de tocador, sábanas, todo. Venía el que le decían 'El Turco'. Después de tomar la leche salíamos a juntar los huevos, juntábamos 35-40 docenas en el día. Con esa plata, nos vestía y compraba chocolate, fruta abrillantada para el pan dulce, las pasas de uva" (MU). 
residencia urbana, niños y adolescentes se convirtieron en exclusivos consumidores, gracias al dinero aportado por el padre ${ }^{65}$. Como lo describió un productor de Rivadavia:

"...se ha perdido como costumbre, y es una forma de educación también, que el chico criado en el campo vea cómo se debe abastecer a la familia, cómo se deben medir las necesidades, cómo se tienen que aprender a autoabastecerse. Yo creo que forma parte de una cultura agropecuaria que tiende a desaparecer, esto lo digo con un poco de nostalgia porque yo me he criado en un ambiente de ese tipo y realmente no... Al despoblarse, primero desapareció la idea de la necesidad de producir lo que se consume, después desapareció la familia, y después desapareció el último poblador que quedaba, aquello de que 'el último apague la luz'... Y se ha perdido toda una cultura agropecuaria... o se está perdiendo, y eso es lo que yo veo de malo en la nueva situación. Estamos en un sistema de vida consumista exclusivamente, y no veo que sea lo mejor desde el punto de vista de la radicación, del ...no sé si me he explicado bien...." (OB).

Como resultado de estas transformaciones en la socialización primaria, los hijos ya no quedaron "atados" a la explotación familiar. La capacidad paterna de imponer trabajos y sentidos en las vidas de sus hijos se vio sustancialmente mermada por la propia actitud que directa o indirectamente habían tenido hacia sus hijos. Así, por ejemplo, podemos ver esta transformación de un modo claro en el siguiente caso extremo de un productor de Tres Arroyos: nacido en 1928, había tenido un padre "muy tirano" (según sus propios términos), para quien trabajó incluso ya casado y con hijos, sin recibir ni sueldo ni participación en las ganancias ${ }^{66}$; en cambio, cuando quiso poner a sus propios hijos a trabajar en su explotación, no lo consiguió, pues "...se fueron al diablo. No estaban acostumbrados y se rajaban por ahí. Sí, yo los quise meter en el campo y exigirles..." (KA).

${ }_{65}$ Este modelo receptor de bienes paternos puede haber tenido efectos sobre el carácter social de los futuros productores, ya que en vez de promover un carácter productivo, estimularía un carácter receptivo, según la clasificación de Fromm. Sobre carácter social y productores rurales resulta muy interesante el trabajo de Fromm y Maccoby (1970) sobre el campesinado mexicano. Algunas hipótesis sobre los cambios en el carácter social de los productores pampeanos serán presentadas en el siguiente capítulo.

${ }_{66}$ "Yo tenía un hijo de un año, y no tenía un peso para ir al cine, y culpa de eso se armó el despelote en el '57. ¡No nos pagaba nada! [ni a él, ni a sus hermanos]. Teníamos todo lo que precisábamos, pero no teníamos un peso. No sabíamos lo que ganábamos. Si yo tenía que comprar ropa, tenía que decirle 'Tengo que comprar ropa...' ¡Ya era casado con hijos!" (KA). 
En el caso de los productores que no vivían en la explotación, no eran sólo los niños quienes ya no conformaban el equipo de producción que anteriormente constituía la familia: también la mujer se desvinculó casi por completo de la producción. En la medida en que pasó a vivir en la ciudad, y casi nunca viajaba a la explotación (al menos durante los días de semana), ya no podía encargarse de toda la producción secundaria que antes tenía a su cargo ${ }^{67}$.

Entonces, con la radicación urbana, perdieron importancia los aportes laborales de los demás miembros de la familia, y el productor quedó muchas veces como el único aporte de fuerza de trabajo "familiar" (incluso comprendiendo no sólo las labores físicas sino también las administrativas). Así, a mediados de los ochenta, en Pergamino en el estrato de 71 a 200 hectáreas (un estrato bastante familiar, en el que los asalariados aportaban el $45 \%$ del total de días trabajados), el productor proveía el $81,8 \%$ de total del trabajo familiar (INTA/CONICET-CEIL, 1988: 134) ${ }^{68}$.

En fin, al descomponerse la familia como equipo de producción ${ }^{69}$, todo el carácter doméstico de las explotaciones se disolvió. Consecuentemente, la producción para el autoconsumo dejó de ser "rentable" ya que, si debía ser realizada con trabajo asalariado ( por lo tanto remunerado) resultaba claramente deficitaria. Esa producción era posible porque no se contabilizaba el costo de oportunidad del trabajo empleado,

67 Tort (1983) también encontró, estudiando el partido de Bolívar, que "la mujer abandona totalmente su rol productivo y aun de subsistencia en lo que hace a las tareas rurales." Lo mismo halló Bardomás (1994: 152-153) en Pigüé: "si bien en la primera generación de colonos fue importante el trabajo de la mujer en el campo, participando en las tareas de arada, siembra y cosecha -como dan cuenta las fuentes escritas y los relatos de nuestros entrevistados-; la incorporación temprana de maquinarias ahorradoras de mano de obra liberó a la mujer de estos duros quehaceres, reduciendo su participación a la economía de subsistencia (cría de aves y cerdos y trabajo en la huerta). En las generaciones posteriores, la generalización del cambio de la residencia rural a la urbana observada en los años '70 y '80, contribuyeron a la desaparición del ciclo doméstico y del trabajo femenino en las explotaciones familiares".

68 Sólo en el estrato de 20 a 70 hectáreas, en el que el productor y sus familiares aportaban el $70,6 \%$ de los días trabajados, los familiares alcanzaban a constituir el $44,2 \%$ de este porcentaje (INTA/CONICET-CEIL, 1988: 32 y 134).

69 Sobre las cuestiones teóricas en torno a la familia como equipo de producción rural, puede consultarse Galeski (1977). 
sino que se lo consideraba una forma de ocupar el tiempo de niños, mujeres y ancianos que, por sus características físicas o por tradición, no se orientaban hacia las actividades principales de la producción de cereales o vacunos. En algunos casos, el productor que viajaba diariamente desde la ciudad intentó continuar con los cuidados de la quinta, pero casi ninguno lo logró ${ }^{70}$.

Como vimos en el primer capítulo, a comienzos del período existía una intensa producción secundaria orientada esencialmente al autoconsumo y eventualmente al trueque (a vendedores ambulantes) o a la venta del sobrante. Todos los entrevistados enumeraron: la cría de cerdos y su posterior procesamiento (elaborando facturas que duraban todo el año, de invierno a invierno, conservadas en grasa), el ordeñe de algunas vacas lecheras y la preparación de crema, manteca y quesos, la cría de pavos y pollos (con recolección de infinidad de huevos), y el cultivo de hortalizas y, eventualmente, de árboles frutales. Además, las mujeres confeccionaban la mayor parte de la ropa ${ }^{71}$. De los elementos de consumo cotidiano, únicamente el pan (o la galleta), la yerba, el azúcar, la sal y el vino eran adquiridos en el pueblo, y eventualmente la carne (en el caso de familias que no tenían ovejas para el consumo). Pero todas estas actividades se abandonaron rápidamente cuando la familia se radicó en la ciudad ${ }^{72}$.

Unicamente algunos de los pocos productores que continuaron viviendo en el campo siguieron produciendo buena parte de estos elementos de consumo ${ }^{73}$. Pero incluso quienes han regresado al campo, luego de una larga estadía en la ciudad, no retomaron estas actividades. Los testimonios han sido muy concordantes con respecto al abandono de la producción para el autoconsumo.

70 También Tort (1983) encontró, en el partido de Bolívar, que el ciclo de subsistencia había desaparecido entre los productores que no vivían en su explotación.

71 Una encuesta realizada a mediados de los sesenta en Pergamino, muestra que las amas de casa que continuaban viviendo en sus chacras dedicaban 1,6 horas diarias a "tareas de chacra", y 2,3 horas a "vestidos", además de afectar 6,1 horas a "comida", y 1,4 horas a "limpieza". Cabe señalar que pocas esposas de productores ayudaban durante la cosecha, un $17 \%$ en la cosecha de verano y un 11\% en la de invierno (Baca, 1966: 35).

72 En el mismo sentido Bardomás (1994: 109) señala que el "cambio en la residencia significó el abandono de la producción para el autoconsumo: la huerta, la cría de cerdos y aves".

73 Como nos comentó un ingeniero agrónomo de Pergamino "... hubo otros que nunca abandonaron eso, que se preparan los dulces..., y en épocas de crisis esa es la gente que mejor resiste" (ZR). 
Por su parte, los datos censales no permiten dar cuenta de este proceso de un modo directo ${ }^{74}$. En cambio sí es posible analizar, de modo indirecto, la fuerte reducción de la cría de porcinos a pequeña escala, seguramente destinada al autoconsumo. Como podemos observar en el Cuadro 4.2, en 1937 practicaban la cría de cerdos la gran mayoría de las explotaciones de la zona Norte y la zona Oeste, y algo más de la mitad de las de la zona Sur. La mayor parte de esta cría se realizaba en pequeña escala. Como podemos ver en el Cuadro 4.4, las unidades que criaban hasta 25 cabezas poseían el $46 \%$ de los porcinos en la zona Norte, el $20 \%$ en la zona Oeste y el $63 \%$ en la zona Sur.

Para 1960 ya había tenido lugar, en las tres zonas en estudio, una sustancial disminución de la proporción de explotaciones que criaban ganado porcino, y para 1988 la cría se había acotado a una minoría de establecimientos (ver Cuadro 4.2). Este indicador nos parece mejor que el de la cantidad total de porcinos (ver Cuadro 4.3), ya que el otro fenómeno que ocurrió durante estas décadas fue la expansión de la cría de cerdos en mayor escala: en el Cuadro 4.4 podemos observar la concentración en explotaciones de más de 50 cabezas, sobre todo en la zona Norte.

Cuadro 4.2. Porcentaje de explotaciones que poseen ganado porcino.

\begin{tabular}{|l|c|c|c|}
\hline & zona Norte & zona Oeste & zona Sur \\
\hline $\mathbf{1 9 3 7}$ & $78 \%$ & $66 \%$ & $54 \%$ \\
$\mathbf{1 9 6 0}$ & $63 \%$ & $40 \%$ & $37 \%$ \\
$\mathbf{1 9 8 8}$ & $29 \%$ & $19 \%$ & $19 \%$ \\
\hline
\end{tabular}

74 Algunas encuestas brindan información sobre la producción para autoconsumo:

Una encuesta realizada en Pergamino a mediados de los años sesenta encontró que, entre las familias que residían en su explotación, un $75 \%$ tenía al menos una vaca para ordeñar, un $73 \%$ poseía cerdos y casi todas las chacras tenían gallinas, en un término medio de 143 aves por explotación (Baca, 1966: 14).

En cambio, una encuesta realizada en el año 2000 entre los productores rurales santafesinos que residen en áreas rurales nos permite observar la reducción de la importancia de este tipo de producción: sólo el 17\% del consumo de alimentos provino de la autoproducción (el $81 \%$ de compra, el 3\% de asistencia y el $1 \%$ de trueque), según los datos del PROINDER (Gerardi, 2001: 75). Cabe aclarar que se han incluido en la muestra a los productores hortícolas periurbanos. 
Fuentes: Cálculos propios efectuados en base a la información desagregada por partidos de los Censos Agropecuarios Nacionales de 1937, 1960 y 1988.

Cuadro 4.3. Cantidad de ganado porcino, 1937, 1960 y 1988.

\begin{tabular}{|l|c|c|c|}
\hline & zona Norte & zona Oeste & zona Sur \\
\hline $\mathbf{1 9 3 7}$ & 283.645 & 243.154 & 83.539 \\
$\mathbf{1 9 6 0}$ & 315.008 & 131.126 & 74.037 \\
$\mathbf{1 9 8 8}$ & 263.057 & 76.031 & 41.610 \\
\hline
\end{tabular}

Fuentes: Idem 4.2. 
Cuadro 4.4. Porcentaje de ganado porcino según la cantidad de animales por explotación, 1937, 1960 y 1988.

\begin{tabular}{|l|l|c|c|c|}
\hline & & hasta 25 cabezas & $\begin{array}{c}\text { de 26 a 50 } \\
\text { cabezas }\end{array}$ & $\begin{array}{c}\text { más de 51 } \\
\text { cabezas }\end{array}$ \\
\hline zona Norte & 1937 & $46 \%$ & $14 \%$ & $40 \%$ \\
& 1960 & $27 \%$ & $17 \%$ & $56 \%$ \\
\multirow{3}{*}{ zona Oeste } & 1988 & $6 \%$ & $8 \%$ & $86 \%$ \\
& 1937 & $20 \%$ & $18 \%$ & $62 \%$ \\
& 1960 & $19 \%$ & $18 \%$ & $63 \%$ \\
\multirow{3}{*}{ zona Sur } & 1988 & $11 \%$ & $12 \%$ & $77 \%$ \\
& 1937 & $63 \%$ & $14 \%$ & $23 \%$ \\
& 1960 & $46 \%$ & $15 \%$ & $39 \%$ \\
& 1988 & $31 \%$ & $15 \%$ & $54 \%$ \\
\hline
\end{tabular}

Fuentes: Idem Cuadro 4.2.

Un análisis más detenido de los datos censales de 1988, permite relacionar la cría de porcinos con el lugar de residencia de los productores. Tal como puede observarse en el Cuadro 4.5, hemos encontrado que, si bien un porcentaje mayoritario de las explotaciones en las que residía el productor no realizaban cría de cerdos en 1988, las proporciones se reducían notoriamente para el caso de aquellos productores que no vivían en sus explotaciones (en la zona norte, por ejemplo, del 48\% al 15\%). 
Cuadro 4.5. Proporción de explotaciones que crían cerdos según residencia del productor, 1988

\begin{tabular}{|r|r|r|}
\hline ZONA & Residencia en la explotación & $\begin{array}{r}\text { Proporción que cría } \\
\text { cerdos }\end{array}$ \\
\hline Norte & Reside & .482 \\
\hline & No reside & .155 \\
\hline & Total & .294 \\
\hline Oeste & Reside & .282 \\
\hline & No reside & .098 \\
\hline & Total & .161 \\
\hline Sur & Reside & .258 \\
\hline & No reside & .122 \\
\hline & Total & .186 \\
\hline
\end{tabular}

Fuente: Reprocesamiento del Censo Nacional Agropecuario de 1988.

Por último, en la mayoría de los testimonios recogidos se percibe cierta nostalgia por la "pérdida" de la producción para el autoconsumo, y de las múltiples habilidades que ésta entrañaba. Sin embargo, varios productores mostraron una actitud más racional y moderna frente a este tipo de actividades, considerándolas una pérdida de dinero y tiempo ${ }^{75}$, y en uno de los casos surgió cierta asociación entre la producción para el autoconsumo y una situación inicial de "arrancar desde abajo" y que luego se la dejó de hacer, al "progresar"76.

75 Por ejemplo, estos dos productores de Tres Arroyos afirmaron que:

"eso de agarrar una lata y tirarles trigo al aire [a 400 o 500 gallinas, como hacía su madre]... Todas las cosas tienen que tener su medida de gastos, porque si vos agarrás y decís 'yo como huevos de mi casa, yo no compro', sale más caro que los huevos de oro" (ER).

"No ahorraba nada [con su quinta], me salía más caro que comprar las cosas; es más, ordeñar una vaca es más caro que comprar la leche, porque tenés que perder tiempo..." (GN).

76 "...como se arrancaba bastante de abajo... Yo recuerdo que con la grasa de ovejas hacíamos las velas y el jabón, lo hacíamos en el campo, esos fueron mis primeros pasos. Después mi tío progresó..." (CH). 
Así, con la urbanización y la desaparición de la producción para el autoconsumo, se ha mercantilizado el acceso a los bienes de consumo. Pero además, la radicación urbana provocó un fuerte incremento en los gastos de las familias. Es que la urbanización generó, en primer lugar, un mayor gasto en transporte, ya que el productor debía viajar todos los días hasta la explotación, aumentando el consumo de combustible y el desgaste de autos y camionetas. En algunos casos, la mujer tenía otro automóvil.

En segundo lugar, generó una erogación importante en la compra de la casa, además de los gastos de mantenimiento de dos casas (excepto que se abandonase por completo la casa en el campo, lo cual provocaba una mayor desvinculación con la explotación, ya que se tornaba imposible quedarse a dormir cuando era necesario, especialmente en época de trabajos más duros). Según algunos entrevistados, varios la mantuvieron como casa de fin de semana o de veraneo. En fin, la inversión en la/las casa/s originó la desviación de fondos que podrían haber sido destinados a la producción.

En tercer lugar, la propia vida urbana produjo un incremento notorio en los gastos de consumo familiares, ya que la sociabilidad urbana requería consumos más variados y costosos; se aceleró el consumismo, menos marcado entre quienes permanecieron residiendo en el campo ${ }^{77}$. La austeridad que caracterizaba al chacarero desapareció rápidamente ${ }^{78}$. Los gastos de los productores agropecuarios se fueron asemejando cada vez más a la clase media-alta urbana ${ }^{79}$.

77 Un productor de Rivadavia fue particularmente claro en señalar esta transformación: "... la familia agropecuaria demanda más insumos viviendo en el pueblo, viviendo como vive actualmente de lo que vivía anteriormente, y el volumen general de producción secundaria [de autoconsumo] ha desaparecido..." (OB).

78 Como nos relató un productor de Tres Arroyos: "[Antes] se conformaban con vivir y comer, sin ningún otro horizonte. Venían con esa mentalidad [de campesinos europeos] y la mantenían acá. A lo sumo ahorraban para la vejez. Pero, en la ciudad se vivía mejor. Se enriquecieron y se sentía la diferencia. Se vivía pobremente, pero sin molestar al resto de la sociedad [...] Había posibilidad de independizarse y se conformaban con eso, no con enriquecerse. Con una quintita se vive. El efecto de la radio, las revistas y la TV [generó que hubiera] que aspirar a más." (AA*).

79 Debido a que, todavía en los noventa, la vida que se realizaba en el campo era mucho más austera de la vida urbana (incluso cuando los servicios resultan más caros) un productor de Pergamino manifestó que "por cuestiones económicas me convendría vivir en el campo porque es mucho más barato" (RS). 
Este incremento en los gastos fue cada vez más difícil de afrontar por los pequeños productores. Como relata un productor mediano-grande, que se siente afuera de este problema debido a su solvencia económica:

"... en el campo tienen la chacrita, no tienen comodidades, la generación vieja le digo... los hijos se han apiolado... 'vamos, viejo, por 50 hectáreas... vámonos a vivir al pueblo'. Entonces ellos sí se van a vivir al pueblo, y en el pueblo gastan guita como locos y así les va...

P: - O sea... 'apiolados', ¿no?

- Sí, en el sentido de que quieren mayor bienestar, pero no tienen las espaldas cubiertas, porque con 50 hectáreas no se pueden dar el lujo de venir a vivir al pueblo, entonces gastan en el pueblo, gastan en el campo...cuando en el campo podrían tener sus gallinas, sus pavos, sus chanchos... Le hablo del chacarero de nivel chacarero...vivir mucho más barato en el campo.... que era lo que hacían los viejos. Los hijos bacanes, cafishos todos, dijeron 'no, viejo, nos vamos a vivir al pueblo...que el cine...'

P- Eso es lo que a mí me sorprende más...

- El que se viene a vivir al pueblo, que tiene 50 hectáreas... ese tipo está sonado. Por eso se están haciendo pelota los productores chicos, no solamente por un problema de escala... No viven como sus padres, tienen otros requerimientos, otras necesidades" (RS).

La distancia entre los estándares de vida de los productores en los años treinta y en los ochenta se puede inferir de la percepción que hoy tienen de la vivienda que tenían en esos primeros años, y en cómo ha cambiado su propia concepción de la pobreza (pues antes, para no ser pobre, alcanzaba con que no faltara la comida):

"Yo le puedo decir una cosa, que le digo siempre a mi señora, que la casa nuestra era de chorizos, en el campo, y me acuerdo que todos los años había que acomodarla un poquito [...] Que si uno ve hoy dice "una casa de pobre", pero lo que yo quería decirle con eso que yo nunca me sentí pobre, porque comida, que es lo principal para una persona, la comida siempre había abundancia" (PL). 


\title{
4. Asalarización, terciarización y rol gerencial
}

\author{
"Prefiero asumir el costo de pagarle a un contratista por hectárea, \\ que la diferencia es un 20 o un $25 \%$ más de costo por hectárea trabajada, \\ [y] que el problema de los 'fierros' sea de ellos. Vivo más tranquilo"
}

No sólo la mujer y los hijos dejaron de trabajar en la explotación: el propio productor redujo su aporte de trabajo físico a las tareas agropecuarias. Lo que resulta más paradójico es que este proceso tuvo lugar justo cuando estas labores disminuyeron notoriamente sus exigencias: en las décadas en estudio se pasó del requerimiento de acarrear bolsas, conducir una docena de caballos en una cosechadora de arrastre, o cosechar el maíz a mano, a la comodidad de manejar un tractor o una cosechadora automotriz con cabinas calefaccionadas, o en algunos casos incluso con aire acondicionado ${ }^{80}$.

Este paulatino abandono de las labores físicas, se vinculó con un cambio en el rol laboral del productor e incluso en su identidad social. Asociado con la radicación urbana, se fue construyendo un rol más gerencial, que no necesariamente identificaba al productor con alguien que realizaba trabajo físico, sino más bien con un organizador de la producción. El trabajo físico más importante fue quedando en manos de asalariados permanentes o transitorios, o directamente de contratistas de servicios. La principal actividad del productor fue, cada vez más, organizar la comercialización, la

80 Como comparó un productor de Pergamino: "... antes había que ir con los caballos y de a pie atrás de las herramientas. Ahora se va con el tractor, para cosechar va con la máquina, y antes tenía que hacerlo a mano. En ese sentido cambió un montón. Antes no se conocía los reflectores, ni las máquinas ni nada, mucho sacrificio, a la mañana había que salir con esas heladas, ahora con los tractores ya tienen cabina, los más nuevos hasta aire acondicionado, entonces se trabaja distinto, más rápido, con menos tiempo se trabaja más" (FL). O un productor de Tres Arroyos: "... nosotros tenemos un tractor que, estos días de frío, hay que andar casi en manga de camisa, tiene aire acondicionado, también, para el verano. Antes [...] el arado de dos rejas con 8 caballos, y el de 3 rejas con 10 caballos..." (VD). 
financiación ${ }^{81}$, las decisiones de producción y el ritmo de los trabajos ${ }^{82}$. Al mismo tiempo, si no terciarizaba las tareas, brindaba un apoyo logístico a las labores de los asalariados, llevando a reparar las herramientas (de una complejidad creciente con la mayor mecanización), transportando los insumos (cada vez más importantes en la actividad agrícola) o alcanzando los alimentos entre otras actividades ${ }^{83}$.

Dos ingenieros agrónomos de Pergamino y Tres Arroyos describieron claramente esta transformación:

81 La propia situación económica de alta inflación prolongada reforzó este cambio de rol, como señalaron dos ingenieros agrónomos entrevistados:

"El desarrollo empresarial, en general, no se hace en el campo, porque, sobre todo en estas décadas pasadas, la parte comercial, la parte financiera empezó a tener una importancia fundamental en la economía de la empresa. Lo obliga al tipo a estar mucho más atento a todas esas cosas que antes tenían una dinámica totalmente distinta" (CJ).

"... antes cuando te volvías loco con la inflación, y los plazos fijos, era una carrera, tenías que estar a lo mejor muy al pie del cañón, y a parte la comercialización. No te podías dar el lujo de vender trigo y no venirlo a cobrar ese día, venir a cobrarlo al otro día, porque perdías" (HU).

82 La radio y la telefonía celular han permitido que los asalariados a cargo de las tareas consulten inmediatamente al productor, con lo cual se redujo la necesidad de viajar diariamente a la explotación. Sin embargo, muchos productores pequeños o medianos que entrevistamos no contaban con estos servicios ni siquiera a mediados de los noventa.

83 A continuación transcribimos un día de trabajo del hijo de un productor, que se encarga de la explotación, mientras que el padre sólo realiza las tareas administrativas en la ciudad.

Hijo: - ...[el trabajo] me lleva más del tiempo que lo que usa un tractorista, por ejemplo. Yo arranco a las seis de la mañana y son las once de la noche y todavía estoy...

$[\ldots]$

P: - Contame todo el día de ayer, por ejemplo.

Hijo: - [El campo que estábamos sembrando] está a 25 kilómetros del campo donde vivo yo. Ayer, por ejemplo... Bueno, me levanto a las seis y media, ayer, tomo mate y voy al campo a ver si todo arrancó bien, al potrero, y estaba todo bien, y charlo con uno, charlo con el otro para... como para ver...

P: - ¿Estaban sembrando ya?

Hijo: - Un tractor estaba sembrando y el otro tractor estaba pasando el vibrocultivador que es una cama de siembra, justo el trabajo anterior a la siembra. Entonces charlo con uno, charlo con el otro para ver si realmente estaba todo bien. Y... me vuelvo a mi casa, agarro unos fierros que tenía que soldar y entonces voy al herrero, a nuestro herrero que está allá en Cascallares y arreglamos eso y cuando llego a casa me vienen a avisar que se le había roto un fierro del vibro, una de las herramientas.

P: - ¿Esto en el campo donde está tu casa, o en el campo que está a 25 kilómetros?

Hijo: - No, siempre en el campo, porque siempre tratamos de trabajar todos los tractores en el mismo lugar ¿no es cierto? No siempre se puede hacer, ¿no es cierto? y bueno, entonces voy para allá y el que estaba sembrando le habíamos calculado mal la semilla, nos faltó, nos faltaron mil kilos de semilla, así que tuvimos que volver a casa, prepara la semilla, volver a llevarlo, ya para eso se hacen las cuatro, las cinco de la tarde.

Padre: - Eso lo lleva con la camioneta, con un carro. 
"[En los años setenta], quizás a fines del '60 también, empieza a convertirse en un manager, en un administrador, que no está mal si sabe cumplir la función, porque cuando se trabaja en superficies grandes es tanto o más importante que subir al tractor, controlar, planificar y usar la cabeza. Eso no está mal, lo que está mal es en superficies chicas, porque un chacarero de 50 hectáreas que mira cómo el peón maneja el tractor, sentado bajo una planta tomando mate, está mal, porque no da para eso" (SY).

"... La filosofía CREA hace mucho hincapié en el rol de gerente, de un productor agropecuario, es decir, que además de producir bien, compra bien, por ejemplo, planificar bien.

P: - Y eso, ¿vos decís que compensa la 'falta' [término utilizado previamente por el entrevistado] de estar en la explotación?

- Yo te diría que la 'falta' de estar en la explotación probablemente fuera una consecuencia de que el productor agropecuario vio otro rol para sí mismo, dentro de la empresa.

P- Para el cual, ¿convenía estar en la ciudad?

- Para el cual no era necesario estar en el campo. Entonces si le sumás a eso la mejor oferta educativa, el mayor confort, etc., etc., hay un cúmulo de razones para que el productor se trasladara a la ciudad. [...] Creo que algo de eso hubo en estas dos últimas décadas. El movimiento CREA, y a través del movimiento CREA, como modelo del movimiento CREA, se desarrollaron a su vez muchos grupos en las cooperativas locales que también tienen mucha fuerza, hay muchos grupos desde donde se expandió, digamos, esa filosofía del manejo del campo y ese rol del productor como empresario rural y no como un productor que solamente sabía producir bien" (VH).

Hijo: - Y cuando todo se terminó, estaba todo listo y nos veníamos para casa, en el camino, a mitad del camino, yendo desde el campo ese a casa, cuando yo los encuentro estaba todo bien, salgo, y habré hecho tres, cuatro mil metros y se le rompió otra vez una herramienta en el enganche, y yo ni me enteré, porque recién me había ido yo. [El personal no tiene teléfono celular, ni hay teléfono en los campos]

$[\ldots]$

Padre: - Ese tractor que iba llevando con una herramienta de un campo al otro, se rompe el enganche donde enganchaba la herramienta y el tractor no lo podía trasportar más, el tractor sí podía pero la herramienta no. Entonces, la herramienta quedó en una vía pública, y es un peligro. Entonces, él tiene que buscar una solución para sacar esa herramienta...

Hijo: - Muchas veces, con el sólo hecho de dar una opinión y organizar el asunto, porque si hay cuatro o cinco, '¿qué hacemos, hacemos esto, hacemos lo otro?' 'Bueno, pará. Vamos a hacer esto'. Eso es un poco lo que hay que hacer.

P: - Pero lo que te lleva más ... ¿Eso no te lleva tanto tiempo? Lo que te lleva más tiempo...

Hijo: - Lo que me lleva más tiempo es estar en todos lados en el momento justo, eso es un poco de... eso la misma experiencia te va llevando a que, a estar en el momento justo, siempre. Un poco difícil de explicar, cómo es eso..." (Padre e hijo RY). 
La contrapartida de la disolución de la familia como equipo de producción y la reducción del aporte físico del productor, fue la asalarización de la mano de obra rural. Por cierto, detrás de este cambio se encuentra también el abandono de la esfera productiva por parte de muchos de los pequeños agricultores familiares, que analizamos en los capítulos anteriores.

En primer lugar, la cantidad de trabajadores por hectárea se redujo abruptamente en todas las zonas (tal como puede observarse en el Cuadro 4.6, primera columna): cayó casi tres veces el número de personal permanente por hectárea ${ }^{84}$. Las innovaciones tecnológicas ahorradoras de fuerza de trabajo fueron las que posibilitaron estas reducciones, más significativas en términos absolutos en la zona norte. Si analizamos el número de familiares del productor y de asalariados permanentes (excluyendo a los productores, cuyo trabajo directo en las labores del campo resulta difícil de equiparar en ambos momentos ${ }^{\mathbf{8 5}}$ ), resulta más clara la reducción en la cantidad de trabajadores permanentes cada 1.000 hectáreas, y que la disminución fue más intensa en la zona norte (ver la segunda columna del Cuadro).

Cuadro 4.6. Cantidad de trabajadores permanentes cada mil hectáreas, 1937 y 1988.

\begin{tabular}{|l|c|c|c|}
\hline & & $\begin{array}{c}\text { Total de } \\
\text { trabajadores } \\
(*)\end{array}$ & $\begin{array}{c}\text { Familiares y } \\
\text { asalariados } \\
(* *)\end{array}$ \\
\hline zona Norte & 1937 & 42,3 & 35,0 \\
zona Oeste & 1988 & 12,8 & 6,2 \\
& 1937 & 14,3 & 12,2 \\
zona Sur & 1988 & 5,4 & 3,4 \\
& 1937 & 11,0 & 9,3 \\
& 1988 & 4,5 & 2,8 \\
\hline
\end{tabular}

(*) incluye a los productores. (**) excluye a los productores.

Fuente: Cálculos propios efectuados en base a la información desagregada por partidos de los Censos Agropecuarios Nacionales de 1937 y 1988.

${ }^{84}$ No resulta posible comparar seriamente la información sobre trabajadores transitorios entre estos censos.

85 El productor siempre es registrado por los censos como alguien que trabaja en la explotación, aunque en muchos casos no desempeñe tareas directas. En cambio los familiares son diferenciados cuando trabajan y cuando sólo residen en la explotación. 
Además, la disminución en la cantidad de trabajadores fue mayor que la reducción en el número total de explotaciones, por lo cual observamos, en el Cuadro 4.7, un descenso en el número de personal por establecimiento.

Cuadro 4.7. Cantidad de trabajadores por explotación, 1937 y 1988.

\begin{tabular}{|l|l|c|c|}
\hline & & $\begin{array}{c}\text { Total de } \\
\text { trabajadores } \\
(*)\end{array}$ & $\begin{array}{c}\text { Familiares y } \\
\text { asalariados } \\
(* *)\end{array}$ \\
\hline zona Norte & 1937 & 4,18 & 3,45 \\
zona Oeste & 1988 & 2,21 & 1,10 \\
& 1937 & 4,26 & 3,64 \\
zona Sur & 1988 & 2,49 & 1,62 \\
& 1937 & 4,03 & 3,38 \\
& 1988 & 2,30 & 1,39 \\
\hline
\end{tabular}

$(*)$ incluye a los productores.

$(* *)$ excluye a los productores.

Fuente: Cálculos propios efectuados en base a la información desagregada por partidos de los Censos Agropecuarios Nacionales de 1937 y 1988.

Para estudiar los cambios en la composición de la fuerza de trabajo sólo podemos comparar la cantidad de trabajadores permanentes agrupados a nivel de partido de los censos de 1937, 1969 y 1988. Como podemos observar en el Cuadro 4.8, el número de trabajadores familiares del productor sufrió una drástica disminución en las tres zonas en estudio. Más allá de las diferencias en los criterios de registro censal, se observa que esta reducción había sido ya muy intensa entre 1937 y 1969, en torno a las tres cuartas partes del número inicial. Pero en el siguiente período tuvo lugar una disminución de similar magnitud relativa, ya que para 1988 sólo quedaba un cuarto de los trabajadores familiares presentes en 1969. Mientras tanto, la cantidad de asalariados permanentes sólo disminuyó levemente a lo largo de estos cincuenta años. Por lo tanto, los asalariados se convirtieron en la fuerza de trabajo que predominaba dentro de la mano de obra permanente (incluso superando en la zonas Sur y Oeste a la cantidad de productores por explotación). 
Cuadro 4.8. Número de personas que trabajan en forma permanente en las explotaciones agropecuarias, 1937,1969 y 1988

\begin{tabular}{|l|c|c|c|c|c|}
\hline & & Productores & Familiares & Asalariados & Total \\
\hline zona Norte & 1937 & 14.589 & 58.629 & 10.491 & 83.709 \\
& 1969 & 24.049 & 13.166 & 8.965 & 46.180 \\
& 1988 & 12.132 & 3.450 & 8.513 & 24.560 \\
& & & & & \\
zona Oeste & 1937 & 7.147 & 29.758 & 11.879 & 48.784 \\
& 1969 & 11.194 & 7.365 & 10.308 & 28.867 \\
& 1988 & 6.625 & 2.570 & 9.709 & 19.725 \\
& & & & & \\
& 1937 & 9.446 & 32.971 & 16.383 & 58.800 \\
& 1969 & 18.143 & 11.615 & 12.282 & 42.040 \\
& 1988 & 9.442 & 3.474 & 11.079 & 23.995 \\
\hline
\end{tabular}

Fuente: Cálculos propios efectuados en base a la información desagregada por partidos de los Censos Agropecuarios Nacionales de 1937, 1969 y 1988.

Cuadro 4.9. Número de personas por explotación que trabajan en forma permanente y proporción entre familiares y asalariados, 1937, 1969 y 1988

\begin{tabular}{|l|c|c|c|c|c|c|}
\hline Zona & & Product. & Famil. & Asalar. & Fliar. & Asal. \\
\hline Norte & 1937 & 0,73 & 2,93 & 0,52 & $85 \%$ & $15 \%$ \\
& 1969 & 1,33 & 0,73 & 0,50 & $59 \%$ & $41 \%$ \\
& 1988 & 1,11 & 0,32 & 0,78 & $29 \%$ & $71 \%$ \\
\multirow{4}{*}{ Oeste } & & & & & & \\
& 1937 & 0,62 & 2,60 & 1,04 & $71 \%$ & $29 \%$ \\
& 1969 & 1,23 & 0,81 & 1,14 & $42 \%$ & $58 \%$ \\
& 1988 & 0,87 & 0,34 & 1,28 & $21 \%$ & $79 \%$ \\
& & & & & & \\
& 1937 & 0,65 & 2,26 & 1,12 & $67 \%$ & $33 \%$ \\
& 1969 & 1,25 & 0,80 & 0,85 & $48 \%$ & $52 \%$ \\
& 1988 & 0,91 & 0,33 & 1,06 & $24 \%$ & $76 \%$ \\
\hline
\end{tabular}

Fuente: Cálculos propios efectuados en base a la información desagregada por partidos de los Censos Agropecuarios Nacionales de 1937, 1969 y 1988. 
Por otra parte, los productores han desarrollado, como segunda alternativa a la producción familiar, una novedosa forma de organizar la agricultura: la terciarización de las actividades a través de la utilización de servicios de maquinarias. Como ya hemos comentado, según cálculos propios en base a datos inéditos del Censo Agropecuario Nacional de 1988, el $57 \%$ de la superficie cultivada con cereales y oleaginosas en la zona norte era cosechado con contratistas de maquinaria; el porcentaje era del $53 \%$ en la zona oeste, y del $37 \%$ en la zona sur (y estos niveles elevados estaban presentes en todos los tamaños de explotaciones). En el caso extremo, el propietario se convertía en un rentista puro, cediendo su campo a un contratista tantero. Coscia lo asocia con el último paso que sigue a la urbanización ${ }^{86}$. Esta cesión, si bien no estaba tan extendida como la contratación de servicios de maquinaria, representaba alrededor del 19\% de la superficie de la zona norte en 1988 y del 10\% de la zona sur (de hecho correspondía al $26 \%$ del área agrícola de la zona norte y al 13\% de los cultivos del sur, aunque tan sólo al $3 \%$ en el oeste).

A partir del análisis de los datos originales del Censo Agropecuario de 1988 hemos podido comprobar que la no residencia en la explotación se encontraba asociada a un mayor peso de la organización de la producción en base al trabajo asalariado ${ }^{87} \mathrm{o}$ con contratistas de servicios, en detrimento de la producción en base al trabajo del productor y/o su familia. Así, por ejemplo, en la zona norte, sólo el $11 \%$ de las explotaciones en las que residía el productor, organizaba las labores con asalariados ${ }^{88}$;

86 "En el productor chico, y aún en el mediano cuando en la familia no hay personas jóvenes que continúen en las tareas agrícolas, el desplazamiento del productor al medio urbano es generalmente el paso previo para que algunos años después se convierta en rentista, entregando su explotación a un empresario agrícola..." (Coscia, 1983: 79).

87 Un estudio focalizado en el partido de Azul también encontró una asociación entre residencia urbana y forma de producción empresarial. En cambio, en los tipos familiares predomina la residencia en la explotación (González y otros, 1999).

88 Identificamos como explotación basada en mano de obra familiar aquélla que no contaba con trabajo asalariado (permanente o temporario), o bien cuando éste no superaba el $10 \%$ de la fuerza de trabajo total, sin contabilizar al productor (es decir, familiares más asalariados). En el otro extremo, cuando los asalariados representaban más del $80 \%$ de los trabajadores (sin 
en cambio, el 49\% de las unidades donde no habitaba se basaba en el trabajo asalariado. En la zona oeste, las diferencias eran de $13 \%$ frente a $55 \%$, y en la zona sur, de $13 \%$ a $61 \%$, respectivamente. Como contrapartida, entre los establecimientos en donde residía el productor, predominaban los que se estructuraban en base al trabajo familiar, tal como puede observarse en el Cuadro 4.10.

\section{Cuadro 4.10. Explotaciones según la composición de la mano de obra y el lugar de residencia del productor, 1988.}

\begin{tabular}{|r|r|r|r|r|}
\hline & Mano de obra & \multicolumn{2}{|l|}{ Residencia en la explotación } & Tota \\
\hline Zona & & \multicolumn{1}{|c|}{ Reside } & No reside & \\
\hline Norte & Familiar & $69.8 \%$ & $45.3 \%$ & $55.8 \%$ \\
\hline & Familiar y asalariada & $18.9 \%$ & $5.3 \%$ & $11.1 \%$ \\
\hline & Asalariada & $11.3 \%$ & $49.4 \%$ & $33.1 \%$ \\
\hline & & $100.0 \%$ & $100.0 \%$ & $100.0 \%$ \\
\hline Oeste & Familiar & $68.0 \%$ & $40.4 \%$ & $50.3 \%$ \\
\hline & Familiar y asalariada & $18.6 \%$ & $4.9 \%$ & $9.8 \%$ \\
\hline & Asalariada & $13.4 \%$ & $54.7 \%$ & $39.8 \%$ \\
\hline & & $100.0 \%$ & $100.0 \%$ & $100.0 \%$ \\
\hline Sur & Familiar & $51.1 \%$ & $32.5 \%$ & $41.3 \%$ \\
\hline & Familiar y asalariada & $35.9 \%$ & $6.2 \%$ & $20.2 \%$ \\
\hline & Asalariada & $13.1 \%$ & $61.2 \%$ & $38.6 \%$ \\
\hline & & $100.0 \%$ & $100.0 \%$ & $100.0 \%$ \\
\hline
\end{tabular}

Fuente: Cálculos propios en base a una matriz de datos elaborada conjuntamente con la Dirección Provincial de Estadística y Planificación General de la Provincia de Buenos Aires, a partir de la información original del Censo Agropecuario Nacional de 1988.

De modo similar, entre los establecimientos en los que residía el productor, la organización de la producción agrícola estaba directamente a cargo de él en una proporción bastante más elevada que en el caso de los que no residían. Por ejemplo, en la zona norte, el 62\% de las unidades en las que sí residía, la agricultura se realizaba de forma $\operatorname{directa}^{89}$, mientras que así lo hacía el $50 \%$ de las explotaciones donde el

contabilizar al productor) se la consideró una explotación basada en la mano de obra "asalariada". Las situaciones intermedias se catalogaron como con fuerza de trabajo "familiar y asalariada".

89 Hemos diferenciado tres tipos de formas de organizar la producción agrícola según la significación del contratismo de servicios en la roturación-siembra y en la cosecha. 
productor no residía. En la zona sur, la diferencia era de similar magnitud (78\% frente a $64 \%)$, mientras que en la zona oeste era inferior ( $66 \%$ frente a $58 \%$ ), tal como puede observarse en el Cuadro 4.11.

Cuadro 4.11. Explotaciones según la forma de organización de la agricultura y el lugar de residencia del productor, 1988

\begin{tabular}{|c|c|c|c|c|}
\hline & $\begin{array}{l}\text { Forma de organización de } \\
\text { la agricultura }\end{array}$ & Residencia en la & explotación & \multirow[t]{2}{*}{ Total } \\
\hline Zona & & Reside & No reside & \\
\hline Norte & Directa & $62.0 \%$ & $49.9 \%$ & $55.1 \%$ \\
\hline & Directa y por contrato & $25.1 \%$ & $22.6 \%$ & $23.7 \%$ \\
\hline & Por contrato & $13.0 \%$ & $27.5 \%$ & $21.2 \%$ \\
\hline & & $100.0 \%$ & $100.0 \%$ & $100.0 \%$ \\
\hline Oeste & Directa & $65.5 \%$ & $57.7 \%$ & $60.5 \%$ \\
\hline & Directa y por contrato & $15.2 \%$ & $16.4 \%$ & $15.9 \%$ \\
\hline & Por contrato & $19.3 \%$ & $25.9 \%$ & $23.6 \%$ \\
\hline & & $100.0 \%$ & $100.0 \%$ & $100.0 \%$ \\
\hline Sur & Directa & $77.7 \%$ & $63.6 \%$ & $70.2 \%$ \\
\hline & Directa y por contrato & $15.8 \%$ & $19.1 \%$ & $17.6 \%$ \\
\hline & Por contrato & $6.5 \%$ & $17.3 \%$ & $12.2 \%$ \\
\hline & & $100.0 \%$ & $100.0 \%$ & $100.0 \%$ \\
\hline
\end{tabular}

Fuente: Cálculos propios en base a una matriz de datos elaborada conjuntamente con la Dirección Provincial de Estadística y Planificación General de la Provincia de Buenos Aires, a partir de la información original del Censo Agropecuario Nacional de 1988.

Las diferencias entre las unidades en las que residía el productor y en las que no lo hacía se acrecientan cuando combinamos ambas dimensiones (composición de la mano de obra y organización de la producción agrícola) y controlamos la cuestión del tamaño de las unidades productivas y de su orientación productiva. Hemos elegido tres tipos de explotaciones para mostrar estas diferencias. Por ejemplo, en la zona norte entre las explotaciones agrícolas o $\operatorname{mixtas}^{90}$ de 200 a 400 hectáreas, el $74 \%$ de las unidades en las que vivía el productor presentaba un predominio del trabajo familiar (ya

Denominamos "directa" a la unidad en la que las labores de los contratistas -sumando ambas actividades- dieron cuenta de menos del $25 \%$ del trabajo agrícola, medido en superficie. "Por contrato" serían las explotaciones en las que más del 75\% de las labores agrícolas fueron realizadas con contratistas. Las situaciones intermedias las englobamos en la categoría de "Directa y por contrato". 
sea puro o combinado con asalariados o contratismo de servicios). En cambio, en aquellas unidades donde no residía el productor, sólo un 21\% tenía estas características (ver Cuadro 4.12, categorías agregadas de sombreado suave). En la zona sur la diferencia era incluso mayor ( $89 \%$ frente a 30\%, respectivamente), mientras que en la zona oeste era un tanto menor la discrepancia (62\% frente a $24 \%$ ). Como contracara de esta situación, entre las explotaciones en las que no se encontraba el productor, se incrementaba el porcentaje de unidades basadas en el trabajo asalariado. Así, en la zona norte, el $57 \%$ de las unidades donde no vivía el productor se organizaba a partir de asalariados (solos o combinados con trabajo familiar o con contratistas), frente al $16 \%$ de unidades con estas características dentro de las explotaciones en las que residía el productor (ver Cuadro 4.12, categorías agregadas con recuadro resaltado). En la zona sur, la discrepancia era un poco mayor ( $55 \%$ frente a $6 \%$ ), y en la zona oeste un tanto menor (44\% frente a 19\%). Por último, la incidencia de la residencia también era importante en el peso de la organización de la producción agrícola en base al contratismo de servicios. En la zona norte, el porcentaje de explotaciones en las que se realizaba casi totalidad de las labores agrícolas de este modo se incrementaba del 4\% al $19 \%$, según el productor habitaba o no en ellas. En la zona oeste, la diferencia era del $14 \%$ frente al 29\%, y en la zona sur, del 2\% frente al 14\% (tal como puede observarse en la última columna del Cuadro 4.12, sombreado intenso).

90 Consideramos como tales a las unidades en las que se encontraba cultivada más del $20 \%$ de la superficie total. 
Cuadro 4.12. Explotaciones agrícolas o mixtas de 200 a 400 hectáreas discriminadas según la residencia del productor, la composición de la mano de obra y la forma de producción agrícola, 1988. Zonas norte, oeste y sur.

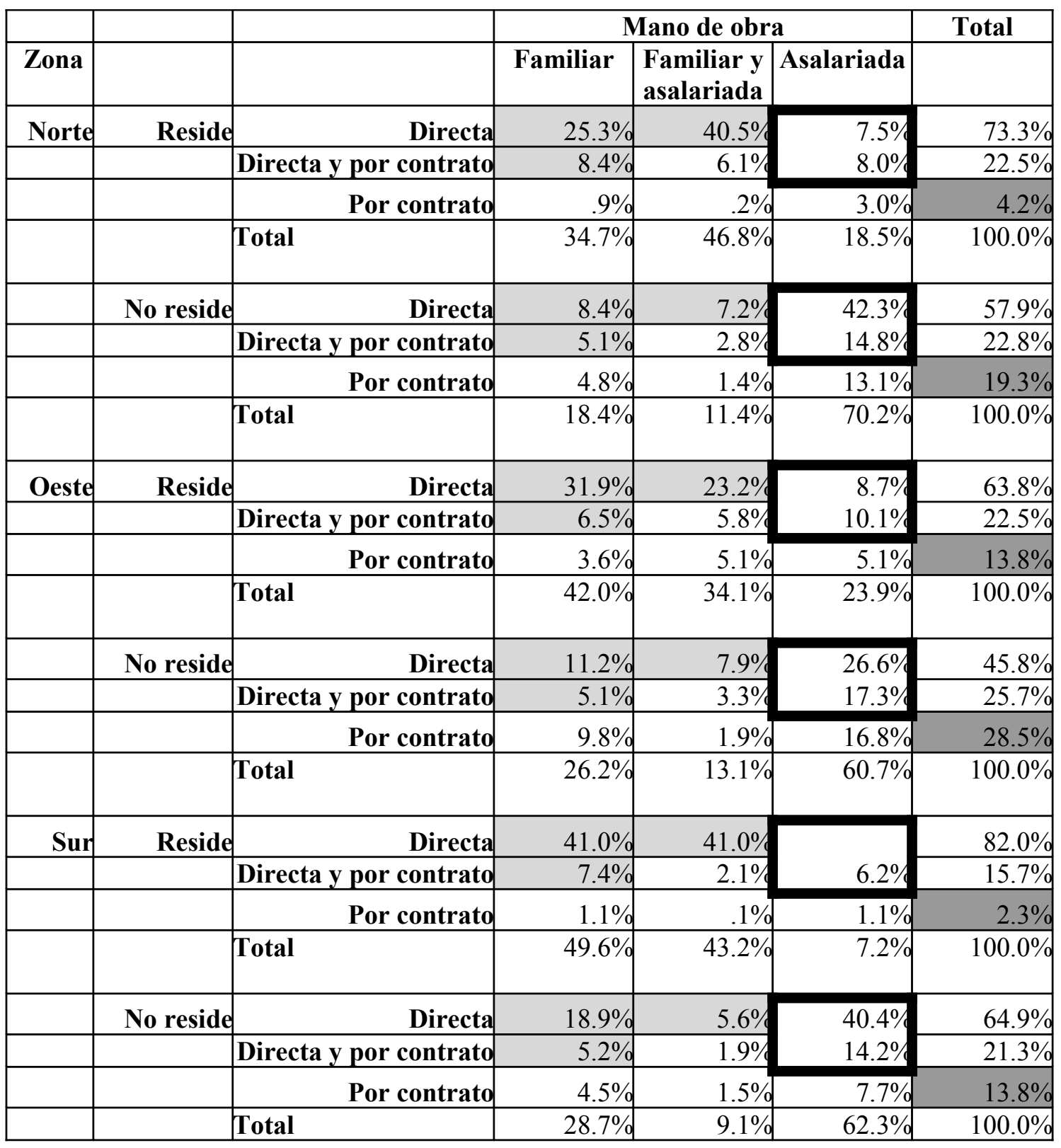

Agregación de categorías:

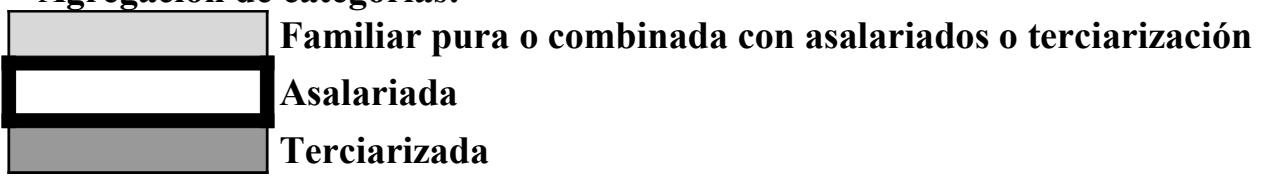

Fuente: cálculos propios en base a una matriz de datos elaborada conjuntamente con la Dirección Provincial de Estadística y Planificación General de la Provincia de Buenos Aires, a partir de la información original del Censo Agropecuario Nacional de 1988. 
De modo similar, en las explotaciones agrícolas o mixtas de 400 a 1.000 hectáreas (ver Cuadro 4.13), la no residencia se asociaba con una reducción del peso de las unidades basadas en el trabajo familiar, con un incremento de las caracterizadas por la fuerza de trabajo asalariada y con la utilización de contratistas. Sin embargo, en el caso de las zonas norte y oeste, las diferencias según el lugar de residencia del productor eran menores que para las unidades de 200 a 400 hectáreas. En cambio, en la zona sur, estas discrepancias presentaban una magnitud mayor. Así, entre las unidades en las que vivía el productor, el $86 \%$ se basaba en la mano de obra familiar (pura o con apoyo asalariado o terciarización parcial), mientras que sólo el $15 \%$ de los establecimientos en los cuales no habitaba el productor presentaba este tipo de organización del trabajo. Entre éstos, en cambio, el 71\% se basaba en la fuerza de trabajo asalariada, frente a sólo un $10 \%$ de las unidades con residencia del productor que tenía este perfil (ver Cuadro 4.13). 
Cuadro 4.13. Explotaciones agrícolas o mixtas de 400 a 1.000 hectáreas discriminadas según la residencia, mano de obra y la forma de producción agrícola, 1988. Zonas norte, oeste y sur.

\begin{tabular}{|c|c|c|c|c|c|c|}
\hline & & & \multicolumn{3}{|c|}{ Mano de obra } & \multirow[t]{2}{*}{ Total } \\
\hline Zona & & & Familiar & \begin{tabular}{|l|} 
Familiar y \\
asalariada
\end{tabular} & Asalariada & \\
\hline \multirow[t]{8}{*}{ Norte } & Reside & Directa & $14.9 \%$ & $37.8 \%$ & $26.6 \%$ & $79.3 \%$ \\
\hline & & Directa y por contrato & $2.3 \%$ & $5.0 \%$ & $8.6 \%$ & $15.8 \%$ \\
\hline & & Por contrato & $.5 \%$ & $1.4 \%$ & $3.2 \%$ & $5.0 \%$ \\
\hline & & Total & $17.6 \%$ & $44.1 \%$ & $38.3 \%$ & $100.0 \%$ \\
\hline & No reside & Directa & $4.5 \%$ & $6.9 \%$ & $46.2 \%$ & $57.6 \%$ \\
\hline & & Directa y por contrato & $1.1 \%$ & $2.5 \%$ & $18.1 \%$ & $21.7 \%$ \\
\hline & & Por contrato & $3.6 \%$ & $.9 \%$ & $16.3 \%$ & $20.8 \%$ \\
\hline & & Total & $9.2 \%$ & $10.3 \%$ & $80.6 \%$ & $100.0 \%$ \\
\hline \multirow[t]{8}{*}{ Oeste } & Reside & Directa & $11.5 \%$ & $32.7 \%$ & $30.8 \%$ & $75.0 \%$ \\
\hline & & Directa y por contrato & $3.8 \%$ & $2.9 \%$ & $7.7 \%$ & $14.4 \%$ \\
\hline & & Por contrato & $1.0 \%$ & $2.9 \%$ & $6.7 \%$ & $10.6 \%$ \\
\hline & & Total & $16.3 \%$ & $38.5 \%$ & $45.2 \%$ & $100.0 \%$ \\
\hline & No reside & Directa & $2.9 \%$ & $9.8 \%$ & $37.5 \%$ & $50.2 \%$ \\
\hline & & Directa y por contrato & $2.5 \%$ & $2.5 \%$ & $15.3 \%$ & $20.4 \%$ \\
\hline & & Por contrato & $2.5 \%$ & $1.8 \%$ & $25.1 \%$ & $29.5 \%$ \\
\hline & & Total & $8.0 \%$ & $14.2 \%$ & $77.8 \%$ & $100.0 \%$ \\
\hline \multirow[t]{8}{*}{ Sur } & Reside & Directa & $24.8 \%$ & $58.2 \%$ & $3.2 \%$ & $86.2 \%$ \\
\hline & & Directa y por contrato & $2.9 \%$ & $1.9 \%$ & $6.4 \%$ & $11.2 \%$ \\
\hline & & Por contrato & $.4 \%$ & $.8 \%$ & $1.4 \%$ & $2.6 \%$ \\
\hline & & Total & $28.1 \%$ & $60.9 \%$ & $11.0 \%$ & $100.0 \%$ \\
\hline & No reside & Directa & $5.1 \%$ & $8.3 \%$ & $56.2 \%$ & $69.6 \%$ \\
\hline & & Directa y por contrato & $1.6 \%$ & $2.5 \%$ & $15.0 \%$ & $19.1 \%$ \\
\hline & & Por contrato & $1.5 \%$ & $1.0 \%$ & $8.8 \%$ & $11.3 \%$ \\
\hline & & Total & $8.2 \%$ & $11.9 \%$ & $79.9 \%$ & $100.0 \%$ \\
\hline
\end{tabular}

Agregación de categorías:

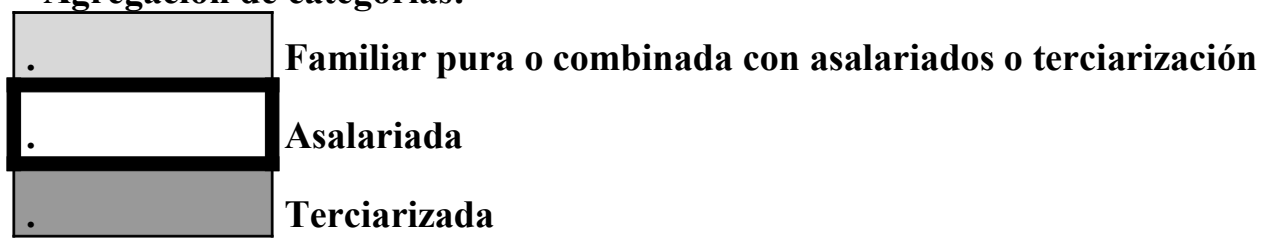

Fuente: Cálculos propios en base a una matriz de datos elaborada conjuntamente con la Dirección Provincial de Estadística y Planificación General de la Provincia de Buenos Aires, a partir de la información original del Censo Agropecuario Nacional de 1988. 
Por último, en las explotaciones exclusivamente ganaderas, las diferencias de organización social del trabajo, según la residencia o no del productor en el campo, presentaban el mismo sentido y eran también muy importantes, especialmente entre las unidades pequeñas y medianas. Tal como puede observarse en el Cuadro 4.14, en la zona norte en las unidades menores a las 400 hectáreas existía una proporción mucho más elevada de explotaciones basadas en el trabajo asalariado entre los establecimientos donde no vivía el productor, que en aquellos donde sí lo hacía. En cambio, por encima de esta extensión, las diferencias perdían importancia ${ }^{91}$. En la zona oeste, las discrepancias en la composición de la mano de obra entre las unidades con o sin residencia del productor resultaban importantes hasta las 1.000 hectáreas, y en la zona sur la diferencia era sustancial incluso para las explotaciones ganaderas de 1.000 a 2.500 hectáreas; aquí el $20 \%$ de las unidades de este intervalo de tamaño en las que residía el productor, se basaban en el trabajo familiar, y el $27 \%$ se organizaban con la mano de obra familiar combinada con asalariados (ver Cuadro 4.14).

91 No corresponde otorgar mayor importancia a la celda de mayor a 2.500 hectáreas y productor residente, ya que existía una única explotación con estas características. 
Cuadro 4.14. Explotaciones ganaderas discriminadas según la residencia del productor, el tamaño y la composición de la mano de obra, 1988. Zonas norte, oeste y sur.

\begin{tabular}{|c|c|c|c|c|c|c|}
\hline & & & \multicolumn{3}{|c|}{ Mano de obra } & \multirow[t]{2}{*}{ Total } \\
\hline Zona & Tamaño & & Familiar & $\begin{array}{l}\text { Familiar y } \\
\text { asalariada }\end{array}$ & Asalariada & \\
\hline \multirow{14}{*}{$\begin{array}{r}\text { Nort } \\
\text { e }\end{array}$} & hasta 25 ha & Reside & $97.7 \%$ & $1.2 \%$ & $1.2 \%$ & $100.0 \%$ \\
\hline & & No reside & $42.9 \%$ & $1.9 \%$ & $55.3 \%$ & $100.0 \%$ \\
\hline & 25 a 100 & Reside & $84.8 \%$ & $3.1 \%$ & $12.0 \%$ & $100.0 \%$ \\
\hline & & No reside & $52.6 \%$ & $2.2 \%$ & $45.2 \%$ & $100.0 \%$ \\
\hline & 100 a 200 & Reside & $46.0 \%$ & $33.3 \%$ & $20.6 \%$ & $100.0 \%$ \\
\hline & & No reside & $20.5 \%$ & $3.3 \%$ & $76.3 \%$ & $100.0 \%$ \\
\hline & 200 a 400 & Reside & $17.1 \%$ & $29.3 \%$ & $53.7 \%$ & $100.0 \%$ \\
\hline & & No reside & $15.2 \%$ & $4.8 \%$ & $80.0 \%$ & $100.0 \%$ \\
\hline & 400 a 1000 & Reside & $6.3 \%$ & $18.8 \%$ & $75.0 \%$ & $100.0 \%$ \\
\hline & & No reside & $8.3 \%$ & $8.3 \%$ & $83.3 \%$ & $100.0 \%$ \\
\hline & 1000 a 2500 & Reside & & & $100.0 \%$ & $100.0 \%$ \\
\hline & & No reside & & $2.8 \%$ & $97.2 \%$ & $100.0 \%$ \\
\hline & más de 2500 & Reside & $100.0 \%$ & & & $100.0 \%$ \\
\hline & & No reside & & & $100.0 \%$ & $100.0 \%$ \\
\hline \multirow[t]{14}{*}{$\begin{array}{r}\text { Oest } \\
\text { e }\end{array}$} & hasta 25 ha & Reside & $97.8 \%$ & & $2.2 \%$ & $100.0 \%$ \\
\hline & & No reside & $93.3 \%$ & $2.2 \%$ & $4.5 \%$ & $100.0 \%$ \\
\hline & 25 a 100 & Reside & $87.2 \%$ & $8.9 \%$ & $3.9 \%$ & $100.0 \%$ \\
\hline & & No reside & $76.0 \%$ & $.7 \%$ & $23.3 \%$ & $100.0 \%$ \\
\hline & 100 a 200 & Reside & $81.3 \%$ & $16.4 \%$ & $2.3 \%$ & $100.0 \%$ \\
\hline & & No reside & $51.7 \%$ & $2.5 \%$ & $45.8 \%$ & $100.0 \%$ \\
\hline & 200 a 400 & Reside & $64.2 \%$ & $31.7 \%$ & $4.2 \%$ & $100.0 \%$ \\
\hline & & No reside & $33.2 \%$ & $7.3 \%$ & $59.5 \%$ & $100.0 \%$ \\
\hline & 400 a 1000 & Reside & $35.1 \%$ & $44.8 \%$ & $20.1 \%$ & $100.0 \%$ \\
\hline & & No reside & $4.2 \%$ & $7.6 \%$ & $88.2 \%$ & $100.0 \%$ \\
\hline & 1000 a 2500 & Reside & $8.0 \%$ & $16.0 \%$ & $76.0 \%$ & $100.0 \%$ \\
\hline & & No reside & $.5 \%$ & $3.7 \%$ & $95.8 \%$ & $100.0 \%$ \\
\hline & más de 2500 & Reside & & & $100.0 \%$ & $100.0 \%$ \\
\hline & & No reside & $1.4 \%$ & & $98.6 \%$ & $100.0 \%$ \\
\hline \multirow[t]{13}{*}{ Sur } & hasta 25 ha & Reside & $58.3 \%$ & $33.3 \%$ & $8.3 \%$ & $100.0 \%$ \\
\hline & & No reside & & $16.7 \%$ & $83.3 \%$ & $100.0 \%$ \\
\hline & 25 a 100 & Reside & $82.4 \%$ & $9.8 \%$ & $7.8 \%$ & $100.0 \%$ \\
\hline & & No reside & $72.9 \%$ & & $27.1 \%$ & $100.0 \%$ \\
\hline & 100 a 200 & Reside & $75.4 \%$ & $14.9 \%$ & $9.7 \%$ & $100.0 \%$ \\
\hline & & No reside & $52.3 \%$ & $.3 \%$ & $47.4 \%$ & $100.0 \%$ \\
\hline & 200 a 400 & Reside & $57.8 \%$ & $29.9 \%$ & $12.3 \%$ & $100.0 \%$ \\
\hline & & No reside & $31.6 \%$ & $4.6 \%$ & $63.8 \%$ & $100.0 \%$ \\
\hline & 400 a 1000 & Reside & $38.9 \%$ & $48.2 \%$ & $13.0 \%$ & $100.0 \%$ \\
\hline & & No reside & $10.4 \%$ & $9.5 \%$ & $80.1 \%$ & $100.0 \%$ \\
\hline & 1000 a 2500 & Reside & $20.0 \%$ & $26.7 \%$ & $53.3 \%$ & $100.0 \%$ \\
\hline & & No reside & $1.4 \%$ & $8.9 \%$ & $89.7 \%$ & $100.0 \%$ \\
\hline & más de 2500 & Reside & & & $100.0 \%$ & $100.0 \%$ \\
\hline
\end{tabular}




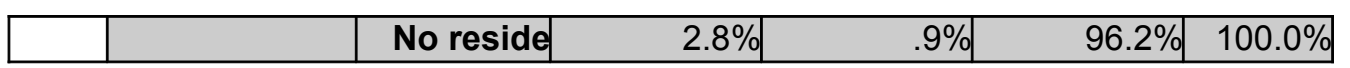

Fuente: Cálculos propios en base a una matriz de datos elaborada conjuntamente con la Dirección Provincial de Estadística y Planificación General de la Provincia de Buenos Aires, a partir de la información original del Censo Agropecuario Nacional de 1988. 
Además de las transformaciones que pueden detectarse con datos cuantitativos, existió un cambio cualitativo en la relación del productor con los asalariados. Todos los entrevistados (recordemos son productores rurales o, unos pocos, ingenieros agrónomos, pero ninguno es asalariado rural) hablaron de una época previa de "armonía" en la cual peones y productores (o sus hijos) trabajaban "codo a codo"92 y comían juntos $^{93}$. Incluso el peón era considerado como "uno más de la familia"94. Este trato igualitario, se habría complementado con un gran respeto del asalariado hacia el productor. Sin embargo, la relación también se establecía a través de una rígida disciplina, especialmente en las estancias ${ }^{95}$. Los asalariados no tenían derechos laborales

92 Por dar uno de los numerosos testimonios coincidentes, transcribimos el de un productor de Tres Arroyos acerca de sus inicios en 1938 en el campo de sus tíos, propietarios de 500 hectáreas: "Empecé trabajando, manejando tractor, en ese tiempo se hacía mucho trabajo personal, incluso ahí los patrones trabajaban igual que los peones. [...] Mis tíos trabajaban igual que los peones" $(\mathrm{CH})$.

Agregamos el relato de otro productor de Tres Arroyos que, durante su adolescencia, entró a trabajar como mensual en una chacra arrendada de 600 hectáreas: afirmó que si bien el chacarero ya no trabajaba pues "ya era un hombre grande", sus hijos "tenían que arar y sembrar igual que nosotros [...]; lo único que ellos dormían adentro y nosotros... [en una casita con] muy buena comodidad" (PS).

93 Pero esto ocurría "antes", como bien marca la entrevistada de Rivadavia: "Antes...yo recuerdo... el peón que tenías en el campo era uno más de la familia, en la chacra nuestra comía... mis tres hermanos así... en la otra punta el empleado, el que los ayudaba cuando había mucho trabajo..." (MD).

También lo recordó así el entrevistado que había sido asalariado en su adolescencia: "comíamos todos juntos [...] en la misma mesa." (PS).

94 "Ellos nunca tuvieron problemas con el personal porque trabajaban a la par. El patrón así debe hacer. Iban juntos, Siempre, siempre comieron juntos, eran como de la familia. Vivían en la misma casa, pared de por medio." (DP*).

95 Un productor de Rivadavia comentó que "en los años 40 al personal se lo trataba de una manera muy distinta, no se le proveía mayores comodidades, no se lo consideraba demasiado seriamente, el personal era totalmente subalterno. Yo recuerdo, por ejemplo, el capataz pegarle un levante de la gran flauta a un peón porque tenía el botón del puño de la bombacha desabrochado, cosas así... había una relación de patrón y peón, así con guión y mayúscula, y eso no se da actualmente aunque hay casos... [...] En los años 40, el peón era un tipo totalmente subalternizado y no podía vivir con la familia en el campo, no tenía ninguna clase de seguridad en cuanto a sueldo futuro, empleo futuro ni a salud futura. Se ha evolucionado notablemente, probablemente con arreglo a las leyes que impuso Perón en su momento, que 
y muchos patrones sacaban partido de esta situación, según reconocieron algunos pocos entrevistados ${ }^{96}$.

Desde la óptica del productor, a partir de la intervención estatal y la mayor organización sindical durante el primer peronismo "se sembraron odios"97. El vínculo personal se fue deteriorando, la "entrega" del peón hacia el establecimiento se diluyó ${ }^{\mathbf{8}}$, como así también el "respeto" hacia el patrón. Como contrapartida, el productor fue regulando, cada vez más, la relación laboral de un modo más impersonal. Explicado en términos simples y paradigmáticos, se profundizó la división de roles: el productor se asumió como empresario que empleaba asalariados, y no como trabajador que sumaba a otros trabajadores porque no le alcanza con su fuerza de trabajo. Resulta sintomático que en las entrevistas los productores no otorgaron al trabajo de sus asalariados mayor importancia en sus procesos de acumulación (salvo una honrosa excepción ${ }^{99}$ ). En no fueron buenas pero removieron un poco el tema" (OB).

96 Un gran propietario y arrendatario de Tres Arroyos confesó que "en cierto modo, más de cuatro de nosotros éramos demasiado abusivos con la gente. Ese fue uno de los motivos fundamentales [por lo que se puso la legislación peronista]. [...] antes, no nos vamos a engañar, éramos muy abusadores de la gente, el 90\% éramos por demás abusadores de la gente de trabajo, y eso es real. Venía esa pobre gente de Santiago del Estero y todo, pobres trabajadores como no se qué, por cuatro pesos, sin leyes, sin cargas sociales, ni nada" (UB).

97 La mayoría de los entrevistados tiene esa imagen de la acción de Perón, que podemos sintetizarla, con sus matices, en el testimonio de un productor de Tres Arroyos: "En aquel momento se sembró más vale odios, junto con esas leyes se hablaba mucho de 'los patrones explotadores', que los había, y que hoy tal vez todavía los hay. Pero se formaron unas divisiones y unos odios que tal vez no fueron necesarios" (VS).

98 Incluso el productor de Rivadavia que fue crítico de cómo eran tratados los peones en los años cuarenta, sostuvo que "es común encontrar en el personal rural falta de cuidado, falta de atención, falta de responsabilidad... que por otra parte ha aumentado también la responsabilidad. No es lo mismo andar a caballo recorriendo alambrados que manejar un tractor que vale 150.000 pesos" (OB).

99 Este productor, crítico de las opiniones y actitudes de muchos de sus pares hacia los asalariados, sostuvo repetidamente que todo lo que tenía se lo debía a su excelente personal, que dándoles buenos sueldos, comodidades, libertad de acción y estímulos, se preocupan tanto o más que el patrón por la marcha de la explotación:

"El patrón debe ser patrón y compañero del operario. Si no el operario no anda. Hay que compartir la vida, no sólo cuando se lo necesita. Y el personal tiene que estar cómodo en el campo, porque no es un día o dos. No es cosa de que esté maltratado en una mala habitación, que no tenga heladera o agua caliente, que no tenga buena comida. Ahora, el personal tratándolo bien y pagándole buenos sueldos, rinde. Eso de que dicen que no hay buen personal, son todas macanas. [...] Me lo enseñó que yo anduve de croto, fui peón, mi padre fue peón entonces le tengo mucho respeto al personal. El personal es una cosa sagrada [...] Sabe quiénes tratan bien al personal, que son muy sensibles, los dinamarqueses y los holandeses, por eso adelantan" (MÑ). 
síntesis, como resultado de estas transformaciones el chacarero se fue considerando cada vez más un empleador y no un trabajador; en el conflicto con el asalariado se objetivizó como capitalista, más allá de que continuara trabajando y de que ya antes contratara asalariados. ${ }^{100}$

Como contrapartida de este proceso, el productor fue dejando el campo "en manos de los asalariados, al cual el patrón iba, con suerte, una vez por día", según lo describió CJ, un ingeniero agrónomo de Tres Arroyos. Así, fue perdiendo la capacidad de imponer respeto, porque ya no conoce (a diferencia del asalariado) la forma concreta de realizar algunas tareas ${ }^{\mathbf{1 0 1}}$.

Con seguridad, estos cambios en la organización social del trabajo tuvieron consecuencias sobre el carácter social de los productores rurales. Se habrían incentivado los elementos explotadores de su carácter, por encima de las características productivas que predominaban con anterioridad ${ }^{\mathbf{1 0 2}}$. Pero al mismo tiempo, su condición de propietario y, por tanto, de perceptor (explícita o implícitamente) de la renta del suelo favorecieron las conductas rentísticas o cuasi-rentísticas, en el sentido de desentenderse total o parcialmente de los problemas de la producción. Tal como lo sintetizó un productor de Pergamino: "Prefiero asumir el costo de pagarle a un contratista por hectárea, que la diferencia es un 20 o un $25 \%$ más de costo por hectárea trabajada, [y] que el problema de los 'fierros' sea de ellos. Vivo más tranquilo" (RS). Como analizaremos más adelante, esta situación habría estimulado el desarrollo de elementos receptivos de su carácter social.

${ }^{100}$ Sobre los conflictos entre agricultores y asalariados rurales, consultar Mascali (1986).

101 Como lo describió ese mismo ingeniero agrónomo "... si el empresario rural es un empresario en serio, tiene que tener un conocimiento de todos y cada uno de los aspectos de su explotación, superiores, en su conjunto, al del asalariado. [...] Un buen productor agropecuario [...], viviendo en el campo, hacía rendir toda su explotación... y no es porque explotaban a su gente, sino porque armaban toda la dinámica diaria, y de todo el año, con una solvencia infernal" (CJ).

${ }^{102}$ Para una descripción del carácter social rural, aunque aplicado al campesinado mejicano, puede consultarse Fromm y Maccoby (1970). En el siguiente capítulo desarrollaremos algunas hipótesis sobre las transformaciones en el carácter social de los productores pampeanos. 


\section{Confort, sociabilidad y negocios en la ciudad}

"...se dan cuenta que la vida es peor en el campo, en el campo la vida es triste..."

El productor se fue habituando a las comodidades existentes en la ciudad, que en los años sesenta eran notoriamente superiores a las existentes en el campo. En este sentido, el segundo factor más nombrado por los entrevistados como generador de la radicación urbana fue la búsqueda de "confort", término que se repite insistentemente en casi todas las entrevistas asociado indefectiblemente con la ciudad ${ }^{\mathbf{1 0 3}}$.

Evidentemente, para los productores medios, las aspiraciones de un mejor nivel de vida llegaron mucho antes que las posibilidades de que los servicios se difundiesen en el campo. La clase media rural, ahora más estabilizada y con la propiedad de sus campos, aspiró a los estándares de vida de la clase media-alta urbana. Tal vez esta clase, conformada especialmente por los profesionales, los grandes comerciantes de las ciudades pampeanas y también los estancieros afincados en las mismas (según el análisis de De Imaz, $1965^{\mathbf{1 0 4}}$ ), funcionó como grupo de referencia ${ }^{\mathbf{1 0 5}}$ para los productores medios. En el extremo opuesto, lo que seguramente debía resultar intolerable era que las condiciones de vida de los productores que vivían en el campo a veces se encontraban por debajo del acceso a bienes y servicios de la clase obrera urbana. En este sentido, el contraste podía resultar muy fuerte para los chacareros, según se desprende del siguiente testimonio:

${ }^{103}$ Ver, por ejemplo, los siguientes testimonios: "[uno] piensa en vivir en el pueblo porque tiene más confort..." (GA); "[en la ciudad] empiezan progresos del confort, que en el campo no llegan..." (CJ); "... la mayor parte de la gente se vino a la ciudad buscando mejor calidad de vida, mejor educación para sus hijos, más confort..." (VH); "[En la ciudad] es otro confort" (OF).

${ }^{104}$ En su interesante estudio sobre la estratificación social de una ciudad pampeana (Río Cuarto) en los años sesenta encontramos que la categoría A de la escala de prestigio, correspondiente a la "clase media superior", estaba conformada por "Profesionales" (38\%), "Grandes comerciantes" (36\%), "Ganaderos" y "Rentistas" (11\% cada uno), e "Industriales" (5\%). En total, esta clase constituía el $5.6 \%$ de la población activa de la ciudad de Río Cuarto (De Imaz, 1965: capítulo 8).

105 Sobre el concepto de grupos de referencia puede consultarse Merton (1964). 
"Yo me acuerdo que un vecino nuestro ocupó un peón, porque era un matrimonio con un hijo sólo y el hijo vino al colegio acá en Tres Arroyos y el hombre no estaba muy fuerte de salud y entonces ocupó un peón. El peón que vino, vino con su Ford A, con una radio, eso era lo que él tenía. Eso era lo que él con su sueldo pudo lograr comprar, pero había habido muchos años malos y este vecino no tenía ni radio ni auto" (PL).

Con una vida aun más dura que la de los productores medianos, muchos de los pequeños productores arrendatarios, y especialmente sus hijos, optaron por irse a vivir a las ciudades como obreros industriales. En el extremo opuesto, ésta no era la situación de los grandes productores, quienes sí contaban con muchas comodidades en sus explotaciones $\mathrm{y}$, en los casos en que no residían en ellas de forma permanente, las seguían habitando por temporadas.

Algunas referencias al escaso confort existente en las explotaciones pueden observarse a través de las encuestas rurales, como la realizada a mediados de los años sesenta en el partido de Pergamino. En ese caso se muestrearon probabilísticamente 123 explotaciones en las que residía el ama de casa como único requisito muestral. Se encontró que menos de la mitad de las casas tenían provisión de agua en la cocina, sólo un cuarto de las familias poseía su propio generador eléctrico (una única casa tenía conexión con el servicio eléctrico público) y la mayoría utilizaba iluminación con lámparas a kerosene. Si bien casi todas las familias tenían radio, sólo dos contaban con aparatos de televisión (Baca, 1966: 11).

De este modo, había un desarrollo espacialmente desigual del acceso al confort, que recién se redujo relativamente a partir de los años ochenta ${ }^{106}$. Pero estos servicios

106 Como contó un veterinario y productor de Tres Arroyos: "Y en la década del 60, la diferencia entre la calidad de vida en el campo y la calidad de vida en la ciudad era muy grande, cosa que no sucede ahora, por eso la gente está pensando en volver a vivir al campo, porque vale la pena y no le resulta inconveniente ni gravoso, hoy tenés televisión, tenés teléfono, tenés electricidad, tenés cosas perfectamente confortables construidas en el campo, una vida plácida, que no tenés en la ciudad" (VH). 
llegaron al campo tarde ${ }^{\mathbf{1 0 7}}$, cuando ya se habían ido casi todos ${ }^{\mathbf{1 0 8}}$, como lo sintetizó uno de nuestros entrevistados: "unos años atrás no había luz tampoco, y las comodidades que hay en el pueblo son distintas. Ahora en algunas partes hay luz, ya en los campos tenemos luz, heladera. Ahora, que están las comodidades, no está la gente" (FL). Pero esta asociación entre campo y falta de confort, se observa que todavía pervive en el testimonio de un entrevistado que aclara, para destacar que ahora hay comodidades similares a las urbanas, que "el campo no es el campo: tenés la ruta, tenés luz eléctrica, todo lo que te gustaría tener, televisión" (RE).

La falta de servicios y el éxodo hacia las ciudades se retroalimentaron, ya que cuanta menos gente fue quedando en el campo, más costoso se fue haciendo el acceso a los servicios, porque por ejemplo había que repartir la inversión del tendido de la red eléctrica, en un área extensa, entre un número de usuarios cada vez más reducido ${ }^{109}$. Al mismo tiempo, aunque muchos productores se habrían ido a la ciudad por otros motivos, una vez que accedieron a estas comodidades urbanas, les resultó muy difícil resignarlas, para volver a irse a vivir en el campo (por caso, cuando sus hijos finalizaron sus estudios). Como comentó un ingeniero agrónomo de la zona de Pergamino, "pasar del esfuerzo al confort y la comodidad le resulta fácil, lo difícil es lo inverso" (SY).

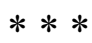

${ }^{107} \mathrm{Y}$ además a un gran costo: "... y mucho más barato, porque es caro vivir en el campo. Es lindo pero es caro. $\mathrm{Y}$, todos los servicios en el campo son mucho más caros. El servicio de luz es mucho más caro, el servicio de gas es mucho más caro. El servicio de comunicaciones, de teléfono es mucho más caro. Todo es mucho más caro" (RY).

108 En este sentido, Coscia sostuvo que el esfuerzo en la electrificación rural en muchas zona agrícolas no se justificó plenamente, pues "el beneficio que se obtuvo no fue el que se esperaba. Cuando la electrificación llegó al medio rural comenzó a operarse el proceso de urbanización de los productores, no cumpliendo así, por lo menos en un porcentaje importante de casos, el propósito de llevar confort al campo, que en el caso de las áreas agrícolas era la principal razón que la justificaba" (Coscia, 1983: 109).

109 En cambio, este problema no afecta a la televisión satelital, y en menor grado a la telefonía celular. 
La búsqueda de un mayor confort se asoció con un cambio generacional en la actitud vital de los productores. De la generación del esfuerzo, el sacrificio, la austeridad en pos de alcanzar un lugar en la sociedad pampeana, las siguientes generaciones, en líneas generales, fueron orientándose a mantener la posición lograda y a disfrutar de las posibilidades brindadas por ésta.

El contexto de socialización de los hijos de los inmigrantes habría sido sin duda muy diferente al de sus padres en Europa. A partir de 1930-40 se operó un cambio generacional en los productores. Ya no estaban a cargo de las explotaciones los inmigrantes, con toda su práctica campesina europea (al menos, durante su socialización primaria), sino sus hijos ${ }^{110}$. Estos, si bien habrían sido socializados esencialmente por sus padres, crecieron en un medio totalmente diferente y, al hacerse cargo de las explotaciones, se encontraron ya en una posición social relativamente establecida. Según algunos de los entrevistados, los padres chacareros les señalaban, a través del discurso o de su accionar, que debían salir de esa vida de enormes sacrificios e ignorancia ${ }^{111}$.

En las décadas del cincuenta y el sesenta, el objetivo de construirse un lugar en la sociedad argentina como productores rurales ya estaría relativamente asegurado, obviamente para aquellos que habían logrado mantenerse como tales, pues (tal como vimos en el capítulo segundo) muchos habían tenido que abandonar sus chacras. La estabilización social como productores rurales les parecía (sobre todo a los medianos), algo que en general no peligraba. Se habían hecho un lugar en la estructura social local que no parecía amenazado con la quiebra y la proletarización. El acceso a la propiedad de la tierra, uno de los objetivos de la etapa anterior e importante reaseguro de estabilidad social, había sido logrado por la mayoría de los que continuaban siendo

110 Así, por ejemplo, una encuesta realizada a 123 amas de casa que residían en chacras del partido de Pergamino a mediados de los años sesenta, encontró que casi todas habían nacido en la Argentina, pero que la mayoría de sus padres eran inmigrantes; sólo un $28 \%$ de las entrevistadas tenían ambos padres argentinos, y un $21 \%$ ambos suegros (padres argentinos y de otra nacionalidad eran menos frecuentes). En cambio, un $49 \%$ de los padres eran ambos italianos o españoles, y en el caso de los suegros, un 55\% (Baca, 1966: 8-9).

111 Así lo visualizaron dos productores de Tres Arroyos:

"Los mismos padres no querían que sus hijos pasaran lo mismo que ellos. No había que hacer el mismo sacrificio. Aunque no lo decían directamente lo demostraban con los hechos" $\left(\mathrm{AA}^{*}\right)$.

"Cada generación ha ido aflojando con sus hijos..." (PL). 
chacareros $^{112}$. Esta percepción de haber obtenido una situación relativamente segura habría inducido a buscar otros objetivos de vida de los que tenía la generación anterior de productores, o incluso de los que tenía la generación de los hijos de inmigrantes, al comienzo de sus vidas adultas. Al sacrificio le sucedió generacionalmente el disfrute de las posiciones alcanzadas. Que sus hijos accedieran a la educación secundaria (y en algunos casos, universitaria) funcionó como uno de sus objetivos fundamentales. Preguntados los entrevistados sobre cuáles eran sus aspiraciones al momento de independizarse de sus padres, en general respondieron "ser buenos productores agropecuarios" (como sus padres), "acceder a la propiedad de un campo" (objetivo que, si no había alcanzado ya su familia -y llegaría entonces por herencia-, lo lograría entre las décadas del cuarenta al sesenta), "darle una buena educación a sus hijos", o "que su familia no sufriera privaciones", pues "la gran riqueza no hacía la felicidad, pero la pobreza era muy cruel"113. Se observa que buscaban mantener la posición social paterna, más que ascender a otros lugares. En el caso de los hijos de productores pequeños con

112 Recordemos que analizamos sólo los que logran permanecer y que quedan fuera de nuestro análisis aquéllos que fueron expulsados de los campos y los que voluntariamente abandonaron las actividades rurales.

${ }^{113}$ El siguiente testimonio de un productor de Tres Arroyos sobre sus expectativas al momento de independizarse de su padre son particularmente interesantes para reflexionar sobre esta cuestión: "Mis objetivos eran llegar a tener un establecimiento, más o menos bien puesto, y tener un bienestar más o menos bueno, familia, y bueno, con todo un montón de cosas que se necesitaba eso, y yo diría que los objetivos que yo tenía en el arranque es más o menos lo que tengo hoy. Y el estilo de vida al cual yo apuntaba, más o menos, es el que tenemos ahora. [...]Yo me había fijado esta idea cuando yo era jovencito: que una persona para vivir bien, para realmente vivir bien, debía tener una situación más o menos estable, que es difícil de ponerla en números o explicarla exactamente cómo era la idea, pero más o menos un determinado nivel de vida ¿no es cierto? económico. Y al mismo tiempo un estilo, una forma de vida, ¿no es cierto? que implica muchas cosas ¿no es cierto?.[...] Que en lo económico todos los problemas esenciales la familia lo tenga... [resuelto]. Que no haya que no se puede ir al médico, que no se puede vestirse bien, que no se puede terminar la escuela, por razones, por restricciones económicas ¿no es cierto? No poder vivir en una casa, más o menos, buena, todas esas son restricciones, ¿no es cierto?, entonces, digamos en lo económico, una casa buena, tener uno o dos vehículos buenos, para andar, poder darle, hasta donde los chicos decidan estudiar, poder estudiar, poder viajar cuando uno quiere viajar, bueno. En lo material, que no haya abundancia pero que tampoco falte, [...] Yo siempre pensé que la gran riqueza no hacía la felicidad, pero la pobreza era muy cruel. Esa fue una cosa que yo tuve siempre presente. Por eso yo no quisiera estar en la situación de pobreza y sentir la crueldad de la pobreza, que la familia lo sienta, entonces yo quiero estar en el escalón siguiente ¿no es cierto?, y con eso me basta en lo económico. Si puedo mejorar bien, macanudo, pero no era la aspiración inicial, yo lo que quiero es estar por encima de esa situación de pobreza donde continuamente uno no puede hacer las cosas esenciales por cuestiones económicas, quería estar por encima de eso" (RY). 
varios hermanos, el objetivo básico era lograr convertirse en un productor independiente, no caer en la proletarización, "independizarme, no trabajar bajo patrón" y "salir de la miseria"114. Pero incluso los hijos de los productores medios no tenían como objetivo vital "hacerse ricos", sino que trataban de lograr una situación de estabilidad sin pasar privaciones ${ }^{115}$. Sólo unos pocos entrevistados querían ser "ricos" o convertirse en grandes estancieros ${ }^{116}$; para la mayoría, este objetivo se habría encontrado fuera de su horizonte mental, al menos en su juventud (ya que en la actualidad algunos poseen un capital importante) ${ }^{117}$.

La vida urbana se relacionó con esta actitud de disfrute de las posiciones sociales alcanzadas, no sólo a través del acceso a una serie de comodidades que no se encontraban en el campo, sino también porque vivir en la ciudad abría las puertas a otro tipo de sociabilidad ${ }^{118}$. Así, otro de los factores que atrajo al productor a la ciudad

114 Como nos contó un productor de Pergamino: "La ambición mía era ser productor, trabajar por mi cuenta. Cuando salí de mi casa, yo salí con la idea de trabajar unos años de peón, porque otra cosa no podía, y después independizarme, y a todo esto se pasaron siete años, con el mismo patrón, con el mismo dueño, fue cuando se vendió el campo... Mi aspiración siempre fue independizarme, era trabajar solo, no trabajar bajo patrón" (ML).

115 Recordar el testimonio de la cita previa a la anterior, al que podemos agregar el de un productor de Rivadavia: "... ser rico no, para nada. La ilusión fue siempre disponer de capital para trabajar bien, y tener una empresa evolucionada... lo necesario para hacer una empresa efectiva, eso sí siempre aspiré y nunca lo tuve..." (OB).

116 Un caso excepcional entre nuestros entrevistados fue el de un productor de Rivadavia que, habiendo comenzado desde una posición social muy baja, era hijo de un alambrador de campos, ya desde entonces tenía como objetivo vital llegar a ser "rico": "Yo, cuando tenía 12, 13, 14 años, le decía a mis amigos, a papá, a mamá: 'yo cuando sea viejo, voy a ser rico'." (LM).

117 En los años noventa, cuando efectuamos las entrevistas, estas posiciones sociales no estaban para nada aseguradas, y así lo sentían los productores más jóvenes, como se observa en el siguiente testimonio del hijo de un productor, que ya se estaba haciendo cargo del campo paterno (de unas 150 hectáreas de extensión): " yo estoy bien creído que voy a tener que poner garra para llegar hasta acá, rasguñando hasta ahí, si yo llego hasta un nivel allá arriba ... entro dentro del nivel económico donde puedo llegar a viejo y tener mi jubilación propia, vivir de lo que yo hice durante mi vida. Si me quedo un poco achanchado me comen los indios, muy poco...Todo el mundo está al salto a ver a quién le puede arrendar el campo, para vender" (hijo de PL). 
fueron sus instancias de sociabilidad. Tal como lo afirmó enfáticamente uno de nuestros entrevistados:

[vinieron a la ciudad de América, cabecera del partido de Rivadavia] "porque se dan cuenta que la vida es peor en el campo, en el campo la vida es triste, poco trato con la gente. La gente le gusta... la señora, ir un día a una fiesta, salir un rato a tomar algo al centro, cenar un día en un restaurant. Se van dando cuenta que es otra vida. Ahora le puedo decir que no me animo a nombrar uno que viva en el campo, ya se lo habrán dicho" (LM).

En un tono no tan marcado, otro productor de Rivadavia sostuvo que:

"...te atraen un poco esas ciertas comodidades... que en el pueblo se tiene otra posibilidad. Eso hace que toda persona que vive en el campo termine detestando un poco la soledad y todos tendemos a venirnos a vivir al pueblo o a la capital, en el caso de algunos, a vivir con más comodidades en un pueblo rodeado de gente... Lo cierto es que todos tendemos a venirnos a vivir al pueblo llegada a cierta edad, reunirnos con los amigos frecuentemente, tener un poco de vida social más intensa, y lo cierto es que el campo se ha despoblado" (OB).

Coincidentemente, un productor de Tres Arroyos afirmó que: "Si uno vive aislado, en el campo, ¿con qué tiene algo en común con los vecinos, con los otros productores agropecuarios? [En cambio] uno estando [en la ciudad], teniendo la facilidad de contactarse con otra gente, con otras actividades y cosas, se abre el panorama" (RY).

$\mathrm{Y}$ este proceso se retroalimentó, ya que como el campo que se iba quedando cada vez más despoblado, la sociabilidad rural anterior fue desapareciendo. Preguntado sobre si se seguían visitando con sus vecinos, como cuando ellos habían sido chicos, un productor de Pergamino y su mujer respondieron que:

"Mujer: - Allá no quedaban vecinos...

Hombre:- Cuando éramos chicos sí había vecinos pero después, ya de grande, ya no.

P: - ¿No quedó nadie?

Hombre: - No.

118 De hecho, así lo relató uno de nuestros productores entrevistados: "...acá es otra vida [en Pergamino]; allá teníamos todo [servicios y comodidades] pero como ya no hay gente allá, nos gusta más acá..." (MU). 
Mujer: - Cuando nosotros nos vinimos, éramos los únicos que estábamos en el campo.

Hombre: - Cuando nos vinimos, en el '77, hacía rato que no había más vecinos" (FL).

La mujer, que a veces percibía el campo como un espacio esencialmente masculino, disfrutó especialmente de la sociabilidad urbana, y varios de los entrevistados señalaron que la mayoría de las esposas de los productores insistieron con mudarse a la ciudad, y luego jugaron un papel clave para retener al productor en ella, una vez que los hijos habían finalizado su educación ${ }^{119}$.

Entonces, con la urbanización fue desapareciendo la vida rural propia de la primera expansión y que describiéramos en el capítulo primero. Toda la vida social en torno a los almacenes de campo o a los pequeños pueblos, se apagó paulatinamente. Las "colonias" se despoblaron, los boliches ya no tenían parroquianos, los campeonatos de fútbol se quedaron sin jugadores ni espectadores... ${ }^{\mathbf{1 2 0}}$. Los lazos sociales ligados al ocio colectivo en el campo se fueron diluyendo ${ }^{\mathbf{1 2 1}}$.

Y esto ocurrió a pesar de que, durante algunos años la propia mecanización (al reducir los requerimientos de trabajo y dejar más tiempo libre) había promovido una mayor vida social en el campo. De hecho, algunos entrevistados dijeron que estos

119 "El estudio de los hijos es lo que obliga a venir al pueblo. Se casan y se van al campo [primero], pero con los hijos, la señora viene al pueblo y después no la saca ¡ni con sulfuro!" $\left(\mathrm{HA}^{*}\right)$.

${ }^{120}$ En algunos testimonios, como en el de este productor de Pergamino, se recuerda este pasado con fuerte añoranza: "Hace muchos años cada colonia tenía su equipo de futbol. Era una vida más linda, había mucha más gente en el campo. Ahora se despobló el campo..." (GR)

Y esta nostalgia también refiere a una vinculación más estrecha entre los miembros de la familia, tal como lo señaló la esposa de un productor de Rivadavia: "Añoro, me encantaba la vida del campo y la vida en familia, y me parece también que ese es otro mal... que si desaparece la familia..." (MD).

Del mismo modo, una visión crítica y la crisis de la familia aparecieron en este relato de un veterinario y productor de Tres Arroyos: "... al despoblarse primero desapareció la idea de la necesidad de producir lo que se consume, después desapareció la familia, y después desapareció el último poblador que quedaba, aquello de que 'el último apague la luz'..." (OF).

${ }^{121}$ Como relató un productor de Tres Arroyos: "... tengo vecinos de hace 50 años y andamos bien [de salud], pero en el campo, no nos encontramos más [...] porque ahora ninguno vive en el campo." (DS). 
encuentros se habían hecho más frecuentes y que seguían manteniendo la escasa formalidad de antaño $^{122}$. Sin embargo, como el campo se fue despoblando inexorablemente, "no fue quedando nadie para visitar".

La sociabilidad urbana trajo aspectos positivos y negativos para la dinámica de la explotación. Por un lado, requería la asistencia a reuniones formales e informales, diversos juegos y deportes, cenas y diferentes eventos sociales. En la ciudad los productores se acostaban más tarde y no se levantaban tan temprano como en el campo. En la mañana, muchas veces se quedaban conversando al pasar por algún negocio, antes de viajar hasta el campo. En este sentido, algunos entrevistados que fueron críticos de esta urbanización de los productores, señalaron que en vez de estar trabajando en el campo a las seis o siete de la mañana, recién llegaban a las nueve, diez o incluso al mediodía. También criticaron que muchos se volvían rápido a la ciudad para conseguir mesa en el club o para cenar (se fue perdiendo la costumbre que había, en un comienzo del proceso de urbanización, de que el productor se quedase a veces a dormir en el campo $^{123}$ ). Estos entrevistados sostuvieron que muchos productores desatendieron sus campos para dedicarse a las actividades sociales de la ciudad ${ }^{124}$.

${ }^{122}$ Como nos explicó un productor de Tres Arroyos, en referencia a los años setenta: "... hay muy poco formalismo en la gente de campo para visitarse, por ahí no precisás invitar, vos llegás un día a la entrada del sol, que es la hora normal, y ya saben que vas a cenar, de la misma manera que llega alguien a tu casa..., por lo menos era así en esa zona y en aquella época." (GN).

${ }^{123}$ En cambio en los años treinta o cuarenta, algunos productores, que se habían ido a vivir a la ciudad para darle una mejor educación a sus hijos, se iban al campo durante toda la semana, y sólo estaban con su familia durante el fin de semana (en los dos casos en que entrevistamos a sus hijos, sus padres eran estancieros medianos de Rivadavia y Tres Arroyos).

124 "...yo los conozco porque van acá, al club de pelota, los veo pasar por delante de mi casa, está bien que muchos de los que van son gente que ya está retirada..., pero hay otros bastante más jóvenes, todavía podrían estar trabajando. Ahora han vuelto otra vez, pero por razones económicas, pero hubo un período en que el éxodo de los empresarios rurales a la ciudad fue total. Y el campo quedó en manos de los asalariados, al cual el patrón iba, con suerte, una vez por día. O si no, a veces, hasta una vez por semana, a llevarle los vicios, la galleta y todas esas cosas, y a darle algunas indicaciones, y a ver cómo iban las cosas" (CJ).

" [Vivir en la ciudad] posibilita jugar a las cartas en el boliche o al billar. Aquí el club de pelotas estaba lleno de gente de campo, se peleaban por ir bien temprano si no perdían la 
Sin embargo, por otro lado, esta sociabilidad urbana trajo beneficios de otro tipo a la economía de la explotación. Muchas de las reuniones sociales presentaban un costado vinculado a las oportunidades de negocios rurales. En general, la mayoría de los participantes estaban directa o indirectamente vinculados con la actividad agropecuaria y estos encuentros brindaban oportunidades para mantenerse informado y captar negocios. En una economía con un régimen de alta inflación prolongada, el acceso a la información bien actualizada, al manejo financiero, a los negocios de corto plazo, tenían una importancia vital (Frenkel, 1989). Por lo tanto, estar en la ciudad y frecuentar determinados círculos sociales permitía captar estas oportunidades. En esa dinámica se cruzaban redes de sociabilidad y de negocios. Pero para ello había que pertenecer a estas redes, pues ya no alcanzaba con las "reuniones en los almacenes de campo", y había que dejar de ser "medios ratas", tal como recuerda esta transformación generacional uno de nuestros entrevistados de Tres Arroyos:

"... si vengo del campo, me baño y me voy al club, [desde] cuando me empecé a manejar solo. Cuando manejaba mi padre las cosas y éramos medios ratas, mucho roce con el club no teníamos, con el vecindario sí. Algunas reuniones en casas de campo o almacenes de campo. Y si venía al pueblo iba alguna vez al club. Ahora cuando quedé estable en el pueblo, yo empecé a andar por los clubes. He ido a muchas fiestas, bailes y comilonas. [...] Cuando uno empieza a tener capital tiene que hacer las dos cosas. Dedicarle algún poquito más de tiempo al capital y tratar con gente capacitada, con gente de negocios." (MÑ)

Un par de testimonios son tan elocuentes en relación a esta dinámica que articula sociabilidad y negocios, que los hemos reproducido en su totalidad:

"En estos pueblos hay centros neurálgicos de la cosa. Acá [en América] el Club Atlético es uno de esos centros, o el único tal vez. Uno es la casa del remate feria, del consignatario de hacienda, otro lugar de reunión, de chismerío agropecuario, del dato, de la noticia, del precio, es el acopiador de

mesa" (DS).

"...yo siempre digo que si tuviera que vivir en un pueblo o una ciudad yo me tendría que buscar alguna cosita para hacer, no podría estar como alguna gente que se va al pueblo y se queda sentado en la cocina. A lo mejor hay gente que le gusta ir al club todos los días, eso yo lo comprendo, que se entretienen en el club, pero yo no podría estar ahí, todos los días en el club." (VD) 
cereales, y otro es el Club Atlético; que acá se llama Club Atlético y en otros lados se llamará Club Libertad. Donde nos juntamos todos los días a tomar un café, a hablar pavadas, a parar la oreja a ver quién vendió el campo, quién alquiló el campo, quién vendió el trigo, quién cosechó tantos kilos, quién sembró tal variedad de sorgo, de maíz o de soja. Son centros de información y de divulgación, no secreto pero tampoco demasiado público. En donde se macanea bastante en cuanto al rendimiento de la última cosecha en mi campo y donde se minimiza el precio que sacó el otro, porque son así las reglas del juego." (OB).

"Porque uno acá [en América], en el pueblo, está en contacto con el que compra novillos, con el que vende novillos, con el cerealista, no es lo mismo estar en el campo. Por ejemplo, después de cenar, uno va al club, se encuentra con... dice: 'che, tengo 200 novillos'... El comisionista: '¿cuánto pesan...cuánto valen'... La otra noche le ofrecen un lote para sembrar, la otra noche... Está en contacto con la gente." (LM)

"Los mercados, viste, que son muy cambiantes, muy ágiles, entonces es como que la gente quiere estar acá [en Tres Arroyos] para ver si pesca algo a la pasada, creo que por ahí pasa más la cosa. Por ahí algún pico de venta de cereal, o algún negocito puntual que sale con los herbicidas, si vos estás todo el tiempo acá, en contacto, te permite además ir analizando todos los días las tendencias. Vos venís el lunes y ves que el trigo está a 230, y el martes está a 231, el miércoles 235, vos sabés que está la tendencia. [...] [Lo palpás] en las cooperativas, en las casas de cereales, en las agronomías [...] generalmente eso te permite pescar algún negocito [...] 'vos sabés que justo se está armando un lote que si juntamos mil toneladas vamos a sacar tres pesos más...' " (GN)

El costo de quedar fuera de estos espacios, no sólo era el de perderse negocios, sino de ser "estafado", como lo describió un productor de Rivadavia:

"Participaba de las reuniones, de las charlas, del café en el club, de la charla con el martillero, de la charla con el acopiador, y uno está enterado, de esa manera, de cuál es el precio que está vendiéndose el novillo en la zona, en qué condiciones se está vendiendo, en qué condiciones de pago se está vendiendo. Es una información que es variable porque la situación del mercado es permanentemente variable. Entonces, si uno se queda encerrado en el campo corre riesgo de que un día, le ha pasado a tantos...., le parecía buen precio el que le ofrecían y resulta que estaba ante una suba general del mercado... Eso ha pasado. [...] El ganadero era antes estanciero, con información propia $\mathrm{y}$ de gente que lo mantiene más o menos bien 
informados porque les conviene tenerlos bien informados para conservarlos como clientes... No es el caso del chacarero chico, de gente con poco nivel cultural, que lo que saben o lo que sabían era trabajar el campo y se entierran todo el día y no tenían mayor información. Esa gente tendía a vivir encerrada, no eran los más, eran los menos, pero había, y esa gente solía ser sorprendida por el consignatario poco escrupuloso... 'te pago los chanchos tanto...' y les sacaba los chanchos por mitad de precio. Menciono el chancho porque es una mercadería de precios muy oscilantes, lo mismo podía pasar con la lana o con el cordero o con... por supuesto también los novillos." (OB).

Incluso aquellos con opiniones favorables a que el productor viva en su campo, destacaron los riesgos de no venir periódicamente a la ciudad. Por ejemplo, un productor de Tres Arroyos advirtió:

"Encerrarse en el campo ¡no! Usted no está actualizado de las cosas, hay que estar actualizado. Hay que atender las dos cosas: la producción y los negocios. Y cuando uno tiene que hacer negocio no sólo tiene que buscar precio sino responsabilidad, así si no los joden a muchos.

P: - Ud. esta información ¿dónde la consigue?

Yendo a las casas responsables" (MÑ).

Sin embargo, para algunos pocos entrevistados, los periódicos, la radio y la televisión rompieron con esta situación de aislamiento, de modo que el productor se puede mantener perfectamente informado por estas vías ${ }^{125}$ (aunque cabe aclarar que

125 "P- Hay gente que me ha dicho que se venía al pueblo para estar más en contacto...

- No, si uno tiene televisor, ahí le da todos los días el precio que valen los cereales, y la hacienda y todo..."(ML).

"P- Alguna gente dice que conviene ir al pueblo porque uno está más enterado de los negocios, de cuándo conviene vender, cuándo conviene comprar, ese tipo de cosas. ¿Eso no lo ve como una carencia estando acá?

- No, porque tenemos el diario, sale de Buenos Aires y lo tenemos en Copetona el mismo día, tenemos la radio, la televisión, nosotros tenemos el cable, agarramos varios canales con antena, tenemos teléfono, así que uno, cualquier cosita, está al tanto. Se va dos veces por semana al pueblo a hacer los mandados, mi hijo anda más porque él es el que anda con los asuntos de papelerío ahora, así que uno está al tanto de las cosas." (VD)

"No se le puede atribuir a que se quede en el campo que sea un atrasado... con los medios de comunicación que hay... Porque usted puede vivir en el campo y tener teléfono, televisión, la radio, o sea... A los cerealistas ¿qué los jorobó? Los jorobó la radio. Yo le hablo de cuando acá tenía la agencia Dreyfus, tenía Bunge y Born... Porque el colono... si el trigo había subido, salían rajando los representantes, iban y le compraban el trigo a $\$ 5$ y el colono no estaba enterado que había subido a $\$ 6$. Lo primero que los jorobó a todos esos representantes 
algunos entrevistados fueron explícitos en menospreciar estos canales de información $\left.{ }^{126}\right)$. Otros sostuvieron que alcanzaba con las cooperativas, las casas cerealistas y el uso del teléfono ${ }^{127}$.

A pesar de la importancia que muchos entrevistados concedieron al estar relacionado con los espacios urbanos de sociabilidad, en los testimonios casi nunca se asoció esta oportunidad de captar negocios con el irse a vivir a la ciudad. Es decir, no fue mencionada como un factor que generó la urbanización, como lo hicieron con la educación de los hijos o el acceso al confort. La única causa de urbanización relativamente vinculada a los negocios que ellos señalaron fue el "papelerío" (impuestos, trámites bancarios) que obliga al productor a ir demasiado seguido a la ciudad, al punto que, según algunos, casi todos los días debe hacerlo: "Al productor le

de grandes cereales fue la radio, porque el gringo, aunque tenga una radio a batería, empezó a escuchar los precios. La comunicación hoy... difícil que un campo... acá en América, todos estos muchachos que usted ve, todos andan con el Movicom." (LP).

${ }^{126}$ Un productor de Tres Arroyos afirmó que "las cosas que te pasan por radio o por televisión no son la realidad, eso que lo palpás vos... el ambiente... [...] en las cooperativas, en las casa de cereales, en las agronomías." (GN).

127 "P- ¿Es importante, necesario, estar en el pueblo, por la venta de cereales, el tema de bancos, vinculaciones?

- No, están las cooperativas, las casas cerealistas, que son las que compran, y vender puede vender cualquiera que tiene.

P- ¿Ud. no sintió la ventaja de estar en el pueblo?

- No, lo mismo que sale en el pueblo es lo que sale en el campo. Para hacer las ventas es lo mismo. " (ML)

"Con teléfono, con todas las comodidades que tengo ahora...no veo ninguna limitante de estar acá... Lo que sí tiene... que será lo que le dice esta gente... es el contacto con la gente para estar en combinación con los negocios... Pero estar en el campo no significa estar todo el día en el campo, una vez a la semana se puede reunir con un grupo CREA, se puede reunir con los amigos, con problemas afines. Y conversan y se charlan los problemas y por ahí surge alguna cosa. Pero no necesariamente hay que estar viviendo acá en Pergamino para que los negocios salgan. Teniendo teléfono... se habla por teléfono. Yo no lo veo así, como que económicamente, para la magnitud de la empresa, sea necesario vivir en la ciudad, no me parece. Depende de cada uno, de la forma de ser de cada uno, pero a mi no me parece." (RS) 
han complicado la vida"128. Sin embargo, otros sostuvieron que alcanza con ser organizado e ir una vez por semana, como mucho ${ }^{129}$.

Más allá de la conciencia que tienen los productores de las relaciones causales que incidieron en su urbanización, consideramos que los factores hasta ahora analizados se articularon junto con un proceso de diferenciación social, y determinaron una profunda transformación en el modo de vida de los productores rurales medios que describimos en el siguiente apartado.

\section{Modo de vida, estructuras del sentir y aburguesamiento}

"Si usted tuviera un capital de un millón de dólares, ¿trabajaría...?"

Recapitulando las transformaciones estudiadas en los anteriores apartados de este capítulo, podemos observar una sustancial transformación en los modos de vida de los productores rurales, especialmente en el caso de los medianos productores. Como hemos visto, la mayoría de ellos se radicaron en las ciudades cabeceras de sus partidos; otorgaron una centralidad en sus vidas a lograr un alto nivel educativo para sus hijos (aspirando en muchos casos a que se convirtieran en profesionales universitarios) y dejaron de socializarlos en un contexto rural, empleándolos como auxiliares en la producción; de hecho, abandonaron todas las numerosas actividades de producción de alimentos y otros bienes para el autoconsumo que tradicionalmente se realizaban en las

128 "La gente cada dos o tres días tenía que estar acá, porque una operación de banco, un impuesto, una declaración... se empezó a complicar la vida en el campo [el quedarse]". (OF)

"Todos los días tiene que venir a la ciudad, hay trámites que hacer, venir al contador, los bancos, etcétera." (RY)

${ }^{129}$ Un productor de Tres Arroyos que vive en su explotación manifestó que con ir a la ciudad "tres veces por mes estaría [sería suficiente], organizándote [...] Si vos venís del campo con una lista bien hecha, yo hasta las 12 tengo que terminar hasta acá y a la tarde me queda el resto, lo tenés que hacer sí o sí, no te quedás charlando, te vas y hacés efectiva esa lista. Es organización, ninguna duda." (hijo de RY). 
explotaciones; la mujer también se desentendió de las actividades del establecimiento; incluso muchos de los productores dejaron las labores físicas en sus campos y asumieron un rol más gerencial, quedando las tareas en manos de asalariados (con quienes cambió sustancialmente la relación) o de contratistas de servicios; las pautas de consumo se asimilaron a las de la clase media-alta urbana, abandonando la austeridad característica de los chacareros pampeanos, y pasaron a valorar en mucho el grado de "confort" del que se disponía en las ciudades, a la vez que se integraron a sus espacios de sociabilidad. En síntesis, no fue quedando casi nada del modo de vida rural que tenían una o dos generaciones atrás, que describiéramos al final del primer capítulo ${ }^{130}$.

Varios de los productores entrevistados manifestaron espontáneamente ${ }^{131} \mathrm{su}$ conciencia de esta drástica transformación en la forma de vida ${ }^{\mathbf{1 3 2}}$. Por la forma de referirse al pasado (a su niñez o incluso a sus primeros años como productor independiente) los testimonios revelan el contraste que perciben entre aquel modo de vida y el que tenían a mediados de los noventa, cuando los entrevistamos: "una vida monótona, una vida de trabajo, dura", aunque "nunca nos faltó nada de lo

${ }^{130}$ Coscia señaló que si "hasta hace algunas décadas la agricultura pampeana era una actividad económica y, además, una forma de vida con un conjunto de rasgos particulares que la diferenciaba de la del medio urbano. En la actualidad [a comienzos de los años ochenta] este segundo aspecto se está borrando casi totalmente [...] Un agricultor joven o sus hijos en nada se diferencian del resto de la población de las áreas agrícolas; tienen prácticamente los mismos hábitos y comportamiento y frecuentan los mismos medios sociales" (Coscia, 1983: 108).

131 En realidad, toda la situación de entrevista no estructurada es poco espontánea (nunca debe olvidarse lo extraordinario de la experiencia de que alguien le cuente su vida a un extraño), e incluso el tema del cambio en la vida en el campo fue presentado como nuestro tema de investigación. Sin embargo, las frases aquí reproducidas no fueron respuestas a una pregunta puntual, sino que fueron enunciadas en medio de sus relatos sobre su historia de vida.

${ }^{132}$ Así, por ejemplo, un productor de Tres Arroyos manifestó que "cambió fundamentalmente la vida, en tan pocos años ha habido una transformación importantísima, de acuerdo a cómo se han criado mis hijos y como me crié yo..." (CH).

Incluso lo califican como un cambio de mentalidad, tal como lo describió un ingeniero agrónomo de Pergamino: "ha cambiado la mentalidad del productor, la evolución, las comodidades, el confort que trajo la nueva tecnología; ha habido un cambio de vida y un cambio de mentalidad de la gente." (SY).

Para algunos, el mero hecho de trasladarse más habitualmente a la ciudad fue percibido como un cambio en el sistema de vida: "Desde que me casé, ya empecé a cambiar de sistema de vida. Salíamos, veníamos a Tres Arroyos, volvíamos tarde, ya fue una vida un poco distinta." $(\mathrm{CH})$. 
elementalísimo"133. Además, son concientes de que antes, a diferencia de ahora no había opciones ${ }^{134}$, "era duro pero no había muchas más alternativas", ya que "esa era un poco la vida del campo", muchas veces sin siquiera una radio. Una vida sacrificada y austera, consecuentemente con pocos gastos ${ }^{135}$, a diferencia de la actualidad, cuando "algunos no se conforman con nada" (MÑ).

Con todas las transformaciones enumeradas se desvaneció el mundo de sentido común chacarero en el que fueron socializados los hijos de los inmigrantes. Las estructuras de la vida cotidiana que configuran la escena de la vida social se modificaron. Ese mundo intersubjetivo del sentido común pasó a tener una base material diferente y una intersubjetividad distinta, en tanto el productor se interrelacionaba con otros tipos de sujetos sociales, y ya no sólo con sus vecinos rurales $^{136}$. Si la realidad social de la vida cotidiana se organiza alrededor del aquí de mi cuerpo y el ahora de mi presente ${ }^{137}$, el aquí se trasladó de la chacra a la ciudad, un contexto por cierto muy diferente. El niño ya crecía en este nuevo espacio de socialización, y éste se constituía en su mundo por excelencia, independientemente que también conociera al campo. Las coordenadas de la experiencia se habían modificado sustancialmente: los horizontes de la acción se ampliaron. "El modo de vida que los miembros del endogrupo consideran natural, bueno y correcto"138 se modificó. La naturalización de un modo de vida rural por parte del productor agropecuario desapareció. Si, como hemos visto, antes era "natural" vivir en el campo y reemplazar a

133 "Teníamos esas 350 hectáreas, nos manejábamos, hacíamos casi todo mi hermano y yo a partir de ese período, nosotros teníamos una participación en esta explotación, éramos gente humilde. Era una chacra corriente, nunca nos faltó nada de lo elementalísimo, de lo demás nos faltó todo. Era una vida monótona, una vida de trabajo, dura, yo amenizaba mucho leyendo, toda mi vida fui un gran lector así que me leí media Biblioteca Sarmiento, eso me dio alguna perspectiva, andaba en el movimiento cooperativo." (ET).

${ }^{134}$ Como dijo un productor de Tres Arroyos en relación a la dureza de las labores agrícolas: "no se conocía otra cosa, entonces nadie pensaba si era difícil o no". (RY).

${ }^{135}$ Como sintetizó un productor de Tres Arroyos: "no se gastaba, se vivía de otra manera, más rudimentario, más económico, en el campo el medio ambiente, el medio de vida era muy distinto, hoy hay un costo más para poder vivir..." (ME).

${ }^{136}$ Sobre el mundo del sentido común, puede consultarse Schutz (1974)

${ }^{137}$ Berger y Luckman, (1986: 39).

${ }^{138}$ Según la conceptualización de Schutz (1974: 43). 
los padres en el trabajo a cargo de la explotación, ahora esto último pasó a ser una opción, y el vivir en el campo, "una cosa rara". Si bien algunos entrevistados exaltaron la vida rural, la mayoría de las veces lo hicieron en tono nostálgico; lo "bueno y correcto" parecía ser la adopción de un modo de vida urbano, con las múltiples ventajas ya enumeradas.

Esto ha sido el resultado de un largo proceso. Sin duda, la propia urbanización de algunos productores fue socavando la legitimidad de ese modo de vida chacarero. A medida que la mayoría de los vecinos se iban yendo a la ciudad, los productores que todavía quedaban en el campo debieron sentir que se ponía en entredicho la seguridad de que ellos estaban viviendo correctamente. Como dirían Berger y Luckmann (1974: 129 y 185-190), los otros significantes (algunos de sus propios vecinos) estarían poniendo en cuestión que la realidad aprehendida como inevitable (o relativamente inevitable) durante la socialización primaria, lo fuera realmente. De modo que para muchos se desestabilizó el mantenimiento de su realidad subjetiva. El irse a vivir a la ciudad, con todas sus consecuencias, no era una mera fantasía propia del mundo de los sueños, era algo que comenzaban a realizar sus vecinos cercanos que, de este modo, complotaban contra la legitimación y el mantenimiento de la realidad subjetiva como ineludible ${ }^{139}$.

Pero incluso antes de que comenzara el proceso de urbanización, la propia inconformidad de los padres hacia el orden establecido constituyó un elemento disruptivo intenso. Ellos no terminaban de aceptar su posición de no propietarios como un lugar social deseable. Todos anhelaban el acceso a la propiedad de la tierra, por lo cual no se naturalizaba completamente el mundo social chacarero. Pero además, como ya comentamos, muchos transmitían a sus hijos la idea de que intentaran salir de esa

139 Como sostienen Berger y Luckman "la socialización primaria internaliza una realidad aprehendida como inevitable. Esta internalización puede considerarse lograda si el sentido de inevitabilidad se halla presente casi todo el tiempo, al menos, mientras el individuo está en actividad en el mundo de la vida cotidiana [...] Siempre existe la presencia obsesionante de las metamorfosis, las que realmente se recuerdan y las que solo se sienten como siniestras posibilidades. Existen también las definiciones en competencia de la realidad que pueden presentarse socialmente y que resultan una amenaza más directa. Una cosa es que un decoroso padre de familia sueñe con orgías indescriptibles en la soledad de la noche, y otra muy distinta ver que esos sueños se representan empíricamente por una vecina colonia de libertinos..." (Berger y Luckman, 1986: 185) 
vida de sacrificios, que no se enterraran en la chacra, que no era el único mundo posible. E incluso, no debe olvidarse que los propios padres no eran un ejemplo de conducta tradicional, sino que habían atravesado miles de kilómetros desde sus países de origen en busca de otro lugar en el mundo.

Entonces, por varios motivos, el mundo social chacarero no se transmitió a las nuevas generaciones con un carácter naturalizado. Para estos hijos de inmigrantes el mundo social no se presentaba como totalmente presupuesto, incuestionable. No era un mundo reificado. Es cierto que la socialización en la chacra los llevaba a naturalizar su modo de vida chacarero y la "opción" por continuar con la dirección de la explotación agropecuaria familiar. Pero, por otro lado, los fenómenos recién comentados, les permitían recordar que este mundo era una creación humana y, por lo tanto, su situación personal era percibida como modificable en muchos aspectos. Una transformación que podía ser el resultado de un accionar colectivo (especialmente a través de la lucha por la propiedad y la organización cooperativa de la comercialización ${ }^{140}$ ), pero también, y quizás especialmente, a partir de las decisiones individuales sobre dónde vivir, cómo producir, qué consumir, qué educación darles a sus hijos. Especialmente una vez que accedieron a la propiedad (los que lo consiguieron), los productores tuvieron cierto abanico de opciones relativamente abiertas en sus mentes sobre estas cuestiones a resolver desde su individualidad.

En otro plano de análisis, podemos decir que tuvo lugar un cambio en las "estructuras del sentir" de los productores medios. Este concepto, elaborado por Williams (1980), hace referencia a cómo son vividos y sentidos los significados y los valores vitales ${ }^{141}$. El concepto de Williams es, sin dudas, más amplio, pero aquí nos sirve para destacar que en nuestros entrevistados se percibe un cambio generacional en la relación afectiva con el campo. La mayoría hizo referencia a que le gustaba la vida de

140 Ver en Ansaldi (1998) los factores que limitaron la conciencia de clase de los chacareros.

141 Williams ha elegido el término "sentir", con la finalidad de acentuar una distinción respecto de los conceptos más formales de "concepción del mundo" o "ideología" (Williams, 1980: 154). 
campo y las actividades que desde pequeños aprendieron a realizar. Sienten un "cariño" por el campo, están "enamorados" del campo, de sus ritmos, de la naturaleza, de la labor bien hecha. Muchos, aunque retirados, viajan diariamente a la explotación. En cambio, según los productores entrevistados, las jóvenes generaciones en general no tenían estos sentimientos: a los jóvenes "no les gusta más el campo", prefieren la vida de la ciudad $^{142}$; en otro plano, tienen una relación exclusivamente mercantil ${ }^{143}$. Si bien los productores más jóvenes que hemos entrevistado no explicitaron estas valoraciones, tampoco manifestaron el vínculo afectivo tan intenso que casi todos los más viejos testimoniaron. El campo no los "atrapó", como sí lo hiciera con los entrevistados de mayor edad, quienes, cuando eran jóvenes, se encontraban mucho más a gusto en el campo que en el pueblo, tal como analizamos en el capítulo primero. Un indicio del proceso de cambio en las "estructuras del sentir", la encontramos en la mencionada encuesta, realizada a comienzos de los años setenta entre los productores medios pampeanos. Allí vemos que, si bien el 70\% dijo que prefería vivir en el campo y no en la ciudad, entre quienes tenían al menos educación secundaria este porcentaje se reducía al $48 \%$, mientras que el $15 \%$, se inclinaba por la ciudad, y el $37 \%$ restante manifestaba que le era igual, y optaba (sintomáticamente) según el nivel de confort (Brie y otros, 1977: 44) $)^{144}$.

Este cambio en la relación afectiva con el campo, no se reduce a una cuestión meramente contemplativa, sino que incluye un vínculo diferente con la práctica agropecuaria, una valoración distinta de las actividades rurales $\mathrm{y}$, en un sentido más amplio, del modo de vida. En este sentido, el concepto de "estructuras del sentir" hace, justamente, referencia a los "elementos específicamente afectivos de la conciencia y las relaciones", no oponiendo "sentimiento contra pensamiento", sino concibiendo

${ }^{142}$ Como sintetizó un productor de Tres Arroyos: "En ese entonces [los años treinta y cuarenta] la juventud no queríamos al pueblo, era distinto [...] Eso se cambió el cien por ciento. Hoy en el campo no quiere quedar ninguno." (DS).

Algunos señalaron que la propia mecanización contribuyó a este proceso, al disminuir el contacto físico con el campo.

${ }^{143}$ Con cierto tono de reproche hacia las nuevas generaciones, un productor de Tres Arroyos nos manifestó que "al campo hay que estimarlo, hay que estar con él. Es un amigo fiel, pero hay que cuidarlo [...] No se puede acordar de él sólo cuando se necesita el dinero." (MÑ).

${ }^{144}$ Cabe aclarar que los autores no tomaron nota de la diferencia que muestran sus cuadros, y destacaron que "el apego a la tierra configura sin duda alguna un valor fuertemente enraizado en el sentimiento" (Brie y otros, 1977: 44). 
"pensamiento tal como es sentido y sentimiento tal como es pensado; una conciencia práctica de tipo presente, dentro de una continuidad viviente e interrelacionada." (Williams, 1980: 155). Es esta "conciencia práctica" la que consideramos se ha modificado durante estas décadas.

Siguiendo a Williams, consideramos que estos cambios cualitativos no deben ser conceptualizados como "epifenómenos de instituciones, formaciones y creencias modificadas, o simplemente como una evidencia secundaria de relaciones económicas y sociales modificadas entre las clases y dentro de ellas" y que deben entenderse "como experiencia social antes que como experiencia 'personal' o como el 'pequeño cambio' simplemente superficial o incidental de la sociedad" (Williams, 1980: 154). La transformación en los modos de vida y en la relación afectiva con el campo ha sido un proceso de cambio social, pero que no tuvo la relativa claridad y fijeza de una transformación ideológica, de allí la pertinencia del concepto de cambios en las "estructuras del sentir"145. Sin embargo, esto no significa que estas transformaciones se encuentren desvinculadas de las modificaciones en la posición de clase de los productores agropecuarios, tal como veremos a continuación.

Proponemos conceptualizar todas estas transformaciones en las características del productor medio pampeano, como su "aburguesamiento"146. Este concepto remitiría

145 Como dice Williams, "'sentir' ha sido elegido con la finalidad de acentuar una distinción respecto de los conceptos más formales de 'concepción del mundo' o 'ideología'. No se trata solamente de que debamos ir más allá de las creencias sistemáticas y formalmente sostenidas, aunque siempre debamos incluirlas. Se trata de que estamos interesados en los significados y valores tal como son vividos y sentidos activamente; y las relaciones existentes entre ellos y las creencias sistemáticas o formales, en la práctica son variables (incluso históricamente variables) en una escala que va desde un asentimiento formal con una disensión privada hasta la interacción más matizada existente entre las creencias seleccionadas e interpretadas y las experiencias efectuadas y justificadas." (Williams, 1980: 154-155).

146 Este concepto fue empleado por Engels en su carta a Marx del 7 de octubre de 1858 para referirse a la clase obrera inglesa: "El proletariado inglés prácticamente se está aburguesando cada vez más ["mehr und mehr verbürgert", en el original alemán], de modo que ésta, la más burguesa de las naciones, aparentemente aspira a poseer una aristocracia burguesa y un proletariado burgués, junto a la burguesía. Para una nación que explota a todo el mundo, esto, por supuesto, hasta cierto punto se justifica" (carta reproducida en Marx y Engels, 1973: 84). Luego retomó esta cuestión en el Prólogo a la segunda edición de La situación de la clase 
a una serie de dimensiones que consideramos se actualizan en este caso. En primer lugar, a su origen etimológico, en tanto el productor se ha radicado en el "burgo", con todos los cambios en la sociabilidad que esto conllevó y con una modificación en sus pautas de consumo (una mercantilización de los bienes y servicios consumidos, y una participación del incremento en el consumo que ocurrió en las ciudades durante el siglo $\mathrm{XX}$ ). En segundo lugar, da cuenta de un cambio en el rol laboral del productor, que de realizar labores físicas, ha dejado éstas a cargo de terceros (asalariados o contratistas de servicios). En tercer lugar, y muy vinculado a la transformación anterior, el concepto evoca una relajación en la constricción laboral que caracterizaba al chacarero de la etapa anterior, en tanto que ha pasado del sacrificio al disfrute de la posición social obtenida. En este sentido, no debe confundirse el "aburguesamiento" con la adopción de una cultura burguesa del trabajo y el ahorro (de tipo weberiano ${ }^{147}$ ) sino más bien con una cultura sesgada por importantes elementos rentísticos, como corresponde a un sujeto cuyo principal recurso económico es, ahora, la propiedad de la tierra ${ }^{148}$. Ya en los años sesenta, en su detallado estudio de la ciudad de Río Cuarto, de Imaz comentaba que la

obrera en Inglaterra (1892) sosteniendo la idea del surgimiento de una aristocracia dentro de la clase obrera, pero también que el conjunto de la clase ha disfrutado de ciertos beneficios producto del capitalismo monopólico. Esta idea es luego retomada por Lenin cuando afirma que como efecto del imperialismo, "parte del proletariado inglés se aburguesa" (1916: 133). Sin embargo, el concepto de "aburguesamiento" no fue utilizado por los clásicos del marxismo para analizar a las clases rurales.

Hemos encontrado sí dos trabajos más recientes que lo emplean para sujetos rurales. Por un lado, ha sido utilizado para conceptualizar el desarrollo de la producción familiar rural dentro economías centrales planificadas, más específicamente el caso húngaro (Szelenyi, 1988). Con mayores puntos de contacto con nuestro enfoque, ha servido para analizar los cambios en la clase media rural del estado Kerala, India (Morrison, 1997).

${ }^{147}$ La sobriedad y el ahorro (frente al derroche y los lujos), y la constricción al trabajo con perseverancia y devoción, evitando toda pérdida de tiempo (ya que el tiempo es dinero) son elementos claves del "espíritu del capitalismo", para Weber. Por ello, uno de sus elementos claves es la racionalización de la conducta sobre la base de la idea profesional. Para más detalles, puede consultarse Weber (1905).

148 En este sentido, tal vez podría haberse utilizado el concepto de "aristocratización", no sólo por el anterior uso de Engels (comentado en la nota anterior), sino por el que le da Weber (1905: 249) al señalar que, por el propio efecto de la racionalización de la economía, se va acumulando una riqueza que promueve una "aristocratización", o la relajación de la disciplina (citando los ejemplos de los monasterios medioevales y del puritanismo en la sociedad inglesa).

Sin embargo, consideramos que el término "aristocratización" contiene resonancias demasiado grandilocuentes, y podría evocar la conducta de los grandes terratenientes pampeanos derrochando sus fortunas en París. Situación, por cierto, demasiado lejana de la de los productores medianos pampeanos. 
"nueva burguesía rural" o "nueva clase media rural"149 mostraba un patrón de ostentación que la situaba "muy lejos del ascetismo que caracterizara al modelo [de burguesía] clásico" (de Imaz, 1965: 168).

En relación con este último punto, la transformación en el modo de vida está condicionada (aunque no determinada en sus características) por el cambio en la posición social del productor mediano típico: de pequeño burgués, con elementos campesinos, pasó a ser una especie de terrateniente-capitalista pequeño. Sería un "terrateniente" en tanto percibe una renta del suelo, sin que este término encierre otro tipo de connotaciones vinculadas a la extensión de tierra en propiedad o relacionadas con el poder. Podría conceptualizarse como un "capitalista pequeño" en tanto que no contrata sino a un pequeño número de asalariados, que no alcanzarían a convertirlo en un capitalista típico (recordar las indicaciones al respecto formuladas por Ghorayshi, que comentamos en la Introducción).

El acceso a la propiedad en primer plano, y la capitalización en maquinaria en un segundo lugar, produjeron un cambio sustancial en la dotación de recursos con que contaba un productor medio. Para fines de los años treinta la mano de obra resultaba el recurso más importante de un arrendatario (sobre todo para uno pequeño, dueño de alguna maquinaria y unos pocos animales; pero también para un productor mediano, pues el interés de sus bienes de capital no superaba el aporte de la mano de obra familiar). En cambio, para fines de los ochenta la tierra, la maquinaria y los requerimientos de capital necesarios para la producción ${ }^{\mathbf{1 5 0}}$ habían reducido a una mínima significación el aporte del trabajo físico que podían brindar el productor y sus familiares. La posesión de estos bienes hacían relativamente poco necesario el aporte personal de trabajo físico, tal como lo sintetizara uno de nuestro entrevistados, contrapreguntándonos "Si usted tuviera un millón de dólares de capital, ¿trabajaría...?"151.

149 Cabe aclarar que no traza una definición de este sujeto, sino que aparece mencionado como tal sólo en la "Conclusión y algo más" del trabajo.

${ }^{150}$ Sobre esta última cuestión puede consultarse Pizarro y Cascardo (1991).

151 Durante los años noventa, un productor mediano reunía fácilmente un capital superior al medio millón de dólares. Sin contar la maquinaria agrícola, las instalaciones, ni la casa (que podían sumar alrededor de 300.000 dólares), con un precio por hectárea de 2.800 dólares los campos maiceros, y 1.100 dólares, los campos de invernada y los campos trigueros (datos de "Campos: un mercado cada vez más polarizado", CREA, 220, febrero de 1999; p.p.8-12), la tierra de un campo de 357 hectáreas en la zona maicera valía un millón de dólares, y lo 
No hemos podido reconstruir la evolución de la dotación de recursos de los productores de un modo sistemático. Sin embargo, un simple ejercicio de estimación nos permite tomar conciencia de la importancia de estas transformaciones. Hemos estimado el valor de la tierra, la maquinaria, los ganados y el aporte de trabajo físico en una explotación de 260 hectáreas de Tres Arroyos en tres momentos: 1928, 1958 y 1992; y para una pequeña explotación (de 85-96 hectáreas) de la zona norte, para 1928 y 1992. En ambos ejemplos, para 1928 supusimos que era un arrendatario, y en los dos siguientes años, un propietario ${ }^{152}$.

En el caso de Tres Arroyos, como podemos ver en el Cuadro 4.15a, entre 1928 y 1958, el cambio en la forma de tenencia produjo una sustancial reducción de la importancia del recurso mano de obra familiar. En el siguiente período se observa un incremento de la importancia de la maquinaria, aunque la tierra sigue siendo el recurso más importante (la diferencia en el peso del trabajo entre 1958 y 1988 puede deberse a imperfecciones en la estimación; pero, de todos modos se observa un aumento en la relación capital/trabajo).

Para el caso de la zona norte (los datos corresponden a Salto, el de 1928 y a Pergamino, el de 1992), la tendencia es muy similar: fuerte reducción del peso del aporte de la fuerza de trabajo familiar dentro del conjunto de los recursos con que contaba un productor (del $77 \%$ al $20 \%$ ), incluso considerando que la cantidad de mano de obra familiar se haya mantenido estable (dos hombres) y que el productor no haya adquirido capacidad de cosecha propia (cuando muchos pudieron hacerse de una cosechadora durante estas décadas).

Queremos volver a aclarar que éste es sólo un ejercicio de estimación y que, de hecho, presenta imprecisiones que un estudio más detenido podría corregir. Sin embargo, creemos que las tendencias que se manifiestan sirven para tener una aproximación a la importancia de las transformaciones en la dotación de recursos que tuvieron los productores medios a lo largo del período considerado, incluso sin

mismo ocurría con 909 hectáreas en las zonas de invernada o triguera.

152 En la primera fecha, la estructura productiva era la que tenía el promedio de unidades registradas por la Editorial Kraft en Estancias y chacras, en el segundo, la consignada en Halliburton (1963), y en el tercero supusimos una orientación total hacia la agricultura producto de la "agriculturización". 
considerar el incremento en la extensión de las explotaciones promedio, y sin tener en cuenta la reducción en la cantidad de hijos que también ocurrió. 
Cuadro 4.15a. Dotación de recursos de un productor medio de Tres Arroyos (260 hectáreas) en 1928, 1958 y 1992.

\begin{tabular}{|c|c|c|c|}
\hline RECURSOS & $\begin{array}{c}1928 \\
\text { Arrendatario } 260 \mathrm{ha} .\end{array}$ & $\begin{array}{c}1958 \\
\text { Propietario } 260 \text { ha. }\end{array}$ & $\begin{array}{c}1992 \\
\text { Propietario 260 ha. }\end{array}$ \\
\hline \multicolumn{4}{|l|}{ En valores nominales: } \\
\hline Int.del Capital Fijo 1 (6\%) 2 & $\$ 766$ & $\$ 301.996$ & $\$ 23.272$ \\
\hline Tierra & $\$ 0$ & $\$ 258.854$ & $\$ 12.559$ \\
\hline Maquinas y ganados & $\$ 766$ & $\$ 43.142$ & $\$ 10.713$ \\
\hline Trabajo familiar (2 hombres) & $\$ 1.440^{3}$ & $\$ 28.4644$ & $\$ 4.160^{5}$ \\
\hline TOTAL & $\$ 2.206$ & $\$ 330.460$ & $\$ 27.432$ \\
\hline \multicolumn{4}{|l|}{ En valores porcentuales: } \\
\hline \% Capital Fijo (interés) & $35 \%$ & $91 \%$ & $85 \%$ \\
\hline \% Tierra & $0 \%$ & $78 \%$ & $46 \%$ \\
\hline \% Maquinas+ganados & $35 \%$ & $13 \%$ & $29 \%$ \\
\hline$\%$ Trabajo familiar & $65 \%$ & $9 \%$ & $15 \%$ \\
\hline
\end{tabular}

1 En base a un Capital Fijo (incluida la tierra) de \$ 12.769 para 1928 según cálculos propios a partir de los datos de Estancias y chacras; de $\$ 5.033 .170$ para 1958 según los datos elaborados por Halliburton (1963), y de \$ 387.869 para 1992, según datos de Pizarro y Cacciamani (1993a) sobre Pergamino, adaptados a la zona triguera.

2 Interés utilizado por Halliburton para la renta de la tierra. Queremos aclarar que para las mejoras y el resto de los bienes de capital utiliza un interés del $8 \%$, que de haberlo utilizado hubiera incrementado más aun el peso del capital fijo dentro de los recursos del productor.

3 En base al sueldo de peón mensual, datos recogidos en las entrevistas realizadas durante la investigación anterior.

4 Díaz Alejandro (1983: 392) (datos para trabajadores no calificados de actividades agropecuarias, por mes, para Argentina, fuente: CONADE, planillas inéditas).

5 Según sueldo de peón general, consignado en Sociedad Rural Argentina (1991: 87). 
Cuadro 4.15b. Dotación de recursos de un pequeño productor de la zona norte en 1928 y 1992.

\begin{tabular}{|l|c|c|}
\hline RECURSOS & $\begin{array}{c}\mathbf{1 9 2 8} \\
\text { Arrendatario 85 ha. }\end{array}$ & $\begin{array}{c}1992 \\
\text { Propietario 96 ha. }\end{array}$ \\
\hline En valores nominales: & & \\
\hline Int.del Capital Fijo 1 (6\%) & $\$ 426$ & $\$ 16.211$ \\
\hline Tierra & $\$ 0$ & $\$ 13.248$ \\
\hline Mejoras, Instalaciones & $\$ 102$ & $\$ 844$ \\
\hline Maquinas y ganados & $\$ 324$ & $\$ 2.119$ \\
\hline Trabajo familiar (2 hombres) & $\$ 1.440$ & $\$ 4.160^{3}$ \\
\hline TOTAL & $\$ 1.866$ & $\$ 23.621$ \\
\hline & & \\
\hline En valores porcentuales: & & $80 \%$ \\
\hline \% Capital Fijo (interés) & $23 \%$ & $65 \%$ \\
\hline \% Tierra & $0 \%$ & $4 \%$ \\
\hline \% Mejoras, Intalaciones & $5 \%$ & $11 \%$ \\
\hline \% Maquinas+ganados & $17 \%$ & $20 \%$ \\
\hline \% Trabajo familiar & $77 \%$ & \\
\hline & & \\
\hline
\end{tabular}

1 En base a un Capital Fijo (incluida la tierra) de $\$ 7.100$ para 1928 según Campolieti (1929) y de $\$$ 270.186 para 1992, según datos de Pizarro y Cacciamani (1993a).

2 En base al sueldo de peón mensual, datos recogidos en las entrevistas realizadas durante la investigación anterior.

3 Según sueldo de peón general, consignado en Sociedad Rural Argentina (1991: 87).

Incluso, la propiedad de la tierra permite la percepción de renta sin necesidad de desarrollar otra actividad que encontrar a alguien que la ponga en producción ${ }^{153}$. Desde los años sesenta se expandió la presencia de un agente capaz de hacerlo -los chacareros sobremecanizados en relación con los campos que poseían- y a ellos se agregarán en los noventa los "pools de siembra". La conducta rentística o cuasi-rentística tuvo entonces una posibilidad muy concreta de efectivizarse, sin necesidad de ceder el campo en riesgosos arriendos prolongados ${ }^{154}$, aunque en muchos casos el propietario continuara

153 La propiedad de la tierra también habría generado cambios en la autopercepción de los productores medios, como lo "denunció" un entrevistado que había sido dirigente de la Federación Agraria de Tres Arroyos: "Cuando se hacían propietarios, dejaban la Federación Agraria. [...] Pueden comprar y se creen de la oligarquía, dejan los campos. [...] Se creían los hijos de Anchorena" (AD*).

154 En los estudios historiográficos nunca debería olvidarse el requisito de que exista concretamente el sujeto social necesario para las opciones alternativas que se plantean. Así, por ejemplo, la opción de encarar la producción de unidades medianas o mediano-grandes 
administrando el campo y asumiendo parte del riesgo empresario, tal como ya hemos analizado.

A fin de ejemplificar la importancia de la renta del suelo para un propietario mediano, brindamos las estimaciones de los ingresos que obtendría por el pago de aparcerías al 30\% en el año 1999 (todavía dentro del esquema de convertibilidad que suponemos facilita la evaluación por parte del lector). Una hectárea sembrada con maíz y rendimientos de 70 quintales por hectárea estaba dando \$ 127 en el año 1999 (cuando el maíz estaba a \$ 9 el quintal, muy por debajo del promedio 1993-97 de $\$ 12,5)^{155}$. Por lo tanto un propietario de unas 200 hectáreas, percibía de renta de $\$ 25.400$ por dicha campaña (un ingreso mensualizado de \$2.117). En el caso de la soja de primera, los valores eran similares, y en el trigo eran un tanto inferiores, porque el precio de este cereal estaba particularmente bajo a comienzos de 1999. De todos modos, un propietario que alquilase un campo de 500 hectáreas dedicadas al trigo al 30\%, recibía de canon unos $\$ 31.500^{156}$. Como vemos, incluso en coyunturas relativamente desfavorables la renta del suelo permitía un ingreso importante con sólo alquilar el campo.

Sin embargo, no postulamos una determinación mecánica de estos cambios en la dotación de recursos sobre los modos de vida de los productores medios. Como ya hemos expuesto, se conjugaron otros factores sobre esta base estructural. El ejemplo del agro norteamericano obliga a desarmar cualquier rápida explicación determinista. En el Corn Belt, la gran mayoría de las explotaciones de 200 a 810 hectáreas no tenía asalariados permanentes: en 1997, sólo un $23 \%$ de estas unidades contrataban asalariados por más de 150 días al año, y las que lo hacían tomaban en promedio algo

con encargados asalariados casi nunca fue posible por la carencia de este sujeto (los que podían hacerlo, preferían casi siempre convertirse en pequeños productores arrendatarios).

155 "Precios y Resultados", CREA, 220, p. 102-114.

156 En todos los casos, los resultados varían con los tipos de fertilización, de siembra y el rendimiento finalmente obtenido. En los ejemplos utilizamos valores medios. 
menos de dos trabajadores ${ }^{157}$. Además, como hemos visto, la mayoría de los productores del Corn Belt residían en su explotación ${ }^{\mathbf{1 5 8}}$.

\title{
7. Valoraciones del campo y la ciudad, y estrategias de diferenciación social
}

\author{
"Venirse al pueblo [...] lo veían [...] \\ como una consecuencia lógica del progreso" \\ "La gente está acá yo creo que \\ por una cuestión de status..."
}

En comparación con el Corn Belt norteamericano, podemos pensar la urbanización y el "aburguesamiento" como producto de la no consolidación de un vínculo entre la profesión de agricultor o productor agropecuario y un modo de vida rural. Pareciera que en la sociedad argentina, a la profesión de agricultor que vive y trabaja en su campo no se le reconoció un status social relevante o, al menos, equivalente al de la clase media urbana, cuyos ingresos equiparaba o superaba especialmente a partir del acceso a la propiedad de la tierra. De algún modo, no consiguió pasar de "clase" a "estamento" en términos weberianos ${ }^{159}$. Si el modo de vivir desempeña un papel decisivo en la constitución del honor de los estamentos (tal como lo analiza Weber y lo retoma luego Bourdieu, 1979), en el caso del agro pampeano, pareciera que no logró consolidarse un estamento-profesión de productores residentes

157 En cambio, recordemos que en la zona norte bonaerense (también maicera y sojera) para 1988, el $78 \%$ de las unidades de 200 a 1.000 hectáreas contrataban asalariados permanentes (en un promedio de 1,6 trabajadores por establecimiento).

158 ver nota 38 del presente capítulo.

159 "Los 'estamentos' [se organizan] según los principios de su consumo de bienes en las diversas formas específicas de su 'manera de vivir' [y] un 'gremio' es también un 'estamento', es decir, aspira con éxito al 'honor' social sólo en virtud del 'modo de vivir' específico condicionado eventualmente por la profesión." (Weber, 1922: 692). 
en su explotación, que dedicasen su vida y la de los miembros de su familia al progreso de la misma ${ }^{160}$. El status ocupacional no se identificó con un modo de vida; en cambio se flexibilizó la identidad laboral (de "chacarero" a "productor agropecuario") englobando no sólo diferentes escalas económicas, sino también muy distintos modos de vida detrás de una identidad más abstracta/flexible. En vez de celebrarse un modo de vida "chacarero", muchos anhelaron acceder al modo de vida de los profesionales urbanos exitosos o el de los estancieros (quienes en general ya se habían urbanizado durante el período previo a 1930, dejando sus campos a cargo de asalariados).

La clave de este proceso podría encontrarse en que, en Argentina, la clase media apareció siempre asociada con la urbanización ${ }^{161}$. La vida rural se habría identificado indefectiblemente con una vida pobre, si hacemos excepción de los grandes estancieros (quienes sólo pasaban en sus campos algunas temporadas). Esta asociación resulta sorprendente en una región donde, tanto por la fertilidad del suelo como por el tamaño de las explotaciones, la mayoría de los productores medios gozan de ingresos muy superiores a los de la clase media urbana. Las duras condiciones de vida de los agricultores arrendatarios y medieros (debido a la capacidad originaria de los terratenientes para captar la mayor parte de la renta, y quizás incluso otros ingresos

160 La escuela pública no habría contribuido tampoco en este sentido. Ya en 1930 un artículo alentando la formación de los "clubs agrícolas de niños" publicado por el Museo Social Argentino señalaba el "peligro" de que las escuelas rurales alienten las profesiones liberales y no exalten la profesión de los padres y eduquen a los niños en el orgullo de la vida campesina:

"Mientras la escuela pública se mantenga como hasta aquí, y sobre todo la escuela rural, ajena a las preocupaciones del medio que la rodea; mientras siga prestigiando con su labor meramente intelectualista la acción de los que destacaron en la vida de las instituciones, sin tener un recuerdo para los que mediante el trabajo afianzaron el bienestar nacional; mientras el niño no encuentre un nexo simpático entre su labor del aula y la cotidiana de sus padres, la escuela será un factor adverso a su radicación futura en la campiña; habrá creado en su ánimo una subconciencia, tanto más profunda cuanto más prolongado sea su paso por ella, de que los prestigios, honores y riquezas, únicos a ambicionar, son los que se cosechan con las ocupaciones y profesiones liberales, y no es arriesgado suponer, que en muchos nazca el menosprecio a la labor paterna, y como consecuencia, un relajamiento del respeto filial. Otra será la posición, cuando la escuela refleje en sus actividades las propias del ambiente; cuando con recursos simples vivifique su enseñanza creando en el aula una atmósfera simpática a la agricultura; cuando al lado del prócer militar o civil, hermane las figuras de los pioners del progreso; cuando el niño encuentre en su tarea escolar, materia de espiritual acercamiento a la profesión del padre. En síntesis, cuando la escuela impregnada de sugerencias del ambiente rural, lo eduque en la consideración, el respeto y aún el orgullo de la vida campesina" (Barneda, 1930: 103).

${ }^{161}$ Así se observa en Míguez (1999). 
producidos por los agricultores) seguramente explican parte de esta valoración negativa de la vida rural, que luego pervivió. Es así que, incluso en las zonas de mayor desarrollo de explotaciones medias y en propiedad, la vida rural no se estabilizó como un objetivo final para estos productores agropecuarios. Si en los años veinte la construcción de viviendas apropiadas pareció abonar esta posibilidad (en Tres Arroyos, al menos), de todos modos la siguiente generación migró mayoritariamente hacia las ciudades.

Entonces, no se habría alcanzado cierta "celebración del narcisismo de las similitudes", necesaria para mantener los estilos de vida (Stebbins, 1997: 349-350). Ante esta baja valoración de la vida en el campo, no es extraño que no se haya generalizado, a diferencia del "farmer" norteamericano, una racionalidad sustantiva en torno a los valores asociados a una vida rural estructurada sobre la mediana explotación familiar ${ }^{162}$. Según Mooney (1988), el "farmer tipo" no se dedica a la agricultura para hacer dinero, sino porque es un buen modo de vida (obviamente, en tanto que el dinero se lo permite, pues tampoco es un desinteresado por la obtención de mayores ingresos). Asimismo, el "farmer tipo" valora particularmente ser "su propio jefe", y que sus hijos crezcan en un establecimiento rural. Además, no le agrada la vida urbana y se disgusta frente a la imposición de racionalidades formales, que le llegan, por ejemplo, a través de los bancos (Mooney, 1988). En cambio, los productores medios pampeanos presentan una racionalidad mucho más formal y/o poseen otros valores en su racionalidad sustantiva, asociados a los elementos ya enumerados de su nuevo modo de vida urbano. Precisar exactamente el tipo de racionalidad de los productores pampeanos exigiría un estudio específico que excede el tema de esta tesis, pero consideramos que es factible afirmar que no se asemeja a la racionalidad sustantiva del farmer norteamericano que describe Mooney. Si en el caso norteamericano la perpetuación de la unidad productiva es en sí misma (junto con la vida rural familiar) el objetivo final de las acciones del productor, en el caso pampeano es, muchas veces, un mero instrumento para alcanzar otros objetivos externos a la propia dinámica de la unidad productiva.

162 Sobre la cuestión de la racionalidad económica de los productores, volveremos más extensamente en el próximo capítulo. 
Esta baja valoración del modo de vida chacarero y del mundo social que conformaba, fue favorecida por la inexistencia de una tradición cultural que los celebrara, seleccionando elementos del pasado (aun de este pasado reciente) para confirmar el orden contemporáneo en términos culturales e históricos ${ }^{163}$. Esa celebración de la vida familiar rural de los colonos sí existió para el caso del Midwest, tanto en la literatura como en la cultura de masas norteamericanas ${ }^{164}$. Aquí, en cambio, el campo quedó reducido al gaucho, el indio y el estanciero, tanto en la tradición criollista, como en la reelaboración que efectuó la vanguardia y la postvanguardia argentinas. Así por ejemplo, Güiraldes, en Don Segundo Sombra, ignora directamente la chacra y el gringo, como lo señala Borges (1955: 88-89), y lo analiza detenidamente Sarlo (1988: Capítulo II). Esta pastoral "moderna", deja de lado la modernización que ya tenía el agro pampeano en el tiempo ficcional de la novela, que se ubicaría después de 1900 (Sarlo, 1988: 36). Pero ésta no es exclusivamente una estrategia discursiva de Güiraldes, sino que se continuará a lo largo de todo el siglo $\mathrm{XX}^{\mathbf{1 6 5}}$. La pampa chacarera es una gran ausente en la literatura argentina y las pocas veces que aparece, en obras de escasa significación, no lo hace en función celebratoria ${ }^{\mathbf{1 6 6}}$.

163 Tal como Williams (1980: 138) propone conceptualizar la cuestión de la tradición.

164 Por citar el ejemplo más conocido, la exaltación de los colonos pioneros con su espíritu independiente y su capacidad para sobrellevar las adversidades constituye el centro de la saga de nueve libros escritos por Laura Ingalls Wilder en los años treinta y cuarenta, en obras que luego, en las décadas del setenta y ochenta, fueron adaptadas para una serie televisiva que alcanzó gran popularidad (incluso en la Argentina).

165 Como lo analiza Montaldo, "cuando los sectores más arcaicos y conservadores -incluso reaccionarios- de la cultura argentina, se apropian de la tradición gaucha y rural, en el mismo momento en que se continúa desarrollando la gauchesca aún popular, los sectores más modernos del campo cultural, también se lanzan a ella. Con la intención no de mantener una tradición, no de continuarla, sino de reconstruirla íntegramente, es decir, usarla, cada vez que son afectados por los requerimientos de la modernidad. La tradición para los modernos, no es una forma de dar respuesta a la avalancha de lo nuevo, ni de resistir la modernización (esos serían los casos de los textos populares o los conservadores) sino de experimentar con tiempos y formaciones culturales diversas, es decir, tener a mano y transformar diferentes discursos entremezclados. Sin embargo, los resultados no siempre recogen la pluralidad de la que parecen proceder y muchas veces se convierten en texto leídos unilateralmente. [...] ... los tópicos que la modernidad vuelve a interrogar: la perplejidad ante la naturaleza, la violencia política, el nomadismo, la mujer y el hombre errantes, la amenaza de un Otro salvaje. Pero todos estos tópicos no se trabajan en un sentido 'paisajístico' romántico sino como arraigada tradición cultural que sin embargo se presenta bajo la forma del enigma o, al menos, de la incomprensión y la incertidumbre." (Montaldo, 1993: 120-121). Observamos que, en este listado de tópicos que realiza Montaldo no aparece el chacarero.

${ }^{166}$ En su exhaustiva revisión de la representación de la pampa en la novela argentina, Williams Alzaga (1955) encuentra (además del conflicto entre peones y estancieros en El campo arde 
En el caso de la plástica tampoco la figura del chacarero se convirtió en un motivo relevante ${ }^{167}$. En general, la pampa ha quedado asociada a la imagen de un espacio vacío e inmenso $\mathrm{y} / \mathrm{o}$ a la idea de desierto ${ }^{168}$. Las pocas figuras humanas representadas en este contexto son casi siempre gauchos, indios o soldados ${ }^{169}$. Los agricultores sólo son representados en otros contextos regionales, como dentro del paisaje serrano de Faber ${ }^{170}$, o transmiten una imagen de pobreza y desolación como en

de Juan Manuel Prieto, escrita en 1936) la descripción de una pampa agrícola, chacarera (donde "el gaucho, el paisano, es reemplazado por el colono...") en solo dos novelas de los años treinta y cuarenta. Por un lado, aparece en La pampa gringa de Alcides Greca, escrita en 1936. En esta obra, la pampa es descripta desde los puntos de vista de diferentes actores. En muchos casos con cierta nostalgia por la pampa gaucha frente a la agrícola del presente, polvorienta, triste, "acribillada de sol", con "monotonía" y "mediocridad", pero también es vista por otro personaje desde el intento de representar su belleza de forma pictórica. Por otro lado, esta pampa agrícola surge en Puerto América de Luis María Albamonte, de 1942. En este caso el protagonista es un inmigrante italiano que en un momento va a trabajar de peón a una chacra. Pero esta experiencia termina al cabo de cinco años, cuando los dueños, cansados de la sucesión de granizo, sequía y langostas, deciden vender la chacra, y el protagonista regresa a Buenos Aires. Como vemos, incluso estas dos únicas novelas que abordan de algún modo la vida chacarera no pueden considerarse celebratorias de esta vida o enaltecedoras del esfuerzo "pionero" de los agricultores.

Concluye Williams Alzaga que "escasamente representada se halla aún la pampa agrícola, en nuestra literatura. Falta todavía la novela que profundice en la psicología y en los problemas del colono. Tampoco en el cuento y en el teatro, aunque hay anticipos, se ha llegado a una obra cumbre" (Williams Alzaga, 1955: 324). En este sentido, cabe aclarar que ni las mencionadas dos novelas, ni ninguna otra posterior que abordara la problemática chacarera logran hacerse un lugar en el cánon literario argentino, incluso en un sentido amplio y no restringido a la literatura más consagrada.

167 Así, por ejemplo, analizando una compilación dedicada especialmente al paisaje en la pintura argentina durante el siglo XX (Perazzo y Whitelow, 1980) en ninguna de las más de cien obras seleccionadas aparece la figura del chacarero. Ni siquiera es representado en la obra de Castagnino titulada "Chacra" (1964), en la que en cambio, se destaca una rastra olvidada al lado de un cardo. A veces, en este pintor esta imagen de maquinaria agrícola abandonada es asociada con la muerte, como en "Osamenta en el paisaje" (1964), donde un arado con asiento está junto con una osamenta vacuna. Incluso en "Tierra arada" (1963) apenas se distingue un tractor, sin que aparezcan figuras humanas.

${ }^{168}$ En este sentido existe una tradición que comenzó con Sívori y llega hasta nuestros días, de obras que representan la pampa utilizando solamente la tierra, el cielo y entre ambos un horizonte muy bajo, sin interrupciones. Incluso en las últimas décadas se ha vuelto al tema de la inmensidad del paisaje pampeano, con la infinitud, la soledad, como único motivo según analizan Malosetti Costa y Penhos. Como sintetizan estos autores, "A más de un siglo de su conquista la pampa sigue siendo, en buena medida, un desierto" (Malosetti Costa y Penhos, 1991: 203).

169 Una tradición iconográfica que, centrada en indios y soldados, nace con el proyecto de ocupación de la pampa (Rodríguez Otero, 1991), pero que continuará luego con los gauchos; 
algunas obras de Castagnino ${ }^{171}$. Tal vez la única excepción en la que los agricultores pampeanos se constituyen en el centro de la escena pictórica sea el cuadro "Chacareros" de Berni ${ }^{172}$.

Incluso el cine se mantuvo hegemonizado por el discurso criollista ${ }^{173}$. Este era un imaginario social que, invisibilizando a los chacareros, fortalecía, en última instancia, el poder de los terratenientes. Sin embargo, a pesar de algunos intentos de construir una tradición propia ${ }^{174}$, los chacareros no tuvieron otro imaginario del que asirse para consolidar su identidad y, de hecho, terminó primando esta imagen "estanciera-gaucha" de la pampa.

por ejemplo, los gauchos dibujados en tinta por Castagnino o los popularizados de Molina Campos. Justamente, indios, soldados y gauchos hegemonizaron la historieta argentina (Carlón, 1991).

170 En la obra de Faber, agricultores y pastores son situados dentro de un paisaje serrano (identificado como el paisaje nacional), representados con rasgos campesinos, bien imbricados dentro de un paisaje inmóvil, sin conflictividad, ni cosmopolitismo (Wechsler, 1991: 348); por ejemplo, "Mañana de trabajo" (1918) o "La reja" (1926). Estas obras encajaban en la definición de "paisaje nacional" que se construyó a fines del XIX y comienzos del XX, en el que el nacionalismo aparecía asociado a las ideas de regionalismo, criollismo e indigenismo, atravesados por una mirada burguesa que buscaba reconocer a su patria en esas estampas (Wechsler, 1995).

171 Como por ejemplo, "Figuras en el camino" de 1938, u "Hombre en la tierra, o cosechador" de 1941, en la que un hombre desnudo se agacha frente a una pequeña planta.

172 Esta obra, realizada en 1935, presenta un colectivo social heterogéneo a nivel étnico (visible en los rostros) y cultural (indumentaria), con distintos grados de modernización (como se trasluce en la adopción, por parte de algunos, de patrones urbanos de vestimenta). Pero, a pesar de la diversidad, los sujetos aparecen homogenizados en tanto todos están representados como integridades plenas, sólidas que, combinadas con ciertos elementos clásicos como la figura maternal en el centro y el caballo escultórico de la derecha, sugieren una imagen de fuerza, productividad y fertilidad. Por último, todos aparecen nucleados en torno a la mesa, el diario, el reclamo. Los gestos y la masividad traducen cierta actitud combativa, en la que se unen firmeza y paciencia.

173 En el cine conservó una fuerte presencia el criollismo, con sus gauchos y estancieros (por cierto, muchas veces vistos críticamente), tal como lo analiza Tranchini (2000). Aunque los chacareros y sus problemas aparecieron al menos en alguna película (como por ejemplo, Kilómetro 111, de Mario Soffici, 1937), persistieron en el nuevo medio las funciones de consolación y reaseguro frente a los cambios introducidos por la modernización propias del criollismo, a través de sus viejos y tradicionales símbolos de identificación (Tranchini, 2000).

${ }^{174}$ Como el caso de los documentales de la Federación Agraria Argentina, "En pos de la tierra" de junio de 1922 y "Aurora pampeana" de marzo de 1935, analizados por Marrone y Moyano Walker (2002). 
Esta falta de valoración de una vida rural chacarera, se potenció por la carencia de vida comunitaria (ya señalada por Taylor, en contraste con el Corn Belt). No se desarrolló plenamente una comunidad rural desde donde defender el estilo de vida chacarero $^{175}$, sin renegar del acceso a ciertos servicios que pudieran ubicarse en pequeñas localidades. El amplio desarrollo de las cooperativas agrícolas no llegó a revertir esta situación. Esto ocurrió a pesar de que a partir sobre todo de los años treinta (como respuesta frente a la crisis) y luego, durante el primer peronismo como resultado de una política planificada de impulso del cooperativismo desde el propio Estado ${ }^{176}$, se incrementó notoriamente el número de cooperativas rurales y casi toda localidad de cierta importancia pasó a tener su cooperativa. Si bien la cooperativa habría favorecido la vida social comunitaria de estos pueblos, no llegó a contrabalancear los factores que la disminuían en favor de las ciudades cabeceras de los partidos. En este sentido, en nuestras entrevistas encontramos que varios productores que residían en la ciudad operaban con la cooperativa ubicada en el pueblo más cercano a su explotación. De algún modo, el desarrollo de las cooperativas no logró proyectarse sobre la cuestión del desarrollo local, no generó la preocupación y alternativas de enriquecimiento de la vida social y cultural a nivel de las pequeñas localidades. Probablemente, la concepción de la cooperativa como una herramienta meramente comercial por parte de la mayoría de sus miembros (tal como fue detectada por un estudio del INTA de comienzos de los años sesenta ${ }^{177}$ ) no haya colaborado en la constitución de ésta como pilar para la acción

${ }^{175}$ Como ya señalamos en el capítulo primero, el estilo de vida no implica la existencia de una comunidad, ya que el compartir un "estilo de vida" sólo implica tener en común algunas características de la vida individual (Stebbins, 1997: 349). Sin embargo, la existencia de una comunidad (con, entre otros elementos, la interdependencia de sus miembros, la actuación en conjunto y una historia compartida) permite, sin lugar a dudas, reforzar la continuidad de un estilo de vida.

176 Sobre el impulso del cooperativismo en la provincia de Buenos Aires durante los gobiernos peronistas puede consultarse Mateo (2002). Un muy interesante trabajo sobre la articulación entre productores, cooperativistas, movimiento cooperativo y Estado focalizado en una cooperativa cordobesa entre 1951 y 1956 se encuentra en Olivera (2002).

177 El 78\% de los miembros de las cooperativas del partido de Pergamino se habían incorporado pensando solamente en las ventajas comerciales que ésta le brindaba, y sólo un $22 \%$ por "espíritu de cooperación". Coincidentemente muy pocos de los socios conocían el principio cooperativo de "un solo voto por cada socio [...] que implica anteponer el hombre 
colectiva en pro de un desarrollo local que posibilitara la permanencia de los productores en sus campos con una mejor calidad de vida.

En un sentido similar, la carencia de un "sentido comunitario" por parte de las "nuevas burguesías zonales", que "proyectan sobre la comunidad su más que nunca exacerbado individualismo", también fue destacado por de Imaz (1965: 168-169).

El atractivo de las ciudades -que a través de los medios de comunicación masiva estaban cada vez más cerca de los chacareros ${ }^{178}$ - resultó muy fuerte. No sólo por sus comodidades sino porque aparecían como el lugar de realización del ascenso social y como el espacio de una sociabilidad "civilizada". Como hemos visto en el primer capítulo, fue en los pueblos-ciudades donde un tipo de sociabilidad se propuso alcanzar un registro "civilizado" (Hourcade, 1999). Podemos agregar que esta imagen no fue alterada a lo largo del siglo XX. En este sentido, nuestros entrevistados percibieron que si sus vecinos (o ellos mismos) se iban a vivir a la ciudad, esto formaba parte de un proceso "natural" propio del "progreso social": iban "evolucionando". Entonces los productores contaron con un esquema interpretativo que explicaba/legitimaba el abandono de su situación anterior y les garantizaba una continuidad biográfica ${ }^{179}$. También los ingenieros agrónomos entrevistados destacaron que hasta los años sesenta

al capital" (Arroyo, 1963).

${ }^{178}$ Coscia es muy claro al respecto: "La gran ciudad proyectaba con creciente nitidez su imagen al medio rural. La mayor alfabetización de los productores, especialmente de los jóvenes, les permitía un mayor contacto con los medios impresos de comunicación masal; a su vez, la radio comenzaba a adquirir una gran difusión en el medio rural, como también el cine nacional que contaba con mucha aceptación en las localidades del interior. Todo ello contribuyó a que la población rural, especialmente su juventud, comenzara a 'descubrir' la ciudad, especialmente Buenos Aires, a sentirse atraída por ella" (Coscia, 1983: 29).

179 Al respecto ver Berger y Luckmann (1986: 203) afirman que existen esquemas interpretativos ya preparados que permiten encarar la movilidad social sin plantear una metamorfosis total del individuo. En general, estos esquemas están internalizados por el individuo antes de adquirir movilidad él mismo, garantizando la continuidad biográfica y suavizando las incoherencias que puedan surgir. 
existía una fuerte distinción cultural entre el hombre de campo y el de ciudad (en las formas de hablar, de vestir, en su nivel educativo), y, entonces, la radicación urbana era percibida por ellos y sus colegas como parte de la "modernización de la sociedad"180.

Pero si desde el punto de vista individual, el tránsito de lo rural a lo urbano no tuvo características traumáticas, como fenómeno social concitó algunas preocupaciones, especialmente en los años sesenta. En este sentido, un síntoma de la tensión entre "progreso" y forma de vida rural es la situación contradictoria en que quedaron sumidas las revistas agropecuarias en estos años con respecto a la atracción de la ciudad. Algunos artículos recordaban con nostalgia el pasado en el que distintas generaciones se iban sumando a una misma explotación (o a campos cercanos) y compartían la producción en conjunto ${ }^{181}$, y señalaban que la atracción ejercida por la ciudad estaba captando "indiscriminadamente a la juventud" ${ }^{182}$. Contradictoriamente, en los artículos

180 Preguntado un ingeniero agrónomo de la Chacra Experimental de Barrow (Tres Arroyos), acerca de qué comentaban entre los ingenieros de la chacra, afirmó que

"... parecía un hecho normal, parecía que era parte de la modernización o el progreso...me parece a mí. Si uno hablaba con ellos, ellos veían como una consecuencia lógica..., porque, además, las explotaciones agropecuarias, incluso, con la tenencia de la tierra que les había dado, la década anterior, el peronismo, muchos de ellos... que habían sido arrendatarios por años... habían pasado a ser propietarios, y los precios agrícolas eran más o menos buenos, la productividad más o menos buena, y además alguna circunstancia de tipo familiar hacía que encontraran, como le explicaba mi propio caso, encontraban razonable venirse a vivir al pueblo... Todas esas cosas, entonces lo veían ese cambio de situación como una consecuencia lógica del progreso." (CJ)

181 "Pedestal y columna sobre los cuales se levanta el edificio agrícolaganadero, la familia afincada en los medios rurales es la firme sustentación de la continuidad productiva del país. No puede hablarse del hombre de campo sin incluir la familia de que forma parte y a la cual sustenta, al tiempo que recibe fuerza, unidad y sostén de su cohesión natural. Si la familia en cualquier parte es el núcleo central a cuyo alrededor se expande la sociedad entera, en el campo constituye una fuerza indisoluble con el medio, una unidad social. La familia campesina fue siempre una entidad estable y permanente. Padres e hijos no solo convivían, trabajaban juntos y participaban de todo cuanto hicieran para bien de la comunidad a la que pertenecían sus vecinos y entidades zonales, sino que al casarse los hijos y fundar otras familias éstas se anexaban a la primera, vivían juntas o muy cercanamente. De tal manera, la familia se agrandaba, crecía con los años y las nuevas generaciones. Los nietos y bisnietos estaban siempre junto a 'los viejos', se quedaban. Las tierras crecían, una concesión al lado de otras concesiones familiares, hectáreas anexadas a otras hectáreas. No había subdivisión, sino condominio. La familia rural era una potencia, humana y económicamente." En: "La familia rural", Mundo Rural, 148, agosto-septiembre de 1962; p. 79.

182 " Después, un signo de nuestro tiempo permitió que esa unidad se resquebrajara. La industrialización en zonas cercanas a la gran ciudad atrajo indiscriminadamente a la juventud, que fue abandonando el campo para radicarse junto a mayores salarios, la vida ciudadana, la comodidad, la apresurada actividad y los descansos efectivos semanales." En: "La familia rural", Ibid. 
la ciudad aparecía como el lugar del confort y la activa vida social y cultural ${ }^{183}$, a la vez que se intentaba desmitificar este "espejismo"184, señalando que estos objetivos a veces no eran "más que una simple aspiración, finalmente truncada en las "villas miseria",185. En un plano más abstracto, los textos buscaban reponer las virtudes de la vida rural, y asociaban la urbe con imágenes negativas (la "esterilidad" o "la sofocación" que generaban "las multitudes y los objetos") ${ }^{186}$. Sin embargo, no dejaban de reconocer las carencias de la dura vida rural, y emprendían un reclamo constante en favor de su

183 "El despoblamiento de las poblaciones desde el campo a la ciudad no obedece solamente a diferencias en los niveles de salarios y a la existencia en ella de un mayor repertorio de posibilidades vitales, lo que permite una satisfacción más adecuada de las vocaciones individuales, sino también a razones de orden cultural que calan más hondo en la personalidad. El 'mundo' del hombre del siglo XX se ha expandido, en el sentido de que la ciencia y la técnica han puesto a su alcance un sistema de instrumentos que le permitan extender el ámbito de la esfera de acción personal. El hombre que cuenta con radio, televisión, diarios, bibliotecas, teatro, cine y medios motorizados de transporte transciende los límites cerrados de su existencia cotidiana y se siente transportado a niveles más promisorios de vida. Estos medios masivos de entretenimiento tienen la aptitud de crear un clima de 'encantamiento' por el que la vida puede discurrir, mientras ese clima perdura, con relegación u olvido de las limitaciones impuestas por la existencia cotidiana. EI hombre de campo quiere ser parte de esta aventura cultural. El no se conforma en la privación, ante la evidencia de que otros poseen los medios o los encuentran a su alcance con sólo trasladar su domicilio a las grandes ciudades." En: "Campo argentino", por Julio Cesar Cueto Rúa, La chacra, 377, abril de 1962; pp. 17-28. (Subrayado en el original).

184 Tal como se aprecia en el término "encantamiento" en la anterior cita, pero también en el "espejismo" de esta otra:

"Debemos acercar al niño a su propio ambiente, encariñarlo con él, capacitarlo para que sea un hombre eficiente en su medio y un continuador de la obra de sus mayores y lo que aprende en la escuela le sirva para vivir, sin necesidad de alejarse del medio rural y con los recursos que tenga a su alcance, que son los mismos que le sirvieron a sus padres para criarlo, enseñarle a seguir el buen ejemplo de éstos a vivir como ellos, del agro que da más que el espejismo de las grandes ciudades que son ellas las que van absorviendo a esa juventud agraria." En: "Los conocimientos deben empezar en la escuela", por Albino Alberto Aguilar, El campo en marcha, 63, diciembre de 1972; p. 5.

185 “... La Argentina tienen un problema importante. Su macrocefalismo. La gran cabeza que usurpa fuerzas al resto del cuerpo, y que amenaza con consumirlo todo. En el campo hay un antiguo problema emergente de la emigración de brazos hacia la ciudad y sus centros de influencia. Ello es lógico, por otra parte, como que el hombre busca constantemente un mejoramiento en su nivel de vida, que no halla en los últimos lustros en el campo, sujeto a las tareas campesinas, y sí, en cambio puede encontrarlo -a veces no es más que una simple aspiración, finalmente truncada en las 'villa miseria' que como un cordón vergonzante aún rodean a la ciudad, e inclusive se enquistan en ella- en la orgullosa capital de la República." En: "Industria y producción agropecuaria: dos fuerzas para el desarrollo nacional", por Valentín Vergara, Mundo Rural, 145, abril de 1962; pp. 9-10.

186 "Crisis psicológica", por Manuel Luis Olivas, La Chacra, 340, marzo de 1959; p. 14. 
urgente mejoría ${ }^{187}$. Por esta razón en particular, concedían justos fundamentos para que las mujeres pujaran por mudarse a las ciudades (a pesar de los resultados negativos que tendría esta decisión para la propuesta rural subyacente en los textos). Las mujeres aparecían como las principales perjudicadas por el aislamiento -que reducía su vida social- y la falta de electricidad -que impedía el uso de electrodomésticos "que simplifican la vida del ama de casa de la ciudad"-. Es por ello que para estas publicaciones "la despoblación del campo [se debía] frecuentemente a la iniciativa de la mujer, que desea librarse de la esclavitud del trabajo rural"188. Lograr que la mujer no sólo no pujase por radicarse en las ciudades, sino que se convirtiese en un freno al éxodo rural e incluso la base de una campaña civilizadora, había sido a comienzos de los cuarenta, la propuesta de Tomás Amadeo ${ }^{\mathbf{1 8 9}}$.

Algunos indicios permiten pensar la urbanización, y todos los elementos que agrupamos en torno al concepto de "aburguesamiento", como el núcleo de una estrategia de diferenciación social ${ }^{190}$. En las primeras décadas de este siglo, cuando se

187 "Industria y producción ...", art.cit.; y "El extensionismo rural que falta", El campo en marcha, 51, noviembre de 1971; pp. 22-23.

188 " La que más sufre por la falta de los mencionados elementos de civilización es la mujer, encerrada en el aislamiento tan típico del campo y sin contar siquiera con los artefactos que simplifican la vida del ama d casa de la ciudad. ¿Debe extrañar, entonces, que la despoblación del campo se deba frecuentemente a la iniciativa de la mujer, que desea librarse de la esclavitud del trabajo rural?" En: "Racionalización psicológica en las chacras", por Roberto Schopflocher, La Chacra, 334, septiembre de 1958; pp. 64-65.

189 Ver su artículo "La mujer en el hogar agrícola", Boletín del Museo Social Argentino, 211-212, enero-febrero de 1940; p.p. 3-12. Allí señalaba que "en las provincias más ricas y progresistas [...] hay un éxodo evidente de la población rural hacia pueblos y ciudades. Se dan a este fenómenos muchas explicaciones; pero creo que en gran parte es debido a que el campesino no siente la atracción del hogar ni la seducción del campo y en cuanto le es posible huye al poblado". Frente a esta situación propone "la utilización de la mujer campesina para realizar una misión verdaderamente redentora", y de allí su creación de una escuela para señoritas, que para entonces había sido cerrada.

190 Además de la perspectiva desarrollada por Bourdieu (1979), un enfoque inteligente para esta cuestión es el elaborado por la antropóloga Mary Douglas y el economista Baron Isherwood (1990). Proponen que "en lugar de suponer que los bienes son fundamentalmente necesarios para la subsistencia y el despliegue competitivo, asumamos que son necesarios para hacer visibles y estables las categorías de una cultura [...] Los bienes materiales proporcionan 
conformaron las sociedades locales en cada uno de los partidos bonaerenses (o se reconstruyeron en el caso de la zona norte), la condición de "propietario de campos relativamente extensos" debía ser suficiente para la ubicación en la cúspide de estas sociedades, condición que se reforzaba si se era un buen productor (con animales premiados en las exposiciones rurales, extensos sembradíos, etc.). Pero cuando se “democratizó" el acceso a la propiedad de la tierra, a partir de la década del cuarenta, progresivamente se desmoronó esta barrera diferenciadora. Siguió estando presente la cuestión del tamaño de las propiedades (no es lo mismo ser el dueño de 100 hectáreas que de 3000); sin embargo, la desaparición de buena parte de las pequeñas unidades en propiedad y la subdivisión por herencia de los latifundios, dieron lugar a una relativa homogeneización en la estructura de la propiedad de la tierra, tal como ya hemos analizado, especialmente entre los propietarios que están a cargo de sus campos (y no los dan en arriendo, como hacen la mayoría de los pequeños propietarios) y que residen en los partidos (ya que los más grandes habitualmente viven en la Capital Federal).

En este contexto, nuevas pautas de diferenciación social se fueron erigiendo y complementaron el capital económico: la residencia en un importante chalet urbano, la asistencia a prácticas de sociabilidad urbanas (entre otras, la concurrencia cotidiana a los clubes y a las reuniones privadas) y la educación universitaria. Además, los autos y camionetas cada vez funcionaron más como bienes de ostentación y diferenciación ${ }^{191}$. De Imaz (1965: 168) señala que la "nueva clase media rural" de la ciudad de Río Cuarto efectuaba "una exhibición limitada de ciertos indicadores ostensibles del nuevo status (casa y auto)". En un sentido similar, Peyrou cuando tiene que definir si incluye a los automotores como bienes de capital, opta por una respuesta negativa, ya que "los productores aparentemente los considerarían más bien un bien de consumo, y, por lo tanto, sujeto a todas las características de estos. Así, se advirtió que prácticamente todos los productores al determinar la vida útil de los vehículos (fueran automóviles o

alimento y abrigo, y ello debe ser bien comprendido. Sin embargo, todo parece indicar que, al mismo tiempo, las mercancías tienen otro importante uso: sirven para establecer y mantener relaciones sociales. He aquí, entonces, un más que probado y fructífero enfoque dirigido hacia el lado material de la existencia, que ofrece una idea de los significados sociales muchísimo más rica que la referida a la simple competitividad individual" (Douglas y Isherwood, 1990: 74-75).

191 Resulta muy gráfico uno de los testimonios de un productor de Rivadavia, quien señaló que "cuando tuve vehículo adecuado a la sociedad, yo venía todos los días al pueblo [especialmente para ir al Club]" (OB). 
camionetas) le fijaban tipos de vida útil ridículamente cortos (1, 2 ó 3 años), que más parecen relacionados con la duración de objetos de uso suntuario que de bienes de capital" (Peyrou, 1971: 19).

Sería entonces posible entender este proceso de urbanización y el propio "aburguesamiento" como una estrategia para el ascenso y/o la asimilación a la elite local por parte de los ex-arrendatarios. Al parecer, muchas familias captaron la importancia social de la radicación urbana en términos de status social ${ }^{192}$. Pero, probablemente se generalizó una dinámica menos conciente, en la que los productores se vieron compelidos a radicarse en la ciudad para sincronizar sus actividades de ocio y de consumo con las de sus amigos que ya se habían trasladado. Incluso, intentaron que sus hijos no quedaran fuera de estos círculos que se conformaban en torno al colegio, atendiendo a las salidas propias de la adolescencia ${ }^{193}$. Además, tal como ya hemos analizado, el mantener activos esos contactos brindó importantes beneficios económicos.

La propia sociabilidad urbana exigió incrementar el consumo y disponer de mucho más "tiempo libre" que la vida rural ${ }^{194}$. Por ello cada vez resultó más difícil vivir

192 "Venían a instalarse en Tres Arroyos. Si no tenían casa acá, en Tres Arroyos, no estaba bien" (Mujer de ER).

"La gente está acá yo creo que por una cuestión de status, o porque la gente te ve con una auto nuevo, una casa linda en el centro..." (hijo de PL).

"...en cierto momento por status, era más status venir a Tres Arroyos que mandar a los chicos al Colegio Danés." (UN)

193 Tampoco se quiso privar a los adolescentes del acceso a estos espacios de sociabilidad: "no se pudo continuar [llevando y trayendo, la mujer, a los hijos en auto] por los horarios de los chicos y porque empezaron toda esa etapa de que querían hacer deportes, que los invitaban a una fiesta y era mucho estar yendo y viniendo con ellos ¿no?, o prohibirles también de todo eso que no se justificaba, entonces ahí fue cuando nos vinimos." (mujer de ME).

194 Douglas y Isherwood afirman que "al responder al cambio en las estructuras de la sociedad, la familia transfire al mercado sus procesos de producción y, en ese ámbito, compra cada vez más y más de las mercancías que requiere con el dinero que ha ganado. No es de extrañar que los alimentos enlatados hayan ocupado el lugar de las conservas caseras, ni tampoco que los congeladores domésticos compitan con los productos enlatados. La familia, lo mismo que el fabricante, busca economías a escala de su tiempo y energía en los procesos productivos" (Douglas y Isherwood, 1990: 120).

Y más adelante explicitan que su "teoría supone que un ascenso en el ingreso real tenderá a ser acompañado por un incremento en la frecuencia de acontecimientos sociales privados de gran escala. El aumento en el ingreso real será indicado por una demanda de pertrechos y servicios que releve a los individuos de la cadena de tareas de alta frecuencia involucradas en la producción doméstica." (Douglas y Isherwood, 1990: 128). 
parte del tiempo en la casa del campo y, por ende, se debieron abandonar las labores directas, entre ellas la producción para el autoconsumo, que no resultaba rentable encararla con asalariados ${ }^{195}$.

Lentamente, la vida urbana se fue convirtiendo en una necesidad en la medida en que quedarse en el campo significaba quedar fuera de las relaciones sociales ${ }^{\mathbf{1 9 6}}$, no sólo de las nuevas, sino también de las previas, ya que los amigos/vecinos se iban mudando a la ciudad ${ }^{197}$. De modo que permanecer en el campo empezó a ser percibido como un signo de atraso, de desconexión. Resultan sintomáticos los términos utilizados por varios de los entrevistados para referirse a quienes se habían quedado en el campo: "enterrado", "encerrado", "con la cabeza metida en el campo", que no sólo hacen referencia a permanecer aislados de los circuitos de negocios, sino que transmiten la idea de permanecer fuera de la sociedad ${ }^{\mathbf{1 9 8}}$. Si bien algunos entrevistados han exaltado

195 Como relató la mujer de un productor de Tres Arroyos que en un comienzo producía hasta manteca: "[lo dejé] por.. cuatro hijos y otras cosas... Aparte que uno va aspirando también a hacer un curso de esto, una cosa de lo otro, se empieza a meter en otras cosas [...] Cuando los chicos eran muy chicos entonces estábamos mucho en el campo. Después [ya radicada en la ciudad] uno ya va cambiando, la vida a uno lo va llevando a distintas cosas y distintos gustos..." (mujer de ME).

196 Como lo conceptalizaron Douglas y Isherwood: "Algunas decisiones individuales, ya sea la elección de trabajo o residencia, permiten a quien las toma una mejor adaptación o una más eficaz intercepción de la siempre cambiante corriente principal de la vida en sociedad".

"Si una persona está fuera de cualquier posición de control, otras podrán entonces manipular el tablero a su antojo, en forma tal que los registros de la primera resultarán obsoletos y el significado se evaporará en medio del estrépito. En consecuencia, el objetivo del consumidor racional implica asimismo un esfuerzo por acercarse al centro de transmisión y por reforzar las fronteras del sistema. Para hallarse cerca del centro se requiere una estrategia que organice el intercamcbio de servicios marcados, a fin de no ser excluidos de las formalidades compartidas, esto es, ni de las bebidas ni de la mesa, ni tampoco de la posible cama matrimonial" (Douglas y Isherwood, 1990: 96 y 111).

${ }^{197}$ Como lo relató un productor de Tres Arroyos: "si viene uno [de los vecinos] ... entonces el otro se queda medio sólo en el campo, entonces también se viene más fácil..." (PL).

${ }^{198}$ Los siguiente testimonios son muy claros al respecto:

"... yo pienso que se puede seguir viviendo en el campo, lo que no se puede es lo de antes, de meter la cabeza en el campo y olvidarse de todo lo que va en aumento, alrededor, pero que es muy importante lo que se está cambiando y lo que está pasando en la producción agropecuaria, muy importante..., y si uno se queda, me parece a mí enterrado, por decir algo, en el campo y nada más con lo que sabe, pierde, ahí seguro que pierde." (mujer de ME)

"Encerrarse en el campo ¡no! Usted no está actualizado de las cosas, hay que estar actualizado. Hay que atender las dos cosas: la producción y los negocios. Y cuando uno tiene que hacer negocio no solo tiene que buscar precio sino responsabilidad, así sino lo joden a muchos." (MÑ) 
las cualidades de varios de los productores que permanecieron viviendo en sus campos (por lo general, nombrados puntualmente) en el sentido de que están "muy bien organizados" y que no necesitan venir a la ciudad, o que logran altísimos rindes agrícolas gracias al cuidado que le dedican a sus labores; otro grupo de entrevistados calificaron a aquellos que siguieron en el campo como "conformistas"199, "de bajo nivel cultural" o "sin alternativas" por lo reducido de sus explotaciones, como para irse a la ciudad.

Ahora bien, no todos los productores han podido urbanizarse, y muchos de los que lo intentaron han tenido graves dificultades económicas, especialmente durante la década del noventa. La situación crítica ha abierto dos caminos: abandonar la explotación directa de los campos, entregándolos a contratistas tanteros, o regresar al campo, realizando una "retirada" en términos de lucha por la diferenciación social200.

La combinación de factores objetivos y subjetivos generó una dinámica de retroalimentación, ya que la mayoría de los determinantes se potenciaban entre sí. Ya

"... el caso del chacarero chico, de gente con poco nivel cultural, que lo que saben o lo que sabían era trabajar el campo y se entierra todo el día y no tenían mayor información, esa gente tendía a vivir encerrada, no eran los más eran los menos pero había, y esa gente solía ser sorprendida por el consignatario poco escrupuloso..." (OB)

199 "... esa gente [que vive en el campo]...conformista, ¿vio?... tiene su campito, su novillito, vende 50 compra otros 50 , y ahí están... No tiene el afán de progresar, de tener cada vez más novillos, de tener cada vez más campo. Hay mucha gente que son conformistas, subsisten, viven y van a estar 50 años y tienen lo mismo que hace 50 años atrás. Yo conozco una cantidad de amigos... el padre les dejó 500 hectáreas, 500 novillos, un autito y un tractor, y ahora tienen eso o uno menos tal vez, hay muchos que tienen algún novillo menos, tractores capaz que no tienen y conservan el autito. Mucha gente tiene menos que hace años y están conformes... Uno le ofrece un lote para sembrar y te dicen: 'no, no me compliqués la vida'." (LM)

200 "La exclusión del club de los ricos puede significar que no hay manera de ordenar una experiencia racional en un nivel más modesto del mismo universo. Para los ricos, las cosas también están en un continuo proceso de cambio. El precio del orden y la racionalidad para quienes ni son ricos, ni tienen en sus manos el control, ni se encuentran en posición de desafiar el control, es la retirada. Solo en una perspectiva apropiada y permanentemente pobre, pueden realizar sus evaluaciones sobre sí mismos y crear las condiciones de racionalidad económica limitada" (Douglas y Isherwood, 1990: 110). 
hemos descripto cómo la radicación urbana con el objetivo de asegurar una mejor educación para los hijos, permitió a los productores acceder a las comodidades de la vida en la ciudad, y éstas se convirtieron en una motivación muy fuerte para sostener la permanencia del productor allí, incluso cuando los hijos habían terminado sus estudios secundarios. Además, el abandono de la casa del campo obliga a que se realice una inversión importante en reparaciones (si se la quiere volver a habitar) ${ }^{\mathbf{2 0 1}}$, lo que se convierte en un obstáculo para la re-ruralización. También hemos analizado cómo la radicación en las ciudades abrió las puertas a una sociabilidad urbana que, a su vez, favoreció el acceso a mejores negocios agropecuarios. La propia mecanización había dejado más tiempo libre para la sociabilidad, pero al haberse mudado muchos productores a las ciudades, la sociabilidad rural se fue desvaneciendo, estimulando la radicación urbana de los que aún permanecían en el campo. La vida en la ciudad cambiaba el contexto de socialización primaria de los niños, alejándolos de un tránsito "natural" hacia la asunción de labores físicas en la explotación durante su adolescencia o su finalización. Esta nueva socialización y la mayor dotación de capital de los productores que pudieron mantenerse en pie, promovió un cambio de rol laboral hacia una actitud más gerencial... En fin, existieron varios fenómenos que se retroalimentaron sin que surgieran otros que lo frenaran.

Este proceso, llevado a un extremo, produjo problemas de reemplazo generacional: los hijos ya no querían asumir el rol de productores agropecuarios ("Al campo van las vacas", pensaba un joven productor cuando terminó su escuela secundaria a fines de los setenta ${ }^{202}$. En algunos casos, optaron por desvincularse completamente de la producción rural, arrendaron el campo y se convirtieron en rentistas $^{203}$. Este fenómeno ${ }^{204}$ pareciera darse con particular importancia en dos tipos de propietarios. Por un lado, se convirtieron en rentistas los dueños de parcelas tan

201 "... y ya una vez que te vas no volvés, porque la casa que tenés en el campo, más o menos buena, una vez que la abandonás se va deteriorando, allá para vivir de nuevo en el campo hay que hacer una casa nueva, encima que no era una buena construcción está que se viene abajo. Si uno quisiera dice: "los chicos ya se casaron, ahora nos vamos a vivir al campo"...pero tenés que hacer una casa nueva." (Mujer de FL)

${ }^{202}$ Coscia, a comienzos de los años ochenta, señalaba que la "formación profesional [...] en muchos casos contribuye a alejarlos del medio rural. Es así como muchos productores, cuyos hijos se orientaron a otras actividades, al llegar al final de su vida activa se ven obligados a arrendar su campo, hecho que está contribuyendo al proceso de concentración agrícola..." (Coscia, 1983: 107). 
pequeñas que no sólo no son viables de trabajar con maquinaria propia, sino que por sus reducidas dimensiones generan ingresos tan pequeños que sus titulares deben buscar otros empleos para poder mantenerse económicamente. Por otro lado, muchos de los propietarios que son a su vez profesionales no vinculados a la actividad agropecuaria, prefieren dedicarse de lleno a su profesión y no preocuparse con una explotación, por lo cual también la ceden en arriendo. En varios de los casos entrevistados, el hijo que se ha hecho cargo de la explotación es el que no quiso/pudo terminar una carrera universitaria.

Concientes del problema que la falta de socialización primaria en el campo genera para el reemplazo generacional, uno de nuestros entrevistados había enviado su hijo al campo, yéndose él y su mujer a la ciudad antes de lo que hubieran deseado: "hicimos un cambio, se fue el hijo allá y nosotros nos vinimos [a Tres Arroyos], porque también tiene que ir acostumbrándose a vivir allá [en el campo]" (ER).

Un factor disruptivo de este proceso de retroalimentación ha sido la reducción de ingresos por hectárea que se generó en los años noventa. Menores ingresos impidieron a muchos productores medianos continuar con el ritmo de vida urbana y con los gastos que éste traía aparejados ${ }^{\mathbf{2 0 5}}$. Por lo tanto, se generó una "vuelta al campo". Con ironía, un productor y veterinario de Tres Arroyos comentaba que para muchos productores "...

${ }^{203}$ No se ha generalizado la venta de las pequeñas parcelas, como sí ocurrió en el caso del agro norteamericano, tal como lo ha diferenciado Barsky (1992: 35-36).

${ }^{204}$ En las revistas agropecuarias el tema generó cierta alarma. Así, por ejemplo, a fines de los años setenta se sostenía que "los jóvenes agrarios pertenecen a ese sector insustituible que quiere vivir en el campo, trabajar la tierra y realizarse plenamente en el medio rural. Los jóvenes de las ciudades no van al campo. Los que se van del campo no vuelven a él. Poderosas razones de orden psicológico, económico y social, hacen que ello sea así. Aún más: el proceso del éxodo rural es creciente y al parecer irreversible por el momento. Ante este hecho evidente, la juventud agraria debería ser atendida y asistida en todas sus necesidades, desde que ella conforma el recurso humano que tiene el país -el único-, que asumirá en su momento la plenitud de la responsabilidad de la producción agropecuaria." En "Juventud Agraria: Reserva nacional", de Ernesto Rossi, El campo en marcha, Año XV, n $106,1977$.

205 Tal como se relata en el siguiente diálogo con la mujer de un productor de Tres Arroyos:

"[En los noventa] muchos levantaron sus casas acá [en Tres Arroyos] y se fueron a vivir al campo.

P: - ¿Por una cuestión de dinero? 
ahora 'es lindo andar en tractor'... Yo veo que ahora mucha gente anda en el tractor [...] hay mucha gente que nunca, jamás había andado y ahora anda. Y mucha gente que está volviendo al campo otra vez, muchas personas, conocidos, que se están volviendo con sus mujercitas al campo otra vez" (VP) ${ }^{206}$

Ahora bien, estos productores re-ruralizados no reproducen el mundo chacarero previo. Es "gente que vio otro mundo", y no vuelven al campo para vivir como sus abuelos. Así, por ejemplo, la mayoría no tiene producción para el autoconsumo, y los que la realizan la hacen de un modo muy acotado.

El modo de vida chacarero desapareció y el mundo rural de la primera mitad del siglo XX perdió su sustento subjetivo. Pero, además, en términos demográficos, esto significó el despoblamiento de los campos y la muerte de los pequeños pueblos y de los parajes rurales, tal como analizaremos en el siguiente apartado.

\section{El campo despoblado y los pueblos que desaparecen}

"En una época hubo una población, hubo hotel, estación de servicio... ahora no existe..."

En estrecha relación con la urbanización de los productores, tuvo lugar un intenso despoblamiento del campo en las tres zonas estudiadas. Tal como puede verse en el Cuadro 4.16, para 1991 quedaba en el campo de la zona norte solo el 29\% de la población que había en 1947; en la zona oeste sólo el 38\%, y en la zona sur el 41\%. Dicho de otro modo, si en 1947 había 97 habitantes cada 1.000 hectáreas en el campo de la zona norte, para 1991 sólo vivían 28 personas cada 1.000 hectáreas. En las otras

- Por cuestión económica, pienso, alguno se habrá ido por gusto, pero..., Sí, los que yo conozco es por cuestiones económicas, sacaron el gasto de la ciudad" (mujer de ME).

${ }^{206}$ El término "mujercitas" sugiere que esas mujeres antes no se rebajaban a vivir en el campo y que estaban totalmente desvinculadas de la actividad agropecuaria. 
dos zonas, si bien la reducción fue proporcionalmente menor, en términos absolutos quedó muy poca gente viviendo en los campos: de 24 habitantes cada 1.000 hectáreas que había en la zona oeste en 1947, sólo quedaron 9 para 1991, y en la zona sur esta reducción fue de 18 a 7 habitantes. 
Cuadro 4.16. Población "en el campo", 1947-1991

\begin{tabular}{|l|c|c|c|c|}
\hline & $\mathbf{1 9 4 7}$ & $\mathbf{1 9 9 1}$ & $\mathbf{1 9 4 7 - 1 9 9 1}$ & $\mathbf{1 9 4 7 - 1 9 9 1}$ \\
\hline zona Norte & 186.504 & 54.709 & -131.795 & $-71 \%$ \\
zona Oeste & 87.810 & 33.669 & -54.141 & $-62 \%$ \\
zona Sur & 96.620 & 39.765 & -56.855 & $-59 \%$ \\
\hline
\end{tabular}

Fuente: cálculos propios efectuados en base a la información de los Censos Nacionales de Población de 1947 y 1991, en este último caso a partir del análisis realizado por la Dirección Provincial de Estadística a partir de los informes por partido.

El campo no sólo se vació por la radicación urbana de los productores, ya que también intervinieron al menos otros tres fenómenos. En primer lugar, tal como vimos en los capítulos anteriores, la fuerte concentración de la producción redujo el número de explotaciones de un modo sustancial: entre un tercio y algo más de la mitad, según las zonas (ver Cuadro 4.17).

Cuadro 4.17. Cantidad de explotaciones censadas

\begin{tabular}{|l|c|c|c|}
\hline & $\mathbf{1 9 4 7}$ & $\mathbf{1 9 8 8}$ & Variación \\
\hline Zona norte & 22.572 & 10.478 & $-54 \%$ \\
\hline Zona oeste & 10.063 & 5.782 & $-43 \%$ \\
\hline Zona sur & 14.554 & 9.310 & $-36 \%$ \\
\hline
\end{tabular}

Fuente: Censos Agropecuarios de 1947 y 1988

Por otro lado, también incidió la reducción en el tamaño de las familias de los productores que continuaron viviendo en el campo. Si bien no contamos con datos censales que permitan corroborar esta transformación, las referencias bibliográficas son todas coincidentes en este sentido. Ya hemos transcripto los comentarios de Coscia (1983: 107) acerca de la reducción en el número de hijos a uno, dos o tres por familia. Por su parte Sánchez Albornoz (1985: 264) identificó que, para 1960, las pautas de natalidad estaban ya modernizadas. Por otra parte, según datos para el norte de Santa Fe, en 1920 el número promedio de hijos por cada productor agropecuario era de 11,4; para 1950 había declinado a 6,4, y para 1980 era de 3,5 (Stolen, 1996: 184). 
En tercer lugar, se redujo levemente la cantidad de asalariados permanentes en las explotaciones, entre el $18 \%$ y el $32 \%$ (ver Cuadro 4.18). Sin embargo, este último factor sólo puede explicar un ínfimo porcentaje de la reducción de la población que habitaba en el campo (ver última columna del mencionado cuadro).

Cuadro 4.18. Cantidad de asalariados permanentes

\begin{tabular}{|l|c|c|c|c|c|}
\hline & $\mathbf{1 9 3 7}$ & $\mathbf{1 9 6 9}$ & $\mathbf{1 9 8 8}$ & $\begin{array}{c}\text { Variación } \\
\mathbf{1 9 3 7 - 1 9 8 8}\end{array}$ & $\begin{array}{c}\text { Porcentaje } \\
\text { de la } \\
\text { reducción } \\
\text { poblacional }\end{array}$ \\
\hline Zona norte & 10.491 & 8.965 & 8.513 & $-19 \%$ & $1,5 \%$ \\
\hline Zona oeste & 11.879 & 10.308 & 9.709 & $-18 \%$ & $4 \%$ \\
\hline Zona sur & 16.383 & 12.282 & 11.079 & $-32 \%$ & $9 \%$ \\
\hline
\end{tabular}

Fuente: Censos Agropecuarios de 1937, 1969 y 1988.

Este extraordinario despoblamiento rural no fue acompañado por una disminución en la población total de las zonas, sino por su aumento (en la zona norte la población total de los partidos creció en un 49\% entre 1947 y 1991, en la zona oeste en un $9 \%$ y en la zona sur en un 18\%). Por lo tanto, esto implicó que la población "en el campo" perdió importancia relativa en el contexto zonal. Si al comienzo del período estudiado alrededor de la mitad de la población de las tres zonas se encontraba residiendo en el campo, para comienzos de los noventa sólo lo hacía un porcentaje marginal. Los residentes "en el campo" pasaron de representar el $46 \%$ de la población de la zona norte en 1947 a sólo el $9 \%$ en 1991, en la zona oeste del $51 \%$ al $18 \%$, y en la zona sur del 38 \% en 1947 cayó al $13 \%$ en 1991 (ver Cuadro 4.19, última fila). 
Cuadro 4. 19. Distribución porcentual de la población en cada zona, 1947 y 1991.

\begin{tabular}{|l|c|c|c|c|c|c|}
\hline & \multicolumn{2}{|c|}{ Zona norte } & \multicolumn{2}{c|}{ Zona oeste } & \multicolumn{2}{c|}{ Zona sur } \\
\hline & $\mathbf{1 9 4 7}$ & $\mathbf{1 9 9 1}$ & $\mathbf{1 9 4 7}$ & $\mathbf{1 9 9 1}$ & $\mathbf{1 9 4 7}$ & $\mathbf{1 9 9 1}$ \\
\hline Ciudades medianas & $32 \%$ & $60 \%$ & $14 \%$ & $27 \%$ & $28 \%$ & $47 \%$ \\
Cuidades pequeñas & $12 \%$ & $21 \%$ & $18 \%$ & $33 \%$ & $16 \%$ & $24 \%$ \\
Pueblos grandes & $5 \%$ & $5 \%$ & $5 \%$ & $9 \%$ & $12 \%$ & $11 \%$ \\
Pueblos chicos & $5 \%$ & $5 \%$ & $12 \%$ & $13 \%$ & $6 \%$ & $4 \%$ \\
“En el campo" & $46 \%$ & $9 \%$ & $51 \%$ & $18 \%$ & $38 \%$ & $13 \%$ \\
\hline
\end{tabular}

Fuente: cálculos propios efectuados en base a la información de los Censos Nacionales de Población de 1947 y 1991, en este último caso a partir del análisis realizado por la Dirección Provincial de Estadística a partir de los informes por partido.

Como se puede observar en ese mismo cuadro, las que crecieron fueron las ciudades ubicadas en los partidos estudiados. Las localidades que tenían más de 3.000 habitantes en 1947 crecieron en población en un 175\% en la zona Norte, en un 106\% en la zona Oeste y en un $89 \%$ en la zona Sur. En los Cuadros 4.20 a 4.22 puede observarse la desagregación entre ciudades medianas (con más de 10.000 habitantes en 1947) y ciudades pequeñas (de 3.000 a 10.000). Entonces, las ciudades mantuvieron hasta cierto punto el dinamismo demográfico, con tasas de crecimiento poblacional del 2,32\% anual para el período 1947-1991 en la zona norte -donde se incluyen las ciudades del cinturón industrial del Paraná-; del 1,66\% en la zona oeste, y del 1,46\% en la zona sur (excluyendo a la ciudad de Bahía Blanca). El ritmo de crecimiento fue similar al del conjunto del país (que presentó una tasa del 1,65\%), pero claramente inferior a la del Gran Buenos Aires (3,52\%).

En cambio, como consecuencia del proceso de urbanización de los productores, perdieron todo dinamismo los pequeños poblados, cuya vida dependía de los servicios que brindaban a los habitantes de los campos cercanos. Muy pocos productores optaron por establecer su residencia en estos pueblos, pues preferían claramente las ciudades cabeceras de partido. Entonces, la mayoría de las pequeñas localidades se estancaron, 
decrecieron o directamente desaparecieron ${ }^{207}$. Tuvieron esta evolución 96 de los 140 "pueblos" de las tres zonas estudiadas, es decir las localidades que en 1947 tenían menos de 3.000 habitantes. En los Cuadros 4.23 a 4.25 se detalla la evolución de cada una de las poblaciones de las tres zonas estudiadas.

En realidad, los que denominamos "grandes pueblos" (localidades de 1.000 a 3.000 habitantes en 1947) lograron mantener una dinámica de leve crecimiento poblacional. El número de sus habitantes aumentó en un $49 \%$ en la zona norte, un $83 \%$, en la zona Oeste, aunque sólo un $7 \%$ en la zona Sur. Por lo tanto, las tasas de crecimiento anuales fueron notoriamente inferiores a las del conjunto del país: $0,90 \%$ anual en la zona norte, $1,38 \%$ en la zona oeste, y $0,15 \%$ en la zona sur. Cabe destacar que en esta última zona, de los 16 pueblos grandes que había en 1947, sólo tres incrementaron su tamaño, mientras que seis se estancaron y siete decrecieron entre 1947 y 1991.

Por último, los "pueblos chicos" (localidades y parajes con menos de 1.000 habitantes en 1947) fueron las localidades más afectadas por el despoblamiento del campo, ya que dejaron de funcionar como centros de aprovisionamiento de los productores residentes en sus explotaciones. Estos "pueblos chicos" crecieron sólo un $30 \%$ en la zona norte, un $19 \%$ en la zona oeste y se redujeron un $2 \%$ en la zona sur. Esto significó tasas de crecimiento casi nulas en las dos primeras zonas (del 0,61\% anual y del $0,40 \%$, respectivamente) y una leve tasa negativa en la zona sur $(-0,05 \%)$. Corresponde aclarar que una gran cantidad de estos pequeños pueblos se estancaron o se redujeron, tal como se observa en los Cuadros 4.23 a 4.25. Por otra parte, un buen número de pueblos pequeños directamente no fueron registrados por el censo de 1991, en muchos casos seguramente por haber quedado con muy pocos o ningún habitante (la

${ }^{207}$ En el estudio publicado por el CEAL ya encontramos detectado este fenómeno de declinación de los pueblos en favor de las ciudades:

"Así, en la década del sesenta comienza a esfumarse ese semillero de pequeños pueblos de campaña [cuya descripción hemos reproducido en el primer apartado]... La decadencia de estos pueblos es ya irreversible, el yuyal invade sus calles de tierra mientras las hierbas crecen entre los ladrillos cementados con barro de las viejas casonas abandonadas. En la era de la mecanización y motorización de las labores del campo, en la era del auge del automotor, se revitalizan en cambio los pocos centros originariamente mejor dotados, cuyo radio de influencia se duplica y en ciertos casos se proyecta hasta distancias hasta ayer insospechadas." (Cammarata y otros, 1975: 152) 
publicación provincial con los datos por localidad del censo de 1991 es particularmente detallada).

Una tesis que analiza la evolución de las localidades de menos de 2.000 habitantes entre 1980 y 1991, detalla que de las 270 poblaciones que fueron descriptas por ambos censos en la provincia de Buenos Aires, 132 presentaron una reducción en el número de sus habitantes en este lapso intercensal (Benítez Martínez, 1998: 92). También brinda otros datos agrupados a nivel regional, donde puede observarse que alrededor de la mitad de las localidades que se redujeron demográficamente en la región pampeana tenían entre 80 y 399 habitantes, un tercio de ellas entre 400 y 1.999, y sólo un 20\% menos de 80 habitantes (Benítez Martínez, 1998: 119), aunque debemos recordar que el censo de 1980 no registró a muchas pequeñas localidades.

Cuadro 4.20. Población en la zona Norte según su localización, 1947 y 1991.

\begin{tabular}{|l|c|c|c|}
\hline & $\mathbf{1 9 4 7}$ & $\mathbf{1 9 9 1}$ & variación \\
\hline Ciudades grandes & 131.522 & 362.963 & $+176 \%$ \\
Ciudades pequeñas & 48.038 & 130.559 & $+172 \%$ \\
Pueblos grandes & 20.754 & 30.834 & $+49 \%$ \\
Pueblos pequeños & 21.185 & 28.113 & $+33 \%$ \\
Pueblos desapar. & 484 & - & \\
Pueblos nuevos & - & 146 & $-71 \%$ \\
"En el campo" & 186.504 & 54.709 & \\
& & & $+49 \%$ \\
Total & 408.487 & 607.324 & \\
\hline
\end{tabular}

La población del conjunto de los partidos en 1938 era de 407.706 habitantes.

Fuente: cálculos propios efectuados en base a la información de los Censos Nacionales de Población de 1947 y 1991, en este último caso a partir del análisis realizado por la Dirección Provincial de Estadística a partir de los informes por partido. 
Cuadro 4.21. Población en la zona Oeste según su localización, 1947 y 1991.

\begin{tabular}{|l|c|c|c|}
\hline & $\mathbf{1 9 4 7}$ & $\mathbf{1 9 9 1}$ & variación \\
\hline Ciudades grandes & 23.582 & 49.915 & $+117 \%$ \\
Ciudades pequeñas & 30.878 & 62.309 & $+102 \%$ \\
Pueblos grandes & 8.879 & 16.202 & $+83 \%$ \\
Pueblos pequeños & 17.659 & 24.060 & $+36 \%$ \\
Pueblos que & 2.991 & - & \\
desaparecen & & 514 & $-62 \%$ \\
Pueblos nuevos & - & 33.669 & \\
"En el campo" & 87.810 & & $+9 \%$ \\
\hline
\end{tabular}

La población del conjunto de los partido en 1938 era de 195.564 habitantes, reduciéndose en un $12 \%$ entre esa fecha y 1947.

Fuente: cálculos propios efectuados en base a la información de los Censos Nacionales de Población de 1947 y 1991, en este último caso a partir del análisis realizado por la Dirección Provincial de Estadística a partir de los informes por partido.

Cuadro 4.22. Población en la zona Sur según su localización, 1947 y 1991.

\begin{tabular}{|l|c|c|c|}
\hline & $\mathbf{1 9 4 7}$ & $\mathbf{1 9 9 1}$ & variación \\
\hline Ciudades grandes & 71.781 & 140.961 & $+96 \%$ \\
Ciudades pequeñas & 41.674 & 73.268 & $+76 \%$ \\
Pueblos grandes & 30.975 & 33.150 & $+7 \%$ \\
Pueblos pequeños & 13.609 & 13.499 & $-1 \%$ \\
Pueblos que & 1.252 & - & \\
desaparecen & & 1.050 & $-59 \%$ \\
Pueblos nuevos * & - & 39765 & \\
"En el campo" & 96.620 & & $+18 \%$ \\
Total & & 301.693 & \\
\hline
\end{tabular}

* La mayor parte de los pueblos nuevos en esta zona son pequeñas localidades balnearias.

La población del conjunto de partidos en 1938 era de 259.820 habitantes, reduciendose en un 1,5\% entre esa fecha y 1947.

Fuente: cálculos propios efectuados en base a la información de los Censos Nacionales de Población de 1947 y 1991, en este último caso a partir del análisis realizado por la Dirección Provincial de Estadística a partir de los informes por partido. 
Cuadro 4.23. Localidades de la zona Norte, evolución entre 1947 y 1991.

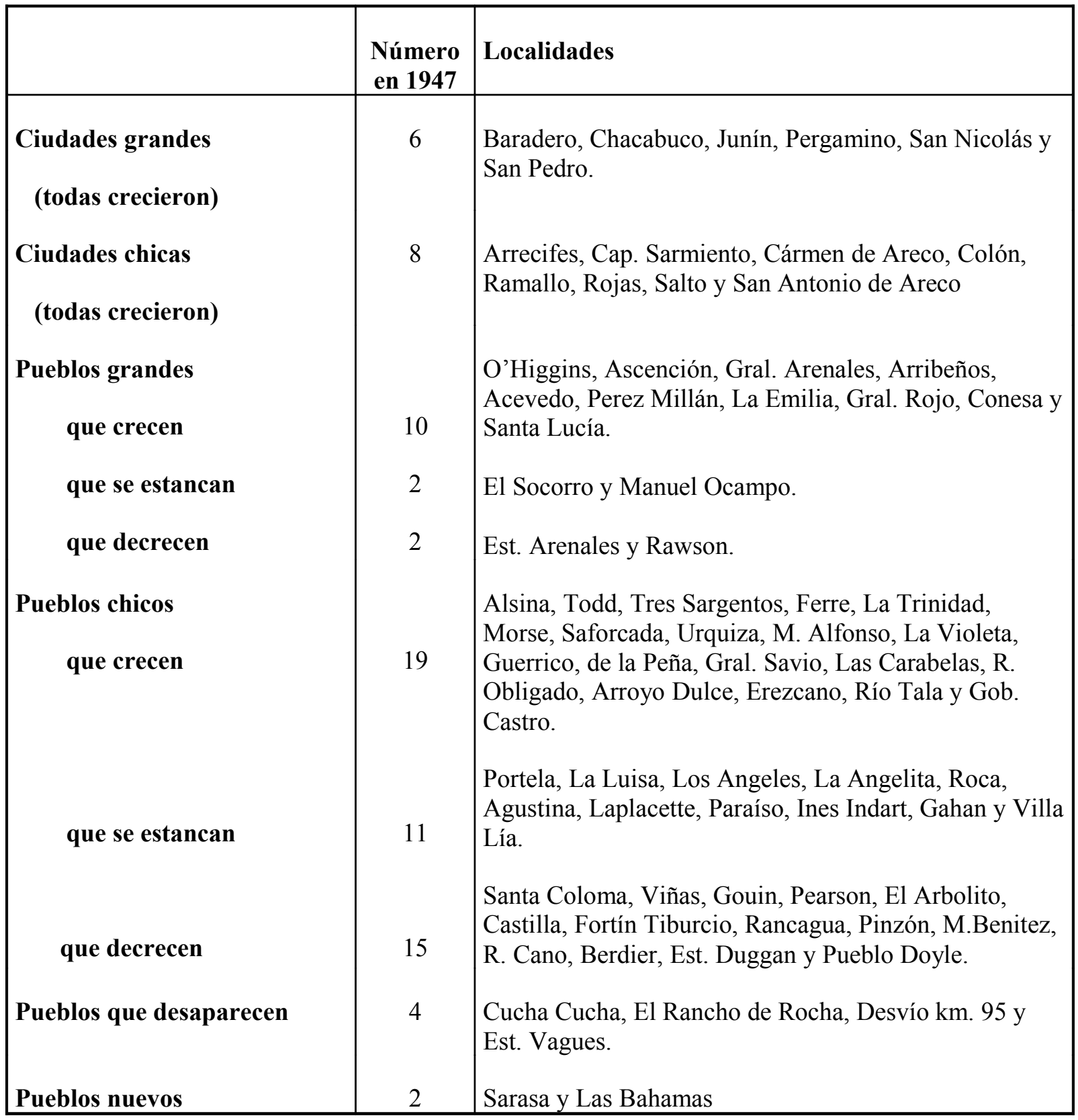

Fuente: cálculos propios efectuados en base a la información de los Censos Nacionales de Población de 1947 y 1991, en este último caso a partir del análisis realizado por la Dirección Provincial de Estadística a partir de los informes por partido. 
Cuadro 4.24. Localidades en la zona Oeste, evolución entre 1947 y 1991.

\begin{tabular}{|c|c|c|}
\hline & $\begin{array}{l}\text { Número } \\
\text { en } 1947\end{array}$ & Localidades \\
\hline $\begin{array}{l}\text { Ciudades grandes } \\
\text { (todas crecieron) }\end{array}$ & 2 & Lincoln y Trenque Lauquen \\
\hline $\begin{array}{l}\text { Ciudades chicas } \\
\text { (todas crecieron) }\end{array}$ & 9 & $\begin{array}{l}\text { Carlos Tejedor, Gral. Pinto, Ameghino, Gral. Villegas, } \\
\text { Vedia, Pellegrini, Tres Lomas, Salliqueló y América. }\end{array}$ \\
\hline Pueblos grandes & & \\
\hline $\begin{array}{l}\text { que crecen } \\
\text { que se estancan }\end{array}$ & 6 & $\begin{array}{l}\text { Tres Algarrobos, Germania, J.B. Alberdi, Pasteur, } \\
\text { González Moreno y } 30 \text { de Agosto. }\end{array}$ \\
\hline que decrecen & - & \\
\hline $\begin{array}{l}\text { Pueblos chicos } \\
\text { que crecen }\end{array}$ & 17 & $\begin{array}{l}\text { Sere, Cararu, Granada, Iriarte, Blaquier, Banderaló, } \\
\text { V.Sauce, Emilio Bunge, Piedritas, Santa Regina, L.N. } \\
\text { Alem, Roberts, Arenaza, M.de Hoz, El Triunfo, } \\
\text { Queroma y Roosvelt. }\end{array}$ \\
\hline que se estancan & 6 & $\begin{array}{l}\text { El Porvenir, V.Saboya, Sansinena, Fortín Olavarría, } \\
\text { Berruti e Ing. Thompson. }\end{array}$ \\
\hline que decrecen & 13 & $\begin{array}{l}\text { Timote, V.Roth, El Dorado, Fortín Acha, Bajauca, } \\
\text { Carlos Salas, Bocayuva, De Barry, San Mauricio, } \\
\text { Sunblad, Mira Pampa, Girodias y La Carreta. }\end{array}$ \\
\hline Pueblos que desaparecen & 9 & $\begin{array}{l}\text { Santa Inés, Esteban de Luca, Husares, Elordi*, Santa } \\
\text { Eleudora*, Charlone*, Cañada Seca*, Bermudez y } \\
\text { Triunvirato. }\end{array}$ \\
\hline Pueblos nuevos & 3 & Est. Gunther, Pichincha y Las Toscas. \\
\hline
\end{tabular}

Fuente: cálculos propios efectuados en base a la información de los Censos Nacionales de Población de 1947 y 1991, en este último caso a partir del análisis realizado por la Dirección Provincial de Estadística a partir de los informes por partido. 
Cuadro 4.25. Localidades en la zona Sur, evolución entre 1947 y 1991.

\begin{tabular}{|c|c|c|}
\hline & $\begin{array}{l}\text { Número } \\
\text { en } 1947\end{array}$ & Localidades \\
\hline $\begin{array}{l}\text { Ciudades grandes } \\
\text { (todas crecieron) }\end{array}$ & 4 & Pringles, Coronel Suárez, Necochea y Tres Arroyos. \\
\hline $\begin{array}{l}\text { Ciudades chicas } \\
\text { (todas crecieron) }\end{array}$ & 8 & $\begin{array}{l}\text { González Chaves, Dorrego, Lobería, Quequén, San } \\
\text { Cayetano, Púan, Pigüé y Tornquist**. }\end{array}$ \\
\hline Pueblos grandes & & \\
\hline que crecen & 3 & Huangelén, La Dulce y Darragueira. \\
\hline que se estancan & 6 & $\begin{array}{l}\text { Oriente, Cnia. San José, Cnia. Santa María, Saavedra, } \\
\text { Saldungaray y Orense. }\end{array}$ \\
\hline que decrecen & 7 & $\begin{array}{l}\text { Guisasola, Indio Rico, Juan N. Fernandez, } \\
\text { Santamarina, Villa Iris, Bordenave y Copetonas. }\end{array}$ \\
\hline Pueblos chicos & & \\
\hline que crecen & 8 & $\begin{array}{l}\text { De la Garma, Cnia. Santa Trinidad, V.Arcadia, San } \\
\text { Manuel, Espartillar, Sierra de la Ventana*, Chasicó* y } \\
\text { Claromecó* }\end{array}$ \\
\hline que se estancan & 3 & Juan E.Barra, Aparicio y Claraz. \\
\hline que decrecen & 24 & $\begin{array}{l}\text { Faro, Irene, El Divisorio, El Pensamiento, Pasman, } \\
\text { Curamalal Cascada, Tamangueyu, Felipe Solá, } 17 \text { de } \\
\text { Agosto, San Germán, Lepez Lecube, Azopardo, } \\
\text { Estela, Erize, Goyena, Arroyo Corto, Dufaur, Tres } \\
\text { Picos, Cascallares, San Mayol, San Francisco de B. y } \\
\text { Ochandio. }\end{array}$ \\
\hline Pueblos que desaparecen & 11 & $\begin{array}{l}\text { Gil, Descalzi, Las Mostazas, Quinihual, V.Belgrano, } \\
\text { San José, Defferrari, Lumb, Barrow, La Sortija y Lin } \\
\text { Calel. }\end{array}$ \\
\hline Pueblos nuevos & 20 & $\begin{array}{l}\text { San Román, La Ruta, Marisol*, Sauce Grande*, } \\
\text { Caballeros*, Lartigau, D’Orbigny, Pieres, Matienzo, } \\
\text { Costa Bonita*, Energía, Baln.San Cayetano*, } \\
\text { V.Ventana*, La Gruta*, Dique Paso P., Encantada, } \\
\text { Reta*, V.Rodriguez, Dunamar* y Baln.Orense*. }\end{array}$ \\
\hline
\end{tabular}

* Pueblos de clara orientación turística.

** Tornquist en 1947 tenía 2.782 habitantes, pero incluimos esta localidad entre las ciudades pequeñas por su condición de cabecera de partido y su población muy cercana a los 3.000 habitantes.

Los "pueblos nuevos" son casi todos de carácter turístico o sino muy pequeños (por lo cual probablemente por ello no fueron registrados en 1947).

Fuente: cálculos propios efectuados en base a la información de los Censos Nacionales de Población de 1947 y 1991, en este último caso a partir del análisis realizado por la Dirección Provincial de Estadística a partir de los informes por partido. 
Para analizar las variaciones intercensales 1947-1960-1970-1980-1991 tenemos que unificar los habitantes de los "pueblos pequeños" con los residentes "en el campo", ya que no todos los censos discriminaron exhaustivamente a las localidades que tenían menos de 1.000 habitantes en $1947^{208}$.

Como podemos observar en el Gráfico 4.1, en la zona norte las "grandes” y las "pequeñas ciudades" crecieron de un modo intenso y continuo durante todo el período. Los "pueblos grandes" tuvieron un lento crecimiento, mientras que decreció drásticamente la población de los "pueblos pequeños" y la residente "en el campo". Más de la mitad de la reducción de la población de este estrato tuvo lugar entre 1947 y 1960.

En la zona oeste, las "ciudades grandes", que no son tan significativas como en las otras dos zonas, crecieron en forma continua durante todo el período, y las "ciudades pequeñas" lo hicieron sobre todo a partir de 1960 (ver Gráfico 4.2). Los "pueblos grandes" se mantuvieron prácticamente estancados, a excepción de un pequeño crecimiento entre 1970 y 1980. La población ubicada en “pequeños pueblos" y "en el campo" tuvo una reducción muy importante, que fue más drástica aun entre 1947 y 1960. También aquí más de la mitad de la reducción de este estrato se desarrollo en entre estos años.

En la zona sur, las "grandes ciudades" crecieron de forma intensa y continua. Las “ciudades pequeñas" crecieron a partir de 1960 (y especialmente durante la década del sesenta). Los "pueblos grandes" han estado estancados, mientras que la población ubicada en "pequeños pueblos" y "en el campo" se redujo constantemente, pero sobre todo durante los años sesenta (cuando parece haber habido un traslado de población más intenso del campo hacia las ciudades). A diferencia de las otras dos zonas, en el Sur la mayor reducción de la población en este último estrato no tuvo lugar entre 1947 y 1960 , sino en el período intercensal siguiente (ver Gráfico 4.3).

208 Sí lo hicieron, en cambio, con las localides que tenían más de 1.000 habitantes en 1947. Tan sólo una localidad de este tamaño por cada zona no fue registrada en el censo de 1970: Estación Arenales en la zona Norte, Pasteur en la zona Oeste y Santamarina en la zona Sur. Hemos ignorado esta falencia. 


\section{Gráfico 4.1}

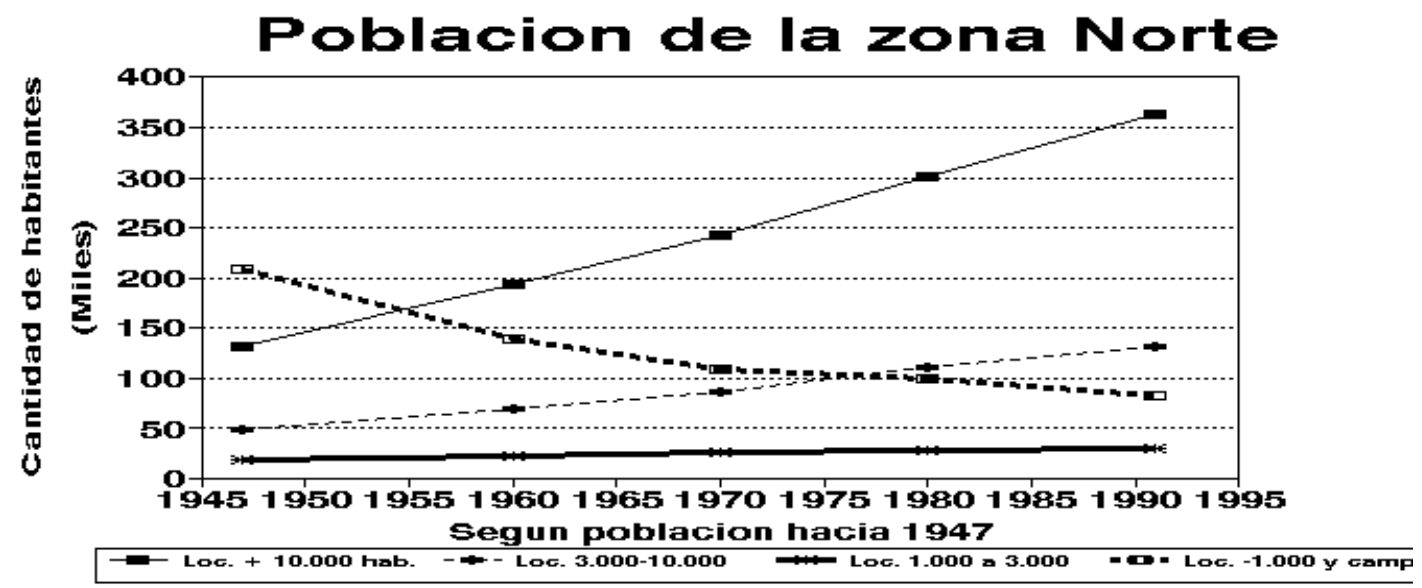

Fuente: cálculos propios efectuados en base a la información de los Censos Nacionales de Población de 1947, 1960, 1979, 1980 y 1991, en este último caso a partir del análisis realizado por la Dirección Provincial de Estadística a partir de los informes por partido.

\section{Gráfico 4.2}

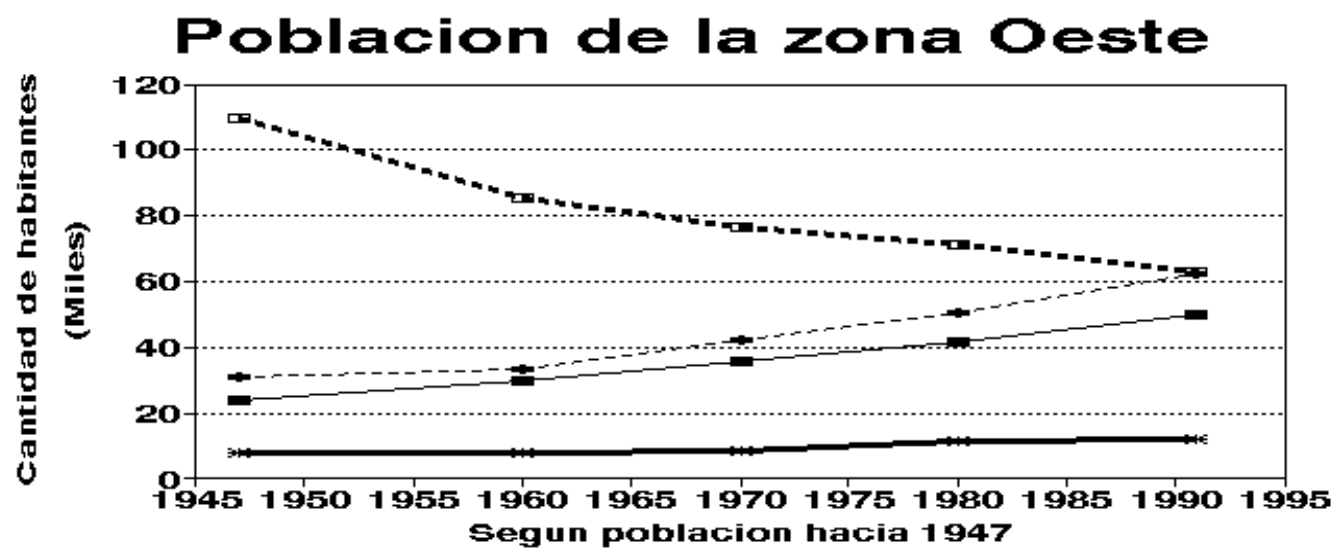

- O - Loc. -1.000 y Gampo

Fuente: cálculos propios efectuados en base a la información de los Censos Nacionales de Población de 1947, 1960, 1979, 1980 y 1991, en este último caso a partir del análisis realizado por la Dirección Provincial de Estadística a partir de los informes por partido. 


\section{Gráfico 4.3}

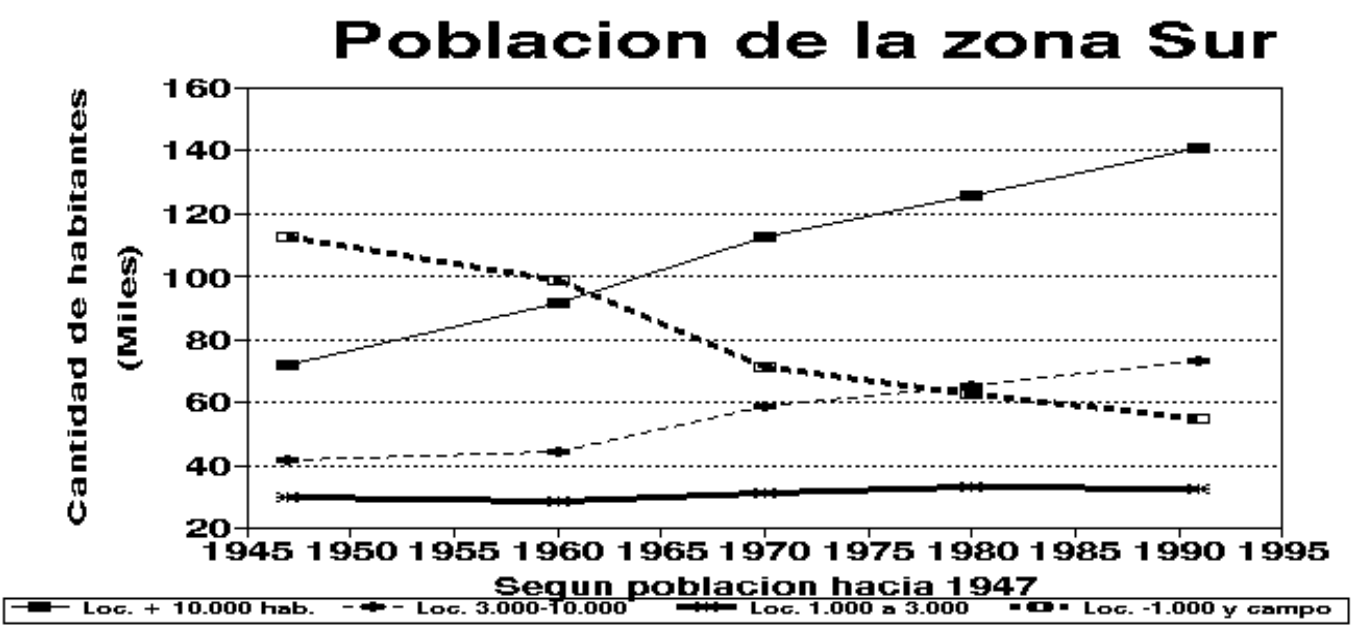

Fuente: cálculos propios efectuados en base a la información de los Censos Nacionales de Población de 1947, 1960, 1979, 1980 y 1991, en este último caso a partir del análisis realizado por la Dirección Provincial de Estadística a partir de los informes por partido.

Según los relatos, los pequeños poblados recibieron dos fuertes golpes: la declinación del transporte ferroviario (e incluso, en varios casos, el levantamiento de las vías férreas) ${ }^{\mathbf{2 0 9}}$, y el desarrollo de caminos asfaltados. Estos últimos, si bien habían sido un reclamo de los habitantes de las pequeñas localidades, tuvieron como efecto el acercar a los productores a los centros urbanos, disminuyendo el uso de los servicios radicados en los pueblos ${ }^{\mathbf{2 1 0}}$. Algunos indicadores permiten afirmar que no sería un problema de acceso a los servicios básicos (como la escuela primaria, la telefonía o la televisión) lo que generó el despoblamiento ${ }^{211}$.

209 El análisis de las localidades de menos de 2.000 habitantes de la región pampeana que redujeron su población entre 1980 y 1991 muestra que un tercio habían tenido ferrocarril, pero que ya no lo tenían, un $22 \%$ continúan teniéndolo, y que algo menos de la mitad nunca había contado con este medio de transporte (Benítez Martínez, 1998: 132).

210 De todos modos, cabe aclarar que algo más de la mitad de los pueblos que redujeron su población entre 1980 y 1991 en la región pampeana, no contaban con acceso asfaltado (Benítez Martínez, 1998: 120). Lamentablemente, el análisis dejó fuera a los pueblos que no decayeron, por lo cual es imposible medir el efecto de los diferentes factores y pasar de un nivel descriptivo a uno explicativo.

${ }^{211}$ La totalidad de los pueblos pampeanos en los que se redujo la población entre 1980 y 1991, contaban con escuela primaria (incluso el 10\% tenían secundaria), el $72 \%$ poseían telefonía y el $87 \%$ televisión abierta o por cable (elaboración propia a partir de los datos de Benítez Martínez, 1998) 
Lo cierto es que en un par de décadas algunos parajes quedaron totalmente deshabitados. Así por ejemplo, dos productores describieron La Sortija (una localidad ubicada en el Norte de Tres Arroyos):

"Ahora en La Sortija quedan uno o dos ranchitos. Nunca fue una población importante, había varias casas, dos almacenes, la escuela, un club que lo hicimos entre todos." (OF)

"En una época hubo una población, hubo hotel, estación de servicio..., ahora no existe [...] [Se murió] entre el '70 y el ' 80 , entre el '70 y el '75, te diría. Esos pueblos vivían del tren, que era el que llevaba y traía hacienda y cereales, y de la cosecha, precisamente cuando se cosechaba en bolsa, porque hay brutos galpones del ferrocarril donde se metía en bolsa. Donde se generalizó todo lo que es la cosecha a granel, los camiones para transporte, se muere el pueblo." (GN)

O esta descripción de la evolución de Valentín Gómez, en el partido de Rivadavia:

"Valentín Gomez, es un pueblo que está... no es pueblo... ahora no existe nada. Cuando yo fui había dos almacenes, y antiguamente había telégrafo, era cruce de vía, uno hoy lo dice y no lo pueden creer... No existe ni vía, después de la inundación no quedó nada en Valentín, se levantaron también las casas de los ferroviarios, nada, los almacenes se deshicieron, no hay nada." (MD)

Los pueblos de un tamaño mayor han logrado sobrevivir, con suerte diversa, pero encontrándose cada vez más distantes del desarrollo de las ciudades de la zona. Hourcade (1999) afirma que habría habido un estancamiento o retroceso en la vida cultural y social de muchas de estas ciudades pampeanas. Personalmente nos ha resultado muy fuerte el contraste entre las descripciones de la vida pueblerina en los años veinte que recogimos de nuestros entrevistados, y la imagen que pudimos observar de los mismos pueblos en los años noventa. Un interesante indicio de la percepción de lo irreversible del proceso ya en los años sesenta, es un artículo de una revista agropecuaria que propone rearmar los pueblos pampeanos. Por entonces, ya se evidenciaba que la planta urbana de dichos pueblos, diseñada en general a comienzos del siglo XX para un porvenir de crecimiento ilimitado, resultaba totalmente desproporcionada. De allí la propuesta de reacomodar la planta a esta situación de 
estancamiento, agrupando las viviendas en unas pocas manzanas a fin de evitar encarecimientos innecesarios de la red de $\operatorname{servicios}^{212}$.

Entonces, con la radicación urbana de los productores no sólo se despobló el campo, sino que fueron desapareciendo las pequeñas localidades que vivían de las demandas de consumo de bienes y servicios a los habitantes del campo, y perdieron dinamismo incluso los pueblos de mayor tamaño. De este modo, todo el mundo chacarero que se había construido entre fines del siglo XIX y 1930, con sus luces y sus sombras, se desvaneció casi por completo.

El acceso a la propiedad por parte de los chacareros medianos, en vez de consolidar ese mundo rural, fue paradójicamente otro elemento más entre un complejo conjunto de factores que contribuyó a disolverlo. Entonces quedó un paisaje asombrosamente vacío, que se puebla únicamente durante el día con los productores, los trabajadores asalariados y los contratistas que se trasladan a realizar las labores específicas desde las ciudades.

Hemos podido ver la forma en que la modificación en el modo de vida de los productores cambió la organización social del trabajo en las explotaciones. En el siguiente y último capítulo, plantearemos algunas hipótesis acerca de las relaciones entre las transformaciones en el modo de vida y en el carácter social de los productores, las formas sociales de producción y el modelo de desarrollo agrario de la región pampeana durante la segunda mitad del siglo XX.

212 "Poblaciones rurales: su presente y su futuro", por E. Alberto Ringuelet, La Chacra, 318, mayo de 1957; pp. 108-110. 
Reflexiones finales

Algunas hipótesis acerca de la relación entre los cambios en el modo de vida, las formas sociales de producción y las vías de desarrollo del capitalismo en el agro pampeano 


\section{Cambios estructurales, modo de vida, carácter social y formas de producción}

Consideramos que los cambios en el modo de vida de los productores medios (entendidos éstos en un sentido amplio del término ${ }^{1}$ ) tuvieron una fuerte incidencia sobre las formas sociales de producción en la agricultura bonaerense. Hemos encontrado que no pueden inferirse estas formas a partir sólo de los datos estructurales con los que usualmente se han organizado los estudios sobre el agro regional (la tenencia del suelo y el tamaño de las explotaciones, y, a veces, los bienes de capital), ya que con las mismas dotaciones de estos recursos podían constituirse formas sociales de producción diferentes. En particular para fines de la década de 1980, la mayoría de los productores medianos presentaban una dotación de recursos semejante a la de un farmer norteamericano: tenían la propiedad de la tierra (en muchos casos combinada con tierras en arriendo, del mismo modo que los farmers), un importante parque de maquinarias y una explotación de un tamaño considerable (en general, bastante más grandes que las del Corn Belt ${ }^{2}$ ), pero que podían ser trabajada por unos dos hombres, es decir, por la mano de obra de una familia promedio. Sin embargo, a pesar de estas semejanzas estructurales, no resulta correcto conceptualizar a la mayoría de los medianos productores bonaerenses de fines de los años ochenta como "farmers". Al menos si este concepto evoca a productores a cargo de unidades basadas en la fuerza de trabajo familiar (con nulo o escaso aporte de mano de obra asalariada). Menos aun, si también agregamos, al concepto de farmer, el requisito de que la familia se organice como un equipo de producción y que presente una racionalidad sustantiva en torno a la preservación de la explotación y a mantenerse como actores relativamente "independientes" -en el sentido de no tener un patrón-, según el análisis de Mooney (1988) que comentáramos en el capítulo anterior.

1 Esto es, dejando por debajo a los productores minifundistas, o pequeños productores con ingresos no muy superiores a un asalariado rural, y por encima a los productores capitalistas que utilizan cinco o más asalariados o que trabajan con contratistas de servicios superficies similares a estos últimos.

2 Incluso cotejando sólo las unidades de la zona norte bonaerense con las de los estados típicos del Corn Belt (Illinois y Iowa), observamos diferencias significativas: en 1988 el tamaño medio en la zona norte era 176 hectáreas, mientras que en Illinos era de 139 y en Iowa de sólo 122 hectáreas. 
Sobre la categoría de farmer necesitamos realizar una breve digresión teórica. Esta es una particular forma social de producción dentro de la producción mercantil simple (PMS) ${ }^{3}$. Un caso particular, no sólo porque produce alimentos (y en este sentido podría tener relativamente resuelta su subsistencia alimentaria, a diferencia de un artesano), sino porque posee la propiedad de la tierra y el productor se convierte, entonces, en perceptor de renta capitalista del suelo. Además, farmer supone una "family farm". Si bien es cierto que el concepto de producción mercantil simple no implica al de familia, ambos se articulan en el de "empresa familiar"4. Como to ha desarrollado Friedmann (1986a y 1986b), ésta no es una relación en la que estén ausentes las tensiones: históricamente la familia ha sido un lugar de dominación y subordinación patriarcal. Pero, para sus miembros, independizarse de la familia (y de la propiedad familiar) puede significar caer bajo la dependencia del capital (proletarizarse). De hecho, las empresas familiares mercantiles contienen dos relaciones contradictorias: una entre valor y familia, y la otra entre propiedad y trabajo. La primera remite a que el valor crea las bases para el cálculo (de "ganancia" para la empresa y de "salarios" para los individuos), y opone estos cálculos a los lazos emocionales y las obligaciones tradicionales propias de la familia. La segunda contradicción surge de que, en el capitalismo, la propiedad permite una relativa "independencia", en el sentido de no necesitar de un empleo asalariado, aunque a veces genere grandes demandas de energía y sacrificios en el estándar de vida de sus dueños. La interacción entre estas dos relaciones contradictorias genera una inusual indeterminación de las conductas individuales en las formas mercantiles simples dentro del capitalismo (Friedmann, 1986b: 53).

Por otra parte, en una economía capitalista es muy difícil que se sostenga la producción mercantil simple sin una base familiar (y las esperanzas de heredar la unidad) que permita soportar las privaciones y exigencias laborales habitualmente necesarias para mantener competitiva a este tipo de unidades de producción ${ }^{5}$. Pero, al

3 Sobre el concepto de producción mercantil simple aplicado al caso rural, consultar Friedmann (1980) y Byres (1996).

4 De hecho la unión entre unidad de producción, lugar de residencia y parentesco, históricamente ha sido muy anterior a la PMS, aunque debe evitarse conceptualizar esta situación como "natural" (Friedmann, 1986b: 49).

5 Berteaux y Bertaux-Wiame (1993) lo han analizado para el caso de las panaderías francesas: sólo su carácter estrechamente familiar, con el hombre trabajando extensas jornadas, a partir 
mismo tiempo, el desarrollo del capitalismo genera una presión sobre la PMS, no sólo por la propia competencia a que la someten las unidades típicamente capitalistas (con sus economías de tamaño), sino porque va minando las bases de sustentación del patriarcalismo, al punto en que puede dislocar a la empresa familiar. La opción del trabajo individualizado asalariado, y la presión sobre la dominación patriarcal (el poder paterno, legal y práctico, se ha reducido al valorarse al individuo y al cálculo económico) le han hecho difícil a las empresas pequeñas mantener su carácter familiar.

Sin embargo, en muchos casos históricos, dentro de las economías capitalistas más avanzadas, se ha recreado el lazo familiar, con un patriarcalismo distinto (no siempre menor, aunque por lo general menos autoritario), y la unidad continua funcionando de un modo relativamente exitoso ${ }^{6}$. De hecho esto ha ocurrido en algunas ramas de la producción secundaria y el sector servicios que continúan bajo una producción artesanal, pero especialmente en la producción agrícola de los países desarrollados.

No ha sido éste el caso en la región pampeana. Aquí parecieran haberse desplegado los elementos disolventes sobre la empresa familiar al punto que, con la urbanización, la familia se desvinculó del proceso productivo (abandonándose la producción para autoconsumo) y las labores quedaron a cargo de asalariados o fueron terciarizadas.

Claramente ya no son unidades de producción mercantil simple. El "aburguesamiento" bloqueó la consolidación de una forma social de producción farmer. En este proceso, no habría sido tan importante el desplazamiento de la PMS por parte de las unidades capitalistas, sino la transformación de las PMS basadas en el arriendo, en unidades en propiedad con rasgos más capitalistas (aunque difíciles de conceptualizar por varias cuestiones vinculadas con la propiedad de la tierra y la continuidad de ciertas asociaciones entre familia y empresa que analizaremos más adelante).

de la noche, y la mujer atendiendo durante el día, le permite a esta forma artesanal pervivir en medio del capitalismo.

$6 \quad$ Friedmann afirma que, sin negar y criticar los efectos del patriarcalismo y la propiedad, la familia y la PMS pueden ser, junto con la comunidad, la vecindad y la amistad, las bases para ideas y prácticas basadas en principios más humanistas que los de las relaciones meramente comerciales del capitalismo (Friedmann, 1986b: 55). 
La clave de esta discontinuidad como PMS podemos ubicarla en la pérdida de su carácter familiar y, como vimos en el capítulo anterior, esta pérdida se encuentra estrechamente relacionada con la urbanización y el cambio en el modo de vida de los productores medios ${ }^{7}$. Por lo tanto, el cambio en el modo de vida de los productores medios produjo sustanciales modificaciones en aspectos claves de las formas sociales de producción predominantes en la agricultura bonaerense, como la organización social del trabajo y la producción para el autoconsumo.

Siempre cabe la posibilidad de invertir el orden causal de esta asociación: pensar que la disolución de la familia como equipo de producción, el abandono del autoconsumo y la asalarización o terciarización de las labores fueron las que generaron la urbanización y/o la transformación en el modo de vida ${ }^{8}$. Sin embargo, encontramos que las unidades mantenían su carácter familiar hasta el momento de que sus integrantes se fueron a vivir a la ciudad. Así, todavía el productor realizaba la mayor parte de las tareas físicas, y la mujer y los hijos continuaban realizando las actividades de autoconsumo (aunque en menor escala que al comienzo del período). En casi todos los casos recién cuando se establecieron en la ciudad, se abandonó esta producción, se redujo el aporte de trabajo del productor y el trabajo físico quedó en su mayor parte a cargo de un peón permanente.

Reconocer el impacto del modo de vida sobre las formas sociales de producción, no implica negar la importancia de la incidencia de los cambios estructurales ocurridos durante las décadas en estudio, tales como el acceso a la propiedad de la tierra, el incremento en las extensiones controladas y la sustancial mecanización de aquellos productores que lograron sobrevivir a los procesos de concentración. En primer lugar, estas cuestiones constituyen dimensiones básicas de las formas sociales de producción. Pero, además, fueron estos cambios en las relaciones con los medios de producción los

7 También puede haber jugado un papel, especialmente en el caso de las unidades más pequeñas, la opción laboral que reforzaba la individualización de los hijos, generada por la demanda de las industrias ubicadas en el Gran Buenos Aires y en el cordón litoral del Paraná.

8 No podemos negar que esto puede haber sido así en algunos casos. 
que, en última instancia, posibilitaron la transformación en el modo de vida $y$, de este modo, también indirectamente incidieron sobre dichas formas.

Para pensar las vinculaciones entre estas dimensiones, proponemos la hipótesis de que tuvo lugar una modificación en el carácter social ${ }^{9}$ de los productores medios y que estos cambios operaron como mediación entre las transformaciones en las formas de tenencia del suelo y el proceso de mecanización/capitalización de los productores medios, por un lado, y los modos de vida de los productores, por el otro.

No hemos efectuado un sociopsicoanálisis de los productores, por cierto, muy difícil de realizar de modo restrospectivo y que, además, escapa a nuestra formación académica. Sin embargo, al desarrollar las entrevistas en profundidad hemos observado notorias diferencias entre los rasgos de carácter de los entrevistados de mayor edad y los de aquellos más jóvenes. Por otro lado, nos era evidente que las actitudes que tenían los productores durante las primeras décadas del siglo XX -según los mismos relatos, pero también la bibliografía especializada- revelaban rasgos de carácter muy distintos de los que tenían los productores en los años noventa.

Si bien el concepto del carácter social de Fromm incluye una serie de aspectos desvinculados de la actividad económica (el tipo de sexualidad, el modo de relación sociopolítica -en especial con la autoridad-, las capacidades de percepción de la realidad, entre otras cuestiones), aquí nos centraremos sólo en aquellos aspectos claramente articulados con lo económico y que, de hecho, son evocados por los términos escogidos por Fromm para denominar a los tipos de carácter social: productivo, improductivo, receptivo, explotador y acumulativo ${ }^{\mathbf{1 0}}$.

$9 \quad$ Este es un concepto elaborado por Erich Fromm, quien sostiene que "el modo de obrar, de sentir y de pensar de una persona es en gran parte determinado por la especificidad de su carácter y no es ni aproximadamente el resultado de respuestas racionales a situaciones reales" (Fromm, 1953: 65). Pero, diferenciándose de Freud, afirma que la base fundamental del carácter no es la organización de la libido, sino los modos específicos de relación de la persona con el mundo exterior. "El concepto del carácter social se basa en la premisa de que la energía del individuo no sólo está estructurada en términos del concepto dinámico del carácter, de Freud, sino que hay una estructura de carácter común a la mayoría de los miembros de los grupos o clases dentro de una sociedad dada [...] no se refiere a la estructura de carácter completa o altamente individualizada, de hecho, única, tal como existe en un individuo, sino a una 'matriz de carácter', un síndrome de rasgos de carácter que se ha desarrollado como adaptación a las condiciones económicas, sociales y culturales comunes a ese grupo" (Fromm y Maccoby, 1970: 34). 
Para desarrollar esta hipótesis acerca del cambio en el carácter social de los productores medios pampeanos, nos ha sido particularmente sugerente el análisis que realizaron Fromm y Maccoby (1970) sobre el campesinado mexicano. Además hemos utilizado las obras más generales de Fromm (1932a y b, 1953 y 1956).

Antes de avanzar en esta hipótesis, quisiéramos aclarar que no queremos patologizar el carácter social de los productores. Fromm (1953: 118) afirma que las orientaciones improductivas tienen también sus aspectos positivos, que se desarrollan cuando se combinan con una estructura de carácter en la cual predomina la orientación productiva $^{11}$. E, indudablemente, en los productores rurales existen numerosos rasgos del carácter productivo.

En la región pampeana, el chacarero arrendatario de las primeras décadas del siglo XX se distinguía por valorar la independencia, la responsabilidad, el apego al trabajo y el ahorro en pos de progresar en la escala social. Tanto el análisis de nuestras entrevistas, como las descripciones sobre las características de los productores de la primera mitad del siglo presentes en la bibliografía, son coincidentes en señalar estas características, tal como lo reseñamos en el capítulo primero. El chacarero tenía, entonces, rasgos de los caracteres productivo y acumulativo. Una actitud de realización en el trabajo, a la vez creativa e independiente, que no soportaba la pasividad ${ }^{12}$, pero con

10 No hemos incluido el tipo mercantil, ya que no lo hemos encontrado relevante para el análisis de los productores medios pampeanos.

11 Así, por ejemplo, el mismo rasgo negativo de ser pasivo o sin iniciativa que caracteriza a la orientación de carácter receptiva, tiene un cariz positivo como capacidad de aceptar, si es alto el grado de productividad de la estructura total del carácter. $\mathrm{O}$, en el caso del carácter explotador, el ser agresivo, puede transformarse en ser capaz de tomar iniciativa; o el acumulativo puede no ser obsesionado, sino metódico. El detalle de estas cuestiones se encuentra en Fromm (1953: 119-121).

12 Encontramos semejanzas entre algunas frases de nuestros entrevistados que continúan viviendo en el campo y que dijeron que no soportarían irse a la ciudad y estar sin hacer nada (que comentamos en el capítulo anterior), con el siguiente análisis de Fromm y Maccoby sobre el campesinado mexicano: "El ejidario productivo-acumulativo dice que siente vergüenza cuando no está trabajando, y prefiere un trabajo que exija más, especialmente si también le va dar más ganancias. Considera que la caña [cuyo cultivo es mucho más sencillo que trabajar el arroz y además permite obtener un serie de beneficio sociales que brinda el ingenio, ya que los ingresos que se obtienen de la caña son menores a los del arroz] es cosecha de hombres flojos. Por contraste, el ejidario receptivo le atrae sembrar caña porque le gusta tener más tiempo para pasear alrededor de la plaza, beber, chismear, y 'descansar', actividades que el campesino acumulativo consideraría "no hacer nada'." (Fromm y 
ciertos rasgos propios del carácter acumulativo en sus aspectos positivos, tales como ser práctico, cauteloso, constante, ahorrativo y reservado. Este carácter sería resultado de la simbiosis entre una socialización campesina europea y el contexto agrario pampeano que, sin garantizar nada, abría las posibilidades a un ascenso social, que en algunos pocos casos (que justamente incitaban a ser copiados) llegaba al extremo de convertir al hijo de un campesino pobre europeo en un mediano estanciero pampeano o un importante agricultor capitalista. Era, entonces, un contexto que, si bien no aseguraba la propiedad de la tierra, permitía mantener ciertas expectativas de ascenso social, a diferencia de una situación de subordinación campesina tradicional ${ }^{13}$.

A partir de las décadas del cuarenta y del cincuenta, el acceso a la propiedad de los campos y el reemplazo de la mano de obra familiar por asalariados habrían ido moldeando un nuevo carácter social de los productores medios. La percepción de una renta (en forma pura o combinada con la administración del campo) y la obtención del producto del trabajo asalariado habrían ido introduciendo (o quizás, reforzando) elementos de los caracteres receptivo y explotador ${ }^{14}$.

Por un lado, la condición de propietarios de una porción de tierra genera la percepción de una renta que no requiere otra actividad que la de conseguir alguien que la quiera arrendar y ponerla en producción. Se posibilita, entonces, una desvinculación del proceso productivo ${ }^{15}$ y se incentivan las actitudes pasivas y los gastos suntuarios, ya

Maccoby, 1970: 177).

13 Fromm y Maccoby (1970: 160-161) sostienen que, en el caso mexicano, "podemos explicar la presencia del tipo productivo-acumulativo por la influencia específica del modo de producción campesino, el cual a veces demuestra ser más fuerte que la influencia feudal general, pero sólo cuando el campesino tiene su propio pedazo de tierra". Y afirman más adelante, luego de enumerar las razones por las cuales la orientación acumulativa es adaptable a su modo de producción, que "la orientación acumulativa, comparada con la orientación receptiva, da al campesino una mejor base psicológica para el cultivo independiente del campo".

14 Sobre esta combinación Fromm afirma que "la orientación receptiva se encuentra con más frecuencia combinada con la explotadora" (Fromm, 1953: 118).

15 Si bien Fromm no aborda directamente la situación del rentista rural, sí se describe la nueva actitud del propietario en el siglo XX, cuando en la gran empresa, se desvincula de la actividad productiva. El no tiene ninguna obligación con la empresa ni relación concreta con ella. Una actitud que la caracteriza como de "enajenación" (Fromm, 1956: 110-113). 
que, en tanto rentista, no necesita reinvertir sus ingresos en la explotación ${ }^{16}$. Incluso en el caso en que el propietario tenga a cargo el proceso productivo, está percibiendo esta renta -sea o no conciente de ello- sin aportar ni trabajo ni asumir casi riesgo ${ }^{17}$. De hecho, con la difusión del contratismo de servicios (es decir, la posibilidad de contratar a terceros para que realicen cada una de las labores principales) se ha potenciado una conducta cuasi-rentística, sin la necesidad de que el propietario deje de ser un "productor", al menos en el sentido de asumir el riesgo empresarial y captar una ganancia por ser inversor en insumos ${ }^{18}$.

Seguramente, esta nueva posición social propietaria, en tanto captadora de renta del suelo, habrá incidido potenciando los rasgos receptivos del carácter social de los productores medios. Recordemos que el carácter receptivo se distingue por asimilar las cosas pasivamente, “la persona siente que 'la fuente de todo bien' se halla en el exterior, y cree que la única forma de lograr lo que desea -ya sea algo material, sea afecto, amor, conocimiento o placer- es recibiéndolo de esa fuente externa" (Fromm, 1953: 70). En el caso del propietario de la tierra, no se establecería una relación de dependencia hacia una persona en particular (tal como lo describe Fromm), sino que, a nuestro entender, la relación de dependencia sería hacia la sociedad capitalista en general, que es la que garantiza no sólo dicha propiedad (ante la "amenaza" de expropiación colectivista) sino

16 Kautsky, aunque refiriéndose a los grandes propietarios, había previsto esta relación entre la propiedad de la tierra (que no está sometida a las leyes de la competencia capitalista) y la desvinculación con las actividades productivas, la vida urbana, los altos consumos y los lujos (Kautsky, 1899: 246-251).

17 Es cierto que siempre cabe la posibilidad de que el proceso productivo y/o la coyuntura de precios le resulte tan desfavorable que no sólo la inversión de capital no dé ganancias, sino que ni siquiera perciba una renta del suelo (como sí lo hubiera hecho si el campo estuviera arrendado), pero ésta sería una situación por demás excepcional.

18 Esta forma de organizar la producción en base a terceros puede deberse a limitaciones económicas para poder capitalizarse en maquinarias, a evaluaciones de la escasa rentabilidad de dichas inversiones si no se logra un mínimo de escala, o a determinadas conductas vinculadas con la percepción de enormes rentas que históricamente han recibido los terratenientes pampeanos. Independientemente de su origen, resulta indudable que la terciarización de labores implica reducir el compromiso inversor-productivo del productor ya que evita inmovilizar inversiones y asumir el riesgo empresario que esto implica (y obviamente, captar sus beneficios), pero también el esfuerzo de lidiar con trabajadores y maquinarias. En este sentido, se convierte en un cuasi-rentista: la mayor parte de sus ingresos deben provenir de la renta del suelo, ya que el costo de la contratación de servicios se calcula de un modo bastante "científico", computándose los costos y la rentabilidad del capital. 
también la percepción de la renta capitalista del suelo o al menos de parte de ella ${ }^{19}$. Tal vez por ello, los propietarios, y sobre todo aquéllos con dotaciones de capital menos abundantes, fueron particularmente sensibles a los intentos de imponer tributos especiales a la renta del suelo, tal como se intentó en la primera parte de los años setenta. Como vimos en el capítulo tercero, fueron los medianos terratenientescapitalistas, según Murmis (1979), quienes reaccionaron de modo más agresivo contra estos intentos. Una conducta violenta que podría haber estado guiada por la ansiedad, actitud típica del carácter receptivo cuando los sujetos ven amenazada su "fuente de abastecimientos" (Fromm, 1953: 72).

Asimismo, en el proceso de socialización primaria, la desvinculación de las actividades productivas y la transformación de los niños en un meros consumidores de los ingresos familiares (producto de la radicación urbana) podrían también haber colaborado en el desarrollo de rasgos receptivos en el carácter de los futuros productores. En cambio, el niño que crecía inserto en el equipo de trabajo familiar, no sólo adquiría rasgos productivos, sino que también se interiorizaba de la dinámica económica de la unidad (por cierto, desde un lugar marginal y con amplio desconocimiento de muchas cuestiones de la economía familiar), adoptando, entonces, aspectos del carácter acumulativo ${ }^{20}$.

Por otra parte, en tanto que el productor se ha convertido en un empleador de fuerza de trabajo asalariada, y que ésta ha cambiado el lugar que antes tenía en la explotación (de ser colaboradora/auxiliar del trabajo familiar, se transformó en la base del trabajo de la explotación), se han profundizado los rasgos explotadores del carácter social del productor medio. El carácter explotador se destaca porque, aunque también como el receptivo tiene "la creencia de que la fuente de todo bien está en el exterior,

19 Decimos de parte de la renta ya que la propia dinámica del capitalismo implica la capacidad de otros sectores sociales de apropiarse de una porción de la renta (capital comercial y financiero), como también el que el Estado capte parte de la renta, a través de los impuestos a la tierra.

20 Al respecto, recordar el testimonio reproducido en el capítulo anterior, del productor que de niño planchaba y de vez en cuando miraba los billetes que había logrado ahorrar en base a su trabajo. 
que cualquier cosa que uno quiera obtener debe buscarse allí y que no puede producir nada por sí mismo, [...] no espera recibir cosas de los demás pasivamente, sino quitárselas..." (Fromm y Maccoby, 1970: 103).

Durante las décadas en estudio, la relación cualitativa entre productor $y$ asalariados cambió sustancialmente, tal como vimos en el capítulo anterior. De la época de "armonía" en la cual productores (o sus hijos) y peones trabajaban "codo a codo", se pasó a una relación más impersonal, y en la que el productor se asumió como empresario que empleaba asalariados y no como trabajador que sumaba a otros trabajadores porque no le alcanza con su fuerza de trabajo. Ahora, los productores medios se piensan y se expresan como empresarios, administradores de la explotación agropecuaria. Si bien dicen "hice", "aré" o "sembré", en general casi todo el trabajo es realizado por asalariados (o por contratistas de servicios, en este caso con menor, o nula, capacidad para explotarlos). Lo que resulta sintomático del cambio en el carácter social es que en las entrevistas no otorgaron mayor importancia en sus procesos de acumulación al trabajo de sus asalariados.

Asimismo, según se pudo inferir durante la realización de las entrevistas, en los productores medios ya no estaría la necesidad de trabajar como un impulso interior ${ }^{21}$. Este impulso, que parece haber sido característico de los chacareros de comienzos de siglo, se habría debilitado en tanto rasgo del carácter social, aunque en algunos perdura. Así vemos que algunos de los productores más ancianos siguen todavía intentando trabajar en el campo. Otros, al menos quieren ir al campo todos los días y realizar alguna tarea. Y los que siguen en el campo, no se imaginan yéndose a la ciudad a "no hacer nada".

Entonces, a lo largo de la segunda mitad del siglo XX, habrían crecido en importancia los elementos improductivos (receptivos y explotadores) del carácter social de los productores medios y estos rasgos de carácter habrían estimulado el cambio en los modos de vida y en las conductas económicas de los productores. Sin embargo, no

21 Para Fromm (1956: 72) este impulso interior es el que el capitalismo ha logrado instalar dentro de los propios trabajadores. 
debemos extremar esta línea de análisis, ya que muchos de los elementos del carácter productivo-acumulativo aún se hallan presentes en la mayoría de los productores, mientras que en otros predomina los elementos productivo-explotadores, propios de los empresarios capitalistas. ${ }^{22}$ Como puntualiza Fromm (1953: 118) "siempre se trata de combinaciones, pues un carácter jamás representa exclusivamente a una de las orientaciones improductivas o a la orientación productiva".

A pesar de que Fromm y Maccoby sostienen que los cambios en el carácter social suelen ser muy lentos, y demorar varias generaciones ${ }^{23}$, varios factores pueden haber acelerado esta transformación. En primer lugar, el contexto que rodeó a estos sujetos sufrió fuertes modificaciones durante el siglo XX, lo cual no permitió la cristalización de un carácter social que se transmitiera a través de la familia o de otras instituciones sociales. Primero, los inmigrantes cambiaron drásticamente de medio. El contraste entre una aldea campesina europea y la pampa argentina, en términos espaciales, culturales, sociales y económicos era por demás intenso. Luego, el agro bonaerense no cristalizó en una estructura social relativamente fija (como de algún modo sucedió en las praderas de Estados Unidos y Canadá). Por el contrario, tuvieron lugar continuas modificaciones. A este cambiante contexto social, político y económico,

22 Para el caso de la aldea mexicana analizada, "los aldeanos productivo-explotadores son los empresarios modernos que han sido los primeros en explotar las nuevas oportunidades del capitalismo" y son quienes "adoptan los valores del progreso por medio de las escuelas y la nueva tecnología y movilidad social que respaldan al nuevo sistema industrial" (Fromm y Maccoby, 1970: 167-169).

Quisiéramos aclarar que compartimos plenamente la opinión de Fromm y Maccoby (1970: 271) cuando sostienen que "no pensamos que todos los rasgos psicológicos que sirven para apresurar el proceso de desarrollo económico sean deseables desde el punto de vista humano".

23 "La adaptación al modo de producción no es asunto de una o posiblemente dos generaciones. El viejo tipo de producción ha formado el carácter de los padres, sus sistemas de valores, ideología y prácticas educativas las cuales continúan existiendo y ejercen su influencia mientras los nuevos métodos de producción están ya operando. El pasado pone un sello en el presente con el hecho de que el carácter del individuo se forma a través de los patrones establecidos; sólo por medio de un proceso mucho más largo debilitan las nuevas condiciones económicas a la antigua estructura de carácter y reducen la importancia de la estructura tradicional de valores, de modo que la nueva práctica económica pueda ejercer su influencia total en el desarrollo del carácter de la nueva generación." (Fromm y Maccoby, 1970: 172-173). 
se agregó la enorme capacidad de modificar el carácter social que poseen los medios masivos de comunicación ${ }^{24}$. Estos fueron socabando rápidamente las pautas culturales previas $^{25}$. La radicación urbana, por su parte, potenció estos efectos, tal como lo desarrollamos en el capítulo anterior. En este sentido, el cambio en el contexto de socialización primaria sería de particular importancia en la conformación del carácter social de los futuros productores ${ }^{26}$.

Entonces, las bases inconscientes del carácter social habrían "armonizado" los cambios estructurales, con las transformaciones en los modos de vida de los productores medios $^{27}$. Si las modificaciones estructurales en la dotación de recursos de los

24 Fromm y Maccoby detallan que el "principio general de 'rezago' necesita un requisito importante. Parece que se contradice por el hecho de que el carácter acumulativo que prevaleció en la clase media europea y americana hasta aproximadamente 1930, ha cambiado drásticamente hacia un carácter de consumo en sólo una generación. En este caso la influencia de las condiciones económicas en el carácter fue prácticamente instantánea. ¿Por qué pasó esto?

El elemento más importante para hacer posible este cambio rápido parece ser la posibilidad sin precedente de influir en el carácter del hombre a través de los nuevos medios de comunicación. Estos medios no atraen al intelecto, pero tienen un poder sugerente por su habilidad para poner a las audiencias en un estado de ánimo pasivo repitiendo el mismo tema sin fin y así, creando una situación que se parece en muchas formas al procedimiento hipnótico. Nunca antes había sido posible alcanzar y penetrar en gente de todas las edades de un modo tan efectivo como por medio de la electrónica, el cual no requería esfuerzo activo por parte del individuo y satisfacía su deseo de diversión sin esfuerzo. Otros elementos que ayudaron a cambiar el carácter rápidamente fueron la nueva abundancia de bienes de consumo, la publicidad y las compras a plazos, es decir, un sistema constante e insistente de tentación y seducción" (Fromm y Maccoby, 1970: 308-309).

25 Acerca del campesinado mexicano (Fromm y Maccoby, 1970: 192-193) sostienen que “... hay evidencia de que el campesino productivo-acumulativo está siendo alejado de los valores tradicionales y guiado hacia aquellos de la nueva sociedad industrial. Su posición es todavía viable, y lo será mientras esté protegido por el sistema ejidal y por la política del gobierno que refuerza su posición negociable. Sin embargo, está amenazado económicamente por los nuevos empresarios y psicológicamente por su apetito por nuevas cosas. Como miembros de una parte dependiente de una sociedad más grande en proceso de industrialización, las aldeas están comenzando a sentir las nuevas exigencias de adaptación que tendrán un efecto cada vez mayor en la nueva generación".

26 Al respecto, compartimos la valoración de Bastide (1961: 136), en el sentido de que el planteo de Fromm descuida el papel de la familia y del status del niño en su grupo doméstico en la conformación del carácter social.

27 Este papel armonizador se basa en que "cada tipo principal de carácter está moldeado por, y se adapta a las condiciones socioeconómicas distintivas [...] Pero, secundariamente los 
productores que lograron sobrevivir como tales (esencialmente el acceso a la propiedad y la mecanización) brindaron el sustento material al cambio en los modos de vida, ha sido la transformación del carácter social la que aportó el substrato psicológico de este cambio.

Consideramos que el concepto de "aburguesamiento" permite conjugar estos tres niveles de análisis. Como comentáramos en el capítulo anterior, la idea de "aburguesamiento" implica un cambio en la relación con los medios de producción (la conversión en un propietario, especialmente de tierra, pero también de bienes de capital), una transformación en el rol laboral (de productor directo a empleador de asalariados o contratador de servicios de terceros), al tiempo que la adopción de un modo de vida urbano, pero también -debemos agregar ahora- un carácter social distinto, más asociado al disfrute, al aprovechamiento del trabajo del otro, al consumismo y a cierta pasividad, y menos apegado al sacrificio, al ahorro y al trabajo duro.

Si hemos utilizado el concepto de carácter social para dar cuenta de la articulación entre los determinantes estructurales y los cambios en los modos de vida y en las formas sociales de producción, no debe entenderse que pensamos que éste fue un camino predeterminado por el acceso a la propiedad de la tierra y la adopción de maquinaria más potente. Los contextos culturales y socio-políticos también pesan en la determinación del carácter social y de las formas sociales de producción ${ }^{28}$.

valores de cada tipo racionalizan el carácter y también respaldan el sistema económico al cual se adapta el carácter" (Fromm y Maccoby, 1970: 169).

28 Nos parece pertinente, a pesar del contexto tan diferente, tener presente el análisis de las transformaciones en la aldea mexicana de Fromm y Maccoby (1970: 165): “...mientras que el tipo de producción campesina favorece y en gran medida determina el carácter acumulativo, el grado de productividad varía de acuerdo al estímulo cultural en una sociedad campesina. En el grado en que la cultura esté orientada a la vida, al placer, a los valores humanísticos, al arte, al juego y a la celebración, más que a la ganancia personal y la simple supervivencia, habrá más individuos productivos. En el pueblo se acentúa la ganancia material y el apetitos mellados por el atractivo de nuevos productos y del nuevo estilo de vida en la sociedad industrial moderna. En vez de las celebraciones y fiestas coloridas, los placeres de la vida, en la mayoría de los pueblos, consisten ahora en beber, ver televisión, y 'andar por ahí', o no hacer nada. En verdad, uno puede preguntar por qué los campesinos acumulativos son aún 
De hecho, sin proponer que el "aburguesamiento" sea exclusivo de la región pampeana argentina, podemos ver que en la mayoría de las regiones con esquemas productivos similares no tuvo lugar un proceso de "aburguesamiento". En general, en las demás regiones cerealeras se mantuvo el predominio de las unidades familiares y en propiedad (total o parcial). Abramovay (1998) en su estudio comparativo de los desarrollos agrarios de Estados Unidos, Inglaterra y Europa Occidental durante el siglo $\mathrm{XX}$, encontró que la agricultura de los países capitalistas avanzados continuó basada en las empresas familiares ( $\mathrm{y}$ en propiedad, aunque este aspecto no lo enfatiza particularmente).

Sin embargo, consideramos que tampoco deben generalizarse en exceso estas regularidades que encontró Abramovay, ya que una serie de factores políticos y culturales "interfirieron" con el desarrollo del capitalismo en el agro de estos países centrales.

Tal vez sea útil analizar cómo, en el caso de la producción agropecuaria, la conjugación de varios factores generó durante el siglo XX múltiples situaciones de indeterminación de las formas sociales de producción por parte de estas dimensiones estructurales (tamaño, tenencia y maquinaria).

En primer lugar, ya hemos visto al comienzo de este apartado que una fuente de indeterminación de las formas sociales de producción surge por el entrecruzamiento entre familia, propiedad, producción mercantil simple y capitalismo.

En segundo lugar, la incorporación de capital no determinó un agro concentrado en un reducido número de enormes unidades de producción capitalistas. Existió una tendencia en todas las economías agrarias de los países centrales y también en la región pampeana, hacia la concentración de la producción en unidades cada vez mayores y con dotaciones de capital más importantes, pero su resultado no ha sido un agro dominado

moderadamente productivos. La respuesta, como dijimos, es que el trabajo agrícola, en contraste, por ejemplo, con la repetición mecánica muerta de una línea de ensamblaje. El campesino puede decidir por sí mismo qué sembrar, y al cuidar de sus plantas o animales, debe responder a la vida y a la naturaleza. Los aldeanos más productivos reconocen esto, y agradecen la oportunidad que su trabajo les da de una responsividad activa". 
por una pequeña cantidad de grandes empresas con un gran número de asalariados cada una (como sí ocurre en otras ramas de la producción).

Por un lado, la propia mecanización produjo que esta concentración no implicara necesariamente que estas explotaciones tuvieran una organización del trabajo de tipo capitalista. Esta ha sido una particularidad de la producción agrícola: el propio desarrollo tecnológico generó maquinaria cada vez más grande y potente que permitía cultivar superficies de creciente extensión con uno o dos trabajadores ${ }^{29}$. Sin embargo, este bajo requisito de fuerza de trabajo no asegura que la producción mantenga su carácter familiar, ya que, al mismo tiempo, la mecanización implica que estos productores sean dueños de un capital significativo, situación que promueve su desvinculación de las labores directas. La indeterminación sobre la organización social de trabajo queda también estructuralmente planteada en esta cuestión ${ }^{30}$.

Por otro lado, la concentración de la producción en el agro, si bien ha sido innegable, tuvo importantes limitaciones. La creciente incorporación de capital en el agro, a través de maquinaria y de insumos, no implicó niveles de concentración equiparables con los del sector industrial (donde varias ramas están controladas por un puñado de empresas). Una serie de fenómenos se combinan para mantener la libre concurrencia en el sector agrícola (además de la propia intervención estatal en los países

29 Madden (1967) afirmaba que las explotaciones de tamaño intermedio pueden ser operadas por uno o como mucho unos pocos hombres a dedicación completa, usando tecnología moderna y capital adecuado.

Tal vez como ejemplo de una intensa y planificada utilización de maquinaria y fuerza de trabajo, observamos que, a comienzos de los noventa, un productor con una gran cosechadora y el trabajo de sus dos peones permanentes (uno en dicha máquina y el otro con el tractor y el carrito), más el auxilio de su hijo (a cargo del sin fin), cosechó 900 hectáreas de cosecha fina y 900 hectáreas de cosecha gruesa en la zona de Tres Arroyos.

30 A los productores medios les corresponden las consideraciones de Strumpel acerca de que en el siglo XX, "la elevación en los ingresos de las masas y el acortamiento de las jornadas de trabajo hicieron que fuera posible para mucha gente escoger entre ahorrar y gastar, así como entre el trabajo y el ocio. Para algunos, un mejoramiento firme y continuo en el ingreso real, común en la sociedad moderna, es una razón para descansar y para disfrutar las bondades de la prosperidad. Para otros, es un reto para fijarse más objetivos de metas y aumentar sus esfuerzos para lograrlos. Así, la mayoría de los hogares en las sociedades occidentales toman sus decisiones en un marco caracterizado por la discreción respecto a la adquisición de ingresos -empleo, trabajo/ocio, tipo de educación- así como a la asignación de ingresos; elección no sólo entre diversos bienes de consumo, sino entre ahorrar o gastar" (Strumpel, 1979: 97-98). 
centrales en pro de asegurarla; cuestión que aquí no analizaremos ${ }^{31}$ ). El desarrollo tecnológico no generó ganancias extraordinarias de carácter relativamente prolongado para aquellos productores que adoptaron las innovaciones en primer lugar. A diferencia de lo que ocurre en amplios sectores de la industria, aquí las innovaciones son de fácil acceso para un amplio rango de productores (obviamente, no para todos), de modo que su adquisición se generaliza con rapidez y caen los precios de los productos, evaporándose la ganancia extraordinaria (Abramovay, 1998: 214-220). Esto dificulta el proceso de concentración, ya que solo van quedando fuera los más rezagados, y no el grueso de aquellos productores que no lideran el avance tecnológico (como ha ocurrido en muchas ramas de la industria).

La posibilidad de que perduren una gran cantidad de empresas medianas (incluso muchas mediano-pequeñas) también se debe a que las economías de tamaño ${ }^{32}$ no las han afectado sustancialmente, como hemos visto en el capítulo tercero. Asimismo, el propio cálculo de las economías de tamaño incluye una serie de consideraciones subjetivas que generan un amplio rango de indeterminación. Como lo analiza Madden (1967), para este cálculo resulta imprescindible el análisis de los recursos fijos y variables de las unidades productivas; y resulta muy complicado delimitar cuáles son recursos de uno u otro tipo, pues esto depende enteramente de la estructura mental del productor ${ }^{33}$. En definitiva, incluso muchos de quienes no hacen uso de la última tecnología y no

31 Sobre la acción estatal en los países desarrollados para asegurar la supervivencia de las unidades agrarias medianas puede encontrarse una interesante compilación de información en Abramovay (1998).

32 Madden (1967: 1) aclara que resulta más apropiado hablar de "economías de tamaño" (y no economías de escala), cuando las proporciones de los factores productivos no se incrementan de un modo constante, como sería claramente el caso de aumentar la extensión de las explotaciones agropecuarias, sin que trabajo y capital se incrementen en igual forma.

33 El cálculo de los costos de producción, sobre la base de los cuales se analizan las economías de tamaño, incluye los costos de oportunidad de los factores de producción. El cálculo de los costos de oportunidad de los factores necesita de la distinción entre factores fijos y variables, $\mathrm{y}$ esto depende en gran medida de la subjetividad del productor. Todo recurso que se considere fijo (como podría ser la tierra, la mano de obra familiar o la propia capacidad gerencial del productor) tiene costo de oportunidad cero y se buscará maximizar su uso. Sin embargo, tan pronto como el productor considere que un recurso es variable, su precio se hace relevante e interviene en la determinación del costo de producción, que a su vez incide en las economías de tamaño (Madden, 1967: 5).

También, agregamos nosotros, incide hasta dónde pesa el deseo, o las ventajas, de trabajar con maquinaria propia para desechar la contratación de servicios externos. 
alcanzan las máximas economías de tamaño, no están necesariamente forzados a salir de la producción ${ }^{34}$.

Todo esto no implica afirmar que el desarrollo tecnológico no haya impulsado la concentración. Pero este proceso no se efectuó tanto a través de las economías de tamaño, como por vía de la reducción de los ingresos netos por unidad de superficie. La difusión de la tecnología llevó a la caída de los precios de los productos que, combinada con un incremento en los costos generado por la mayor inversión, produjo una reducción en los ingresos netos por unidad de superficie. Esta tendencia provocó que las unidades de menor extensión tuvieran crecientes problemas para afrontar las necesidades de consumo del grupo familiar. Nuevamente, los modos de vida rurales o urbanos, con sus diferentes pautas de consumo y de autoconsumo, y, por ende, sus distintos niveles de gastos familiares (junto con las posibilidades de ingresos por empleos urbanos) han estado incidiendo fuertemente en los cálculos sobre la viabilidad de las pequeñas unidades, generando otro nuevo factor de indeterminación acerca de la continuidad de las unidades pequeñas o mediano-pequeñas.

En tercer y último lugar, otra fuente de indeterminación se produce porque la propiedad de la tierra no implica necesariamente ni un mayor compromiso con la explotación, ni la desvinculación de la producción. Esto último es una posibilidad, generada, como ya vimos, por la percepción de la renta capitalista del suelo. Pero, por otro lado, el acceso a la propiedad estimula el afincarse en la explotación, ya que ahora pueden realizarse mejoras en la vivienda, que para un arrendatario o un mediero eran muy riesgosas de realizar porque podía durar poco en ese predio. De hecho, la mayor parte de las explotaciones agrícolas en los países capitalistas están a cargo de productores que son dueños de la tierra que trabajan, o al menos de su mayor parte.

34 Las explotaciones más pequeñas que aquellas en las que el costo medio sea el mínimo, no están necesariamente forzadas a salir de la producción, mientras que sus beneficios potenciales sean suficientes para cubrir los costos de oportunidad y el precio de reserva del productor. Los costos de oportunidad tienden a mantenerse relativamente bajos para las capacidades de trabajo físico, gerencial o la capacidad empresarial que tienen los productores pequeños al analizar las oportunidades de trabajo fuera de la explotación propia (Madden, 1967: 18). 
Para ejemplificar la situación de indeterminación que la dotación de tierra y capital, y el desarrollo tecnológico genera en los medianos productores agropecuarios podemos cotejar las siguientes dos opciones que se le presentan a un propietario de unas 100 o 200 hectáreas en la zona norte bonaerense y con una relativamente escasa dotación de capital, pero suficiente como para encarar el ciclo productivo. Puede trabajarlas personalmente junto a su familia (en tanto ésta se mantenga interesada en el porvenir de la unidad y la vida rural) con una maquinaria un tanto vieja que ha heredado o comprado hace muchos años (sin preocuparse por los costos de reposición, hasta que una buena cosecha, en volumen y precios, permita cambiarla), y produciendo buena parte de su propio consumo (carne, verduras, frutas, embutidos, parte de la ropa). Un bajo nivel de gastos familiares le permitiría afrontar ingresos netos por hectárea cada vez más reducidos o, tal vez, una fuerte dedicación al trabajo podría diversificar y aumentar los volúmenes de producción. Además, puede realizar alguna rotación con ganado, como para mantener la fertilidad de un modo natural, sin tanto consumo de fertilizantes.

La opción opuesta, sería arrendar esa superficie (asegurándose un ingreso anual fijo $^{35}$, pero con el consiguiente riesgo de un menor cuidado del suelo), vender la maquinaria (si consigue comprador) y el ganado. Establecido en la ciudad, pueden buscar empleo urbano tanto él como su esposa, y darles una mayor escolarización a sus hijos, de modo de que tengan otras expectativas laborales.

Personalmente, considero que no resulta posible decidir entre estas opciones con un cálculo meramente económico, sin considerar los objetivos vitales y el carácter social que tienen los miembros de esta familia, su dinámica interna, y el modo de vida que persiguen, conciente o inconscientemente.

Por lo tanto, no alcanza con los factores estructurales de la tenencia del suelo, el tamaño de la explotación y la dotación de maquinaria, para determinar ni el carácter

35 Como vimos en el capítulo cuarto, incluso en años de precios relativamente bajos (1999), con el alquiler de un campo de 200 hectáreas que se dedicase al maíz o la soja se conseguía una renta de unos $\$ 25.000$. 
social, ni las formas sociales de producción en el caso de los productores rurales medios. Como hemos podido observar, las modificaciones en el modo de vida, las transformaciones en la dinámica familiar y los cambios en el contexto cultural en el que los productores están insertos, especifican importantes dimensiones de las formas sociales de producción, como la organización social del trabajo o la racionalidad económica.

Justamente, en la región pampeana, los cambios en los modos de vida habrían contribuido a la desaparición de las características familiares de la mayor parte de las unidades medianas para fines de los años ochenta, que a su vez concentraban la principal proporción de la producción agrícola regional. Sin embargo, en los años sesenta no era tan claro que expansión agrícola no iba a basarse en formas familiares de producción, e incluso creemos que se había abierto la posibilidad de un desarrollo "farmer" en la pampa.

\section{La posibilidad de una vía farmer de desarrollo agrario en las pampas}

Durante los años sesenta el agro bonaerense se había acercado notablemente a las características estructurales del Corn Belt norteamericano. La tenencia había cambiado hacia la propiedad o formas combinadas de propiedad y arriendo, que eran las formas que predominaban en el Corn Belt ${ }^{36}$. Tenían, entonces, seguridad para invertir en sus campos, tanto en mejoras productivas, como en comodidades habitacionales.

36 Como vimos en el capítulo segundo, en 1969 en Iowa, el 46\% de los productores eran propietarios puros, un $28 \%$ eran propietarios que además arrendaban otros lotes, y un $26 \%$ eran arrendatarios. Si consideramos sólo a las unidades de más de 105 hectáreas, también predominan los propietarios, pero ahora en formas mixtas $(47 \%$, frente al $25 \%$ de los propietarios puros), mientras que el peso numérico de los arrendatarios se mantiene en valores similares (28\%) (cálculos propios en base al Census of Agriculture, 1969, Iowa: Tabla 24). 
Al mismo tiempo, los arriendos a corto plazo (contratos accidentales) permitían flexibilizar el tamaño de la superficie trabajada, ampliándose sin inmovilizar importantes sumas de capital en la compra de tierra. De hecho, los tamaños eran importantes y no aparecían graves problemas para el uso pleno de las nuevas y más potentes maquinarias. Comparativamente con las unidades del Corn Belt, las de la región pampeana eran mucho más extensas, incluso las de la pampa maicera ${ }^{37}$. Además, la mecanización permitía el desarrollo de empresas de tamaños considerables basadas en la mano de obra familiar.

Incluso, estos productores medios pampeanos tenían una serie de factores que favorecían su desarrollo. Habían amplios subsidios estatales que posibilitaban la mecanización y las mejoras necesarias para una ganadería moderna. Contaban con el apoyo de un INTA en su momento de esplendor, y los potenciales de incremento en los rendimientos, en comparación con el resto del mundo, eran altos.

En este sentido, nuestra hipótesis es que se habría abierto la posibilidad de consolidar una vía farmer de desarrollo agrario. De algún modo, así como en la segunda mitad del siglo XIX había existido la oportunidad de construir un modelo de desarrollo agrario en torno a las unidades familiares en propiedad, cien años más tarde volvía a generarse esta opción.

37 Para 1969, el tamaño medio de las explotaciones de Iowa era de 97 hectáreas, y de 93 en el caso de Illinois, mientras que en la zona norte bonaerense el promedio era de 117 hectáreas. Vemos que, a pesar del intenso proceso de concentración que había tenido lugar en el Corn Belt, sus explotaciones seguían siendo algo menos extensas que las de la pampa maicera. En los Estados Unidos se habían implementado costosas políticas de auxilio a los productores rurales, pero también se propuso abiertamente, en los años cuarenta a sesenta, el aumento de la escala, y se favorecía el abandono de las pequeñas explotaciones (el "farm size adjustment", como se titulan varios de los trabajos de las estaciones experimentales del Corn Belt de estos años). Las políticas de subsidios a los productos agropecuarios no incorporaron ninguna medida que exceptuara a las grandes unidades y, de este modo, atenuara el proceso de concentración. De hecho la favorecía, porque a mayor producción, mayores beneficios (así, por ejemplo, en 1969, el 42,4\% de los beneficios gubernamentales fueron hacia el 5\% más rico, mientras que el $20 \%$ más pobre de los productores rurales sólo recibió el 1,1\% según Mann y Dickinson, 1980). El único intento de poner un límite a la recepción de la ayuda estatal, previendo que sólo la recibiesen las unidades pequeñas y medianas (con un máximo que estimamos en una cosecha de alrededor de 150 hectáreas de maíz) fue llevado adelante en 1949 por Charles Brannan (el Secretario de Agricultura de Truman, de tendencias liberales) y terminó en un fracaso legislativo (al respecto puede consultarse Benedict, 1953; Brewster, 1979 y Dean, 1996). 
No pretendemos desarrollar aquí un contrafáctico acerca de lo que hubiera ocurrido si se hubiera consolidado, a partir de 1970, un modelo de agricultura farmer en la región pampeana ${ }^{38}$. Tan sólo queremos enfatizar que esta posibilidad estaba abierta. De hecho, el ideal de un desarrollo agrario basado en la mediana explotación familiar en propiedad se había mantenido en el discurso agrario argentino durante varias décadas.

Existía, entonces, la posibilidad estructural junto con un discurso social favorable e incluso el interés de los sectores urbanos en favor de un modelo agrario farmer que se suponía podía generar tanto un incremento de la producción agraria exportable -eliminando el "cuello de botella" de la industrialización por sustitución de importaciones; ver al respecto Braun y Joy (1981)-, como también la expansión del mercado interno de bienes de capital y de consumo.

Sin embargo, este modelo no se consolidó. Como vimos en el capítulo tercero, la expansión productiva fue muy importante en los años setenta y comienzos de los ochenta, pero no se estructuró centralmente en base a las formas sociales de producción de tipo farmer. Por el contrario las coyunturas económicamente favorables minaron aun más el modo de vida chacarero, tal como ya hemos analizado, e indirectamente socavaron esta oportunidad.

Al respecto, constituye un error de percepción habitual entre los pequeños y medianos productores creer que una coyuntura económicamente favorable en términos de precios les asegura su éxito económico, cuando justamente se benefician más quienes están en mejores condiciones para aprovecharlas (por ejemplo, las grandes empresas que, con mayores capacidades financieras, les arrebatan los campos que tradicionalmente arrendaban los pequeños propietarios para alcanzar alguna escala). Incluso, una mejor situación económica no implica consolidar una posición social determinada: el éxito puede generar un ascenso hacia una mejor ubicación, pero sin garantizarse una continuidad temporal en esta nueva posición. Dicho esto, corresponde

38 No es que seamos conceptualmente críticos de los contrafácticos en historiografía, de hecho pensamos que casi siempre el historiador trabaja con contrafácticos implícitos a la hora de elaborar explicaciones causales de los procesos históricos. En este sentido, más allá de las limitaciones teóricas y los problemas metodológicos del uso de contrafácticos por parte de los historiadores de la New Economic History, nos parecen muy acertadas las valoraciones positivas que ha efectuado Elster (1994) sobre este tema. 
aclarar que también sería un error pensar que toda coyuntura favorable deteriora la capacidad de resistencia de estos productores y/o los conduce a su "aburguesamiento".

Este "fracaso" de la vía farmer fue el resultado de una compleja una serie de factores de índole diversa que a continuación intentamos discriminar:

En primer lugar, como vimos en el capítulo tercero, durante las décadas del setenta, ochenta y noventa tuvo lugar un crecimiento de las economías de tamaño y de los mínimos de extensión necesarios para el pleno uso de la mecanización propia. Pero, lo que resultó especialmente grave para las pequeñas unidades fue que disminuyeron los ingresos netos por unidad de superficie. Una familia requería cada vez más hectáreas para poder hacer frente a sus necesidades de consumo, por cierto, también crecientes en la medida en que los productores iban internalizando las pautas de consumo de la clase media urbana.

En segundo lugar, la dictadura implementó una serie de políticas de liberalización que fueron contrarias a un desarrollo farmer, como el fin de los créditos subsidiados que promovían la mecanización y la modernización de la producción ganadera, y la desarticulación de la estructura estatal de regulación de la producción y de colonización.

En tercer lugar, más allá de estas políticas puntuales, existió un proceso social regresivo que asoló a la sociedad argentina, especialmente durante la última dictadura militar, pero que en varios aspectos había comenzado un par de años antes. Tal como desarrollamos en el capítulo tercero, la dictadura no fue sólo represión, sino la producción de un nuevo orden que disciplinó a la movilizada sociedad argentina, y modificó las bases sociales que sostenían a las propuestas populistas y a la capacidad combativa de los sectores populares. Este no fue un proceso desarrollado sólo desde el Estado, sino que atravesó a toda la sociedad. En el caso particular del sector agrario, la reacción fue más temprana y se estructuró desde un sector de los propios productores, tal vez porque aquí se habían planificado algunas medidas concretas de origen fiscal pero con objetivos claramente reformistas, como el Impuesto a la renta potencial de la tierra. No sólo la ley ya sancionada nunca se efectivizó, sino que en la opinión pública 
(incluso luego del retorno a la democracia) se fue borrando el discurso agrarista que había predominado desde los años treinta.

En este sentido, no fueron sólo políticas agrarias puntuales, sino que tuvo lugar la imposición de todo un modelo ideológico neoliberal. Esta ideología operaba a través de la negación de la posibilidad de discutir el modelo de desarrollo agrario: tan sólo había que dejar que incidiera el Mercado, "optimizando" el tipo de unidades productivas, eliminando las "distorsiones" que el intervencionismo populista había instaurado ${ }^{39}$. El tema de discutir cuál modelo de desarrollo era deseable se convirtió en un tabú que perduró, luego, durante la vuelta a la democracia ${ }^{40}$. Predominó, entonces, la indiferencia acerca de los efectos que tenían una serie de factores (como el desarrollo tecnológico, la liberalización financiera, y la retracción de las políticas estatales de apoyo al productor, entre otros) sobre la estructura agraria y la comunidad rural.

En las mismas décadas, en cambio, estos temas fueron motivo de profundos debates académicos y políticos en los Estados Unidos, con una importante movilización de los productores afectados y sus comunidades en general, especialmente a partir de la crisis de los primeros años ochenta (Friedberger, 1988). Con altibajos -presidencia de Reagan mediante- lograron políticas favorables y una intensa preocupación institucional por el desarrollo comunitario. En Argentina, por el contrario, iban permeando los valores neoliberales, articulándose con una base liberal-conservadora y una actitud individualista que ya tenían muchos de los productores medianos, especialmente, pero no exclusivamente, aquellos que provenían del fraccionamiento de los latifundios y de su puesta en producción en forma directa (después de la experiencia de las prórrogas de

39 Más allá que el Estado intervino para otorgarle ganancias extraordinarias en muchos rubros a los grandes capitalistas.

40 Un ejemplo elocuente de este tabú fueron los "debates" frustrados en el .Seminario "Juicio a nuestra agricultura. Hacia el Desarrollo de una Agricultura Sostenible" organizado por el INTA en 1990 y al que asistimos. Así por ejemplo, se manifestó una negativa cerrada a la discusión de la legislación sobre arrendamientos, ante la sugerencia que se desprendía de la ponencia de Llovet y Tort (1990) sobre analizar posibles reformas que, prolongando los plazos de los contratos accidentales, permitieran interesar al arrendatario en la conservación del suelo. De modo similar, la propuesta de Gamundi (1990) de "interesar a la actividad privada con capitales nacionales" para que se desarrollasen plaguicidas específicos en pos de un control estable en el largo plazo (más allá de las tendencias de "las poderosas empresas multinacionales" que imponen sus productos), fue rechazada y excluida de las consideraciones finales ante la abierta oposición de los representantes del sector comercializador de estos productos. 
los arriendos de los años cuarenta a sesenta). La coyuntura social regresiva de 1974 a 1982, habría debilitado aun más la siempre difusa identidad chacarera ${ }^{41}$. Esta falta de una identidad compartida, estructurada en torno a las explotaciones familiares y un modo de vida rural impidió la articulación de intereses comunes entre los propios productores que querían permanecer en el campo, y con otros sectores sociales que podían estar interesados en la defensa de un "desarrollo farmer" (los habitantes de las pequeñas localidades $\mathrm{y}$, en última instancia, también de las ciudades cabeceras de cada partido, en tanto que la concentración de la población en ellas finalmente empobrece el desarrollo global y, por ende, el propio de estas localidades, aunque en un comienzo pareciera que la radicación urbana podía favorecerlas).

El resultado de los diferentes derroteros de ambos países se sintetiza en el aumento de velocidad de la concentración que tuvo lugar en las pampas, y su desaceleración en el Corn Belt. Mientras que en Iowa el tamaño medio de los predios se incrementó en un 25\% entre 1969 y 1987, en la zona norte de Buenos Aires aumentó en un 50\%; y en la década del noventa esta diferenciación continuó, pues allá sólo se incrementó el tamaño medio en un $14 \%$, y aquí en un $26 \%{ }^{42}$.

Más allá de algunos casos aislados, podemos afirmar que nadie defendió orgánicamente esta posibilidad de modelo de desarrollo farmer para el agro pampeano. Ni los intelectuales, ni los ingenieros agrónomos, ni los productores o sus asociaciones. Pareciera que nadie hubiera percibido esta posibilidad. El discurso favorable a una reforma agraria, u otras medidas de tipo reformista (además de la feroz represión que sufrieron sus defensores), quedó desacreditado ante el extraordinario crecimiento de la

41 Para Ansaldi, a partir de la última década del siglo XIX o de la primera del XX hasta la década de 1940, hubo un proceso constitutivo de una identidad colectiva chacarera, aun cuando ella sea "una identidad de clase parcial, recortada y quizás mejor, inconclusa" (Ansaldi, 1998: 5). Pero luego la situación estructural se complejiza pues parte de los chacareros se convierten "en farmers (en términos de categoría analítica, aunque mantengan la denominación histórica chacareros) [...] en el presente la categoría histórica chacareros contiene a dos sujetos sociales agrarios analíticamente diferenciados, los chacareros (arrendatarios) y los farmers (propietarios)" (Ansaldi, 1998: 9).

42 El tamaño medio de las explotaciones de Iowa pasó de 97 hectáreas en 1969 a 122 en 1987 y a 139 en 1997, mientras que en la zona norte era de 117 en 1969, alcanzó las 176 hectáreas para 1988 y las 221 en 1999 (esta última cifra según nuestras estimaciones realizadas a partir de los datos del Censo Experimental de Pergamino de 1999). 
producción agrícola pampeana ocurrida durante las décadas del setenta y comienzos del ochenta, cuando justamente ese discurso negaba esta posibilidad sino se concretaban previamente estas reformas. Al mismo tiempo, este crecimiento contribuyó a dejar de lado la preocupación de los sectores urbanos por el modelo de desarrollo agrario que había generado tanto debate en los años cincuenta y sesenta, pues el agro pampeano no producía el nivel de exportaciones necesarias para la plena expansión del modelo de industrialización por sustitución de importaciones. Desde dentro del sector, los reclamos puntuales (en general vinculados a medidas estatales que afectaban el precio de los productos y las disputas en torno al sistema tributario) fueron el eje de las preocupaciones manifiestas. Muy probablemente el "mal recuerdo" de la intervención estatal peronista, no tanto por la regulación del mercado de tierra con la prórroga indefinida de los arriendos (sobre la que las opiniones en las entrevistas estuvieron un tanto divididas), como por la imposición de precios bajos para la producción agropecuaria durante los primeros años de la primer presidencia de Perón ${ }^{43}$ o por el apoyo brindado a la sindicalización de los peones rurales (estos dos temas, especialmente este último, aparecieron recurrentemente en las entrevistas), parece haber generado un rechazo profundo hacia toda planificación estatal, y una cierta adhesión a los principios del liberalismo económico en muchos productores rurales. Así, no resultó extraño que en los años noventa, no sólo la mayoría calló, sino que muchos aplaudieron la desarticulación de la estructura estatal de regulación (mientras que en el resto de los países, los productores son los principales defensores de este tipo de instituciones económicas).

Pero no sólo nadie defendió al modelo farmer, sino que cada vez menos productores lo actuaron, lo encarnaron. En este sentido creemos que más que una cuestión estrictamente ideológico-política, la no consolidación de este modelo ${ }^{44}$ se debe a los cambios profundos que como tendencia semi-secular se estaban operando en el carácter social de los productores medios y en su modo de vida. Los productores se habían "aburguesado" y estuvieron poco interesados en luchar por un modelo de desarrollo que no sentían como propio.

43 A pesar de que luego se revirtieron (ver Novick, 1986).

${ }_{44} \mathrm{Ni}$ siquiera puede ser planteado como un "fracaso", pues este término implica la no realización de un objetivo buscado intencionalmente. 
Para finalizar queda el interrogante acerca de cómo conceptualizar el desarrollo agrario pampeano de la segunda mitad del siglo XX.

\section{3. ¿Una vía realmente capitalista de desarrollo agrario?}

Resulta claro que, entre 1940 y 1970, se desarticuló casi por completo la "vía pampeana". El esquema de desarrollo agrícola basado en unidades familiares en arriendo o aparcería, característico de la inserción pampeana en el mercado mundial, no se sostuvo en el tiempo. Si bien en términos económicos había evidenciado una fuerte consistencia, e incluso resultó una fórmula flexible para atravesar los duros años treinta, no tuvo solidez socio-política. En general, los arrendatarios y aparceros siempre mantuvieron la esperanza de convertirse en propietarios y dejar de depender de las arbitrariedades de los terratenientes. La intervención estatal sobre el mercado de tierra, desde los años cuarenta hasta fines de los sesenta, influyó notoriamente en resguardo de los arrendatarios y aparceros, y promovió -de un modo indirecto- su acceso a la propiedad.

Sin embargo, no todos los arrendatarios y aparceros accedieron a la propiedad. Alrededor de la mitad tuvieron que abandonar sus parcelas, voluntaria o involuntariamente, y casi todos ellos marcharon hacia las grandes ciudades en plena expansión industrial. Ya hemos descripto, en el capítulo segundo, este proceso de concentración hacia las medianas-grandes explotaciones.

Luego, a pesar de la presencia desde los años sesenta de una serie de características estructurales favorables a una "vía farmer" de desarrollo agrario, no fue éste el camino que finalmente se consolidó durante la expansión agrícola de las décadas del setenta y ochenta. Si bien esto resulta claro, no es tan fácil caracterizar la situación resultante para fines de esta última década. Como pudimos analizar en el capítulo tercero, la estructura social para 1988 era muy heterogénea. Pero incluso utilizando el recurso de focalizarnos en el tipo social característico de ese momento (especialmente en términos de su importancia productiva), nos encontramos con una forma social de 
producción muy compleja y de difícil definición. A continuación repasaremos estas características.

El productor "típico" de los años ochenta combinaba la tenencia en propiedad con el arriendo accidental de algunos lotes para conseguir una escala suficiente que le permitiera la mejor utilización de su maquinaria. Era, entonces, un sujeto doblemente complejo. Por un lado, combinaba la inversión de capital (propia del capitalista) con la propiedad de la tierra (terrateniente), siendo en este sentido un terrateniente-capitalista Pero este término tampoco resulta el más adecuado por varias cuestiones. En principio, el vocablo "terrateniente" encierra demasiadas connotaciones (acerca del tamaño de las unidades, y el poder económico y hasta político del productor). Pero, además, muchos de estos productores a la vez tomaban otras parcelas en arriendo, por lo cual serían, parcialmente, arrendatarios capitalistas. Por otra parte, estos productores "típicos" contrataban uno o dos asalariados permanentes. Nuevamente son difíciles de conceptualizar en esta dimensión, ya que no eran estrictamente ni empresas familiares, ni unidades capitalistas propiamente dichas, por el bajo número de asalariados que contrataban. Incluso, surge un grado de complejidad mayor, pues muchos productores sumaban al trabajo de los asalariados, el aporte de su trabajo y el de los miembros de su familia (siendo, entonces, productores directos), al tiempo que una gran cantidad también contrataban servicios de maquinarias, convirtiéndose el productor en un cuasirentista, que ni aporta su trabajo físico ni emplea asalariados.

Por último, para complejizar aun más la conceptualización de estos productores, la mayoría de ellos ni se regían por una racionalidad completamente formal, en la que la empresa y la familia estuvieran totalmente disociadas, ni por una racionalidad sustantiva de tipo farmer ${ }^{45}$. Sobre esta cuestión necesitamos detenernos un poco más.

45 En los estudios sobre el agro pampeano habitualmente se acepta la simplificación neoclásica que asigna una racionalidad capitalista a todos los productores. Este es un planteo implícito en la mayoría de los trabajos, pero incluso está presente en un artículo dedicado, en buena medida, a la cuestión de la racionalidad de los productores pampeanos (Posada, 1995). En este trabajo, luego de recorrer una serie de cuestiones teóricas, se simplifica rápidamente el problema, planteando que "para el caso de la región pampeana, donde no es posible sugerir la idea de un desarrollo no capitalista, se deduce que necesariamente esos objetivos deben estar de acuerdo con ese tipo de desarrollo capitalista [una ganancia capitalista], aun sea combinado con la minimización del riesgo" (Posada, 1995: 89). Consideramos que Posada confunde los niveles macro y micro ya que, desde Kautsky y Weber en adelante, ha quedado 
Como adelantábamos al comienzo de este capítulo, la ruptura entre empresa y familia no ha sido completa. Una diferenciación total solo se logra en las sociedades anónimas. En ellas, la suerte de la empresa no afecta el patrimonio de las familias, más allá de lo estrictamente invertido en ellas. Pero, además, las decisiones de gestión son independientes de las necesidades familiares, tanto porque no se las incluye en el cálculo, como porque toda la mano de obra es asalariada y, al menos en teoría, no se considera de forma especial la contratación de miembros de las familias propietarias de las acciones. Al respecto Weber (1922: 311) afirma que la sociedad anónima es "el tipo de asociación capitalista separado totalmente, al menos de un modo normal, de toda base personal y de clan". Las empresas capitalistas están regidas por una racionalidad formal, solo basada en reflexiones sujetas a número y cálculo, en absoluta indiferencia de toda suerte de postulados materiales. "Lo opuesto a 'empresa' -un tipo de orientación económica (por la ganancia)- es por el contrario 'hacienda' (orientación por la cobertura de necesidades)" (Weber, 1922: 89).

En este sentido, en el caso de los productores medios pampeanos, la disociación entre familia y empresa no ha sido completa. En primer lugar, el gerenciamiento y la propiedad están unidos ${ }^{46}$ e, incluso, el productor también realiza una serie de trabajos auxiliares de la producción. Aunque esto no alcanza para seguir caracterizando a estas unidades como "familiares"47, no son empresas típicamente capitalistas. En segundo

en claro que es factible la existencia de unidades no estrictamente capitalistas dentro de un contexto capitalista, y ésta es justamente la cuestión que queremos destacar.

En otra línea de reflexión, Sábato (1980) complejiza la lógica económica de los productores pampeano sin proponer una racionalidad no capitalista. Para este autor, "los empresarios rurales pampeanos actuarían de manera parecida al tenedor de una cartera de títulos; lo que desean es optimizar la tasa de ganancias del conjunto de su producción minimizando los riesgos, y no la máxima tasa de ganancia que puede aportar un producto en particular" (Sábato, 1980. 49). Sin embargo, Sábato no aborda la distinción que nos preocupa, entre racionalidad formal y racionalidad material.

46 Según el enfoque de Errington y Gasson, por este motivo seguiría siendo una empresa "familiar", o como ellos la denominan una "farm family business", pues la propiedad de la empresa está en combinación con el control gerencial en manos del productor. Esta sería para ellos una situación muy particular, ya que una de las transformaciones socio-económicas más profundas que ocurrieron en los últimos 150 años en los países desarrollados ha sido justamente el auge de formas económicas en las que la propiedad del capital se ha ido separando del control gerencial (Errington y Gasson, 1994).

47 En este sentido comparto la crítica de Djurfeldt (1996) al trabajo de Errington y Gasson (ya comentada en la Introducción a la presente tesis) y considero que no es conveniente seguir denominando a este tipo de unidades, como empresas familiares. 
lugar, al no haber una separación total entre la unidad de producción y la unidad de consumo, esta última le impone objetivos y límites a la primera. Por lo tanto no tienen una racionalidad enteramente capitalista ${ }^{48}$. Sin embargo, tampoco nos encontramos con la racionalidad sustantiva de los farmers del medio oeste norteamericano. Más bien pareciera que prevalece una situación intermedia, que combina cierta racionalidad formal orientada hacia la maximización de beneficios, pero limitada por algunos objetivos familiares como el de mantener un nivel de vida de la clase media-alta urbana y el de de enviar los hijos a la universidad, que pueden conspirar contra la mejor reinversión de los beneficios, según un cálculo meramente formal ${ }^{49}$.

Entonces, en la medida en que unidad de reproducción y unidad de producción se encuentran asociadas, en que la mano de obra no requiere ser remunerada a precios de mercado, pero sobre todo, en tanto que medios y fines se entremezclan, el modo de vida del productor y de su familia juega un papel crucial en determinar la lógica económica de la explotación. La radicación urbana (con su consiguiente cambio en el modo de vida) y la asalarización de la mano de obra (contracara de la desarticulación de la familia como equipo de trabajo) han estimulado, en cierta medida, el cálculo de todos los factores de producción a precios de mercado. Pareciera haberse avanzado en un proceso de "mercantilización" de la forma de producción, que ahora no afecta sólo a la realización de la producción sino al consumo y al trabajo, según el enfoque propuesto por Friedmann (1978b y 1980) para pensar la transición desde unidades mercantiles simples hacia empresas capitalistas. En fin, la urbanización torna más formal la racionalidad económica de los productores, aunque en muchos casos siga habiendo objetivos materiales por encima de la maximización de beneficios. En cambio, en

48 Si bien no tenemos mediciones precisas, en las entrevistas se vislumbra que muy pocos productores habrían tenido, como objetivo rector de su desenvolvimiento, la maximización de su tasa de ganancia, y casi ninguno había calculado los costos de oportunidad de los factores puestos en juego. En general, los productores medios sólo habían comenzado a realizar estos cálculos en los últimos años en los casos en que se vincularon a los grupos CREA o si sus hijos eran contadores o ingenieros agrónomos.

49 Algunos de los factores de producción (trabajo y tierra), que para un capitalista serían simples medios empleados para un fin, son muchas veces los fines de la actividad económica para un productor familiar. Por ejemplo, toda su actividad puede estar buscando asegurar la continuidad de la explotación como un bien intergeneracional. De modo similar, otro objetivo para muchos importante es que su hijo alcance una educación universitaria, y en este sentido no es posible que lo piense como mano de obra disponible, sino más bien como receptor de buena parte de los excedentes. 
algunos pocos casos el mantenimiento de un modo de vida rural habitualmente permite a la familia seguir funcionando como un equipo de trabajo, priorizar el mantenimiento intergeneracional de la unidad familiar, con ciertos niveles de producción para el autoconsumo y con un consumo frugal; en fin, sostener una racionalidad material. Pero, como hemos visto, sin una tradición que la sostenga y sin nuevos elementos de legitimación, el modo de vida rural no se constituyó el elemento central de una racionalidad sustantiva que consolidara la forma social de producción farmer.

En fin, existe demasiada complejidad como para conceptualizar la forma social que predominaba en el agro bonaerense de fines de los ochenta, al menos con un nivel de abstracción que se distancie relativamente de tantas particularidades empíricas. Al mismo tiempo, además de la dificultad que surge de la complejidad, tampoco presenta una estabilidad en el tiempo (tener en cuenta la crisis de los medianos productores en los años noventa) que justifique caracterizar esta realidad como otro modelo de desarrollo agrario.

Ante esta situación, nos propusimos avanzar en otro sentido: identificar las principales tendencias del desarrollo agrario regional retomando los interrogantes que abriéramos en la Introducción acerca de las relaciones entre desarrollo del capitalismo en el agro y el tamaño de las unidades, la tenencia del suelo y las formas de organización social del trabajo (consideramos que las reflexiones sobre la articulación con la racionalidad económica y los modos de vida ya las hemos explicitado en el capítulo cuarto y la primera parte del presente capítulo). Para abordar estas cuestiones, consideraremos las tendencias que recorrieron todo el período estudiado, pero con especial atención a lo acontecido en las últimas décadas del siglo XX.

En primer lugar, encontramos una clara tendencia hacia unidades de producción con mayores inversiones de capital por unidad de superficie, tanto en bienes de capital 
como en insumos. La tendencia sería hacia unidades más capitalizadas, en el sentido de que tendrían una mayor relación capital/tierra y capital/trabajo.

En segundo lugar, tuvo lugar un importante proceso de concentración, de modo que las unidades fueron cada vez más grandes en extensión territorial. Lo cual, combinado con la tendencia anterior, generó que las inversiones de capital por explotación se elevaran aún más que las por unidad de superficie.

En tercer lugar, la mayor extensión y las más altas inversiones de capital no generaron necesariamente una organización del trabajo en base a asalariados, tal como ya hemos explicado. Sin embargo, en el caso pampeano, sí se ha evolucionado hacia explotaciones basadas en la fuerza de trabajo asalariada que, sin llegar a ser empresas típicamente capitalistas (pues la mayoría sólo tenían uno o dos asalariados permanentes), con certeza ya no eran explotaciones familiares. El cambio en el modo de vida habría incidido fundamentalmente en esta transformación.

La cuarta tendencia fue un incremento en el peso de las formas combinadas de tenencia del suelo, con cada vez más importancia del arriendo de corto plazo. Sobre esta cuestión necesitamos extendernos con más detalle.

Podemos afirmar que en la región pampeana la conjunción entre propiedad y producción se debe, en buena medida, a la intervención estatal en favor de la consolidación del modelo de las unidades productivas en propiedad y basadas en el trabajo familiar. Así como éste había sido el objetivo perseguido por las políticas de colonización norteamericanas durante el siglo XIX, fue la ideología que, sin llegar a implementar una reforma agraria, sostuvo la regulación estatal de los arriendos a mediados del siglo XX en la Argentina y la que terminó propiciando el acceso a la propiedad de buena parte de estos arrendatarios.

Sin embargo, cuando la intervención estatal se diluyó, se tendió a una expansión de la superficie en arriendo, en la forma combinada con parcelas en propiedad ${ }^{50}$. Entonces, la importancia de la propiedad se debe más bien a la permanencia de resultados de políticas previas, que a una tendencia propia del desarrollo económico.

50 El mismo fenómeno ocurrió en el Corn Belt norteamericano. 
A pesar de la afirmación anterior, cabe aclarar que las formas de tenencia que más se expandieron no fueron las del arriendo puro, sino aquellas que lo combinaban con un predio en propiedad. Estas formas mixtas de tenencia se adaptaron al proceso de concentración de la producción en unidades cada vez más grandes ocurrido durante este período. Con esta forma mixta de tenencia, el productor tiene un espacio relativamente seguro donde edificar su casa, los galpones, silos y construcciones para la ganadería. También adquiere una serie de ventajas a partir de la propiedad: una renta, una garantía para el acceso al crédito, respeto social, pero también una inversión relativamente segura para la vejez, para el traspaso generacional y hasta un bien simbólico importante, en tanto que ser un propietario se ha conservado como una meta vital durante la segunda mitad del siglo XX. Por otro lado, la expansión de la explotación bajo la forma del arriendo o de alguna forma de aparcería presenta la ventaja de no requerir grandes inmovilizaciones de capital en la compra de más tierra (el fonds perdu de Weber, 1906: 138). Todo este dinero puede volcarse al arriendo de grandes superficies y su puesta en producción agrícola. De este modo, combinando propiedad y arriendo, el productor puede alcanzar la escala necesaria para la plena utilización de las grandes maquinarias que se desarrollaron en estas décadas ${ }^{51}$.

Entonces, hemos identificado una clara tendencia en el agro bonaerense hacia unidades más cercanas al modelo de agro capitalista clásico, sobre todo si pensamos la situación más próxima al modelo farmer que existían en los años sesenta. Creció la importancia de las inversiones de capital, del trabajo asalariado y del arriendo. Sin embargo, para 1988 todavía se estaba lejos del modelo tripartido de tres sujetos claramente diferenciados: el arrendatario capitalista, el terrateniente meramente rentístico y los asalariados rurales.

Por otra parte, la enorme expansión de la contratación de terceros para la realización de las labores agrícolas, introduce un elemento que no estaba previsto en el

51 También es una fórmula menos conflictiva socialmente ya que, por un lado, permite paliar los problemas de escala que afectan a las pequeñas unidades en propiedad pura $\mathrm{y}$, por otro lado, no genera sujetos tan desamparados como los arrendatarios o aparceros, siempre bajo algún grado de arbitrio por parte de los terratenientes. 
modelo clásico. Sin embargo, sin que sea posible conceptualizarlo claramente como un arrendatario (pues no asume el riesgo empresario de la producción), estos contratistas de labores serían un tipo de capitalistas rurales, en tanto invierten en maquinarias y no en tierras, y, en general, utilizan asalariados, especialmente los más grandes.

En fin, el proceso de "aburguesamiento" de los productores medios promovió un desarrollo agrario más capitalista, tanto porque invirtieron en maquinarias propias, se expandieron en arriendo y contrataron más asalariados, como porque estimularon el crecimiento de un sector de contratistas de servicios. Sin embargo, no debe concluirse de esto que los productores "aburguesados" habían logrado un lugar seguro dentro del esquema productivo pampeano. Es cierto que, una mejor formación gerencial, un conocimiento más estrecho de los avances tecnológicos y una integración más fluida con el mundo de los negocios que giran en torno a las ciudades pampeanas, habían incrementado su capacidad competitiva. Pero, por otro lado, el "aburguesamiento" había disuelto las ventajas que tienen las unidades familiares, y especialmente las agrarias, para competir frente a las grandes empresas capitalistas ${ }^{52}$.

Sin las características de la empresa familiar, sin una racionalidad sustantiva que las guíe, y en un contexto de desprotección por parte del Estado y de desinterés por parte del resto de la sociedad, las pequeñas y muchas de las medianas explotaciones tuvieron graves dificultades a pesar del crecimiento productivo de la agricultura pampeana durante los años setenta, ochenta y noventa ${ }^{53}$. Así, por ejemplo, según nuestras estimaciones para 1999, en la zona norte, sólo habrían quedado la mitad de las explotaciones presentes en $1969^{54}$.

52 Ventajas que han destacado desde Kautsky (1899) hasta Friedmann (1978b) y Reinhardt y Barlett (1989), tal como reseñamos en la Introducción.

53 Sobre la crisis de las pequeñas, pero también de las medianas explotaciones pampeanas durante los años noventa, y los efectos de las políticas neoliberales puede consultarse Azcuy Ameghino (2000).

${ }^{54}$ Estimaciones realizadas a partir de extrapolar la evolución de la cantidad de unidades en Pergamino, según el Censo Agropecuario de 1969 y el Censo Agropecuario Experimental de Pergamino realizado en 1999. 
¿Quiénes se expandieron concentrando las superficies que abandonaban estos pequeños y medianos productores, que en general trataban de retener la propiedad de sus parcelas? Esta es una cuestión que requiere una comparación específica entre los datos de 1988 y del Censo del 2002. Sin embargo, podemos estimar que hubo dos tipos de productores que se expandieron durante los noventa. Por un lado, el tipo de productores que acabamos de describir como predominantes hacia 1988, esto es los más exitosos de los productores que combinan propiedad y arriendo, junto con trabajo asalariado y/o contratistas de servicios. Pero, por otro lado, también habrían jugado un papel destacado diferentes formas de arrendatarios capitalistas. A través del arriendo de corto plazo parece haberse solucionado el problema que la concentración de la propiedad impone al desarrollo del capital en el agro ${ }^{55}$. Sin negar la existencia de procesos de concentración de la propiedad en manos de grandes terratenientes, el fenómeno más importante sería la concentración de la producción sin controlar la propiedad, sino arrendando una gran cantidad de pequeños y medianos lotes de exproductores (o sus herederos) que se han convertido en rentistas de residencia urbana, o en algunos casos cuasi-rentistas.

En los años noventa incrementaron su importancia tres tipos de capitalistas agrarios relativamente novedosos: los grandes contratistas tanteros, los contratistas de servicios y los "pools de siembra". Los primeros, a partir de unas pocas hectáreas en propiedad o sin campos propios, se expanden arrendando varios miles de hectáreas a lo largo de toda la región, de modo de poder aprovechar (en base a los distintos tiempos de maduración) todo el potencial de trabajo de sus enormes maquinarias. Como vimos en el capítulo tercero, los contratistas tanteros (muchos de ellos con algún predio en propiedad) fueron los responsables de la mayor parte de la expansión agrícola de los años setenta y ochenta en las zonas sur y, especialmente, norte de la provincia de Buenos Aires ${ }^{56}$. Los segundos, los grandes contratistas de servicios, tienen una importante dotación de maquinaria, como los primeros, pero en vez de encarar en forma directa la producción agrícola, ofrecen sus servicios de arada, siembra y cosecha a los productores rurales. Más allá de que la mitad de estos grandes contratistas de servicios

55 Recordar la síntesis del planteo de Kautsky (1899) que realizamos en la Introducción.

56 Aunque cabe aclarar que muchos de estos contratistas todavía tenían un carácter relativamente familiar. 
tenían alguna pequeña extensión en la que eran los productores, la verdadera escala la alcanzaban trabajando campos de terceros, así, en promedio, cosechaban casi tres mil hectáreas por año (Della Valle y Vicien, 1995). Los terceros, los "pools de siembra", son organizados por empresas encargadas tradicionalmente de la administración de explotaciones agropecuarias, que invierten capital propio, de sus clientes y eventuales aportantes particulares, utilizando los servicios de ingenieros agrónomos y de contratistas de maquinaria ${ }^{57}$. Los "pools" chicos trabajan un promedio de 10.000 hectáreas, pero los grandes presentan un tamaño medio de 60.000 hectáreas dedicadas a la agricultura (!). Esta figura ha cobrado especial importancia en los años noventa: según Posada (1998), los "pools" habrían controlado entre un 15\% y un 20\% de la superficie sembrada en $1997^{58}$, aunque es probable que este haya sido un fenómeno relativamente coyuntural. Recién con un detallado análisis del Censo Agropecuario Nacional 2002 se revelará la verdadera importancia de estos distintos tipos de arrendatarios capitalistas.

La contracara de estos grandes capitalistas agrarios, es la presencia de una enorme cantidad de pequeños rentistas, con tamaños cada vez menores por la subdivisión hereditaria, y que deben buscar empleos urbanos porque los ingresos del alquiler de los campos son cada vez menores.

Entonces, cuando la dinámica económica se desenvolvió con niveles de intervención estatal menos intensos (más cercanos al patrón liberal) y las explotaciones debilitaron sus rasgos familiares, el desarrollo agrario presentó una tendencia hacia el modelo ideal descripto por Marx, y casi olvidado en el cajón de las ideas equivocadas ${ }^{59}$.

57 En este sentido se acercan al pronóstico de Kautsky (1899) cuando señalaba que, además de la posibilidad de aplicar plenamente los avances tecnológicos, la ventaja más importante que se obtiene de la gran empresa es la capacidad de utilizar la división del trabajo entre manual e intelectual, habilitando una "dirección científica" de la explotación.

58 En cada una de las zonas donde opera (lo hace así para diversificar riesgos), contratan a agrónomos que se encargan de monitorear la evolución de las labores y de los cultivos, detectar los campos a alquilar, y contactar a los contratistas locales que se ocuparán de las labores. Pero se centraliza la adquisición de insumos y la comercialización, utilizando toda una serie de instrumentos de ingeniería comercial, logrando importantes economías de escala (Posada, 1998).

59 Ya que, incluso en Inglaterra, durante el siglo XX tuvo lugar un importante desarrollo de la explotación familiar y de las unidades en propiedad frente a las que estaban en arriendo 
La perspectiva pareciera ser que de no mediar modificaciones se avanzará lenta pero inexorablemente hacia un agro cada vez más capitalista: con grandes arrendatarios capitalistas o productores mediano-grandes que combinan una parte en propiedad con otras en alquiler, pequeños y medianos rentistas, y predominio de la mano de obra asalariada (algunos con altos niveles de capacitación). Consideramos que esta tendencia será inexorable en la medida en que se pierdan las características familiares de las unidades de producción, que no se defienda un modo de vida rural, ni se genere una red social que articule alianzas económicas, sociales y políticas con otros sectores interesados en un modelo de desarrollo agrario que potencie el (re)poblamiento del campo, la dinamización de la vida de las localidades intermedias y la generación de circuitos de valorización de la producción al interior de las zonas.

En el aspecto social, el resultado de la expansión de un modelo "inglés" de agro capitalista sería, entonces, una mayor reducción del empleo rural, un campo despoblado, pueblos fantasmas, y una baja circulación del capital al interior de cada una de las zonas $^{60}$. Entonces un agro típicamente capitalista no significará un agro más desarrollado, en el sentido positivo que encerraba tradicionalmente este término. Puede ser un agro socialmente vacío ${ }^{61}$, y, en este sentido, tal vez hasta sea un agro menos conflictivo socialmente, con muy pocos asalariados de una altísima productividad y con remuneraciones no necesariamente muy reducidas.

Pero tampoco un agro más capitalista, significa necesariamente un agro más desarrollado en términos ecónomicos. Si bien estas grandes empresas podrían poner en práctica todos los adelantos tecnológicos, por otra parte el volumen de la producción quedaría mucho más sensible a las coyunturas de precios. Estos grandes capitalistas, algunos estrechamente vinculados al capital financiero, solo invierten en los momentos

(Abramovay, 1998: 163-173).

60 El ejemplo más claro al respecto, son los escasos consumos locales que realizan las empresas contratistas que se movilizan a lo largo de las distintas zonas escalonando las cosechas.

${ }_{61}$ Nuevamente, el modelo inglés nos recuerda que, justamente, un desarrollo agrario típicamente capitalista se construyó con el vaciamiento de los campos, en este caso con una intensa violencia, tal como Marx (1867: capítulo XXVII) describió detenidamente para explicar la acumulación originaria. 
en que se avizoran importantes tasas de ganancia en el sector. Una conducta totalmente opuesta a la del productor familiar que sólo sabe reproducir su ciclo maximizando ingresos a través de la maximización de la producción, incluso cuando los precios se reducen como se vio en los años treinta.

El devenir del agro pampeano no es un problema de rentabilidades, de precios relativos y niveles impositivos, sino de fuertes diferenciales en las oportunidades reales para acceder a los beneficios extraordinarios producidos por estos movimientos de precios y por los incrementos en la producción derivados de mayores inversiones de capital por unidad de superficie y/o de producto. En última instancia, esta es una cuestión de políticas públicas y de estrategias particulares y colectivas en torno a diferentes modelos de desarrollo agrario ${ }^{62}$. Y este no es un problema meramente sectorial. Como hemos visto en nuestra historia, el modelo de desarrollo agrario posee importantes consecuencias sobre el resto de la sociedad, especialmente sobre las economías locales, aquellas que aseguran la sobrevivencia de localidades y ciudades intermedias a lo largo de toda la región pampeana.

62 Recién en los últimos años han comenzado a plantearse luchas, movimientos de resistencia y debates académicos que, desde distintas perspectivas, reclaman la necesidad de pensar el modelo de desarrollo agrario deseado para la Argentina. Una interesante muestra de estas propuestas han sido las mesas redondas de las Segundas Jornadas Interdisciplinarias de Estudios Agrarios y Agroindustriales (realizadas en la Facultad de Ciencias Económicas de la UBA en noviembre de 2001) donde los pequeños y los medianos productores no sólo explicaron sus luchas, sino que propusieron explícitamente repensar el desarrollo agrario argentino. En este mismo sentido avanzaron algunos de los investigadores (Carballo, $2001 \mathrm{y}$ Manzanal, 2001, entre otros). 
Apéndices

*

Fuentes y Bibliografía 


\section{Apéndice 1. Metodología y datos complementarios del Capítulo Primero}

\section{Metodología utilizada en las estimaciones basadas en los datos del Censo Nacional Agropecuario de 1937}

A fin de estimar la importancia numérica, territorial y en la actividad agrícola de los distintos tipos de explotaciones en 1937, discriminadas según su tamaño, forma de tenencia del suelo y organización social del trabajo, hemos formulado una serie de supuestos, ya que los cuadros publicados de dicho censo ${ }^{1}$ eran, en la mayoría de los casos, univariados a nivel de partidos.

\section{Proporción de agricultura realizada en cada tipo de explotación:}

En el censo se discriminan los establecimientos según diferentes tipos (chacras, mixtas, de cría, invernada, con ganadería, tambo, granja, quinta, etc), pero en ningún lugar se especifican los criterios empleados para codificarlos (esta no era una pregunta del cuestionario). Para poder estimar la distribución de la superficie agrícola, hemos partido del supuesto de que las chacras dedicaban el $90 \%$ de su superficie a la agricultura. La superficie agrícola restante de cada partido se adjudicó a las explotaciones "mixtas". Sabemos que una parte de la agricultura se debía realizar en establecimientos catalogados como ganaderos, pero nos resulta imposible de discriminar en relación con las unidades "mixtas", que como su nombre lo indica, seguramente tendrían una orientación hacia la agricultura más marcada que las explotaciones ganaderas.

$\underline{\text { Superficie ocupada por los distintos tamaños de explotaciones: }}$

En la publicación sólo se consignaron la cantidad de unidades por intervalo de tamaño por tipo de explotación. Para estimar la superficie que ocupaban hemos utilizado el valor medio de cada uno de los intervalos. Como la publicación del censo

\footnotetext{
${ }^{1}$ A pesar de extensas búsquedas no hemos localizado información inédita de este censo.
} 
presentaba los casos discriminados en intervalos mucho más pequeños que otros censos (al menos, en los niveles más bajos), la posibilidad de error por usar el valor medio se reduce sustancialmente. Hemos considerado que podría ocurrir que las explotaciones se hubieran concentrado en los valores más bajos de los intervalos, ya que la frecuencia global presenta esta distribución sesgada hacia abajo (es decir, casi siempre hay más casos en el intervalo anterior que en el superior). Sin embargo, como los intervalos incluían al número redondo en el estrato más bajo (por ejemplo, el estrato de 150 a 200 incluía a las unidades de 200 hectáreas) y nuestros análisis ${ }^{2}$ nos mostraron que en estos números redondos se concentraba una elevada cantidad de casos, continuamos prefiriendo el valor medio del intervalo, frente a cualquier otra estimación en base a una función de distribución.

En el caso particular de las chacras y mixtas de mayor tamaño, nos encontramos frente al problema de que se encuentran encasilladas en la categoría "de más de 625 hectáreas", sin establecerse un límite superior. Frente a esta dificultad, Barsky (1997) ha optado por adjudicarles un tamaño medio de 1.250 hectáreas, el valor más elevado del intervalo siguiente que sí existe para las unidades ganaderas (625 a 1.250). Sin embargo, estimamos que en este caso resulta claro que sí existía una clara concentración de las unidades en la parte inferior del intervalo (hemos analizado los establecimientos de Tres Arroyos hacia $1928^{3}$ ).

\section{Tenencia del suelo:}

En el censo se consigna sólo la cantidad de explotaciones que se encontraban en arriendo en dinero o en especies, por tipo de explotación. En base a las proporciones en arriendo de chacras y mixtas, hemos estimado la superficie agrícola según el tipo de tenencia del suelo. El supuesto utilizado en esta estimación es que había una relación

${ }^{2}$ Estos análisis se basaron en los planos catastrales de 1937/39 y en el estudio de las explotaciones presentes en Tres Arroyos hacia fines de los años veinte (Balsa, 1994a)

${ }^{3}$ Las explotaciones de más de 625 hectáreas en las que la agricultura representaba como mínimo el $25 \%$ de la superficie total (lo que podría equipararse con las chacras y las mixtas) tenían un tamaño medio de 1.086 hectáreas, con una mediana ubicada en las 889 hectáreas y una media $5 \%$-podada en 1.007. Por lo tanto, utilizamos el tamaño medio del intervalo de 625 a 1.250 hectáreas, y adjudicamos un tamaño de 937.5 hectáreas a todas las chacras y mixtas incluidas en el estrato de "más de 625 hectáreas". 
propiedad-arriendo constante a lo largo de todos los intervalos de tamaño de cada tipo de explotación. Probablemente, las chacras o las unidades "mixtas" de mayor tamaño presentaran una proporción mayor de explotaciones en propiedad, que las pequeñas. Sin embargo, también sabemos de la existencia de numerosas propiedades pequeñas. En fin, nuevamente no tenemos ningún indicador para corregir la estimación, por lo cual nos vemos obligados a utilizar el mencionado supuesto. Cabe precisar dos cuestiones: en primer lugar, los márgenes de error se acotan al trabajar todas las estimaciones a nivel de partidos (y no de zonas); en segundo lugar, debido a la escasa importancia de la agricultura en muy grandes unidades, las diferencias que pudieran surgir por la invalidez de este supuesto sólo podrían tener significación en el caso de la zona sur.

Corresponde realizar una aclaración. No queda para nada claro cómo codificaron los censistas a las explotaciones que declararon tener campos en propiedad y campos en arriendo. Resulta probable que en estos casos, algunos productores hayan consignado que poseían varias explotaciones (el censo aclaraba que debía llenarse una libreta por cada explotación). Sin embargo, esta no debe haber sido la conducta de la mayoría, ya que no observamos mayores diferencias con la cantidad total de unidades consignadas en 1947. Por lo tanto, resulta probable que, o bien los productores respondieran considerándose como propietarios, si tenían al menos una porción en propiedad ${ }^{4}$, o bien fueran catalogados como propietarios todos aquellos que eran dueños de al menos una parcela.

En todo caso, probablemente no serían una gran cantidad de unidades productivas las que presentaban esta forma mixta de tenencia, si tenemos en cuenta los valores consignados en el censo de 1947, que sí diferenció este tipo de unidades ${ }^{5}$. En

\footnotetext{
${ }^{4}$ Las preguntas del cuestionario sobre tenencia eran: "10. ¿Es PROPIETARIO de la chacra o establecimiento rural? 11. Si no es propietario, diga quién es el dueño del campo? 12. Y el domicilio del dueño 13. Es ARRENDATARIO? ...".

${ }^{5}$ Durante los diez años que median entre ambos censos ocurrieron cambios significativos en la legislación que generaron dinámicas contradictorias respecto de las formas mixtas de tenencia. Por una parte, si el arrendatario era al mismo tiempo propietario, el terrateniente que quería volver a disponer de su campo podía desalojarlo de su predio por estar exceptuado de la prórroga de los arriendos. Sin embargo, debido a la existencia de esta misma cláusula, aquellos terratenientes que querían dar sus campos en arriendo buscaban especialmente a productores que tuvieran al menos una parte de sus explotaciones en propiedad. En fin, si estas tendencias opuestas fueran de igual significación, podrían extrapolarse las cifras de 1947 para estimar la importancia de las formas mixtas de tenencia en 1937.
} 
esta última fecha, entre el $6 \%$ y un $8 \%$ de las unidades censadas en cada zona fueron catalogadas con formas mixtas de tenencia que incluían la propiedad. En cuanto a la superficie que ocupaban, su importancia habría sido tan solo un poco mayor (en 1947, controlaban entre un $10 \%$ a un $16 \%$ según las zonas).

\section{Mano de obra:}

En el censo no se discrimina a las unidades por su organización social del trabajo. Tan sólo se consignan el número total de explotaciones que contrataban asalariados fijos y la cantidad de estos trabajadores por partido. También se consignaron los mismos datos para los trabajadores transitorios, pero que estuviesen trabajando el día del censo (30 de junio de 1937). Por lo tanto, tal como lo aclaran en varios cuadros de la publicación del propio censo, se encuentran claramente subregistrados los trabajadores contratados eventualmente, cuyo número sería mucho mayor para los momentos de la cosecha fina y, sobre todo, para la recolección, aún manual, del maíz.

A partir del número de unidades que contrataban asalariados permanentes ${ }^{6}$ hemos estimado cuáles intervalos de tamaño habrían hecho uso de este tipo de mano de obra, bajo el supuesto de que serían las unidades de mayor tamaño las que utilizaban mano de obra asalariada en forma permanente. Reconocemos que es un supuesto muy simplificador, pero también muy plausible. Evidentemente, todos los testimonios indican que también había pequeñas unidades que utilizaban asalariados (no tanto por un uso más intenso del recurso suelo, sino porque les faltaban brazos en la estructura familiar -tal el caso de unidades a cargo de mujeres viudas, o matrimonios sin hijos con capacidad de trabajo, etc.), también existían unidades con una abundante cantidad de hombres dentro de la estructura familiar, y que, entonces, podían trabajar importantes extensiones (500 o 700 hectáreas, por ejemplo), sin recurrir a asalariados de forma permanente. Nuestra estimación, de este modo, ya que atiende a la superficie ocupada por las diferentes formas de organizar la producción, ha subrepresentado a las unidades familiares, y sobrerepresentado la extensión en manos de explotaciones con asalariados.

6 En muy pocos partidos había más unidades que contrataban trabajo asalariado transitoriamente, que unidades que lo hacían de modo permanente. 
Se procedió, en primer lugar, a restar a la cantidad acumulada de explotaciones, el número de establecimientos con asalariados permanentes, comenzando desde las unidades de mayor tamaño. En el intervalo correspondiente, se calculó la proporción de establecimientos con y sin asalariados permanentes.

En segundo lugar, hemos estimado el número de asalariados permanentes para cada explotación de los diferentes intervalos, según la cantidad de hectáreas ocupadas por los distintos estratos de tamaño. Si bien en las explotaciones de menor tamaño podría haber habido una mayor cantidad de trabajo por hectárea, es justamente en estas unidades donde el trabajo del productor y de sus familiares habría tenido un mayor peso en el conjunto de la fuerza de trabajo. Por lo tanto, resulta muy plausible que sólo contaran con un asalariado, o en todo caso dos en las de un tamaño mediano. Las entrevistas realizadas confirman las estimaciones realizadas de este modo. En última instancia, la existencia de pequeñas unidades con asalariados sólo acrecentaría el peso de la producción familiar en el conjunto de la agricultura. Además, estas estimaciones se consolidan con el total de asalariados de cada partido, por lo cual no existen muchas posibilidades de que la cantidad de asalariados permanentes por cada intervalo de explotación sea muy distinto al estimado ${ }^{7}$.

\footnotetext{
${ }^{7}$ Existe una restricción aritmética. Así por ejemplo, si incrementásemos la cantidad estimada de asalariados permanentes presentes en las unidades medianas, se reducirían sustancialmente la cantidad de trabajadores permanentes en las explotaciones grandes hasta niveles totalmente inverosímiles, sobre todo porque eran muy pocas unidades.
} 


\section{Los grandes terratenientes bonaerenses en los tres partidos considerados, 1939}

Identificación social de las grandes propiedades de Pergamino, 1937

\begin{tabular}{|l|l|c|}
\hline Tamaño & Propiedad & Porcentaje \\
\hline \multirow{5}{*}{+5.000 ha } & Instituciones & - \\
& Grandes familias & $100 \%$ \\
& Estancieros locales & - \\
\hline \multirow{2}{*}{ 2501-5000 ha } & Instituciones & $20 \%$ \\
& Grandes familias & $60 \%$ \\
& Estancieros locales & $20 \%$ \\
\hline \multirow{2}{*}{$501-1000$ ha } & Instituciones & $9 \%$ \\
& Grandes familias & $41 \%$ \\
& Estancieros locales & $50 \%$ \\
\hline & Instituciones & - \\
& Grandes familias & $100 \%$ \\
\hline
\end{tabular}

Fuente: Estimaciones propias basadas en el Mapa Catastral de 1939, cruzadas con los datos sobre los terratenientes bonaerenses hacia 1923 elaborados por Harispuru (1986).

Nota: en "Instituciones" hemos consignado las propiedades a nombre de los Bancos, Sociedades Anóminas e Instituciones oficiales. En los tres partidos, predominaban en este rubro las propiedades de los Bancos (resultado en buena medida del fracaso de los créditos hipotecarios durante la Crisis del treinta). 
Identificación social de las grandes propiedades de Rivadavia, 1937

\begin{tabular}{|l|l|c|}
\hline Tamaño & Propiedad & Porcentaje \\
\hline \multirow{3}{*}{+5.000 ha } & Instituciones & $10 \%$ \\
& Grandes familias & $60 \%$ \\
& Estancieros locales & $30 \%$ \\
\hline \multirow{2}{*}{$2501-5000$ ha } & Instituciones & - \\
& Grandes familias & $29 \%$ \\
& Estancieros locales & $71 \%$ \\
\hline \multirow{2}{*}{$1001-2500$ ha } & Instituciones & $8 \%$ \\
& Grandes familias & $42 \%$ \\
& Estancieros locales & $50 \%$ \\
\hline
\end{tabular}

Fuente: Estimaciones propias basadas en el Mapa Catastral de 1939, cruzadas con los datos sobre los terratenientes bonaerenses hacia 1923 elaborados por Harispuru (1986).

Identificación social de las grandes propiedades de Tres Arroyos, 1937.

\begin{tabular}{|l|l|c|}
\hline Tamaño & Propiedad & Porcentaje \\
\hline \multirow{3}{*}{+5.000 ha } & Instituciones & $33 \%$ \\
& Grandes familias & $56 \%$ \\
& Estancieros locales & $11 \%$ \\
\hline \multirow{3}{*}{ 2501-5000 ha } & Instituciones & $38 \%$ \\
& Grandes familias & $38 \%$ \\
& Estancieros locales & $25 \%$ \\
\hline \multirow{2}{*}{$1001-2500$ ha } & Instituciones & $18 \%$ \\
& Grandes familias & $29 \%$ \\
& Estancieros locales & $53 \%$ \\
\hline
\end{tabular}

Fuente: Estimaciones propias basadas en el Mapa Catastral de 1939, cruzadas con los datos sobre los terratenientes bonaerenses hacia 1923 elaborados por Harispuru (1986). 


\section{Apéndice 2. Estadísticas y Análisis complementarios del Capítulo Segundo}

\section{Evolución del área sembrada y el volumen cosechado entre 1938 y 1969}

\subsection{La región pampeana y la provincia de Buenos Aires}

Considerando la superficie sembrada, observamos en el Gráfico A.2.1 que en el conjunto de la región pampeana tuvo lugar una considerable reducción de esta área durante la década del cuarenta (con una extensión mínima en 1951). Si discriminamos entre los cultivos para cosecha (graficados con fondo de color gris ${ }^{1}$ ) y aquellos usados también como forrajeras (especialmente, la avena y el centeno, con fondo de color blanco), podemos ver que aumentó levemente la superficie destinada a estas últimas, mientras se reducían las primeras, destacándose por su intensidad la caída del área sembrada con maíz, que disminuyó de unos seis millones de hectáreas a sólo dos (en cambio, el girasol comenzaba su expansión en estos años).

Luego, durante los años cincuenta, la superficie sembrada con cultivos para cosecha se mantuvo estable en niveles claramente inferiores a los del 1938 (mientras se expandía el área ocupada por el centeno). Recién en la década del sesenta se observa una cierta recuperación de los cultivos para cosecha (el maíz llegó en 1969 a unos cuatro millones de hectáreas).

1 Incluimos dentro de esta categoría al trigo, el maíz, el lino, el girasol, la soja (aunque sólo comenzó a sembrarse a fines de los años sesenta) y la cebada cervecera. Cabe acotar que nunca se cosechó la totalidad del área sembrada. Como podemos ver en el siguiente cuadro, en los años cuarenta y cincuenta alrededor del $30 \%$ de la superficie sembrada con maíz, no era cosechada. Algo similar ocurría con la cebada cervecera. En el caso de la avena, menos de la mitad era cosechada, y sólo un tercio del centeno.

Porcentaje de superficie cosechada sobre total de superficie sembrada

Región pampeana1938-19471948-571958-67trigo81\%81\%87\%maíz70\%68\%82\%lino81\%77\%87\%girasol 81 $\% 76 \% 84 \%$ avena $47 \% 48 \% 44 \%$ centeno37\%36\%27\%cebada cervecera $72 \% 72 \% 71 \%$ Fuente: Cálculos propios en base a las Estimaciones Agrícolas de la Secretaría de Agricultura y Ganadería de la Nación. 
Gráfico A.2.1.

\section{Región pampeana. Superficie sembrada}

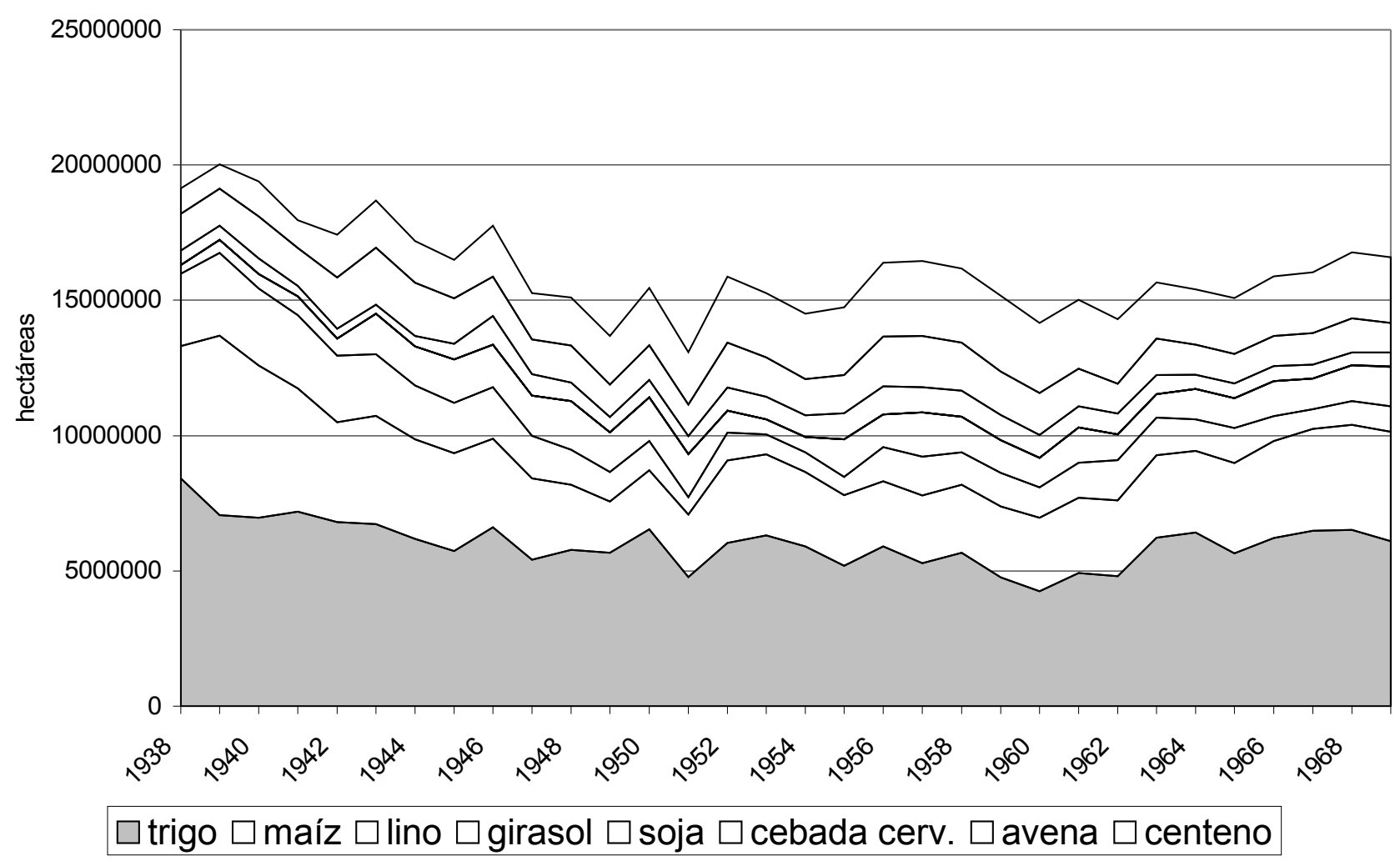

Fuente: Cálculos propios en base a las Estimaciones Agrícolas de la Secretaría de Agricultura y Ganadería. 
En la provincia de Buenos Aires, la evolución de la superficie sembrada fue muy similar al del conjunto de la región pampeana (ver Gráfico A.2.2). Tal vez, la diferencia más significativa es que en los años sesenta la recuperación fue un poco más importante en esta provincia, alcanzándose casi los niveles de fines de los años treinta (se destaca, en este sentido, el incremento en el área destinada al trigo).

\section{Gráfico A.2.2.}

\section{Buenos Aires. Superficie sembrada}

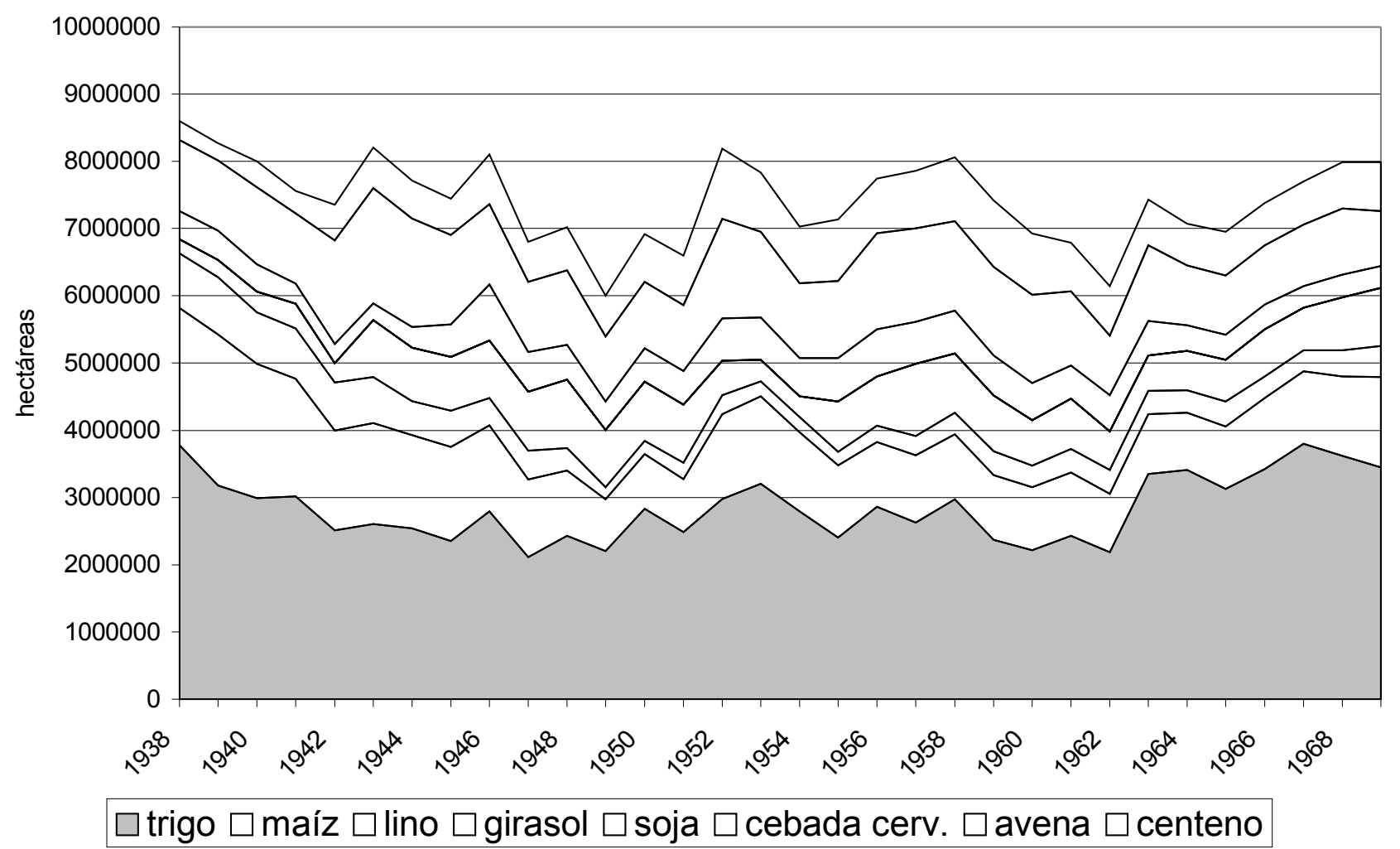

Fuente: Cálculos propios en base a las Estimaciones Agrícolas de la Secretaría de Agricultura y Ganadería. 
En cuanto a los volúmenes cosechados en el conjunto de la región pampeana, durante los años cuarenta tuvieron lugar fuertes oscilaciones con una tendencia claramente decreciente (su punto más bajo ocurrió en la cosecha 1951/52), tal como se observa en el Gráfico A.2.3. Discriminando entre cultivos, vemos que la principal causal de estas oscilaciones descendentes fue la reducción de la producción de maíz.

En la década del cincuenta el volúmen cosechado se estabilizó, pero en niveles inferiores a los presentes a fines de los treinta, observándose cierto aumento de la importancia de la cosecha de avena y centeno. Recién en los años sesenta, tuvo lugar cierta recuperación productiva (gracias al leve incremento del área sembrada y a un aumento en los rindes, tal como se observa en el Cuadro A.2.1) alcanzándos en 1969 los niveles de 1938. En el Apéndice 5 se consigna la evolución de la superficie cosechada y los rendimientos en cada año.

\section{Cuadro A.2.1. Rendimientos, promedios decenales de kilogramos por hectárea cosechada}

\begin{tabular}{|l|c|c|c|}
\hline Región pampeana & $1938-1947$ & $1948-57$ & $1958-67$ \\
\hline trigo & 1106 & 1217 & 1380 \\
\hline maíz & 1859 & 1605 & 2044 \\
\hline lino & 655 & 631 & 658 \\
\hline girasol & 868 & 699 & 705 \\
\hline avena & 1003 & 1171 & 1229 \\
\hline centeno & 644 & 691 & 727 \\
\hline cebada cervecera & 1223 & 1252 & 1200 \\
\hline
\end{tabular}

Fuente: Cálculos propios en base a las Estimaciones Agrícolas de la Secretaría de Agricultura y Ganadería de la Nación. 
Gráfico A.2.3.

\section{Región Pampeana. Producción}

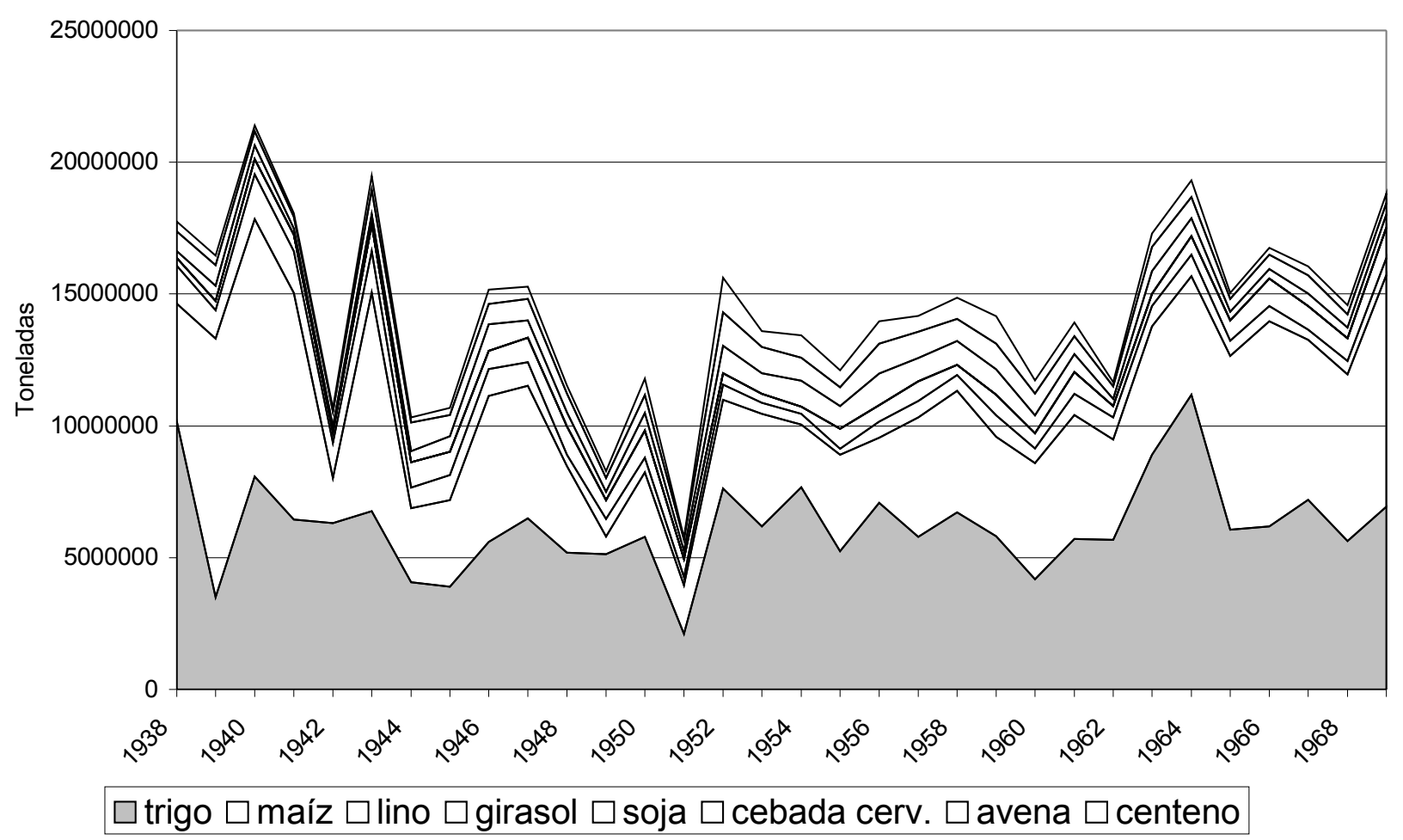

Fuente: Cálculos propios en base a las Estimaciones Agrícolas de la Secretaría de Agricultura y Ganadería. 
La evolución de la producción agrícola de la provincia de Buenos Aires fue muy similar a la del conjunto de la región (ver Gráfico A.2.4), tan sólo puede destacarse que la expansión del volumen cosechado de trigo en los años sesenta fue más importante en esta provincia, así como en la década del cincuenta, la cosecha de avena y centeno también había sido más significativa.

\section{Gráfico A.2.4.}

\section{Buenos Aires. Producción}

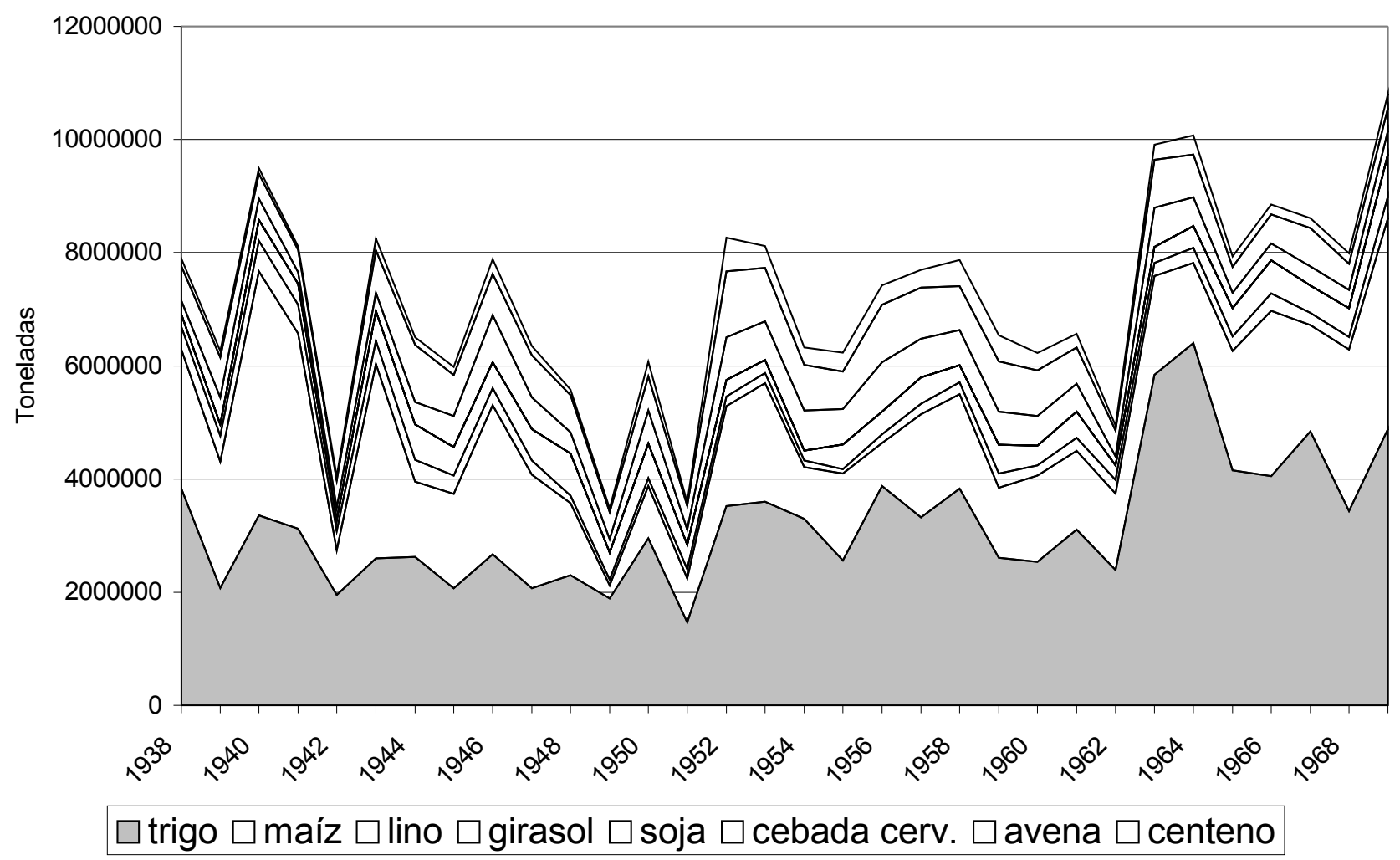

Fuente: Cálculos propios en base a las Estimaciones Agrícolas de la Secretaría de Agricultura y Ganadería. 


\subsection{Las tres zonas analizadas}

A partir de las Estimaciones Agrícolas elaboradas por la Secretaría de Agricultura y Ganadería de la Nación, hemos calculado la superficie sembrada y cosechada, el volumen cosechado y los rendimientos de las tres zonas en estudio para cada uno de los años analizados. Para ello hubo que procesar la información de los ocho principales cultivos de cada uno de los cuarenta partidos (para ejemplificar el modo en que hemos trabajado, en el Apéndice 5 reprodujimos uno de estos cuadros). A fin de sintetizar la presentación, omitimos los cuadros con los datos por partido, y sólo insertamos los gráficos con la información agregada para cada una de las tres zonas sobre el área sembrada y el volumen cosechado. En algunos casos, hemos agregado la información decenal sobre el porcentaje de superficie cosechada o el rendimiento de los cultivos. En el mismo Apéndice 5 hemos reproducido los cuadros con la información agregada por zonas sobre las cuatro variables procesadas y analizadas.

\section{Cambios productivos en la zona norte}

Durante la década del cuarenta, observamos una clara disminución del área sembrada en esta zona. Si analizamos la composición de los cultivos, vemos en el Gráfico A.2.5 que el principal responsable de este fenómeno fue el maíz, cuya superficie sembrada se redujo a la mitad de la que tenía a comienzos del período. En cambio, el trigo aumentó su significación en esta zona (a fines de los años treinta el maíz cuadruplicaba la importancia del trigo) y pasó a constituirse en el principal cultivo en las cosechas de 1950/51 y 1951/52. Otro cultivo que creció en importancia en los años cuarenta, y luego se mantuvo, fue el girasol; al tiempo que el lino perdía el papel destacado que había tenido hasta fines de los años treinta.

Este retroceso agrícola, fue acompañado por una expansión de la ganadería vacuna. Entre 1937 y 1947 el número de vacunos presentes en la zona norte aumentó en 471.000 cabezas, lo que representa un incremento del $65 \%$ (mientras que los ovinos y los equinos disminuyeron su importancia). En el Cuadro A.2.2., podemos observar las variaciones tanto en términos absolutos como en cantidad de animales por hectárea.

En los años cincuenta y sesenta, el área sembrada en la zona norte se mantuvo en niveles notoriamente más bajos que los de comienzo del período (oscilando entre las 900.000 y el millón de hectáreas, frente al 1.200.000 de fines de los años treinta). Tuvo lugar una relativa recuperación del maíz, pero a costa del área sembrada con trigo o girasol (especialmente en los sesenta). Las forrajeras anuales (avena y centeno) sólo tuvieron un muy leve crecimiento en estos años. En cambio podemos observar una importante expansión de las forrajeras 
permanentes, que para 1960 ocupaban el 18\% de la superficie total de la zona norte (frente al $7 \%$ que habían tenido en 1937) ${ }^{2}$. Es que la ganadería vacuna continuaba expandiéndose: en 1960 duplicaba con creces la cantidad de cabezas que había habido en $1937^{3}$ (ver Cuadro A.2.2). Durante el resto de los años sesenta, los vacunos mantendrían este lugar de importancia. Por otra parte, debido a la retracción de la agricultura, a la tractorización, y a la difusión de las cosechadoras automotrices y el transporte automotor, se redujo intensamente el número de equinos (fenómeno que ocurrió en las tres zonas estudiadas).

\section{Gráfico A.2.5.}

\section{Zona norte. Superficie sembrada}

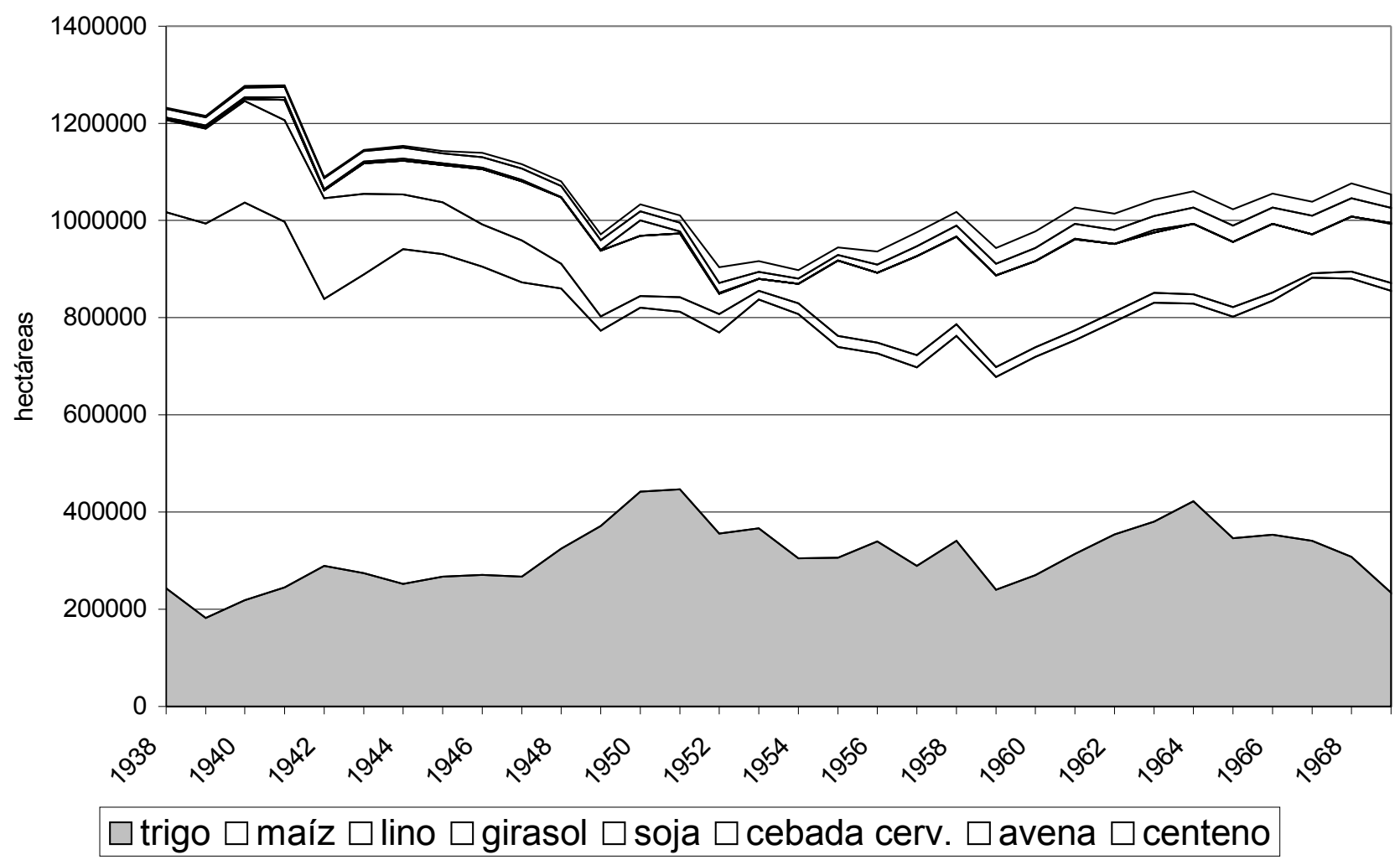

Fuente: Cálculos propios en base a las Estimaciones Agrícolas de la Secretaría de Agricultura y Ganadería.

2 Los técnicos del INTA señalaban, en 1961, que la rotación entre cultivos para cosecha y la alfalfa era muy positiva para la conservación de los suelos, y opinaban que "desgraciadamente, sólo fracciones reducidas de las chacras de la región [de Pergamino] se someten al beneficio de la rotación con alfalfa" (INTA, 1964: 17).

3 En el mismo informe del INTA se concluía que "la ganadería se ha visto favorecida por el parcelamiento de las tierras. Un arrendatario que pasa a ser propietario cambia de actitud ante el suelo. Al ser un bien propio, lo cuida, vale decir, lo restaura con alfalfa o pasturas, cuyo destino lógico será la ganadería" (INTA, 1964: 23). 
Cuadro A.2.2. Proporción de superficie implantada, sobre el total censado y cabezas de ganado por hectárea

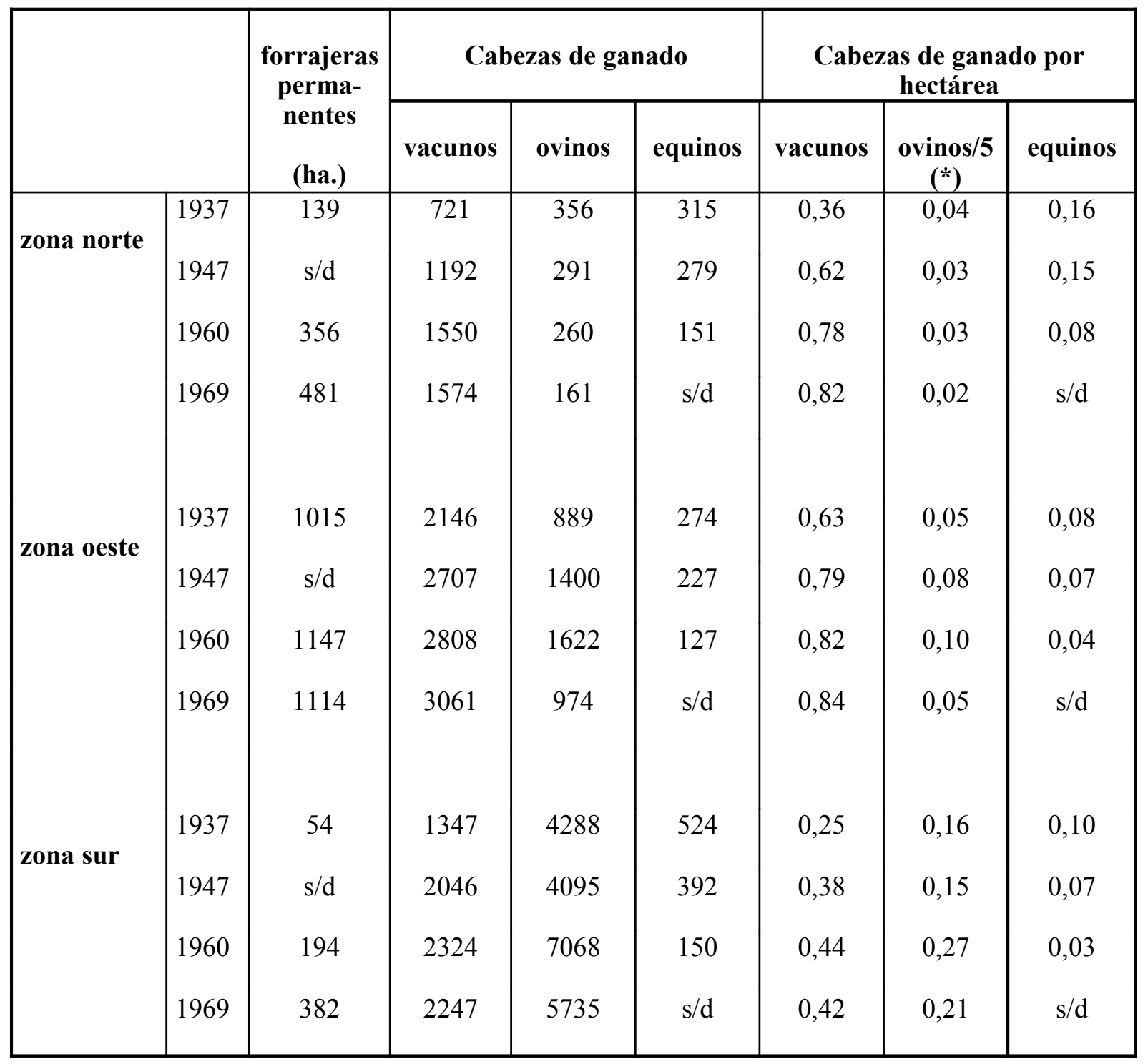

(*) Hemos dividido a los ovinos por cinco a fin de hacer relativamente equiparable su carga ganadera con la de un vacuno o un equino.

Fuente: cálculos propios efectuados en base a la información desagregada por partidos de los Censos Agropecuarios Nacionales de 1937, 1947, 1960 y 1969.

En cuanto a los niveles de producción agrícola, en la zona norte tuvieron lugar fuertes oscilaciones durante la década del cuarenta, pero que terminaron en volúmenes de cosecha muy bajos para los últimos años de esta década y casi toda la siguiente (siendo el maíz el principal responsable de estas fluctuaciones ${ }^{4}$ ). Como vemos en el Gráfico A.2.6, recién en los años

4 Según las conclusiones de los coloquios organizados por el INTA Pergamino en el año 1961buena parte de la declinación en la producción del maíz se debió a que desde 1927 a 
sesenta, con el aumento de la producción triguera, primero, y maicera, luego, los volúmenes cosechados se aproximaron a los de comienzos de la década del cuarenta 5 .

\section{Gráfico A.2.6.}

\section{Zona norte. Producción}

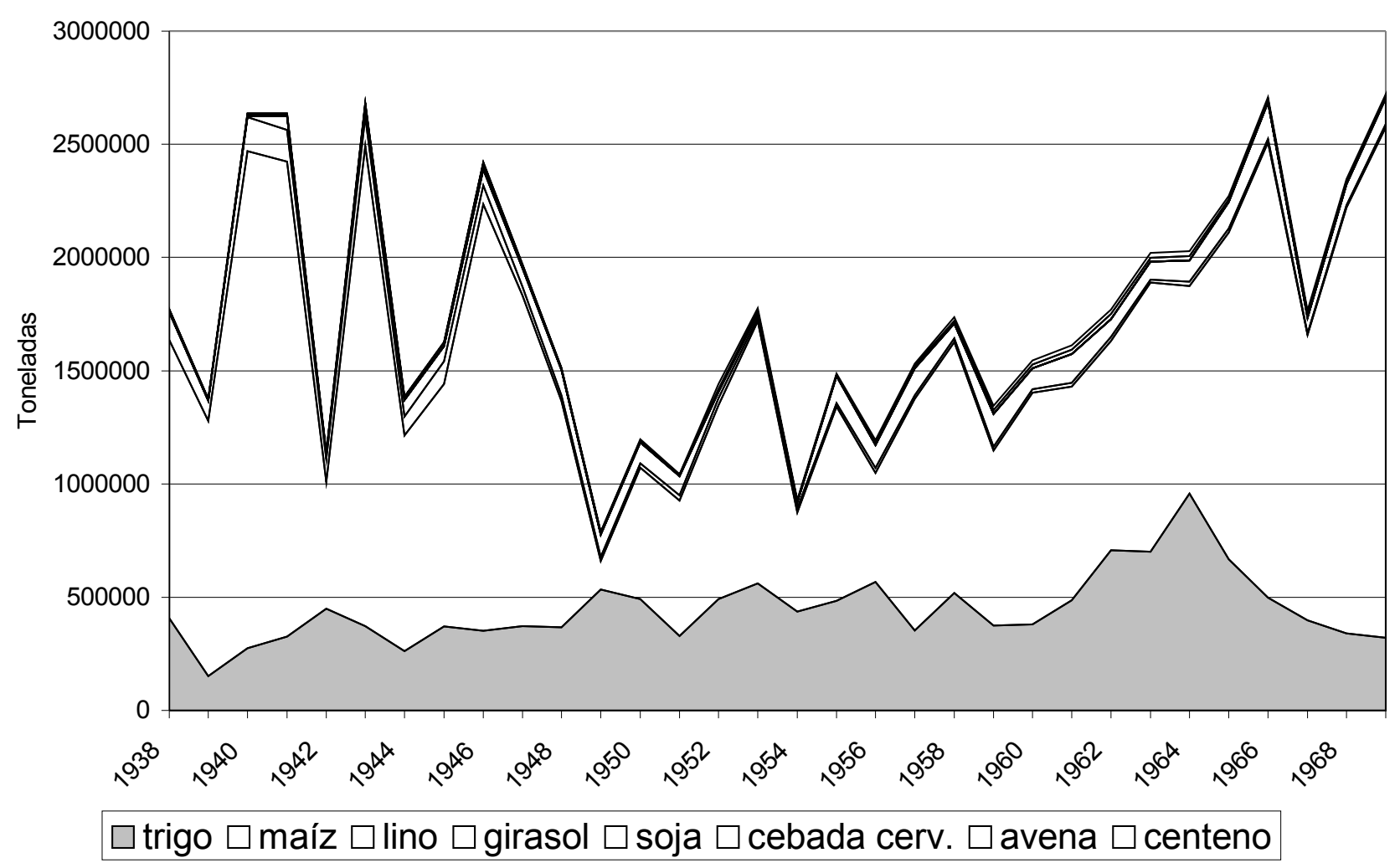

Fuente: Cálculos propios en base a las Estimaciones Agrícolas de la Secretaría de Agricultura y Ganadería.

1958 aumentó la frecuencia de años con sequía de verano, que deprimieron sensiblemente el rendimiento del maíz (INTA, 1964: 4-5).

5 Los rendimientos del maíz, que habían sido particularmente bajos en la zona norte entre 1945 y 1954 (1.958 kilogramos por hectárea en promedio), subieron algo entre 1955 y 1964 (a 2.312 kilogramos) y se incrementaron notoriamente en la segunda mitad de la década del sesenta (alcanzando un promedio de 3.401 kilogramos por hectárea). Para mayores detalles sobre la evolución de la superficie sembrada y los rendimientos ver los cuadros reproducidos en el Apéndice V. 
Cambios productivos en la zona oeste

En la zona oeste, el área sembrada mostró una reducción durante los años cuarenta, pero que se recuperó rápidamente en los cincuenta (ver Gráfico A.2.7). En realidad, si observamos los cultivos agrícolas (grisados), vemos que la reducción fue muy importante en los cuarenta (de 800.000 hectáreas a menos de 400.000) y que se mantuvo en niveles muy bajos durante la década del cincuenta e incluso los comienzos de los sesenta (sobre todo por la reducción del maíz, pero también del trigo, especie que recién se expandió en la segunda parte de la década del sesenta). La aparición del girasol no alcanzó a compensar la caída en estos dos cereales. En cambio, fue muy significativo el aumento en el área sembrada con centeno (una forrajera anual): de 100.000 hectáreas que ocupaba a fines de los treinta, llegó a sembrarse alrededor de medio millón de hectáreas en los años cincuenta.

\section{Gráfico A.2.7}

\section{Zona oeste. Superficie sembrada}

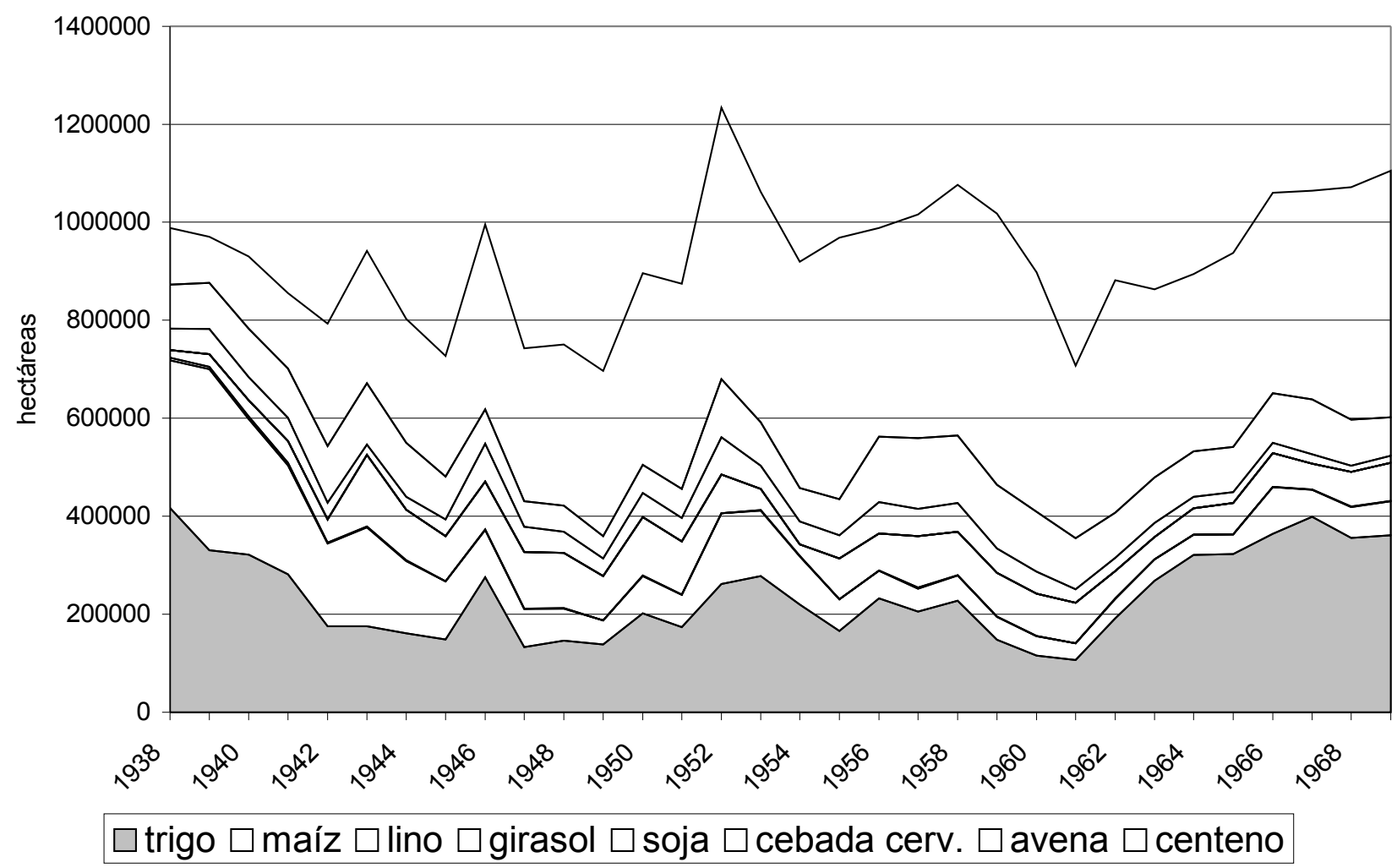

Fuente: Cálculos propios en base a las Estimaciones Agrícolas de la Secretaría de Agricultura y Ganadería. 
Esta expansión del centeno, paralela a la retracción del área sembrada con cultivos para cosecha, se vincula con el aumento de la ganadería vacuna y ovina en la zona oeste. Como vemos en el Cuadro A.2.2, el número de vacunos tuvo un incremento de 561.000 cabezas entre 1937 y 1947 (un aumento del 26\%), mientras que los ovinos se incrementaron en 511.000 animales (57\%). En las décadas del cincuenta y sesenta continuó incrementándose, levemente, la cantidad de vacunos, reduciéndose en los sesenta la de ovinos. Como también puede verse en el mencionado cuadro, sólo ocurrió un leve aumento en la cantidad de hectáreas sembradas con forrajeras permanentes. Este escaso desarrollo de las forrajeras permanentes, además de los factores agronómicos que habrían favorecido la expansión de las forrajeras anuales, puede estar vinculado con la reducción de la actividad de invernada en esta zona, y el incremento de la cría de vacunos durante estas décadas, que generó una intensa preocupación entre los especialistas, dando lugar a varias investigaciones sobre el tema ${ }^{6}$.

En relación al volumen cosechado, en la zona oeste el desmoronamiento productivo fue dramático durante los años cuarenta (de hecho, fue la zona más afectada por este retroceso de las tres áreas analizadas). Como se observa en el Gráfico A.2.8, a lo largo de los años cincuenta tuvo lugar una cierta recuperación en el volumen cosechado, especialmente gracias a la producción de centeno (a pesar de que sólo se cosechaba alrededor del $40 \%$ de la superficie sembrada con este cereal). Recién en los años sesenta el trigo volvió a los niveles de fines de los treinta y comienzos de los cuarenta.

\section{Gráfico A.2.8.}

6 Como afirma un estudio dirigido por Nocetti y Rossi, "el área en estudio de condiciones y vocación para la invernada vio aumentar en los últimos años en forma notoria los animales de cría en sus rodeos." (INTA-AACERA, 1969: 32). "Partidos como Pehuajó que en 1947 tenían una relación novillo-novillito a vaca de 148,5, en 1957, esta relación pasó a ser de 112,3 y en 1964, de 98,6. Con diferentes guarismos, esta tendencia decreciente se observa en los demás partidos de la zona (INTA-AACREA, 1969: 15). Esta limitación en la especialización en las actividades de invernada, fue evaluada en la tesis de Nocetti (1970) como generadora de menor productividad y rentabilidad, especialmente en las unidades de mayor tamaño. Asimismo, esta situación motivó un complejo e interesante estudio a partir de un sistema de regresiones múltiples sobre las series de datos anuales desde 1948 hasta 1968 de un amplio conjunto de variables (Egea, 1970). Este trabajo concluye que la disminución en la especialización en invernada (operacionalizada en la relación novillos más novillitos dividido el número de vacas) se encuentra determinada por la caída en los precios del ganado vacuno, por un clima desfavorable, un aumento en la inflación (que promueve la inversión en ganado de cría), un incremento en la actividad de invernada en las zonas de ganadería mixta (cría e invernada) que resta oferta de terneros para la zona de invernada, y la tendencia previa en la proporción de novillitos en esta zona (Egea, 1970). Tal vez, la que sea la más relevante, a nuestro entender, es la competencia que se genera con las zonas de ganadería mixta, dada cierta inflexibilidad en la oferta de terneros por parte de las áreas que tradicionalmente se especializan en la cría. 


\section{Zona oeste. Producción}

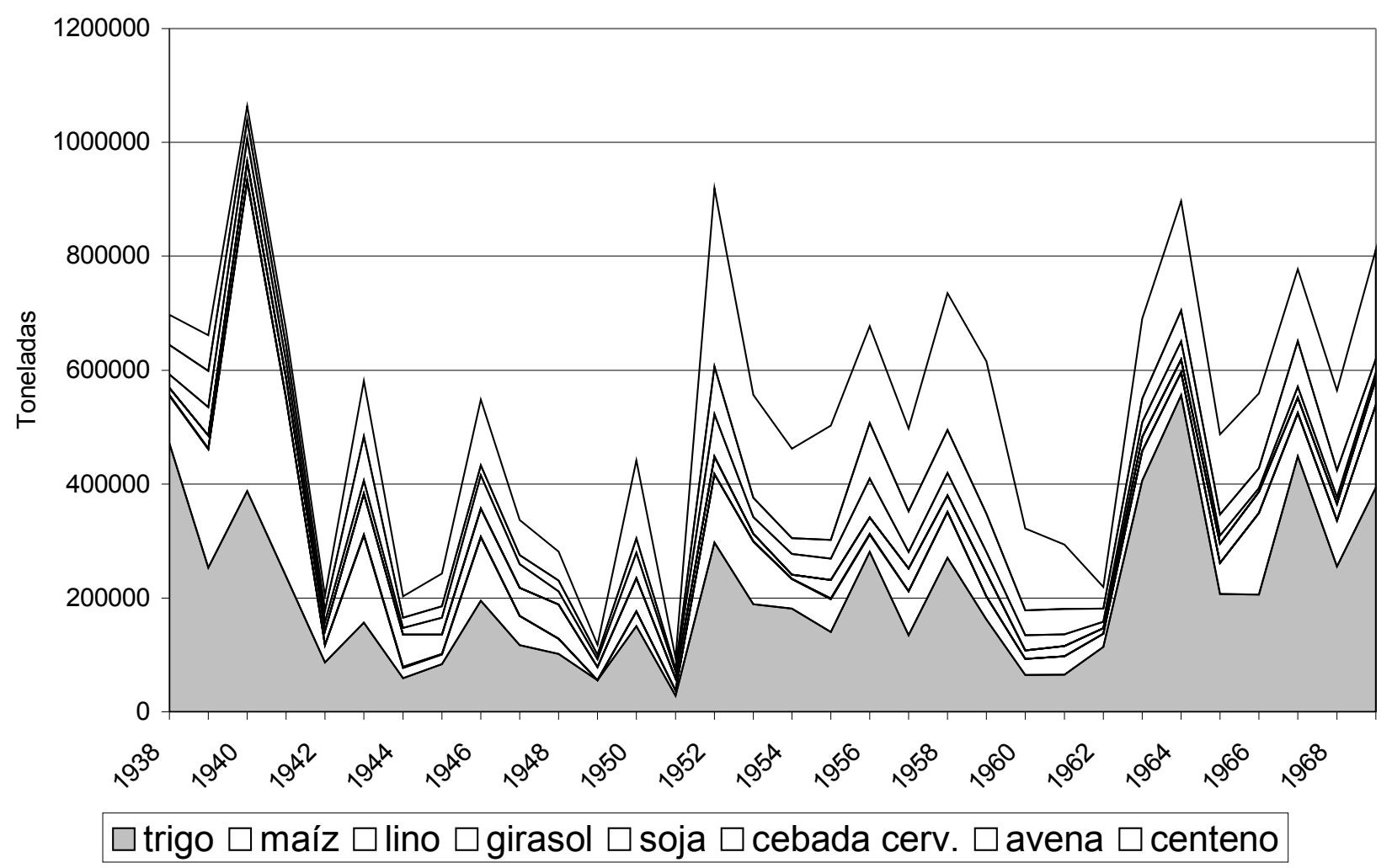

Fuente: Cálculos propios en base a las Estimaciones Agrícolas de la Secretaría de Agricultura y Ganadería.

\section{Cambios productivos en la zona sur}

Esta zona fue la menos afectada por la retracción agrícola. Como vemos en el Gráfico A.2.9, aquí la superficie sembrada sufrió un leve retroceso durante los años cuarenta, en buena medida recuperado en los cincuenta y mantenido en los sesenta, a excepción de la notoria caída en las áreas sembradas en las cosechas entre 1960/1 y 1962/3 (especialmente esta última). En todo el período, ni siquiera tuvo lugar un cambio importante en la composición de los cultivos: el trigo continuó hegemonizando la superficie sembrada, seguido por la avena, la cebada y el lino.

Por otra parte, entre 1937 y 1960 tuvo lugar una expansión de la ganadería vacuna y ovina en la zona sur (ver Cuadro A.2.2). Entre estos años, el número de vacunos se incrementó en un millón de cabezas (lo que constituye un aumento del 73\%) y el de lanares en 2.780 .000 cabezas (65\%). Luego, durante los sesenta se redujeron levemente estas cantidades, pero continuaron siendo mucho mayores que las de 1937. Seguramente por la más temprana 
mecanización de los productores de esta zona, la cantidad de equinos se redujo más rápidamente que en las otras dos zonas estudiadas.

\section{Gráfico A.2.9.}

\section{Zona sur. Superficie sembrada}

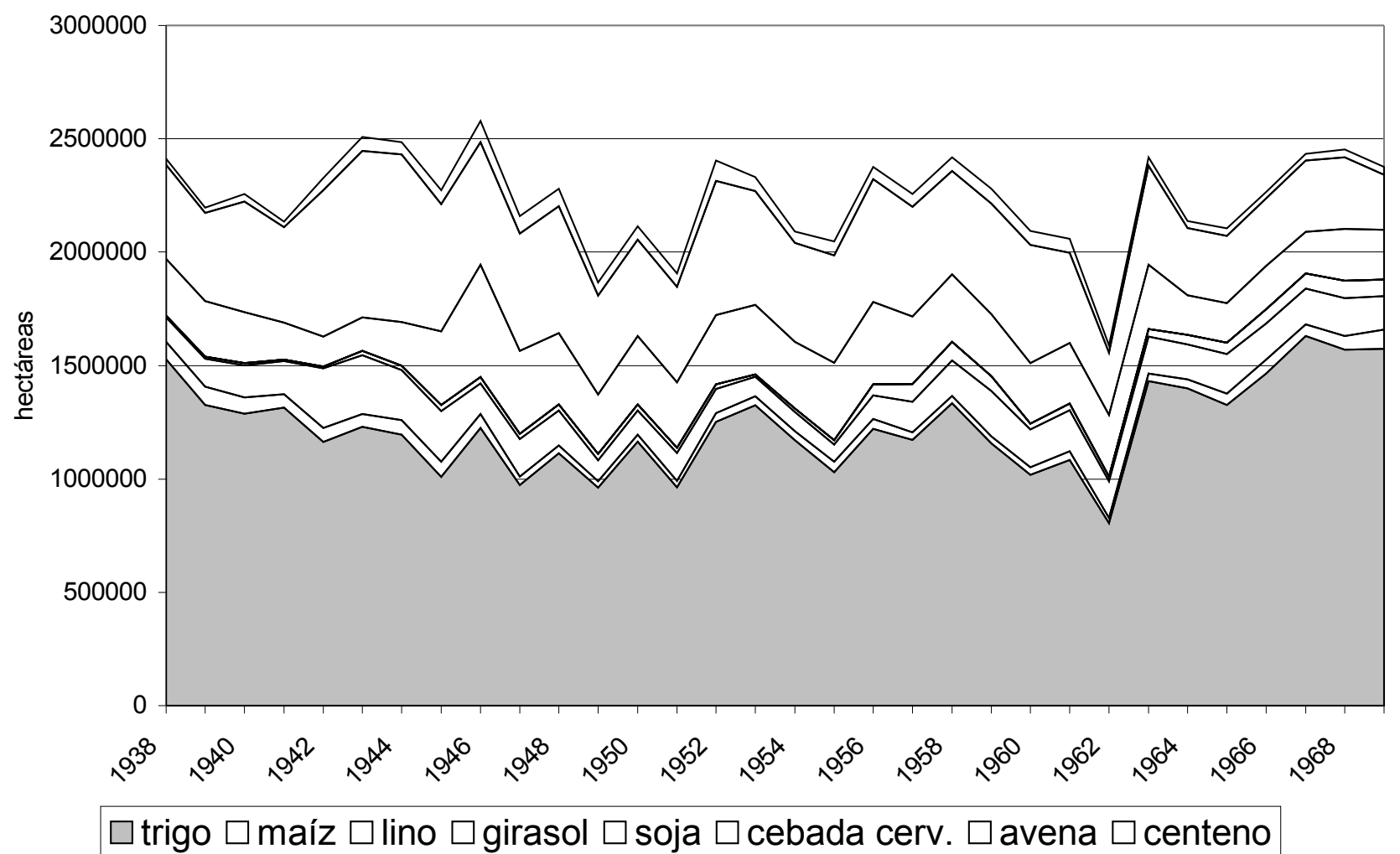

Fuente: Cálculos propios en base a las Estimaciones Agrícolas de la Secretaría de Agricultura y Ganadería.

Tampoco en el volumen producido tuvo lugar aquí el retroceso que se evidenció en las otras zonas o el conjunto de la región pampeana durante los años cuarenta y cincuenta. Como podemos ver en el Gráfico A.2.10, en la zona sur las oscilaciones y la propia tendencia decreciente en el volumen producido durante los años cuarenta fueron bastante moderadas. En la década del cincuenta, la producción fue superior a la de fines de los años treinta (destacándose el aumento de la cosecha de avena y cebada cervecera ${ }^{7}$ ). Luego, a partir de

7 La avena, que ya era bastante cosechada en los años 1938-47 (54\% del área sembrada era cosechada), se cosechó aun más, llegándose a cosechar el 64\% de la superficie sembrada con este cereal entre 1958 y 1967. Por su parte, la cebada cervecera era cosechada en un 80\%. La información detallada sobre esta variable se encuentra disponible en el Apéndice ??. 
1963/4, el trigo mostró una importante expansión productiva, basada tanto en el aumento del área sembrada como de los rendimientos ${ }^{8}$.

\section{Gráfico A.2.10}

\section{Zona sur. Producción}

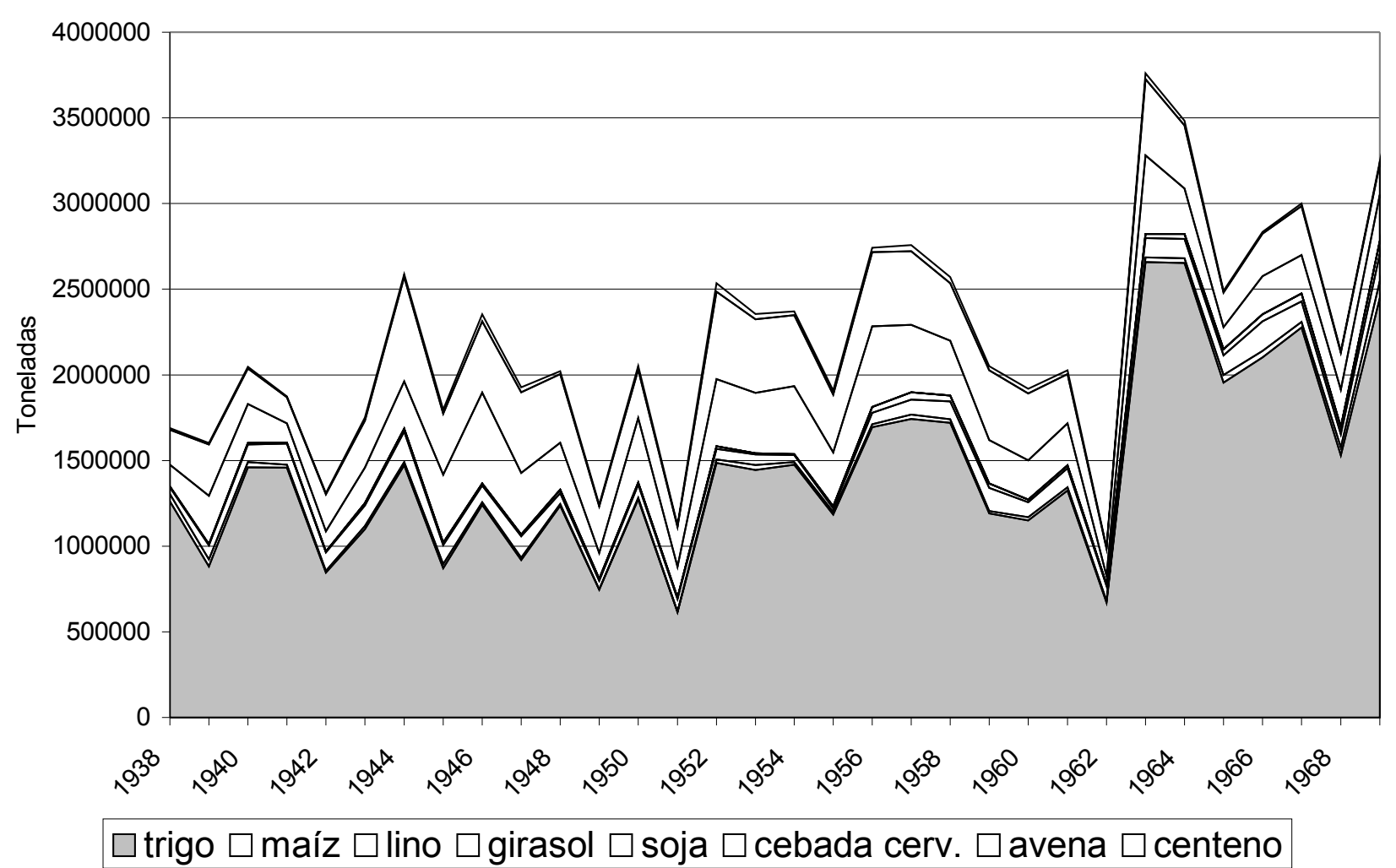

Fuente: Cálculos propios en base a las Estimaciones Agrícolas de la Secretaría de Agricultura y Ganadería.

8 De 1.106 kilogramos por hectárea cosechada que había rendido en promedio el trigo en los años cuarenta y 1.276 en los cincuenta, se pasó a 1.567 kilogramos entre 1963/64 y 1969/70. En el Apéndice ??, se transcribe la evolución anual de estos rendimientos. 


\section{Análisis detallado del proceso de concentración}

Entre 1937 y 1969 se produjo una fuerte reducción en la cantidad de pequeñas explotaciones ${ }^{9}$-en la zona sur también de las medianas-, al tiempo que se incrementó el número de las grandes unidades productivas, y en la zona norte también de las medianas explotaciones. En esta última zona tuvo lugar una fuerte reducción del número de unidades en los estratos de 25 a 200 hectáreas y un aumento en el número en las de 300 a 2.500 hectáreas (ver Cuadro A.2.3). Más específicamente, en el estrato de 25 a 100 hectáreas, en 1969 había 29\% menos unidades que en 1937, y en el de 100 a 200, 36\% menos (ver los valores absolutos en el mencionado cuadro). Los mayores incrementos, en términos relativos a la cantidad existente en 1937, estuvieron localizados en los estratos de 300 a 625 hectáreas (+70\%), 625 a $1250(+90 \%)$ y 1250 a $2500(+153 \%)$. Si, a fin de evitar errores con los datos de $1937^{10}$, agrupamos los estratos de más de 625 hectáreas, observamos un incremento del 92\% en la cantidad de establecimientos de este estrato.

9 Hemos dejado fuera de la comparación a las explotaciones de menos de 25 hectáreas, porque los censos las han registrado con diferente exhaustividad, y, en todo caso, nunca han resultado de gran relevancia en la producción cerealera pampeana.

10 En el censo de 1937 se agrupó a todas las chacras y las "mixtas" de más de 625 hectáreas en un único intervalo. Nosotros incorporamos a todas ellas a un intervalo de 625 a 1.250 hectáreas (existente para los diversos tipos de explotaciones ganaderas). Sin embargo, resulta muy probable que un número desconocido de las explotaciones (especialmente de las "mixtas") que fueran catalogadas como con "más de 625 hectáreas" tuvieran más de 1.250 hectáreas. Por lo tanto, resulta preferible considerar a todas las unidades con más de 625 hectáreas como un todo, y no prestar mayor atención a las diferencias internas. 
Cuadro A.2.3. Cantidad de explotaciones según tamaño

\begin{tabular}{|c|c|c|c|c|c|c|c|}
\hline & & \multicolumn{4}{|c|}{ Casos } & \multicolumn{2}{|c|}{ Sobre el total } \\
\hline & & 1937 & 1969 & diferencia & $\begin{array}{r}\text { diferencia } \\
\text { porcentual }\end{array}$ & \begin{tabular}{|c|}
1937 \\
\end{tabular} & 1969 \\
\hline \multirow{9}{*}{$\begin{array}{c}\text { Zona } \\
\text { norte }\end{array}$} & hasta 25 ha & 5270 & 5964 & 694 & $13 \%$ & $26.4 \%$ & $34.9 \%$ \\
\hline & 25 a 100 ha & 10040 & 7104 & -2936 & $-29 \%$ & $50.3 \%$ & $41.6 \%$ \\
\hline & 100 a 200 ha & 3394 & 2183 & -1211 & $-36 \%$ & $17.0 \%$ & $12.8 \%$ \\
\hline & 200 a 300 ha & 575 & 661 & 86 & $15 \%$ & $2.9 \%$ & $3.9 \%$ \\
\hline & 300 a 625 ha & 381 & 646 & 265 & $70 \%$ & $1.9 \%$ & $3.8 \%$ \\
\hline & 625 a 1250 ha & 167 & 317 & 150 & $90 \%$ & $0.8 \%$ & $1.9 \%$ \\
\hline & 1250 a 2500 ha & 58 & 147 & 89 & $153 \%$ & $0.3 \%$ & $0.9 \%$ \\
\hline & más de 2500 ha & 48 & 60 & 12 & $24 \%$ & $0.2 \%$ & $0.4 \%$ \\
\hline & Total & 19965 & 17081 & -2884 & $-14 \%$ & $100 \%$ & $100 \%$ \\
\hline \multirow{9}{*}{$\begin{array}{c}\text { Zona } \\
\text { oeste }\end{array}$} & hasta 25 ha & 1981 & 1808 & -173 & $-9 \%$ & 1050 & $201 \%$ \\
\hline & 25 a 100 ha & 3293 & 2453 & -840 & $-26 \%$ & $32.4 \%$ & $27.4 \%$ \\
\hline & 100 a 200 ha & 2060 & 1749 & -311 & $-15 \%$ & $20.3 \%$ & $19.5 \%$ \\
\hline & 200 a 300 ha & 1010 & 811 & -199 & $-20 \%$ & $9.9 \%$ & $9.1 \%$ \\
\hline & 300 a 625 ha & 961 & 956 & -5 & $-1 \%$ & $9.4 \%$ & $10.7 \%$ \\
\hline & 625 a 1250 ha & 517 & 581 & 64 & $12 \%$ & $5.1 \%$ & $6.5 \%$ \\
\hline & 1250 a 2500 ha & 142 & 331 & 189 & $133 \%$ & $1.4 \%$ & $3.7 \%$ \\
\hline & más de 2500 ha & 207 & 265 & 58 & $28 \%$ & $2.0 \%$ & $3.0 \%$ \\
\hline & Total & 10171 & 8955 & -1216 & $-12 \%$ & $100 \%$ & $100 \%$ \\
\hline \multirow{9}{*}{$\begin{array}{r}\text { Zona } \\
\text { sur }\end{array}$} & hasta 25 ha & 1769 & 2115 & 346 & $20 \%$ & $12.1 \%$ & $16.7 \%$ \\
\hline & 25 a 100 ha & 2493 & 1963 & -530 & $-21 \%$ & $17.1 \%$ & $15.4 \%$ \\
\hline & 100 a 200 ha & 2848 & 2251 & -597 & $-21 \%$ & $19.5 \%$ & $17.7 \%$ \\
\hline & 200 a 300 ha & 2203 & 1713 & -490 & $-22 \%$ & $15.1 \%$ & $13.5 \%$ \\
\hline & 300 a 625 ha & 3404 & 2679 & -725 & $-21 \%$ & $23.3 \%$ & $21.1 \%$ \\
\hline & 625 a 1250 ha & 1536 & 1213 & -323 & $-21 \%$ & $10.5 \%$ & $9.5 \%$ \\
\hline & 1250 a $2500 \mathrm{ha}$ & 145 & 493 & 348 & $240 \%$ & $1.0 \%$ & $3.9 \%$ \\
\hline & más de 2500 ha & 178 & 268 & 90 & $51 \%$ & $1.2 \%$ & $2.1 \%$ \\
\hline & Total & 14602 & 12696 & -1906 & $-13 \%$ & $100 \%$ & $100 \%$ \\
\hline
\end{tabular}

Fuente: Datos por partido del Censo Agropecuario de 1937 y reprocesamiento de los datos originales del de 1969 
En la zona oeste, la concentración afectó a todos los estratos de 25 a 300 hectáreas (el número de unidades de estos estratos se redujo en un $21 \%$ en relación con 1937), mientras se incrementaba la cantidad de unidades en el estrato de más de 625 hectáreas (36\%). Por último, en la zona sur tuvo lugar una reducción muy generalizada en el número de explotaciones: entre las 25 y las 625 hectáreas, todos los estratos disminuyeron el número de sus unidades en un $21 \%$. Por el contrario, el estrato de más de 625 hectáreas presentó un incremento del $6 \%$ (para mayores detalles ver el Cuadro A.2.3).

La lógica consecuencia de estas transformaciones en el número de unidades por estrato, fue la concentración de la superficie agropecuaria en las grandes explotaciones (ver Cuadro A.2.4). En la zona norte, las unidades de 25 a 200 hectáreas perdieron un $18 \%$ de la superficie total de la zona, que fueron tomadas por las unidades de 300 a 2500 hectáreas. En la zona oeste, donde la concentración ya era más importante en 1937, la transformación fue menor que en la zona norte. Las explotaciones de 25 a 625 hectáreas perdieron un 6\% del área, mientras que las de 1250 a 2500 tomaban un 9\% (un 3\% habría sido cedido por las unidades de más de 2500 hectáreas). Y en la zona sur, las unidades de menos de 1250 hectáreas cedieron 12\% del área (aunque aquí puede estar sobreestimada la superficie de las explotaciones de 625 a 1250 en 1937). Esta superficie fue tomada por las explotaciones de 1250 a 2500 hectáreas (10\%) y de más de $2500(2 \%)$.

Podemos concluir que en las tres zonas perdieron peso numérico y territorial las unidades pequeñas y mediano-pequeñas (especialmente las de 25 a 200 hectáreas en la zona norte, las de 25 a 300 en la zona oeste, y las de 25 a 625 en la zona sur). En cambio, se incrementó la importancia de las explotaciones de 1.250 a 2.500 hectáreas, el sector de los terratenientes-capitalistas medianos, quienes lograron expulsar a los arrendatarios a quienes alquilaban sus campos, tal como lo analizan Slutzky (1968) y Murmis (1979), entre otros. Entonces, la crisis de las pequeñas unidades fortaleció la presencia de estos propietarios mediano-grandes, pero no dio lugar a la reconstitución de las grandes estancias ganaderas (de más de 2.500 hectáreas) que, como tales, tan solo incrementaron un poco su número durante estas décadas. 
Cuadro A.2.4. Superficie según tamaño

\begin{tabular}{|c|c|c|c|c|}
\hline & & 1937 & 1969 & diferencia \\
\hline \multirow[t]{9}{*}{ Zona norte } & hasta 25 ha & $2.65 \%$ & $3.10 \%$ & $0.45 \%$ \\
\hline & 25 a 100 ha & $30.14 \%$ & $20.40 \%$ & $-9.74 \%$ \\
\hline & \begin{tabular}{|l|}
100 a 200 ha \\
\end{tabular} & $23.56 \%$ & $15.30 \%$ & $-8.26 \%$ \\
\hline & 200 a 300 ha & $6.94 \%$ & $8.20 \%$ & $1.26 \%$ \\
\hline & 300 a 625 ha & $8.77 \%$ & $13.80 \%$ & $5.03 \%$ \\
\hline & 625 a $1250 \mathrm{ha}$ & $7.79 \%$ & $13.80 \%$ & $6.01 \%$ \\
\hline & 1250 a 2500 ha & $5.41 \%$ & $12.60 \%$ & $7.19 \%$ \\
\hline & más de 2500 ha & $14.74 \%$ & $12.80 \%$ & $-1.94 \%$ \\
\hline & & $100.00 \%$ & $100.00 \%$ & $0.00 \%$ \\
\hline & & & & \\
\hline \multirow[t]{9}{*}{ Zona oeste } & hasta $25 \mathrm{ha}$ & $0.77 \%$ & $0.50 \%$ & $-0.27 \%$ \\
\hline & 25 a 100 ha & $5.85 \%$ & $4.40 \%$ & $-1.45 \%$ \\
\hline & 100 a 200 ha & $9.10 \%$ & $7.50 \%$ & $-1.60 \%$ \\
\hline & 200 a 300 ha & $7.39 \%$ & $5.70 \%$ & $-1.69 \%$ \\
\hline & 300 a 625 ha & $13.19 \%$ & $12.00 \%$ & $-1.19 \%$ \\
\hline & 625 a 1250 ha & $14.39 \%$ & $14.40 \%$ & $0.01 \%$ \\
\hline & 1250 a 2500 ha & $7.90 \%$ & $17.00 \%$ & $9.10 \%$ \\
\hline & más de 2500 ha & $41.41 \%$ & $38.40 \%$ & $-3.01 \%$ \\
\hline & & $100.00 \%$ & $100.00 \%$ & $0.00 \%$ \\
\hline & & & & \\
\hline \multirow{9}{*}{ Zona sur } & hasta 25 ha & $0.34 \%$ & $0.40 \%$ & $0.06 \%$ \\
\hline & 25 a 100 ha & $2.59 \%$ & $2.40 \%$ & $-0.19 \%$ \\
\hline & 100 a 200 ha & $7.50 \%$ & $6.70 \%$ & $-0.80 \%$ \\
\hline & 200 a 300 ha & $9.47 \%$ & $8.30 \%$ & $-1.17 \%$ \\
\hline & 300 a 625 ha & $27.16 \%$ & $22.30 \%$ & $-4.86 \%$ \\
\hline & 625 a 1250 ha & $24.85 \%$ & $20.00 \%$ & $-4.85 \%$ \\
\hline & 1250 a 2500 ha & $6.81 \%$ & $16.50 \%$ & $9.69 \%$ \\
\hline & más de 2500 ha & $21.31 \%$ & $23.50 \%$ & $2.19 \%$ \\
\hline & & $100.00 \%$ & $100.00 \%$ & $0.00 \%$ \\
\hline
\end{tabular}

Fuente: Estimaciones a partir de la cantidad de explotaciones por intervalo de tamaño de cada uno de los partido, del Censo Agropecuario de 1937 y reprocesamiento de los datos originales del de 1969 


\section{Análisis del proceso de concentración a partir de los datos de 1960 reprocesados por el CONADE}

El reprocesamiento de los datos originales del Censo Nacional Agropecuario de 1960 realizado por el CONADE (1965) permite calcular la distribución relativa de la superficie agrícola en 1960, el valor de las producción agrícola y ganadera y la combinación de ambas actividades en cada uno de los estratos de tamaño.

\subsection{Distribución de la Superficie agrícola según extensión}

Comparando el Cuadro A.2.5 con el Gráfico.2.10 (del capítulo segundo), en la zona $\underline{\text { norte }}^{11}$, el proceso de concentración de la producción agrícola no había avanzado tanto entre 1937 y 1960, como lo haría a lo largo de la década del sesenta ${ }^{12}$. Más allá de las diferencias que existen en las metodologías de estimación y en que en el caso del CONADE incluya cuatro departamentos santafecinos, podemos inferir que el proceso de concentración se incrementó en esta zona en los años sesenta. Lo cual resulta coherente con la mecanización, en especial de la cosecha de maíz, que ocurrió durante esta década, y con la expulsión de arrendatarios y aparceros en 1968 con la ley Raggio.

En el caso de la zona oeste ${ }^{13}$, el procesamiento de los datos del CONADE permiten observar que, a diferencia de la zona norte, la mayor parte de la concentración ya había tenido lugar antes de $1960^{14}$. Mientras que en el caso de la zona sur ${ }^{15}$ no hubo un proceso de

11 En el caso del estudio de la CONADE es la zona 10-a, que incluye algunos departamentos del sur de Santa Fe. Más específicamente La zona 10a incluye los partidos boanerenses de Baradero, Bartolomé Mitre, Campana, Colón, Chacabuco, Gral. Arenales, Junín, Pergamino, Ramallo, Rojas, Salto, San Antonio de Areco, San Nicolás, San Pedro y Zárate, y los departamentos santafecinos de Caseros, Constitución, Rosario y San Lorenzo (CONADE, 1965: Anexo A, p. 2).

12 Así, por ejemplo, en esta zona, las unidades de hasta 100 hectáreas detentaban el $45 \%$ de la superficie agrícola (frente al $48 \%$ que tenían en 1937, según nuestras estimaciones para la zona norte bonaerense, y el 30\% que tenían en 1969). En el extremo opuesto, las de más de 400 hectáreas ocupaban en 1960 el 20\% de la superficie agrícola (mientras que en 1937 habían tenido el $11 \%$ y en 1969 el 43\%).

13 En este caso, hemos sumado las zonas $5 \mathrm{a}$ y $5 \mathrm{~b}$ del procesamiento del CONADE, que incluyen los ocho partidos de nuestra zona oeste, agregando Pehaujó, Adolfo Alsina, Carlos Casares, Caseros, Guaminí e Hipólito Yrigoyen, y los departamentos del Este de La Pampa: Catriló, Chapaleufú, Quemú Quemú y Maracó.

14 Las explotaciones de menos de 100 hectáreas pasaron a detentar sólo el 5\% de la superficie agrícola (mientras que en 1937 habían tenido el 17\%). En cambio, las mayores de 400 hectáreas tenían el 69\% (similar al 75\% que presentarán en 1969). 
concentración importante, pues ya en 1937 la agricultura estaba situada en unidades de gran extensión ${ }^{16} .{ }^{17}$

Cuadro A.2.5. Distribución de la superficie y la producción según el tamaño de las unidades productivas, 1960.

\section{Zona 10a (zona norte)}

\begin{tabular}{|l|r|r|r|r|r|r|r|r|}
\hline \multirow{4}{*}{} & \multicolumn{4}{|c|}{ Superficie } & \multicolumn{4}{|c|}{ Valor } \\
\cline { 2 - 9 } & (miles de ha) & & & (millones de pesos) & \\
\cline { 2 - 9 } & Agricultura & Ganadería & Agricultura & Ganadería & Agricultura & Ganadería & Agricultura & Ganadería \\
\hline $\mathbf{0 - 2 5}$ & 45 & 67 & $3 \%$ & $5 \%$ & 538 & 331 & $4 \%$ & $4 \%$ \\
\hline $\mathbf{2 5 - 1 0 0}$ & 557 & 330 & $42 \%$ & $23 \%$ & 6574 & 2033 & $44 \%$ & $27 \%$ \\
\hline $\mathbf{1 0 0 - 4 0 0}$ & 461 & 431 & $35 \%$ & $30 \%$ & 5234 & 2388 & $35 \%$ & $32 \%$ \\
\hline $\mathbf{4 0 0 - 1 0 0 0}$ & 113 & 235 & $9 \%$ & $16 \%$ & 1235 & 1016 & $8 \%$ & $14 \%$ \\
\hline $\mathbf{1 0 0 0 - 2 5 0 0}$ & 83 & 212 & $6 \%$ & $15 \%$ & 858 & 994 & $6 \%$ & $13 \%$ \\
\hline $\mathbf{2 5 0 0 +}$ & 60 & 163 & $5 \%$ & $11 \%$ & 560 & 737 & $4 \%$ & $10 \%$ \\
\hline \multicolumn{1}{r|}{ Total } & 1319 & 1438 & $100 \%$ & $100 \%$ & 14999 & 7499 & $100 \%$ & $100 \%$ \\
\hline
\end{tabular}

15 En este caso tomamos la zona 7 del CONADE que incluye a todos los partidos de nuestra zona sur, con excepción de Coronel Suárez, y agrega a Balcarce, General Pueyredón y Villarino.

16 Tal vez puedan haber ocurrido algunos cambios en los estratos medios no es posible analizarlos, debido a que los estratos construidos en 1937 y en 1960 son muy diferentes. La distribución de la superficie agrícola en 1960 era muy similar a la de 1969. Tan sólo se observa un leve incremento en los años sesenta del peso de las unidades de 1000 a 2500 hectáreas en detrimento de las de 100 a 400.

17 Asimismo, los datos de 1960 permiten analizar la distribución de la superficie dedicada a la ganadería (y el valor producido por dicha actividad). Podemos ver que en la zona norte, las unidades de 25 a 400 hectáreas no sólo concentraban el 77\% de la superficie agrícola, sino que también predominaban en la ganadería. Aunque en ellas era más importante la agricultura, su producción ganadera era de mayor significación que la que presentaban las unidades de mayor tamaño (a pesar que éstas tenían una orientación más fuerte hacia la ganadería que hacia la agricultura, según se observa en la distribución de la superficie utilizada). En la zona oeste, la ganadería se concentraba en las unidades de más de 2.500 hectáreas $(35 \%$ del valor de la producción ganadera), pero también era importante la producción en el estrato de 100 a 400 hectáreas (24\%), seguido por el de 400 a 1.000 y el de 1.000 a 2.500 . La agricultura también se distribuía en estos cuatro estratos, aunque en este caso la concentración era menor. En la zona sur, la ganadería se repartía en partes similares entre las unidades de 100 a 400 , de 400 a 1.000 , de 1.000 a 2.500 y de más de 2.500 hectáreas. Mientras que la agricultura se concentraba entre las 100 y las 1.000 hectáreas. 
Zonas 5a y b (zona oeste)

\begin{tabular}{|l|r|r|r|r|r|r|r|r|}
\hline \multirow{4}{*}{} & \multicolumn{4}{|c|}{ Superficie } & \multicolumn{4}{c|}{ Valor } \\
\cline { 2 - 9 } & \multicolumn{2}{|c|}{ (miles de ha) } & & & (millones de pesos) & \\
\cline { 2 - 9 } & Agricultura & Ganadería & Agricultura & Ganadería & Agricultura & Ganadería & Agricultura & Ganadería \\
\hline $\mathbf{0 - 2 5}$ & 9 & 22 & $0 \%$ & $1 \%$ & 45 & 205 & $0 \%$ & $1 \%$ \\
\hline $\mathbf{2 5 - 1 0 0}$ & 106 & 185 & $5 \%$ & $4 \%$ & 506 & 1152 & $5 \%$ & $7 \%$ \\
\hline $\mathbf{1 0 0 - 4 0 0}$ & 554 & 803 & $26 \%$ & $19 \%$ & 2667 & 4184 & $28 \%$ & $24 \%$ \\
\hline $\mathbf{4 0 0 - 1 0 0 0}$ & 415 & 670 & $19 \%$ & $16 \%$ & 1872 & 2825 & $20 \%$ & $16 \%$ \\
\hline $\mathbf{1 0 0 0 - 2 5 0 0}$ & 413 & 799 & $19 \%$ & $19 \%$ & 1741 & 2922 & $18 \%$ & $17 \%$ \\
\hline $\mathbf{2 5 0 0 +}$ & 636 & 1714 & $30 \%$ & $41 \%$ & 2702 & 5972 & $28 \%$ & $35 \%$ \\
\hline Total & 2133 & 4193 & $100 \%$ & $100 \%$ & 9533 & 17260 & $100 \%$ & $100 \%$ \\
\hline
\end{tabular}

\section{Zona 7 (zona sur)}

\begin{tabular}{|c|c|c|c|c|c|c|c|c|}
\hline & \multicolumn{4}{|c|}{ Superficie } & \multicolumn{4}{|c|}{ Valor } \\
\hline & \multicolumn{2}{|c|}{ (miles de ha) } & \multirow[b]{2}{*}{ Agricultura } & \multirow[b]{2}{*}{ Ganadería } & \multicolumn{2}{|c|}{ (millones de pesos) } & \multirow[b]{2}{*}{ Agricultura } & \multirow[b]{2}{*}{ Ganadería } \\
\hline & Agricultura & Ganadería & & & Agricultura & Ganadería & & \\
\hline $0-25$ & 7 & 29 & $0 \%$ & $1 \%$ & 43 & 78 & $0 \%$ & $1 \%$ \\
\hline $25-100$ & 50 & 105 & $3 \%$ & $3 \%$ & 335 & 276 & $3 \%$ & $3 \%$ \\
\hline $100-400$ & 603 & 873 & $36 \%$ & $21 \%$ & 4338 & 2880 & $38 \%$ & $26 \%$ \\
\hline $400-1000$ & 537 & 1070 & $32 \%$ & $26 \%$ & 3721 & 3157 & $33 \%$ & $29 \%$ \\
\hline $1000-2500$ & 263 & 838 & $16 \%$ & $20 \%$ & 1734 & 2212 & $15 \%$ & $20 \%$ \\
\hline $2500+$ & 194 & 1187 & $12 \%$ & $29 \%$ & 1224 & 2338 & $11 \%$ & $21 \%$ \\
\hline Total & 1654 & 4102 & $100 \%$ & $100 \%$ & 11395 & 10941 & $100 \%$ & $100 \%$ \\
\hline
\end{tabular}

Fuente: reagrupamiento personal de los datos del reprocesamiento de las fichas originales del Censo Nacional Agropecuario de 1960, efectuado por el CONADE (1965).

\subsection{Distribución del Valor de la producción según extensión}

Como puede observarse cotejando las columnas porcentuales en el Cuadro A.2.5, el valor de la producción agrícola (en pesos) no presenta mayores diferencias en su distribución por estratos con la distribución que tenía la superficie agrícola ${ }^{18}$. Pero, analizando las cifras con más detalle, es posible notar que el estrato de 25 a 100 hectáreas en las zonas norte y oeste y el de 100 a 400 hectáreas en las tres zonas, presentaban una mayor importancia en términos de valor de la producción que en la proporción de la superficie que ocupaban, en cada actividad, pero especialmente en la ganadería. La causa de esta diferencia es que la productividad por hectárea era más elevada en estos estratos que en los de mayor extensión.

18 La estimación del valor bruto de la producción agrícola y ganadera se realizó con precios del año 1963 (pero estabilizados según el promedio de precios de 1959 a 1963). 
Analizando los datos consignados en el Cuadro A.2.6, es posible observar que la zona norte se destaca por su altísima productividad, duplicando a la de la zona sur y (casi) a la de la zona oeste. En la zona norte sobresalen por su productividad por hectárea las unidades de 25 a 100 hectáreas, seguidas por las de 100 a 400 hectáreas. En cambio, la explotaciones de más de 2.500 hectáreas producen un $40 \%$ menos que las de 25 a 100. Estos datos resultan congruentes con los análisis de la encuesta efectuada en Pergamino en 1960 por Gilles y Nocetti ${ }^{19}$. También en una encuesta realizada en 1968 por Peyrou (1971) se encontró que la producción era más intensiva en las unidades más pequeñas ${ }^{20}$.

\section{Cuadro A.2.6. Valor de la producción agropecuaria por hectárea}

En pesos por hectárea (agricultura y ganadería)

\begin{tabular}{|c|c|c|c|}
\hline & zona norte & zona oeste & zona sur \\
\hline $0-25$ & 7793 & 7740 & 3369 \\
\hline $25-100$ & 9706 & 5698 & 3936 \\
\hline $100-400$ & 8544 & 5049 & 4893 \\
\hline $400-1000$ & 6460 & 4329 & 4279 \\
\hline $1000-2500$ & 6270 & 3847 & 3581 \\
\hline $2500+$ & 5812 & 3691 & 2580 \\
\hline Total & 8159 & 4235 & 3880 \\
\hline
\end{tabular}

Fuente: Reagrupamiento personal de los datos del reprocesamiento de las fichas originales del Censo Nacional Agropecuario de 1960, efectuado por el CONADE (1965).

En la zona oeste, se observa una progresiva reducción del valor a medida que se incrementa el tamaño. Entre los estratos con alguna importancia productiva (por encima de las 100 hectáreas), se ve que las de más de 2.500 producen un cuarto menos por unidad de superficie que las de 100 a 400 hectáreas. En el mismo sentido, un estudio sobre la zona de invernada realizado en 1967 encontró que el margen bruto por hectárea, entre las empresas que realizaban al menos algo de invernada de vacunos, presentaba "un valor promedio superior en el

19 Gilles y Nocetti afirman, habiendo analizado tres estratos (de 18 a 55 hectáreas, de 55 a 100 y de 100 a 200 hectáreas), que "es un hecho generalizado, el que en los predios de menor superficie se haga un uso más intensivo del recurso tierra que en los de superficie mayores" (Gilles y Nocetti, 1962: 7).

20 La producción bruta era de $\$ 27.152$ por hectárea en el estrato de 50 a 120 hectáreas, de $\$ 22.129$ en el de 120 a $200 ; \$ 15.013$ en el de 200 a 450 , y $\$ 14.183$ en el de más de 450 hectáreas (Peyrou, 1971: 30). Su autor recalcaba que "los altos valores de capital bovino por hectárea en los dos estratos de menor superficie, acompañados con la más alta tasa de utilización 'agrícola' de la tierra indican la mayor intensidad de uso agrícola y ganadero (bovino) de la tierra en estos estratos" (Peyrou, 1971: 34). Y concluía que "a mayores tamaños no se realiza -en forma notable- un proceso de cambio de mano de obra por capital en maquinarias o mejoras sino de mano de obra y capital por tierra." (Peyrou, 1971: 57). 
estrato de menor superficie, que se explica por el mayor grado de intensidad en que se desarrollan esas explotaciones" (INTA-AACREA, 1969: 53) ${ }^{21}$.

En la zona sur, la máxima productividad se encuentra entre las de 100 a 400 hectáreas, y son seguidas por las de 400 a 1.000. En cambio, las unidades más grandes (más de 2.500 hectáreas) producen por unidad de superficie casi la mitad que las de 100 a 400.

\subsection{Relación entre agricultura y ganadería en cada estrato de extensión}

Otra lectura del Cuadro A.2.5 permite analizar la combinación entre agricultura y ganadería que se realizaba en cada uno de los distintos estratos de tamaño. En la zona norte se observa que los productores muy pequeños (con explotaciones de menos de 25 hectáreas) dedicaban una proporción mayor de su predio a la ganadería que a la agricultura, a pesar que el valor de esta última producción era superior al de la primera. En el caso de las explotaciones de 25 a 100 hectáreas, era clara la orientación hacia la agricultura, que triplicaba en valor a la

21 Sin embargo, analizando los datos de cada una de las explotaciones (publicados en los cuadros anexos), encontramos, por un lado, que los valores medios -si bien disminuyen al incrementarse el tamaño, hasta las 3.000 hectáreas- no son muy diferentes y que existe una fuerte dispersión al interior de los estratos $\mathrm{y}$, por otro lado, que los márgenes brutos por hectárea se elevan en el estrato de más de 3.000 hectáreas, tal como vemos en el siguiente gráfico:

Márgenes brutos por hectárea, según superficie de las explotaciones. Zona de invernada, 1967

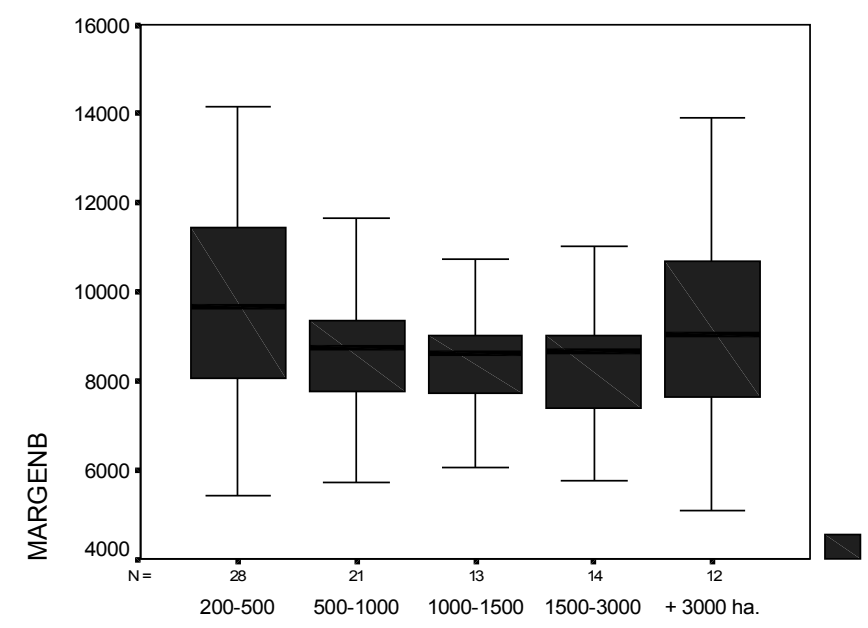

ESTRATO

Fuente: Cálculos propios en base a los datos de INTA-AACREA, 1969: 83-87.

Nota: Como en todo "box-plot", la línea fuerte representa a la mediana, la "caja" contiene al 50\% central de las explotaciones, y las líneas verticales comprenden al $25 \%$ superior e inferior (no hay casos extremos). 
ganadería. En el estrato siguiente, si bien la superficie de ambas actividades era similar, la producción agrícola más que duplicaba al valor de la ganadera. En todos los estratos por encima de las 400 hectáreas, la superficie ganadera era mucho más importante que el área agrícola, aunque en valor eran bastante similares ${ }^{22}$.

En la zona oeste, los datos de 1960 muestran que en todos los estratos la ganadería duplicaba la importancia de la agricultura, tanto en superficie como en valor de la producción. En este año, como en $1969^{23}$, las diferencias en las orientaciones productivas eran muy pequeñas entre los estratos. Sin embargo, un estudio realizado en varios partidos de esta zona en 1967 (INTA-AACREA, 1969) ${ }^{24}$, encontró, entre las unidades que hacían, al menos algo, de invernada, una disminución de la orientación hacia la agricultura a medida que aumentaba el tamaño de las explotaciones ${ }^{25}$.

22 Según nuestro reprocesamiento de los datos de 1969, la proporción de superficie dedicada a la agricultura (cultivos anuales para cosecha) en la zona norte presentaba una distribución similar, destacándose el estrato de menos de 25 hectáreas porque sólo el 37\% de la superficie estaba afectada a esta actividad, y, en cambio, el siguiente estrato dedicaba el 55\%. Ver el siguiente cuadro:

\section{Porcentaje de superficie agrícola sobre la superficie total, según estratos de tamaño, 1969}

Tamañozona nortezona oestezona surhasta 25 ha37\% $7 \% 33 \% \mathbf{2 5}$ a $\mathbf{1 0 0 5 5 \% 1 1 \% 5 1 \% 1 0 0}$ a $20052 \% 13 \% 53 \% 200$ a $40046 \% 15 \% 51 \% 400$ a $100040 \% 15 \% 46 \% 1000$ a $250034 \% 13 \% 37 \% 2500$ ha $+23 \% 10 \% 25 \%$ Total $47 \% 12 \% 46 \%$ Fuente: reprocesamiento personal de los datos originales del Censo Nacional Agropecuario de 1969.

23 Como se puede observar en el cuadro de la nota anterior, para 1969 sólo entre el $10 \%$ y el $15 \%$ de la superficie de los estratos de más de 25 hectáreas, estaba dedicada a los cultivos anuales para cosecha.

24 Tomando la totalidad del partido de Hipólito Yrigoyen y parte de los partidos de Caseros, Trenque Lauquen y Pehuajó.

25 En dicho trabajo se afirmaba que "la proporción que se utiliza hoy con agricultura varía con el tamaño de superficie de los establecimientos, pues mientras que en las empresas de menor tamaño [200 a 500 hectáreas] se ocupa una tercera parte del suelo con esos cultivos, en las de mayor tamaño sólo se les destina un 14\% de la misma. En general se nota una disminución en la importancia de la agricultura a medida que existe un aumento en el tamaño de las empresas. La excepción a esta regla la constituyen las empresas del estrato de 1.000 a 1.500 hectáreas, donde se nota un sorpresivo descenso de la superficie agrícola con respecto a los estratos de mayor tamaño. En muchas características, este estrato de superficie se aparta de las tendencias lógicas, lo que se explica por su carácter de transición entre la mediana y la gran empresa" (INTA-AACREA, 1969: 32).

Por otra parte, ese mismo estudio analiza, con gran detalle, las diferencias en la producción ganadera que presentaban los distintos estratos. La diferencia más visible es que "mientras las empresas de 200 a 500 hectáreas tienen aproximadamente la mitad de animales de cría en su rodeo, en las empresas de mayor tamaño esa proporción se reduce a algo más de la tercera parte del total." Aclarando que "prácticamente no existe la invernada pura, ni es tampoco común la invernada exclusiva de la propia producción. Lo general es invernar la propia 
En la zona sur, la importancia de la agricultura sobre la ganadería aumentaba en 1960 a medida que crecía el tamaño hasta el estrato de 100 a 400 hectáreas (en el mismo la agricultura ocupaba el $40 \%$ de la superficie y el $60 \%$ del valor de la producción). Luego, al continuar incrementándose el tamaño, el peso de la agricultura disminuía ${ }^{26}$.

\section{Algunos datos acerca de los cambios en la composición de la mano de obra}

En 1958, Schaefer había encontrado que, en las unidades de 25 a 150 ubicadas en un área del partido de Pergamino,

"...la mano de obra está constituida casi exclusivamente con personal permanente con preponderancia absoluta del trabajo familiar no remunerado, integrado por el trabajo del propio productor y miembros de su familia.

El personal no permanente corresponde en una gran proporción al necesario para la cosecha de maíz, cuando la misma se efectúa en forma manual. Circunscribiéndose entonces a lo primordial, trabajo permanente familiar, parecería que no hay relación entre tamaño y/o tenencia y fuerza del trabajo.

La misma, a juzgar por los datos de la muestra, no estaría relacionada con la organización del trabajo a realizar, sino más bien, con la composición de la familia. Este problema revista gran interés y está ligado íntimamente a la organización. Siendo en la práctica difícil ajustar el personal familiar a las necesidades del trabajo de una gran estructura dada, hay que buscar la solución en sentido inverso, es decir, adaptar la organización a la máxima capacidad de trabajo disponible. Se impone en consecuencia la necesidad de intensificarla incorporándole a la misma actividades complementarias." (Schaefer, 1960: 101-102).

Un par de años más tarde, Gilles y Nocetti (1962) también encontraron un predominio de la fuerza de trabajo familiar entre las unidades pequeñas y medianas-chicas (de 18 a 200 hectáreas), medido en jornadas laborales. Este peso del trabajo familiar desciende sólo levemente por encima de las 55 hectáreas, tal como puede observarse en el Cuadro A.2.7.

producción y adquirir animales para invernada fuera de la firma, a los efectos de su terminación en el establecimiento". Es más, como comentábamos al comienzo del capítulo, este trabajo afirma que "el área en estudio de condiciones y vocación para la invernada vio aumentar en los últimos años en forma notoria los animales de cría en sus rodeos." (INTAAACERA, 1969: 32).

26 En 1969, las unidades de entre 25 y 400 hectáreas dedicaban algo más de la mitad del predio a cultivos anuales para cosecha. En cambio, se afectaba a esta actividad un cuarto del área de las explotaciones de más de 2.500 hectáreas. 
Cuadro A.2.7. Tipo de Mano de obra, según estratos de superficie, porcentaje. Pergamino, 1960

\begin{tabular}{|c|c|c|c|}
\hline & 18 a 55 hectáreas & 55 a 100 hectáreas & 100 a 200 hectáreas \\
\hline Productor & 44,37 & 43,40 & 41,59 \\
\hline Familiares & 43,47 & 35,00 & 36,99 \\
\hline Sub-Total Familiar & 87,84 & 78,40 & 78,58 \\
\hline Asal. Permanentes & --- & 3,30 & 6,00 \\
\hline Asal. Transitorios & 12,10 & 18,30 & 15,42 \\
\hline Total & 100,00 & 100,00 & 100,00 \\
\hline
\end{tabular}

Fuente: Gilles y Nocetti (1962: 15)

En cambio, para fines de la década del sesenta, en los datos presentes en el trabajo de Peyrou (1971) sobre el área en torno a Pergamino ${ }^{27}$, es posible observar que se ha reducido la importancia del trabajo familiar. En el estrato de 50 a 120 hectáreas, la mano de obra aportada por el productor y su familia representaba el $58,3 \%$ del total de horas trabajadas, y en el estrato de 120 a 200 hectáreas, sólo el 26,7\% (cálculos propios en base a los datos presentes en Peyrou, 1971: 26).

27 El estudio se basó en una encuesta a 118 productores-propietarios seleccionados a azar en torno a la ciudad de Pergamino (en un área de 40 km.) en el año 1968. 


\section{La relación entre el tamaño de las explotaciones y la cantidad de asalariados en 1969}

Como decíamos en la Introducción siempre se debe tener mucha precaución al suponer asociaciones directas entre dos dimensiones. Este cuidado debe extremarse en el caso en que hayan tenido lugar recientes transformaciones, pues se producen "desfasajes", y también en el caso de las posiciones sociales intermedias, donde existe cierta indeterminación estructural de la organización social del trabajo. Por ejemplo, los productores de escala media no están obligados a contratar asalariados (al menos, no en gran número) porque puede serles suficiente con la fuerza de trabajo familiar. Pero, al mismo tiempo, estos productores habitualmente se encuentran en una situación económica que les permite contratar algunos peones (a diferencia de un pequeño productor).

En nuestro reprocesamiento de los datos originales del censo de 1969 es posible observar la heterogeneidad que surge de estas indeterminaciones. Si bien existe una relación positiva entre tamaño y presencia de asalariados permanentes, no son escasas las superposiciones de situaciones en cada uno de los estratos, tal como puede observarse en el Cuadro A.2.8 (los porcentajes están calculados para cada estrato de tamaño, por columnas). Como era previsible, entre las explotaciones menores a las 100 hectáreas de la zona norte existía un claro predominio de las unidades que no contrataban asalariados. Sin embargo, ya en el estrato de 100 a 200 hectáreas, aunque siguen siendo mayoría las unidades sin asalariados, un cuarto tenían uno o dos peones permanentes. Una situación claramente heterogénea se presentaba en las explotaciones de 200 a 400 hectáreas, pero también en las de 400 a 1000; la mayoría de estas últimas tenía uno o dos asalariados, y las unidades con tres a cinco representaban el $31 \%$, pero también tenían su importancia los establecimientos sin asalariados permanentes, que constituían el $17 \%$ de las unidades de este estrato. Sólo por encima de las 1.000 hectáreas existía un claro predominio de las explotaciones empresariales.

En las zonas oeste y $\underline{\text { sur, }}$ estas distribuciones eran muy similares, aunque "corridas" un estrato de tamaño hacia arriba. Así, por ejemplo, entre las explotaciones de 200 a 400 hectáreas seguían predominando las unidades sin asalariados, seguidas por los establecimientos con uno o dos peones. 
Cuadro A.2.8. Distribución de las explotaciones según cantidad de asalariados y estratos de tamaño. Porcentajes según tamaño, 1969

\begin{tabular}{|c|c|c|c|c|c|c|c|c|c|}
\hline & & \multicolumn{7}{|c|}{ TAMAÑO } & \multirow[t]{2}{*}{ Total } \\
\hline & & hasta 25 & 25 a 100 & 100 a 200 & 200 a 400 & 400 a 1000 & 1000- 2500 & más 2500 & \\
\hline \multirow{6}{*}{\begin{tabular}{r|} 
zona \\
norte
\end{tabular}} & Sin asalariados & $91.0 \%$ & $82.8 \%$ & $60.1 \%$ & $30.8 \%$ & $11.1 \%$ & $7.7 \%$ & $4.6 \%$ & $76.1 \%$ \\
\hline & $\begin{array}{r}\text { Con asal. } \\
\text { transitorios }\end{array}$ & $4.1 \%$ & $6.8 \%$ & $10.6 \%$ & $13.3 \%$ & $5.6 \%$ & $1.3 \%$ & $1.5 \%$ & $6.6 \%$ \\
\hline & $\begin{array}{r}1-2 \text { asal. } \\
\text { permanentes }\end{array}$ & $4.4 \%$ & $9.7 \%$ & $26.2 \%$ & $46.0 \%$ & $41.3 \%$ & $14.9 \%$ & $6.2 \%$ & $13.1 \%$ \\
\hline & $\begin{array}{r}\text { 3-5 asal. } \\
\text { permanentes }\end{array}$ & $.4 \%$ & $.5 \%$ & $2.3 \%$ & $8.2 \%$ & $30.7 \%$ & $28.5 \%$ & $6.2 \%$ & $2.5 \%$ \\
\hline & $\begin{array}{r}\text { más } 5 \text { asal. } \\
\text { permanentes }\end{array}$ & $.1 \%$ & $.2 \%$ & $.8 \%$ & $1.6 \%$ & $11.2 \%$ & $47.7 \%$ & $81.5 \%$ & $1.6 \%$ \\
\hline & & $100.0 \%$ & $100.0 \%$ & $100.0 \%$ & $100.0 \%$ & $100.0 \%$ & $100.0 \%$ & $100.0 \%$ & $100.0 \%$ \\
\hline \multirow{6}{*}{$\begin{array}{l}\text { zona } \\
\text { oeste }\end{array}$} & Sin asalariados & $92.4 \%$ & $84.1 \%$ & $69.6 \%$ & $51.6 \%$ & $25.9 \%$ & $6.0 \%$ & $3.2 \%$ & $65.5 \%$ \\
\hline & $\begin{array}{r}\text { Con asal. } \\
\text { transitorios }\end{array}$ & $1.7 \%$ & $3.4 \%$ & $4.8 \%$ & $7.6 \%$ & $5.0 \%$ & $2.8 \%$ & $.4 \%$ & $4.0 \%$ \\
\hline & $\begin{array}{r}1-2 \text { asal. } \\
\text { permanentes }\end{array}$ & $4.9 \%$ & $11.6 \%$ & $22.8 \%$ & $33.5 \%$ & $51.3 \%$ & $29.0 \%$ & $4.6 \%$ & $20.5 \%$ \\
\hline & $\begin{array}{r}\text { 3-5 asal. } \\
\text { permanentes }\end{array}$ & $.5 \%$ & $.5 \%$ & $2.5 \%$ & $5.3 \%$ & $14.5 \%$ & $40.6 \%$ & $10.2 \%$ & $5.5 \%$ \\
\hline & $\begin{array}{r}\text { más } 5 \text { asal. } \\
\text { permanentes }\end{array}$ & $.5 \%$ & $.4 \%$ & $.3 \%$ & $2.0 \%$ & $3.4 \%$ & $21.6 \%$ & $81.7 \%$ & $4.5 \%$ \\
\hline & & $100.0 \%$ & $100.0 \%$ & $100.0 \%$ & $100.0 \%$ & $100.0 \%$ & $100.0 \%$ & $100.0 \%$ & $100.0 \%$ \\
\hline \multirow[t]{6}{*}{$\begin{array}{r}\text { zona } \\
\text { sur }\end{array}$} & Sin asalariados & $91.2 \%$ & $85.3 \%$ & $75.9 \%$ & $57.0 \%$ & $32.0 \%$ & $11.3 \%$ & $4.9 \%$ & $61.8 \%$ \\
\hline & $\begin{array}{r}\text { Con asal. } \\
\text { transitorios }\end{array}$ & $3.1 \%$ & $7.3 \%$ & $10.4 \%$ & $11.9 \%$ & $8.9 \%$ & $4.1 \%$ & $1.0 \%$ & $8.2 \%$ \\
\hline & $\begin{array}{r}\text { 1-2 asal. } \\
\text { permanentes }\end{array}$ & $4.9 \%$ & $6.8 \%$ & $12.5 \%$ & $29.0 \%$ & $44.3 \%$ & $28.9 \%$ & $4.6 \%$ & $21.0 \%$ \\
\hline & $\begin{array}{r}\text { 3-5 asal. } \\
\text { permanentes }\end{array}$ & $.7 \%$ & $.4 \%$ & $1.0 \%$ & $2.0 \%$ & $12.7 \%$ & $36.7 \%$ & $22.3 \%$ & $5.9 \%$ \\
\hline & $\begin{array}{r}\text { más } 5 \text { asal. } \\
\text { permanentes }\end{array}$ & $.2 \%$ & $.1 \%$ & $.2 \%$ & $.1 \%$ & $2.1 \%$ & $19.0 \%$ & $67.2 \%$ & $3.1 \%$ \\
\hline & & $100.0 \%$ & $100.0 \%$ & $100.0 \%$ & $100.0 \%$ & $100.0 \%$ & $100.0 \%$ & $100.0 \%$ & $100.0 \%$ \\
\hline
\end{tabular}

Fuente: reprocesamiento de los datos originales del Censo Nacional Agropecuario de 1969. 
El Cuadro A.2.9 permite otra lectura de los mismos datos. La heterogeneidad se ve aquí en la distribución del tipo de explotaciones según los estratos de tamaño (porcentajes calculados para cada fila). Se observa que el peso numérico de las unidades más pequeñas, genera, por ejemplo, que incluso muchas de las explotaciones familiares con uno o dos asalariados permanentes se concentren por debajo de las 100 hectáreas ( $42 \%$ en la zona norte).

Cuadro A.2.9. Distribución de las explotaciones según cantidad de asalariados y estratos de tamaño. Porcentajes según asalariados, 1969

\begin{tabular}{|c|c|c|c|c|c|c|c|c|c|}
\hline & & \multicolumn{7}{|c|}{ TAMAÑO } & \multirow[t]{2}{*}{ Total } \\
\hline & & hasta 25 & 25 a 100 & 100 a 200 & 200 a 400 & 400 a 1000 & $1000-2500$ & más 2500 & \\
\hline \multirow{6}{*}{$\begin{array}{r}\text { zona } \\
\text { norte }\end{array}$} & Sin asalariados & $41.8 \%$ & $45.2 \%$ & $10.1 \%$ & $2.3 \%$ & $.5 \%$ & $.1 \%$ & $.0 \%$ & $100.0 \%$ \\
\hline & $\begin{array}{r}\text { Con asal. } \\
\text { transitorios }\end{array}$ & $21.6 \%$ & $43.1 \%$ & $20.5 \%$ & $11.7 \%$ & $2.9 \%$ & $.3 \%$ & $.1 \%$ & $100.0 \%$ \\
\hline & $\begin{array}{r}1-2 \text { asal. } \\
\text { permanentes }\end{array}$ & $11.7 \%$ & $30.6 \%$ & $25.4 \%$ & $20.2 \%$ & $10.5 \%$ & $1.5 \%$ & $.2 \%$ & $100.0 \%$ \\
\hline & $\begin{array}{r}\text { 3-5 asal. } \\
\text { permanentes }\end{array}$ & $5.6 \%$ & $8.5 \%$ & $11.5 \%$ & $18.7 \%$ & $40.3 \%$ & $14.5 \%$ & $.9 \%$ & $100.0 \%$ \\
\hline & $\begin{array}{r}\text { más } 5 \text { asal. } \\
\text { permanentes }\end{array}$ & $2.4 \%$ & $5.2 \%$ & $6.5 \%$ & $5.8 \%$ & $23.4 \%$ & $38.5 \%$ & $18.2 \%$ & $100.0 \%$ \\
\hline & & $34.9 \%$ & $41.6 \%$ & $12.8 \%$ & $5.8 \%$ & $3.3 \%$ & $1.3 \%$ & $.4 \%$ & $100.0 \%$ \\
\hline \multirow[t]{6}{*}{$\begin{array}{r}\text { zona } \\
\text { oeste }\end{array}$} & Sin asalariados & $28.4 \%$ & $35.2 \%$ & $20.7 \%$ & $10.7 \%$ & $4.4 \%$ & $.5 \%$ & $.1 \%$ & $100.0 \%$ \\
\hline & $\begin{array}{r}\text { Con asal. } \\
\text { transitorios }\end{array}$ & $8.8 \%$ & $23.6 \%$ & $23.6 \%$ & $26.0 \%$ & $13.9 \%$ & $3.8 \%$ & $.3 \%$ & $100.0 \%$ \\
\hline & $\begin{array}{r}1-2 \text { asal. } \\
\text { permanentes }\end{array}$ & $4.8 \%$ & $15.5 \%$ & $21.7 \%$ & $22.1 \%$ & $27.7 \%$ & $7.5 \%$ & $.7 \%$ & $100.0 \%$ \\
\hline & $\begin{array}{r}\text { 3-5 asal. } \\
\text { permanentes }\end{array}$ & $1.9 \%$ & $2.7 \%$ & $8.7 \%$ & $12.9 \%$ & $29.0 \%$ & $39.2 \%$ & $5.6 \%$ & $100.0 \%$ \\
\hline & $\begin{array}{r}\text { más } 5 \text { asal. } \\
\text { permanentes }\end{array}$ & $2.1 \%$ & $2.1 \%$ & $1.2 \%$ & $5.9 \%$ & $8.3 \%$ & $25.5 \%$ & $54.8 \%$ & $100.0 \%$ \\
\hline & & $20.1 \%$ & $27.4 \%$ & $19.5 \%$ & $13.5 \%$ & $11.1 \%$ & $5.3 \%$ & $3.0 \%$ & $100.0 \%$ \\
\hline \multirow[t]{6}{*}{$\begin{array}{r}\text { zona } \\
\text { sur }\end{array}$} & Sin asalariados & $24.6 \%$ & $21.3 \%$ & $21.7 \%$ & $21.4 \%$ & $9.7 \%$ & $1.1 \%$ & $.2 \%$ & $100.0 \%$ \\
\hline & $\begin{array}{r}\text { Con asal. } \\
\text { transitorios }\end{array}$ & $6.3 \%$ & $13.8 \%$ & $22.5 \%$ & $33.7 \%$ & $20.4 \%$ & $3.1 \%$ & $.3 \%$ & $100.0 \%$ \\
\hline & $\begin{array}{r}\text { 1-2 asal. } \\
\text { permanentes }\end{array}$ & $3.9 \%$ & $5.0 \%$ & $10.5 \%$ & $32.0 \%$ & $39.6 \%$ & $8.4 \%$ & $.5 \%$ & $100.0 \%$ \\
\hline & $\begin{array}{r}\text { 3-5 asal. } \\
\text { permanentes }\end{array}$ & $1.9 \%$ & $1.2 \%$ & $3.0 \%$ & $7.7 \%$ & $40.3 \%$ & $37.9 \%$ & $8.0 \%$ & $100.0 \%$ \\
\hline & $\begin{array}{r}\text { más } 5 \text { asal. } \\
\text { permanentes }\end{array}$ & $.9 \%$ & $.4 \%$ & $1.3 \%$ & $.7 \%$ & $13.0 \%$ & $37.7 \%$ & $46.0 \%$ & $100.0 \%$ \\
\hline & & $16.7 \%$ & $15.4 \%$ & $17.7 \%$ & $23.2 \%$ & $18.8 \%$ & $6.1 \%$ & $2.1 \%$ & $100.0 \%$ \\
\hline
\end{tabular}

Fuente: reprocesamiento de los datos originales del Censo Nacional Agropecuario de 1969. 


\section{Análisis de la distribución de la producción según las formas de tenencia del suelo a partir de los datos de 1960 reprocesados por el CONADE, de estudios técnicos de la época y de nuestro reprocesamiento del Censo de 1969}

Podemos recurrir al reprocesamiento de los datos del censo de 1960 efectuados por el CONADE para estimar la situación para ese año (ver Cuadro A.2.10). Para entonces, en la zona norte, el proceso de transformación en la distribución de la agricultura según las formas de tenencia del suelo se encontraría a mitad de camino: los no propietarios (agregando "Arrendatarios" y "Otros") sumaban el 42\% de la superficie agrícola ${ }^{28}$ (mientras que en 1969 sólo detentarían el $21 \%$ de la misma). Por otra parte, la ganadería se asociaba de un modo más fuerte a la propiedad (propietarios puros o que combinaban la propiedad con el arriendo, sumaban el $71 \%$ de la superficie ganadera).

Para la zona de Pergamino, en 1959 los estudios de Schaefer encontraron que "en todos los tamaños la superficie dedicada a ganadería, medida por hectáreas y en porcentaje de SU [superficie utilizable] con pasturas, es mayor en los propietarios que en los aparceros." (Schaefer, 1960: 97). Explica este fenómeno en base a la transformación que acababa de ocurrir en las formas de tenencia: "Los actuales propietarios, ex-aparceros, al adquirir recientemente el campo que ocupaban, que habían sido trabajados con agricultura en forma continuada durante muchos años, le imprimieron una fuerte orientación ganadera, con el objeto de recuperar campo. Su objetivo fue incorporar fertilidad mediante la implantación de alfalfares. Aunque no se tienen datos generales es de presumir que esta condición de nuevos propietarios no se manifiesta en toda la región maicera, ni necesariamente en el tamaño encontrado en esta zona" (Schaefer, 1960: 98). En cambio, a pesar de la autorización legal existente, él encuentra que los arrendatarios están en la práctica seriamente limitados para dedicar parte de su campo a la ganadería. Pese a la autorización legal (la ley 13.246 que en su artículo $9^{\circ}$ establecía que el arrendatario podrá destinar hasta el 30\% de la superficie para la explotación ganadera), "parecería que resultó inoperante, a nuestro juicio, por: No establecer la forma de pago de ese $30 \%$. De acuerdo a lo manifestado por los productores en el caso que optaren por hacer uso del a autorización mencionada, los dueños le exigen el pago a un precio en dinero equivalente al valor de la producción agrícola como si hubiese sido dedicado a cereales." (Schaefer, 1960: 173). Entonces, cuando "la producción bruta comparada que suministran los cereales es muy superior a la de la ganadería (vacunos) [...] esa exigencia en el precio casi equivaldría a la entrega del valor de toda la producción anual por hectárea que suministra dicha actividad".

28 Medido en valor de la producción agrícola, los no propietarios tenían una significación similar en esta zona. 
Luego aclara que los funcionarios y técnicos de la Cámara Central de Arrendamiento manifestaron que los aparceros podrían apelar a las cámaras para que fijen los precios, pero que no lo hacen, tal vez porque desconocían esta situación (Schaefer, 1960: 173-175).

Otro estudio realizado en el partido de Pergamino en 1961 encontró que los aparceros ${ }^{29}$ dedicaban una proporción de trabajo mucho más importante a los cultivos que los propietarios de igual escala (el trabajo se centró en las unidades de 50 a 125 hectáreas), mientras que éstos se volcaban a la cría de vacunos con mayor intensidad ${ }^{30}$. Por otra parte, los propietarios obtuvieron mayores rendimientos en sus cultivos (Gilles, 1965).

Nuestro procesamiento de los datos originales del censo de 1969 permiten observar (Cuadro A.2.11) que los arrendatarios y, más aún, los aparceros dedicaban a la agricultura una proporción de sus predios sustancialmente mayor que los propietarios $(53 \%$ y $67 \%$, frente a 44\%, respectivamente; ver fila "Total"). Este trabajo demuestra que esta diferente orientación productiva según las formas de tenencia del suelo se mantiene para cada uno de los estratos de tamaño en la zona norte. En algunos estratos la diferencia resulta especialmente marcada. Así, por ejemplo, en el estrato de 400 a 1.000 hectáreas, los propietarios sólo afectaban el 31\% de la superficie a la agricultura, mientras que los arrendatarios destinaban el 50\% y los aparceros, el $77 \%$.

Volviendo a los datos de 1960, en la zona oeste, la agricultura ya se había ubicado en los productores propietarios, y los arrendatarios y las otras formas sólo detentaban el 29\% de la superficie agrícola (cercano al 22\% que tendrían en 1969). La ganadería se ubicaba entre los propietarios: el $74 \%$ de la superficie ganadera estaba a cargo de propietarios (puros o mixtos), tal como puede observarse en el Cuadro A.2.10.

Los datos de 1969, permiten visualizar que entre propietarios y arrendatarios no había notorias diferencias en el porcentaje de superficie que dedicaban a cultivos anuales para cosecha ( $11 \%$, frente a $14 \%$, respectivamente), y que incluso en los distintos estratos de tamaño, no había fuertes discrepancias entre estas dos formas de tenencia (ver Cuadro A.2.11). La aparcería

29 El estudio dejó de lado a los arrendatarios que pagaban en cánon en dinero, como así también a las formas mixtas de tenencia, ya que su número era muy pequeño (Gilles, 1965: 23).

30 La distribución de la proporción de unidades de trabajo empleadas en las distintas actividades era la siguiente:

ActividadPropietariosArrendatariosCultivos26.055.9Ganado de carne40.07.7Cerdos11.314.5Avicultura16.117.9Nota: sólo unidades de 50 a 125 hectáreas del partido de Pergamino Fuente: Gilles (1965: 28). 
sí estaba volcada a la agricultura, pero era una forma de tenencia de una importancia muy reducida en la zona oeste.

Para 1960, en la zona sur, todavía los no propietarios tenían el 38\% de la superficie agrícola, es decir, que el proceso de asociación de agricultura y propiedad se encontraba a mitad de camino (en 1969 sólo el 23\% del área agrícola estará en manos de arrendatarios u otras formas de tenencia). El $67 \%$ de la superficie ganadera estaba en manos de propietarios puros o mixtos.

Los datos de 1969 muestran que los arrendatarios tenían un perfil más agrícola que los propietarios ( $52 \%$ de la superficie dedicada a cultivos anuales para cosecha, frente a $42 \%$ ), y que esta diferencia se mantiene en esa magnitud a lo largo de los distintos estratos de tamaño (ver Cuadro A.2.11). También aquí, la aparcería (de escasa importancia territorial) tenía una fuerte orientación hacia la agricultura.

Cuadro A.2.10. Distribución de la superficie y la producción según la tenencia del suelo, 1960.

Zona 10a (zona norte)

\begin{tabular}{|l|r|r|r|r|r|r|r|r|}
\hline \multirow{2}{*}{} & \multicolumn{4}{|c|}{ Superficie } & \multicolumn{4}{c|}{ Valor } \\
\cline { 2 - 9 } & \multicolumn{2}{|c|}{ (miles de ha) } & & & (millones de pesos) & \\
\cline { 2 - 9 } & Agricultura & Ganadería & Agricultura & Ganadería & Agricultura & Ganadería & Agricultura & Ganadería \\
\hline Propietario & 587 & 836 & $45 \%$ & $58 \%$ & 6596 & 4159 & $44 \%$ & $55 \%$ \\
\hline Arrend. & 317 & 239 & $24 \%$ & $17 \%$ & 3678 & 1382 & $25 \%$ & $18 \%$ \\
\hline Prop. y arr. & 173 & 181 & $13 \%$ & $13 \%$ & 1952 & 1096 & $13 \%$ & $15 \%$ \\
\hline Otros & 242 & 182 & $18 \%$ & $13 \%$ & 2773 & 862 & $18 \%$ & $11 \%$ \\
\hline \multicolumn{1}{r|}{ Total } & 1319 & 1438 & $100 \%$ & $100 \%$ & 14999 & 7499 & $100 \%$ & $100 \%$ \\
\hline
\end{tabular}


Zonas 5a y b (zona oeste)

\begin{tabular}{|l|r|r|r|r|r|r|r|r|}
\hline \multirow{4}{*}{} & \multicolumn{4}{|c|}{ Superficie } & \multicolumn{4}{c|}{ Valor } \\
\cline { 2 - 9 } & \multicolumn{2}{|c|}{ (miles de ha) } & & & (millones de pesos) & \\
\cline { 2 - 9 } & Agricultura & Ganadería & Agricultura & Ganadería & Agricultura & Ganadería & Agricultura & Ganadería \\
\hline Propietario & 1179 & 2444 & $55 \%$ & $58 \%$ & 5258 & 9754 & $55 \%$ & $57 \%$ \\
\hline Arrend. & 419 & 701 & $20 \%$ & $17 \%$ & 1858 & 3170 & $19 \%$ & $18 \%$ \\
\hline Prop. y arr. & 337 & 650 & $16 \%$ & $16 \%$ & 1510 & 2806 & $16 \%$ & $16 \%$ \\
\hline Otros & 198 & 398 & $9 \%$ & $9 \%$ & 907 & 1530 & $10 \%$ & $9 \%$ \\
\hline \multicolumn{1}{r|}{ Total } & 2133 & 4193 & $100 \%$ & $100 \%$ & 9533 & 17260 & $100 \%$ & $100 \%$ \\
\hline
\end{tabular}

Zona 7 (zona sur)

\begin{tabular}{|l|r|r|r|r|r|r|r|r|}
\hline \multirow{4}{*}{} & \multicolumn{4}{|c|}{ Superficie } & \multicolumn{4}{c|}{ Valor } \\
\cline { 2 - 9 } & \multicolumn{2}{|c|}{ (miles de ha) } & & & (millones de pesos) & \\
\cline { 2 - 9 } & Agricultura & Ganadería & Agricultura & Ganadería & Agricultura & Ganadería & Agricultura & Ganadería \\
\hline Propietario & 896 & 2097 & $54 \%$ & $51 \%$ & 6326 & 5570 & $56 \%$ & $51 \%$ \\
\hline Arrend. & 510 & 757 & $31 \%$ & $18 \%$ & 3689 & 2502 & $32 \%$ & $23 \%$ \\
\hline Prop. y arr. & 133 & 649 & $8 \%$ & $16 \%$ & 728 & 1638 & $6 \%$ & $15 \%$ \\
\hline Otros & 115 & 599 & $7 \%$ & $15 \%$ & 652 & 1231 & $6 \%$ & $11 \%$ \\
\hline Total & 1654 & 4102 & $100 \%$ & $100 \%$ & 11395 & 10941 & $100 \%$ & $100 \%$ \\
\hline
\end{tabular}

Fuente: reagrupamiento personal de los datos del reprocesamiento de las fichas originales del Censo Nacional Agropecuario de 1960, efectuado por el CONADE (1965). 
Cuadro A.2.11. Superficie con cultivos anuales para cosecha, sobre total de la superficie de la explotación, según tamaño y forma de tenencia del suelo, 1969

\begin{tabular}{|c|c|c|c|c|c|c|c|c|c|}
\hline Zona & Tamaño & Prop. & $\begin{array}{l}\text { Prop. }{ }^{+} \\
\text {Arriendo } \\
\end{array}$ & $\begin{array}{l}\text { Prop. + } \\
\text { Aparc. }\end{array}$ & \begin{tabular}{|l} 
Prop. + \\
Otras \\
\end{tabular} & Arriendo & Aparc. & Otras & Total \\
\hline \multirow[t]{8}{*}{ norte } & hasta 25 ha & $36 \%$ & $41 \%$ & $60 \%$ & $39 \%$ & $42 \%$ & $56 \%$ & $27 \%$ & $37 \%$ \\
\hline & 25 a 100 & $53 \%$ & $57 \%$ & $67 \%$ & $57 \%$ & $59 \%$ & $71 \%$ & $51 \%$ & $55 \%$ \\
\hline & 100 a 200 & $46 \%$ & $60 \%$ & $67 \%$ & $58 \%$ & $55 \%$ & $78 \%$ & $35 \%$ & $52 \%$ \\
\hline & 200 a 400 & $37 \%$ & $55 \%$ & $69 \%$ & $48 \%$ & $50 \%$ & $80 \%$ & $46 \%$ & $46 \%$ \\
\hline & 400 a 1000 & $31 \%$ & $51 \%$ & $64 \%$ & $36 \%$ & $50 \%$ & $77 \%$ & $33 \%$ & $40 \%$ \\
\hline & 1000 a 2500 & $28 \%$ & $33 \%$ & $51 \%$ & $34 \%$ & $47 \%$ & $69 \%$ & $0 \%$ & $34 \%$ \\
\hline & 2500 ha + & $21 \%$ & $23 \%$ & $37 \%$ & $17 \%$ & $31 \%$ & $70 \%$ & $12 \%$ & $23 \%$ \\
\hline & \begin{tabular}{|l|} 
Total \\
\end{tabular} & $44 \%$ & $55 \%$ & $66 \%$ & $51 \%$ & $53 \%$ & $67 \%$ & $34 \%$ & $47 \%$ \\
\hline \multirow{9}{*}{ oeste } & & & & & & & & & \\
\hline & hasta 25 ha & $7 \%$ & $3 \%$ & $57 \%$ & $4 \%$ & $7 \%$ & $43 \%$ & $3 \%$ & $7 \%$ \\
\hline & 25 a 100 & $11 \%$ & $11 \%$ & $20 \%$ & $12 \%$ & $11 \%$ & $40 \%$ & $8 \%$ & $11 \%$ \\
\hline & 100 a 200 & $12 \%$ & $11 \%$ & $11 \%$ & $11 \%$ & $18 \%$ & $79 \%$ & $12 \%$ & $13 \%$ \\
\hline & 200 a 400 & $13 \%$ & $13 \%$ & $47 \%$ & $14 \%$ & $16 \%$ & $66 \%$ & $12 \%$ & $15 \%$ \\
\hline & 400 a 1000 & $13 \%$ & $15 \%$ & $48 \%$ & $12 \%$ & $19 \%$ & $59 \%$ & $13 \%$ & $15 \%$ \\
\hline & 1000 a 2500 & $12 \%$ & $15 \%$ & $33 \%$ & $14 \%$ & $18 \%$ & $39 \%$ & $11 \%$ & $13 \%$ \\
\hline & 2500 ha + & $9 \%$ & $13 \%$ & $34 \%$ & $8 \%$ & $12 \%$ & $12 \%$ & $13 \%$ & $10 \%$ \\
\hline & \begin{tabular}{|l|} 
Total \\
\end{tabular} & $11 \%$ & $12 \%$ & $36 \%$ & $11 \%$ & $14 \%$ & $56 \%$ & $7 \%$ & $12 \%$ \\
\hline & & & & & & & & & \\
\hline \multirow[t]{8}{*}{ sur } & hasta 25 ha & $32 \%$ & $54 \%$ & $60 \%$ & $40 \%$ & $38 \%$ & $61 \%$ & $27 \%$ & $33 \%$ \\
\hline & 25 a 100 & $48 \%$ & $55 \%$ & $65 \%$ & $48 \%$ & $56 \%$ & $76 \%$ & $44 \%$ & $51 \%$ \\
\hline & 100 a 200 & $50 \%$ & $55 \%$ & $71 \%$ & $38 \%$ & $59 \%$ & $75 \%$ & $52 \%$ & $53 \%$ \\
\hline & 200 a 400 & $47 \%$ & $54 \%$ & $64 \%$ & $54 \%$ & $56 \%$ & $77 \%$ & $54 \%$ & $51 \%$ \\
\hline & 400 a 1000 & $42 \%$ & $50 \%$ & $62 \%$ & $42 \%$ & $49 \%$ & $72 \%$ & $48 \%$ & $46 \%$ \\
\hline & 1000 a 2500 & $31 \%$ & $44 \%$ & $58 \%$ & $42 \%$ & $39 \%$ & $51 \%$ & $26 \%$ & $37 \%$ \\
\hline & 2500 ha + & $23 \%$ & $31 \%$ & $40 \%$ & $30 \%$ & $24 \%$ & $40 \%$ & $8 \%$ & $25 \%$ \\
\hline & Total & $42 \%$ & $51 \%$ & $62 \%$ & $45 \%$ & $52 \%$ & $73 \%$ & $38 \%$ & $46 \%$ \\
\hline
\end{tabular}

Fuente: reprocesamiento de los datos originales del Censo Nacional Agropecuario de 1969. 
Por último, el reprocesamiento del CONADE permite analizar la productividad de la tierra que generaban las distintas formas de tenencia en 1960. Como se observa en el Cuadro A.2.12, la constante en las tres zonas es que los arrendatarios presentaban una productividad por hectárea más elevada que el resto de las formas de tenencia. La diferencia con los propietarios puros era por demás importante.

Cuadro A.2.12. Valor de la producción agropecuaria por hectárea, 1960

En pesos por hectárea (agricultura y ganadería)

\begin{tabular}{|c|c|c|c|}
\hline & zona norte & zona oeste & zona sur \\
\hline Propietario & 7557 & 4144 & 3976 \\
\hline Arrendatario & 9097 & 4489 & 4885 \\
\hline Propietario y arrend. & 8618 & 4373 & 3025 \\
\hline Otros & 8568 & 4089 & 2635 \\
\hline Total & 8159 & 4235 & 3880 \\
\hline
\end{tabular}

Fuente: reagrupamiento personal de los datos del reprocesamiento de las fichas originales del Censo Nacional Agropecuario de 1960, efectuado por el CONADE (1965).

Muy probablemente estas diferencias se deban a que los arrendatarios tenían un menor tamaño que los propietarios y, como ya hemos visto, la extensión presentaba una relación inversa con la productividad por hectárea. En todo caso, estos datos deberían servir para relativizar tantos comentarios que insistían en que los arrendatarios y aparceros eran menos productivos que los propietarios, o que la inestabilidad a la que estaban sometidos los llevaba a disminuir su nivel de reinversión al punto de hacer que su productividad fuera muy reducida. 


\section{Distribución de las formas sociales de producción según su tamaño}

Cuadro A.2.13. Distribución de explotaciones según su tamaño (en hectáreas), discriminadas en las distintas formas sociales, 1969

Percentiles $^{(*)}$

\begin{tabular}{|c|c|c|c|c|c|c|c|c|}
\hline \multirow[b]{2}{*}{ Zona } & \multirow[b]{2}{*}{ FORMA } & \multicolumn{7}{|c|}{ Percentiles } \\
\hline & & 5 & 10 & 25 & 50 & 75 & 90 & 95 \\
\hline \multirow[t]{8}{*}{ norte } & arrendatario fliar & 1 & 4 & 13 & 39 & 70 & 121 & 183 \\
\hline & arr. fliar c/asalariados & 5 & 20 & 60 & 125 & 262 & 550 & 940 \\
\hline & Capitalista pequeño & 4 & 39 & 141 & 615 & 999 & 1321 & 1761 \\
\hline & Cap. mediano o grande & 75 & 104 & 558 & 1333 & 2012 & 3179 & 4932 \\
\hline & farmer & 2 & 4 & 12 & 37 & 75 & 126 & 181 \\
\hline & farmer c/asalariados & 8 & 20 & 60 & 126 & 243 & 437 & 601 \\
\hline & Terrateniente-Cap. pequeño & 25 & 73 & 196 & 447 & 800 & 1185 & 1500 \\
\hline & Terr-Cap. med. o grande & 74 & 137 & 545 & 1153 & 1993 & 3736 & 4521 \\
\hline \multirow[t]{8}{*}{ oeste } & arrendatario fliar & 2 & 5 & 20 & 55 & 156 & 269 & 411 \\
\hline & arr. fliar c/asalariados & 20 & 53 & 121 & 295 & 623 & 1063 & 1321 \\
\hline & Capitalista pequeño & 51 & 168 & 346 & 828 & 1970 & 2938 & 3058 \\
\hline & Cap. mediano o grande & 392 & 707 & 1673 & 3499 & 5232 & 9895 & 13343 \\
\hline & farmer & 3 & 6 & 23 & 76 & 160 & 287 & 439 \\
\hline & farmer c/asalariados & 30 & 60 & 121 & 254 & 553 & 930 & 1176 \\
\hline & Terrateniente-Cap. pequeño & 113 & 170 & 381 & 900 & 1507 & 2129 & 2500 \\
\hline & Terr-Cap. med. o grande & 115 & 333 & 1310 & 2640 & 4161 & 5789 & 7440 \\
\hline \multirow{8}{*}{ sur- } & arrendatario fliar & 3 & 7 & 40 & 129 & 250 & 409 & 580 \\
\hline & arr. fliar c/asalariados & 40 & 101 & 227 & 360 & 601 & 934 & 1220 \\
\hline & Capitalista pequeño & 77 & 284 & 489 & 873 & 1342 & 2095 & 2767 \\
\hline & Cap. mediano o grande & 358 & 627 & 1109 & 2671 & 4322 & 6443 & 7885 \\
\hline & farmer & 3 & 5 & 31 & 140 & 280 & 460 & 620 \\
\hline & farmer c/asalariados & 44 & 120 & 247 & 400 & 632 & 962 & 1250 \\
\hline & Terrateniente-Cap. pequeño & 170 & 350 & 585 & 960 & 1498 & 2423 & 2793 \\
\hline & Terr-Cap. med. o grande & 538 & 771 & 1335 & 2230 & 3809 & 5952 & 7326 \\
\hline
\end{tabular}

Fuente: Cálculos propios en base a los datos originales del Censo Nacional Agropecuario de 1969.

(*) Los percentiles son los valores de una determinada variable (en este caso, la extensión en hectáreas de las explotaciones) que dejan un determinado porcentaje (equivalente al número del percentil) de casos (aquí explotaciones) acumulado por debajo de su valor. Así, por ejemplo, el percentil 10, en los arrendatarios familiares de la zona norte, es igual a 4 hectáreas, ya que el $10 \%$ de este tipo de explotaciones tienen menos de 4 hectáreas de extensión. 
Gráfico A.2.11. Distribución de explotaciones según su tamaño (en hectáreas), discriminadas en las distintas formas sociales. Diagrama de caja ${ }^{(*)}$

Zona norte, 1969

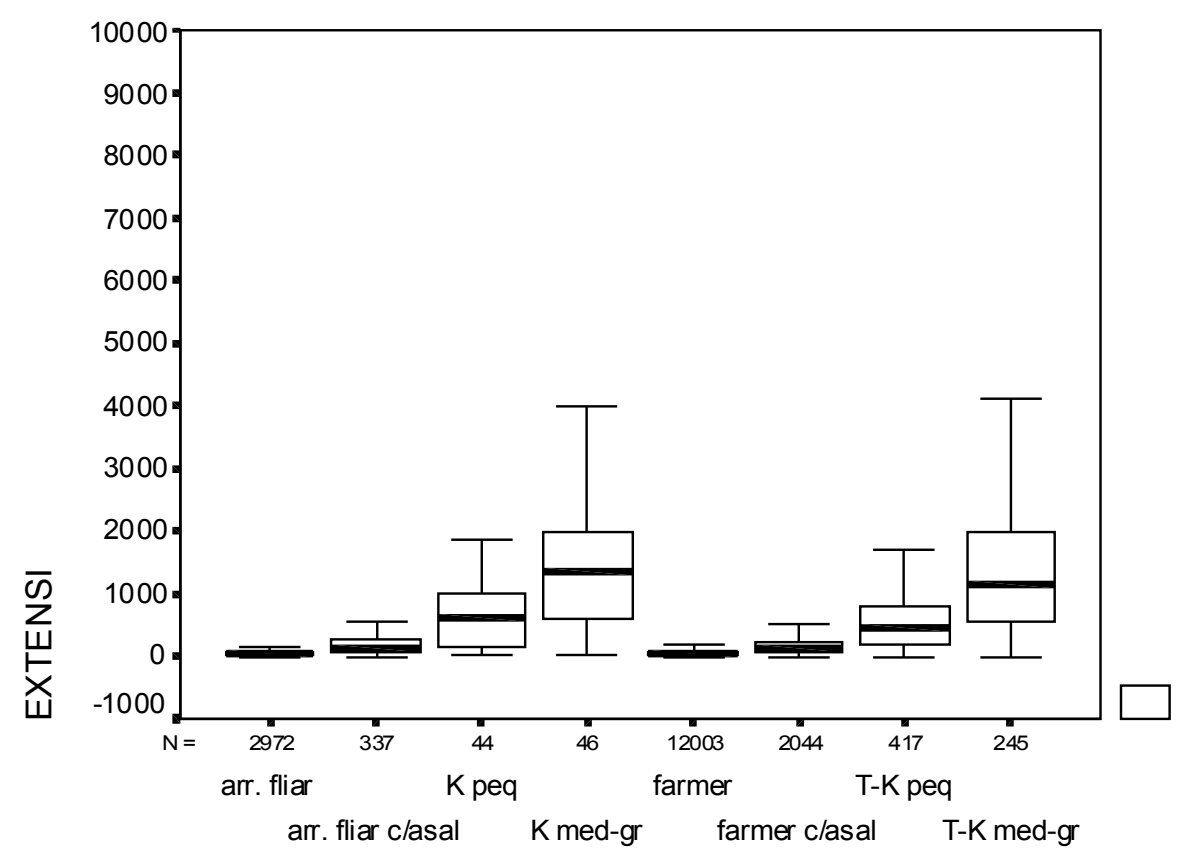

FORMA

(*) En los diagramas de caja o "box-plot", la línea gruesa representa a la mediana, la caja encierra al 50\% central de las explotaciones, y las líneas verticales al $25 \%$ superior e inferior (los casos extremos no han sido representados para simplificar el gráfico).

Fuente: Cálculos propios en base a los datos originales del Censo Nacional Agropecuario de 1969. 
Gráfico A.2.12. Distribución de explotaciones según su tamaño (en hectáreas), discriminadas en las distintas formas sociales. Diagrama de caja

Zona oeste, 1969

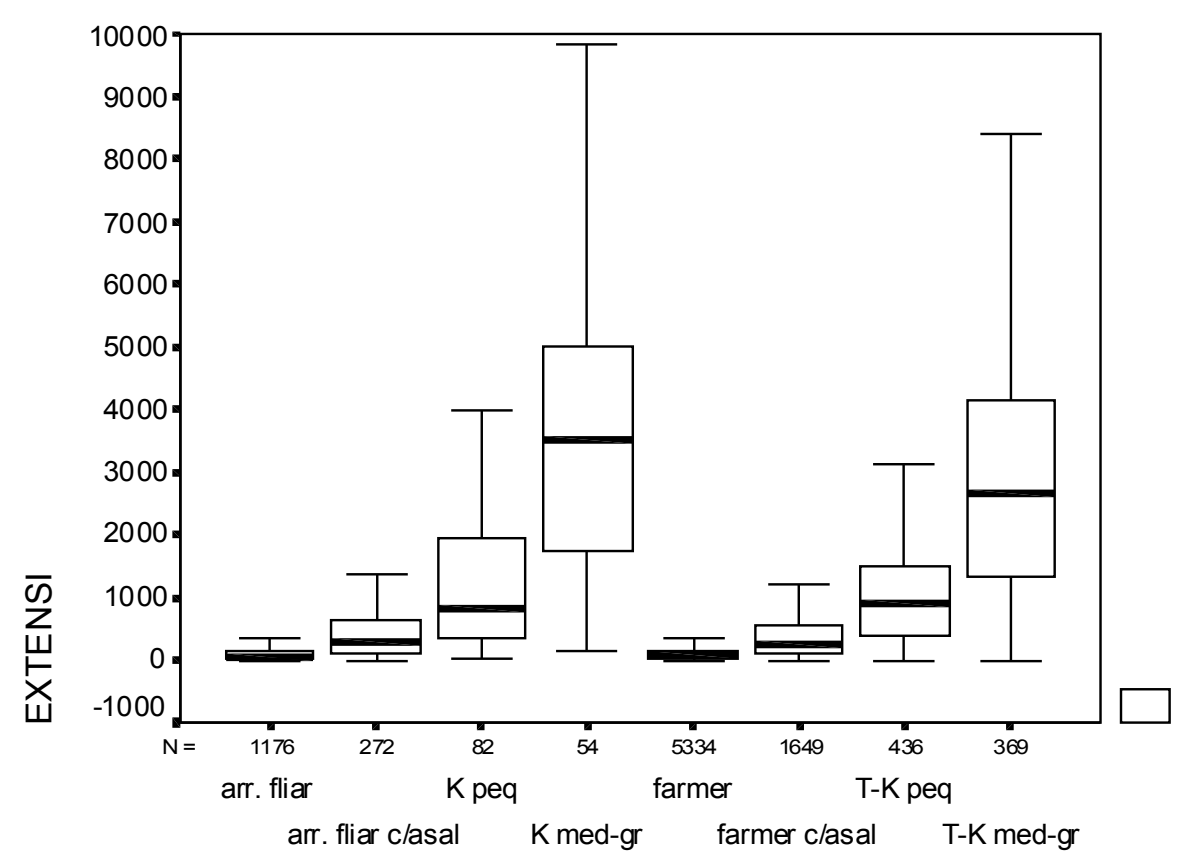

FORMA

Fuente: Cálculos propios en base a los datos originales del Censo Nacional Agropecuario de 1969. 
Gráfico A.2.13. Distribución de explotaciones según su tamaño (en hectáreas), discriminadas en las distintas formas sociales. Diagrama de caja

Zona sur, 1969

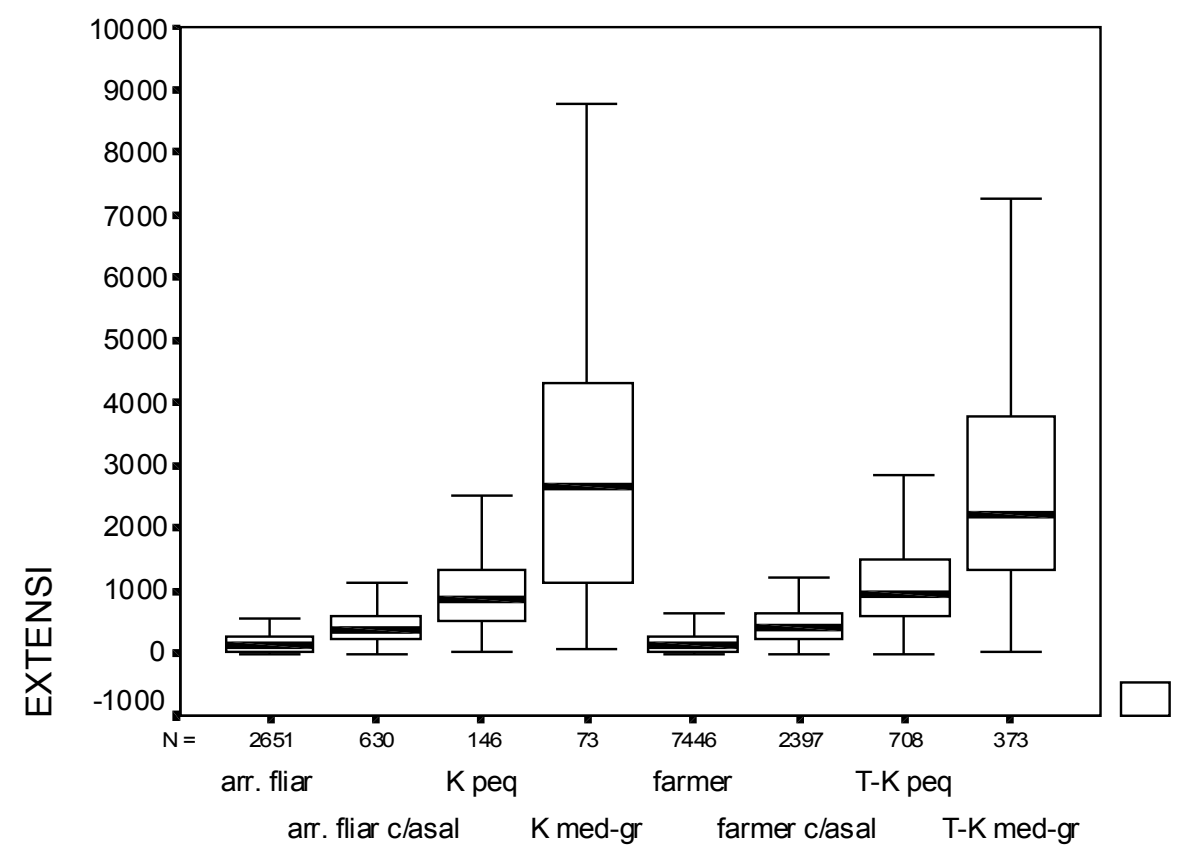

FORMA

Fuente: Cálculos propios en base a los datos originales del Censo Nacional Agropecuario de 1969. 


\section{Apéndice 3. Estadísticas y Análisis complementarios del Capítulo Tercero}

\section{Evolución del área sembrada y el volumen cosechado entre 1969 y 1988}

Durante los años setenta asistimos a cierta expansión de la superficie sembrada en la región pampeana, especialmente a partir de la cosecha 1974/75, que se hizo más intensa en los primeros años de la década del ochenta ${ }^{31}$ (ver Gráfico A.3.1). La superficie máxima se alcanzó entre 1982/83 y 1985/86, para decaer luego. El área sembrada con cultivos para cosecha (grisados en el gráfico) se incrementó en un 25\% entre 1969 y 1985. Descomponiendo esta información por cultivos, observamos que fue extraordinaria la expansión de la soja. También se incrementó el área sembrada con trigo (cuyo cultivo se efectuaba muchas veces combinado con el de la soja en un mismo año) y con girasol, mientras que el maíz presentó una tendencia decreciente a lo largo de todo el período, lo mismo que el centeno y la cebada cervecera.

Gráfico A.3.1.

\section{Región pampeana. Superficie sembrada}

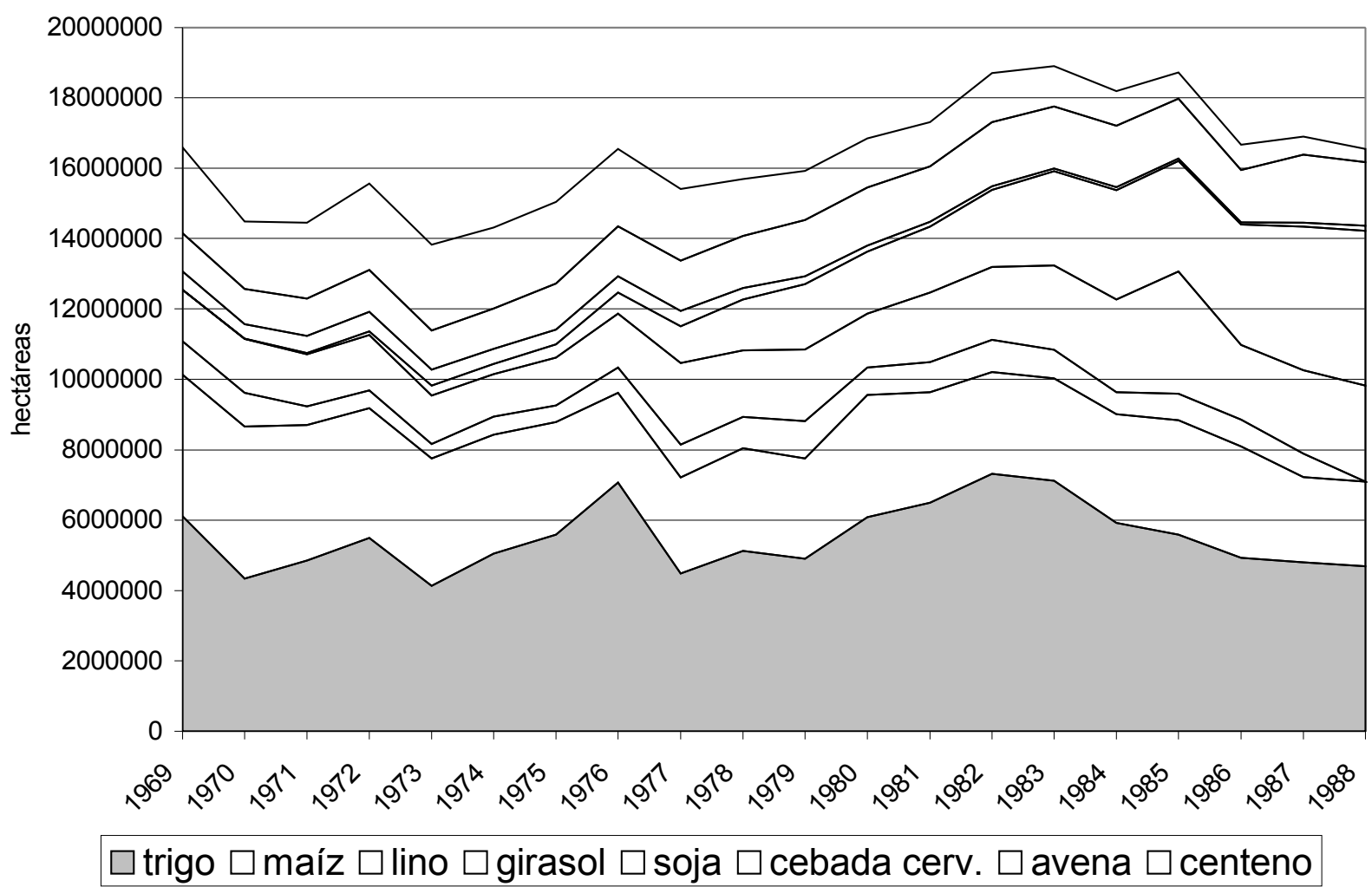

Fuente: Cálculos propios en base a las Estimaciones Agrícolas de la Secretaría de Agricultura y Ganadería.

31 Una expansión que se correspondía con las estimaciones más elevadas de las proyecciones realizadas a comienzos de esta década (Cirio, 1984). 
Si la expansión del área sembrada fue importante, el aumento en el volumen de producción resultó mucho más significativo: en 1984/5 se cosechó un 89\% más que en 1969/70, tal como puede observarse en el Gráfico A.3.2. Esta diferencia se debe a un notorio aumento en los rendimientos de los cultivos. Para observar este fenómeno puede consultarse los datos anuales transcriptos en el Apéndice 5. Un análisis de este incremento en la productividad por unidad de superficie puede encontrarse en Pizarro y Cascardo (1991: 152-180). Además del explosivo incremento de la producción de soja ${ }^{32}$, también el trigo y el girasol presentaron una tendencia creciente hasta mediados de los ochenta. En cambio, el maíz se mantuvo estancado en sus niveles productivos, más allá de fuertes oscilaciones anuales, pues el incremento en los rindes se compensó con la reducción en el área sembrada ${ }^{33}$.

\section{Gráfico A.3.2.}

\section{Región Pampeana. Producción}

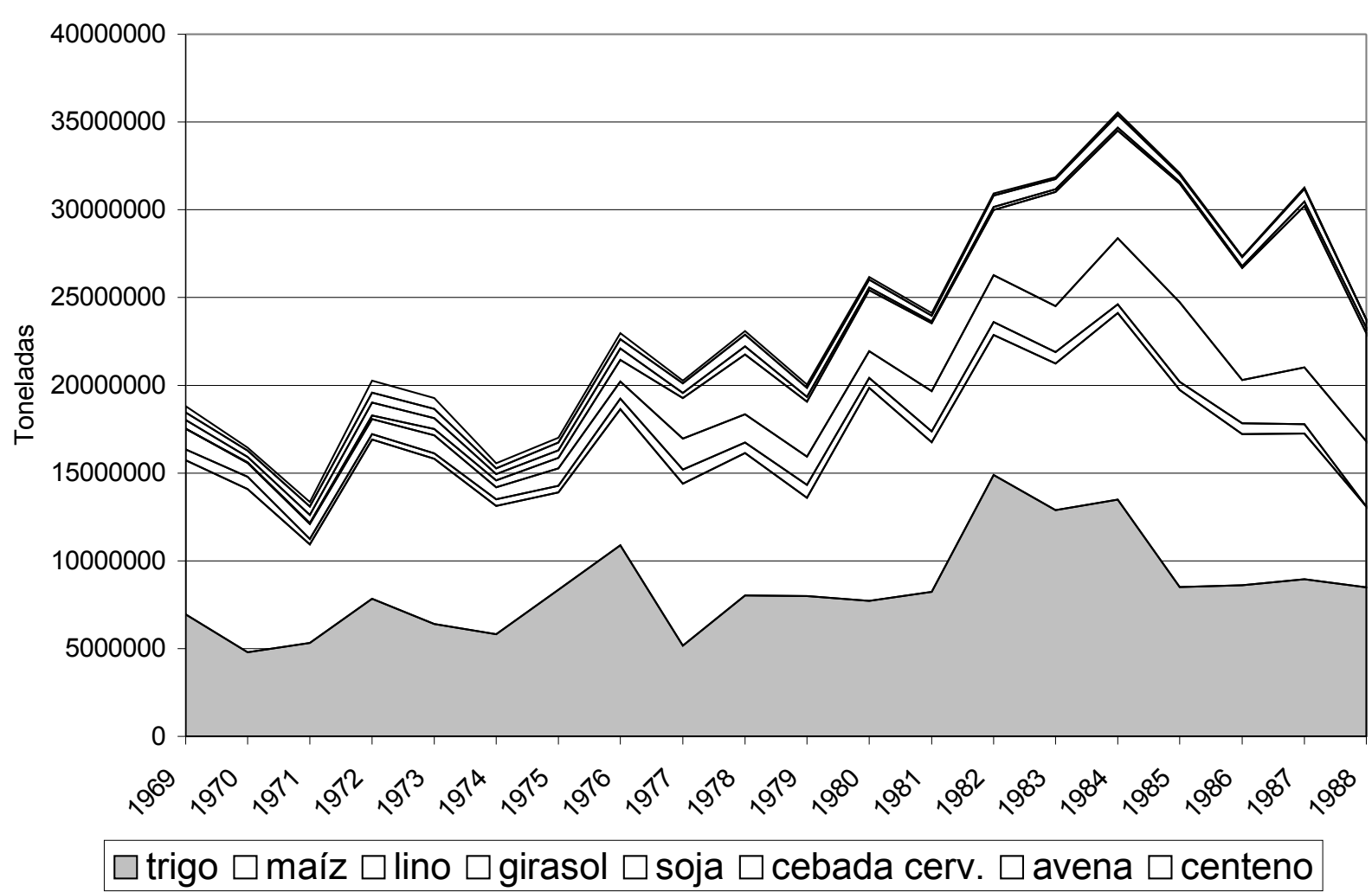

Fuente: Cálculos propios en base a las Estimaciones Agrícolas de la Secretaría de Agricultura y Ganadería.

32 A pesar de que los márgenes brutos de la soja se fueron reduciendo a lo largo de estos años (Actis y Justo, 1989), aunque menos que lo que disminuyeron los del maíz (Actis, 1989).

33 El fenómeno fue en realidad más complejo, ya que el maíz fue desplazado (por la combinación trigo-soja) de la zona predominantemente agrícola (donde se encuentra nuestra zona norte) hacia las áreas mixtas (agrícolo-ganaderas) donde sus rindes son comparativamente menores. Para más detalles puede consultarse Pizarro y Cascardo (1991: 166-170). 
En la bibliografía se ha distinguido una primer etapa hasta 1977 en la que agricultura y ganadería se expandieron relativamente juntas y una segunda, llamada de "agriculturización", ya que a partir de esa fecha se contrapuso la evolución de ambas actividades (ver Cuadro A.3.1). Campos que durante las tres o cuatro décadas anteriores se habían destinado a la ganadería, ahora se dedicaban a la agricultura.

Cuadro A.3.1. Existencias bovinas en la región pampeana

\begin{tabular}{|l|l|}
\hline & Existencias bovinas (cabezas) \\
\hline 1960 & 39.920 .000 \\
\hline 1974 & 38.597 .000 \\
\hline 1977 & 41.363 .000 \\
\hline 1982 & 34.758 .000 \\
\hline 1986 & 34.489 .000 \\
\hline
\end{tabular}

Fuente: Peretti y Gómez (1991:272). 
En el caso de la provincia de Buenos Aires, la evolución del área sembrada fue muy similar a la del conjunto de la región pampeana, con un crecimiento del orden del $23 \%$ en el caso de los cultivos para cosecha (ver Gráfico A.3.3). Tal vez la única diferencia digna de mención es que la superficie sembrada con maíz no disminuyó sino que se mantuvo relativamente estable.

Gráfico A.3.3.

\section{Buenos Aires. Superficie sembrada}

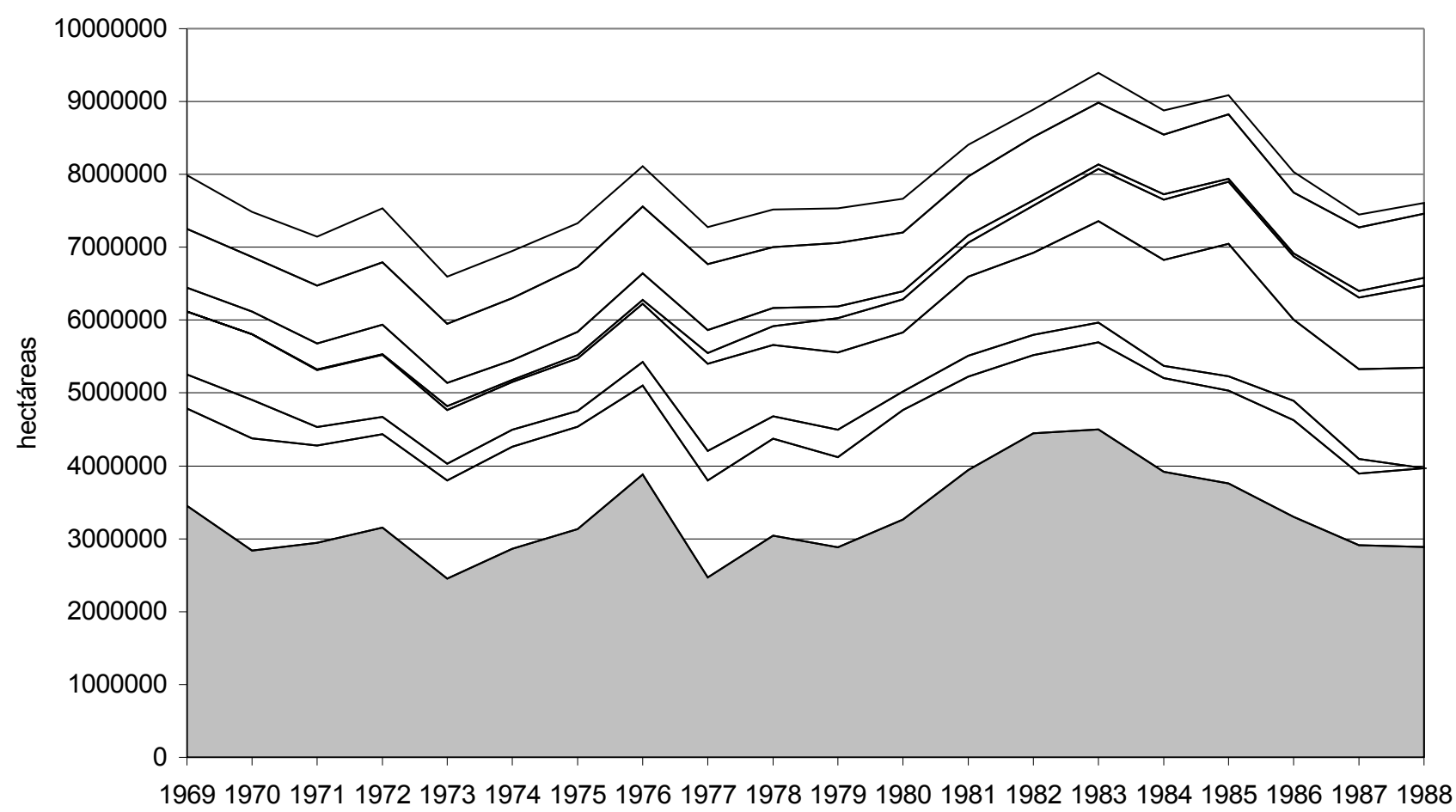

\section{$\square$ trigo $\square$ maíz $\square$ lino $\square$ girasol $\square$ soja $\square$ cebada cerv. $\square$ avena $\square$ centeno}

Fuente: Cálculos propios en base a las Estimaciones Agrícolas de la Secretaría de Agricultura y Ganadería. 
Del mismo modo que en el conjunto de la región, el aumento en el volúmen cosechado en la provincia de Buenos Aires (70\%) fue superior al del área sembrada. Como se observa en el Gráfico A.3.4, tanto el trigo como el girasol y la soja presentaron sustanciales incrementos en sus niveles de producción, especialmente durante la primera mitad de la década del ochenta; mientras que el maíz tuvo una tendencia estable, con importantes oscilaciones anuales.

\section{Gráfico A.3.4.}

\section{Buenos Aires. Producción}

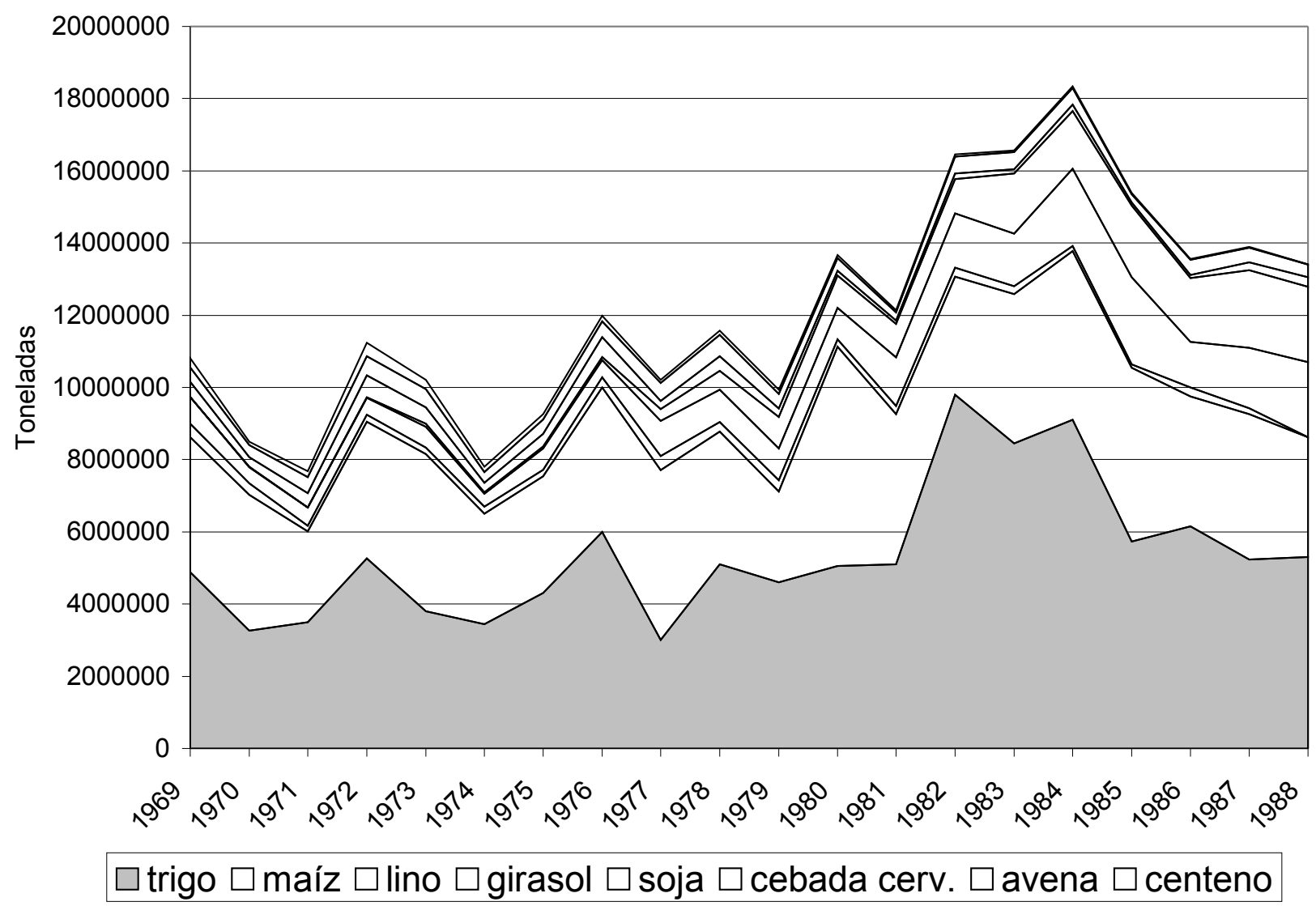

Fuente: Cálculos propios en base a las Estimaciones Agrícolas de la Secretaría de Agricultura y Ganadería. 


\section{Cambios productivos en la zona norte}

En esta zona tuvo lugar un extraordinario aumento de la superficie sembrada, del orden del 44\% entre 1969/70 y 1985/86. Este incremento se explica no sólo por la reducción del área con pasturas naturales y por la disminución de la cantidad de hectáreas con forrajeras permanentes (ver Cuadro A.3.2), sino por la realización de dos siembras durante el mismo año agrícola gracias a la combinación de trigo y soja, que reemplazaron al maíz como principal cultivo de esta zona, tal como puede observarse en el Gráfico A.3.5. De este modo, para comienzos de los años ochenta se alcanzó la superficie que se sembraba en los años treinta en esta zona, y luego, a mediados de los ochenta, se la superó ampliamente.

\section{Gráfico A.3.5.}

\section{Zona norte. Superficie sembrada}

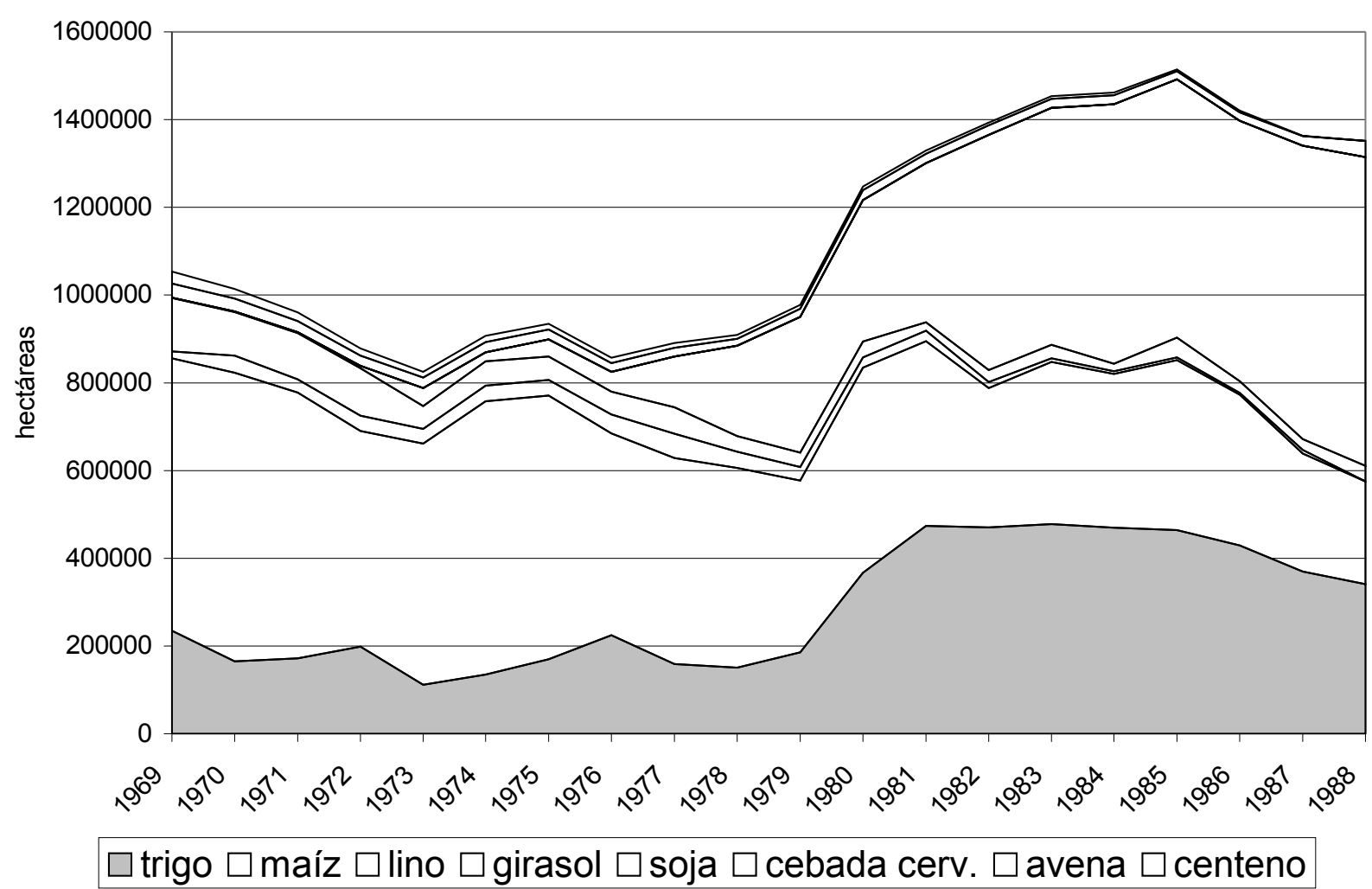

Fuente: Cálculos propios en base a las Estimaciones Agrícolas de la Secretaría de Agricultura y Ganadería. 
Durante estos años la ganadería vacuna redujo su importancia en la zona norte (el número de cabezas disminuyó en un 37\% entre 1969 y 1988), al tiempo que los ovinos desaparecían de esta zona (ver Cuadro A.3.2). La disminución de la cantidad de vacunos ocurrió a partir de 1978 (se había mantenido estable desde mediados de los sesenta), y desde 1977 aumentó la relación novillos más novillitos sobre vaca (de 57,5 en 1973 a 80,6 en 1978), lo cual indica una tendencia hacia la especialización en invernada (Devoto, 1989: 3).

Cuadro A.3.2. Forrajeras anuales, existencias ganaderas y cabezas de ganado por hectárea, 1969 y 1988.

\begin{tabular}{|c|c|c|c|c|c|c|c|c|}
\hline & \multirow{2}{*}{$\begin{array}{c}\text { forrajeras } \\
\text { perma- } \\
\text { nentes } \\
\text { (ha.) } \\
\end{array}$} & \multicolumn{3}{|c|}{ Cabezas de ganado } & \multicolumn{3}{|c|}{$\begin{array}{c}\text { Cabezas de ganado por } \\
\text { hectárea }\end{array}$} \\
\hline & & & vacunos & ovinos & equinos & vacunos & $\begin{array}{c}\operatorname{ovinos} / 5 \\
(*)\end{array}$ & equinos \\
\hline \multirow[t]{2}{*}{ zona norte } & 1969 & 481 & 1574 & 161 & $\mathrm{~s} / \mathrm{d}$ & 0,82 & 0,02 & $\mathrm{~s} / \mathrm{d}$ \\
\hline & 1988 & 305 & 997 & 34 & 27 & 0,50 & 0,00 & 0,01 \\
\hline \multirow[t]{2}{*}{ zona oeste } & 1969 & 1114 & 3061 & 974 & $\mathrm{~s} / \mathrm{d}$ & 0,90 & 0,05 & $\mathrm{~s} / \mathrm{d}$ \\
\hline & 1988 & 902 & 2972 & 182 & 59 & 0,87 & 0,01 & 0,02 \\
\hline \multirow[t]{2}{*}{ zona sur } & 1969 & 382 & 2247 & 5735 & $\mathrm{~s} / \mathrm{d}$ & 0,42 & 0,21 & $\mathrm{~s} / \mathrm{d}$ \\
\hline & 1988 & 695 & 2661 & 1556 & 52 & 0,50 & 0,06 & 0,01 \\
\hline
\end{tabular}

Fuente: Cálculos propios en base a los datos de los respectivos Censos Nacionales Agropecuarios. 
En términos de volúmen cosechado, en esta zona la expansión tuvo una magnitud similar a la expansión del área sembrada (47\%, entre 1969/70 y 1985/86). Ocurre que, a pesar de que el trigo y la soja aumentaron su rindes durante este período, estos cultivos tenían un rendimiento por hectárea de apenas la mitad de los kilogramos que brindaba la cosecha del maíz (para mayores detalles ver el cuadro de evolución de los rindes en el Apéndice 5). Es por ello que el maíz, aunque desde comienzos de los ochenta había sido superado tanto por el trigo como por la soja en la cantidad de hectáreas sembradas, continuaba siendo el cultivo que generaba un mayor volumen cosechado hasta la campaña 1985/86, tal como se observa en el Gráfico A.3.6.

\section{Gráfico A.3.6.}

\section{Zona norte. Producción}

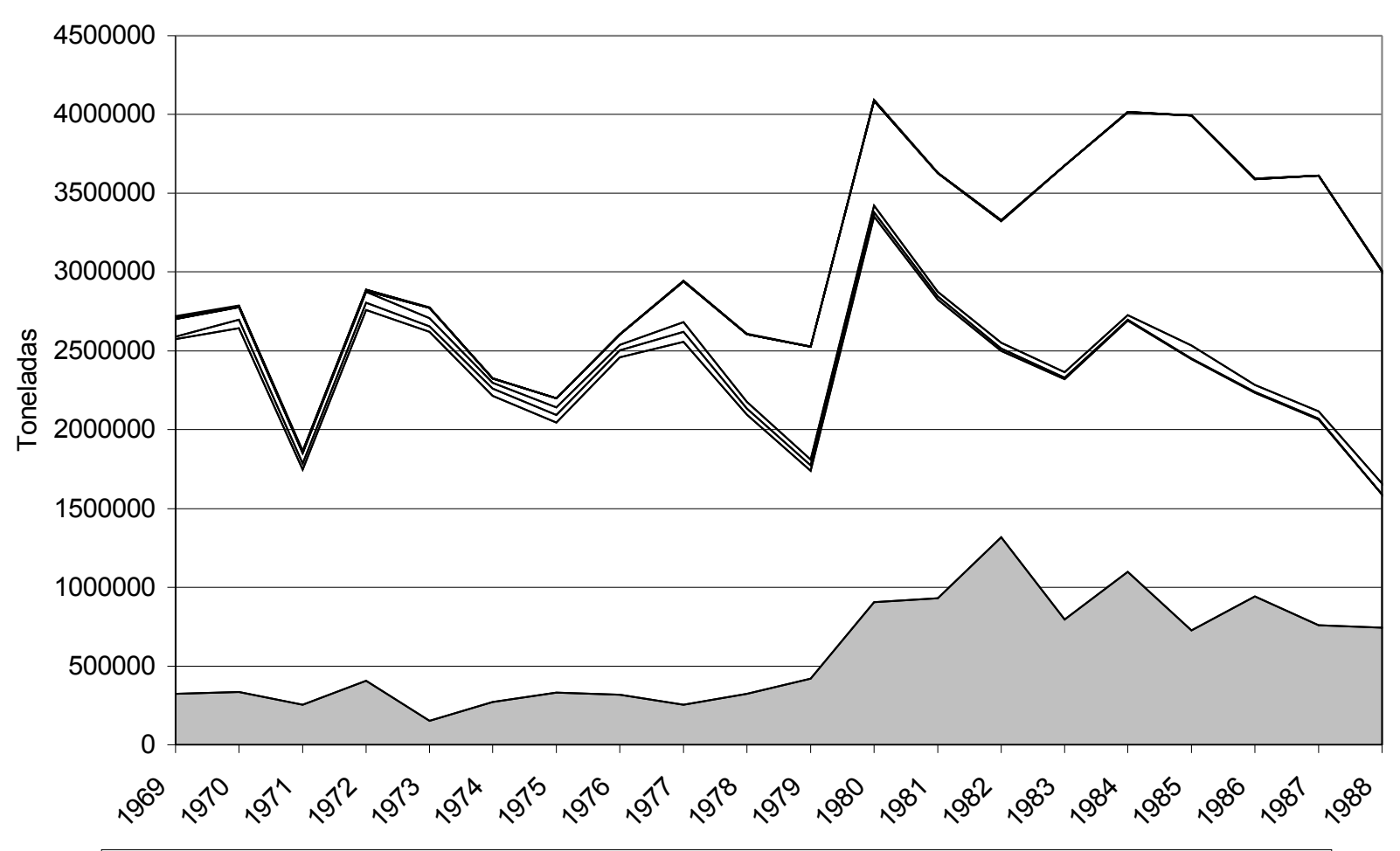

trigo $\square$ maíz $\square$ lino $\square$ girasol $\square$ soja $\square$ cebada cerv. $\square$ avena $\square$ centeno

Fuente: Cálculos propios en base a las Estimaciones Agrícolas de la Secretaría de Agricultura y Ganadería. 


\section{Cambios productivos en la zona oeste}

En esta zona tuvo lugar un extraordinario y sostenido aumento del área sembrada con cultivos para cosecha (series sombreadas en el Gráfico A.3.7) a partir de 1973/74 y hasta 1985/86. Entre estas dos fechas esta superficie se triplicó, destacándose el comportamiento del trigo, el girasol y la soja (aunque en términos absolutos este cultivo no alcanzó gran relieve), pero también incrementaron su superficie el maíz y la avena ${ }^{34}$. Merece señalarse que redujeron su importancia tanto el centeno (una forrajera anual) como las forrajeras permanentes (aunque en este caso sólo levemente), al tiempo que en estas décadas la cantidad de vacunos en la zona oeste se mantuvo relativamente estable (en cambio, los ovinos prácticamente desaparecieron de la escena productiva).

\section{Gráfico A.3.7.}

\section{Zona oeste. Superficie sembrada}

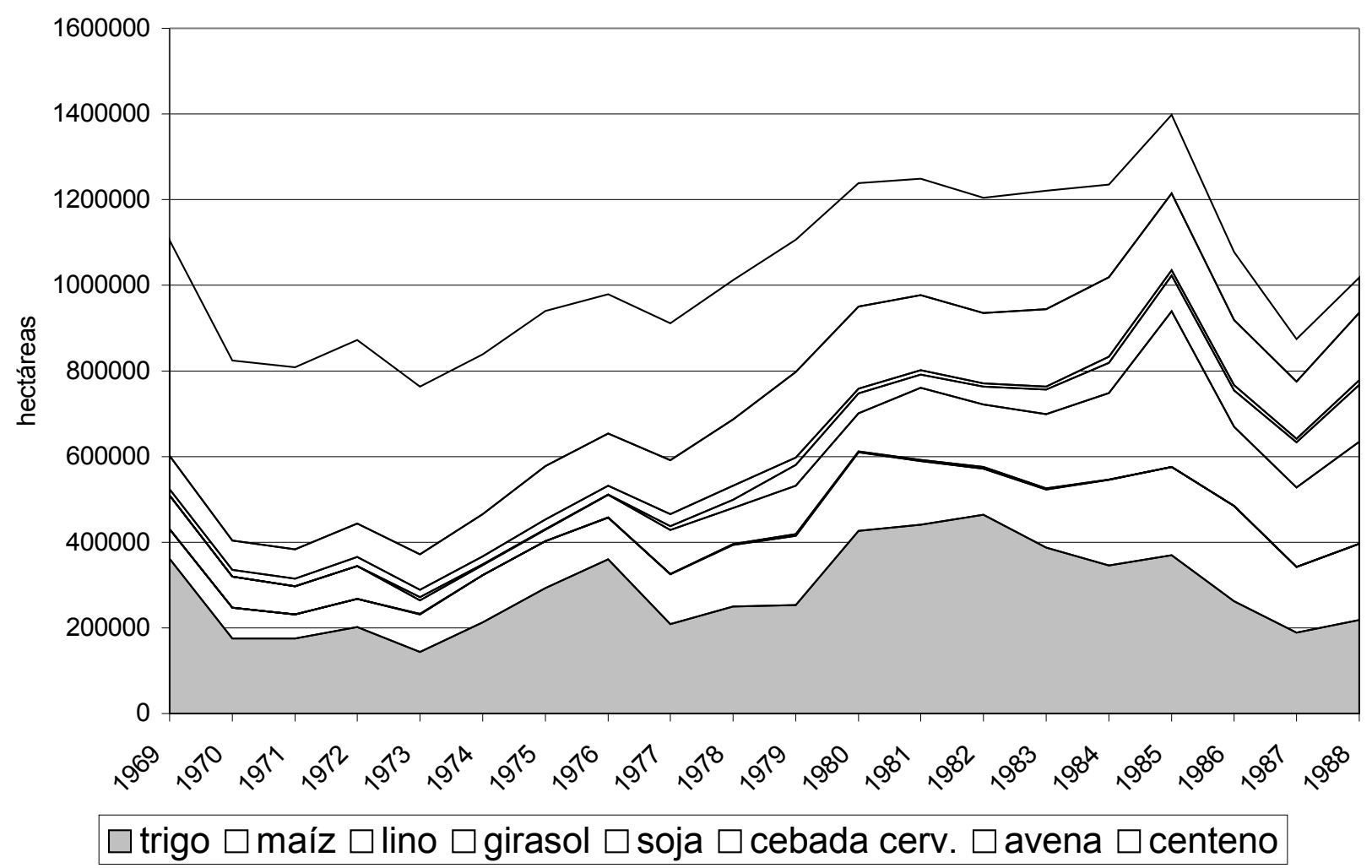

Fuente: Cálculos propios en base a las Estimaciones Agrícolas de la Secretaría de Agricultura y Ganadería.

En una perspectiva de análisis de más largo plazo, recién a comienzos de los ochenta el área sembrada con cultivos para cosecha alcanzó los niveles que había tenido a fines de la década del treinta.

34 En esta zona fue particularmente aguda la reducción de la superficie sembrada en 1986 y 1987, ya que se conjugó la adversa coyuntura económica con las graves inundaciones que azotaron esta subregión en dichos años. 
En términos productivos la expansión fue incluso más notable que la del área sembrada: la cosecha 1985/86 fue cuatro veces mayor que la de 1971/72, tal como puede verse en el Gráfico A.3.8. Se destacan los incrementos productivos del trigo, el maíz y el girasol.

\section{Gráfico A.3.8.}

\section{Zona oeste. Producción}

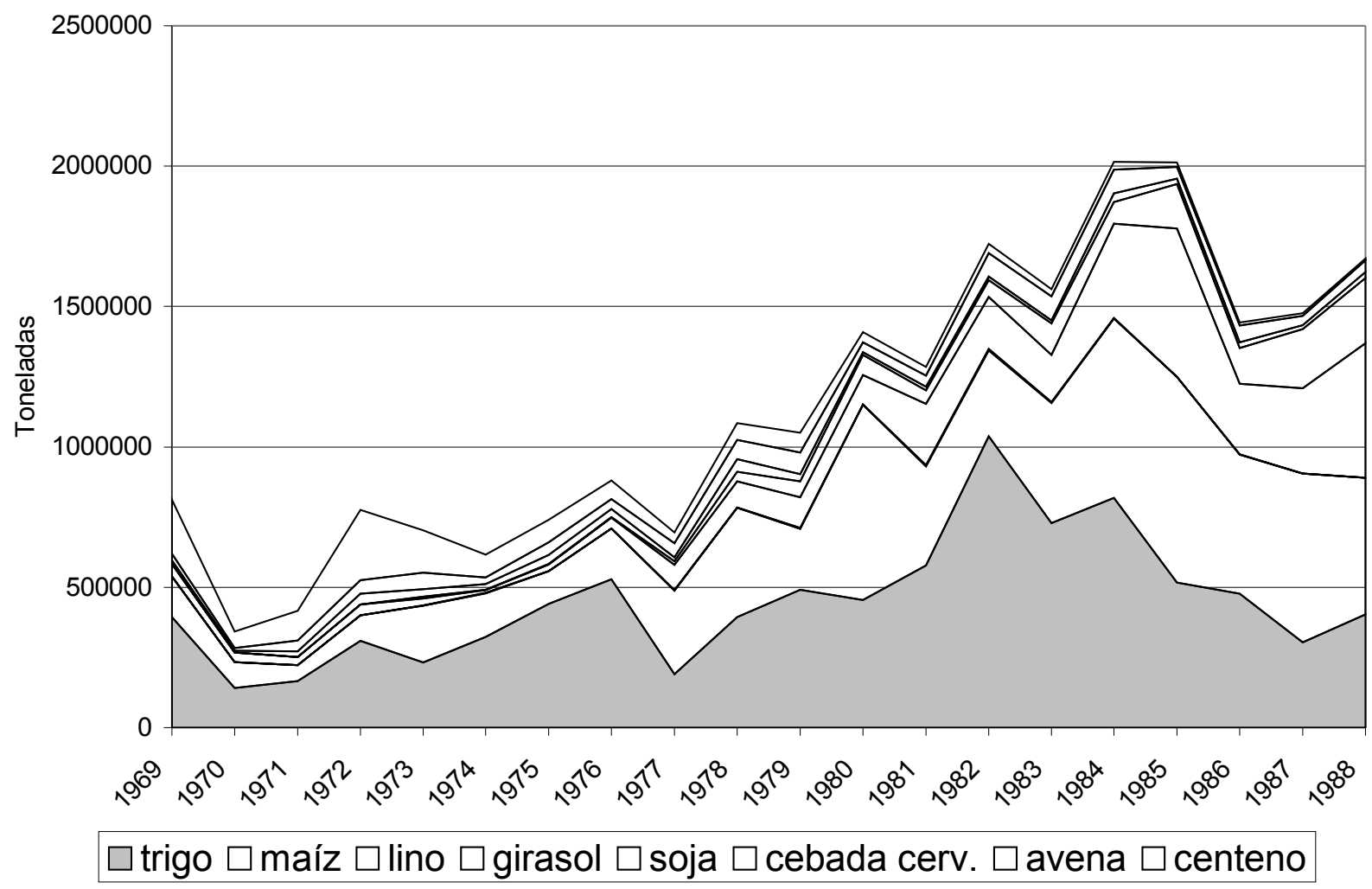

Fuente: Cálculos propios en base a las Estimaciones Agrícolas de la Secretaría de Agricultura y Ganadería. 


\section{Cambios productivos en la zona sur}

Así como en el período anterior esta zona se había destacado porque la reducción en el área sembrada había sido muy leve, en esta etapa la expansión no alcanzó la magnitud que tuvo en las otras dos zonas estudiadas. Como se observa en el Gráfico A.3.9, sólo las campañas entre 1982/83 y 1985/86 presentaron una superficie sembrada claramente superior a la del promedio del período. Al mismo tiempo, sólo el girasol mostró un proceso expansivo y la cebada cervecera una reducción, mientras que el resto de los cultivos prácticamente no tuvo variaciones en el porcentaje del área que ocupaban, manteniéndose el claro predominio del trigo que ha caracterizado históricamente a la zona sur.

\section{Gráfico A.3.9.}

\section{Zona sur. Superficie sembrada}

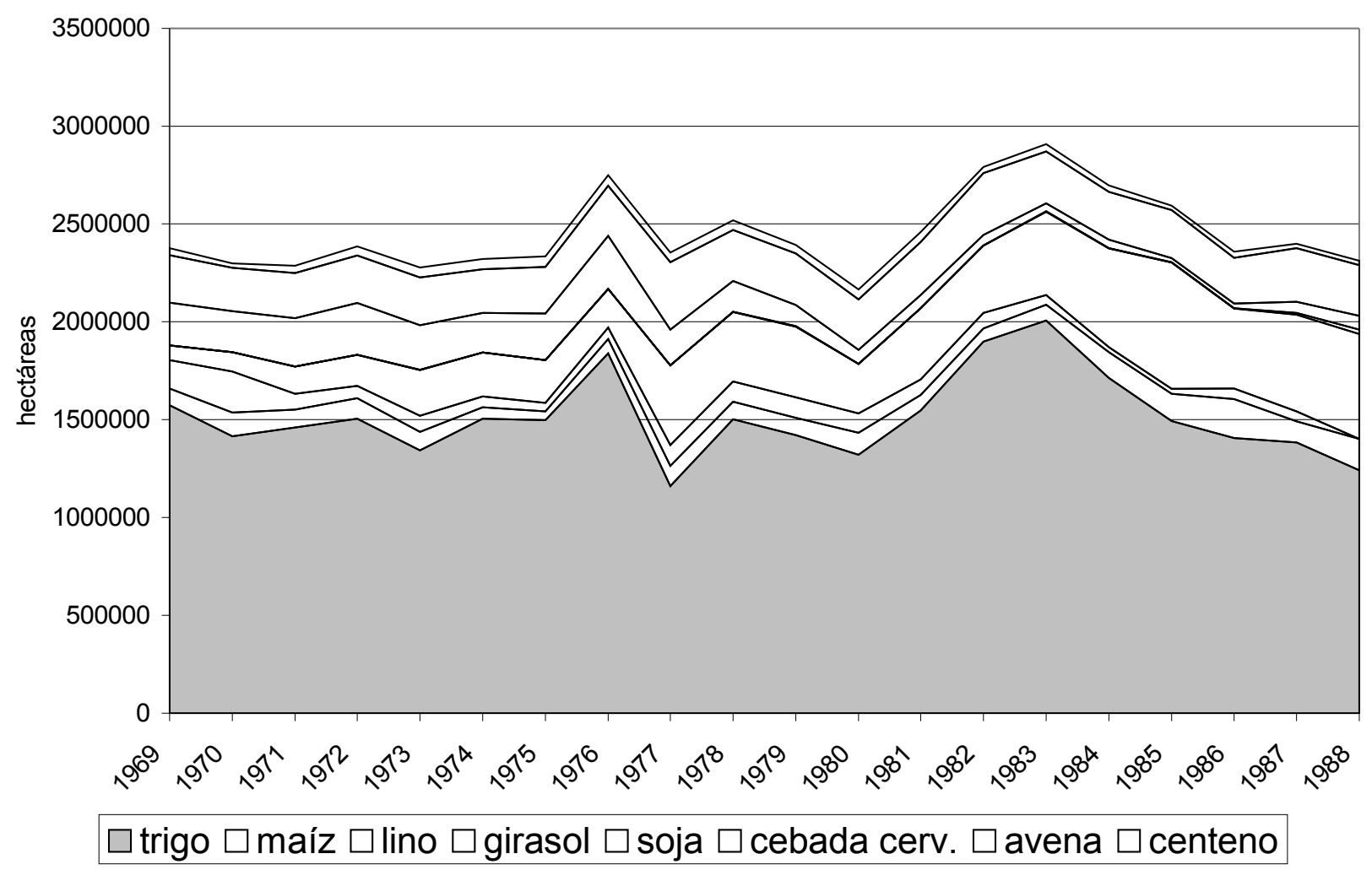

Fuente: Cálculos propios en base a las Estimaciones Agrícolas de la Secretaría de Agricultura y Ganadería.

En cuanto a la actividad ganadera observamos en el Cuadro A.3.2 una espectacular reducción de la cantidad de ovinos (en 1988 quedaban menos de un ovino de cada tres que había en 1969), que no fue compensada por el leve aumento del número de vacunos (18\%). Sin embargo, el área sembrada con forrajeras permanentes casi se duplicó en este lapso. 
En el nivel productivo, se destacan las excepcionales cosechas de las campañas 1982/83 a 1984/85, cuando el volumen cosechado casi duplicó al promedio del período 1969/70-1981/82. Tal como podemos ver en el Gráfico A.3.10, el principal responsable de esta expansión fue el trigo, seguido en un muy segundo plano por el girasol y por una tímida expansión de la producción maicera en la zona sur (pero que fue alcanzando rindes mucho más elevados de los de los años sesenta, al respecto pueden consultarse los cuadros con la evolución de los rendimientos en el Apéndice 5).

\section{Gráfico A.3.10}

\section{Zona sur. Producción}

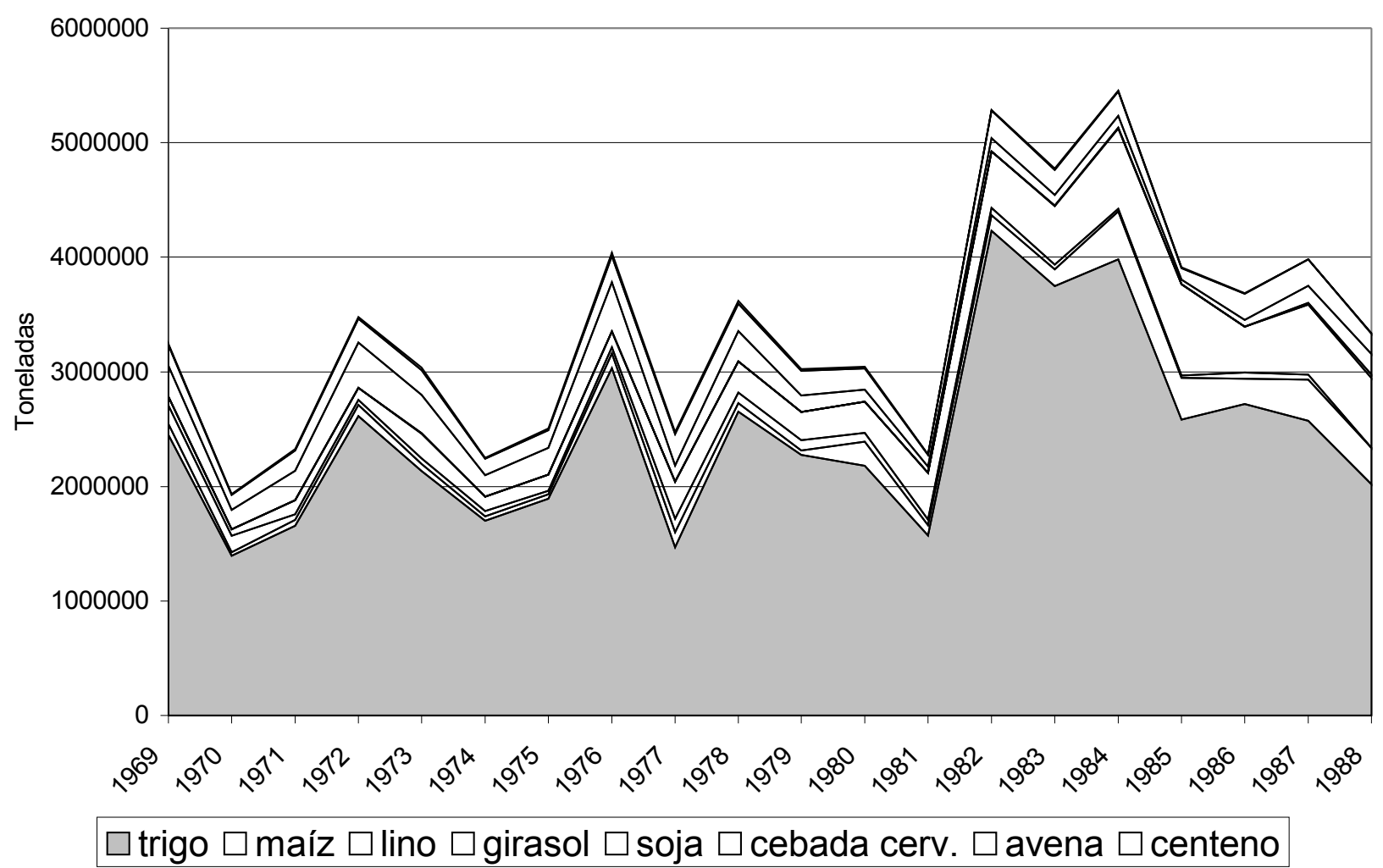

Fuente: Cálculos propios en base a las Estimaciones Agrícolas de la Secretaría de Agricultura y Ganadería. 


\section{La concentración entre 1969 y 1988}

Si medimos la concentración a través de la evolución de la cantidad de explotaciones, nos encontramos con una importante reducción del número de unidades productivas ${ }^{35}$. En la zona norte en 1988 había un 37\% menos de explotaciones agropecuarias que las registradas en 1969 (de 16.596 quedaron 10.478). En la zona oeste la reducción fue del 21\% (de 7.349 quedaron 5.782) y en la zona sur del $27 \%$ (de 12.792 restaron 9.310$)^{36}$.

Sin embargo, al discriminar por intervalos de tamaño, observamos que la mayor reducción en términos absolutos tuvo lugar entre las unidades de menos de 25 hectáreas. Como los censos no han registrado siempre de igual modo a estas muy pequeñas unidades, la concentración en el número de explotaciones podría deberse a un cambio en el registro censal. En todo caso, para analizar la producción pampeana de granos y oleaginosas sabemos que casi no tuvieron importancia estas unidades muy pequeñas. Por ese motivo, hemos dejado de lado las unidades menores a 25 hectáreas. Sin considerar estas muy pequeñas unidades, la reducción en la cantidad de explotaciones resulta bastante menor, afectando a un $22 \%$ de las unidades presentes en 1969 en la zona norte, un 9\% en la zona oeste, y en 16\% en la zona sur. En total, en las tres zonas desaparecieron alrededor de 4.600 unidades productivas de más de 25 hectáreas: en la zona norte se pasó de 10.801 a 8.388 explotaciones, en la zona oeste, de 5.865 a 5.328, y en la sur, de 10.660 a $9.004^{37}$.

Si discriminamos a los distintos intervalos de tamaño, podemos ver que, además de la ya mencionada muy drástica reducción en la cantidad de explotaciones de menos de 25

35 Cabe realizar una aclaración, el censo agropecuario de 1988 integró dentro de una misma explotación a todas las parcelas que compartieran una dirección común y usasen en común los mismos medios de producción de uso durable y parte de la mano de obra (siempre dentro de una misma provincia). Esto a llevado a considerar que buena parte del proceso de concentración que aparece en la comparación con los datos del censo nacional agropecuario de 1960 se habrían debido a los diferentes criterios censales (Pucciarelli, 1997). Sin embargo, el censo de 1969 no difiere tanto de los criterios usados en 1988 para la agregación de lotes no linderos a fin de conformar una única explotación: se agregaron todos los lotes que estaban trabajados por el mismo personal (a diferencia de 1988, cuando solo se exigía para agregar que compartieran parte del personal), empleasen los mismos elementos de trabajo (este requisito parece haber sido igual en ambos censos) y respondieran a una misma dirección técnica, pudiendo estar los lotes en diferentes partidos.

36 En realidad, la cantidad de explotaciones registradas en 1969 fue mayor, pero también la superficie censada fue muy superior. Para poder hacer comparables ambos censos hemos estimado la cantidad de explotaciones que en 1969 hubieran existido en el área censada en 1988 (el número total de unidades censadas en 1969 fue de $18.023,9.319$ y 14.346 en las zonas norte, oeste y sur respectivamente).

37 Nuevamente, el número real de explotaciones de más de 25 hectáreas censadas en 1969 fue muy superior: $11.730,7.437$ y 11.956 para las zonas norte, oeste y sur respectivamente. Sin embargo, hemos ajustado la cantidad de explotaciones según el área registrada, tal como explicamos en la nota anterior. 
hectáreas, las explotaciones de 25 a 100 hectáreas fueron fuertemente afectadas por el proceso de concentración (ver Cuadro A.3.3). Según las zonas, entre un cuarto y dos quintos de las unidades de este último intervalo desaparecieron durante las dos décadas analizadas, siendo la zona norte donde la reducción fue más intensa (de 6.903 unidades de 25 a 100 hectáreas presentes en 1969, sólo quedaban 4.112 en 1988). Del mismo modo, las unidades medianas de la zona sur sufrieron un importante reducción en su número: un cuarto de las explotaciones de 100 a 400 hectáreas presentes en 1969 no estaban en 1988 (de 5.230 a 3.971). En el extremo superior de la escala también observamos una reducción en la cantidad de explotaciones: las unidades de más de 2.500 hectáreas redujeron su número entre un $21 \%$ y un $37 \%$ según las zonas, aunque es probable que aquí los cambios del registro censal hayan llevado a agrupar unidades ubicadas en distintos partidos de un modo más intenso que en el caso de las pequeñas explotaciones. En todo caso, al ser números muy reducidos, unos pocos casos modifican drásticamente los porcentuales, por lo cual no resulta confiable destacar estas modificaciones.

En cambio, los tipos de unidades que vieron incrementar significativamente su número han sido las explotaciones de 200 a 1.000 hectáreas en la zona norte (que pasaron de 1.506 a 2.092), y las de 400 a 2.500 en el oeste y en el sur, especialmente las de 1.000 a 2.500 hectáreas (en el oeste, estas unidades pasaron de ser 390 a 467, y en el sur, de 782 a 954).

Cuadro A.3.3. Cantidad de explotaciones agropecuarias según tamaño

\begin{tabular}{|l|r|r|r|r|r|r|r|r|r|}
\hline & \multicolumn{3}{|c|}{ Zona norte } & \multicolumn{3}{|c|}{ Zona oeste } & \multicolumn{3}{|c|}{ Zona sur } \\
\hline & $\mathbf{1 9 6 9}$ & $\mathbf{1 9 8 8}$ & difer. & $\mathbf{1 9 6 9}$ & $\mathbf{1 9 8 8}$ & difer. & $\mathbf{1 9 6 9}$ & $\mathbf{1 9 8 8}$ & difer. \\
\hline hasta 25 ha & 5795 & 2090 & -3705 & 1484 & 454 & -1030 & 2131 & 306 & -1825 \\
\hline $\mathbf{2 5}$ a 100 & 6903 & 4112 & -2791 & 2013 & 1548 & -465 & 1978 & 1352 & -626 \\
\hline $\mathbf{1 0 0}$ a 200 & 2121 & 1905 & -216 & 1435 & 1222 & -213 & 2268 & 1700 & -568 \\
\hline $\mathbf{2 0 0}$ a 400 & 951 & 1273 & 322 & 993 & 988 & -5 & 2962 & 2271 & -691 \\
\hline $\mathbf{4 0 0}$ a 1000 & 555 & 819 & 264 & 816 & 891 & 75 & 2400 & 2444 & 44 \\
\hline $\mathbf{1 0 0 0}$ a 2500 & 214 & 231 & 17 & 390 & 467 & 77 & 782 & 954 & 172 \\
\hline más de 2500 & 58 & 48 & -10 & 218 & 212 & -6 & 270 & 283 & 13 \\
\hline Total & 16596 & 10478 & -6118 & 7349 & 5782 & -1567 & 12792 & 9310 & -3482 \\
\hline Total > 25 ha & 10801 & 8388 & -2413 & 5865 & 5328 & -537 & 10660 & 9004 & -1656 \\
\hline
\end{tabular}

Fuente: Reprocesamiento de los datos originales de los Censos Agropecuarios de 1969 y 1988.

Si consideramos la concentración a partir de los cambios en la distribución de la superficie total, observamos que el proceso no habría alcanzado gran envergadura. Analizando las variaciones más importantes, encontramos que en la zona norte un $12 \%$ de la superficie total pasó de las unidades de menos de 200 hectáreas a las de 200 a 1.000; tan sólo un 3\% en la zona oeste pasó de las de menos de 200 a las de 400 a 2.500, y en la zona sur un 7\% pasó de las de 
menos de 400 a las de más de 400 hectáreas (ver cuadro A.3.4). Por otra parte, al interior de los estratos no pareciera haber habido procesos de concentración, ya que la superficie media de cada uno de ellos se mantuvo en los mismo valores, o incluso se redujo, especialmente en el intervalo de más de 2.500 hectáreas (ver Cuadro A.3.5). La aparente contradicción entre una importante reducción en el número de unidades y una escasa concentración de la superficie total se resuelve si tenemos en cuenta que fueron especialmente las pequeñas unidades las que desaparecieron, por lo cual el área que ellas controlaban -que es la que se habría concentradoera de escasa importancia ${ }^{38}$.

El hecho de que la concentración de la superficie tuviera mayor importancia en la zona norte, caracterizada en 1969 por la importancia de las unidades pequeñas, condujo a cierta reducción de las diferencias zonales. Sin embargo, debido a que no afectaron un porcentaje importante del área total, las disparidades no desaparecieron, y la estructura agraria resultante

38 Un estudio realizado a partir de las nuevas explotaciones que se empadronaron en el Registro Nacional de Productores Agropecuarios (como en teoría era obligatorio hacer) entre abril de 1976 y diciembre de 1977, nos permite observar las características de las explotaciones que se establecían en esos años, ya que se analizaron los cuestionarios de las explotaciones agropecuarias que se iniciaron ya sea por herencia, compra, arrendamiento o aparcería (Basco y Neiman, 1979). El estudio habla de "nuevas explotaciones", aunque en realidad, tal vez podría también hablarse de "nuevos productores", ya que un cambio por herencia podría no implicar una nueva unidad y sí un nuevo productor. En cuanto al tamaño, vemos que en la zona norte (las zonificación utilizada en este estudio es muy similar a la nuestra) la mitad de las unidades nuevas tenían entre 25 y 200 hectáreas, repartiéndose otros dos cuartos entre las de menos de 25 hectáreas y de 200 a 2.500. Sin embargo, analizando la superficie que ocupaban, se observa que fueron estas últimas las que concentraron el $80 \%$ del área de las nuevas unidades, mientras que las más pequeñas sólo poseían el 1\% de la misma. Se observa, entonces, que el sector dinámico estaba en este estrato de unidades que podríamos denominar medianas y medianas-grandes (de hecho, el tamaño medio de las unidades de este estrato era de 695 hectáreas). El tamaño medio de todas las nuevas explotaciones en la zona norte era de 234 hectáreas.

En el caso de la zona oeste, la superficie de las nuevas explotaciones se distribuyó entre tres estratos (para cada zona los estratos construidos en el estudio son diferentes, intentando reflejar cuatro tipos de unidades según su potencial demanda de mano de obra): las unidades de 100 a 1.000 hectáreas dieron cuenta del 37\% de la superficie (aquí se concentraba la mitad de las nuevas unidades), las de 1.000 a 2.500 , del $29 \%$ y las de más de 2.500 hectáreas, del $30 \%$ (las unidades de menos de 100 hectáreas no tenían significación territorial, aunque constituyeron un cuarto de las nuevas unidades). Vemos así una gran heterogeneidad de situaciones, pero el elevado porcentaje en el estrato de 100 a 1.000 no debe transmitirnos la imagen de una expansión de las unidades medianas-pequeñas, ya que el tamaño medio de las unidades en este estrato, según nuestro cálculos, era de 443 hectáreas. Podemos concluir que en la zona oeste, las nuevas unidades eran casi todas medianas-grandes o grandes. El tamaño medio de todas las nuevas explotaciones en la zona oeste era de 656 hectáreas.

En la zona sur, la enorme mayoría de la superficie de las nuevas unidades se concentraba entre las que tenían más de 400 hectáreas (85\%). Si bien las explotaciones de 25 a 400 hectáreas constituyeron el $58 \%$ de las nuevas explotaciones, tan sólo poseían el $15 \%$ de la superficie. De hecho el tamaño medio de todas las nuevas unidades era de 687 hectáreas, según nuestro cálculos en base a Basco y Neiman (1979). 
continuaba mostrando situaciones diferenciales entre las zonas. En la zona norte, todos los estratos de tamaño (con excepción de las unidades menores a 25 hectáreas) presentaban en 1988 un peso territorial importante (ver Cuadro A.3.4), aunque las unidades de 25 a 200 hectáreas perdieron la importancia que tenían en 1969 (e incluso el rol predominante que habían poseído en 1937, cuando concentraban el 30\% de la zona). En cambio, la mayor parte de la superficie se ubicaba ahora en las explotaciones de 200 a 1.000 hectáreas (45\% del área total, frente al 32\% que habían tenido en 1969).

En la zona oeste, como ya comentamos, hubo pocos cambios, de modo que continuaron predominando las unidades de más de 400 hectáreas, que concentraban el $80 \%$ de la superficie de la zona. Entre ellas, aunque perdieron algo de su área, continuaban destacándose las grandes explotaciones de más de 2.500 hectáreas (ver detalles en cuadro A.3.4).

En la zona sur, también predominaban las unidades de más de 400 hectáreas $(81 \%$, frente al 74\% que tenían en 1969). Entre ellas, aquí tenían más importancia las unidades de 400 a 1.000 y, ahora también, las de 1.000 a 2.500 hectáreas.

Cuadro A.3.4. Distribución de la superficie censada según tamaño de las explotaciones

\begin{tabular}{|l|r|r|r|r|r|r|r|r|r|}
\hline & \multicolumn{3}{|c|}{ Norte } & \multicolumn{3}{|c|}{ Oeste } & \multicolumn{3}{|c|}{ Sur } \\
\hline & $\mathbf{1 9 6 9}$ & $\mathbf{1 9 8 8}$ & difer. & $\mathbf{1 9 6 9}$ & $\mathbf{1 9 8 8}$ & difer. & $\mathbf{1 9 6 9}$ & $\mathbf{1 9 8 8}$ & difer. \\
\hline hasta 25 ha & $3.20 \%$ & $1.30 \%$ & $-1.90 \%$ & $0.50 \%$ & $0.20 \%$ & $-0.30 \%$ & $0.40 \%$ & $0.10 \%$ & $-0.30 \%$ \\
\hline $\mathbf{2 5}$ a 100 & $20.50 \%$ & $12.20 \%$ & $-8.30 \%$ & $4.50 \%$ & $3.50 \%$ & $-1.00 \%$ & $2.40 \%$ & $1.70 \%$ & $-0.70 \%$ \\
\hline $\mathbf{1 0 0}$ a 200 & $15.40 \%$ & $14.20 \%$ & $-1.20 \%$ & $7.70 \%$ & $6.50 \%$ & $-1.20 \%$ & $6.70 \%$ & $5.00 \%$ & $-1.70 \%$ \\
\hline $\mathbf{2 0 0}$ a 400 & $13.80 \%$ & $18.70 \%$ & $4.90 \%$ & $9.90 \%$ & $10.10 \%$ & $0.20 \%$ & $16.50 \%$ & $12.80 \%$ & $-3.70 \%$ \\
\hline $\mathbf{4 0 0}$ a 1000 & $18.00 \%$ & $25.90 \%$ & $7.90 \%$ & $18.40 \%$ & $20.10 \%$ & $1.70 \%$ & $28.00 \%$ & $29.10 \%$ & $1.10 \%$ \\
\hline $\mathbf{1 0 0 0}$ a 2500 & $16.60 \%$ & $17.90 \%$ & $1.30 \%$ & $22.00 \%$ & $25.80 \%$ & $3.80 \%$ & $22.50 \%$ & $27.10 \%$ & $4.60 \%$ \\
\hline más de 2500 & $12.50 \%$ & $9.80 \%$ & $-2.70 \%$ & $36.90 \%$ & $33.80 \%$ & $-3.10 \%$ & $23.50 \%$ & $24.30 \%$ & $0.80 \%$ \\
\hline & $100.00 \%$ & $100.00 \%$ & & $100.00 \%$ & $100.00 \%$ & & $100.00 \%$ & $100.00 \%$ & \\
\hline
\end{tabular}

Fuente: Reprocesamiento de los datos originales de los Censos Agropecuarios de 1969 y 1988. 
Cuadro A.3.5. Tamaño medio de las explotaciones según tamaño

\begin{tabular}{|l|r|r|r|r|r|r|r|r|r|}
\hline & \multicolumn{3}{|c|}{ Norte } & \multicolumn{3}{|c|}{ Oeste } & \multicolumn{3}{|c|}{ Sur } \\
\hline & $\mathbf{1 9 6 9}$ & $\mathbf{1 9 8 8}$ & difer. & $\mathbf{1 9 6 9}$ & $\mathbf{1 9 8 8}$ & difer. & $\mathbf{1 9 6 9}$ & $\mathbf{1 9 8 8}$ & difer. \\
\hline hasta 25 ha & 17 & 12 & -5 & 17 & 11 & -6 & 16 & 13 & -3 \\
\hline $\mathbf{2 5}$ a 100 & 65 & 57 & -8 & 72 & 63 & -9 & 72 & 65 & -7 \\
\hline $\mathbf{1 0 0}$ a 200 & 144 & 143 & -1 & 157 & 149 & -8 & 162 & 154 & -8 \\
\hline $\mathbf{2 0 0}$ a 400 & 286 & 282 & -4 & 291 & 285 & -6 & 302 & 296 & -6 \\
\hline $\mathbf{4 0 0}$ a 1000 & 661 & 607 & -54 & 678 & 633 & -45 & 646 & 623 & -23 \\
\hline $\mathbf{1 0 0 0}$ a 2500 & 1593 & 1488 & -105 & 1658 & 1544 & -114 & 1591 & 1486 & -105 \\
\hline más de 2500 & 4584 & 3884 & -700 & 7146 & 4474 & -2672 & 5098 & 4498 & -600 \\
\hline Total & 718 & 166 & -552 & 2768 & 457 & -2311 & 1318 & 547 & -771 \\
\hline
\end{tabular}

Fuente: Reprocesamiento de los datos originales de los Censos Agropecuarios de 1969 y 1988. 


\section{Apéndice 4. Evolución de la población de las localidades}

Los siguientes cuadros han sido confeccionados a partir de los datos de los Censos Nacionales de Población de 1947, 1960, 1970, 1980 y 1991, y del Censo Provincial de 1938 (anulado por la intervención federal, por lo cual sólo se recuperó la población total por partido).

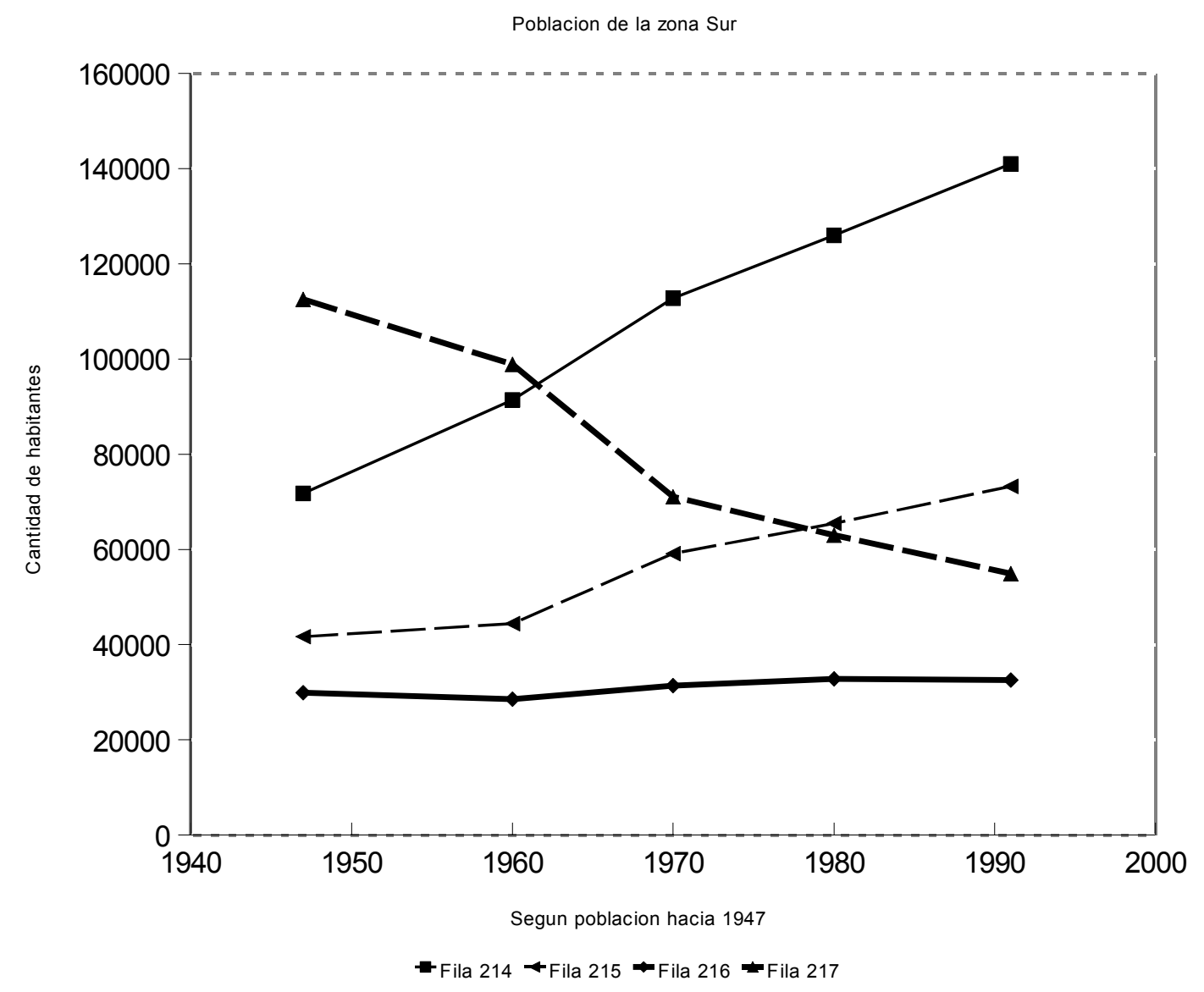



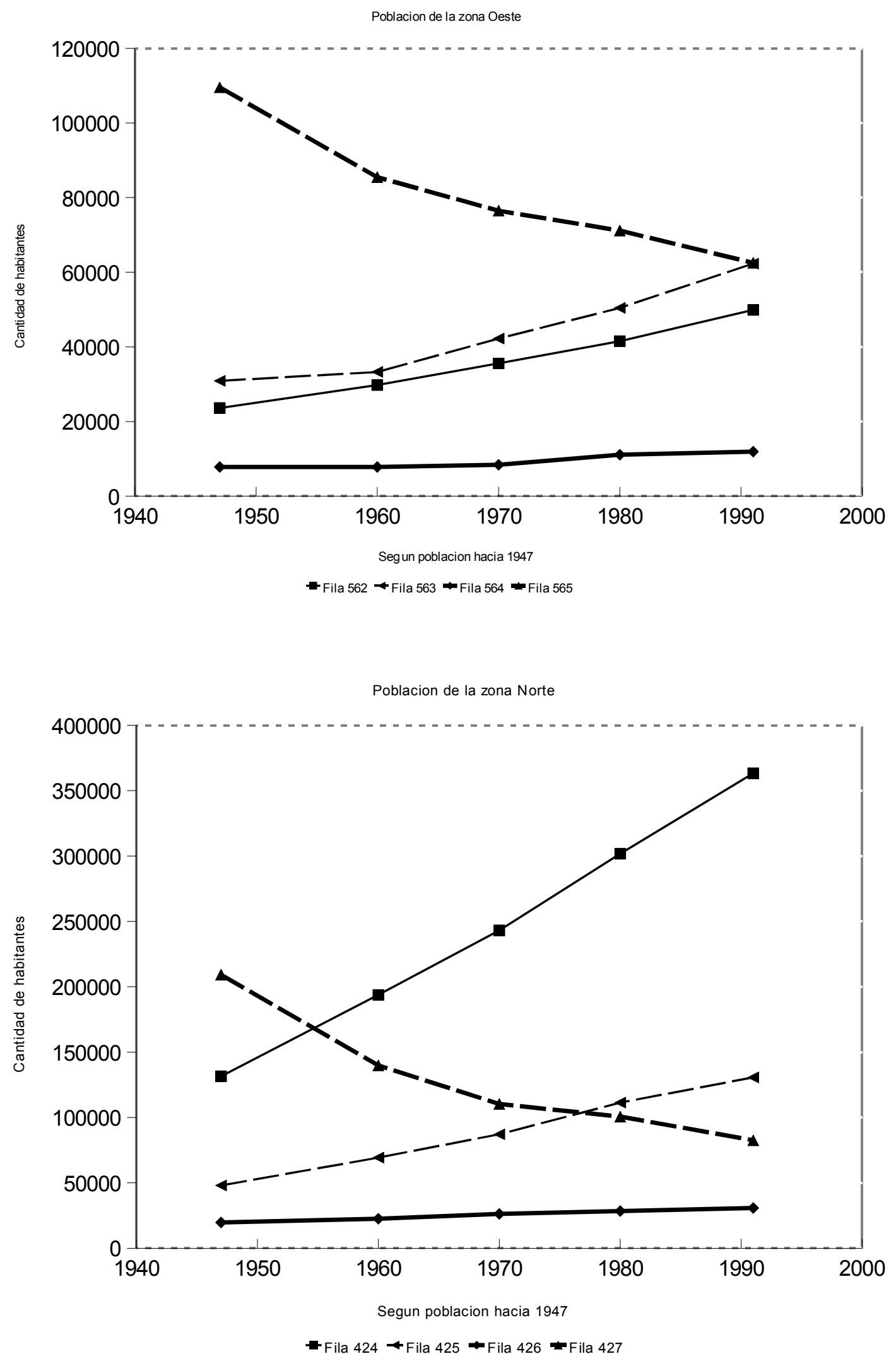
Población por localidades, zona rural y total partido

1938

1947

1960

1970

1980

1991

Zona Sur

A. Gonzalez Chaves

De la Garma

4718

730

Juan E. Barra

Vasquez

Zona Rural

Total

14714

5661

1587

8276

1798

323

364

405

5144

12797

2736

13133

13239

112597

Bahia Blanca

Ing. White

Daniel Cerri

Cabildo

Grumbein

Aldea Romana

Sauce Chico

Villa Bordeu

Villa Harding Green

Villa Libre

Base C.Espora

Zona Rural

total

115148

122059

Cnel. Rosales

Col. Puerto Belgrano

Pehuenco

Calderon

Arroyo Pareja

Ciudad Atlantica

villa Gral. Arias

villa del Mar

Bajo Hondo

Zona rural

total

ZRURAL BB+RO

TOTAL BB+RO

Cnel. Dorrego

Oriente

Guisasola

Aparicio

Faro

San Roman

Irene

PJE. LA RUTA

BAL.OR-MARISOL

Monte Hermoso

Gil

Nicolas Descalzi

Zubiaurre

Zona Rural

total

20779

0
115148

136137

173898

8260

3748

2643

1002

684

259

368

131

178

432

282

19852

19852

5044

3207

$\begin{array}{rr}8557 & 8653 \\ 1952 & 1783 \\ 178 & 224 \\ 79 & 55 \\ 1994 & 1941 \\ 12760 & 12656\end{array}$

$214353 \quad 239144$

$9374 \quad 11109$

$5057 \quad 5798$

$1901 \quad 2195$

$868 \quad 2440$

589

1853

1241

2824

150354

8129

197680

1242

2394

233947

4539

269220

$\begin{array}{rr}21113 & 36805 \\ 9739 & 14398\end{array}$

54375

52144

316

215

221

442

1541

415

106

316

760

582

261

266

$1998 \quad 5028$

24503

33871

57079

1936

297

1747

242

205

928

175

58094

985

55471

$4822 \quad 13157$

3322

5524

146562

184225

254759

292041

324691

7245

2160

1621

187

183

133

8281

10448

1954

1447

10661

2077

1068

11354

1456

93

118

180

2158

967

167

$\begin{array}{ll}71 & 26\end{array}$

$\begin{array}{ll}80 & 47\end{array}$

80

57

38

39

18

1939

2891

3372

166

141

$\begin{array}{rrrr} & 141 & & \\ & & & 27 \\ 20779 & & 9765 & 5198 \\ & 20471 & 20750 & 21416\end{array}$

27

1916

4518

2883

18712

17697 
Población por localidades, zona rural y total partido

$\begin{array}{llllll}1938 & 1947 & 1960 & 1970 & 1980 & 1991\end{array}$

Monte Hermoso

VA. CABALLEROS

Brio. Sauce Grande

Zona rural

1938

1960

1970

991

total

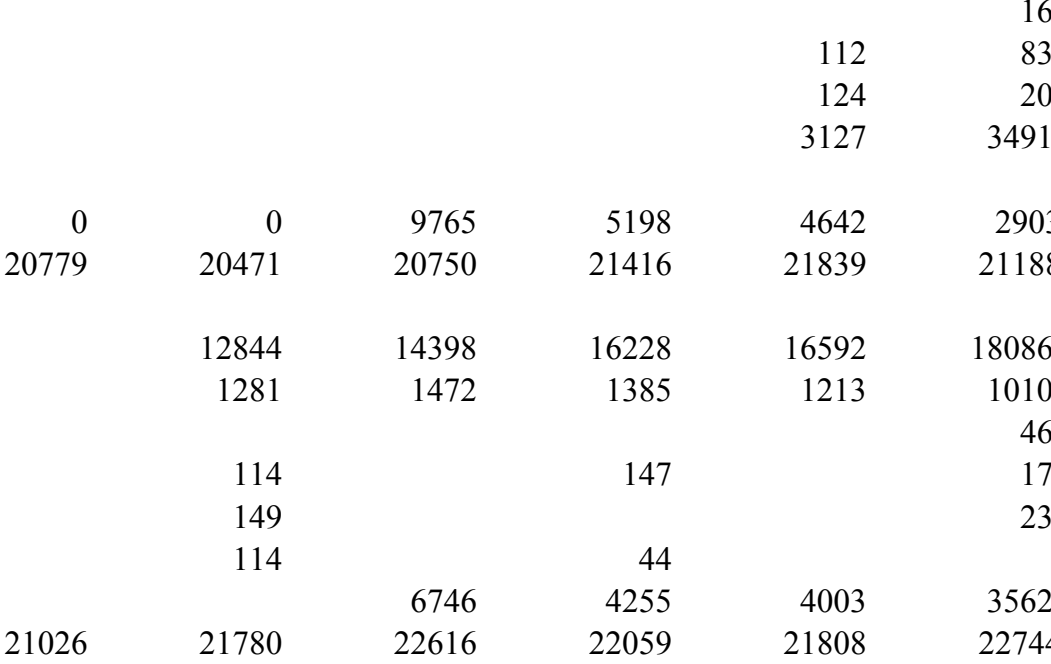

ZRURAL DORR+MH

TOTAL DORR+MH

Cnel. Pringles

Indio Rico

21780

22616

22059

22744

Cnel. Suarez

Huanguelen

11133

13150

18659

2990

3189

3924

1968

Cnia. San Jose

1753

nia. Santa Maria

357

Villa Arcadia

Pasman

Curamalal

D'orbigny

Cascada

1590

1735

934

651

691

16

83

Colonia Numero 3

Quinihual

344

Villa Belgrano

330

Bathurst

Zona rural

total

31848

30645

190

234

331

Miramar (Gral. Alvarado)

3537

1476

481

Mechongue

109

Iraizoz

Mar del Sur

Blvard. Atlantico

Zona rural

total

10884

1269

5542

150

8540

3184

5613

4240

29656

30535

32128

35016

Loberia

Quequen

7916

8932

10512

15473

19155

3279

5129

5017

5619

1064

1173

1415

302

Pieres

San Manuel

Matienzo

Tamangueyu

Las nutrias

Playas verdes

Zona rural

4760

8232

5834

9923

9299

862

300

5428

2627

3076

22247

25152

29565

709

1023

8898

10827

11737

13985

$55 \quad 36$

$\begin{array}{lrr}926 & 1042 & 1275\end{array}$

450

601

677

71

94

$307 \quad 305$

113

3

11259

7904

5861 
Población por localidades, zona rural y total partido

\begin{tabular}{|c|c|c|c|c|c|c|}
\hline & 1938 & 1947 & 1960 & 1970 & 1980 & 1991 \\
\hline total & 26403 & 27481 & 26949 & 28729 & 17347 & 17613 \\
\hline TOTAL LO+QUEQUEN $19 ؛$ & 26403 & 27481 & 26949 & 28729 & 29084 & 31598 \\
\hline Necochea & & 17808 & 30394 & 39868 & 50939 & 58310 \\
\hline Quequen & & & & & 11737 & 13985 \\
\hline Juan N. Fernandez & & 3253 & 2816 & 3021 & 2869 & 2766 \\
\hline San Cayetano & & 5193 & 3692 & 6025 & 5960 & 6090 \\
\hline La Dulce & & 1326 & 2207 & 2185 & 1856 & 2004 \\
\hline Santamarina & & 1064 & & 947 & 582 & 607 \\
\hline Claraz & & 795 & 558 & 913 & 668 & 705 \\
\hline San Jose (V.Diego) & & 249 & & & 89 & \\
\hline Defferrari & & 422 & & 321 & & \\
\hline COSTA BONITA & & & & & & 55 \\
\hline Lumb & & 178 & & & & \\
\hline Energia & & & & & 119 & 80 \\
\hline Zona rural & & & 8153 & 4744 & 4804 & 5118 \\
\hline total & 47702 & 49449 & 44128 & 51678 & 73663 & 83630 \\
\hline \multicolumn{7}{|l|}{ San Cayetano } \\
\hline Baln. San Cayetano & & & & & 6 & 11 \\
\hline Ochandio & & & 265 & 185 & 186 & 49 \\
\hline Zona rural & & & 6591 & 3151 & 2677 & 2448 \\
\hline total & & & 10548 & 9682 & 8829 & 8598 \\
\hline ZRURAL NEC+SC & 0 & 0 & 14744 & 7895 & 7481 & 7566 \\
\hline TOTAL NEC+SC-QUEQUE & 47702 & 49449 & 54411 & 61175 & 70569 & 78194 \\
\hline Puan & & 3191 & 2756 & 3406 & 4148 & 4381 \\
\hline Darragueira & & 2865 & 3975 & 4794 & 5600 & 5231 \\
\hline Bordenave & & 1315 & 868 & 1080 & 997 & 853 \\
\hline Villa Iris & & 2422 & 1911 & 2135 & 2114 & 2019 \\
\hline Felipe Sola & & 504 & & 887 & 655 & 355 \\
\hline 17 de Agosto & & 416 & & 397 & 373 & 396 \\
\hline San German & & 490 & 330 & 362 & 215 & 179 \\
\hline Lopez Lecube & & 142 & & 96 & 75 & 62 \\
\hline Azopardo & & 374 & 550 & 168 & & 135 \\
\hline Saenz & & & 429 & & & \\
\hline Estela & & 106 & & & & 11 \\
\hline V.Castelar (Erize) & & 227 & & & 156 & 50 \\
\hline Zona rural & & & 8992 & 5504 & 4095 & 3687 \\
\hline total & 21426 & 19600 & 19811 & 18829 & 18428 & 17359 \\
\hline Saavedra & & 2130 & 2351 & 2491 & 2409 & 2244 \\
\hline Pigue & & 5869 & 6943 & 8703 & 10793 & 12386 \\
\hline Espartillar & & 638 & 666 & 801 & 781 & 866 \\
\hline Goyena & & 846 & 701 & 692 & 683 & 674 \\
\hline Arroyo Corto & & 760 & 681 & 698 & 555 & 469 \\
\hline Dufaur & & 399 & 341 & 331 & 257 & 223 \\
\hline Zona rural & & & 5234 & 3421 & 2779 & 2278 \\
\hline total & 15029 & 15619 & 16917 & 17137 & 18257 & 19140 \\
\hline Tornquist & & 2782 & 3008 & 3054 & 4696 & 5592 \\
\hline Saldungaray & & 1170 & 1245 & 1301 & 1239 & 1210 \\
\hline
\end{tabular}


Población por localidades, zona rural y total partido

\begin{tabular}{|c|c|c|c|c|c|c|}
\hline & 1938 & 1947 & 1960 & 1970 & 1980 & 1991 \\
\hline Sierra de la Ventana & & 204 & & 605 & 668 & 882 \\
\hline Tres Picos & & 193 & & 150 & 113 & 101 \\
\hline Chasico & & 122 & & 197 & 131 & 185 \\
\hline Villa Ventana & & & & & 42 & 100 \\
\hline Pelicura & & & & 70 & & \\
\hline Paraje La Gruta & & & & & 17 & 8 \\
\hline DQUE.PASO PIED & & & & & & 44 \\
\hline LAS ENCADENADA & & & & & & 5 \\
\hline Zona rural & & & 5096 & 4933 & 3137 & 2539 \\
\hline total & 10028 & 9158 & 9349 & 10310 & 10043 & 10666 \\
\hline Tres Arroyos & & 29996 & 33462 & 37991 & 42118 & 44404 \\
\hline Barrow & & 102 & & & 31 & \\
\hline Cascallares & & 784 & 1116 & 885 & 782 & 674 \\
\hline San Mayol & & 263 & 256 & 220 & 208 & 90 \\
\hline Reta & & & & 187 & 249 & 167 \\
\hline Copetonas & & 1712 & 1058 & 873 & 1231 & 1245 \\
\hline San Fco. de Bellocq & & 809 & 736 & 787 & 757 & 673 \\
\hline Claromeco & & 281 & 379 & 650 & 1039 & 893 \\
\hline La Sortija & & 129 & & & & \\
\hline VA. RODRIGUEZ & & & & & & 39 \\
\hline Ochandio & & 296 & 265 & & 186 & 49 \\
\hline Dunamar & & & & & 68 & 84 \\
\hline Orense & & 1945 & 1712 & 2099 & 2279 & 2182 \\
\hline Lin Calel & & 172 & & 492 & & \\
\hline Baln. Orense & & & & & 25 & 31 \\
\hline Zona rural & & & 10982 & 8717 & 6281 & 5973 \\
\hline total & 50865 & 48757 & 49701 & 52901 & 55068 & 56455 \\
\hline TOTAL + OCHANDIO & 50865 & 48757 & 49966 & 52901 & 55254 & 56504 \\
\hline \multicolumn{7}{|l|}{ ZONA SUR } \\
\hline total cabeceras & 0 & 206792 & 262000 & 332998 & 396369 & 445476 \\
\hline total nuevas cabeceras & 0 & 25333 & 24805 & 44769 & 63226 & 61606 \\
\hline total47 loc. +2000 no cab. & 0 & 26492 & 29235 & 39138 & 43264 & 46973 \\
\hline total91 loc. +2000 no cab., -4 & 0 & 5498 & 6193 & 7021 & 6935 & 8669 \\
\hline Total Poblacion & 385852 & 415455 & 466166 & 553230 & 607363 & 659321 \\
\hline rural (tot-tot. loc.) & 385852 & 151340 & 143933 & 129304 & 97569 & 96597 \\
\hline \multicolumn{7}{|c|}{ ZONA SUR - BAHIA BLANCA - RO } \\
\hline total nuevas cabeceras & 0 & 5481 & 3692 & 7964 & 8851 & 9462 \\
\hline total47 loc. +2000 no cab. & 0 & 22056 & 24811 & 32747 & 36306 & 38980 \\
\hline total91 loc. +2000 no cab., -4 & 0 & 5239 & 5509 & 6019 & 6067 & 6229 \\
\hline Total Poblacion & 270704 & 268893 & 281941 & 298471 & 315322 & 334630 \\
\hline \multirow[t]{2}{*}{ rural (tot-tot. loc.) } & 270704 & 141922 & 127110 & 100901 & 91456 & 84736 \\
\hline & & 1947 & 1960 & 1970 & 1980 & 1991 \\
\hline mas de 10.000 & & 71781 & 91404 & 112746 & 126008 & 140961 \\
\hline de 3000 a 10.000 & & 41674 & 44407 & 59134 & 65450 & 73268 \\
\hline de 1000 a 3000 & & 29911 & 28520 & 31358 & 32811 & 32543 \\
\hline menos de 1000 y campo & & 112545 & 98891 & 71047 & 63010 & 54921 \\
\hline
\end{tabular}


Población por localidades, zona rural y total partido 
Población por localidades, zona rural y total partido

1938

1970

1980

1991

Zona norte

Baradero

Alsina

Portela

Santa Coloma

Islas

Zona rural

total

20082

10194

16026

20103

23816

884

921

1059

1040

468

263

415

$263 \quad 141$

Arrecifes (B.Mitre)

7635

19858

5086

278

110

Todd

9858

19867

4593

3874

3091

Cap.Sarmiento

462

3725

11585

22008

25840

28613

La Luisa

219

Vinas

Zona rural

total

25742

623

524

13503

17719

20852

5954

1216

666

697

$8137 \quad 9628$

$282 \quad 234$

$\begin{array}{llll}344 & 466 & 837 & 458\end{array}$

8751

4351

3109

2452

8751
27158

19536

22331

24459

Cap. Sarmiento

La Luisa

Zona rural

total

9479

1767

1476

10186

11338

ZRURAL MI+SAR

0

0

8751

4351

4876

3928

TOTAL MI+SA

25742

27158

29015

32517

35797

Carmen de Areco

4411

5933

6556

7882

9535

Tres Sargentos

322

374

271

381

413

116

131

Zona rural

3287

3232

2529

2450

total

10592

9632

9594

10059

10908

12529

Colon

5628

8604

12530

16070

17686

418

211

216

242

303

El Arbolito

292

290

308

Sarasa

Zona rural

total

15191

110
5456

178

3282

1480

14573

14673

16519

18082

2592

Chacabuco

12530

16066

20801

26492

30353

Rawson

2425

1999

1987

901

2133

1029

1869

1140

1346

Castilla

961

884

892

966

828

El Rancho de Rocha

106

Los Angeles

Zona rural

total

36938

16324

12191

40699

8133

35759

38072

42888

Gral. Arenales

2182

2043

2855

3332

3540

1032

202

2888

59

1775

2105

128

3932

Desvio km.95

107

Est. Ascension

507

901

174

441

1384

1654 
Población por localidades, zona rural y total partido

\begin{tabular}{|c|c|c|c|c|c|c|}
\hline & 1938 & 1947 & 1960 & 1970 & 1980 & 1991 \\
\hline La Trinidad & & 133 & 324 & 202 & 248 & 298 \\
\hline La Angelita & & 296 & 377 & 335 & 361 & 319 \\
\hline Arribenos & & 1739 & 1902 & 2286 & 2586 & 2787 \\
\hline Zona rural & & & 7415 & 1161 & 3635 & 2405 \\
\hline total & 18071 & 22190 & 15269 & 14931 & 15146 & 14994 \\
\hline Junin & & 36149 & 52054 & 56748 & 62080 & 73658 \\
\hline Morse & & 621 & 1029 & 1036 & 1093 & 1164 \\
\hline Saforcada & & 146 & & 379 & 361 & 304 \\
\hline A.G. Roca & & 920 & 689 & 765 & 878 & 866 \\
\hline Agustina & & 353 & 306 & 330 & 307 & 337 \\
\hline Laplacette & & 108 & & & & 121 \\
\hline BO. REAL & & & & & & 29 \\
\hline BO. JARDIN & & & & & & 29 \\
\hline BO.SAN CARLOS & & & & & & 3 \\
\hline BO. PASO PIEDR & & & & & & 46 \\
\hline PJE.LA AGRARIA & & & & & & 75 \\
\hline BO. ROQUE VAZQ & & & & & & 42 \\
\hline BAL.LGA. GOMEZ & & & & & & 59 \\
\hline Fortin Tiburcio & & 422 & 427 & 415 & & 366 \\
\hline Zona rural & & & 11976 & 10552 & 10620 & 5509 \\
\hline total & 56816 & 54452 & 66481 & 70225 & 75339 & 82608 \\
\hline Pergamino & & 32382 & 45366 & 56078 & 68989 & 78931 \\
\hline Acevedo & & 1057 & 1134 & 1263 & 1391 & 1537 \\
\hline El Socorro & & 1259 & 1080 & 1037 & 1314 & 1222 \\
\hline Manuel Ocampo & & 1010 & 867 & 866 & 1149 & 1090 \\
\hline Urquiza (Juan Anchorena) & & 582 & 652 & 123 & 1258 & 1062 \\
\hline Rancagua & & 705 & 517 & 615 & 765 & 613 \\
\hline Mariano Alfonzo & & 779 & 667 & 828 & 908 & 1006 \\
\hline La Violeta & & 850 & 818 & 838 & 879 & 1040 \\
\hline Guerrico & & 495 & 469 & 587 & 702 & 721 \\
\hline Pinzon & & 660 & 518 & 472 & 522 & 448 \\
\hline Mariano Benitez & & 443 & 317 & 288 & 232 & 205 \\
\hline Barrio Champagnan & & & & 376 & & \\
\hline Fontezuela & & & & 71 & & \\
\hline Arroyo del Medio & & & & 67 & & \\
\hline Maguirre & & & & 42 & & \\
\hline J.A. de la Pena & & 157 & 209 & & 222 & 238 \\
\hline Zona rural & & & 14647 & 10069 & 5087 & 6129 \\
\hline total & 68373 & 69609 & 67261 & 73620 & 83418 & 94242 \\
\hline Ramallo & & 4824 & 4903 & 6704 & 8248 & 10169 \\
\hline Villa Ramallo & & & 3663 & 5477 & 7662 & 9775 \\
\hline Perez Millan & & 1477 & 1370 & 1388 & 2116 & 3139 \\
\hline Villa Gral Savio (Sanchez) & & 298 & & & 776 & 906 \\
\hline Paraiso & & 343 & & 129 & 237 & 308 \\
\hline Las Bahamas & & & & & 52 & 56 \\
\hline Islas & & & & & 32 & 19 \\
\hline Zona rural & & & 7197 & 4594 & 3330 & 2386 \\
\hline total & 18384 & 16441 & 17133 & 18292 & 22423 & 26758 \\
\hline Rojas & & 6608 & 10149 & 10074 & 14247 & 17049 \\
\hline Las Carabelas & & 803 & 963 & 1029 & 1035 & 1090 \\
\hline
\end{tabular}


Población por localidades, zona rural y total partido

\begin{tabular}{|c|c|c|c|c|c|c|}
\hline & 1938 & 1947 & 1960 & 1970 & 1980 & 1991 \\
\hline Rafael Obligado & & 618 & 954 & 917 & 942 & 916 \\
\hline Roberto Cano & & 105 & 207 & 292 & & 56 \\
\hline Los Indios & & 157 & & & 110 & 106 \\
\hline VA.PQUE.CECIR & & & & & & 17 \\
\hline BO.LAS MARGARI & & & & & & 21 \\
\hline VA. POMAR & & & & & & 81 \\
\hline LA BEBA & & & & & & 77 \\
\hline SOL DE MAYO & & & & & & 29 \\
\hline Zona rural & & & 8547 & 8462 & 5044 & 3080 \\
\hline total & 28622 & 28075 & 20820 & 20774 & 21378 & 22522 \\
\hline Salto & & 7771 & 10226 & 14551 & 18462 & 20719 \\
\hline Arroyo Dulce & & 805 & 756 & 1278 & 1472 & 1654 \\
\hline Ines Indart & & 979 & 1148 & 1082 & 1194 & 1006 \\
\hline Gahan & & 603 & 583 & 534 & 560 & 644 \\
\hline Berdier & & 416 & 345 & 397 & 346 & 174 \\
\hline La Invencible & & & 200 & 152 & & 119 \\
\hline Tacuari & & & & & 45 & \\
\hline Zona rural & & & 8328 & 4177 & 3545 & 3485 \\
\hline total & 23525 & 25746 & 21586 & 22171 & 25624 & 27801 \\
\hline San Antonio de Areco & & 7436 & 8320 & 10788 & 12932 & 15146 \\
\hline Villa Lia & & 781 & 774 & 758 & 840 & 815 \\
\hline Est. Duggan & & 621 & 487 & 465 & 557 & 553 \\
\hline Est. Vagues & & 106 & & & 153 & \\
\hline Zona rural & & & 3642 & 2190 & 1763 & 2023 \\
\hline total & 13174 & 12841 & 13223 & 14201 & 16245 & 18537 \\
\hline San Nicolas & & 25039 & 48728 & 61376 & 96313 & 104270 \\
\hline Villa San Nicolas & & & & & 1866 & \\
\hline CERNADAS & & & & & & \\
\hline BO. SAN MARTIN & & & & 593 & & 2200 \\
\hline Bo. Las Lomas & & & & 1030 & & \\
\hline Bo Novomur & & & & 778 & & \\
\hline Bo. Santa Clara & & & & 633 & & \\
\hline Bo. Nueve de Julio & & & & 396 & & \\
\hline Bo. Los Churrinches & & & & 259 & & \\
\hline Bo. Osania & & & & 163 & & \\
\hline Bo. Siderurgia & & & & 3246 & & \\
\hline Va. Minoldo & & & & 134 & & \\
\hline BO. SUIZO & & & & & & 1525 \\
\hline BO.S.FRANCISCO & & & & & & 1380 \\
\hline BO. MORENO & & & & 217 & & 1463 \\
\hline VA. RICCIO & & & & 325 & & 990 \\
\hline BO.L. MELLIZAS & & & & 85 & & 1133 \\
\hline BO. COLOMBINI & & & & 213 & & 768 \\
\hline BO. CASTELLI & & & & & & 964 \\
\hline BO.B. YAGUARON & & & & & & 523 \\
\hline BO. C. SALLES & & & & 515 & & 484 \\
\hline VA. CANTO & & & & & & 552 \\
\hline BO. SANDRINA & & & & & & 397 \\
\hline BO. SN. JORGE & & & & & & 243 \\
\hline BO.V. DE LUJAN & & & & & & 378 \\
\hline BO.S. TERESITA & & & & 60 & & 235 \\
\hline
\end{tabular}


Población por localidades, zona rural y total partido

\begin{tabular}{|c|c|c|c|c|c|c|}
\hline & 1938 & 1947 & 1960 & 1970 & 1980 & 1991 \\
\hline BO. SIRONI & & & & & & 227 \\
\hline BO.CUME-HUE & & & & & & 40 \\
\hline BO.GRL.MOSCONI & & & & & & 191 \\
\hline VA. HERMOSA & & & & & & 215 \\
\hline BO. LA FLORIDA & & & & & & 156 \\
\hline BO.LAS MALVINA & & & & & & 128 \\
\hline BO.SIN NOMBRE & & & & & & 166 \\
\hline BO.SIN NOMBRE & & & & & & 22 \\
\hline La Emilia & & 1181 & 3802 & 4076 & 5053 & 3257 \\
\hline Gral. Rojo & & 1377 & 1914 & 2229 & 2476 & 2520 \\
\hline Conesa & & 1199 & 1297 & 1669 & 2021 & 2172 \\
\hline erezcano & & 239 & 239 & 287 & 453 & 460 \\
\hline Villa Campi & & & & & 405 & 631 \\
\hline Villa Esperanza & & & & 117 & 279 & 260 \\
\hline Islas & & & & & 11 & 10 \\
\hline Zona rural & & & 7141 & 3877 & 4810 & 2849 \\
\hline total & 41621 & 39352 & 63121 & 82278 & 113687 & 130809 \\
\hline San Pedro & & 13778 & 18145 & 23365 & 27058 & 36664 \\
\hline Las Canaletas & & 1450 & & & & \\
\hline Santa Lucia & & 1831 & 2002 & 1817 & 2033 & 2100 \\
\hline Rio Tala & & 454 & 691 & 811 & 1377 & 1004 \\
\hline Gob. Castro & & 295 & 777 & 850 & 1400 & 2127 \\
\hline Pueblo Doyle & & & & & 386 & 469 \\
\hline Obligado & & & & 145 & 170 & 199 \\
\hline Ing. Moreja & & & & & 100 & 42 \\
\hline Islas & & & & & 90 & 75 \\
\hline Km. 158 & & 500 & & 443 & & \\
\hline Zona rural & & & 11289 & 7350 & 8376 & 5567 \\
\hline total & 30575 & 29971 & 32904 & 34781 & 40990 & 48247 \\
\hline Zona Norte & & & & & & \\
\hline total cabeceras & 0 & 176567 & 255556 & 311955 & 399927 & 462388 \\
\hline total nuevas cabeceras & 0 & 3725 & 5954 & 7007 & 8137 & 9628 \\
\hline total47 loc. +2000 no cab. & 0 & 2425 & 1999 & 1987 & 901 & 2133 \\
\hline total91 loc. +2000 no cab., -4 & 0 & 9497 & 16918 & 20451 & 25902 & 29289 \\
\hline Total Poblacion & 407706 & 408487 & 425529 & 466946 & 542296 & 607324 \\
\hline rural (tot-tot. loc.) & 407706 & 216273 & 145102 & 125546 & 107429 & 103886 \\
\hline mas de 10.000 & & 131522 & 193793 & 243158 & 301719 & 363246 \\
\hline de 3000 a 10.000 & & 48038 & 69337 & 87190 & 111359 & 130678 \\
\hline de 1000 a 3000 & & 19722 & 22544 & 26230 & 28543 & 30775 \\
\hline menos de 1000 y campo & & 209205 & 139855 & 110368 & 100675 & 82625 \\
\hline
\end{tabular}


Población por localidades, zona rural y total partido

1960

1970

1980

1991

Zona oeste

C. Tejedor

Tres Algarrobos

Colonia Sere

1892

2914

3555

4421

4719

Santa Ines

484

1975

2020

2513

2768

Timote

114

Esteban de Luca

669

558

651

632

650

Cararu

246

664

299

509

Husares

383

Husares

total

17221

15280

419

464

402

Gral. Pinto

Ameghino

2770

1085

Germania

671

Cnel. Granada

536

6647

5829

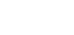

2959

13086

12474

12589

12007

Iriarte (Col.San Ricardo)

2290

3566

3348

5427

2512

3195

2775

5168

1038

1247

1316

1367

1038

1002

Est. Gunther

El Porvenir

128

Est. Dusaud

Blaquier

Villa Roth (Ing.Balbin)

Zona rural

total

691

710

678

811

64

$135 \quad 121$

124

484

144

469

72

557

698

543
195

212

6751

7997

96

22644

19484

17279

17096

17921

2510

F. Ameghino

BLAQUIER

PORVENIR

ZONA RURAL

total

1500

ZRURAL PI+AME

TOTAL PI+AME

0
22644

0

9470

6751

17096

7997

17921

4010

18767

Gral. Villegas

4738

7261

8884

11307

12956

Elordi

969

1097

1153

Villa Sauce

488

551

984

518

616

Emilio Bunge

Piedritas

810

888

1028

1193

1302

Santa Eleudora

362

Charlone

644

Santa Regina

360

805

1211

1401

Canada Seca

Villa Saboya

671

Pichincha

Zona rural

total

31101

463

L.N. Alem

Vedia

Juan B. Alberdi

1773

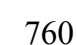

423

1064

$297 \quad 448 \quad 543$

563

656

706

406

419

347

470

50

18

11100

9813

7385

6535

23673

25000

26118

27405

ALBERDI (V)

1780

2153

2379

2517

4287

5139

6273

7189

1892

2061

2898

2769

400 
Población por localidades, zona rural y total partido

\begin{tabular}{|c|c|c|c|c|c|c|}
\hline & 1938 & 1947 & 1960 & 1970 & 1980 & 1991 \\
\hline El Dorado & & 528 & 360 & 424 & 415 & 337 \\
\hline Fortin Acha & & 226 & & 183 & 116 & 85 \\
\hline De Bruyn & & & 171 & & & \\
\hline Zona rural & & & 5386 & 4854 & 3939 & 3186 \\
\hline total & 18214 & 15203 & 13876 & 14814 & 16020 & 16483 \\
\hline Lincoln & & 12695 & 14777 & 17391 & 19009 & 24258 \\
\hline Roberts & & 925 & 2063 & 2051 & 2482 & 2719 \\
\hline Pasteur & & 1060 & & 1252 & 1788 & 1917 \\
\hline Arenaza & & 931 & 629 & 711 & 988 & 1113 \\
\hline Martinez de Hoz & & 696 & 643 & 682 & 769 & 938 \\
\hline Bayauca & & 780 & 678 & 717 & 641 & 638 \\
\hline Carlos Salas & & 524 & 380 & 512 & 433 & 328 \\
\hline El Triunfo & & 794 & 1177 & 1419 & 1470 & 1727 \\
\hline LAS TOSCAS & & & & & & 432 \\
\hline Bermudez & & 238 & 292 & 187 & & \\
\hline Triunvirato & & 262 & 158 & 149 & & \\
\hline Balsa & & & & 97 & & \\
\hline Zona rural & & & 12736 & 10273 & 8221 & 6479 \\
\hline total & 44238 & 38944 & 33533 & 35441 & 35801 & 40549 \\
\hline Pellegrini & & 2310 & 2206 & 2974 & 3940 & 4569 \\
\hline Tres Lomas (J.M.Blanco) & & 3425 & 3292 & 4249 & 5408 & 6357 \\
\hline Bocayuva & & 179 & & 158 & 154 & 58 \\
\hline De Barry & & 180 & & 150 & 139 & 125 \\
\hline Salliquelo & & 3938 & 3794 & 4566 & 5479 & 6930 \\
\hline Queroma & & 470 & 469 & & & \\
\hline Ing. Thompson & & 157 & 240 & 246 & 199 & \\
\hline Zona rural & & & 6240 & 3701 & 2667 & 1021 \\
\hline total & 18850 & 18031 & 16241 & 11478 & 12507 & 5773 \\
\hline \multicolumn{7}{|l|}{ Saliquelo } \\
\hline Quenuma & & & & 540 & 583 & 610 \\
\hline Zona rural & & & & 893 & 1114 & 827 \\
\hline total & & & & 5999 & 7176 & 8367 \\
\hline \multicolumn{7}{|l|}{ Tres Lomas } \\
\hline P.M. MORENO & & & & & & 166 \\
\hline ZONA RURAL & & & & & & 1023 \\
\hline total & & & & & & 7546 \\
\hline ZRURAL PE+SA+3L & 0 & 0 & 6240 & 4594 & 3781 & 2871 \\
\hline TOTAL PE+SA+3L & 18850 & 18031 & 16241 & 17477 & 19683 & 21686 \\
\hline Rivadavia & & 4925 & 4716 & 6081 & 7485 & 8994 \\
\hline Sansinena & & 445 & 379 & 185 & 508 & 437 \\
\hline Gonzalez Moreno & & 1154 & 779 & 616 & 1400 & 1494 \\
\hline San Mauricio & & 151 & & & 105 & 39 \\
\hline Sunblad & & 133 & & & 155 & 57 \\
\hline Rooselvelt & & 229 & 219 & 228 & 272 & 337 \\
\hline Mira Pampa & & 221 & 130 & 108 & 81 & 50 \\
\hline Fortin Olavarria & & 841 & 843 & 730 & 1020 & 886 \\
\hline Zona rural & & & 5107 & 4145 & 2435 & 2596 \\
\hline total & 15731 & 13832 & 12173 & 12093 & 13461 & 14890 \\
\hline
\end{tabular}


Población por localidades, zona rural y total partido

\begin{tabular}{|c|c|c|c|c|c|c|}
\hline & 1938 & 1947 & 1960 & 1970 & 1980 & 1991 \\
\hline Trenque Lauquen & & 10887 & 14970 & 18169 & 22504 & 25657 \\
\hline 30 de Agosto & & 1915 & 2139 & 2469 & 2962 & 3536 \\
\hline Berutti & & 848 & 1050 & 1215 & 1102 & 921 \\
\hline Girodias & & 370 & & 154 & 176 & 179 \\
\hline La Carreta & & 229 & & 92 & & 47 \\
\hline Francisco de Victoria & & & & 72 & & \\
\hline Tronge & & & & 64 & & 27 \\
\hline Zona rural & & & 8289 & 6022 & 5848 & 4515 \\
\hline total & 27565 & 24624 & 26448 & 28257 & 32592 & 34882 \\
\hline ZONA OESTE & & & & & & \\
\hline total cabeceras & 0 & 44327 & 53421 & 65759 & 78287 & 93769 \\
\hline $\begin{array}{l}\text { total nuevas cabeceras } \\
\text { total } 47 \text { loc. }+2000 \text { no cab. }\end{array}$ & 0 & 10133 & 9598 & 12010 & 13662 & 18455 \\
\hline tota191 loc. +2000 no cab., -4 & 0 & 7327 & 9849 & 10754 & 13234 & 14309 \\
\hline Total Poblacion & 195564 & 171799 & 156309 & 162652 & 174185 & 186669 \\
\hline rural (tot-tot. loc.) & 195564 & 110012 & 83441 & 74129 & 69002 & 60136 \\
\hline mas de 10.000 & & 23582 & 29747 & 35560 & 41513 & 49915 \\
\hline de 3000 a 10.000 & & 30878 & 33272 & 42209 & 50436 & 62309 \\
\hline de 1000 a 3000 & & 7819 & 7823 & 8413 & 11089 & 11934 \\
\hline menos de 1000 y campo & & 109520 & 85467 & 76470 & 71147 & 62511 \\
\hline
\end{tabular}




\section{Apéndice 5. Estadísticas Agrícolas}

En las siguientes páginas se transcriben las superficies sembradas, los volúmenes

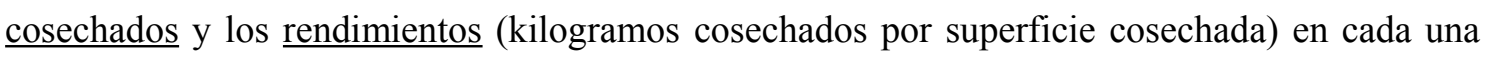
de las campañas entre 1938/39 y 1988/89, con los cuales se construyeron los gráficos sobre la evolución productiva en los primeros apartados de los Capítulos Segundo y Tercero, como también de los apartados correspondientes en los Apéndices 2 y 3.

Las "Estadísticas Agrícolas" fueron elaboradas por la Secretaría de Agricultura, Ganadería y Pesca, para cada uno de los partidos que conforman las zonas por nosotros construidas. Por una cuestión de espacio, resulta prácticamente imposible reproducir aquí la totalidad de datos por partido (necesitaríamos unas seiscientas páginas). Entonces, nos limitamos a consignar los cuadros con las sumatorias a nivel de cada una de las tres zonas estudiadas.

A modo de ejemplo de cómo hemos trabajado, podemos ver que para obtener el área sembrada con trigo en la zona norte en la campaña 1938/39 (que se observa en la primera fila y primer columna del cuadro de la página siguiente: 242.740 hectáreas), tuvimos que sumar el valor para cada uno de los catorce partidos que por entonces conformaban esta zona:

Superficie sembrada, Trigo $1938 / 39$

Baradero

Bartolome Mitre

Carmen de Areco

Colon

Chacabuco

38400

Gral. Arenales

43712

Junin

75570

Marc. Ugarte (Salto)

10500

Pergamino

13671

Ramallo

Rojas

San Antonio de Areco

San Nicolas

San Pedro 
Zona norte, sup. sembrada

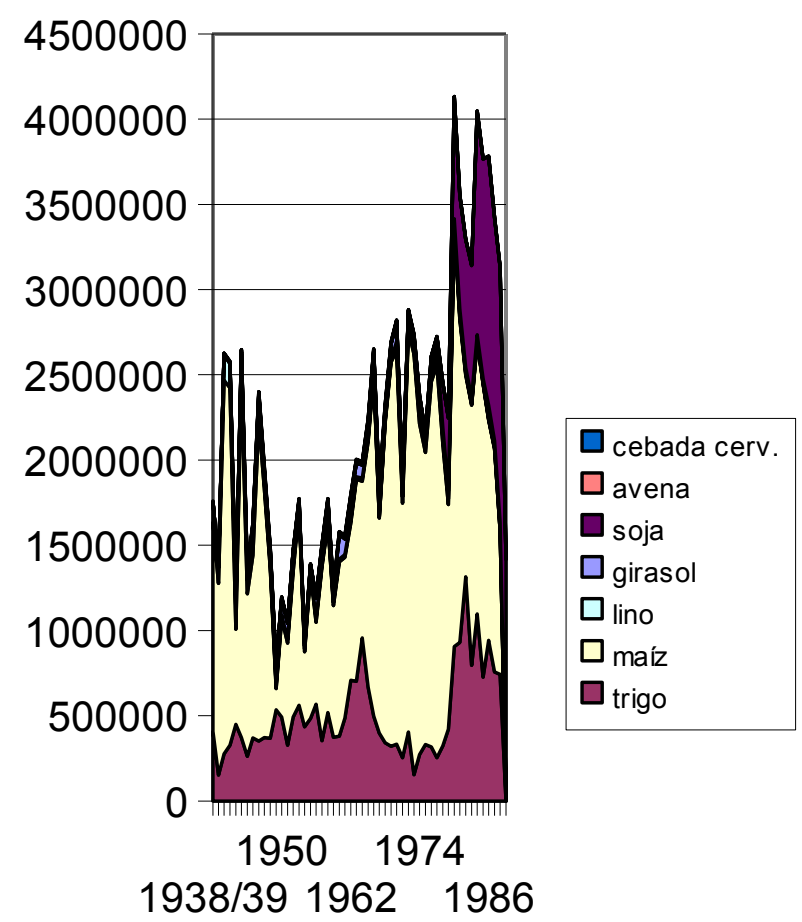

RP Volumen

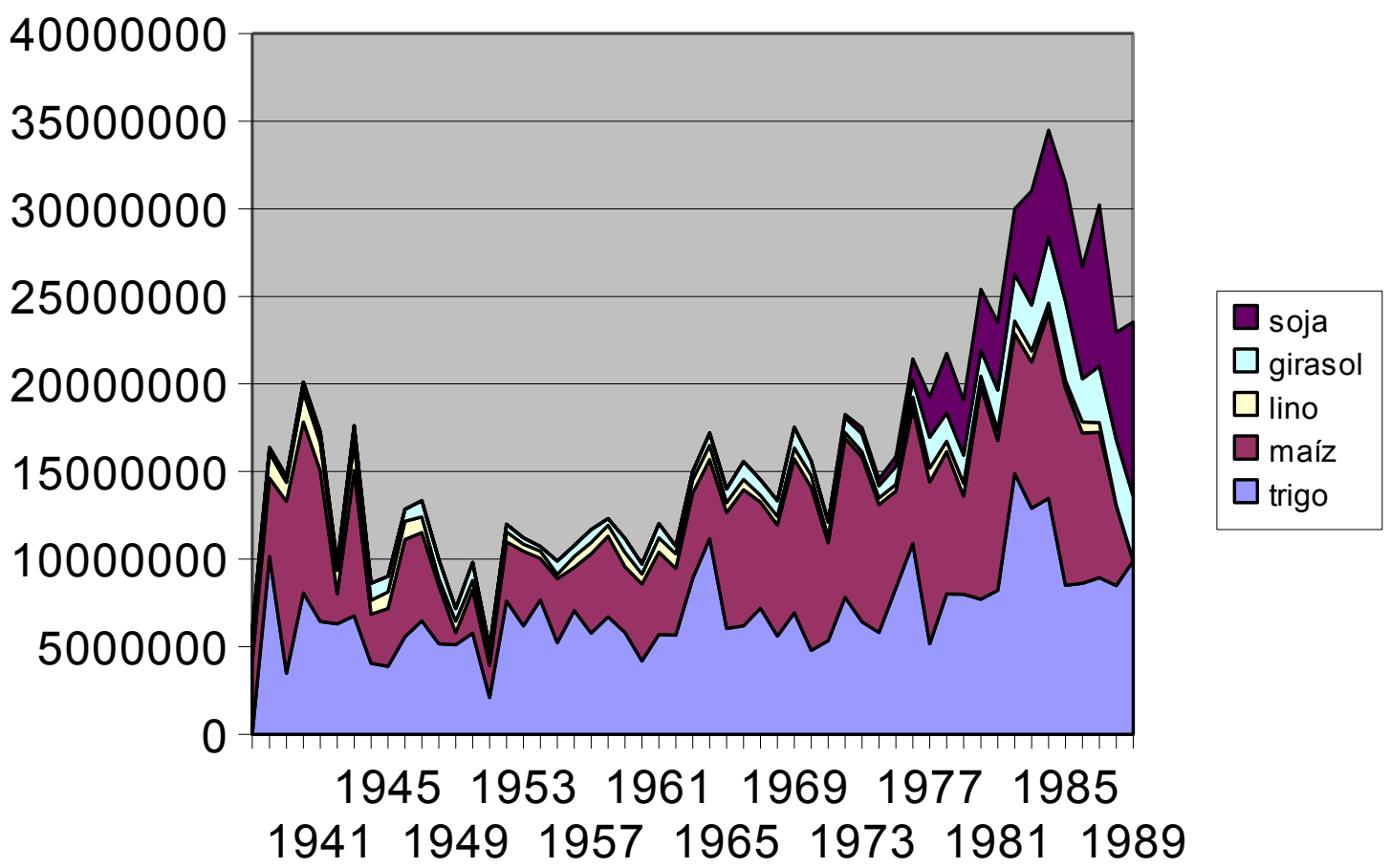


Volumen cosechado. Buenos Aires

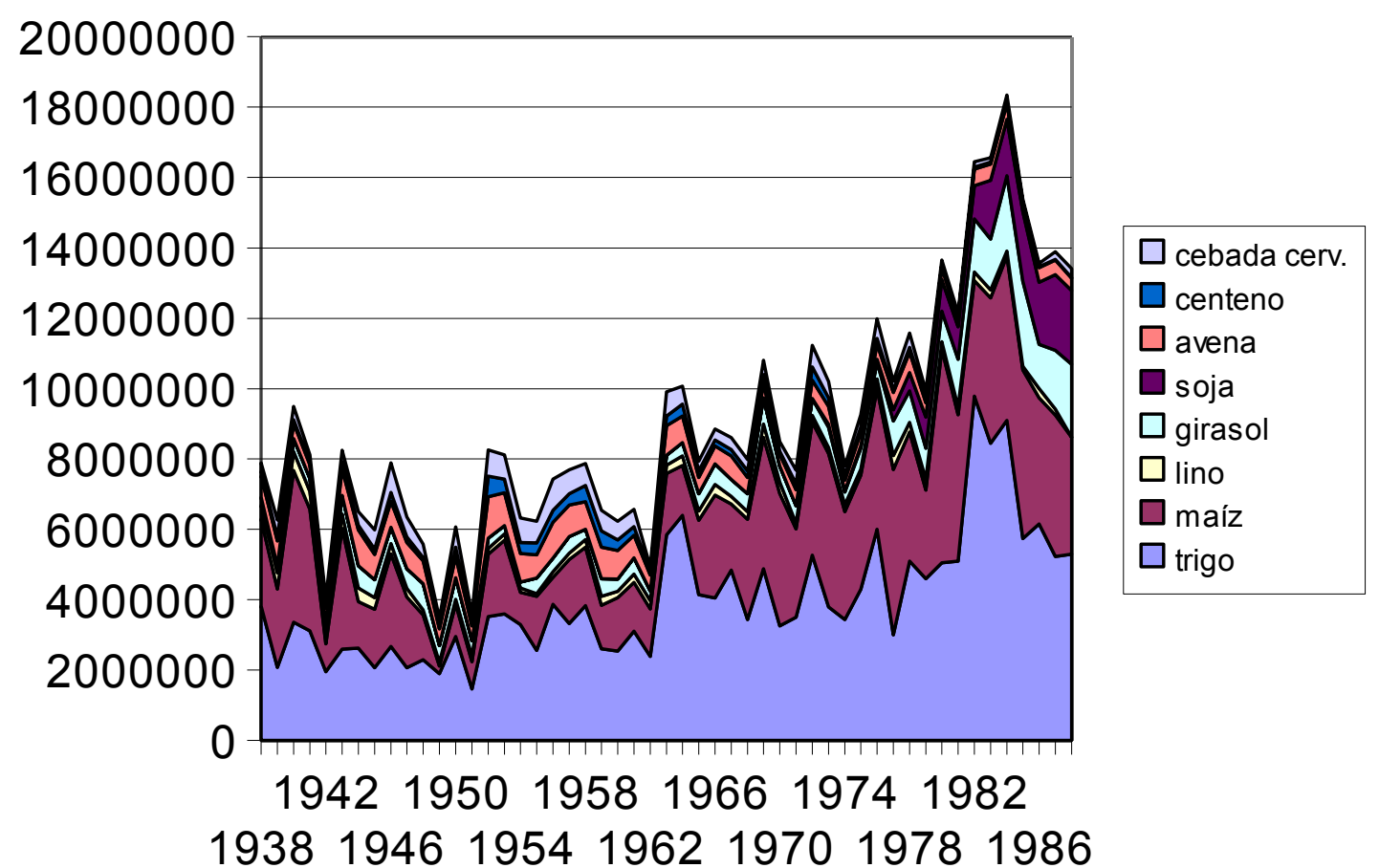


Superficie sembrc 1938/39

\begin{tabular}{|c|c|c|c|c|c|c|c|c|c|}
\hline Zona norte & $1938 / 39$ & 1939 & 1940 & 1941 & 1942 & 1943 & 1944 & 1945 & 1946 \\
\hline trigo & 408175 & 152610 & 275510 & 327523 & 449272 & 372962 & 261192 & 370937 & 352431 \\
\hline maíz & 1226732 & 1124940 & 2193693 & 2095500 & 559300 & 2119455 & 954200 & 1071122 & 1882280 \\
\hline lino & 122924 & 89952 & 150421 & 140754 & 103106 & 128483 & 82181 & 100068 & 83731 \\
\hline girasol & 656 & 1746 & 6127 & 61385 & 15624 & 41343 & 71970 & 66393 & 69554 \\
\hline \multicolumn{10}{|l|}{ soja } \\
\hline avena & 11084 & 5043 & 8528 & 9580 & 10820 & 18526 & 12797 & 16170 & 14936 \\
\hline centeno & 3179 & 838 & 2213 & 2333 & 1460 & 1844 & 1784 & 3194 & 4750 \\
\hline cebada cerv. & 0 & 0 & 0 & 0 & 0 & 0 & 1500 & 0 & 14200 \\
\hline \multicolumn{10}{|l|}{ Zona oeste } \\
\hline trigo & 471325 & 252600 & 387210 & 237483 & 86879 & 157018 & 59082 & 83670 & 195378 \\
\hline maíz & 83613 & 208470 & 544370 & 312293 & 30172 & 153120 & 17550 & 17215 & 111150 \\
\hline lino & 1637 & 1374 & 2228 & 1504 & 834 & 1000 & 2857 & 222 & 597 \\
\hline $\begin{array}{l}\text { girasol } \\
\text { soja }\end{array}$ & 12240 & 22883 & 32250 & 34230 & 24134 & 71470 & 55963 & 34041 & 49613 \\
\hline avena & 51675 & 63504 & 32500 & 27656 & 21027 & 77293 & 17701 & 20130 & 18110 \\
\hline centeno & 53175 & 61930 & 25143 & 27718 & 25287 & 97826 & 37283 & 56950 & 115140 \\
\hline cebada cerv. & 23554 & 50082 & 40080 & 29518 & 15566 & 23327 & 12390 & 30309 & 58084 \\
\hline \multicolumn{10}{|l|}{ Zona sur } \\
\hline trigo & 1260407 & 881702 & 1459600 & 1459180 & 846797 & 1099675 & 1469587 & 871152 & 1240619 \\
\hline maíz & 44330 & 40970 & 30820 & 16160 & 8675 & 17570 & 22350 & 23548 & 13726 \\
\hline lino & 38190 & 82780 & 103867 & 123082 & 108161 & 120361 & 176695 & 113562 & 99690 \\
\hline girasol & 5925 & 6817 & 7179 & 5537 & 4266 & 13774 & 16996 & 12476 & 12461 \\
\hline \multicolumn{10}{|l|}{ soja } \\
\hline avena & 201440 & 299105 & 207600 & 151012 & 214330 & 273605 & 610220 & 356535 & 413385 \\
\hline centeno & 9889 & 8538 & 10283 & 3850 & 8229 & 17323 & 18935 & 24246 & 40897 \\
\hline cebada cerv. & 127837 & 281500 & 227211 & 113890 & 119330 & 207794 & 273881 & 395983 & 530780 \\
\hline \multicolumn{10}{|c|}{ Fuente: Estimaciones Agrícolas de la SEAGyP } \\
\hline & 1476689 & 1293769 & 1828677 & 1717849 & 1087229 & 1459174 & 1959509 & 1416721 & 1897276 \\
\hline
\end{tabular}




\section{Buenos Aires}

\begin{tabular}{|c|c|c|c|c|c|c|c|c|c|}
\hline trigo & 3779920 & 3175489 & 2993200 & 3015035 & 2508171 & 2607950 & 2544900 & 2348055 & 2790260 \\
\hline maíz & 2035000 & 2253000 & 1995000 & 1753000 & 1487408 & 1497501 & 1381380 & 1405176 & 1285925 \\
\hline lino & 816555 & 848396 & 765600 & 746730 & 712188 & 688952 & 504510 & 535961 & 399685 \\
\hline $\begin{array}{l}\text { girasol } \\
\text { soja }\end{array}$ & 212830 & 258000 & 305131 & 368000 & 290600 & 845500 & 796250 & 805474 & 85755 \\
\hline avena & 1055565 & 1046378 & 1147170 & 1042728 & 1539537 & 1717633 & 1612840 & 1335440 & 119157 \\
\hline centeno & 283150 & 257570 & 382120 & 336129 & 533498 & 600297 & 567730 & 538042 & 73794 \\
\hline cebada cerv. & 415570 & 433243 & 413710 & 300627 & 284330 & 246340 & 307680 & 478040 & 83866 \\
\hline & 8598590 & 8272076 & 8001931 & 7562249 & 7355732 & 8204173 & 7715290 & 7446188 & 8101607 \\
\hline & 7259875 & 6968128 & 6472641 & 6183392 & 5282697 & 5886243 & 5534720 & 5572706 & 617209 \\
\hline
\end{tabular}

Región pampeana

trigo

maíz

lino

girasol

soja

avena

centeno

cebada cerv.

\begin{tabular}{|c|c|c|c|c|c|c|c|c|}
\hline 8424230 & 7069663 & 6965000 & 7187841 & 6799919 & 6730470 & 6178600 & 5732935 & 6613660 \\
\hline 4883000 & 6627000 & 5616200 & 4554000 & 3696353 & 4000809 & 3688640 & 3614896 & 3273505 \\
\hline 2680085 & 3051650 & 2850100 & 2705115 & 2459158 & 2265467 & 1985020 & 1860751 & 1901305 \\
\hline 320455 & 476600 & 543131 & 702000 & 621800 & 1515143 & 1442570 & 1602625 & 1573612 \\
\hline 1362315 & 1361638 & 1558360 & 1384718 & 1902527 & 2113355 & 1980460 & 1677640 & 1463402 \\
\hline 949165 & 889025 & 1297730 & 1026527 & 1587025 & 1748280 & 1537830 & 1430907 & 1886052 \\
\hline 525720 & 538003 & 567140 & 388927 & 364911 & 318540 & 375190 & 583775 & 1044313 \\
\hline 197003 & 20013579,04 & 19397661,03 & 17949128,02 & 17431693,03 & 18692064,02 & 17188310,02 & 16503529,03 & 17755849,03 \\
\hline 833490,03 & 17762916,04 & 16541571,03 & 15537883,02 & 13942141,03 & 14830429,02 & 13670020,02 & 13394982,03 & 14406395,03 \\
\hline
\end{tabular}

Control proprcional

\section{Zona norte}

trigo

$11 \%$

$5 \%$

$9 \%$

$11 \%$

$120 \%$

$18 \%$

$14 \%$

$10 \%$

$16 \%$

$13 \%$

maíz

$60 \%$

$50 \%$

$110 \%$

$38 \%$

$142 \%$

$69 \%$

$76 \%$

$146 \%$ 


\begin{tabular}{|c|c|c|c|c|c|c|c|c|c|}
\hline Zona norte & $1938 / 39$ & 1939 & 1940 & 1941 & 1942 & 1943 & 1944 & 1945 & 1946 \\
\hline lino & $15 \%$ & $11 \%$ & $20 \%$ & $19 \%$ & $14 \%$ & $19 \%$ & $16 \%$ & $19 \%$ & $21 \%$ \\
\hline girasol & $0 \%$ & $1 \%$ & $2 \%$ & $17 \%$ & $5 \%$ & $5 \%$ & $9 \%$ & $8 \%$ & $8 \%$ \\
\hline soja & \#DIV/0! & \#DIV/0! & \#DIV/O! & \#DIV/O! & \#DIV/O! & \#DIV/O! & \#DIV/0! & \#DIV/0! & \#DIV/O! \\
\hline avena & $0 \%$ & $1 \%$ & $1 \%$ & $1 \%$ & $1 \%$ & $1 \%$ & $1 \%$ & $1 \%$ & $1 \%$ \\
\hline centeno & $1 \%$ & $0 \%$ & $1 \%$ & $1 \%$ & $0 \%$ & $0 \%$ & $0 \%$ & $1 \%$ & $1 \%$ \\
\hline cebada cerv. & $0 \%$ & $0 \%$ & $0 \%$ & $0 \%$ & $0 \%$ & $0 \%$ & $0 \%$ & $0 \%$ & $2 \%$ \\
\hline \multicolumn{10}{|l|}{ Zona oeste } \\
\hline trigo & $12 \%$ & $8 \%$ & $13 \%$ & $8 \%$ & $3 \%$ & $6 \%$ & $2 \%$ & $4 \%$ & $7 \%$ \\
\hline maíz & $4 \%$ & $9 \%$ & $27 \%$ & $18 \%$ & $2 \%$ & $10 \%$ & $1 \%$ & $1 \%$ & $9 \%$ \\
\hline lino & $0 \%$ & $0 \%$ & $0 \%$ & $0 \%$ & $0 \%$ & $0 \%$ & $1 \%$ & $0 \%$ & $0 \%$ \\
\hline girasol & $6 \%$ & $9 \%$ & $11 \%$ & $9 \%$ & $8 \%$ & $8 \%$ & $7 \%$ & $4 \%$ & $6 \%$ \\
\hline soja & \#DIV/0! & \#DIV/0! & \#DIV/0! & \#DIV/0! & \#DIV/O! & \#DIV/O! & \#DIV/0! & \#DIV/0! & \#DIV/O! \\
\hline avena & $5 \%$ & $6 \%$ & $3 \%$ & $3 \%$ & $1 \%$ & $4 \%$ & $1 \%$ & $2 \%$ & $2 \%$ \\
\hline centeno & $19 \%$ & $24 \%$ & $7 \%$ & $8 \%$ & $5 \%$ & $16 \%$ & $7 \%$ & $11 \%$ & $16 \%$ \\
\hline cebada cerv. & $6 \%$ & $12 \%$ & $10 \%$ & $10 \%$ & $5 \%$ & $9 \%$ & $4 \%$ & $6 \%$ & $7 \%$ \\
\hline \multicolumn{10}{|l|}{ Zona sur } \\
\hline trigo & $33 \%$ & $28 \%$ & $49 \%$ & $48 \%$ & $34 \%$ & $42 \%$ & $58 \%$ & $37 \%$ & $44 \%$ \\
\hline maíz & $2 \%$ & $2 \%$ & $2 \%$ & $1 \%$ & $1 \%$ & $1 \%$ & $2 \%$ & $2 \%$ & $1 \%$ \\
\hline lino & $5 \%$ & $10 \%$ & $14 \%$ & $16 \%$ & $15 \%$ & $17 \%$ & $35 \%$ & $21 \%$ & $25 \%$ \\
\hline girasol & $3 \%$ & $3 \%$ & $2 \%$ & $2 \%$ & $1 \%$ & $2 \%$ & $2 \%$ & $2 \%$ & $1 \%$ \\
\hline soja & \#DIV/0! & \#DIV/O! & \#DIV/0! & \#DIV/O! & \#DIV/O! & \#DIV/O! & \#DIV/O! & \#DIV/O! & \#DIV/O! \\
\hline avena & $19 \%$ & $29 \%$ & $18 \%$ & $14 \%$ & $14 \%$ & $16 \%$ & $38 \%$ & $27 \%$ & $35 \%$ \\
\hline centeno & $3 \%$ & $3 \%$ & $3 \%$ & $1 \%$ & $2 \%$ & $3 \%$ & $3 \%$ & $5 \%$ & $6 \%$ \\
\hline cebada cerv. & $31 \%$ & $65 \%$ & $55 \%$ & $38 \%$ & $42 \%$ & $84 \%$ & $89 \%$ & $83 \%$ & $63 \%$ \\
\hline
\end{tabular}


Superficie sembrz

\begin{tabular}{|c|c|c|c|c|c|c|c|c|c|}
\hline Zona norte & 1947 & 1948 & 1949 & 1950 & 1951 & 1952 & 1953 & 1954 & 1955 \\
\hline trigo & 371927 & 367570 & 534821 & 492510 & 328025 & 492350 & 560800 & 435880 & 484795 \\
\hline maíz & 1459810 & 999770 & 124010 & 580260 & 598944 & 854486 & 1157822 & 438880 & 856807 \\
\hline lino & 37958 & 23073 & 20491 & 18270 & 22361 & 31878 & 16081 & 16856 & 15484 \\
\hline $\begin{array}{l}\text { girasol } \\
\text { soia }\end{array}$ & 82493 & 112895 & 97886 & 93479 & 84941 & 27489 & 18670 & 27904 & 119525 \\
\hline avena & 13701 & 6584 & 8646 & 7470 & 5242 & 12641 & 9072 & 5410 & 5467 \\
\hline $\begin{array}{l}\text { centeno } \\
\text { cebada cerv. }\end{array}$ & 4106 & 2834 & 4736 & 6101 & 3716 & 22195 & 12440 & 5555 & 5870 \\
\hline \multicolumn{10}{|l|}{ Zona oeste } \\
\hline trigo & 116773 & 101185 & 55037 & 150965 & 28150 & 297483 & 189180 & 181500 & 139700 \\
\hline maíz & 51540 & 27210 & 550 & 25320 & 9250 & 119882 & 110155 & 51180 & 58205 \\
\hline lino & 101 & 0 & 3 & 298 & 21 & 103 & 145 & 784 & 1111 \\
\hline $\begin{array}{l}\text { girasol } \\
\text { soja }\end{array}$ & 49070 & 59720 & 22895 & 57620 & 21139 & 30738 & 13240 & 7380 & 32400 \\
\hline avena & 16090 & 19360 & 7670 & 25290 & 4754 & 84139 & 33610 & 28050 & 32905 \\
\hline centeno & 61720 & 50185 & 17376 & 136560 & 19220 & 312405 & 180590 & 156450 & 200700 \\
\hline cebada cerv. & 41560 & 23327 & 14034 & 44853 & 11990 & 74540 & 29480 & 36350 & 37965 \\
\hline \multicolumn{10}{|l|}{ Zona sur } \\
\hline trigo & $\begin{array}{r}920736 \\
13145\end{array}$ & $\begin{array}{r}1235543 \\
8958\end{array}$ & 744768 & $\begin{array}{r}1274640 \\
7813\end{array}$ & 614965 & $\begin{array}{r}1485964 \\
21195\end{array}$ & $\begin{array}{r}1444100 \\
28919\end{array}$ & $\begin{array}{r}1474980 \\
15110\end{array}$ & $\begin{array}{r}1183070 \\
17294\end{array}$ \\
\hline $\begin{array}{l}\text { maíz } \\
\text { lino }\end{array}$ & $\begin{array}{r}13145 \\
123550\end{array}$ & $\begin{array}{r}8958 \\
66013\end{array}$ & $\begin{array}{r}4154 \\
47975\end{array}$ & $\begin{array}{r}7813 \\
74590\end{array}$ & $\begin{array}{r}2207 \\
75807\end{array}$ & 21195 & 28919 & 15110 & $\begin{array}{l}17294 \\
19865\end{array}$ \\
\hline $\begin{array}{l}\text { lino } \\
\text { girasol }\end{array}$ & $\begin{array}{r}123550 \\
10746\end{array}$ & 18472 & $\begin{array}{l}4 / 915 \\
12569\end{array}$ & $\begin{array}{l}74590 \\
14765\end{array}$ & 75807 & 61592 & 62210 & 41640 & 19865 \\
\hline $\begin{array}{l}\text { girasol } \\
\text { soja }\end{array}$ & $10 / 46$ & & 12509 & $14 / 65$ & 6999 & 14202 & $11 / 2$ & 6360 & 11493 \\
\hline avena & 470235 & 399135 & 271155 & 281560 & 234319 & 510770 & 428980 & 410650 & 336080 \\
\hline centeno & 27690 & 18867 & 10623 & 24010 & 9259 & 47345 & 30236 & 24740 & 25380 \\
\hline cebada cerv. & 359855 & 274985 & 152473 & 375920 & 178637 & 392110 & 352210 & 397240 & 316450 \\
\hline & 1428032 & 1603971 & 961939 & 1747728 & 878615 & 1975063 & 1894671 & 1935330 & 1548172 \\
\hline
\end{tabular}




\section{Buenos Aires}

\begin{tabular}{|c|c|c|c|c|c|c|c|c|c|}
\hline trigo & 2113100 & 2430000 & 2201300 & 2833500 & 2487300 & 2981400 & 3202500 & 2791500 & 2402700 \\
\hline maíz & 1151735 & 969590 & 771950 & 810930 & 785390 & 1257072 & 1298395 & 1181664 & 1078970 \\
\hline lino & 430120 & 337800 & 180600 & 200900 & 241100 & 284200 & 228200 & 225000 & 195500 \\
\hline girasol & 881325 & 1017365 & 847700 & 874963 & 867575 & 511870 & 319350 & 304775 & 749090 \\
\hline \multicolumn{10}{|l|}{ soja } \\
\hline avena & 1047700 & 1110000 & 965870 & 989500 & 982500 & 1474500 & 1273000 & 1117900 & 1146500 \\
\hline centeno & 595950 & 643800 & 609350 & 707200 & 735800 & 1050400 & 887300 & 834400 & 913300 \\
\hline \multirow[t]{3}{*}{ cebada cerv. } & 586450 & 515000 & 424180 & 500300 & 499400 & 630800 & 629100 & 570400 & 649700 \\
\hline & 6806380 & 7023555 & 6000950 & 6917293 & 6599065 & 8190242 & 7837845 & 7025639 & 7135760 \\
\hline & 5162730 & 5269755 & 4425730 & 5220593 & 4880765 & 5665342 & 5677545 & 5073339 & 5075960 \\
\hline \multicolumn{10}{|c|}{ Región pampeanć } \\
\hline trigo & 5413400 & 5778100 & 5665100 & 6534800 & 4771700 & 6039800 & 6318000 & 5911100 & 5181200 \\
\hline maíz & 3009035 & 2400590 & 1899620 & 2180130 & 2310390 & 3044472 & 2985445 & 2736114 & 2612210 \\
\hline lino & 1569670 & 1302900 & 1075820 & 1082700 & 640800 & 1018700 & 730600 & 736900 & 672100 \\
\hline \multicolumn{10}{|l|}{ soja } \\
\hline avena & 1290895 & 1364100 & 1201620 & 1282100 & 1163900 & 1677500 & 1468800 & 1344500 & 1418400 \\
\hline centeno & 1710420 & 1777500 & 1785270 & 2116200 & 1946030 & 2422550 & 2369220 & 2414950 & 2492250 \\
\hline \multirow[t]{3}{*}{ cebada cerv. } & 773760 & 695490 & 571580 & 638360 & 654520 & 849326 & 831900 & 814602 & 960700 \\
\hline & 15264907,03 & 15107350,03 & 13673560,04 & 15453423,03 & 13085838,03 & 15866658,04 & 15269225,03 & 14513576,05 & 14729430,03 \\
\hline & 12263592,03 & 11965750,03 & 10686670,04 & 12055123,03 & 9975908,03 & 11766608,04 & 11431205,03 & 10754126,05 & 10818780,03 \\
\hline
\end{tabular}

Control proprciona

\section{Zona norte}

trigo 


\begin{tabular}{|c|c|c|c|c|c|c|c|c|c|}
\hline Zona norte & 1947 & 1948 & 1949 & 1950 & 1951 & 1952 & 1953 & 1954 & 1955 \\
\hline lino & $9 \%$ & $7 \%$ & $11 \%$ & $9 \%$ & $9 \%$ & $11 \%$ & $7 \%$ & $7 \%$ & $8 \%$ \\
\hline girasol & $9 \%$ & $11 \%$ & $12 \%$ & $11 \%$ & $10 \%$ & $5 \%$ & $6 \%$ & $9 \%$ & $16 \%$ \\
\hline soja & \#DIV/O! & \#DIV/O! & \#DIV/O! & \#DIV/O! & \#DIV/O! & \#DIV/0! & \#DIV/O! & \#DIV/O! & \#DIV/O! \\
\hline avena & $1 \%$ & $1 \%$ & $1 \%$ & $1 \%$ & $1 \%$ & $1 \%$ & $0 \%$ & $0 \%$ & $1 \%$ \\
\hline centeno & $1 \%$ & $0 \%$ & $1 \%$ & $1 \%$ & $1 \%$ & $2 \%$ & $1 \%$ & $1 \%$ & $1 \%$ \\
\hline cebada cerv. & $0 \%$ & $0 \%$ & $0 \%$ & $0 \%$ & $0 \%$ & $0 \%$ & $0 \%$ & $0 \%$ & $0 \%$ \\
\hline \multicolumn{10}{|l|}{ Zona oeste } \\
\hline trigo & $6 \%$ & $4 \%$ & $3 \%$ & $5 \%$ & $1 \%$ & $10 \%$ & $6 \%$ & $7 \%$ & $6 \%$ \\
\hline maíz & $4 \%$ & $3 \%$ & $0 \%$ & $3 \%$ & $1 \%$ & $10 \%$ & $8 \%$ & $4 \%$ & $5 \%$ \\
\hline lino & $0 \%$ & $0 \%$ & $0 \%$ & $0 \%$ & $0 \%$ & $0 \%$ & $0 \%$ & $0 \%$ & $1 \%$ \\
\hline girasol & $6 \%$ & $6 \%$ & $3 \%$ & $7 \%$ & $2 \%$ & $6 \%$ & $4 \%$ & $2 \%$ & $4 \%$ \\
\hline soja & \#DIV/O! & \#DIV/0! & \#DIV/0! & \#DIV/O! & \#DIV/0! & \#DIV/0! & \#DIV/0! & \#DIV/O! & \#DIV/0! \\
\hline avena & $2 \%$ & $2 \%$ & $1 \%$ & $3 \%$ & $0 \%$ & $6 \%$ & $3 \%$ & $3 \%$ & $3 \%$ \\
\hline centeno & $10 \%$ & $8 \%$ & $3 \%$ & $19 \%$ & $3 \%$ & $30 \%$ & $20 \%$ & $19 \%$ & $22 \%$ \\
\hline cebada cerv. & $7 \%$ & $5 \%$ & $3 \%$ & $9 \%$ & $2 \%$ & $12 \%$ & $5 \%$ & $6 \%$ & $6 \%$ \\
\hline \multicolumn{10}{|l|}{ Zona sur } \\
\hline trigo & $44 \%$ & $51 \%$ & $34 \%$ & $45 \%$ & $25 \%$ & $50 \%$ & $45 \%$ & $53 \%$ & $49 \%$ \\
\hline maíz & $1 \%$ & $1 \%$ & $1 \%$ & $1 \%$ & $0 \%$ & $2 \%$ & $2 \%$ & $1 \%$ & $2 \%$ \\
\hline lino & $29 \%$ & $20 \%$ & $27 \%$ & $37 \%$ & $31 \%$ & $22 \%$ & $27 \%$ & $19 \%$ & $10 \%$ \\
\hline girasol & $1 \%$ & $2 \%$ & $1 \%$ & $2 \%$ & $1 \%$ & $3 \%$ & $2 \%$ & $2 \%$ & $2 \%$ \\
\hline soja & \#DIV/0! & \#DIV/0! & \#DIV/0! & \#DIV/O! & \#DIV/0! & \#DIV/0! & \#DIV/0! & \#DIV/O! & \#DIV/0! \\
\hline avena & $45 \%$ & $36 \%$ & $28 \%$ & $28 \%$ & $24 \%$ & $35 \%$ & $34 \%$ & $37 \%$ & $29 \%$ \\
\hline centeno & $5 \%$ & $3 \%$ & $2 \%$ & $3 \%$ & $1 \%$ & $5 \%$ & $3 \%$ & $3 \%$ & $3 \%$ \\
\hline cebada cerv. & $61 \%$ & $53 \%$ & $36 \%$ & $75 \%$ & $36 \%$ & $62 \%$ & $56 \%$ & $70 \%$ & $49 \%$ \\
\hline
\end{tabular}


Superficie sembrz

\section{Zona norte}

trigo

maíz

lino

girasol

soja

avena

centeno

cebada cerv.

\section{Zona oeste}

trigo

maíz

lino

girasol

soja

avena

centeno

cebada cerv.

\section{Zona sur}

trigo

maíz

lino

girasol

soja

avena

centeno

cebada cerv.

Fuente: Estimacic
1956

567694

480825

22535

100990

12046

9975

280740

30550

1860

27912

97780

169200

68855

134200

77200

603

39416

71250

145600

29120

1693530

19428

64951

34647

431430

25774

471220

1742525
26845

86263

44035

431220

35590

390590
1959

374105

773250

17053

144645

16456

20639

18170

270680

161920

40010

644

41495

67115

267750

36880

64630
28470

179

14300

43445

143700

27310

1191720

13620

135954

25736

1149820

18565

88479

14724

407775

22560

390300

27250

34857

319825

253065

229065

2199285

1620095

$1500653 \quad 1717556,25$

1962

707900

923540

17719

78282

22440

19770

18205

65580

31940

22660

406130

52060

304

23895

40670

140440

26682

17554

44400

20890

37600

11840

1325470

17405

113000

670550

10540

88750

7343

2656507

28850

112215

23917

159750

5212

447030

31540

458436

50876

45836

828059

3279925

3087928
555788

1964

957925

916713

18629

94218

18385

22359

235

22499

54555

192125

31502

2652971

26551

114350

28047

367532

25787

266009 


\section{Buenos Aires}

\begin{tabular}{|c|c|c|c|c|c|c|c|c|c|}
\hline trigo & 2860700 & 2625700 & 2975600 & 2370300 & 2214500 & 2430500 & 2185500 & 3350400 & 3407200 \\
\hline maíz & 965650 & 999100 & 966360 & 960000 & 935000 & 940000 & 872000 & 890000 & 850800 \\
\hline lino & 239400 & 291600 & 315600 & 362800 & 319500 & 351400 & 348400 & 344500 & 333300 \\
\hline $\begin{array}{l}\text { girasol } \\
\text { soja }\end{array}$ & 732300 & 1074850 & 888900 & 823000 & 684700 & 749000 & 577000 & 528000 & 59190 \\
\hline avena & 1431900 & 1387400 & 1329000 & 1318700 & 1310700 & 1100200 & 883900 & 1126000 & 88960 \\
\hline centeno & 810900 & 861300 & 948100 & 986500 & 910000 & 727300 & 740800 & 680500 & 6240 \\
\hline cebada cerv. & 701800 & 620700 & 634400 & 595600 & 551300 & 494400 & 538400 & 511500 & 37620 \\
\hline & 7742650 & 7860650 & 8057960 & 7416900 & 6925700 & 6792800 & 6146000 & 7430900 & 7073000 \\
\hline & 5499850 & 5611950 & 5780860 & 5111700 & 4705000 & 4965300 & 4521300 & 5624400 & 5559400 \\
\hline
\end{tabular}

Región pampeané

trigo
maíz
lino
girasol
soja
avena
centeno
cebada cerv.

\begin{tabular}{|c|c|c|c|c|c|c|c|c|}
\hline 5912400 & 5279000 & 5674300 & 4756400 & 4241700 & 4913000 & 4803000 & 6222000 & 6421900 \\
\hline 2394500 & 2508600 & 2508360 & 2634500 & 2718700 & 2788100 & 2800000 & 3043000 & 3008500 \\
\hline 1277100 & 1440400 & 1197150 & 1218300 & 1121800 & 1298300 & 1496650 & 1406200 & 1169000 \\
\hline 1194130 & 1636410 & 1323700 & 1231420 & 1100100 & 1304200 & 942720 & 857850 & 1120520 \\
\hline 1854600 & 1889300 & 1767700 & 1599850 & 1562000 & 1382800 & 1113650 & 1354100 & 1107800 \\
\hline 2711675 & 2768710 & 2745650 & 2806500 & 2569900 & 2550700 & 2379000 & 2084070 & 2051060 \\
\hline 1035930 & 925960 & 961050 & 917700 & 837500 & 785460 & 766900 & 701720 & 535740 \\
\hline 80335,07 & 16448380,07 & 16177910,09 & 15164670,08 & 14151700,04 & 15022560,04 & 14301920,04 & 15668940,06 & 15414520,07 \\
\hline 814060,07 & 11790370,07 & 11664560,09 & 10758320,08 & 10019800,04 & 11089060,04 & 10809270,04 & 12230770,06 & 12255660,07 \\
\hline
\end{tabular}

Control proprcion:

\section{Zona norte}

trigo 


\begin{tabular}{|c|c|c|c|c|c|c|c|c|c|}
\hline Zona norte & 1956 & 1957 & 1958 & 1959 & 1960 & 1961 & 1962 & 1963 & 1964 \\
\hline lino & $9 \%$ & $5 \%$ & $5 \%$ & $5 \%$ & $5 \%$ & $5 \%$ & $5 \%$ & $4 \%$ & $6 \%$ \\
\hline girasol & $14 \%$ & $11 \%$ & $7 \%$ & $18 \%$ & $13 \%$ & $17 \%$ & $14 \%$ & $15 \%$ & $16 \%$ \\
\hline soja & \#DIV/O! & \#DIV/O! & \#DIV/O! & \#DIV/O! & \#DIV/O! & \#DIV/0! & \#DIV/O! & \#DIV/O! & \#DIV/O! \\
\hline avena & $1 \%$ & $1 \%$ & $1 \%$ & $1 \%$ & $1 \%$ & $2 \%$ & $2 \%$ & $2 \%$ & $1 \%$ \\
\hline centeno & $1 \%$ & $1 \%$ & $2 \%$ & $2 \%$ & $2 \%$ & $3 \%$ & $3 \%$ & $3 \%$ & $4 \%$ \\
\hline cebada cerv. & $0 \%$ & $0 \%$ & $0 \%$ & $0 \%$ & $0 \%$ & $0 \%$ & $0 \%$ & $0 \%$ & $0 \%$ \\
\hline \multicolumn{10}{|l|}{ Zona oeste } \\
\hline trigo & $10 \%$ & $5 \%$ & $9 \%$ & $7 \%$ & $3 \%$ & $3 \%$ & $5 \%$ & $12 \%$ & $16 \%$ \\
\hline maíz & $3 \%$ & $8 \%$ & $8 \%$ & $4 \%$ & $3 \%$ & $3 \%$ & $3 \%$ & $6 \%$ & $5 \%$ \\
\hline lino & $1 \%$ & $0 \%$ & $0 \%$ & $0 \%$ & $0 \%$ & $0 \%$ & $0 \%$ & $0 \%$ & $0 \%$ \\
\hline girasol & $4 \%$ & $4 \%$ & $3 \%$ & $5 \%$ & $2 \%$ & $2 \%$ & $2 \%$ & $5 \%$ & $4 \%$ \\
\hline soja & \#DIV/O! & \#DIV/O! & \#DIV/0! & \#DIV/O! & \#DIV/0! & \#DIV/0! & \#DIV/0! & \#DIV/O! & \#DIV/O! \\
\hline avena & $7 \%$ & $5 \%$ & $6 \%$ & $5 \%$ & $3 \%$ & $4 \%$ & $3 \%$ & $4 \%$ & $6 \%$ \\
\hline centeno & $21 \%$ & $17 \%$ & $25 \%$ & $27 \%$ & $16 \%$ & $16 \%$ & $5 \%$ & $21 \%$ & $31 \%$ \\
\hline cebada cerv. & $10 \%$ & $5 \%$ & $6 \%$ & $6 \%$ & $5 \%$ & $4 \%$ & $2 \%$ & $5 \%$ & $8 \%$ \\
\hline \multicolumn{10}{|l|}{ Zona sur } \\
\hline trigo & $59 \%$ & $66 \%$ & $58 \%$ & $50 \%$ & $52 \%$ & $55 \%$ & $31 \%$ & $79 \%$ & $78 \%$ \\
\hline maíz & $2 \%$ & $3 \%$ & $2 \%$ & $1 \%$ & $2 \%$ & $2 \%$ & $1 \%$ & $3 \%$ & $3 \%$ \\
\hline lino & $27 \%$ & $30 \%$ & $34 \%$ & $37 \%$ & $28 \%$ & $32 \%$ & $25 \%$ & $33 \%$ & $34 \%$ \\
\hline girasol & $5 \%$ & $4 \%$ & $4 \%$ & $3 \%$ & $2 \%$ & $2 \%$ & $1 \%$ & $5 \%$ & $5 \%$ \\
\hline soja & \#DIV/0! & \#DIV/0! & \#DIV/0! & \#DIV/O! & \#DIV/0! & \#DIV/0! & \#DIV/0! & \#DIV/O! & \#DIV/O! \\
\hline avena & $30 \%$ & $31 \%$ & $25 \%$ & $31 \%$ & $30 \%$ & $26 \%$ & $18 \%$ & $40 \%$ & $41 \%$ \\
\hline centeno & $3 \%$ & $4 \%$ & $4 \%$ & $2 \%$ & $3 \%$ & $3 \%$ & $1 \%$ & $5 \%$ & $4 \%$ \\
\hline cebada cerv. & $67 \%$ & $63 \%$ & $50 \%$ & $42 \%$ & $42 \%$ & $50 \%$ & $9 \%$ & $90 \%$ & $71 \%$ \\
\hline
\end{tabular}


Superficie sembrz

\section{Zona norte}

trigo

maíz

lino

girasol

soja

avena

centeno

cebada cerv.

\section{Zona oeste}

trigo

maíz

lino

girasol

soja

avena

centeno

cebada cerv.

\section{Zona sur}

trigo

maíz

lino

girasol

soja

avena

centeno

cebada cerv.

Fuente: Estimacic

1965
666615
1442925
18158
116275

12980
14635

1966
497782
2010474

2010474

14302

161335

14638

9035

\section{5}

54230

205826

142890

34050

37160

140150

14445

144

37150

34118

131325

7170

449020
75320
468
27515

79985
126390
18665

255500

80085

210

29053

47360

139554

12190

1956155

41520

115485

2100110

39176

171212

42545

2275149

34750

118285

47612

201830

247573

12510

129631

222159

287125

15200

222458

1530300

45450

77212

44000

215858

8060

217101

2137980,5

1914063

1969
321875
2252650
13662
113425
1600
8370
10105

1970

333700

2310880

53037

79600

1600

6225

3000

393800
145100

112
44300

0

23375

192120

12720

141600
91759

0

34600

8860

60170

6190

2447547

98615

159500

75354

0115

180115
11930

270450

3243511

3051466
1394650
32290

141925

55700

130355

4590

172065

1931575

1796630
167300
56035

308500
91400

1971
254350
1493500
36300
67927
1958
8200
1870

1972

405600

2354421

44877

69829

6096

7350

1150

28600

0

37890

105850

20470

1657700

49810

49340

121730

175005

14946

258724

2327255

2137304

$\begin{array}{rr}0 & 855 \\ 38150 & 23757 \\ 0 & 7326 \\ 48750 & 58700 \\ 249648 & 152045 \\ 38430 & 26600\end{array}$

2612750

97210

46120

103276

189

206320

17423

395714

3479002

3255259
232950

1973

153530

2468000

32887

51113

66490

2255

665

2132600

62320

48580

218225

215215

22670

334750

3035068

2797183 


\section{Zona norte}

Buenos Aires

trigo

maíz

lino

girasol

soja

avena

centeno

cebada cerv.
1965

1966

1967

1969

3796300
1076700
318200
634800

917800
641800
317200
7702800
6143200

3621700

1173700

392600

788100

980000

695000

337600

7988700

6313700

6950300

7380100

5870900

6143200

Región pampeanc

trigo

maíz

lino

girasol

soja

avena

centeno

cebada cerv.

$$
\begin{array}{r}
3449000 \\
1340000 \\
464200 \\
865600 \\
1270 \\
811900 \\
733100 \\
323700 \\
7988770 \\
6443770
\end{array}
$$

\begin{tabular}{|c|c|c|c|c|c|c|c|c|}
\hline 5651800 & 6215000 & 6492400 & 6523200 & 6105200 & 4343200 & 4850150 & 5495600 & 4134200 \\
\hline 3340500 & 3587700 & 3765300 & 3872600 & 4030000 & 4315200 & 3847600 & 3684800 & 3616700 \\
\hline 1290250 & 919050 & 707800 & 874200 & 947400 & 968450 & 534500 & 507180 & 413420 \\
\hline \multirow[t]{2}{*}{1110700} & 1292230 & 1137150 & 1329000 & 1456650 & 1524650 & 1482300 & 1573050 & 1378420 \\
\hline & & & & 10070 & 11900 & 39380 & 107185 & 284200 \\
\hline 1090300 & 1114900 & 1166500 & 1266800 & 1097000 & 995050 & 1067150 & 1188100 & 1117800 \\
\hline 2071150 & 2213200 & 2244900 & 2437800 & 2433650 & 1928550 & 2152650 & 2469790 & 2433700 \\
\hline 539010 & 552480 & 512650 & 469450 & 517200 & 406300 & 483900 & 545140 & 451400 \\
\hline 08 & 15894560,09 & 16026700,11 & 16773050,1 & 16597170,08 & 14493300,11 & 14457630,18 & 15570845,19 & 13829840,32 \\
\hline 932260,08 & 12566460,09 & 12615300,11 & 13068450,1 & 13066520,08 & 11569700,11 & 11237830,18 & 11912955,19 & 10278340,32 \\
\hline
\end{tabular}

Control proprcion:

\section{Zona norte}

trigo

$21 \%$

$15 \%$

$10 \%$

$190 \%$

$117 \%$

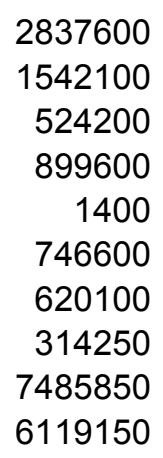

7485850

6119150

3150000

1284700

234500

856700

5185

861300

743500

401840

7537725

5932925
2450400

1348500

231400

731070

57100

810800

651000

316600

6596870

5135070

maíz

$155 \%$

$9 \%$
$160 \%$

$9 \%$

$12 \%$

$9 \%$
$112 \%$

$13 \%$

$183 \%$

$6 \%$

$183 \%$ 


\begin{tabular}{|c|c|c|c|c|c|c|c|c|c|}
\hline Zona norte & 1965 & 1966 & 1967 & 1968 & 1969 & 1970 & 1971 & 1972 & 1973 \\
\hline lino & $5 \%$ & $4 \%$ & $2 \%$ & $3 \%$ & $3 \%$ & $10 \%$ & $14 \%$ & $19 \%$ & $14 \%$ \\
\hline girasol & $19 \%$ & $23 \%$ & $11 \%$ & $12 \%$ & $13 \%$ & $9 \%$ & $9 \%$ & $8 \%$ & $7 \%$ \\
\hline soja & \#DIV/O! & \#DIV/O! & \#DIV/0! & \#DIV/0! & $126 \%$ & $114 \%$ & $124 \%$ & $118 \%$ & $116 \%$ \\
\hline avena & $2 \%$ & $2 \%$ & $1 \%$ & $1 \%$ & $1 \%$ & $1 \%$ & $1 \%$ & $0 \%$ & $0 \%$ \\
\hline centeno & $2 \%$ & $1 \%$ & $2 \%$ & $2 \%$ & $1 \%$ & $0 \%$ & $0 \%$ & $0 \%$ & $0 \%$ \\
\hline cebada cerv. & $0 \%$ & $0 \%$ & $0 \%$ & $0 \%$ & $0 \%$ & $0 \%$ & $0 \%$ & $0 \%$ & $0 \%$ \\
\hline \multicolumn{10}{|l|}{ Zona oeste } \\
\hline trigo & $7 \%$ & $6 \%$ & $12 \%$ & $7 \%$ & $11 \%$ & $5 \%$ & $6 \%$ & $10 \%$ & $10 \%$ \\
\hline maíz & $6 \%$ & $13 \%$ & $7 \%$ & $7 \%$ & $11 \%$ & $6 \%$ & $4 \%$ & $7 \%$ & $15 \%$ \\
\hline lino & $0 \%$ & $0 \%$ & $0 \%$ & $0 \%$ & $0 \%$ & $0 \%$ & $0 \%$ & $0 \%$ & $0 \%$ \\
\hline girasol & $5 \%$ & $5 \%$ & $4 \%$ & $4 \%$ & $5 \%$ & $4 \%$ & $4 \%$ & $4 \%$ & $3 \%$ \\
\hline soja & \#DIV/0! & \#DIV/0! & \#DIV/0! & \#DIV/O! & $0 \%$ & $0 \%$ & $0 \%$ & $0 \%$ & $13 \%$ \\
\hline avena & $4 \%$ & $4 \%$ & $9 \%$ & $5 \%$ & $3 \%$ & $1 \%$ & $5 \%$ & $6 \%$ & $7 \%$ \\
\hline centeno & $22 \%$ & $21 \%$ & $20 \%$ & $20 \%$ & $26 \%$ & $10 \%$ & $16 \%$ & $34 \%$ & $23 \%$ \\
\hline cebada cerv. & $4 \%$ & $2 \%$ & $6 \%$ & $4 \%$ & $4 \%$ & $2 \%$ & $6 \%$ & $10 \%$ & $8 \%$ \\
\hline \multicolumn{10}{|l|}{ Zona sur } \\
\hline trigo & $63 \%$ & $61 \%$ & $60 \%$ & $42 \%$ & $71 \%$ & $49 \%$ & $56 \%$ & $83 \%$ & $87 \%$ \\
\hline maíz & $4 \%$ & $4 \%$ & $3 \%$ & $4 \%$ & $7 \%$ & $2 \%$ & $4 \%$ & $8 \%$ & $5 \%$ \\
\hline lino & $31 \%$ & $53 \%$ & $37 \%$ & $20 \%$ & $34 \%$ & $27 \%$ & $20 \%$ & $20 \%$ & $21 \%$ \\
\hline girasol & $6 \%$ & $6 \%$ & $8 \%$ & $6 \%$ & $9 \%$ & $6 \%$ & $15 \%$ & $12 \%$ & $30 \%$ \\
\hline soja & \#DIV/0! & \#DIV/O! & \#DIV/0! & \#DIV/O! & $0 \%$ & $0 \%$ & $0 \%$ & $4 \%$ & $1 \%$ \\
\hline avena & $23 \%$ & $28 \%$ & $31 \%$ & $22 \%$ & $22 \%$ & $17 \%$ & $22 \%$ & $24 \%$ & $27 \%$ \\
\hline centeno & $1 \%$ & $2 \%$ & $2 \%$ & $1 \%$ & $2 \%$ & $1 \%$ & $2 \%$ & $2 \%$ & $3 \%$ \\
\hline cebada cerv. & $35 \%$ & $61 \%$ & $70 \%$ & $64 \%$ & $84 \%$ & $55 \%$ & $73 \%$ & $98 \%$ & $106 \%$ \\
\hline
\end{tabular}


Superficie sembrz

\section{Zona norte}

trigo

maíz

lino

girasol

soja

avena

centeno

cebada cerv.

\section{Zona oeste}

trigo

maíz

lino

girasol

soja

avena

centeno

cebada cerv.

\section{Zona sur}

trigo

maíz

lino

girasol

soja

avena

centeno

cebada cerv.

Fuente: Estimacic

$\begin{array}{rr}1974 & 1975 \\ 271600 & 330450 \\ 1942790 & 1714453 \\ 44788 & 46920 \\ 39461 & 50652 \\ 26256 & 55849 \\ 1905 & 1400 \\ 600 & 780\end{array}$

1976

316980
2143178

41148

36621

65988

1260

700

324000
155500
770
9945
2078
23330
81700
19360

$$
\begin{array}{r}
440600 \\
116600 \\
0 \\
24055 \\
1136 \\
43980 \\
80280 \\
32970
\end{array}
$$

527730
181540
440
38370
1360
34440
67575
29180

$$
\begin{array}{r}
191000 \\
297500 \\
1459 \\
89135 \\
14030 \\
49840 \\
39000 \\
13406
\end{array}
$$

1697500

38520

46075

129068

314

140520

9148

187995

2249140

2099472

1889400
38911
31238
142294
368
153525
16135
234400

2506271
2336611

\section{9}

125860

53497

138664

36

225840

30875

430470

4039271

3782556

$\begin{array}{rr}1469500 & 2651305 \\ 129900 & 73450 \\ 116959 & 91486 \\ 323654 & 273500 \\ 583 & 1255 \\ 271107 & 239625 \\ 17724 & 27935 \\ 144510 & 263883 \\ & \\ 2473937 & 3622439 \\ 2185106 & 3354879\end{array}$

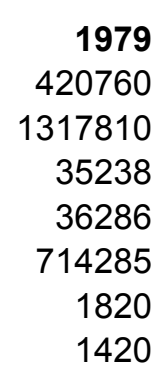

491250

216120

3494

109315

56806

76185

70640

26900

2276300
36970
89700

89700
244790

485

215000

15608

147068

3025921

2795313

1980
905500
2446237
28209
40847
664300
4310
1654

1981

930000

1894630

20835

30000

750423

3535

714

455500

694450

1669

103710

73000

35500

36396

9440

578900

352350

3378

217750

48850

39790

29760

13525

2178900

213700

75085

273225

455

182750

17490

103385

3044990

2844750
1570320

89230

49445

409900

280

101640

3315

53262

2277392

2172437
1982

1316000

1182400

13947

37700

774700

3790

1930

1038290

306040

4010

186300

59450

84240

32235

12080

4232000

133150

66660

491580

242600

5950

114214

5286384

5037834 


\section{Zona norte}

1974

1975

1977

1979

1980

1981

1982

Buenos Aires

trigo

maíz

lino

girasol

soja

avena

centeno

cebada cerv.

$\begin{array}{rr}2866000 & 3133000 \\ 1396000 & 1402500 \\ 234400 & 214200 \\ 653900 & 725400 \\ 30400 & 43500 \\ 849400 & 899300 \\ 647000 & 594700 \\ 270600 & 316300 \\ 6947700 & 7328900 \\ 5451300 & 5834900\end{array}$

3884000
1220000
321800
800000
52000
920500
550200
361000
8109500
6638800

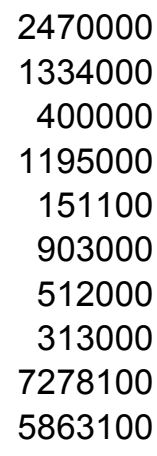

3040000

1330000

306000

981000

262000

834000

513000

250000

7516000

6169000

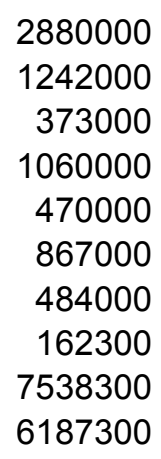

3262000

1500000

257600

811000

456000

809000

462200

107200

7665000

6393800

3940000

1281500

288700

1090000

462300

806400

432100

102700

8403700

7165200

4446000

1075000

280000

1120000

650000

860000

384500

77000

8892500

7648000

Región pampeanć

trigo

5054000

4480000

5125000

4908100

6081000

6494000

3146200

849300

884350

944530

2314300

1357570

369800

717260

1521100

600000

1041400

1902400

296600

1300600

2317030

1429000

2201200

1436000

2043000

1439300

2293080

435050

465100

425500

1481000

1618000

325900

2837000

3480900

779100

2037950

1860850

1525450

1760100

1975650

1872850

1575500

1259200

137000
309700,33

216200

1401500

171350

$11422070,3 \quad 12925460,25 \quad 11935730,34$ 


\begin{tabular}{|c|c|c|c|c|c|c|c|c|c|}
\hline Zona norte & 1974 & 1975 & 1976 & 1977 & 1978 & 1979 & 1980 & 1981 & 1982 \\
\hline lino & $19 \%$ & $22 \%$ & $13 \%$ & $16 \%$ & $12 \%$ & $9 \%$ & $11 \%$ & $7 \%$ & $5 \%$ \\
\hline girasol & $6 \%$ & $7 \%$ & $5 \%$ & $5 \%$ & $4 \%$ & $3 \%$ & $5 \%$ & $3 \%$ & $3 \%$ \\
\hline soja & $86 \%$ & $128 \%$ & $127 \%$ & $173 \%$ & $163 \%$ & $152 \%$ & $146 \%$ & $162 \%$ & $119 \%$ \\
\hline avena & $0 \%$ & $0 \%$ & $0 \%$ & $0 \%$ & $0 \%$ & $0 \%$ & $0 \%$ & $0 \%$ & $0 \%$ \\
\hline centeno & $0 \%$ & $0 \%$ & $0 \%$ & $0 \%$ & $0 \%$ & $0 \%$ & $0 \%$ & $0 \%$ & $1 \%$ \\
\hline cebada cerv. & $0 \%$ & $0 \%$ & $0 \%$ & $0 \%$ & $0 \%$ & $0 \%$ & $0 \%$ & $0 \%$ & $0 \%$ \\
\hline \multicolumn{10}{|l|}{ Zona oeste } \\
\hline trigo & $11 \%$ & $14 \%$ & $14 \%$ & $8 \%$ & $13 \%$ & $17 \%$ & $14 \%$ & $15 \%$ & $23 \%$ \\
\hline maíz & $11 \%$ & $8 \%$ & $15 \%$ & $22 \%$ & $29 \%$ & $17 \%$ & $46 \%$ & $27 \%$ & $28 \%$ \\
\hline lino & $0 \%$ & $0 \%$ & $0 \%$ & $0 \%$ & $0 \%$ & $1 \%$ & $1 \%$ & $1 \%$ & $1 \%$ \\
\hline girasol & $2 \%$ & $3 \%$ & $5 \%$ & $7 \%$ & $10 \%$ & $10 \%$ & $13 \%$ & $20 \%$ & $17 \%$ \\
\hline soja & $7 \%$ & $3 \%$ & $3 \%$ & $9 \%$ & $12 \%$ & $12 \%$ & $16 \%$ & $11 \%$ & $9 \%$ \\
\hline avena & $3 \%$ & $5 \%$ & $4 \%$ & $6 \%$ & $8 \%$ & $9 \%$ & $4 \%$ & $5 \%$ & $10 \%$ \\
\hline centeno & $13 \%$ & $13 \%$ & $12 \%$ & $8 \%$ & $12 \%$ & $15 \%$ & $8 \%$ & $7 \%$ & $8 \%$ \\
\hline cebada cerv. & $7 \%$ & $10 \%$ & $8 \%$ & $4 \%$ & $18 \%$ & $17 \%$ & $9 \%$ & $13 \%$ & $16 \%$ \\
\hline \multicolumn{10}{|l|}{ Zona sur } \\
\hline trigo & $59 \%$ & $60 \%$ & $78 \%$ & $59 \%$ & $87 \%$ & $79 \%$ & $67 \%$ & $40 \%$ & $95 \%$ \\
\hline maíz & $3 \%$ & $3 \%$ & $10 \%$ & $10 \%$ & $6 \%$ & $3 \%$ & $14 \%$ & $7 \%$ & $12 \%$ \\
\hline lino & $20 \%$ & $15 \%$ & $17 \%$ & $29 \%$ & $30 \%$ & $24 \%$ & $29 \%$ & $17 \%$ & $24 \%$ \\
\hline girasol & $20 \%$ & $20 \%$ & $17 \%$ & $27 \%$ & $28 \%$ & $23 \%$ & $34 \%$ & $38 \%$ & $44 \%$ \\
\hline soja & $1 \%$ & $1 \%$ & $0 \%$ & $0 \%$ & $0 \%$ & $0 \%$ & $0 \%$ & $0 \%$ & $0 \%$ \\
\hline avena & $17 \%$ & $17 \%$ & $25 \%$ & $30 \%$ & $29 \%$ & $25 \%$ & $23 \%$ & $13 \%$ & $28 \%$ \\
\hline centeno & $1 \%$ & $3 \%$ & $6 \%$ & $3 \%$ & $5 \%$ & $3 \%$ & $4 \%$ & $1 \%$ & $2 \%$ \\
\hline cebada cerv. & $69 \%$ & $74 \%$ & $119 \%$ & $46 \%$ & $106 \%$ & $91 \%$ & $96 \%$ & $52 \%$ & $148 \%$ \\
\hline
\end{tabular}


Superficie sembre

\begin{tabular}{|c|c|c|c|c|c|c|c|c|}
\hline & \multirow[b]{2}{*}{1983} & \multirow[b]{2}{*}{1984} & \multirow[b]{2}{*}{1985} & \multirow[b]{2}{*}{1986} & \multirow[b]{2}{*}{1987} & \multirow[b]{2}{*}{1988} & \multicolumn{2}{|c|}{$1990 / 91$} \\
\hline \multirow{2}{*}{ Zona norte } & & & & & & & 1989 & 1990 \\
\hline & 796510 & 1098000 & 726010 & 942900 & 757850 & 743250 & 296350 & \\
\hline maíz & 1525523 & 1593500 & 1721100 & 1291750 & 1306000 & 846000 & & \\
\hline lino & 6319 & 7069 & 3480 & 4685 & 6428 & & & \\
\hline girasol & 36900 & 27940 & 82800 & 43110 & 45060 & 69380 & 79400 & \\
\hline soja & 1310710 & 1286900 & 1460340 & 1307700 & 1496000 & 1346000 & 745100 & \\
\hline avena & 650 & 1790 & 330 & 2190 & 2040 & 6336 & 53600 & \\
\hline $\begin{array}{l}\text { centeno } \\
\text { cebada cerv. }\end{array}$ & 0 & 0 & 0 & 0 & 0 & 0 & 0 & \\
\hline \multicolumn{9}{|l|}{ Zona oeste } \\
\hline trigo & 728400 & 819020 & 517600 & 476600 & 304350 & 404200 & 297100 & \\
\hline maíz & 428020 & 638450 & 731200 & 496000 & 599760 & 487000 & & \\
\hline lino & 2517 & 884 & 421 & 381 & 280 & & & \\
\hline girasol & 168510 & 337700 & 527700 & 251700 & 305350 & 477600 & 280000 & \\
\hline soja & 112800 & 75600 & 158880 & 127370 & 209260 & 232100 & 145300 & \\
\hline avena & 85200 & 84700 & 40960 & 58420 & 34400 & 41219 & 185500 & \\
\hline centeno & 24540 & 26810 & 16270 & 12440 & 8750 & 7330 & 94300 & \\
\hline cebada cerv. & 11140 & 31690 & 19990 & 20530 & 14330 & 21600 & 8700 & 12600 \\
\hline \multicolumn{9}{|l|}{ Zona sur } \\
\hline trigo & 3747800 & 3983510 & 2582190 & 2717500 & 2571400 & 2017200 & 1422500 & \\
\hline maíz & 145660 & 415850 & 366500 & 223355 & 361200 & 318300 & & \\
\hline lino & 40950 & 23120 & 18630 & 53580 & 43755 & & & \\
\hline girasol & 512400 & 702900 & 794900 & 397750 & 609000 & 607250 & 535000 & \\
\hline soja & 5462 & 4738 & 5840 & 2752 & 15960 & 32700 & 26750 & \\
\hline avena & 220310 & 210490 & 99100 & 232300 & 228950 & 179386 & 246100 & \\
\hline centeno & 9400 & 10180 & 6800 & 2820 & 1705 & 1250 & 22700 & \\
\hline \multirow{3}{*}{$\begin{array}{l}\text { cebada cerv. } \\
\text { Fuente: Estimacic }\end{array}$} & 90050 & 104760 & 38293 & 56760 & 151640 & 179000 & 79350 & 56800 \\
\hline & 4772032 & 5455548 & 3912253 & 3686817 & 3983610,33 & 3335086,48 & & \\
\hline & 4542322 & 5234878 & 3806353 & 3451697 & 3752955 & 3154450 & 2063600 & \\
\hline
\end{tabular}




\section{Zona norte}

1983

1984

1985

Buenos Aires

trigo

maíz

lino

girasol

soja

avena

centeno

cebada cerv.

$\begin{array}{rrr}4500000 & 3915000 & 3760000 \\ 1195000 & 1290000 & 1274000 \\ 270000 & 167000 & 197000 \\ 1392000 & 1450000 & 1815000 \\ 715000 & 830000 & 851500 \\ 846000 & 817500 & 880000 \\ 411900 & 329800 & 263100 \\ 62000 & 76000 & 45000 \\ 9391900 & 8875300 & 9085600 \\ 8134000 & 7728000 & 7942500 \\ & 0,11 & 0,14 \\ & & 0,23\end{array}$

Región pampeanć

trigo

maíz

lino

girasol

soja

avena

centeno

cebada cerv.

$\begin{array}{rrrrrrr}7128000 & 5917100 & 5581000 & 4937800 & 4801500 & 4691000 & 5424500 \\ 2905000 & 3096000 & 3264500 & 3160000 & 2425000 & 2405000 & \\ 807500 & 618600 & 748000 & 756900 & 667700 & & \\ 2400000 & 2636700 & 3480700 & 2122350 & 2369200 & 2733800 & 2587000 \\ 2674500 & 3111000 & 3139100 & 3426200 & 4073400 & 4389500 & 4703000 \\ 1766100 & 1741400 & 1703800 & 1495550 & 1926500 & 1798500 & 2066600 \\ 1138600 & 987400 & 743800 & 708920 & 510150 & 393200 & 541000 \\ 76900 & 87600 & 58500 & 57800 & 121600 & 147800 & 177200\end{array}$

1989

1990

$\begin{array}{lllllll}18896600,31 & 18195800,35 & 18719400,36 & 16665520,37 & 16895050,4 & 16558800,39\end{array}$

$\begin{array}{llllll}15991900,31 & 15467000,35 & 16271800,36 & 14461050,37 & 14458400,4 & 14367100,39\end{array}$

Control proprcion:

\section{Zona norte}

trigo

$18 \%$

$28 \%$

$19 \%$

$29 \%$

2910000

2890000

3250000

200000

$1118200 \quad 1230000$

075000

860000

987000

1130000

1550000

279350

45000

8030750

179400

900000

170000

88000

105300

121700

$7449400 \quad 7610500$

6580300

maíz

$128 \%$

$124 \%$

$135 \%$

$97 \%$

$26 \%$

$26 \%$

$9 \%$

\#DIV/0!

$79 \%$

\#DIV/0!

\#DIV/O! 


\begin{tabular}{|c|c|c|c|c|c|c|c|c|}
\hline \multirow[b]{2}{*}{ Zona norte } & \multirow[b]{2}{*}{1983} & \multirow[b]{2}{*}{1984} & \multirow[b]{2}{*}{1985} & \multirow[b]{2}{*}{1986} & \multirow[b]{2}{*}{1987} & \multirow[b]{2}{*}{1988} & \multicolumn{2}{|c|}{ 1990/91 } \\
\hline & & & & & & & 1989 & 1990 \\
\hline lino & $2 \%$ & $4 \%$ & $2 \%$ & $2 \%$ & $3 \%$ & \#DIV/0! & \#DIV/0! & \#DIV/0! \\
\hline girasol & $3 \%$ & $2 \%$ & $5 \%$ & $4 \%$ & $4 \%$ & $5 \%$ & $5 \%$ & \#DIV/O! \\
\hline soja & $183 \%$ & $155 \%$ & $172 \%$ & $152 \%$ & $152 \%$ & $119 \%$ & $59 \%$ & \#DIV/O! \\
\hline avena & $0 \%$ & $0 \%$ & $0 \%$ & $0 \%$ & $1 \%$ & $6 \%$ & \#REF! & \#DIV/0! \\
\hline centeno & $0 \%$ & $0 \%$ & $0 \%$ & $0 \%$ & $0 \%$ & $0 \%$ & $0 \%$ & \#DIV/0! \\
\hline cebada cerv. & $0 \%$ & $0 \%$ & $0 \%$ & $0 \%$ & $0 \%$ & $0 \%$ & $0 \%$ & $0 \%$ \\
\hline \multicolumn{9}{|l|}{ Zona oeste } \\
\hline trigo & $16 \%$ & $21 \%$ & $14 \%$ & $14 \%$ & $10 \%$ & $14 \%$ & $9 \%$ & \#DIV/O! \\
\hline maíz & $36 \%$ & $49 \%$ & $57 \%$ & $37 \%$ & $61 \%$ & $45 \%$ & \#DIV/O! & \#DIV/0! \\
\hline lino & $1 \%$ & $1 \%$ & $0 \%$ & $0 \%$ & $0 \%$ & \#DIV/0! & \#DIV/0! & \#DIV/O! \\
\hline girasol & $12 \%$ & $23 \%$ & $29 \%$ & $23 \%$ & $25 \%$ & $35 \%$ & $18 \%$ & \#DIV/0! \\
\hline soja & $16 \%$ & $9 \%$ & $19 \%$ & $15 \%$ & $21 \%$ & $21 \%$ & $12 \%$ & \#DIV/O! \\
\hline avena & $10 \%$ & $10 \%$ & $5 \%$ & $7 \%$ & $4 \%$ & $5 \%$ & $21 \%$ & \#DIV/O! \\
\hline centeno & $6 \%$ & $8 \%$ & $6 \%$ & $4 \%$ & $5 \%$ & $5 \%$ & $55 \%$ & \#DIV/O! \\
\hline cebada cerv. & $18 \%$ & $42 \%$ & $44 \%$ & $46 \%$ & $16 \%$ & $21 \%$ & $7 \%$ & $11 \%$ \\
\hline \multicolumn{9}{|l|}{ Zona sur } \\
\hline trigo & $83 \%$ & $102 \%$ & $69 \%$ & $82 \%$ & $88 \%$ & $70 \%$ & $44 \%$ & \#DIV/0! \\
\hline maíz & $12 \%$ & $32 \%$ & $29 \%$ & $17 \%$ & $37 \%$ & $30 \%$ & \#DIV/O! & \#DIV/0! \\
\hline lino & $15 \%$ & $14 \%$ & $9 \%$ & $20 \%$ & $22 \%$ & \#DIV/0! & \#DIV/0! & \#DIV/O! \\
\hline girasol & $37 \%$ & $48 \%$ & $44 \%$ & $36 \%$ & $50 \%$ & $44 \%$ & $35 \%$ & \#DIV/O! \\
\hline soja & $1 \%$ & $1 \%$ & $1 \%$ & $0 \%$ & $2 \%$ & $3 \%$ & $2 \%$ & \#DIV/O! \\
\hline avena & $26 \%$ & $26 \%$ & $11 \%$ & $28 \%$ & $26 \%$ & $20 \%$ & $27 \%$ & \#DIV/O! \\
\hline centeno & $2 \%$ & $3 \%$ & $3 \%$ & $1 \%$ & $1 \%$ & $1 \%$ & $13 \%$ & \#DIV/0! \\
\hline cebada cerv. & $145 \%$ & $138 \%$ & $85 \%$ & $126 \%$ & $172 \%$ & $170 \%$ & $65 \%$ & $48 \%$ \\
\hline
\end{tabular}


Superficie sembrø1938/39

Superficie Sembrada (hectáreas)

\begin{tabular}{|c|c|c|c|c|c|c|c|c|c|}
\hline Zona norte & $1938 / 39$ & 1939 & 1940 & 1941 & 1942 & 1943 & 1944 & 1945 & 1946 \\
\hline trigo & 242740 & 181749 & 219200 & 244900 & 289317 & 274416 & 252195 & 267400 & 270800 \\
\hline maíz & 774282 & 812400 & 817755 & 752540 & 549000 & 614305 & 689000 & 663646 & 634000 \\
\hline lino & 190100 & 195236 & 208480 & 209253 & 207853 & 166149 & 112663 & 106800 & 87100 \\
\hline $\begin{array}{l}\text { girasol } \\
\text { soja }\end{array}$ & 900 & 2385 & 5131 & 41800 & 15600 & 62788 & 68600 & 75780 & 113700 \\
\hline avena & 17230 & 17345 & 19300 & 20900 & 22362 & 21920 & 22510 & 20400 & 22100 \\
\hline centeno & 3370 & 2100 & 3770 & 3420 & 2448 & 2645 & 4015 & 4150 & 8600 \\
\hline cebada cerv. & 4065 & 3835 & 3650 & 5050 & 3200 & 3000 & 4650 & 4020 & 2520 \\
\hline \multicolumn{10}{|l|}{ Zona oeste } \\
\hline trigo & 416773 & 330700 & 321800 & 281986 & 176216 & 175374 & 161773 & 148500 & 275500 \\
\hline maíz & 301553 & 369500 & 276700 & 222085 & 168217 & 201910 & 147150 & 118500 & 96500 \\
\hline lino & 5600 & 4380 & 5530 & 4965 & 2144 & 1843 & 52 & 473 & 1330 \\
\hline $\begin{array}{l}\text { girasol } \\
\text { soja }\end{array}$ & 14800 & 26765 & 32400 & 44450 & 47204 & 146700 & 102900 & 92000 & 97700 \\
\hline avena & 89750 & 94120 & 98650 & 100085 & 115521 & 125059 & 109707 & 87000 & 69600 \\
\hline centeno & 115600 & 93900 & 146910 & 154521 & 249437 & 269818 & 253268 & 246500 & 377800 \\
\hline cebada cerv. & 43860 & 50856 & 48260 & 47500 & 33779 & 20560 & 26476 & 34000 & 77200 \\
\hline \multicolumn{10}{|l|}{ Zona sur } \\
\hline trigo & 1528500 & 1326245 & 1286900 & 1313800 & 1163665 & 1229280 & 1196200 & 1009000 & 1223500 \\
\hline maíz & 75700 & 80100 & 72300 & 60500 & 61200 & 56450 & 62850 & 67550 & 61900 \\
\hline lino & 109000 & 123900 & 141720 & 145750 & 263165 & 259500 & 221600 & 222090 & 135265 \\
\hline $\begin{array}{l}\text { girasol } \\
\text { soja }\end{array}$ & 6240 & 9235 & 9800 & 6800 & 7550 & 18945 & 19295 & 27414 & 27520 \\
\hline avena & 414600 & 389865 & 487800 & 420093 & 646474 & 734660 & 740600 & 562000 & 539700 \\
\hline centeno & 27200 & 23000 & 33750 & 24950 & 53102 & 61570 & 52800 & 61450 & 93550 \\
\hline cebada cerv. & 251000 & 244207 & 224900 & 162500 & 132400 & 147600 & 191300 & 324300 & 497300 \\
\hline \multicolumn{10}{|c|}{ Fuente: Estimaciones Agrícolas de la SEAGyP } \\
\hline & 1970440 & 1783687 & 1735620 & 1689350 & 1627980 & 1711775 & 1691245 & 1650354 & 1945485 \\
\hline
\end{tabular}

Fuente: "Estimaciones Agrícolas" de la SEAGyP 


\section{Superficie Sembrada (hectáreas)}

Zona norte $\quad 1938 / 39$

Buenos Aires

maíz

lino

girasol

soja

avena

centeno

cebada cerv.
1939

1940
1941

1942

1943

1944

1945

1946

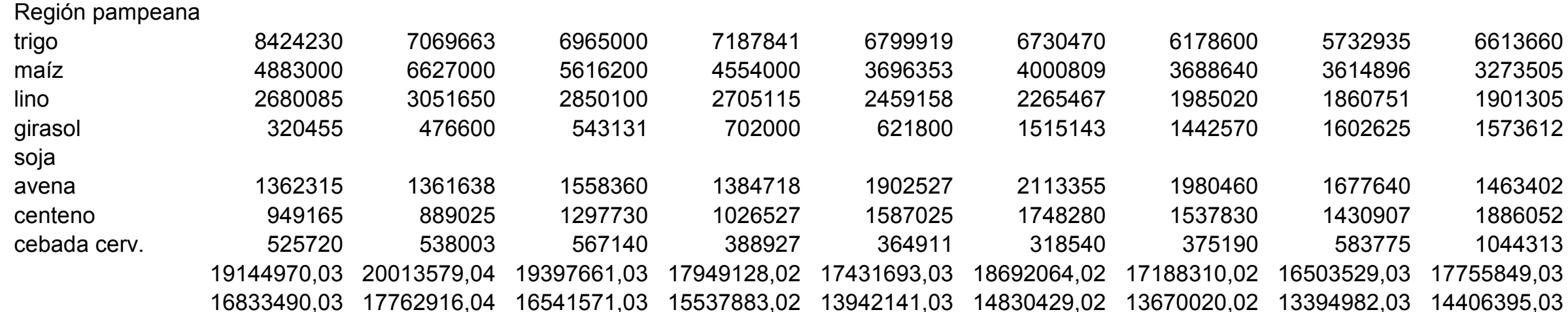

Control proprcional

Zona norte

Fuente: "Estimaciones Agrícolas" de la SEAGyP 
Superficie Sembrada (hectáreas)

\begin{tabular}{|c|c|c|c|c|c|c|c|c|c|}
\hline Zona norte & $1938 / 39$ & 1939 & 1940 & 1941 & 1942 & 1943 & 1944 & 1945 & 1946 \\
\hline trigo & $6 \%$ & $6 \%$ & $7 \%$ & $8 \%$ & $12 \%$ & $11 \%$ & $10 \%$ & $11 \%$ & $10 \%$ \\
\hline maíz & $38 \%$ & $36 \%$ & $41 \%$ & $43 \%$ & $37 \%$ & $41 \%$ & $50 \%$ & $47 \%$ & $49 \%$ \\
\hline lino & $23 \%$ & $23 \%$ & $27 \%$ & $28 \%$ & $29 \%$ & $24 \%$ & $22 \%$ & $20 \%$ & $22 \%$ \\
\hline girasol & $0 \%$ & $1 \%$ & $2 \%$ & $11 \%$ & $5 \%$ & $7 \%$ & $9 \%$ & $9 \%$ & $13 \%$ \\
\hline soja & \#DIV/0! & \#DIV/O! & \#DIV/0! & \#DIV/O! & \#DIV/O! & \#DIV/0! & \#DIV/0! & \#DIV/0! & \#DIV/O! \\
\hline avena & $2 \%$ & $2 \%$ & $2 \%$ & $2 \%$ & $1 \%$ & $1 \%$ & $1 \%$ & $2 \%$ & $2 \%$ \\
\hline centeno & $1 \%$ & $1 \%$ & $1 \%$ & $1 \%$ & $0 \%$ & $0 \%$ & $1 \%$ & $1 \%$ & $1 \%$ \\
\hline cebada cerv. & $1 \%$ & $1 \%$ & $1 \%$ & $2 \%$ & $1 \%$ & $1 \%$ & $2 \%$ & $1 \%$ & $0 \%$ \\
\hline \multicolumn{10}{|l|}{ Zona oeste } \\
\hline trigo & $11 \%$ & $10 \%$ & $11 \%$ & $9 \%$ & $7 \%$ & $7 \%$ & $6 \%$ & $6 \%$ & $10 \%$ \\
\hline maíz & $15 \%$ & $16 \%$ & $14 \%$ & $13 \%$ & $11 \%$ & $13 \%$ & $11 \%$ & $8 \%$ & $8 \%$ \\
\hline lino & $1 \%$ & $1 \%$ & $1 \%$ & $1 \%$ & $0 \%$ & $0 \%$ & $0 \%$ & $0 \%$ & $0 \%$ \\
\hline girasol & $7 \%$ & $10 \%$ & $11 \%$ & $12 \%$ & $16 \%$ & $17 \%$ & $13 \%$ & $11 \%$ & $11 \%$ \\
\hline soja & \#DIV/0! & \#DIV/0! & \#DIV/0! & \#DIV/O! & \#DIV/0! & \#DIV/O! & \#DIV/0! & \#DIV/O! & \#DIV/O! \\
\hline avena & $9 \%$ & $9 \%$ & $9 \%$ & $10 \%$ & $8 \%$ & $7 \%$ & $7 \%$ & $7 \%$ & $6 \%$ \\
\hline centeno & $41 \%$ & $36 \%$ & $38 \%$ & $46 \%$ & $47 \%$ & $45 \%$ & $45 \%$ & $46 \%$ & $51 \%$ \\
\hline cebada cerv. & $11 \%$ & $12 \%$ & $12 \%$ & $16 \%$ & $12 \%$ & $8 \%$ & $9 \%$ & $7 \%$ & $9 \%$ \\
\hline \multicolumn{10}{|l|}{ Zona sur } \\
\hline trigo & $40 \%$ & $42 \%$ & $43 \%$ & $44 \%$ & $46 \%$ & $47 \%$ & $47 \%$ & $43 \%$ & $44 \%$ \\
\hline maíz & $4 \%$ & $4 \%$ & $4 \%$ & $3 \%$ & $4 \%$ & $4 \%$ & $5 \%$ & $5 \%$ & $5 \%$ \\
\hline lino & $13 \%$ & $15 \%$ & $19 \%$ & $20 \%$ & $37 \%$ & $38 \%$ & $44 \%$ & $41 \%$ & $34 \%$ \\
\hline girasol & $3 \%$ & $4 \%$ & $3 \%$ & $2 \%$ & $3 \%$ & $2 \%$ & $2 \%$ & $3 \%$ & $3 \%$ \\
\hline soja & \#DIV/O! & \#DIV/O! & \#DIV/O! & \#DIV/O! & \#DIV/O! & \#DIV/O! & \#DIV/0! & \#DIV/O! & \#DIV/O! \\
\hline avena & $39 \%$ & $37 \%$ & $43 \%$ & $40 \%$ & $42 \%$ & $43 \%$ & $46 \%$ & $42 \%$ & $45 \%$ \\
\hline centeno & $10 \%$ & $9 \%$ & $9 \%$ & $7 \%$ & $10 \%$ & $10 \%$ & $9 \%$ & $11 \%$ & $13 \%$ \\
\hline cebada cerv. & $60 \%$ & $56 \%$ & $54 \%$ & $54 \%$ & $47 \%$ & $60 \%$ & $62 \%$ & $68 \%$ & $59 \%$ \\
\hline
\end{tabular}




\section{Superficie Sembrada (hectáreas)}

Superficie sembre

\begin{tabular}{|c|c|c|c|c|c|c|c|c|c|}
\hline Zona norte & 1947 & 1948 & 1949 & 1950 & 1951 & 1952 & 1953 & 1954 & 1955 \\
\hline trigo & 267500 & 324900 & 371300 & 442500 & 446500 & 355750 & 367000 & 304600 & 305600 \\
\hline maíz & 605000 & 535240 & 401500 & 378500 & 366500 & 413400 & 470700 & 503000 & 434000 \\
\hline lino & 86600 & 51310 & 29640 & 24150 & 29100 & 37725 & 17570 & 22390 & 22630 \\
\hline $\begin{array}{l}\text { girasol } \\
\text { soia }\end{array}$ & 122000 & 136400 & 136000 & 123400 & 130900 & 42250 & 24250 & 39650 & 155500 \\
\hline avena & 23800 & 21650 & 20650 & 18650 & 17950 & 20280 & 14150 & 11000 & 11000 \\
\hline centeno & 8630 & 9900 & 11250 & 15150 & 15650 & 32620 & 22800 & 17450 & 15550 \\
\hline cebada cerv. & 2030 & 940 & 830 & 31200 & 4490 & 2250 & 450 & 50 & 0 \\
\hline \multicolumn{10}{|l|}{ Zona oeste } \\
\hline trigo & 132500 & 145800 & 138000 & 202000 & 174000 & 262300 & 278000 & 219500 & 165500 \\
\hline maíz & 78500 & 66300 & 49100 & 76000 & 65700 & 143600 & 134000 & 98800 & 64600 \\
\hline lino & 630 & 140 & 50 & 880 & 350 & 250 & 570 & 856 & 650 \\
\hline $\begin{array}{l}\text { girasol } \\
\text { soia }\end{array}$ & 115500 & 113000 & 91000 & 119000 & 108400 & 79300 & 42600 & 23500 & 83500 \\
\hline avena & 52200 & 53500 & 45300 & 57500 & 59000 & 117700 & 88540 & 68500 & 73500 \\
\hline centeno & 311900 & 329000 & 337400 & 390700 & 419200 & 554100 & 470300 & 462000 & 534000 \\
\hline cebada cerv. & 51200 & 43100 & 36000 & 50000 & 47800 & 76400 & 47800 & 46500 & 47300 \\
\hline \multicolumn{10}{|l|}{ Zona sur } \\
\hline trigo & 973000 & 1113000 & 960600 & 1165000 & 962500 & 1251300 & 1324000 & 1169800 & 1029700 \\
\hline maíz & 38150 & 33800 & 29500 & 31000 & 28810 & 38150 & 39620 & 41020 & 46350 \\
\hline lino & 165665 & 154850 & 91100 & 104810 & 122900 & 108450 & 87585 & 84780 & 75810 \\
\hline girasol & 23030 & 27140 & 29760 & 27690 & 22700 & 18395 & 9870 & 14760 & 19400 \\
\hline \multicolumn{10}{|l|}{ soja } \\
\hline avena & 517400 & 559200 & 436500 & 423800 & 420500 & 592400 & 501600 & 436000 & 473300 \\
\hline centeno & 75800 & 78600 & 57700 & 59840 & 59600 & 89400 & 60830 & 51400 & 61200 \\
\hline cebada cerv. & 365000 & 313500 & 261250 & 301450 & 289100 & 305200 & 307700 & 293800 & 341100 \\
\hline & 1564845 & 1642290 & 1372210 & 1629950 & 1426010 & 1721495 & 1768775 & 1604160 & 1512360 \\
\hline
\end{tabular}

Fuente: "Estimaciones Agrícolas" de la SEAGyP 


\section{Superficie Sembrada (hectáreas)}

\section{Zona norte}

1947
1948

1949
1950

1951
1952

1953
1955
Buenos Aires

maíz

lino

girasol

soja

avena

centeno

cebada cerv.

$\begin{array}{rrr}2113100 & 2430000 & 2201300 \\ 1151735 & 969590 & 771950 \\ 430120 & 337800 & 180600 \\ 881325 & 1017365 & 847700 \\ & & \\ 1047700 & 1110000 & 965870 \\ 595950 & 643800 & 609350 \\ 586450 & 515000 & 424180 \\ 6806380 & 7023555 & 6000950 \\ 5162730 & 5269755 & 4425730\end{array}$

2833500
810930
200900
874963
989500
707200
500300
6917293
5220593

\section{0}

785390

241100

867575

982500

735800

499400

6599065

4880765

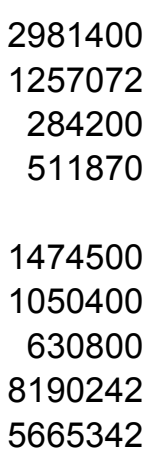

5665342

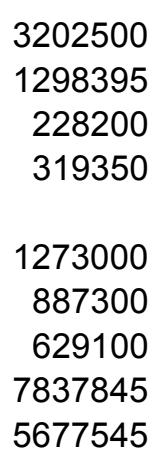

Región pampeanć

trigo
maíz
lino
girasol
soja
avena
centeno
cebada cerv.

\begin{tabular}{|c|c|c|c|c|c|c|c|c|}
\hline 5413400 & 5778100 & 5665100 & 6534800 & 4771700 & 6039800 & 6318000 & 5911100 & 5181200 \\
\hline 3009035 & 2400590 & 1899620 & 2180130 & 2310390 & 3044472 & 2985445 & 2736114 & 2612210 \\
\hline 1569670 & 1302900 & 1075820 & 1082700 & 640800 & 1018700 & 730600 & 736900 & 672100 \\
\hline 1497727 & 1788670 & 1474550 & 1619133 & 1598498 & 814310 & 565260 & 555410 & 1392570 \\
\hline 1290895 & 1364100 & 1201620 & 1282100 & 1163900 & 1677500 & 1468800 & 1344500 & 1418400 \\
\hline 1710420 & 1777500 & 1785270 & 2116200 & 1946030 & 2422550 & 2369220 & 2414950 & 249225 \\
\hline 773760 & 695490 & 571580 & 638360 & 654520 & 849326 & 831900 & 814602 & 96070 \\
\hline 63592,03 & 11965750,03 & 10686670,04 & 12055123,03 & 9975908,03 & 11766608,04 & 11431205,03 & 10754126,05 & 10818780,0 \\
\hline
\end{tabular}

Control proprcion

\section{Zona norte}

Fuente: "Estimaciones Agrícolas" de la SEAGyP 
Superficie Sembrada (hectáreas)

\begin{tabular}{|c|c|c|c|c|c|c|c|c|c|}
\hline Zona norte & 1947 & 1948 & 1949 & 1950 & 1951 & 1952 & 1953 & 1954 & 1955 \\
\hline trigo & $13 \%$ & $13 \%$ & $17 \%$ & $16 \%$ & $18 \%$ & $12 \%$ & $11 \%$ & $11 \%$ & $13 \%$ \\
\hline maíz & $53 \%$ & $55 \%$ & $52 \%$ & $47 \%$ & $47 \%$ & $33 \%$ & $36 \%$ & $43 \%$ & $40 \%$ \\
\hline lino & $20 \%$ & $15 \%$ & $16 \%$ & $12 \%$ & $12 \%$ & $13 \%$ & $8 \%$ & $10 \%$ & $12 \%$ \\
\hline girasol & $14 \%$ & $13 \%$ & $16 \%$ & $14 \%$ & $15 \%$ & $8 \%$ & $8 \%$ & $13 \%$ & $21 \%$ \\
\hline soja & \#DIV/0! & \#DIV/0! & \#DIV/0! & \#DIV/O! & \#DIV/O! & \#DIV/0! & \#DIV/0! & \#DIV/O! & \#DIV/O! \\
\hline avena & $2 \%$ & $2 \%$ & $2 \%$ & $2 \%$ & $2 \%$ & $1 \%$ & $1 \%$ & $1 \%$ & $1 \%$ \\
\hline centeno & $1 \%$ & $2 \%$ & $2 \%$ & $2 \%$ & $2 \%$ & $3 \%$ & $3 \%$ & $2 \%$ & $2 \%$ \\
\hline cebada cerv. & $0 \%$ & $0 \%$ & $0 \%$ & $6 \%$ & $1 \%$ & $0 \%$ & $0 \%$ & $0 \%$ & $0 \%$ \\
\hline \multicolumn{10}{|l|}{ Zona oeste } \\
\hline trigo & $6 \%$ & $6 \%$ & $6 \%$ & $7 \%$ & $7 \%$ & $9 \%$ & $9 \%$ & $8 \%$ & $7 \%$ \\
\hline maíz & $7 \%$ & $7 \%$ & $6 \%$ & $9 \%$ & $8 \%$ & $11 \%$ & $10 \%$ & $8 \%$ & $6 \%$ \\
\hline lino & $0 \%$ & $0 \%$ & $0 \%$ & $0 \%$ & $0 \%$ & $0 \%$ & $0 \%$ & $0 \%$ & $0 \%$ \\
\hline girasol & $13 \%$ & $11 \%$ & $11 \%$ & $14 \%$ & $12 \%$ & $15 \%$ & $13 \%$ & $8 \%$ & $11 \%$ \\
\hline soja & \#DIV/O! & \#DIV/0! & \#DIV/0! & \#DIV/O! & \#DIV/O! & \#DIV/0! & \#DIV/0! & \#DIV/O! & \#DIV/O! \\
\hline avena & $5 \%$ & $5 \%$ & $5 \%$ & $6 \%$ & $6 \%$ & $8 \%$ & $7 \%$ & $6 \%$ & $6 \%$ \\
\hline centeno & $52 \%$ & $51 \%$ & $55 \%$ & $55 \%$ & $57 \%$ & $53 \%$ & $53 \%$ & $55 \%$ & $58 \%$ \\
\hline cebada cerv. & $9 \%$ & $8 \%$ & $8 \%$ & $10 \%$ & $10 \%$ & $12 \%$ & $8 \%$ & $8 \%$ & $7 \%$ \\
\hline \multicolumn{10}{|l|}{ Zona sur } \\
\hline trigo & $46 \%$ & $46 \%$ & $44 \%$ & $41 \%$ & $39 \%$ & $42 \%$ & $41 \%$ & $42 \%$ & $43 \%$ \\
\hline maíz & $3 \%$ & $3 \%$ & $4 \%$ & $4 \%$ & $4 \%$ & $3 \%$ & $3 \%$ & $3 \%$ & $4 \%$ \\
\hline lino & $39 \%$ & $46 \%$ & $50 \%$ & $52 \%$ & $51 \%$ & $38 \%$ & $38 \%$ & $38 \%$ & $39 \%$ \\
\hline girasol & $3 \%$ & $3 \%$ & $4 \%$ & $3 \%$ & $3 \%$ & $4 \%$ & $3 \%$ & $5 \%$ & $3 \%$ \\
\hline soja & \#DIV/0! & \#DIV/0! & \#DIV/O! & \#DIV/0! & \#DIV/0! & \#DIV/0! & \#DIV/0! & \#DIV/0! & \#DIV/0! \\
\hline avena & $49 \%$ & $50 \%$ & $45 \%$ & $43 \%$ & $43 \%$ & $40 \%$ & $39 \%$ & $39 \%$ & $41 \%$ \\
\hline centeno & $13 \%$ & $12 \%$ & $9 \%$ & $8 \%$ & $8 \%$ & $9 \%$ & $7 \%$ & $6 \%$ & $7 \%$ \\
\hline cebada cerv. & $62 \%$ & $61 \%$ & $62 \%$ & $60 \%$ & $58 \%$ & $48 \%$ & $49 \%$ & $52 \%$ & $53 \%$ \\
\hline
\end{tabular}




\section{Superficie Sembrada (hectáreas)}

Superficie sembre

\begin{tabular}{|c|c|c|c|c|c|c|c|c|c|}
\hline Zona norte & 1956 & 1957 & 1958 & 1959 & 1960 & 1961 & 1962 & 1963 & 1964 \\
\hline trigo & 339800 & 289500 & 340500 & 240200 & 269900 & 313800 & 354000 & 379900 & 422300 \\
\hline maíz & 386900 & 408000 & 422000 & 437800 & 449300 & 440000 & 438100 & 450950 & 406000 \\
\hline lino & 22120 & 25630 & 23730 & 20680 & 20260 & 20480 & 20130 & 20530 & 19860 \\
\hline $\begin{array}{l}\text { girasol } \\
\text { soja }\end{array}$ & 143800 & 203100 & 180300 & 188000 & 176910 & 187304 & 139500 & 123150 & 144900 \\
\hline avena & 16650 & 20740 & 22450 & 24569 & 26700 & 30700 & 28750 & 29550 & 33500 \\
\hline centeno & 27200 & 29100 & 29250 & 32400 & 34850 & 33950 & 34150 & 33630 & 33400 \\
\hline cebada cerv. & 0 & 0 & 0 & 0 & 0 & 500 & 0 & 5300 & \\
\hline \multicolumn{10}{|l|}{ Zona oeste } \\
\hline trigo & 232500 & 205200 & 227600 & 147700 & 115700 & 106400 & 191600 & 268400 & 321000 \\
\hline maíz & 56000 & 47100 & 50900 & 46500 & 39500 & 34000 & 40200 & 43600 & 41000 \\
\hline lino & 1455 & 2030 & 1730 & 1030 & 1000 & 320 & 920 & 520 & 410 \\
\hline $\begin{array}{l}\text { girasol } \\
\text { soja }\end{array}$ & 75000 & 105000 & 88500 & 89100 & 86000 & 82736 & 55000 & 45200 & 53600 \\
\hline avena & 133000 & 144500 & 138500 & 129960 & 121750 & 103400 & 92500 & 91950 & 93500 \\
\hline centeno & 426000 & 456500 & 511500 & 553000 & 489000 & 352500 & 474000 & 384300 & 361000 \\
\hline cebada cerv. & 64150 & 55500 & 57800 & 50600 & 45000 & 27900 & 27100 & 29050 & 23350 \\
\hline \multicolumn{10}{|l|}{ Zona sur } \\
\hline trigo & 1220000 & 1171500 & 1333000 & 1156800 & 1018900 & 1083700 & 805300 & 1431000 & 1399700 \\
\hline maíz & 45470 & 34330 & 33930 & 31040 & 32550 & 39500 & 23250 & 33800 & 40500 \\
\hline lino & 102140 & 134220 & 155150 & 199250 & 167250 & 180400 & 160900 & 163700 & 153300 \\
\hline $\begin{array}{l}\text { girasol } \\
\text { soja }\end{array}$ & 49400 & 77850 & 81750 & 65400 & 24800 & 27921 & 22120 & 31600 & 42850 \\
\hline avena & 542500 & 484000 & 457000 & 488215 & 519800 & 399000 & 274000 & 435200 & 296900 \\
\hline centeno & 53100 & 55400 & 58700 & 66300 & 62050 & 60500 & 32490 & 37300 & 30440 \\
\hline cebada cerv. & 362000 & 298300 & 298000 & 272650 & 267500 & 267200 & 270700 & 285650 & 173800 \\
\hline & 1779010 & 1716200 & 1901830 & 1725140 & 1511000 & 1598721,4 & 1282270 & 1945750 & 1810150 \\
\hline
\end{tabular}

Fuente: "Estimaciones Agrícolas" de la SEAGyP 


\section{Superficie Sembrada (hectáreas)}

\section{Zona norte}

1956

1957
1958

1959
1960

1961
1962

1963

Buenos Aires

maíz

2860700

965650

2625700

2975600

966360

lino

girasol

soja

avena

centeno

cebada cerv.

291600

315600

888900

2370300

960000

362800

823000

\section{0}

935000

319500

684700

2430500

940000

351400

749000

1318700

986500

595600

7416900

5111700

1310700

910000

551300

701800

620700

634400

8057960

5780860

6925700

4705000

1100200

727300

494400

6792800

4965300

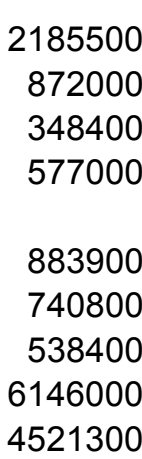

3350400

890000

344500

528000

850800

333300

591900

1126000

889600

624000

376200

511500

7430900

7073000

$4521300 \quad 5624400$

5559400

Región pampeanć

5912400

5279000

5674300

4756400

4241700

4913000

2788100

4803000

6222000

3043000

6421900

maíz

1277100

1440400

2508360

2634500

1218300

1298300

2800000

1406200

3008500

1323700

1100100

1304200

942720

857850

120520

soja

avena

1854600

1889300

1767700

$1599850 \quad 1562000$

1382800

1113650

1354100

1107800

centeno

2711675

2768710

2745650

2806500

2569900

2550700

2379000

2084070

2051060

$\begin{array}{llllllllll}16380335,07 & 16448380,07 & 16177910,09 & 15164670,08 & 14151700,04 & 15022560,04 & 14301920,04 & 15668940,06 & 15414520,07\end{array}$

$\begin{array}{lllllllll}11814060,07 & 11790370,07 & 11664560,09 & 10758320,08 & 10019800,04 & 11089060,04 & 10809270,04 & 12230770,06 & 12255660,07\end{array}$

Control proprciona

Zona norte

Fuente: "Estimaciones Agrícolas" de la SEAGyP 
Superficie Sembrada (hectáreas)

\begin{tabular}{|c|c|c|c|c|c|c|c|c|c|}
\hline Zona norte & 1956 & 1957 & 1958 & 1959 & 1960 & 1961 & 1962 & 1963 & 1964 \\
\hline trigo & $12 \%$ & $11 \%$ & $11 \%$ & $10 \%$ & $12 \%$ & $13 \%$ & $16 \%$ & $11 \%$ & $12 \%$ \\
\hline maíz & $40 \%$ & $41 \%$ & $44 \%$ & $46 \%$ & $48 \%$ & $47 \%$ & $50 \%$ & $51 \%$ & $48 \%$ \\
\hline lino & $9 \%$ & $9 \%$ & $8 \%$ & $6 \%$ & $6 \%$ & $6 \%$ & $6 \%$ & $6 \%$ & $6 \%$ \\
\hline girasol & $20 \%$ & $19 \%$ & $20 \%$ & $23 \%$ & $26 \%$ & $25 \%$ & $24 \%$ & $23 \%$ & $24 \%$ \\
\hline soja & \#DIV/0! & \#DIV/0! & \#DIV/0! & \#DIV/O! & \#DIV/O! & \#DIV/0! & \#DIV/0! & \#DIV/O! & \#DIV/O! \\
\hline avena & $1 \%$ & $2 \%$ & $2 \%$ & $2 \%$ & $2 \%$ & $3 \%$ & $3 \%$ & $3 \%$ & $4 \%$ \\
\hline centeno & $3 \%$ & $3 \%$ & $3 \%$ & $3 \%$ & $4 \%$ & $5 \%$ & $5 \%$ & $5 \%$ & $5 \%$ \\
\hline cebada cerv. & $0 \%$ & $0 \%$ & $0 \%$ & $0 \%$ & $0 \%$ & $0 \%$ & $0 \%$ & $1 \%$ & $0 \%$ \\
\hline \multicolumn{10}{|l|}{ Zona oeste } \\
\hline trigo & $8 \%$ & $8 \%$ & $8 \%$ & $6 \%$ & $5 \%$ & $4 \%$ & $9 \%$ & $8 \%$ & $9 \%$ \\
\hline maíz & $6 \%$ & $5 \%$ & $5 \%$ & $5 \%$ & $4 \%$ & $4 \%$ & $5 \%$ & $5 \%$ & $5 \%$ \\
\hline lino & $1 \%$ & $1 \%$ & $1 \%$ & $0 \%$ & $0 \%$ & $0 \%$ & $0 \%$ & $0 \%$ & $0 \%$ \\
\hline girasol & $10 \%$ & $10 \%$ & $10 \%$ & $11 \%$ & $13 \%$ & $11 \%$ & $10 \%$ & $9 \%$ & $9 \%$ \\
\hline soja & \#DIV/O! & \#DIV/0! & \#DIV/0! & \#DIV/O! & \#DIV/O! & \#DIV/0! & \#DIV/0! & \#DIV/O! & \#DIV/O! \\
\hline avena & $9 \%$ & $10 \%$ & $10 \%$ & $10 \%$ & $9 \%$ & $9 \%$ & $10 \%$ & $8 \%$ & $11 \%$ \\
\hline centeno & $53 \%$ & $53 \%$ & $54 \%$ & $56 \%$ & $54 \%$ & $48 \%$ & $64 \%$ & $56 \%$ & $58 \%$ \\
\hline cebada cerv. & $9 \%$ & $9 \%$ & $9 \%$ & $8 \%$ & $8 \%$ & $6 \%$ & $5 \%$ & $6 \%$ & $6 \%$ \\
\hline \multicolumn{10}{|l|}{ Zona sur } \\
\hline trigo & $43 \%$ & $45 \%$ & $45 \%$ & $49 \%$ & $46 \%$ & $45 \%$ & $37 \%$ & $43 \%$ & $41 \%$ \\
\hline maíz & $5 \%$ & $3 \%$ & $4 \%$ & $3 \%$ & $3 \%$ & $4 \%$ & $3 \%$ & $4 \%$ & $5 \%$ \\
\hline lino & $43 \%$ & $46 \%$ & $49 \%$ & $55 \%$ & $52 \%$ & $51 \%$ & $46 \%$ & $48 \%$ & $46 \%$ \\
\hline girasol & $7 \%$ & $7 \%$ & $9 \%$ & $8 \%$ & $4 \%$ & $4 \%$ & $4 \%$ & $6 \%$ & $7 \%$ \\
\hline soja & \#DIV/0! & \#DIV/0! & \#DIV/0! & \#DIV/0! & \#DIV/O! & \#DIV/0! & \#DIV/0! & \#DIV/0! & \#DIV/O! \\
\hline avena & $38 \%$ & $35 \%$ & $34 \%$ & $37 \%$ & $40 \%$ & $36 \%$ & $31 \%$ & $39 \%$ & $33 \%$ \\
\hline centeno & $7 \%$ & $6 \%$ & $6 \%$ & $7 \%$ & $7 \%$ & $8 \%$ & $4 \%$ & $5 \%$ & $5 \%$ \\
\hline cebada cerv. & $52 \%$ & $48 \%$ & $47 \%$ & $46 \%$ & $49 \%$ & $54 \%$ & $50 \%$ & $56 \%$ & $46 \%$ \\
\hline
\end{tabular}


Superficie sembre

Superficie Sembrada (hectáreas)

\section{Zona norte}

trigo

maíz

lino

girasol

soja

avena

centeno

cebada cerv.

\section{Zona oeste}

trigo

maíz

lino

girasol

soja

avena

centeno

cebada cerv.

\section{Zona sur}

\section{trigo}

maíz

lino

girasol

soja

avena

centeno

cebada cerv.

Fuente: Estimacic

323000

323000

40200

63300

364200

95200

690

68700

101100

409000

396000

22200

21050

1325500

51200

173800

1465000

60500

160350

62500

298650

28440

189930

175350

1776300

1938280

2089950

1967

341000

541500

8850

80050

38025

28800

399000

55100

890

52200

111400

426000

19550

1629000

53100

156900

67250

314050

29500

183700

Fuente: "Estimaciones Agrícolas" de la SEAGyP

1968
308000
573000
14300
113200
37000
31000

1969
234400
621000
16250
121400
1270
31500
27870

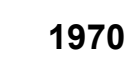

1972

199200

165500

658000

38350

99500

1400

29400

21300

172500

605000

29850

106000

1530

26100

19600

490500

34750

108500

5080

23800

16080

1973

112000

549000

33600

53000

40500

23900

13550

\section{0}

63000

500

71100

361600

69000

174800

174800

201600

65800

143500

72650

72500

78500

93700

474600

12950

77700

503500

14200

69000

420000

15400

57300

65000

0

69000

425800

17300

76500

0

78000

428500

21650

88000

32500

6680

83100

391000

17700

\section{0}

59100

167000

1574000

1415000

1459000

93200

1504000

106500

61400

209500

100000

140500

159700

105

241000

47700

264900

2385305

2096605

1342700

95200 


\section{Superficie Sembrada (hectáreas)}

\section{Zona norte}

1965
1966

1967
1968

1969

1970
1971

1972
Buenos Aires

trigo

maíz

lino

girasol

soja

avena

centeno

cebada cerv.
Región pampeanć

trigo
maíz
lino
girasol
soja
avena
centeno
cebada cerv.

$\begin{array}{rrr}5651800 & 6215000 & 6492400 \\ 3340500 & 3587700 & 3765300 \\ 1290250 & 919050 & 707800 \\ 1110700 & 1292230 & 1137150 \\ & & \\ 1090300 & 1114900 & 1166500 \\ 2071150 & 2213200 & 2244900 \\ 539010 & 552480 & 512650\end{array}$

3872600

874200

1329000

1266800

2437800

469450

6105200

4030000

947400

1456650

10070

1097000

2433650

$15093710,08 \quad 15894560,09$

16026700,11

12615300,11

11932260,08 12566460,09

$\begin{array}{rrrrr}3124000 & 3421300 & 3796300 & 3621700 & 3449000 \\ 928300 & 1059200 & 1076700 & 1173700 & 1340000 \\ 372000 & 320300 & 318200 & 392600 & 464200 \\ 626900 & 704300 & 634800 & 788100 & 865600 \\ & & & & 1270 \\ 883600 & 883200 & 917800 & 980000 & 811900 \\ 647300 & 626000 & 641800 & 695000 & 733100 \\ 368200 & 365800 & 317200 & 337600 & 323700 \\ 6950300 & 7380100 & 7702800 & 7988700 & 7988770 \\ 5419400 & 5870900 & 6143200 & 6313700 & 6443770\end{array}$

5419400

6143200

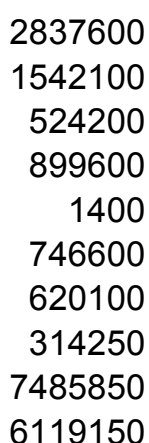

2940450

1337700

252600

786650

1580

796100

671000

356500

7142580

5675480

3150000

1284700

234500

856700

5185

861300

743500

401840

7537725

5932925

2450400

1348500

231400

731070

57100

810800

651000

316600

6596870

5135070

\section{0}

4315200

968450

1524650

11900

995050

1928550

406300

\section{0}

5495600

4134200

3847600

3684800

3616700

534500

507180

413420

1573050

378420

39380

107185

284200

1067150

17800

2152650

2469790

2433700

483900

545140

451400

Control proprcion

Zona norte

Fuente: "Estimaciones Agrícolas" de la SEAGyP 
Superficie Sembrada (hectáreas)

\begin{tabular}{|c|c|c|c|c|c|c|c|c|c|}
\hline Zona norte & 1965 & 1966 & 1967 & 1968 & 1969 & 1970 & 1971 & 1972 & 1973 \\
\hline trigo & $11 \%$ & $10 \%$ & $9 \%$ & $9 \%$ & $7 \%$ & $6 \%$ & $6 \%$ & $6 \%$ & $5 \%$ \\
\hline maíz & $49 \%$ & $45 \%$ & $50 \%$ & $49 \%$ & $46 \%$ & $43 \%$ & $45 \%$ & $38 \%$ & $41 \%$ \\
\hline lino & $5 \%$ & $5 \%$ & $3 \%$ & $4 \%$ & $4 \%$ & $7 \%$ & $12 \%$ & $15 \%$ & $15 \%$ \\
\hline girasol & $21 \%$ & $20 \%$ & $13 \%$ & $14 \%$ & $14 \%$ & $11 \%$ & $13 \%$ & $13 \%$ & $7 \%$ \\
\hline soja & \#DIV/0! & \#DIV/0! & \#DIV/0! & \#DIV/O! & $100 \%$ & $100 \%$ & $97 \%$ & $98 \%$ & $71 \%$ \\
\hline avena & $4 \%$ & $4 \%$ & $4 \%$ & $3 \%$ & $4 \%$ & $3 \%$ & $3 \%$ & $3 \%$ & $3 \%$ \\
\hline centeno & $5 \%$ & $5 \%$ & $4 \%$ & $4 \%$ & $4 \%$ & $3 \%$ & $3 \%$ & $2 \%$ & $2 \%$ \\
\hline cebada cerv. & $0 \%$ & $0 \%$ & $0 \%$ & $0 \%$ & $0 \%$ & $0 \%$ & $0 \%$ & $0 \%$ & $0 \%$ \\
\hline \multicolumn{10}{|l|}{ Zona oeste } \\
\hline trigo & $10 \%$ & $11 \%$ & $11 \%$ & $10 \%$ & $10 \%$ & $6 \%$ & $6 \%$ & $6 \%$ & $6 \%$ \\
\hline maíz & $4 \%$ & $9 \%$ & $5 \%$ & $5 \%$ & $5 \%$ & $5 \%$ & $4 \%$ & $5 \%$ & $7 \%$ \\
\hline lino & $0 \%$ & $0 \%$ & $0 \%$ & $0 \%$ & $0 \%$ & $0 \%$ & $0 \%$ & $0 \%$ & $0 \%$ \\
\hline girasol & $10 \%$ & $10 \%$ & $8 \%$ & $9 \%$ & $9 \%$ & $8 \%$ & $8 \%$ & $9 \%$ & $4 \%$ \\
\hline soja & \#DIV/0! & \#DIV/0! & \#DIV/0! & \#DIV/O! & $0 \%$ & $0 \%$ & $0 \%$ & $0 \%$ & $12 \%$ \\
\hline avena & $10 \%$ & $11 \%$ & $12 \%$ & $10 \%$ & $10 \%$ & $9 \%$ & $9 \%$ & $9 \%$ & $10 \%$ \\
\hline centeno & $61 \%$ & $65 \%$ & $66 \%$ & $68 \%$ & $69 \%$ & $68 \%$ & $63 \%$ & $58 \%$ & $60 \%$ \\
\hline cebada cerv. & $6 \%$ & $6 \%$ & $6 \%$ & $4 \%$ & $4 \%$ & $5 \%$ & $5 \%$ & $5 \%$ & $6 \%$ \\
\hline \multicolumn{10}{|l|}{ Zona sur } \\
\hline trigo & $42 \%$ & $43 \%$ & $43 \%$ & $43 \%$ & $46 \%$ & $50 \%$ & $50 \%$ & $48 \%$ & $55 \%$ \\
\hline maíz & $6 \%$ & $6 \%$ & $5 \%$ & $5 \%$ & $6 \%$ & $8 \%$ & $7 \%$ & $8 \%$ & $7 \%$ \\
\hline lino & $47 \%$ & $50 \%$ & $49 \%$ & $43 \%$ & $32 \%$ & $40 \%$ & $31 \%$ & $26 \%$ & $36 \%$ \\
\hline girasol & $8 \%$ & $9 \%$ & $11 \%$ & $10 \%$ & $8 \%$ & $11 \%$ & $18 \%$ & $19 \%$ & $32 \%$ \\
\hline soja & \#DIV/O! & \#DIV/O! & \#DIV/O! & \#DIV/O! & $0 \%$ & $0 \%$ & $0 \%$ & $2 \%$ & $1 \%$ \\
\hline avena & $33 \%$ & $34 \%$ & $34 \%$ & $32 \%$ & $30 \%$ & $30 \%$ & $29 \%$ & $28 \%$ & $30 \%$ \\
\hline centeno & $5 \%$ & $5 \%$ & $5 \%$ & $5 \%$ & $5 \%$ & $4 \%$ & $6 \%$ & $6 \%$ & $8 \%$ \\
\hline cebada cerv. & $48 \%$ & $52 \%$ & $58 \%$ & $68 \%$ & $68 \%$ & $66 \%$ & $69 \%$ & $66 \%$ & $72 \%$ \\
\hline
\end{tabular}

Fuente: "Estimaciones Agrícolas" de la SEAGyP 
Superficie sembre

Superficie Sembrada (hectáreas)

\begin{tabular}{|c|c|c|c|c|c|c|c|c|c|}
\hline Zona norte & 1974 & 1975 & 1976 & 1977 & 1978 & 1979 & 1980 & 1981 & 1982 \\
\hline trigo & 135500 & 170100 & 224400 & 159000 & 151000 & 185300 & 366820 & 474000 & 470400 \\
\hline maíz & 621500 & 600500 & 459850 & 469400 & 454500 & 392100 & 467400 & 420500 & 317500 \\
\hline lino & 36380 & 36300 & 43550 & 55100 & 36730 & 30080 & 23302 & 23430 & 13680 \\
\hline girasol & 55000 & 53300 & 52400 & 61100 & 36675 & 33450 & 36265 & 20000 & 28100 \\
\hline soja & 20990 & 38200 & 44800 & 115500 & 205458 & 309200 & 323060 & 362500 & 535400 \\
\hline avena & 23650 & 23000 & 19600 & 19400 & 15800 & 18250 & 22000 & 21900 & 21250 \\
\hline $\begin{array}{l}\text { centeno } \\
\text { cebada cerv. }\end{array}$ & 13650 & 13650 & 11800 & 11500 & 9400 & 9600 & 8350 & 7000 & 6900 \\
\hline \multicolumn{10}{|l|}{ Zona oeste } \\
\hline trigo & 213000 & 293000 & 360000 & 209000 & 250500 & 252700 & 426780 & 441000 & 464200 \\
\hline maíz & 109500 & 109500 & 97500 & 115900 & 142800 & 162000 & 183000 & 148000 & 108000 \\
\hline lino & 700 & 0 & 500 & 1500 & 1890 & 4520 & 1750 & 3700 & 3950 \\
\hline girasol & 23500 & 26700 & 52000 & 101600 & 85000 & 112500 & 89400 & 167400 & 145500 \\
\hline soja & 1790 & 980 & 1710 & 9190 & 19424 & 48480 & 46100 & 31500 & 41600 \\
\hline avena & 98500 & 125600 & 122000 & 126000 & 155100 & 199700 & 191500 & 175400 & 165000 \\
\hline centeno & 374000 & 361400 & 325000 & 319900 & 324500 & 308750 & 288100 & 272100 & 269400 \\
\hline cebada cerv. & 17950 & 22500 & 20400 & 27800 & 32200 & 17360 & 11400 & 9700 & 7030 \\
\hline \multicolumn{10}{|l|}{ Zona sur } \\
\hline trigo & 1504000 & 1498500 & 1839500 & 1161300 & 1502000 & 1422000 & 1321500 & 1547300 & 1899900 \\
\hline maíz & 57900 & 44000 & 73700 & 103100 & 90000 & 87600 & 112000 & 78000 & 66600 \\
\hline lino & 56500 & 42100 & 56950 & 106260 & 103160 & 105200 & 96850 & 80100 & 78800 \\
\hline girasol & 225300 & 220900 & 197100 & 406300 & 354600 & 360450 & 254750 & 363950 & 344450 \\
\hline soja & 180 & 280 & 50 & 710 & 1788 & 2870 & 470 & 200 & 200 \\
\hline avena & 224000 & 239000 & 256000 & 347200 & 259250 & 264000 & 259000 & 270000 & 317000 \\
\hline centeno & 52000 & 52800 & 53800 & 49050 & 49300 & 44000 & 52000 & 51500 & 30350 \\
\hline \multirow{3}{*}{$\begin{array}{l}\text { cebada cerv. } \\
\text { Fuente: Estimacic }\end{array}$} & 201500 & 236020 & 271150 & 181000 & 156950 & 106950 & 70300 & 67770 & 53100 \\
\hline & 2321380 & 2333600 & 2748250 & 2354920 & 2517048 & 2393070 & 2166870 & 2458820 & 2790400 \\
\hline & 2045380 & 2041800 & 2438450 & 1958670 & 2208498 & 2085070 & 1855870 & 2137320 & 2443050 \\
\hline
\end{tabular}

Fuente: "Estimaciones Agrícolas" de la SEAGyP 


\section{Superficie Sembrada (hectáreas)}

\section{Zona norte}

1974
1975

1976
1978

1979
1980

1981
Buenos Aires

$\begin{array}{lr}\text { trigo } & 2866000 \\ \text { maíz } & 1396000 \\ \text { lino } & 234400 \\ \text { girasol } & 653900 \\ \text { soja } & 30400 \\ \text { avena } & 849400 \\ \text { centeno } & 647000 \\ \text { cebada cerv. } & 270600 \\ & 6947700\end{array}$

Región pampeanć

trigo

maíz

lino

girasol

soja

avena

centeno

cebada cerv.
5054000

3372300

516030

1206700

296600

1161900

2293080

415200

14315810,34

10860830,34

$$
\begin{array}{r}
3133000 \\
1402500 \\
214200 \\
725400 \\
43500 \\
899300 \\
594700 \\
316300 \\
7328900 \\
5834900
\end{array}
$$

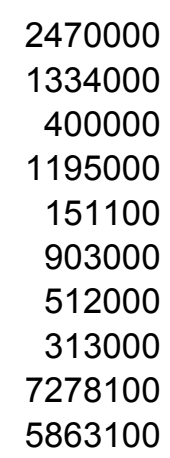

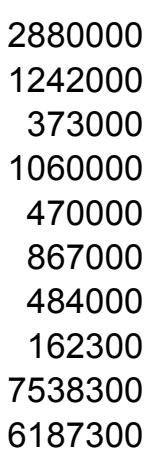

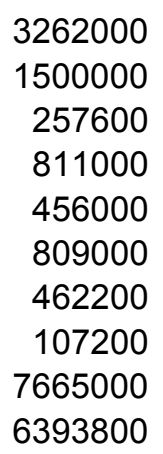

4446000

1075000

280000

1120000

650000

860000

384500

77000

8892500

7648000

\section{Control proprciona}

\section{0}

3212100

467450

1357570

369800

1300600

2317030

435050

11422070,3
7069000

2553000

717260

1521100

600000

1429000

2201200

465100

12925460,25
4480000

2730000

944530

2314300

1041400

1436000

2043000

425500

5125000

2917000

884350

1902400

1439300

1481000

1618000

325900

$1935730,34 \quad 12593950,36$
4908100

2837000

1063500

2037950

1860850

1608300

1393000

216200

15924900,34

12923600,34

\section{0}

3480900

779100

1525450

1760100

1649950

1401500

171350

16849350,31

13797900,31

\section{0}

3146200

849300

1975650

1872850

1575500

1259200

137000

7309700

$14475000,3315488100,31$

\section{Zona norte}

Fuente: "Estimaciones Agrícolas" de la SEAGyP 
Superficie Sembrada (hectáreas)

\begin{tabular}{|c|c|c|c|c|c|c|c|c|c|}
\hline Zona norte & 1974 & 1975 & 1976 & 1977 & 1978 & 1979 & 1980 & 1981 & 1982 \\
\hline trigo & $5 \%$ & $5 \%$ & $6 \%$ & $6 \%$ & $5 \%$ & $6 \%$ & $11 \%$ & $12 \%$ & $11 \%$ \\
\hline maíz & $45 \%$ & $43 \%$ & $38 \%$ & $35 \%$ & $34 \%$ & $32 \%$ & $31 \%$ & $33 \%$ & $30 \%$ \\
\hline lino & $16 \%$ & $17 \%$ & $14 \%$ & $14 \%$ & $12 \%$ & $8 \%$ & $9 \%$ & $8 \%$ & $5 \%$ \\
\hline girasol & $8 \%$ & $7 \%$ & $7 \%$ & $5 \%$ & $4 \%$ & $3 \%$ & $4 \%$ & $2 \%$ & $3 \%$ \\
\hline soja & $69 \%$ & $88 \%$ & $86 \%$ & $76 \%$ & $78 \%$ & $66 \%$ & $71 \%$ & $78 \%$ & $82 \%$ \\
\hline avena & $3 \%$ & $2 \%$ & $2 \%$ & $2 \%$ & $2 \%$ & $3 \%$ & $3 \%$ & $3 \%$ & $2 \%$ \\
\hline centeno & $2 \%$ & $2 \%$ & $2 \%$ & $2 \%$ & $2 \%$ & $2 \%$ & $2 \%$ & $2 \%$ & $2 \%$ \\
\hline cebada cerv. & $0 \%$ & $0 \%$ & $0 \%$ & $0 \%$ & $0 \%$ & $0 \%$ & $0 \%$ & $0 \%$ & $0 \%$ \\
\hline \multicolumn{10}{|l|}{ Zona oeste } \\
\hline trigo & $7 \%$ & $9 \%$ & $9 \%$ & $8 \%$ & $8 \%$ & $9 \%$ & $13 \%$ & $11 \%$ & $10 \%$ \\
\hline maíz & $8 \%$ & $8 \%$ & $8 \%$ & $9 \%$ & $11 \%$ & $13 \%$ & $12 \%$ & $12 \%$ & $10 \%$ \\
\hline lino & $0 \%$ & $0 \%$ & $0 \%$ & $0 \%$ & $1 \%$ & $1 \%$ & $1 \%$ & $1 \%$ & $1 \%$ \\
\hline girasol & $4 \%$ & $4 \%$ & $7 \%$ & $9 \%$ & $9 \%$ & $11 \%$ & $11 \%$ & $15 \%$ & $13 \%$ \\
\hline soja & $6 \%$ & $2 \%$ & $3 \%$ & $6 \%$ & $7 \%$ & $10 \%$ & $10 \%$ & $7 \%$ & $6 \%$ \\
\hline avena & $12 \%$ & $14 \%$ & $13 \%$ & $14 \%$ & $19 \%$ & $23 \%$ & $24 \%$ & $22 \%$ & $19 \%$ \\
\hline centeno & $58 \%$ & $61 \%$ & $59 \%$ & $62 \%$ & $63 \%$ & $64 \%$ & $62 \%$ & $63 \%$ & $70 \%$ \\
\hline cebada cerv. & $7 \%$ & $7 \%$ & $6 \%$ & $9 \%$ & $13 \%$ & $11 \%$ & $11 \%$ & $9 \%$ & $9 \%$ \\
\hline \multicolumn{10}{|l|}{ Zona sur } \\
\hline trigo & $52 \%$ & $48 \%$ & $47 \%$ & $47 \%$ & $49 \%$ & $49 \%$ & $41 \%$ & $39 \%$ & $43 \%$ \\
\hline maíz & $4 \%$ & $3 \%$ & $6 \%$ & $8 \%$ & $7 \%$ & $7 \%$ & $7 \%$ & $6 \%$ & $6 \%$ \\
\hline lino & $24 \%$ & $20 \%$ & $18 \%$ & $27 \%$ & $34 \%$ & $28 \%$ & $38 \%$ & $28 \%$ & $28 \%$ \\
\hline girasol & $34 \%$ & $30 \%$ & $25 \%$ & $34 \%$ & $36 \%$ & $34 \%$ & $31 \%$ & $33 \%$ & $31 \%$ \\
\hline soja & $1 \%$ & $1 \%$ & $0 \%$ & $0 \%$ & $1 \%$ & $1 \%$ & $0 \%$ & $0 \%$ & $0 \%$ \\
\hline avena & $26 \%$ & $27 \%$ & $28 \%$ & $38 \%$ & $31 \%$ & $30 \%$ & $32 \%$ & $33 \%$ & $37 \%$ \\
\hline centeno & $8 \%$ & $9 \%$ & $10 \%$ & $10 \%$ & $10 \%$ & $9 \%$ & $11 \%$ & $12 \%$ & $8 \%$ \\
\hline cebada cerv. & $74 \%$ & $75 \%$ & $75 \%$ & $58 \%$ & $63 \%$ & $66 \%$ & $66 \%$ & $66 \%$ & $69 \%$ \\
\hline
\end{tabular}

Fuente: "Estimaciones Agrícolas" de la SEAGyP 


\section{Superficie Sembrada (hectáreas)}

Superficie sembre

\begin{tabular}{|c|c|c|c|c|c|c|c|c|}
\hline \multirow[b]{2}{*}{ Zona norte } & \multirow[b]{2}{*}{1983} & \multirow[b]{2}{*}{1984} & \multirow[b]{2}{*}{1985} & \multirow[b]{2}{*}{1986} & \multirow[b]{2}{*}{1987} & \multirow[b]{2}{*}{1988} & \multicolumn{2}{|c|}{ 1990/91 } \\
\hline & & & & & & & 1989 & 1990 \\
\hline trigo & 477500 & 469000 & 464200 & 429100 & 369900 & 341000 & 296350 & \\
\hline maíz & 369800 & 351200 & 388000 & 343800 & 268200 & 233900 & & \\
\hline lino & 8320 & 5560 & 5300 & 4350 & 8490 & & & \\
\hline girasol & 31200 & 17300 & 45500 & 26100 & 24800 & 35900 & 79400 & \\
\hline soja & 540000 & 592000 & 588300 & 594000 & 669400 & 702850 & 745100 & \\
\hline avena & 20600 & 20200 & 18550 & 18800 & 21510 & 37083 & 53600 & \\
\hline $\begin{array}{l}\text { centeno } \\
\text { cebada cerv. }\end{array}$ & 5850 & 6140 & 4400 & 4450 & 1429 & 0 & 0 & \\
\hline & & & 0 & & & & & \\
\hline Zona oeste & & & 0 & & & & & \\
\hline trigo & 387000 & 345500 & 370400 & 262900 & 188300 & 218600 & 297100 & \\
\hline maíz & 136000 & 200000 & 205300 & 221700 & 153600 & 178000 & & \\
\hline lino & 3070 & 830 & 620 & 480 & 400 & & & \\
\hline girasol & 173000 & 202000 & 363000 & 184500 & 185300 & 237500 & 280000 & \\
\hline soja & 57600 & 70700 & 83200 & 84700 & 106100 & 133800 & 145300 & \\
\hline avena & 181000 & 185000 & 179500 & 152500 & 132800 & 157852 & 185500 & \\
\hline centeno & 276700 & 217100 & 183500 & 158100 & 99737 & 82000 & 94300 & \\
\hline cebada cerv. & 6520 & 14300 & 12300 & 11940 & 7900 & 10000 & 8700 & 12600 \\
\hline Zona sur & & & & & & & & \\
\hline trigo & 2007700 & 1713850 & 1494000 & 1406900 & 1383500 & 1243200 & 1422500 & \\
\hline maíz & 79300 & 131500 & 138800 & 198400 & 106500 & 157300 & & \\
\hline lino & 50300 & 25600 & 23150 & 52840 & 52950 & & & \\
\hline girasol & 425500 & 502900 & 646000 & 408400 & 493700 & 537800 & 535000 & \\
\hline soja & 3070 & 2810 & 3100 & 2360 & 8800 & 20300 & 26750 & \\
\hline avena & 264350 & 244500 & 246300 & 235000 & 274000 & 258890 & 246100 & \\
\hline centeno & 38200 & 32700 & 23500 & 30600 & 22307 & 20900 & 22700 & \\
\hline cebada cerv. & 39900 & 43400 & 20220 & 24260 & 57700 & 72200 & 79350 & 56800 \\
\hline & 2908320 & 2697260 & 2595070 & 2358760 & 2399457,3 & 2310590,27 & & \\
\hline & 2605770 & 2420060 & 2325270 & 2093160 & 2103150 & 2030800 & 2063600 & \\
\hline
\end{tabular}

Fuente: "Estimaciones Agrícolas" de la SEAGyP 


\section{Superficie Sembrada (hectáreas)}

\section{Zona norte}

1983

1984

1985

1986

1987

1988

1989

1990
Buenos Aires

$\begin{array}{lr}\text { trigo } & 4500000 \\ \text { maíz } & 1195000 \\ \text { lino } & 270000 \\ \text { girasol } & 1392000 \\ \text { soja } & 715000 \\ \text { avena } & 846000 \\ \text { centeno } & 411900 \\ \text { cebada cerv. } & 62000 \\ & 9391900\end{array}$

8134000

3915000
1290000
167000
1450000
830000
817500
329800
76000
8875300
7728000

3760000

1274000

197000

1815000

851500

880000

263100

45000

9085600

7942500

0,14

0,23

Región pampeanć

trigo
maíz
lino
girasol
soja
avena
centeno
cebada cerv.

7128000

2905000

807500

2400000

2674500

1766100

1138600

76900

18896600,31

$15991900,31 \quad 15467000,35$

5917100

3264500

748000

3480700

2636700

3111000

1741400

3139100

1703800

743800

58500

87600

$18719400,3616665520,37$

$16271800,36 \quad 14461050,37$

0,25

4937800

3160000

756900

2122350

3426200

1495550

708920

$\begin{array}{rrr}3300000 & 2910000 & 2890000 \\ 1327000 & 985000 & 1075000 \\ 265200 & 200000 & \\ 1118200 & 1230000 & 1380000 \\ 860000 & 987000 & 1130000 \\ 836000 & 870000 & 880000 \\ 279350 & 179400 & 150200 \\ 45000 & 88000 & 105300 \\ 8030750 & 7449400 & 7610500 \\ 6915400 & 6400000 & 6580300\end{array}$

Control proprcion

\section{Zona norte}

Fuente: "Estimaciones Agrícolas" de la SEAGyP
$25 \%$

$1990 / 91$

1900

3250000

1550000

1260000

900000

170000

121700

119000

4801500

4691000

2405000

667700

2369200

2733800

4389500

1798500

1926500

510150

121600

393200

147800

$16895050,4 \quad 16558800,39$

$14458400,4 \quad 14367100,39$
5424500

2587000

4703000

2066600

541000

177200

147300 
Superficie Sembrada (hectáreas)

\begin{tabular}{|c|c|c|c|c|c|c|c|c|}
\hline \multirow[b]{2}{*}{ Zona norte } & \multirow[b]{2}{*}{1983} & \multirow[b]{2}{*}{1984} & \multirow[b]{2}{*}{1985} & \multirow[b]{2}{*}{1986} & \multirow[b]{2}{*}{1987} & \multirow[b]{2}{*}{1988} & \multicolumn{2}{|c|}{ 1990/91 } \\
\hline & & & & & & & 1989 & 1990 \\
\hline trigo & $11 \%$ & $12 \%$ & $12 \%$ & $13 \%$ & $13 \%$ & $12 \%$ & $9 \%$ & \#DIV/0! \\
\hline maíz & $31 \%$ & $27 \%$ & $30 \%$ & $26 \%$ & $27 \%$ & $22 \%$ & \#DIV/O! & \#DIV/0! \\
\hline lino & $3 \%$ & $3 \%$ & $3 \%$ & $2 \%$ & $4 \%$ & \#DIV/O! & \#DIV/O! & \#DIV/0! \\
\hline girasol & $2 \%$ & $1 \%$ & $3 \%$ & $2 \%$ & $2 \%$ & $3 \%$ & $5 \%$ & \#DIV/0! \\
\hline soja & $76 \%$ & $71 \%$ & $69 \%$ & $69 \%$ & $68 \%$ & $62 \%$ & $59 \%$ & \#DIV/0! \\
\hline avena & $2 \%$ & $2 \%$ & $2 \%$ & $3 \%$ & $4 \%$ & $6 \%$ & \#REF! & \#DIV/O! \\
\hline centeno & $1 \%$ & $2 \%$ & $2 \%$ & $2 \%$ & $1 \%$ & $0 \%$ & $0 \%$ & \#DIV/O! \\
\hline cebada cerv. & $0 \%$ & $0 \%$ & $0 \%$ & $0 \%$ & $0 \%$ & $0 \%$ & $0 \%$ & $0 \%$ \\
\hline \multicolumn{9}{|l|}{ Zona oeste } \\
\hline trigo & $9 \%$ & $9 \%$ & $10 \%$ & $8 \%$ & $6 \%$ & $8 \%$ & $9 \%$ & \#DIV/0! \\
\hline maíz & $11 \%$ & $16 \%$ & $16 \%$ & $17 \%$ & $16 \%$ & $17 \%$ & \#DIV/O! & \#DIV/O! \\
\hline lino & $1 \%$ & $0 \%$ & $0 \%$ & $0 \%$ & $0 \%$ & \#DIV/O! & \#DIV/O! & \#DIV/0! \\
\hline girasol & $12 \%$ & $14 \%$ & $20 \%$ & $16 \%$ & $15 \%$ & $17 \%$ & $18 \%$ & \#DIV/O! \\
\hline soja & $8 \%$ & $9 \%$ & $10 \%$ & $10 \%$ & $11 \%$ & $12 \%$ & $12 \%$ & \#DIV/0! \\
\hline avena & $21 \%$ & $23 \%$ & $20 \%$ & $18 \%$ & $15 \%$ & $18 \%$ & $21 \%$ & \#DIV/O! \\
\hline centeno & $67 \%$ & $66 \%$ & $70 \%$ & $57 \%$ & $56 \%$ & $55 \%$ & $55 \%$ & \#DIV/0! \\
\hline cebada cerv. & $11 \%$ & $19 \%$ & $27 \%$ & $27 \%$ & $9 \%$ & $9 \%$ & $7 \%$ & $11 \%$ \\
\hline \multicolumn{9}{|l|}{ Zona sur } \\
\hline trigo & $45 \%$ & $44 \%$ & $40 \%$ & $43 \%$ & $48 \%$ & $43 \%$ & $44 \%$ & \#DIV/O! \\
\hline maíz & $7 \%$ & $10 \%$ & $11 \%$ & $15 \%$ & $11 \%$ & $15 \%$ & \#DIV/O! & \#DIV/O! \\
\hline lino & $19 \%$ & $15 \%$ & $12 \%$ & $20 \%$ & $26 \%$ & \#DIV/O! & \#DIV/O! & \#DIV/0! \\
\hline girasol & $31 \%$ & $35 \%$ & $36 \%$ & $37 \%$ & $40 \%$ & $39 \%$ & $35 \%$ & \#DIV/0! \\
\hline soja & $0 \%$ & $0 \%$ & $0 \%$ & $0 \%$ & $1 \%$ & $2 \%$ & $2 \%$ & \#DIV/0! \\
\hline avena & $31 \%$ & $30 \%$ & $28 \%$ & $28 \%$ & $31 \%$ & $29 \%$ & $27 \%$ & \#DIV/0! \\
\hline centeno & $9 \%$ & $10 \%$ & $9 \%$ & $11 \%$ & $12 \%$ & $14 \%$ & $13 \%$ & \#DIV/O! \\
\hline cebada cerv. & $64 \%$ & $57 \%$ & $45 \%$ & $54 \%$ & $66 \%$ & $69 \%$ & $65 \%$ & $48 \%$ \\
\hline
\end{tabular}




\section{Volumen Cosechado (Toneladas)}

Superficie cosechada

\begin{tabular}{|c|c|c|c|c|c|c|c|c|c|c|c|}
\hline Zona norte & 1938 & 1939 & 1940 & 1941 & 1942 & 1943 & 1944 & 1945 & 1946 & 1947 & 1948 \\
\hline trigo & 237140 & 169600 & 211960 & 231903 & 277608 & 250716 & 235605 & 257167 & 249175 & 243010 & 264950 \\
\hline maíz & 757449 & 796800 & 782003 & 746000 & 363500 & 613855 & 596900 & 625696 & 621100 & 586100 & 501047 \\
\hline lino & 181300 & 168300 & 187797 & 192100 & 195351 & 135854 & 95476 & 94409 & 81483 & 70840 & 39310 \\
\hline $\begin{array}{l}\text { girasol } \\
\text { soja }\end{array}$ & 730 & 2364 & 4931 & 41800 & 15600 & 50194 & 66700 & 71830 & 95810 & 111000 & 124800 \\
\hline avena & 9730 & 8335 & 8850 & 9650 & 10550 & 16385 & 12610 & 13130 & 11960 & 10790 & 6130 \\
\hline centeno & 3030 & 1054 & 1945 & 2530 & 1409 & 1561 & 1875 & 3427 & 5375 & 3880 & 3270 \\
\hline cebada cerv. & 0 & 0 & 0 & 0 & 900 & 2500 & 3920 & 2845 & 7868 & 6130 & 3470 \\
\hline \multicolumn{12}{|l|}{ Zona oeste } \\
\hline trigo & 390073 & 299500 & 314200 & 223353 & 97448 & 150380 & 70979 & 101400 & 223500 & 92750 & 105800 \\
\hline maíz & 85463 & 218700 & 250500 & 156184 & 24811 & 95200 & 27310 & 28390 & 52500 & 28900 & 23200 \\
\hline lino & 3800 & 2660 & 3086 & 3770 & 1834 & 1495 & 220 & 358 & 1019 & 250 & 0 \\
\hline $\begin{array}{l}\text { girasol } \\
\text { soja }\end{array}$ & 10300 & 25985 & 31650 & 42000 & 32509 & 102000 & 69475 & 71085 & 75250 & 87200 & 87850 \\
\hline avena & 60250 & 64120 & 33700 & 33356 & 27850 & 76786 & 21535 & 27300 & 21600 & 15900 & 19000 \\
\hline centeno & 76050 & 65471 & 26090 & 39992 & 45652 & 150272 & 70591 & 99000 & 173700 & 109400 & 88300 \\
\hline cebada cerv. & 32060 & 36056 & 36110 & 24945 & 17773 & 15940 & 11707 & 27580 & 57580 & 31900 & 24100 \\
\hline \multicolumn{12}{|l|}{ Zona sur } \\
\hline trigo & 1450800 & 1085470 & 1253200 & 1240500 & 898513 & 1036600 & 1149650 & 824900 & 1132070 & 829980 & 1016450 \\
\hline maíz & 40500 & 38200 & 28200 & 15350 & 8600 & 14400 & 21750 & 24382 & 14660 & 11610 & 10270 \\
\hline lino & 92300 & 103000 & 127690 & 132250 & 231971 & 223500 & 205250 & 164800 & 120435 & 154653 & 128800 \\
\hline $\begin{array}{l}\text { girasol } \\
\text { soja }\end{array}$ & 5200 & 7432 & 8770 & 5690 & 5040 & 13630 & 16910 & 21057 & 20068 & 15546 & 22250 \\
\hline avena & 250600 & 299800 & 174600 & 126100 & 242600 & 391278 & 482300 & 282400 & 315250 & 348100 & 322400 \\
\hline centeno & 15450 & 14416 & 12500 & 5600 & 15450 & 24820 & 22700 & 31110 & 55255 & 38100 & 27700 \\
\hline cebada cerv. & $\begin{array}{r}162300 \\
1751100\end{array}$ & 212200 & 192560 & 76300 & 99400 & 135460 & 166300 & 279810 & 415075 & 287600 & 228700 \\
\hline
\end{tabular}

Buenos Aires

Fuente: "Estimaciones Agrícolas" de la SEAGyP 


\section{Volumen Cosechado (Toneladas)}

\begin{tabular}{|c|c|c|c|c|c|c|c|c|c|c|c|}
\hline trigo & 3594335 & 2595620 & 2903060 & 2718961 & 1841841 & 2277938 & 2221910 & 1863017 & 2480676 & 1724200 & 1974000 \\
\hline maíz & 1583240 & 1732450 & 1784800 & 1452350 & 604210 & 1198663 & 887934 & 1042026 & 1014529 & 901280 & 715582 \\
\hline lino & 713690 & 636315 & 686348 & 650345 & 633762 & 568351 & 453290 & 413750 & 356594 & 374950 & 264200 \\
\hline girasol & 184820 & 216798 & 297546 & 346987 & 224275 & 653254 & 705792 & 667595 & 667474 & 730114 & 877579 \\
\hline avena & 618890 & 736255 & 420814 & 371445 & 495872 & 867901 & 865930 & 616358 & 605309 & 594260 & 546000 \\
\hline centeno & 180900 & 145949 & 109950 & 93636 & 108697 & 297903 & 188160 & 225809 & 381477 & 251230 & 160680 \\
\hline cebada cerv. & 286420 & 359756 & 327000 & 151962 & 195767 & 217057 & 249800 & 409260 & 674215 & 453400 & 323970 \\
\hline \multicolumn{12}{|c|}{ Región pampeana } \\
\hline trigo & 8005328 & 4985166 & 6621759 & 5874729 & 4808408 & 5932974 & 4337360 & 4020344 & 5576046 & 4566310 & 4326700 \\
\hline maíz & 3208400 & 5282975 & 4565700 & 3767100 & 1494271 & 3380233 & 1887256 & 2370530 & 2363519 & 2400280 & 1835207 \\
\hline lino & 2386940 & 2164825 & 2387998 & 2299952 & 2256785 & 2002645 & 1252270 & 1380397 & 1535059 & 1337868 & 868060 \\
\hline $\begin{array}{l}\text { girasol } \\
\text { soja }\end{array}$ & 260786 & 401193 & 511510 & 637150 & 463883 & 1209837 & 1097187 & 1259953 & 1047750 & 1248704 & 1445675 \\
\hline ena & 792110 & 867093 & 553001 & 459829 & 619661 & 1056923 & 1015910 & 734721 & 705350 & 674020 & 635080 \\
\hline nteno & 557090 & 528219 & 284714 & 205212 & 211217 & 771973 & 324830 & 555609 & 903843 & 691420 & 555830 \\
\hline bada cerv. & 343305 & 448626 & 443863 & 187467 & 216167 & 275663 & 272480 & 479928 & 829433 & 535140 & 449205 \\
\hline
\end{tabular}

Control proprcional

$\begin{array}{lrrr}\text { Zona norte } & & & \\ \text { trigo } & 7 \% & 7 \% & 7 \% \\ \text { maíz } & 48 \% & 46 \% & 44 \% \\ \text { lino } & 25 \% & 26 \% & 27 \% \\ \text { girasol } & 0 \% & 1 \% & 2 \% \\ \text { soja } & \text { \#DIV/O! } & \text { \#DIV/0! } & \text { \#DIV/0! } \\ \text { avena } & 2 \% & 1 \% & 2 \% \\ \text { centeno } & 2 \% & 1 \% & 2 \% \\ \text { cebada cerv. } & 0 \% & 0 \% & 0 \%\end{array}$

$9 \%$
$51 \%$
$30 \%$
$12 \%$
\#DIV/0!
$3 \%$
$3 \%$
$0 \%$

$15 \%$
$60 \%$
$31 \%$
$7 \%$
\#DIV $/ 0 !$
$2 \%$
$1 \%$
$0 \%$

$11 \%$
$51 \%$
$24 \%$
$8 \%$
\#DIV/0!
$2 \%$
$1 \%$
$1 \%$

$11 \%$
$67 \%$
$21 \%$
$9 \%$
\#DIV/0!
$1 \%$
$1 \%$
$2 \%$

$14 \%$
$60 \%$
$23 \%$
$11 \%$
\#IV/0!
$2 \%$
$2 \%$
$1 \%$

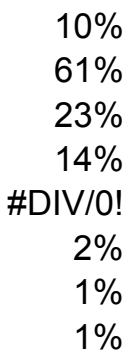

$14 \%$ 


\section{Volumen Cosechado (Toneladas)}

\section{Zona oeste}

$\begin{array}{lr}\text { trigo } & 11 \% \\ \text { maíz } & 5 \% \\ \text { lino } & 1 \% \\ \text { girasol } & 6 \% \\ \text { soja } & \text { \#DIV/0! } \\ \text { avena } & 10 \% \\ \text { centeno } & 42 \% \\ \text { cebada cerv. } & 11 \%\end{array}$

$12 \%$
$13 \%$
$0 \%$
$12 \%$
$\#$ DIV $/ 0 !$
$9 \%$
$45 \%$
$10 \%$

$11 \%$
$14 \%$
$0 \%$
$11 \%$
$\#$ DIV $/ 0 !$
$8 \%$
$24 \%$
$11 \%$

$8 \%$
$11 \%$
$1 \%$
$12 \%$
\#DIV/0!
$9 \%$
$43 \%$
$16 \%$

$5 \%$
$4 \%$
$0 \%$
$14 \%$
\#DIV/0!
$6 \%$
$42 \%$
$9 \%$

$7 \%$
$8 \%$
$0 \%$
$16 \%$
\#DIV/O!
$9 \%$
$50 \%$
$7 \%$

$3 \%$
$3 \%$
$0 \%$
$10 \%$
\#DIV/0!
$2 \%$
$38 \%$
$5 \%$

$5 \%$
$3 \%$
$0 \%$
$11 \%$
\#DIV/0!
$4 \%$
$44 \%$
$7 \%$

$9 \%$
$5 \%$
$0 \%$
$11 \%$
\#DIV/0!
$4 \%$
$46 \%$
$9 \%$

$\begin{array}{rr}5 \% & 5 \% \\ 3 \% & 3 \% \\ 0 \% & 0 \% \\ 12 \% & 10 \% \\ \text { \#DIV/0! } & \text { \#DIV/0! } \\ 3 \% & 3 \% \\ 44 \% & 55 \% \\ 7 \% & 7 \%\end{array}$

\section{Zona sur}

trigo

maíz

lino

girasol

soja

avena

centeno

cebada cerv.

$\begin{array}{rrr}40 \% & 42 \% & 43 \% \\ 3 \% & 2 \% & 2 \% \\ 13 \% & 16 \% & 19 \% \\ 3 \% & 3 \% & 3 \% \\ \text { \#DIV/0! } & \text { \#DIV/0! } & \text { \#DIV } / 0 ! \\ 40 \% & 41 \% & 41 \% \\ 9 \% & 10 \% & 11 \% \\ 57 \% & 59 \% & 59 \%\end{array}$

$46 \%$
$1 \%$
$20 \%$
$2 \%$
\#DIV/0!
$34 \%$
$6 \%$
$50 \%$

$49 \%$
$1 \%$
$37 \%$
$2 \%$
\#DIV $/ 0 !$
$49 \%$
$14 \%$
$51 \%$

$46 \%$
$1 \%$
$39 \%$
$2 \%$
\#DIV/0!
$45 \%$
$8 \%$
$62 \%$

$52 \%$
$2 \%$
$45 \%$
$2 \%$
\#DIV/0!
$56 \%$
$12 \%$
$67 \%$

$44 \%$
$2 \%$
$40 \%$
$3 \%$
\#DIV/0!
$46 \%$
$14 \%$
$68 \%$

$46 \%$
$1 \%$
$34 \%$
$3 \%$
\#DIV/0!
$52 \%$
$14 \%$
$62 \%$

$48 \%$
$1 \%$
$41 \%$
$2 \%$
\#DIV/0!
$59 \%$
$15 \%$
$63 \%$

$51 \%$
$1 \%$
$49 \%$
$3 \%$
\#DIV/0!
$59 \%$
$17 \%$
$71 \%$




\section{Volumen Cosechado (Toneladas)}

Superficie cos

\section{Zona norte}

trigo

maíz

lino

girasol

soja

avena

centeno

cebada cerv.

1949
350750
196050
27745
121620
7570
3980
4260

1950
337700
323130
21645
105795
6600
5080
2012

1951
318250
332150
26360
107050
5300
4080
2635

1952
320500
391225
35340
35640

9070
17500
7473

1953
344800
450700
16450
22380

6240
9400
10230

1954
288000
322500
21510
36020

4100
4800
5930

1955
271050
404000
18950
134150

3790
5150
7390

\section{Zona oeste}

trigo

maíz

lino

girasol

soja

avena

centeno

cebada cerv.

$\begin{array}{rr}69200 & 160900 \\ 1300 & 22600 \\ 5 & 485 \\ 38950 & 94650 \\ & \\ 10000 & 27300 \\ 42850 & 178600 \\ 16080 & 34080\end{array}$

\section{0}

11390

90

49750

6030

32200

12300

\section{0}

98060

130

55190

69790

282050

60450

167800

75000

268

22700

31860

$$
210800
$$

21800

175000

50300

1110

15200

27500

$$
207000
$$

27750

Zona sur

trigo

maíz

lino

girasol

soja

avena

centeno

cebada cerv.

$\begin{array}{rrr}777755 & 1066160 & 685400 \\ 6980 & 9470 & 3300 \\ 79430 & 91580 & 105730 \\ 18190 & 20975 & 11950 \\ & & \\ 229550 & 257100 & 208260 \\ 17170 & 30650 & 16080 \\ 160950 & 265100 & 181265\end{array}$

1155420
19264
92770
17402
385700
57850
270700

1177500
25880
78388
9033
310900
37570
254900

1075900
15300
74150
8080

291000
30600
271000

122500
46200
1410
60500

34000
243200
31650


958800
17760
56405
14180

284800
35200
292500

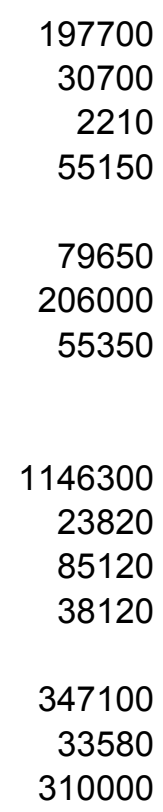

$\begin{array}{rr}1958 & 1959 \\ 314600 & 227300 \\ 379400 & 375900 \\ 20590 & 19380 \\ 96600 & 169130 \\ & \\ 9250 & 11498 \\ 15400 & 17630\end{array}$

$5040 \quad 5040$

$\begin{array}{rrr}126700 & 186900 & 123200 \\ 37300 & 42750 & 32200 \\ 1100 & 930 & 930 \\ 77360 & 60200 & 74600 \\ & & \\ 66000 & 77500 & 64611,79 \\ 199000 & 266500 & 334000 \\ 32600 & 41500 & 36400\end{array}$

Buenos Aires

\footnotetext{
Fuente: "Estimaciones Agrícolas" de la SEAGyP
} 


\section{Volumen Cosechado (Toneladas)}

\begin{tabular}{|c|c|c|c|c|c|c|c|c|c|c|c|}
\hline trigo & 1700450 & 2439100 & 1595460 & 2695700 & 2761500 & 2520900 & 2044900 & 2633600 & 2285200 & 2764400 & 2122600 \\
\hline maíz & 306210 & 573180 & 486970 & 956794 & 999353 & 689795 & 834904 & 598185 & 812900 & 722030 & 717300 \\
\hline lino & 153800 & 173300 & 203100 & 236740 & 202700 & 194500 & 148200 & 207800 & 246600 & 277000 & 324200 \\
\hline girasol & 617383 & 744448 & 625225 & 417013 & 268159 & 245135 & 604843 & 582800 & 804235 & 577800 & 714100 \\
\hline avena & 422070 & 528190 & 389000 & 863500 & 677700 & 602800 & 578400 & 802400 & 737800 & 696200 & 703900 \\
\hline centeno & 116300 & 328400 & 100300 & 588300 & 438300 & 384800 & 426800 & 421000 & 398600 & 501500 & 561600 \\
\hline cebada cerv. & 240780 & 417550 & 269910 & 534603 & 485600 & 487600 & 533000 & 603300 & 510300 & 518600 & 495900 \\
\hline \multicolumn{12}{|l|}{ Región pamp } \\
\hline trigo & 4512270 & 5230810 & 2735660 & 5562340 & 4980650 & 5445890 & 4045400 & 5363100 & 4371800 & 5223200 & 4352100 \\
\hline maíz & 765975 & 1512180 & 1246790 & 2154694 & 2216093 & 1675770 & 2021012 & 1677940 & 2156650 & 2053100 & 2068300 \\
\hline lino & 958180 & 844400 & 448400 & 868280 & 551200 & 632700 & 442500 & 1072400 & 1069800 & 990700 & 1108400 \\
\hline $\begin{array}{l}\text { girasol } \\
\text { soja }\end{array}$ & 944694 & 1315249 & 1056263 & 624087 & 450409 & 403213 & 1088373 & 960875 & 1297835 & 846130 & 1077500 \\
\hline rena & 511800 & 629470 & 416430 & 960980 & 727120 & 692800 & 652500 & 954000 & 874100 & 793800 & 795500 \\
\hline nteno & 432570 & 981310 & 149970 & 1395143 & 815450 & 1092030 & 872714 & 1190290 & 859050 & 1040520 & 1290865 \\
\hline bada cerv. & 309700 & 499045 & 309910 & 723143 & 571880 & 670700 & 739700 & 873025 & 697550 & 761150 & 764750 \\
\hline
\end{tabular}

Control propre

$\begin{array}{lrrr}\text { Zona norte } & & & \\ \text { trigo } & 21 \% & 14 \% & 20 \% \\ \text { maíz } & 64 \% & 56 \% & 68 \% \\ \text { lino } & 18 \% & 12 \% & 13 \% \\ \text { girasol } & 20 \% & 14 \% & 17 \% \\ \text { soja } & \text { \#DIV/O! } & \text { \#DIV/0! } & \text { \#DIV/O! } \\ \text { avena } & 2 \% & 1 \% & 1 \% \\ \text { centeno } & 3 \% & 2 \% & 4 \% \\ \text { cebada cerv. } & 2 \% & 0 \% & 1 \%\end{array}$

$12 \%$
$41 \%$
$15 \%$
$9 \%$
\#DIV/0!
$1 \%$
$3 \%$
$1 \%$

$12 \%$
$45 \%$
$8 \%$
$8 \%$
\#DIV/0!
$1 \%$
$2 \%$
$2 \%$

$11 \%$
$47 \%$
$11 \%$
$15 \%$
\#DIV/0!
$1 \%$
$1 \%$
$1 \%$

$13 \%$
$48 \%$
$13 \%$
$22 \%$
\#DIV/0!
$1 \%$
$1 \%$
$1 \%$

$12 \%$
$56 \%$
$12 \%$
$21 \%$
\#DIV/0!
$1 \%$
$2 \%$
$2 \%$

$10 \%$
$48 \%$
$8 \%$
$23 \%$
\#DIV/0!
$1 \%$
$2 \%$
$1 \%$

$11 \%$
$53 \%$
$7 \%$
$17 \%$
\#DIV/0!
$1 \%$
$3 \%$
$1 \%$

$11 \%$
$52 \%$
$6 \%$
$24 \%$
\#DIV/0!
$2 \%$
$3 \%$
$1 \%$

Fuente: "Estimaciones Agrícolas" de la SEAGyP 


\section{Volumen Cosechado (Toneladas)}

\section{Zona oeste}

\begin{tabular}{|c|c|c|c|c|c|c|c|c|c|c|c|}
\hline trigo & $4 \%$ & $7 \%$ & $3 \%$ & $9 \%$ & $6 \%$ & $7 \%$ & $6 \%$ & $8 \%$ & $6 \%$ & $7 \%$ & $6 \%$ \\
\hline maíz & $0 \%$ & $4 \%$ & $2 \%$ & $10 \%$ & $8 \%$ & $7 \%$ & $6 \%$ & $5 \%$ & $5 \%$ & $6 \%$ & $4 \%$ \\
\hline lino & $0 \%$ & $0 \%$ & $0 \%$ & $0 \%$ & $0 \%$ & $1 \%$ & $1 \%$ & $1 \%$ & $0 \%$ & $0 \%$ & $0 \%$ \\
\hline girasol & $6 \%$ & $13 \%$ & $8 \%$ & $13 \%$ & $8 \%$ & $6 \%$ & $10 \%$ & $9 \%$ & $10 \%$ & $10 \%$ & $10 \%$ \\
\hline soja & \#DIV/O! & \#DIV/0! & \#DIV/0! & \#DIV/O! & \#DIV/O! & \#DIV/O! & \#DIV/0! & \#DIV/O! & \#DIV/O! & \#DIV/0! & \#DIV/O! \\
\hline avena & $2 \%$ & $5 \%$ & $2 \%$ & $8 \%$ & $5 \%$ & $5 \%$ & $6 \%$ & $10 \%$ & $9 \%$ & $11 \%$ & $9 \%$ \\
\hline centeno & $37 \%$ & $54 \%$ & $32 \%$ & $48 \%$ & $48 \%$ & $54 \%$ & $57 \%$ & $49 \%$ & $50 \%$ & $53 \%$ & $59 \%$ \\
\hline cebada cerv. & $7 \%$ & $8 \%$ & $5 \%$ & $11 \%$ & $4 \%$ & $6 \%$ & $6 \%$ & $9 \%$ & $6 \%$ & $8 \%$ & $7 \%$ \\
\hline \multicolumn{12}{|l|}{ Zona sur } \\
\hline trigo & $46 \%$ & $44 \%$ & $43 \%$ & $43 \%$ & $43 \%$ & $43 \%$ & $47 \%$ & $44 \%$ & $48 \%$ & $46 \%$ & $49 \%$ \\
\hline maíz & $2 \%$ & $2 \%$ & $1 \%$ & $2 \%$ & $3 \%$ & $2 \%$ & $2 \%$ & $4 \%$ & $2 \%$ & $2 \%$ & $2 \%$ \\
\hline lino & $52 \%$ & $53 \%$ & $52 \%$ & $39 \%$ & $39 \%$ & $38 \%$ & $38 \%$ & $41 \%$ & $48 \%$ & $50 \%$ & $55 \%$ \\
\hline girasol & $3 \%$ & $3 \%$ & $2 \%$ & $4 \%$ & $3 \%$ & $3 \%$ & $2 \%$ & $7 \%$ & $8 \%$ & $12 \%$ & $8 \%$ \\
\hline soja & \#DIV/O! & \#DIV/O! & \#DIV/O! & \#DIV/0! & \#DIV/O! & \#DIV/O! & \#DIV/O! & \#DIV/O! & \#DIV/O! & \#DIV/O! & \#DIV/O! \\
\hline avena & $54 \%$ & $49 \%$ & $54 \%$ & $45 \%$ & $46 \%$ & $48 \%$ & $49 \%$ & $43 \%$ & $44 \%$ & $41 \%$ & $45 \%$ \\
\hline centeno & $15 \%$ & $9 \%$ & $16 \%$ & $10 \%$ & $9 \%$ & $8 \%$ & $8 \%$ & $8 \%$ & $9 \%$ & $8 \%$ & $6 \%$ \\
\hline cebada cerv. & $67 \%$ & $63 \%$ & $67 \%$ & $51 \%$ & $52 \%$ & $56 \%$ & $55 \%$ & $51 \%$ & $52 \%$ & $48 \%$ & $46 \%$ \\
\hline
\end{tabular}




\section{Volumen Cosechado (Toneladas)}

Superficie cos

\section{Zona norte}

trigo

maíz

lino

girasol

soja

avena

centeno

cebada cerv.

\section{Zona oeste}

trigo

maíz

lino

girasol

soja

avena

centeno

cebada cerv.

\section{Zona sur}

trigo

maíz

lino

girasol

soja

avena

centeno

cebada cerv.

Buenos Aires

$\begin{array}{rrrr}1960 & 1961 & 1962 & 1963 \\ 245950 & 296200 & 343000 & 367900 \\ 416800 & 414700 & 416800 & 437000 \\ 18370 & 19320 & 18840 & 18630 \\ 142800 & 173870,9 & 115980 & 111800 \\ & & & \\ 13760 & 13800 & 13200 & 14740 \\ 16500 & 15600 & 16000 & 17130 \\ 5165 & 3060 & 3290 & 5295\end{array}$

70900

24300

370

34000

51300

183250

28500

60800
22700
255
37559,14
45000
145250
19300

95400

13900

540

22500

21500

75000

12900

531800

7700

118700

10750

130000

8200

89350

1964
412960
393775
19070
128500
13000
18000
2725

1965
332150
446100
18570
126600
9900
12050

248700

1966
319800
474611
16170
138750

10950
7800
1495

305600

36300

470

38400

32700

137300

21990

1389100

$$
18550
$$

147500

29110

308400

30650

264240

201400

26450

175

385

37100

41650

210200

20410

55300

36100

163500

12930

1375000
21400
146750
40050

245180
24550
162090

1281300
31800
163600
47770

185800
14200
122030

1967
318900
499100
7410
68500
15375
10000
3210

196

295022

560620

13930

100850

11150

9500

4270
334400

44600

890

44200

71100

214000

15250

171000

10000

1405000

27900

150480

59000

190200

14250

174560
1559500
29390
142650
57750

197000
15360
155470
258350

48450

380

45400

48500

216900

9250

1472600
27260
151200
70250

173500
10190
210400
1969

229450

615500

15800

117400

1270

7750

8970

2920

284100

57550

280

57500

0

23850

217600

10700

1521450
48300
129500
70650
0
129600
13350
202100
1970

162550

650700

37960

92700

1390

4550

2720

2710

124600

52150

54700

0

12700

125120

6750

$$
\begin{array}{r}
1231400 \\
18900 \\
182600 \\
83700 \\
0 \\
114600 \\
7250
\end{array}
$$

175600

Fuente: "Estimaciones Agrícolas" de la SEAGyP 


\section{Volumen Cosechado (Toneladas)}

\begin{tabular}{|c|c|c|c|c|c|c|c|c|c|c|c|}
\hline trigo & 1992300 & 2239700 & 1572800 & 3217100 & 3315000 & 2830100 & 3006600 & 3454200 & 3236100 & 3238650 & 2503500 \\
\hline maíz & 756300 & 719400 & 695300 & 760400 & 706200 & 800600 & 891300 & 875200 & 979300 & 1178600 & 1195400 \\
\hline lino & 271400 & 309550 & 284400 & 302800 & 317170 & 346500 & 297000 & 284300 & 365800 & 423700 & 425700 \\
\hline girasol & 530000 & 644450 & 429300 & 454300 & 506665 & 576470 & 635250 & 548440 & 676200 & 823500 & 713300 \\
\hline soja & & & & & & & & & & 1270 & 1390 \\
\hline avena & 709900 & 522200 & 371100 & 622700 & 509500 & 392500 & 375800 & 490600 & 403000 & 299900 & 268450 \\
\hline centeno & 371400 & 298600 & 128200 & 285200 & 355700 & 215920 & 215000 & 271600 & 273000 & 286700 & 186500 \\
\hline cebada cerv. & 457600 & 420400 & 191200 & 438200 & 321800 & 238900 & 263000 & 252900 & 300400 & 294200 & 256100 \\
\hline \multicolumn{12}{|l|}{ Región pamp } \\
\hline igo & 3607400 & 4400000 & 3713100 & 5637400 & 6078280 & 4564300 & 5167200 & 5708000 & 5726600 & 5106050 & 3600200 \\
\hline maíz & 2339200 & 2309800 & 2182300 & 2525650 & 2505950 & 2883100 & 2964100 & 2926510 & 3003000 & 3511250 & 3550200 \\
\hline lino & 950900 & 1164650 & 1311080 & 1215060 & 1081620 & 1001450 & 796300 & 612960 & 805300 & 786200 & 828950 \\
\hline girasol & 882050 & 1156270 & 719210 & 729230 & 971345 & 1003600 & 1178920 & 997740 & 1177750 & 1342550 & 1264450 \\
\hline soja & & & & & & & & & & 7520 & 11390 \\
\hline avena & 765100 & 594100 & 409200 & 690300 & 566650 & 417500 & 409450 & 512200 & 438900 & 323900 & 297300 \\
\hline centeno & 709200 & 671730 & 262830 & 634600 & 756320 & 317170 & 406850 & 541800 & 587100 & 518000 & 357720 \\
\hline \multirow[t]{2}{*}{ cebada cerv. } & 608360 & 616480 & 291845 & 576000 & 437060 & 309985 & 344230 & 394200 & 383950 & 390000 & 304600 \\
\hline & & & & & & & & & & \multicolumn{2}{|c|}{10214810,12} \\
\hline
\end{tabular}

Control propre

Zona norte

$\begin{array}{lrrr}\text { trigo } & 12 \% & 13 \% & 22 \% \\ \text { maíz } & 55 \% & 58 \% & 60 \% \\ \text { lino } & 7 \% & 6 \% & 7 \% \\ \text { girasol } & 27 \% & 27 \% & 27 \% \\ \text { soja } & \text { \#DIV } / 0 ! & \text { \#DIV } / 0 ! & \text { \#DIV } / 0 ! \\ \text { avena } & 2 \% & 3 \% & 4 \% \\ \text { centeno } & 4 \% & 5 \% & 12 \% \\ \text { cebada cerv. } & 1 \% & 1 \% & 2 \%\end{array}$

$\begin{array}{rr}11 \% & 12 \% \\ 57 \% & 56 \% \\ 6 \% & 6 \% \\ 25 \% & 25 \% \\ \text { \#DIV/0! } & \text { \#DIV/0! } \\ 2 \% & 3 \% \\ 6 \% & 5 \% \\ 1 \% & 1 \%\end{array}$

$12 \%$
$56 \%$
$5 \%$
$22 \%$
\#DIV/0!
$3 \%$
$6 \%$
$1 \%$

$11 \%$
$53 \%$
$5 \%$
$22 \%$
\#DIV/0!
$3 \%$
$4 \%$
$1 \%$

$9 \%$
$57 \%$
$3 \%$
$12 \%$
\#DIV/0!
$3 \%$
$4 \%$
$1 \%$

$9 \%$
$57 \%$
$4 \%$
$15 \%$
\#DIV/0!
$3 \%$
$3 \%$
$1 \%$

$7 \%$
$52 \%$
$4 \%$
$14 \%$
$100 \%$
$3 \%$
$3 \%$
$1 \%$

$6 \%$
$54 \%$
$9 \%$
$13 \%$
$100 \%$
$2 \%$
$1 \%$
$1 \%$

Fuente: "Estimaciones Agrícolas" de la SEAGyP 


\section{Volumen Cosechado (Toneladas)}

\section{Zona oeste}

\begin{tabular}{|c|c|c|c|c|c|c|c|c|c|c|c|}
\hline trigo & $4 \%$ & $3 \%$ & $6 \%$ & $8 \%$ & $9 \%$ & $7 \%$ & $8 \%$ & $10 \%$ & $8 \%$ & $9 \%$ & $5 \%$ \\
\hline maíz & $3 \%$ & $3 \%$ & $2 \%$ & $5 \%$ & $4 \%$ & $3 \%$ & $8 \%$ & $5 \%$ & $5 \%$ & $5 \%$ & $4 \%$ \\
\hline lino & $0 \%$ & $0 \%$ & $0 \%$ & $0 \%$ & $0 \%$ & $0 \%$ & $0 \%$ & $0 \%$ & $0 \%$ & $0 \%$ & $0 \%$ \\
\hline girasol & $6 \%$ & $6 \%$ & $5 \%$ & $8 \%$ & $7 \%$ & $10 \%$ & $8 \%$ & $8 \%$ & $7 \%$ & $7 \%$ & $8 \%$ \\
\hline soja & \#DIV/O! & \#DIV/0! & \#DIV/0! & \#DIV/O! & \#DIV/O! & \#DIV/O! & \#DIV/0! & \#DIV/O! & \#DIV/O! & $0 \%$ & $0 \%$ \\
\hline avena & $7 \%$ & $9 \%$ & $6 \%$ & $5 \%$ & $8 \%$ & $9 \%$ & $9 \%$ & $14 \%$ & $12 \%$ & $8 \%$ & $5 \%$ \\
\hline centeno & $49 \%$ & $49 \%$ & $59 \%$ & $48 \%$ & $59 \%$ & $76 \%$ & $80 \%$ & $79 \%$ & $79 \%$ & $76 \%$ & $67 \%$ \\
\hline cebada cerv. & $6 \%$ & $5 \%$ & $7 \%$ & $5 \%$ & $6 \%$ & $5 \%$ & $4 \%$ & $6 \%$ & $3 \%$ & $4 \%$ & $3 \%$ \\
\hline \multicolumn{12}{|l|}{ Zona sur } \\
\hline trigo & $46 \%$ & $45 \%$ & $34 \%$ & $43 \%$ & $41 \%$ & $45 \%$ & $47 \%$ & $45 \%$ & $46 \%$ & $47 \%$ & $49 \%$ \\
\hline maíz & $2 \%$ & $2 \%$ & $1 \%$ & $2 \%$ & $3 \%$ & $4 \%$ & $3 \%$ & $3 \%$ & $3 \%$ & $4 \%$ & $2 \%$ \\
\hline lino & $52 \%$ & $51 \%$ & $42 \%$ & $49 \%$ & $46 \%$ & $47 \%$ & $51 \%$ & $50 \%$ & $41 \%$ & $31 \%$ & $43 \%$ \\
\hline girasol & $4 \%$ & $3 \%$ & $3 \%$ & $6 \%$ & $8 \%$ & $8 \%$ & $9 \%$ & $11 \%$ & $10 \%$ & $9 \%$ & $12 \%$ \\
\hline soja & \#DIV/O! & \#DIV/O! & \#DIV/O! & \#DIV/O! & \#DIV/O! & \#DIV/O! & \#DIV/O! & \#DIV/O! & \#DIV/O! & $0 \%$ & $0 \%$ \\
\hline avena & $49 \%$ & $45 \%$ & $35 \%$ & $50 \%$ & $48 \%$ & $47 \%$ & $51 \%$ & $40 \%$ & $43 \%$ & $43 \%$ & $43 \%$ \\
\hline centeno & $10 \%$ & $11 \%$ & $6 \%$ & $11 \%$ & $7 \%$ & $7 \%$ & $7 \%$ & $6 \%$ & $4 \%$ & $5 \%$ & $4 \%$ \\
\hline cebada cerv. & $49 \%$ & $54 \%$ & $47 \%$ & $60 \%$ & $50 \%$ & $51 \%$ & $66 \%$ & $61 \%$ & $70 \%$ & $69 \%$ & $69 \%$ \\
\hline
\end{tabular}




\section{Volumen Cosechado (Toneladas)}

Superficie cos

\begin{tabular}{|c|c|c|c|c|c|c|c|c|c|c|c|}
\hline Zona norte & 1971 & 1972 & 1973 & 1974 & 1975 & 1976 & 1977 & 1978 & 1979 & 1980 & 1981 \\
\hline trigo & 170400 & 193000 & 111350 & 135500 & 170100 & 188800 & 148900 & 147200 & 183900 & 366420 & 465000 \\
\hline maíz & 561200 & 481700 & 541200 & 595600 & 589170 & 414610 & 451000 & 454500 & 366500 & 465800 & 420500 \\
\hline lino & 29400 & 34330 & 33400 & 36380 & 36300 & 38695 & 55100 & 36730 & 29280 & 23222 & 23430 \\
\hline girasol & 102415 & 103940 & 52820 & 53020 & 53135 & 48150 & 56624 & 36505 & 29600 & 36115 & 19000 \\
\hline soja & 1530 & 5045 & 38580 & 20910 & 38200 & 41040 & 115330 & 205018 & 307600 & 320640 & 362500 \\
\hline avena & 6150 & 5400 & 1500 & 1300 & 1000 & 900 & 1400 & 1150 & 1450 & 2650 & 2650 \\
\hline centeno & 1800 & 1200 & 650 & 550 & 650 & 600 & 0 & 1000 & 1110 & 1040 & 620 \\
\hline cebada cerv. & 4580 & 4020 & 2520 & 2030 & 940 & 830 & 21290 & 3790 & 1750 & 450 & 50 \\
\hline \multicolumn{12}{|l|}{ Zona oeste } \\
\hline trigo & 140800 & 167100 & 127400 & 191700 & 252000 & 312000 & 158000 & 213000 & 248250 & 329600 & 371000 \\
\hline maíz & 31150 & 34200 & 52500 & 52400 & 49500 & 52600 & 70400 & 110700 & 91300 & 158600 & 115500 \\
\hline lino & 0 & 0 & 800 & 700 & 0 & 400 & 1350 & 1460 & 3460 & 1490 & 3595 \\
\hline girasol & 51000 & 58450 & 30450 & 15000 & 23900 & 45700 & 82586 & 77100 & 99450 & 87159 & 163710 \\
\hline soja & 0 & 0 & 5772 & 1630 & 945 & 1220 & 8370 & 18424 & 46330 & 43930 & 31000 \\
\hline avena & 29900 & 30500 & 35950 & 24700 & 31800 & 28200 & 38600 & 49000 & 52850 & 27500 & 27100 \\
\hline centeno & 185300 & 221300 & 137000 & 94300 & 73600 & 58400 & 41500 & 66200 & 67650 & 34330 & 29200 \\
\hline cebada cerv. & 16000 & 21650 & 16300 & 15650 & 20000 & 18200 & 11890 & 27500 & 14630 & 8000 & 8453 \\
\hline \multicolumn{12}{|l|}{ Zona sur } \\
\hline trigo & 1362500 & 1433500 & 1304900 & 1293200 & 1431500 & 1723400 & 1053400 & 1449800 & 1404400 & 1292100 & 1438300 \\
\hline maíz & 31600 & 41800 & 23200 & 21550 & 19320 & 42950 & 58400 & 31500 & 18750 & 68700 & 27700 \\
\hline lino & 72050 & 56050 & 78150 & 52950 & 40910 & 53000 & 100160 & 100060 & 102550 & 96850 & 77100 \\
\hline girasol & 124300 & 147485 & 219850 & 197820 & 206590 & 178730 & 384300 & 331000 & 337750 & 254750 & 356590 \\
\hline soja & 0 & 105 & 496 & 180 & 262 & 40 & 670 & 1678 & 750 & 280 & 200 \\
\hline avena & 125900 & 133200 & 149700 & 104600 & 119200 & 142700 & 177950 & 154500 & 138000 & 117500 & 91100 \\
\hline centeno & 20045 & 17095 & 24650 & 11050 & 21000 & 27020 & 20910 & 24850 & 16740 & 20600 & 3180 \\
\hline cebada cerv. & 218850 & 243600 & 208660 & 154900 & 218120 & 251650 & 119740 & 152350 & 102050 & 69800 & 48250 \\
\hline
\end{tabular}

Buenos Aires

Fuente: "Estimaciones Agrícolas" de la SEAGyP 


\section{Volumen Cosechado (Toneladas)}

\begin{tabular}{|c|c|c|c|c|c|c|c|c|c|c|c|}
\hline trigo & 2741350 & 2938100 & 2358600 & 2362000 & 2947000 & 3528000 & 2210000 & 2840000 & 2789000 & 3024000 & 3660800 \\
\hline maíz & 1033200 & 911480 & 1082200 & 1023500 & 1129100 & 968000 & 1100000 & 1068000 & 805000 & 1340000 & 1089000 \\
\hline lino & 210500 & 216000 & 220000 & 227300 & 201000 & 293000 & 376000 & 290000 & 348000 & 255200 & 284700 \\
\hline girasol & 700650 & 678600 & 684900 & 535800 & 680200 & 645000 & 1100000 & 903600 & 971000 & 804600 & 1060000 \\
\hline soja & 1580 & 5150 & 52180 & 29500 & 43200 & 47000 & 149100 & 260000 & 460000 & 450000 & 460900 \\
\hline avena & 323100 & 337800 & 347500 & 250800 & 293500 & 292300 & 342000 & 390000 & 280400 & 234000 & 180800 \\
\hline centeno & 270500 & 341400 & 239500 & 172250 & 150700 & 140800 & 99000 & 136000 & 115000 & 82900 & 57400 \\
\hline cebada cerv. & 323000 & 376840 & 284600 & 208200 & 287160 & 328800 & 190000 & 235500 & 147300 & 96500 & 71900 \\
\hline \multicolumn{12}{|l|}{ Región pamp } \\
\hline rigo & 4218650 & 4882500 & 3858700 & 4122300 & 5131500 & 6332000 & 3815000 & 4610000 & 4711100 & 4964000 & 5856600 \\
\hline maíz & 2879300 & 3076180 & 3030300 & 2704550 & 2468850 & 2157900 & 2333000 & 2449500 & 2029800 & 2983100 & 2644600 \\
\hline lino & 446560 & 439830 & 388420 & 497510 & 442700 & 670820 & 879340 & 808780 & 973880 & 725100 & 816340 \\
\hline girasol & 1254260 & 1274385 & 1251520 & 1001920 & 1236190 & 1278730 & 2113400 & 1730800 & 1872050 & 1476000 & 1918490 \\
\hline soja & 36610 & 100050 & 262040 & 286850 & 361500 & 551200 & 1000300 & 1416600 & 1799850 & 1725600 & 1823020 \\
\hline rena & 354360 & 396200 & 391380 & 280010 & 334800 & 377500 & 424700 & 489000 & 402600 & 343700 & 294800 \\
\hline nteno & 429960 & 740830 & 634600 & 367800 & 289300 & 339250 & 237000 & 254800 & 215300 & 201500 & 156700 \\
\hline bada cerv. & 401000 & 489440 & 396400 & 299800 & 367330 & 407700 & 246800 & 285300 & 195700 & 130000 & 95700 \\
\hline
\end{tabular}

$10020700,1811399415,2210213360,32 \quad 9560740,37 \quad 10632170,312115100,28$ 11049540,35 12044780,37 12200280,35 12549000,32 13606250,34

12242710

Control proprs

$\begin{array}{lrrr}\text { Zona norte } & & & \\ \text { trigo } & 6 \% & 7 \% & 5 \% \\ \text { maíz } & 54 \% & 53 \% & 50 \% \\ \text { lino } & 14 \% & 16 \% & 15 \% \\ \text { girasol } & 15 \% & 15 \% & 8 \% \\ \text { soja } & 97 \% & 98 \% & 74 \% \\ \text { avena } & 2 \% & 2 \% & 0 \% \\ \text { centeno } & 1 \% & 0 \% & 0 \% \\ \text { cebada cerv. } & 1 \% & 1 \% & 1 \%\end{array}$

Fuente: "Estimaciones Agrícolas" de la SEAGyP

$6 \%$
$52 \%$
$18 \%$
$8 \%$
$88 \%$
$0 \%$
$0 \%$
$0 \%$

$5 \%$
$43 \%$
$13 \%$
$7 \%$
$87 \%$
$0 \%$
$0 \%$
$0 \%$

$5 \%$
$43 \%$
$13 \%$
$4 \%$
$79 \%$
$0 \%$
$1 \%$
$2 \%$

$12 \%$
$35 \%$
$9 \%$
$4 \%$
$71 \%$
$1 \%$
$1 \%$
$0 \%$

$13 \%$

$39 \%$

$8 \%$

$79 \%$

$1 \%$

$1 \%$

$0 \%$ 


\section{Volumen Cosechado (Toneladas)}

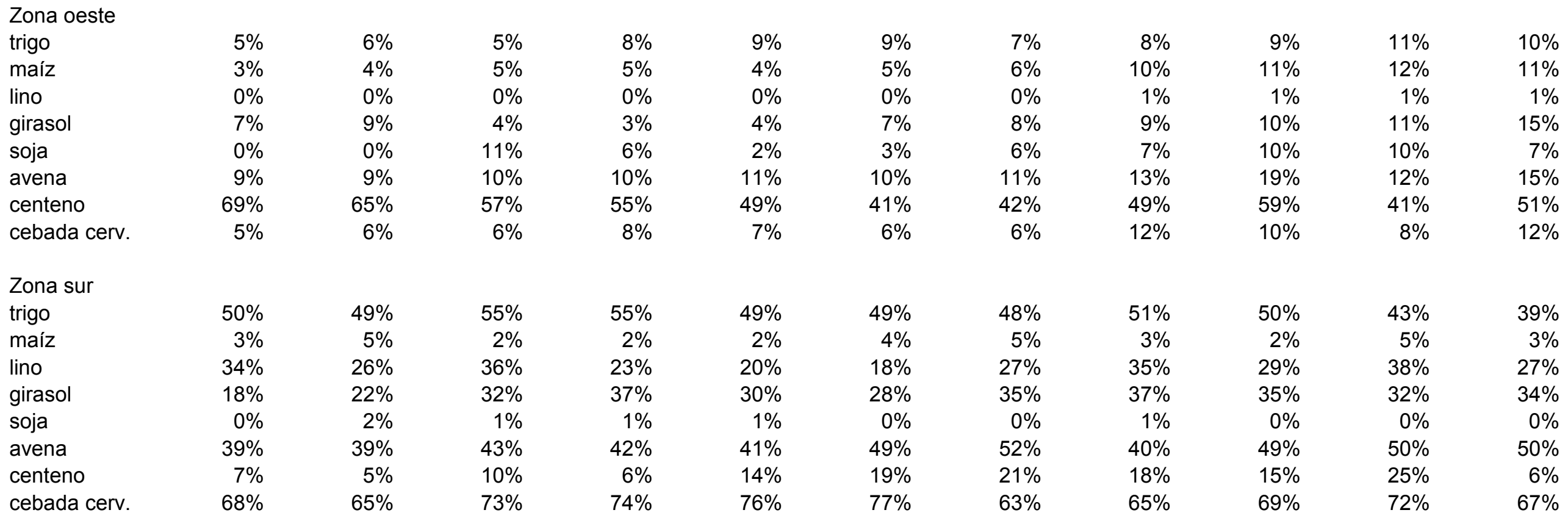




\section{Volumen Cosechado (Toneladas)}

Superficie cos

$\begin{array}{lr}\text { Zona norte } & 1982 \\ \text { trigo } & 469700 \\ \text { maíz } & 308600 \\ \text { lino } & 13680 \\ \text { girasol } & 28100 \\ \text { soja } & 535400 \\ \text { avena } & 2750 \\ \text { centeno } & 1400 \\ \text { cebada cerv. } & 0\end{array}$

$\begin{array}{rr}1983 & 1984 \\ 449700 & 469000 \\ 360770 & 351200 \\ 8100 & 5560 \\ 29900 & 17300 \\ 539100 & 591800 \\ 650 & 1000 \\ 0 & 0 \\ 0 & 0\end{array}$

1985
454200
385000
4650
45500
588300
500
0
0

1986
429100
343800
4350
26100
590700
1000
0
0

1987
369870
268200
8440
24800
667800
1000
0
0

$\begin{array}{rr}1988 & 1989 \\ 341000 & 296350 \\ 228000 & \\ & \\ 35900 & 76950 \\ 701000 & 745100 \\ 3994 & 8000 \\ 0 & 0 \\ 500 & 0\end{array}$

5300

\section{Zona oeste}

$\begin{array}{lr}\text { trigo } & 459500 \\ \text { maíz } & 89600 \\ \text { lino } & 3800 \\ \text { girasol } & 144740 \\ \text { soja } & 40650 \\ \text { avena } & 42800 \\ \text { centeno } & 26250 \\ \text { cebada cerv. } & 6610\end{array}$

$\begin{array}{rr}377300 & 342300 \\ 102214 & 178500 \\ 2880 & 765 \\ 145700 & 199900 \\ 56600 & 66700 \\ 49000 & 43000 \\ 30400 & 31700 \\ 6100 & 13900\end{array}$

339400
165600
540
331800
81500
34000
11800
12300

259000
158500
420
157000
71000
35500
14100
10990

182400
140100
320
174200
105100
22100
11450
7900

$\begin{array}{rr}210600 & 290400 \\ 140100 & \\ 233100 & 269700 \\ 123700 & 138600 \\ 31064 & 44800 \\ 11150 & 18300 \\ 9050 & 8300\end{array}$

\section{Zona sur}

$\begin{array}{lr}\text { trigo } & 1899000 \\ \text { maíz } & 39920 \\ \text { lino } & 73800 \\ \text { girasol } & 343550 \\ \text { soja } & 200 \\ \text { avena } & 140800 \\ \text { centeno } & 5400 \\ \text { cebada cerv. } & 53100\end{array}$

$\begin{array}{rr}1981400 & 1679450 \\ 45940 & 118500 \\ 50300 & 25600 \\ 417500 & 502900 \\ 3070 & 2810 \\ 130980 & 121800 \\ 9500 & 9600 \\ 39800 & 43400\end{array}$




\section{Volumen Cosechado (Toneladas)}

\begin{tabular}{|c|c|c|c|c|c|c|c|c|c|}
\hline trigo & 4432000 & 4420000 & 3854000 & 3510000 & 3252000 & 2893000 & 2830000 & 3200000 & \\
\hline maíz & 938200 & 1045600 & 1190000 & 1125000 & 1039800 & 898400 & 898550 & & \\
\hline lino & 270000 & 266000 & 157200 & 153000 & 257000 & 190000 & & & \\
\hline girasol & 1113600 & 1300000 & 1445000 & 1749000 & 1033700 & 1210000 & 1366100 & 1500000 & \\
\hline soja & 648100 & 713000 & 825000 & 849350 & 835000 & 984200 & 1109150 & 1245000 & \\
\hline avena & 280000 & 289000 & 264800 & 215300 & 238300 & 246600 & 260000 & 300000 & \\
\hline centeno & 46000 & 59900 & 58800 & 28800 & 30900 & 22650 & 20100 & 30000 & \\
\hline cebada cerv. & 73700 & 60000 & 75000 & 45000 & 43500 & 88000 & 102100 & 120000 & 117700 \\
\hline \multicolumn{10}{|l|}{ Región pamp } \\
\hline trigo & 7237000 & 7004000 & 5824600 & 5267200 & 4836900 & 4748700 & 4598000 & 5219300 & \\
\hline maíz & 2442130 & 2495400 & 2842000 & 2832000 & 2593900 & 2087370 & 1506250 & & \\
\hline lino & 860610 & 801900 & 601600 & 686000 & 743400 & 652200 & & & \\
\hline girasol & 2051850 & 2279200 & 2617100 & 3377400 & 1996870 & 2296700 & 2659135 & 2487605 & \\
\hline soja & 2134950 & 2665500 & 3081000 & 3119100 & 3314850 & 4034900 & 3727050 & 4575700 & \\
\hline avena & 404900 & 407400 & 432100 & 331040 & 310800 & 474345 & 354200 & 441520 & \\
\hline centeno & 169100 & 155950 & 155000 & 85440 & 57870 & 89800 & 49050 & 74010 & \\
\hline cebada cerv. & 93500 & 72000 & 85100 & 58500 & 54855 & 111898 & 131000 & 156220 & 146000 \\
\hline
\end{tabular}

$15394040,3115881350,3215638500,3515756680,3613909445,3914495913,4113024685,39$ $\begin{array}{lllllll}13865930 & 14444100 & 14364700 & 14595700 & 12742520 & 13167670 & 12490435\end{array}$

Control propre

\begin{tabular}{|c|c|c|c|c|c|c|c|c|c|}
\hline $\begin{array}{l}\text { Zona norte } \\
\text { trigo }\end{array}$ & $11 \%$ & $10 \%$ & $12 \%$ & $13 \%$ & $13 \%$ & $13 \%$ & $12 \%$ & $9 \%$ & \#DIV/0! \\
\hline maíz & $33 \%$ & $35 \%$ & $30 \%$ & $34 \%$ & $33 \%$ & $30 \%$ & $25 \%$ & \#DIV/0! & \#DIV/0! \\
\hline lino & $5 \%$ & $3 \%$ & $4 \%$ & $3 \%$ & $2 \%$ & $4 \%$ & \#DIV/O! & \#DIV/O! & \#DIV/0! \\
\hline girasol & $3 \%$ & $2 \%$ & $1 \%$ & $3 \%$ & $3 \%$ & $2 \%$ & $3 \%$ & $5 \%$ & \#DIV/O! \\
\hline soja & $83 \%$ & $76 \%$ & $72 \%$ & $69 \%$ & $71 \%$ & $68 \%$ & $63 \%$ & $60 \%$ & \#DIV/O! \\
\hline avena & $1 \%$ & $0 \%$ & $0 \%$ & $0 \%$ & $0 \%$ & $0 \%$ & $2 \%$ & $3 \%$ & \#DIV/0! \\
\hline centeno & $3 \%$ & $0 \%$ & $0 \%$ & $0 \%$ & $0 \%$ & $0 \%$ & $0 \%$ & $0 \%$ & \#DIV/0! \\
\hline cebada cerv. & $0 \%$ & $0 \%$ & $0 \%$ & $0 \%$ & $0 \%$ & $0 \%$ & $0 \%$ & $0 \%$ & $5 \%$ \\
\hline
\end{tabular}

Fuente: "Estimaciones Agrícolas" de la SEAGyP 


\section{Volumen Cosechado (Toneladas)}

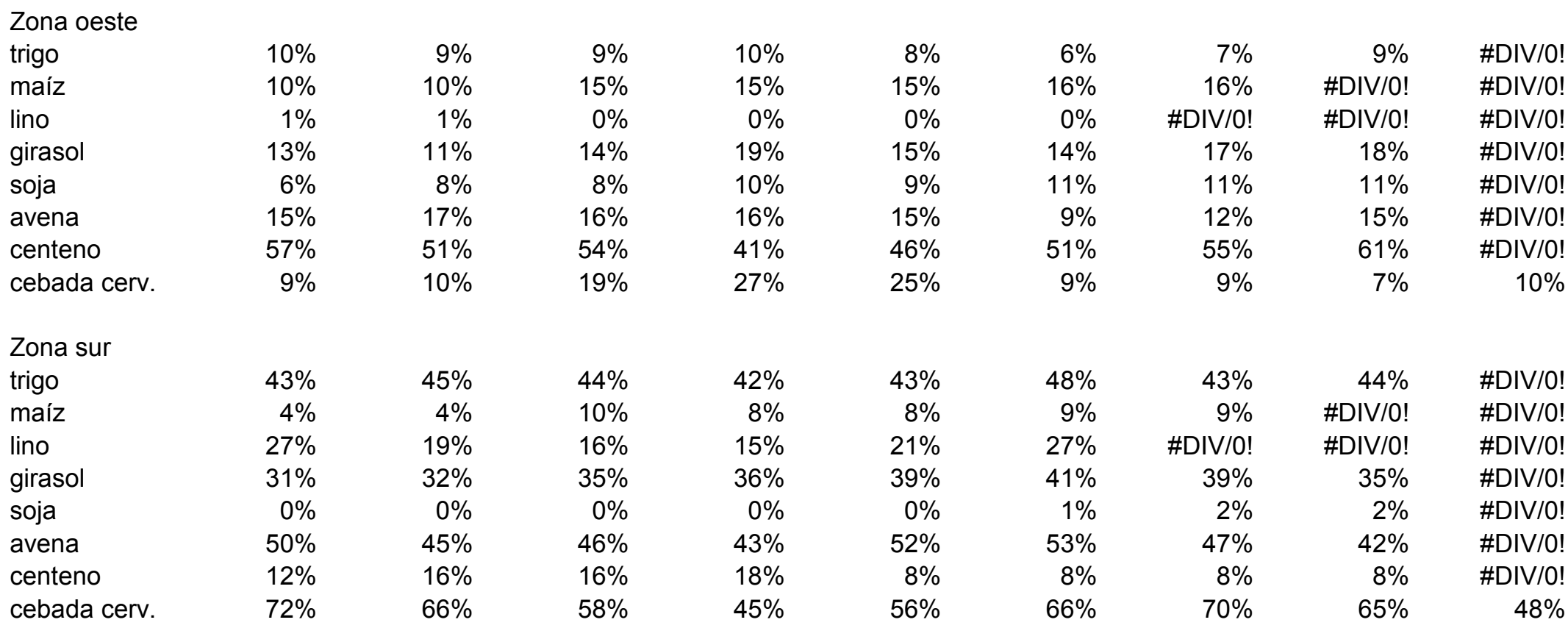


Volúmen cosechado

$\begin{array}{lrrrrrr} & & 1938 & 1939 & 1940 & 1941 & 1942 \\ \text { Zona norte } & & 408175 & 152610 & 275510 & 327523 & 449272 \\ \text { trigo } & 1222460 & 1226732 & 1124940 & 2193693 & 2095500 & 559300 \\ \text { maíz } & 167185 & 122924 & 89952 & 150421 & 140754 & 103106 \\ \text { lino } & 1600 & 656 & 1746 & 6127 & 61385 & 15624 \\ \text { girasol } & & & & & & \\ \text { soja } & & 11084 & 5043 & 8528 & 9580 & 10820 \\ \text { avena } & & 3179 & 838 & 2213 & 2333 & 1460 \\ \text { centeno } & 988 & 0 & 0 & 0 & 0 & 0 \\ \text { cebada cerv. } & & 1772750 & 1375129 & 2636492 & 2637075 & 1139582 \\ & & 1758487 & 1369248 & 2625751 & 2625162 & 1127302\end{array}$

Zona oeste

trigo

maíz

lino

girasol

soja

avena

centeno

cebada cerv.

$\begin{array}{rrrrrr} & 471325 & 252600 & 387210 & 237483 & 86879 \\ 53882 & 83613 & 208470 & 544370 & 312293 & 30172 \\ 2840 & 1637 & 1374 & 2228 & 1504 & 834 \\ 14723 & 12240 & 22883 & 32250 & 34230 & 24134 \\ & & & & & \\ 22244 & 51675 & 63504 & 32500 & 27656 & 21027 \\ & 53175 & 61930 & 25143 & 27718 & 25287 \\ & 23554 & 50082 & 40080 & 29518 & 15566 \\ & 697219 & 660843 & 1063781 & 670402 & 203899 \\ & 592369 & 535409 & 1006138 & 615028 & 157585\end{array}$

Zona sur

trigo

maíz

lino

girasol

soja

avena

centeno

cebada cerv.

13024
73687
2915

1260407

881702

1459600

1459180

846797

$40970 \quad 30820 \quad 16160$

8675

44330

82780

103867

123082

108161

5925

6817

7179

5537

4266

201440

299105

207600

151012

214330

$8538 \quad 10283$

3850

8229

127837

$\begin{array}{rr}281500 & 227211 \\ 1601412 & 2046560\end{array}$

113890

119330

1688018

1872711

1309788

Buenos Aires

trigo

maíz

lino

girasol

soja

avena

centeno

$\begin{array}{rr}1706727 & 3829724 \\ 572915 & 397460 \\ 145917 & 225683 \\ & 611408 \\ 69638 & 131333 \\ & 236508 \\ 7893116 \\ 7150375\end{array}$

2075031
2227500
467183
196900
707560
117881
474112
6266167
5440726

3356539

3117335

1953754

4314400

3452800

791691

$540440 \quad 508000 \quad 334173$

$371395 \quad 371550 \quad 195570$

cebada cerv.

$\begin{array}{rrr}438213 & 387000 & 486070 \\ 95849 & 65000 & 66381 \\ 373395 & 210500 & 212787 \\ 9490231 & 8112185 & 4040426 \\ 8956169 & 7660185 & 3487975\end{array}$




$\begin{array}{lrrrrrr}\begin{array}{l}\text { Región pampeana } \\ \text { trigo }\end{array} & & 10164835 & 3490946 & 8066991 & 6440619 & 6317861 \\ \text { maíz } & 4182061 & 4467200 & 9814910 & 9768200 & 8604300 & 1705882 \\ \text { lino } & 1545856 & 1444638 & 1073196 & 1710970 & 1585500 & 1334452 \\ \text { girasol } & 232052 & 286411 & 350870 & 562434 & 623700 & 389377 \\ \text { soja } & & & & & \\ \text { avena } & & 747503 & 793230 & 528650 & 442300 & 573970 \\ \text { centeno } & 130352 & 369232 & 364553 & 232128 & 135000 & 118175 \\ \text { cebada cerv. } & 263733 & 580244 & 527803 & 233613 & 224017 \\ & 17743552,03 & 16467949,03 & 21397176,02 & 18065032,01 & 10663734,02 \\ & 16626817,03 & 15310166,0320636398,02 & 17487732,01 & 9971589,02\end{array}$

Control proprcional

\begin{tabular}{|c|c|c|c|c|c|c|}
\hline $\begin{array}{l}\text { Zona norte } \\
\text { trigo }\end{array}$ & \#DIV/OI & $11 \%$ & $7 \%$ & $8 \%$ & $11 \%$ & $23 \%$ \\
\hline maíz & $72 \%$ & $50 \%$ & $51 \%$ & $51 \%$ & $61 \%$ & $71 \%$ \\
\hline lino & $29 \%$ & $31 \%$ & $19 \%$ & $28 \%$ & $28 \%$ & $31 \%$ \\
\hline girasol & $1 \%$ & $0 \%$ & $1 \%$ & $2 \%$ & $17 \%$ & $8 \%$ \\
\hline soja & \#DIV/O! & \#DIV/0! & \#DIV/0! & \#DIV/0! & \#DIV/O! & \#DIV/O! \\
\hline avena & \#DIV/O! & $2 \%$ & $1 \%$ & $2 \%$ & $2 \%$ & $2 \%$ \\
\hline centeno & $1 \%$ & $2 \%$ & $1 \%$ & $2 \%$ & $4 \%$ & $2 \%$ \\
\hline cebada cerv. & \#DIV/O! & $0 \%$ & $0 \%$ & $0 \%$ & $0 \%$ & $0 \%$ \\
\hline Zona oeste & & & & & & \\
\hline trigo & \#DIV/O! & $12 \%$ & $12 \%$ & $12 \%$ & $8 \%$ & $4 \%$ \\
\hline maíz & $3 \%$ & $3 \%$ & $9 \%$ & $13 \%$ & $9 \%$ & $4 \%$ \\
\hline lino & $0 \%$ & $0 \%$ & $0 \%$ & $0 \%$ & $0 \%$ & $0 \%$ \\
\hline girasol & $10 \%$ & $5 \%$ & $12 \%$ & $9 \%$ & $9 \%$ & $12 \%$ \\
\hline soja & \#DIV/O! & \#DIV/O! & \#DIV/O! & \#DIV/O! & \#DIV/O! & \#DIV/0! \\
\hline avena & \#DIV/O! & $8 \%$ & $9 \%$ & $7 \%$ & $7 \%$ & $4 \%$ \\
\hline centeno & $32 \%$ & $40 \%$ & $53 \%$ & $26 \%$ & $43 \%$ & $38 \%$ \\
\hline cebada cerv. & \#DIV/O! & $10 \%$ & $11 \%$ & $11 \%$ & $14 \%$ & $7 \%$ \\
\hline Zona sur & & & & & & \\
\hline trigo & \#DIV/O! & $33 \%$ & $42 \%$ & $43 \%$ & $47 \%$ & $43 \%$ \\
\hline maíz & $1 \%$ & $2 \%$ & $2 \%$ & $1 \%$ & $0 \%$ & $1 \%$ \\
\hline lino & $13 \%$ & $10 \%$ & $18 \%$ & $19 \%$ & $24 \%$ & $32 \%$ \\
\hline girasol & $2 \%$ & $3 \%$ & $3 \%$ & $2 \%$ & $1 \%$ & $2 \%$ \\
\hline soja & \#DIV/O! & \#DIV/O! & \#DIV/O! & \#DIV/0! & \#DIV/0! & \#DIV/0! \\
\hline avena & \#DIV/O! & $33 \%$ & $42 \%$ & $47 \%$ & $39 \%$ & $44 \%$ \\
\hline centeno & $14 \%$ & $8 \%$ & $7 \%$ & $11 \%$ & $6 \%$ & $12 \%$ \\
\hline cebada cerv. & \#DIV/O! & $54 \%$ & $59 \%$ & $61 \%$ & $54 \%$ & $56 \%$ \\
\hline
\end{tabular}




$\begin{array}{rrrrrrr}1943 & 1944 & 1945 & 1946 & 1947 & 1948 & 1949 \\ 372962 & 261192 & 370937 & 352431 & 371927 & 367570 & 534821 \\ 2119455 & 954200 & 1071122 & 1882280 & 1459810 & 999770 & 124010 \\ 128483 & 82181 & 100068 & 83731 & 37958 & 23073 & 20491 \\ 41343 & 71970 & 66393 & 69554 & 82493 & 112895 & 97886 \\ & & & & & & \\ 18526 & 12797 & 16170 & 14935,5 & 13701 & 6584 & 8646 \\ 1844 & 1784 & 3194 & 4750 & 4106 & 2834 & 4736 \\ 0 & 1500 & 0 & 14200 & & & \\ 2682613 & 1385624 & 1627884 & 2421881,5 & 1969995 & 1512726 & 790590 \\ 2662243 & 1371043 & 1608520 & 2402196 & 1952188 & 1503308 & 777208 \\ & & & & & & \\ 157018 & 59082 & 83670 & 195378 & 116773 & 101185 & 55037 \\ 153120 & 17550 & 17215 & 111150 & 51540 & 27210 & 550 \\ 1000 & 2857 & 222 & 597 & 101 & & 0 \\ 71470 & 55963 & 34041 & 49613 & 49070 & 59720 & 22895 \\ 77293 & 17701 & 20130 & 18110 & 16090 & 19360 & 7670 \\ 97826 & 37283 & 56950 & 115140 & 61720 & 50185 & 17376 \\ 23327 & 12390 & 30309 & 58084 & 41560 & 23327 & 14034 \\ 581054 & 202826 & 242537 & 548072 & 336854 & 280987 & 117565 \\ 405935 & 147842 & 165457 & 414822 & 259044 & 211442 & 92519\end{array}$

$\begin{array}{rrrrrrr}1099675 & 1469587 & 871152 & 1240619 & 920736 & 1235543 & 744768 \\ 17570 & 22350 & 23548 & 13726 & 13145 & 8958 & 4154 \\ 120361 & 176695 & 113562 & 99690 & 123550 & 66013 & 47975 \\ 13774 & 16996 & 12476 & 12461 & 10746 & 18472 & 12569 \\ & & & & & & \\ 273605 & 610220 & 356535 & 413385 & 470235 & 399135 & 271155 \\ 17323 & 18935 & 24246 & 40897 & 27690 & 18867 & 10623 \\ 207794 & 273881 & 395983 & 530780 & 359855 & 274985 & 152473 \\ 1750102 & 2588664 & 1797502 & 2351558 & 1925957 & 2021973 & 1243717\end{array}$

$\begin{array}{rrrrrrr}2601472 & 2623670 & 2069300 & 2670891 & 2066400 & 2300000 & 1894200 \\ 3432303 & 1323900 & 1663673 & 2630630 & 2008900 & 1273000 & 226500 \\ 406171 & 389170 & 326400 & 300991 & 254000 & 134900 & 98000 \\ 527508 & 628140 & 508923 & 460290 & 551210 & 745400 & 478200 \\ & & & & & & \\ 746454 & 1016880 & 716546 & 732923 & 749300 & 655800 & 477800 \\ 210024 & 131070 & 151850 & 258817 & 158600 & 94800 & 65500 \\ 323267 & 391720 & 547469 & 833216 & 561260 & 373750 & 238550 \\ 8247199 & 6504550 & 5984161 & 7887758 & 6349670 & 5577650 & 3478750 \\ 7290721 & 5356600 & 5115765 & 6896018 & 5441770 & 4827050 & 2935450\end{array}$




$\begin{array}{rrrrrrr}6755505 & 4060960 & 3884500 & 5582383 & 6478400 & 5186000 & 5124100 \\ 8306383 & 2804848 & 3292680 & 5544063 & 5040100 & 3280310 & 670300 \\ 1566008 & 785800 & 962158 & 1033247 & 899750 & 432530 & 675006 \\ 1000440 & 964544 & 876778 & 679720 & 923640 & 1083400 & 707800 \\ & & & & & & \\ 917534 & 1092700 & 787081 & 780797 & 815700 & 725900 & 537020 \\ 540916 & 187470 & 286440 & 542369 & 457861 & 299369 & 257087 \\ 406368 & 417220 & 599592 & 1009279 & 657660 & 521310 & 311980 \\ 19493154,0310313542,0310689229,0215171858,0315273111,02 & 11528819,02 & 8283293,03 \\ 18034704,03 & 9033372,03 & 9615708,0213848692,0313999550,02 & 10503550,02 & 7489186,03\end{array}$

$\begin{array}{rrrrrrr}14 \% & 10 \% & 18 \% & 13 \% & 18 \% & 16 \% & 28 \% \\ 62 \% & 72 \% & 64 \% & 72 \% & 73 \% & 79 \% & 55 \% \\ 32 \% & 21 \% & 31 \% & 28 \% & 15 \% & 17 \% & 21 \% \\ 8 \% & 11 \% & 13 \% & 15 \% & 15 \% & 15 \% & 20 \% \\ \text { \#DIV/0! } & \text { \#DIV/0! } & \text { \#DIV/O! } & \text { \#DIV/0! } & \text { \#DIV/O! } & \text { \#DIV/O! } & \text { \#DIV/O! } \\ 2 \% & 1 \% & 2 \% & 2 \% & 2 \% & 1 \% & 2 \% \\ 1 \% & 1 \% & 2 \% & 2 \% & 3 \% & 3 \% & 7 \% \\ 0 \% & 0 \% & 0 \% & 2 \% & 0 \% & 0 \% & 0 \%\end{array}$

$\begin{array}{rrrrrrr}6 \% & 2 \% & 4 \% & 7 \% & 6 \% & 4 \% & 3 \% \\ 4 \% & 1 \% & 1 \% & 4 \% & 3 \% & 2 \% & 0 \% \\ 0 \% & 1 \% & 0 \% & 0 \% & 0 \% & 0 \% & 0 \% \\ 14 \% & 9 \% & 7 \% & 11 \% & 9 \% & 8 \% & 5 \% \\ \text { \#DIV/0! } & \text { \#DIV/O! } & \text { \#DIV/O! } & \text { \#DIV/O! } & \text { \#DIV/0! } & \text { \#DIV/O! } & \text { \#DIV/0! } \\ 10 \% & 2 \% & 3 \% & 2 \% & 2 \% & 3 \% & 2 \% \\ 47 \% & 28 \% & 38 \% & 44 \% & 39 \% & 53 \% & 27 \% \\ 7 \% & 3 \% & 6 \% & 7 \% & 7 \% & 6 \% & 6 \% \\ & & & & & & \\ 42 \% & 56 \% & 42 \% & 46 \% & 45 \% & 54 \% & 39 \% \\ 1 \% & 2 \% & 1 \% & 1 \% & 1 \% & 1 \% & 2 \% \\ 30 \% & 45 \% & 35 \% & 33 \% & 49 \% & 49 \% & 49 \% \\ 3 \% & 3 \% & 2 \% & 3 \% & 2 \% & 2 \% & 3 \% \\ \text { \#DIV/0! } & \text { \#DIV/0! } & \text { \#DIV/0! } & \text { \#DIV/0! } & \text { \#DIV/0! } & \text { \#DIV/0! } & \text { \#DIV/0! } \\ 37 \% & 60 \% & 50 \% & 56 \% & 63 \% & 61 \% & 57 \% \\ 8 \% & 14 \% & 16 \% & 16 \% & 17 \% & 20 \% & 16 \% \\ 64 \% & 70 \% & 72 \% & 64 \% & 64 \% & 74 \% & 64 \%\end{array}$




$\begin{array}{rrrrrrr}1950 & 1951 & 1952 & 1953 & 1954 & 1955 & 1956 \\ 492510 & 328025 & 492350 & 560800 & 435880 & 484795 & 567694 \\ 580260 & 598944 & 854486 & 1157822 & 438880 & 856807 & 480825 \\ 18270 & 22361 & 31878 & 16081 & 16856 & 15484 & 22535 \\ 93479 & 84941 & 27489 & 18670 & 27904 & 119525 & 100990 \\ 7470 & 5242 & 12641 & 9072 & 5410 & 5467 & 12046 \\ 6101 & 3716 & 22195 & 12440 & 5555 & 5870 & 9975 \\ & & & & & & \\ 1198090 & 1043229 & 1441039 & 1774885 & 930485 & 1487948 & 1194065 \\ 1184519 & 1034271 & 1406203 & 1753373 & 919520 & 1476611 & 1172044 \\ & & & & & & \\ 150965 & 28150 & 297483 & 189180 & 181500 & 139700 & 280740 \\ 25320 & 9250 & 119882 & 110155 & 51180 & 58205 & 30550 \\ 298 & 21 & 103 & 145 & 784 & 1111 & 1860 \\ 57620 & 21139 & 30738 & 13240 & 7380 & 32400 & 27912 \\ & & & & & & \\ 25290 & 4754 & 84139 & 33610 & 28050 & 32905 & 97780 \\ 136560 & 19220 & 312405 & 180590 & 156450 & 200700 & 169200 \\ 44853 & 11990 & 74540 & 29480 & 36350 & 37965 & 68855 \\ 440906 & 94524 & 919290 & 556400 & 461694 & 502986 & 676897 \\ 279056 & 70550 & 522746 & 342200 & 277194 & 269381 & 409917\end{array}$

$\begin{array}{rrrrrrr}1274640 & 614965 & 1485964 & 1444100 & 1474980 & 1183070 & 1693530 \\ 7813 & 2207 & 21195 & 28919 & 15110 & 17294 & 19428 \\ 74590 & 75807 & 61592 & 62270 & 41640 & 19865 & 64951 \\ 14765 & 6999 & 14202 & 7172 & 6360 & 11493 & 34647 \\ & & & & & & \\ 281560 & 234319 & 510770 & 428980 & 410650 & 336080 & 431430 \\ 24010 & 9259 & 47345 & 30236 & 24740 & 25380 & 25774 \\ 375920 & 178637 & 392110 & 352210 & 397240 & 316450 & 471220 \\ 2053298 & 1122193 & 2533178 & 2353887 & 2370720 & 1909632 & 2740980\end{array}$

$\begin{array}{rrrrrrr}2954500 & 1466700 & 3522700 & 3599000 & 3300000 & 2563700 & 3875000 \\ 921000 & 775000 & 1768000 & 2096400 & 912400 & 1535000 & 760300 \\ 139400 & 161500 & 168400 & 179400 & 118000 & 77500 & 157500 \\ 610700 & 432800 & 292400 & 230310 & 175650 & 440050 & 392874 \\ & & & & & & \\ 607000 & 421500 & 1174700 & 942200 & 808800 & 659700 & 1013600 \\ 258300 & 60700 & 585200 & 383900 & 307200 & 339600 & 345500 \\ 582620 & 272570 & 749170 & 684100 & 702900 & 616900 & 881300 \\ 6073520 & 3590770 & 8260570 & 8115310 & 6324950 & 6232450 & 7426074 \\ 5208220 & 3108570 & 6500670 & 6789210 & 5208950 & 5233150 & 6066974\end{array}$




$\begin{array}{rrrrrrr}5788200 & 2095400 & 7619100 & 6189300 & 7678400 & 5237200 & 7073800 \\ 2445800 & 1852700 & 3363000 & 4269145 & 2368950 & 3660600 & 2463380 \\ 557960 & 313400 & 583700 & 409400 & 404400 & 237000 & 616800 \\ 1018500 & 690640 & 426700 & 343436 & 281440 & 752010 & 625904 \\ & & & & & & \\ 671300 & 436600 & 1267500 & 989800 & 888400 & 721700 & 1138500 \\ 628775 & 79500 & 1321055 & 599658 & 834600 & 642909 & 857935 \\ 676665 & 296837 & 1036912 & 788370 & 973888 & 857988 & 1196753 \\ 11787200,02 & 5765077,0215617967,0513589109,0313430078,04 & 12109407,03 & 13973072,09 \\ 10487125,02 & 5248977,0213029412,0511999651,0311707078,04 & 10744798,03 & 11976637,09\end{array}$

$\begin{array}{rrrrrrr}17 \% & 22 \% & 14 \% & 16 \% & 13 \% & 19 \% & 15 \% \\ 63 \% & 77 \% & 48 \% & 55 \% & 48 \% & 56 \% & 63 \% \\ 13 \% & 14 \% & 19 \% & 9 \% & 14 \% & 20 \% & 14 \% \\ 15 \% & 20 \% & 9 \% & 8 \% & 16 \% & 27 \% & 26 \% \\ \text { \#DIV/0! } & \text { \#DIV/0! } & \text { \#DIV/0! } & \text { \#DIV/0! } & \text { \#DIV/0! } & \text { \#DIV/0! } & \text { \#DIV/0! } \\ 1 \% & 1 \% & 1 \% & 1 \% & 1 \% & 1 \% & 1 \% \\ 2 \% & 6 \% & 4 \% & 3 \% & 2 \% & 2 \% & 3 \% \\ 0 \% & 0 \% & 0 \% & 0 \% & 0 \% & 0 \% & 0 \% \\ & & & & & & \\ 5 \% & 2 \% & 8 \% & 5 \% & 6 \% & 5 \% & 7 \% \\ 3 \% & 1 \% & 7 \% & 5 \% & 6 \% & 4 \% & 4 \% \\ 0 \% & 0 \% & 0 \% & 0 \% & 1 \% & 1 \% & 1 \% \\ 9 \% & 5 \% & 11 \% & 6 \% & 4 \% & 7 \% & 7 \%\end{array}$

\#DIV/0! \#DIV/O! \#DIV/O! \#DIV/O! \#DIV/O! \#DIV/O! \#DIVIO!

$\begin{array}{rrrrrrr}4 \% & 1 \% & 7 \% & 4 \% & 3 \% & 5 \% & 10 \% \\ 53 \% & 32 \% & 53 \% & 47 \% & 51 \% & 59 \% & 49 \% \\ 8 \% & 4 \% & 10 \% & 4 \% & 5 \% & 6 \% & 8 \%\end{array}$

$\begin{array}{rrrrrrr}43 \% & 42 \% & 42 \% & 40 \% & 45 \% & 46 \% & 44 \% \\ 1 \% & 0 \% & 1 \% & 1 \% & 2 \% & 1 \% & 3 \% \\ 54 \% & 47 \% & 37 \% & 35 \% & 35 \% & 26 \% & 41 \% \\ 2 \% & 2 \% & 5 \% & 3 \% & 4 \% & 3 \% & 9 \% \\ \text { \#DIV/O! } & \text { \#DIV/O! } & \text { \#DIV/O! } & \text { \#DIV/0! } & \text { \#DIV/O! } & \text { \#DIV/O! } & \text { \#DIV/O! } \\ 46 \% & 56 \% & 43 \% & 46 \% & 51 \% & 51 \% & 43 \% \\ 9 \% & 15 \% & 8 \% & 8 \% & 8 \% & 7 \% & 7 \% \\ 65 \% & 66 \% & 52 \% & 51 \% & 57 \% & 51 \% & 53 \%\end{array}$




$\begin{array}{rrrrrrr}1957 & 1958 & 1959 & 1960 & 1961 & 1962 & 1963 \\ 353175 & 518610 & 374105 & 381205 & 486264 & 707900 & 701295 \\ 1022105 & 1107730 & 773250 & 1022450 & 942890 & 923540 & 1187100 \\ 15614 & 16614 & 17053 & 15219 & 17467 & 17719 & 14660 \\ 120269 & 65141 & 144645 & 91098 & 127608,69 & 78282 & 79025 \\ & & & & & & \\ 10115 & 11675 & 16455,71 & 17708 & 19225 & 22440 & 17442 \\ 10395 & 18170 & 20639 & 17375 & 18205 & 19770 & 19899 \\ & & & & & & \\ 1531673 & 1737940 & 1346147,71 & 1545055 & 1611659,69 & 1769651 & 2019421 \\ 1511163 & 1708095 & 1309053 & 1509972 & 1574229,69 & 1727441 & 1982080\end{array}$

$\begin{array}{rrrrrrr}134200 & 270680 & 161920 & 64630 & 65580 & 114000 & 406130 \\ 77200 & 79920 & 40010 & 28470 & 31940 & 22660 & 52060 \\ 603 & 644 & 644 & 179 & 147 & 408 & 304 \\ 39416 & 28528 & 41495 & 14300 & 17554,06 & 9400 & 23895 \\ & & & & & & \\ 71250 & 75300 & 67115,46 & 43445 & 44400 & 23450 & 40670 \\ 145600 & 239800 & 267750 & 143700 & 113100 & 37600 & 140440 \\ 29120 & 39950 & 36880 & 27310 & 20890 & 11840 & 26682 \\ 497389 & 734822 & 615814,46 & 322034 & 293611,06 & 219358 & 690181 \\ 280539 & 419722 & 280949 & 134889 & 136111,06 & 158308 & 509071\end{array}$

$\begin{array}{rrrrrrr}1742525 & 1719395 & 1191720 & 1149820 & 1325470 & 670550 & 2656507 \\ 26845 & 19310 & 13620 & 18565 & 17405 & 10540 & 28850 \\ 86263 & 106210 & 135954 & 88479 & 113000 & 88750 & 112215 \\ 44035 & 34545 & 25736 & 14724 & 16071,25 & 7343 & 23917 \\ & & & & & & \\ 431220 & 335970 & 407775,43 & 390300 & 285900 & 159750 & 447030 \\ 35590 & 34857 & 22560 & 27250 & 23560 & 5212 & 31540 \\ 390590 & 319825 & 253065 & 229065 & 245610 & 50876 & 458436 \\ 2757068 & 2570112 & 2050430,43 & 1918203 & 2027016,25 & 993021 & 3758495\end{array}$

$\begin{array}{rrrrrrr}3323000 & 3830300 & 2607400 & 2540000 & 3107000 & 2390000 & 5840000 \\ 1822100 & 1663000 & 1239000 & 1522000 & 1390000 & 1350000 & 1750000 \\ 180700 & 221200 & 253000 & 182000 & 234000 & 238900 & 231100 \\ 470600 & 294000 & 502000 & 345000 & 458000 & 267000 & 285000 \\ & & & & & & \\ 898000 & 776100 & 889700 & 806800 & 642400 & 460000 & 842000 \\ 317000 & 462800 & 468300 & 311000 & 242500 & 81800 & 275000 \\ 685300 & 627900 & 586400 & 520000 & 493000 & 153600 & 689000 \\ 7696700 & 7875300 & 6545800 & 6226800 & 6566900 & 4941300 & 9912100 \\ 6481700 & 6636400 & 5187800 & 5109000 & 5682000 & 4399500 & 8795100\end{array}$




$\begin{array}{rrrrrrr}5785100 & 6704700 & 5812200 & 4186500 & 5707000 & 5668500 & 8898000 \\ 4534970 & 4613800 & 3758600 & 4405350 & 4696100 & 3805000 & 4871800 \\ 624200 & 616900 & 819625 & 559000 & 815300 & 835900 & 770320 \\ 752660 & 381250 & 789830 & 574560 & 819810 & 433523 & 460667 \\ & & & & & \\ 993500 & 848300 & 981300 & 841300 & 698200 & 485500 & 903700 \\ 606420 & 802304 & 1043816 & 491100 & 497900 & 148693 & 526367 \\ 870575 & 902334 & 952531 & 662600 & 676200 & 274177 & 871780 \\ 14167425,0914869588,1214157902,0511720410,0413910510,0411651293,03 & 17302634,08 \\ 2567505,09 & 13218984,1212132786,0510388010,0412714410,0411017100,0315872567,08\end{array}$

$\begin{array}{rrrrrrr}11 \% & 14 \% & 14 \% & 15 \% & 16 \% & 30 \% & 12 \% \\ 56 \% & 67 \% & 62 \% & 67 \% & 68 \% & 68 \% & 68 \% \\ 9 \% & 8 \% & 7 \% & 8 \% & 7 \% & 7 \% & 6 \% \\ 26 \% & 22 \% & 29 \% & 26 \% & 28 \% & 29 \% & 28 \% \\ \text { \#DIV/0! } & \text { \#DIV/0! } & \text { \#DIV/0! } & \text { \#DIV/0! } & \text { \#DIV/0! } & \text { \#DIV/0! } & \text { \#DIV/0! } \\ 1 \% & 2 \% & 2 \% & 2 \% & 3 \% & 5 \% & 2 \% \\ 3 \% & 4 \% & 4 \% & 6 \% & 8 \% & 24 \% & 7 \% \\ 0 \% & 0 \% & 0 \% & 0 \% & 0 \% & 0 \% & 0 \% \\ & & & & & & \\ 4 \% & 7 \% & 6 \% & 3 \% & 2 \% & 5 \% & 7 \% \\ 4 \% & 5 \% & 3 \% & 2 \% & 2 \% & 2 \% & 3 \% \\ 0 \% & 0 \% & 0 \% & 0 \% & 0 \% & 0 \% & 0 \% \\ 8 \% & 10 \% & 8 \% & 4 \% & 4 \% & 4 \% & 8 \%\end{array}$

$\begin{array}{rrrrrrr}\text { \#DIV/0! } & \text { \#DIV/0! } & \text { \#DIV/0! } & \text { \#DIV/0! } & \text { \#DIV/0! } & \text { \#DIV/0! } & \text { \#DIV/0! } \\ 8 \% & 10 \% & 8 \% & 5 \% & 7 \% & 5 \% & 5 \% \\ 46 \% & 52 \% & 57 \% & 46 \% & 47 \% & 46 \% & 51 \% \\ 4 \% & 6 \% & 6 \% & 5 \% & 4 \% & 8 \% & 4 \% \\ & & & & & & \\ 52 \% & 45 \% & 46 \% & 45 \% & 43 \% & 28 \% & 45 \% \\ 1 \% & 1 \% & 1 \% & 1 \% & 1 \% & 1 \% & 2 \% \\ 48 \% & 48 \% & 54 \% & 49 \% & 48 \% & 37 \% & 49 \% \\ 9 \% & 12 \% & 5 \% & 4 \% & 4 \% & 3 \% & 8 \% \\ \text { \#DIV/0! } & \text { \#DIV/0! } & \text { \#DIV/0! } & \text { \#DIV/0! } & \text { \#DIV/0! } & \text { \#DIV/0! } & \text { \#DIV/0! } \\ 48 \% & 43 \% & 46 \% & 48 \% & 45 \% & 35 \% & 53 \% \\ 11 \% & 8 \% & 5 \% & 9 \% & 10 \% & 6 \% & 11 \% \\ 57 \% & 51 \% & 43 \% & 44 \% & 50 \% & 33 \% & 67 \%\end{array}$




$\begin{array}{rrrrrrr}1964 & 1965 & 1966 & 1967 & 1968 & 1969 & 1970 \\ & & & & & & \\ 957925 & 666615 & 497782 & 397910 & 340700 & 321875 & 333700 \\ 916713 & 1442925 & 2010474 & 1260800 & 1878430 & 2252650 & 2310880 \\ 18629 & 18158 & 14302 & 5041 & 12536 & 13662 & 53037 \\ 94218 & 116275 & 161335 & 69805 & 92536 & 113425 & 79600 \\ & & & & & 1600 & 1600 \\ 18385 & 12980 & 14637,5 & 21580 & 11480 & 8370 & 6225 \\ 22359 & 14635 & 9035 & 11535 & 11240 & 10105 & 3000 \\ & & & & & & \\ 2028229 & 2271588 & 2707565,5 & 1766671 & 2346922 & 2721687 & 2788042 \\ 1987485 & 2243973 & 2683893 & 1733556 & 2324202 & 2703212 & 2778817 \\ & & & & & & \\ 555788 & 207005 & 205826 & 449020 & 255500 & 393800 & 141600 \\ 40230 & 54230 & 142890 & 75320 & 80085 & 145100 & 91759 \\ 235 & 61 & 144 & 468 & 210 & 112 & 0 \\ 22499 & 34050 & 37150 & 27515 & 29053 & 44300 & 34600 \\ & & & & & 0 & 0 \\ 54555 & 37160 & 34117,5 & 79985 & 47360 & 23375 & 8860 \\ 192125 & 140150 & 131325 & 126390 & 139554 & 192120 & 60170 \\ 31502 & 14445 & 7170 & 18665 & 12190 & 12720 & 6190 \\ 896934 & 487101 & 558622,5 & 777363 & 563952 & 811527 & 343179 \\ 650254 & 309791 & 393180 & 570988 & 377038 & 596032 & 274149\end{array}$

$\begin{array}{rrrrrrr}2652971 & 1956155 & 2100110 & 2275149 & 1530300 & 2447547 & 1394650 \\ 26551 & 41520 & 39176 & 34750 & 45450 & 98615 & 32290 \\ 114350 & 115485 & 171212 & 118285 & 77212 & 159500 & 141925 \\ 28047 & 36070 & 42545 & 47612 & 44000 & 75354 & 55700 \\ & & & & & 0 & 0 \\ 367532 & 201830 & 247572,5 & 287125 & 215857,5 & 180115 & 130355 \\ 25787 & 9620 & 12510 & 15200 & 8060 & 11930 & 4590 \\ 266009 & 129631 & 222159 & 222458 & 217101 & 270450 & 172065 \\ 3481247 & 2490311 & 2835284,5 & 3000579 & 2137980,5 & 3243511 & 1931575\end{array}$

$\begin{array}{rrrrrrr}6404000 & 4150000 & 4054000 & 4840000 & 3440000 & 4882600 & 3255000 \\ 1414000 & 2113000 & 2922000 & 1880000 & 2850000 & 3730000 & 3770000 \\ 271500 & 258500 & 305000 & 216600 & 219500 & 382000 & 321000 \\ 378400 & 495000 & 580000 & 482000 & 506000 & 743300 & 448000 \\ & & & & & 1600 & 1600 \\ 753000 & 462500 & 515000 & 673000 & 462000 & 404700 & 336300 \\ 342000 & 186000 & 170000 & 179700 & 184000 & 252500 & 92500 \\ 507500 & 271000 & 304000 & 340000 & 325000 & 412800 & 273300 \\ 10070400 & 7936000 & 8850000 & 8611300 & 7986500 & 10809500 & 8497700 \\ 8975400 & 7287500 & 8165000 & 7758600 & 7340500 & 10152300 & 8068900\end{array}$




$\begin{array}{rrrrrrr}11181000 & 6050000 & 6187000 & 7195000 & 5618000 & 6939000 & 4792700 \\ 4504200 & 6607850 & 7783400 & 6061600 & 6330300 & 8785000 & 9305300 \\ 812980 & 567980 & 573680 & 382200 & 506000 & 636000 & 675800 \\ 696867 & 778220 & 1038595 & 896612 & 875300 & 1156804 & 812100 \\ & & & & & 8800 & 18600 \\ 802200 & 477700 & 537800 & 687600 & 487300 & 422700 & 358040 \\ 637160 & 236300 & 262630 & 339200 & 349500 & 371200 & 178370 \\ 679240 & 327416 & 368813 & 490200 & 400000 & 496100 & 315000 \\ 19313647,0715045466,0716751918,07 & 16052412,114566400,09 & 18815604,116455910,12 \\ 17874287,0714331466,0715951488,07 & 15025612,113729600,09 & 18021704,115919500,12\end{array}$

$\begin{array}{rrrrrrr}15 \% & 16 \% & 12 \% & 8 \% & 10 \% & 7 \% & 10 \% \\ 65 \% & 68 \% & 69 \% & 67 \% & 66 \% & 60 \% & 61 \% \\ 7 \% & 7 \% & 5 \% & 2 \% & 6 \% & 4 \% & 17 \% \\ 25 \% & 23 \% & 28 \% & 14 \% & 18 \% & 15 \% & 18 \% \\ \text { \#DIV/0! } & \text { \#DIV/0! } & \text { \#DIV/O! } & \text { \#DIV/0! } & \text { \#DIV/0! } & 100 \% & 100 \% \\ 2 \% & 3 \% & 3 \% & 3 \% & 2 \% & 2 \% & 2 \% \\ 7 \% & 8 \% & 5 \% & 6 \% & 6 \% & 4 \% & 3 \% \\ 0 \% & 0 \% & 0 \% & 0 \% & 0 \% & 0 \% & 0 \%\end{array}$

$\begin{array}{rrrrrrr}9 \% & 5 \% & 5 \% & 9 \% & 7 \% & 8 \% & 4 \% \\ 3 \% & 3 \% & 5 \% & 4 \% & 3 \% & 4 \% & 2 \% \\ 0 \% & 0 \% & 0 \% & 0 \% & 0 \% & 0 \% & 0 \% \\ 6 \% & 7 \% & 6 \% & 6 \% & 6 \% & 6 \% & 8 \% \\ \text { \#DIV/0! } & \text { \#DIV/O! } & \text { \#DIV/O! } & \text { \#DIV/O! } & \text { \#DIV/O! } & 0 \% & 0 \% \\ 7 \% & 8 \% & 7 \% & 12 \% & 10 \% & 6 \% & 3 \% \\ 56 \% & 75 \% & 77 \% & 70 \% & 76 \% & 76 \% & 65 \% \\ 6 \% & 5 \% & 2 \% & 5 \% & 4 \% & 3 \% & 2 \% \\ & & & & & & \\ 41 \% & 47 \% & 52 \% & 47 \% & 44 \% & 50 \% & 43 \% \\ 2 \% & 2 \% & 1 \% & 2 \% & 2 \% & 3 \% & 1 \% \\ 42 \% & 45 \% & 56 \% & 55 \% & 35 \% & 42 \% & 44 \% \\ 7 \% & 7 \% & 7 \% & 10 \% & 9 \% & 10 \% & 12 \% \\ \text { \#DIV/0! } & \text { \#DIV/0! } & \text { \#DIV/0! } & \text { \#DIV/0! } & \text { \#DIV/0! } & 0 \% & 0 \% \\ 49 \% & 44 \% & 48 \% & 43 \% & 47 \% & 45 \% & 39 \% \\ 8 \% & 5 \% & 7 \% & 8 \% & 4 \% & 5 \% & 5 \% \\ 52 \% & 48 \% & 73 \% & 65 \% & 67 \% & 66 \% & 63 \%\end{array}$




$\begin{array}{rrrrrrr}1971 & 1972 & 1973 & 1974 & 1975 & 1976 & 1977 \\ 254350 & 405600 & 153530 & 271600 & 330450 & 316980 & 254450 \\ 1493500 & 2354421 & 2468000 & 1942790 & 1714453 & 2143178 & 2303000 \\ 36300 & 44877 & 32887 & 44788 & 46920 & 41148 & 63350 \\ 67927 & 69829 & 51113 & 39461 & 50652 & 36621 & 59422 \\ 1958 & 6096 & 66490 & 26256 & 55849 & 65988 & 260800 \\ 8200 & 7350 & 2255 & 1905 & 1400 & 1260 & 1910 \\ 1870 & 1150 & 665 & 600 & 780 & 700 & 0 \\ & & & & & & \\ 1864105 & 2889323 & 2774940 & 2327400 & 2200504 & 2605875 & 2942932 \\ 1854035 & 2880823 & 2772020 & 2324895 & 2198324 & 2603915 & 2941022 \\ & & & & & & \\ 167300 & 308500 & 232950 & 324000 & 440600 & 527730 & 191000 \\ 56035 & 91400 & 201600 & 155500 & 116600 & 181540 & 297500 \\ 0 & 0 & 855 & 770 & 0 & 440 & 1459 \\ 28600 & 38150 & 23757 & 9945 & 24055 & 38370 & 89135 \\ 0 & 0 & 7326 & 2078 & 1136 & 1360 & 14030 \\ 37890 & 48750 & 58700 & 23330 & 43980 & 34440 & 49840 \\ 105850 & 249648 & 152045 & 81700 & 80280 & 67575 & 39000 \\ 20470 & 38430 & 26600 & 19360 & 32970 & 29180 & 13406 \\ 416145 & 774878 & 703833 & 616683 & 739621 & 880635 & 695370 \\ 272405 & 476480 & 493088 & 511653 & 615361 & 778620 & 606530\end{array}$

$\begin{array}{rrrrrrr}1657700 & 2612750 & 2132600 & 1697500 & 1889400 & 3034029 & 1469500 \\ 49810 & 97210 & 62320 & 38520 & 38911 & 125860 & 129900 \\ 49340 & 46120 & 48580 & 46075 & 31238 & 53497 & 116959 \\ 121730 & 103276 & 218225 & 129068 & 142294 & 138664 & 323654 \\ 0 & 189 & 708 & 314 & 368 & 36 & 583 \\ 175005 & 206320 & 215215 & 140520 & 153525 & 225840 & 271107 \\ 14946 & 17423 & 22670 & 9148 & 16135 & 30875 & 17724 \\ 258724 & 395714 & 334750 & 187995 & 234400 & 430470 & 144510 \\ 2327255 & 3479002 & 3035068 & 2249140 & 2506271 & 4039271 & 2473937\end{array}$

$\begin{array}{rrrrrrr}3500000 & 5270000 & 3794000 & 3440000 & 4300000 & 6000000 & 3000000 \\ 2510000 & 3776000 & 4360000 & 3060000 & 3240000 & 4000000 & 4700000 \\ 160600 & 193000 & 172600 & 200000 & 173500 & 273000 & 400000 \\ 502100 & 475000 & 577000 & 358300 & 595000 & 490000 & 980000 \\ 2020 & 6285 & 85000 & 37000 & 62300 & 74000 & 320000 \\ 450000 & 520000 & 506000 & 304500 & 390600 & 430000 & 486000 \\ 168000 & 373000 & 250000 & 144000 & 150700 & 160000 & 88000 \\ 391000 & 620000 & 456000 & 258300 & 346900 & 560000 & 232000 \\ 7683720 & 11233285 & 10200600 & 7802100 & 9259000 & 11987000 & 10206000 \\ 7065720 & 10340285 & 9444600 & 7353600 & 8717700 & 11397000 & 9632000\end{array}$




$\begin{array}{rrrrrrr}5338700 & 7830000 & 6418800 & 5816000 & 8355000 & 10888000 & 5170000 \\ 5593400 & 9072000 & 9402000 & 7300700 & 5532200 & 7742000 & 9227000 \\ 311930 & 329000 & 296050 & 378730 & 374600 & 615160 & 806200 \\ 856760 & 839276 & 1031625 & 692969 & 1020894 & 967864 & 1762654 \\ 42340 & 198922 & 355000 & 388800 & 583020 & 1222000 & 2294000 \\ 472800 & 563800 & 558270 & 324800 & 430400 & 523300 & 564000 \\ 253300 & 685480 & 595800 & 300200 & 264200 & 329200 & 168000 \\ 472300 & 756200 & 604300 & 361300 & 443300 & 664340 & 286000\end{array}$

$13341530,2420274678,2219261845,3815563499,3617003614,2422951864,2820277854,33$ $12615430,2419025398,22$ 18107775,38 14938499,36 16309014,24 22099364,28 19545854,33

$\begin{array}{rrrrrrr}7 \% & 8 \% & 4 \% & 8 \% & 8 \% & 5 \% & 8 \% \\ 60 \% & 62 \% & 57 \% & 63 \% & 53 \% & 54 \% & 49 \% \\ 23 \% & 23 \% & 19 \% & 22 \% & 27 \% & 15 \% & 16 \% \\ 14 \% & 15 \% & 9 \% & 11 \% & 9 \% & 7 \% & 6 \% \\ 97 \% & 97 \% & 78 \% & 71 \% & 90 \% & 89 \% & 82 \% \\ 2 \% & 1 \% & 0 \% & 1 \% & 0 \% & 0 \% & 0 \% \\ 1 \% & 0 \% & 0 \% & 0 \% & 1 \% & 0 \% & 0 \% \\ 0 \% & 0 \% & 0 \% & 0 \% & 0 \% & 0 \% & 0 \% \\ & & & & & & \\ 5 \% & 6 \% & 6 \% & 9 \% & 10 \% & 9 \% & 6 \% \\ 2 \% & 2 \% & 5 \% & 5 \% & 4 \% & 5 \% & 6 \% \\ 0 \% & 0 \% & 0 \% & 0 \% & 0 \% & 0 \% & 0 \% \\ 6 \% & 8 \% & 4 \% & 3 \% & 4 \% & 8 \% & 9 \% \\ 0 \% & 0 \% & 9 \% & 6 \% & 2 \% & 2 \% & 4 \% \\ 8 \% & 9 \% & 12 \% & 8 \% & 11 \% & 8 \% & 10 \% \\ 63 \% & 67 \% & 61 \% & 57 \% & 53 \% & 42 \% & 44 \% \\ 5 \% & 6 \% & 6 \% & 7 \% & 10 \% & 5 \% & 6 \% \\ & & & & & & \\ 47 \% & 50 \% & 56 \% & 49 \% & 44 \% & 51 \% & 49 \% \\ 2 \% & 3 \% & 1 \% & 1 \% & 1 \% & 3 \% & 3 \% \\ 31 \% & 24 \% & 28 \% & 23 \% & 18 \% & 20 \% & 29 \% \\ 24 \% & 22 \% & 38 \% & 36 \% & 24 \% & 28 \% & 33 \% \\ 0 \% & 3 \% & 1 \% & 1 \% & 1 \% & 0 \% & 0 \% \\ 39 \% & 40 \% & 43 \% & 46 \% & 39 \% & 53 \% & 56 \% \\ 9 \% & 5 \% & 9 \% & 6 \% & 11 \% & 19 \% & 20 \% \\ 66 \% & 64 \% & 73 \% & 73 \% & 68 \% & 77 \% & 62 \% \\ & & & & & & \end{array}$




$\begin{array}{rrrrrrr}1978 & 1979 & 1980 & 1981 & 1982 & 1983 & 1984 \\ 322510 & 420760 & 905500 & 930000 & 1316000 & 796510 & 1098000 \\ 1772790 & 1317810 & 2446237 & 1894630 & 1182400 & 1525523 & 1593500 \\ 37696 & 35238 & 28209 & 20835 & 13947 & 6319 & 7069 \\ 44130 & 36286 & 40847 & 30000 & 37700 & 36900 & 27940 \\ 428104 & 714285 & 664300 & 750423 & 774700 & 1310710 & 1286900 \\ 1460 & 1820 & 4310 & 3535 & 3790 & 650 & 1790 \\ 1230 & 1420 & 1654 & 714 & 1930 & 0 & 0 \\ & & & & & & \\ 2607920 & 2527619 & 4091057 & 3630137 & 3330467 & 3676612 & 4015199 \\ 2605230 & 2524379 & 4085093 & 3625888 & 3324747 & 3675962 & 4013409 \\ & & & & & & \\ 394000 & 491250 & 455500 & 578900 & 1038290 & 728400 & 819020 \\ 388620 & 216120 & 694450 & 352350 & 306040 & 428020 & 638450 \\ 1510 & 3494 & 1669 & 3378 & 4010 & 2517 & 884 \\ 93800 & 109315 & 103710 & 217750 & 186300 & 168510 & 337700 \\ 32718 & 56806 & 73000 & 48850 & 59450 & 112800 & 75600 \\ 68330 & 76185 & 35500 & 39790 & 84240 & 85200 & 84700 \\ 59130 & 70640 & 36396 & 29760 & 32235 & 24540 & 26810 \\ 45900 & 26900 & 9440 & 13525 & 12080 & 11140 & 31690 \\ 1084008 & 1050710 & 1409665 & 1284303 & 1722645 & 1561127 & 2014854 \\ 956548 & 903885 & 1337769 & 1214753 & 1606170 & 1451387 & 1903344\end{array}$

$\begin{array}{rrrrrrr}2651305 & 2276300 & 2178900 & 1570320 & 4232000 & 3747800 & 3983510 \\ 73450 & 36970 & 213700 & 89230 & 133150 & 145660 & 415850 \\ 91486 & 89700 & 75085 & 49445 & 66660 & 40950 & 23120 \\ 273500 & 244790 & 273225 & 409900 & 491580 & 512400 & 702900 \\ 1255 & 485 & 455 & 280 & 230 & 5462 & 4738 \\ 239625 & 215000 & 182750 & 101640 & 242600 & 220310 & 210490 \\ 27935 & 15608 & 17490 & 3315 & 5950 & 9400 & 10180 \\ 263883 & 147068 & 103385 & 53262 & 114214 & 90050 & 104760 \\ 3622439 & 3025921 & 3044990 & 2277392 & 5286384 & 4772032 & 5455548 \\ & & & 2865828,62 & & 5171321,33 & \end{array}$

$\begin{array}{rrrrrrr}5100000 & 4600000 & 5053000 & 5100000 & 9790000 & 8450000 & 9100000 \\ 3670000 & 2520000 & 6073000 & 4160000 & 3280000 & 4130000 & 4680000 \\ 270000 & 303000 & 212700 & 221000 & 244000 & 223000 & 134000 \\ 900000 & 882000 & 860000 & 1352000 & 1510000 & 1450000 & 2140000 \\ 520000 & 883000 & 900000 & 924500 & 950000 & 1670000 & 1600000 \\ 583000 & 407000 & 342800 & 229600 & 470000 & 463000 & 455000 \\ 129000 & 117000 & 83800 & 64400 & 55000 & 53300 & 56800 \\ 406000 & 227000 & 136000 & 92500 & 152000 & 126000 & 179000 \\ 11578000 & 9939000 & 13661300 & 12144000 & 16451000 & 16565300 & 18344800 \\ 10866000 & 9415000 & 13234700 & 11850000 & 15926000 & 16049000 & 17833000 \\ & & & & & & 0,7\end{array}$




$\begin{array}{rrrrrrr}8014000 & 8000000 & 7719000 & 8222000 & 14895000 & 12897000 & 13478000 \\ 8124000 & 5580000 & 12130000 & 8544000 & 7972600 & 8337000 & 10627000 \\ 593150 & 739450 & 584300 & 599050 & 727900 & 658300 & 499100 \\ 1612900 & 1622590 & 1495325 & 2276900 & 2669880 & 2595400 & 3749700 \\ 3410000 & 3113400 & 3482400 & 3870000 & 3720660 & 6520700 & 6127600 \\ 665200 & 515600 & 428300 & 334400 & 634000 & 590300 & 714900 \\ 206000 & 193900 & 149100 & 144600 & 143600 & 125600 & 151600 \\ 467000 & 283400 & 167500 & 113300 & 176500 & 138400 & 198500 \\ 23092250,320048340,28 & 26155925,32 & 24104250,330940140,3331862700,3535546400,33 \\ 22221050,319338840,28 & 25578525,32 & 23625250,330162540,3331146800,3534679900,33 \\ c, 07 & 0,59 & & \end{array}$

$\begin{array}{rrrrrrr}6 \% & 9 \% & 18 \% & 18 \% & 13 \% & 9 \% & 12 \% \\ 48 \% & 52 \% & 40 \% & 46 \% & 36 \% & 37 \% & 34 \% \\ 14 \% & 12 \% & 13 \% & 9 \% & 6 \% & 3 \% & 5 \% \\ 5 \% & 4 \% & 5 \% & 2 \% & 2 \% & 3 \% & 1 \% \\ 82 \% & 81 \% & 74 \% & 81 \% & 82 \% & 78 \% & 80 \% \\ 0 \% & 0 \% & 1 \% & 2 \% & 1 \% & 0 \% & 0 \% \\ 1 \% & 1 \% & 2 \% & 1 \% & 4 \% & 0 \% & 0 \% \\ 0 \% & 0 \% & 0 \% & 0 \% & 0 \% & 0 \% & 0 \% \\ & & & & & & \\ 8 \% & 11 \% & 9 \% & 11 \% & 11 \% & 9 \% & 9 \% \\ 11 \% & 9 \% & 11 \% & 8 \% & 9 \% & 10 \% & 14 \% \\ 1 \% & 1 \% & 1 \% & 2 \% & 2 \% & 1 \% & 1 \% \\ 10 \% & 12 \% & 12 \% & 16 \% & 12 \% & 12 \% & 16 \% \\ 6 \% & 6 \% & 8 \% & 5 \% & 6 \% & 7 \% & 5 \% \\ 12 \% & 19 \% & 10 \% & 17 \% & 18 \% & 18 \% & 19 \% \\ 46 \% & 60 \% & 43 \% & 46 \% & 59 \% & 46 \% & 47 \% \\ 11 \% & 12 \% & 7 \% & 15 \% & 8 \% & 9 \% & 18 \% \\ & & & & & & \\ 52 \% & 49 \% & 43 \% & 31 \% & 43 \% & 44 \% & 44 \% \\ 2 \% & 1 \% & 4 \% & 2 \% & 4 \% & 4 \% & 9 \% \\ 34 \% & 30 \% & 35 \% & 22 \% & 27 \% & 18 \% & 17 \% \\ 30 \% & 28 \% & 32 \% & 30 \% & 33 \% & 35 \% & 33 \% \\ 0 \% & 0 \% & 0 \% & 0 \% & 0 \% & 0 \% & 0 \% \\ 41 \% & 53 \% & 53 \% & 44 \% & 52 \% & 48 \% & 46 \% \\ 22 \% & 13 \% & 21 \% & 5 \% & 11 \% & 18 \% & 18 \% \\ 65 \% & 65 \% & 76 \% & 58 \% & 75 \% & 71 \% & 59 \% \\ & & & & & & \end{array}$




\begin{tabular}{|c|c|c|c|c|c|}
\hline 1985 & 1986 & 1987 & 1988 & 1989 & \\
\hline 726010 & 942900 & 757850 & 743250 & 742500 & \\
\hline 1721100 & 1291750 & 1306000 & 846000 & & \\
\hline 3480 & 4685 & 6428 & & & \\
\hline 82800 & 43110 & 45060 & 69380 & 114355 & \\
\hline 1460340 & 1307700 & 1496000 & 1346000 & 1830840 & \\
\hline 330 & 2190 & 2040 & 6336,19 & 14690 & \\
\hline 0 & 0 & 0 & 0 & 0 & \\
\hline 3994060 & 3592335 & 3613378 & 3010966,19 & & \\
\hline $\begin{array}{r}3993730 \\
0,47 \\
0,48\end{array}$ & 3590145 & 3611338 & 3004630 & & \\
\hline 517600 & 476600 & 304350 & 404200 & 552670 & \\
\hline 731200 & 496000 & 599760 & 487000 & & \\
\hline 421 & 381 & 280 & & & \\
\hline 527700 & 251700 & 305350 & 477600 & 403950 & \\
\hline 158880 & 127370 & 209260 & 232100 & 250100 & \\
\hline 40960 & 58420 & 34400 & 41219,1 & 71460 & \\
\hline 16270 & 12440 & 8749,98 & 7330 & 14450 & \\
\hline 19990 & 20530 & 14330 & 21600 & 15950 & 28800 \\
\hline 2013021 & 1443441 & 1476479,98 & 1671049,1 & & \\
\hline $\begin{array}{r}1955791 \\
3,84 \\
6,18\end{array}$ & 1372581 & 1433330 & 1622500 & & \\
\hline 2582190 & 2717500 & 2571400 & 2017200 & 3172000 & \\
\hline 366500 & 223355 & 361200 & 318300 & & \\
\hline 18630 & 53580 & 43755 & & & \\
\hline 794900 & 397750 & 609000 & 607250 & 838500 & \\
\hline 5840 & 2752 & 15960 & 32700 & 49360 & \\
\hline 99100 & 232300 & 228950 & 179386,48 & 220600 & \\
\hline 6800 & 2820 & 1705,33 & 1250 & 2500 & \\
\hline 38293 & 56760 & 151640 & 179000 & 196850 & 119700 \\
\hline 3912253 & 3686817 & 3983610,33 & 3335086,48 & & \\
\hline
\end{tabular}

$\begin{array}{rrrrrr}5735000 & 6150000 & 5230000 & 5300000 & 6700000 & \\ 4800000 & 3595000 & 4023000 & 3319000 & & \\ 100000 & 260000 & 170000 & & & \\ 2414000 & 1260000 & 1670000 & 2072400 & 2400000 & \\ 1988000 & 1760000 & 2150000 & 2100000 & 2800000 & \\ 230600 & 412000 & 412000 & 350000 & 470000 & \\ 39300 & 33000 & 20140 & 14900 & 27000 & \\ 79000 & 92400 & 220000 & 255700 & 300000 & 275400 \\ 15385900 & 13562400 & 13895140 & 13412000 & & \\ 15116000 & 13117400 & 13463000 & 13047100 & & \\ 0,42 & & & & & \end{array}$




\begin{tabular}{|c|c|c|c|c|c|}
\hline 8514000 & 8621000 & 8954000 & 8479000 & 9917000 & \\
\hline 11229000 & 8592300 & 8293400 & 4603000 & & \\
\hline 458600 & 621280 & 532600 & & & \\
\hline 4514900 & 2456250 & 3223500 & 3718650 & 3673000 & \\
\hline 6774800 & 6381000 & 9209400 & 6154000 & 9935000 & \\
\hline 398000 & 493900 & 715800 & 448600 & 664350 & \\
\hline 90040 & 53790 & 82440 & 36690 & 57745 & \\
\hline 98000 & 112660 & 258800 & 319000 & 357800 & 323400 \\
\hline \multicolumn{6}{|c|}{$32077340,3327332180,3231269940,3623758940,29$} \\
\hline \\
\hline \multicolumn{6}{|c|}{0,7} \\
\hline \multicolumn{6}{|l|}{0,75} \\
\hline $13 \%$ & $15 \%$ & $14 \%$ & $14 \%$ & $11 \%$ & \#DIV/0! \\
\hline $36 \%$ & $36 \%$ & $32 \%$ & $25 \%$ & \#DIV/O! & \#DIV/0! \\
\hline $3 \%$ & $2 \%$ & $4 \%$ & \#DIV/O! & \#DIV/O! & \#DIV/0! \\
\hline $3 \%$ & $3 \%$ & $3 \%$ & $3 \%$ & $5 \%$ & \#DIV/0! \\
\hline $73 \%$ & $74 \%$ & $70 \%$ & $64 \%$ & $65 \%$ & \#DIV/0! \\
\hline $0 \%$ & $1 \%$ & $0 \%$ & $2 \%$ & $3 \%$ & \#DIV/0! \\
\hline $0 \%$ & $0 \%$ & $0 \%$ & $0 \%$ & $0 \%$ & \#DIV/0! \\
\hline $0 \%$ & $0 \%$ & $0 \%$ & $0 \%$ & $0 \%$ & $0 \%$ \\
\hline $9 \%$ & $8 \%$ & $6 \%$ & $8 \%$ & $8 \%$ & \#DIV/0! \\
\hline $15 \%$ & $14 \%$ & $15 \%$ & $15 \%$ & \#DIV/0! & \#DIV/0! \\
\hline $0 \%$ & $0 \%$ & $0 \%$ & \#DIV/O! & \#DIV/0! & \#DIV/0! \\
\hline $22 \%$ & $20 \%$ & $18 \%$ & $23 \%$ & $17 \%$ & \#DIV/0! \\
\hline $8 \%$ & $7 \%$ & $10 \%$ & $11 \%$ & $9 \%$ & \#DIV/0! \\
\hline $18 \%$ & $14 \%$ & $8 \%$ & $12 \%$ & $15 \%$ & \#DIV/0! \\
\hline $41 \%$ & $38 \%$ & $43 \%$ & $49 \%$ & $54 \%$ & \#DIV/0! \\
\hline $25 \%$ & $22 \%$ & $7 \%$ & $8 \%$ & $5 \%$ & $10 \%$ \\
\hline $45 \%$ & $44 \%$ & $49 \%$ & $38 \%$ & $47 \%$ & \#DIV/0! \\
\hline $8 \%$ & $6 \%$ & $9 \%$ & $10 \%$ & \#DIV/0! & \#DIV/0! \\
\hline $19 \%$ & $21 \%$ & $26 \%$ & \#DIV/O! & \#DIV/0! & \#DIV/0! \\
\hline $33 \%$ & $32 \%$ & $36 \%$ & $29 \%$ & $35 \%$ & \#DIV/0! \\
\hline $0 \%$ & $0 \%$ & $1 \%$ & $2 \%$ & $2 \%$ & \#DIV/0! \\
\hline $43 \%$ & $56 \%$ & $56 \%$ & $51 \%$ & $47 \%$ & \#DIV/0! \\
\hline $17 \%$ & $9 \%$ & $8 \%$ & $8 \%$ & $9 \%$ & \#DIV/0! \\
\hline $48 \%$ & $61 \%$ & $69 \%$ & $70 \%$ & $66 \%$ & $43 \%$ \\
\hline
\end{tabular}


Rendimiento (volumen/superficie cosechada)

1938

Zona norte

trigo

maíz

lino

girasol

soja

avena

centeno

cebada cerv.

Zona oeste

trigo

maíz

lino

girasol

soja

avena

centeno

cebada cerv.

Zona sur

trigo

maíz

lino

girasol

soja

avena

centeno

cebada cerv.

Buenos Aires

trigo

maíz

lino

girasol

soja

avena

centeno

cebada cerv.

\#DIV/0!

1139

1049

\#DIV/0!

1188

\#DIV/0!

858

699

735

869
1095

414

1139

\#DIV/O!

804

640

788

$$
1065
$$

1554

557

1221

\#DIV/O!

988

726

826
Región pampeana

trigo

maíz

lino

girasol

soja

avena

centeno

cebada cerv.
1270

1392

605

1098

\#DIV/0!

944

663

768
1939

1610

900

1412

534

739

\#DIV/0!

605

795

\#DIV/O!

843

953

517

881

\#DIV/0!

990

946

1389

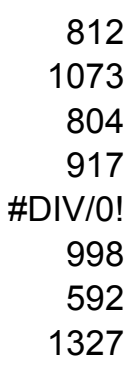

1327

1940

1300

2805

801

1243

\#DIV/0!

964

1138

\#DIV/0!

123

2173

722

1019

\#DIV/O!

964

964

1110

$$
\begin{array}{r}
1165 \\
1093 \\
813 \\
819
\end{array}
$$

\#DIV/0!

1189

823

1180

799

1286

734

908

\#DIV/0!

961

808

1318

$$
1156
$$

2417

787

1248

\#DIV/O!

1041

872

1142

700
1858

496

875

\#DIV/0!

915

690

1293
1218
2139

716

1100

\#DIV/O!

956

815

1189
1941

1942

1943

1412
2809
733
1469
\#DIV/0!
993
922
\#DIV/O!

$\begin{array}{rr}1618 & 1488 \\ 1539 & 3453 \\ 528 & 946 \\ 1002 & 824 \\ \text { \#DIV/0! } & \text { \#DIV/O! } \\ 1026 & 1131 \\ 1036 & 1181 \\ 0 & 0\end{array}$

1063

2000

399

815

\#DIV/0!

829

693

1183

1176
1053

931

973

\#DIV/O!

1198

688

1493

1147

2377

781

1071

\#DIV/O!

1042

694

1385

1061

1310

527

872

\#DIV/0!

980

611

1087

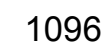

2284

689

979

\#DIV/O!

962

658

1246
1314
1142

591

839

\#DIV/O!

926

559

1036

$$
\begin{array}{r}
1044 \\
1608 \\
669 \\
701
\end{array}
$$

\#DIV/0!

1007

651

$\begin{array}{rr}554 & 651 \\ 876 & 1463\end{array}$

\begin{tabular}{ll}
942 & 1061 \\
\hline & 1220
\end{tabular}

639
666

1011

\#DIV/0!

699

698

1534

1142

2863

715

808

\#DIV/0!

860

705

1489

1139

2457

782

827

\#DIV/0!

868

701

1474 


\begin{tabular}{|c|c|c|c|c|c|c|}
\hline 1944 & 1945 & 1946 & 1947 & 1948 & $\begin{array}{l}1949 \\
1423\end{array}$ & 1950 \\
\hline 2441 & & & & & $\begin{array}{l}1423 \\
1972\end{array}$ & \\
\hline 1109 & 1442 & 1414 & 1531 & 1387 & 1525 & 1458 \\
\hline 1599 & 1712 & 3031 & 2491 & 1995 & 633 & 1796 \\
\hline 861 & 1060 & 1028 & 536 & 587 & 739 & 844 \\
\hline 1079 & 924 & 726 & 743 & 905 & 805 & 884 \\
\hline \#DIV/O! & \#DIV/O! & \#DIV/O! & \#DIV/O! & \#DIV/O! & \#DIV/O! & \#DIV/0! \\
\hline 1015 & 1232 & 1249 & 1270 & 1074 & 1142 & 1132 \\
\hline 951 & 932 & 884 & 1058 & 867 & 1190 & 1201 \\
\hline 383 & 0 & 1805 & 0 & 0 & 0 & 0 \\
\hline 832 & 825 & 874 & 1259 & 956 & 795 & 938 \\
\hline 643 & 606 & 2117 & 1783 & 1173 & 423 & 1120 \\
\hline 12986 & 620 & 586 & 404 & \#DIV/0! & 600 & 614 \\
\hline 806 & 479 & 659 & 563 & 680 & 588 & 609 \\
\hline \#DIV/0! & \#DIV/0! & \#DIV/0! & \#DIV/O! & \#DIV/0! & \#DIV/0! & \#DIV/0! \\
\hline 822 & 737 & 838 & 1012 & 1019 & 767 & 926 \\
\hline 528 & 575 & 663 & 564 & 568 & 406 & 765 \\
\hline \multirow[t]{2}{*}{1058} & 1099 & 1009 & 1303 & 968 & 873 & 1316 \\
\hline & & & & & 1106 & \\
\hline 1278 & 1056 & 1096 & 1109 & 1216 & 958 & 1196 \\
\hline 1028 & 966 & 936 & 1132 & 872 & 595 & 825 \\
\hline 861 & 689 & 828 & 799 & 513 & 604 & 814 \\
\hline 1005 & 592 & 621 & 691 & 830 & 691 & 704 \\
\hline \#DIV/O! & \#DIV/O! & \#DIV/O! & \#DIV/O! & \#DIV/O! & \#DIV/O! & \#DIV/O! \\
\hline 1265 & 1263 & 1311 & 1351 & 1238 & 1181 & 1095 \\
\hline 834 & 779 & 740 & 727 & 681 & 619 & 783 \\
\hline 1647 & 1415 & 1279 & 1251 & 1202 & 947 & 1418 \\
\hline 1181 & 1111 & 1077 & 1198 & 1165 & 1114 & 1211 \\
\hline 1491 & 1597 & 2593 & 2229 & 1779 & 740 & 1607 \\
\hline 859 & 789 & 844 & 677 & 511 & 637 & 804 \\
\hline 890 & 762 & 690 & 755 & 849 & 775 & 820 \\
\hline \#DIV/O! & \#DIV/O! & \#DIV/O! & \#DIV/O! & \#DIV/O! & \#DIV/0! & \#DIV/O! \\
\hline 1174 & 1163 & 1211 & 1261 & 1201 & 1132 & 1149 \\
\hline 697 & 672 & 678 & 631 & 590 & 563 & 787 \\
\hline 1568 & 1338 & 1236 & 1238 & 1154 & 991 & 1395 \\
\hline 936 & 966 & 1001 & 1419 & 1199 & 1136 & 1107 \\
\hline 1486 & 1389 & 2346 & 2100 & 1787 & 875 & 1617 \\
\hline 628 & 697 & 673 & 673 & 498 & 704 & 661 \\
\hline 879 & 696 & 649 & 740 & 749 & 749 & 774 \\
\hline \#DIV/O! & \#DIV/O! & \#DIV/O! & \#DIV/O! & \#DIV/O! & \#DIV/0! & \#DIV/O! \\
\hline 1076 & 1071 & 1107 & 1210 & 1143 & 1049 & 1066 \\
\hline 577 & 516 & 600 & 662 & 539 & 594 & 641 \\
\hline 1531 & 1249 & 1217 & 1229 & 1161 & 1007 & 1356 \\
\hline
\end{tabular}




\begin{tabular}{|c|c|c|c|c|c|c|}
\hline 1951 & 1952 & 1953 & 1954 & 1955 & 1956 & 1957 \\
\hline & & & 1943 & & & \\
\hline 1031 & 1536 & 1626 & 1513 & 1789 & 1812 & 1505 \\
\hline 1803 & 2184 & 2569 & 1361 & 2121 & 1425 & 2618 \\
\hline 848 & 902 & 978 & 784 & 817 & 870 & 786 \\
\hline 793 & 771 & 834 & 775 & 891 & 810 & 653 \\
\hline \#DIV/0! & \#DIV/0! & \#DIV/O! & \#DIV/O! & \#DIV/O! & \#DIV/O! & \#DIV/0! \\
\hline 989 & 1394 & 1454 & 1320 & 1442 & 1404 & 1178 \\
\hline 911 & 1268 & 1323 & 1157 & 1140 & 1111 & 1124 \\
\hline 0 & 0 & 0 & 0 & 0 & 0 & 0 \\
\hline 547 & 1268 & 1127 & 1037 & 1140 & 1420 & 1059 \\
\hline 812 & 1223 & 1469 & 1017 & 1260 & 995 & 2070 \\
\hline 233 & 792 & 541 & 706 & 788 & 842 & 548 \\
\hline 425 & 557 & 583 & 486 & 536 & 506 & 510 \\
\hline \#DIV/0! & \#DIV/0! & \#DIV/0! & \#DIV/0! & \#DIV/0! & \#DIV/O! & \#DIV/0! \\
\hline 788 & 1206 & 1055 & 1020 & 968 & 1228 & 1080 \\
\hline 597 & 1108 & 857 & 756 & 825 & 821 & 732 \\
\hline 975 & 1233 & 1352 & 1310 & 1200 & 1244 & 893 \\
\hline 897 & 1286 & 1226 & 1371 & 1234 & 1477 & 1581 \\
\hline 669 & 1100 & 1117 & 988 & 974 & 816 & 1451 \\
\hline 717 & 664 & 794 & 562 & 352 & 763 & 729 \\
\hline 586 & 816 & 794 & 787 & 811 & 909 & 723 \\
\hline \#DIV/O! & \#DIV/O! & \#DIV/O! & \#DIV/O! & \#DIV/O! & \#DIV/O! & \#DIV/O! \\
\hline 1125 & 1324 & 1380 & 1411 & 1180 & 1243 & 1325 \\
\hline 576 & 818 & 805 & 808 & 721 & 768 & 980 \\
\hline 986 & 1449 & 1382 & 1466 & 1082 & 1520 & 1458 \\
\hline 919 & 1307 & 1303 & 1309 & 1254 & 1471 & 1454 \\
\hline 1591 & 1848 & 2098 & 1323 & 1839 & 1271 & 2241 \\
\hline 795 & 711 & 885 & 607 & 523 & 758 & 733 \\
\hline 692 & 701 & 859 & 717 & 728 & 674 & 585 \\
\hline \#DIV/0! & \#DIV/0! & \#DIV/0! & \#DIV/0! & \#DIV/0! & \#DIV/O! & \#DIV/O! \\
\hline 1084 & 1360 & 1390 & 1342 & 1141 & 1263 & 1217 \\
\hline 605 & 995 & 876 & 798 & 796 & 821 & 795 \\
\hline 1010 & 1401 & 1409 & 1442 & 1157 & 1461 & 1343 \\
\hline 766 & 1370 & 1243 & 1410 & 1295 & 1319 & 1323 \\
\hline 1486 & 1561 & 1926 & 1414 & 1811 & 1468 & 2103 \\
\hline 699 & 672 & 743 & 639 & 536 & 575 & 583 \\
\hline 654 & 684 & 762 & 698 & 691 & 651 & 580 \\
\hline \#DIV/0! & \#DIV/O! & \#DIV/O! & \#DIV/O! & \#DIV/0! & \#DIV/O! & \#DIV/O! \\
\hline 1048 & 1319 & 1361 & 1282 & 1106 & 1193 & 1137 \\
\hline 530 & 947 & 735 & 764 & 737 & 721 & 706 \\
\hline 958 & 1434 & 1379 & 1452 & 1160 & 1371 & 1248 \\
\hline
\end{tabular}




\begin{tabular}{|c|c|c|c|c|c|c|}
\hline 1958 & $\begin{array}{l}1959 \\
1557\end{array}$ & 1960 & 1961 & 1962 & 1963 & 1964 \\
\hline & 2228 & & & & & 2397 \\
\hline 1648 & 1646 & 1550 & 1642 & 2064 & 1906 & 2320 \\
\hline 2920 & 2057 & 2453 & 2274 & 2216 & 2716 & 2328 \\
\hline 807 & 880 & 828 & 904 & 940 & 787 & 977 \\
\hline 674 & 855 & 638 & 734 & 675 & 707 & 733 \\
\hline \#DIV/O! & \#DIV/O! & \#DIV/O! & \#DIV/O! & \#DIV/O! & \#DIV/O! & \#DIV/0! \\
\hline 1262 & 1431 & 1287 & 1393 & 1700 & 1183 & 1414 \\
\hline 1180 & 1171 & 1053 & 1167 & 1236 & 1162 & 1242 \\
\hline 0 & 0 & 0 & 0 & 0 & 0 & 0 \\
\hline 1448 & 1314 & 912 & 1079 & 1195 & 1633 & 1819 \\
\hline 1869 & 1243 & 1172 & 1407 & 1630 & 1434 & 1298 \\
\hline 692 & 692 & 484 & 576 & 756 & 647 & 610 \\
\hline 474 & 556 & 421 & 467 & 418 & 622 & 606 \\
\hline \#DIV/O! & \#DIV/O! & \#DIV/O! & \#DIV/O! & \#DIV/O! & \#DIV/O! & \#DIV/0! \\
\hline 972 & 1039 & 847 & 987 & 1091 & 1244 & 1310 \\
\hline 900 & 802 & 784 & 779 & 501 & 1023 & 914 \\
\hline \multirow[t]{2}{*}{963} & 1013 & 958 & 1082 & 918 & 1213 & 1543 \\
\hline & 1276 & & & 1275 & & \\
\hline 1356 & 1136 & 1244 & 1308 & 1261 & 1912 & 1929 \\
\hline 1110 & 946 & 1234 & 1188 & 1369 & 1555 & 1241 \\
\hline 769 & 768 & 631 & 713 & 748 & 761 & 779 \\
\hline 510 & 457 & 693 & 766 & 683 & 822 & 700 \\
\hline \#DIV/O! & \#DIV/O! & \#DIV/O! & \#DIV/O! & \#DIV/O! & \#DIV/O! & \#DIV/O! \\
\hline 1173 & 1280 & 1114 & 1227 & 1229 & 1450 & 1499 \\
\hline 892 & 635 & 736 & 739 & 636 & 1029 & 1050 \\
\hline 1274 & 1109 & 1022 & 1083 & 569 & 1735 & 1641 \\
\hline 1386 & 1228 & 1275 & 1387 & 1520 & 1815 & 1932 \\
\hline 2303 & 1727 & 2012 & 1932 & 1942 & 2301 & 2002 \\
\hline 799 & 780 & 671 & 756 & 840 & 763 & 856 \\
\hline 509 & 703 & 651 & 711 & 622 & 627 & 747 \\
\hline \#DIV/O! & \#DIV/O! & \#DIV/O! & \#DIV/O! & \#DIV/O! & \#DIV/O! & \#DIV/O! \\
\hline 1115 & 1264 & 1136 & 1230 & 1240 & 1352 & 1478 \\
\hline 923 & 834 & 837 & 812 & 638 & 964 & 961 \\
\hline 1211 & 1182 & 1136 & 1173 & 803 & 1572 & 1577 \\
\hline 1284 & 1335 & 1161 & 1297 & 1527 & 1578 & 1840 \\
\hline 2247 & 1817 & 1883 & 2033 & 1744 & 1929 & 1797 \\
\hline 623 & 739 & 588 & 700 & 638 & 634 & 752 \\
\hline 451 & 733 & 651 & 709 & 603 & 632 & 717 \\
\hline \#DIV/O! & \#DIV/O! & \#DIV/O! & \#DIV/O! & \#DIV/O! & \#DIV/O! & \#DIV/O! \\
\hline 1069 & 1234 & 1100 & 1175 & 1186 & 1309 & 1416 \\
\hline 771 & 809 & 692 & 741 & 566 & 829 & 842 \\
\hline 1185 & 1246 & 1089 & 1097 & 939 & 1514 & 1554 \\
\hline
\end{tabular}




\begin{tabular}{|c|c|c|c|c|c|c|}
\hline 1965 & 1966 & 1967 & 1968 & $\begin{array}{l}1969 \\
1685 \\
3401\end{array}$ & 1970 & 1971 \\
\hline 2007 & 1557 & 1248 & 1155 & 1403 & 2053 & 1493 \\
\hline 3235 & 4236 & 2526 & 3351 & 3660 & 3551 & 2661 \\
\hline 978 & 884 & 680 & 900 & 865 & 1397 & 1235 \\
\hline 918 & 1163 & 1019 & 918 & 966 & 859 & 663 \\
\hline \#DIV/O! & \#DIV/O! & \#DIV/O! & \#DIV/O! & 1260 & 1151 & 1280 \\
\hline 1311 & 1337 & 1404 & 1030 & 1080 & 1368 & 1333 \\
\hline 1215 & 1158 & 1154 & 1183 & 1127 & 1103 & 1039 \\
\hline 0 & 0 & 0 & 0 & 0 & 0 & 0 \\
\hline 1028 & 906 & 1343 & 989 & 1386 & 1136 & 1188 \\
\hline 2050 & 1932 & 1689 & 1653 & 2521 & 1760 & 1799 \\
\hline 349 & 288 & 526 & 553 & 400 & \#DIV/0! & \#DIV/0! \\
\hline 616 & 702 & 623 & 640 & 770 & 633 & 561 \\
\hline \#DIV/O! & \#DIV/0! & \#DIV/0! & \#DIV/O! & \#DIV/O! & \#DIV/O! & \#DIV/0! \\
\hline 1029 & 1006 & 1125 & 976 & 980 & 698 & 1267 \\
\hline 857 & 768 & 591 & 643 & 883 & 481 & 571 \\
\hline 1117 & 717 & 1224 & 1318 & 1189 & 917 & 1279 \\
\hline & & & & 1567 & & \\
\hline 1527 & 1495 & 1459 & 1039 & 1609 & 1133 & 1217 \\
\hline 1306 & 1404 & 1182 & 1667 & 2042 & 1708 & 1576 \\
\hline 706 & 1138 & 829 & 511 & 1232 & 777 & 685 \\
\hline 755 & 721 & 824 & 626 & 1067 & 665 & 979 \\
\hline \#DIV/O! & \#DIV/0! & \#DIV/O! & \#DIV/O! & \#DIV/O! & \#DIV/O! & \#DIV/O! \\
\hline 1086 & 1302 & 1457 & 1244 & 1390 & 1137 & 1390 \\
\hline 677 & 878 & 990 & 791 & 894 & 633 & 746 \\
\hline 1062 & 1273 & 1431 & 1032 & 1338 & 980 & 1182 \\
\hline 1466 & 1348 & 1401 & 1063 & 1508 & 1300 & 1277 \\
\hline 2639 & 3278 & 2148 & 2910 & 3165 & 3154 & 2429 \\
\hline 746 & 1027 & 762 & 600 & 902 & 754 & 763 \\
\hline 859 & 913 & 879 & 748 & 903 & 628 & 717 \\
\hline \#DIV/0! & \#DIV/O! & \#DIV/O! & \#DIV/O! & 1260 & 1151 & 1278 \\
\hline 1178 & 1370 & 1372 & 1146 & 1349 & 1253 & 1393 \\
\hline 861 & 791 & 662 & 674 & 881 & 496 & 621 \\
\hline 1134 & 1156 & 1344 & 1082 & 1403 & 1067 & 1211 \\
\hline 1326 & 1197 & 1261 & 981 & 1359 & 1331 & 1265 \\
\hline 2292 & 2626 & 2071 & 2108 & 2502 & 2621 & 1943 \\
\hline 567 & 720 & 624 & 628 & 809 & 815 & 699 \\
\hline 775 & 881 & 899 & 743 & 862 & 642 & 683 \\
\hline \#DIV/0! & \#DIV/O! & \#DIV/O! & \#DIV/O! & 1170 & 1633 & 1157 \\
\hline 1144 & 1313 & 1342 & 1110 & 1305 & 1204 & 1334 \\
\hline 745 & 646 & 626 & 595 & 717 & 499 & 589 \\
\hline 1056 & 1071 & 1244 & 1042 & 1272 & 1034 & 1178 \\
\hline
\end{tabular}




\begin{tabular}{|c|c|c|c|c|c|c|}
\hline 1972 & 1973 & 1974 & 1975 & 1976 & 1977 & 1978 \\
\hline 2102 & 1379 & 2004 & 1943 & 1679 & 1709 & 2191 \\
\hline 4888 & 4560 & 3262 & 2910 & 5169 & 5106 & 3901 \\
\hline 1307 & 985 & 1231 & 1293 & 1063 & 1150 & 1026 \\
\hline 672 & 968 & 744 & 953 & 761 & 1049 & 1209 \\
\hline 1208 & 1723 & 1256 & 1462 & 1608 & 2261 & 2088 \\
\hline 1361 & 1503 & 1465 & 1400 & 1400 & 1364 & 1270 \\
\hline 958 & 1023 & 1091 & 1200 & 1167 & \#DIV/0! & 1230 \\
\hline 0 & 0 & 0 & 0 & 0 & 0 & 0 \\
\hline 1846 & 1828 & 1690 & 1748 & 1691 & 1209 & 1850 \\
\hline 2673 & 3840 & 2968 & 2356 & 3451 & 4226 & 3511 \\
\hline \#DIV/0! & 1069 & 1100 & \#DIV/0! & 1100 & 1081 & 1034 \\
\hline 653 & 780 & 663 & 1006 & 840 & 1079 & 1217 \\
\hline \#DIV/0! & 1269 & 1275 & 1202 & 1115 & 1676 & 1776 \\
\hline 1598 & 1633 & 945 & 1383 & 1221 & 1291 & 1394 \\
\hline 1128 & 1110 & 866 & 1091 & 1157 & 940 & 893 \\
\hline 1775 & 1632 & 1237 & 1649 & 1603 & 1128 & 1669 \\
\hline 1823 & 1634 & 1313 & 1320 & 1760 & 1395 & 1829 \\
\hline 2326 & 2686 & 1787 & 2014 & 2930 & 2224 & 2332 \\
\hline 823 & 622 & 870 & 764 & 1009 & 1168 & 914 \\
\hline 700 & 993 & 652 & 689 & 776 & 842 & 826 \\
\hline 1800 & 1427 & 1744 & 1405 & 900 & 870 & 748 \\
\hline 1549 & 1438 & 1343 & 1288 & 1583 & 1524 & 1551 \\
\hline 1019 & 920 & 828 & 768 & 1143 & 848 & 1124 \\
\hline 1624 & 1604 & 1214 & 1075 & 1711 & 1207 & 1732 \\
\hline 1794 & 1609 & 1456 & 1459 & 1701 & 1357 & 1796 \\
\hline 4143 & 4029 & 2990 & 2870 & 4132 & 4273 & 3436 \\
\hline 894 & 785 & 880 & 863 & 932 & 1064 & 931 \\
\hline 700 & 842 & 669 & 875 & 760 & 891 & 996 \\
\hline 1220 & 1629 & 1254 & 1442 & 1574 & 2146 & 2000 \\
\hline 1539 & 1456 & 1214 & 1331 & 1471 & 1421 & 1495 \\
\hline 1093 & 1044 & 836 & 1000 & 1136 & 889 & 949 \\
\hline 1645 & 1602 & 1241 & 1208 & 1703 & 1221 & 1724 \\
\hline 1604 & 1663 & 1411 & 1628 & 1720 & 1355 & 1738 \\
\hline 2949 & 3103 & 2699 & 2241 & 3588 & 3955 & 3317 \\
\hline 748 & 762 & 761 & 846 & 917 & 917 & 733 \\
\hline 659 & 824 & 692 & 826 & 757 & 834 & 932 \\
\hline 1988 & 1355 & 1355 & 1613 & 2217 & 2293 & 2407 \\
\hline 1423 & 1426 & 1160 & 1286 & 1386 & 1328 & 1360 \\
\hline 925 & 939 & 816 & 913 & 970 & 709 & 808 \\
\hline 1545 & 1524 & 1205 & 1207 & 1629 & 1159 & 1637 \\
\hline
\end{tabular}




\begin{tabular}{|c|c|c|c|c|c|c|}
\hline 1979 & 1980 & 1981 & 1982 & 1983 & 1984 & 1985 \\
\hline 2288 & 2471 & 2000 & 2802 & 1771 & 2341 & 1598 \\
\hline 3596 & 5252 & 4506 & 3831 & 4229 & 4537 & 4470 \\
\hline 1203 & 1215 & 889 & 1020 & 780 & 1271 & 748 \\
\hline 1226 & 1131 & 1579 & 1342 & 1234 & 1615 & 1820 \\
\hline 2322 & 2072 & 2070 & 1447 & 2431 & 2175 & 2482 \\
\hline 1255 & 1626 & 1334 & 1378 & 1000 & 1790 & 660 \\
\hline 1279 & 1590 & 1152 & 1379 & \#DIV/O! & \#DIV/O! & \#DIV/O! \\
\hline 0 & 0 & 0 & \#DIV/O! & \#DIV/O! & \#DIV/O! & \#DIV/O! \\
\hline 1979 & 1382 & 1560 & 2260 & 1931 & 2393 & 1525 \\
\hline 2367 & 4379 & 3051 & 3416 & 4187 & 3577 & 4415 \\
\hline 1010 & 1120 & 940 & 1055 & 874 & 1156 & 780 \\
\hline 1099 & 1190 & 1330 & 1287 & 1157 & 1689 & 1590 \\
\hline 1226 & 1662 & 1576 & 1462 & 1993 & 1133 & 1949 \\
\hline 1442 & 1291 & 1468 & 1968 & 1739 & 1970 & 1205 \\
\hline 1044 & 1060 & 1019 & 1228 & 807 & 846 & 1379 \\
\hline 1839 & 1180 & 1600 & 1828 & 1826 & 2280 & 1625 \\
\hline 1621 & 1686 & 1092 & 2229 & 1891 & 2372 & 1768 \\
\hline 1972 & 3111 & 3221 & 3335 & 3171 & 3509 & 3899 \\
\hline 875 & 775 & 641 & 903 & 814 & 903 & 814 \\
\hline 725 & 1073 & 1149 & 1431 & 1227 & 1398 & 1250 \\
\hline 647 & 1625 & 1400 & 1150 & 1779 & 1686 & 1884 \\
\hline 1558 & 1555 & 1116 & 1723 & 1682 & 1728 & 1069 \\
\hline 932 & 849 & 1042 & 1102 & 989 & 1060 & 1308 \\
\hline 1441 & 1481 & 1104 & 2151 & 2263 & 2414 & 1894 \\
\hline 1649 & 1671 & 1393 & 2209 & 1912 & 2361 & 1634 \\
\hline 3130 & 4532 & 3820 & 3496 & 3950 & 3933 & 4267 \\
\hline 871 & 833 & 776 & 904 & 838 & 852 & 654 \\
\hline 908 & 1069 & 1275 & 1356 & 1115 & 1481 & 1380 \\
\hline 1920 & 2000 & 2006 & 1466 & 2342 & 1939 & 2341 \\
\hline 1451 & 1465 & 1270 & 1679 & 1602 & 1718 & 1071 \\
\hline 1017 & 1011 & 1122 & 1196 & 890 & 966 & 1365 \\
\hline 1541 & 1409 & 1287 & 2062 & 2100 & 2387 & 1756 \\
\hline 1698 & 1555 & 1404 & 2058 & 1841 & 2314 & 1616 \\
\hline 2749 & 4066 & 3231 & 3265 & 3341 & 3739 & 3965 \\
\hline 759 & 806 & 734 & 846 & 821 & 830 & 669 \\
\hline 867 & 1013 & 1187 & 1301 & 1139 & 1433 & 1337 \\
\hline 1730 & 2018 & 2123 & 1743 & 2446 & 1989 & 2172 \\
\hline 1281 & 1246 & 1134 & 1566 & 1449 & 1654 & 1202 \\
\hline 901 & 740 & 923 & 849 & 805 & 978 & 1054 \\
\hline 1448 & 1288 & 1184 & 1888 & 1922 & 2333 & 1675 \\
\hline
\end{tabular}




\begin{tabular}{|c|c|c|c|c|}
\hline 1986 & 1987 & 1988 & 1989 & \\
\hline 2197 & 2049 & 2180 & 2505 & \\
\hline 3757 & 4870 & 3711 & \#DIV/O! & \\
\hline 1077 & 762 & \#DIV/O! & \#DIV/O! & \\
\hline 1652 & 1817 & 1933 & 1486 & \\
\hline 2214 & 2240 & 1920 & 2457 & \\
\hline 2190 & 2040 & 1586 & 1836 & \\
\hline \#DIV/O! & \#DIV/O! & \#DIV/O! & \#DIV/O! & \\
\hline \#DIV/O! & \#DIV/O! & 0 & \#DIV/O! & \\
\hline 1840 & 1669 & 1919 & 1903 & \\
\hline 3129 & 4281 & 3476 & \#DIV/O! & \\
\hline 907 & 875 & \#DIV/O! & \#DIV/O! & \\
\hline 1603 & 1753 & 2049 & 1498 & \\
\hline 1794 & 1991 & 1876 & 1804 & \\
\hline 1646 & 1557 & 1327 & 1595 & \\
\hline 882 & 764 & 657 & 790 & \\
\hline 1868 & 1814 & 2387 & 1922 & \\
\hline 1945 & 1865 & 1647 & 2241 & \\
\hline 2558 & 4244 & 3740 & \#DIV/O! & \\
\hline 1014 & 864 & \#DIV/O! & \#DIV/O! & \\
\hline 999 & 1234 & 1142 & 1619 & \\
\hline 1166 & 1814 & 1611 & 1880 & \\
\hline 1858 & 1761 & 1462 & 1765 & \\
\hline 1128 & 953 & 806 & 1042 & \\
\hline 2340 & 2628 & 2511 & 2512 & \\
\hline 1891 & 1808 & 1873 & 2094 & \\
\hline 3457 & 4478 & 3694 & \#DIV/O! & \\
\hline 1012 & 895 & \#DIV/O! & \#DIV/O! & \\
\hline 1219 & 1380 & 1517 & 1600 & \\
\hline 2108 & 2185 & 1893 & 2249 & \\
\hline 1729 & 1671 & 1346 & 1567 & \\
\hline 1068 & 889 & 741 & 900 & \\
\hline 2124 & 2500 & 2504 & 2500 & 2340 \\
\hline 1782 & 1886 & 1844 & 1900 & \\
\hline 3313 & 3973 & 3056 & \#DIV/O! & \\
\hline 836 & 817 & \#DIV/O! & \#DIV/O! & \\
\hline 1230 & 1404 & 1398 & 1477 & \\
\hline 1925 & 2282 & 1651 & 2171 & \\
\hline 1589 & 1509 & 1267 & 1505 & \\
\hline 929 & 918 & 748 & 780 & \\
\hline 2054 & 2313 & 2435 & 2290 & 2215 \\
\hline
\end{tabular}


Rendimiento (kilos por hectárea)

Superficie sembre 1938/39

\begin{tabular}{|c|c|c|c|c|c|c|c|c|c|}
\hline Zona norte & $1938 / 39$ & 1939 & 1940 & 1941 & 1942 & 1943 & 1944 & 1945 & 1946 \\
\hline trigo & 1721 & 900 & 1300 & 1412 & 1618 & 1488 & 1109 & 1442 & 1414 \\
\hline maíz & 1620 & 1412 & 2805 & 2809 & 1539 & 3453 & 1599 & 1712 & 3031 \\
\hline lino & 678 & 534 & 801 & 733 & 528 & 946 & 861 & 1060 & 1028 \\
\hline $\begin{array}{l}\text { girasol } \\
\text { soja }\end{array}$ & 899 & 739 & 1243 & 1469 & 1002 & 824 & 1079 & 924 & 726 \\
\hline avena & 1139 & 605 & 964 & 993 & 1026 & 1131 & 1015 & 1232 & 1249 \\
\hline centeno & 1049 & 795 & 1138 & 922 & 1036 & 1181 & 951 & 932 & 884 \\
\hline cebada cerv. & & & & & 0 & 0 & 383 & 0 & 1805 \\
\hline \multicolumn{10}{|l|}{ Zona oeste } \\
\hline trigo & 1208 & 843 & 1232 & 1063 & 892 & 1044 & 832 & 825 & 874 \\
\hline maíz & 978 & 953 & 2173 & 2000 & 1216 & 1608 & 643 & 606 & 2117 \\
\hline lino & 431 & 517 & 722 & 399 & 455 & 669 & 12986 & 620 & 586 \\
\hline $\begin{array}{l}\text { girasol } \\
\text { soja }\end{array}$ & 1188 & 881 & 1019 & 815 & 742 & 701 & 806 & 479 & 659 \\
\hline avena & 858 & 990 & 964 & 829 & 755 & 1007 & 822 & 737 & 838 \\
\hline centeno & 699 & 946 & 964 & 693 & 554 & 651 & 528 & 575 & 663 \\
\hline cebada cerv. & 735 & 1389 & 1110 & 1183 & 876 & 1463 & 1058 & 1099 & 1009 \\
\hline \multicolumn{10}{|l|}{ Zona sur } \\
\hline trigo & 869 & 812 & 1165 & 1176 & 942 & 1061 & 1278 & 1056 & 1096 \\
\hline maíz & 1095 & 1073 & 1093 & 1053 & 1009 & 1220 & 1028 & 966 & 936 \\
\hline lino & 414 & 804 & 813 & 931 & 466 & 539 & 861 & 689 & 828 \\
\hline $\begin{array}{l}\text { girasol } \\
\text { soja }\end{array}$ & 1139 & 917 & 819 & 973 & 846 & 1011 & 1005 & 592 & 621 \\
\hline avena & 804 & 998 & 1189 & 1198 & 883 & 699 & 1265 & 1263 & 1311 \\
\hline centeno & 640 & 592 & 823 & 688 & 533 & 698 & 834 & 779 & 740 \\
\hline cebada cerv. & 788 & 1327 & 1180 & 1493 & 1201 & 1534 & 1647 & 1415 & 1279 \\
\hline
\end{tabular}

Fuente: "Estimaciones Agrícolas" de la SEAGyP 


\section{Rendimiento (kilos por hectárea)}

Zona norte $\quad 1938 / 39$

4304,18
1939

4932,31
1940

5069,57
1941

5625,5

\section{2}

4464,36
1943

1944

1945

5364,07

5818,75

4718,63

\section{Buenos Aires}

trigo

3779920

2035000

816555

212830

girasol

soja

avena

centeno

cebada cerv.

1055565

283150

415570

8598590

7259875

3175489

2253000

848396

258000

$\begin{array}{rrr}2993200 & 3015035 & 2508171 \\ 1995000 & 1753000 & 1487408 \\ 765600 & 746730 & 712188 \\ 305131 & 368000 & 290600 \\ & & \\ 1147170 & 1042728 & 1539537 \\ 382120 & 336129 & 533498 \\ 413710 & 300627 & 284330 \\ 8001931 & 7562249 & 7355732 \\ 6472641 & 6183392 & 5282697\end{array}$

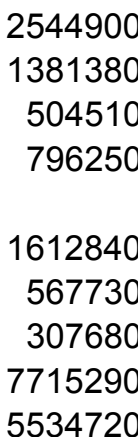

5534720

$\begin{array}{rr}2348055 & 2790260 \\ 1405176 & 1285925 \\ 535961 & 399685 \\ 805474 & 857555 \\ & \\ 1335440 & 1191570 \\ 538042 & 737945 \\ 478040 & 838667 \\ 7446188 & 8101607 \\ 5572706 & 6172092\end{array}$

\section{0}

4883000

2680085

320455

girasol

soja

avena

centeno

cebada cerv.

\section{5}

525720
1362315

7069663

6627000

3051650

476600

6965000

5616200

2850100

543131

1361638

889025

538003

1558360

1297730

567140

$19144970,03 \quad 20013579,04 \quad 19397661,03$

$16833490,03 \quad 17762916,04 \quad 16541571,03$

$\begin{array}{rrrrrr}7187841 & 6799919 & 6730470 & 6178600 & 5732935 & 6613660 \\ 4554000 & 3696353 & 4000809 & 3688640 & 3614896 & 3273505 \\ 2705115 & 2459158 & 2265467 & 1985020 & 1860751 & 1901305 \\ 702000 & 621800 & 1515143 & 1442570 & 1602625 & 1573612 \\ & & & & & \\ 1384718 & 1902527 & 2113355 & 1980460 & 1677640 & 1463402 \\ 1026527 & 1587025 & 1748280 & 1537830 & 1430907 & 1886052 \\ 388927 & 364911 & 318540 & 375190 & 583775 & 1044313 \\ 949128,02 & 17431693,03 & 18692064,02 & 17188310,02 & 16503529,03 & 17755849,03 \\ 537883,02 & 13942141,03 & 14830429,02 & 13670020,02 & 13394982,03 & 14406395,03\end{array}$

Fuente: "Estimaciones Agrícolas" de la SEAGyP 
Rendimiento (kilos por hectárea)

Zona norte $\quad 1938 / 39$

1939

1940

1941

1942

1943

1944

1945

1946

Control proprcional

Zona norte
trigo
maíz
lino
girasol
soja
avena

centeno

cebada cerv.

$\begin{array}{rr}0 \% & 0 \% \\ 0 \% & 0 \% \\ 0 \% & 0 \% \\ 0 \% & 0 \% \\ \text { \#DIV } / 0 ! & \text { \#DIV } / 0 ! \\ 0 \% & 0 \% \\ 0 \% & 0 \% \\ 0 \% & 0 \%\end{array}$

$0 \%$
$0 \%$
$0 \%$
$0 \%$
$\#$ DIV/0!
$0 \%$
$0 \%$
$0 \%$

$0 \%$
$0 \%$
$0 \%$
$0 \%$
$\#$ DIV/0!
$0 \%$
$0 \%$
$0 \%$

$0 \%$
$0 \%$
$0 \%$
$0 \%$
\#DIV/0!
$0 \%$
$0 \%$
$0 \%$

$0 \%$
$0 \%$
$0 \%$
$0 \%$
\#DIV/0!
$0 \%$
$0 \%$
$0 \%$

$0 \%$
$0 \%$
$0 \%$
$0 \%$
$\#$ DIV/0!
$0 \%$
$0 \%$
$0 \%$

$0 \%$

$0 \%$

Zona oeste

trigo

maíz

lino

girasol

soja

avena

centeno

cebada cerv.

$\begin{array}{rr}0 \% & 0 \% \\ 0 \% & 0 \% \\ 0 \% & 0 \% \\ 1 \% & 0 \% \\ \text { \#DIV/0! } & \text { \#DIV/0! } \\ 0 \% & 0 \% \\ 0 \% & 0 \% \\ 0 \% & 0 \%\end{array}$

$0 \%$
$0 \%$
$0 \%$
$0 \%$
\#DIV/0!
$0 \%$
$0 \%$
$0 \%$

$0 \%$
$0 \%$
$0 \%$
$0 \%$
$\#$ DIV/0!
$0 \%$
$0 \%$
$0 \%$

$0 \%$
$0 \%$
$0 \%$
$0 \%$
$\#$ \#IV/0!
$0 \%$
$0 \%$
$0 \%$

$0 \%$
$0 \%$
$0 \%$
$0 \%$
\#DIV/0!
$0 \%$
$0 \%$
$1 \%$

$0 \%$
$0 \%$
$3 \%$
$0 \%$
\#DIV/0!
$0 \%$
$0 \%$
$0 \%$

$0 \%$
$0 \%$

$0 \%$

Zona sur

trigo

$0 \%$
$0 \%$
$0 \%$
$1 \%$

$0 \%$

$0 \%$

$0 \%$

maíz

lino

girasol

soja

\#DIV/O!

avena

$0 \%$
$0 \%$
$0 \%$
$0 \%$
\#DIV/0!
$0 \%$

$0 \%$
$0 \%$
$0 \%$
$0 \%$
\#DIV/0!
$0 \%$

$\begin{array}{rr}0 \% & 0 \% \\ \text { \#DIV/O! } & \text { \#DIV/O! } \\ 0 \% & 0 \% \\ 0 \% & 0 \% \\ 0 \% & 0 \%\end{array}$

Fuente: "Estimaciones Agrícolas" de la SEAGyP 
Rendimiento (kilos por hectárea)

\begin{tabular}{|c|c|c|c|c|c|c|c|c|c|}
\hline Zona norte & $1938 / 39$ & 1939 & 1940 & 1941 & 1942 & 1943 & 1944 & 1945 & 1946 \\
\hline centeno & $0 \%$ & $0 \%$ & $0 \%$ & $0 \%$ & $0 \%$ & $0 \%$ & $0 \%$ & $0 \%$ & $0 \%$ \\
\hline cebada cerv. & $0 \%$ & $0 \%$ & $0 \%$ & $0 \%$ & $0 \%$ & $1 \%$ & $1 \%$ & $0 \%$ & $0 \%$ \\
\hline
\end{tabular}


Rendimiento (kilos por hectárea)

Superficie sembre

\begin{tabular}{|c|c|c|c|c|c|c|c|c|c|}
\hline Zona norte & 1947 & 1948 & 1949 & 1950 & 1951 & 1952 & 1953 & 1954 & 1955 \\
\hline trigo & 1531 & 1387 & 1525 & 1458 & 1031 & 1536 & 1626 & 1513 & 1789 \\
\hline maíz & 2491 & 1995 & 633 & 1796 & 1803 & 2184 & 2569 & 1361 & 2121 \\
\hline lino & 536 & 587 & 739 & 844 & 848 & 902 & 978 & 784 & 817 \\
\hline $\begin{array}{l}\text { girasol } \\
\text { soja }\end{array}$ & 743 & 905 & 805 & 884 & 793 & 771 & 834 & 775 & 891 \\
\hline avena & 1270 & 1074 & 1142 & 1132 & 989 & 1394 & 1454 & 1320 & 1442 \\
\hline centeno & 1058 & 867 & 1190 & 1201 & 911 & 1268 & 1323 & 1157 & 1140 \\
\hline cebada cerv. & 0 & 0 & 0 & 0 & 0 & 0 & 0 & 0 & 0 \\
\hline \multicolumn{10}{|l|}{ Zona oeste } \\
\hline trigo & 1259 & 956 & 795 & 938 & 547 & 1268 & 1127 & 1037 & 1140 \\
\hline maíz & 1783 & 1173 & 423 & 1120 & 812 & 1223 & 1469 & 1017 & 1260 \\
\hline lino & 404 & & 600 & 614 & 233 & 792 & 541 & 706 & 788 \\
\hline $\begin{array}{l}\text { girasol } \\
\text { soja }\end{array}$ & 563 & 680 & 588 & 609 & 425 & 557 & 583 & 486 & 536 \\
\hline avena & 1012 & 1019 & 767 & 926 & 788 & 1206 & 1055 & 1020 & 968 \\
\hline centeno & 564 & 568 & 406 & 765 & 597 & 1108 & 857 & 756 & 825 \\
\hline cebada cerv. & 1303 & 968 & 873 & 1316 & 975 & 1233 & 1352 & 1310 & 1200 \\
\hline \multicolumn{10}{|l|}{ Zona sur } \\
\hline trigo & 1109 & 1216 & 958 & 1196 & 897 & 1286 & 1226 & 1371 & 1234 \\
\hline maíz & 1132 & 872 & 595 & 825 & 669 & 1100 & 1117 & 988 & 974 \\
\hline lino & 799 & 513 & 604 & 814 & 717 & 664 & 794 & 562 & 352 \\
\hline $\begin{array}{l}\text { girasol } \\
\text { soja }\end{array}$ & 691 & 830 & 691 & 704 & 586 & 816 & 794 & 787 & 811 \\
\hline avena & 1351 & 1238 & 1181 & 1095 & 1125 & 1324 & 1380 & 1411 & 1180 \\
\hline centeno & 727 & 681 & 619 & 783 & 576 & 818 & 805 & 808 & 721 \\
\hline $\begin{array}{l}\text { cebada cerv. } \\
\text { Fuente: Estimacic }\end{array}$ & 1251 & 1202 & 947 & 1418 & 986 & 1449 & 1382 & 1466 & 1082 \\
\hline
\end{tabular}

Fuente: "Estimaciones Agrícolas" de la SEAGyP 


\section{Rendimiento (kilos por hectárea)}

\begin{tabular}{|c|c|c|c|c|c|c|c|c|c|}
\hline \multirow[t]{2}{*}{ Zona norte } & 1947 & 1948 & 1949 & 1950 & 1951 & 1952 & 1953 & 1954 & 1955 \\
\hline & 4982,92 & 4632,91 & 3795,02 & 4957,01 & 3854,2 & 5314,86 & 5313,96 & 5173,03 & 4452,24 \\
\hline \multicolumn{10}{|l|}{ Buenos Aires } \\
\hline trigo & 2113100 & 2430000 & 2201300 & 2833500 & 2487300 & 2981400 & 3202500 & 2791500 & 2402700 \\
\hline maíz & 1151735 & 969590 & 771950 & 810930 & 785390 & 1257072 & 1298395 & 1181664 & 1078970 \\
\hline lino & 430120 & 337800 & 180600 & 200900 & 241100 & 284200 & 228200 & 225000 & 195500 \\
\hline girasol & 881325 & 1017365 & 847700 & 874963 & 867575 & 511870 & 319350 & 304775 & 749090 \\
\hline \multicolumn{10}{|l|}{ soja } \\
\hline avena & 1047700 & 1110000 & 965870 & 989500 & 982500 & 1474500 & 1273000 & 1117900 & 1146500 \\
\hline centeno & 595950 & 643800 & 609350 & 707200 & 735800 & 1050400 & 887300 & 834400 & 913300 \\
\hline \multirow[t]{3}{*}{ cebada cerv. } & 586450 & 515000 & 424180 & 500300 & 499400 & 630800 & 629100 & 570400 & 649700 \\
\hline & 6806380 & 7023555 & 6000950 & 6917293 & 6599065 & 8190242 & 7837845 & 7025639 & 7135760 \\
\hline & 5162730 & 5269755 & 4425730 & 5220593 & 4880765 & 5665342 & 5677545 & 5073339 & 5075960 \\
\hline \multicolumn{10}{|c|}{ Región pampeaná } \\
\hline trigo & 5413400 & 5778100 & 5665100 & 6534800 & 4771700 & 6039800 & 6318000 & 5911100 & 5181200 \\
\hline maíz & 3009035 & 2400590 & 1899620 & 2180130 & 2310390 & 3044472 & 2985445 & 2736114 & 2612210 \\
\hline lino & 1569670 & 1302900 & 1075820 & 1082700 & 640800 & 1018700 & 730600 & 736900 & 672100 \\
\hline \multicolumn{10}{|l|}{ soja } \\
\hline avena & 1290895 & 1364100 & 1201620 & 1282100 & 1163900 & 1677500 & 1468800 & 1344500 & 1418400 \\
\hline centeno & 1710420 & 1777500 & 1785270 & 2116200 & 1946030 & 2422550 & 2369220 & 2414950 & 2492250 \\
\hline \multirow[t]{3}{*}{ cebada cerv. } & 773760 & 695490 & 571580 & 638360 & 654520 & 849326 & 831900 & 814602 & 960700 \\
\hline & 15264907,03 & 15107350,03 & 13673560,04 & 15453423,03 & 13085838,03 & 15866658,04 & 15269225,03 & 4513576,05 & 4729430,03 \\
\hline & 12263592.03 & 11965750,03 & 10686670,04 & 12055123,03 & 9975908,03 & 11766608,04 & 11431205,03 & 10754126.05 & 0818780 \\
\hline
\end{tabular}

Fuente: "Estimaciones Agrícolas" de la SEAGyP 
Rendimiento (kilos por hectárea)

Zona norte

1947

1948

1949

1950

1952

1953

1954

1955

Control proprcion:

Zona norte
trigo
maíz
lino
girasol
soja
avena

centeno

cebada cerv.

$\begin{array}{rr}0 \% & 0 \% \\ 0 \% & 0 \% \\ 0 \% & 0 \% \\ 0 \% & 0 \% \\ \text { \#DIV/0! } & \text { \#DIV } / 0 ! \\ 0 \% & 0 \% \\ 0 \% & 0 \% \\ 0 \% & 0 \%\end{array}$

$0 \%$
$0 \%$
$0 \%$
$0 \%$
$\#$ \#IV/0!
$0 \%$
$0 \%$
$0 \%$

$0 \%$
$0 \%$
$0 \%$
$0 \%$
\#DIV/0!
$0 \%$
$0 \%$
$0 \%$

$0 \%$
$0 \%$
$0 \%$
$0 \%$
\#DIV/0!
$0 \%$
$0 \%$
$0 \%$

$0 \%$
$0 \%$
$0 \%$
$0 \%$
$\#$ DIV/0!
$0 \%$
$0 \%$
$0 \%$

$0 \%$
$0 \%$
$0 \%$
$0 \%$
$\#$ DIV/0!
$0 \%$
$0 \%$
$0 \%$

$\begin{array}{rr}0 \% & 0 \% \\ 0 \% & 0 \% \\ 0 \% & 0 \% \\ 0 \% & 0 \% \\ \text { \#DIV/O! } & \text { \#DIV/0! } \\ 0 \% & 0 \% \\ 0 \% & 0 \% \\ 0 \% & 0 \%\end{array}$

Zona oeste

trigo

maíz

lino

girasol

soja

avena

centeno

cebada cerv.

$\begin{array}{rr}0 \% & 0 \% \\ 0 \% & 0 \% \\ 0 \% & 0 \% \\ 0 \% & 0 \% \\ \text { \#DIV/0! } & \text { \#DIV } / 0 ! \\ 0 \% & 0 \% \\ 0 \% & 0 \% \\ 0 \% & 0 \%\end{array}$

$0 \%$
$0 \%$
$0 \%$
$0 \%$
\#DIV/0!
$0 \%$
$0 \%$
$0 \%$

$0 \%$
$0 \%$
$0 \%$
$0 \%$
\#DIV/0!
$0 \%$
$0 \%$
$0 \%$

$0 \%$
$0 \%$
$0 \%$
$0 \%$
\#DIV/0!
$0 \%$
$0 \%$
$0 \%$

$0 \%$
$0 \%$
$0 \%$
$0 \%$
\#DIV/0!
$0 \%$
$0 \%$
$0 \%$

$0 \%$
$0 \%$
$0 \%$
$0 \%$
$\#$ DIV/0!
$0 \%$
$0 \%$
$0 \%$

$0 \%$
$0 \%$
$0 \%$
$0 \%$
\#DIV/0!
$0 \%$
$0 \%$
$0 \%$

$0 \%$
$0 \%$
$0 \%$
$0 \%$
\#DIV/0!
$0 \%$
$0 \%$
$0 \%$

\section{Zona sur}

trigo

maíz

lino

girasol

soja

avena

$0 \%$
$0 \%$
$0 \%$
$0 \%$
\#DIV/0!
$0 \%$

$0 \%$
$0 \%$
$0 \%$
$0 \%$
\#DIV/0!
$0 \%$

$0 \%$
$0 \%$
$0 \%$
$0 \%$
\#DIV/0!
$0 \%$

$\begin{array}{rr}0 \% & 0 \% \\ 0 \% & 0 \% \\ 0 \% & 0 \% \\ 0 \% & 0 \% \\ \text { \#DIV/O! } & \text { \#DIV } / 0 ! \\ 0 \% & 0 \%\end{array}$

$0 \%$
$0 \%$
$0 \%$
$0 \%$
\#DIV/0!
$0 \%$

$0 \%$
$0 \%$
$0 \%$
$0 \%$
\#DIV/0!
$0 \%$

$\begin{array}{rr}0 \% & 0 \% \\ 0 \% & 0 \% \\ 0 \% & 0 \% \\ 0 \% & 0 \% \\ \text { \#DIV/O! } & \text { \#DIV/O! } \\ 0 \% & 0 \%\end{array}$

Fuente: "Estimaciones Agrícolas" de la SEAGyP 
Rendimiento (kilos por hectárea)

\begin{tabular}{|c|c|c|c|c|c|c|c|c|c|}
\hline Zona norte & 1947 & 1948 & 1949 & 1950 & 1951 & 1952 & 1953 & 1954 & 1955 \\
\hline centeno & $0 \%$ & $0 \%$ & $0 \%$ & $0 \%$ & $0 \%$ & $0 \%$ & $0 \%$ & $0 \%$ & $0 \%$ \\
\hline cebada cerv. & $0 \%$ & $0 \%$ & $0 \%$ & $0 \%$ & $0 \%$ & $0 \%$ & $0 \%$ & $0 \%$ & $0 \%$ \\
\hline
\end{tabular}


Rendimiento (kilos por hectárea)

Superficie sembre

\begin{tabular}{|c|c|c|c|c|c|c|c|c|c|}
\hline Zona norte & 1956 & 1957 & 1958 & 1959 & 1960 & 1961 & 1962 & 1963 & 1964 \\
\hline trigo & 1812 & 1505 & 1648 & 1646 & 1550 & 1642 & 2064 & 1906 & 2320 \\
\hline maíz & 1425 & 2618 & 2920 & 2057 & 2453 & 2274 & 2216 & 2716 & 2328 \\
\hline lino & 870 & 786 & 807 & 880 & 828 & 904 & 940 & 787 & 977 \\
\hline girasol & 810 & 653 & 674 & 855 & 638 & 734 & 675 & 707 & 733 \\
\hline \multicolumn{10}{|l|}{ soja } \\
\hline avena & 1404 & 1178 & 1262 & 1431 & 1287 & 1393 & 1700 & 1183 & 1414 \\
\hline centeno & 1111 & 1124 & 1180 & 1171 & 1053 & 1167 & 1236 & 1162 & 1242 \\
\hline cebada cerv. & 0 & 0 & 0 & 0 & 0 & 0 & 0 & 0 & 0 \\
\hline \multicolumn{10}{|l|}{ Zona oeste } \\
\hline trigo & 1420 & 1059 & 1448 & 1314 & 912 & 1079 & 1195 & 1633 & 1819 \\
\hline maíz & 995 & 2070 & 1869 & 1243 & 1172 & 1407 & 1630 & 1434 & 1298 \\
\hline lino & 842 & 548 & 692 & 692 & 484 & 576 & 756 & 647 & 610 \\
\hline girasol & 506 & 510 & 474 & 556 & 421 & 467 & 418 & 622 & 606 \\
\hline \multicolumn{10}{|l|}{ soja } \\
\hline avena & 1228 & 1080 & 972 & 1039 & 847 & 987 & 1091 & 1244 & 1310 \\
\hline centeno & 821 & 732 & 900 & 802 & 784 & 779 & 501 & 1023 & 914 \\
\hline cebada cerv. & 1244 & 893 & 963 & 1013 & 958 & 1082 & 918 & 1213 & 1543 \\
\hline \multicolumn{10}{|l|}{ Zona sur } \\
\hline trigo & 1477 & 1581 & 1356 & 1136 & 1244 & 1308 & 1261 & 1912 & 1929 \\
\hline maíz & 816 & 1451 & 1110 & 946 & 1234 & 1188 & 1369 & 1555 & 1241 \\
\hline lino & 763 & 729 & 769 & 768 & 631 & 713 & 748 & 761 & 779 \\
\hline girasol & 909 & 723 & 510 & 457 & 693 & 766 & 683 & 822 & 700 \\
\hline \multicolumn{10}{|l|}{ soja } \\
\hline avena & 1243 & 1325 & 1173 & 1280 & 1114 & 1227 & 1229 & 1450 & 1499 \\
\hline centeno & 768 & 980 & 892 & 635 & 736 & 739 & 636 & 1029 & 1050 \\
\hline cebada cerv. & 1520 & 1458 & 1274 & 1109 & 1022 & 1083 & 569 & 1735 & 1641 \\
\hline
\end{tabular}

Fuente: "Estimaciones Agrícolas" de la SEAGyP 


\section{Rendimiento (kilos por hectárea)}

\begin{tabular}{|c|c|c|c|c|c|c|c|c|c|}
\hline \multirow[t]{2}{*}{ Zona norte } & 1956 & 1957 & 1958 & 1959 & 1960 & 1961 & 1962 & 1963 & 1964 \\
\hline & 5485,01 & 5942,35 & 5019,05 & 4415,9 & 4824,01 & 5057,82 & 4629,89 & 6784,96 & 6290,77 \\
\hline \multicolumn{10}{|l|}{ Buenos Aires } \\
\hline trigo & 2860700 & 2625700 & 2975600 & 2370300 & 2214500 & 2430500 & 2185500 & 3350400 & 3407200 \\
\hline maíz & 965650 & 999100 & 966360 & 960000 & 935000 & 940000 & 872000 & 890000 & 850800 \\
\hline lino & 239400 & 291600 & 315600 & 362800 & 319500 & 351400 & 348400 & 344500 & 333300 \\
\hline girasol & 732300 & 1074850 & 888900 & 823000 & 684700 & 749000 & 577000 & 528000 & 591900 \\
\hline \multicolumn{10}{|l|}{ soja } \\
\hline avena & 1431900 & 1387400 & 1329000 & 1318700 & 1310700 & 1100200 & 883900 & 1126000 & 889600 \\
\hline centeno & 810900 & 861300 & 948100 & 986500 & 910000 & 727300 & 740800 & 680500 & 624000 \\
\hline \multirow[t]{3}{*}{ cebada cerv. } & 701800 & 620700 & 634400 & 595600 & 551300 & 494400 & 538400 & 511500 & 376200 \\
\hline & 7742650 & 7860650 & 8057960 & 7416900 & 6925700 & 6792800 & 6146000 & 7430900 & 7073000 \\
\hline & 5499850 & 5611950 & 5780860 & 5111700 & 4705000 & 4965300 & 4521300 & 5624400 & 5559400 \\
\hline \multicolumn{10}{|c|}{ Región pampeaná } \\
\hline trigo & 5912400 & 5279000 & 5674300 & 4756400 & 4241700 & 4913000 & 4803000 & 6222000 & 6421900 \\
\hline maíz & 2394500 & 2508600 & 2508360 & 2634500 & 2718700 & 2788100 & 2800000 & 3043000 & 3008500 \\
\hline lino & 1277100 & 1440400 & 1197150 & 1218300 & 1121800 & 1298300 & 1496650 & 1406200 & 1169000 \\
\hline girasol & 1194130 & 1636410 & 1323700 & 1231420 & 1100100 & 1304200 & 942720 & 857850 & 1120520 \\
\hline \multicolumn{10}{|l|}{ soja } \\
\hline avena & 1854600 & 1889300 & 1767700 & 1599850 & 1562000 & 1382800 & 1113650 & 1354100 & 1107800 \\
\hline centeno & 2711675 & 2768710 & 2745650 & 2806500 & 2569900 & 2550700 & 2379000 & 2084070 & 2051060 \\
\hline \multirow[t]{3}{*}{ cebada cerv. } & 1035930 & 925960 & 961050 & 917700 & 837500 & 785460 & 766900 & 701720 & 535740 \\
\hline & 16380335,07 & 16448380,07 & 16177910,09 & 15164670,08 & 14151700,04 & 15022560,04 & 14301920,04 & 15668940,06 & 15414520,07 \\
\hline & 11814060,07 & 11790370,07 & 11664560,09 & 10758320,08 & 10019800,04 & 11089060,04 & 10809270,04 & 12230770,06 & 12255660,07 \\
\hline
\end{tabular}

Fuente: "Estimaciones Agrícolas" de la SEAGyP 
Rendimiento (kilos por hectárea)

Zona norte

1956

1957

1958

1959

1960

1961

1962

1963

1964

Control proprcion:

Zona norte
trigo
maíz
lino
girasol
soja
avena

centeno

cebada cerv.

$\begin{array}{rr}0 \% & 0 \% \\ 0 \% & 0 \% \\ 0 \% & 0 \% \\ 0 \% & 0 \% \\ \text { \#DIV/0! } & \text { \#DIV } / 0 ! \\ 0 \% & 0 \% \\ 0 \% & 0 \% \\ 0 \% & 0 \%\end{array}$

$0 \%$
$0 \%$
$0 \%$
$0 \%$
$\#$ DIV/0!
$0 \%$
$0 \%$
$0 \%$

$0 \%$
$0 \%$
$0 \%$
$0 \%$
$\#$ DIV/0!
$0 \%$
$0 \%$
$0 \%$

$0 \%$
$0 \%$
$0 \%$
$0 \%$
\#DIV/0!
$0 \%$
$0 \%$
$0 \%$

$0 \%$
$0 \%$
$0 \%$
$0 \%$
$\#$ DIV/0!
$0 \%$
$0 \%$
$0 \%$

$0 \%$
$0 \%$
$0 \%$
$0 \%$
$\#$ DIV/0!
$0 \%$
$0 \%$
$0 \%$

$0 \%$

$0 \%$

Zona oeste

trigo

maíz

lino

girasol

soja

avena

centeno

cebada cerv.

$\begin{array}{rr}0 \% & 0 \% \\ 0 \% & 0 \% \\ 0 \% & 0 \% \\ 0 \% & 0 \% \\ \text { \#DIV/0! } & \text { \#DIV/O! } \\ 0 \% & 0 \% \\ 0 \% & 0 \% \\ 0 \% & 0 \%\end{array}$

$0 \%$
$0 \%$
$0 \%$
$0 \%$
\#DIV/0!
$0 \%$
$0 \%$
$0 \%$

$0 \%$
$0 \%$
$0 \%$
$0 \%$
\#DIV $/ 0 !$
$0 \%$
$0 \%$
$0 \%$

$0 \%$
$0 \%$
$0 \%$
$0 \%$
\#DIV/0!
$0 \%$
$0 \%$
$0 \%$

$0 \%$
$0 \%$
$0 \%$
$0 \%$
\#DIV $/ 0 !$
$0 \%$
$0 \%$
$0 \%$

$0 \%$
$0 \%$
$0 \%$
$0 \%$
$\#$ DIV/0!
$0 \%$
$0 \%$
$0 \%$

$0 \%$
$0 \%$

$0 \%$

Zona sur

trigo

maíz

lino

girasol

soja

$0 \%$
$0 \%$
$0 \%$
$0 \%$
\#DIV/0!

avena

$0 \%$
$0 \%$
$0 \%$
$0 \%$
\#DIV/0!
$0 \%$

$0 \%$
$0 \%$
$0 \%$
$0 \%$
$\#$ DIV/0!
$0 \%$

$0 \%$
$0 \%$
$0 \%$
$0 \%$
\#DIV/0!
$0 \%$

$0 \%$
$0 \%$
$0 \%$
$0 \%$
$\#$ DIV 0 !
$0 \%$

$0 \%$
$0 \%$
$0 \%$
$0 \%$
\#DIV/0!
$0 \%$

\begin{tabular}{r}
$0 \%$ \\
$0 \%$ \\
$0 \%$ \\
$0 \%$ \\
\hline$D I V / 0 !$ \\
$0 \%$
\end{tabular}

$\begin{array}{rr}0 \% & 0 \% \\ \text { \#DIV/0! } & \text { \#DIV/0! } \\ 0 \% & 0 \% \\ 0 \% & 0 \% \\ 0 \% & 0 \%\end{array}$

Fuente: "Estimaciones Agrícolas" de la SEAGyP 
Rendimiento (kilos por hectárea)

\begin{tabular}{|c|c|c|c|c|c|c|c|c|c|}
\hline Zona norte & 1956 & 1957 & 1958 & 1959 & 1960 & 1961 & 1962 & 1963 & 1964 \\
\hline centeno & $0 \%$ & $0 \%$ & $0 \%$ & $0 \%$ & $0 \%$ & $0 \%$ & $0 \%$ & $0 \%$ & $0 \%$ \\
\hline cebada cerv. & $0 \%$ & $0 \%$ & $0 \%$ & $0 \%$ & $0 \%$ & $0 \%$ & $0 \%$ & $0 \%$ & $0 \%$ \\
\hline
\end{tabular}


Rendimiento (kilos por hectárea)

Superficie sembre

\begin{tabular}{|c|c|c|c|c|c|c|c|c|c|}
\hline Zona norte & 1965 & 1966 & 1967 & 1968 & 1969 & 1970 & 1971 & 1972 & 1973 \\
\hline trigo & 2007 & 1557 & 1248 & 1155 & 1403 & 2053 & 1493 & 2102 & 1379 \\
\hline maíz & 3235 & 4236 & 2526 & 3351 & 3660 & 3551 & 2661 & 4888 & 4560 \\
\hline lino & 978 & 884 & 680 & 900 & 865 & 1397 & 1235 & 1307 & 985 \\
\hline girasol & 918 & 1163 & 1019 & 918 & 966 & 859 & 663 & 672 & 968 \\
\hline soja & & & & & 1260 & 1151 & 1280 & 1208 & 1723 \\
\hline avena & 1311 & 1337 & 1404 & 1030 & 1080 & 1368 & 1333 & 1361 & 1503 \\
\hline centeno & 1215 & 1158 & 1154 & 1183 & 1127 & 1103 & 1039 & 958 & 1023 \\
\hline cebada cerv. & 0 & 0 & 0 & 0 & 0 & 0 & 0 & 0 & 0 \\
\hline \multicolumn{10}{|l|}{ Zona oeste } \\
\hline trigo & 1028 & 906 & 1343 & 989 & 1386 & 1136 & 1188 & 1846 & 1828 \\
\hline maíz & 2050 & 1932 & 1689 & 1653 & 2521 & 1760 & 1799 & 2673 & 3840 \\
\hline lino & 349 & 288 & 526 & 553 & 400 & & & & 1069 \\
\hline girasol & 616 & 702 & 623 & 640 & 770 & 633 & 561 & 653 & 780 \\
\hline soja & & & & & & & & & 1269 \\
\hline avena & 1029 & 1006 & 1125 & 976 & 980 & 698 & 1267 & 1598 & 1633 \\
\hline centeno & 857 & 768 & 591 & 643 & 883 & 481 & 571 & 1128 & 1110 \\
\hline cebada cerv. & 1117 & 717 & 1224 & 1318 & 1189 & 917 & 1279 & 1775 & 1632 \\
\hline \multicolumn{10}{|l|}{ Zona sur } \\
\hline trigo & 1527 & 1495 & 1459 & 1039 & 1609 & 1133 & 1217 & 1823 & 1634 \\
\hline maíz & 1306 & 1404 & 1182 & 1667 & 2042 & 1708 & 1576 & 2326 & 2686 \\
\hline lino & 706 & 1138 & 829 & 511 & 1232 & 777 & 685 & 823 & 622 \\
\hline girasol & 755 & 721 & 824 & 626 & 1067 & 665 & 979 & 700 & 993 \\
\hline soja & & & & & & & & 1800 & 1427 \\
\hline avena & 1086 & 1302 & 1457 & 1244 & 1390 & 1137 & 1390 & 1549 & 1438 \\
\hline centeno & 677 & 878 & 990 & 791 & 894 & 633 & 746 & 1019 & 920 \\
\hline $\begin{array}{l}\text { cebada cerv. } \\
\text { Fuente: Estimacic }\end{array}$ & 1062 & 1273 & 1431 & 1032 & 1338 & 980 & 1182 & 1624 & 1604 \\
\hline
\end{tabular}

Fuente: "Estimaciones Agrícolas" de la SEAGyP 


\section{Rendimiento (kilos por hectárea)}

Zona norte

1965

1966

5355,62
1967

5725,79
1968
610,41

4875,31

\author{
1969 \\ 9570,26 \\ 7286,85
}

\section{0}

7034,21

5263,62

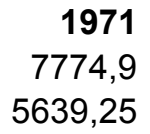

1972

11663,9

9095,76
1973

11323,76

8966,45

\section{Buenos Aires}

trigo

maíz

lino

girasol

soja

avena

centeno

cebada cerv.

$\begin{array}{rr}3124000 & 3421300 \\ 928300 & 1059200 \\ 372000 & 320300 \\ 626900 & 704300 \\ & \\ 883600 & 883200 \\ 647300 & 626000 \\ 368200 & 365800 \\ 6950300 & 7380100 \\ 5419400 & 5870900\end{array}$

5419400

\section{0 \\ 1076700 \\ 318200 \\ 634800 \\ 917800 \\ 641800 \\ 317200 \\ 7702800 \\ 6143200}

$\begin{array}{rr}3621700 & 3449000 \\ 1173700 & 1340000 \\ 392600 & 464200 \\ 788100 & 865600 \\ & 1270 \\ 980000 & 811900 \\ 695000 & 733100 \\ 337600 & 323700 \\ 7988700 & 7988770 \\ 6313700 & 6443770\end{array}$

2012600

\section{Región pampean}

\section{trigo}

maíz

lino

girasol

soja

avena

cebada cerv.

\section{0}

3340500

1290250

1110700

1090300

2071150

539010

\section{0}

3587700

919050

1292230

1114900

2213200

552480

15093710,08

11932260,08
512650

6492400

3765300

707800

1137150

1166500

6026700,11

12615300,11

\section{0 \\ 1542100 \\ 524200 \\ 899600 \\ 1400 \\ 746600 \\ 620100 \\ 314250 \\ 7485850}

6119150
3150000

1284700

234500

856700

5185

861300

743500

401840

7537725

5932925

$\begin{array}{rrrrrr}6523200 & 6105200 & 4343200 & 4850150 & 5495600 & 4134200 \\ 3872600 & 4030000 & 4315200 & 3847600 & 3684800 & 3616700 \\ 874200 & 947400 & 968450 & 534500 & 507180 & 413420 \\ 1329000 & 1456650 & 1524650 & 1482300 & 1573050 & 1378420 \\ & 10070 & 11900 & 39380 & 107185 & 284200 \\ 1266800 & 1097000 & 995050 & 1067150 & 1188100 & 1117800 \\ 2437800 & 2433650 & 1928550 & 2152650 & 2469790 & 2433700 \\ 469450 & 517200 & 406300 & 483900 & 545140 & 451400 \\ 6773050,1 & 16597170,08 & 14493300,11 & 14457630,18 & 15570845,19 & 13829840,32 \\ 3068450,1 & 13066520,08 & 11569700,11 & 11237830,18 & 11912955,19 & 10278340,32\end{array}$

Fuente: "Estimaciones Agrícolas" de la SEAGyP 
Rendimiento (kilos por hectárea)

Zona norte

1965

1966

1967

1969

1970

1971

1972

1973

Control proprcion:

\section{Zona norte}

trigo

maíz

lino

girasol

soja

avena

centeno

cebada cerv.

$\begin{array}{rr}0 \% & 0 \% \\ 0 \% & 0 \% \\ 0 \% & 0 \% \\ 0 \% & 0 \% \\ \text { \#DIV/O! } & \text { \#DIV/0! } \\ 0 \% & 0 \% \\ 0 \% & 0 \% \\ 0 \% & 0 \%\end{array}$

$0 \%$
$0 \%$
$0 \%$
$0 \%$
$\#$ DIV/0!
$0 \%$
$0 \%$
$0 \%$

$0 \%$
$0 \%$
$0 \%$
$0 \%$
$\#$ \#IV/0!
$0 \%$
$0 \%$
$0 \%$

$0 \%$
$0 \%$
$0 \%$
$0 \%$
$99 \%$
$0 \%$
$0 \%$
$0 \%$

$0 \%$
$0 \%$
$0 \%$
$0 \%$
$82 \%$
$0 \%$
$0 \%$
$0 \%$

$0 \%$
$0 \%$
$0 \%$
$0 \%$
$81 \%$
$0 \%$
$0 \%$
$0 \%$

$\begin{array}{rr}0 \% & 0 \% \\ 0 \% & 0 \% \\ 1 \% & 0 \% \\ 0 \% & 0 \% \\ 23 \% & 3 \% \\ 0 \% & 0 \% \\ 0 \% & 0 \% \\ 0 \% & 0 \%\end{array}$

Zona oeste

trigo

maíz

lino

girasol

soja

avena

centeno

cebada cerv.

$\begin{array}{rr}0 \% & 0 \% \\ 0 \% & 0 \% \\ 0 \% & 0 \% \\ 0 \% & 0 \% \\ \text { \#DIV/0! } & \text { \#DIV/0! } \\ 0 \% & 0 \% \\ 0 \% & 0 \% \\ 0 \% & 0 \%\end{array}$

$0 \%$
$0 \%$
$0 \%$
$0 \%$
\#DIV/0!
$0 \%$
$0 \%$
$0 \%$

$0 \%$
$0 \%$
$0 \%$
$0 \%$
\#DIV/0!
$0 \%$
$0 \%$
$0 \%$

$0 \%$
$0 \%$
$0 \%$
$0 \%$
$0 \%$
$0 \%$
$0 \%$
$0 \%$

$0 \%$
$0 \%$
$0 \%$
$0 \%$
$0 \%$
$0 \%$
$0 \%$
$0 \%$

$0 \%$
$0 \%$
$0 \%$
$0 \%$
$0 \%$
$0 \%$
$0 \%$
$0 \%$

$\begin{array}{ll}0 \% & 0 \% \\ 0 \% & 0 \% \\ 0 \% & 0 \% \\ 0 \% & 0 \% \\ 0 \% & 2 \% \\ 0 \% & 0 \% \\ 0 \% & 0 \% \\ 0 \% & 1 \%\end{array}$

Zona sur

trigo

maíz

lino

girasol

soja

avena

$0 \%$
$0 \%$
$0 \%$
$0 \%$
\#DIV/0!
$0 \%$

$0 \%$
$0 \%$
$0 \%$
$0 \%$
\#DIV/0!
$0 \%$

$\begin{array}{rr}0 \% & 0 \% \\ 0 \% & 0 \% \\ 0 \% & 0 \% \\ 0 \% & 0 \% \\ \text { \#DIV/0! } & \text { \#DIV } / 0 ! \\ 0 \% & 0 \%\end{array}$

$0 \%$
$0 \%$
$0 \%$
$0 \%$
$0 \%$
$0 \%$

$0 \%$
$0 \%$
$0 \%$
$0 \%$
$0 \%$
$0 \%$

$0 \%$
$0 \%$
$0 \%$
$0 \%$
$0 \%$
$0 \%$

$\begin{array}{rr}0 \% & 0 \% \\ 0 \% & 0 \% \\ 0 \% & 0 \% \\ 0 \% & 0 \% \\ 35 \% & 2 \% \\ 0 \% & 0 \%\end{array}$

Fuente: "Estimaciones Agrícolas" de la SEAGyP 
Rendimiento (kilos por hectárea)

\begin{tabular}{|c|c|c|c|c|c|c|c|c|c|}
\hline Zona norte & 1965 & 1966 & 1967 & 1968 & 1969 & 1970 & 1971 & 1972 & 1973 \\
\hline centeno & $0 \%$ & $0 \%$ & $0 \%$ & $0 \%$ & $0 \%$ & $0 \%$ & $0 \%$ & $0 \%$ & $0 \%$ \\
\hline cebada cerv. & $0 \%$ & $0 \%$ & $0 \%$ & $0 \%$ & $0 \%$ & $0 \%$ & $0 \%$ & $0 \%$ & $1 \%$ \\
\hline
\end{tabular}


Rendimiento (kilos por hectárea)

Superficie sembre

\begin{tabular}{|c|c|c|c|c|c|c|c|c|c|}
\hline Zona norte & 1974 & 1975 & 1976 & 1977 & 1978 & 1979 & 1980 & 1981 & 1982 \\
\hline trigo & 2004 & 1943 & 1679 & 1709 & 2191 & 2288 & 2471 & 2000 & 2802 \\
\hline maíz & 3262 & 2910 & 5169 & 5106 & 3901 & 3596 & 5252 & 4506 & 3831 \\
\hline lino & 1231 & 1293 & 1063 & 1150 & 1026 & 1203 & 1215 & 889 & 1020 \\
\hline girasol & 744 & 953 & 761 & 1049 & 1209 & 1226 & 1131 & 1579 & 1342 \\
\hline soja & 1256 & 1462 & 1608 & 2261 & 2088 & 2322 & 2072 & 2070 & 1447 \\
\hline avena & 1465 & 1400 & 1400 & 1364 & 1270 & 1255 & 1626 & 1334 & 1378 \\
\hline centeno & 1091 & 1200 & 1167 & & 1230 & 1279 & 1590 & 1152 & 1379 \\
\hline cebada cerv. & 0 & 0 & 0 & 0 & 0 & 0 & 0 & 0 & \\
\hline \multicolumn{10}{|l|}{ Zona oeste } \\
\hline trigo & 1690 & 1748 & 1691 & 1209 & 1850 & 1979 & 1382 & 1560 & 2260 \\
\hline maíz & 2968 & 2356 & 3451 & 4226 & 3511 & 2367 & 4379 & 3051 & 3416 \\
\hline lino & 1100 & & 1100 & 1081 & 1034 & 1010 & 1120 & 940 & 1055 \\
\hline girasol & 663 & 1006 & 840 & 1079 & 1217 & 1099 & 1190 & 1330 & 1287 \\
\hline soja & 1275 & 1202 & 1115 & 1676 & 1776 & 1226 & 1662 & 1576 & 1462 \\
\hline avena & 945 & 1383 & 1221 & 1291 & 1394 & 1442 & 1291 & 1468 & 1968 \\
\hline centeno & 866 & 1091 & 1157 & 940 & 893 & 1044 & 1060 & 1019 & 1228 \\
\hline cebada cerv. & 1237 & 1649 & 1603 & 1128 & 1669 & 1839 & 1180 & 1600 & 1828 \\
\hline \multicolumn{10}{|l|}{ Zona sur } \\
\hline trigo & 1313 & 1320 & 1760 & 1395 & 1829 & 1621 & 1686 & 1092 & 2229 \\
\hline maíz & 1787 & 2014 & 2930 & 2224 & 2332 & 1972 & 3111 & 3221 & 3335 \\
\hline lino & 870 & 764 & 1009 & 1168 & 914 & 875 & 775 & 641 & 903 \\
\hline girasol & 652 & 689 & 776 & 842 & 826 & 725 & 1073 & 1149 & 1431 \\
\hline soja & 1744 & 1405 & 900 & 870 & 748 & 647 & 1625 & 1400 & 1150 \\
\hline avena & 1343 & 1288 & 1583 & 1524 & 1551 & 1558 & 1555 & 1116 & 1723 \\
\hline centeno & 828 & 768 & 1143 & 848 & 1124 & 932 & 849 & 1042 & 1102 \\
\hline cebada cerv. & 1214 & 1075 & 1711 & 1207 & 1732 & 1441 & 1481 & 1104 & 2151 \\
\hline
\end{tabular}

Fuente: "Estimaciones Agrícolas" de la SEAGyP 


\section{Rendimiento (kilos por hectárea)}

Zona norte

1974

9752,09

7580,82
1975

9321,77

7265,47

$\begin{array}{rr}1976 & 1977 \\ 11811,96 & 10077,38 \\ 9086,67 & 7706,25\end{array}$

2470000
1334000
400000
1195000
151100
903000
512000
313000
7278100
5863100
1978

11056,19 8381,08
1979
9770,18
7279,83

1980

2155,25

9750,9
1981

10765,92

8607,77
1982

14023,88

11199,02
Buenos Aires

trigo

maíz

lino

girasol

soja

avena

centeno

cebada cerv.

$\begin{array}{rrr}2866000 & 3133000 & 3884000 \\ 1396000 & 1402500 & 1220000 \\ 234400 & 214200 & 321800 \\ 653900 & 725400 & 800000 \\ 30400 & 43500 & 52000 \\ 849400 & 899300 & 920500 \\ 647000 & 594700 & 550200 \\ 270600 & 316300 & 361000 \\ 6947700 & 7328900 & 8109500 \\ 5451300 & 5834900 & 6638800\end{array}$

3040000

1330000

306000

981000

262000

834000

513000

250000

7516000

6169000

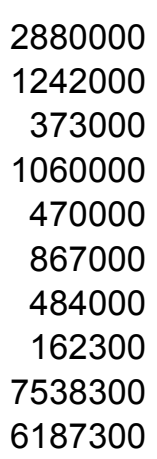

6187300

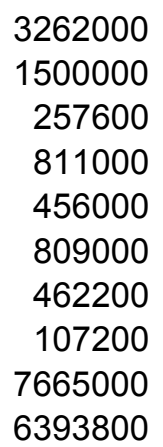

$\begin{array}{rr}3940000 & 4446000 \\ 1281500 & 1075000 \\ 288700 & 280000 \\ 1090000 & 1120000 \\ 462300 & 650000 \\ 806400 & 860000 \\ 432100 & 384500 \\ 102700 & 77000 \\ 8403700 & 8892500 \\ 7165200 & 7648000\end{array}$

Región pampeanc

$\begin{array}{lr}\text { trigo } & 5054000 \\ \text { maíz } & 3372300 \\ \text { lino } & 516030 \\ \text { girasol } & 1206700 \\ \text { soja } & 296600 \\ \text { avena } & 1161900 \\ \text { centeno } & 2293080 \\ \text { cebada cerv. } & 415200 \\ & 14315810,34 \\ & 10860830,34\end{array}$

$\begin{array}{rrrr}5580100 & 7069000 & 4480000 & 5125000 \\ 3212100 & 2553000 & 2730000 & 2917000 \\ 467450 & 717260 & 944530 & 884350 \\ 1357570 & 1521100 & 2314300 & 1902400 \\ 369800 & 600000 & 1041400 & 1439300 \\ 1300600 & 1429000 & 1436000 & 1481000 \\ 2317030 & 2201200 & 2043000 & 1618000 \\ 435050 & 465100 & 425500 & 325900\end{array}$

4908100

6081000

3480900

779100

1525450

2037950

1860850

1608300

1760100

1649950

1393000

1401500

171350

6494000

3146200

849300

1975650

1872850

1575500

1259200

137000

$15039700,3 \quad 16555660,25$

15414730,34

15692950,36

216200

6849350,31

17309700,33

12923600,34

13797900,31
7321200

2893500

906600

2074650

2191250

1818200

1398700

100900

Fuente: "Estimaciones Agrícolas" de la SEAGyP 
Rendimiento (kilos por hectárea)

Zona norte

1974

1975

1976

1980

1981

1982

Control proprciona

Zona norte
trigo
maíz
lino
girasol
soja
avena

\section{centeno}

cebada cerv.

$\begin{array}{ll}0 \% & 0 \% \\ 0 \% & 0 \% \\ 1 \% & 1 \% \\ 0 \% & 0 \% \\ 4 \% & 3 \% \\ 0 \% & 0 \% \\ 0 \% & 0 \% \\ 0 \% & 0 \%\end{array}$

$0 \%$
$0 \%$
$0 \%$
$0 \%$
$3 \%$
$0 \%$
$0 \%$
$0 \%$

$0 \%$
$0 \%$
$0 \%$
$0 \%$
$1 \%$
$0 \%$
$0 \%$
$0 \%$

$0 \%$
$0 \%$
$0 \%$
$0 \%$
$1 \%$
$0 \%$
$0 \%$
$0 \%$

$0 \%$
$0 \%$
$0 \%$
$0 \%$
$0 \%$
$0 \%$
$0 \%$
$0 \%$

$0 \%$
$0 \%$
$0 \%$
$0 \%$
$0 \%$
$0 \%$
$0 \%$
$0 \%$

$\begin{array}{ll}0 \% & 0 \% \\ 0 \% & 0 \% \\ 0 \% & 0 \% \\ 0 \% & 0 \% \\ 0 \% & 0 \% \\ 0 \% & 0 \% \\ 0 \% & 0 \% \\ 0 \% & 0 \%\end{array}$

Zona oeste

trigo

$0 \%$

$0 \%$
$0 \%$
$0 \%$
$0 \%$
$3 \%$
$0 \%$
$0 \%$
$1 \%$

$0 \%$
$0 \%$
$0 \%$
$0 \%$
$2 \%$
$0 \%$
$0 \%$
$0 \%$

\section{$0 \%$}

maíz

girasol

soja

avena

cebada cerv.

$0 \%$
$0 \%$
$0 \%$
$4 \%$
$0 \%$
$0 \%$
$0 \%$

Zona sur

trigo

maíz

lino

girasol

soja

avena

$\begin{array}{ll}0 \% & 0 \% \\ 0 \% & 0 \% \\ 0 \% & 0 \% \\ 0 \% & 0 \% \\ 6 \% & 3 \% \\ 0 \% & 0 \%\end{array}$

$\begin{array}{ll}0 \% & 0 \% \\ 0 \% & 0 \% \\ 0 \% & 0 \% \\ 0 \% & 0 \% \\ 2 \% & 1 \% \\ 0 \% & 0 \%\end{array}$

$0 \%$
$0 \%$
$0 \%$
$0 \%$
$1 \%$
$0 \%$
$0 \%$
$1 \%$

$\begin{array}{ll}0 \% & 0 \% \\ 0 \% & 0 \% \\ 0 \% & 0 \% \\ 0 \% & 0 \% \\ 0 \% & 0 \% \\ 0 \% & 0 \% \\ 0 \% & 0 \% \\ 1 \% & 1 \%\end{array}$

$\begin{array}{ll}0 \% & 0 \% \\ 0 \% & 0 \% \\ 0 \% & 0 \% \\ 0 \% & 0 \% \\ 0 \% & 0 \% \\ 0 \% & 0 \% \\ 0 \% & 0 \% \\ 2 \% & 2 \%\end{array}$

Fuente: "Estimaciones Agrícolas" de la SEAGyP 
Rendimiento (kilos por hectárea)

\begin{tabular}{|c|c|c|c|c|c|c|c|c|c|}
\hline Zona norte & 1974 & 1975 & 1976 & 1977 & 1978 & 1979 & 1980 & 1981 & 1982 \\
\hline centeno & $0 \%$ & $0 \%$ & $0 \%$ & $0 \%$ & $0 \%$ & $0 \%$ & $0 \%$ & $0 \%$ & $0 \%$ \\
\hline cebada cerv. & $0 \%$ & $0 \%$ & $0 \%$ & $0 \%$ & $1 \%$ & $1 \%$ & $1 \%$ & $1 \%$ & $3 \%$ \\
\hline
\end{tabular}




\section{Rendimiento (kilos por hectárea)}

Superficie sembre

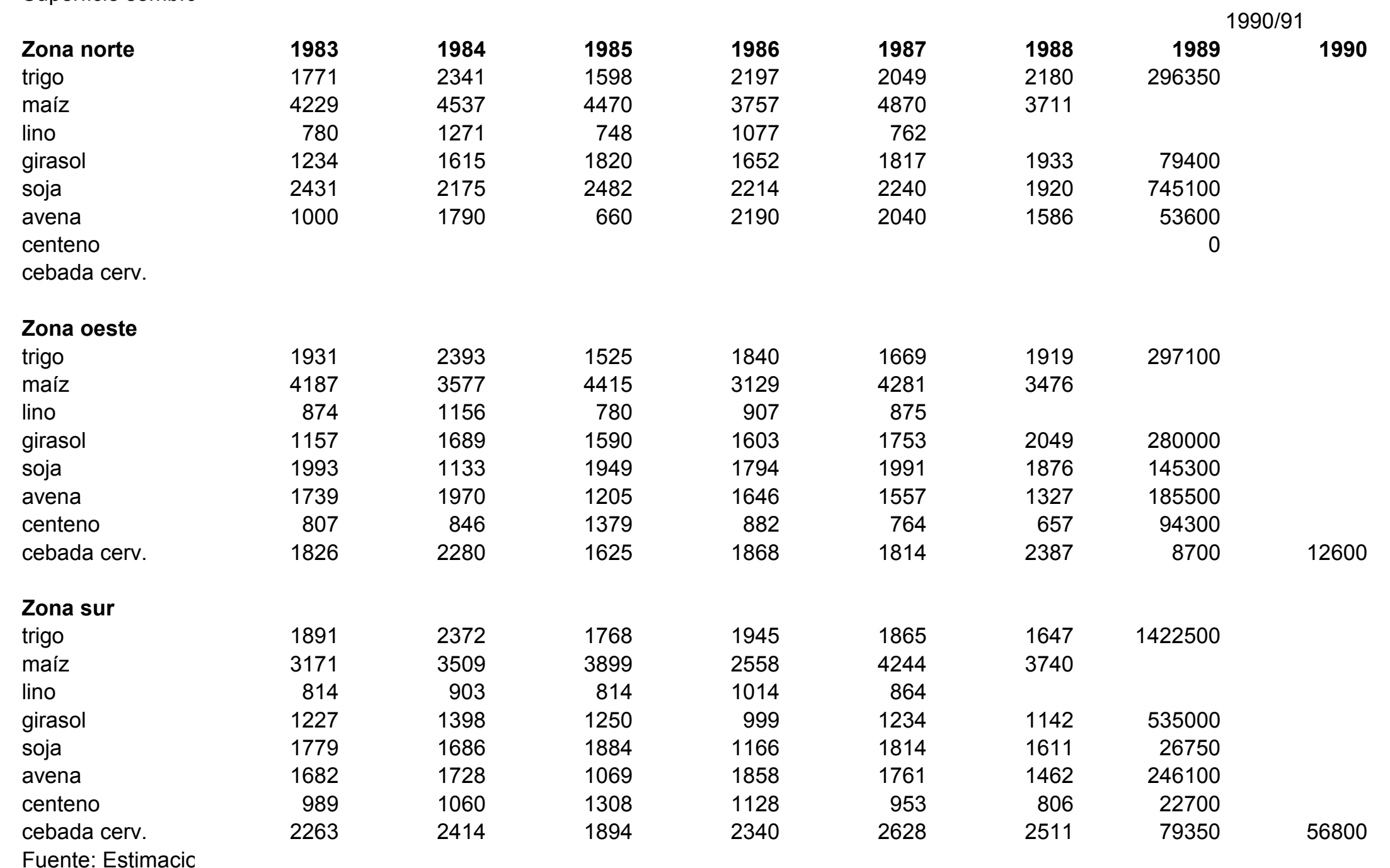

Fuente: "Estimaciones Agrícolas" de la SEAGyP 
Rendimiento (kilos por hectárea)

\begin{tabular}{|c|c|c|c|c|c|c|c|c|}
\hline \multirow{2}{*}{ Zona norte } & \multirow[b]{2}{*}{1983} & \multirow[b]{2}{*}{1984} & \multirow[b]{2}{*}{1985} & \multirow[b]{2}{*}{1986} & \multirow[b]{2}{*}{1987} & \multirow[b]{2}{*}{1988} & \multicolumn{2}{|c|}{ 1990/91 } \\
\hline & & & & & & & 1989 & 1990 \\
\hline & 13816,77 & 15070,54 & 13885,22 & 13008,3 & 15362,77 & 12919,26 & & \\
\hline & 11145,28 & 12281,96 & 11508,49 & 10021,9 & 12648,7 & 10650,8 & 2063600 & \\
\hline \multicolumn{9}{|l|}{ Buenos Aires } \\
\hline trigo & 4500000 & 3915000 & 3760000 & 3300000 & 2910000 & 2890000 & 3250000 & \\
\hline maíz & 1195000 & 1290000 & 1274000 & 1327000 & 985000 & 1075000 & & \\
\hline lino & 270000 & 167000 & 197000 & 265200 & 200000 & & & \\
\hline girasol & 1392000 & 1450000 & 1815000 & 1118200 & 1230000 & 1380000 & 1550000 & \\
\hline soja & 715000 & 830000 & 851500 & 860000 & 987000 & 1130000 & 1260000 & \\
\hline avena & 846000 & 817500 & 880000 & 836000 & 870000 & 880000 & 900000 & \\
\hline centeno & 411900 & 329800 & 263100 & 279350 & 179400 & 150200 & 170000 & \\
\hline \multirow[t]{5}{*}{ cebada cerv. } & 62000 & 76000 & 45000 & 45000 & 88000 & 105300 & 121700 & 119000 \\
\hline & 9391900 & 8875300 & 9085600 & 8030750 & 7449400 & 7610500 & & \\
\hline & 8134000 & 7728000 & 7942500 & 6915400 & 6400000 & 6580300 & & \\
\hline & & 0,11 & 0,14 & & $25 \%$ & & & \\
\hline & & & 0,23 & & & & & \\
\hline \multicolumn{9}{|c|}{ Región pampeaná } \\
\hline trigo & 7128000 & 5917100 & 5581000 & 4937800 & 4801500 & 4691000 & 5424500 & \\
\hline maíz & 2905000 & 3096000 & 3264500 & 3160000 & 2425000 & 2405000 & & \\
\hline lino & 807500 & 618600 & 748000 & 756900 & 667700 & & & \\
\hline girasol & 2400000 & 2636700 & 3480700 & 2122350 & 2369200 & 2733800 & 2587000 & \\
\hline soja & 2674500 & 3111000 & 3139100 & 3426200 & 4073400 & 4389500 & 4703000 & \\
\hline avena & 1766100 & 1741400 & 1703800 & 1495550 & 1926500 & 1798500 & 2066600 & \\
\hline centeno & 1138600 & 987400 & 743800 & 708920 & 510150 & 393200 & 541000 & \\
\hline \multirow[t]{3}{*}{ cebada cerv. } & 76900 & 87600 & 58500 & 57800 & 121600 & 147800 & 177200 & 147300 \\
\hline & 18896600,31 & 18195800,35 & 18719400,36 & 16665520,37 & 16895050,4 & 16558800,39 & & \\
\hline & 15991900,31 & 15467000,35 & 16271800,36 & 14461050,37 & 14458400,4 & 14367100,39 & & \\
\hline
\end{tabular}

Fuente: "Estimaciones Agrícolas" de la SEAGyP 
Rendimiento (kilos por hectárea)

Zona norte

1983

1984

1985

0,25

Control proprciona

\section{Zona norte}

trigo

maíz

lino

girasol

soja

avena

centeno

cebada cerv.

Zona oeste

trigo

maíz

lino

girasol

soja

avena

centeno

cebada cerv.

$0 \%$
$0 \%$
$0 \%$
$0 \%$
$0 \%$
$0 \%$
$0 \%$
$0 \%$

$0 \%$
$0 \%$
$1 \%$
$0 \%$
$0 \%$
$0 \%$
$0 \%$
$0 \%$

$0 \%$
$0 \%$
$0 \%$
$0 \%$
$0 \%$
$0 \%$
$0 \%$
$0 \%$

$0 \%$
$0 \%$
$0 \%$
$0 \%$
$0 \%$
$0 \%$
$0 \%$
$0 \%$

$0 \%$
$0 \%$
$0 \%$
$0 \%$
$0 \%$
$0 \%$
$0 \%$
$0 \%$

$0 \%$
$0 \%$
\#DIV/0!
$0 \%$
$0 \%$
$6 \%$
$0 \%$
$0 \%$

$\begin{array}{rr}9 \% & \text { \#DIV/0! } \\ \text { \#DIV/0! } & \text { \#DIV/0! } \\ \text { \#DIV/0! } & \text { \#DIV/0! } \\ 5 \% & \text { \#DIV/0! } \\ 59 \% & \text { \#DIV/0! } \\ \text { \#REF! } & \text { \#DIV/0! } \\ 0 \% & \text { \#DIV/0! } \\ 0 \% & 0 \%\end{array}$

Zona sur

trigo

maíz

lino

girasol

soja

avena

$0 \%$
$0 \%$
$1 \%$
$0 \%$
$0 \%$
$0 \%$
$0 \%$
$3 \%$

\section{$0 \%$}

$0 \%$

$0 \%$

$0 \%$

$0 \%$

$0 \%$

$1 \%$

$4 \%$

\section{$0 \%$}

$0 \%$

$0 \%$

$0 \%$

$0 \%$

$0 \%$

$0 \%$

$4 \%$

$0 \%$
$0 \%$
$0 \%$
$0 \%$
$0 \%$
$0 \%$
$0 \%$
$2 \%$

$0 \%$
$0 \%$
\#DIV/0!
$0 \%$
$0 \%$
$0 \%$
$0 \%$
$2 \%$

$\begin{array}{rr}9 \% & \text { \#DIV/0! } \\ \text { \#DIV/0! } & \text { \#DIV/0! } \\ \text { \#DIV/0! } & \text { \#DIV/0! } \\ 18 \% & \text { \#DIV/0! } \\ 12 \% & \text { \#DIV/0! } \\ 21 \% & \text { \#DIV/0! } \\ 55 \% & \text { \#DIV/0! } \\ 7 \% & 11 \%\end{array}$

$$
\begin{aligned}
& 0 \% \\
& 0 \% \\
& 1 \% \\
& 0 \% \\
& 0 \% \\
& 0 \%
\end{aligned}
$$

$0 \%$
$0 \%$
$0 \%$
$0 \%$
$0 \%$
$0 \%$

$0 \%$
$0 \%$
$0 \%$
$0 \%$
$0 \%$
$0 \%$

$0 \%$
$0 \%$
$0 \%$
$0 \%$
$0 \%$
$0 \%$

$0 \%$
$0 \%$
\#DIV/0!
$0 \%$
$0 \%$
$0 \%$

$\begin{aligned} 44 \% & \text { \#DIV/0! } \\ \text { \#DIV/0! } & \text { \#DIV/0! } \\ \text { \#DIV/0! } & \text { \#DIV/0! } \\ 35 \% & \text { \#DIV/0! } \\ 2 \% & \text { \#DIV/0! } \\ 27 \% & \text { \#DIV/0! }\end{aligned}$

Fuente: "Estimaciones Agrícolas" de la SEAGyP 
Rendimiento (kilos por hectárea)

\begin{tabular}{|c|c|c|c|c|c|c|c|c|}
\hline \multirow{2}{*}{ Zona norte } & \multirow[b]{2}{*}{1983} & \multirow[b]{2}{*}{1984} & \multirow[b]{2}{*}{1985} & \multirow[b]{2}{*}{1986} & \multirow[b]{2}{*}{1987} & \multirow[b]{2}{*}{1988} & \multicolumn{2}{|c|}{ 1990/91 } \\
\hline & & & & & & & 1989 & 1990 \\
\hline centeno & $0 \%$ & $0 \%$ & $0 \%$ & $0 \%$ & $1 \%$ & $1 \%$ & $13 \%$ & \#DIV/0! \\
\hline cebada cerv. & $4 \%$ & $3 \%$ & $4 \%$ & $5 \%$ & $3 \%$ & $2 \%$ & $65 \%$ & $48 \%$ \\
\hline
\end{tabular}




\section{Apéndice 6. Características de los entrevistados}

El símbolo (*) indica que es una de nueve entrevistas que no pudimos grabar y que se recogió en forma semi-taquigráfica.

AA*: Productor de Tres Arroyos, nacido en 1914. Su padre era propietarios unas 1.500 hectáreas, dedicadas en su mayor parte a la ganadería, por ser de no muy aptas. Cuando se independiza se desempeña como administrador de campos de la firma Sansot $(2.500$ hectáreas); campos dedicados en general al lanar y con pasturas realizadas en base a un sistema trianual. Luego hereda 450 hectáreas donde realiza agricultura contratando los servicios de chacareros de la zona.

AD*: Productor de Tres Arroyos, nacido en 1919, en Italia. En 1935 su padre arrendó unas 300 hectáreas y en 1937 agregó otras 250.. En 1945 sigue él con un hermano en el campo del padre, que se retira. En 1951 le ofrecen más campo en arriendo. En 1959 compra 340 hectáreas, y luego, vende y compra otro de 580 hectáreas. En 1977 compró otras 280 hectáreas y en 1978250 más.

AG*: Cerealista y Productor de Tres Arroyos, nacido en 1916. En sociedad con sus tíos, su padre tenían unas 6.200 hectáreas en propiedad a comienzos de los años cuarenta. En 1962 se subdivide en tres explotaciones. A él le tocan 2100 ha a las que agrega hacia 1973 unas 700 ha más, donde realiza ganadería y agricultura.

AGa: Productor de Tres Arroyos. Su padre arrendaba 1.700 ha entre 1915 y 1942, cuando compra 418 ha. Pero ya en la década del veinte, su padre había comprado 500 hectáreas, además del campo arrendado. El va a atender este último campo, siendo soltero. El padre se retira en 1960 y como hermano mayor siguió hasta 1968 en sociedad con sus hermanos. Compraron varios campos en los sesenta: agregando unas 600 hectáreas. Cuando se separaron, le tocaron 280 hectáreas, y continuó comprando hasta hacer las 780 que tenía a comienzos de los noventa, a las que agregaba otras 200 , que trabaja con su hijo.

BM: Productor de Tres Arroyos, nacido en 1906. Su padre tenía varios campos, y él se encargaba de administrar la estancia principal de 2.500 hectáreas, desde fines de los veinte. Se casa en 1930, y en 1936 su padre reparte los campos y le tocan 1.300 hectáreas, con el casco. En 1950 se muda a la ciudad de Tres Arroyos y a mediados de los sesenta forma una sociedad con su hijo y se desentiende de las cuestiones productivas.

CG: Productor de Tres Arroyos y Agrimensor, nacido en 1923. Su padre había sido acopiador de cereales, pero en los años treinta compró primero un campo de 500 hectáreas y luego lo cambió por otro de 1.100. El se dedicó a la agrimensura y la construcción desde fines de los cuarenta hasta mediados de los sesenta. Siempre vivió en la ciudad y administró el campo con un capataz y dos o tres peones.

CH: Productor de Tres Arroyos, nacido en 1924. El padre era propietario de 700 hectáreas en Olavarría, dedicado al a ganadería. En 1939 él va a Tres Arroyos a trabajar en un campo de 500 hectáreas propiedad de sus tíos, y a partir de 1946 queda como encargado del mismo. En 1948 compra 300 hectáreas (con ayuda de su padre), pero continúa con sus tíos. En 1956 se casa y se va a su campo, que ahora eran 400 hectáreas, a las que luego les va agregando otras hectáreas en arriendo, además de seguir administrando el campo de sus tíos. Para su propio campo tenía un matrimonio y un empleado permanentes, además de contratar personal temporario. En 1970 se radica en la ciudad de Tres Arroyos.

CJ: Ingeniero Agrónomo de Tres Arroyos. Dedicado siempre al trabajo experimental y de extensión. 
CP*: Productor de Tres Arroyos, nacido en 1914. Su padre hizo el ascenso de peón a mediero y luego arrendatario de unas 100 hectáreas. Para los años veinte ya arrendaba 300 hectáreas. Desde 1929, cuando su padre se retira y se dedica a la quinta, él y sus hermanos se hacen cargo del campo. En 1937 con su padre y sus hermanos compran 600 hectáreas, pero les fue muy mal con una serie de cosechas y terminaron vendiendo ese campo, y arrendándoselo a los nuevos dueños. En 1946 él logra comprar 368 hectáreas, y en los años sesenta agregó otras 184 hectáreas.

DO: Mujer de productor de Pergamino, nacida en 1947. Su padre fue un chacarero que trabajaba a porcentaje 150 hectáreas de una gran estancia. Luego compran 35 hectáreas cercanas al pueblo, donde se radican. A los 22 años se casa con un hijo de chacarero. Trabaja 50 hectáreas, y sale también de contratista de maquinaria. En 1984 se va a vivir a Pergamino, cuando la hija comienza la secundaria. Para mediados de los noventa, su marido trabaja junto con su cuñado, el hijo y un peón eventual, tienen cuatro tractores y dos cosechadoras, y alquilan unas 650 hectáreas por quintales fijos.

DP*: Productor de Tres Arroyos, nacido en 1958. Su padre en 1938 arrendaba unas 540 hectáreas. En 1952 compran 690 hectáreas, que era el campo que entonces arrendaban. En 1956 el padre se retira, y quedan en sociedad con su hermano, hasta 1966. En 1960 él se va a uno de las parcelas, de 200 hectáreas.

DS: Productor de Tres Arroyos, nacido en 1919. Su padre tenía en propiedad unas 390 hectáreas, pero falleció en 1930. Desde 1960 su madre lo hace socio, y desde 1965 se hace cargo de la parte de su madre y de sus hermanas. Desarrolló una cabaña de lanares. Al morir su madre, se queda sólo con 160 hectáreas en propiedad. Desde 1988 se lo arrienda a un vecino, y se fue a vivir a la ciudad.

EG*: Productor de Tres Arroyos, nacido en 1908. Su padre arrendaba en sociedad con sus tíos unas 875 hectáreas, donde hacían agricultura y ganadería. En 1962 compra casa en Tres Arroyos y se va a vivir allí. Siempre arrendaron el mismo campo y no compraron. En 1978 debieron dejarlo.

EH*: Productor de Tres Arroyos, nacido en 1918. Su padre había comprado en 1917365 hectáreas. Además, era administrador de 1.500 ha de un familiar (1935-39). El arrienda el campo de su padre, y 170 de su madre. Desde 1940 hasta 1975 trabaja en sociedad con sus hermanos. Desde entonces forma una nueva sociedad con sus hijos.

ER: Productor de Tres Arroyos, nacido en 1922. Su padre era propietario de 800 hectáreas. En 1939 se hacen cargo del campo en conjunto con un hermano. En 1944 se casa y el padre le deja el campo, en carácter de "empleado", junto con su hermano. Además arrendaban algunas parcelas para poner parte del ganado. En 1952 ya tenía cosechadora automotriz y se dedicaba a la cría de vacunos y de ovinos. En ese año se radica en la ciudad de Tres Arroyos y el campo queda a cargo de un capataz con tres peones. En 1972, cuando su hijo se fue a la Universidad, regresó al campo. Recién, en los noventa volvió a Tres Arroyos.

ET: Productor de Tres Arroyos, nacido en 1925. Su padre era propietario de 200 hectáreas. El, luego de trabajar algunos años como mensual, en 1947 arrienda 150 hectáreas. Trabaja junto con su hermano. En 1952 heredan 40 hectáreas. Se casa en 1960. Siempre en sociedad con su hermano se van expandiendo hasta trabajar a comienzos de los noventa, nueve campos (incluyendo las partes heredadadas por su madre y sus hermanas) totalizando unas 1.560 hectáreas. En 1975 se había trasladado a la ciudad de Tres Arroyos.

FL: Productor de Pergamino, nacido en 1933. Su padre era arrendatario de 67 hectáreas. En 1947 muere su padre y quedan cinco hermanos a cargo de la chacra. En 1953 logran 
comprar el campo. Además con dos tractores comienzan a salir a trabajar fuera. En 1963 se casa. En 1965 compran un lote vecino (otras 67 hectáreas), siempre en sociedad con sus otros tres hermanos varones. Durante los años sesenta se maquinizan, cambiando tractores y comprando una cosechadora automotriz y luego una segunda. Hasta mediados de los noventa, siguen trabajando los cuatro hermanos, sin haber contratado nunca peones. En 1977 se había radicado en la ciudad de Pergamino.

GA: Productor de Rivadavia, nacido en 1932. Su padre era arrendatario tambero, de 100 hectáreas (antes de que él naciera había arrendado sólo 25, y luego 50 hectáreas). En 1948 él comienza a trabajar de aprendiz en un escritorio de su pueblo, y dos años más tarde su padre compra el tambo, y se retira al pueblo y pone un mediero a cargo del mismo. En 1954 entra de empleado de una gran estancia, donde fue ascendiendo a cargo de más jerarquía (la entrevista no pudo continuarse, por lo cual no conocemos mucho de su actividad como productor a partir de los años setenta).

GL*: Productor de Tres Arroyos, nacido en 1918. Su padre llegó desde España hacia 1906 y luego de trabajar de peón se casa con la hija de un estanciero, y pasa a arrendar 1.700 hectáreas hasta 1942, cuando compra 418 hectáreas (antes había adquirido campos menores). En 1960, al retirarse su padre, forma una sociedad con sus hermanos y continúan comprando campos. A fines de los sesenta se disuelve la sociedad y él recibe 270 hectáreas, que luego fue ampliando con sucesivas adquisiciones hasta llegar a las 783 hectáreas que tiene en los noventa.

GN: Productor de Tres Arroyos, nacido en 1950. Su padre, residente en el Gran Buenos Aires, compró un campo de 666 hectáreas en zona baja de Tres Arroyos en 1971. Para 1974, le arrienda el campo a su propio padre y se dedica a la ganadería, y algo de agricultura. En 1978 se suma a un grupo CREA. Desde 1982 se radica en la ciudad de Tres Arroyos y viaja diariamente al campo, hasta 1990 cuando lo cede en arriendo a terceros, y se dedica a un trabajo urbano de servicios.

GR: Productor de Pergamino, nacido en 1917. Su padre era arrendatario de 40 hectáreas, que para fines de los años treinta se había expandido hasta unas 100 hectáreas. El comienza como arrendatario de unas 70 hectáreas en 1948, y para 1958 logró comprarlas. Ya unos años antes salía con su tractor a trabajarle campo a otros chacareros. Continuó realizando arada y siembra con su tractor durante los años sesenta, pero nunca tuvo cosechadora propia. En 1972 se fue a la ciudad de Pergamino y dejó el campo con un yerno.

HA*: Productor de Tres Arroyos, nacido en 1921. Su padre administraba 250 hectáreas de su propiedad y sus hermanas. En 1943 el padre heredó 31 hectáreas y fue comprando las otras partes. En 1949 compra otras 250, logrando constituir una propiedad de unas 500 hectáreas. En 1950 él se casa y se independiza: le compra al padre (que se retira a Tres Arroyos) las maquinarias y le arrienda el campo. En los noventa el campo está a cargo de su hijo.

HU: Productor de Tres Arroyos e Ingeniero Agrónomo, nacido en 1952. Su abuelo había tenido unas 900 hectáreas en propiedad, pero en 1945 las había arrendado. En 1958 su madre logra recuperar el campo y pone un encargado. El viene a Tres Arroyos en 1984, una vez recibido, y se encarga del campo que trabaja con tres peones.

IG: Propietaria de Rivadavia, nacida en 1923. Su abuelo era propietario de 2.000 hectáreas, de las que su madre hereda 500. Su padre luego agrega en arriendo unas 400 hectáreas más. Ella estudia de maestra en La Plata y luego ejerce en América. En los sesenta hereda 350 hectáreas y luego hereda otras 150. El campo estaba arrendado a un tío, pero desde 1973 lo trabaja, primero con contratistas y ahora se lo arrienda a sus hijastros. 
KA: Productor de Tres Arroyos, nacido en 1928. Su padre era un productor, propietario de 2.000 hectáreas y arrendatario de otras 4.000. El comenzó trabajando bajo las órdenes de su padre, hasta que en 1957 junto con sus otros dos hermanos se separaron trabajando unas 1.500 hectáreas en propiedad y otras 1.000 en arriendo. En 1963 se dividió la sociedad, cada uno quedó con 1.000 hectáreas en propiedad. En 1964 se radica en la ciudad y desde fines de los sesenta incursiona en otro tipo de negocios, con suerte dispar. En 1981 regresa a vivir al campo, para volver a la ciudad en los noventa.

LM: Productor de Rivadavia, nacido en 1922. Su padre trabajaba de alambrador de campos en La Pampa. En 1934 compran una pequeña quinta (7 hectáreas) en las afueras de América. De adolescente se dedica al reparto de leche, luego es camionero. En 1949 se casa y en 1951 alquila junto con un hermano un pequeño campo, donde crían unos 200 terneros. Luego compra tractores y amplía la hacienda, alquilando campos. En la década del cincuenta alquila una casa en América. En los años sesenta compra 600 hectáreas pero continúa trabajando campos como contratista de servicios (llegó a tener hasta siete campamentos simultáneamente). En 1970 compra otras 800 hectáreas. Hoy se especializa en ganadería dando su hacienda en capitalización.

LP: Veterinario de Rivadavia, nacido en 1920. Trabajaba en Buenos Aires, pero también tuvo un tambo en Rivadavia desde 1949. Luego dejó la profesión y compró campos en Córdoba, dedicándose a la ganadería. Desde 1986 reside en América.

MD: Mujer de un productor de Rivadavia, nacida en 1934. Su padre era propietario de 300 hectáreas y arrendatario de 250 más que trabajaba junto a sus hermanos y un peón. En 1953 se recibe de maestra, estudiando en La Plata, y regresa a América. En 1957 se casa y se instalan en el campo de su suegro, quien tenía unas 2.700 hectáreas. Ella se desempeñó como maestra rural hasta 1980, cuando se jubiló.

ME: Productor de Tres Arroyos, nacido en 1930. Su padre era un arrendatario que había ido progresando desde arrendar 200 hectáreas hasta tomar unas mil. Para 1938 compra 390 hectáreas, pero continúa también como arrendatario. El comienza en 1953 en sociedad con su padre (quien se retira a la ciudad). En 1962 se rematan los bienes de su padre y compra la maquinaria y 285 hectáreas. En los años sesenta hereda un campo de su mujer (170 hectáreas) y compra otras 340. Para los años sesenta trabaja unas 1.500 a 1.800 hectáreas, utilizando contratistas de servicios. En 1969 se habían mudado a la ciudad de Tres Arroyos, y en 1985 los hijos se hacen cargo de los campos (ellos se los arriendan).

ML: Productor de Pergamino, nacido en 1915. Su padre arrendaba unas 33 hectáreas, pero para fines de los años veinte logró alquilar a porcentaje 80 hectáreas. Para fines de los años treinta, su padre arrendaba unas 176 hectáreas. En 1944 se casa y compra en sociedad con su padre y su suegra, 110 hectáreas, que antes arrendaba su familia. Entre 1948 y 1953 pone un horno de ladrillos junto a sus hermanos. Durante los años sesenta, junto a su cuñado y su sobrino se mecanizan y salen a hacer entre 700 y 1.000 hectáreas por año, de arada, siembra y cosecha. En 1969 se radica en la ciudad de Pergamino.

MÑ: Productor de Tres Arroyos, nacido en 1925. Su padre que había comenzado como peón, luego se desempeñó como administrados de los campos de su tía. En 1927 había comprado 290 hectáreas. Al fallecer su padre en 1949, él queda a cargo de este campo, propiedad también de su madre y sus hermanas. En 1957, su madre se muda al pueblo. Desde fines de los cincuenta comienza un proceso de adquisición de parcelas, 200 hectáreas primero, luego otras 400 , hasta llegar a trabajar unas 4.000 hectáreas para fines de los ochenta (divididas en seis partes). En general campos en propiedad. 
MU: Mujer de un productor de Pergamino, nacida en 1929. Su padre era un arrendatario de 60 hectáreas que junto a su abuelo y su tío compraron una parcela de esa extensión en 1942. Ella se casó en 1955 y se instaló en el campo de su suegro (un arrendatario). Luego su esposo y su cuñado compraron 100 hectáreas. En 1982 se van a la ciudad de Pergamino, y ella trabaja de obrera en una fábrica textil. En 1984 fallece su esposo y su hijo queda a cargo del campo, pero viviendo en la ciudad.

OB: Productor de Rivadavia, nacido en 1933. Su padre había trabajado de peón en el campo de su cuñado, siendo luego capataz. En 1945 había comprado 230 hectáreas y sumaba en arriendo unas 1.000 hectáreas de su tía. Para 1952 vende las 230 y compra otras 600 hectáreas. Allí realizaba invernada de vacunos y algo de agricultura con contratistas. En 1960 él deja la carrera de Ingeniería y se va al campo, como arrendatario. En 1962 se hace cargo de la administración de las 600 hectáreas de su padre. Luego, compra unas 200 hectáreas linderas con un hermano. En 1986 se disuelve la sociedad con el hermano y cada uno se queda con 400 hectáreas. En ese año se radica en América.

OF: Ingeniero Agrónomo y Productor de Tres Arroyos, nacido en 1927. Durante sus estudios, trabajaba en la cosecha como asalariado. Al recibirse en 1954 le arrienda a su madre el campo que ella tenía de unas 450 hectáreas, sólo aptas para ganadería. A partir de entonces, gracias a los planes oficiales lo va equipando, ya que estaba "pelado", y vive durante ocho años en una pequeña casita en el campo. A medida que va consiguiendo trabajos como profesional, pasa varios días en un departamento alquilado en la ciudad de Tres Arroyos, donde finalmente se instala en 1962. Hasta comienzos de los años noventa, siguió dedicado a la ganadería, dejando un peón encargado del campo.

PL: Productor de Tres Arroyos, nacido en 1923. Su padre fue arrendatario de unas 300 hectáreas, entre 1927 y 1956, cuando falleció. El, junto con su hermano, compraron ese campo en 1963 y lo dividieron en dos partes iguales, compartiendo el uso de las herramientas. La señora se instaló con sus hijos en la ciudad de Tres Arroyos a comienzos de los ochenta, para que asistieran a la escuela, pero él recién fue a vivir allí en 1992. Su hijo está a cargo del campo (las 150 hectáreas originales) y asociado con un vecino salen a cosechar campos vecinos.

PLh: Hijo de PL, nacido en 1958. Actualmente le arrienda el campo a su padre (150 hectáreas) y sale a cosechar otros campos en sociedad con un vecino. Reside en la explotación, con su esposa y una hija.

PS: Productor de Tres Arroyos, nacido en 1920. Su padre era un pastor de la iglesia protestante. El comenzó en 1933 como mensual en una estancia, y luego pasó a una chacra. En 1949, luego de trabajar de camionero, se instaló como arrendatario de 430 hectáreas, asociado con dos amigos. En 1951 se separa y se queda con 120 hectáreas, sin maquinaria ni caballos propios. En ese año, además, se casa. Continúo arrendando esa parcela hasta 1978 , cuando lo echaron.

RE: Productor de Tres Arroyos, nacido en 1950. Su abuelo había comprado 1.100 hectáreas en Tres Arroyos en 1940, aunque vivía en Buenos Aires. El campo era trabajado por contratistas y un puestero. Desde 1957 fue administrado por su madre, desde Buenos Aires. En 1977, ya recibido de Ingeniero Agrónomo, se viene a Tres Arroyos y se instala en el campo. Durante tres años tuvo una agronomía en un pueblo cercano. Trabajó en sociedad con un chacarero como contratistas tanteros (llegaron a hacer 3.000 hectáreas), separándose al cabo de cinco años. Actualmente toma en arriendo unas 3.000 hectáreas, es asesor de cuatro grandes campos y reside en la ciudad de Tres Arroyos. 
RS: Productor de Pergamino, nacido en 1947. Su abuelo, residente en Buenos Aires, había comprado 1.700 hectáreas en Pergamino en los años treinta. Su padre adquirió campos en Juárez (1.400 hectáreas) y en Dolores (1.200). El campo de Pergamino estaba totalmente arrendado, y recién lograron recuperarlo en 1968. En 1971 se casa, se hace cargo del campo y se muda al casco. Trabajó siempre con contratistas de servicios. Se incorporó a un grupo CREA y desde 1984 reside en la ciudad de Pergamino. En el campo trabaja un capataz y dos peones.

RY: Productor de Tres Arroyos, nacido en 1928. Su padre había sido un arrendatario de 400 hectáreas, a las que en 1940 le agregó otras 210 hectáreas pero en propiedad. En 1955 él se casa y forma una sociedad junto a su padre (que se retira) y a un hermano. Desde entonces hasta fines de los sesenta, van tomando otros campos a porcentaje (totalizando unas 1.000 hectáreas) y compran otras 210 hectáreas. Arman dos equipos de trabajo. Para fines de los ochenta, ya separado de su hermano, tiene unas 1.300 hectáreas en propiedad, casi todo dedicado a la agricultura, que trabaja junto con su hijo.

SY: Ingeniero Agrónomo de Pergamino, nacido en 1923. Su padre había sido un pequeño productor propietario (50 hectáreas) en Junín. El se dedicó siempre a la investigación y la extensión.

UB: Productor de Tres Arroyos, nacido en 1912. Su padre había sido un gran arrendatario (que a su vez subarrendaba campos), y él, en sociedad con sus hermanos, lograron comprar unas 3.000 hectáreas en 1947, cuando se fraccionó una enorme propiedad. En sociedad llegaron a trabajar unas 14.000 hectáreas, haciendo ganadería y agricultura. Se casa en 1940 y en 1946 se instala en la ciudad de Tres Arroyos.

UN: Cerealista de Tres Arroyos, nacido en 1930. Reside en la ciudad desde 1945 y luego de trabajar de camionero y otros oficios, desde 1975 posee una pequeña casa de cereales.

VD: Productor de Tres Arroyos, nacido en 1933. Su padre era propietario de 390 hectáreas, que luego fue ampliando hasta unas 600 hectáreas. En los años cincuenta se forma una sociedad con su padre y sus otros dos hermanos varones. En 1980 disuelven la sociedad con sus hermanos. Siempre residió en el campo.

VH: Veterinario de Tres Arroyos, nacido en 1960, hijo de VP.

VP: Veterinario y Productor de Tres Arroyos, nacido en 1925. Su padre había sido arrendatario, junto con otros dos socios, de 2.000 hectáreas. En los años treinta, por problemas de salud, vendió la maquinaria, se trasladó a la ciudad y compró 200 hectáreas, cediéndolas en arriendo. En 1954 él pone una veterinaria en Tres Arroyos, al tiempo que recupera el campo y lo entrega en arriendo a porcentaje a sus vecinos. A fines de los ochenta le pasa la veterinaria a su hijo, y se instaló en el campo junto con su mujer.

VS: Productor de Tres Arroyos, nacido en 1930. Su padre había sido arrendatario, en sociedad con sus tíos, de unas 1.000 hectáreas. A mediados de los años treinta se hizo cargo de una de las estancias de su abuelo (6.000 hectáreas). En 1937 la familia se instaló en la ciudad de Tres Arroyos. A mediados de los cincuenta, su padre se separa de sus tíos, y forma una sociedad con él y sus hermanos. En 1962 hereda unas 350 hectáreas, a las que le agrega luego unas 115 hectáreas más, y algunos campos en arriendo. En 1975 se radica en la ciudad de Tres Arroyos.

ZR: Ingeniero Agrónomo de Pergamino. Llegado a la zona a comienzos de los sesenta, luego de una breve estadía en Tres Arroyos. 


\section{Fuentes y Bibliografía}

\section{Censos y Estadísticas oficiales}

\section{Argentina:}

Datos demográficos:

Primer Censo de la República Argentina, 1869

Censo General de la provincia de Buenos Aires, 1881

Segundo Censo de la República Argentina, 1895

Tercer Censo Nacional, 1914

Censo de Población de la provincia de Buenos Aires, 1938 (anulado por la Intervención Federal, datos publicado en 1942).

Cuarto Censo General de la Nación, 1947

Censo Nacional de 1960 (Población, vivienda y agropecuario)

Censo Nacional de Población, Familia y Vivienda, 1970

Censo Nacional de Población y Vivienda, 1980

Censo Nacional de Población y Vivienda, 1991

Datos agropecuarios:

Censo General de la provincia de Buenos Aires, 1881

Segundo Censo de la República Argentina, 1895

Censo Agropecuario Nacional en la República Argentina, 1908

Tercer Censo Nacional, 1914

Censo Agropecuario Nacional, 1937

Cuarto Censo General de la Nación, 1947

Censo Nacional Agropecuario, 1960 (datos editados y procesamientos especiales realizados por el CONADE en 1965).

Censo Agropecuario Nacional, 1969 (datos editados y datos originales en archivos magnéticos, INDEC).

Censo Nacional Agropecuario, 1988 (datos editado y datos originales en archivos magnéticos, Dirección Provincial de Estadística).

Censo Nacional de Población y Vivienda, 1991

"Estimaciones agrícolas" de la SEAGyP, 1938/39-1988/89.

Estados Unidos de Norteamérica:

Census of Agiculture, 1969. Illinois y Iowa.

Census of Agiculture, 1988. Illinois y Iowa.

Census of Agiculture, 1997. Illinois y Iowa. 


\section{Mapas}

Registro Gráfico de la Propiedad de la provincia de Buenos Aires, 1890.

Plano del partido de Tres Arroyos, elaborado por el agrimensor José Montano, 1919.

Mapa Catastral del partido de Pergamino, elaborado por la Dirección de Geodesia, Catastro y Mapas de la provincia de Buenos Aires, 1923.

Mapa Catastral del partido de Rivadavia, elaborado por la Dirección de Geodesia, Catastro y Mapas de la provincia de Buenos Aires, 1923.

Mapa Catastral del partido de Tres Arroyos, elaborado por la Dirección de Geodesia, Catastro y Mapas de la provincia de Buenos Aires, 1926.

Plano Catastral de la provincia de Buenos Aires, Partidos de Pergamino, Rivadavia y Tres Arroyos, 1939.

Mapa Rural del partido de Pergamino, elaborado por la empresa Mapas Rurales en 1960.

Mapa Rural del partido de Pergamino, elaborado por la empresa Mapas Rurales en 1989.

Mapa Rural del partido de Rivadavia, elaborado por la empresa Mapas Rurales en 1964.

Mapa Rural del partido de Rivadavia, elaborado por la empresa Mapas Rurales en 1988.

Mapa Rural del partido de Tres Arroyos, elaborado por la empresa Mapas Rurales en 1964.

Mapa Rural del partido de Tres Arroyos, elaborado por la empresa Mapas Rurales en 1989.

\section{Publicaciones periódicas revisadas}

Anales de la Sociedad Rural Argentina

Boletín del Museo Social Argentino

Boletín de la Chacra Experimental de "La Previsión" (en Barrows). Tres Arroyos.

Boletín del Comercio Exterior Argentino.

CREA. Revista de los CREA

Dinámica Rural

Gaceta Agronómica

El campo en marcha

La chacra y campo moderno

Memorias de la CARBAP

Mundo agrario

Mundo rural

Proyección rural 


\section{Entrevistas en profundidad}

43 entrevistas a productores rurales y 5 entrevistas a ingenieros agrónomos y veterinarios de los partidos de Pergamino, Rivadavia y Tres Arroyos, realizadas con la técnica de la historia de vida. En el Apéndice 6 se presenta una descripción sintética de la trayectoria de cada uno de los entrevistados, respetándose el carácter anónimo que se les aseguró al pautar la entrevista.

\section{Material primario editado}

(artículos, legislación, informes técnicos y tesis elaboradas durante el período estudiado)

Actis, Juan José (1989). "Evolución de los márgenes brutos de los principales cultivos: el maíz. Período 1971/72 - 1987/88", Temas de Investigación, 37. Carpeta de Economía Agrícola. E.E.A. Pergamino.

Actis, Juan José y Alicia Justo (1989). "Evolución de los márgenes brutos de los principales cultivos: la soja. Período 1971/72 - 1987/88", Temas de Investigación, 41. Carpeta de Economía Agrícola. E.E.A. Pergamino.

Arroyo, Ricardo (1963). Conducta de los productores rurales del partido de Pergamino como miembros de cooperativas agropecuarias. Informe Técnico $\mathrm{n}^{\circ} 16$. Pergamino, INTA.

Baca, Mary A de (1966). Análisis de la situación actual del estado de las familias residentes en el partido de Pergamino, Bs. As. Serie Formación Técnica, 116. Buenos Aires, INTA.

Barneda, Joaquín (1930). "Los Clubs agrícolas de niños", Boletín del Museo Social Argentino. Buenos Aires. Entrega 92, Febrero de 1930; p.p. 102-107.

Barry, Alfredo M. (1968). Leyes agrarias, Tomo I, Buenos Aires, Editorial Plus Ultra.

Basco, Mercedes Caracciolo de, y Guillermo Neiman (1979). Evaluación socio-económica de las explotaciones agropecuarias constituidas en la provincia de Buenos Aires en el período abril 1976 a diciembre 1977. Publicación ESR/119/79. Buenos Aires, SEAyG.

Baumeister, Eduardo (1980). Estructura Agraria, Ocupacional y Cambio Tecnológico en la Región Cerealera Maicera. La Figura del Contratista de Máquina. Buenos Aires, CEIL, Documento de Trabajo Nro. 10.

Billard, Juan (1957). Análisis de los aspectos económicos de las máquinas juntadoras y cosechadoras de maíz en la República Argentina. Buenos Aires, Asociación Argentina de Productores Agrícolas.

Brie, Roberto y otros (1977). Estructura social de los sectores medios rurales. Un análisis de la Región Pampeana. Buenos Aires, INTA.

Campolieti, Roberto (1929). La organización de la agricultura argentina. Ensayo de política agraria. Buenos Aires, Pedro Aquino \& Cía. 
Cámara de Diputados de la Nación (1943). Ley 12.771, Reajuste de arrendamientos agrícolas. Antecedentes y debate en el Honorable Congreso Nacional (recopilación de Antonio M. Jantus y Máximo P. Butta). Buenos Aires, Imprenta del Congreso Nacional.

Cánepa, Luis Rodolfo (1940). "Razones de una economía agraria nacional y bases para su organización". Teisi doctoral inédita. Facultad de Ciencias Económicas, Universidad de Buenos Aires.

CEPAL (1959), Comisión Económica para América Latina. Análisis y proyecciones del desarrollo económico. Vol. V: El desarrollo económico de la Argentina. Parte I: Los problemas y perspectivas del crecimiento económico argentino. México.

Cernuda, Juan Carlos (1973). "Determinación de actitudes hacia el cambio socio-económico y su relación con otros factores en grupos de productores y asalariados en una zona de Entre Ríos". Tesis de Maestría inédita. Escuela para Graduados en Ciencias Agropecuarias de la República Argentina, Castelar.

CONADE (1965), Consejo Nacional de Desarrollo. Comentarios sobre tabulados del Censo Nacional Agropecuario de 1960. Tema de Divulgación Interna n ${ }^{\circ} 31$. Buenos Aires.

CONADE (1968), Consejo Nacional de Desarrollo. Relación de precios tractor-productos agropecuarios. Segunda edición actualizada. Buenos Aires, CONADE.

Coni, Emilio (1920). ¿Arrendamiento o propiedad? Encuesta del Seminario de Economía Rural. La Plata, Facultad de Agronomía y Veterinaria, UNLP.

Coscia, Adolfo (1965). La desocupación y el éxodo en el medio rural. Estación Experimental Agropecuaria Pergamino. Informe Técnico n ${ }^{\circ} 44$.

Coscia, Adolfo (1978). La productividad de la mano de obra en el trigo. Pergamino, EERA, Informe Técnico $n^{\circ} 141$.

Coscia, Adolfo y Juan Torchelli (1968). La productividad de la mano de obra en el maíz. INTA, Estación Experimental Agropecuaria Pergamino.

Devoto, Rubén (1989). "Cambios en la superficie sembrada con los principales cultivos (1970-1985) y en las existencias ganaderas (1965-1982) del área maicera de la E.E.A. Pergamino", Temas de Investigación, 38. Carpeta de Economía Agrícola. E.E.A. Pergamino.

Egea, Andrés Rodolfo (1970). "Formulación de un modelo para determinar las variaciones de la composición de las existencias ganaderas en la zona tradicional de invernada de la República Argentina". Tesis de Maestría inédita. Escuela para Graduados en Ciencias Agropecuarias de la República Argentina, Castelar.

Elena, Nora (1973). "Algunos factores relacionados a la percepción de la situación de dependencia femenina, en esposas de asalariados y de productores de un área rural del departamento Diamante". Tesis de Maestría inédita. Escuela para Graduados en Ciencias Agropecuarias de la República Argentina, Castelar.

Felizia, Juan Carlos (1970). "Factores socio-económicos asociados con patrones de participación en la toma de decisiones familiares y su relación con la adopción de prácticas agropecuarias mejoradas". Tesis de Maestría inédita. Escuela para Graduados en Ciencias Agropecuarias de la República Argentina, Castelar.

Frank, Rodolfo (1968). "La administración eficiente de la maquinaria (3). Capacidad de trabajo y contratistas", Proyección Rural, 7. 
Frank, Rodolfo Guillermo (1970). "Evolución de la productividad del trabajo en el cultivo del trigo", en Revista de Investigaciones Agropecuarias. Serie 6, vol. IV, n 1 . Buenos Aires, INTA.

Gamundi, Juan (1990). "Rol de los plaguicidas en el enfoque ecológico del control de las plagas. Tendencias futuras". Ponencia presentada al Seminario "Juicio a nuestra agricultura. Hacia el desarrollo de una agricultura sostenible". INTA.

Garbarini Islas, "No hay razón para una reforma agraria", Boletín del Museo Social Argentino, Entrega 307, Julio-Diciembre de 1958; p.p. 5-7.

Giberti, Horacio (1965). "Evolución del precio del tractor en los últimos 30 años", Idia, Suplemento ${ }^{\circ}$ 14. Buenos Aires, INTA; p.p. 29-34.

Giberti, Horacio (1969). Economía de la producción. Separata del libro Simposio del Trigo. Buenos Aires, Academia Nacional de Agronomía y Veterinaria.

Gilles, Edgardo (1965). Influencia del régimen de tenencia sobre explotaciones rurales de la región maicera argentina. Informe Técnico $n^{\circ} 35$. Pergamino, INTA.

Gilles, Edgardo y J. A. Nocetti (1962). Organización y resultados económicos de predios rurales en un área de extensión, Pergamino, Argentina, 1960. Pergamino, INTA.

Halliburton, Horacio (dir.) (1963). Análisis económico de establecimientos agropecuarios: zona mixta Necochea y Tres Arroyos. Buenos Aires, INTA.

Ibarbía, Diego J. (1956). "Plan de Transformación Agraria". Entregado al Ministro de Agricultura y Ganadería (mimeo).

Instituto de Colonización (1937). Memoria del primer ejercicio. Año 1937. Buenos Aires, Imprenta y Casa editora "Coni".

Instituto de Colonización (1940). Memoria del ejercicio 1938-39. La Plata, Taller de Impresiones oficiales.

Instituto de Colonización (1942). Memoria del ejercicio 1940-41. La Plata, Taller de Impresiones oficiales.

INTA (1964). La productividad del suelo en la región de Pergamino en relación con factores ambientales, tecnológicos, económicos y sociales. Síntesis de coloquios celebrados en Pergamino por técnicos de la Estación Experimental, 18 de Febrero - 13 de Mayo de 1961. Informe Técnico n 23. Pergamino, EEA Pergamino, 1964.

INTA/CONICET-CEIL (1986). Hipótesis de trabajo y planteo operativo del proyecto: "Evolución de las formas de producción en el área maicera". Documento I del Proyecto. Buenos Aires, EEA Pergamino - CEIL.

INTA/CONICET-CEIL (1988). Caracterización de las unidades productivas: operacionalización de la tierra, la maquinaria y la fuerza de trabajo (Partidos de Colón y Pergamino). Documento III. Serie B, $\mathrm{n}^{\circ} 1$ del Proyecto "Evolución de las formas de producción en el área maicera". Elaborado por R. Devoto, J. Pizarro, S. Bearzotti, M.A. Cacciamani y M.I. Tort. Buenos Aires, EEA Pergamino-CEIL.

INTA-AACREA (1969). Estudio de organización y manejo de las empresas agropecuarias del área tradicional de invernada del Oeste de la provincia de Buenos Aires. Informe preliminar, base de discusión. Buenos Aires, INTA- AACREA.

Junta de Planificación Económica de la Provincia de Buenos Aires (1958). Distribución de la propiedad agraria en la provincia de Buenos Aires. Serie Estudios $n^{\circ} 2$. Separata de la Revista Desarrollo Económico, 1. La Plata. 
Kraft, Editorial (1929). Estancias y Chacras de nuestra tierra. Publicación gráfica y descriptiva de los establecimientos agrícolas de la provincia de Buenos Aires. Volúmen 1: Partido de Tres Arroyos.

Labarthe, Alberto (1973). "Estudio técnico, económico y social del área de influencia de la Agencia Cooperativa de Extensión Rural de Tornquist (Pcia. de Buenos Aires)". Tesis de Maestría inédita. Escuela para Graduados en Ciencias Agropecuarias de la República Argentina, Castelar.

Lahitte, Emilio (1912). Crédito agrícola. La cooperación rural. Buenos Aires.

Legislatura de la Provincia de Buenos Aires (1936). Instituto de Colonización de la Provincia de Buenos Aires. Leyes 4.418 y 4.566. La Plata.

Liceaga, José V. (1947). "La reforma de la ley de Colonización de la Provincia de Buenos Aires", Reseñas del Instituto Agrario Argentino, VII, n 52; p.p. 23-39.

Luparia, Carlos H. (1973). El grito de la tierra. Reforma agraria y sindicalismo. Buenos Aires, La Bastilla.

Miatello, Hugo (1904). Investigación agrícola en la provincia de Santa Fe. Buenos Aires, Compañía Sudamericana de Billetes de Banco.

Ministerio de Agricultura de la Nación (1925). Sistemas y máquinas para cosecha de trigo. Resultado de una encueta realizada por la oficina de Ingeniería Rural del MAN. Buenos Aires, Talleres gráficos del MAN.

Ministerio de Asuntos Agrarios (1958). Proyecto de Ley Reforma Agraria. La Plata, M.A.A.

Museo Social Argentino (1933). "A propósito de arrendamientos agrarios", Boletín del Museo Social Argentino. Buenos Aires. Entrega 133-134, Julio-Agosto de 1933; p.p. 161-164.

Nemirovsky, Lázaro (1933). Estructura económica y orientación política de la agricultura en la República Argentina. Buenos Aires, Jesús Menendez.

Nocetti, Juan (1963a). Costos comparativos de tres alternativas para realizar labores culturales en predios de la zona de Pergamino. Informe técnico 20. Pergamino, INTA.

Nocetti, Juan (1963b). Insumos de mano de obra en la agricultura y ganadería de Pergamino. Informe Técnico $\mathrm{n}^{\circ} 14$. Pergamino, INTA.

Nocetti, Juan (1970). "Análisis de productividad de recursos en el área tradicional de invernada, Argentina, 1970". Tesis de Maestría inédita. Escuela para Graduados en Ciencias Agropecuarias de la República Argentina, Castelar.

Oddone, Jacinto (1930). La burguesía terrateniente argentina. Buenos Aires, Libera, 1975.

Ostrowski, Bernardo (1970). "Calculo de eficiencia física y económica de maquinaria agrícola", Revista de los CREA, 25.

Parellada, Gabriel y G. Rusch (1989). Economías de escala y respuesta productiva en el tambo argentino: algunas evidencias para la formulación de políticas sectoriales. Buenos Aires, INTA.

Peretti, Miguel (1994). "Reaccionar antes de que sea tarde", en Chacra y campo moderno, junio de 1994.

Peyrou, Alejandro (1971). "La adopción del cambio tecnológico y la intensidad del uso de la tierra en el área maicera de la zona pampeana". Tesis de Maestría de la Escuela para Graduados en Ciencias Agropecuarias de la República Argentina. Castelar (inédita). 
Piñeiro, Martín (1975). Una interpretación sobre las causas del crecimiento relativo de la agricultura pampeana durante el período 1960-73. Escuela para Graduados en Ciencias Agropecuarias, Serie Investigación, ${ }^{\circ}$ 15. Buenos Aires, INTA.

Pizarro, José y Cacciamani, Miguel Angel (1979). Insumos de mano de obra en cultivos agrícolas. Información Básica n ${ }^{\circ}$ 5. Economía Agrícola. Pergamino, INTA.

Pizarro, José y Cacciamani, Miguel Angel (1981). Evaluación económica-financiera de una alternativa de inversión en maquinaria agrícola. Informe Técnico 171. Pergamino, INTA.

Pizarro, José y Cacciamani, Miguel Angel (1993a). Rentabilidad de algunos sistemas agrícolas pampeanos. Temas de Investigación, $\mathrm{n}^{\circ}$ 64. Carpeta de Economía Agrícola. Pergamino, INTA.

Pizarro, José y Cacciamani, Miguel Angel (1993b). Desarrollo de un modelo de unidad productiva para la zona agrícola pampeana argentina. Sistema agrícola. Grupo: productor propietario-contratista. Informe Técnico $n^{\circ} 272$. Pergamino, INTA.

Ramperti, Eduardo y Amigo, Alberto (1963). Ahorre cosechando y almacenando a granel.

Santamarina, Arturo (1971). "Análisis económico de los equipos de maquinaria agrícola". Revista CREA, 32.

Schaefer, Walter (1960). Análisis económico de las explotaciones agrarias. Buenos Aires, INTA.

Sociedad Rural Argentina (1953). Informe sobre la producción rural argentina. Buenos Aires, SRA.

Sociedad Rural Argentina (1991). Indicadores. Revista del Instituto de Estudios Económicos de la SRA. Abril-Junio de 1991.

Tenenbaum, Juan L. (1946). Orientación económica de la agricultura argentina. Buenos Aires, Editorial Losada.

Torchelli, Juan Carlos (1972). "El minifundio de la región maicera argentina". Tesis de Maestría de la Escuela para Graduados en Ciencias Agropecuarias de la República Argentina. Castelar (inédita).

Urien, Julio Cesar (presidente) (1933). Despacho de la comisión especial designada por decreto del Poder Ejecutivo del 5 de Abril de 1933 para estudiar el régimen de los arrendamientos agrícolas y la situación económica de la agricultura. Buenos Aires.

Valenti, Osvaldo (1965) "Aprovechamiento múltiple e integral de la cosechadora", Idia, Suplemento ${ }^{\circ}$ 14. Buenos Aires, INTA; p.p. 93-98. 


\section{Bibliografía}

Abramovay, Ricardo (1998). Paradigmas do capitalismo agrário em questao. San PabloCampinas, Editoria Hucitec - Editora da Unicamp.

Adelman, Jeremy (1989). "Frontier development: Land, Labour and Capital on the Wheatlands of Argentina and Canada, 1890-1914". Tesis doctoral, St. Antony's College, University of Oxford (inédita).

Alvarez, Norberto y Blanca Zeberio (1991). "Los inmigrantes y la tierra. Labradores europeos en la región sur de la campaña bonaerense (Argentina) a principios del siglo XX", Estudios Migratorios Latinoamericanos, 17.

Ansaldi, Waldo (1993). "La pampa es ancha y ajena. La lucha por las libertades capitalistas y la construcción de los chacareros como clase", en Marta Bonaudo y Alfredo Pucciarelli (comp.) La problemática agraria. Nuevas aproximaciones. Vol II. Buenos Aires, Centro Editor de América Latina.

Ansaldi, Waldo (1998). "¡Ojalá que llueva! Una vez más sobre la propuesta de conceptualizar a los chacareros pampeanos". Ponencia presentada en el Simposio ¿Qué era un chacarero?, XVI Jornadas de Historia Económica, Universidad Nacional de Quilmes.

Archetti, Eduardo (1985). "Introducción" a Chayanov, Alexander. La organización de la unidad económica campesina. Buenos Aires, Nueva Visión, 1985.

Archetti, Eduardo y Stölen, Kristi Anne (1975). Explotación familiar y acumulación de capital en el campo argentino. Buenos Aires, Siglo XXI.

Ascolani, Adrián y Sartelli, Eduardo (1990), "Estrategias de la lucha sindical rural (1918-1928)", presentada al Congreso Internacional de Historia Económica de América Latina. Luján, 1990; mimeo.

Azcuy Ameghino, Eduardo (1997). "Buenos Aires, Iowa, y el desarrollo agropecuario en las pampas y las praderas", Cuadernos del PIEA, 3.

Azcuy Ameghino, Eduardo (2000). "Las reformas económicas neoliberales y el sector agropecuario pampeano (1991-1999)", Ciclos, 20.

Bagú, Sergio (1949). "La clase media en la Argentina". Reeditado por la Cátedra de Sociología General de la Facultad de Humanidades y Ciencias de la Educación, UNLP, 1984.

Balsa, Javier (1993). "La conformación de la burguesía rural local en el Sur de la pampa argentina, desde finales del siglo XIX hasta la década del treinta. El partido de Tres Arroyos", en Marta Bonaudo y Alfredo Pucciarelli (comp.) La problemática agraria. Nuevas aproximaciones. Vol II. Buenos Aires, Centro Editor de América Latina.

Balsa, Javier (1994a). La crisis de 1930 en el agro pampeano. Buenos Aires, Centro Editor de América Latina.

Balsa, Javier (1994b). "La comparación intercensal para el estudio de la estructura productiva bonaerense, 1914-1937", Ruralia, 4. Buenos Aires, FLACSO.

Balsa, Javier (2001). "El estado democrático y la gobernabilidad. Sus efectos en la sociedad y la economía", en N. Girbal-Blacha (coord.). Estado, sociedad y economía en la Argentina (1930-1997). Bernal, Universidad Nacional de Quilmes Ediciones.

Barba, Fernando (1976). Los autonomistas del 70. Auge y frustración de un movimiento provinciano con vocación nacional. Buenos Aires entre 1868 y 1878. Buenos Aires, Editorial Pleamar. 
Bardomas, Silvia (1994). "Trayectorias en la agricultura familiar. Tierra, producción y herencia en Pigüé (1920-1994)". Tesis de Maestría inédita. Buenos Aires, FLACSO.

Barlett, Peggy (1986). "The "Disappearing Middle" and other myths of the changing structure of agriculture", en J. Molnar (ed.), Agricultural Change, Boulder and London, Westview Press.

Barlett, Peggy (1993). American Dreams, Rural Realities. Family Farms in Crisis. Chapel Hill and London, The University of North Carolina Press.

Barlett, Peggy (1993). American Dreams, Rural Realities. Family Farms in Crisis. Chapel Hill and London, The University of North Carolina Press.

Barsky, Andrés (1997). "La puesta en valor y producción del territorio como generadora de nuevas geografías. Propuesta metodológica de zonificación agroproductiva de la Pampa Argentina a partir de los datos del Censo Nacional Agropecuario 1988", en Osvaldo Barsky, El agro pampeano. El fin de un período. Buenos Aires, FLACSO-CBC.

Barsky, Osvaldo (1988). "La caída de la producción agrícola en la década de 1940", en Barsky et al. La Agricultura Pampeana. Transformaciones productivas y sociales. Buenos Aires, CFE-IICA-CISEA.

Barsky, Osvaldo (1992). "Explotaciones familiares en el agro pampeano: procesos, interpretaciones y políticas", en Barsky, Osvaldo (comp). Explotaciones familiares en el agro pampeano. Buenos Aires, CEAL.

Barsky, Osvaldo (1993). "La evolución de las políticas agrarias en Argentina", en Marta Bonaudo y Alfredo Pucciarelli (comp.) La problemática agraria. Nuevas aproximaciones. Vol III. Buenos Aires, Centro Editor de América Latina.

Barsky, Osvaldo (1997). "La información estadística y las visiones sobre la estructura agraria pampeana", en O. Barsky y A. Pucciarelli, El agro pampeano. El fin de un período. Buenos Aires, FLACSO-UBA.

Barsky, Osvaldo y otros (1992). EI pensamiento agrario argentino. Buenos Aires, CEAL.

Barsky, Osvaldo y Pucciarelli, Alfredo (1991). "Cambios en el tamaño y el régimen de tenencia de las explotaciones agropecuarias pampeanas", en Barsky (editor). El desarrollo agropecuario pampeano. Buenos Aires, INDEC-INTA-IICA.

Barsky, Osvaldo; Ciafardini, Horacio; y Cristiá, Carlos Alberto (1971). "Producción y tecnología en la región pampeana", en Historia Integral Argentina. Vol.6, La clase media en el poder. Buenos Aires, Centro Editor de América Latina; p.p. 113-140.

Barsky, Osvaldo y Jorge Gelman (2001). Historia del agro argentino. Desde la Conquista hasta fines del siglo XX. Buenos Aires, Grijalbo-Mondadori.

Barton, Allen (1973). "Concepto de espacio de atributos en sociología", en R. Boudon y P. Lazarsfeld, Metodología de las ciencias sociales. I. Conceptos e índices. Barcelona, Laia.

Basco, Mercedes C. de y otros (1981). Esquema conceptual y metodología para el estudio de tipos de establecimientos agropecuarios, con énfasis en el minifundio. Buenos Aires, Grupo de Sociología Rural, Secretaría de Agricultura y Ganadería de la Nación.

Bastide, Roger (1961). Sociología y psicoanálisis. Buenos Aires, Compañía General Fabril Editora.

Basualdo, Eduardo M. (1995). "El nuevo poder terrateniente: una respuesta", en Realidad Económica, 132; p. 126-149. 
Basualdo, Eduardo (1998). "Características e incidencia de los terratenientes bonaerenses", Informe de Coyuntura, 36, CEB, La Plata.

Basualdo, Eduardo M. y Khavisse, Miguel (1993). El nuevo poder terrateniente. Investigación sobre los nuevos y viejos propietarios de tierras de la provincia de Buenos Aires. Buenos Aires, Planeta.

Benedict, Murray (1953). Farm policies of the United States, 1790-1950. A stdy of their origins and development. New York, The Twentieth Century Fund.

Benítez Martínez, Marcela (1998). "La Argentina que desaparece. Desintegración de comunidades rurales y poblados en vías de desaparición". Tesis doctoral inédita, Universidad de Belgrano, Buenos Aires.

Bennett, John W. (1980). "Management Style: A Concept and a Method for the Analysis of Family-Operated Agricultural Enterprise", en A.A.V.V. Agricultural Decision Making. Anthropological Contributions to Rural Development. Academic Press.

Berger, Peter y Thomas Luckmann (1968). La construcción social de la realidad. Buenos Aires, Amorrortu.

Bertaux, Daniel e Isabelle Bertaux-Wiame (1993). "Historias de vida del oficio de panadero", en J.M. Marinas y C. Santamarina (ed.), La historia oral: métodos y experiencias. Madrid, Debate.

Blanco, Mónica (1994). "El funcionamiento del sistema de arrendamientos rurales entre 1940-60. Una aproximación regional comparativa", Res Gesta, 33, Facultad de Derecho y Ciencias Sociales, UCA; p.p. 83-115.

Blanco, Mónica (2001). "Planificación estatal, política agraria y tenencia de la tierra en la provincia de Buenos Aires (1940-60). Una aproximación regional". Tesis doctoral inédita. Facultad de Humanidades y Ciencias de la Educación, Universidad Nacional de La Plata.

Bocco, Arnaldo M. (1991). "El empleo asalariado", en Osvaldo Barsky (editor). El desarrollo agropecuario pampeano. Buenos Aires, INDEC-INTA-IICA; p. 493-564.

Boglich, José (1937). La cuestión agraria. Buenos Aires, Editorial Claridad.

Bonaudo, Marta y Cristina Godoy (1985). "Una corporación y su inserción en el proyecto agroexportador: la Federación Agaria Argentina (1912-1933), Anuario, 11 (segunda época), Escuela de Historia, UNR, Rosario; p.p. 151-216.

Bonaudo, Marta y Elida Sonzogni (1998). "La constitución histórica de un actor: el chacarero de la pampa santafesina, 1850-1912". Ponencia presentada en el Simposio ¿Qué era un chacarero?, XVI Jornadas de Historia Económica, Universidad Nacional de Quilmes.

Borges, Jorge Luis (1955). "Notas, sobre Adolfo Bioy Casares, El sueño de los héroes", Sur, 235. Julio y Agosto de 1955; p.p. 88-89.

Bourdieu, Pierre (1979). La distinction, Critique sociale du jugement. París, Les Éditions de Minuit.

Bourdieu, Pierre, J.C. Chamboredon y J.C. Passeron (1975). El oficio de sociologo. Presupuestos epistemológicos. Buenos Aires, Siglo XXI.

Braun, Oscar y Joy, Leonard (1981). "Un modelo de estancamiento económico. Estudio de caso sobre la economía argentina", Desarrollo Económico, vol. 20, nº 80.

Brewster, David (1979). "Historical Notes On Agricultural Structure", en U.S. Department of Agriculture. Structure Issues of American Agriculture. Agricultural Economic Report 438. Washington DC. 
Burton, Boyd y H. Jensen (1968). Economies of Size in Minnesota Dairy Farming. Agricultural Experiment Station-University of Minnesota. Station Bulletin 488.

Buttel, F. y H. Newby (1980), eds. The Rural Sociology of the Advanced Societies. Allanheld Osmun.

Byres, Terence (1996). Capitalism from Above and Capitalism from Below. An Essay in Comparative Political Economy. Londres, Macmillan Press.

Cammarata, Emilce, A. Iglesias y V. Giagante (1975). "La configuarción espacial", en E. Chiozza (coord.), El país de los argentinos: Las pampas. Buenos Aires, CEAL.

Capstick, Margaret (1977). La economía de la agricultura. México, FCE.

Carballo, Carlos (2001). "Nueva institucionalidad para el desarrollo rural en Argentina", ponencia presentada a las Segundas Jornadas Interdisciplinarias de estudios agrarios y agroindustriales. Buenos Aires, PIEA, CD-ROM.

Carlón, Mario (1991). "Placer y goce en los retratos del hombre de campo argentino", en Ciudad / Campo en las Artes en Argentina y Latinoamérica. Terceras Jornadas de Teoría e Historia de las Artes. Buenos Aires, CAIA.

Cascardo, Antonio y otros (1991). "Sistemas de producción predominantes", en Barsky (editor). El desarrollo agropecuario pampeano. Buenos Aires, INDEC-INTA-IICA.

CEPA, Centro de Estudios y Promoción Agraria (1990). "Transformaciones sociales en el agro pampeano, 1970-1985", Realidad Económica, n 92/93, 1er. y 2do. bimestre de 1990.

Chayanov, Alexander (1924). La organización de la unidad económica campesina. Buenos Aires, Nueva Visión, 1985.

CIDA, Comité Interamericano de Desarrollo Agrícola (1965). Tenencia de la tierra y desarollo socioeconómico del sector agrícola. Argentina. Washington, Ed. Unión Panamericana, OEA.

Cirio, Felix (1984). Evolución reciente y perspectivas de crecimiento de la agricultura en la región pampeana. Buenos Aires, CISEA, Documento $n^{\circ} 6$.

Cirio, Felix (1988). "Situación del sector ante la crisis", en Barsky et al. La Agricultura Pampeana. Transformaciones productivas y sociales. Buenos Aires, CFE-IICA-CISEA.

Cloquell, Silvia y Rubén Devoto (1992). "El arrendamiento en la región pampeana", en Osvaldo Barsky y otros. Explotaciones familiares en el agro pampeano. Buenos Aires, CEAL; vol. 2, p. 7-40.

Consejo Agrario Nacional (1977). La colonización nacional en la República Argentina. Buenos Aires, Secretaría de Estado de Agricultura y Ganadería.

Cortés Conde, Roberto (1979). El progreso argentino. 1880-1914. Buenos Aires, Editorial Sudamericana.

Coscia, Adolfo (1983). Segunda revolución agrícola en la región pampeana. Buenos Aires, Editorial Cadia.

Dean, Virgil (1996). "Why Not the Brannan Plan?", Agricultural History, vol. 70, 2.

de Imaz, José Luis (1965). Estructura social de una ciudad pampeana. Cuaderno de Sociología 1-2. La Plata, Universidad Nacional de La Plata, Facultad de Humanidades y Ciencias de la Educación.

Della Valle, Carlos y Vicien, Carmen (1995). Los contratistas rurales: un sector dinámico. Buenos Aires, Secretaría de Agricultura, Ganadería y Pesca, Documentos de trabajo, $\mathrm{n}^{\circ}$ 2. 
Díaz Alejandro, Carlos (1983). Ensayos sobre la historia económica argentina. Buenos Aires, Amorrortu editores.

Djurfeldt, Göran (1996). "Defining and Operationalizing Family Farming from a Sociological Perspective", Sociologia Ruralis, vol. 36, no. 3.

Domínguez Martín, Rafael (1993). "Caracterizando al campesinado y a la economía campesina: pluriactividad y dependencia del mercado como nuevos atributos de la 'campesinidad'", Agricultura y Sociedad, 66. Enero-Marzo de 1993; p.p. 97-136.

Douglas, Mary y Isherwood, Baron (1990). El mundo de los bienes. Hacia una antropología del consumo. México, Grijalbo.

Egusquiza, Elena (1988). Juan Alberto Harriet. Pionero de la Pampa. Buenos Aires, Ediciones Tres Tiempos.

Eirás, Cármen y M.E. Pérez Vassolo (1981). Historia del partido de Tres Arroyos. Desde sus orígenes hasta 1910. Tres Arroyos, Municipalidad de Tres Arroyos.

Elías, Norbert (1998). "La civilización de los padres", en N. Elías, La civilización de los padres y otros ensayos. Bogotá, Editorial Universidad Nacional - Norma.

Elster, Jon (1994). "Los contrafácticos y la nueva historia económica", en J. Elster, Lógica y sociedad. Contradicciones y mundos posibles. Barcelona, Gedisa.

Engels, Friedrich (1892). "Prólogo" a La situación de la clase obrera en Inglaterra".

Errington, Andrew (1996). “A Comment on Djurfeldt's Definition of Family Farming", Sociologia Ruralis, vol. 36, no. 3.

Errington, Andrew y Ruth Gasson (1994). "Labour use in the farm family business", Sociologia Ruralis, XXXIV-4.

Ferrer, Aldo (1963). La economía argentina. Las etapas de su desarrollo y problemas actuales. Buenos Aires, Fondo de Cultura Económica.

Fiorentino, Raúl (1984). La política agraria para la región pampeana en las últimas décadas. Buenos Aires, CISEA (Doc. $\mathrm{N}^{\circ} 5$ ).

Fiorentino, Raúl (1998). "Aspectos económicos de la producción agropecuaria pampeana", en O. Solbrig y L. Vainesman (comp.), Hacia una agricultura productiva y sostenible en la pampa. Buenos Aires, Harvard University y CPIA.

Flichman, Guillermo (1971). "Modelo sobre la asignación de recursos en el sector agropecuario", en Desarrollo Económico. Nro.39-40. Buenos Aires, IDES.

Flichman, Guillermo (1977). La renta del suelo y el desarrollo agrario argentino. México, Siglo XXI.

Flichman, Guillermo (1978). Notas sobre el desarrollo agropecuario en la región pampeana argentina (o por qué Pergamino no es Iowa). Buenos Aires, CEDES.

Flichman, Guillermo y Daniel Deybe (1988). Alternativas tecnológicas y política agropecuaria. La producción de granos en la región pampeana. IICA.

Fogarty, John y otros (1979). Argentina y Australia. Buenos Aires, Instituto Torcuato Di Tella.

Forni, Floreal y Tort, María Isabel (1984). Las explotaciones familiares en la producción de cereales de la región pampeana argentina. Buenos Aires, CEIL.

Forni, Floreal y María Isabel Tort (1991). De chacareros a "farmers contratistas". Serie Documentos de Trabajo ${ }^{\circ} 25$. Buenos Aires, CEIL. 
Forni, Floreal y Tort, María I. (1992). "Las transformaciones de la explotación familiar en la producción de cereales de la región pampeana", en Jorrat, Jorge y Sautu, Ruth (comp.). Después de Germani. Exploraciones sobre estructura social de la Argentina. Buenos Aires, Paidós.

Frenkel, Roberto (1989). Decisiones de precio en alta inflación. Buenos Aires, CEDES.

Friedberger, Mark (1988). Farm Families \& Change in $\mathbf{2 0}^{\text {th }}$-Century America. Lexington, The University Press of Kentucky.

Friedmann, Harriet (1978a). "Simple Commodity Production and Wage Labour in the American Plains", The Journal of Peasant Studies, Vol. 6 (1).

Friedmann, Harriet (1978b). "World Market, State, and Family Farm: Social Bases of Household Production in the Era of Wage Labor", en Comparative Studies in Society and History, Vol. 20, No. 4, Oct. 1978; p.p. 545-586.

Friedmann, Harriet (1980). "Household Production and the National Economy: Concepts for the Analysis of Agrarian Formations", Journal of Peasant Studies, 7 (2); p.p. 158-184.

Friedmann, Harriet (1986a). "Patriarchy and Property. A reply to Goodman and Redclift", Sociologia Ruralis, Wol XXVI-2; p.p. 186-193.

Friedmann, Harriet (1986b). "Patriarchal Commodity Production", Social Analysis, 20. Special Issue: "Rethinking Petty Commodity Production" (edited by Alison MacEwen Scott). Diciembre de 1986; p.p. 47-55.

Friedmann, Harriet (1993). "The Political Economy of Food: a Global Crisis", New Left Review, 197; p. 29-57.

Frigerio, Reinaldo (1953). Introducción al estudio del Problema Agrario Argentino. Buenos Aires, Ediciones Clase Obrera.

Fromm, Erich (1932a). "Método y función de una psicología social analítica", en E. Fromm, La crisis del psicoanálisis. Barcelona, Paidós, 1993.

Fromm, Erich (1932b). "La caracterología psicoanalítica y su pertinencia para la psicología social", en E. Fromm, La crisis del psicoanálisis. Barcelona, Paidós, 1993.

Fromm, Erich (1953). Etica y psicoanálisis. México, FCE.

Fromm, Erich (1956). Psicoanálisis de la sociedad contemporánea. Hacia una sociedad sana. México, FCE.

Fromm, Erich y Maccoby, Michael (1970). Sociopsicoanálisis del campesino mexicano. México, Fondo de Cultura Económica, 1992.

Gaignard, Romain (1989). La pampa argentina. Ocupación-Poblamiento-Explotación. De la Conquista a la Crisis Mundial (1550-1930). Buenos Aires, Ediciones Solar.

Galeski, Boguslaw (1977). Sociología del campesinado. Barcelona, Península.

Gallo, Ezequiel (1983). La pampa gringa. La colonización agrícola en Santa Fe (1870-1895). Buenos Aires, Sudamericana.

Gerardi, Alejandro (2001). Ingresos, niveles de pobreza y gasto de los hogares rurales de Mendoza, Río Negro y Santa Fe. Buenos Aires, PROINDER.

Ghersa, Claudio, María Martínez-Gherza y Rolando León (1998). "Cambios en el paisaje pampeano y sus efectos sobre los sistemas de soporte de la vida", en Otto Solbrig y Laura Vainesman (comp.), Hacia una agricultura productiva y sostenible en la pampa. Buenos Aires, Harvard University y Consejo Profesional de Ingeniería Agronómica. 
Ghorayshi, Parvin (1986). "The identification of capitalist farms. Theoretical and methodological considerations", Sociologia Ruralis, Vol. XXVI-2.

Giberti, Horacio (1964). El desarrollo agrario argentino. Estudio de la región pampeana. Buenos Aires, EUDEBA.

Giberti, Horacio (1981). Historia económica de la ganadería argentina. Nueva edición, actualizada y corregida. Buenos Aires, Ediciones Solar.

Giberti, Horacio (1988). "Evolución y perspectivas del sector agropecuario argentino", en Congreso Internacional de Economistas Agrarios, XX. La Economía Agraria Argentina. Consideraciones sobre su evolución actual. Buenos Aires, Asociación Argentina de Economía Agraria.

Giberti, Horacio (1994). "El crédito y la situación agropecuaria", Realidad Económica, 123. Buenos Aires, abril-mayo de 1994; p.p. 79-83.

Giberti, Horacio (1998). "Una estructura agraria chacarera: el partido de Pergamino (Buenos Aires) en 1937". Ponencia publicada en las Actas de las XVI Jornadas de Historia Económica. Quilmes, septiembre de 1998.

Giberti, Horacio (2001). "Unidades ganaderas y carga ganadera". Ponencia enviada a las VIII Jornadas InterEscuelas/Departamentos de Historia. Salta, mimeo.

Giberti, Horacio (2002). "CONINAGRO y la última dictadura militar", Revista Interdisciplinaria de Estudios Agrarios, 17. Buenos Aires, $2^{\circ}$ semestre del 2002; p.p. 129-137.

Girbal-Blacha, Noemí (1980). Los centros agrícolas en la provincia de Buenos Aires, Buenos Aires, Fundación para la Educación, la Ciencia y la Cultura.

Girbal-Blacha, Noemí (1992). "Reforma financiera y crédito a la producción: el caso del Banco de la Provincia de Buenos Aires, 1946-1950", en Ciclos en la historia, la economía y la sociedad, 3, p. 73-93.

Girbal-Blacha, Noemí (1988). Estado, chacareros y terratenientes. (1916-1930). Buenos Aires, Centro Editor de América Latina.

Girbal-Blacha, Noemí (1989). Política de tierras (1916-1930). ¿Reforma, orden o "reparación agraria"?. Buenos Aires, Centro Editor de América Latina.

Girbal-Blacha, Noemí (1990). "Tradición y modernización en la agricultura cerealera argentina, 1910-1930. Comportamiento y propuestas de los ingenieros agrónomos", Jahrbuch fur Geschicte von Staat, Wirtschaft und Gesellschaft Lateinamerikas, 1992

Girbal-Blacha, Noemí (1993). Historia del Banco de la Provincia de Buenos Aires. Gestión del Doctor Arturo Jauretche. Buenos Aires, Ediciones del Banco de la Provincia de Buenos Aires.

Girbal-Blacha, Noemí (1997). "La provincialización estatal del Banco y su ingreso al régimen nacional", en Alberto de Paula y Noemí Girbal-Blacha (dir.), Historia del Banco de la Provincia de Buenos Aires, 1822-1992, Buenos Aires, BPBA.

Gladwin, Christina (1989). "The case for the disappearing mid-size farm in the U.S." en Food and Farm. Current Debates and Policies. Monographs in Economic Anthropology, No. 7 (Christina Gladwin y Kathleen Truman, ed. Lanham), University Press of America.

Glaser, Barney y A. Strauss. The discovery of Grounded Theory. Strategies for Qualitative Research. New York, Aldine, 1967; cap. III: "El muestreo teórico" (Trad.).

Gómez, Pedro y otros (1991). "Delimitación y caracterización de la región", en Barsky (editor). El desarrollo agropecuario pampeano. Buenos Aires, INDEC-INTA-IICA. 
González, María del Cármen y otros (1999), "Heterogeneidad de las formas empresariales agrarias pampeanas. El caso del partido de Azul", Realidad Económica, 160/161.

Gorenstein, Silvia y Graciela Peri (1991). "Cambios tecnológicos y productivos en la agricultura pampeana. Algunas repercusiones en nivel intrarregional", Realidad económica, 103, octubre-noviembre de 1991; p. 114-133.

Gori, Gastón (1987). El pan de los argentinos. Panorama social de las regiones cerealistas argentinas. Segunda edición corregida (la primera se denominaba "El pan nuestro"). Santa Fe, Ediciones Lux.

Gutiérrez, Talía (1998). "La enseñanza agrícola y la política agraria peronista, 1943-1955", en Noemí Girbal-Blacha (comp.), Agro, universidad y enseñanza. Dos momentos de la Argentina rural (1910-1955). La Plata, Editorial de la UNLP.

Halperín Donghi, Tulio (1982). Una nación para el desierto argentino. Buenos Aires, CEAL

Halperín Donghi, Tulio (1984). "Canción de otoño en primavera: previsiones sobre la crisis de la agricultura cerealera argentina (1894-1930)", Desarrollo Económico, No. 95.

Harispuru, Adela (1986). "Familia y gran propiedad rural en la Provincia de Buenos Aires". Universidad Nacional de La Plata, Facultad de Humanidades y Ciencias de la Educación. Tesis doctoral (inédita).

Hora, Roy (2002). Los terratenientes de la pampa argentina. Una historia social y política, 1860-1945. Buenos Aires, Siglo XXI.

Hourcade, Eduardo (1999). "La pampa gringa, invención de una sociabilidad europea en el desierto", en F. Devoto y M. Madero (dir.), Historia de la vida privada en la Argentina, Tomo II: La Argentina plural: 1870-1930, Buenos Aires, Taurus.

Katona, George (1979a). Psicología de la economía. Buenos Aires, El Ateneo.

Katona, George (1979b). “Teoría de las expectativas”, en B. Strumpel, J. Morgan y E. Zahn, La conducta humana en las relaciones económicas. México, De. Trillas.

Kautsky, Karl (1899). La cuestión agraria. México, Siglo XXI, 1983.

Korol, Juan Carlos e Hilda Sábato (1981). Cómo fue la inmigración irlandesa en Argentina. Buenos Aires, Plus Ultra.

Lattes, Alfredo E. (1978). La dinámica de la población rural en la Argentina entre 1870 y 1970. Buenos Aires, Cuaderno del CENEP, $n^{\circ} 9$.

Lattuada, Mario (1986). La política agraria peronista, (1943-1983). Buenos Aires, CEAL.

Lattuada, Mario (1994). "Una lectura sobre el Nuevo Poder Terrateniente y su significado en la Argentina actual", (mimeo).

Lattuada, Mario (1996). "Un nuevo escenario de acumulación. Subordinación, concentración y heterogeneidad", Realidad Económica, 139.

Lattuada, Mario (2002). "La política agraria radical en el marco de la transición democrática argentina (1983-1989)". Ponencia editada en las Actas del XIII Economic History Congress. Buenos Aires, Julio de 2002.

Lázzaro, Silvia (1991). "El impuesto al latifundio en la provincia de Buenos Aires durante la década de 1940. Primeras iniciativas", Estudios de Historia Rural, I, UNLP, La Plata; p.p. 39-79.

Lázzaro, Silvia (1993). "Política de arrendamientos rurales entre 1948 y 1957", ponencia presentada en las 4as. Jornadas Interescuelas/Departamentos de Historia, Mar del Plata, Octubre de 1993. 
Lázzaro, Silvia (1996). "Demandas sectoriales y políticas públicas agrarias: los arrendamientos rurales durante la década de 1950". Ponencia presentada en las XV Jornadas de Historia Económica, Tandil (mimeo).

Lázzaro, Silvia (1997). “¿Reforma o contrareforma? Condicionantes, retórica y diseños en el agro pampeano". Ponencia presentada en las VI Jornadas Interescuelas Departamentos de Historia, Santa Rosa (mimeo).

Lenin, V.I. (1899). El desarrollo del capitalismo en Rusia. Obras Completas, Tomo III. Buenos Aires, Cartago, 1969.

Lenin, V.I. (1916). El imperialismo, etapa superior del capitalismo. Buenos Aires, Editorial Anteo, 1974.

Lenin, V.I. (1917). "Nuevos datos sobre las leyes de desarrollo del capitalismo en la agricultura. El capitalismo y la agricultura en Estados Unidos de Norteamérica", en Obras Completas. Tomo XXII. Buenos Aires, Cartago, 1960; p.p. 9-108.

León, Carlos (1991). "El sector agropecuario durante la década de los '80: de la euforia productivista a la crisis de improvisación", Realidad Económica, 99, 2do. bimestre de 1991; p. 137-144.

Llovet, Ignacio (1988). "Tenencia de la tierra y estructura social en la provincia de Buenos Aires. 1960-1980" en Barsky y otros La Agricultura Pampeana. Transformaciones productivas y sociales. Buenos Aires, CFE-IICA-CISEA.

Llovet, Ignacio (1991). "Contratismo y Agricultura" en Barsky (editor). El desarrollo agropecuario pampeano. Buenos Aires, INDEC-INTA-IICA.

Llovet, Ignacio (1992). "Clasificación socioeconómica de explotaciones agropecuarias de la región pampeana", en Cesar E. Peón (compilador). Sociología rural latinoamericana. Buenos Aires, CEAL, 1992; p. 192-223.

Llovet, Ignacio y María I. Tort (1990). "Modernización de la agricultura, tenencia de la tierra y conservación del suelo: algunas reflexiones sobre la problemática del contratismo", en Seminario Juicio a nuestra agricultura. Hacia el desarrollo de una agricultura sostenible. Buenos Aires, INTA, 1990.

Madden, Patrick (1967). Economies of Size in Farming. U.S. Department of Agriculture, Agricultural Economic Report.

Malosetti Costa, Laura y Marta Penhos (1991). "Imágenes para el desierto argentino. Apuntes para una iconografía de la pampa", en Ciudad / Campo en las Artes en Argentina y Latinoamérica. Terceras Jornadas de Teoría e Historia de las Artes. Buenos Aires, CAIA.

Manchado, Juan Carlos (1988). "Estimación de economías de escala y eficiencia técnica en la zona mixta cerealera" (mimeo).

Mann, Susan y J. Dickinson (1978). "Obstacles to the Development of a Capitalist Agriculture", Journal of Peasant Studies, vol. 5 (4).

Mann, Susan y J. Dickinson (1980). "State and Agriculture in Two Eras of American Capitalism", en F. Buttel y H. Newby (ed.), The Rural Sociology of the Advanced Societies. Allanheld Osmun.

Mann, Susan y J. Dickinson (1987a). "One Furrow Forward, Two Furrows Back: A MarxWeber Synthesis for Rural Sociology?", Rural Sociology, 52(2).

Mann, Susan y J. Dickinson (1987b). "Collectivizing Our Thoughts: A Reply to Patrick Mooney", Rural Sociology, 52(2). 
Mansfield, Edwin. Microeconomía. Teoría y aplicaciones. Buenos Aires, Ed. Tesis, 1987; cap. 17: "Las elecciones intertemporales y el cambio tecnológico".

Manzanal, Mabel (2001). "Políticas, instituciones y gestión del desarrollo rural en Argentina de fin de siglo", ponencia presentada a las Segundas Jornadas Interdisciplinarias de estudios agrarios y agroindustriales. Buenos Aires, PIEA, CD-ROM.

Margulis, Mario (1979). Contradicciones en la estructura agraria y transferencias de valor. México, El Colegio de México.

Marrone, Irene y Mercedes Moyano Walker. "Imaginarios contrapuestos en la filmografía del agro pampeano argentino", Mundo Agrario, 3. La Plata, CEHR-UNLP; www.mundoagrario.unlp.edu.ar.

Martínez de Ibarreta, Mariano y Pablo Pucciarelli (1992). "Subdivisión ficticia de la propiedad rural y elusión impositiva en la provincia de Buenos Aires: la situación actual", Ciclos, 3.

Martínez Dougnac, Gabriela (2001). "Un nuevo sujeto social? Aportes para la definición del 'chacarero' pampeano en la segunda mitad del siglo XX". Ponencia presentada a las VIII Jornadas Interescuelas/departamentos de Historia, Salta.

Marx, Karl (1850). Las luchas de clases en Francia de 1848 a 1850. Buenos Aires, Editorial Anteo, 1973.

Marx, Karl (1852). El dieciocho brumario de Luis Bonaparte. Buenos Aires, Editoral Anteo, 1973.

Marx, Karl (1867/1894). El capital. México, Ed. Cartago, 1983.

Marx, Karl y Engels, Friedrich (1973). Correspondencia. Buenos Aires, Editorial Cartago.

Mascali, Humberto (1986). Desocupación y conflictos laborales en el campo argentino (1940-1965). Buenos Aires, Centro Editor de América Latina, Biblioteca Política Argentina Nro.139.

Mascali, Humberto (1990). "Trabajo y ciclo doméstico en las explotaciones familiares", Ruralia, Revista argentina de estudios agrarios, 1, octubre de 1990; p. 81-106.

Mateo, Graciela (2002). "El cooperativismo agrario en la provincia de Buenos Aires (1946-1955)". Ponencia editada en las Actas de las XVIII Jornadas de Historia Económica, Mendoza, Septiembre de 2002 (CD-Rom).

McKinney, John C. (1968). Tipología constructiva y teoría social. Buenos Aires, Amorrortu editores.

Meillassoux, Claude (1987). Mujeres, graneros y capitales. Economía doméstica y capitalismo. México, Siglo XXI.

Merton, Robert (1964). Teoría y estructura sociales. México, FCE.

Míguez, Eduardo (1999). "Familias de clase media: la formación de un modelo", en F. Devoto y M. Madero (dir.), Historia de la vida privada en la Argentina, Tomo II: La Argentina plural: 1870-1930, Buenos Aires, Taurus.

Milesi, Matilde (1975). "La pampa en cifras", en El país de los argentinos. Buenos Aires, CEAL.

Molinero, Fernando (1990). Los espacios rurales. Agricultura y sociedad en el mundo. Barcelona, Ariel.

Montaldo, Graciela (1993). De pronto, el campo. Literatura argentina y tradición rural. Buenos Aires, Beatriz Viterbo editora. 
Mooney, Patrick (1987). "Desperately Seeking: One-dimensional Mann and Dickinson", Rural Sociology, 52(2).

Mooney, Patrick (1988). My Own Boss? Class, Rationality, and the Family Farm. Boulder and London, Westview Press.

Morrison, Barrie M. (1997). "The Embourgeoisement of the Kerala Farmer", Modern Asian Studies, 31.

Murmis, Miguel (1979). "Sobre una forma de apropiación del espacio rural: el terrateniente pampeano y un intento por transformarlo", en Murmis, Bengoa y Barsky. Teratenientes y desarrollo capitalista en el Agro. Quito, Ed. Ceplaes.

Murmis, Miguel (1980). "El agro serrano y la vía prusiana de desarrollo capitalista", en Barsky y otros, Ecuador: cambios en el agro serrano. Quito, FLACSO-CEPLAES.

Murmis, Miguel (1988). "Sobre expansión capitalista y heterogeneidad social", en Barsky et al. La Agricultura Pampeana. Transformaciones productivas y sociales. Buenos Aires, CFE-IICA-CISEA.

Murmis, Miguel (1995). "Algunos temas para la discusión en la sociología rural latinoamericana: reestructuración y problemas de excluidos e incluidos", en Mónica Bjerg y Andrea Reguera (comp.) Problemas de la Historia Agraria. Nuevos debates y perspectivas de investigación. Tandil, IEHS.

Murray, W.G. (1946). "Struggle For Land Ownership", en A Century of Farming in Iowa, 1846-1946, elaborado por los miembros del Iowa State College y de la Iowa AES. Ames, Iowa, The Iowa State College Press.

Neiman, Guillermo, S. Bardomás y D. Jiménez (2001). "Estrategias productivas y laborales en explotaciones familiares pluriactivas de la provincia de Buenos Aires", en G. Neiman (comp.), Trabajo de campo. Producción, tecnología y empleo en el medio rural. Buenos Aires, Ediciones Ciccus.

Nemirovsky, Ada S. de (1995). "Debates sobre la perdurabilidad de los farmers en Estados Unidos", Ruralia, 6.

Neocosmos, Michael (1986). "Marx's Third Class: Capitalist Landed Property and Capitalist Development", The Journal of Peasant Studies, Vol. 13 (3).

Newby, Howard (1983). "La Sociología Rural Institucionalizada", primera parte de H. Newby y E. Sevilla Guzmán, Introducción a la sociología rural. Madrid, Alianza.

Novick, Susana (1986). IAPI: auge y decadencia. Buenos Aires, CEAL.

Obschatko, Edith S. de (1986). La transformación económica y tecnológica de la agricultura pampeana. 1950-1984. Buenos Aires, Ediciones Culturales Argentinas.

Obschatko, Edith S. de. (1988). "Las etapas del cambio tecnológico", en Barsky et al. La Agricultura Pampeana. Transformaciones productivas y sociales. Buenos Aires, CFEIICA-CISEA.

Olivera, Gabriela (2002). "Conformación institucional y organización cooperativa. El caso de la cooperativa de Los Cóndores (Córdoba, Argentina; 1951-1956)". Ponencia editada en las Actas de las XVIII Jornadas de Historia Económica, Mendoza, Septiembre de 2002 (CD-Rom).

Pagliettini, Liliana y otros (2002). "El impacto de las políticas en la evolución del agro pampeano 1976-1983". Ponencia editada en las Actas del XIII Economic History Congress. Buenos Aires, Julio de 2002. 
Palacio, Juan Manuel (1992a). "Notas para el estudio de la estructura productiva en la región pampeana. Buenos Aires, 1914-1937", Ruralia, 3.

Palacio, Juan Manuel (1992b). "Arrendatarios agrícolas en una empresa ganadera. El caso de 'Cruz de Guerra', 1927-1938", Desarrollo Económico, 32.

Palacio, Juan Manuel (2002). "La estancia mixta y el arrendamiento agrícola: algunas hipótesis sobre su evolución histórica en la región pampeana, 1880-1940". Ponencia editada en las Actas de las XVIII Jornadas de Historia Económica, Mendoza, Septiembre de 2002 (CD-Rom).

Perazzo, Nelly y Guillermo Whitelow (1980). El paisaje en la Argentina a través de sus pintores en el siglo XX. Buenos Aires, Municipalidad de la Ciudad de Buenos Aires.

Perelman, Michael (1979). "Obstacles to the Development of a Capitalist Agriculture: A Comment on Mann and Dickinson", Journal of Peasant Studies, vol. 7 (1).

Peretti, Miguel y Pedro Gómez (1991). "Evolución de la ganadería", en Osvaldo Barsky (editor). EI desarrollo agropecuario pampeano. Buenos Aires, INDEC-INTA-IICA.

Pizarro, José y Cascardo, Antonio (1991). "La evolución de la agricultura pampeana", en Barsky, Osvaldo (ed). El desarrollo agropecuario pampeano. Buenos Aires, INDECINTA-IICA, FCE.

Posada, Marcelo Germán (1995). "Enfoque de sistemas y racionalidad de los productores. Situaciones de producción específicas: el caso de los productores pampeanos", en Realidad Económica, 133.

Posada, Marcelo G. (1998). "Agricultura, economía y sociedad: pools y fondos de inversión en la pampa argentina", Informe de Coyuntura, 36, CEB, La Plata.

Pucciarelli, Alfredo (1986). El capitalismo agrario pampeano. Buenos Aires, Hyspamérica.

Pucciarelli, Alfredo (1992). "Evolución reciente de la economía agraria pampeana. Buenos Aires 1960-1988", ponencia presentada a las XII Jornadas de Historia Económica, Mendoza.

Pucciarelli, Alfredo (1993). "Estancias y estancieros. El rol de las grandes explotaciones en las transformaciones recientes de la estructura agraria de la pampa bonaerense", en Marta Bonaudo y Alfredo Pucciarelli (comp.) La problemática agraria. Nuevas aproximaciones. Vol III. Buenos Aires, Centro Editor de América Latina.

Pucciarelli, Alfredo (1997a). "Estructura agraria de la pampa bonaerense. Los tipos de explotaciones predominantes en la provincia de Buenos Aires", en O. Barsky y A. Pucciarelli (ed.) El agro pampeano. El fin de un período. Buenos Aires, FLACSO CBC, UBA.

Pucciarelli, Alfredo (1997b). "Las grandes estancias de la pampa bonaerense", en O. Barsky y A. Pucciarelli, El agro pampeano. El fin de un período. Buenos Aires, FLACSOUBA.

Ras, Norberto y Levis, Roberto (1980). El precio de la tierra. Su evolución entre los años 1916 y 1978. Buenos Aires, Sociedad Rural Argentina.

Reca, Lucio (1967). The price and production duality within Argentine agriculture, 1923-1965. A dissertation submitted to the Faculty of the division of the Social Sciences in candidacy for the degree of Doctor of Philosophy, Department fo Economics. Chicago, The University of Chicago.

Reca, Lucio (1969). "Determinantes de la oferta agropecuaria en la Argentina. 1934/35 1966/67", en: Estudios sobre la economía argentina. Buenos Aires, Nro. 5. 
Reca, Lucio y Katz, Luis (1991). "Procesos de ajuste y políticas agropecuaria y alimentaria: algunas reflexiones sobre la experiencia argentina", en J. Garramón y otros. Ajuste macroeconómico y sector agropecuario en América Latina. Buenos Aires, Legasa.

Reguera, Andrea (1993). "Arrendamientos y formas de acceso a la producción en el Sur bonaerense: el caso de una estancia del partido de Necochea, primera mitad del siglo XX", en R. Mandrini y A. Reguera (comp.), Huellas en la tierra. Indios, agricultores y hacendados en la pampa bonaerense. Tandil, IEHS.

Reguera, Andrea (2000). "Estrategias de inversión en las estancias pampeanas del siglo XIX. El caso de un gran empresario y propietario de tierras", Ciclos, 20.

Reinhardt, Nola y Barlett, Peggy (1989). "Family Farm competitiveness in United States Agriculture", en Food and Farm. Current Debates and Policies. Monographs in Economic Anthropology, No. 7 (Christina Gladwin y Kathleen Truman, ed. Lanham, University Press of America.

Reiss. Franklin (1961). Farm Lease Practice in East-Central Illinois. Urbana (Illinois). Agricultural Experiment Station, Bulletin 677.

Reiss. Franklin (1968). Farm Lease Practice in Western Illinois. Urbana (Illinois). Agricultural Experiment Station, Bulletin 728.

Rocci, Fernando (2002). "Estilos de vida", en Carlos Altamirano (director), Términos críticos de sociología de la cultura. Buenos Aires, Paidós.

Rodríguez Otero, Mariano y Graciela Sarti (1991). "Del desierto indómito al campo manso: iconografía de la pampa hasta su 'dominación'", en Ciudad / Campo en las Artes en Argentina y Latinoamérica. Terceras Jornadas de Teoría e Historia de las Artes. Buenos Aires, CAIA.

Rösener, Werner (1995). Los campesinos en la historia europea. Barcelona, Crítica.

Ruffini, Martha (1993). "Un aspecto de la relación Yrigoyen-Crotto. Agro y política en la Pcia. de Buenos Aires", Estudios de Historia Rural III, Serie Estudios e Investigaciones (15), La Plata, Universidad Nacional de La Plata; p.p. 33-58.

Sábato, Jorge F. (1979). "Notas sobre la formación de la clase dominante en la Argentina moderna (1880-1914)"; en: Sábato, Jorge F. La clase dominante en la Argentina moderna. Formación y características. Buenos Aires, CISEA-Grupo Editor Latinoamericano, 1988.

Sábato, Jorge F. (1980). La pampa pródiga: Claves de una frustración. El agro pampeano argentino y la adopción de tecnología entre 1950 y 1978: Un análisis a través del cultivo del maíz. Buenos Aires, CISEA.

Sábato, Hilda (1989). Capitalismo y ganadería en Buenos Aires: la fiebre del lanar, 1850-1890. Buenos Aires, Sudamericana.

Sahlins, Marshall (1983). Economía de la edad de piedra. Madrid, Akal.

Salamon, S., K. Genenbacher y D. Penas (1986). "Family factors affecting the intergenerational succession to farming", Human Organization, vl 45, $\mathrm{n}^{\circ} 1$.

Salamon, Sonya (1980). "Ethnic Differences in Farm Family Land Transfers", Rural Sociology, 45 (2); p.p. 290-308.

Salamon, Sonya (1989). "Persistence among Middle-range Corn Belt Farmers", en Food and Farm. Current Debates and Policies. Monographs in Economic Anthropology, No. 7 (Christina Gladwin y Kathleen Truman, ed. Lanham, University Press of America; p.p. 345-365 
Salamon, Sonya (1992). Prairie Patrimony. Family, farming and community in the Midwest. Chapel Hill y Londres, The University of North Carolina Press.

Saltalamacchia, Homero (1992). Historia de vida: reflexiones a partir de una experiencia de investigación. Caguas, Puerto Rico, CIJUP.

Saltalamacchia, Homero (1994). "Historia de vida y reconstrucción articulada: reflexiones teórico-metodológicas a partir de una experiencia de investigación", en Suplementos, 45 (Círculos de reflexión latinoamericana en Ciencias Sociales). Barcelona, Anthropos.

Saltalamacchia, Homero R. (1997). Los datos y su creación. Caguas (Puerto Rico), Kryteria.

Samaja, Juan (1994). Epistemología y metodología. Elementos para una teoría de la investigación científica. Buenos Aires, Eudeba.

Sanchez-Albornoz, Nicolás (1985). "Poblamiento y despoblación rural de la provincia de Buenos Aires, 1869-1960", Anuario, 11. Escuela de Historia, Facultad de Humanidades y Artes de la Universidad Nacional de Rosario.

Sarlo, Beatriz (1988). Una modernidad periférica: Buenos Aires, 1920 y 1930. Buenos Aires, Nueva Visión.

Sartelli, Eduardo (1993). "El estancamiento de la agricultura pampeana y el mercado mundial (1900-1960)", ponencia presentada a las 4as. Jornadas Interescuelas/ Departamentos de Historia, Mar del Plata, Octubre de 1993.

Sartelli, Eduardo (1993). "El nivel tecnológico de la agricultura pampeana, 1880-1940. A propósito del 'atraso' de la mecanización de la cosecha maicera", Estudios Sociales, 5. Santa Fe, Año 3, Segundo semestre de 1993; p.p. 93-108.

Sartelli, Eduardo (1994). "La vida secreta de las plantas: el proletariado agrícola pampeano y su participación en la producción rural", ponencia presentada a las XIV Jornadas de Historia Económica, Córdoba.

Sartelli, Eduardo (1997). "Ríos de oro y gigantes de acero. Tecnología y clases sociales en la región pampeana (1870-1940)", Razón y Revolución, 3. Invierno de 1997.

Sartelli, Eduardo (2000). "Procesos de trabajo y desarrollo capitalista en la agricultura. La región pampeana, 1870-1940", Razón y Revolución, 6. Otoño de 2000.

Schütz, Alfred (1974). El problema de la realidad social. Buenos Aires, Amorrortu.

Scott, John y C. Cagley (1968). The economics of machinery choice in corn production. Agricultural Experiment Station, University of Illinois, Bulletin 729, Urbana, Illinois.

Sesto, Carmen (2002). "La maduración del programa de cambio racial: ¿un fenómeno de la incorporación al mercado internacional (1856-1894)?", ponencia publicada en las Actas de las XVIII Jornadas de Historia Económica, Mendoza (CD-ROM).

Shejtman, Alexander (1980). Economía campesina, lógica interna y articulación. México, Doc. del Programa de Capacitación de la CEPAL.

Singer, E., G. Green y J. Gilles (1984). "The Mann-Dickinson thesis: reject or revise?", Sociologia Ruralis, vol. 23 (3/4).

Slutzky, Daniel (1968). "Aspectos sociales del desarrollo rural en la pampa húmeda argentina", en Desarrollo Económico, Nro.29. Buenos Aires, IDES.

Scobie, James (1968). Revolución en las pampas. Historia social del trigo argentino, 1860-1910. Buenos Aires, Solar/Hachette. 
Solá, Felipe (1985). Empresas agrícolas, diferenciación, rentabilidad e impactos de políticas alternativas. Documento $\mathrm{n}^{\circ} 12$. Buenos Aires, CISEA.

Solá, Felipe (1991). "Los tipos de empresas agropecuarias", en Barsky (editor). El desarrollo agropecuario pampeano. Buenos Aires, INDEC-INTA-IICA.

Solberg, Carl (1987). The prairies and the pampas. Agrarian Policy in Canada and Argentina, 1880-1930. Stanford, Stanford University Press.

Stebbins, Robert (1997). "Lifestyle as a generic concept in ethnographic research", Quality \& Quantity, Vol. 31 (4). Noviembre de 1997; p.p. 347-360.

Stolen, Kristi Anne (1996). The Decency of Inequality. Gender, Power and Social Change on the Argentine Prairie. Oslo, Scandinavian University Press.

Strohbehn, Roger y John Timmons (1960). Ownership of Iowa's Farmland. Ames (Iowa), Agricultural and Home Economics Experiment Station, Iowa State University, Research Bulletin 489 .

Strumpel, Burkhard (1979). "Conducta y bienestar económico: modelo y enfoque interdisciplinarios", en B. Strumpel, J. Morgan y E. Zahn, La conducta humana en las relaciones económicas. México, De. Trillas.

Szelenyi, Ivan (1988). Socialist Entrepreneurs. Embourgeoisement in Rural Hungary. Madison, The University of Wisconsin Press.

Taylor, Carl (1948). Rural Life in Argentina. Baton Rouge, Lousiana State University Press.

Tecuanhuey Sandoval, Alicia (1988). La revolución de 1943: políticas y conflictos rurales. Buenos Aires, CEAL.

Tehrborn, Göran (1987). La ideología del poder y el poder de la ideología. México, Siglo XXI.

Timmons, John y R. Barlowe (1949). Farm Ownership in the Midwest. Ames (Iowa), Agricultural Experiment Station, Iowa State College of Agriculture and Mechanic Arts, Research Bulletin 361.

Tort, María Isabel (1980). Tecnología y mano de obra en el cultivo del maíz y el trigo en la región pampeana. Documento de trabajo Nro. 8. Buenos Aires, CEIL.

Tort, María Isabel y Nora Mendizábal (1980). "La fuerza de tracción en la agricultura argentina: maquinaria agrícola y estructura agraria, el caso de las zonas cerealeras pampeanas", en M.I. Tort, Tecnología y empleo en el agro, el caso argentino. Recopilación de ensayos. Volumen II. Buenos Aires, CEIL.

Tort, María Isabel (1983). "Tecnificación agraria y formas de producción. Su impacto en las condiciones de vida rural. Un estudio de caso". Tesis del curso tutorial de posgrado, FLACSO-Argentina (inédita).

Tort, María Isabel, S. Bearzotti y G. Neiman (1991). "Trabajo y producción en las explotaciones familiares", en Osvaldo Barsky (editor). El desarrollo agropecuario pampeano. Buenos Aires, INDEC-INTA-IICA; p. 565-606.

Tranchini, Elina (2000). "Persistence of Rural Images and 'Criollistas' Identities in the Argentine Cinema, 1915-1945". Ponencia editada en las Actas del X World Congress of Rural Sociology. Río de Janeiro, Agosto de 2000.

Vapñarsky, Cesar A. (1995). "Primacía y macrocefalía en la Argentina: la transformación del sistema de asentamiento humano desde 1950", Desarrollo Económico, 35, nº 138.

Veal, A. J. (1993). "The concept of lifestyle: a review", Leisure Studies, 12. 
Villar Araujo, Carlos (1974). "¿Es intocable la pampa húmeda? En torno a la ley agraria", Crisis, $\mathrm{n}^{\circ}$ 20, Buenos Aires, diciembre de 1974; p.p. 19-32.

Villarreal, Juan (1985). "Los hilos sociales del poder", en E. Jozami y otros, Crisis de la dictadura argentina. Política económica y cambio social (1976-1983). Buenos Aires, Siglo XXI.

Villarruel, José (1988). El ocaso de un paradigma: la Argentina en la depresión mundial. Buenos Aires, Biblos.

Villarruel, José (1992). "Las ventajas competitivas de una estepa humedecida: la pampa, 1890-1914", Ciclos, No. 3.

Viñas, Ismael (1973). Tierra y clase obrera. Buenos Aires, Achával solo.

Weber, Max (1905). La ética protestante y el espíritu del capitalismo. Buenos Aires, Hyspamérica, 1988.

Weber, Max (1906). "Capitalismo y sociedad rural en Alemania", en Weber, Max. Ensayos de sociología contemporánea II. Barcelona, Planeta-Agostini, 1985.

Weber, Max (1922). Economía y Sociedad. Esbozo de sociología comprensiva. México, FCE, 1984.

Wechsler, Diana (1991). "Paisaje, crítica e ideología", en Ciudad / Campo en las Artes en Argentina y Latinoamérica. Terceras Jornadas de Teoría e Historia de las Artes. Buenos Aires, CAIA.

Wechsler, Diana (1995). "La crítica del arte. Condicionadora del gusto, el consumo y la consagración de obras de arte. Buenos Aires, 1920-30. Prensa, crítica y campo artístico". Tesis doctoral en Historia del Arte, Universidad de Granada.

Wells, Miriam (1987). "Sharecropping in the United States: A Political Economy Perspective", en M. Chibnik (ed.), Farm Work and Fieldwork, Ithaca and London, Cornell University Press.

Williams, Raymond (1980). Marxismo y literatura. Barcelona, Ediciones Península.

Williams Alzaga, Enrique (1955). La pampa en la novela argentina. Buenos Aires, Angel Estrada Editores.

Wimberley, Ronald (1986). "Trends and dimensions in U.S. agricultural structure", en J. Molnar (ed.), Agricultural Change, Boulder and London, Westview Press.

Winson, Anthony (1994). "La 'vía prusiana' de desarrollo agrario: una reconsideración", Ruralia, 4. Buenos Aires, FLACSO.

Yoder, Frank (1997). "Retinking Midwestern Farm Tenure: A Cultural Perspective", Agricultural History, 71 (4).

Zeberio, Blanca (1993). "La situación de los chacareros arrendatarios en la pampa húmeda. Una discusión inacabada", en R. Mandrini y A. Reguera (comp.), Huellas en la tierra. Indios, agricultores y hacendados en la pampa bonaerense. Tandil, IEHS.

Zeberio, Blanca (1995). "El estigma de la preservación. Familia y reproducción del patrimonio entre los agricultores del sur de Buenos Aires, 1880-1930", en M. Bjerg y A. Reguera, Problemas de la historia agraria. Nuevos debates y perspectivas de investigación. Tandil, IEHS. 
Zemelman, Hugo (1992). Los horizontes de la razón. T.I. Dialéctica y apropiación del presente y T.II. Historia y necesidad de utopía. Barcelona, Anthopos-El Colegio de México. 